\title{
Claves para entender las reformas del Derecho de Familia español: Principios Informadores
}

\author{
Tesis doctoral \\ Departamento de Derecho Civil, Facultad de Derecho \\ Universidad de Valladolid \\ Directora de tesis: Sra. Dra. Cristina Guilarte Martín-Calero \\ Doctorando: Sr. Martín Rocha Espíndola
}

Año 2013 
Indice 


\section{CAPÍTULO I}

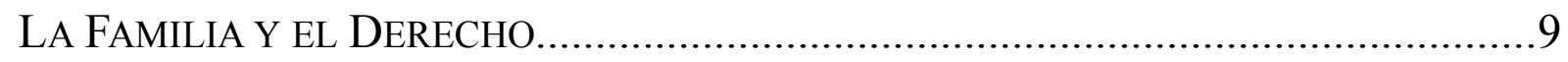

$1 \mid$ Consideraciones previas...........................................................................................

2 | La Familia como comunidad de personas. Análisis desde sus funciones.......................13

3 | Etimología del término familia, su constante evolución................................................18

4 | Consideraciones para la conceptualización del término familia desde el punto de vista

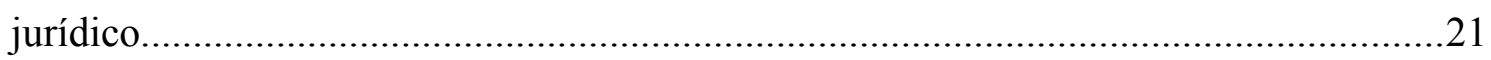

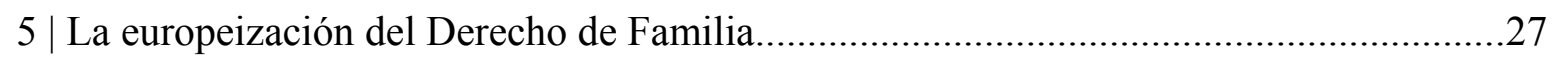

6 | El Estado de las Autonomías y el Derecho de Familia, el rompecabezas de las

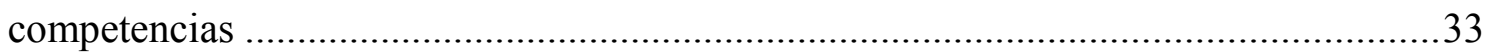

\section{CAPÍTULO II}

EL PRINCIPIO DE IGUALDAD Y EL DERECHO DE FAMILIA....................................49

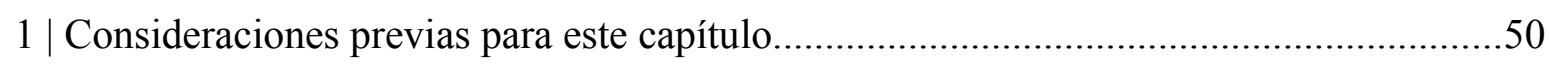

1.1 Distinción entre el Derecho de Igualdad y otros conceptos afines. Equidad, identidad

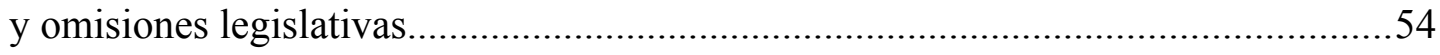

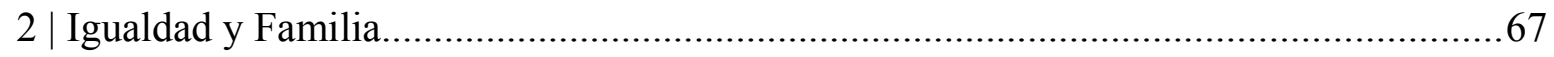

2.1 ¿De qué igualdad hablamos cuando nos referimos a la familia?..............................67

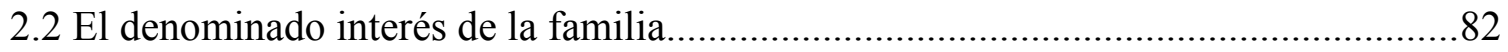

2.3 La igualdad de las familias ante la Constitución, ¿Familia o modelos de familia?....91

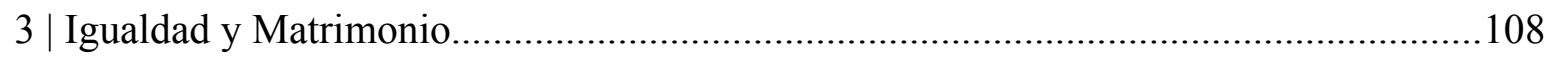

3.1 La evolución de la garantía institucional del matrimonio........................................108

3.2 La Ley 13/2005, que modifica el Código Civil en lo referente al matrimonio. El matrimonio homosexual y el fin de la necesaria heterosexualidad para contraer matrimonio.

3.3 ¿Qué se entiende en la actualidad por matrimonio?, especial referencia a la relación entre el art. 12 del Convenio Europeo de Derechos Humanos y la actualidad española. La intervención social del mismo.

3.4 El principio de igualdad como criterio rector en materia de efectos personales del 
matrimonio. El deber de socorro mutuo

3.5 El principio de igualdad entre los progenitores en la guarda y custodia compartida 169

3.6 Especial referencia a la maternidad, paternidad y familia. Comentarios a propósito de la Ley orgánica para la igualdad efectiva de mujeres y hombres. 182

4 | Igualdad de género y Derecho civil. La situación de la mujer. Una relación que se intenta armonizar vía reformas legislativas y jurisprudencialmente.

5 | El principio de igualdad que inspira las relaciones patrimoniales en el matrimonio.....203

6 | Igualdad y Filiación, en relación al Derecho a la identidad.....

6.1 La filiación como institución del Derecho de familia: La convergencia de factores biológicos y legales

6.2 La Dignidad Humana y el Derecho a la Identidad................................................230

6.3 ¿Qué puede entenderse por Derecho a la identidad?.............................................242

6.4 El libre desarrollo de la personalidad y la libre investigación de la paternidad........250

6.5 El reconocimiento jurídico del Derecho a la identidad........................................256

6.6 Verdad biológica y autonomía, en relación con la determinación de la filiación.....267

6.7 El derecho a la identidad y la libre investigación de la paternidad en el caso de la adopción.

\section{CAPÍTULO III}

AutonOMÍA DE LA VOLUnTAD Y DERECHO DE FAMILIA................................278

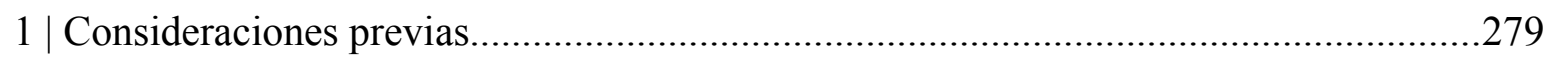

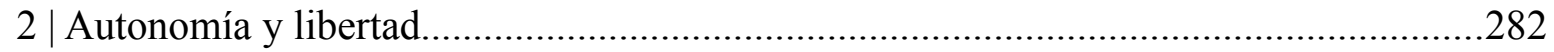

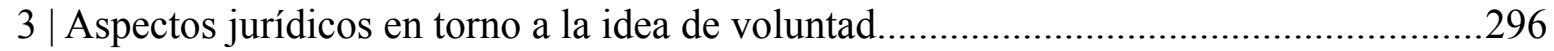

3.1 Elementos constitutivos del acto jurídico. Voluntad y manifestación........................297

4 | El principio de autonomía de la voluntad en la Constitución española de 1978..........300

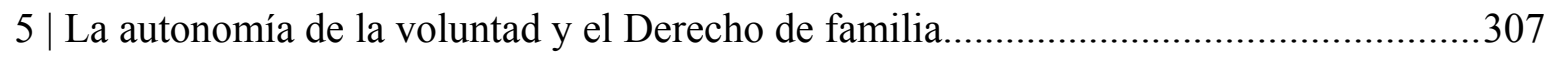

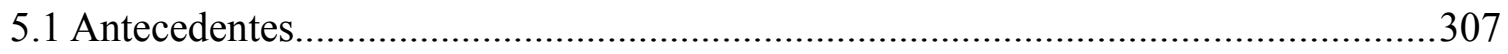

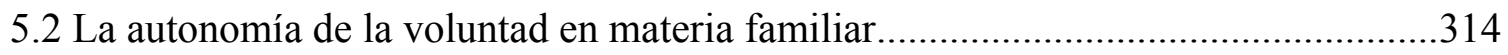

5.3 Modificaciones en el concepto de la familia que pudieran haber influido en la 
autonomía de la voluntad.

5.4 Acerca de los límites generales a la autonomía de la voluntad en el ámbito de las relaciones conyugales.

5.5 Autonomía de la voluntad y crisis matrimoniales.

5.6 Principios generales de la mediación familiar, fruto de la autonomía de la voluntad, en el ámbito de las crisis familiares

6 | La autonomía de la voluntad del menor. 371

6.1 Autonomía del menor en el ámbito sanitario: el consentimiento informado. .384

\section{CAPÍtUlo IV}

\section{EL PRINCIPIO DEL INTERÉS SUPERIOR DEL MENOR Y EL DERECHO DE FAMILIA 388}

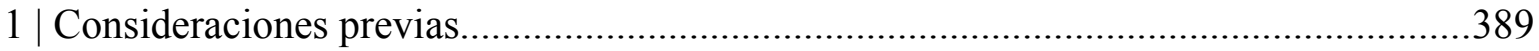

2 | El desarrollo de la persona y el ordenamiento jurídico..................................................396

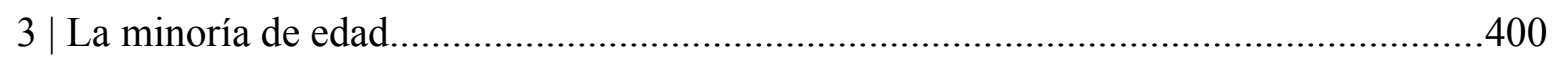

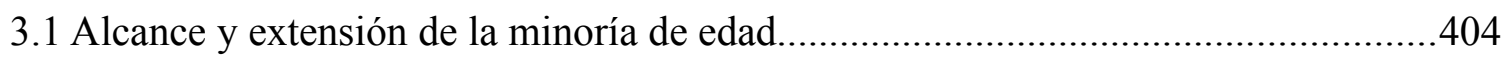

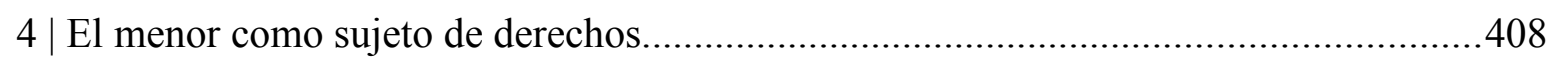

4.1 Las necesidades de la infancia, la respuesta familiar formulada.............................415

5 | Algunas consideraciones en torno al interés del menor y la Carta Europea de Derechos

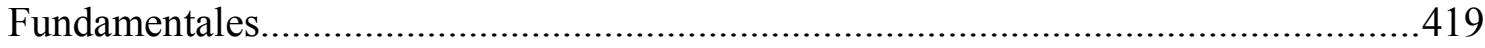

6 | El interés del menor como concepto jurídico indeterminado.....................................423

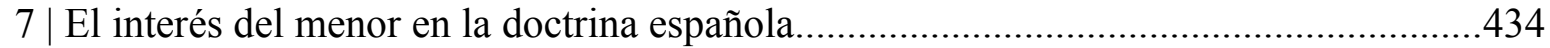

8 | El interés del menor tras la Constitución de 1978 .......................................................442

9 | El interés del menor y la interpretación restrictiva de las limitaciones a la capacidad de obrar de los menores en la Ley Orgánica 1/1996, de 15 de enero, de protección jurídica del menor.

10 | Análisis del interés del menor como principio general.............................................454

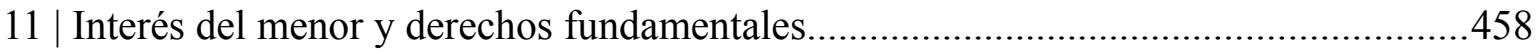

12 | Los significados del concepto de principio para comprender el interés del menor como tal.

13 | Interferencias parentales e interés del menor..

14 | Algunas conclusiones en torno al interés del menor. 485 


\section{CAPÍTULO V}

EL PRINCIPIO DEL LIBRE DESARROLLO DE LA PERSONALIDAD Y EL DERECHO DE FAMILIA. Su INFLUENCIA EL PRINCIPIO DE IGUALDAD, EN LA AUTONOMÍA DE LA VOLUNTAD Y EN EL INTERÉS SUPERIOR DEL MENOR......................................492

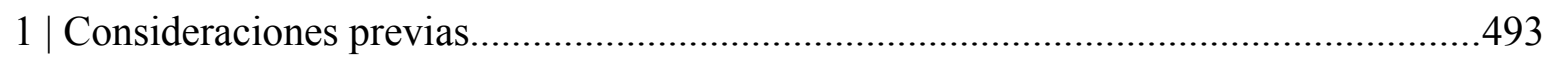

2 | El fundamento del principio del libre desarrollo de la personalidad: la dignidad y la

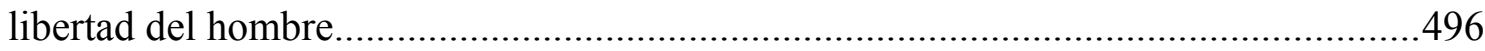

3 | El principio del libre desarrollo de la personalidad y el Derecho de Familia................507

4 | El libre desarrollo de la personalidad y la transexualidad...............................................520

5 | El libre desarrollo de la personalidad en el menor......................................................531

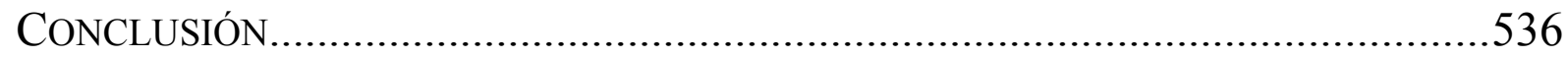

Consideraciones finales del presente trabajo. Una visión antropológica y civilista, influenciada por el Derecho Constitucional, de la problemática actual del Derecho de

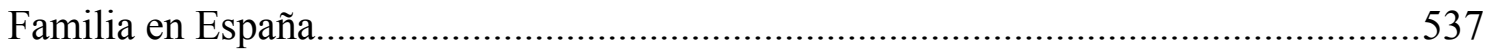

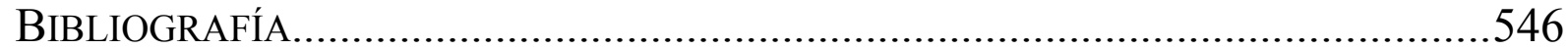




\section{INTRODUCCIÓN}


España es rica en personajes entrañables para la literatura universal, entre ellos el Lazarillo de Tormes, Don Juan, el Mio Cid y los que más Don Quijote de La Mancha y Sancho Panza. El Quijote universal es un entramado de sabiduría popular y sentido común, y claro está, que para todo conocedor del Derecho, este es, en sentido estricto ratio scripta, sentido común, o por lo menos esto debiese reflejarse en los diversos preceptos que forman nuestra normativa. Pero ¿es realmente así?

En uno de los capítulos más famosos de la ya clásica obra, el caballero de la Triste figura le pide a su escudero, a la sazón Gobernador de la ínsula Barataria que gobierne y legisle con criterio, cito, por ello, los famosos versos que describen el dialogo: "sobre todo que se guarden y que se cumplan, que las pragmáticas que no se guardan, lo mismo que si no lo fueran"1. Esta cita me parece muy importante porque es de plena actualidad, por el caótico panorama presentado en el ordenamiento jurídico español, especialmente en al ámbito que nos interesa, el Derecho de Familia. Aunque reconozco, no es esa la hipótesis que se plantea como hilo conductor del presente trabajo, sin embargo es importante justamente porque ante la dispersión de leyes son los principios los que ejercen un papel unificador.

Existe un normativismo exagerado, con disparidad de criterio, lo que ha provocado la desconfiguración de ciertas instituciones que fueron creadas para determinadas situaciones y que ahora mismo regulan otras que exceden sus fronteras ${ }^{2}$. Eso si, se atisban rayos de luz, en-

1 CERVANTES Y SAAVEDRA, M DE. “Don Quijote de la Mancha”, Centro Virtual Cervantes, Literatura, ClásicosHispánicos. http://cvc.cervantes.es/literatura/clasicos/quijote/edicion/parte2/cap51/cap51 02.htm

2 SORO RUSSELL, O (Trad.). "Coloquio de las tergiversaciones en el Derecho de Familia”, Revista Aranzadi Doctrinal, Pamplona, año 2011, páginas 195 a 201. El citado autor sostiene que un interesante punto de vista lo constituye el enunciado por LEMOULAND, J. J, para quien en relación con la tergiversación de instituciones familiares para la consecución de fines civiles de carácter extra-patrimonial, definió el «détournement» como una transgresión del orden jurídico establecido sobre el que se asienta la institución tergiversada. Y destacó que si dichas transgresiones constituyen habitualmente una perversión del espíritu de las instituciones, en ocasiones también pueden significar un primer paso para la evolución del Derecho. Así, en el primer sentido distinguiría, atendiendo al grado de desnaturalización de la institución, entre transgresiones duras y suaves ( détournements durs et doux), citando para ello los ejemplos de la adopción de menores con el fin de crear, formalizar o consolidar un concubinato cuando dicha finalidad debería realizarse mediante la celebración del matrimonio, y en segundo lugar el de la adopción de hijos procedentes de madres de alquiler que, pese a todo, confiere al niño una filiación que antes no tenía. Desde un segundo punto de vista, que considera estas tergiversaciones como un modo para promover la evolución del Derecho, destaca la opinión de MURAT, P para quien una de las consecuencias positivas de dichas prácticas puede situarse precisamente en la eventual respuesta que frente a ellas puede ofrecer el Derecho. En efecto, bajo su punto de vista, aunque la mayor parte de estas prácticas responden a intereses estrictamente egoístas y conllevan un «despiece» de las instituciones al buscar únicamente aprovecharse de unos efectos u eliminar aquéllos que no convienen, en ciertas ocasiones pueden constituir un síntoma de la necesidad de transformar el Derecho o de colmar las deficiencias de algunas instituciones. Así, desde esta perspectiva, mientras que las primeras constituirían una negación del Derecho existente, las segundas 
tre tantas normas, existen claves que nos permiten procurar entender este edificio gigantesco que parece ser el Derecho en cuestión, o por lo menos intentarlo, no es del todo imposible.

A pesar de que el desconocimiento de la ley no exime de su cumplimiento, hoy por hoy resulta a todas luces inabarcable la telaraña normativa que invade todos los aspectos de la vida cotidiana $^{3}$. Es problemático el legislar por todos y para todos e imposible dejar a todo el mundo contento. Si bien el segundo aspecto es clásico, el primero resulta a todas luces crítico. Cualquier despacho, de cualquier institución, de cualquier comunidad autónoma siente la necesidad de regular, pero lo que ocurre a nivel macro sucede a nivel micro, es decir, desde Bruselas hasta el último trozo de tierra de España. Pero eso no es todo, porque, existen pocas áreas del Derecho donde el tinte ideológico, llámese conservador o progresista sea tan notorio como en la presente. Posiblemente el regular un contrato, sus reformas y modificaciones no influya tanto en la configuración de la sociedad que queremos, pero el normar la familia e incluso, el reformar al matrimonio, dice mucho sobre el país que se quiere construir.

En relación a lo anterior, me he percatado sobre la importancia de estudiar los principios que informan el ordenamiento jurídico, debido a que constituyen el sustrato que lo fundamenta, lo explica y le da coherencia. A tales principios le he denominado claves porque a mi juicio son de vital importancia para procurar entender las reformas acaecidas en los últimos años, especialmente la última década, sin perjuicio de que este período de tiempo bastante cercano no puede entenderse sin las discusiones, reflexiones e innovaciones acaecidas años antes.

Como se sabe el término "principio" puede adoptar significados diversos, en palabras de RUIZ MANERO, principios como normas muy generales; principios como normas redactadas en términos especialmente vagos; principios como normas que expresen valores superiores de un ordenamiento jurídico o de un sector del mismo; principios como normas programáticas o directrices; Principios como normas dirigidas a órganos de aplicación y que señalan cómo se deben seleccionar o interpretar las normas aplicables y principios como enunciados generales que permiten la sistematización y comprensión de un ordenamiento o de un sector del mis-

podrían representar una contribución a la evolución del Derecho. Y, en su opinión, en este último caso las decisiones de los órganos jurisdiccionales asumirían un papel determinante.

3 Cfr. ORTÍZ DE ZÁRATE HIERRO, F. J. “Acceso a la justicia de los nuevos grupos sociales”, Actualidad Jurídica, Ed. Aranzadi, S. A., Pamplona, año 2005. En dicha obra se alude a lo disperso de la normas en relación al surgimiento de diversos grupos de carácter social. 
$\mathrm{mo}^{4}$. Las claves que se tratarán en el presente trabajo participan de estos diversos conceptos que se entienden como principios. Hay que subrayar, en tal sentido, que los principios son normas con caracteres especiales y no meros orientadores programáticos. Son normas con un carácter fundamental ${ }^{5}$, ya que su alteración provoca la transformación del ordenamiento o del sector del ordenamiento donde operan al ser considerados pautas preferenciales en la interpretación.

Estos principios se enmarcan en el ámbito del Derecho, pero un sector del mismo que tiene por objeto a la familia. En lo referente a ella, no es necesario descubrir la importancia que tiene esta, pero ¿realmente sabemos a que realidad nos estamos refiriendo cuando empleamos el término familia?, ¿es necesario conceptualizar dicha realidad o más bien encontrar y dilucidar ciertos elementos que contribuyan a su estimación?

No a cualquier forma de convivencia se le puede llamar familia. Para evitar confusiones, hace falta que a cada realidad o experiencia le corresponda un nombre preciso. LÉVI-STRAUSS hablaba de un fenómeno universal, presente en todos y cada uno de los tipos de sociedad $^{6}$. Esta importante afirmación indica la existencia de una suerte de universal social y cultural que señala el propium (lo propio) de la familia. Ella, por consiguiente, corresponde a una forma de comunidad, derivada de tres tipos de relaciones; la filiación, la consanguinidad y la convivencia de dos personas que puede ser conyugal o simplemente de hecho.

La familia pone en evidencia el vínculo de pertenencia que se instaura entre los sujetos que la componen, es esa forma específica de sociedad primaria lo que une y lo que de hecho permite un desarrollo armónico de las diferencias constitutivas del ser humano. La relación "tú-yo" cotidiana y estable que pasa a través de las relaciones primarias que se viven en la familia favorece también el crecimiento equilibrado de la persona. La autoconciencia del hom-

4 "Principios jurídicos", en GARZÓN VALDÉS, E. y LAPORTA, J. (Eds): “El Derecho y la justicia”, Madrid, Ed. Trotta-CSIC-BOE, año 1996 página 151.

5 BETEGÓN, J.; GASCÓN, M.; PÁRAMO, J. R. DE; PRIETO, L. "Lecciones de Teoría del Derecho", Ed. McGraw Hill, Madrid, año 1997, página 166. Se estima que la nota de la fundamentalidad se puede entender de diversas formas: 1) fundamentalidad jerárquica: se identifica con la jerarquía normativa; 2) fundamentalidad lógico-deductiva: es la que tienen aquellas normas de las que pueden ser deducidas, por vía lógica, otras normas; 3 ) fundamentalidad teleológica: es la que caracteriza las normas que establecen fines $\mathrm{u}$ objetivos respecto a otras, y 4) fundamentalidad axiológica: se predica de aquellas normas que contienen los valores políticos y éticos sobre los que se asienta una determinada estructura política y social.

6 http://seminariolecturasfeministas.files.wordpress.com/2012/01/la-familia- claude-1 vi-strauss .pdf, página 2. 
bre, incluso de forma inconsciente, se apoya por tanto en un vínculo y en una pertenencia originaria en la que es posible volver a encontrarse en todo momento. La familia, así entendida, se difunde en la sociedad no como un bien privado sino como un auténtico y verdadero bien común: saca a la luz la intrínseca naturaleza relacional de la experiencia humana. En este sentido, pertenencia familiar y pertenencia social se interrelacionan y remiten la una a la otra: la relación entre las dos desarrolla la confianza entre los sujetos y la capacidad de cooperar responsablemente al bien común en un incesante intercambio recíproco. Reconocer a la familia como sujeto social es uno de los desafíos cruciales a los que se enfrenta nuestra sociedad individualizada y fragmentada.

Que duda cabe, la familia influye en la configuración del Derecho y a su vez es influida por éste, hasta tal punto que muchas veces el Derecho puede quedar atrás en relación a la realidad que intenta regular, pero ¿puede suceder al revés, puede el Derecho ir por delante y regular determinadas situaciones incorporándolas al campo propio de la familia e influir en esta hasta tal punto de ampliar y modificar lo que se entiende por ella?

Al ser un campo tan amplio y abierto no podía ser estudiado tan sólo desde la órbita del Derecho Privado, específicamente del Derecho Civil, por ello quise desarrollar una tesis pluridisciplinar, que abarcase el Derecho Constitucional y la Filosofía del Derecho. Esto me resulta importante de destacar porque si bien en un principio pensé en hacer una tesis en Derecho de Familia, debo reconocer que durante los últimos años mis intereses han sido la Filosofía y la Literatura, y en el ámbito jurídico siempre he sentido predilección por el Derecho Constitucional y el Derecho Civil. No podía ser de otra manera, mi estudio debía implicar los tres enfoques antes mencionados.

Esto resultaba muy ambicioso y a su vez casi inabarcable, por ello se hacía necesario acotar los aspectos que a mi juicio siempre tuviesen un trasfondo civilista, sin perjuicio de comprender que justamente en el marco antropológico era donde con mayor riqueza se estudiaba la realidad familiar. Eso si, reconozco mis limitaciones como incipiente jurista, por ello escogí las claves que, a mi juicio, mejor explicaban la evolución del Derecho de Familia en el último tiempo, porque a su vez englobaban otros principios importantes.

Conjuntamente con lo anterior es importante precisar que el Derecho privado es la Ley de la vida diaria, su objetivo consiste en regular las relaciones jurídicas derivadas de lazos fa- 
miliares y de la propiedad privada. Si nos imaginamos todo el entramado de relaciones que ocurren entre las personas y que tales pueden ser conflictivas y que por ello requieren de una solución justa y clara, entonces de inmediato nos percatamos de que resulta imposible que la Ley llegue a cada rincón de dicho entramado, de allí la importancia de los principios, de las denominadas claves del entendimiento jurídico, para por lo menos intentar hacer del contexto normativo un sistema más expedito y estable ${ }^{7}$.

Sin duda el Derecho Privado no puede anclarse en su parcela ius privatum, cada vez se hace más necesario entender que hoy en día el Código Civil, norma ius privatista por excelencia, debe leerse, estudiarse, analizarse e interpretarse a la luz de la Constitución. Con esto no se busca restarle personalidad, al contrario, significa resaltar que así como la Carta Magna vela y rescata como centro del ordenamiento a la persona, existe otra rama del Derecho cuya trayectoria histórica ha sido, asimismo, buscar la protección de la persona en sus relaciones fundamentales, ya sean familiares o con terceros, este rama es sin duda el Derecho Civil ${ }^{8}$. Sin

7 Cfr. LEIBLE S. "El futuro del Derecho Privado Europeo", Diario La Ley, núm. 7085/2008, Año XXIX, parte Tribuna, Ed. La Ley - Actualidad, Las Rozas, año 2008.

8 DAJCZAK, W. "La revolución antiformalista del Derecho Privado", en VV. AA. "Hacia un Derecho Global”, Ed. Thomson Aranzadi, The global law collection, Cizur Menor, año 2006, páginas 85 a 88. .Los rasgos fundamentales del civil law, basado en las codificaciones de los siglos XIX y XX, responden a una vocación nacionalista, a una estructura lógica positivista y dogmática, y a su estricta vinculación con el texto de la ley. En este sistema, la solución de disputas legales gira en torno a los métodos de argumenta ción formal, de acuerdo a nociones abstractas recogidas de manera sistemática por las grandes codificaciones. Obviamente, una ley no puede describir cabalmente la riqueza de la vida, ni mucho menos. Durante el auge de los códigos legales, la imagen del mundo percibida, tanto por los codificadores como por los jueces, no difería mucho. Por ello, las cortes podían pronunciarse sobre la nueva casuística con relativa soltura. Esto se evidencia en la creatividad judicial que caracteriza al sistema civilista de aquellos días. Sin embargo, hoy la realidad es diametralmente opuesta a la de los codificadores de tales épocas. En el nuevo contexto la herencia formalista se muestra insuficiente para la solución de los conflictos judiciales. Si permanecemos anclados en una visión positivista, tendríamos que afrontar los problemas de la actualidad publicando nuevas leyes. Bajo tal perspectiva, los textos legales estarían destinados a multiplicarse ad infinitum, intentando, vanamente, superar el frenético proceso de cambios derivados de la globalización. Tal proceder equivaldría a perseguir nuestras propias sombras. Los nuevos desafíos no pueden ser encarados con antiguos métodos, heredados del radicalismo positivista y amparados por un modelo formalista.- La revolución europea contra el formalismo se halla en el centro de la discusión sobre el desarrollo del derecho privado en el viejo continente inspirada en el realismo legal norteamericano. En esencia, se busca concebir el derecho privado no sólo como un sistema formal del cual deducir soluciones, sino también como un sistema capaz de alcanzar objetivos políticos, económicos, sociales y culturales. En vista de la caducidad práctica del modelo actual, esta visión se presenta como sumamente atractiva. No obstante, el posible simplismo de una aproximación instrumental podría acarrear ciertos riesgos El Derecho regula los conflictos de intereses, lo cual implica una discusión valorativa. Si se considera que el derecho es únicamente un instrumento al servicio de la utilidad económica, el conflicto axiológico puede pasar inadvertido. Por ello aunque la propuesta de acabar con el formalismo es válida, es preciso enfatizar la necesaria autonomía axiológica del derecho privado. La orientación práctica del derecho no debe terminar por instrumentalizarlo. Al tiempo que se busca abolir el formalismo, se deben crear las garantías que salvaguarden el carácter autónomo de un derecho privado más flexible y pragmático. 
perjuicio de lo anterior, me pregunto asimismo si también es necesario que ciertas instituciones con anclajes constitucionales, pero que sin duda tienen una base antiquísima en el Derecho común, puedan a su vez protegerse dentro de la potestad constitucional que sobre ellas se cierne, a la luz de su raíz civilista.

La autonomía del ius privatum debe buscarse en la materialización de los valores y principios que le son inherentes y que a la larga servirán para delinear los límites y las directrices que deberán guiar la actividad de los jueces, necesariamente independientes y experimentados. Es entonces cuando surge la pregunta si esta afirmación abarca también al Derecho de Familia. Sin duda, y para ello no se entrará a analizar el debate si esta materia del Derecho Civil es Derecho Privado o Público, su importancia es social, no cabe dudas, es pública, es fundamental, y tiene mucha relación con estos valores y principios. Estás directrices o luces son las que en el presente trabajo se han denominado claves, tal cual se expresó y para descubrirlas es esencial recurrir a estudios jurídicos que abarquen diversas perspectivas académicas. Por tal motivo en el presente estudio aunque su columna principal sea el Derecho Civil han habido diversas incursiones al Derecho Constitucional y a la Filosofía del Derecho, lo repito porque me parece importante destacarlo.

En un principio las diversas claves, llámense Igualdad, Autonomía de la voluntad e Interés superior del menor implicaban, cada una, un mundo propio, pero estos estaban conectados entre sí y justamente son estas conexiones las que permiten entender el Derecho común que late bajo ellas, el cual implica principios informadores, pero dichas conexiones eran desconocidas para este doctorando.

Poco a poco fue surgiendo una cuarta clave que como la cuarta pata de una mesa permitía el equilibrio de ella, o mejor dicho, empleando una metáfora, si el Derecho de Familia constituía un mar donde desembocaban diversos ríos, a su vez estos diversos ríos eran alimentados por otros, y sin duda de todos ellos el actualmente más caudaloso lo constituye el "Libre desarrollo de la personalidad". Y esta es la hipótesis que planteo, el determinar no tan sólo como ha influido este último principio en la familia, o mejor dicho en los miembros que la forman, sino también ahondar en la manera de cómo tal clave, a su vez, ha ido conformando las otras tres, y resalto que podrían haber muchas otras, tales como la solidaridad, la coparentalidad, la responsabilidad, pero a mi juicio son esas las que pueden englobar al resto y por lo 
tanto su análisis no sólo se restringe a ellas sino que abarca a los demás principios diseminados en el ordenamiento jurídico familiar.

Esta tesis doctoral no es exclusivamente sobre el libre desarrollo de la personalidad, pero a lo largo de ella aparece reiteradamente porque ha sido uno de los caballos de batalla empleados por el legislador para justificar algunas de las reformas más importantes acaecidas en el último cuarto de siglo en el Derecho de Familia y su conexión con la igualdad, la autonomía de la voluntad y el interés superior del menor, tal cual se ha esgrimido, nos permiten entender algunas de estas reformas, o por lo menos procurar entenderlas.

Finalmente deseo manifestar que toda la jurisprudencia del presente trabajo ha sido extraída de Westlaw Aranzadi. www.westlaw.es 
Capítulo I

La Familia y el Derecho 


\section{1| Consideraciones previas}

La familia no es una abstracción, sino una realidad de carácter único, que exige una reflexión especial, esta especialidad también debe darse en el Derecho. Existe un modo de acercarse a la familia que consiste en considerarla como un objeto de estudio puramente cuantitativo y experimental, algo más de lo que existe entre todo lo existente, pero debido a la importancia que ella reviste es bastante mezquino un análisis así propiciado, procurar entender a la familia simplemente con base a sus relaciones con el todo social es una manera limitada y bastante injusta de estudiarla, porque sin duda la realidad familiar desborda, con creces, esta apreciación.

En la actualidad se suele definir a la familia como una agrupación social cuyos miembros se unen por lazos de parentesco, por lo tanto lo que daría forma y esencia a la familia sería justamente los lazos entre quienes la integran, los cuales se reducen a tres relaciones básicas, la primera tiene un polo masculino y otro femenino en la mayoría de los casos, sin perjuicio actualmente pueden ser ambos masculinos o ambos femeninos, es más, puede que sólo sea uno de ellos, cuando existen dos polos estamos ante una relación afectiva, reconocida principalmente como matrimonio por los demás miembros de la comunidad al cual se pueden agregar también las parejas de hecho. La segunda se da entre aquel polo y los hijos y se denomina relación paterno filial, mientras que la tercera tiene lugar entre los hermanos y es denominada relación fraternal. Claro que estas partes entendidas por separado no permiten procurar comprender la importancia de esta sociedad natural, pero estimo que para un estudio de su tratamiento en el Derecho de Familia, y especialmente en el análisis de la evolución que han tenido los principios de este sector del Derecho común y privado es necesario considerarles individualmente y en relación al todo, posiblemente este sea uno de los aspectos más críticos que se observan en la actualidad, en donde se ha dado preferencia prácticamente exclusiva a los miembros individualmente considerados y muy poco al grupo familiar propiamente tal $^{9}$, al fin y al cabo, aunque la familia sea un proyecto de vida, hoy por hoy priman los proyectos personales. Por esto, traigo a colación el Preámbulo de la Ley 25 de 2010 que constituye el Libro II del Código Civil de Cataluña, donde se manifiesta: "Finalmente, hoy predomina una mayor tolerancia hacia formas de vida y realización personal diferentes a las tradicionales. En una sociedad abierta, la confi-

9 La familia sin perjuicio de ser un grupo de personas, importan los individuos que la conforman a modo de ejemplo cito Ley 25/2010, Libro II del Código Civil de Cataluña, en lo referente a la persona y la familia. En el Preámbulo de dicha Ley se dice de manera textual: "Por otra parte, las transformaciones sociales han hecho que hoy la familia se entienda más bien como un ámbito en que la comunicación y el respeto a los deseos y aspiraciones individuales de los miembros que la componen ocupan un lugar importante en la definición del proyecto de vida en común. Es por ello que se pone énfasis en el desarrollo individual, en la libertad y autonomía del individuo, pero también en su responsabilidad. Esta concepción de la familia también inspira todo el derecho del menor y la regulación de las relaciones entre los progenitores y los hijos en potestad.". 
guración de los proyectos de vida de las personas y de las propias biografías vitales no puede venir condicionada por la prevalencia de un modelo de vida sobre otro, siempre y cuando la opción libremente escogida no entrañe daños a terceros. Éste es el principio del que parte el libro segundo en cuanto al reconocimiento de las modalidades de familia. Por ello, a diferencia del Código de familia, el presente libro acoge las relaciones familiares basadas en formas de convivencia diferentes a la matrimonial, como las familias formadas por un progenitor sólo con sus descendientes, la convivencia en pareja estable y las relaciones convivenciales de ayuda mutua. La nueva regulación acoge también la familia homoparental, salvando las diferencias impuestas por la naturaleza de las $\operatorname{cosas}{ }^{10}$.

El conjunto más elemental de estas relaciones es denominado como familia nuclear, porque desde ella se desarrollan otros grupos más complejos denominados como: la familia conjunta o la familia tomada en un sentido más amplio, tal como se verá más adelante.

La familia, sería aquella forma o estructura donde el ser humano se personaliza y se socializa, es decir, el lugar propio y primario del devenir del individuo y de la sociedad ${ }^{11}$. Es únicamente en la familia donde el ser humano es o debería ser absolutamente aceptado por sí mismo y no únicamente a condición de que sea considerado inteligente o simpático, posiblemente en la historia personal de cada uno la influencia más importante sea la propiciada por la familia. Las personas somos seres sociales, pero aportaría que el hecho de ser seres sociales se funda en que somos seres familiares. En la familia se aprende el significado y la bondad esencial de la persona individual y de la sociedad al mismo tiempo. Ser significa siempre ser ante otro, esto se comprende mejor afirmando que cuanto más riqueza tenga una sociedad, la vida que se desarrolla en su interior es impensable que se desarrolle y enriquezca sin relación con los demás, y particularmente la vida del espíritu, y esto quiere decir que por lo mismo que me relaciono con otro me distingo de él. No podría relacionarme sin distinguirme. La intensificación de la relación me intensifica como individuo, la persona por lo tanto es esencialmente un ser individual y relacional.

Esta síntesis práctica no se logra si se pretende realizar sólo desde el énfasis de lo individual, sería incompleto, la persona al no tener espejos en los que mirarse crece desarrollando una personalidad frágil y pobre, carente de contenido. Ahora bien, si se considera el otro extremo, es decir, si a la persona se le estima únicamente en relación a un ente colectivo, esta adquiere un cariz abstracto y carente del sentido necesario, incluso su existencia será más bien una situación accidental y no es-

10 Preámbulo de la Ley 25/2010, Libro II del Código Civil de Cataluña, en lo referente a la persona y la familia, página 3.

11 Vid. ALVIRA, R. "Sobre la esencia de la familia”, en CRUZ CRUZ, J. (Edit.), “Metafisica de la familia”, Ed. EUNSA, Pamplona, año 1995, página 15. 
encial. Es en la familia el lugar donde una persona debiese ser aceptada de modo absoluto y no sólo a condición de algo, debido a que el hogar más que los materiales y los objetos que lo configuran, está sobre todo hecho del amor y comprensión de los que en él viven y esta vivencia contribuye al desarrollo de su personalidad, compartir la vida con otros, es en el fondo, desenvolverse en la propia humanidad.

En directa relación con esta opinión cito a CARD CIPRIANI ${ }^{12}$ para quien la familia es una institución enraizada en la misma naturaleza humana, la vida en común de un conjunto de personas emparentadas entre sí, formando un mismo hogar. La institución familiar es importante en la vida de las personas y de la sociedad, porque sólo en ella la persona puede desarrollarse plenamente como tal, al arraigarse dicha experiencia en su mismo ser; la persona no puede vivir de otro modo, si lo hace corre el riesgo de no realizarse.

Así, tan real y verdadero es el carácter social del ser humano, como su carácter individual. Uno y otro, lejos de estar en oposición dialéctica, se requieren de manera armónica, la encarnación práctica de esta armonía de lo social y lo individual es lo que encierra justamente el concepto de persona, además dado que el hombre no vive en sentido propio de instinto, sino de aprendizaje, ha de aprender a ser lo que es, es decir, ha de humanizarse y personalizarse de la manera más plena que le sea posible. Este aprendizaje práctico se realiza en la figura esencial de la familia, de tal manera que cualquier otra institución que quiera sustituirla lo ha de hacer asumiendo las mismas funciones de ella, si acaso existe la institución que pueda hacerlo adecuadamente.

La familia debe ser concebida como una unidad legal, social, económica pero sobre todo como una unidad de amor personal, por ello resultan imprescindibles las referencias que deben formularse hacia la persona, al amor de entrega o donación y a la vida personal que se comunica ${ }^{13}$. Al igual que las personas, cada familia es única, irrepetible e insustituible, por ello se afirma que la vida familiar es vida personal, singular. En la familia, en su interioridad, las vidas que se suceden biográficamente descriptibles, no se explican sólo por las características de la naturaleza humana, sino que sobre todo por su mismo sujeto individual que subsiste en ella, por la persona. De hecho, el acontecer humano toma realidad en cada persona concreta, es este ser singular al que se debe admirar detenidamente. La persona representa la perfección humana real, concreta y singular, su primacía es esta singularidad.

12 CARD CIPRIANI, J. L. "La familia, forjadora de humanidad”, en "Matrimonio, Familia y Vida. Homenaje al profesor Dr. Augusto Sarmiento”, Ed. EUNSA, Pamplona, año 2010, página 17

13 FORMENT, E, “Familia y libertad” en "Metafísica de la familia”, Ed. EUNSA, Pamplona, año 1995, página 183. 
En la familia, la vida personal de cada una de sus miembros que la integran, es puesta en común. Esta comunión vital que se da en la vida familiar es un efecto del amor, de la amistad. Es la donación que reina entre sus componentes y que abarca todos los grados y tipos de amor personal. Esta comunión de vida personal no es totalmente perfecta, como tampoco lo es en las demás relaciones personales. El amor de donación admite grados, y aunque posibilita los más elevados y, por tanto, la mayor comunión vital, no alcanza la plenitud, es un ideal.

Por ser el amor el fundamento de la vida familiar esta implica una perfección, una dignidad que no puede explicarse por determinaciones de diferencias sobre géneros o sobre especies, trasciende todos los géneros y toda las especies, así como todas las categorías. La familia, para una análisis más exacto debe ser concebida en sentido propio, como conexionada directamente con las personas que la integran y, por tanto, con el ser, de que participan máximamente las personas, y que es su constitutivo formal ${ }^{14}$.

\section{La Familia como comunidad de personas. Análisis desde sus funciones}

Tal como lo aprecia MORANDÉ COURT ${ }^{15}$, y como acaba de manifestarse, la familia se puede analizar de muchas maneras. Tal vez sea el enfoque que se concentra en el análisis de sus funciones sociales, la perspectiva, sociológica y psicológica, la más comúnmente utilizada, en palabras del mismo autor. Suele, por tal motivo, hacerse una larga lista de las diversas funciones sociales que antiguamente habría desempeñado la familia y que hoy día ya no desempeña o sólo lo hace esporádicamente. Se trata de una visión bastante razonable y necesaria de considerar, pues la familia ha jugado un papel trascendental en la evolución de la sociedad, ya sea en su aspecto económico, político, educacional, generacional, tal como ya se apreció en el apartado anterior.

Con el paulatino proceso de diferenciación de las funciones familiares, ellas comenzaron a ser asumidas, total o parcialmente, por otras instituciones, hasta llegar a la actual situación, en la cual la familia queda limitada al desarrollo de algunas tareas poco reguladas y nada específicas.

Sin embargo la fortaleza de la familia, no reside precisamente en las funciones que ella cumple. Este es sólo un aspecto de su trascendencia. El real valor de ella, es dado por una trascendencia antropológica intrínseca como experiencia de libertad y de comunidad ${ }^{16}$. De tal manera que es im-

14 FORMENT, E., ibídem., página 186.

15 “Persona, Matrimonio y Familia”, Ed. Universidad Católica de Chile, 2º edición, Santiago de Chile, año 1994, página 22.

16 La persona, como bien se sabe, es de naturaleza social, Toda persona tiene naturalmente una dimensión social, es decir, tiene a formar grupos; y es más, solamente en unión con los demás, la persona puede desarrollarse perso nalmente. 
portante estudiar a la familia como una sociedad natural, es decir, como una experiencia de la sociabilidad humana vinculada directa e inseparablemente a la persona, y que si bien ha cumplido y cumple con distintos encargos sociales, que las circunstancias sociales le han asignado, su existencia no está determinada por dichos encargos, en afirmación del propio MORANDÉ COURT ${ }^{17}$.

Como ha reconocido siempre la tradición judeocristiana, lo que sin duda a formado el pensamiento occidental de la misma, la familia es, antes que cualquier otra cosa, una comunidad de personas. Pero para comprenderla en tal sentido, antes se detalla que la comunidad es una forma de organización que se diferencia de las formas contractuales de las organizaciones racionalizadas, al menos en estos tres aspectos fundamentales: a)Las personas no escogen pertenecer a ella sino que han nacido en su interior, o se integran libremente pero estableciendo un vínculo que es definitivo y que sólo en ciertos casos puede estar sujeto a revisión; b) Las responsabilidades no son limitadas ni por montos ni por tipologías, como son las obligaciones contraídas en las distintas convenciones reconocidas por el derecho; y c) Las funciones y roles sociales son inseparables de la individualidad y subsistencia de las personas que las sirven. Por este motivo, se puede afirmar que el vínculo que une a los miembros de una comunidad es de pertenencia y no de carácter funcional ${ }^{18}$.

Para constituir la familia, debo saber que no puedo comprometerme con cualquier persona, sino con alguien exclusivo e imprescindible para mi. Asimismo quien sea mi hijo no me es indiferente, si me falta uno, no puedo reemplazarlo por otro y borrón y cuenta nueva. No es así, porque todo lo concerniente a ella es personal, es esencial.

La familia, y esto ya se manifestó en la introducción del presente estudio, corresponde a una forma de comunidad, derivada de tres tipos de relaciones; la filiación, la consanguinidad y la convivencia de dos personas que puede ser conyugal o simplemente de hecho. En el caso de las dos primeros es evidente de que no existe elección. Si la relación de pareja, afectiva y estable, presenta la naturaleza de matrimonio entonces se está ante un contrato libremente aceptado por las partes, que presenta el carácter de revocable, por medio del divorcio ${ }^{19}$.

17 Este tema es ampliamente tratado por NAVARRO-VALLS, en su obra "Matrimonio y Derecho", Ed. Tecnos, Madrid, año 2004.

18 Vid. MORANDÉ COURT, P. "Persona, Matrimonio y Familia”., ...op. cit, página 22.

19 En relación a los cónyuges, en palabras del mismo MORANDÉ COURT, su alianza se constituye, efectivamente, por un acto de libre elección que, de no existir, viciaría el consentimiento. Sin embargo, no se trata del ejercicio de una libertad fundada en el principio de indiferencia. No se selecciona al cónyuge de entre varias posibilidades existentes e igualmente apreciadas. Para quien está enamorado, la persona amada representa la única elección posible, incomparable a cualquier otra. El amor constituye siempre un acto de predilección frente a otra persona. y en el caso del amor conyugal tal predilección es exclusiva. Por ello, la libertad se ejerce, en este caso, en virtud de un acontecimiento previo que es el encuentro de un hombre y una mujer, encuentro único y personalizado que no admite sustitutos. De modo que antes que elegirse uno al otro, se trata más bien de aceptar o rechazar el encuentro de dos historias que buscan hacerse común, por razones que, por más que se estudien y analizan, perma - 
La experiencia de comunión y su forma de organización propia que llamamos comunidad, tiene a la persona como "único sujeto óntico", es decir, cada uno de sus integrantes es irrepetible, tal que no puede ser sustituido por otro, precisamente porque en ello consiste la experiencia de comunicación, en una autodonación libre y personalizada de cada uno de sus miembros por el bien de todos.

La familia es la célula de la sociedad, no por ser la parte en relación al todo, sino por el mismo valor antropológico, puesto que un conjunto de familias no hace ni un Estado, ni una economía, ni un sistema de educación. Se considera célula, en el sentido de que la familia es el lugar donde reside la memoria o el código de una vida humana libre, abierta a la comunión afectiva, filial y fraternal.

Pese a que la organización del espacio público tiene sus propias reglas funcionales y no se parecen necesariamente a las que rigen la familia, ella es propiamente la célula de la sociedad porque es depositaria de la memoria que implica la anterioridad y superioridad de la persona sobre cualquier tipo de organización social, a pesar de que haya cambiado el entorno de los sistemas racionales que la apoyan. Es una suerte de memoria ontológica que pone a cada sujeto en el umbral de su propia identidad y de su propia realidad. En ella cada persona tiene la experiencia elemental de que sus integrantes no se eligen funcionalmente, ni tienen la posibilidad de inventarse a sí mismos, sino que el ejercicio de su libertad es inseparable de la personal autodonación. Ni los padres eligen a los hijos ni los hijos a los padres. Pero los padres se eligen entre si, de manera libre y ojalá responsable. Resalto el término de autodonación, porque sin duda no hay experiencia más profunda que el dar la propia persona, de manera libre, de manera total.

La familia es el lugar donde se nace y generalmente donde se muere, aunque no es necesario que siempre sea así, donde se recibe la vida en donación y donde se le entrega de igual forma a las nuevas generaciones.

MORANDÉ COURT escribe sobre el análisis de la familia como una comunidad de personas, un aspecto que me parece importante de resaltar y que tiene directa relación con lo que posteriormente se reflejará en el capítulo concerniente a la autonomía de la voluntad: “ El ejercicio de la libertad en la sociedad funcionalmente organizada se orienta cada vez más hacia la elección entre las alternativas relativamente indiferentes, lo que se aplica en propiedad en el ámbito de los objetos o de procesos sustituibles. Lo funcional es, por su propia naturaleza y definición, aquello que admite sustitución. Así se lo experimenta cotidianamente en el plano de la economía de precios libres, donde se ofrece la posibilidad de escoger entre diversos productos prescindiendo totalmente

necerán siempre en el horizonte del misterio. Ibidem., página 22 y siguientes. 
de las relaciones personales, incluso, en muchos casos, con devolución garantizada por insatisfacción del consumidor. Algo análogo comienza a ocurrir en la mayoría de los sistemas educacionales, donde se multiplican las alternativas de elección, y donde las expectativas sobre rentabilidad futura de los estudios realizados suelen tener mayor peso que las tradicionales consideraciones vocacionales. Se trata de una sociedad que, desde el horizonte funcional, despliega toda la experiencia humana en torno a la elección entre alternativas, o la comparación entre opciones, a la capacidad de escoger la mejor oportunidad, sea en términos económicos, políticos, estéticos o de cualquier naturaleza. "20 .

Enfocando esta apreciación específicamente en la situación española, uno de los cambios más importantes que ha presentado esta comunidad es el lento tránsito hacia una redefinición de los roles conyugales, con una distribución de las tareas domésticas más igualitaria que la que caracteriza a la familia nuclear tradicional. Este cambio es, en primer término, particularmente acentuado en el plano de las actitudes y de las opiniones generales, donde no es automática su traducción a comportamientos concretos, aunque sí los erosione, tal como opina POLO SABAU ${ }^{21}$.

Todo estudio filosófico de la familia podría partir del hecho patente de su estructura comunitaria, no es ésta una posición teórica o una hipótesis, sino una mera descripción del fenómeno familiar. Sin duda este es el camino para encontrar su sentido, debido a que el que busca tan sólo la utilidad nunca encontrará lo esencial que no tiene porque ser útil, y acabará por perder la utilidad misma. Al considerar a la familia dentro de las instituciones públicas, y no estimando más que los servicios que puede prestar a la sociedad, por ejemplo, se le degrada interiormente y se llegan a arruinar incluso los mencionados servicios por sólo perseguirlos, pero analizando su verdadera naturaleza para alcanzar su sentido más profundo, se desvela además su utilidad.

20 MORANDE COURT, P. "Persona, Matrimonio y Familia”, ...op. cit., página 22 y siguientes, prosigue expresando que: "Esta visión no es enteramente aplicable a las relaciones entre personas. Puede serlo sólo en sus aspectos funcionales, como por ejemplo la libertad que cada uno tiene de consultar un médico o a otro. Pero cuando en la relación queda involucrada la totalidad de la persona, ya no es aplicable el principio de indiferencia. La familia, precisamente, por el hecho de que sus relaciones no se constituyen arbitrariamente por la capacidad de elegir, nos enfrenta a una experiencia que es enteramente distinta. Es la experiencia de sentir que cada uno de nosotros pertenece a una realidad que lo trasciende, de una realidad que incluye personas que tienen un vínculo objetivo entre sí y que, sin embargo, no se escogieron. Eso hace que la experiencia de la familia sea única y, aun cuando no sea instrumental desde el punto de vista de la funcionalidad de la sociedad, no deja de ser una de las experiencias más fundamentales de la condición humana. La libertad se presenta aquí inseparablemente a la experiencia de descubrirse participando de una realidad que trasciende a cada sujeto y que, a la vez, los envuelve, de tal manera que su ejercicio tiene, por este hecho, consecuencias objetivas y determinantes para la vida de todos quienes están involucrados en esta relación. La familia enseña que, en el plano de las relaciones entre personas, no hay libertad sin responsabilidad, porque ambas se despliegan al interior de un espacio desarrollado por un vínculo de pertenencia.”.

“Matrimonio y Constitución ante la Reforma del Derecho”, Ed. Thomson Civitas, Cizur Menor, año 2006. 
Tal como ya se ha manifestado, al referirse aquí a la familia estamos aludiendo a un tipo concreto de grupo, a una comunidad de personas, este tiene las mismas características que ya se han descubierto para el ser personal: consistir en una constelación de dones, tener un sentido existencial, crecer hacia su plenitud y estar intencionalmente abierta. Es quizás lo que HEGEL, quien estudió con rigor a la familia definió como "comunidad ética natural" 22 .

Por tanto, tiene una estructura universal, más allá de los vínculos concretos de sus miembros: "La familia se halla dentro de su esencia ética, no es tanto que es el comportamiento natural de sus miembros o en tanto que la relación de estos es la relación inmediata entre sus miembros singulares reales [...] Siendo ético lo en sí universal, la relación ética entre los miembros de la familia no es la relación de sensibilidad ni el comportamiento del amor. Lo ético parece que deba cifrarse ahora en el comportamiento del miembro singular de la familia hacia la familia en su totalidad como la subsistencia, de modo que su obrar y su realidad sólo tengan como fin y contenido a la familia",23.

En la familia se dan varios hechos particulares, esta irrumpe propiamente tal cuando surge un tercero, el sentido más profundo sería la argumentación de que este tercero es fruto del amor de la comunidad afectiva. Esta irrupción arranca a cada uno de los miembros de la comunidad afectiva de si mismos y de la atención al otro. El hijo irrumpe y, en su irrupción, descentra y exige ampliar la atención al que llega ${ }^{24}$. Esto es posible donde exista una disponibilidad previa, donde la comunidad no sea un sistema cerrado, una realidad hermética. La familia surge de la disponibilidad de atender a quien irrumpe, surge por un descentramiento. Y, desde ese momento, la disponibilidad al otro que llega e irrumpe se constituye en actitud básica del ser familiar. Se trata, en realidad de una especie de ampliación de la capacidad de acogida y de la donación ${ }^{25}$.

DOMINGUEZ PRIETO ${ }^{26}$ plantea una segunda peculiaridad, al ampliarse la comunidad inicial surge una nueva, que sin disolver la anterior, se presenta ya como un grupo de pertenencia. La persona se define ya por su pertenencia a una familia. Este hecho que sociológicamente y genéticamente resulta patente, también tiene una expresión en el ámbito antropológico: la vinculación a la fami-

22 HEGEL, G.W. “Fenomenología del espíritu”, Ed. Fondo de Cultura Económica de España S. L., Madrid, año 1996, página 262.

23 Vid. HEGEL, G.W., Ibidem, página 264.

24 PHILIPPE, M. D. "En el corazón del amor. Entrevista sobre el amor, el matrimonio y la familia”, Ed. Palabra, Madrid, año 2008, página 160 y 161. "El hijo es la prolongación de la vida de los padres, es para ellos aquel que los mira con amor en filial dependencia. Poder decir a alguien "mamá” o "papá" supone un lazo afectivo de extraordinaria profundidad...Creo que podemos definir ese gran misterio como el misterio de la prolongación de los padres en su hijo, prolongación que permite una victoria sobre la erosión del tiempo con un nuevo ser...”

25 DOMinguez PRIETO, X. M. “Antropología de la familia. Persona, matrimonio y familia”. Ed. Biblioteca de Autores Cristianos, serie de Estudios y ensayos, Madrid, año 2009, página 201. 
lia es ya pertenencia. Pero esta pertenencia no es alineante, sino una respectividad: ser respecto de otros a los que me siento $\mathrm{y}$, sobre todo, a los que estoy vinculado. No se trata de pertenecer como pertenece la cosa al dueño, sino de descubrirse a si mismo siendo-con y siendo-de esta comunidad, como miembro de esta comunidad.

Sin embargo, hay varias formas de pertenencia. Inicialmente, la del hijo es una pertenencia que implica una vocación, es vocativa, una pertenencia que apela a la persona del otro. Mientras que la pertenencia por parte de los padres es dativa, ellos se dan al otro, al hijo, dan su tiempo, su trabajo, su afecto, en definitiva donan su persona. No obstante esta vocatividad y esta datividad son relativas, o mejor dicho no permanecen estáticas en el tiempo, pues poco a poco se descubre también al hijo como responsable de la vida familiar y se descubre también que los padres son necesitados de la presencia del hijo, presencia liberadora y dinamizante. Existe en la familia una pertenencia, la cual es una forma de responsabilidad colectiva, donde todos son responsables de todos, de la promoción de la vocación de cada uno de los demás. Claro que esto ocurre desde dos niveles distintos, pues la datividad de los padres y la vocatividad y el menester de los hijos les inviste a los primeros de autoridad, reconociendo los segundos dicha autoridad, esta reflexión proviene de DOMÍNGUEZ PRIETO, quien reflexiona sobre el matrimonio en tiempos críticos pero amparándose en una antropología personalista de la familia ${ }^{27}$.

\section{Etimología del término familia, su constante evolución}

La palabra "familia", podría provenir del sánscrito: de los vocablos "dhá"(asentar) y "dhaman" (asiento, morada, casa). De acuerdo a esto, "familia”, en un principio designaba la casa doméstica y, en un sentido más restringido, los bienes pertenecientes a esa casa, vale decir, el patrimonio. También el término tendría su cuna en la lengua osca, según CORRAL TALCIANI ${ }^{28}$. Pero aquí las opiniones se dividen; para unos, familia vendría del vocablo "famel" o "fames" que quiere decir "hambre"; la conexión entre ambas palabras residiría en que en el seno de la familia se satisface esa primera necesidad. Ahora bien, el origen se puede encontrar también en el término "famulus" con el cual se designaba a los que moraban con el señor de la casa y particularmente a los esclavos. Además se vincula el vocablo famulus con el verbo osco "faamat" que significaba "habitar" el que a su vez, provendría del sánscrito "Vama" (hogar, habitación). Familia significaría, pues, en sus orí-

27 Cfr. En el mismo sentido SARMIENTO, A. "Matrimonio y familia en la actual encrucijada" (en colaboración con FRANCESCHI, H), Ed. Ediplena, San vicente de Cañete-Lima, año 2001, página 308.

28 CORRAL TALCIANI, H. "Familia y derecho. Estudios sobre la realidad jurídica de la familia". Ed. de la Universidad de los Andes, Santiago de Chile, año 1994, páginas 7 y siguientes. 
genes, el hogar, comprendido por la mujer, los hijos y los esclavos domésticos, por oposición a los rurales.

Por ende, tal como lo ha afirmado el autor recién citado, el vocablo familia, al parecer, se fue forjando tomando como base la casa o sede física donde residían ciertas personas, ampliándose luego su significado para comprender elementos esencialmente ligados a la casa, como los bienes patrimoniales y los esclavos y, finalmente, llegar a abarcar el conglomerado de personas que la habitaban.

Si intentamos efectuar un análisis histórico de la familia puede comprobarse que en la antigua Grecia, para hablar de familia existían dos vocablos diferentes. El primero oikos, quería decir en estricto sentido "casa" y por extensión, patrimonio. El segundo, más preciso, oikeat, hacía alusión directa al conjunto de personas sujetas al señor de la casa: mujer, hijos y esclavos. ARISTÓTELES ${ }^{29}$ en "La Política", define la familia como "la comunidad construida naturalmente para la satisfacción de las necesidades cotidianas", y prosigue señalando que, para que esta comunidad natural sea completa deben estimarse integrantes de ella a los esclavos de la casa.

Para los romanos, la palabra familia, en una primera etapa, alude más que a las personas al caudal de bienes pertenecientes a la comunidad, considerando al patrimonio en su totalidad o al menos en lo que se refiere a las rei mancipi. Más adelante, se entenderán incluidas esencialmente en el concepto, junto a los bienes, las personas integrantes del grupo familiar ${ }^{30}$.

Se discute cuál fue el elemento esencial que constituía a la familia romana. Algún romanista ha creído verlo en los bienes patrimoniales, la familia, en tal sentido, se organizaría en torno al patrimonio del grupo. Otros piensan que está en el vínculo de sangre o parentesco que da vida al grupo familiar romano. No obstante, desde VON SAVIGNY ${ }^{31}$ en adelante, la romanística se inclina hacia la consideración de la relación familiar fundamentada en un vínculo de autoridad y subordinación: las potestas. Esta es el poder del jefe de familia sobre el resto de los integrantes (manus sobre la mujer, patria potestas sobre los hijos, potestas sobre los esclavos y mancipium sobre los ciudadanos romanos reducidos a condición servil), lo que constituye la comunidad que se denomina familia.

29 Vid. ARISTÓTELES. “La Politica”, Libro I, Clásicos Políticos, Madrid, año 1989, páginas 1 a 26.

30 Cfr. RASCON GARCÍA, C, "Síntesis de historia e instituciones de derecho romano", Ed. Tecnos, Madrid, año 2006; FAYER, C, "La familia romana aspetti giuridici ed antiquari", Editor L' Ermua de Brestschneider, año 2005, Universidad de Huelva, VV. AA., Congreso Internacional de Derecho romano, "El derecho de familia de Roma al Derecho de familia actual", Huelva, año 2004.

VON SAVIGNY, C. "Sistema de Derecho Romano actual”, Ed. Comares, Granada, año 2005, páginas 265 a 285. 
Entre los pueblos germánicos, la palabra tiene una significación variada, al igual que en Roma. La base de la familia se reconoce en el parentesco, y al matrimonio se atribuye exclusivamente la posibilidad de dar origen a las relaciones propiamente familiares. Es cierto, no obstante, que si bien la haus (casa) se compone de un grupo restringido: padre, madre e hijos, la familia en su más amplio sentido (sibbe, sippschaft) se forma por la reunión de varias casas procedentes de dos troncos, cuyos miembros vivos se hallan entre sí en determinadas relaciones, por la posición de sus respectivos jefes, con referencia a un antepasado común ${ }^{32}$.

En la época medieval no se observan mayores modificaciones respecto de la noción de familia. La institución familiar experimenta, en cambio cierta evolución propiciada por la influencia de la filosofía cristiana y el Derecho Canónico. La familia en el medioevo se nos presenta como un organismo de ética muy estricta y como uno de los núcleos sociales más fuertemente constituidos. La potestad marital y la autoridad paterna, como contrapartida, se suavizan transformándose en poderes de tutela y protección.

La Baja Edad Media marca el inicio de un proceso, que terminará por desembocar en estos días: la reducción de la familia a los parientes más próximos.

Posteriormente los filósofos jusnaturalistas insistirán en la idea de circunscribir el grupo familiar a los padres e hijos, y tratarán de fundamentar la existencia de la sociedad doméstica en una especie de relación convencional.

Estos criterios influirán en el proceso codificador y por consiguiente en la actual legislación.

Es importante intentar comprender que el estudio de la familia en la historiografía ha sido más bien reciente, pero con un constante desarrollo, pues en ciertas épocas tal evolución influyó de manera notoria en procesos sociales que desencadenaron cambios históricos, como la crisis de los hacinamientos familiares del proletariado a raíz de la cuestión obrera. Por otra parte el estudio del menor a través de la Historia, como persona integrante de la familia y que presenta una relevante actualidad es quizás aún menos notorio y su carácter es más bien esporádico. Pero los cambios en la estructura familiar produjeron modificaciones en el tratamiento legal de los menores, adquiriendo estos, paulatinamente, cierta autonomía en su obrar y una protección más específica, atendida sus especiales características, respecto de otras materias del Derecho de Familia ${ }^{33}$.

\footnotetext{
32 CORRAL TALCIANI, H. loc. cit.

33 FE, B. y BELTRÁN, J. L. “Breve historia de la infancia”. Ed. Temas de Hoy, 1ª edición, Madrid, año 1998, páginas 11 a 13 .
} 


\section{4 | Consideraciones para la conceptualización del término familia desde el punto de vista jurídico}

Para obtener un concepto de familia se puede recurrir, en primer lugar, al concepto que el común y corriente de las personas maneja de tal término, tanto en el presente como en el pasado, el que por supuesto no ha sido constante, careciendo de exactitud.

Se puede y debe indagar en las concepciones jurídicas de cada momento histórico debido a que cada época ha imprimido su sello en tan esencial institución, siguiendo en este punto lo propiciado por LACRUZ ${ }^{34}$. Este afirma que, en sentido normativo, la familia aparece en la historia y en la actualidad como una comunidad creada, en principio por el matrimonio, está compuesta, al menos, por progenitores y por procreados (es decir menores), y en la que pueden participar otras personas convivientes o no. Al lado de aquel tipo principal, existen relaciones familiares extramatrimoniales que constituyen también "familia", como lo es la compuesta por un sólo progenitor y los hijos, o por pareja no casada, etc ${ }^{35}$.

La ley, siguiendo el razonamiento del autor recién citado, no define de modo general a la familia, tampoco es posible dar un concepto legal general de ella porque el grupo familiar tiene muy distinta amplitud en los diversos aspectos en los que es considerado ${ }^{36}$. NIMKOFF, señala LACRUZ, define la familia como "una comunidad más o menos duradera de esposo y esposa, con o sin hijos, o de hombre y mujer solos o con hijos", y para BURGESS y LOCKE es “una multiplicidad de personas vinculadas por matrimonio, vínculos de sangre o adopción, que constituyen conjuntamente un sólo núcleo de convivencia o household”.

Existe la denominada familia nuclear, compuesta de varón y mujer con su prole, o por dos hombres o dos mujeres y uno de ellos en solitario con su hijo o hijos, también está la familia extensa, en cuya denominación se considera, de una parte, la familia polinuclear, constituidas por varias

34 LACRUZ BeRDEJO, J. L. y otros: "Elementos de Derecho Civil, IV (Derecho de Familia)", Ed. Dykinson, $4^{\mathrm{a}}$ edición, Madrid, año 2010.

35 O'CAllaghan MUÑOZ, X. "Compendio de Derecho Civil, Derecho de Familia", Tomo IV, Editorial Universitaria Ramón Aceres, año 2012; NAVARRO VIÑUALES, J. Ma " "El nuevo Derecho de Familia, modificaciones legislativas y tendencias doctrinales", Ed. Thomson - Civitas, $1^{\text {a }}$ edición, año 2006; GONZALEZ POVEDA, P. "Tratado de Derecho de Familia, aspectos sustantivos y procesales: adaptados a las leyes 13/2005 y 15/2005", Ed. Sepin, Madrid, año 2005.

36 El artículo 815 del Código Civil chileno, incluido en el Título X referente a los Derechos de Uso y Habitación da un concepto de familia, el cual se ha entendido únicamente para tales derechos: "El uso y la habitación se limitan a las necesidades personales del usuario o del habitador.- En las necesidades personales del usuario o del habitador se comprenden las de su familia.- La familia comprende al cónyuge y los hijos, tanto los que existen al momento de la constitución, como los que sobrevienen después, y esto aun cuando el usuario o el habitador no esté casado, ni haya reconocido hijo alguno a la fecha de la constitución. - Comprende, además, las personas que a la misma fecha vivían con el habitador o usuario y a costa de éstos; y las personas a quienes estos deben alimentos." 
familias nucleares (varias generaciones de una misma unidad residencial), y, de otra, la familia nuclear ampliada, en la cual al núcleo familiar se añaden otros parientes, etc.

Pero existen otros grupos de familia que se agrupan bajo el nombre de familia incompleta; viudo con o sin hijos, divorciados, madres solteras, etc. A esto se agrega que en la civilización occidental mayoritariamente no se admite la familia poligámica; hombre con varias mujeres; ni tampoco la poliandria; mujer con varios hombres.

Poco a poco se puede constatar que el modelo familiar que el legislador no puede dejar de considerar, es uno de carácter bastante diverso, según los lugares y los tiempos, en donde se incluya el mayor número de modelos posibles. Si en un primer momento el modelo arcaico aludía a la familia extensa, el moderno sería el nuclear compuesto por los padres y los hijos menores o que todavía no tienen independencia económica.

Dentro de la simple familia extensa o también nuclear, a la que se le añaden otras personas aisladas, se debe incluir, según algunos, no sólo a los parientes convivientes o familia residencial, sino a aquellos que, con residencias separadas, mantienen vínculos intensos y peculiares: apoyo económico y moral, control de los individuos por parte del grupo, subordinación de todos los miembros casados o solteros a una misma autoridad, que es la del depositario del patrimonio familiar, este último tipo de familia tiene lugar, ya sea entre el campesinado, como en la burguesía tradicional.

Otra opinión que debe destacarse es la de ALBALADEJO ${ }^{37}$, para quien la palabra familia en un primer momento denominó a las personas cuyo grupo estaba formado por aquellos unidos en matrimonio y los hijos que se hallaban bajo su potestad y los emancipados que con ellos residían, de tal manera que se puede distinguir la familia de origen matrimonial y la no matrimonial. Respecto a la primera afirmó que: “...Con la palabra familia se venía denominando al grupo de personas compuesto por quienes están unidos en matrimonio y los hijos que se hallan bajo su potestad, o (a lo más), aun emancipados, no abandonaron el hogar paterno. Pero los hijos crecen, y se rompe la unidad de dicho hogar, y aquellos casándose, crean nuevas familias. Más aunque así se formen otras integradas por los nuevos matrimonios y sus hijos (si los tienen), sin embargo, también cada padre-además de formar familia con el otro- sigue perteneciendo a aquella de que procede, y los hijos -además de a la formada por ellos y sus padres-pertenecen a la de cada uno de estos dos, pues son tan nietos de unos abuelos como de los otros". Ello pudo probar que, siguiendo el funda-

37 Vid. AlBaladejO, M, “Curso de Derecho Civil. Tomo IV Derecho de Familia”. Ed. Bosch, S.L. 10 edición, Barcelona, año 2002, páginas 9 y siguientes. 
mento de este destacado autor, con la palabra familia se designaba no sólo al matrimonio más hijos bajo su potestad, sino que también agregó al grupo de personas ligadas por vínculo de parentesco matrimonial de sangre (padres, hijos, tíos, abuelos, primos, etc.). Además, la familia de cada uno de los esposos pasaba a ser familia política del otro. Y en tal sentido éste último pasaba a formar parte de ella.

Se puede concluir que lo anterior demuestra que cuando se hacía referencia al concepto de familia se podía aludir a diferentes grupos de personas. Es evidente que los vínculos que ligaban a las personas componentes de la familia, tomando este término en un sentido o en otro, eran: o el vínculo de parentesco matrimonial de sangre, o el de parentesco político (llamado parentesco de afinidad), o el vínculo conyugal. Así que la familia se edificaba o sobre el matrimonio o sobre el parentesco procedente del matrimonio, sin duda actualmente ha cambiado bastante esta realidad, tal como en su momento se fundamentará, ya no es posible hablar jurídicamente de familia únicamente sino que de familias o quizás siendo más exactos de modelos de familia.

Respecto a la familia no matrimonial, el mismo ALBALADEJO ${ }^{38}$ expresó que: “... hoy con la palabra familia se llega a denominar también al grupo que, no originado en el matrimonio, sino apoyado en una situación de hecho, bien de puro hecho, bien cumpliendo algunos otros requisitos, vive unido, derivando de ello ciertas consecuencias jurídicas, que varían según los casos (aunque en ninguno son iguales a las que produce el matrimonio) entre los convivientes de hecho, hayan o no hayan hecho constar documentalmente su unión o inscrito ésta en un Registro ad hoc. Que por lo que toca a las consecuencias que se producen entre los convivientes y sus hijos son rigurosamente las mismas que se dan entre los padres y los hijos matrimoniales, ya que hoy todos los hijos, sean o no de matrimonio, son iguales ante la ley, lo que implica que la relación paterno-filial es igual entre cualesquiera de los hijos y cualesquiera padres, omisión hecha que aquellos hayan sido habidos dentro o fuera del matrimonio, o incluso de que lo hayan sido dentro o fuera de una situación de unión estable de hecho entre sus padres."

Etimológicamente, manifiesta SERRANO ALONSO ${ }^{39}$, que sigue en este aspecto a CASTÁN TOBEÑAS ${ }^{40}$, el término familia procede del latín familia, significando "el conjunto de personas que moraban con el señor de la casa". Dejando a un lado este tipo de interpretaciones, agrega, lo

38 ALBALADEJO, $\mathrm{M}$, ibídem, página 9 y siguientes.

39 SERRANO ALONSO, E (Coord.), "Manual de Derecho de Familia”. Ed. Edisofer S.L. Madrid, año 2000, página 21.

40 CASTAN tOBEÑAS, J. "Derecho civil y foral”. Tomo V, volumen I. Ed. Reus S.A. 11 a edición, Madrid, año 1987, páginas 33 a 53. 
que sí es cierto es que cualquier acepción de la familia trae consigo la idea que tradicionalmente ha estado unida a ella: el conjunto de personas, de extensión variable, que viven bajo un mismo techo y sometidos a la dirección o dependencia de una de ellas que asume las funciones directivas y de coordinación entre todos ellos. Jurídicamente el rasgo fundamental de toda familia es la existencia de un vínculo de parentesco o matrimonial, de manera que, en sentido estricto, únicamente aquellos grupos que parten de un matrimonio o de una relación de parentesco pueden ser calificados como familia. Lógicamente el propio desarrollo de la sociedad y las nuevas realidades es el que plantea la posibilidad de aplicar el concepto de familia a otro tipo de uniones no incluidas necesariamente en el esquema anterior ${ }^{41}$.

Por otra parte, la ausencia de una definición constitucional resulta positiva, al dar entrada por vía interpretativa a una serie de posibilidades familiares que no hubiesen sido regulada de otra manera por la Constitución. La interpretación que acepta varios tipos de familia intenta articular diversos modelos de la misma que tienen lugar en la sociedad y sobre ellos procura aplicar los criterios democráticos propios del Estado social que define el orden constitucional español, por ejemplo el art. 68 de la Ley 3/2011 de apoyo a la familia y a la convivencia en Galicia, al referirse al acogimiento alude a modalidad familiar y la diferencia de la familia propiamente tal, el artículo 40 RCL 2006/1450 del Estatuto de Autonomía de Cataluña (RCL 2006/1450) dispone que los poderes públicos deben garantizar la protección jurídica, económica y social de las diversas modalidades de fami$\operatorname{lia}^{42}$.

Sin duda existe una falta de definición de la familia por parte de la Constitución, pero sin embargo esta opción es correcta, porque aunque parezca paradójico la familia queda protegida y si se hubiese dado un definición constitucional de familia habría sido un problema otorgar protección a otros modelos, por lo cual hubieran quedado desprotegidos. Además al excluir dichos modelos probablemente se estarían violentando los principios del Estado democrático y social, esta indefinición es necesaria para adaptarse a la realidad social. La opción vigente permite que sea el propio legisla-

41 Cfr. ELVIRA BENAYAS, M. J. "Introducción a ciertas cuestiones del Derecho de familia en las sociedades multiculturales”, Revista jurídica de la Universidad Autónoma de Madrid, núm. 18, año 2008, II, páginas 149 a 163.

42 Ley 25/2010, Libro II del Código Civil de Cataluña, Persona y Familia, artículo 231 1. : “La heterogeneidad del hecho familiar. 1. La familia goza de la protección jurídica determinada por la ley, que ampara sin discriminación las relaciones familiares derivadas del matrimonio o de la convivencia estable en pareja y las familias formadas por un progenitor sólo con sus descendientes. 2. Se reconocen como miembros de la familia, con los efectos que legalmente se determinen, los hijos de cada uno de los progenitores que convivan en el mismo núcleo familiar, como consecuencia de la formación de familias reconstituidas. Este reconocimiento no altera los vínculos con el otro progenitor." 
dor el que dependiendo de cada momento opte por una mayor o menor apertura, lo cual no significa crear a la carta los diversos modelos ${ }^{43}$.

PÉREZ VILLALOBOS ${ }^{44}$ señalando los elementos que definen a la familia ha propuesto los siguientes. En primer lugar, es un grupo humano, lo que descarta la existencia de familias de un sólo miembro; en segundo lugar, la familia cumple funciones de tipo social, aunque estas hayan decrecido considerablemente en la actualidad, sin perjuicio de su función económica al ser también una unidad de producción y consumo; en tercer lugar debe existir una relación de jerarquía y dependencia dentro del grupo, lo que supone una diferenciación definitiva de la familia de otros modos de convivencia en grupo; en cuarto lugar plantea la relación matrimonio y familia, si el primero define a la segunda, es decir procura responder la pregunta si el matrimonio es por si mismo una familia. Sobre este punto la autora recién citada plantea que un matrimonio no es necesariamente una familia porque requiere además de un elemento dependiente, por lo demás requiere la familia una relación de dependencia y jerarquía entre sus miembros, mientras que el matrimonio es un pacto igualitario, además la relación matrimonial es voluntaria mientras que la familiar tiene su origen en la filiación o el parentesco. Consecuentemente con el segundo motivo recién indicado, en el matrimonio se genera relaciones iguales para ambas partes, no así en la familia, donde se generan derechos y obligaciones desiguales. Finalmente argumenta que el matrimonio provoca la relación de dos familias, no sólo de dos personas, por ello antiguamente familia y matrimonio estaban unidas. Pero el matrimonio por si solo no formará una familia si no existe descendencia o personas dependientes a su cargo, sin perjuicio de ello la Constitución otorga una diferente protección para cada uno lo cual también contribuye para indicar de que no son lo mismo .

Para concluir este apartado es importante señalar algunas de las consideraciones que deben apreciarse en el estudio de la evolución del término, y en tal sentido ROCA I TRÍAS ${ }^{45}$ ha formulado que: "Podemos estar de acuerdo con que los cambios se han producido y también en que esto demuestra, por una parte, que la familia no es un grupo estático y, por otra parte, que nunca existe una situación que provoque un periodo más o menos largo de estabilidad. En cualquier caso, los

43 Vid MARTÍNEZ LÓPEZ-MUÑIZ, J. L. "La familia en la Constitución española”, en Revista de Derecho Constitucional, núm. 58, enero-abril, Madrid, año 2000, páginas 11 y siguientes.

44 PÉREZ VILLALOBOS, M. C. “Las leyes autonómicas reguladoras de las parejas de hecho”, Ed. Thomson-Civitas, Cizur Menor, año 2008, páginas 98 a 100.

45 Cfr. ROCA I TRÍAS, E. “Familia y cambio social (De la casa a la persona)”. Ed. Civitas, Madrid, año 1999 , páginas 42 a 47. La autora sostiene que en la Constitución se pueden encontrar perfiles básicos suficientemente determinados que impide señalar como familia cualquier tipo de asociación, reunión o convivencia. 
cambios tienen unas bases, cuyo control hace prever con mayor o menor seguridad, no sólo que se están produciendo, sino también la dirección en que se producirán."

Por ello los actuales estudios sobre Derecho de familia tienen una base empírica, porque se considera que sin conocer cuál es la realidad de las familias no puede tomarse una decisión legal que tenga posibilidades de éxito en su aplicación.

Los elementos a tener en cuenta en este análisis empírico vienen proporcionados por ciencias auxiliares a la del jurista, como la demografía, la sociología, la economía.

Los datos demográficos, prosigue la autora, aportan las características de la población, en base a los censos o a estadísticas nacionales. A través de tales datos y en lo que se refiere básicamente a la cuestión familiar, se pueden comprobar las características referidas a los matrimonios, como la edad en que se contraen y el número de los mismos; el número de personas que vuelve a contraerlo una vez divorciadas; la duración de estos nuevos matrimonios, y la convivencia con hijos de anteriores uniones.

Respecto de los divorcios, el número de separaciones y de los mismos, la característica de estos procesos: si se trata de procesos contenciosos o por acuerdo mutuo. Y la consecuencia que se deduce de ellos: la duración de los matrimonios.

En lo referido a las personas que conviven sin haber contraído matrimonio, se puede deducir el número de estas parejas, cuántas personas conviven con otras de su mismo sexo, la duración de la convivencia, si tienen o no hijos; cuál es la clase social a la que pertenecen.

La demografía proporciona, acerca de los grupos familiares no tradicionales, datos sobre familias monoparentales, su número y composición; su localización: si se encuentran en grandes ciudades o no y su origen, es decir, si provienen de personas divorciadas, viudas o que nunca han contraído matrimonio. Ello es interesante, para poder lograr que tales grupos sean beneficiarios de prestaciones sociales por parte del Estado más acentuadas, debido a que pueden presentar la carencia de uno de los aportes en el sostenimiento familiar, al ser el otro progenitor inubicable o al existir la posibilidad de un posible pleito que logre la asunción de la responsabilidad alimentaria.

Por lo que se refiere a los hijos, los datos se referirán al número de nacimientos que se produce dentro del matrimonio y fuera del mismo, adopciones; edad de los progenitores; número de hijos reconocidos, cuando el nacimiento se produce fuera del matrimonio; problemas de la convivencia cuando se produce un divorcio, con quien viven los hijos y de quién dependen; situaciones producidas como consecuencias de nuevos matrimonios; problemas de protección de menores en situaciones de desamparo o violencia. 
En cuanto a los denominados datos sociológicos. Ellos permiten apreciar las distintas opiniones de la población sobre determinadas materias y, por lo que se refiere al Derecho de Familia, los datos sobre las razones y las consecuencias que los diferentes acontecimientos provocan en el sector de la población estudiado. La sociología, en todo caso, no aporta datos, sino que ofrece una interpretación de los que les proporcionan otras ciencias auxiliares que permiten obtener una base para futuras soluciones.

Los datos económicos, por su parte son relevantes debido a que los problemas que se producen en el ámbito del Derecho de Familia tienen una gran incidencia económica. Es más, se debe recordar que una de las características de la evolución de la familia reside en la transformación de la base económica en que se sustenta. Interesa acotar que tales datos permiten adoptar unas determinadas soluciones en aspectos problemáticos, sobre todo en situaciones de crisis matrimoniales o de convivencia. La influencia de la economía tiene dos consecuencias según ROCA I TRÍAS ${ }^{46}$. La autora afirma que la economía influye en la estructuración de la economía familiar, mediante la adopción de unas determinadas reglas en los Códigos y en la legislación en general, con soluciones respecto al régimen de bienes, la contribución a las cargas del matrimonio, el mantenimiento de los hijos y la atribución de un régimen específico a la vivienda.

Quiero destacar en este punto que es prácticamente unánime la opinión de la importancia que tiene la familia en la sociedad española, por ello como corolario citaré la Ley de apoyo a la familia y a la convivencia de Galicia, Ley 3/2011, de 30 de junio. Esta en su exposición de motivos señala que: "La evolución histórica y la complejidad progresiva de la organización social encuentran reflejo y acogida en la familia como institución en permanente evolución. Fórmulas de convivencia que sin ser nuevas eran hasta ahora infrecuentes tienen cabida en la familia como estructura básica de la sociedad y como medio natural de desarrollo y crecimiento de la persona. Por ello es deber de los poderes públicos reconocer y amparar a la familia y todas sus manifestaciones y formas de organización, dándoles un especial apoyo y protección.".

\section{5 | La europeización del Derecho de Familia}

La riqueza de tipos familiares que se han dado en Europa responde a la diversidad de las condiciones económicas, políticas sociales y culturales que han marcado en cada tiempo y lugar las diferentes sociedades que la conforman. Esta íntima relación entre familia y sociedad tiene mucho que ver con las funciones que desempeña la familia en relación a sus miembros y respecto de la sociedad en 46 ROCA I TRIAS, E., ibídem, página 12. 
que se integra. VALPUESTA FERNÁNDEZ ${ }^{47}$ ha entendido como funciones de la familia, los cometidos que ésta, entendida como organización ha cumplido respecto a todos o algunos de sus miembros con un cierto carácter de generalidad y continuidad; en tal sentido no se refiere a la dedicación que por alguna coyuntura se haya prestado por la familia a sus integrantes en un tiempo concreto, sino al conjunto de tareas que dirigen unos comportamientos hacía un objetivo u objetivos determinados, modelando las relaciones en el interior de la familia, con la independencia de que se tenga mayor o menor conciencia de ello.

Ahora bien, estas funciones también las ha desempeñado la familia respecto del conjunto de la sociedad cuando se han asumido por el grupo familiar objetivos que repercuten sobre la colectividad, por lo que su determinación, así como su realización, tienen mucho que ver con el nivel de organización de la sociedad en que se inserta.

La llamada europeización del Derecho de Familia se ha convertido en los últimos años en uno de los objetivos prioritarios de la Unión Europea, consciente desde hace tiempo de las profundas transformaciones que ha venido sufriendo la estructura y la concepción de la familia, no tan sólo a nivel de Europa sino en el mundo en su conjunto. Los cambios demográficos y el descenso de la natalidad han tenido consecuencias directas sobre el mismo mercado laboral, los sistemas de seguridad social y la propia realización del mercado laboral. Ello ha provocado que la familia se haya convertido en un elemento esencial en la economía que sin duda provoca la intervención de la comunidad internacional, debido a que la intervención interna, de cada Estado puede ser insuficiente. De este modo, la integración comunitaria de un área como el Derecho de Familia, en el que emergen intereses muy concretos como el del menor o el respeto a la vida familiar, no deja de ocultar un transfondo, tal cual lo pregona ESPINOZA CALABUIG ${ }^{48}$. En tal sentido el Legislador comunitario ha tenido un creciente interés, así lo puso de manifiesto el Consejo de la Unión Europea (Comité de Derecho Civil) con motivo del "Proyecto de informe del Consejo sobre la necesidad de aproximar las legislaciones de los Estados miembros en materia civil”49. En tal sentido el Parlamento Europeo, el Tribunal de Justicia de las Comunidades Europeas y el Consejo se han venido pronunciando en ámbitos relacionados con la unidad familiar, los hijos o el cónyuge y, por lo tanto, con el estatuto personal de los ciudadanos comunitarios.

47 VALPUESTA FERNÁNDEZ, R. "La disciplina constitucional de la familia en la experiencia europea”, Ed. Tirant Lo Blanch, año 2010, Valencia, páginas 55 y 56.

48 Cfr. ESPINOZA CALABUIG, R. "La construcción de un Derecho de Familia en Europa”, en AMIN FERRAZ, D. “Manual de Integración Regional”, Ed. Mandamientos, Belo Horizonte, año 2004, páginas 445 a 487.

49 Bruselas, 29 de octubre de 2001. 
Asimismo las autoridades comunitarias se han pronunciado sobre otras cuestiones de gran trascendencia para el Derecho de Familia, por ejemplo entre tales materias tenemos: la adopción de menores $^{50}$, la protección y mejora de los matrimonios fraudulentos ${ }^{51}$, así como la igualdad de derechos de los homosexuales y lesbianas en la Comunidad Europea ${ }^{52}$, o el "Derecho de los ciudadanos de la Unión y de los miembros de sus familias a circular y residir libremente en el territorio de los Estados miembros" ${ }^{\text {} 53}$. Junto a ello también la jurisprudencia del Tribunal de Justicia ha expresado su interés creciente por cuestiones de diversa índole como el estado de la persona (su calidad de hijo, descendiente, cónyuge $)^{54}$, el derecho de alimentos, la patria potestad y su ejercicio ${ }^{55}$, el respeto a la vida familiar, etc ${ }^{56}$.

Sin duda ha sido una labor incesante, en el afán de armonizar algunos aspectos del Derecho de Familia, tal cual se puede dejar entrever del Programa de la Haya publicado en $2005^{57}$, destacando entre otros la Propuesta de Reglamento del Consejo por el que se modifica el Reglamento 2201/2003 por lo que se refiere a la competencia, y se introducen normas relativas a la ley aplicable en materia de régimen matrimonial, con especial referencia a las cuestiones de competencia jurisdiccional y reconocimiento mutuo ${ }^{58}$, el Libro Verde sobre la legislación aplicable y la competencia en asuntos de divorcio ${ }^{59}$, el Libro Verde sobre legislación aplicable, el reconocimiento y la ejecución de las resoluciones judiciales y la cooperación en materia de obligaciones de alimentos ${ }^{60}$, finalmente se menciona el vigente Reglamento 2201/2003 sobre competencia judicial y reconocimiento y ejecución de resoluciones judiciales en materia matrimonial y de responsabilidad parental.

50 Resolución de 20 de enero de 1997 sobre la mejora del Derecho y de la Cooperación entre los Estados miembros en materia de adopción de menores, DOCE , núm. C20, año 1997, página 176.

51 Resolución del Parlamemto Europeo, de 18 de julio de 1996, sobre el secuestro de niños de matrimonios de distinta nacionalidad en los Estados miembros (DOCE, núm. C261/157, 1996).

52 Resolución del Parlamento Europeo, de 8 de febrero de 1994, sobre la igualdad de derechos de los homosexuales y de las lesbianas en la Comunidad Europea (DOCE, núm. 1994, C 61/40)

53 A través de la Directiva del Parlamento Europeo y del Consejo presentada el 29 de junio de 2001 (DOCE, núm. C $270 \mathrm{E} / 150$, de 25 de septiembre de 2001).

54 SSTCJE, Pleno, Caso Ingetraut Scholz contra Opera Universitaria di Cagliariotros, de 23 febrero 1994. TJCE 1994/21; Caso Lisa Jacqueline Grant contra South-West Trains Ltd. de 17 febrero 1998. TJCE 1998/28.

55 STJCE, Sala 6 ${ }^{\mathrm{a}}$, Caso Kathleen Hill Ann Stapleton contra The Revenue Commissioners Department of Finance. de 17 junio TJCE 1998/142.

56 STJCE, Pleno, Caso Mary Carpenter contra Secretary of State for the Home Department, de 11 julio 2002. TJCE 2002/222.

57 DOUE, núm. 53, de 3 de marzo de 2005, página 13.

58 El libro verde es uno de los objetivos del programa de La Haya adoptado por el Consejo Europeo los días 4 y 5 de noviembre de 2004.

59 Cfr. Dictamen del Comité Económico y Social sobre el Libro Verde sobre la legislación aplicable y la competen cia en asuntos de divorcio, DOUE, 31 de enero 2006.

60 Cfr. Comunicación de la Comisión al Consejo y al Parlamento Europeo relativa a los Comentarios sobre los artículos de dicha Propuesta, el 12 de mayo de 2006. 
La comunitarización del Derecho internacional privado derivada de la entrada en vigor del Tratado de Amsterdam ha supuesto consecuencias en relación con la celebración de Tratados con terceros estados y la participación en organizaciones internacionales. La transformación de los convenios preexistentes en el seno de la Unión Europea en instrumentos comunitarios no sólo se ha debido a unos objetivos de rapidez e inmediata entrada en vigor, sino también porque de tal manera la comunitarización puede tener efectos ad extra.

En relación a la familia o a las familias, y lo cual tiene una considerable importancia para el Derecho Europeo, y especialmente en España, se puede contemplar una serie de elementos que tienen relación con el Derecho Internacional Privado y el Derecho Comunitario. El primero es la diversidad de modelos de familia en Occidente, la realidad en tal sentido indica que no existe una "familia", sino que por el contrario existen modelos de ella, de entre ellos se alude a la familia tradicional, basada en el matrimonio de los progenitores; las familias de hecho, en las cuales los convivientes no están casados entre sí; las familias monoparentales, integradas por un sólo progenitor y sus hijos; finalmente familias reconstruidas, formadas por agregación de individuos procedentes de familias anteriores ya disueltas. El segundo es la multiculturalidad de la familia, debido a que la idea de familia es de diversa naturaleza en cada rincón del mundo. Es claro que las diversas migraciones que han ocurrido hacia Occidente han provocado que las personas provenientes de diferentes círculos sociales, culturales y jurídicos hayan traído consigo modelos de familia distintos, que han influido en el entorno en el cual se desenvuelven.

Como consecuencia de lo anterior, Europa en general y España en particular presenta diversos modelos de familia, lo cual provoca que pueda hablarse de sociedades multiculturales ya sea en este como en otro aspecto. En tercer lugar se menciona la internacionalización de la familia, a causa de la libre circulación de las familias, así como a todo el proceso de globalización ampliamente conocido, lo cual ha desencadenado que existan muchas familias compuestas por miembros de diversas nacionalidades.

Hoy en día en Europa existen diversos aspectos que preocupan, de entre ellos destaco, en primer lugar, el mantenimiento post-divorcio de los miembros de la familia. Esta situación puede provocar conflictos con la libertad de las personas que sufren tales situaciones, al mismo tiempo tiene lugar el deber de solidaridad que existe entre los miembros que formaban el disuelto grupo familiar. Este conflicto se justifica porque cualquier persona, después de haber vivido una experiencia que puede incluso ser traumática, al extinguirse un matrimonio o una relación afectiva análoga, quiere emprender diversos proyectos personales, algunos de ellos de naturaleza afectiva. Sobre todo en lo 
concerniente a aquellos miembros de la familia que tras la ruptura se ven más desfavorecidos en su situación, los diversos ordenamientos jurídicos procuran la creación de fórmulas que logren otorgarle cierta estabilidad, en referencia a los hijos y a los cónyuges, en palabras de PEREDA GÁMEZ ${ }^{61}$. Ante tal realidad se procuró la unificación de normas de conflicto de leyes en materia de crisis matrimoniales y por ello se dictó el Reglamento (UE) N $N^{0} 1259 / 2010^{62}$.

En segundo lugar resalta la fijación de la filiación, con los nuevos retos de la bioética, ante ello emerge el imperativo de establecer límites de los derechos de la paternidad y la maternidad responsable así como la protección del concepturus y del nasciturus. El Derecho de Familia, con sus diversas limitaciones, procura dar solución a los diversos conflictos de intereses a través de la protección pública de la filiación y la determinación de reglas jurídicas respecto a la biología, con presunciones iuris tantum de paternidad y maternidad y con determinaciones de filiación iuris et de iure en lo referente a las técnicas de inseminación autónoma y heterónoma. En tercer lugar se destaca la existencia de una legislación paido-céntritarea educativa en la que el Estado y las familias se reparten, con base en un sistema mixto, la tarea educativa ${ }^{63}$. El derecho a conocer los propios orígenes, los límites de la intervención pública en el ámbito de las familias biológicas en aras a la protección de los menores, el control de la educación y la salud en estándares aceptables desde los principios y valores democráticos y el respeto a los derechos individuales.

Finalmente se encuentra la desregulación del matrimonio, con la consolidación de las uniones de hecho y la aparición y progresivo reconocimiento de otras formas de convivencia lo cual no hace sino eternizar el conflicto que acaece en el Derecho con motivo del respeto a ciertas exigencias formales y la libertad de vínculo amparada en el principio de la autonomía de la voluntad.

En relación a lo anterior es necesario dejar entrever la diferente aproximación que tiene el Consejo de Europa y la UE en lo referente a la protección de la familia. Si bien las políticas de familia continúan siendo un campo fundamentalmente de competencia estatal, en tal sentido la protección de la misma se articula en primer lugar sobre el derecho interno de los Estados, dicha legislación obviamente constituirá la mayor parte de las normas de derecho material, que se aplicará a la

61 PEREDA GÁMEZ, J. "El cambio de las estructuras familiares y la modernización del Derecho de Familia (Notas para una tertulia)”, en “Matrimonio homosexual y adopción”, Ed. Reus, Madrid, año 2006, páginas 200 y 201.

62 VELÁZQUEZ SÁNCHEZ Ma " "La unificación de normas de conflicto de leyes en materia de crisis matrimoniales: el nuevo Reglamento (UE) No 1259/2010. (RI §410541)”. Ed. Iustel, Revista General de Derecho Europeo, núm. 24, julio de 2011, http://www.iustel.com/v2/revistas/detalle_revista.asp?id_noticia $=410541 \& \mathrm{~d}=1$ tas para una tertulia)”... op. cit., página 101. 
célula familiar $^{64}$. Sin perjuicio de esto se generan diversas exigencias que se pueden ver impuesta a los Estados por participar en organizaciones internacionales europeas que se ocupan de la familia y que procuran conseguir la homogeneización de la legislación en los Estados que son partes, homogeneizacion que no me atrevo a decir que sea del todo neutra. Por ello, aunque en principio se configure como una exigencia nacional, también, paulatinamente se ha consagrado como una exigencia europea.

La pertenencia a ambas instituciones trae aparejado muy diversas consecuencias, por cuanto el Consejo de Europa es sólo una organización de cooperación y únicamente le obligarán las disposiciones de tipo convencional que se aprueben en su seno, en las que ese Estado exprese claramente que quiere participar y siempre que manifieste su consentimiento en obligarse por ellas. Por otra parte, el pertenecer a la Unión Europea, trae como consecuencias el cumplir obligaciones positivas por la mera aprobación de actos por parte de las instituciones positivas ${ }^{65}$. Los actos que se pueden aprobar en relación con la familia pueden obligar a los Estados, aunque sólo sea a través de políticas compartidas. Es al interior de la Unión Europea, por los especiales poderes de que goza esta, donde pueden surgir normas obligatorias para todos los Estados y que generan derechos a su vez para los particulares, y las familias, lo cual no puede confundirse con políticas sociales.

En este sentido concuerdo plenamente con lo planteado por SANZ CABALLERO ${ }^{66}$, la inclinación hacia una u otra posibilidad refleja e indica realmente una distinta concepción de la protección de la familia, ya sea como derechos oponibles al Estado y a la UE, bien como prestaciones o gracias que conceden el Estado y la UE.

Los órganos del Consejo de Europa y de la UE con competencias potenciales en materia de derechos de la familia pueden concluir actos con un efecto vinculante muy diferente entre sí. Lo mismo ocurre con la jurisprudencia de sus tribunales. Las sentencias del TEDH y del TJCE se centran por lo general en derechos diversos. Por ejemplo el TJCE es mucho mas vasto y prolijo en el sector de los derechos socio-económicos, debido a que su objeto primordial es velar por la correcta aplicación del Derecho Comunitario, un derecho que pretende contribuir a desarrollar y afianzar un mercado único entre los Estados miembros. En las sentencias de este tribunal, los derechos fundamentales, aún revistiendo mucha relevancia en si mismos, lo son sobre todo en su aspecto de me-

64 Cfr. ESCOBAR HERNÁNDEZ. C. “Instituciones de la Unión Europea”, Ed. Tirant Lo Blanch, Valencia, año 2012.

65 Cfr. FERNÁNDEZ NAVARRETE, D. "Historia de la Unión Europea”, Ed. Delta Publicaciones, Madrid, año 2013.

66 SANZ CABALLERO, S. “La familia en perspectiva internacional y europea”, ...op. cit., páginas 358 a 361. 
dios e instrumentos para alcanzar la prosperidad y desarrollo económico estable, creciente y equilibrado en la Unión Europea ${ }^{67}$.

Sin duda puede parecer caótico que instancias conformadas por miembros iguales ya sea del Consejo y la Unión puedan adoptar una posición diversa en materia de derechos fundamentales, ello es debido a que sus objetivos son distintos. Lo anterior, sin duda, me parece bastante confuso. Incluso en este aspecto SANZ CABALLERO habla de cierta esquizofrenia jurídica, amparada en dos extremos, el centrarse en la persona humana y el lograr un mercado único. Por tal motivo, para el presente trabajo sobre todo se ha considerado a nivel europeo la jurisprudencia del Tribunal Europeo de Derechos Humanos, lo cual no es por otra parte el principal objetivo de este estudio que quiere suscribirse al ámbito español básicamente.

\section{EI Estado de las Autonomías y el Derecho de Familia, el rompecabezas de las competencias}

La coexistencia dentro de un mismo Estado de diferentes bloques de normas sustantivas reguladoras de una misma materia es lo que hace que se califique de plurilegislativo al Estado en cuestión, este es caso del Estado español. Sin perjuicio, en tal descripción pueden caber realidades diferentes ${ }^{68}$. Se puede tratar de bloques de normas que rijan, cada uno, una parte diferente del territorio del Estado y sean de aplicación a quienes posean vínculos con ese territorio o como resultado de haberse producido en él determinados hechos. Pero también puede tratarse de bloques de normas, que pueden regir en todo el Estado o sólo en una parte de él, cuya aplicación se reserve sólo a determinados grupos de personas, atendiendo a su pertenencia a una determinada etnia o a una determinada religión. En ocasiones incluso pueden acumularse ambas características: normas que rigen sólo en una parte del territorio del Estado, destinadas a ser aplicadas sólo a ciertos colectivos de personas identificados por su etnia o religión, en cuyo caso para su aplicación no sólo hay que estar ante una persona perteneciente al colectivo en cuestión, sino también debe darse algún tipo de vínculo entre esta persona y el territorio donde rige la norma ${ }^{69}$.

67 Cfr. MATÍA PORTILLA, F. J. “La protección de los Derechos Fundamentales en la Unión Europea”, Ed. Civitas, Madrid, año 2002 ; STEFAN, P. "Soft Law in Court. competition Law, state aid and the Court of Justice of the European Union”, Ed. Wolters Kluwer Law \& Business, Alphen aan den Rijn. Países Bajos, año 2013.

68 GARAU JUANEDA, L. "Los conflictos de leyes entre las diferentes regulaciones en materia de régimen económico matrimonial vigentes en España y cuestiones de Derecho Intertemporal asociadas a los mismos”, en LLEDRÓ YAGÜE, F y FERRER VANRELL, M ${ }^{\text {a }} \mathrm{P}$. (Dirs.) "Los regímenes económicos matrimoniales en los Derechos civiles especiales y forales”, Ed. Dykinson S.L., Madrid, año 2010, página 51.

69 ESPINAR VICENTE, J. M. "Ensayos sobre teoría general del Derecho internacional privado. Breve introducción al Derecho internacional privado contemporáneo, con especial referencia al tratamiento de las relaciones de familia”, Ed. Civitas, Madrid, año 1997. 
En relación con el primer modelo se habla en ocasiones de sistema plurilegislativo de base territorial y, en relación con el segundo, de sistema plurilegislativo de base personal. En el Estado moderno todas las normas tienen una base territorial, todas rigen todo o en parte de su territorio, y el hecho de que en un mismo territorio existen normas diversas para diversos grupos de personas se debe a las materias que tales grupos pueden regular, no a la consideración de las personas.

Las relaciones entre norma jurídica y espacio presentan, al igual que las existentes entre norma jurídica y tiempo, diferentes facetas, con un claro paralelismo entre unas y otras. Para describir esas relaciones se utilizan los términos "ámbito de vigencia”, “ámbito de aplicación” y "ámbito de eficacia", ya sea espacial, ya sea temporal ${ }^{70}$.

Tal como explica GARAU JUANEDA con el término “ámbito de vigencia espacial” de una norma nos referimos al territorio en el que rige esa norma. Como regla general el ámbito territorial de vigencia de una norma de origen estatal coincide con el territorio del Estado, o con el territorio de la comunidad autónoma si es una norma autonómica. Con el término ámbito de aplicación espacial nos referimos al territorio en el que debe situarse el supuesto de hecho contemplado en la norma para que esta sea de aplicación. Para determinarlo se recurre unas veces a conexiones puramente territoriales, otras a conexiones que responden a la vinculación de una persona con un territorio ${ }^{71}$. A su vez, el "ámbito de aplicación temporal” se refiere a qué supuestos puede aplicarse la norma, por razón del momento en el que éstos se han producido. Aunque normalmente ámbito de vigencia y ámbito de aplicación temporal coinciden. Por último, por “ámbito de eficacia territorial” se entiende

70 Cfr. GOLDSCHMIDT, W. "Derecho internacional privado Derecho de la tolerancia. Basado en la teoría trialista del mundo jurídico”, Ed. Abeledo Perrot S.A., Buenos Aires, año 2011.

71 STC, Pleno, núm. 156/1993 de 6 mayo. RTC 1993/156. "Sin embargo, es reiterada doctrina constitucional la que afirma la necesidad de agotar la posibilidad de una interpretación "concorde a la Constitución» de la norma antes de su expulsión, por inconstitucional, del ordenamiento. Se observa -dicho esto- que el precepto impugnado debe ser interpretado teniendo en cuenta por un lado, la consideración del Derecho civil de Baleares como común o normal en su territorio y, por otro, el precedente inmediato contenido en el art. 7 del Estatuto de Autonomía. Este precepto, refiriéndose no sólo a las normas y disposiciones de los poderes públicos de la Comunidad Autónoma, sino también a su Derecho Civil especial, pregona, como regla general, que "tendrá eficacia territorial» sin perjuicio, en lo que aquí importa, de las situaciones que se hayan de regir por el Estatuto personal o por otras normas extraterritoriales. La doctrina que ha examinado esta norma ha destacado que la excepción en favor del estatuto personal debe considerarse, para delimitar el ámbito de aplicación del Derecho civil balear, regla general, que supone la remisión al Título Preliminar del Código Civil, lo que conlleva vaciar de contenido la anunciada regla general de eficacia territorial. En sus líneas fundamentales esta doctrina es correcta, si bien se le ha de dotar de un contenido, que no es otro que el de establecer un criterio de territorialidad residual y subordinado al estatuto personal, que conduce a la vecindad civil del Título Preliminar del Código, para los supuestos en que exista duda o no pueda probarse cuál sea aquélla, todo lo cual es consecuencia obligada de la configuración del Derecho civil balear como ordenamiento jurídico «común» y «propio» en su ámbito territorial. En definitiva, la eficacia territorial del art. 7 del Estatuto constituye una lex fori residual y subordinada a que no pueda determinarse el estatuto personal que, aunque se enuncia como excepción, se configura, en realidad, como regla general para resolver los conflictos de leyes y el ámbito de aplicación del Derecho civil balear." 
el territorio o territorios en los que una norma es aplicada, donde puede constituir fuente de derechos y obligaciones. El ámbito de eficacia territorial de una norma coincide normalmente con el territorio en el que se rige dicha norma, pero también es posible que una norma que rige en un territorio sea aplicada por una autoridad judicial de un territorio diferente ${ }^{72}$.

Por lo que respecta al ámbito de vigencia territorial de las normas estatales, su límite máximo, el territorio del Estado y, en su caso, zonas más allá del mismo en la que puede ejercer determinadas competencias, viene determinado por el Derecho internacional público. Su límite ad intra responde al reparto de competencias entre el Estado y las comunidades autónomas. Desde el momento en que una comunidad autónoma tiene competencia para dictar normas en una materia y la ejerce, las normas estatales dejan de regir donde rigen las autonómicas. En cuanto estas últimas su límite máximo lo constituye el territorio de la comunidad. Sus limites ad intra los puede establecer libremente la comunidad autónoma con el único límite de no entrar en contradicción con su estatuto de autonomía. En el caso del País Vasco, a modo de ejemplo, y en relación en particular con su derecho civil propio, el estatuto, en su art. 10.5, fija los límites para legislar sobre el mismo, la “conservación, modificación y desarrollo del Derecho Civil Foral y especial, escrito o consuetudinario propio de los Territorios Históricos que integran el País Vasco y la fijación del ámbito territorial de su vigen$\mathrm{cia}^{, 73}$.

En cuanto al ámbito de aplicación por razón del espacio, los Estados establecen libremente el ámbito de aplicación espacial de sus normas, sin perjuicio de la creación de reglas comunes con otros Estados. Cuestión muy distinta es la del ámbito de aplicación espacial de las normas sustantivas autonómicas. De acuerdo con lo establecido en el art. 149.1.8 de la Constitución, el Estado tiene competencia exclusiva en materia de "normas para resolver los conflictos de leyes". Esto significa que las normas que establecen el ámbito de aplicación por razón del espacio de los diferentes ordenamientos jurídicos-privados que existen en España y en su caso la aplicación en España de normas extranjeras sólo puede emanar del Estado ${ }^{74}$.

72 GARAU JUANEDA, L. "Los conflictos de leyes entre las diferentes regulaciones en materia de régimen económico matrimonial vigentes en España y cuestiones de Derecho Intertemporal asociadas a los mismos”... op. cit., página 52.

73 Cfr. GIL RODRIGUEZ, J. “Derecho foral versus Derecho civil: Persona, familia y patrimonio”, http://www.derechocivil.ehu.es/s0125con/es/contenidos/informacion/publicaciones/es_publicac/adjuntos/Gil\%20-\%20DERECHO\%20FORAL\%20versus\%20DERECHO\%20CIVIL.pdf

74 Cfr. PARDO GATO, J. R. "Derechos civiles forales y especiales. concordancias a partir del Código Civil. Legislación foral y especial de Aragón, Cataluña, Galicia, Islas Baleares, Navarra y País Vasco”, Ed. Bosh S.A., Barcelona, año 2013. 
A partir de la promulgación de la Constitución de 1978, los derechos civiles especiales de las regiones españolas han experimentado un gran cambio como consecuencia del reconocimiento y garantía de la autonomía de las nacionalidades y regiones que integran la nación española. En tal sentido el art 2 CE afirma que: “La Constitución se fundamenta en la indisoluble unidad de la Nación española., patria común e indivisible de todos los españoles, y reconoce y garantiza el derecho a la autonomía de las nacionalidades y regiones que la integran y la solidaridad entre todas ellas”. Desarrollando este precepto se encuentra el art. 143.1 CE: "En el ejercicio del derecho a la autonomía reconocido en el artículo 2 de la Constitución, las provincias limitrofes con características históricas, culturales y económicas comunes, los territorios insulares y las provincias con entidad regional histórica podrán acceder a su autogobierno y constituirse en Comunidades Autónomas con arreglo a lo previsto en este Título y en los respectivos Estatutos”. Por ello la asunción de competencias por las comunidades autónomas una vez creadas debía corresponder a los Estatutos de autonomía, y estos a su vez, dentro de la estructura de la Constitución se diferenciaban en Estatutos Largos y Estatutos Cortos $^{75}$.

Los Estatutos Largos se reservaron para las regiones que históricamente hubieran ya alcanzado un Estatuto de autonomía, es el caso de Galicia, Cataluña y el País Vasco, así como los de aquellas regiones que alcanzaron la autonomía en base al Art. $151 \mathrm{CE}$.

Los Estatutos Cortos sólo pudieron asumir competencias dentro del repertorio fijado en el art. $148 \mathrm{CE}$ en el que no se hace referencia a las materias de Derecho Civil o Derecho Privado en general. Ahora bien, la Constitución incide en los Derechos Forales desde 3 puntos de vista. El primero es que la Constitución es norma superior a las compilaciones forales. El segundo es que tiene respecto de ellos efecto derogatorio directo, y finalmente, sus principios son esenciales para la interpretación de los preceptos de las compilaciones.

La Constitución se encontraba en el momento de su promulgación con una situación de coexistencia dentro del territorio nacional español con ordenamientos jurídicos - privados diferentes, esta situación es asumida y además potenciada, provocando la diversidad de ordenamientos jurídicos, desde el momento en que los arts. 148 y149 establecen el sistema constitucional de competencia del estado y de las comunidades autónomas.

La Constitución atribuye competencias legislativas sobre los Derechos Forales a aquellas comunidades autónomas en que existan esos Derechos Forales. Los Estatutos de autonomía corres-

75 APARICIO PÉREZ, M. A. (Ed.). “Derechos y principios rectores en los estatutos de autonomía”, Ed. Atelier, Barcelona, año 2008, páginas 39 a 60. 
pondientes han asumido esta competencia como exclusiva y las comunidades autónomas han legislado sobre Derecho Civil en el ámbito de su competencia.

El proyecto inicial para la redacción del art. 149.1.8 CE incluía la legislación civil entre las competencias que podía asumir cualquier comunidad autónoma, Sin embargo, la redacción definitiva restringió esta posibilidad a las comunidades autónomas en que existiese Derecho Civil Especial o Foral. La citada disposición dispuso que: "El Estado tiene competencia exclusiva sobre las siguientes materias. Legislación civil, sin perjuicio de la conservación, modificación y desarrollo por las Comunidades Autónomas de los derechos civiles, forales o especiales, allí donde existan. En todo caso, las reglas relativas a la aplicación y eficacia de las normas jurídicas, relaciones jurídico-civiles relativas a las formas de matrimonio, ordenación de los registros e instrumentos públicos, bases de las obligaciones contractuales, normas para resolver los conflictos de leyes y determinación de las fuentes del Derecho, con respecto, en este último caso, a las normas de derecho foral o especial”.

De la interpretación de este precepto, parece deducirse una marginación de los derechos civiles forales o especiales pretéritos, sólo puede conservarse, modificarse o desarrollarse lo que ya existe. En consecuencia, sólo tienen competencia legislativa civil las comunidades autónomas que el día de la promulgación de la Constitución tuviesen un Derecho Civil Foral o Especial propio, es decir, comunidades autónomas con Derecho Civil compilado.

Con esta expresión se hace referencia a la vigencia actual del Derecho Foral como una determinada porción de territorio ${ }^{76}$, quedando por tanto excluidas las comunidades cuyo Derecho Foral dejó de estar vigente. En definitiva, podemos extraer de este artículo tres reglas: Una regla general, la competencia exclusiva del Estado en materia de legislación civil; Una regla de Salvaguarda, sobre la conservación, modificación y desarrollo por las comunidades autónomas de los derechos fo-

76 STC, Pleno, núm. 156/1993 de 6 mayo. RTC 1993/156. "El art. 149.1.8 de la Constitución, tras atribuir al Estado competencia exclusiva sobre la legislación civil, introduce una garantía de la foralidad civil a través de la autonomía política, garantía que no se cifra en la intangibilidad de los Derechos civiles especiales o forales , sino en la previsión de que los Estatutos de las Comunidades Autónomas en cuyo territorio aquéllos rigieran a la entrada en vigor de la Constitución puedan atribuir a dichas Comunidades competencia para su conservación, modificación y desarrollo. Tales son los conceptos, dijimos también entonces (fundamento jurídico $1 .^{\circ}$ ), que dan positivamente la medida y el límite primero de las competencias así atribuibles y ejercitables, de modo que la ulterior reserva al Estado, por el mismo art. 149.1.8., determinadas regulaciones en todo caso sustraídas a la normación autonómica no puede ser vista como norma competencial de primer grado que deslinde aquí los ámbitos respectivos que corresponden al Estado y que pueden asumir ciertas Comunidades Autónomas, pues a aquél la Constitución le atribuye ya la «legislación civil», sin más posible excepción que la conservación, modificación y desarrollo autonómico del Derecho civil especial o foral. El sentido de esta segunda reserva competencial en favor del legislador estatal no es otro, pues, que el de delimitar un ámbito dentro del cual nunca podrá estimarse subsistente ni susceptible, por tanto, de conservación, modificación o desarrollo, Derecho civil especial o foral alguno, ello sin perjuicio de lo que en el último inciso del art. 149.1.8 se dispone en orden a la determinación de las fuentes del Derecho." 
rales en ellas existentes, como una atribución de competencias a estas comunidades autónomas; Y finalmente una reserva final, son competencia exclusiva del Estado las que menciona la segunda parte del precepto.

Podíamos añadir además a todo ello tres conclusiones del proceso de interpretación de este precepto: 1.- Los antiguos Derechos Civiles Especiales han pasado a formar parte del ordenamiento jurídico de las comunidades autónomas, y por lo tanto son Derecho Autonómico ${ }^{77}$. 2.- A partir de la aprobación de los Estatutos de Autonomía, las competencias legislativas en orden a la conservación, modificación y desarrollo, y en general a la legislación que los Estatutos permiten, son obras de las asambleas parlamentarias de las comunidades autónomas. 3.- La delimitación de competencias en materia de Derecho Civil, a salvo siempre la reserva final, está en función de los Estatutos de Autonomía para las comunidades autónomas con Estatutos Largos. En las comunidades autónomas con Estatutos Cortos, los Estatutos podían asumir la conservación, modificación y desarrollo de los Derechos Civiles Forales o Especiales.

Ante este panorama, ¿cuál es la competencia general del Estado en materia de legislación civil? Presenta dos grados de competencia: Reserva al Estado un bloque del ordenamiento considerado en su conjunto, lista una serie de materias que corresponden en todo caso al Estado ${ }^{78}$.

Son competencia exclusiva del Estado las reglas relativas a la aplicación y eficacia de las normas jurídicas. El ordenamiento jurídico tiene una coherencia entera y la Constitución ha querido que el intérprete cuente con unos mismos criterios que permitan esa coherencia del ordenamiento. Así, se está refiriendo a toda clase de normas, no sólo a las normas jurídicas civiles. La segunda ma-

77 STC, Pleno, núm. 47/2004 de 25 marzo. RTC 2004/47. “El Derecho civil propio de una Comunidad Autónoma está integrado por el Derecho compilado y, a medida que vaya ejerciendo sus competencias, por el Derecho emanado de sus órganos, siendo obvio que ese Derecho que se vaya dictando puede ser distinto del recopilado en las compilaciones, dado que el aludido título competencial, no sólo habilita para la conservación de los Derechos civiles, sino también para su modificación y desarrollo. Así pues, aunque la Constitución y los diferentes Estatutos de Autonomía han partido de los Derechos civiles, forales o especiales tal y como existían en el momento de la entrada en vigor de la norma constitucional, nada impide que la legislación autonómica, aun cuando inicialmente mantenga conexión con ellos, se renueve con el paso del tiempo y se amplíe, con el límite de la competencia exclusiva del Estado en aquellas materias a las que se refiere el art. 149.1.8 ${ }^{a}$ CE. Se puede, por tanto, convenir en que el Derecho civil que puede emanar ahora de los órganos legislativos de las Comunidades Autónomas deja de ser Derecho foral stricto sensu para ser Derecho propio de las mismas, por cuanto la legislación sobre la materia foral entra dentro del marco de sus competencias exclusivas. Si no fuera así debería denominarse Derecho foral a todo lo creado por el órgano legislativo competente en cada Comunidad Autónoma, lo cual sería evidentemente absurdo. De este modo, al abarcar la expresión «Derecho civil, foral o especial» toda la producción normativa que en el ejercicio de sus competencias dicten los órganos de las Comunidades Autónomas, es evidente que el recurso de casación ante los Tribunales Superiores de Justicia podrá fundamentarse en la compilación o Derecho foral o especial y cualquier otra norma del ordenamiento jurídico civil propio de la Comunidad Autónoma que haya sido objeto de una regulación específicas dentro de sus competencias legislativas."

PÉREZ VILLALOBOS, M. C. “Las leyes autonómicas reguladoras de las parejas de hecho”, ...op. cit. 
teria son las relaciones jurídico - civiles relativas a las formas de matrimonio. Es competencia del Estado la regulación del matrimonio, de las diferentes formas de contraerlo, y regular los derechos y deberes entre los cónyuges. Queda excluido de la competencia del Estado el régimen económico conyugal. La tercera materia es la ordenación de los registros e instrumentos públicos. Por "Registros" hay que entender los que producen efectos en la ordenación jurídica privada, en especial el Registro Civil y el Registro de la Propiedad, pero también otros registros secundarios, y por “Instrumentos Públicos” entendemos los documentos públicos notariales protocolizados. La cuarta materia son las bases de las obligaciones contraídas. Es de competencia estatal todo lo relativo a las reglas generales sobre las obligaciones contractuales, la regulación de los contratos y de las obligaciones exrtacontractuales. La quinta materia son las normas para resolver los conflictos de leyes. El Estado tiene competencia exclusiva en las normas de derecho interregional que reglan los conflictos de leyes del Estado en el espacio, es decir, el orden de aplicación de cada uno de los ordenamientos jurídicos vigentes en España, y también es competente para establecer las normas, para resolver los conflictos de leyes en el tiempo. Es el Derecho Transitorio. La sexta materia sería la determinación de las fuentes del Derecho. Es competencia exclusiva del Estado, pero aquí el legislador estatal debe respetar las normas de Derecho Foral o Especial, Esta limitación a la competencia estatal regirá para la determinación de las fuentes del Derecho Civil, pero no para las fuentes del Derecho en los demás sectores del ordenamiento jurídico

La Comunidades autónomas que han asumido como exclusiva la competencia para conservar, modificar y desarrollar su propio Derecho Civil, no pueden legislar sobre cualquier materia de Derecho Civil. Pueden regular materias no previamente reguladas por su Derecho Foral, siempre que se trate de instituciones conexas con las ya reguladas en la compilación dentro de una actualización o innovación de los contenidos de ésta según los principios informadores peculiares del Derecho foral $^{79}$. Es la doctrina de la conexión recogida por el Tribunal Constitucional en las sentencias

79 ATSJG, Sala de lo Civil y Penal, Sección $1^{\text {a }}$, Auto de 13 noviembre 2006. JUR 2007/245811. "El concepto constitucional ( RCL 1978, 2836) (art. 149.1.8) y estatutario (art. 35.1.4 EAA) de "desarrollo" del propio Derecho civil, especial o foral, debe ser identificado a partir de la "ratio" de la garantía autonómica de la foralidad civil que establece -según indicamos en el f. j. $1^{\circ}$ - aquel precepto de la Norma fundamental. La Constitución permite, así, que los Derechos civiles especiales o forales preexistentes puedan ser objeto no ya de "conservación" y "modificación", sino también de una acción legislativa que haga posible su crecimiento orgánico y reconoce, de este modo, no sólo la historicidad y la actual vigencia, sino también la vitalidad hacia el futuro, de tales ordenamientos preconstitucionales.- Ese crecimiento, con todo, no podrá impulsarse en cualquier dirección ni sobre cuales quiera objetos, pues no cabe aqui olvidar que la posible legislación autonómica en materia civil se ha admitido por la Constitución no en atención, como vimos, a una valoración general y abstracta de lo que pudieran demandar los intereses respectivos (art. 137 CE [RCL 1978, 2836] ) de las Comunidades Autónomas, en cuanto tales, sino a fin de garantizar, más bien, determinados Derechos civiles forales o especiales vigentes en ciertos territorios. El término "allí donde existan" a que se refiere el art. 149.1.8 CE, al delimitar la competencia autonómica en la materia, ha de entenderse más por referencia al Derecho foral en su conjunto que a institucio- 
STC, Pleno, núm. 88/1993 de 12 marzo. RTC 1993/88 ${ }^{80}$ y la STC, Pleno, núm. 156/1993 de 6 mayo. RTC 1993/156 y el Auto del Tribunal Constitucional, Pleno, núm. 434/1990 de 11 diciembre. RTC 1990/434 AUTO $^{81}$.

\section{La primera sentencia resuelve el recurso de inconstitucionalidad presentado por el Presidente}

de Gobierno frente a la Ley 3/1988, de 25 de abril, de las Cortes de Aragón, sobre equiparación de los hijos adoptivos por entender que se trata de una institución nueva e inédita por la ausencia de toda norma sobre adopción en los textos legales sobre Derecho foral aragonés. La ley modifica la

nes forales concretas.- Sin duda que la noción constitucional de "desarrollo" permite una ordenación legislativa de ámbitos hasta entonces no normados por aquel Derecho, pues lo contrario llevaría a la inadmisible identificación de tal concepto con el más restringido de "modificación". El "desarrollo" de los Derechos civiles forales o especiales enuncia, pues, una competencia autonómica en la materia que no debe vincularse rígidamente al contenido actual de la Compilación y otras normas de su ordenamiento. Cabe, pues, que las Comunidades Autónomas dotadas de Derecho civil, foral o especial regulen instituciones conexas con las ya reguladas en la Compilación dentro de una actualización o innovación de los contenidos de ésta según los principios informadores peculiares del Derecho foral.- Lo que no significa, claro esta, en consonancia con lo anteriormente expuesto, una competencia legislativa civil ilimitada "ratione materiae" dejada a la disponibilidad de las Comunidades Autónomas, que pugnaría con lo dispuesto en el art. 149.1.8 CE, por lo mismo que no podría reconocer su fundamento en la singularidad civil que la Constitución ha querido por vía competencial, garantizar.”

80 STC, Pleno, núm. 88/1993 de 12 marzo. RTC 1993/88. "El citado precepto constitucional, tras atribuir al Estado competencia exclusiva sobre la «legislación civil», introduce una garantía de la foralidad civil a través de la autonomía política, garantía que no se cifra, pues, en la intangibilidad o supralegalidad de los Derechos civiles especiales o forales, sino en la previsión de que los Estatutos de las Comunidades Autónomas en cuyo territorio aquéllos rigieran a la entrada en vigor de la Constitución puedan atribuir a dichas Comunidades competencia para su conservación, modificación y desarrollo. Son estos los conceptos que dan positivamente la medida y el límite primero de las competencias asi atribuibles y ejercitables y con arreglo a los que habrá que apreciar -como después haremos- la constitucionalidad o inconstitucionalidad de las normas en tal ámbito dictadas por el Legislador autonómico. La ulterior reserva al Estado, por el mismo art. 149.1.8, de determinadas regulaciones en todo caso sustraídas a la normación autonómica no puede ser vista, en coherencia con ello, como norma competencial de primer grado que deslinde aqui los ámbitos respectivos que corresponden al Estado y que pueden asumir ciertas Comunidades Autónomas, pues a aquél -vale reiterar- la Constitución le atribuye ya la «legislación civil», sin más posible excepción que la conservación, modificación y desarrollo autonómico del Derecho civil especial o foral. El sentido de ésta, por así decir, segunda reserva competencial en favor del Legislador estatal no es otro, pues, que el de delimitar un ámbito dentro del cual nunca podrá estimarse subsistente ni susceptible por tanto, de conservación, modificación o desarrollo, Derecho civil especial o foral alguno, ello sin perjuicio , claro está, de lo que en el último inciso del art. 149.1.8 se dispone en orden a la determinación de las fuentes del Derecho."

81 ATC, pleno, núm. 434/1990 de 11 diciembre. RTC 1990/434 AUTO “A tenor de lo establecido en el art. 161.2 CE, las impugnaciones que el Gobierno efectúe ante el Tribunal Constitucional de las disposiciones y resoluciones adoptadas por los órganos de las Comunidades Autónomas producirán la suspensión de dicha disposición o resolución recurrida. Por su parte, la Ley Orgánica del Tribunal Constitucional establece, en su art. 30, que la admisión de un recurso de inconstitucionalidad suspenderá la vigencia y aplicación de la Ley recurrida por el Gobierno, si éste se ampara en lo dispuesto en el precepto constitucional mencionado, y en el art. 77, que la formulación de la impugnación comunicada por el Tribunal producirá la suspensión de la disposición o resolución recurrida. Más concretamente, dentro del título referente a los conflictos constitucionales, señala la LOTC, en su art. 64, que la formalización de los conflictos de competencia entablados por el Gobierno, con invocación del art. 161.2 CE, comunicada por el Tribunal, suspenderá inmediatamente la vigencia de la disposición, resolución o acto que hubiese dado origen al conflicto. Además, el art. 65.2 LOTC dispone que el plazo de cinco meses dentro del cual el Tribunal deberá ratificar o levantar la suspensión se contará desde la iniciación del conflicto.- Si bien la normativa indicada de la LOTC vincula el efecto suspensivo de la vigencia y aplicación de las disposiciones autonómicas resumidas por el Gobierno, cuando éste hace uso de la prerrogativa otorgada por el art. 
Compilación aragonesa el disponer que los hijos adoptivos en Aragón tendrán los mismos derechos y obligaciones que los hijos por naturaleza y determina que en tanto las Cortes de Aragón no aprueben una legislación propia sobre adopción, en la Comunidad de Autónoma será de aplicación la normativa del Código Civil y demás leyes generales del Estado en la materia.

El Tribunal Constitucional resuelve en contra de la inconstitucionalidad de la ley mediante la denominada “teoría de la conexión”, tal cual lo explica PÉREZ VILLALOBOS ${ }^{82}$, debido a que no se está ante un supuesto de conservación del Derecho civil foral. El supuesto constitucional de conservación del Derecho foral o especial permite la asunción o integración en el ordenamiento autonómico de las Compilaciones u otras normas derivadas de las fuentes propias de su ordenamiento y puede hacer también viable, la formalización legislativa de costumbres vigentes en el propio ámbito territorial, pero ninguna de estas dos operaciones ocurren en el supuesto en cuestión, afirma el Tribunal Constitucional. Así como la norma impugnada no puede considerarse como si modificase el Derecho foral aragonés, debido a que este no contenía norma alguna sobre la adopción y sus efectos.

Sin embargo el concepto constitucional de "desarrollo" del Derecho civil, especial o foral, debe ser identificado a partir de la ratio de la garantía autonómica de la foralidad civil que establece aquel precepto de la norma fundamental. La Constitución permite que los derechos civiles forales preexistentes puedan ser objeto no ya de “conservación” y “modificación”, sino también una acción

161.2 CE, al momento de la formulación del recurso, siempre que éste sea admitido a trámite y la práctica del Tribunal corrobora esta interpretación, es lo cierto que no debe desconocerse la posible inseguridad jurídica que para los terceros puede suponer dicha práctica. Además, como acertadamente ponen de manifiesto los representantes del Gobierno y Parlamento de Baleares en el presente caso, la publicación de las Leyes es un requisito de eficacia frente a terceros, reconocido con carácter general en los arts. 91 de la Constitución y 2 del Código Civil. Asimismo, el art. 38 LOTC, consecuente con el carácter constitutivo de las sentencias recaídas en los procedimientos de inconstitucionalidad y, por tanto, con la extensión de sus efectos erga omnes y ex nunc, establece que producirán efectos generales desde la fecha de su publicación en el «Boletín Oficial del Estado.(...) Sin perjuicio, por lo tanto, de que, en cumplimiento de la normativa indicada, los efectos suspensivos derivados de la interposición de una impugnación por el Gobierno deben retrotraerse, una vez admitida a trámite la demanda, a dicho momento de interposición, resulta necesario modular esta aplicación, si no se quiere desconocer el principio de publicidad de las normas respecto de terceros. En este sentido, hay que entender que el momento de la interposición de la demanda al que se retrotraen los efectos suspensivos afecta únicamente a las partes del recurso, mientras que para los terceros dicho momento ha de ser a partir de la publicación del acuerdo suspensivo en el Boletín Oficial del Estado; todo ello en virtud de la litispendencia de estas pretensiones constitutivas.- Por lo expuesto, el Pleno acuerda rectificar el punto tercero de la Providencia de 29 de octubre de 1990 de la Sección Segunda, en el sentido de que la suspensión de la vigencia de los preceptos impugnados se produce para las partes del recurso desde la fecha de interposición y para los terceros desde que el acuerdo aparece publicado en el «Boletín Oficial del Estado». Dicha eficacia suspensiva ha de entenderse referida conforme se dispone en la providencia de 5 de diciembre de 1990 a los arts. 2 y 52 de la Compilación del Derecho Civil de las Islas Baleares, aprobada por Decreto Legislativo 79/1990, de 6 de septiembre, del Gobierno balear."

82 PÉREZ VILLALOBOS, M. C. “Las leyes autonómicas reguladoras de las parejas de hecho”, ...op. cit., página 164. 
legislativa que haga posible su crecimiento orgánico y reconoce, de este modo, no sólo la historicidad y la actual vigencia, sino también la vitalidad hacia el futuro de tales ordenamientos preconstitucionales. El término "allá donde existan" a que se refiere el artículo 149. 1.8 CE, al delimitar la competencia autonómica en la materia, ha de entenderse más por referencia al Derecho foral en su conjunto que a instituciones forales concretas.

La noción constitucional de “desarrollo" permite una ordenación legislativa de ámbitos hasta entonces no normados por aquel Derecho, pues lo contrario llevaría a la inadmisible identificación de tal concepto con el más restringido de "modificación". El "desarrollo" de los Derechos civiles forales o especiales enuncia, pues, una competencia autonómica en la materia que no debe vincularse rígidamente al contenido actual de la Compilación u otras normas de su ordenamiento. Cabe, pues que las Comunidades Autónomas dotadas de Derecho civil foral o especial regulen instituciones conexas con las ya reguladas en la Compilación dentro de una actualización o innovación de los contenidos de ésta según los principios informadores peculiares del Derecho civil foral.

Para aplicar la doctrina del Tribunal Constitucional de la conexión es necesario determinados requisitos. En primer lugar debe existir previamente una institución regulada aunque esta institución sea incompleta y que, con posterioridad se proceda a una ampliación de esta regulación. En segundo lugar, puede pensarse que es base normativa previa que sirve de punto de conexión, tiene que encontrarse en la propia Compilación. Sin embargo, por ejemplo, la Comunidad Valenciana, ha asumido competencia exclusiva para desarrollar su propio Derecho civil, y no tiene ni ha tenido compilación foral.

Son las materias o instituciones reguladas en cada uno de los Derechos civiles autonómicos lo que proporciona la base con la que establecer la relación de conexión con las materias o instituciones nuevamente reguladas al desarrollar el propio Derecho civil.

Las comunidades que hayan asumido competencias para desarrollar, conservar y modificar su propio Derecho civil, pueden gradualmente, mediante sucesivos desarrollos que van creando sucesivas conexiones, generar un sistema completo de Derecho civil, respetando las materias que en todo caso son de competencia exclusiva del Estado a tenor del art. 149.1.8 CE.

Esto queda claro en relación a las Comunidades que tienen Derecho civil propio, otra cuestión distinta es si cualquier Comunidad Autónoma tiene competencia para legislar en materia de Derecho civil, si esto es necesario para ejercitar una competencia diferente claramente asumida. En este caso estamos en presencia de las competencias implícitas a las que también el Tribunal Constitucio- 
nal ha acudido en la sentencia núm. 37/1987 de 26 marzo. RTC 1987/37³. En esta sentencia el Tribunal establece que cualquier Comunidad puede legislar en materia de Derecho civil, si ello es instrumento necesario para el ejercicio efectivo de otra competencia asumida. En el caso de la Ley andaluza que da origen al proceso, de la función social del Derecho se puede extraer la habilitación a cualquier Comunidad Autónoma para no detenerse ante la propiedad privada al ejercitar competencias asumidas como la de desarrollo y reforma agraria, por tanto no se excluirían la regulación de relaciones tanto de Derecho Público como de Derecho Privado en materia de propiedad privada ya

83 STC, Pleno, núm. 37/1987 de 26 marzo. RTC 1987/37. "Esta pretendida inconstitucionalidad se imputa genéricamente a toda la Ley de Reforma Agraria, en la medida en que regula la función social de la propiedad y, en consecuencia, el derecho mismo de propiedad que, según creen los demandantes, es el núcleo de la legislación civil. Pero este argumento no es convincente. En el fondo del mismo subyace una vez más una concepción de la propiedad privada como institución unitaria, regulada en el Código Civil, que sólo admite limitaciones externas a su libre ejercicio en virtud de Leyes especiales. Por el contrario, como se ha expuesto, el derecho a la propiedad privada que la Constitución reconoce y protege tiene una vertiente institucional, precisamente derivada de la función social que cada categoría o tipo de bienes sobre los que se ejerce el señorío dominical está llamado a cumplir, lo que supone, como ya sabemos, la definitiva incorporación del interés general o colectivo junto al puro interés individual del titular en la propia definición de cada derecho de propiedad o, si se prefiere, en la delimitación concreta de su contenido. Como es lógico, esta delimitación no se opera ya sólo en la legislación civil, sino también en aquellas otras Leyes que cuidan principalmente de los intereses públicos a los que se vincula la propiedad privada. Así ocurre en el caso de la propiedad urbana, cuyas Leyes de ordenación están muy lejos de establecer sólo, como los recurrentes pretenden, «medidas de policía concretas», respetando, como regulación ajena, "la imposición de obligaciones y limitaciones al ejercicio de los derechos dominicales», sino que, muy al contrario, establecen por sí mismas, o por remisión a los instrumentos normativos del planeamiento, los deberes y límites intrínsecos que configuran la función social de la propiedad del suelo, desde el punto de vista de la ordenación del territorio. Y asi ha sucedido y sucede también en el caso de la legislación agraria, cuyos objetivos conducen a una regulación de la propiedad de la tierra destinada a usos agrícolas, que se superpone a la legislación civil propiamente dicha. Así las cosas, resulta también evidente que si la Comunidad Autónoma andaluza es titular de una competencia especifica para legislar en materia de reforma y desarrollo del sector agrario, como efectivamente así es según dispone el art. 18.1.4. ${ }^{a}$ de su Estatuto de Autonomía, dicha competencia incluye la posibilidad de legislar asimismo sobre la propiedad de la tierra y su función social, dentro del territorio de Andalucía. De todo lo cual se desprende que la Ley de Reforma Agraria impugnada no ha invadido las competencias exclusivas que al Estado reserva el artículo 149.1.8. ${ }^{a}$ de la Constitución.- Más en concreto los recurrentes dirigen su queja, por la misma razón, contra el art. 58 de dicha Ley, que se remite a la legislación general del Estado en lo relativo a las cesiones por arrendamiento y subarriendo de tierras y derechos de titularidad del Instituto Andaluz de Reforma Agraria sin perjuicio del desarrollo legislativo que corresponda a la Comunidad Autónoma. Pero, lo cierto es que este precepto no establece regulación material alguna ni afirma siquiera la competencia autonómica sobre la regulación sustantiva de tales cesiones, sino que simplemente salva la posibilidad de una legislación autonómica de desarrollo sobre aspectos indeterminados relacionados con las mismas, que podrían ser de tipo organizativo, procedimental u otros, salvedad que en si misma no puede reputarse inconstitucional.- También se impugna el art. 61, por entender los recurrentes que contiene un régimen sucesorio distinto del establecido en determinados preceptos de la Ley de Reforma y Desarrollo Agrario. Pero, con independencia de que, como destaca la representación del Parlamento de Andalucía, los preceptos estatales aludidos (arts. 32, 35 y 41) han sido en su mayor parte derogados por la Ley 49/1981, de 24 de diciembre, de Explotaciones Familiares Agrarias, a la que se remite el párrafo $2 .^{\circ}$ del art. 61 recurrido en lo referente al régimen sucesorio de las adjudicaciones de tierras públicas en propiedad, la posibilidad que en el párrafo $3 .^{\circ}$ se contempla de someter a autorización administrativa la subrogación en favor del causahabiente de las adjudicaciones a título de concesión, arrendamiento o subarriendo afecta especificamente a la transmisión mortis causa de un derecho de aprovechamiento sobre bienes o derechos públicos, y tiene por finalidad asegurar la permanencia de la causa de interés público que legitima la adjudicación. Por tanto, tampoco es posible hallar aquí una invasión de las competencias estatales en materia de legislación civil, porque el precepto autonómico impugnado se sitúa fuera de aquel ámbito material de atribuciones.- Finalmente se impugna por idéntico motivo la disposición adi- 
que de la función social de ese derecho pueden extraerse reglas aplicables a uno y otro ámbito de relaciones.

Sin embargo esta es una posición que no comparte un importante sector doctrinal por cuanto la competencia habría que entenderla en relación a instituciones de Derecho civil, y no con referencia a Comunidades Autónomas que no tengan Derecho civil propio, tal como se manifiesta en la sentencia recién citada y en la STC, Pleno, núm. 61/1997 de 20 marzo. RTC 1997/611 esta última deja claro que al Estado le corresponde como legislación civil la dimensión jurídico privada del do-

cional de la Ley de Reforma Agraria, que introduce un supuesto de fraude de Ley, lo que, en opinión de los recurrentes, es también materia que está reservada al Estado por el art. 149.1.8 de la Constitución, porque el concepto de fraude de Ley es un concepto que se contempla en el título preliminar del Código Civil. La objeción carece de sentido por varios motivos. Ante todo, es preciso dejar constancia, como primera observación, que el fraude de Ley, en cuanto institución jurídica que asegura la eficacia de las normas frente a los actos que persiguen fines prohibidos por el ordenamiento o contrarios al mismo, es una categoría jurídica que despliega idénticos efectos invalidantes en todos los sectores del ordenamiento jurídico. En rigor ni siquiera podría sostenerse hoy que el art. 6.4 del Código Civil, que contempla con carácter general el fraude de Ley, es una norma exclusiva de la legislación civil. El citado precepto, como la mayor parte de los que integran el título preliminar, es aplicable a todo el ordenamiento, y sólo por tradición histórica, sin duda respetable, conserva en el Código Civil su encaje normativo." 
minio $^{84}$. Sin embargo la STC, Pleno, núm. 14/1998 de 22 enero. RTC 1998/14, relativa a la Ley Extremeña de Caza vuelve en favor de cualquier Comunidad Autónoma ${ }^{85}$.

Como conclusión puede expresarse que de lo expuesto en el art. 149.1. ${ }^{\mathrm{a}}$, puede concluirse que no se puede afirmar que al Estado corresponda una competencia exclusiva para regular el matrimonio en cualquiera de las ramas de Derecho y no solo en la civil. En el art. 149.1.8 sólo contempla la legislación civil y no otras ramas del ordenamiento. Si se hubiese querido reservar al Estado todo lo relativo al matrimonio, no sólo la legislación civil sino también la mercantil, laboral, etc., lo lógi-

84 STC, Pleno, núm. 61/1997 de 20 marzo. RTC 1997/61. Esta sentencia destaca las facultadas conferidas a la Co munidades en determinadas materias y su no invasión por parte del Estado incluso con leyes de bases. "Que el legislador estatal pueda regular sobre las condiciones básicas que garanticen la igualdad en el ejercicio de los derechos y deberes constitucionales no implica que pueda incidir en todas las materias de competencia autonómica en conexión con esos derechos. No es la materia la que exige la igualdad de regulación, sino tan sólo los derechos y deberes constitucionales en sus aspectos básicos o esenciales. Ciertamente, el art. 149.1.1 es una regla competencial a favor del Estado, y por lo mismo un límite competencial para las Comunidades Autónomas. Esta cláusula permite, en efecto, que las instituciones estatales incidan normativamente en la esfera de actuación autonómica, si bien su carácter claramente finalista no habilita al Estado para ir más allá de la fijación de aquellos principios o criterios esenciales del ejercicio de los derechos, o del cumplimiento de los deberes constitucionales que resulten indispensables para garantizar la igualdad sustancial de todos los españoles. En el presente caso, existe una competencia exclusiva de las Comunidades Autónomas sobre el urbanismo que guarda, evidentemente, relación con el derecho constitucionalmente garantizado -art. 33- a la propiedad en su vertiente urbanística. Pero el binomio urbanismo-propiedad no siempre ha de reconducirse a las condiciones básicas del ejercicio de un derecho. El Tribunal Constitucional, en la Sentencia 37/1987, ha optado por reconocer una mayor libertad decisoria a las Comunidades Autónomas. Por lo tanto, el contenido esencial de la institución de la propiedad privada, que hace que este derecho sea socialmente reconocible como tal, puede quedar reducido al principio de apropiación, disfrute y transmisión por los particulares de unos determinados bienes. Más allá de él, en relación con la propiedad urbanística el Estado sólo sería competente para determinar, en su caso, los principios vertebrales de su ejercicio como derecho y del cumplimiento de los deberes que comporta. Ello es suficiente para garantizar un contenido esencial uniforme, compatible con regulaciones plurales. En conclusión, la regla del art. 149.1.1 CE no justifica en modo alguno una regulación estatal detallada y minuciosa de la propiedad urbanística. El título competencial estatal no puede ser utilizado para ampliar las competencias del Estado en las diversas materias relacionadas en el art. 149.1 CE ni, lógicamente, para atribuir al Estado nuevas facultades de intervención en los ámbitos de competencia autonómica. En consecuencia, el art.149.1.1 no permite el establecimiento de bases, o legislación básica referida a sectores materiales confiados, con carácter exclusivo, a la responsabilidad de las Comunidades Autónomas. La virtualidad del precepto se agota, en definitiva, en la determinación de aquellas condiciones del ejercicio de los derechos o del cumplimiento de los deberes que, por tratarse de condiciones básicas o esenciales y de necesaria vigencia en la totalidad del territorio estatal, no pueden ser establecidas por las instancias autonómicas. Consiguientemente, en el ámbito de la propiedad urbanistica, el que el legislador estatal pueda regular el contenido esencial de un derecho constitucional y las condiciones básicas de su ejercicio no le habilita para regular la materia en su totalidad, ni más allá de dichos elementos."

85 STC, Pleno, núm. 14/1998 de 22 enero. RTC 1998/14. En esta sentencia se alude a la limitación de la competencia en materia civil de las Comunidades Autónoma a favor del Estado: "A juicio de los actores, el precepto transcrito opera una demanialización legislativa por la que se despoja a los propietarios de los terrenos cinegéticos de sus derechos dominicales sobre las piezas de caza sin mediar indemnización compensatoria, lo que se considera contrario al art. 33 de la Constitución y a las garantías en él previstas para la protección de la propiedad privada. Pero, además, al atribuir la titularidad del derecho de caza y de las piezas cazadas a la Administración autonómica extremeña o a quienes obtuvieran la correspondiente concesión administrativa (art. 6), estaría invadiendo la competencia exclusiva del Estado que, en materia de legislación civil, le reconoce el art. 149.1.8. ${ }^{a}$ de la Constitución. Y ello, porque el art. 610 del Código Civil considera que las piezas de caza son res nullius que se adquieren por ocupación y, puesto que la ocupación es uno de los modos originarios de adquirir la propie- 
co habría sido dedicarle una regla específica del art. 149.1 CE exclusivamente referida al matrimonio. De otro lado, no se puede afirmar que todo el Derecho Civil matrimonial le queda reservado al Estado y que sólo el Estado pueda legislar sobre el matrimonio. Esto supondría mutilar la competencia de "conservar", "desarrollar" y "modificar" el propio Derecho que tiene algunas Comunidades Autónomas y que se refieren a las consecuencias económicas del matrimonio o a su extensión (que eran materias reguladas en estos derechos). Por tanto al Estado correspondería la legislación civil del sistema matrimonial (requisitos materiales y formales, causas de extinción), sin incluir la regulación de sus consecuencias económicas ni los demás efectos del matrimonio salvo en lo relativo a derechos y deberes de los cónyuges que coincidiría con el contenido del art. 13.1 del CC.

Pasando a ocuparnos de las Compilaciones vigentes, nos referiremos sucesivamente a las Compilaciones de Aragón, Navarra, País Vasco, Cataluña, Islas Baleares y Galicia.

a.-Aragón. En cuanto a la Compilación de Derecho Civil de Aragón, ésta fue aprobada por Ley de 8 de abril de 1967 y se recogió en primer lugar en una Ley de 21 de mayo de 1985 que consta de un Titulo Preliminar y tres Libros dedicados al Derecho de Familia, el Derecho de Bienes y el Derecho de Obligaciones. Posteriormente el Decreto Legislativo 1/2011 refunde el Código de Derecho Civil aragonés, en relación a las siguientes leyes: a) El Título preliminar de la Compilación del Derecho Civil de Aragón (RCL 1967/704, 756; NDL 1451); b) La Ley 1/1999, de 24 de febrero (LARG 1999/52), de sucesiones por causa de muerte; c) La Ley 6/1999, de 26 de marzo (LARG 1999/79), relativa a parejas estables no casadas.; d) La Ley 2/2003, de 12 de febrero (LARG 2003/62), de régimen económico matrimonial y viudedad; e) La Ley 13/2006, de 27 de diciembre (LARG 2006/404), de Derecho de la persona; f) La Ley 2/2010, de 26 de mayo (LARG 2010/253), de igualdad en las relaciones familiares ante la ruptura de convivencia de los padres; g) La propia Ley de Derecho civil patrimonial. En lo que respecta al Derecho de Familia, hay que destacar instituciones como la Junta de Parientes o las especialidades en materia de capacidad de los menores. Por otro lado, la Ley sobre Régimen Económico Matrimonial y Viudedad de 2003 dispuso que el régimen económico del matrimonio será el pactado en capitulaciones y, en su defecto, el llamado régimen de consorcio conyugal. Finalmente, hay que destacar una institución propia del Derecho aragonés como es la comunidad conyugal continuada en virtud de la cual el consorcio conyugal no

dad, la demanialización efectuada por el art. 6 de la Ley de Caza de Extremadura, reservando su exclusiva propiedad a la Administración de aquella Comunidad Autónoma, habría alterado radicalmente el régimen de adquisición de la propiedad de las piezas cazadas y, por tanto, la previsión general contenida en la legislación civil, invadiendo una competencia constitucionalmente reservada al Estado." 
se extingue a la muerte de uno de los cónyuges sino que continúa entre el supérstite y los herederos del difunto.

b.- Navarra. La Compilación de Derecho Civil de Navarra, fue aprobada por Ley de 1 de marzo de 1973. En relación con ella, hay que señalar que la misma atribuye a la costumbre un orden de prelación superior a la ley. No obstante, la doctrina ha puesto de manifiesto que esta previsión sólo resulta aplicable a la costumbre contraria a la ley foral pero no a las leyes de aplicación general. Por otra parte, la Compilación consta de un Libro Preliminar y tres Libros dedicados al Derecho de Familia, Derecho de Sucesiones y Donaciones y Derecho de Bienes. Respecto al Derecho de Personas y Familia, cabe destacar la figura de los Parientes Mayores, el régimen económico matrimonial de sociedad conyugal de conquistas y la institución de la casa que carece de personalidad jurídica pero puede ser titular de derechos y obligaciones.

c.- Cataluña. En cuanto a la Compilación de Derecho Civil Especial de Cataluña, ésta fue aprobada por Ley de 21 de julio de 1960. No obstante, la misma ha sido objeto de múltiples modificaciones entre las cuales hay que destacar la Ley del Código Civil de Cataluña de 30 de diciembre de 2002 que viene a configurar la estructura de un futuro Código Civil catalán. En relación al Derecho de Familia, el Código de Familia de 1998 contempla la primacía del régimen de separación de bienes en defecto de capitulaciones. Asimismo se destaca la Ley de 15 de julio de 1998 sobre Uniones Estables de Pareja que se ocupa tanto de las uniones heterosexuales como homosexuales así como la reforma introducida por la Ley del Parlamento Catalán de 8 de abril de 2005, que reconoce capacidad de adoptar a las parejas del mismo sexo. Actualmente estas materias del Derecho de Familia están reunidas en la Ley 25/2010, Persona y Familia, Libro segundo del Código Civil de Cataluña, relativo a la persona y la familia.

d.- Baleares. La Compilación de Derecho Civil de Baleares fue aprobada por Ley de 19 de abril de 1961 y se encuentra actualmente recogida en un Real Decreto Legislativo de 6 de septiembre de 1990, que consta de en un Titulo Preliminar y tres Libros dedicados a la Isla de Mallorca, la Isla de Menorca y las Islas de Ibiza y Formentera. La Compilación de Baleares contempla especialidades en materia familiar como la primacía del régimen de separación de bienes a falta de capitulaciones matrimoniales.

e.- País Vasco. En cuanto al Derecho Foral de los Territorios Históricos Vascos, éste aparece regulado por la Ley de Derecho Civil Foral del País Vasco de 1 de julio de 1992 que consta de un Título Preliminar y tres Libros sucesivamente dedicados al Derecho de Vizcaya, Álava y Guipúzcoa En cuanto al Territorio Histórico de Vizcaya, dentro del mismo distinguimos entre el Infanzonado o 
Tierra Llana que se rige por su Fuero propio y las ciudades de Orduña y Bilbao así como las denominadas Villas que se rigen por el Derecho Civil del Estado. Por otro lado, cabe señalar instituciones como el principio de concentración patrimonial de cada caserío, el régimen económico de comunidad foral de bienes y el principio de troncalidad en la sucesión. En cuanto al Territorio Histórico de Álava, cabe distinguir los municipios de Llodio y Aramayona que se rigen por el Fuero de Vizcaya y la Tierra de Ayala que se rige por el Fuero de Ayala. En particular, este último regu la dos instituciones fundamentales como el usufructo poderoso y el principio de libertad de testar. Finalmente el Territorio Histórico de Guipúzcoa, éste aparece regulado en Ley del Parlamento Vasco de 1999 que regula instituciones como el testamento mancomunado y la transmisión del caserío por testamento y por contrato sucesorio.

f.- Galicia. Pasando a ocuparnos del Derecho Foral de Galicia, éste aparece regulado por la Ley de Derecho Civil de Galicia de 14 de junio de 2006 que consta de Título Preliminar y diez títu los. En relación al Derecho de Familia, cabe destacar la regulación de instituciones como la protección de los menores, la autotutela y la situación de ausencia no declarada, así como su protección transversal en la Ley 3/2011 de apoyo a la familia y a la convivencia en Galicia.

En muchas ocasiones, sin duda se ha podido constatar la vitalidad del Derecho autonómico en comparación al Derecho civil estatal, el que lamentablemente a veces ha sido un mero espectador de los cambios y reformas propiciados desde los parlamentos autonómicos, cabe aun discernir si a futuro logran conciliarse diversas políticas concernientes a los dos ámbitos en cuestión, políticas que contribuyan a esclarecer el caótico escenario en que se ha convertido el ordenamiento jurídico español. La pregunta que se debe contestar es si los diversos grupos políticos están dispuestos a pagar el precio de menor soberanía a cambio de mayor unicidad. No me parece que ese sea el sentimiento que embarga a las autoridades de todas las comunidades autonómicas. 
Capítulo II

El Principio de igualdad y el Derecho de Familia 


\section{Consideraciones previas para este capítulo}

La Constitución española recoge la igualdad en numerosos preceptos, y cada uno de ellos presenta un diverso alcance. A la igualdad como valor reconocido en el artículo 1.1. de la Constitución, sigue en el texto constitucional, la igualdad como principio que se distingue del valor, tanto por su diferente intensidad normativa, como por su diferente grado de determinación. En este sentido el valor de la igualdad, que junto con la justicia, la libertad y el pluralismo político, constituyen los valores superiores del ordenamiento constitucional, es una aspiración social que la Constitución proyecta como meta a conseguir por una comunidad, sin duda puede señalarse como una aspiración que guía todo el ordenamiento ${ }^{86}$. El artículo 9.2 CE contiene un mandato a los poderes públicos, como medio de conseguir la realización práctica de la libertad y de la igualdad, obliga a los poderes públicos a la remoción de los obstáculos para el cumplimiento de la igualdad real y efectiva. Puede decirse que de las normas constitucionales que califican al Estado el nivel de exigencia a los poderes públicos, en relación con las demandas de la ciudadanía, define muy bien el modelo de Estado ${ }^{87}$.

En términos generales y en relación con lo anterior se afirma que la cláusula general de igualdad, en su doble vertiente de igualdad ante la ley y de proscripción de toda discriminación, se encuentra recogida en el artículo 14 de la Constitución, que actúa como pórtico del Capítulo II del Título I, que es la parte de la Constitución consagrada a la declaración de los derechos y libertades más relevantes, aquellos que merecen, en sentido amplio, el nombre de "fundamentales" ye, a juicio de GÁLVEZ MUÑOZ, la antesala tanto de la sección primera de este Capítulo (artículos 15 a 29; que son los que cuentan con un grado de protección jurisdiccional reforzada), como de la sección segunda (artículos 30 a 38, que tienen un nivel de protección jurisdiccional que se podría denominar ordinario). Con ello se ha querido poner de relieve su compleja naturaleza de derecho genérico y, por tanto, prototípica o esencialmente relacional, lo cual sin duda está directamente implicado con las denominadas relaciones familiares. Es un derecho que, aunque tiene entidad propia,

86 BALAGUER CALLEJÓN, Ma . L. "Igualdad y Constitución española”, Ed. Tecnos, Madrid, año 2010, página 23 y siguientes.

87 STC núm. 188/2001 de 20 septiembre. RTC 2001/188, manifiesta bastante bien la necesidad de una igualdad material en el Estado de las Autonomías, sin perjuicio de las diferencias entre ellas: " En definitiva, la gestión unitaria del sistema de becas es una condición básica para la igualdad en el ejercicio del derecho a la educación, pues remueve el principal obstáculo para su efectividad, que no es otro que la insuficiencia de recursos. Por tanto, no sólo la normación básica, sino también la de desarrollo y su ejecución han de ser realizadas con absoluta igualdad. El Abogado del Estado rechaza, en consecuencia, los criterios estadísticos que invoca la demanda, pues se refieren a condiciones académicas que, ciertamente, difieren de unas Comunidades Autónomas a otras, pero no a las condiciones económicas personales o familiares del titular del derecho a la educación, que es el aspecto decisivo para el respeto de la igualdad."

88 BAÑO LEÓN, J. M. "La igualdad como derecho subjetivo”, Revista de Administración Pública, núm. 114, Madrid, año 1987. 
siempre se presenta acompañado de otro ${ }^{89}$; es un derecho general que se proyecta necesariamente en los distintos tipos de relaciones jurídicas y; es, en suma, un derecho y un principio general a la vez ${ }^{90}$.

En primer lugar debe saberse que no es fácil definir a la igualdad, conforme a esto debemos reflexionar hasta dónde puede llegar la exigencia del art. 9.2. CE, y desde este punto de vista, la doctrina ha venido considerando que no estamos ante una norma atributiva de competencias, sino que esta norma solamente asigna a los poderes públicos una función promocional. El art. 9.2 tiene una función en la Constitución claramente vinculada al desarrollo del Estado social, y por consiguiente dentro de este marco en el ordenamiento jurídico-familiar ${ }^{91}$. Su contenido finalista permite una importante graduación en la concepción de la igualdad desde el punto de vista material. Así ha sido considerada por el Tribunal Constitucional, hasta el punto de justificar la desigualdad material para llegar a la igualdad real, si bien esa desigualdad compensatoria debe tener limitaciones tempo-

89 CABAÑAS GARCÍA, J. C. “El Derecho a la Igualdad en la Aplicación Judicial de la Ley”, Ed. Thomson Reuters, Cizur Menor, año 2009, páginas 32 a 42. Este autor lo relaciona con el Principio de Seguridad Jurídica, el principio de Interdicción de la arbitrariedad judicial, el principio de Independencia judicial y sujeción del juez a la legalidad.

90 GÁlVEZ MUÑOZ, L. "La cláusula general de igualdad”, Revista de la Universidad de Murcia, núm. 21, año 2003, páginas 195 a 206.

91 Las mujeres han sido tradicionalmente uno de los grupos de población que ha sufrido mayores discriminaciones a lo largo de la historia en diferentes ámbitos de su realidad vital. Y si ciertamente, la población femenina ha sido objeto de tratamientos diferenciales en la norma por constatarse diferencias de facto, que era necesario restablecer (empleo, violencia de género, participación política), la exigencia de generalidad de la ley, o la necesidad de que las normas se apliquen al máximo número de destinatarios posible (igualdad formal), obliga al legislador a analizar, de modo constante, la evolución del objetivo de igualdad perseguido por la norma, para adaptarla en la medida de lo posible a la evolución de la realidad presente. En puridad, la creación de diferencias entre grupos de personas que se encuentran en una situación concreta de desigualdad, fundamento de la exigencia material de igualdad (artículo 9.2) no puede debilitar, e incluso olvidar el significado formal del mandato de igualdad, cual es la creación de diferencias normativas que tengan en cuenta el máximo número de destinatarios posible. Es decir, la creación de diferencias objetivas y razonables y, en consecuencia, la proscripción de diferencias por razones personales. Cfr. ZOCO ZABALA, C. "Violencia de género ocasional desde la perspectiva de la igualdad material y formal: Sentencias del Tribunal Constitucional, 100/2008, de 24 de julio, 82/2008, de 17 de julio, y 59/2008, de 14 de mayo", Repertorio Aranzadi del Tribunal Constitucional, núm. 20/2008, parte Estudio. Ed. Aranzadi S.A., Pamplona, año 2008. Sostiene que: "En la actualidad, la proliferación normativa y la práctica de la jurisprudencia, a nivel comunitario o nacional, sensibilizada con las diferencias reales y efectivas entre hombres y mujeres que todavía existen en ámbitos concretos de la realidad social, produce, en algunos casos, el efecto contrario al objetivo de igualdad de oportunidades que persigue la exigencia de igualdad en el contenido de la ley. Así pues, no sólo resulta discriminatoria por razón de sexo aquélla normativa que ignora a los hombres y sobre todo a las mujeres en la consecución de derechos y deberes (discriminación directa); o que siendo neutra produce consecuencias desfavorables para uno de los dos sexos, por cuanto la lógica de la ley no ha previsto a todos sus destinatarios (discriminación indirecta); también se vulnera la prohibición de discriminación por razón de sexo cuando la regulación normativa otorga derechos a las mujeres porque en el pasado estuvieron discriminadas, pues sitúa a las mujeres en una posición privilegiada respecto de los hombres, no justificada en una concreta diferencia factual; dicha regulación produce, pro futuro, la perpetuación de la desigualdad de oportunidades entre mujeres y hombres no sólo en el momento en el que se aprueba la norma, sino también cuando la evolución de la realidad social regulada determina que la diferencia entre hombres y mujeres por razones objetivas, se restablece de modo progresivo de tal manera que la norma siendo todavía razonable, ya no prevea el máximo número de destinatarios posible, o a mayor abundamiento, no esté basada en razones objetivas." 
rales, y nunca puede llegar a imponer una total igualdad. Sin embargo el Tribunal Constitucional ha estimado recursos de amparo en base al art. 9.2 y el cumplimiento en un plazo razonable de tiempo de una previsión legislativa ${ }^{92}$.

En cuanto al desarrollo legislativo del artículo 14 de la Constitución hay que apuntar que el mismo es enteramente singular. El carácter relacional y no autónomo del principio de igualdad, es decir, el que la igualdad no pueda predicarse en abstracto, sino únicamente respecto de relaciones jurídicas concretas, impide que este principio pueda ser objeto de una regulación o desarrollo normativo con carácter general, aunque posiblemente su tratamiento global, tranversal es posiblemente en la actualidad la manera de provocar su imperio en diversas materias, no siempre muy afines.

El contenido del artículo 9 no llega a una interpretación del artículo 14 que exija la desigualdad compensatoria, aunque la permita. A mi juicio, en el mismo, se indica un criterio de interpretación para que el Legislador y los Poderes Públicos, en general, interpreten el derecho fundamental a la igualdad en un sentido favorable a la igualdad material, pero sin llegar a constituir una exigencia de desigualdad por las diversas circunstancias que implica cualquier situación concreta que amerita distinciones.

La exigencia de la igualdad es de naturaleza condicional, lo que implica la necesidad de una promoción, es una concepción de los derechos fundamentales no como límites a los poderes públicos, sino como políticas activas orientadas al cumplimiento de fines específicos de justicia e igual$\operatorname{dad}^{93}$. Y esto conlleva una obligación de promover actuaciones concretas de desarrollo de la igual-

92 JIMÉNEZ CAMPO, J. “La igualdad jurídica como límite al legislador”. Revista Española de Derecho Constitucional, núm. 9, Madrid, año 1983, páginas 73 a 75.

93 ZOCO ZABALA, C. , loc. cit. "Cuando la realidad vital, en ocasiones impredecible, determina que la finalidad de la norma ya no es razonable, o que siendo razonable ya no prevé el máximo número de destinatarios a los que debe ser aplicable, la creación de diferencias objetivas y razonables en que la igualdad consiste, ya no puede menoscabar su significado formal cual es la prohibición de discriminaciones por criterios personales y a mayor abundamiento, por razones de sexo, uno de los criterios subjetivos indeclinables que tradicionalmente han sido más conculcados. En realidad, la confusión se origina por entender que la evolución material del mandato de igualdad ante la ley, trae como consecuencia la anulación del significado formal de la exigencia de igualdad como proscripción de diferencias por los criterios subjetivos indeclinables, de tal manera que, a partir de ahora, sea posible que la norma establezca diferencias objetivas y razonables en el contenido de las normas, incluso por estos motivos tasados cuyo tratamiento legal era antes prohibido. Y es que el sexo, la raza, o la ideología, antes y ahora, no son susceptibles de diferencias en el contenido de la norma, dado que la raza o el sexo, en sí mismos, no constituyen per se criterios objetivos ni razonables. La exigencia de generalidad de la ley, por tanto, significa que finalidad de la norma debe ser neutra por lo que no puede estar basada en ser hombre o mujer. Es la diferencia factual entre los hombres y las mujeres, y no el sexo per se, el criterio que debe ser tenido en cuenta por la norma. Sin embargo, ello no quiere decir que el significado material y formal del mandato de igualdad material en la ley constituyan compartimentos estancos. A contrario sensu, la evolución material del mandato de igualdad añade a su significado formal, la posibilidad de que el legislador pueda observar las diferencias reales y efectivas que existen entre mujeres y hombres en ámbitos concretos de la realidad social para restablecer dichas diferencias factuales a través de las normas. En definitiva, es expresión de la posibilidad de verificar en qué ámbitos de la realidad vital las mujeres se encuentran en una situación de desigualdad real y efectiva, mas no ampara distinciones en la ley por razón de sexo que no traigan justificación en desigualdades reales y efectivas que puedan existir al día de hoy, pues ésta sigue siendo la exigencia de la igualdad formal. Será la di- 
dad, lo que sin duda abarca todos los ápices del comportamiento humano, incluso los más importantes como puede ser el ámbito familiar ${ }^{94}$.

La exigencia de que ese desarrollo de la igualdad no se reduzca al aspecto individual, sino que opere como un mandato a los poderes públicos para la remoción de obstáculos al cumplimiento de la igualdad en esos grupos puede conducir a que en el caso del Derecho de familia, la implantación de estas políticas deba ser llevadas en la generalidad del mismo, lo que legítimamente llevaría a plantear la hipótesis de que nos encontramos frente a un Derecho de familia "social", como consecuencia de la lectura del art. 9.2 $2^{95}$.

Finalmente del artículo 9.2 se deriva un sentido poco discutible y que se ha puesto de manifiesto reiteradamente por la doctrina. Atiende a su finalidad compensatoria de situaciones fácticas desigualitarias. De ahí que haya servido a políticas públicas de género (cuotas, planes de igualdad). Y que haya podido cobijar cualquier actividad pública prestacional ${ }^{96}$.

El estado social impone una nueva concepción de la igualdad ${ }^{97}$ para el cumplimiento de los fines del artículo 9.2 es necesario superar el concepto de igualdad formal. En tal sentido es muy im-

ferencia ad casum en relación con el sexo, mas no el sexo en sí mismo, el criterio objetivo y razonable que permita establecer diferencias. Desde una perspectiva material, el mandato de igualdad en la ley se traduce en la equiparación de las desigualdades factuales existentes por razón de sexo, mas no la en sobreprotección de la mujer porque en el pasado estuvo discriminada, o la omisión del colectivo femenino cuando de la posibilidad de alcanzar una igualdad de oportunidades se trata."

94 ZOCO ZABALA, C. loc. cit. En dicho artículo la autora expone que : "Verdaderamente, el ser hombre o mujer, o las diferencias históricas de roles habidas entre ambos sexos, no pueden constituir un criterio razonable que permita el establecimiento de diferencias normativas entre hombres y mujeres; la creación de diferencias objetivas y razonables, en que la igualdad material consiste, determina que no es el sexo, sino las diferencias ad casum en relación con el sexo las que legitiman el establecimiento de acciones positivas razonables en defensa del grupo de población femenino. Debe tratarse, por tanto, de diferencias presentes que se producen entre los sexos en un ámbito concreto de la realidad social (la violencia intrafamiliar, en este caso), mas no de un mero recordatorio de las diferencias históricas entre sexos que han empañado el pasado, por discriminatorias que éstas hayan sido."

95 C. DE CABO, C. "Teoría constitucional de la solidaridad”. Ed. Marcial Pons, Madrid, año 2006, página 64. En esta obra el autor sostiene la denominada constitución de los débiles y que exigiría una particular intervención por la vía del art. 9.2, en el denominado constitucionalismo del Estado Social, toda situación de desigualdad que se traduzca en situación de debilidad, debe de tener relevancia constitucional.

96 NAVARRO, V. “La familia en España”, en el País de 19 de enero de 2002, página 14. La tradición presentó a la familia como unidad en la que el hombre, a través de sus ingresos, fue generalmente responsable de la viabilidad de familia y la mujer a su vez fue responsable de la reproducción y cuidado de los niños, jóvenes y ancianos. Un panorama en el que las políticas estatales desempeñan un papel ínfimo. Por esta razón durante siglos el Estado no entró a regular esta institución y, en consecuencia, no la proveyó de servicios y ayudas públicas que facilitaran su desarrollo.

97 ALEXY, R. “Teoría de los derechos fundamentales”. Centro de estudios Políticos y Constitucionales, $2^{\mathrm{a}}$ edición en español, Madrid, año 2008, página 366 a 378. En dicha obra el autor sostiene que durante mucho tiempo la igualdad ha sido un derecho a la igualdad de trato por la ley, es decir en la aplicación de la ley, pero ahora hay que construir otro concepto de igualdad que exige diferenciaciones entre los diferentes estatus jurídicos, para tratar igual lo que es igual y desigual lo que es desigual. Es el evitar la arbitrariedad, lo que exige un proceso de razonabilidad permanente, porque ahora ya $n$ todo tratamiento desigualdad es arbitrario. Lo es el que no encuentra en su justificación argumentos razonables y comprensibles. 
portante analizar como la igualdad opera siendo factor de uniformidad hasta tal punto que muchos derechos sociales han sido considerados como derechos de igualdad, según PRIETO SANCHÍS ${ }^{98}$.

No es fácil abordar la igualdad como principio jurídico, por ello se hace necesario procurar ser ordenado y claro, por ello en el presente capítulo se tratará la igualdad en primer lugar respecto de la familia, en segundo lugar respecto del matrimonio, luego en relación a la igualdad hombre-mujer, la cual es también denominada paridad, para finalmente reflexionar sobre dicho principio en materia de filiación, donde destaca su papel en el denominado Derecho de identidad.

\subsection{Distinción entre el Derecho de Igualdad y otros conceptos afines. Equidad, identidad y omisiones legislativas ${ }^{99}$}

Pese a que la equidad es un término que no aparece recogido en la Constitución, hay una tendencia reciente a considerar este término como sinónimo de la igualdad, incluso en ciertos textos legislativos se ha buscado de sobremanera relacionarlo con la denominada igualdad material ${ }^{100}$.

Sin embargo, la equidad ha tenido una evolución histórica y una relación en el derecho positivo diferente de la igualdad ${ }^{101}$, tanto en el derecho continental como el anglosajón, donde si bien hay una evidente relación de contenido no se pueden confundir ambos conceptos.

El concepto de equidad se encuentra recogido en nuestro ordenamiento en el art. 3.2 de Código Civil que regula las fuentes del derecho y establece taxativamente que "la equidad habrá de

98 PIETRO SANCHÍS, L. “Los derechos sociales y el principio de igualdad sustancial”. Revista del Centro de Estudios Constitucionales, núm. 22, septiembre-diciembre, año 1995, página 17. Según el articulista esta relación vendría determinada por el artículo 9.2.

99 Vid. BALAGUER CALLEJON, Ma . L. “Igualdad y constitución española”, ...,op. cit., páginas 35 a 54.

100 En la actualidad en casi todos los ordenamientos jurídicos existe un retorno a la equidad, un siglo de legalismo y de justicia positivista y legalista ha mostrado los serios inconvenientes que le son consustanciales, por ello en el presente han surgido diversos movimientos enderezados contra la rigidez del imperio de la norma genérica y abs tracta y en la consideración de los elementos individualísimos que definen cada caso como una realidad diversa y única frente a las demás. Todo el movimiento de ideas que se agrupa hoy bajo las banderas de la Escuela del Derecho libre, de la teoría sociológica del Derecho y de la jurisprudencia de intereses, ha logrado abrir a la equidad los ventanales de la interpretación y la aplicación del Derecho al proclamar, como canon fundamental, que el juez debe investigar minuciosamente las circunstancias y situaciones sociales, que son como el subsuelo del caso jurídico sometido a su consideración, y para poder juzgar adecuadamente todas estas particularidades debe gozar, frente a las reglas del Derecho, de la mayor libertad posible.

101 FALCÓN Y TELLA, Mª J. “Equidad, Derecho y Justicia”. Ed. Universitaria Ramón Areces, Madrid, año 2005, página 51 y siguiente. La equidad, por ejemplo en Roma, se concibe principalmente como una excepción al Derecho estricto. Ya CICERON advertía que el Derecho en su aplicación rigurosa es la fuente máxima de injusticias - summun ius, summa iniuria. El contraste entre Derecho estricto y Derecho equitativo se aprecia a lo largo de toda la historia de la Humanidad y en todos los ordenamientos jurídicos. Es la oposición que ya en Grecia se producía entre "nomos" y "epieíkeia", en Inglaterra entre el "common law" y la "equity" o en el mundo germano en tre el "strenges Rechts" y la "Billigkeit". Esta misma oposición se opera, y con gran fuerza, en Roma. En efecto, toda la historia del Derecho Romano se cifra en un constante esfuerzo por superar el ius estrictum con el ius aequum, haciendo triunfar la equidad del ius gentium, frente a las concepciones formalistas del Derecho Civil antiguo. Esto se produce por medio de una doble via. La primera el Edicto del Pretos que dio lugar al ius praetorium o ius honorarium y la segunda, la tarea de los juriconsultos romanos, que asesoraban al pretor creando la iurisprudentia. 
ponderarse en la aplicación de las normas, si bien las resoluciones de los Tribunales sólo podrán descansar de manera exclusiva en ella cuando la ley expresamente lo permita”. Por lo tanto, la equidad se relaciona con la igualdad como un precepto claramente diferenciado de los principios generales del derecho, que surtiría su mayor efecto en la fase de aplicación de las normas. Aunque comparte en buena parte alguno de los aspectos de la igualdad material. Así se puede ver en el reconocimiento de la equidad que se contiene tanto en la Constitución como en las leyes. En la Constitución apenas se recogen referencias a la equidad. Solamente en el artículo 31.2, a exigir la Constitución un reparto equitativo de los recursos públicos ${ }^{102}$.

Igualmente, el Código Civil recoge en varios preceptos referencias concretas a la equidad ${ }^{103}$. Además de la referencia del art. 3.2 que se refiere a la función de ponderación en la aplicación de las normas, sin que pueda basarse en la equidad, la resolución de un tribunal, salvo que la ley expresamente lo permita ${ }^{104}$. De estas posibilidades, algunas se contienen en el mismo Código. Así cuando

102 El art. 31.2 CE dice que "el gasto público realizará una asignación equitativa de los recursos públicos y su programación y ejecución responderán a los criterios de eficiencia y economía".

103 FALCÓN Y TELLA, M ${ }^{\mathrm{a}} \mathrm{J}$, "Equidad, Derecho y Justicia”, ...op. cit., página 289 y 290. La equidad desarrolla su función tanto en el Derecho privado continental, como en el Derecho público continental, especialmente en el Derecho Internacional público. Tomando como ejemplo el Derecho español, en el Derecho privado la equidad era contemplada en el antiguo artículo 6 del Título Preliminar del Código civil, antes de la reforma operada en 1974. El proyecto de Código civil no regulaba con precisión la materia de fuentes del Derecho y se limitaba a establecer en su artículo 12 que "el juez que rehúse fallar a pretexto de silencio, oscuridad o insuficiencia de las leyes incurrirá en responsabilidad", y en el artículo 13 que "se prohibe a los jueces proveer en los negocios de su competencia por vía de disposición general y reglamentaria". El Código civil de 1889 ha mantenido en el artículo 6, párrafo $1^{\circ}$ la disposición del artículo 12 del Proyecto de 1851, sobre la inexcusabilidad del fallo, que tenía largo tracto en el Derecho español. En el Código civil existen otros reflejos en relación a la equidad, asimismo en leyes especiales, por ejemplo, en el Derecho foral se alude claramente a la equidad en las compilaciones forales de Cataluña y Aragón. Por otra parte, la Ley de Bases de 17 de marzo de 1973, dictada para llevar a cabo la modificación del Título Preliminar del Código civil, establecía en su Base II, apartado segundo, que "dentro del obligado respeto para la seguridad jurídica, la equidad presidirá la aplicación de las normas, pero en ellas sólo podrán fundamentar sus resoluciones los tribunales cuando la ley expresamente lo permita". No obstante, al redactarse el art. 3, apartado 2 del Título Preliminar del Código se suprimió la mención hecha al necesario "respeto de la seguridad jurídica". En el Derecho civil español actual, la equidad aparece contemplada en el art. 3.2 del Código Civil, según la redacción que se le dio por Decreto de 31 de mayo de 1974, dentro del capítulo dedicado a la aplicación de las normas jurídicas, inmediatamente después de la regulación de los criterios de interpretación de las mismas. A tenor de dicho precepto "la equidad habrá de ponderarse en la aplicación de las normas, si bien la resoluciones de los tribunales sólo podrán descansar de manera exclusiva en ella cuando la ley expresamente lo permita" Antes de esta reforma no existía en nuestro Código civil una regulación genérica similar a la equidad, lo cual no era obstáculo para su consideración por los textos legales y su aplicación por los Tribunales.

104 Vid. FALCON Y TELLA, M J J. ibídem, páginas 290 y 291. La autora manifiesta que : "Según el mencionado artículo 3.2 del Código civil, la función de la equidad es doble. En primer lugar como justicia del caso concreto, a modo de criterio interpretativo, junto a los demás criterios del art. 3.1 del Código Civil, en el sentido expresado en la Exposición de Motivos del Decreto de 31 de mayo de 1974. En este primer sentido la función de la equidad es la siguiente: a) Como algo necesario, significa tomar en cuenta las peculiaridades del caso, del supuesto de hecho, en la tarea de subsunción, inherente a toda interpretación. b) Como algo cuestionable y problemático, la equidad interviene también en la decisión de consecuencias, a la hora de determinar qué consecuencias corresponden al caso subsumido en la Ley, moderando las previstas literalmente por ella en el supuesto de que sean excesivamente rigurosas, y resulten por ello inicuas. Se dice que la admisión de esta segunda posibilidad es más problemática, porque por esta vía podrán llegar a vaciarse de efecto las normas. Por eso hay que manejarla con cautela.- La segunda función de la equidad mencionada en el art. 3.2 del Código Civil es la de servir de exclusi- 
se permite al juez la graduación de la responsabilidad del deudor ${ }^{105}$, o cuando se valora la conducta de los socios en una relación de pérdidas o ganancias ${ }^{106} \mathrm{o}$ el art. $1154 \mathrm{CC}$.

Recientemente, se viene utilizando la palabra equidad en los textos legislativos como sinónimo de igualdad ${ }^{107}$. Es en el ámbito de la educación, donde se utiliza la palabra equidad en un sentido cualitativamente diferente al del Código Civil ${ }^{108}$. La equívoca equiparación de la igualdad y la equidad es abundante por ejemplo en la LO 2/2006, de 3 de mayo, de Educación. En ella se confunde claramente equidad con igualdad al considerar la equidad como una exigencia de la escolarización del alumnado en relación con la igualdad de oportunidades de las personas en situación de dependencia, o de diferenciación cultural ${ }^{109}$. Más llamativo resulta el art. 4 de la LO 6/2006, de 19 de ju-

vo sustento del fallo judicial, lo cual será sólo posible cuando la ley expresamente lo permita, debiendo entenderse, por tanto, en un sentido restrictivo, en parte también porque esa función viene ya desarrollada a través del libre juego de los principios generales del Derecho.-Además aunque no lo mencione el artículo 3.2, la equidad ha de utilizarse también en el Derecho privado en materia de contratos. En primer lugar, como límite que no pueden superar la autonomía de la voluntad en la celebración de los mismos, en segundo lugar como canon interpretativo o ponderador de las consecuencias del contrato y, finalmente, como canon integrador. Pero el régimen de la equidad, pese a ser importante en el Derecho de las obligaciones y contratos, funciona no sólo en esa parcela del Derecho privado, ni en toda ella."

105 El art. 1.154 del Código Civil dice que: "el juez modificará equitativamente la pena cuándo la obligación principal hubiera sido en parte o irregularmente cumplida por el deudor".

106 El art. 1.690 del Código Civil dice a este respecto que: "si los socios se han convenido en confiar a un tercero la designación de la parte de cada uno en las ganancias y las pérdidas, solamente podrá ser impugnada la designación cuando evidentemente se haya faltado a la equidad".

107 La encontramos en las Exposiciones de Motivos de algunas leyes como la Ley 39/2006, de 14 de diciembre, de promoción de la autonomía personal y atención a las personas en situación de dependencia, donde se declara que "el Sistema atenderá de forma equitativa a todos los ciudadanos en situación de dependencia" (Motivo no 3 ).

108 Sobre esta confusión, el art. 4 de la Orden del Ministerio de Educación y Cultura, por la que se conceden ayudas de educación de educación especial para el curso 1996-1997, en su art. 4 dice que "sobre la base de los principios de equidad, solidaridad y compensación, la Administraciones públicas cooperarán para articular sistemas eficaces de información, verificación, y control de becas y ayudas financieras con fondos públicos y para el mejor logro de los objetivos señalados en los apartados anteriores". Tal Orden ha sido objeto de un conflicto de competencias presentado por la Generalitat de Cataluña, sin que el TC haya dicho nada al respecto de ese concepto de equidad utilizado aquí claramente como sinónimo de igualdad.

109 La Ley Orgánica 2/2006, de 3 de mayo, de Educación, en su preámbulo establece los principios sobre los que se asienta la ley, como la calidad y el de equidad, y ambos son tratados como indisociables. Ese concepto de equidad, que nunca se explicita en la Ley, y que se pretende conciliar con la calidad, parece referirse a una idea de distribución de recursos en la medida en que dice que algunos alumnos requieren esencial atención, o apoyo educativo. En tal sentido, la equidad sería una suerte de desigualdad compensatoria. El art. 1.b) lo conceptúa como un principio que garantiza la igualdad de oportunidades, la inclusión educativa, y la no discriminación, y un elemento compensador de las desigualdades personales, culturales, económicas y sociales, con especial atención a las que deriven de discapacidades. El art. 7 al hablar de las políticas educativas establece como fin también el de garantizar la equidad junto con la mejora del sistema educativo. Sin embargo, en otros artículos de la ley, bastan te numerosos, se alude de forma completamente separada a la igualdad de mujeres y hombres, por lo que no parece que el concepto de equidad se relacione con el género, sino más bien con el nivel educativo. Así, ya en el Preámbulo, se pretende garantizar la igualdad efectiva de oportunidades entre hombres y mujeres, y a lo largo del articulado se reitera "el desarrollo de la igualdad de derechos y oportunidades y el fomento de la igualdad efectiva entre hombres y mujeres". Curiosamente esta ley atribuye a la equidad funciones que el ordenamiento no había considerado. La equidad se cita hasta diez veces en el preámbulo de la Ley, justificando exigencias de muy diferente naturaleza, y luego en el texto articulado, se habla de una escolarización "equitativa", de la equidad como principio, para el alumnado que requiera determinados apoyos, como garantía, al regular las políticas educativas, e la transmisión de los valores, en la calidad de la educación, etc. Ciertamente, en algunos casos parece 
nio, de reforma del Estatuto de Autonomía de Cataluña que obliga a los poderes públicos a comprometerse con la equidad de género.

También en el Derecho administrativo, la equidad tiene atribuidas específicas funciones en la aplicación de las normas. La legislación administrativa contiene referencias a la equidad como criterio interpretativo que puede condicionar una resolución administrativa ${ }^{110}$.

La equidad resulta muy importante en materia de justicia arbitral, por ello frente a la pregunta de: ¿Qué sucede con la regulación de la equidad por ley en cuanto criterio de decisión por los árbitros? Tal respuesta tiene lugar en la Ley 60/2003, de 23 de diciembre. Específicamente en su art. 34 se establece que: "los árbitros sólo decidirán en equidad si las partes le han autorizado expresamente para ello”. La propia ley en el punto VI de su Exposición de Motivos razona acerca del cambio que se produce de invertir la regla de arbitraje de equidad por el arbitraje de derecho. En defecto de acuerdo de las partes, se irá al arbitraje de derecho. No había ninguna razón para presumir la equidad como sistema de resolución de conflictos, en un ordenamiento jurídico relativamente cerrado. Las partes pueden remitir a la equidad, o en términos similares: a "en conciencia", "amigable componedor", o "ex aquo et bono". Lo que da una idea del sentido de la equidad en el ordenamiento, como criterio de justicia material, que no de igualdad. Congruentemente con el artículo 34, el art. 15 exige para el nombramiento de los árbitros la condición de abogado en ejercicio, salvo acuerdo expreso en contrario, en aquellos arbitrajes internos en los que no se decida por equidad.

Se conceptúa de este modo la equidad como una concesión a la justicia material, en el entendimiento de que el cumplimiento rigorista de la ley va a producir una mayor injusticia de la que se pretende evitar ${ }^{111}$. Es decir, el anhelo es la amortiguación del rigor de la ley en cada caso concreto ${ }^{112}$.

hablarse tanto de igualdad como de justicia material, el criterio de formulación no es claro, y depende también de la materia de regulación (arts. 1, 7, 71, 140 y 148).

110 Sin duda la estructura de la Administración Pública y las características de sus manifestaciones excluyen aquel carácter de libertad en la Administración Pública se manifiesta a través de la noción de potestad discrecionalidad. Pero la discrecionalidad de la Administración pública, al igual que los poderes del juez en materia de equidad no son ilimitados sino que presentan ciertas cortapisas y fronteras, para no degenerar en poder arbitrario, en exceso o desviación de poder, iniquidad. De tal manera se enlaza el concepto de equidad con el límite del ejercicio del poder discrecional que hay quien identifica violación del principio de equidad con el exceso de poder. La carga de ser un buen administración no es otra cosa que la equidad administrativa, sin duda que se trata de un límite a la discrecionalidad, similar a la obligación del juez de equidad de emplearla en determinado sentido y dentro de ciertos márgenes, sin caer en el arbitrio de equidad o ejercicio arbitrario de la misma. Libertad de juicio sí, pero no arbitrariedad. Potestad discrecional sí, pero no exceso o desviación de poder. Sin embargo, es patente la distinción entre equidad y facultad discrecional. Mientras la equidad tiene a ampliar los derechos individuales, el control administrativo tiende a restringir y disminuir la esfera de los derechos individuales, en interés del orden o el bienestar públicos.

111 ARISTÓTELES. “Ética a Nicómaco”, Ed. UNAM, México, año 1954, página 122 y siguientes.

112 En tal sentido, la justicia como equidad es un tema abordado por el filósofo del Derecho estadounidense RAWLS, J., quien en su libro "Una teoría de la justicia”, desarrollado en escritos posteriores , "Justicia como equidad. Materiales para una teoría de la justicia”. RODILLA, M. A. (Trad.), Ed. Tecnos, $2^{\mathrm{a}}$ edición, Madrid, 
Por ello se requiere de un equilibrio reflexivo, es decir una negociación equitativa, la cual traerá aparejada resultados equitativos, consecuentemente deben seleccionarse las más fuertes y seguras convicciones morales como punto de partidas provisionales y luego trabajar retrospectivamente sobre los principios que justificarían tales intuiciones. Ahora bien en materia familiar tal proceder es a todas luces bastante complicado, por cuanto este equilibrio reflexivo debe estar lo suficiente consolidado para no fundarse única y exclusivamente en criterios extrajurídicos, de lo contrario la flexibilidad se convertirá en arbitrariedad.

En un sistema jurídico jerarquizado, formalizado y positivizado como es el modelo continental de derecho, el tema de la equidad exige un tratamiento científico muy condicionado por este modelo, y sobre todo, una toma de consideración de las diferentes concepciones de la equidad en el tiempo y en el espacio. Precisamente porque la equidad lo que pretende, no es la aplicación de la norma a un supuesto de hecho, sino, de alguna manera, eludir su aplicación, prevista para la generalidad de los casos, ante la eventual injusticia que pueda producir en un caso concreto, dadas las circunstancias específicas y hasta cierto punto irrepetibles, respecto de esa generalidad. No se trata de que esta norma sea en si misma injusta en su contenido, sino de que en determinados casos puede resultar así, lo que fuerza a una interpretación conforme a la equidad ${ }^{113}$. La igualdad sería un término de comparación, en tanto la equidad es el derecho a un proceso justo.

En el Derecho europeo, la equidad se contiene en el art. 6 del Convenio Europeo de Derechos Humanos, como una garantía esencial en el proceso. Del contenido de esta norma se han desgajado un número importante de derechos atinentes al proceso que originalmente no estaban en la mente del legislador, como la extensión a otras jurisdicciones para las que en principio no se consideró, la reformatio in peius ${ }^{114}$, la exigencia de vista oral siempre que se juzgue sobre hechos, aunque sea en

año 1999. Este autor se basa en la equidad procedimental de una posición originaria, que es su versión del denominado "estado de naturaleza" del cual hablaban los contractualistas clásicos, en que todas las causas de parcialidad estarían excluídas, lográndose así un resultado imparcial y equitativo.

113 Es el sentido que le da la Real Academia de la Lengua como un término derivado de latín aequitias-atis, "como igualdad de ánimo, como bondadosa templanza habitual; propensión a dejarse guiar, o a fallar, por el sentimiento det deber o de la conciencia, más bien que por las prescripciones rigurosas de la justicia o por el texto terminante de la ley, justicia natural, por oposición a la letra de la ley positiva, moderación en el precio de las cosas, o en las condiciones de los contratos, y finalmente como la disposición de ánimo que mueve a dar a cada uno lo que merece".

114 STEDH caso Hermi contra Italia, 18 de octubre de 2006, TEDH 2006/59. Recurre el actor porque el art. 6 no permitía una reformatio in peius. Se invoca en el recurso que se había denegado la prueba de la reproducción de una audición en segunda instancia. Por último, aunque la defensa corresponde esencialmente al acusado y a su abogado, tanto de oficio como elegido libremente, previamente citada, pág. 32-33, ap. 65 y, serie A núm. 282-A, pg. 11, ap. 28), los tribunales internos son los últimos garantes de la equidad del proceso, incluso en lo que respecta a la eventual falta de traducción o de interpretación a favor de un acusado extranjero. 
El art. 6 del Convenio Europeo de los Derechos Humanos sí que mantiene una importante relación con la igualdad. Sin embargo, el TEDH ha evitado relacionar el art. 14 del Convenio, que reconoce el derecho de igualdad, con el proceso equitativo ${ }^{116}$. Este art. 6 del Convenio sirvió de inspiración al art. $24 \mathrm{CE}^{117}$. Basta una lectura de su contenido para percibir la identidad de ambos preceptos, aunque probablemente en el art. 24 se concrete un número mayor de derechos. En todo caso, tanto en el Convenio como en el texto constitucional, se tienen normas de máxima apertura en las que se han localizado numerosos derechos nacidos del proceso, que en su origen no figuraron expresamente. Puede argumentarse que cuando se produce en un proceso, cualquiera, alguna situación que pueda provocar indefensión, nace en ese momento por así decirlo, un derecho procesal incardinable en esta norma. Por ejemplo, el incumplimiento de un plazo, no dar traslado de algunas actuaciones, no citar en fecha, o en domicilio, la inadmisión de un escrito o prueba, la ausencia de motivación de una resolución, pueden reconducir a la indefensión. A diferencia de otros derechos fundamentales los derechos que derivan de un proceso, están en permanente revisión, pudiendo aparecer nuevos derechos en función de la realidad viva y cambiante del derecho.

El Tratado de Niza, reconoce estos derechos integrados en parte en el Convenio, pero ampliando también la tutela conforme a la evolución que se ha producido en los nuevos textos constitucionales europeos más recientes ${ }^{118}$. La jurisprudencia que el Tribunal Constitucional ha venido

115 STEDH, caso Dombo Beheer contra los Países Bajos, 27 de de octubre de 1993, TEDH 1993/50. Define el art. 6 como la exigencia de igualdad de armas, de manera que las partes no estén en desventaja. Diferencia la sentencia entre las exigencias de la aplicación de la aplicación del art. 6 en función de que se trate de un proceso civil o penal. Aunque estemos en un proceso civil o penal. Aunque estemos en un procedimiento civil, la negación a la comparecencia de un testigo para probar hechos en los que solamente estaban presente dos personas, rompe esa exigencia de igualdad de armas.

116 STEDH, Engel y otros contra los Países bajos, de 8 de junio de 1976, TEDH 1976/3. Ha excluído la posibilidad de una aplicación conjunta de los arts. 14 y 6 de la Convención. Es un caso de jurisdicción militar. Estima el Tribunal que no hay discriminación por imponer sanciones diferentes entre la jurisdicción civil y militar, que estarían justificadas por la diferente posición. Y ello enerva la aplicación del art. 6.

117 Con bastante amplitud también el art. 24 de la Constitución española, regula los derechos derivados del proceso: "1. Todas las personas tienen derecho a obtener la tutela efectiva de los jueces y tribunales en el ejercicio de sus derechos e intereses legítimos, sin que en ningún caso pueda producirse indefensión. 2. Asimismo, todos tienen derecho al juez ordinario predeterminado por la ley, a la defensa y la asistencia del letrado, a ser informados de la acusación formulada contra ellos, a un proceso público sin dilaciones indebidas, y con todas las garantías, a utilizar los medios de prueba pertinentes para su defensa, a no declarar contra si mismos, a no confesarse culpables, y a la presunción de inocencia. La ley regulará los casos en los que, por razón de parentesco o de secreto profesional, no estará obligado a declarar sobre hechos presuntamente delictivos".

118 La Carta de los Derechos Fundamentales de la Unión Europea dedica a la tutela judicial, el Capítulo VI que se titula "Justicia" y en el que se contienen varios artículos referidos a las garantías del proceso. El art. 47 que se denomina "Derecho a la tutela judicial efectiva y a un juez imparcial" y reconoce el derecho de "toda persona cuyos derechos y libertades garantizados por el Derecho de la Unión hayan sido violados, tiene derecho a la tutela judicial efectiva respetando las condiciones establecidas en el presente artículo. Toda persona tiene derecho a que su causa sea oída equitativa y públicamente, dentro de un pazo razonable por un juez independiente e imparcial establecido previamente previamente por la ley. Toda persona podrá hacerse aconsejar, defender y representar. Se prestará asistencia jurídica gratuita a quienes no dispongan de recursos suficientes siempre y cuándo dicha asistencia sea necesaria para garantizar la efectividad del acceso a la justicia”. 
manteniendo en torno a la equidad tiene mucho que ver con la recepción de la doctrina del TEDH ${ }^{119}$ en cuanto a la aplicación del principio de igualdad de partes en el proceso ${ }^{120}$.

Se reconduce así lo que es un principio interpretativo del derecho, a un derecho fundamental integrado en el proceso, que está en sede del art. $24 \mathrm{CE}$, pero en consonancia con el art. 6 del Convenio. Con ello se busca la adecuación entre el derecho a tutela, y el derecho a un proceso equitativo conforme al TEDH.

Por su parte la jurisprudencia civil ha elaborado una doctrina respecto de concepto de equidad que tiene la base legal en el art. 3.2 del Código Civil ${ }^{121}$. Estamos ante dos diferentes concepciones de la equidad, la que descansa en el Código Civil, como concepto aplicativo del Derecho y la que exige la jurisprudencia del TEDH como criterio interpretativo de las normas jurídicas, para garantizar la justicia del proceso. En este sentido, la jurisprudencia del Tribunal Supremo es relativamente constante. En primer lugar, en cuanto a la necesidad de que la ley establezca expresamente la posibilidad de su aplicación. En segundo lugar, y en cuanto la aplicación de la equidad con los supuestos legalmente establecidos, se exige una prudencia y una ponderación restrictivas. No todas las leyes contienen previsión de equidad, ni su regulación es la misma, pero parece evidente que aquellas

119 STC, núm. 33/2003, de 13 de febrero, RTC 2003/ 33 en ella se expone que: "Hemos de subrayar también que el Tribunal Europeo de Derechos Humanos, partiendo de que las garantías inherentes al proceso justo no son necesariamente las mismas en el proceso civil y en el proceso penal, ha reconocido que incluso en el proceso civil la equidad requerida y la igualdad de armas "implica la obligación de ofrecer a cada parte una posibilidad razonable de presentar su causa -incluyendo en ella sus pruebas-, en condiciones que no la coloquen en situación de neta desventaja en relación con su adversario" (Sentencia de 27 de octubre de 1993, caso Dombo Beheer B. $V$. con los Países Bajos). Por lo que se refiere a los derechos del acusado, el art. 6.3, apartado d), CEDH le reconoce expresamente no sólo el de interrogar a los testigos que declaren contra él, sino también el de "obtener la citación y el interrogatorio de los testigos que declaren a su favor en las mismas condiciones que los testigos que lo hagan en su contra". Y si bien el Tribunal Europeo de Derechos Humanos ha considerado, al interpretar este concreto apartado, que el art. $6.3 \mathrm{CEDH}$ "no exige la convocatoria e interrogatorio de todo testimonio de descargo", sin embargo ha declarado que las palabras “en las mismas condiciones”, tienen por finalidad esencial una completa "igualdad de armas" en esta materia (Sentencias Engel y otros c. Países Bajos, de 8 de junio de 1976, serie A número 22, páginas 38-39, parágrafo 91, y Bricmont con Bélgica, anteriormente citada, serie A número 158, página 31 , parágrafo 89 ”.

120 Pero diferenciando claramente el derecho de igualdad de la equidad. Por todos, el Auto 58/1983, de 16 de febrero, por el que se inadmite un recurso de amparo que se solicitaba la equiparación de haberes entre personal activo y personal en expectativa de servicios civiles. Invocaban los actores "razones de equidad" para su equiparación, que el Tribunal deniega diferenciando expresamente la equidad de la igualdad. La invocación a la equidad que los actores hacen en las instancias previas, ha de entenderse referida a la legalidad ordinaria y no al derecho constitucional de la igualdad, diferente de la equidad regulada en el art. 3.2 del CC y que no es revisable en amparo, precisamente por ser cuestión de legalidad ordinaria Se diferencia así entre la equidad como criterio interpretati vo de las normas e igualdad como derecho fundamental.

121 ZAGREBLESKY, G. “El derecho dúctil”. Ed. Trotta, Madrid, página 148. Este autor plantea la recuperación del concepto de equidad desde una posición no iusnaturalista, por el nuevo papel que representa ahora la ley en el conjunto de las fuentes de derecho y que tanto se aleja de la reproducción mimética de su contenido literal. 
que no la contengan, también podrán ser interpretadas con equidad, si bien la decisión judicial no podrá descansar solamente en este precepto ${ }^{122}$.

La Ley de Arrendamientos Urbanos contiene una previsión de equidad. Pero los tribunales no han entendido que esta sea de aplicación automática, sino que la han excluido expresamente cuando la regulación sea clara, y sólo han considerado la equidad de forma supletoria. El TS ha considerado la aplicación de la equidad cuando la ley lo ha previsto expresamente. O lo que es igual, en aquellos supuestos en los que no hay una previsión expresa de equidad, no lo utiliza como criterio interpretativo de la norma, con lo que hace una lectura muy reductora del art. 3.2 del $\mathrm{CC}^{123}$. Por lo tanto, el límite para la aplicación de la equidad son las propias leyes (STS de 7 de julio de 1992, RJ 6188/1992, que considera en un caso de solidaridad activa de herederos, que la equidad no puede ir contra el Código Civil, o STS de la Sala de Civil, RJ 6389/2006 ${ }^{124}$, establece como límite a la actividad interpretativa de la equidad, la de no privar de valor y sentido a la propia ley. Aquí la equidad es sinónimo de ponderación) $)^{125}$.

122 STS, Sala de lo Militar, núm. 9/1996, de 28 de febrero, RJ 1996/1908 . "Como tercer motivo, también por infracción de ley, se engloban dos cuestiones que en todo caso debieron ser objeto de motivación separada, pues bajo un mismo epígrafe de inobservancia e inaplicación del artículo 24.1 de la Constitución Española, se denuncia indefensión por violación del principio de contradicción -al admitir una prueba pericial en el acto del juicioy conculcación del principio de tutela judicial efectiva por entender que la pena impuesta es absolutamente desproporcionada y «no es ajustada a los términos de equidad y de aplicación escrupulosa de la ley» (sic). Independientemente de ese defecto formal, el motivo ha de ser desestimado en su totalidad, puesto que la indefensión que alega se le ha producido por la admisión y práctica de la prueba pericial psiquiátrica solicitada por el Ministerio Fiscal, no se ha producido, pues la defensa tuvo oportunidad-como efectivamente hizo, según el acta-, de interrogar al perito, sin que solicitara la suspensión del Juicio para una mayor preparación del interrogatorio a formular y además porque tal prueba, ante la no alegación de eximente o atenuante alguna, derivadas de alteraciones psíquicas, no ha tenido, ni podido tener trascendencia práctica alguna, salvo una favorable a la defensa, de minoración de la pena a aplicar, aludida por la sentencia recurrida en el séptimo de sus fundamentos de derecho. "

123 Hay alguna sentencia en la que se da entrada a la equidad como criterio interpretativo, determinando su verdadero alcance. Es el caso de la STS de 14 de mayo de 1993, RJ 3.638/1993, que considera que los tribunales pueden aplicar la equidad en sus resoluciones judiciales, pero sin fundamentarse solamente en ella, y la hace equivalente a la “ponderación”. O el caso de la STS 867/1992, RJ 7539/1992, que la considera como una regla de interpretación, y en su caso de aplicación de las leyes, pero que sólo tiene virtualidad y eficacia ante la existencia de un vacío legal, negando expresamente que sea una fuente de derecho.

124 La equidad tal como la configura el Código Civil es regla de interpretación y, en su caso, de aplicación de las leyes, que cobra eficacia aplicativa ante la existencia de vacío legal (STS 30 de diciembre de 1993 (RJ 1993 / 9904). En igual sentido la STS 8 de octubre 1992 (RJ 1992, 7539 ). La aplicación de la equidad que postula el recurso sólo cabe en los supuestos de vacío legal (Sentencia de 8 octubre 1992 (RJ 1992/7539), entre los que no se encuentra el ahora debatido, respecto del cual no existe una ley, como exige el precepto invocado como infringido, que se remite expresamente a la equidad. (STS 3 de febrero 1995 (RJ 1995/737)). En el mismo sentido Recurso de casación para la unificación de la doctrina número 4771/2002; STS de 21 de noviembre de 2003 (RJ 2003/8085); o STS, de 29 de diciembre de 1998.

125 STS, Sala de lo Civil, núm. 6188/1992, de 7 de julio, RJ 1992/6188. "El motivo ha de ser estimado sin ninguna duda, pues su argumentación, estrictamente jurídica, quiebra el fallo qn equidad-según declara expresamentepronuncia la Sala «a quo», la cual, pese a la estimación correcta de la esencia del pleito -que no fue el de que se declarara a quién pertenecía el dinero depositado, sino quién tenía la disponibilidad de la libreta-, pese a recoger, también correctamente, la doctrina de esta Sala de que en los depósitos bancarios indistintos de dinero son de aplicación las reglas de la solidaridad activa de los depositantes o imponentes frente a la entidad depositaria, 
Respecto de los procedimientos específicos de equidad, los más conocidos son los establecidos en los procedimientos de arbitraje y en los de la LAU. Respecto de estos últimos, también el TS se ha pronunciado en cuanto al ámbito material de la equidad, descartando que se pueda aplicar en materias reguladas expresamente en la ley, y limitándolas a aquellas cuestiones genéricas del art. 17 de la ley 8/1999 (Auto Audiencia Provincial de Córdoba 20/2005 de 18 de febrero).

Ahora bien, qué sucede con la identidad, sin perjuicio de que este término será analizado de manera mucho más detallada junto a la filiación. En este título se debe, mientras, manifestarse que tampoco recoge la Constitución española el término identidad en relación con los derechos de igualdad. El derecho de igualdad se diferencia así de un posible derecho a la identidad, que implicaría la imposibilidad de diferenciación en el tratamiento legal o de hecho de las personas, en función de su situación. Frente a esa concepción de la igualdad como interdicción de la diferencia, que no se concibe en una sociedad plural, el art. 14 de la Constitución regula el derecho a la igualdad en el trato y a la no discriminación, pero permite la diferencia en la ley o en su aplicación, en función de parámetros o estándares de igualdad, que puedan ser delimitados por criterios culturales, geográficos o de cualquier otra consideración ${ }^{126}$.

sin embargo afirma que cuando uno de los titulares ha fallecido, se estima equitativo que sus herederos puedan tener la disponibilidad de la mitad y el titular superviviente la otra mitad, sin perjuicio de las acciones que a aquéllos y a este último correspondan para ventilar la propiedad de los fondos depositados, si se hallaren disconformes con el reparto sobre la disponibilidad que se realiza. Esta Sala no puede compartir estas conclusiones porque: A) La equidad no puede servir de ariete destructor del sistema jurídico establecido por el Código Civil respecto a la solidaridad; es simplemente un criterio a tener en cuenta en la aplicación de las leyes, pero no para fundar sobre ella ninguna solución jurídica salvo cuando el legislador lo permita expresamente (art. $3 .^{\circ}$ 2 del Código Civil). Para resolver ese pretendido problema -muerte de uno de los titulares indistintos- no hay ninguna previsión de este tipo, porque no hay tal problema en realidad, ya que la solución está en la normativa del derecho sucesorio, concretamente en el art. 661 del Código Civil, pues es inadmisible sostener que la solidaridad activa desaparece con la muerte de uno de los acreedores; ningún precepto legal lo establece ni se deduce de la reglamentación legal de la solidaridad. B) Porque esa solución equitativa es contraria a la misma naturaleza de estos depósitos indistintos, en los que cada uno (o sus herederos) tienen derecho al todo frente a la entidad depositaria, sin perjuicio de que entre ellos puedan dilucidar a quién pertenecen las sumas depositadas, retiradas o no."

126 UGARTEMENDÍA ECEIZABARRENA, J. I. "La tutela de la igualdad de trato como cauce de expansión del Derecho comunitario en el ordenamiento interno”, en Revista Española de Derecho Constitucional, núm. 84/2008, año 28, páginas 110 y 112. "En el Derecho comunitario la igualdad de trato o la prohibición de discriminación suele aparecer en un doble formato. Por una parte, formalizada en una serie de disposiciones del Tratado (y de Derecho derivado) expresamente dirigidas a proteger la igualdad de trato en determinados ámbitos sustantivos: Artículos 2 y 3 del Tratado (la promoción de la igualdad entre hombres y mujeres como uno de los fines u objetivos de la comunidad); artículo 12 (prohibición de discriminación por razón de nacionalidad); artículos 34, 39, 43 y 49 (prohibición de discriminación en el contexto de las libertades de circulación); artículo 90 (en el ámbito de la fiscalidad); artículo 137 (igualdad en la esfera de la protección social); artículo 41 (igualdad de retribución entre hombres y mujeres para un mismo trabajo); o, tras el Tratado de Amsterdam, en el artículo 13 (en virtud del cual, y sin "sin perjuicio de las demás disposiciones del presente Tratado y dentro de las competencias atribuidas a la Comunidad por el mismo, el Consejo, por unanimidad, a propuesta de la Comisión y previa consulta al Parlamento Europeo, podrá adoptar acciones adecuadas para luchas contra la discriminación, por motivos de sexo, de origen racial o étnico, religión o convicciones, discapacidad, edad u orientación sexual”) y, obviamente, en las disposiciones de Derecho derivado establecidas sobre dichas bases jurídicas del Tratado. Unido a ello, por lo demás, es necesario tener igualmente presente lo que la Carta de Derechos Funda- 
A partir de esa concepción, no toda desigualdad de trato en la regulación de una materia es necesariamente una desigualdad en la ley, sino solo la que no se sustente en criterios objetivos y razonables de valor generalmente aceptados. En el plano legislativo, la diferencia entre igualdad e identidad deriva de una falsa identificación que no está presente en la Constitución, sino que se debe a un incorrecto entendimiento del contenido del art. 14. El Tribunal Constitucional ha diferenciado tempranamente estos conceptos al considerar ya en la Sentencia 8/1981 que la igualdad no es rigurosa uniformidad ${ }^{127}$. Es en la motivación de la aplicación de las normas jurídicas donde los estudiosos y entendidos del Derecho muestran la posible discriminación ante la ley ${ }^{128}$. Esta opción interpretativa de la igualdad diferenciada de la identidad es muy congruente con la necesaria libertad de opción por parte del legislador de regulación de diferentes posiciones jurídicas entre personas y grupos, no solamente en cuanto a la posibilidad de permitir márgenes inadecuados de desigualdad en función de un esfuerzo personal, sino de desarrollo del concepto de desigualdad compensatoria, cuotas electorales de favorecimiento de integración de las mujeres, o fomento de contratación en materia laboral a edades de mayor dificultad en el acceso al mercado de trabajo, o protección de colectivos marginados.

La discriminación también la puede generar la privación de derechos de un colectivo respecto de la norma general, o la regulación de derechos para ese grupo, cuando estos no se ven contemplados en la norma. Con ello enlazamos con el tercer concepto que suele confundirse con el principio de igualdad y que tiene relación con las omisiones legislativas. Ellas se relacionan de esta forma con el derecho de igualdad ${ }^{129}$, serán inconstitucionales aquellas omisiones del legislador que dejen fuera de cobertura de la norma sin justificación, a aquellas personas o grupos de personas que cum-

mentales de la UE establece sobre los derechos de igualdad".

127 STC, Sala 2a , núm. 8/1981, de 30 de marzo, RTC 1981/8: “En la aplicación jurisdiccional de la Ley puede existir violación del principio de igualdad, cuando un mismo precepto se aplique en casos iguales con notoria desigualdad por motivaciones arbitrarias (esto es, no fundadas en razones jurídicamente atendibles) o con apoyo en alguna de las causas de discriminación explícita o genéricamente incluidas en el artículo 14 de la Constitución. Como nada hay en el caso presente que permite apreciar la existencia de una actuación de este tipo en el Tribunal del que proceden las resoluciones impugnadas, hay que desestimar la pretendida violación del artículo 14 de la Constitución de la que dice ser víctima el recurrente."

128 La igualdad no exige un tratamiento idéntico ante la ley, sino que su aplicación no sea arbitraria. Si hay una motivación razonada en una diferente aplicación de un mismo precepto ante dos situaciones, no hay arbitrariedad (FJ 6). La STC, Sala 2a ${ }^{\text {a }}$ núm 52/1982, de 22 de julio, RTC 1982/52 fija esa doctrina permitiendo que se regulen de manera diferente situaciones jurídicas de fijación de indemnizaciones en función de diferentes circunstancias empresariales, de manera que ante un despido se puedan percibir cantidades distintas, lo que evidencia un diferente trato a la presta que servicios en una u otra empresa. En el mismo sentido la STC, Sala 2a , núm. 34/1984, de 9 de marzo, RTC 1984/34, que permite la diferencia de trato. La diferencia salarial en si misma no supone discriminación, a menos que esa diferencia haya sido debida a una causa de discriminación de las reconocidas en el art. 14.

129 AGUILAR, L. "El Tribunal Constitucional y la función legislativa: el control del procedimiento legislativo y la inconstitucionalidad por omisión”, Revista de Derecho Público, núm. 24, Madrid, año 1997. 
pliendo los requisitos exigidos, no se beneficien de ese derecho, por la sola arbitraria exclusión legal.

La igualdad constituye un límite al legislador como cualquier otro derecho fundamental en su contenido esencial, y es lesionada como derecho por este cuando se ve reducida la cobertura de la norma a un colectivo con omisión de ese carácter general que debe contener. En línea de principio, al legislador compete hacer las leyes y además decidir cuándo las hace. Sin embargo, la falta de regulación puede producir consecuencias para el derecho de igualdad, bien porque una regulación preconstitucional haya generado una discriminación legislativa, o bien porque la propia situación de hecho esté exigiendo de los poderes públicos la regulación o actuación no discriminatoria. Constituye por tanto el incumplimiento de una obligación de hacer que no tiene plazo.

Finalmente, en lo referente a las omisiones legislativas debe enunciarse que el objeto de control de estas lo constituye la ausencia de la norma y su repercusión en el derecho de igualdad, no la mera falta de regulación de un sector del ordenamiento. Ni siquiera la omisión puede estar plenamente justificada, siempre que resista el análisis de racionalidad y proporcionalidad que es exigible en la aplicación de la igualdad ${ }^{130}$.

En un modelo de justicia constitucional en el que la relación entre el Legislador y el Tribunal Constitucionalidad se establece teóricamente por el control negativo de la constitucionalidad de las normas, las omisiones legislativas no debieran tener cabida. Sin embargo, es sabido que el Estado social demanda una superación de ese inicial marco teórico en el que se desenvuelve la justicia constitucional, en la medida en que el Tribunal tiene también como función la del cumplimiento de

130 FERNANDEZ RODRIGUEZ, J.J. "La inconstitucionalidad por omisión. Teoría general, derecho comparado, el caso español”. Ed. Civitas, Madrid, año 1998. 
los fines del Estado social, tal cual pregona PÉREZ VILLALOBOS ${ }^{131}$. De ahí el papel reparador del Tribunal en la inconstitucionalidad por omisión ${ }^{132}$.

A estos efectos, el TC ha intentado distinguir entre la inconstitucionalidad por omisión y algunas técnicas posibles de subsanación en la aplicación de las normas, como la analogía y otras técnicas de integración de las lagunas jurídicas. No siempre puede subsanarse una laguna con la aplicación analógica de un precepto, sino que debe ser de aplicación ese precepto a ese supuesto; en caso contrario, el intérprete se excede de sus capacidades interpretativas, aplicando preceptos que no son pertinentes al caso.

131 PÉREZ VILLALOBOS, M. C. “Las leyes autonómicas reguladoras de las parejas de hecho”, ...op. cit., página 102 Y 103. "Hemos dicho en otro lugar que la mayoría de los paises europeos han mantenido las relaciones familiares en el entorno de las leyes civiles y casi siempre adoptando una legislación que acogía como modelo de familia la tradicional basada en el matrimonio. En el siglo XIX, los modelos de Codificación mantenían estas relaciones en el ámbito privado sin aceptar la ingerencia del Estado, porque tampoco el Estado liberal de Derecho permitía esta implicación estructural. A partir del siglo XX este carácter liberal del Estado va a cambiar y a partir de los años cincuenta, las Constituciones incluyen que obligan al Estado a regular las relaciones familiares basadas en el principio de igualdad y en l carácter social del Estado (...) La jurisprudencia constitucional ha sido quien ha llevado a cabo la determinación del principio social desde el punto de vista del compromiso social con que se ve afectado el Estado. Con el Estado social lo que se persigue, en primer lugar, es la realización del principio de igualdad. Pero la vinculación social del Estado se refiere preferentemente al legislador, lo que significa establecer a través de leyes generales, un sistema social justo con las correspondientes prestaciones que lo realicen; esto es así porque del principio del Estado social no se derivan soluciones concretas sino que estas dependerán de decisiones de carácter político que sólo son recurribles ante la jurisdicción constitucional si el legislador no ha respetado algunos de los elementos estructurales característicos del principio social o del principio de igualdad".

132 JIMENA QUESADA, L. "Inconstitucionalidad por omisión y responsabilidad internacional”, en "Cuadernos constitucionales de la cátedra Fadrique Furiol Cerió”, núm. 58/59, Ed. McGraw-Hill, Madrid, año 1997, páginas 207 a 225. "Sin lugar a dudas, el ejemplo más emblemático de la sanción de una inconstitucionalidad por omisión vino de la mano de la utilización del recurso de amparo con motivo de los pronunciamientos inaugurados con la STC 31/1994, de 31 de enero, y siguientes de ese mismo año (SSTC 47, 98, 240 y 307/1994), sobre libertad de antena en el ámbito del video comunitario y la televisión por cable. En dichas sentencias se otorgó el amparo a los recurrentes, reconociéndoseles su derecho a las libertades de expresión y comunicación garantizadas por los apartados a) y d) del art. 20.1 de la Constitución, lo que llevó aparejado restablecerles en la integri dad de su derecho fundamental y anular las resoluciones gubernativas (y sentencias confirmatorias de ellas) por las que se les requería el cese de las emisiones de televisión local por cable y el desmontaje de sus instalaciones. La concesión de los amparos de referencia se produjo por la vía de la inconstitucionalidad por omisión, esto es, como consecuencia de valorar el perjuicio sufrido por las entidades demandantes a causa de la actitud pasiva del legislador, que no había desarrollado la normativa constitucional en lo relativo a la creación de televisión local por cable como facultad dimanante de los derechos consagrados en el art. 20 de la Constitución. En sintesis, el Tribunal Constitucional, sobre partir de que los derechos de información y comunicación no son absolutos y son consecuentemente susceptibles de limitación por la configuración que de ellos efectúe el legislador, entendió en su ratio decidendi que no obstante ello, éste no puede constreñirlos de tal forma que no respete su contenido esencial, lo que se produce si se suprime (como en los supuestos controvertidos), la posibilidad de su ejercicio. Con la solución expuesta se produjo una inflexión en la jurisprudencia constitucional española precedente, que se había mostrado comedida o, al menos, exigente, respecto al reconocimiento-siquiera, indirecto- de la inconstitucionalidad por omisión. Ciertamente, el Tribunal Constitucional no puede suplir al legislador creando él mismo la ley, 13 aunque en el supuesto de la STC 31/1994 y análogas se haya llegado a un resultado semejante, como sucede en otros supuestos como el de las denominadas sentencias interpretativas, cuya emanación justifica el Tribunal Constitucional «haciendo una interpretación finalista de todo el ordenamiento jurídico; a saber: éste no puede querer lagunas jurídicas que puedan evitarse". 
La aplicación analógica ha sido considerada por el TC en relación con el art. $25.1 \mathrm{CE}^{133}$, con el 9.3, con el 14 y con el principio de tipicidad del Derecho penal. Pese a la exigente plenitud del ordenamiento, que no debería generar vacíos normativos, la realidad social impone que no todas las situaciones supuestas, encuentren normas directamente aplicables a cada supuesto de hecho, lo que obliga a acudir a criterios analógicos para solventar la necesaria aplicación normativa. En tal caso, el art. 4.1 CC establece en su párrafo $1^{\circ}$ que: "procederá la aplicación analógica de las normas cuando estas no contemplen un supuesto específico, pero regulen otro semejante entre las que se aprecie identidad de razón”. Esa posibilidad queda cerrada al derecho penal por el párrafo $2^{\circ}$ que considera que: "las leyes penales, las excepcionales y las de ámbito temporal no se aplicarán a supuestos distintos ni en momentos distintos de los comprendidos expresamente en ellas". Finalmente, el párrafo $3^{\circ}$, concede al Código Civil la supletoriedad en : "las materias reguladas por otras leyes".

Sin embargo, las omisiones legislativas se diferencian de las lagunas en que estas son involuntarias, las omisiones legislativas no necesariamente lo $_{\text {son }}{ }^{134}$. Por ello si el juez, con ocasión de una aplicación normativa, no encuentra la ley aplicable, debe plantearse las dos operaciones, en primer lugar la analogía, y si esta no permite la adecuada resolución, considerar que está ante una omisión legislativa, que puede tener o no repercusión constitucional, en función del derecho lesionado y sus consecuencias. En tal caso, entiende el Tribunal que el juez puede directamente aplicar la Constitución y así extender la norma a supuestos inicialmente no previstos, o plantear la cuestión de inconstitucionalidad. Esta línea doctrinal se inicia con la STC 15/1982 sobre objeción de conciencia ${ }^{135}$. La dilación del legislador en el cumplimiento del deber que la Constitución le impone puede lesionar un derecho reconocido en ella. En la misma línea, la ausencia de una normativa postconstitucional restringe importantes derechos relacionados con el derecho de reunión (STC 36/1982 que deroga re-

133 La reconducción de los límites de la analogía al 25.1 CE, implica la afirmación de la tipicidad como principio de raíz constitucional. STC núm. 232/1997 y STC núm. 233/1999, por las que impide la aplicación analógica de delitos reconocidos en el CP de 1973 una vez vigente el de 1995.

134 JIMENEZ CAMPO, J. “Analogía secundum constitucionem”, Revista del Centro de Estudios constitucionales, $\mathrm{n}^{\circ}$ 13, Madrid, septiembre-diciembre 1992, páginas 8 y siguientes: "Procederá la aplicación analógica de las normas cuando éstas no contemplen un supuesto específico, pero regulen otro semejante entre los que se aprecie identidad de razón») expresa ajustadamente que la integración por esta vía del ordenamiento resultará obligada para el órgano judicial... siempre que se dé el supuesto, normativo y axiológico, al que aquel precepto se refiere. Y ya que la analogía es uno de los modos de realizar la igualdad en el proceso de aplicación del Derecho, no resulta tampoco arduo argumentar que aquella exigencia legal —apreciada por la doctrina mucho antes de la reforma del Título Preliminar del Código Civil- ha quedado reforzada por lo dispuesto en el artículo 14 de la Constitución, presentándose así la integración analógica como un expediente útil, en no pocos casos, para evitar lo que devendría, de no acudirse a ella, un trato discriminatorio. Que esto sea así no parece requerir, como digo, argumentación mayor y es, en todo caso, algo que no ha dejado de afirmar —con cautela primero, después con toda resolución-el Tribunal Constitucional."

135 AHUMADA RUIZ, M.A., “El control de constitucionalidad de las omisiones legislativas”, RECEC, $\mathrm{n}^{\circ}$ 8, Madrid, año 1991, página 187. 
quisitos de la ley preconstitucional que establecía para el ejercicio del derecho de reunión la exigencia de autorización gubernativa. El Tribunal cambia la autorización por una mera comunicación) ${ }^{136}$.

De ahí las precauciones del Tribunal en este tipo de sentencias. Se ha considerado que esa inconstitucionalidad por omisión se produce cuando el legislador viene obligado por un mandato constitucional y no legisla; si bien los contenidos de una ley son de libre configuración del legislador, estos deben de estar naturalmente dentro de los límites constitucionales, entre los que se encuentran las discriminaciones contrarias a la igualdad. En estas situaciones de omisión de personas o colectivos en el ámbito de aplicación de una ley, la inconstitucionalidad de esa ley no lleva a su nulidad, sino a la extensión de la cobertura legislativa a quienes no estaban en ella. Sin embargo, la deficitaria construcción de las normas que regulan los efectos de las sentencias dictadas por el Tribunal Constitucional en los arts. 38 a 40 ambos incluidos, de la LO 2/1979, de 2 de octubre del Tribunal Constitucional, impide que muchas veces las resoluciones del Tribunal puedan tener los efectos que la situación demanda. La limitación al pronunciamiento y de sus efectos, mantiene un binomio inconstitucionalidad - nulidad relativamente inoperante en algunas de las resoluciones del Tribunal.

\section{2| Igualdad y Familia}

\section{1 ¿De qué igualdad hablamos cuando nos referimos a la familia?}

El principio de igualdad no presenta una unidad doctrinal respecto a su concepto como tampoco respecto a su naturaleza jurídica. Tres son fundamentalmente las clasificaciones a las que la igualdad ha sido sometida por la mayoría de la doctrina. Por ejemplo para VALCARCEL ${ }^{137}$, la igualdad es un valor, mientras que otros autores ven en ella un principio, finalmente hay quienes la estudian como un derecho fundamental ${ }^{138}$. Sin embargo, a pasar de estas diferencias de opinión el texto de la Constitución es claro en este punto, la igualdad está señalada como uno de los valores superiores del ordenamiento jurídico, vendría a ser una de las preferencias conscientes básicas expresadas en el

136 En la STC, Sala $1^{\text {a }}$, núm. 109/1988, 8 de junio, RTC 1988/109, el TC se plantea la analogía como una forma de posible restablecimiento del derecho de igualdad. Cfr. STC 63/1994, Sala 1 ${ }^{\text {a }}$, de 28 de febrero, RTC 1994/63.

137 VALCARCEL, A. “El concepto de igualdad”, Ed. Pablo Iglesias, Madrid, año 1994, página 7.

138 PEREZ LUÑO, A. E., en su obra “Derecho humanos, Estado de Derecho y Constitución”, Ed. Tecnos, Madrid, año 1986, páginas 292 y siguientes, la describe como principio, mientas que otros atores como VALDES DALRE en su prólogo a la obra "El principio de igualdad en la Constitución española”, en VV.AA.: "El principio de igualdad en la Constitución Española”, XI Jornadas de Estudio del Centro de Publicaciones de la Secretaría General Técnica del Estado, del Ministerio de Justicia, Madrid, año 1991, páginas 18 y 19, señala que la igualdad aparece ineludiblemente asociada a la propia noción de derecho fundamental 
proceso constituyente como prioritaria y orientadora, fundamentadora de la vida colectiva españo$\mathrm{la}^{139}$. Esto también provoca que su naturaleza sea la del contexto axiológico fundamental o básico para la interpretación de todo el ordenamiento jurídico, por ello se incluyen los preceptos relativos al Derecho de Familia. Incluso puede entenderse no como la descripción de una realidad empírica sino que es una exigencia ética, un valor ético fundamental.

Ahora bien, en términos del presente trabajo me he referido a ella en términos de clave, es decir, como fundamento que antecede y es asimismo elemento teleológico del ordenamiento jurídico familiar, valor, principio. De todas maneras su naturaleza excede con creces los límites de este estudio.

Si bien el derecho de igualdad se reconoce de sobremanera desde la Constitución en el art. 14, hay sin embargo una amplia regulación de la igualdad en el texto constitucional. En un principio, y por la ubicación sistémica del derecho de igualdad, se consideró que no tenía naturaleza de derecho fundamental. Al menos no estaba en la misma situación que el resto de los derechos fundamentales que se regulaban en la misma sección.

De la lectura de los preceptos constitucionales se puede deducir que el artículo 14 que se refiere a la igualdad formal o igualdad de trato se manifiesta en numerosas ocasiones, aunque sea de manera relacional porque este principio actúa como canon general de coherencia, sin perjuicio podríamos indicar su especial inclusión en la Constitución en los artículos 1.1, 9.2 y 14 de la misma, es en este último donde está presente como principio de igualdad formal o de trato y en el que de forma más amplia se contiene y preceptúa el principio de igualdad.

Sin perjuicio de esto último es necesario reafirmar que hay una amplia regulación de la igualdad en el texto constitucional. En un principio, y por la ubicación sistemática del Derecho de igualdad, se consideró que no tenía naturaleza de derecho fundamental. Al menos no estaba en la misma situación que el resto de los derechos fundamentales que se regulaban en la misma sección ${ }^{140}$. Además, la ubicación sistemática del derecho de igualdad fuera de la sección primera del Capítulo y dando entrada además a todos los demás derechos fundamentales, confiere una particularidad a la igualdad con respecto a los demás derechos fundamentales en ella relacionados. Hay que tener en cuenta que cuando en el art. 53 CE se habla de derechos y libertades de especial protección, no se dice que esta protección se refiera a las secciones primera y segunda, sino al capítulo II, lo que com-

139 RICO CASAS, R. M. “QQué igualdad?. El principio de igualdad formal y no discriminación por razón de sexo en el ordenamiento jurídico español.”. Ed. Dykinson, Madrid, año 2010, página 99.

140 Sobre la naturaleza triédica del derecho de igualdad, CÁMARA VILLAR, G “Votos particulares y derechos fundamentales en la práctica del Tribunal Constitucional español”. Ministerio de justicia, Madrid, año 1993, página 108. La igualdad sería tanto un principio general del derecho, como un derecho subjetivo además de una limitación al poder legislativo. 
prende también el derecho de igualdad. Y el apartado segundo del art. 53, cuando exige la protección jurisdiccional de los derechos y libertades, amplía expresamente al art. 14 ese amparo.

Por ello resulta importante la delimitación conceptual de la igualdad en relación con aquellos conceptos similares como la desigualdad de trato, las conductas discriminatorias o la igualdad de oportunidades $^{141}$, sin perjuicio del análisis ya expuesto en relación a la equidad, a la identidad y a las omisiones legislativas.

Cuando hablamos de igualdad, a diferencia de otros derechos fundamentales, que aparecen perfectamente acotados en su definición, e incluso en su extensión como tales derechos fundamentales (pensemos en el derecho de inviolabilidad del domicilio, o en el secreto de las comunicaciones, o en cualquier otro derecho derivado de la libertad o la seguridad), hemos de tener en cuenta que este derecho contiene importantes elementos de interrelación con otros derechos fundamentales, y con principios y valores constitucionales, como puede ser el del libre desarrollo de la personalidad. En tal sentido, se ha considerado que es, de alguna manera instrumental, de otros derechos $(\text { SSTC } 30 \text { y 31/1991) })^{142}$.

141 Hasta la STC núm. 49/1982, no se pronuncia explícitamente el TC respecto de la igualdad como derecho subjetivo. En las STC 4/1981, 10/1981 y 27/1981, el TC habla de una naturaleza de la igualdad como instrumental, principal.

142 STC núm. 30/1991, Pleno, 14 de febrero, RTC 1991/30. "Sobre la lesión al derecho reconocido en el art. 14 de la Constitución, este Tribunal ha tenido ocasión de pronunciarse en anteriores resoluciones de inadmisión de demandas de amparo en supuestos sustancialmente idénticos, declarando que la regulación actual de las pensiones de viudedad del sistema de la Seguridad Social no vulnera lo dispuesto en el art. 14 de la Constitución en cuanto que «el matrimonio y la convivencia matrimonial no son situaciones equivalentes, siendo posible, por ello, que el legislador, dentro de su amplísima libertad de decisión, deduzca razonablemente consecuencias de la diferente situación de partida» (AATC 156/1987 y 788/1987). Doctrina ratificada recientemente por el Pleno del Tribunal en la STC 184/1990, resolutoria de la cuestión de inconstitucionalidad núm. 1.419/1988 planteada en relación con el art. 160 LGSS y la Disposición adicional décima, 2, de la Ley 30/1981, de 7 de julio. Ha de partirse, pues, de la doctrina sentada por este Tribunal, y habiéndose declarado la compatibilidad del art. 160 de la LGSS con el art. 14 en conexión con el art. 39.1 de la Constitución, ha de rechazarse que la Sentencia impugnada, que se limita a aplicar aquella disposición, haya incurrido en lesión de este precepto constitucional. Como se dice en la STC 184/1990, la Constitución no reconoce el derecho a formar una unión de hecho que, «... por imperativo del art. 14, sea acreedora del mismo tratamiento -singularmente por lo que ahora importa, en materia de pensiones de la Seguridad Social- que el dispensado por el legislador a quienes, ejercitando el derecho constitucional del art. 32.1, contraigan matrimonio», $y$ «siendo el derecho a contraer matrimonio un derecho constitucional, cabe concluir que el legislador puede, en principio, establecer diferencias de tratamiento entre la unión matrimonial y la puramente fáctica y que, en concreto la diferencia de trato en la pensión de viudedad entre los cónyuges y quienes conviven de hecho sin que nada les impida contraer matrimonio no es arbitraria o carente de fundamento». También se declara en la STC 184/1990 que el legislador podría extender a las uniones estables de hecho los beneficios de la pensión de viudedad, pero que el no hacerlo así, no lesiona el art. 14 de la Constitución, ni por sí mismo ni en relación al art. 39.1 del Texto constitucional, a lo que ha de añadirse que tampoco se lesiona el art. 14 de la Constitución en conexión con el art. 41 de la Constitución, toda vez que, en su configuración actual la pensión de viudedad no tiene por estricta finalidad atender una situación de necesidad o de defensa económica. Cuestión distinta es que el supérstite no debe quedar desprotegido por el régimen público de Seguridad Social (arts. 41 y 50 de la Constitución). Pero tal protección-como se dice igualmente en la STC 184/1990- no tiene necesariamente que prestarse a través de la actual pensión de viudedad. En suma, la obligada aplicación del art. 160 de la LGSS, cuya constitucionalidad ha declarado este Tribunal en la STC 184/1990 cuyos fundamentos damos por reproducidos íntegramente en la presente, conduce necesariamente a la desestimación de este recurso de amparo". En el mismo sentido puede apreciarse la STC 31/1991, Pleno, de 14 de febrero RTC 
El Tribunal Constitucional no ha considerado que la igualdad tenga un contenido esencial propio, sino más bien que participa del contenido esencial de los demás derechos fundamentales, como una parte de la totalidad de esos derechos. La doctrina aunque no de forma unánime, si ha considerado que la igualdad tenga un contenido mínimo inatacable por el legislador, de la misma forma que los demás derechos. De este modo, en un principio, la igualdad se consideró, no tanto un derecho autónomo como un derecho-puente, e instrumental a otros derechos como el ejercicio de la libertad sindical, el de representación política, o de acceso a la función pública. De esta consideración de igualdad ha extraído el Tribunal Constitucional importantes consecuencias, muchas de ellas precisamente para negar el derecho ${ }^{143}$.

Su carácter relacional, tal y como ha sido establecido entre otras en la STC 76/1983 ${ }^{144}$, no le priva de su naturaleza de derecho subjetivo y fundamental, sino solamente le exige un término de comparación, que en la práctica finalmente ha sido considerado a veces innecesario ${ }^{145}$. El derecho de igualdad como derecho relacional, tiene correspondencia con prácticamente todos los derechos fundamentales, concuerdo en tal sentido con SUAY RINCÓN ${ }^{146}$ para quien una buena parte de los 1991/31.

143 En sus primeros años de desarrollo constitucional, se consideró la relacional de la igualdad, que operaría dentro de relaciones jurídicas concretas, fuera de las cuales dejaría tener sentido (STC 7/1983).

144 STC, Pleno, Caso LOAPA. Sentencia núm. 76/1983 de 5 agosto. RTC 1983/76en tal sentido la sentencia dispone: "Esta equiparación entre las materias que pueden ser objeto de recurso de amparo y las que han de ser reguladas por Ley Orgánica no resulta constitucionalmente defendible. En primer lugar el artículo 53 de la Constitución establece que cualquier ciudadano podrá recabar, a través del recurso de amparo, la tutela de las libertades y derechos reconocidos en el artículo 14 y en la sección primera del capitulo II, mientras que el artículo 81.1, al definir las materias propias de Ley Orgánica, se refiere al «desarrollo de los derechos fundamentales y de las libertades públicas», que es precisamente la rúbrica utilizada para designar el conjunto de los artículos comprendidos en la sección primera del capitulo II. Es preciso señalar que la actual expresión contenida en el artículo 81.1 es el resultado de la transformación experimentada por el texto constitucional a lo largo del debate parlamentario, desde su redacción inicial-«desarrollo de los títulos I y II de la Constitución»- hasta la final aprobada en la Comisión Mixta Congreso-Senado, y que pone de manifiesto la preocupación del legislador constituyente por precisar qué materias dentro del titulo I habrían de quedar sujetas a reserva de Ley Orgánica. Existe, pues, una exclusión expresa del artículo 14 en el artículo 81.1 de la Constitución. Tal exclusión, por otra parte, está justificada porque la igualdad reconocida en el artículo 14 no constituye un derecho subjetivo autónomo, existente por si mismo, pues su contenido viene establecido siempre respecto de relaciones jurídicas concretas. De aqui que pueda ser objeto de amparo en la medida en que se cuestione si tal derecho ha sido vulnerado en una concreta relación jurídica y, en cambio, no pueda ser objeto de una regulación o desarrollo normativo con carácter general.- Por ello, la regulación de las condiciones básicas que garanticen la igualdad de todos los españoles en el ejercicio de los derechos constitucionales a que se refiere el mencionado artículo 149.1.1 de la Constitución podrá tener carácter orgánico, pero no por su referencia a la igualdad, sino por la materia objeto de regulación, que puede coincidir con los derechos fundamentales a que se refiere el artículo 81.1 de la misma. En este sentido, el Proyecto de LOAPA tendría carácter orgánico tan sólo en la medida en que se pretendiera garantizar en él tal igualdad en relación con algún derecho fundamental concreto."

145 Sobre la doble invocación de la igualdad, GIMÉNEZ GLÜCK, D. “Juicio de igualdad y Tribunal Constitucional", Ed. Bosch, Barcelona, año 2004, página 37.

146 SUAY RINCÓN, J. "El principio de igualdad en la justicia constitucional", IEAL, Madrid, año 1985. Para el autor la igualdad es el presupuesto para el ejercicio de la libertad. Página 24. Crf. PACE, A. "Igualdad y libertad" en Revista Española de Derecho Constitucional, año 22, número 64, Centro de Estudios Políticos Constitu- 
derechos del título I se han reconducido en la práctica del recurso de amparo por la vía de la violación del art. $14^{147}$, esto es tan sólo un ejemplo de la importancia del principio de igualdad en relación a la configuración de los derechos fundamentales, y prefiero en este caso hablar de principio más que de derecho para acentuar una cierta diferencia entre ambos debido al carácter de fundamentación que a mi juicio mantiene el término principio.

Como también se ha señalado la igualdad no tiene un contenido esencial delimitable con las mismas posibilidades teóricas que otros derechos fundamentales sino que es de alguna manera transversal a todos los demás derechos, por ello actúa como elemento central de legitimación de orden social, entre ellos el orden familiar ${ }^{148}$.

De ahí que el concepto haya ido experimentando una importante evolución desde su inicio, en el que apenas se consideraba la posibilidad de un derecho autónomo a la igualdad, hasta la consideración de la igualdad como derecho fundamental, directamente aplicable ${ }^{149}$. Ciertamente, el derecho de igualdad muestra también una posición peculiar respecto de los demás derechos, en la medida en que la Constitución ha considerado la igualdad, además de derecho, principio inspirador del ordenamiento y valor constitucional. Esta regulación confiere a la igualdad una especial consideración, no sólo en el sistema de fuentes, que trastoca considerablemente al exigir ahora que la igualdad sea algo más que la generalidad de la ley, sino también porque orienta además de al legislador, a los

cionales, Madrid, año 2002, páginas 53 a 77. “En la voz Igualdad de la Enciclopedia delle Scienze sociali Ronald Dworkin afronta el problema de si los valores de igualdad y de libertad se hallan en una situación de irremediable conflicto entre ellos o si, por el contrario existe la posibilidad de conciliar ambos de tal suerte que puedan extraerse sólo las respectivas ventajas". El estudioso se decanta por esta segunda alternativa.

147 Es llamativa la relación que en la práctica procesal adquiere este derecho con el resto de los derechos fundamentales, tanto procesales como sustantivos. Fundamentalmente con el derecho de tutela judicial o con e derecho de representación sindical, pero también con otros, que afloran recientemente, como el de vivienda, la salud o el medio ambiente. Cfr. MONCHO PASCUAL, J. R., "La sociedad estamental: I. La asimetría como principio rector de la sociedad antigua", en “Algunos hitos del ideal igualitario”, Ed. Nau Llibres, Valencia, año 1997, páginas7 a 23; MONCHO PASCUAL, J. R., "La sociedad estamental: II. La igualdad (y la esclavitud) en el medioevo cristiano", en "Algunos hitos del ideal igualitario”, Ed. Nau Llibres, Valencia, año1997, páginas.25 a 32; MONCHO PASCUAL, J. R., "Recepción de la igualdad moderno-burguesa", en "Algunos hitos del ideal igualitario", Ed. Nau Llibres, Valencia, año 1997, páginas 35-64; MONCHO PASCUAL, J. R., "Reservas a la igualdad burguesa", en “Algunos hitos del ideal igualitario,”, Ed. Nau Llibres, Valencia, año 1997, páginas.67 a 93.

148 BALAGUER, F. “Fuentes del Derecho”, Ed. Tecnos, Madrid, año 1991, páginas 20 y siguientes. Este autor destaca que la ley soporta un juicio de racionalidad que conviene a todo el proceso de generalización de derechos de abstención, con que los revolucionarios afianzaron su carácter de clase frente al Estado. Este juicio la erige como garante de igualdad, frente a la costumbre de desigualdad.

149 MARTÍNEZ TAPIA, R. "Igualdad y razonabilidad en la justicia constitucional española”. Servicio de Publicaciones de la Universidad de Almería, año 2000. Página 79. Marca tres etapas sobre la evolución de la jurisprudencia del TC en el concepto de igualdad. Primero lo niega como tal derecho fundamental en las SSTC 4 y 22 de 1981 y 76/1983, donde exige la vinculación de la igualdad a cualquier otro derecho fundamental. El segundo paso sería su consideración como relacional, en las STC 157/1997, para finalmente admitir su autonomía en una tercera etapa. 
operadores jurídicos, que han de conducirse en todo momento sin producir un trato discriminatorio en la interpretación y en la aplicación de la igualdad.

Si la igualdad inspira y condiciona la creación de la ley, también representa por ello, un modelo de sistema jurídico, lo que permite a través de ella considerar un determinado modelo de Estado, lo que a su vez presenta una gran influencia en la conceptualización de la familia y del derecho que regula sus roles, atribuciones, potestades y relaciones, hasta tal punto de procurar una igualdad total en relación a cada uno de sus miembros, pero no se detiene aquí el intento, sino antes comprende al matrimonio y todas aquellas uniones de facto afines con él, de alguna manera la visión que se tenga sobre el Estado y el principio de igualdad que lo sustenta es la visión que se tiene de la familia ${ }^{150}$.

Volviendo a la idea que se enunciaba, en realidad, el establecimiento de un derecho de igualdad como derecho fundamental directamente aplicable, produce una transformación en el sistema de fuentes el Derecho, que reduce de manera importante el valor de la ley, fundamentalmente en la tradicional consideración jerárquica de la ley, aunque esto es aún una situación más profunda, puede hablarse incluso de la constitucionalización del Derecho, y lo que hasta hace poco se entendía por él de la ley. De ahí el valor de la argumentación que se instala como garantía constitucional, o más bien, exigencia de tal naturaleza, no solamente desde la oposición garantista del art. $24 \mathrm{CE}$, sino también como una exigencia formal de motivación del art. $120 \mathrm{CE}$, de hecho las constituciones principialistas asumen la función de modelar el conjunto de la vida social, pero no como un contrato, porque no hay voluntad originaria de las partes, sino con cierta versatilidad, donde adquiere una posición central la argumentación ${ }^{151}$.

Como derecho fundamental se ha venido considerando por la doctrina que el art. 14 contiene un mandato de igualdad formal que se complementa en cierto modo con un concepto material de igualdad regulado en el art. 9.2 $2^{152}$. La pregunta que se formula entonces ¿Cómo tal mandato influye

150 Cfr. RODRIGUEZ RUIZ, B. “Matrimonio, Género y Familia en la Constitución Española” en Revista Española de Estudios constitucionales, Centro de Estudios Políticos y Constitucionales. № 91, año 31, Madrid, año 2011, páginas 69 a 102. "La concepción social y jurídica de la familia en nuestro país está evolucionando en un sentido que pone en cuestión las premisas de género sobre las que se asienta la familia nuclear moderna. Dicha evolución tiene como trasfondo la constitucionalización del principio de igualdad y de la obligación de los poderes públicos de perseguirla activamente, así como la desvinculación de la protección constitucional de familia y matrimonio. Aunque en principio nuestros operadores jurídicos asumen este marco constitucional, no siempre hacen valer con coherencia su potencial transformador de la familia y de las relaciones entre los sexos dentro de ella. Este artículo defiende la importancia de asumir dicho potencial frente a las inercias que perpetúan la construcción moderna del género."

151 PRIETO SANCHÍS. “Justicia constitucional y derechos fundamentales”, Ed. Trotta, Madrid, año2003, página $122-133$.

152 APARICIO, M. A. “El Estado social en la jurisprudencia del TC”, en Estudios sobre el Estado Social. Ed. Tecnos, Madrid, año 1993. Página 61. 
en el Derecho de familia? En palabras de RODRIGUEZ RUIZ ${ }^{153} \operatorname{los}$ artículos $9.2,14$ y sobre todo $32 \mathrm{CE}$ obligan a redefinir las relaciones conyugales heredadas del ordenamiento preconstitucional y, con ellas, el modelo clásico de familia nuclear, es decir lo transforman. Los tres preceptos están en la base de las profundas reformas operadas en este terreno en casi todos los sectores del ordenamiento jurídico, reformas que incluyen medidas tanto de introducción de la igualdad formal como de acción afirmativa, y cuyo objetivo es redefinir las relaciones familiares para eliminar, con mejor o peor fortuna ${ }^{154}$, la subordinación estructural de las mujeres.

La autora recién citada argumenta que pese a las medidas destinadas a introducir la igualdad entre mujeres y varones en el ámbito del matrimonio, ha sido tanto el tiempo en que los roles tradicionales se han ido desenvolviendo en la sociedad que la legislación española sigue asumiendo los parámetros estructurales de género que informan la familia nuclear moderna, perpetuando en el imaginario social y en el jurídico la simbología del varón como cabeza de familia y de la mujer como ser fundamentalmente doméstico, contribuyendo a retroalimentar perjuicios de género y propiciando que estos sigan impregnando el ordenamiento, notablemente a través de la interpretación de conceptos jurídicos indeterminados ${ }^{155}$. Resulta así elocuente que la obligación de los cónyuges de compartir las responsabilidades domésticas y de cuidado de dependientes a su cargo (art. 68 CC) se introdujera en el ordenamiento en un momento en que la desaparición de las causas de divorcio convertía su incumplimiento en jurídicamente irrelevante (Ley 15/2005, de 8 de julio). Asimismo destaco la resistencia a abandonar la preferencia del apellido a favor de algún criterio neutro de determinación del orden de apellidos en caso de desacuerdo entre madre y padre -o, entre madres y padres en caso de parejas del mismo sexo. Así como la preferencia de que el apellido paterno, mantenido incluso en el contexto de los matrimonios del mismo sexo, regulados por la Ley 13/2005, de 1 de julio. En efecto, el artículo $68 \mathrm{CC}$ es el único en que dicha ley no sustituyó las palabras madre o padre por el termino progenitor.

Sin duda desde una perspectiva de género se puede llegar a subvertir el efecto que la inclusión de las parejas de hecho en la institución matrimonial puede tener de cara a la desconstrucción del género, que no es otro que el cuestionar, o al menos quitarle el velo a los fundamentos de la familia

153 “Matrimonio, Género y Familia en la Constitución Española”, ...op. cit., página 73 a 75.

154 Para una crítica de las políticas de acción afirmativa a favor de las mujeres en el Derecho Penal, como forjadoras de un "paternalismo punitivo" del Estado, vid. RODRIGUEZ ESCANCIANO, en el ámbito del Derecho Laboral; CUBERO TRUYO y JIMENEZ NAVAS, en el Derecho Financiero; VALPUESTA FERNÁNDEZ y VIVAS TESÓN en el civil.

155 Es enorme la importancia de los códigos simbólicos que rigen las relaciones entre sexos. Prueba de ello es la po lémica suscitada por una cuestión aparentemente tan banal como la preferencia del varón en el orden sucesorio a los títulos nobiliarios (vid. STC 126/1997, de 3 de julio; Ley 33/2006, de 30 de octubre, sobre igualdad del hombre y la mujer en el orden de sucesión de los títulos nobiliarios). 
nuclear moderna clásica. En efecto permitir a las parejas del mismo sexo el acceso a la institución matrimonial equivale a permitir la formación de unidades familiares matrimoniales cuya dinámica relacional se desenvuelve al margen de la construcción moderna del género, y de modelo alguno de distribución de roles, o cuanto menos les priva de su prerrogativa como modelo de organización social. Todo ello desde dentro de la propia institución matrimonial, mediante la equiparación del estatus jurídico y social de las parejas del mismo sexo al de los matrimonios de sexos distinto, tanto más cuanto mayor es su equiparación en derechos.

En términos de igualdad el art. 9.2 responde a las exigencias de la igualdad material, en tanto que el art. 14 configura un derecho formal ${ }^{156}$. La igualdad material ${ }^{157}$ responde a una exigencia del Estado social, en tanto que la igualdad formal mantiene una exigencia puramente negativa, de limitación al legislador de aquel liberal impedimento de los privilegios ${ }^{158}$. Sin embargo, este concepto de igualdad no responde al contenido del art. 14.

Tal como se esgrimió, el derecho fundamental a la igualdad tiene un contenido esencial propio, con independencia de su carácter relacional, lo que le exige un mínimo contenido material. El art. 14 no es un derecho de configuración formal, con independencia de las conexiones que puedan establecerse con el mandato de igualdad material. Es importante tener en cuenta que el art. 14 regula materialmente un ámbito de la igualdad, en tanto que el art. 24 configura la igualdad del proceso (SSTC 49/1985 y 58/1986). De ahí que pudiera decirse mejor que el art. 24 contiene el derecho a una igualdad formal, en tanto que el art. 14 responde a un derecho material de igualdad ${ }^{159}$.

156 El TC ha entendido la igualdad material desde el contenido del art. 14y la igualdad formal la ha residenciado en el art. 24. (SSTC núms. 49/1985 y 58/1986).

157 LUJAN ALCARAZ, J. “ La protección de las familias numerosas desde la perspectiva del Derecho del Trabajo y la Seguridad Social”, Aranzadi Social no 19/2005, parte Tribuna, Aranzadi S.A., Pamplona, año 2006: “La consideración, tomada de la exposición de motivos que acompaña a la Ley 40/2003, de 19 diciembre, es reveladora y fundamental. El principio diferenciador que inspira la regulación legal de la " protección social, económica y jurídica de la familia (numerosa)» estriba para el legislador en el dato económico de los mayores gastos que la atención de esta clase de familias comporta. Y es que, como aquellas «circunstancias pueden implicar una diferencia sustancial con el nivel de vida de otras familias con menos hijos o sin ellos», habrá que tener en cuenta que el art. 9.2 CE «establece el principio de igualdad material, que debe llevar al legislador a introducir las medidas correctoras necesarias para que los miembros de las familias numerosas no queden en situación de desventaja en lo que se refiere al acceso a los bienes económicos, culturales y sociales».

158 Para PRIETO SANCHÍS, la igualdad formal permite al TC actuar como legislador negativo al limitarse a declarar la inconstitucional de una ley por discontinuidad con el art. 14. Sin embargo, la igualdad material requiere operaciones de mayor alcance, en cuanto el TC ha de crear normalmente una norma de vinculación, creando así un derecho que exorbita un tanto sus competencias. En "Los derechos sociales y el principio de igualdad sustancial". op. cit., pagina 33.

159 STC núm. 49/1985, de 28 de marzo, RTC 1985/49. "Precisado lo anterior, la cuestión que hemos de resolver consiste en si al actuar asi el Magistrado ha vulnerado el derecho de igualdad. El problema se enmarca en la confrontación entre las exigencias derivadas del mandato de tratamiento igual en los supuestos iguales, y las deducibles de los principios de independencia y autonomía judicial y de sujeción exclusiva del Juez a la legalidad. De estos últimos deriva la imposibilidad de exigir del juzgador un mantenimiento indefinido de sus propios precedentes. De un lado, la propia dinámica jurídica que se manifiesta no sólo en la modificación normativa, sino 
Hasta aquí las referencias a la igualdad, mientras, pero ¿y la familia? La familia es una dimensión básica de la persona, tal cual ya se ha manifestado anteriormente, posiblemente la más inmediata y esencial para el desarrollo humano, sin perjuicio de su pluralidad ${ }^{160}$. La familia es siempre un organismo o comunidad de personas de carácter afectivo no siempre estable, donde unas están al servicio de otras, unidas por lazos de sangre, adopción o afectividad. Es el criterio que con buen sentido acoge recientemente el art. 231-1.1 del Libro segundo del Código Civil de Cataluña: "la familia goza de la protección jurídica determinada por la ley, que ampara sin discriminación las relaciones familiares derivadas del matrimonio o de la convivencia estable de pareja y las familias formadas por un progenitor solo con sus descendientes.- Tienen también la consideración de fami-

también en una razonable evolución en la interpretación y aplicación de la legalidad (STC 63/1984, de 21 de mayo) fundamenta la libertad de cada órgano judicial para modificar sus propios criterios; libertad que, además, no puede ser controlada por este Tribunal en el recurso de amparo en la medida en que no incida en la vulneración de derechos fundamentales, pues es al Juez al que la Constitución reconoce la potestad exclusiva de juzgar. De otro, la posibilidad de modificar el criterio previamente adoptado constituye incluso exigencia ineludible de la propia función judicial cuando aquél se considera posteriormente erróneo, pues el Juez está sujeto a la Ley y no al precedente y está obligado por mandato constitucional a aplicar aquélla, es decir, el sentido de la misma que reconozca como ajustado en el momento de juzgar. Existiendo, en consecuencia, no sólo la facultad de modificación del criterio previo, sino incluso la necesidad de hacerlo cuando se alteren las circunstancias o cambie el propio pensamiento al respecto, es claro que el significado del principio de igualdad en la aplicación de la Ley va a ofrecer un sentido muy diferente del correspondiente al principio de igualdad ante la Ley; mientras éste último es de carácter material y pretende garantizar la identidad de trato de los iguales, aquél es predominantemente formal. Lo que el principio de igualdad en la aplicación de la Ley exige no es tanto que la Ley reciba siempre la misma interpretación a efectos de que los sujetos a los que se aplique resulten siempre idénticamente afectados, sino que no se emitan pronunciamientos arbitrarios por incurrir en desigualdad no justificada en un cambio de criterio que pueda reconocerse como tal, es decir, como solución genérica conscientemente diferenciada de la que anteriormente se venía manteniendo y no como respuesta individualizada al concreto supuesto planteado (S. 63/1984). Basta, pues, que exista dicho cambio de criterio para que la Sentencia, que sigue estableciendo un pronunciamiento desigual, no incurra en inconstitucionalidad.. - Pero, en segundo lugar, no parece que sea necesario siquiera en todos los casos, que la justificación del cambio de criterio se exprese formalmente, pues lo trascendente para evitar la vulneración del principio de igualdad es la existencia del cambio mismo y no su exteriorización. No es dudoso, afirman las Sentencias 63 y 64/1984, de 21 de mayo, que la estricta aplicación de la Constitución exige que el cambio de criterio aparezca suficientemente motivado mediante la expresa referencia al criterio anterior y la aportación de las razones que justifican el apartamiento de los precedentes, pues ello constituye una garantía tanto de la evitación de la arbitrariedad como de la promoción de la seguridad jurídica que exige que los ciudadanos estén razonablemente seguros acerca de la correcta interpretación de la legalidad y puedan ajustar a ella su comportamiento. No obstante, como siguen diciendo las mencionadas Sentencias, no siempre que falta la motivación expresa del cambio de criterio ha de entenderse sin más quebrado el principio de igualdad en la aplicación de la Ley. Puede haber casos en los que de la propia lógica interna de la resolución, o de datos externos a ella como podría ser la innovación de la jurisprudencia del órgano jurisdiccional superior del mismo orden en el que esté inserto el juzgador del caso, pueda inferirse con certeza, o, al menos con relativa seguridad, que el cambio objetivamente perceptible es consciente, y que de él queda excluida tanto la arbitrariedad como la inadvertencia. Bien entendido que, como lo naturalmente exigible es la motivación expresa, la tácita sólo podrá admitirse cuando se de respecto a ella ese alto grado de certeza antes evocado."

160 GARCIA CANTERO, G. “¿Unidad o pluralidad de modelos matrimoniales?” en “Modelos de Matrimonio y de Derecho de Familia en el siglo XXI”, en "Homenaje al Profesor Manuel Cuadrado Iglesias”, Tomo I, Servicios de Publicaciones de la Universidad de Zaragoza, Ed. Aranzadi, Pamplona, año 2008, páginas 589 y 590 . Este autor sostiene que otros autores han hecho de la pluralidad de modelos familiares un dogma o principio del Derecho de familia, lo que merece ulterior revisión. 
lias los hijos de cada progenitor que convivan en el mismo núcleo familiar como consecuencia de la restitución familiar" (Art. 231-1-2).

La familia, como unidad básica de la sociedad, es la estructura mejor adaptada para proveer a las personas de estabilidad, racionalidad, libertad y realización personal ${ }^{161}$. No obstante su magnitud jurídica, no es sujeto autónomo de relaciones jurídicas, centro de imputación per se de derechos y obligaciones. La familia no tiene un nombre específico, ni una nacionalidad o vecindad propia, no es sujeto obligado al pago de impuestos, ni de ninguna obligación, o susceptible de concurso como deudor insolvente. Tales derechos o deberes se predican de las personas que forman el organismo o son titulares del patrimonio familiar ${ }^{162}$.

La familia no tiene su razón de ser en ella misma, circunstancia que justificaría su personalización sino en las funciones y servicios que presta a sus componentes, en cuanto personas físicas unidas entre sí por lazos de sangre, afectos o por vínculos jurídicos. La familia, no es un fin en sí misma, pero si un status consortialis al servicio de la persona ${ }^{163}$. El ser humano y su desarrollo son el verdadero fin al que sirve admirablemente la organización familiar. Por eso, la sabiduría jurídica romana habló no de personae familiae sino de status familiae como posición o situación en un organismo familiar, como vínculo que liga a cada miembro con el agregado familiar.

Los llamados "derechos familiares" van referidos a los miembros de la familia en razón de su posición familiar. Podemos decir para entender, conscientes del grado de abstracción implícito, que la familia jurídicamente es una comunidad de personas unidas por lazos íntimos matrimoniales, paraconyugales (unión heterosexual u homosexual de pareja), afectivos y paterno-filiales (familia cognaticia o nuclear), o por lazos de parentesco y afectividad (familia agnaticia, amplia o consanguínea), sobre la que el Derecho se proyecta en un entramado o red de múltiples relaciones jurídicas.

161 Conferencia Europea de Ministros responsables de Asuntos Familiares, número 11, Estrasburgo, 22 de mayo 1987. Con razón puso de relieve LEVI-STRAUSS, C., que la sociedad pertenece al reino de la cultura mientras que la familia es la emanación, al nivel social, de aquellos requisitos naturales sin los cuales no podría existir la sociedad y, en consecuencia, tampoco la humanidad.

162 IZQUIERDO TOLSADA, M. y CUENA CASAS, M. (Dirts.) en su “Tratado de Derecho de la Familia, Volumen I, Derecho de Familia y Derecho de la familia. La relación jurídico-familiar. El matrimonio y su celebración”. Ed. Aranzadi Thomson Reuters, Pamplona, año 2011, página 58. La tesis que admitió la personalidad jurídica de la familia es bastante antigua. La defendió FIORENTINO (Le persone morali nel diritto civile italiano, Catania, año 1892, páginas 30 y siguientes. Fue criticada por ROCCO (L'oggetto del reato e della tutela giuridica penale, Milano-Torino-Roma, año 1913) pues los intereses familiares no originan derechos subjetivos imputables a la familia como personalidad colectiva frente a los miembros que la componen o frente a los extraños, sino derechos subjetivos-deberes de los singulares integrantes del corpus familiar frente a los restantes. En la misma dirección excluyente de la personalidad jurídica de la familia, FERRARA (Le persone giuridiche, Torino , año 1938, página 80). CICU, por su parte, se opone a la personalidad jurídica de la familia, pero le otorga una estructura orgánica dotada de una organización y de una voluntad familiar, por la que al faltar en las relaciones familiares por esa misma constitución orgánica la libertad e independencia el Derecho de familia se aproxima al Derecho público.

IZQUIERDO TOLSADA, M. y CUENA CASAS, M. (Dirts.), ibídem, página 59. 
Sociedad o comunidad de personas, institución jurídica u organismo son expresiones para indicar que la familia no es per se un centro de imputación normativa o una categoría jurídica autónoma, sino un agregado de personas unidas por lazos conyugales, de sangre y afectivos sobre las que el Ordenamiento jurídico proyecta una regulación normativa, que conforma su integración social ${ }^{164}$.

Cuando se afirma que la familia posee unos derechos propios que son inalienables ${ }^{165}$, se quiere decir que los miembros de la familia, en cuanto personas integradas en un organismo ético y cultural, se hacen acreedores por si mismos a la tutela del Derecho y ostentan derechos subjetivos que el

164 STC núm. 69/2007, de 16 abril, RTC 2007/69. En este interesante fallo el voto particular alude a que el ordenamiento jurídico debe amparar el derecho a contraer matrimonio según las costumbres propias de la minoría a la cual se pertenece. "Por otra parte, la integración y el reconocimiento de derechos de las minorías es una de las prioridades del Consejo de Europa... En toda sociedad pluralista y genuinamente democrática no sólo se debe respetar la identidad étnica, cultural, lingüistica y religiosa de cada persona perteneciente a una minoría, sino también crear las condiciones apropiadas que permitan expresar, preservar y desarrollar esa identidad, con el único límite —obligado- del «orden público constitucional». Sin embargo, la jurisprudencia de este Tribunal no se ha ocupado hasta ahora de la protección de los usos, prácticas o costumbres de una etnia o colectividad caracterizada, o cuándo la no consideración como válidos o susceptibles de protección constitucional de los actos realizados por personas pertenecientes a minorías que reclaman respeto por su tradición cultural debe entenderse discriminatoria. Este Tribunal se ha limitado a afirmar que, desde una perspectiva constitucional, los individuos pueden serlo también como parte de grupos humanos sin personalidad jurídica, pero con una neta y consistente personalidad constituida por cualquier otro rango dominante de su estructura y cohesión, como el histórico, el sociológico, el étnico o el religioso, el carácter odioso de la discriminación racial contra el pueblo gitano como perversión jurídica que rechazamos rotundamente... bajo el manto protector de la libertad ideológica o de la libertad de expresión (art. 20 CE) puedan cobijarse manifestaciones, expresiones o compañas de carácter racista o xenófobo y que tal rechazo absoluto es predicable también de aquellas conductas que, proyectadas sobre un solo individuo encuentra su motivación en la pertenencia de éste a un determinado grupo racial, étnico, o religioso (F. 8 y fallo). La situación que se ha planteado en este recurso de amparo muestra, y además por primera vez en nuestra jurisprudencia, que la protección de las minorías tiene una envergadura constitucional mucho más rica y compleja que la que resulta de estas escuetas declaraciones o de la respuesta que ha recibido doña María Luisa en este recurso de amparo. No hubiera sido necesario que doña María Luisa se vea obligada a recurrir a instancias supranacionales para obtener la protección que reclama. En los supuestos de protección de minorías étnicas, la consecución de la igualdad exige, a mi juicio, medidas de discriminación positiva a favor de la minoría desfavorecida y que se respete, con una sensibilidad adecuada, el valor subjetivo que una persona que integra esa minoría muestra, y exige, por el respeto a sus tradiciones y a su herencia e identidad cultural.... La aplicación del principio de igualdad de trato de las personas independientemente de su origen racial o étnico - que consideró aplicable a favor de doña María Luisa la Sentencia del Juzgado de lo Social de Madrid - afecta a la protección social de las personas, incluida en forma precisa la Seguridad Social y la asis tencia sanitaria (art. 3.1.e). Conforme a dicha Directiva es necesario reconocer que existe discriminación indirecta cuando una disposición, criterio o práctica aparentemente neutros sitúe a personas de un origen racial o étnico concreto en desventaja particular respecto a otras personas (art. 2.1.b). Los gitanos españoles constituyen un grupo étnico formado por más de medio millón de personas, que se asentaron en España hace 500 años. El legislador español se refería ya a la familia gitana como un mero hecho en la Pragmática de Medina del Campo del año 1499 (Ley 1 del Título XVI, Libro XII de la Novísima Recopilación), bastantes siglos antes de que apareciese en nuestro ordenamiento jurídico «la forma de acceso civil al vínculo matrimonial» «de escrupulosa neutralidad desde el punto de vista racial», a que les remite el fundamento jurídico 4 de la Sentencia de la mayoría.No basta, en mi opinión, la «escrupulosa neutralidad» de una norma cuando la realidad que se enfrenta ante ella es la de una persona que, como doña María Luisa, pertenece a una minoría étnica que se queja de la injusta igualación de su situación matrimonial gitana, nacida en la buena fe, conforme a las normas ancestrales de su raza y a la conducta correspondiente a los miembros de su etnia con la situación - dice- de una pareja de hecho o de una convivencia more uxorio . Es deseable que la intervención del legislador respecto de estas parejas pueda cubrir en un futuro próximo la situación de la recurrente, pero su queja era, y es, muy distinta: La de obtener protección y respeto para su identidad cultural, sin que existan en el caso problemas de consentimiento, dignidad femenina o prueba que pudieran ser cuestionados desde la perspectiva de lo que he denomina- 
ordenamiento explícita, reconoce y garantiza. Eso significa que la familia es una institución jurídica: sus miembros, en calidad de personas familiares, tienen asegurada la protección jurídica de sus pretensiones, la regulación de sus derechos de estado. Como cónyuges, como hijos, como padres, como unidos por un sentimiento estable, etc ${ }^{166}$.

Una larga historia va fraguando el estatuto jurídico de la familia desde el Derecho romano hasta las constituciones, los códigos civiles, leyes especiales modernas, textos y declaraciones universales e internacionales de nuestro tiempo. Un breve estudio a través de los siglos pone de relieve la significación jurídica de la familia, hasta llegar a la evidencia en los tiempos modernos de que los derechos de la familia, o mejor, de sus miembros son inviolables. Con todo la última palabra la tiene la Constitución y el resto del Ordenamiento jurídico, que reconoce y tutela los derechos de los miembros de la familia; los poderes públicos (art. $39 \mathrm{CE}$ ), la práctica judicial (art. 53.3 CE).

Ante esto, puede afirmase que el llamado Derecho objetivo impregna de juridicidad a la familia, que si bien es una institución jurídica, es primariamente una sociedad de personas vivificada por la sangre, los afectos y la ayuda mutua. Los llamados derechos inalienables de la familia, en palabras de VALLADARES RASCÓN, tienen que ser reconocidos y garantizados por el ordenamiento jurídico nacional e internacional. El derecho más elemental y embrionario, génesis de los demás derechos familiares, como es el derecho a contraer matrimonio y fundar una familia, tiene que ser normalmente reconocido (art. 16 DUDH, art. 32 CE, art. 44 CC) y así adquirir efectividad ${ }^{167}$.

Como bien se sabe el art. 9 de la Carta de los Derechos Fundamentales de la Unión Europea se refiere al derecho a contraer matrimonio y a fundar una familia. Este derecho es un derecho clásico que forma parte de la tradición jurídica occidental. Este art. 9 reproduce el art. 12 del Convenio Europeo de Derechos Humanos, introduciendo algunas modificaciones de redacción para adaptar este derecho a las exigencias de los nuevos tiempos y acoger la posibilidad de que el estatuto matri-

do orden público constitucional."

165 Así en la "Carta de los Derechos de la familia”, ciudad el Vaticano, año 1983, Preámbulo D) in fine. A veces puede existir la sensación de que determinadas enseñanzas pueden llevar hacia la personificación de la familia. Así, la STC de 31 de octubre de 1986 (RTC 1986, 135), que concede el amparo a la esposa entendiendo que ambos cónyuges tenían atribuido el contrato de arrendamiento de la vivienda familiar, afirma ex, arts, 96 y $1320 \mathrm{CC}$ que "estas normas responden a la moderna tónica legal de protección del interés común familiar, que viene a configurar a la familia como sujeto colectivo, como titular comunitario".

166 IZQUIERDO TOLSADA, M. y CUENA CASAS, M. (Directores), "Tratado de Derecho de la Familia, Volumen I, Derecho de Familia y Derecho de la familia. La relación jurídico-familiar. El matrimonio y su celebración” ... op. cit., página 59.

167 “El Derecho a contraer matrimonio y la Constitución”, Aranzadi Civil-Mercantil, no 9, parte Estudio, Ed. Aranzadi S.A., Pamplona, año 2005. En dicho artículo la autora se enmarca en una visión positivista del derecho en cuestión, pero que resulta interesante por cuanto se refiere a las restricciones del mismo como antagónicas de la autonomía de la voluntad y y de los derechos fundamentales, propios del constitucionalismo actual. 
monial pueda extenderse a la unión de personas del mismo sexo en los Estados miembros que lo deseen, tal cual es el caso español, pero sin imponerlo.

En tal sentido desde el primer momento quedó claro en el seno de la Convención que la Carta de derechos debería contener este derecho. Sin embargo, durante el proceso de elaboración de la Carta se produjo cierta controversia ${ }^{168}$. La redacción dada finalmente a la Carta recoge de manera escueta una garantía del "derecho a contraer matrimonio y el derecho a fundar un familia según las leyes nacionales que rijan el ejercicio de este derecho”. El art. 9 reproduce el art. $12 \mathrm{CEDH}$, pero lo moderniza, eliminando en primer lugar la edad mínima para contraer matrimonio y formar una familia, y en segundo lugar, lo que a mi juicio es más importante elimina la referencia específica al hombre y a la mujer en cuanto al matrimonio, regulándolo en abstracto, así como remitiéndolo a las diversas legislaciones nacionales. En resumidas cuentas ni prohibió ni obligó a que los Estados regulasen sobre la admisibilidad o no de los matrimonios entre personas del mismo sexo ${ }^{169}$.

Lo mismo acontece con los derechos familiares en general, claramente reflejados en los textos positivos. Porque la familia en su perspectiva jurídica ha adquirido consistencia y tutela en la medida en que el Derecho positivo, los poderes constituidos y la actuación judicial han otorgado realización a las pretensiones jurídicas familiares manifestadas en cada momento histórico. No olvidemos, con todo, que los derechos familiares son, en principio, hechura que se inicia en la segunda mitad del siglo XIX y se va conformando en los últimos ciento diez años. Salvo las estrictas normas civiles, la familia vivió durante siglos desprovista de tutela efectiva: en realidad era una parva res publica, un pequeño Estado que se gobernaba económica, política y jurídicamente, lo gobernaba el pater familia desde fuera (potestas) y, en gran medida, la mujer desde dentro (gestión doméstica). Un largo laisse faire se proyectó durante siglos sobre la familia, entidad con vida propia y actividad económica autosuficiente, regida por el ius civile y hasta tiempos recientes por los viejos códigos liberales $^{170}$. Sin perjuicio de la tutela jurídica permanente de la Iglesia, que absorbió durante siglos la

168 La lista originaria de derechos que presentó el Praesidium (CHARTE 4123/00 REV 1 CONV 5, de 15 de febrero de 2000, art. 9) únicamente contenía el derecho a fundar una familia y la exigencia de garantías de protección jurídica, económica y social. En la sesión del Pleno de la Convención de 2 y 3 de marzo se discutió profusamente sobre el alcance que debía de tener este derecho, y más en concreto sobre el propio concepto de familia, ya que resultan patentes las enormes diferencias que existen entre los diversos ordenamientos. Sugieron aspectos como si el concepto deberia incluir también a los hijos o a las personas del mismo sexo, poco a poco la redacción se fue acercando al tenor literal del art. 12 de la CEDH.

169 MARTÍN Y PÉREZ DE NANCLARES, J. M. “Art. 9. Derecho a contraer matrimonio y derecho a fundar una familia”, MANGAS MARTÍN, A. (Dir.) "Carta de los Derechos Fundamentales de la Unión Europea”, Fundación BBVA, Bilbao, año 2008, página 244 y siguientes.

170 Quizás debiéramos comenzar por decir, en lugar de la familia, las familias, en plural, como viene reconociendo la jurisprudencia tanto constitucional como casacional. El concepto de familia, como el de otras instituciones comunes, a fuerza de ser reconocida, resulta de difícil precisión. En este sentido resulta interesante la posición de LA CRUZ para quien el obtener un concepto de familia es una tarea en la que se debe recurrir a lo que como tal con- 
disciplina del matrimonio e influyó cardinalmente en la regulación de las relaciones paterno-filia$\operatorname{les}^{171}$.

La organización política pre estatal, o los Estados modernos a partir del Renacimiento incluidos los de buena parte del siglo XIX, vivieron de espaldas a la familia desde el aspecto normativo y tutelar, por ello si bien en tales tiempos no se era consciente de un principio de igualdad, tampoco interesaba mucho a los diversos tipos de Legisladores, Rey, Consejo, Asamblea, las necesidades y requerimientos del grupo familiar. Se entendía que la familia era un organismo consistente, capaz de vivir por si mismo, perenne gozador de buena salud.

Sin embargo, los textos internacionales del siglo XX y las grandes constituciones del Estado social de Derecho han evidenciado el gran error subyacente en tal concepción: la familia, como toda realidad humana, es un ente frágil, el cual merece la plena tutela del Ordenamiento jurídico, y por consiguiente de su directriz de igualdad. Derecho, Estado y familia se han compenetrado profundamente, esto ha provocado más seguridad y confianza ${ }^{172}$, sin perjuicio de que la familia se ha convertido en una institución profundamente afectada por el Derecho, regulada jurídicamente con profusión normativa. El Derecho de Familia hoy goza de una normativa muy basta y amplia. Ahora bien, esto no quiere decir que necesariamente se le proteja más, es decir más normas no implica necesariamente más protección.

Al referirse a la protección social de la familia nos referimos a ella, tal cual se ha afirmado, como grupo social, como institución básica de la sociedad donde los individuos desarrollan su personalidad y ejercen derechos individuales. Pero también a la protección que merecen desde el punto de vista del Estado social de Derecho, y por tanto, en cuanto grupo necesitado de la protección solidaria del Estado que tiene la obligación de procurar que la igualdad de los individuos y de los grupos en que se integran sean reales. Por tanto, el reconocimiento social implica considerar la existencia del propio grupo, independiente del modelo de que se trate, esta independencia implica necesariamente una igualdad en su protección, se deben eliminar los obstáculos que impidan a los

sidera la gente o las concepciones jurídicas de cada momento: a la representación normativa del instituto. Así la familia aparece en la Historia y en la actualidad como una comunidad, que creada en principio por el matrimonio, está compuesta al menos por progenitores y por procreados, es decir, le antecede un Derecho a contraer tal matrimonio. Pero el qué sucede con respecto a las relaciones de hecho, se sabe que existe un derecho a iniciarlas. Con ello se entiende que la familia es más bien una cuestión de hecho o de Derecho. Pero que siempre será una cuestión que antecede al Derecho.

171 Las sociedades occidentales imbuidas de relativismo, consumistas y atrapadas por el crecimiento ilimitado de la técnica, apoyan en gran medida los valores jurídicos familiares en criterios puramente antropológicos y hedonis tas, sin referencias a instancias éticas superiores. Es la familia del placer y la libertad, sin las ataduras de la responsabilidad.

172 IZQUIERDO TOLSADA, M. y CUENA CASAS, M. (Dirts.), Tratado de Derecho de la Familia, Volumen I, Derecho de Familia y Derecho de la familia. La relación jurídico-familiar. El matrimonio y su celebración”,...op. cit., página 61 . 
ciudadanos formar grupos familiares en igualdad de condiciones. Consecuencia de ello es la protección económica que debe presentar el Estado a los diversos modelos de familia, lo cual se traduce en desgravaciones fiscales, ayudas, subvenciones, etc $^{173}$.

MATA SIERRA $^{174}$, sobre esto último ha señalado que el Tribunal Constitucional ha tenido ocasión de pronunciarse en lo que se refiere al cumplimiento del principio de igualdad en la ley respecto a las modalidades de tributación conjunta contempladas en el art. 87 de la Ley 19/1991. La primera, integrada por los cónyuges no separados legalmente, los hijos menores, con excepción de los que con el consentimiento de los padres, vivan independientes y los hijos mayores de edad incapacitados judicialmente y sujetos a patria potestad, por lo que engloba los supuestos en los que existe un vínculo matrimonial, con independencia de que los cónyuges tengan o no hijos menores a su cargo y; la segunda formada por el padre o madre y todos los hijos menores que convivan con uno o con otro y reúnan todos los requisitos anteriores que abarca los supuestos de las familias monoparentales, esto es, las formadas por el padre o la madre con sus hijos, con independencia de que éstos hayan sido adoptados, sean el fruto de una anterior relación matrimonial o hayan sido concebidos fuera el matrimonio.

La autora en cuestión sostiene que el Derecho tributario no puede permanecer al margen ni de la evolución sufrida por el concepto de familia en los últimos años, ni de la política de no discriminación por razón de género que, junto con la búsqueda de la simplificación de la gestión del impuesto reconoce el propio legislador en la Ley 35/2006, de 28 de noviembre, de hecho "podrán justificar su revisión", no obstante también reconoce que "se mantiene su tratamiento actual en el

173 El Tribunal Constitucional manifestó que la "unidad familiar" en el Impuesto sobre la renta de las Personas Físicas, tal como se reguló en las leyes del impuesto 44/1978 y 48/1985, resultaba discriminatoria en cuanto que STC, Pleno, núm. 45/1989, de 20 de febrero. RTC 1989/45: “... la forzada inclusión de varios sujetos en una unidad tributaria para sujetarlos conjuntamente a un impuesto de naturaleza personal no puede ser arbitraria, pues de otro modo lesionaría, ya por eso, el principio de igualdad... como correlato lógico de un tributo personal y directo sobre la renta de las personas físicas es la imposición separada, esto es, la sujeción separada del impuesto de cada una de ellas, la sujeción conjunta que implica en si misma un trato diferenciado, sólo es constitucionalmente admisible en la medida en la que esté fundada es una razón que sea congruente con el fin de la norma, esto es, en el caso que aquí nos ocupa, en la razón de que esta sujeción conjunta es necesaria o al menos conveniente para determinar la renta de los distintos sujetos". A este tenor, una exigencia derivada del principio de igualdad tributaria en la ley es: "que la sujeción conjunta no incremente la carga tributaria que, con arreglo a las normas generales, le correspondería cada uno de los sujetos pasivos integrados en la unidad tributaria de acuerdo con su propia capacidad económica, de manera que la sujeción conjunta ni actúe como un factor que agrave la obligación propia de cada uno de estos sujetos en relación con la que tendrían si, con la misma capacidad económica, la imposición fuese separada. Dada la existencia de una cuota única que la sujeción conjunta comporta, esta limitación puede concretarse en la afirmación de que tal cuota única no puede exceder en su cuantía de la que resultaría de adicionar las cuotas separadas que corresponderían a cada uno de los sujetos pasivos, aunque, como es obvio, si puede ser menor si el legislador emplea también este instrumento de la sujeción conjunta, como es casi inexcusable, para cumplir la obligación de proteger la familia que le impone el art. 39.1 de la Constitución".

174 MATA SIERRA, Ma. T. “El principio de igualdad tributaria”, Ed. Thomson Reuters, Cizur Menor, año 2009, páginas 98 a 102 . 
impuesto para evitar numerosos perjudicados en los matrimonios en los que alguno de sus miembros no puede acceder al mercado laboral, y por tanto obtiene rendimientos sólo uno de los cónyuges, como podrían ser los casos de determinados pensionistas con rentas de cuantía reducida, o de determinadas familias numerosas ${ }^{\prime 175}$.

\subsection{El denominado interés de la familia}

Esta referencia al grupo, permite centrarse en el interés de la familia. Este aparece configurado como un principio al que han de configurarse los esposos en su comportamiento conyugal o análogo y en su relación con los demás miembros del grupo familiar. Se estima que el término "interés de la familia” puede emplearse como paradigma, modelo de conducta, norma, regla de comportamiento exigible, semejante a la locución "buen padre de familia" ${ }^{176}$, que rige e informa todas las manifestaciones en el ámbito personal y patrimonial de sus componentes, entre sí y en sus relaciones con los

pueda parecer, como ta "del buen padre de familia”. Acudiremos para ello a las fuentes históricas, donde los franceses habian hecho suyo el "bon père de famille", asentando la la idea generalmente acogida de que se trata de un patrón de referencia, que representa una media diligente, razonable y prudente, y que permite evaluar la actitud de un sujeto abstracto (es decir, al margen de sus facultades y cualidades), para determinar si ha cumplido con su obligación.- Para la más reciente versión del concepto en Italia, hay que acudir incluso a parámetros psicológicos. El "buon padre di famiglia” trasciende la realidad psicológica y expresa un concepto regulador de la relación de contradicción entre la voluntad del sujeto (privado) y la voluntad del Estado (social) concretada en la norma. Ahondaremos en esta variante que ofrece numerosos posibilidades legislativas.- Por su parte, el mundo jurídico anglo-norteamericano, y países de su sello, han acogido también el criterio de la diligencia media atribuyéndoselo al "responsable man"..." 
terceros ${ }^{177}$. El principio de igualdad es fundamento del interés de la familia ${ }^{178}$, por cuanto contribuye a la estabilidad del orden familiar y pretende velar por cada uno de sus miembros, aunque tal cual se podrá estudiar más adelante, el interés del menor es primordial en este punto ${ }^{179}$. Un verdadero límite a la autonomía privada de sus miembros, y en especial de los progenitores, principio corrector de abusos y portador de cautelas en los negocios con terceros ajenos al círculo familiar. Criterio hermenéutico con alcance integrador que han de tener muy en cuenta los jueces, fiscales y órganos de la Administración.

Ahora bien, puede plantearse que si existe un interés familiar supraindividual, en relación a una voluntad familiar. Si la familia tiene una estructura orgánica, el interés es percibido por los indi-

177 SAP, Jaén, 9 de julio de 1993, AC 1993/1495. Esta sentencia es un claro ejemplo de la relación existente entre el deber de actuar en interés de la familia y en caso de no hacerlo la separación la crisis familiar que puede causar. "Las crisis legales del matrimonio, como entienden los autores, pueden originar la nulidad del mismo; las crisis de hecho, internas, conyugales, pueden conducir a la separación o al divorcio; la separación matrimonial objeto de este procedimiento, es la cesación legal o de hecho de la convivencia conyugal de los esposos por causas circunstanciales, que están debidamente especificadas en los arts. 81 y siguientes del Código Civil. La actora doña Socorro H. M., pide la separación de su esposo y la basa sustancialmente en la conducta injuriosa o vejatoria y en cualquier otra violación grave de los deberes conyugales y otras causas, que suponen infracción grave y reiterada de deberes conyugales, con base legal en el art. 82.1. ${ }^{\circ}$ del Código Civil. Pero para declarar la separación conyugal (que supone el lazo que une a los esposos, superior a cualquier otra vinculación legal) basta comprobar si existe prueba suficiente (de acuerdo con el sentir y sentido del art. 82.1. ${ }^{\circ}$ del Código Civil) de una quiebra de la convivencia, para que se entienda que los cónyuges no cumplen con el deber reciproco que impone el art. 67 del Código Civil, que impone el respeto y ayuda mutua y el actuar en interés de la familia. Se ha justificado en los autos, por los escritos de demanda y contestación y demás pruebas practicadas a instancia de ambos cónyuges que se ha roto la convivencia matrimonial, que falta el amor y respeto mutuo que debe llevar todo matrimonio y ello junto a que lo han pedido y lo desean ambos esposos, en $1 .^{a}$ instancia, tal como se deduce de sus alegaciones y junto también a la aceptación en esta segunda instancia, se estima procedente declarar la separación, confirmando en este aspecto la resolución apelada, sin necesidad de declarar la responsabilidad concreta de uno de los esposos, sin que esta declaración de separación por su carácter (normalmente provisional) pueda atacar a la subsistencia del principio «favor matrimonii» declarado por la jurisprudencia en la sentencia entre otras de fecha 10-2-1983":

178 En relación con esto cito la Ley 25/2010, Libro II CCcat. Art. 231 4: . "Dirección de la familia. 1. La dirección de la familia corresponde a los dos cónyuges de común acuerdo, teniendo siempre en cuenta el interés de todos sus miembros. 2. En interés de la familia, cualquiera de los cónyuges puede actuar solo para atender a las necesidades y los gastos familiares ordinarios, de acuerdo con los usos y el nivel de vida de la familia, y se presume que el cónyuge que actúa tiene el consentimiento del otro. 3. Ninguno de los cónyuges puede atribuirse la representación del otro si no le ha sido conferida, salvo en situaciones de urgencia o de imposibilidad del otro cónyuge de dar el consentimiento. 4. A la gestión hecha por uno de los cónyuges en nombre del otro, le son de aplicación las reglas en materia de gestión de negocios."; Asimismo cito el art, 2362 . del mismo cuerpo legal donde se indica que el ejercicio de la potestad parental debe realizarse en interés general de la familia, y este interés a su vez lo relaciona con el interés de los hijos: "Ejercicio de la potestad parental. La potestad parental es una función inexcusable que, en el marco del interés general de la familia, se ejerce personalmente en interés de los hijos, de acuerdo con su personalidad y para facilitar su pleno desarrollo."

179 Cfr. GARCÍA GARCIA, M.A. “El deber de actuar en interés de la familia”, Revista de Derecho Privado, página 244, Madrid, año 1984. Para la autora el deber de actuar en interés de la familia se refiere a la suma de los intereses individuales, debido a que el interés no es de la familia como ente distinto de los elementos que la componen. Esta autora en otro artículo "El llamado interés supraindividual o familiar” en Revista General Legislación y Jurisprudencia, Madrid, año 1982, páginas 373 a 403 opina que no parece que en el Derecho de familia, tal como ha quedado configurado en las últimas reformas, haya base para hablar de un interés familiar supraindividual y distinto de los intereses individualque sea merecedor de un nombre propio. 
viduos en calidad de miembros y no como personas singulares. La voluntad familiar también colectiva y no singular, está para actuar y tutelar el interés familiar ${ }^{180}$.

El llamado "interés de la familia" no deja de portar un notable grado de abstracción y buena dosis de misticismo jurídico. Sin duda que el interés de la familia no puede ser otro que el destinado a beneficiar a todas y cada una de las personas de la familia ${ }^{181}$.

Evidentemente cuando el Código Civil alude al interés de la familia (o, por ejemplo, el art. 231-2.1, o el art. 231-4.2 del Libro II el Código Civil de Catalunya, en tema de potestad doméstica; o el art. 183.2 del Código del Derecho Foral de Aragón de 22 de marzo de 2011), está refiriéndose a los intereses de las personas concretas de la familia, lo cual concuerda con la opinión de GARCÍA GARCÍA $^{182}$. Los personificados u orgánicos no tienen intereses personales o individuales, pero si adjetivados familiarmente: en cuanto que nacen por su pertenencia o vinculación a la familia como institución natural, social y cultural, es decir, en cuanto se es cónyuge, hijo, hermano, padre, etc. No únicamente en cuanto se es persona, sino por ser una persona inmersa en el grupo familiar.

Intentando explicar la actual configuración del citado interés, debe justificarse su relación con los denominados deberes matrimoniales, tal idea procede originariamente de la reforma de 1975, donde se introdujo porque se estimaba que debía incluirse un refrendo legislativo de la familia, como institución más general que engloba el matrimonio y le da un sentido trascendente y supraindividual (Exposición de motivos de la Ley 14/1975). Posteriormente, aunque la Constitución amplía el concepto de familia (art. $39 \mathrm{CE}$ ) haciéndolo trascender del modelo matrimonial, este deber se conserva en el Código Civil, para mantener la idea de la unidad familiar. De hecho, no es modifica-

180 SAP, Málaga, sección $7^{\text {a }}$ Melilla, núm. 94/2003, de 26 de diciembre, JUR 2004/60416. En esta sentencia se alude al consentimiento matrimonial, como objetivo de la voluntad, y que si bien no obsta a que la Ley no defina ma trimonio si aludiría a una realidad diversa, una unión estable distinta los miembros que la forman: "El Código Civil no define qué es el consentimiento matrimonial, pero al ser el consentimiento una declaración de voluntad dirigida a un objeto determinado, se hace necesario precisar que debe ser el matrimonio el objeto sobre el que ha de recaer el consentimiento, para que este sea consentimiento matrimonial. Tampoco define el Código qué es el matrimonio, pero de su regulación surgen como notas características del mismo el ser una unión estable entre hombre y mujer, sometido a unas formas legales de celebración, de la que nacen una serie de derechos y obligaciones para ambos contrayentes en plano de igualdad, contenidos esencialmente en los artículos 66, 67 y 68 del Código Civil, como son respetarse y ayudarse mutuamente, actuar en interés de la familia, vivir juntos, guardarse fidelidad, y socorrerse mutuamente. Por tanto, cuando la voluntad en que consiste el consentimiento no se dirige a una unión de estas características, puede afirmarse que falta el consentimiento matrimonial y que el matrimonio así contraído es nulo. “

181 RAGEL SÁNCHEZ, L. “Ejecución sobre bienes gananciales por deudas de un cónyuge”, Ed. Tecnos, Madrid, 1987, página 41. El autor en cuestión, enfatiza que no se debe olvidar que la noción de actuar en interés de la fa milia es un concepto jurídico indeterminado, de equívoco significado y carácter variable, en función de las concretas circunstancias sociales y familiares, lo cual resulta a propósito de la frecuencia con que la ley recurre en el área de los derechos familiares a los conceptos jurídicos indeterminados, que la reglamentación normativa ofrece, por eso, una imagen incompleta del Derecho de familia, que debe ser completada, con profundas y serias reflexiones.

182 GARCÍA GARCIA, M.A. “El deber de actuar en interés de la familia”... op. cit.. 
do sustancialmente por la Ley 30/1981, que se limita a suprimir el adverbio "siempre" que complementaba la expresión y a enunciarlo como artículo 67 CC. La redacción actual en la mención a los cónyuges proviene de la Ley 15/2005 de 8 de julio.

Con ello, se introduce en el esquema de derechos y deberes matrimoniales un enunciado peculiar y ligeramente diferente del resto de los que contienen los artículos 67 y $68 \mathrm{CC}$, en la medida en que refleja un deber que se predica de cada cónyuge, pero no sólo recíprocamente, sino también frente a la familia. De hecho esta obligación, si bien se predica de ambos esposos no se puede considerar realmente como recíproca o mutua entre ellos, sino paralela e indistinta, puesto que no quedan obligados el uno con el otro a mantener un comportamiento que sea acorde con el interés de cada uno, sino que es con la familia con la que cada uno de los contrayentes por separado cumple su obligación.

Así por virtud de este deber conyugal, cada uno de los esposos queda obligado desde el momento en que contrae matrimonio a adecuar su conducta en favor del interés familiar, criterio que ya se ha tildado de sumamente amplio e indeterminado, de ahí que para concretarlo sea necesario, aunque también complejo definir por un lado, en qué consiste el interés de la familia, por otro lado, cuál es la conducta que se exige de los esposos y, finalmente, quién es el sujeto acreedor de esta obligación jurídica.

Respeto del primer punto, hay que partir de que la determinación del interés de la familia entendida aquí como la familia nuclear haya o no hijos ${ }^{183}$, en tal sentido se requiere que existan dos o más. Este interés es difícil de realizar, puesto que requiere poner en conjunto los intereses de los individuos que la componen, que pueden ser coincidentes o no con el interés individual de cada uno de ellos.

No se trata, por tanto, de desarrollar una conducta que pretenda favorecer los intereses propios de uno o varios miembros de la familia, salvo que, por su entidad, dichos intereses individuales repercutan sobre el conjunto del bien de la familia, pasando a constituir el interés familiar, sino de

183 Cfr. ALMOGUERA SALLENT, M . "Hogares, familias y viviendas", Revista de Treballs de la Societat Catalana de Geografia, núm. 41, Barcelona, año 1996, páginas 19 y siguientes; VALERO LOBO, A., "Hogar, familia y matrimonio", en DE MIGUEL (Coord.), “La sociedad española 1992-93”, Madrid, año 1993, páginas 15 y siguientes. .La investigación sociológica en el campo familiar se apoya en ciertos conceptos básicos, como son familia, núcleo familiar y hogar. El término familia supone un grupo de personas (dos o más) que, residiendo en la misma vivienda familiar, comparten algunos gastos en común y están vinculados por lazos de parentesco, ya sean de sangre o políticos, e independientemente de su grado. Según sociólogos, esta conceptualización de la familia se aleja de la compleja realidad social, de manera que la unidad fundamental no debe ser esta "familia ex tendida", sino el "núcleo familiar", que puede comprender una pareja (con independencia de su estado civil), con o sin hijos solteros, o una persona con al menos un hijo soltero. Por otra parte, el concepto de hogar (unidad de convivencia en la que se organiza una solidaridad económica primaria) introduce una lógica distinta. Mientras el núcleo familiar y la familia están estructurados por las relaciones de parentesco, en el caso del hogar lo básico es la vida en común, como forma de organización económica elemental. 
realizar todas las actuaciones que busquen el bienestar familiar común y el equilibrio óptimo entre los derechos y obligaciones de cada uno de sus miembros, permitiendo así el libre desarrollo de la personalidad de todos los integrantes del grupo familiar (art 10.1 CE) aunque ello suponga un cierto sacrificio de los intereses del cónyuge que actúa. Por ello el interés de la familia no se ha de identificar con la mera suma aritmética de los intereses de los miembros de la familia, sino que es algo que los trasciende, por encima incluso de los intereses individuales, en este sentido no estoy de acuerdo con la opinión de GARCÍA GARCÍA ${ }^{184}$.

Este interés familiar de una u otra manera condiciona la conducta de cada uno de los cónyuges y sus decisiones conjuntas o individuales, al verse obligados a guiar sus actuaciones conforme al criterio de favorecer a la familia y a evitar los comportamientos que la puedan perjudicar, aunque la acción u omisión exigida sea contraria a sus propios intereses personales. Por tanto, más que obligaciones o conductas concretas, este deber proporciona una pauta o guía de conducta que no siempre resulta fácil de concretar ${ }^{185}$. Posiblemente sobre este punto sea necesario indicar que el mismo problema acaece respecto al “Interés superior de niño”, el cual vía jurisprudencialmente ha sido paulatinamente conceptualizado.

La definición más clara de la conducta exigida, en tal sentido, se entiende en su vertiente negativa: cada cónyuge ha de abstenerse de realizar aquellos actos en que pueda resultar menoscabado o maltrecho el interés de la familia. La libertad de actuación del cónyuge queda condicionada, por tanto, por el interés del grupo familiar, pero se trata de un límite y no de una privación de libertad, pues sólo queda condicionado el comportamiento o la actuación del cónyuge en aquellos casos en que pueda incidir directa o indirectamente sobre el interés familiar, así este deber de actuación se concreta en sentido negativo, en que cada cónyuge puede exigir de su pareja únicamente la omisión de las conductas que choquen contra las bases de la convivencia o puedan afectar a la unidad familiar, no otras.

Más difícil es la precisión del contenido de este deber matrimonial en positivo: favorecer el interés familiar es contribuir a mantener la familia unida y en armonía, desarrollar las cualidades humanas y la cultura de quienes la integran o aumentar el patrimonio común, con el fin de conseguir una mayor comodidad para todos; pero también actuar de mutuo acuerdo o buscar el consenso en la medida de lo posible. La delimitación del contenido exacto de este deber no es, por tanto, fácil, motivo por el que se ha de señalar que, en caso de que surja discrepancia entre los cónyuges res-

184 GARCÍA GARCIA. “El deber de actuar en interés de la familia”,.... op. cit.

185 Cfr. DORAL GARCÍA DE PAZOS, J . "El interés de la familia” en Documentación Jurídica, monográfico dedicado a la reforma del Derecho de familia de 1981, volumen 1, Madrid, año 1982, páginas 3 a 21. 
pecto a qué actuación es la más apropiada para favorecer el interés de la familia, será posible la intervención judicial para solventar la controversia. En este punto, el juez a la hora de determinar cuál sea el comportamiento exigible, deberá tener en cuenta las concepciones éticas y sociales, las circunstancias e intereses del grupo familiar y los estándares de comportamiento usual y estadístico.

Definido de esta forma el contenido del deber, a groso modo, la última dificultad que plantea el análisis de este derecho y deber matrimonial es la identificación del titular del derecho correlativo al deber del cónyuge de actuación en interés de la familia.

Una primera aproximación al tema podría llevar a sostener que tal titularidad recae sobre la familia, dado que es su favorecimiento el que se persigue; pero esta determinación se enfrenta al obstáculo que supone la ausencia de reconocimiento de personalidad jurídica de la institución familiar: la familia no es sujeto de derechos y deberes; los titulares de éstos son los integrantes de la misma. Ahora bien, atribuir la titularidad de este derecho y la facultad de exigir su cumplimiento a todos los miembros de la familia nuclear supone extender el ámbito de este deber netamente conyugal. De ahí que sea preferible mantener una uniformidad con el resto de los derechos y deberes matrimoniales y afirmar que son los cónyuges los titulares respectivos del derecho, respecto del deber que cada uno ostenta, aunque el contenido de este deber no sólo los considere a ellos o a sus intere$\operatorname{ses}^{186}$.

186 STS, Sala de lo Civil, Sección 1a , núm. 78/2012, de 27 de febrero, RJ 2012/3383. En esta sentencia se discute en torno al interés de uno de los cónyuges y el interés primordial del menor, asimismo se hace referencia al interés familiar no como la suma de ambos, pero si en relación a los dos intereses antes citado: "El marido interpuso recurso de apelación contra dicha sentencia, que fue revocada... Cita diversas sentencias... y la doctrina aplicable al caso y dijo "QUINTO. Expuesta la doctrina aplicable al caso, nos debemos ocupar del supuesto de hecho que nos ocupa en el que la sentencia de instancia entiende que el derecho de uso que ostenta el demandado debe extinguirse al procederse a la división del inmueble, puesto que no puede considerarse amparado en el artículo 96 del Código Civil, ya que el Juzgado de Familia, sin tomar en consideración las necesidades familiares, solamente tuvo cuenta que en la vivienda tenía el demandado su despecho profesional. Esta valoración no la podemos aceptar, ya que en la sentencia dictada en el procedimiento de divorcio, que como ya dijimos es prácticamente de la misma fecha en la que se presentada esa demanda, pues la sentencia es de 18 de enero de 2007 y el día 19 del mismo mes se presentó la demanda que dio inicio a este procedimiento, indica que, "el demandado ostenta el interés más necesitado de protección en términos del Art. 96 del CC, lo que le hace acreedor a que le sea adjudicado su uso", explicando a continuación las razones en las que se basa, teniendo en cuenta el interés del hijo de los litigantes menor de edad, en concreto indicó "que el demandado vería sin duda minorados sus recursos económicos debido al notorio incremento de sus gastos al tener que procurarse otro despacho profesional y, probablemente, otra vivienda, de tal modo que es muy posible que no pudiera hacer frente a una pensión alimenticia por el importe aqui establecido". Por tanto, teniendo en cuenta las situación ante la que nos encontramos, donde el hijo, que vive con su madre en la cuidad de Segovia, tiene de 10 años y recibe una pensión del padre que se ha aumentado en el procedimiento de divorcio, no podemos afirmar que las bases que tuvo en cuenta el Juzgado de Familia, es decir la necesidad del uso de la vivienda para poder atender a sus necesidades y a las del hijo menor de edad, se hayan alterado en este momento, ya que debemos diferenciar los supuestos en que, en función de las condiciones de provisionalidad y temporalidad de esta medida, se aprecie claramente que las bases sobre las que sustentaron se han alterado significativamente, careciendo de sentido mantener el derecho de uso, de aquellos otros en los que no se comparten los razonamientos que han llevado al Juzgado de Familia a conceder tal derecho, que es un materia diferente y sobre la que no se puede entrar, pues la competencia para decidir de esta materia, a través de los procedimientos establecidos al efecto, corresponde a los Juzgados a los 
En caso de incumplimiento, no obstante las sanciones previstas por el Código Civil, para los deberes que tienen los cónyuges entre sí, podrá sin embargo ampliar su radio de ejecución de tal manera de poder favorecer a otros miembros de la familia. Esto se concretará ya sea por la vía del artículo $854.2^{\circ} \mathrm{CC}$, la del $152.4 \mathrm{CC}$ o la del $756.1^{\circ}$ y $2^{\circ} \mathrm{CC}$, la base de esto es que toda conducta contraria a los intereses de la familia podrá llegar a constituir en determinadas situaciones delito de abandono de familia (arts. 226 a 233 CP); o también, a la inversa: el delito de abandono de la familia demostrará el incumplimiento de este deber, ya que es claramente contrario al interés de la familia el comportamiento típico que sirve de base al mismo. De esta forma, la condena de uno de los cónyuges como autor del mencionado delito podrá dar pie a la aplicación del resto de las sanciones civiles anteriormente referidas, ya que se habrá constatado con ello el grave incumplimiento del deber de actuación en interés de la familia, así como el de otros deberes conyugales.

De todas maneras el abandono de hogar, que está tipificado en referencia al interés de la familia no puede estimarse como concepto indeterminado lo cual sería muy peligroso porque estima una sanción, pero a mi juicio es importante que su conceptualización nos permita inferir en que consiste el interés de la familia.

Los cónyuges han contratado al celebrar el matrimonio y, por lo tanto, están vinculados jurídicamente entre sí. La idea del vínculo sugiere inmediatamente la idea de limitación o recorte de libertad. Quien está vinculado jurídicamente está obligado a llevar a cabo un comportamiento determinado a favor de otra u otras personas. Quien se casa, está renunciando voluntariamente a una parcela del bien más preciado, después de la vida: la libertad.

Se renuncia a una parcela de esta libertad no totalmente a este bien. La Constitución ha consagrado el derecho fundamental al libre desarrollo de la personalidad, y no indica que se pierda tal derecho al contraer matrimonio ${ }^{187}$. Es decir esa libertad subsiste en el matrimonio, lo que sucede es que ahora entra en juego un compromiso ante, por y para otro, y ante el Derecho, que a veces colisiona con la libertad personal, pero esta está supeditada en virtud de la ley y no así por la Constitución, al interés de familia.

Este interés cuyo origen es el límite de las facultades del marido ${ }^{188}$, se ha visto bastante ampliado en su radio de acción lo cual es sin duda efecto de su indeterminación. Se trata de un concep-

que les esta asignados las cuestiones relacionadas con el derecho de familia".

187 También ponen en relación el matrimonio y el libre desarrollo de la personalidad DIEZ-PICAZO PONCE DE LEON, L, y GULLÓN BALlESTEROS, A. "Sistema de Derecho Civil”, Volumen IV, Ed. Tecnos, Madrid, año 1992, página 96.

188 Tal es así, que la redacción primitiva del artículo 1386 del Código Civil, obligaba que las obligaciones personales del marido no podían hacerse efectivas sobre los frutos de de los bienes parafernales, a menos que se probare que redundaron en provecho de la familia. 
to de carácter variable, en función de las circunstancias sociales y familiares y personales que resultan difíciles de concretar, tal cual se manifestó anteriormente. Con su formulación a nivel legal, se trata de corregir el egoísmo personal de cada consorte, estableciendo un valor superior al individual, aunque en nuestra sociedad tan acostumbrada a exigir derechos pero poco predispuesta a cumplir deberes, resulta de difícil comprensión esta afirmación. El que se casa debe velar en primer lugar por satisfacer el interés colectivo familiar, es decir del matrimonio y de los hijos convivientes, si los hubiere. Sin duda la exigencia de actuar en interés de la familia es una muestra de explicar una unidad de la familia sin la unidad de dirección, es decir, desde la perspectiva de la igualdad jurídica de los cónyuges, y esta es la clave para entender la relación entre el interés de la familia y la igualdad, al no haber necesariamente una cabeza en la dirección, sino que una paridad de roles al respecto, el interés se estima acorde a los objetos que dicha igualdad presenta, se favorecerá dicho interés cuando se favorezca dicha igualdad, ¿siempre?, no, claro que no, las circunstancias del caso concreto en primer lugar podrán ayudar para saber si es o no adecuado esta relación. En ese mismo sentido, la STC núm. 159/1989 (RTC 1989, 159) señaló que el fruto de las reformas de 1975 y 1981 "es la proclamación de la igualdad jurídica entre marido y mujer (arts. 66 y 1328) y, en general, la desaparición de los vínculos patriarcales y autoritarios, así como la configuración de un nuevo grupo familiar de base asociativa ${ }^{\prime 189}$.

189 STC, Sala 1", núm. 159/1989, 6 de octubre, RTC 1989/159. "Pero en el actual derecho de familia no sólo se ha pasado a un régimen general de cogestión de la Sociedad de gananciales (lo que obliga a replantearse si la titularidad de la relación arrendaticia corresponde exclusivamente al marido), sino que la mujer ha recuperado su plena capacidad de obrar no sólo sobre los bienes adjudicados por separación judicial, sino sobre los propios bienes adjudicados por separación judicial, sino sobre los propios bienes gananciales (e incluso los pendientes de liquidación), de entre los que hay que entender incluidos los derechos arrendaticios, con los que se hace obligado dilucidar si la interpretación restrictiva del art. 31.1. ${ }^{\circ}$ L.A.U. que efectúa la Audiencia conculca o no el principio de igualdad o, dicho en otras palabras, ¿goza de algún género de justificación objetiva y razonable la inaplicación del art. 31.1. ${ }^{\circ}$ L.A.U. a los supuestos de sucesión de la relación arrendaticia a los hijos y esposa como consecuencia de una separación legal?. - La respuesta a la enunciada pregunta ha de ser forzosamente negativa. No existe razón alguna que abone por reputar traspaso de local de negocio a la adjudicación de los derechos de arrendamiento a la esposa (quien, con sus hijos y en nuestro caso, venía regentando el negocio de la panadería) como consecuencia de la disolución de la sociedad de gananciales tras un proceso de separación judicial. Estimar lo contrario significaría admitir un trato discriminatorio en dicha disolución frente a la que puede suceder por causa de muerte del titular formal de la relación arrendaticia y, como se ha expuesto más arriba el principio de igualdad de los arts. 14 y 32.1. ${ }^{\circ}$ ha de informar no sólo la constitución del matrimonio, sino también los «efectos de su disolución y de la separación», por lo que una diferenciación en punto a la exención del traspaso del local de negocio entre los efectos de la disolución de la sociedad de gananciales atendiendo exclusivamente a su causa (la muerte, el divorcio o la separación legal), aparte de carecer de justificación jurídica, conlleva una discriminación social entre el status de «viuda», que podría beneficiarse de la exención del art. 31.1. ${ }^{\circ}$ L.A.U., y el de «separada» (o divorciada) quien quedaría civilmente penalizada mediante la resolución del contrato y consiguiente lanzamiento y ello aun cuando, como acontece en el presente caso, la esposa no hubiere dado lugar a la separación legal.- Mas aún alega la recurrente una segunda violación constitucional, que fundamenta en la lesión del derecho a obtener tutela judicial efectiva, consagrado en el art. 24.1 de la Constitución.- A esta segunda causa en que se basa el recurso de amparo, pudiera oponerse -como así lo verifica la contraparte en sus alegaciones- la propia doctrina de este Tribunal acerca de la satisfacción de aquel derecho mediante la obtención de una respuesta judicial motivada sobre el fondo de la cuestión litigiosa discutida-lo que 
Tal interés superior no anula la posibilidad de que cada cónyuge trate también de satisfacer su propio interés, de cumplir sus anhelos personales, en la medida en que no se contradiga aquel interés de la familia, asimismo lo indicó la STS 25 de noviembre de 1985, RJ 1985/5908 ${ }^{190}$, la comunidad de vida que manifiesta la convivencia conyugal es obviamente con la individual de cada esposo. Se tiene en cuenta, por otro lado que uno de los componentes de la familia es el propio cónyuge y que cuando está desarrollando libremente su personalidad estará normalmente cumpliendo el interés familiar. Cada cónyuge podrá desarrollar libremente su personalidad dedicándose al trabajo y a las aficiones que más le satisfagan, y sólo tendrá el límite de respetar los intereses familiares.

Por otra parte, en un supuesto en que se había declarado la separación matrimonial por incumplimiento de los deberes conyugales por parte de la esposa, que estaba separada de hecho, la STC, Sala segunda, núm. 73/1982, de 2 de diciembre, RTC 1982/73, declaró que "el derecho a la intimidad personal no queda violado porque se imponga a la persona limitaciones de su libertad, como consecuencia de deberes y relaciones jurídicas que el ordenamiento jurídico regula, pues la intimidad es un ámbito o reducto en el que se veda que otros penetren y no guarda por sí sólo relación directa con la libertad de relacionarse con otras personas o derecho a tener amistades, que es lo que la recurrente parece referirse".

Cada uno de los cónyuges puede conservar un ámbito de autonomía personal, una esfera íntima en la que ni siquiera tiene posibilidades de penetrar el otro consorte; podrá manifestar sus opi-

se afirma alcanzado en este supuesto- y manteniendo por ello la improcedencia de revisar en este ámbito el acierto técnico de la decisión o su conformidad a las pretensiones de la parte.

190 STS, Sala de lo civil, núm. 5908/1985, de 25 de noviembre, RJ 5908/1985. Además en esta sentencia claramente se relaciona el deber de actuar en interés de la familia durante la crisis de la misma "La obligación de convivencia que el artículo sesenta y ocho impone a los cónyuges, reflejada en la tradicional expresión de unidad de techo, mesa y lecho (thorum, mensa et cohabitatio), no impide el hecho, harto frecuente, de que no obstante su nota esencial en el matrimonio, es infringida por pacto, expreso o tácito, de marido y mujer, generalmente acompañado de un acuerdo sobre la prestación de alimentos, que no será obstáculo para que el alimentista, según autorizado parecer, pueda acudir al proceso para lograr una pensión más alta cuando circunstancias sobrevenidas (generalmente corrección nominal en la que verdaderamente es deuda de valor, por depreciación de la moneda) asi lo requieren por imperativos de equidad; por ello, y atendiendo a que en las situaciones de normalidad en el desarrollo del matrimonio, con cabal cumplimiento por los esposos de los deberes regulados en los artículos sesenta y siete y sesenta y ocho del Código civil, la deuda alimenticia o de socorro material entre ambos queda comprendida por la más amplia de contribuir a levantar las cargas del matrimonio con arreglo a los artículos mil trescientos dieciocho, mil trescientos sesenta y dos, causa segunda y mil cuatrocientos treinta y ocho, cuando ha sido rota la unidad de vida por mutua conformidad entrará en liza el artículo ciento cuarenta y tres, y en tal sentido la más reciente orientación jurisprudencial, en cuya línea son expresivas las sentencias de veintiocho de febrero de mil novecientos sesenta y nueve y diecisiete de junio de mil novecientos setenta y dos, entiende que la separación de hecho libremente consentida entre los esposos, si bien implica una situación anómala e incompatible con los deberes matrimoniales que impone el actual articulo sesenta y ocho, lo que origina que sus consecuencias no sean jurídicamente protegibles, no por ello priva a cualquiera de los cónyuges, atendidas las circunstancias del caso concreto, a recibir alimentos de su consorte conforme a las normas contenidas en los artículos ciento cuarenta y dos y siguientes, punto de vista que ha de ser reafirmado a la luz de las directrices informantes de la reforma de siete de julio de mil novecientos ochenta y uno, ajena en materia de divorcio a la aplicación de causas culpabilistas (artículo ochenta y seis). “ 
niones, conservar sus amistades, vestirse y arreglarse a su gusto y, sobre todo, tendrá derecho a su intimidad personal, es decir, a guardar para sí sus conversaciones y documentos personales. No se olvide que el art. 18.3 CE garantiza el secreto de las comunicaciones, y en especial de las postales, telegráficas y telefónicas, incluso los e mails, salvo resolución judicial, y que el Código penal considera delito el hecho de apoderarse de papeles y cartas para descubrir los secretos.

$\mathrm{Y}$ es que el matrimonio aunque otorga ciertos derechos a los cónyuges, no da el derecho sobre la persona del otro cónyuge, como vulgarmente se cree, dándose lugar al abuso. Muchas personas cometen el error de pensar que al casarse se adquiere el cuerpo y la voluntad del otro, y que en eso consiste precisamente la seguridad. Aunque se comuniquen los afectos, los bienes, no se hace dueño uno del otro ni mucho menos, hay una pertenencia abstracta.

Finalmente destaco en relación con el interés familiar, el deber de asistencia recíproca mencionado en el art. 58 del Código de Derecho Foral de Aragón, que constituye el contenido esencial de la relación paterno-filial. En esta disposición se comprende el respeto, como contenido de la filiación, y reviste un carácter recíproco, que no se extingue por la emancipación. Lo mismo sucede con el deber de asistencia, este excede la obligación de alimentos y se materializa en la colaboración personal del hijo en las tareas del hogar y en los negocios familiares mientras conviva con la familia, así como en la posibilidad de que los padres que ejerzan la autoridad familiar destinen una parte de los ingresos del hijo a necesidades familiares que resultan diversas a su crianza y educación $^{191}$.

\subsection{La igualdad de las familias ante la Constitución, ¿Familia o modelos de familia?}

Con palabras taxativas se ha dicho, sin excepción, que a lo largo de la historia del mundo occidental puede comprobarse como la función social del matrimonio ha consistido principalmente en ser el momento fundacional de una familia, entendida como progenie o sucesión de generaciones ${ }^{192}$. En el mismo sentido DIEZ PICAZO manifestaba que “...en el art 12 de la Constitución se presta una garantía institucional a una institución muy concreta como es el matrimonio, que es contraído por un hombre y una mujer y que tiene una función institucional como es la creación o fundación de una familia. Porque carecen de perfil institucional, no hay razón alguna para fomentar otro tipo de

191 Cfr. DELGADO ECHEVERRÍA, J. (Dir.), “Manual de Derecho Civil aragonés”, Ed. El Justicia de Aragón, $2^{\mathrm{a}}$ edición, Zaragoza, año 2006.

192 GARCIA CANTERO. "Sobre el llamado matrimonio homosexual. Análisis de algunas cuestiones debatidas", en Libro Homenaje al Profesor Manuel Amorós Guardiola, Centro de Estudios, Colegio de Registradores de la Propiedad y Mercantiles de Madrid, año 2006, página 1561 y ss.. 
uniones, sin perjuicio de encontrar para ellas soluciones justas ${ }^{{ }^{193}}$. Es decir, los datos de procreación y matrimonio nos colocan en el buen camino de encontrar el sustrato último de la idea de familia y por lo tanto del Derecho de familia, mientras otros tipos de uniones, que las personas establezcan entre sí, tienen un carácter asociativo y haciendo abstracción de la procreación, pertenecen al ámbito del Derecho de familia, aunque pueda discutirse si son o no familia, pero están inmersos dentro del Derecho de familia porque sin duda es el sistema legal que les ampara de mejor manera, sin perjuicio de la protección dispensada por otras ramas del Derecho.

Es verdad que el ordenamiento reconoce variantes matrimoniales sin fundación de familia o lo que es lo mismo sin progenie. Ocurre así en los matrimonios de personas de edad avanzada o en los casos de esterilidad por regla general. Más son las excepciones que confirman la regla general. De todas maneras hoy en día hablar de familia puede no ser del todo exacto en el ámbito del Derecho, hay que referirse a los modelos familiares.

Hay autores, entre los que destaca VILADRICH, para quienes la familia en su más profundo sentido se funda en el matrimonio ${ }^{194}$. Con gran claridad también lo explica HERVADA XIBER$\mathrm{TA}^{195}$, otro de los autores que sigue la misma línea del recién citado.

193 Vid. DIEZ PICAZO, Prólogo al libro de ROCA I TRIAS, "Familia y ámbito social (de la casa a la persona", Ed. Civitas, Madrid, año 1999, páginas 20 y siguientes.

194 VILADRICH, P. J., "El modelo antropológico del matrimonio". Instituto de Ciencias para la familia, Ed. Rialp, Pamplona, año 2005, pagina 101. "Esa asociación responde a la verdad y a la bondad. Pues es de justicia que cada persona humana tenga, como suya y su derecho, una genealogía interpersonal con unos padres entre sí unidos en aquella unión de amor y de vida que llamamos matrimonio. Los padres-esposos garantizan a todo nuevo ser un origen genealógico propio de la persona, el ser concebido dentro de una unión de amor, y garantizan el ámbito de convivencia justo a su venida a la existencia y a su crecimiento: el ámbito íntimo e incondicionalidad de la familia propia"

195 Vid. HERVADA XIBERTA, J. "Diálogos sobre el amor y el matrimonio", Universidad de Navarra, Pamplona, año 1987, página 157 y siguientes. Respondiéndose a la pregunta de por qué razón el amor conyugal que se cierre únicamente al aspecto de "amor mutuo" es un amor minimizado, responde: "Porque un amor de tales características sería un amor incompleto y egoísta. Sería incompleto, porque el amor conyugal contiene el amor al otro cónyuge como padre o madre potenciales. Cuando se dice que el amor conyugal está ordenado a la procreación y educación de los hijos, no debe interpretarse esta afirmación como si quisiera referirse solamente a un deber sobreañadido al amor, algo así como una mera carga, extrínseca al amor conyugal, que hubiera sido impuesta a modo de un deber yuxtapuesto, advenedizo. No, no es así la relación entre amor conyugal y su orientación a los hijos. El amor conyugal, por su propia índole, tiende a tener hijos cuando está bien constituido. Los hijos no son deseados por la esposa sólo como algo que ella quiere a modo de prolongación de sí misma, ni únicamente como cumplimiento de un deber impuesto. La mujer, cuando ama con amor verdaderamente conyugal al varón, desea dar hijos al marido. Y el varón desea tener hijos de su esposa, como plenitud de su amor a ella. El hijo es deseado como fruto del amor que ambos se tienen. Y es que el amor conyugal está naturalmente orientado hacia los hijos, de modo que cuando nace con toda su fuerza y orden naturales, espontáneamente desea al hijo.-. "El deseo del hijo, que es normal y natural en los matrimonios, obedece a la constitución natural del varón y de la mujer en cuanto tales y a la inclinación natural del amor conyugal, cuyo objeto es el otro cónyuge en cuanto varón o mujer. Sólo el amor que nace incompleto o desordenado (mal orientado hacia el objeto) excluye positivamente a los hijos como fruto del amor mutuo. En virtud de esa constitución natural del amor, el deseo de no tener hijos obedece a causas sobrevenidas, que pueden ser muy diversas." 
De una u otra manera se intenta rescatar un triángulo cuyos vértices son el amor, el matrimonio y la familia. No entraré a analizar dicho triángulo porque trasciende la perspectiva jurídica del presente trabajo sin perjuicio de lo importante que sin duda es.

En el caso a caso no siempre es el egoísmo el que impide a una pareja el procrear, es decir, una pareja puede carecer de esta apertura hacia la vida por factores que dependen exclusivamente de su voluntad. O también a veces simplemente se debe a una planificación interna, amparada en su autonomía de la voluntad, que no significa un descarte completo a la aventura de ser padres. Asimismo existen diversas maneras en que las personas pueden ser fecundas, no sólo desde la perspectiva biológica.

En relación con la familia matrimonial existen otras situaciones nacidas de una convivencia fáctica, fundadas en lazos afectivos, no son lo mismo que las familias matrimoniales, su principio es diverso, pero ambas interesan al Derecho, no son lo mismo porque de por medio está justamente el matrimonio, pero matrimonio no es lo mismo que familia, eso sí, éste implica un afán de compromiso y estabilidad que en otro tipo de situaciones es más complicado encontrar.

Se estima por ciertos autores que es un dato que salta a la vista el que las funciones estratégicas de transmitir la vida humana, de cuidarla y educarla en comunidad de lazos amorosos y afectivos, y de cohesionar la convivencia y la sucesión intergeneracional de valores y bienes, mediante procesos de maduración sicológica y moral de cada ser humano, incorporándolos gradualmente y sin disfunciones a la sociedad, no pueden ser desempeñadas de forma masiva, estable y permanente por las convivencias meramente afectivas ${ }^{196}$. Sin perjuicio el matrimonio tampoco garantiza el cumplimiento de las tareas recién expuestas.

La familia es el nicho ecológico de la vida. Lo que interesa a la sociedad en su conjunto es que normalmente cuando un hombre y una mujer se quieren y deciden compartir su destino, de ellos puede surgir vida biológica y afectiva, vida plena, ahora bien si son dos personas de igual sexo quienes se unen, puede argumentarse que, mediante las técnicas de reproducción asistida también podrá surgir vida, o incluso mediante la adopción ${ }^{197}$.

196 VILADRICH, J. P., “La palabra de la mujer”, Instituto de Ciencias para la Familia, Ed. Rialp, Pamplona, año 2000, página 83.

197 Cfr. VV. AA. "Polémica sobre el origen y la universalidad de la familia", Ed. Anagrama, Barcelona, año 1986. Normalmente a los hijos se les quiere y ellos quieres a sus padres, la paternidad-filiación se convierte así en la fuente más potente de solidaridad interpersonal que la humanidad ha conocido jamás. Por eso no es lo mismo el matrimonio que la unión homosexual; el primero es de alto interés para la sociedad debido a que es fuente creador de vida. La segunda es de interés para la sociedad debido a que afecta a dos personas pero en ella no puede surgir la vida, sin vida no hay sociedad. Por eso es razonable que el Derecho intente reforzar la permanencia y estabilidad del compromiso matrimonial pues la atención a las nuevas vidas es un proceso de muchos años y soli daridad, y cuando se basa en el parentesco es socialmente necesaria. 
Cuando hoy en día se reivindica a la familia como verdadero estandarte de la seguridad social, cuando se desea desde las políticas públicas sus efectos solidarios y de acogida, se está pensando en la familia, la basada en el compromiso personal y abierta a la vida, ¿por qué?, porque la familia es un agente de bienestar social ${ }^{198}$. Me pregunto, al momento de escribir estas páginas ¿cuántas personas que se han visto afectadas por la actual crisis económica han debido de recurrir a sus familias, cuando ni el Estado ni las Entidades financieras le procuran auxilio?

Estas ideas son conformes con la propia Constitución española, según nos indica una doctrina muy cualificada ${ }^{199}$. MARTÍNEZ LOPEZ-MUÑIZ, señala que en la Constitución hay que señalar ciertos elementos esenciales, en relación con la familia y el matrimonio. Son los siguientes: que la generación es el hecho determinante básico de modelo constitucional de la familia y que el matrimonio es el vínculo que funda la familia.

Tal como indica este autor, respecto al primer punto, afirma que la Constitución contiene unos pocos, pero decisivos elementos, sobre lo que entiende por familia. Recoge la STC 45/1989, de 20 de febrero, sobre la Ley de IRPF, que afirmó claramente que: “cualquier norma que incida sobre la vida de familia debe ser respetuosa con la concepción de ésta que alienta en la Constitución”. En cuanto al segundo punto, manifiesta LOPEZ-MUÑIZ que la simple lectura del art. 39 de la Constitución permite deducir que la familia está intrínseca y esencialmente determinada por el hecho de la generación humana y las consiguientes relaciones de paternidad, maternidad y filiación a las que expresivamente se refiere dicho precepto, que manifiesta, además, bien significativamente, una especial preocupación por los niños, es decir, por las personas menores, dando ha entender que las familias se preocupan o se han de preocupar preferentemente de ellos.

198 ALMENDROS GONZÁLEZ, M.A. “La protección social de la familia”, Ed. Tirant Lo Blanch, Valencia, año 2005, páginas 60 y siguientes. Especial referencia a las familias numerosas realiza LUJÁN ALCARAZ, J. en "La protección de las familias numerosas desde la perspectiva del Derecho del Trabajo y de la seguridad social”, BIB 2005/2700, Aranzadi Social n 19/2005, parte Tribuna, Aranzadi S.A., Pamplona, año 2006. El citado autor expone que: "Y este último es, precisamente, el postulado básico del que parte el legislador actual. Esto es, en primer término, que la familia «como núcleo fundamental de la sociedad, desempeña múltiples funciones sociales, que la hacen merecedora de una protección específica». Y, en segundo lugar, que ciertas clases de familias con son las llamadas numerosas merecen una protección especial en razón al «coste que representa para ellas el cuidado y educación de los hijos o el acceso a una vivienda adecuada a sus necesidades. - La consideración, tomada de la exposición de motivos que acompaña a la Ley 40/2003, de 19 diciembre, es reveladora y fundamental. El principio diferenciador que inspira la regulación legal de la «protección social, económica y jurídica de la familia (numerosa)» estriba para el legislador en el dato económico de los mayores gastos que la atención de esta clase de familias comporta. Y es que, como aquellas «circunstancias pueden implicar una diferencia sustancial con el nivel de vida de otras familias con menos hijos o sin ellos», habrá que tener en cuenta que el art. 9.2 CE «establece el principio de igualdad material, que debe llevar al legislador a introducir las medidas correctoras necesarias para que los miembros de las familias numerosas no queden en situación de desventaja en lo que se refiere al acceso a los bienes económicos, culturales y sociales».

199 MARTINEZ LOPEZ-MUÑIZ, “La familia en la Constitución española”, en Revista española de Derecho Constitucional, año $20 \mathrm{n}^{\circ}$ 58, enero-abril 2000, páginas 11 y siguientes. Cfr. BUSTOS PUECHE, "El Derecho civil ante el reto de la nueva genética”, Ed. Dykinson, Madrid, año 1996, páginas 6 y siguientes. 
En tal sentido la noción constitucional de la familia no alude pues, esencialmente a una simple unidad de convivencia más o menos estable, por muy basada en el afecto o el compromiso de mutua ayuda que pueda estarlo. No se refiere a simples relaciones de afecto o amistad y apoyo mutuo, aunque ciertamente las implique derivadamente, como consecuencia natural de los vínculos de parentesco que le son propios y exclusivos.

Todo ello, afirma MARTINEZ LOPEZ-MUÑIZ, excluye obviamente la legitimidad de cualquier tratamiento legal o jurídico de la familia en nuestro ordenamiento que lo desconecte completamente de su presupuesto institucional básico. Cualquier relación inter-personal no derivada inmediata o mediatamente de la generación (o de algún hecho equiparable, como podría ser la adopción) o que por razones naturales, no constituye una estructura relacional de suyo y en abstracto o de modo general apropiada para generar nuevas vidas humanas, no tendría encaje constitucional en el modelo de la familia que la Constitución obliga a proteger, no sólo social y económicamente, sino también y sobre todo jurídicamente ${ }^{200}$. La Constitución no obliga a proteger del mismo modo todo cuanto pueda darse en la sociedad de manera espontánea, lo que realmente significaría no proteger nada, y hasta suprimir la distinción y diferencia consustancial a la existencia misma del Derecho (todo límite entre lo correcto y lo incorrecto, entre lo justo y lo injusto, lo debido y lo indebido, lo mío y lo tuyo).

La familia que el art. 39 obliga a proteger es una realidad específica, con perfiles básicos pero sin encasillarse en un modelo en particular, no cualquier género de asociación, reunión o convivencia, pues para eso se encuentra la protección que la Constitución garantiza a los derechos de reunión y asociación en los artículos 21 y 22, además de la garantía de la libertad e inviolabilidad del domicilio y de la intimidad personal que garantiza el art. 18, o de la libertad de residencia del art. 19, o en fin, más amplia y genéricamente, la garantía del derecho a la libertad en general que se contiene en el art. 17.

200 Al hablar de familia puede ser necesario hacer una distinción entre un concepto general de familia, que para el presente trabajo resulta importante, de una realidad más concreta, en la que la mayoría de las veces se condensa este término y que resulta ser el denominado hogar familiar. Por ello, ALBERDI, I., En "La nueva familia española", Ed. Taurus, Madrid, año 1999, páginas 82 a 84, se refiere a que: "el concepto de familia es algo genérico, y tiene connotaciones muy amplias: evoca tanto las relaciones de parentesco, como los lazos de afecto y de pertenencia que vinculan a las personas unidas por consanguineidad. $Y$ así vemos como algunas veces se utiliza el término cuando se habla de linajes familiares y se dice de un individuo que viene de una familia muy acomodada o muy pobre, o hablando de una persona se la vincula con sus padres, sus abuelos o sus ascendientes lejanos. Esta acepción que es una utilización muy común del término familia, hace referencia a los orígenes familiares del individuo. Otra forma también frecuente de utilizar este término es cuando hablamos de nuestra red de parentesco". Esta acepción la identifica como la red familiar, con el conjunto de individuos que tienen un origen familiar común entre los cuales suele haber, al menos en la sociedad española, lazos de afecto y de obligaciones mutuas. 
Y desde luego, el primer deber constitucional que dimana del art. 39.1 para los poderes públicos es el de proteger jurídicamente a la familia constitucional, evitando precisamente su desamparo como consecuencia de no hacerla objeto de un tratamiento jurídico distinto y más protector que el que se dispense a formas de convivencia domésticas contrarias precisamente al modelo familiar constitucional. Porque el fondo de la cuestión es que la Constitución quiere propiciar y proteger en consecuencia una forma determinada de producirse y estructurarse las relaciones vinculadas a la generación, fundando en ello el mandato de diferenciación jurídica, de desigualdad de trato jurídico que comporta el deber de proteger jurídicamente a la familia, establecido en el artículo 39.

No está de más decir que la manera en que se generen nuevas vidas y luego se les proteja en sus primeros estadios de existencia no es indiferente al ordenamiento jurídico: hay sólo uno que la Constitución estima regular y ordena protegerlo especialmente mediante la institución familiar. En ningún caso la prohibición prohíbe otros modos diversos al familiar, incluso tiende a protegerlos. Pero, al ordenar, en este campo y el que rodea, señala GARCÍA ABURUZA, que solo la familia goce de la adecuada y suficiente protección, prohíbe a contrario que se dispense protección similar a estructuras distintas que traten de realizar más o menos total o parcialmente sus mismas análogas funciones ${ }^{201}$.

Tal como se ha dicho, el matrimonio es vínculo que puede fundar a la familia, pero no es el único, eso sí, no toda relación basada en la generación o relacionada intrínsecamente con ella constituye una familia en el sentido constitucional. Es obvio que el artículo 39 CE diferencia con claridad entre lo que debe ser la protección a la familia (apartado 1) y la protección integral de los hijos, iguales estos ante la ley con independencia de su filiación y de las madres, cualquiera que sea su estado civil, que los poderes públicos deberán asimismo asegurar.

Hay para la Constitución una maternidad y una filiación que podrán denominarse como familiares, a juicio de BUSTOS PUECHE, producidas en el seno de la institución familiar que deben ser protegidas y pueden haber filiaciones así como maternidades extra familiares no integradas en la

201 GARCÍA ABURUZA, M. P. "La protección a la Familia desde los Procesos Matrimoniales”, Ed. Aranzadi, Pamplona, año 2009, página 16.: “...la elección de una materia como los procesos matrimoniales resulta interesante, porque la familia es la agrupación humana primordial y la más elemental de todas. Las encuestas parecen coincidir en señalar que es un de los valores que más aprecian los ciudadanos. De un modo u otro, a pesar de los vaivenes de los tiempos, la familia tiene una especial consideración entre los ciudadanos como grupo básico social, entendiendo su configuración como una plataforma de ubicación social, núcleo de relación social o palanca para la constitución del patrimonio. Precisamente, el derecho positivo que regula en la actualidad esta materia familiar responde a la determinada concepción que en la sociedad existe con respecto a realidades como la familia, el matrimonio o el divorcio. Los diferentes posicionamientos que sobre estas mismas realidades se han tenido a lo largo de la historia han incidido directa y necesariamente en la regulación legal que de los mismos se ha ido haciendo, constituyendo antecedentes para tener en cuenta para entender también la propia normativa actual." 
realidad familiar, que son igualmente protegidas, y así debe de ser. Precisamente porque esto es o puede ser así de facto, es porque la Constitución de acuerdo también con diversos textos jurídicos internacionales quiere garantizar asimismo de la forma más completa posible a las personas humanas su condición de hijos o de madres, tengan o no tal condición en el seno de una familia. Resulta evidente que lo que se quiere asegurar es la protección más integral posible a los hijos y madres aún cuando sean extrafamilares. Por lo demás, debido a lo anterior, existe la posibilidad de una paternidad familiar y otra extrafamiliar ${ }^{202}$.

Además aunque no se diga expresamente, resulta implícita la relación entre el apartado 2 y el apartado 3 y de éste con el propio apartado 1 del mismo artículo 39, en cuanto 1 y 3 vienen precisamente a concretar que los padres deben prestar asistencia de todo orden a los hijos habidos dentro o fuera del matrimonio, durante su minoría de edad y en los demás casos en que legalmente proceda.

202 STC, Pleno, núm. 171/2012, de 4 de octubre, RTC 2012/171.:Lo anterior pone de manifiesto que el hecho de utilizar el criterio del carácter común de los descendientes o, dicho de otro modo, la existencia de previo vínculo con el beneficiario del usufructo, para circunscribir a éstos el ámbito de la obligación regulada por la norma no puede ser considerado como elemento de diferenciación válido desde la perspectiva de la prohibición de discriminación por razón de filiación derivada del art. 14 CE. El precepto, al establecer una obligación de alimentos que pesa sobre el beneficiario del usufructo y con cargo a los bienes objeto del mismo, trata de hacer frente a las eventuales situaciones de necesidad de aquellos que han visto extinguida la obligación de alimentos por muerte del obligado, extremo éste, el de las concretas necesidades del eventual alimentista en función del cual pueden producirse diferencias entre unos descendientes y otros en la aplicación del precepto que no pueden darse en la existencia y exigencia de un previo vínculo con el usufructuario. En un ámbito como el de la interdicción de la discriminación, en el que regla es la parificación, carece de justificación la diferencia de trato entre unos y otros descendientes, distinción entre situaciones equiparables que resulta perjudicial para la posición jurídica de unos descendientes respecto de los otros, de suerte que los que lo son sólo del causante puedan quedar sumidos en una eventual situación de necesidad tras la muerte del mismo —aun pudiendo ser, según los casos, herederos de sus bienes-, mientras que los que son comunes, siendo la misma la relación que les une con el causante, queden debidamente protegidos por aplicación del precepto que examinamos. De esta forma, al distinguir entre ellos, la norma aplicable no asegura a los descendientes del causante una idéntica cobertura familiar a sus necesidades y discrimina así a unos frente a otros por razón de su filiación. - Un análisis más detenido requiere el segundo de los presupuestos antes aludido, esto es, la homogeneidad o equiparación de las situaciones subjetivas que se pretenden comparar a efectos del juicio de igualdad, constituidas en este caso por las de los hijos adoptivos y las de los hijos por naturaleza. La concurrencia o no de dicha homogeneidad o equiparación pasa necesariamente por abordar la caracterización jurídica de la adopción en nuestro Ordenamiento jurídico y, en concreto, por determinar si la misma constituye o no una forma o modalidad de filiación, ya que sólo en tal caso nos encontraríamos ante dos situaciones que, a efectos de lo establecido en el art. 14 CE, podrían considerarse iguales."

STC, Pleno, núm. 200/2001, de 4 de octubre, RTC 2001/200: “La Constitución no contiene una definición del instituto de la filiación, dejando un amplio espacio a la regulación del legislador, el cual se encuentra obviamente vinculado y constreñido por distintos mandatos constitucionales, entre ellos, en lo que ahora interesa, por la prohibición de discriminación por razón de nacimiento (art. $14 \mathrm{CE}$ ), en cuanto comprensiva de la igualdad entre las distintas clases de filiación, así como por la obligación de asegurar «la protección integral de los hijos, iguales éstos ante la Ley con independencia de su filiación» (art. 39.2 CE). En este sentido no cabe sino compartir los razonamientos del Abogado del Estado y del Fiscal General del Estado de que dentro del margen de libertad del legislador se encontraría la posibilidad de establecer o no una institución a la que denominase adopción o, incluso, de configurarla al margen de la relación genérica de filiación." 
BUSTOS PUECHE ${ }^{203}$, opina que la interpretación gramatical y lógica del artículo 39 concluye inequívocamente que la familia a que este artículo alude es la que tiene su base en el matrimonio. En resumen su argumentación: el apartado 1 del artículo ordena a los poderes públicos proteger a la familia. Si por familia, en ese apartado, se entendiera cualquier modalidad familiar incluyendo la que se podría denominar la familia de hecho, es obvio que estaría de más la previsión del epígrafe siguiente que ordena "asimismo" proteger a "los hijos y a las madres", a los primeros "con independencia de su filiación” y a las segundas “cualquiera sea su estado civil”. En otras palabras, se trataría de proteger a los hijos y a las madres no integradas en la familia del epígrafe anterior, porque si lo estuvieran la reiteración innecesaria sería evidente. Luego es que la familia del apartado 2 son todos, los incluidos en aquélla y los no incluidos, es decir, los integrados en uniones de hecho. Para este autor, tal cual se acaba de mencionar, no hay duda de que la familia que contempla la Constitución española es la familia por antonomasia, fundada en el matrimonio y formada por el marido, la mujer y los hijos que viven en común, a los que a veces se añade alguno de sus ascendientes. Enfatiza en que lo anterior se confirma en virtud de la garantía constitucional de la que goza el matrimonio y de la que carece la familia no matrimonial. Afirma que aunque la familia puede constituirse fuera del matrimonio, la Constitución sólo contempla esta posibilidad indirectamente de modo sectorial o no específico, a través de la protección integral que los poderes públicos aseguran a los hijos, iguales ante la ley con independencia de su filiación, y a las madres, cualquiera que sea su estado civil (art. 39.2), del deber de asistencia de todo orden que los padres tienen para con sus hijos, habidos dentro o fuera del matrimonio (art. 39.3), y de la afirmación de que la ley posibilitará la investigación de la paternidad (art. 39.2). Y recogiendo las anteriores argumentaciones, manifiesta que el art. 39 consta de dos partes netamente diferenciadas: un primer párrafo, donde tutela a la familia basada en el matrimonio; y tres párrafos más donde protege a una serie de personas, constituyan o no una familia, que pueden ser injustamente marginadas, pero, concluye, como regla general, la familia fundada en el matrimonio debe ser objeto de un trato preferencial ${ }^{204}$.

203 BUSTOS PUECHE, J. E. "El Derecho civil ante el reto de la nueva genética”, Ed. Dykinson, Madrid, año 1996, página 108.

204 Cfr. ÁLVAREZ VELEZ, M I I y ALCÓN YUSTAS, F. "EL Menor y su entrono familiar”, en LÁZARO GONZÁLEZ, I. (Coord.), "Los menores en el Derecho español", Ed. Tecnos, Madrid, año 2002, páginas 139 y siguientes. Sería interesante en este punto citar los preceptos que la Constitución dedica a la familia. Empieza por afirmar en su art. 39.1 que "los poderes públicos aseguran la protección social, económica y jurídica de la familia", sin definirla, ni volver a referirse expresamente a ella. Sin embargo esto no significa que aquí termine su regulación. Los términos en que está redactado el párrafo muestran con claridad que se trata de una declaración de principios, confirmándolo el lugar que ocupa, al inicio del capítulo III, de los principios rectores de la política social y económica. Más adelante, el art. 53.2 concreta su alcance cuando dispone, categóricamente, que "el reconocimiento, el respeto y la promoción (de dichos principios) informará la legislación positiva, la práctica judicial y la actuación de los poderes públicos", aunque "sólo podrán ser alegados ante la Jurisdicción ordinaria de acuerdo con lo que dispongan las leyes que lo desarrollen". Otros muchos preceptos constitucionales se refieren 
CHINCHILLA MARÍN ${ }^{205}$, es de la opinión contraria, debido a que en el Anteproyecto de la Constitución, el actual art. 32 (entonces, art. 27) decía "A partir de la edad núbil, el hombre y la mujer tienen el derecho a contraer matrimonio y a crear y mantener en igualdad de derechos relaciones estables de familia”. Ante ello se presentaron sendas enmiendas oponiéndose a esa redacción, por entender que se prestaba a confusión y que podría entenderse que amparaba las puras relaciones permanentes entre el hombre y la mujer, mientras que debían contemplarse en igualdad de condiciones tanto las relaciones nacidas del matrimonio, como las que fueran consecuencia de relaciones estables de familia. Estas cuestiones no produjeron, sin embargo, mayores discusiones en el seno de la Ponencia, pues los problemas fundamentales se plantearon en torno al divorcio. El texto quedaría, finalmente, como hoy lo conocemos, esto es, sin mencionar la familia ni las uniones estables de hecho.

Así, pues, ni en el art. 32 CE aparece la familia, ni en el 39 CE el matrimonio, sin duda ambos están íntimamente relacionados siendo en gran parte de la historia el segundo presupuesto de la primera, pero hoy en día no es así; pero hay que ir un poco más allá, debido a que ninguno de los dos preceptos menciona las uniones de hecho. La Constitución no define, ni prejuzga tampoco, cuáles son las formas de constituir una familia y ello, es decir, la separación que hace de familia y matrimonio, se ha interpretado, acertadamente, como algo no casual, sino, por el contrario, como una opción consciente y deliberada por una concepción abierta y plural de la familia adaptable a los cambios de la sociedad. En este sentido, ROCA I TRÍAS ${ }^{206}$ ha concluido que la protección ofrecida en el art. 39 de la Constitución no puede limitarse a las familias constituidas a partir del matrimonio,

de un modo u otro a la familia y pueden entenderse como manifestaciones concretas de la protección pluridimensional que los poderes públicos sean obligados a prestarle. En este sentido, hay una presencia -patente y latente, según los casos- a lo largo de todo el Título I, relativo a los derechos deberes fundamentales. Así, aparte del derecho al matrimonio - cauce habitual para construir una familia-; el derecho a la intimidad familiar y, en relación a él, el derecho al honor (art. 18.1) -vinculado a un nombre familiar- así como la inviolabilidad del domicilio (art. 18.2) -sede habitual del hogar familiar-; los derechos educativos, mediante los que la familia puede escoger la formación moral y religiosa de los hijos y determinar la orientación general de la enseñanza que reciban (art. 27); el derecho a la propiedad privada y a la herencia (art. 33.1); estrechamente vinculados a la familia; el derecho al salario familiar entendido como la remuneración suficiente para que el trabajador satisfaga sus necesidades y las de su familia (art. 351); el derecho a disfrutar de una vivienda digna y adecuada (art. 47.1), en cuanto el hogar constituye una de las necesidades más perentorias de la familia, la protección a la tercera edad, donde los poderes públicos asumen un claro compromiso asistencial con independencia de las necesidades familiares (art. 50); la protección integral a los hijos y a las madres junto con el principio de investigación de la paternidad (art. 39.2); la obligación asistencial de los padres a los hijos (art. 39.3); etc. Todo ello sin olvidar el derecho a la vida (art. 15), que hace posible y garantiza de modo radical la existencia de la familia, en la medida que protege a sus miembros desde el momento de la concepción hasta el momento de la muerte y sin el que los demás derechos carecen de sentido. Es decir se puede afirmar que la genérica declaración del art. 9.1 puede concretarse en la prácti ca totalidad de los derechos y libertades constitucionalmente reconocidos, que cobran un especial relieve cuando proyectan su potencial eficacia sobre la familia.

205 CHINCHILlA MARIN, C. "La familia en la jurisprudencia del Tribunal Constitucional”, Aranzadi Civil-Mercantil, Volumen I, parte Estudio, Ed. Aranzadi, S.A., Pamplona, año 2005.

“Familia, familias y derecho de la familia”, Anuario de Derecho Civil, tomo XLIII, fasc. IV, oct.-dic. 1990 
porque no hay un modelo constitucional de familia, único acreedor de la protección del art. $39 \mathrm{CE}$. No existe la familia sino familias, esto es, un sistema de modelos plurales, determinados por la consideración de lo que la sociedad tenga en cada momento por familias. Otra cuestión es si el Derecho debe ofrecer una respuesta a todos y cada uno de estos modelos. Y si esta respuesta debe ser uniforme o, por el contrario, debe ajustarse a las particularidades de cada una.

Interesante es la opinión de MOLINA NAVARRETE ${ }^{207}$, aunque en el ámbito de la seguridad social y la familia, para quien la protección de los intereses de familia ha sido una constante en el Derecho del Trabajo español, para el cual a diferencia de antaño no sólo restringe el ámbito familiar a la experiencia matrimonial, sino que también a las parejas de hecho, debido a que acentúa la protección, más que a las parejas y por consiguiente sus formas de constitución, a las cargas familiares, es decir descendientes y ascendientes.

Según PÉREZ VILLALOBOS ${ }^{208}$, y me parece muy acertada su explicación, existen varios modelos de familia que tienen cabida en la Constitución. En primer lugar señala el modelo tradicional: grupo que nace del matrimonio entre hombre y mujer y está compuesto por éstos y su descendencia. Este modelo maneja la relación causa-efecto entre matrimonio y familia que en los debates constituyentes fue un artículo muy debatido precisamente porque se quería incluir este concepto de familia; En segundo lugar, la Constitución inaugura un nuevo modelo de familia diferenciado del anterior, tal diferenciación se ampararía en la admisión de la disolución del matrimonio, la equiparación de los cónyuges y consiguientes instauración de la patria potestad compartida, la equivalencia a todos los efectos de los hijos matrimoniales con los extramatrimoniales, la igualdad social de las madres con independencia de su estado civil, la juridificación de las relaciones de convivencia no basadas en el matrimonio y la no necesariedad del matrimonio como prerrequisito idóneo para poder hablar de la familia ${ }^{209}$; En tercer lugar el modelo de familia de hecho, su protección se debe en tanto grupo en el que existen miembros dependientes, por tanto es perfectamente posible la existencia de una familia en que los padres no se encuentren unidos en matrimonio, puesto que las obligaciones que se generan de dependencia entre hijos y padres son exactamente las mismas, y enfatizo que es esencial entender que en este supuesto conocido como "uniones de hecho" o "parejas de

207 MOLINA NAVARRETE, C. "La multiculturalidad, el pluralismo de las relaciones de convivencia de pareja" en Revista de Derecho Privado y Constitución, Centro español de estudios constitucionales, núm. 21, enero-diciembre 2007, páginas 297 y siguientes.

208 Vid. PÉREZ VILLALOBOS, M. C. “Las leyes autonómicas reguladoras de las parejas de hecho”, ...op. cit., páginas $100 \mathrm{~A} 102$.

209 Cfr. SERRANO, J. L.: "La familia como asunto de estado el matrimonio como derecho del ciudadano. Lectura sintomal de la separación sistémica entre matrimonio y familia en la Constitución española de 1978”, Revista Facultad de Derecho Universidad de Granada, núm. 4, año 2001, página 45. 
hecho", aunque las obligaciones se derivan de la relación afectiva de hecho no son equiparables a las derivadas del matrimonio porque no estamos identificando "parejas de hecho" con matrimonio, sino "familia de hecho" (consecuencia de una unión no matrimonial) con "familia matrimonial" (consecuencia de una unión matrimonial), ello debido a que el grupo familiar no requiere de un acto formal que lo origine; En cuarto lugar, modelo de familia en el que existe un único adulto sustentador y donde además existe personas dependientes de tal sustento como lo puede ser su propia descendencia, por ejemplo las madre solteras, o aquellas personas que consiguen una descendencia legal a través de la adopción; En quinto lugar, el modelo de familia en caso de separación o divorcio, en este caso a diferencia del supuesto anterior, siguen existiendo dos adultos sustentadores de la descendencia; En sexto lugar, familia en la que aparece como sustentador uno de los hermanos en ausencia de los progenitores, siempre que sigan existiendo miembros dependientes; En séptimo lugar la denominada simultaneidad familiar, esta tiene existencia cuando se forma parte de dos familias distintas, sin que pueda considerarse que una persona mantiene dos tipos de relaciones protegibles jurídicamente, una basada en el matrimonio y la otra en una posible unión de hecho. Sería, asimismo, la situación similar a la que se produce entre divorciados si uno de ellos se encuentra nuevamente casado y tiene descendencia ${ }^{210}$; Finalmente, familias con adultos sustentadores del mismo sexo, las parejas homosexuales y los grupos familiares formados por ellas son un límite constitucional al concepto de familia.

Pero frente a la realidad que implican las familias de hecho, la pregunta que me formulo es ¿Cómo lo ha entendido el Tribunal Constitucional?. Lo primero que se deduce de una lectura de la jurisprudencia del Tribunal Constitucional español en materia de familia es que el tribunal no define que se refiere cuando habla de "familia", ni en términos generales, aunque opina MARTIN VIDA ${ }^{211}$ que parece aludir a una realidad social lo suficientemente conocida que no necesita de más precisiones, ni en términos estrictamente constitucionales. Afirma esta autora que incluso evita expresamente llevar a cabo esa definición, como si saber de qué se habla cuando se habla de familia no resultase relevante en los pronunciamientos que emite, opino que no es así, es decir, si el Tribunal Constitucional no ha entrado a definir un concepto de familia es porque sencillamente evita entrar en una polémica, sin perjuicio de que puede ser probable que se puedan desproteger ciertos modelos de familia. Resulta ilustradora la afirmación contenida en la STC, Pleno, núm. 45/1989, RTC 1989/45, la familia es "una institución cuya trascendencia social no necesita ponderación y cuya

210 Vid. VV. AA., "Familia y cambio social en España", Centro de Investigaciones Sociológicas, Madrid, año 1982.

211 MARTIN VIDA, Ma . A. "El concepto constitucional de familia a partir de la jurisprudencia del Tribunal Constitucional", Revista de la Facultad de Derecho de la Universidad de Granada, no 4, año 2001, página 408. 
definición exacta desde el punto de vista constitucional no es problema que ahora debe ocuparnos". Afirma en esa misma sentencia que existe un concepto constitucionalmente adecuado de familia, pero evita expresamente definir cuál puede ser este, y sólo admite que, en todo caso, y con apoyo de diversos convenios internacionales, englobaría a la familia que tiene su origen en el matrimonio $^{212}$ y por exigencias del art. 39, ese modelo de familia no puede recibir un tratamiento peor que el que recae sobre las unidades familiares que no tienen su origen en el matrimonio sino en otras modalidades de convivencia ${ }^{213}$.

Inicialmente el TC incide en el concepto de "familia matrimonial". Es relevante en este sentido STC, Pleno, núm. 184/1990, de 15 noviembre, RTC 1990/184 ${ }^{214}$. Resumidamente, la doctrina recogida en esta sentencia fue la siguiente. La familia constitucionalmente protegida puede tener un origen tanto matrimonial como extramatrimonial, pero sólo el matrimonio está protegido constitucionalmente. Las uniones de hecho constituyen un reflejo de la libertad de los convivientes, pero no estaríamos ante un supuesto de hecho que tenga cabida en el artículo 39 de la Constitución ( “... la unión de hecho more uxorio no es una institución jurídicamente garantizada, ni hay un derecho constitucional expreso para su establecimiento...”). Ahora bien, la unión de hecho no es una familia, como simple pareja no está protegida, sólo será reconocida como familia y protegida como tal cuando existen hijos.

El concepto de familia defendido en esta Sentencia fue modificado en la STC, Pleno, núm. 222/1992, de 14 de diciembre, RTC 1992/222 . En la misma, el Tribunal considera que se debe extender la protección constitucional de la familia contenida en el art. 39 tanto a la familia fundada en el matrimonio como a la que tiene otro origen. Esta extensión de la protección constitucional se fundamentaba en diversos argumentos: la regulación separada de familia y matrimonio (arts. 32 y 39 de la Constitución); la necesidad de interpretar el art. 39.1 teniendo en cuenta el resto del precepto (

212 Sea cual fuere el concepto constitucionalmente adecuado de familia, o es discutible que tal concepto incluye, sin duda, la familia que se origina en el matrimonio es, en todo caso, la que especialmente toman en consideración tanto la Declaración Universal de Derechos Humanos aprobada por la Naciones Unidas en 1958 (art. 16.1), como los Tratados sobre derechos fundamentales suscritos por España (así, el Convenio de Roma, art. 12, el Pacto Internacional de los Derechos Civiles y Políticos, art. 23, y el Pacto Internacional de Derechos Económicos, Sociales y Culturales, art. 10.1.

213 Si la carga tributaria que pesa sobre una persona integrada en una unidad familiar es mayor que las que pesa sobre otro contribuyente con idéntico nivel de renta, pero no integrada en una unidad de este género (o lo que es lo mismo, mayor que la que pesaría sobre esa misma persona si no constituyera parte de una familia, a efectos personales), es evidente que no sólo se lesiona el principio de igualdad, sino que directamente se va en contra del mandato constitucional que ordena la protección de la familia, a la que, al obrar así, no sólo no se protege, sino que directamente se la perjudica".

214 Esta sentencia se pronunció sobre la constitucionalidad del art. 160 de la Ley General de la Seguridad Social y de la Disposición Adicional Décima de la ley 30/1981, debido a la cuestión de inconstitucionalidad planteada por una Magistratura del Trabajo, alegando las posibles vulneraciones de los artículos 10, 14 y 39 de la Constitución. El Tribunal consideró que tales normas eran inconstitucionales. 
“... art. 39.1, cuyo alcance, por lo demás, ha de ser comprendido también a la luz de lo dispuesto en los apartados $2^{\circ}$ y $3^{\circ}$ del mismo artículo”); la protección de los hijos con independencia de su filiación y de las madres con independencia de su estado civil y por último, hay que tener en cuenta que el origen de la protección de la familia está en el carácter social del Estado español, reconocido en los artículos 1.1 y 9.2 de la Constitución ( "Nuestra Constitución no ha identificado la familia a la que manda proteger con la que tiene su origen en el matrimonio, conclusión que se impone no sólo por la regulación bien diferenciada de una institución y otra (arts. 32 y 39) sino también, junto a ello, por el mismo sentido amparador y tuitivo con el que la norma fundamental considera siempre a la familia y, en especial, en el repetido artículo 39, protección que responde a imperativos ligados al carácter social de nuestro Estado (arts. 1.1 y 9.2) y a la atención, por consiguiente, de la realidad efectiva de los modos de convivencia que en la sociedad se expresen") ${ }^{215}$.

En la misma línea que la anterior, la STC, Sala segunda, número 47/1993, de 8 de febrero, RTC 1993/47, manifestó lo siguiente: “En correspondencia con el pluralismo de opciones personales existentes en la sociedad española y la preeminencia que posee el libre desarrollo de la personalidad (art. 10.1 de la CE), la Constitución no sólo protege la familia que se constituye mediante el matrimonio -aunque a ésta se le proteja especialmente (STC 45/1989)- sino también a la familia como realidad social, entendida como tal la que se constituye voluntariamente mediante la unión de hecho, afectiva y estable, de una pareja”.

Apreciación interesante para intentar desentrañar algo el concepto de familia que tiene el Tribunal Constitucional es la siguiente, procedente de la STC, Pleno, núm. 222/1992, de 11 de diciembre, RTC 1992/222: "en el concepto constitucional de "familia” entra, sin duda, el supuesto de matrimonio sin descendencia o sin otros parientes a su cargo, de conformidad con el sonido de otras previsiones constitucionales (art. 18.1), con la orientación de la legislación postconstitucional, con la propia jurisprudencia de este Tribunal (SSTC 45/1989, 192/1991 y 200/1991), y, en definitiva, con la acepción normalizada y arraigada, en nuestra cultura, de la voz "familia" en cuyo

215 En relación con esta Sentencia sin duda es importante destacar unos interesantes votos particulares. En primer lugar está el de RODRIGUEZ BEREIJO que afirma textualmente lo siguiente: "El vínculo matrimonial genera una serie de derechos y deberes de los cónyuges, lo que no ocurren en la convivencia de hecho. El que el legislador civil, deduciendo razonablemente consecuencias de la diferente situación jurídica y constitucional de partida, excluye del derecho a la subrogación arrendaticia a las uniones libres basadas en la convivencia more uxorio dando un trato distinto y más favorable a la unión matrimonial, no es contrario a la Constitución". En cuanto al magistrado GABALDON LOPEZ, en su voto particular se dice textualmente lo siguiente: "La Constitución considera el matrimonio, institución regulada en sus diversas formas y consecuencias jurídicas por la Ley, tal como resulta del art. 32 de la Constitución, como procedimiento de formación de la familia, digna ésta de protección en general y sin que quepa otorgar al artículo 39 consecuencias que no se desprendan de su propia formulación (...) Cuando se han querido prever situaciones familiares dignas de protección fuera de la familia matrimonial se han formulado expresamente: así, igualdad de los hijos y de las madres ante la Ley, investigación de la paternidad, deber de asistencia a los hijos matrimonio o no". 
concepto entra, por consiguiente, también la relación matrimonial de hombre y mujer sin descendencia”.

¿Cuáles serían los rasgos que caracterizarían jurisprudencialmente a la familia? Según MARTIN VIDA ${ }^{216}$, el análisis de las decisiones del Tribunal Constitucional en las que éste se refiere a la familia permite descubrir algunos de los rasgos que, según el Tribunal, caracterizarían esta institución. En la STC 222/1992 la define como “un marco de solidaridades y de dependencia”. En esta misma sentencia hace referencia a la vida en común que supone la vida en familia, convivencia que en el caso de las unidades familiares no matrimoniales ha de probarse a efectos de conseguir las ventajas que se concedan legalmente a las mismas. Esa "vida en común" que se exige, por ejemplo, para que el miembro supérsite de la pareja pueda subrogarse en el contrato de arrendamiento de la vivienda habitual permite, según el Tribunal, "reconocer la existencia de vínculos de dependencia y afectividad entre el fallecido y su cónyuge", en sentido amplio. Critica MARTIN VIDA esta idea de dependencia a la que se refiere el Tribunal Constitucional, sin teorizar a la vez sobre el sonido complejo que la misma tiene en las relaciones en el seno de la familia y en las relaciones humanas en general (como un elemento que no funciona unidireccionalmente y cuya operatividad no puede ser percibida como tal y que puede hacer perder de vista lo que es esencial, en opinión de esta autora, en el tratamiento jurídico de la familia; ésta es digna de tutela en tanto que es el entorno afectivo y material idóneo para el libre y pleno desarrollo de la personalidad de todos y todas sus integrantes [art. 10.1 CE]).

La protección que se proporcione a la familia matrimonial habrá asimismo de respetar la igualdad entre los cónyuges, y en ello se insiste particularmente en la STC, Pleno, núm. 45/1989, de 20 de febrero, RTC 1989/45 en la que el Tribunal evalúa los efectos (desincentivadores) que pesan sobre la realización por las mujeres de un trabajo remunerado podría tener el no dar a las familias matrimoniales la oportunidad de que sus miembros tributen por separado en el Impuesto sobre la Renta de las Personas Físicas: “cualquier norma que incida sobre la vida de las familias debe ser respetuosa con la concepción de esta que alienta la Constitución, de la que forma parte la igualdad entre los cónyuges. Esa igualdad se verá seguramente alterada cuando la libertad de elección u oficio de uno de los cónyuges se vea condicionada por las consecuencias económicas que, en razón de la norma tributaria, se seguirán de su elección y, aunque carecemos de estudios sociológicos que claramente lo establezcan, parece poco dudoso que el sistema de acumulación de rentas, en cuanto que incrementa la carga tributaria de la familia, desestimula, por decir lo menos, el trabajo

216 MARTIN VIDA, "El concepto constitucional de familia a partir de la jurisprudencia del Tribunal Constitucional”, ....op. cit., página 416. 
fuera del hogar del posible perceptor de la segunda renta que es, en la mayor parte de los casos, la esposa. El uso que de la acumulación de rentas se ha hecho en otros países con la finalidad expresa de "devolver la mujer al hogar" avala claramente esta deducción. También desde este punto de vista, pues, el precepto que ahora analizamos se concilia difícilmente con el art. 39.1, en relación con el art. 32, ambos de la CE” (FJ7). Igualdad entre los cónyuges e igualdad entre hombre y mujer pertenecientes a la misma familia que supuso que los arts. 160.2 y 162 de la Constitución, con base a la discriminación que suponía la diferencia notoria de régimen entre el derecho a la pensión de las viudas y los viudos -el primero-, y la exclusión de los varones como beneficiarios de la prestación a favor de familiares -el segundo-."

Sin duda, tal cual se ha dejado entrever, un importante sector de la doctrina ${ }^{217}$ opinó, en su momento que, cabía concluir que la familia también era la fundada en la unión de hecho ${ }^{218}$, aunque hubiese algún trato preferencial a la familia fundada en el matrimonio.

Partiendo de que el modelo familiar por excelencia es el fundado en el matrimonio/relaciones conyugales-relaciones de filiación), el Código Civil debería reconocer esta estrecha relación sin perjuicio de protegerse también a la familia de hecho, en cuanto objeto de la justicia concreta ${ }^{219}$. A mi juicio, en la actualidad, la protección jurídica viene dispensada no al grupo como tal sino singularmente a los individuos que la componen, o las situaciones que ellos protagonizan, en cuanto resultan semejantes, en el juego de algunos intereses particulares, con las que surgen de la familia matrimonial, por lo que no se puede extender a todas las situaciones porque entre la familia y la unión de hecho, no puede haber analogía, pero, en mi opinión, si entre familias cuyo origen es el matrimonio y familias cuyo origen es la unión de hecho. Entiende MARTÍN VIDA que tal criterio, rectamente administrado puede ser muy fructífero y dar satisfacciones a todos. El fundamento de lo anterior se apoyaría, en último término, en la distinción entre Derecho y equidad y tendría la virtud de que, facilitando el juego de la solidaridad social evita conflictos, que no tendrían que darse, entre la familia y las uniones de hecho.

217 PLANA ARNALDOS, "Libertad ideológica y libre opción entre matrimonio y convivencia de hecho (Comentario a la STC 180/2001, de 17 de septiembre de 2001)”, Revista de Derecho Privado y Constitución, núm. 15, Madrid, año 2001, página 269.

218 Opinión rebatida por TALAVERA FERNÁNDEZ, P., en "La unión de hecho y el derecho a no casarse”, Ed. Comares, Granada, año 2001, páginas 116-117. Este autor afirma que en ningún caso se afirma en esta sentencia que la unión de hecho, en cuanto relación de pareja, debe ser considerada como una unidad familiar protegible por el art. 39 de la Constitución. Según este autor es errónea la interpretación según la cual se identifica unión de hecho y familia no matrimonial.

219 DE LOS MOZOS, “Familia y Derecho: de nuevo sobre las parejas no casadas”, La Ley, núm. 7, Madrid, año 2009, pagina 123. 
Otras situaciones que, podríamos denominar, familia-hogar, que acercan a lo que hemos denominado modelo familiar, pero no son familia strictu sensu, tienen ya su propio lugar en la legislación. Serían las situaciones convivenciales de ayuda mutua, reguladas por la Ley de Cataluña 25/2010, el acogimiento familiar o la situación de convivencia creada a partir de los alimentos convencionales de la Ley 41/2003, de 18 de noviembre, de protección patrimonial de las personas con discapacidad.

En el caso de situaciones convivenciales de ayuda mutua, la ley catalana recogió estas formas de relación. Y aunque pudiera estimarse que la ley se refiere casi en exclusiva al problema que para los ancianos puede representar la necesidad de abandonar el domicilio familiar por incapacidad de atender a sus propias necesidades, no se trata de una ley especialmente dictada para resolver tal problema. Su destinatario no es exclusivamente la población senil, sino en general, todas aquellas personas que sin constituir familia nuclear compartan, con voluntad de permanencia y ayuda mutua, los gastos comunes o el trabajo doméstico o ambas cosas. Aunque se ha discutido por la doctrina si estamos ante una familia o no ${ }^{220}$, se podría denominar familia-hogar, por ser un cierto reflejo de la familia.

Más cercana al concepto de familia aparecería el acogimiento familiar, introducido en el Código Civil por la Ley 21/1987, de 11 de noviembre. En el Código se recoge el acogimiento familiar de menores, integrándolos en un núcleo familiar estable. Pero en sede autonómica se habla también de acogimiento de ancianos. En este caso, se trata de que una familia que lo desee podrá acoger e integrar en la misma a una persona mayor que se encuentre sola. Se trataría, pues, de ubicar al anciano en una "familia-sustituta", de la que percibiría todo el apoyo y atención que no obtiene de una propia, bien porque no existe, bien porque, existiendo, no quiere o no puede prestárselos.

En el primer caso, el concepto familia-hogar sigue siendo plenamente válido, probablemente acercándose al modelo de familia conyugal. Las obligaciones de los acogedores, como bien se ha señalado, se aproximan al menos en el aspecto personal, al estatuto de la patria potestad. En cuanto al menor, adquiere el derecho a la plena participación en la vida de la familia de acogida. Lo mismo se podría decir en el caso de acogimiento de ancianos, porque las relaciones entre acogedores y acogidos pueden ser particularmente intensas. Sin duda el acogimiento de ancianos presenta notables coincidencias, en cuanto a la finalidad con los alimentos convencionales en el Código Civil ${ }^{221}$.

220 SANCHEZ GONZALEZ, M․ P. "Las fronteras del concepto jurídico de familia”, La Ley, núm. 5, Madrid, año 2004, página 1402.

221 Cfr. LINACERO DE LA FUENTE, M.: "Protección jurídica de las personas mayores". Actualidad Civil 19/2004, La Ley, Madrid, año 2004, páginas 2262 y siguientes. También SÁNCHEZ GONZÁLEZ, Ma P.: “Acogimiento familiar para personas mayores y otras alternativas al internamiento en centros geriátricos", RJN, núm. 46, abril-junio 2003, página. 211 y siguientes. Comenta la Ley catalana 22/2000 con referencias a la Ley 
Del tenor literal del nuevo art. 1792 CC se deduce que la forma habitual de prestar estos alimentos exige que ambas partes del contrato compartan un mismo domicilio. Este dato sirve para hacernos resaltar que entre estas personas se establecerán relaciones más allá de lo meramente patrimonial, participando, el que ve satisfecho sus necesidades vitales (vivienda, manutención, asistencia), de alguna manera en la vida familiar del que las presta a cambio de la transmisión de los bienes.

En relación a las uniones de homosexuales en strictu sensu es difícil hablar de "familia" en opinión de SÁNCHEZ DE LA TORRE. Esta realidad, incluso en el lenguaje vulgar, es procreación (y responsabilidad por la misma), y ello va contra la propia estructura de las parejas homosexuales. Como señala el autor antes mencionado ${ }^{222}$, ello no significa discriminación alguna, sino el reconocimiento de que la unión de los homosexuales no es un modo de convivencia que se pueda poner bajo el paraguas de la institución familiar, en cuanto que no realiza las funciones y responsabilidades de la misma. Puede ser llamada dicha relación como unión o sociedad y sus miembros tienen derecho a establecer sus relaciones recíprocas del modo que numerosas figuras jurídicas contenidas en un ordenamiento positivo permite. Ahora bien, al tener acceso al matrimonio y poder adoptar, se estaría legalmente ante un modelo familiar, la pregunta que me formulo es si realmente el rol de padre o madre puede desempeñarlo en su total plenitud alguien que no es precisamente un hombre o una mujer, posiblemente desde el punto de vista afectivo, sí, pero ¿dos padres o dos madres, son realmente lo mismo que un padre o una madre?. No lo creo. Me parece que se ha institucionalizado la idea de que no es tan importante para un niño tener una madre o un padre, pero se olvida que son los intereses de los adoptados y no los de los adoptantes los que deben guiar el espíritu de toda ley de adopción. Se cita con frecuencia que es mejor que un niño sea adoptado por una pareja de homosexuales en vez de vivir en un hogar de heterosexuales donde existe violencia doméstica o cualquier otro problema que les afecta, pero sin duda no se trata de elegir entre estas dos situaciones ${ }^{223}$. Se les priva, en definitiva del beneficio que implica tener una figura paterna y materna, tales figuras, tanto por separado como conjuntamente influyen positivamente en el bienestar del menor. Lo anterior no surge de la idea de discriminar a un grupo de personas sino amparándome en la estructura inherente de que un hogar familiar requiere, si es posible, la mayor plenitud posible en el cumplimiento de los

Navarra 34/2002: HERAS HERNÁNDEZ, Ma del M.: "El contrato de acogimiento familiar de personas mayores” . Revista de Derecho Privado, julio-agosto, Madrid, año 2004, página 443 y siguientes.

222 SANCHEZ DE LA TORRE, A., "Concepto jurídico de familia”, Anales de la Real Academia de Jurisprudencia y Legislación, año 2001, página 230.

223 LÓPEZ DEL BURGO, C y DE IRALA, J. "Los estudios de adopción en parejas homosexuales: mitos y falacias”, Cuadernos Bioéticos, núm. XVII, año 2006/3, página 379. 
roles materno y paterno. Se trata en definitiva de buscar y cumplir con el interés superior del menor propiciando la adopción de los mismos por las personas más idóneas.

\section{3 | Igualdad y Matrimonio}

\subsection{La evolución de la garantía institucional del matrimonio}

En principio y confirmando una vez más lo inadecuado del criterio formalista en esta sede, la fijación del núcleo esencial de la garantía institucional no puede hacerse exclusivamente a partir de la literalidad del dato normativo, dada la morfología singularmente abstracta de los enunciados constitucionales en general ${ }^{224}$, y del art. 32 en particular, un precepto del que, en este sentido, se ha dicho que sólo permite deducir un concepto constitucional tenue sobre lo que deba entenderse por matrimonio, en cualquier caso no exento de ciertos elementos propiamente calificadores de la institución, o del que, en un sentido similar, se ha subrayado que sólo define parcialmente y de forma no demasiado precisa el concepto genérico de matrimonio, sin perjuicio igualmente de la existencia de algunos requisitos preordenados en la Constitución.

Por el contrario, el análisis que ha de realizarse en la búsqueda de aquel reducto o núcleo de esencialidad de la institución, incide, desde una perspectiva material, en el sentido y la finalidad de la norma con la que dicha institución se garantiza. En palabras del Tribunal Constitucional y sentando una doctrina hoy plenamente consolidada en esta sede, "la garantía institucional no asegura un contenido concreto o un ámbito competencial determinado y fijado de una vez por todas, son la preservación de una institución en términos recognoscibles para la imagen que de la misma tiene la conciencia social en cada tiempo y lugar. Dicha garantía es desconocida cuando una institución es limitada de tal modo que se le priva prácticamente de sus posibilidades de existencia real como institución para convertirse en un simple nombre. Tales son los límites para su determinación por las normas que la regulan y por la aplicación que se haga de estas. En definitiva, la única interdicción claramente discernible es la de la ruptura clara y neta con esa imagen comúnmente aceptada de la institución que, en cuanto formación jurídica, viene determinada en buena parte por las normas que en cada momento la regulan y la aplicación que de las mismas se hace” (STC, Pleno, núm. 32/1981, de 28 de junio, RTC 1981/32).

Esa imagen institucional del matrimonio podrá ser detectada en la doctrina del Tribunal Constitucional, en su cualificada condición de supremo intérprete del contenido del art. 32, pero debe

224 LOPEZ Y LOPEZ, A., “La garantía institucional de la herencia”, en VV. AA., “Estudios de Derecho Público. Homenaje a Juan José Ruiz-Rico”, Volumen I, Ed. Tecnos, Madrid, año 1997, página 714. 
asimismo encontrarse reflejada en la actividad de los distintos operadores jurídicos, de modo que, si se pretende arrojar alguna luz, sobre este punto, se hace preciso acudir también a la praxis de los órganos administrativos con alguna competencia sobre la materia, así como, naturalmente, a la interpretación jurisprudencial del régimen matrimonial. Las construcciones elaboradas por la doctrina científica a partir de estos datos complementan la tarea de perfilar el núcleo objetivo de la institución en la norma fundamental, contribuyendo en buena medida a esclarecer su significado ${ }^{225}$.

En conjunto, como se ha hecho notar, la dinámica inherente a esta técnica de protección constitucional, respecto de la terminación de esa imagen característica del instituto garantizado, concede un papel esencial a la doctrina jurídica del país, cuyo portavoz autorizado, en última instancia, no es otro que el Tribunal Constitucional ${ }^{226}$.

Ello, a su vez, y ese es sin duda otro debate, por qué se atisba una realidad de la hermenéutica constitucional, ¿cómo incorporar en la determinación de las garantías institucionales o derechos fundamentales elementos exógenos o extraconstitucionales? Sobre esta pregunta es necesario hilar fino, para no incurrir en una interpretación tendencialmente conservadora de aquel contenido que se interpreta, lo que, sin embargo, como se ha advertido en sede doctrinal, no tiene por qué ser una consecuencia inevitable de ese recurso hermenéutico e, incluso, antes bien, éste puede desempeñar una importante función de cristalización de los valores constitucionales, a modo de cláusula de cierre del ordenamiento ${ }^{227}$. Nótese, en este sentido, que la propia determinación, por parte del Tribunal Constitucional, del núcleo de la garantía institucional a partir de esa imagen en la cultura jurídica está por definición, a través del proceso interpretativo que desarrolla el Tribunal, sujeta a su contraste con los restantes preceptos de la Constitución y, como es natural, subordinada a su compatibilidad con el sistema de valores que subyace al texto fundamental.

225 BERCOVITZ RODRÍGUEZ-CANO, R. “Sobre el matrimonio”, Aranzadi Civil Mercantil núm. 22/2010, parte Tribuna, Ed. Aranzadi, Pamplona, año 2010. El autor expone: "Tengo el más profundo respeto por la libertad y la igualdad en relación con las costumbres, las etnias, las creencias religiosas y las ideologías. Todos los avances en esos ámbitos me parecen beneficiosos para la sociedad y el bienestar de las personas. Pero el matrimonio es una institución que debe ser controlada por el Estado, habida cuenta de sus trascendentes efectos sociales y de la protección que los mismos merecen. De ahi que no comparta la opinión de quienes creen positivo, identificándolo con el progreso, atribuir con carácter general, a quienes desean permanecer al margen de dicho control del Estado sus relaciones de pareja, los mismos efectos que si se hubiesen acogido al mismo. Sobre todo, teniendo en cuenta el marco que nuestra Constitución establece para el matrimonio, respetuoso con su naturaleza y función, respetuoso con la libertad de los cónyuges, respetuoso con la igualdad de los ciudadanos. Conviene recordar que no todo cambio se identifica con el progreso"

226 JIMENEZ-BLANCO, A. “Garantías institucionales y derechos fundamentales en la Constitución”, en VVAA, Estudios sobre la Constitución española. Homenaje al Profesor Eduardo García Enterría”, Volumen I, Ed. Civitas, Madrid, año 1991, páginas 645 y 646.

227 PRIETO SANCHÍS, L. “Estudios sobre derechos fundamentales”, Ed. Debate, Madrid, año 1990, páginas 144 a 146. 
Las opiniones varían, las resoluciones cambian, de qué manera lo han hecho en esta materia, a continuación lo veremos.

A partir de las premisas antes mencionadas, un primer elemento a tomar en consideración, en la determinación de esa imagen institucional, lo constituyó la doctrina de la Dirección General de los Registros y del Notariado que, en su resolución de 21 de enero de 1988, asumió el requisito de la heterosexualidad como presupuesto del matrimonio y, por lo tanto, como condición inherente a la prestación de un consentimiento de carácter propiamente matrimonial: "No hace falta resaltar que el matrimonio ha sido siempre entendido como una institución en la que la diferenciación de sexos es esencial. Y este concepto tradicional es el que recogen, sin duda las normas vigentes en España, rectamente interpretadas”; Ulteriormente también, en su resolución de 2 de octubre de 1991, tuvo ocasión de recordar la necesidad de interpretar el art. 32 de la Constitución, de conformidad con el canon hermenéutico del art. 10.2, a la luz de los textos internacionales suscritos por España en la materia, "los cuales, al garantizar el derecho a casarse, se refieren exclusivamente al matrimonio entre personas de distinto sexo biológico".

A juicio de dicha doctrina ésta era efectivamente, la posición adoptada por la Corte de Estrasburgo en su interpretación del significado del artículo 12 del Convenio Europeo, en la que, no sólo se confirmaba el presupuesto de heterosexualidad, sino que se incluía además este requisito en lo que expresamente se designa como la esencia o sustancia del matrimonio en aquel precepto. Así por ejemplo, en ese momento, se declaró que las limitaciones legislativas que debían imponerse al ejercicio del derecho a contraer matrimonio "no deben restringirlo o reducirlo de tal manera, o hasta tal extremo, que afecta a su propia esencia. No obstante, el obstáculo legal que impone el Reino Unido al matrimonio entre personas del mismo sexo biológico no se incluye en la expresada y vetada restricción" (STEDH de 17 de octubre de 1986; en el mismo sentido, la SSTEDH de 27 de septiembre de 1990 y de 30 de julio de 1998).

En la misma orientación, el Tribunal Supremo tuvo oportunidad de referirse a la vigencia del requisito de la heterosexualidad del matrimonio. Lo hizo de un modo incidental, esto es, en el contexto de una serie de consideraciones que, como obiter dicta, formuló al pronunciarse sobre la pretensión de reconocimiento del derecho del transexual a solicitar el cambio de sexo en el registro civil. Por ello mismo, técnicamente y a la luz del concepto de jurisprudencia que asumía el Tribunal, en ese entonces se dejaba entrever que la declaración del derecho al cambio de sexo registral no tenía que ser acompañada del derecho a contraer matrimonio en esos supuestos. En este sentido podía interpretarse que tales consideraciones eran expresivas de una concepción de base del matrimonio, y 
reflejo, en suma, de esa imagen en la que se representa su esencia institucional en el ordenamiento jurídico español. Será en la sentencia de 1991 cuando, tras diversos pronunciamientos sobre el tema, el Tribunal vincule expresamente el requisito de la heterosexualidad a la garantía constitucional del matrimonio: "el libre desarrollo de la personalidad del transexual tiene el límite de no poder, al no ser ello posible, contraer matrimonio, parte de otras limitaciones deducidas de la naturaleza física humana, ya que tales matrimonios serían nulos por inexistentes, como se deduce de los artículos 44 y 73.4 del Código Civil y 32.1 de la Constitución”.

Pocas dudas ofrecía la declaración, por parte del Tribunal Constitucional en su interpretación del significado de la garantía contenida en el art. 32 de la vigencia en el mismo del presupuesto de la heterosexualidad como base de la institución garantizada. Así tras señalar que la "unión entre personas del mismo sexo biológico no es una institución jurídicamente regulada, ni existe un derecho constitucional a su establecimiento; todo lo contrario al matrimonio entre hombre y mujer que es un derecho constitucional", el alto Tribunal proclamaba que "la plena constitucionalidad del principio heterosexual como calificador del vínculo matrimonial ${ }^{\text {"228 }}$. El recurso constante en todas sus resoluciones a los términos marido y mujer para referirse a los cónyuges, a estos efectos, no era más que la manifestación sintomática y la consecuencia de la adopción de ese presupuesto de partida.

Debe resaltarse que toda esta ordenación jurídica se proyecta sobre un entorno social en el que cabe detectar, en los últimos años un notable cambio de actitud hacia la homosexualidad concebida como una parcela más de la reconocida capacidad de autodeterminación del ciudadano que queda al abrigo del sistema de libertades y, significativamente, del principio de libre desarrollo de la personalidad. En este contexto se inscribe el paulatino proceso de despenalización de las conductas homosexuales en el entorno cultural, así como determinadas propuestas orientadas al reconocimiento legal del derecho a contraer matrimonio por parte de personas del mismo sexo entre las que destaca sin lugar a dudas la Resolución del Parlamento Europeo aprobada el 8 de febrero de 1994, en la que se llama a poner fin "a la prohibición de contraer matrimonio o acceder a regímenes jurídicos equivalentes a las parejas de lesbianas y homosexuales" 229 .

228 STC, Sala 2a núm. 222/1994 de 18 julio. RTC 1994/222.

229 FERREIRO, J. "Uniones de hecho: perspectiva histórica y Derecho vigente”, en, en MARTINELL, J. M. y ARECES, M. T. (Edits.), “Uniones de Hecho”, Lleida, año 1998, páginas 222 y siguientes; sobre esto puede verse más ampliamente, GONZALEZ BEILFUSS, C. "Parejas de hecho, parejas registradas y matrimonios de personas del mismo sexo en el derecho internacional privado europeo", en NAVAS NAVARRO, S. (Coord.), "Matrimonio homosexual y adopción : perspectiva nacional e internacional”, Ed. Reus S.A., Madrid, año 2006, páginas 99 a 112. 
Sin embargo, estos datos, pese a su innegable relevancia en otros sectores de las ciencias sociales, carecen de valor hermenéutico en lo que concierne estrictamente a la determinación del significado que el constituyente quiso conferir a sus previsiones, y, por ello, no es extraño que en este plano, estrictamente jurídico, la opinión más extendida entre la doctrina científica, de hecho, como es notorio, la que sostiene la práctica totalidad de la misma permitiendo hablar así de un altísimo consenso sobre el tema ${ }^{230}$, es la de que el constituyente español, al regular la institución del matrimonio, no contempló otra realidad distinta a la del matrimonio heterosexual, opinión compartida además en el informe emitido por el Consejo General del Poder Judicial, así como en el dictamen del Consejo de Estado, relativos a la reciente reforma del Código Civil en este aspecto, los cuales ya detallaréé 231 .

230 AlZAGA VILlamiL, O. "Derecho Político español según la Constitución de 1978”, en VV. AA. "Constitución y Fuentes del Derecho", Centro de estudios Ramón Areces, Madrid, año 1997, página 355.

231 ARRECHENDERRA ARANZADI, L. I. "El matrimonio es heterosexual", Actualidad Jurídica Aranzadi, núm. 658/2005, parte Opinión, Ed. Aranzadi, Pamplona, año 2005, BIB 2005/510. "Cuando uno se pregunta qué es el matrimonio duda de estar ejerciendo sus facultades en plenitud. Pero hasta aqui nos ha traido la vida, precisamente cuando uno comenzaba a despedirse de ella. El matrimonio es el sexo institucionalizado. Y el sexo es una relación por oposición. Se trata de una realidad recíprocamente orientada. Antes de entrar en vigor la Constitución los hombres se sentían atraídos por las mujeres y las mujeres por los hombres. Esto no lo enseñaban en la escuela: lo descubría uno mismo. A los hombres les gustan las mujeres y a las mujeres los hombres. Esto puede calificarse de un dato notorio de carácter universal, en el que debe apoyarse el Derecho, de tal entidad que discutirlo es pelear con lo evidente. ¿Cabe un ejercicio del sexo no institucionalizado? Por supuesto. ¿Cabe un ejercicio del sexo que prescinda de la oposición como reciprocidad? Por supuesto. ¿Cabe calificar esta posibilidad de orientación sexual? No. Tiene el sagrado carácter de lo excepcional, pero la regla es la orientación del sexo por oposición. ¿Puede ser institucionalizado? No, porque a la sociedad no le compete ni pronunciarse ni dar relieve a algo tan respetable como intrascendente. ¿Y por qué cabe institucionalizar el ejercicio heterosexual del sexo? Por tres razones: primera, porque los interesados lo piden; segunda, porque supone el ejercicio del sexo según su orientación intrínseca; y tercero porque garantiza la conservación de la especie. Una cosa es la escisión sexo-reproducción, y otra que sólo la heterosexualidad retiene potencialmente la capacidad de conservar la especie. Una cosa es que el matrimonio del impotente sea válido, y otra que el matrimonio deje de conservar como seña de identidad la posibilidad -no la necesidad-de transmitir la vida....cabe preguntarse por qué la Constitución se refiere al matrimonio . Hay muchas otras figuras, civiles o no, de las que el texto constitucional no se ocupa. ¿Por qué un acuerdo de convivencia heterosexual u homosexual no es mencionado por la Constitución? ¿Qué tiene el matrimonio que no tengan estos acuerdos de convivencia? Piénsese también en el convenio por el que los padres designan a un hijo, entre varios, para que contraiga matrimonio y se quede a vivir en la casa como heredero de todo el patrimonio familiar -pacto sucesorio-, que no pasa de ser un respetable pacto civil. Mientras viven los padres, conviven dos generaciones, posiblemente tres, en el mismo ámbito familiar. ¿Por qué la Constitución no se refiere a este macro-acuerdo convivencial? Porque, a diferencia del acuerdo de convivencia familiar, el matrimonio garantiza la perpetuación de la familia. El pacto sucesorio organiza la convivencia dándole una proyección patrimonial sucesoria. El matrimonio garantiza, en principio, la transmisión de la vida y la continuidad familiar. En el matrimonio está institucionalizado el sexo como origen de la vida. Se objetará que para transmitir la vida no es preciso el matrimonio . Obvio. Luego podemos prescindir del matrimonio . Obvio. Pues prescindamos del matrimonio . De acuerdo: muerto el perro se acabo la rabia. Punto final: no ha lugar al matrimonio de los homosexuales, porque hemos prescindido por innecesario del matrimonio." ; Cfr. SAN, Sala de lo Social, Sección 1a , núm. 66/2007, 25 de junio, AS 2007/2325: "Distinto sería que el Convenio Colectivo de 2006 fijara diferentes regímenes jurídicos a las parejas ligadas por matrimonio, fueren los así ligados del sexo que fueren, y a las parejas no ligadas por tal institución jurídica, fueren los así ligados del sexo que fueren, ya que contraer o no matrimonio es un derecho, pudiéndose diferenciar, como tiene dicho el Tribunal Constitucional, entre quienes lo ejercen y quienes no lo ejercen; pero, una vez que el Convenio Colectivo de 2006 no ha hecho tal diferenciación, lo que no cabe es que diferencie entre parejas de hecho heterosexuales y parejas de hecho homosexuales, para igualar las primeras a las parejas vinculadas por matrimonio y, a la vez, 
No cabe ignorar, en este orden de consideraciones, que la imagen de la institución en la conciencia social que es relevante, a efectos de la determinación del alcance de la garantía institucional del matrimonio en la Constitución en principio y teniendo en cuenta la precisión que después se hará, es la que existe en el momento en el que se verifica el proceso constituyente, y, como se ha hecho notar, el contexto sociológico en el que tal proceso se desarrolla denota que el constituyente sólo estaba pensando en el matrimonio heterosexual ${ }^{232}$.

Una constatación que por lo demás, se ve en efecto refrendada en el marco de los trabajos parlamentarios previos a la promulgación del texto fundamental, al ser rechazadas, y no tener por tanto reflejo en el texto final, las posiciones que sugerían otras fórmulas que hubieran podido suponer la asunción de un modelo matrimonial de base no necesariamente heterosexual; los debates parlamentarios son, no cabe olvidarlo, aun subordinadamente y en combinación con otras fuentes, importantes elementos de interpretación de las previsiones constitucionales y así lo ha proclamado la doctrina del Tribunal Constitucional ${ }^{233}$.

La precisión a la que nos acabamos de referir se encuentra relacionada con la propia dinámica histórica que define el sentido y la función de la garantía institucional como técnica de protección, sin olvidar además que esa misma historicidad es también consustancial a la concreción del contenido esencial de cada derecho fundamental ${ }^{234}$, y en general, al reconocimiento de los derechos fundamentales en el constitucionalismo contemporáneo, razón por la cual es posible identificar estos últimos con aquellos considerados como tales en la conciencia y en la cultura jurídicas en las que se inserta, en un concreto momento histórico, el Estado constitucional ${ }^{235}$.

Ya desde los orígenes de la construcción doctrinal de la categoría en el seno de la doctrina alemana, la garantía institucional se presenta como una técnica de protección que no pretende sino salvaguardar la integridad de ciertos núcleos institucionales considerados esenciales, en un momento

desigualar a las parejas de hecho homosexuales de las heterosexuales. "

232 LLAMAZARES FERNÁNDEZ, D. "El sistema matrimonial español”, Ed. Universidad Complutense, Madrid, año 1994, página 13.

233 ALONSO GARCIA, E. “La interpretación de la Constitución”, Centro de Estudios Constitucionales, Madrid, año 1984, páginas 148 y siguientes.

234 STC, Pleno, núm. 11/1981, de 8 de abril, RTC 1981/11. "Sin embargo el movimiento pendular entre la amplitud y la generosidad o la restricción vuelve a ser una decisión política que tiene que adoptar el legislador ordinario sin más límites que los que el derecho fundamental tenga, pues ningún derecho, ni aun los de naturaleza o carácter constitucional, pueden considerarse como ilimitados.” Cfr. STC, Pleno, núm. 49/2008, de 9 de abril, RTC 2008/49.

235 CRUZ VILLALON, P. “El legislador de los derechos fundamentales” en LÓPEZ PINA, A (Edit.), "La garantía constitucional de los derechos fundamentales: Alemania, España, Francia e Italia”, Ed. Civitas, Madrid, año 1991, páginas 125 a 137. 
histórico y en una sociedad determinada, para la adecuada estructuración de la comunidad ${ }^{236}$. Es, pues, precisamente, esa estrecha vinculación entre institución garantizada y la realidad social a la que sirve, la que lleva implícito el germen de la transformación y el cambio que está implícito en la evolución histórica de esa misma sociedad. De ahí que, en aparente paradoja, la esencialidad del núcleo de la institución garantizada fuese ya entonces considerada compatible con la contingencia derivada de las transformaciones sociales a lo largo de la historia.

En ese contexto, el legislador en tanto que sus previsiones pudieran ser consideradas como receptoras de la realidad social, que convertía en cada momento en realidad jurídica y, a la inversa, en tanto que inductor de la transformación social mediante el proceso legislativo, disponía de una cierta capacidad de transformación efectiva de ese núcleo esencial constitucionalmente garantizado, impidiendo así que la imagen del mismo existente en el período constituyente se perpetuase en el tiempo, contra la finalidad propia del mecanismo de garantía. Sin embargo, la necesidad de incorporar a la hermenéutica constitucional este elemento de atención al proceso de cambio social, encontró, ya entonces, un límite insalvable: la ruptura con los rasgos estructuralmente más característicos de la institución, la solución de continuidad en la ordenación jurídica de sus elementos más básicos e identificadores, que comportase una evolución per saltum, no razonable ${ }^{237}$.

Sin duda, en el caso del matrimonio tal se ha desnaturalizado totalmente, quizás en gran parte porque el propio legislador español ha dado muestras de desconocer la esencia de la realidad jurídica, más allá de los aspectos sociológicos.

Adviértase, a modo de inciso, que desde una óptica más bien colateral al problema de fondo planteado, se ha cuestionado lo que la garantía institucional como técnica de protección implica, respecto de una suerte de petrificación del ordenamiento en torno a ciertas instituciones, de tintes ideológicamente conservadores, haciéndose ver lo que la aparición dogmática de esta técnica supuso en su origen histórico, especialmente en el marco del pensamiento schmittiano ${ }^{238}$.

La garantía institucional, como se sabe, aparece en efecto, en su génesis histórica, con ese perfil, en el contexto doctrinal que se desarrolla especialmente en torno a la Constitución de Weimar,

236 En principio, la ley debe ser respetuosa con los derechos fundamentales del mismo modo que debe serlo con cualquier otra decisión constitucional, y el propio art. 53, 1, lo recuerda al decir que "los derechos y libertades reconocidos en el capítulo segundo del presente título vinculan a todos los poderes públicos. Por consiguiente lo que pretende la cláusula de "contenido esencial" es reforzar la garantía de los derechos fundamentales, haciendo más rigurosa la vinculación del legislador a la Constitución cuando su actividad tiene por objeto el desarrollo del capítulo II del título I.

237 En la descripción de esta institución partimos de un estudio pionero en España, como es sabido de PAREJO ALFONSO, L. “Garantía institucional y autonomías locales”, Ed. Instituto de Estudios de Administración Local, Madrid, año 1981, páginas 46 a 48.

238 ANDRES IBAÑEZ, P. “Matrimonio homosexual: hay derecho”, en El País, edición de 22 de abril de 2005. 
notablemente vinculada aquélla al propósito de otorgar intangibilidad a ciertos institutos considerados socialmente básicos y estructurantes, en un marco constitucional en el que los derechos fundamentales son todavía concebidos primordialmente como una mera manifestación del principio de legalidad de la Administración. Este es, sin embargo, un argumento de escaso peso, en cuanto al singular propósito crítico que lo inspira, porque esa constatación no impide percibir que la garantía institucional ha sido asumida como técnica de protección en nuestro vigente sistema de derechos y libertades, y como tal, se halla penalmente subordinada en su desenvolvimiento a los principios y valores que subyacen al entero ordenamiento constitucional ${ }^{239}$.

Así pues, la breve descripción que hemos hecho del significado de la técnica de protección desde sus orígenes doctrinales, de la idea de la prescripción de cualquier censura radical respecto de los rasgos más caracterizadores de la institución, tiene precisamente el valor explicativo que se deriva en este caso de la asunción como principio rector de la categoría en la doctrina del Tribunal Constitucional. Y así, puede percibirse que este planteamiento se plasma, a nuestro modo de ver muy elocuente, en el límite infranqueable que la jurisprudencia constitucional fija en la ruptura clara y neta con la imagen comúnmente aceptada de la institución (STC, Pleno, num. 32/1981, de 28 de julio, RTC 1981/32 240 ). El legislador no puede ir más allá de aquello que es esencial o nuclear al

239 ESCRIVÁ-IVARS, J. "Sistema matrimonial y derechos fundamentales sobre la nueva legislación matrimonial." en VV. AA., "La reforma del modelo de familia en el Código civil español”, Ed. Comares, $1^{\circ}$ edición, año 2005 , Granada, página 80. "Las recientes iniciativas legislativas sobre el matrimonio y la familia-básicamente aquellas que hacen referencia a la admisión del divorcio sin causa, a los matrimonios entre personas del mismo sexo y a la adopción conjunta por progenitores del mismo sexo- han supuesto un replanteamiento total y absoluto del sistema jurídico que desde el Derecho común clásico, aquel que naciendo de los pronunciamientos de los jurisconsultos romanos configuró la sociedad occidental por mediación de los grandes canonistas medievales, regulaba hasta ahora la institución matrimonial y familiar. Estas reformas parecen plantearnos una incógnita a la dignidad de la persona y al libre desarrollo de su personalidad en una sociedad que propugna como valores superiores de su ordenamiento jurídico la libertad, la justicia, la igualdad y el pluralismo, exige vaciar de cualquier punto de referencia estructural o sustantiva al término matrimonio, convirtiéndolo, por una exigencia de esos valores en un concepto vacio, apto para cualquier tipo de reacción o situación de hecho?."

240 El orden jurídico-político establecido por la Constitución asegura la existencia de determinadas instituciones, a las que se considera como componentes esenciales y cuya preservación se juzga indispensable para asegurar los principios constitucionales, estableciendo en ellas un núcleo o reducto indisponible por el legislador. Las instituciones garantizadas son elementos indispensables del orden constitucional y las normas que las protegen son, sin duda, normas organizativas, pero a diferencia de lo que sucede con las instituciones supremas del Estado, cuya regulación orgánica se hace en el propio texto constitucional, en éstas la configuración institucional concreta se refiere al legislador ordinario al que no se fija más límite que el del reducto indisponible o núcleo esencial de la institución que la Constitución garantiza. Por definición, en consecuencia, la garantía institucional no asegura un contenido concreto o un ámbito competencial determinado y fijado de una vez por todas, sino la preservación de una institución en términos recognoscibles para la imagen que de la misma tiene la conciencia social en cada tiempo y lugar. Dicha garantía es desconocida cuando la institución es limitada de tal modo que se le priva prácticamente de sus posibilidades de existencia real como institución para convertirse en un simple nombre. Tales son los límites para su determinación por las normas que la regulan y por la aplicación que se haga de estas. En defi nitiva, la única interdicción claramente discernible es la de la ruptura clara y neta con esa imagen comúnmente aceptada de la institución que, en cuanto formación jurídica, viene determinada en buena parte por las normas que en cada momento la regulan y la aplicación que de las mismas se hace. 
instituto garantizado, según su arraigada imagen en la cultura jurídica en la que se inscribe la Constitución debiendo ser esta identificada a la luz de las ideas y construcciones generalmente admitidas entre los juristas, los jueces y, en general, los especialistas en Derecho (STC, Pleno, núm. 341/1993, de 18 de nov, RTC 1993/341). Existe, por consiguiente, un mínimo irreductible en la conformación objetiva de la institución, que se muestra por completo refractario a cualquier desarrollo adaptativo en la legislación que lo menoscabe, desnaturalizado con ello el objeto de protección constitucional $^{241}$, ello en relación a STC, Pleno, núm. 159/199, de 6 mayo. RTC 1993/159 ${ }^{242}$.

Una cosa es asumir una dinámica evolutiva que, al ritmo de las transformaciones sociales y de los consiguientes cambios legislativos que las acompañan, module adecuadamente el régimen jurídico de la institución en aquellos aspectos que permiten su adaptación a ese proceso de cambio (la introducción de la figura del divorcio sería tal vez un buen ejemplo de ello), y otra bien distinta es privar a esa institución de su significado constitucional, de sus posibilidades de existencia real como tal institución, al desfigurar su contenido objetivo mínimo en la norma iusfundamental, un contenido mínimo que, como se ha subrayado, depende tanto de la imagen que del instituto se tiene en la cultura jurídica, como de las posibilidades de su funcionamiento efectivo a partir de dicha imagen.

241 Cfr. ESCRIVÁ-IVARS, J. loc. cit. Asimismo MARTÍNEZ LÓPEZ-MUÑIZ, J. L. "Desquiciamiento inconstitucional de la familia protegida por el Derecho Civil", en VV. AA., "La reforma del modelo de familia en el Código civil español", Ed. Comares, $1^{\circ}$ edición, Granada, año 2005, páginas 67 y siguientes.

242 "Ahora bien, antes de proceder a este examen conviene recordar algunos aspectos de la doctrina de este Tribunal sobre la garantía institucional de la foralidad expuestos en la STC 76/1988, a la que para mayores precisiones procede remitirse. Señala la resolución indicada que de la disposición adicional primera de la CE se deriva que el amparo y respeto por parte de la Constitución de los derechos históricos de los territorios forales no puede estimarse como una garantía de toda competencia que legítimamente quepa calificar de histórica. Ya en la STC 123/1984 se declaraba que la idea de derechos históricos no puede considerarse como un título autónomo del que puedan deducirse especificas competencias. «Lo que la Constitución ha venido a amparar y respetar no es una suma o agregado de potestades, facultades o privilegios, ejercidos históricamente, en forma de derechos subjetivos de corporaciones territoriales, susceptibles de ser traducidos en otras tantas competencias de titularidad o ejercicio respaldadas por la Historia . Como resulta de la misma dicción del párrafo segundo de la disposición adicional primera $C E$, lo que se viene a garantizar es la existencia de un régimen foral es decir, de un régimen propio de cada territorio histórico de autogobierno territorial, esto es, de su "foralidad", pero no de todos y cada uno de los concretos derechos que históricamente la hayan caracterizado. La garantía constitucional supone que el contenido de la foralidad debe preservar tanto en sus rasgos organizativos como en su propio ámbito de poder la imagen identificable de ese régimen foral tradicional». Es este núcleo identificable lo que se asegura; no un contenido concreto o un ámbito competencial determinado y fijado de una vez por todas, sino la preservación de una institución en términos recognoscibles para la imagen que de la misma tiene la conciencia social en cada tiempo y lugar (STC 32/1981). Todo ello en el bien entendido de que la garantía institucional de los territorios forales, si bien no especifica exhaustivamente las competencias históricas que protege (esto es, un haz determinado de competencias concretas), sí alcanza, como mínimo irreductible, a proteger un régimen de autogobierno territorial con el que quepa reconocer el régimen foral tradicional de los distintos territorios históricos. La garantía institucional -afirmaba también la STC 32/1981- es desconocida cuando la institución es limitada de tal modo que se le priva prácticamente de sus posibilidades de existencia real para convertirse en un simple nombre. Dentro de estos límites, es al proceso de actualización previsto en la disposición adicional primera CE al que corresponde precisar cuál es el contenido concreto que, en el nuevo marco constitucional y estatutario, se da al régimen foral de cada uno de los citados territorios, garantizado por la Constitución (STC 76/1988, fundamento jurídico 4. ${ }^{\circ}$." 
Desconocer esta premisa conduce indefectiblemente a la relativización absoluta frente al legislador de la técnica de garantía y, en el caso que nos ocupa, del derecho constitucional reconocido en el artículo 32, y ello, al margen de cualquier otra consideración, pone en cuestión el principio de supremacía constitucional que alienta el sistema español de derechos fundamentales y libertades públicas.

Como se ha puesto de relieve, relativizar hasta ese punto el contenido esencial, sobre la base de su adaptación a la realidad social, conlleva el riesgo de anulación del propio mecanismo de garantía, de modo que en ese proceso de actualización el legislador debe siempre actuar dentro de los límites materiales que derivan de la existencia de un determinado contenido constitucionalmente garantizado, es la opinión de BALAGUER CALLEJÓN ${ }^{243}$.

En este marco de reflexión, presenta indudables ventajas aquella posición doctrinal que concibe el proceso de concreción del contenido esencial ${ }^{244}$ como la búsqueda de un equilibrio entre el principio de constitucionalidad y el principio democrático-pluralista (tradición y pluralismo), en el que el Tribunal Constitucional aparece, a un tiempo, como garante tanto de la integridad del contenido de las previsiones constitucionales como del margen de configuración de que dispone el legislador, percibiendo este último, en cada momento, como el cauce de concreción en una forma histórica, adecuada a las sucesivas exigencias culturales, de la imagen institucional constitucionalmente garantizada. Sin duda el procurar el equilibrio de ambas es la clave.

243 “Aplicación de la Constitución y garantías de los derechos”, en Anuario de Derecho Público y Estudios Politicos, núm. 2, Madrid, años 1989 y 1990, páginas 137 y 138.

244 Cfr. NOREÑA SALTO, J. R. “Acerca del contenido esencial de los derechos fundamentales de configuración legal “, Repertorio Aranzadi del Tribunal Constitucional, num.18/2003, parte Estudio, Aranzadi S.A., Pamplona, año 2004, BIB 2003/1523. "Y, aun aceptando la existencia de estos derechos fundamentales de configuración legal, quedará la dificultad de establecer si los mismos, en cuanto reconocidos en la Constitución, ofrecen en todo caso un contenido esencial que ha de ser respetado necesariamente por el legislador ordinario, y, en su caso, el método para determinar dicho contenido esencial o indisponible, que debe ser respetado por las leyes que regulen el correspondiente derecho fundamental, además de incidir en la delimitación que, a este respecto, corresponde a los Tribunales ordinarios, de una parte, y al Tribunal Constitucional, de otra, cuestión que, como veremos posteriormente, no da lugar a una solución unívoca por parte de este último.- El artículo 53.1 de la Constitución española alude expresamente al contenido esencial de todos los derechos reconocidos en el Capitulo segundo del Título Primero (por tanto, no sólo los fundamentales susceptibles de amparo constitucional) contenido esencial que debe ser en todo caso respetado por el legislador) -único competente para su desarrollo-, pero, aparte de que no determina qué ha de entenderse por "contenido esencial", tampoco existe en ninguna de las normas constitucionales mención expresa a esta categoría de derechos fundamentales de configuración legal que, en consecuencia, ha de considerarse en principio como de creación jurisprudencial, y esencialmente casuística, puesto que las resoluciones de nuestro Tribunal Constitucional que califican en este sentido a un determinado derecho fundamental -normalmente en resoluciones de recurso de amparo-, tampoco han definido este concepto... «Pero ni siquiera esta modulación o atemperación es posible en relación con todos los derechos, pues "existen derechos que corresponden por igual a españoles y extranjeros y cuya regulación ha de ser igual para ambos" (...); asi sucede con aquellos derechos fundamentales "que pertenecen a la persona en cuanto tal y no como ciudadano" o, dicho de otro modo, con "aquellos que son imprescindibles para la garantía de la dignidad humana que conforme al art. 10.1 de nuestra Constitución constituye fundamento del orden politico español"»" 
Se trata de un sugestivo planteamiento que, con apoyo en la doctrina del Tribunal Constitucional, propone un entendimiento temporal de la categoría del contenido esencial que, si bien implica en cierto modo su relativización, en tanto que renuncia a la idea de una imagen perfectamente acabada y radicalmente inmune a todo proceso evolutivo, permite hacer compatible la preservación de ese núcleo esencial, constitucionalmente protegido en sus caracteres más definitorios, con su adaptación legislativa a los nuevos requerimientos que van paulatinamente arraigando en la cultura jurídica. Este particular enfoque de la cuestión, que se resume en la idea de la ponderación entre la permanencia y el cambio en el marco de la tradición jurídica, es en efecto constatable en la doctrina del Tribunal Constitucional que, asumiendo la existencia de un mínimo irreductible, admite no obstante su actualización por parte del legislador de desarrollo (STC 76/1988 ${ }^{245}$ ). Pero lo que no puede desconocerse es que hay una gran diferencia entre esa suerte de relativización del contenido esencial, que adopta como premisa la de la preservación de un núcleo identificable cuya actualización legislativa se realiza, precisamente, "concretando y especificando su contenido mínimo" (STC, Pleno, núm. 159/1993, de 6 mayo, RTC 1993/159 ), y lo que más bien supone una relativización absoluta de aquel contenido esencial, a merced de una limitada acción conformadora del legislador; esto último conduce por el contrario a la frustración de la finalidad protectora tanto del derecho fundamental como de la garantía institucional, y a la negación, en última instancia, del principio de suprema-

245 STC, Pleno, núm. 76/1988, de 26 de abril, RTC 1988/76. "En cuanto al primer aspecto -el reconocimiento y garantía genéricos- se confirma la garantía constitucional consagrada en la Disposición adicional primera C.E., en el art. 3 del Estatuto, en cuanto a la organización e instituciones privativas de autogobierno de cada uno de los Territorios Históricos, y en el art. 37.2, respecto, tanto al régimen foral, como a las competencias de los Territorios Históricos, al establecer que «lo dispuesto en el presente Estatuto no supondrá alteración de la naturaleza del régimen foral específico o de las competencias de los regímenes privativos de cada Territorio Histórico». Claramente, esta disposición no representa -como parecen sostener los recurrentes- que el Estatuto no implica ninguna limitación del régimen foral históricamente definido y del correspondiente e indeterminado elenco de derechos históricos. Si tal fuera el caso, el Estatuto no podría, evidentemente, llevar a cabo ninguna actualización, y resultarían inexplicables cláusulas estatutarias -como las referentes al régimen fiscal-que suponen una clara alteración de la posición histórica de los territorios forales. Como resulta de la consideración conjunta de las diversas disposiciones estatutarias, el art. 37.2 lo que viene a establecer es que, tanto los poderes y atribuciones que se confieren a los nuevos órganos que se crean -las Instituciones Comunes-como el reparto competencial que se efectúa en relación con las Instituciones centrales del Estado habrán de entenderse siempre sin menoscabo de la garantía del régimen foral y las inherentes competencias de los Territorios Históricos que el mismo Estatuto determina. Se trata, pues, de una regla de garantía e interpretación, que coloca en lugar preferente, en cuanto a su respeto y protección, a los regímenes forales en su definición estatutaria, tanto frente a las Instituciones Comunes del País Vasco como a los poderes centrales del Estado; regímenes forales que el mismo Estatuto precisa en cuanto a cuál sea su contenido esencial, intocable por los poderes autonómicos o estatales. Ha de tenerse en cuenta, por otra parte, que el mismo Estatuto, en otras ocasiones, recoge el límite que la garantía foral representa respecto a otras instituciones de la Comunidad Autónoma; así, en su art. 10, apartados 1 y 3, al referirse a determinadas competencias de la Comunidad Autónoma, lo hace «sin perjuicio de las facultades correspondientes a los Territorios Históricos, de acuerdo con lo dispuesto en el art. 37 del mismo (Estatuto)», expresión que se repite en el art. 25.1, como límite a los poderes del Parlamento Vasco. “ 
cía constitucional, y por consiguiente el pleno reconocimiento como garante de la misma al Tribunal Constitucional, pero sin duda no el único ${ }^{246}$.

Sentado esto, posiblemente, la crítica más fundada que se ha emitido al planteamiento que realiza el antes citado informe del Consejo General del Poder Judicial ${ }^{247}$ sobre esta materia, sea la de que en el mismo se acude a ciertos parámetros metajurídicos que denotan una particular visión esencialista de la institución, y, como tal, presentan la nota de la heterosexualidad como una exigencia biológica, física o anatómica del matrimonio como un requisito derivado de la naturaleza de las cosas, y no exclusivamente, como debiera de haber sido el caso, como un rasgo deducible de la imagen institucional que se ofrece al intérprete a partir de la cultura jurídica arraigada, a la que la propia Constitución convoca en este punto.

Sobre este punto mi opinión es que indudablemente es necesario que las concepciones metajurídicas no sean contradictorias con la rigurosidad que debe exigir un análisis de esta envergadura, pero es bastante notorio que detrás de las instituciones jurídicas existe una trayectoria que trasciende el punto de vista jurídico, creo además que tal aspecto no hace sino enriquecer al Derecho, y posiblemente pueda confrontarse, con determinados aspectos de la labor legislativa, siendo tachado incluso de falta de objetividad, pero ya había Derecho cuando aún nuestros sistemas políticos ni siquiera residían en la mente de algún mortal.

246 Cfr. STC, Pleno, núm. 49/2008, de 9 de abril, RTC 2008/49. Esta sentencia invoca el principio democrático como esencial en el ejercicio de la potestad del TC, en cuanto límite del mismo y garantía de la supremacía de la Carta magna. "Desde una perspectiva material, son diversos los argumentos que también deben llevarnos a la misma conclusión. Por un lado, no cabe duda de que el legislador orgánico del Tribunal Constitucional goza de una libertad de configuración que no sólo se deriva del principio democrático, sino que también está protegida a través de las diversas reservas de Ley orgánica previstas en el texto constitucional respecto de esta institución [arts. 161.1 d), 162.2 y 165 CE]. Sin que sea éste el momento de pronunciarnos sobre el alcance y la interrelación de tales reservas, debemos partir de la base, como señalamos en la STC 66/1985, de 23 de mayo ( RTC 1985, 66) , F. 4, de que el contenido de dichas Leyes es disponible para el legislador. Al mismo tiempo, sin embargo, y como se deduce de la propia supremacía constitucional (art. 9.1 CE), tal libertad no es absoluta, sino que tiene límites materiales y formales que tienen su origen no sólo en dichas reservas y en los restantes preceptos que integran el Título IX de la Constitución, sino en una interpretación sistemática de todo el texto constitucional. Interesa destacar desde un primer momento que si bien la apertura de la jurisdicción constitucional española al legislador orgánico no es homogénea en todos los ámbitos, sus límites constitucionales no proceden únicamente de una interpretación literal del precepto aducido en cada caso, sino del modelo de Tribunal Constitucional que se deriva de una interpretación conjunta de nuestra Norma Suprema y de los principios constitucionales que se proyectan sobre el mismo. Este hecho, comúnmente aceptado en todos los ámbitos, también fue compartido, por lo menos de forma implícita y respecto de los límites materiales del legislador del Tribunal Constitucional, en la STC 66/1985 al añadirse inmediatamente después de la ya mencionada afirmación sobre el carácter disponible del contenido de la LOTC que «(...) en consecuencia, dentro del respeto a las normas constitucionales y a la independencia y función del Tribunal, (el legislador) puede introducir en ella los cambios o modificaciones que entienda oportunos, sin que haya de limitarse a aquellos indispensables para evitar la inconstitucionalidad o asegurar el cumplimiento de los objetivos constitucionales».

247 CONSEJO GENERAL DEL PODER JUDICIAL, Comisión de Estudios e Informes , “Estudio sobre la reforma del Código Civil en materia de matrimonio entre personas del mismo sexo”, 26 de enero de 2005, Madrid. 
Todo lo antedicho conduce a responder afirmativamente a la pregunta acerca de si el presupuesto de la heterosexualidad forma o no parte del núcleo objetivo de la institución del matrimonio, en la concepción que de la misma asume la Constitución según LLAMAZAREZ FERNÁNDEZ ${ }^{248}$. Por lo demás, y ello no deja de ser muy significativo a la misma conclusión se llega si, descartando aquí el recurso a la garantía institucional, se adopta más bien el enfoque metodológico que, parte directamente, en el marco de la idea de la Constitución normativa, de la posibilidad de detectar un contenido esencial del concepto constitucional matrimonio, afirmándose igualmente, en última instancia, la presencia en dicho contenido del requisito de heterosexualidad ${ }^{249}$.

La consecuencia lógica de esta afirmación no puede ser otra que de la más que probable inconstitucionalidad de la supresión de este requisito en vía legislativa.

\subsection{La Ley 13/2005, que modifica el Código Civil en lo referente al matrimonio. EI matrimonio homosexual y el fin de la necesaria heterosexualidad para contraer matrimonio}

Una de las principales dificultades existentes a la hora de intenta analizar el fenómeno homosexual es su complejidad, la diversidad de conductas, relaciones, causas, problemática psicológica, etc, que se engloban bajo dicho término, lo que convierte en especialmente necesario el intento de delimitación conceptual de la homosexualidad ${ }^{250}$.

En este sentido, insisten los autores en la dificultad de hablar de homosexualidad como una categoría unitaria, comprensiva de una serie definida de elementos caracterizadores, puesto que la homosexualidad al igual que la heterosexualidad, es un fenómeno pluriforme, compuesto por diversas constelaciones de normas, comportamientos, enfoques, perspectivas ${ }^{251}$. Se ha afirmado a este

248 LLAMAZARES FERNÁNDEZ, D. "El matrimonio homosexual”, en SOUTO PAZ, J. A. (Coord.), “El nuevo régimen legal del matrimonio civil en España”, Ed. Comares, Granada, año 2008, páginas 9 a 11. El autor manifiesta que si algo es evidente es que las expresiones literales del art. 32.1 no son todo lo claras y terminantes que hubiera de desear, lo que son duda es un hecho para lamentar. Además "el hombre y la mujer tienen derecho a contraer matrimonio con plena igualdad jurídica, expresión en las que están claras dos cosas: que el hombre y la mujer tienen derecho a contraer matrimonio y que tienen derecho a contraerlo con plena igualdad jurídica. Lo que no añade es "entre si", porque la plena igualdad jurídica es aplicable únicamente al caso de que sea matrimonio heterosexual, también es aplicable al derecho mismo de contraer matrimonio: es decir que el hombre y la mujer tienen un derecho igual a contraer o lo que es lo mismo que el sexo no justifica desigualdad alguna en el ejercicio de ese derecho...El artículo 39, tal como ha sido interpretado por el Tribunal Constitucional, al equipara todo tipo de familias, también las no nacidas del matrimonio (matrimonio de hecho), e incluso las constituidas por parejas de homosexuales, parece apuntar hacia una respuesta positiva... Es competencia del legislador ordinario optar por ese principio como exclusivo o no."

249 En este sentido REY MARTÍNEZ, F. "Homosexualidad y Constitución”, en Revista Española de Derecho Constitucional, núm. 73, año 2005, páginas 150 a 152.

250 PEÑA GARCÍA, C. "Homosexualidad y matrimonio. Estudios sobre la jurisprudencia y la doctrina canónica". Publicaciones de la Universidad Pontificia Comillas, Madrid, año 2004, página 59.

251 MASTERS, W.H. y JOHNSON, V.E. "Homosexualidad en perspectiva”, Ed. Itermedia. Templeton, Buenos Aires, año 1979. Llegan a esta conclusión tras un minucioso estudio los autores, destacando la heterogeneidad que 
respecto de que no existe la homosexualidad sino que homosexuales concretos, en los que cabe encontrar una gama tan variada como entre los heterosexuales ${ }^{252}$, de modo que la homosexualidad constituiría únicamente una abstracción necesaria para el discurso lógico.

Desde una postura ciertamente minoritaria hoy, en la literatura de investigación psicológica, VAN DEN AARDWEG niega la existencia misma de individuos homosexuales, y sostiene que los llamados homosexuales son esencialmente personas heterosexuales con inclinaciones neuróticas homosexuales, cuyo origen se halla en un especial complejo de inferioridad llamado "sentimiento de desplazamiento" 253 . No obstante, lo único que se niega desde esta perspectiva es la existencia de homosexuales constitucionales, al defender expresamente el autor una concepción de la homosexualidad como "forma de neurosis autocompasiva" 254 .

Una crítica más radical a la posibilidad de conceptualizar la homosexualidad, y sobre todo, a la afirmación de la existencia real de los homosexuales, es la defendida por los constructivistas sociales, los cuales siguiendo a FOUCAULT, afirman que la homosexualidad realmente no existe. Según estos autores la homosexualidad es únicamente una construcción social, creada a finales del siglo XVIII y durante el siglo XIX por la comunidad médica, que convirtió al antiguo sodomita en cuanto sujeto que cometía actos religiosamente y penalmente castigados en una verdadera especie, el homosexual, con un pasado, un historial clínico, un determinado tipo de vida, y una anatomía y morfología concreta ${ }^{255}$. Desde esta perspectiva constructivista, no puede hablarse en sentido estricto de homosexualidad ni de individuos homosexuales, sino, en el mejor de los casos, de personas que han adoptado una identidad homosexual, al aceptar unas determinadas pautas de conducta y un rol

atraviesa las líneas base de homosexualidad versus homosexualidad, lo cual complica cualquier intento de estudio del fenómeno homosexual

252 Destaca una autora que además de la presencia de múltiples variables, y al margen de la discusión de si hay o no bisexualidad inicial, la diversidad de opciones de la sexualidad humana es sumamente rica, y los resultados son también variados. No todos los homosexuales son iguales, al igual que no lo son todos los heterosexuales (es decir, no son iguales en absoluto), ni todos son homosexuales en el mismo grado, ni se sienten de igual manera res pecto de su homosexualidad. GIMENO-BAYON COBOS, A. "Homosexualidad e intimidad", en GAFO, J (Edit.), "La homosexualidad un debate abierto", Ed. Desclée de Brouwer, Bilbao, año 1996, página 164.

253 Este autor sostiene que: "las tendencias homosexuales nacen de un tipo especial de complejo de inferioridad, puesto que por constitución una persona no es homosexual, sino heterosexual. Eso es así prescindiendo de las conductas personales; un hombre o una mujer podrán no tener, o sólo muy débilmente, inclinaciones homosexuales, pero aún son esencia heterosexuales. Estrictamente, los "homosexuales" u "homofilos" no existen, como tampoco en el reino animal; si que existen ciertas personas con inclinaciones homosexuales, advirtiendo que, en consecuencia, "debería evitarse el termino homosexual y usar designaciones como personas con inclinaciones homosexuales". VAN DEN AARDWEG, G.J.M. "Homosexualidad y esperanza. Terapia y curación en la experiencia de un psicólogo", Ed. EUNSA, Pamplona, año 1997, página 26.

254 VAN DEN AARDWEG, G.J.M., ibídem, página 26.

255 FOUCAULT, M. "History of sexuality", Ed. Siglo XXI, Madrid, año 2005. En este sentido destaca como la homosexualidad surgió como una de las formas de la sexualidad únicamente cuando la comunidad médica dio el salto de convertir a determinados sujetos que cometían ocasionalmente la aberración de la sodomía en una especie concreta caracterizada por su androgenia o hermafroditismo interior o psicológico. 
en la sociedad. Asimismo, estos autores rechazan también que la condición o identidad homosexualidad sea algo innato y permanente, aunque el individuo lo perciba así. Por el contrario, para esta teoría, la identidad sexual debe concebirse como construida y mantenida socialmente a través de un proceso de interacción social ${ }^{256}$.

Esta opinión, por lo demás ha sido refutada por diversos autores, entre los que destaco a RUSE, que aún aceptando con los constructivistas sociales que la comprensión de la homosexualidad, concepto inevitablemente impregnado de creencias, viene en gran medida determinada por actitudes sociales y por el papel asignado o adoptado por las personas a las que dicho concepto se aplica, rechaza sin embargo que dicha observación pueda legítimamente deducirse la falta de existencia de la realidad de fondo, es decir, de la persona homosexual. RUSE fundamenta su crítica al constructivismo social en tres observaciones, dos de ellas incontrovertibles y la tercera más polémica, según el propio autor ${ }^{257}$.

a) La constatación de la transespecialidad y transtemporalidad de la actividad homosexual en si misma considerada, presente en todas las sociedades a lo largo de la Historia: cada pueblo o comunidad interpretará esos actos homosexuales de un modo distinto, pero la actividad homosexual es un hecho real.

b) La constatación del carácter temporal y transespecial de la existencia de inclinaciones homosexuales en los sujetos, las cuales podrían conducir aunque no invariablemente a la actividad homosexual. Este hecho irrefutable de la existencia de personas con inclinaciones homosexuales en prácticamente todo tipo de sociedades, de cualquier campo y lugar, pone en entredicho la afirmación básica del constructivismo social de que la homosexualidad sea únicamente una construcción social.

c) Es posible la elaboración de un concepto de homosexualidad fundado en algo real, aunque ciertamente variado y pluriforme. En este sentido, cabe señalar que la homosexualidad viene habitualmente conceptuada, según la definición propuesta por la Organización Mundial de la Salud, como la atracción sexual exclusiva o predominante hacia personas del mismo sexo, con o sin relación física ${ }^{258}$. Esta conceptualización tiene la ventaja de ser la más general y neutra posible, al evitar el peligro de dejarse influir por prejuicios y concepciones preconcebidas ya en el mismo acto de la definición del concepto. Sin perjuicio de ello puede argumentarse que

256 PEÑA GARCÍA, C. "Homosexualidad y matrimonio : Estudios sobre la jurisprudencia y la doctrina canónica”, ...op. cit., página 61 .

257 RUSE, M. “La homosexualidad”, Ed. Cátedra, Madrid, año 1989, páginas 31 a 33.

258 ORGANIZACIÓN MUNDIAL DE LA SALUD, CIE-10. “Trastornos mentales y del comportamiento. Descripciones clínicas y pautas para el diagnóstico”, Madrid, año 1992, página 273. 
su misma ventaja es también su principal defecto debido a su excesiva simplicidad. Es necesario completarla con otras definiciones que presten más atención al aspecto antropológico de la homosexualidad además se hecha en falta el tratamiento unitario y personal de la persona y su sexualidad.

En este sentido, podría tomarse como punto de partida abierto a ulteriores precisiones y concreciones, la concepción de la homosexualidad como aquella condición de la persona según la cual ésta se halla constitutivamente inclinada a relacionarse afectiva y sexualmente con personas de su mismo sexo, sea de modo exclusivo o preferente ${ }^{259}$. Esta definición presenta la ventaja de encuadrar más adecuadamente el enfoque sobre la homosexualidad ${ }^{260}$. No debe obviarse que ella no sólo implica la orientación sexual, sino que es la condición antropológica de un ser personal, aunque ciertamente su peculiaridad hace básicamente referencia al nivel de la sexualidad. Es la persona humana integral la que, de un modo constitutivo, no solo a nivel de su comportamiento, detalla la misma autora, se siente y se reconoce y se vivencia a sí misma como atraída por las personas del mismo sexo, excepto en casos patológicos de represión y disociación.

Esta perspectiva personalista en la comprensión de este fenómeno ha llevado a autores como SPIJKER a proponer la utilización del término homotrópica, definida como la orientación real hacia un sujeto del mismo sexo, para expresar en toda su amplitud la complejidad de esta tendencia sexual, la cual, al igual que la heterotrópica, puede desarrollarse en los tres planos propios de la sexualidad humana: el genital, el erótico y el personal ${ }^{261}$. En este sentido, distingue el autor entre:

259 VIDAL, M y FERNÁNDEZ-MARTOS “Aclaraciones fundamentales. Nombre, definición, tipos y normalidad” en "Homosexualidad: ciencia y conciencia”, Ed. Sal Terrae, Santander, año 1981, páginas 10 y 11 . En la elaboración de esta definición de homosexualidad, se ha tomado como punto de partida la ofrecida por ellos, la homosexualidad "como condición humana de un ser personal que en el nivel de la sexualidad se caracteriza por la peculiaridad de sentirse constitutivamente instalado en la forma de expresión exclusiva con un partner del mismo sexo." Aunque puede llamar la atención el aparente carácter restrictivo de la misma, en cuanto que exige como elemento definidor de la homosexualidad la exclusividad, debe hacerse constar que los autores, en su ex plicación de la definición, incluyen dentro de la misma a quienes "siendo capaces y manteniendo relaciones bisexuales , se viven como decididamente inclinados hacia su propio sexo”.

260 PEÑA GARCÍA, C. "Homosexualidad y matrimonio. Estudios sobre la jurisprudencia y la doctrina canóni$c a$ ”...op. cit., página 63 .

261 VAN SPIJKER, H. “La homotropia”, Ed. Sígueme, Salamanca, año 1970. No obstante, no faltan autores, como VICO, que critican por excesivamente simplista esta división. Este autor defiende que en la homosexualidad, como en la heterosexualidad, resulta aplicable la tesis de STERNBERG (STERNBERG, J. "El triángulo del amor. Intimidad, pasión y compromiso”, Ed. Paídos, Barcelona, año 1988) referida a que el amor erótico que incluye necesariamente los elementos de intimidad, pasión y compromiso, supone la plenitud del amor sexual interpersonal, de tal modo que, $\mathrm{s}$ falta alguno de dichos elementos se estará en presencia de otras formas no plenas de amor, como son el cariño o el afecto, el encaprichamiento, el amor vacío, el amor romántico, el compañerismo, el amor fatuo: VICO PENADO, J. "Liberación sexual y ética cristiana”, Ed. San Pablo, Madrid, año 1999, páginas 439 y 440 . 
a) Homsexualidad: Se caracterizaría por un predominio de lo sexual, de lo corporal e incluso de lo genital: serían personas dominadas por una fuerte sensualidad, que impide la relación con el otro como persona, utilizándolo como mero objeto sexual.

b) Homoerotismo: Se caracteriza por un predominio de lo ánimico-sensual, por la atracción hacia los valores de la otra persona. Capta valores como la belleza, la fuerza, la delicadeza etc, que le llevan a amar esos valores en el otro, pero no, en sentido radical, al otro como persona.

c) Homofilia: Es el predominio de lo personal anímico-espiritual. En este estadio, el individuo llega verdaderamente a conocer y relacionarse con el otro como persona, no sólo con su cuerpo o con sus valores, sino con la existencia integral del compañero, este es el amor auténticamente personalizante.

Es necesario afirmar que de conformidad a las conclusiones de las ciencias humanas, esta condición de homosexualidad no es en sí misma patológica, ni indica per se la existencia de trastorno mental alguno en el sujeto. Evidentemente los homosexuales, como los heterosexuales podrán padecer enfermedades o trastornos psíquicos, algunas veces como consecuencia directa del estigma y la exclusión social provocada por una sociedad que rechaza esta condición, pero no puede considerarse toda homosexualidad como patológica o psíquicamente perversa ${ }^{262}$.

Finalmente en opinión de MARTÍN SÁNCHEZ ${ }^{263}$ la unión homosexual se define como : "La unión constituida por dos personas del mismo sexo, mayores de edad, sin vínculo de parentesco en línea recta o segundo en línea colateral y que convivan “more uxorio”, de manera libre, pública y notoria”. Asimismo argumenta que la laguna jurídica en torno a este concepto se debe a la despreocupación que parece provocar la unión de homosexuales en el Derecho, ya que hasta hace bien poco este tipo de uniones resultaban inexistentes para el ordenamiento, sin embargo esto no obsta que no deba reconocerse como una realidad, amparándose en la existencia de un Estado de Derecho basado en los derechos y en la dignidad del individuo.

En el mundo jurídico, se ha eliminado la heterosexualidad como elemento y característica esencial del matrimonio, es decir para que este existe dicho elemento ya no resulta imprescindible , esta eliminación ha sucedido con la controvertida Ley 13/2005, de 1 de julio, por la que se modifica el Código Civil en materia de derecho a contraer matrimonio, saludada con alborozo desde algunos

262 PEÑA GARCÍA, C. "Homosexualidad y matrimonio : Estudios sobre la jurisprudencia y la doctrina canónica”, ...op. cit., página 64 y 65.

263 Vid. MARTÍN SÁNCHEZ, M. “Matrimonio homosexual y Constitución”, Ed. Tirant Lo Blanch, Monografías, núm. 589, Valencia, año 2008, página 28 y 29. 
sectores sociales y con manifiesta hostilidad y recelo, desde otros, y recibida en el ámbito científico, con algunos comentarios especialmente $\operatorname{críticos}^{264}$.

La modificación de este presupuesto básico se verifica al incorporarse un segundo párrafo al art. 44 del Código Civil, en cuya virtud ahora "el matrimonio tendrá los mismos requisitos y efectos cuando ambos contrayentes sean del mismo o de diferente sexo”. A ello se añade, por lo que respecta al contenido del contrato matrimonial, la adaptación nominal a este nuevo presupuesto de los arts. 66 y 67 del mismo cuerpo normativo, de los que se elimina la referencia específica al marido y la mujer, sustituida ahora por la mención genérica a los cónyuges. Otras adaptaciones de la nomenclatura legal a la nueva configuración básica del matrimonio se establecen también en la ley respecto de otros diversos aspectos del Derecho de Familia (relaciones paterno filiales ${ }^{265}$ y régimen económico matrimonial) y, puntualmente en el régimen de las donaciones. Asimismo, una Disposición adicional proclama que "las disposiciones legales y reglamentarias que contengan alguna referencia al matrimonio se entenderán aplicables con independencia del sexo de sus integrantes", introduciéndose por último una serie de cambios en la legislación del Registro Civil.

La Exposición de Motivos de la Ley 13/2005 se refiere al necesario anclaje constitucional de la reforma en los siguientes términos: “...ciertamente, la Constitución, al encomendar al legislador la configuración normativa del matrimonio, no excluye en forma segura alguna una regulación que delimite las relaciones de pareja de una forma diferente a la que haya existido hasta el momento, regulación que de cabida a las nuevas formas de relación afectiva. Pero, además, la opción reflejada en esta Ley tiene unos fundamentos constitucionales que deben ser tenidos en cuenta por el legislador. Así, la promoción de la igualdad efectiva de los ciudadanos en el libre desarrollo de su personalidad (arts. 9.2 y 10.1. de la Constitución), la preservación de la libertad en lo que a las formas de convivencia se refiere (artículo 1.1. de la Constitución) y la instauración de un marco de igualdad real en el disfrute de los derechos sin discriminación alguna por razón de sexo, opinión o

264 Así por ejemplo, TIRAPU, D. "Perplejidades y contradicciones del pretendido matrimonio homosexual. Comentarios al Proyecto de Ley de reforma del Código Civil en materia de matrimonio", Revista General de Derecho Canónico y Derecho Eclesiástico del Estado, núm. 8, Madrid, año 2005. Asimismo destaco el interesante artículo publicado por REY MARTÍNEZ, F. "Homosexualidad y matrimonio", en Revista de Estudios Constitucionales, núm. 73, enero-abril, Madrid, año 2005, páginas 111 a 156; BERCOVITZ RODRIGUEZ-CANO, R. "El matrimonio de los homosexuales", en Aranzadi Civil, núm. 15, Tribuna, Cizur Menor, año 2005, páginas 2271 a 2273; CONSEJO DE ESTADO, Dictamen 16/12/2004, sobre el Anteproyecto de Ley por la que se modifica el Código Civil en materia de derecho a contraer matrimonio, http: www/boe/es/g/es/iberlex/bases_datosce/doc/php?colleccion=ce\&id=2004-2628; CONSEJO GENERAL DEL PODER JUDICIAL, "Estudio de 26/01/2005 sobre la reforma del Código Civil en materia de matrimonio entre personas del mismo sexo" http//www.poderjudicial.es; REAL ACADEMIA DE JURISPRUDENCIA Y LEGISLACION, "Informe aprobado el 21 de febrero de 2005 acerca del proyecto de modificación del Código Civil en materia del derecho a contraer matrimonio", http://rajyl.insde.es

265 Cfr. NAVAS NAVARRO, S. (Dir.), “Matrimonio homosexual y adopción”, Ed. Reus S.A., Zaragoza, año 2006. 
cualquier otra condición personal o social (artículo 14 de la Constitución) son valores consagrados constitucionalmente cuya plasmación debe reflejarse en la regulación de las normas que delimitan el estatus del ciudadano, en una sociedad libre, pluralista y abierta”.

Como consecuencia, pues, de la aplicación a la esfera matrimonial de estos valores constitucionales, anuncia el legislador también en la Exposición de Motivos, "la Ley permite que el matrimonio sea celebrado entre personas del mismo sexo o distinto sexo, con plenitud e igualdad de derechos y obligaciones cualquiera que sea su composición. En consecuencia, los efectos del matrimonio, que se mantienen en su integridad respetando la configuración objetiva de la institución, serán únicos en todos los ámbitos con independencia del sexo de los contrayentes; entre otros, tanto los referidos a derechos y prestaciones sociales como la posibilidad de ser parte en procedimientos de adopción".

Estas consideraciones, en las que se sintetiza el espíritu de la reforma, suscitan de entrada no pocas dudas e interrogantes que merecen un examen más detenido y, de hecho, la doctrina científica ha tenido ocasión de ocuparse de algunos de ellos, en la medida en la que ya se habían planteado con ocasión del debate generado en torno a la equiparación de las uniones de hecho al matrimonio $^{266}$.

Esta claro que el modelo de matrimonio que hace unos dos mil años comenzó a vivir occidente se basó, en su momento, en las siguientes notas: monogamía, heterosexualidad, estabilidad, formalización, orientación hacia la prole (entre otras finalidades) y libertad en la emisión del consentimiento, este modelo fue influenciado mayormente por el cristianismo y su parangón legislativo que fue el matrimonio canónico, de una u otra manera estos elementos han sido poco a poco dejados a la vera del camino por ser analizada dicha institución principalmente como un fenómeno sociológico cuya regulación debe ser adaptada no a lo que es sino que a lo que la sociedad entiende por él, es similar a lo que la STC, Pleno, núm. 198/2012, de 6 de noviembre entiende como una interpretación evolutiva, posiblemente esa interpretación evolutiva deba ir acompañada antes de una reforma constitucional.

En primer lugar, lo que actualmente determina la existencia del matrimonio ante los ojos del Legislador es un concepto más bien vaporoso, la relación de afectividad, causa eficiente del matrimonio oficial, lo que permitiría la equiparación a éste de las uniones basadas en relaciones de convivencia de análoga afectividad a la del matrimonio o, en su caso, la admisión del matrimonio ho-

266 Se aclara que sin perjuicio de la doctrina científica empleada para el presente tema, de gran ayuda es la STC, Pleno, núm. 198/2012, de 6 de noviembre, RTC 2012/198, el cual desestimó el recurso de inconstitucionalidad interpuesto por el grupo popular. 
mosexual fundado en semejante relación afectiva. Este aspecto al menos es contradictorio con la afirmación del consentimiento contractual, cuya validez no depende de la existencia del afecto o del amor, como la verdadera génesis del matrimonio.

La STC núm. 198/2012, plantea el matrimonio como “comunidad de afecto que genera un vínculo, o sociedad de ayuda mutua entre dos personas que poseen idéntica posición en el seno de esta institución, y que voluntariamente deciden unirse en un proyecto de vida familiar común, prestando su consentimiento respecto de los derechos y deberes que conforman la institución y manifestándolo expresamente mediante las formalidades establecidas en el ordenamiento "267.

Frente a esta conceptualización surge la interrogante siguiente : ¿Por qué debe aprobar, proteger o beneficiar la sociedad una relación sexual y sentimental, si la aprobación social ha radicado tradicionalmente en la expectativa de la generación, considerada como un bien social, en cuanto garantizaba la continuidad del grupo social y el relevo generacional?, ¿cuál es el argumento para que prosiga esta intervención social en algo tan íntimo y personal como es la unión sentimental y sexual entre dos personas?.

La sentencia en cuestión parte de una premisa básica. En primer lugar un análisis del matrimonio no como una institución sino como una garantía institucional y por otra parte como un derecho fundamental.

Existen diferencias entre ambas, en el sentido de que las garantías institucionales exigen una protección de carácter objetivo por parte del Tribunal Constitucional, debido a que debe impedir que el Legislador las suprima o vacíe de contenido. Mientas que en el caso de los derechos fundamentales, el objetivo reside en que el ciudadano, titular de dicho derecho, pueda gozar de una posición jurídica derivada de dicho derecho y de su reconocimiento, de tal manera que no sea posible su eliminación o desnaturalización.

Frente al cuestionamiento de si la actual Ley, de conformidad a la consideración del matrimonio como garantía constitucional, hace del mismo una institución irreconocible (en este punto el Tribunal salta de "garantía institucional" a "institución", sin fundar dicho cambio). El inicio de la respuesta a esta importante interrogante se ampara en una interpretación historicista del art. 44 del CC «(E)l hombre y la mujer tienen derecho a contraer matrimonio conforme a las disposiciones de este Código», estableciendo el nuevo párrafo segundo que «(E) l matrimonio tendrá los mismos requisitos y efectos cuando ambos contrayentes sean del mismo o de diferente sexo», en relación al art. $32^{268}$. 
El Tribunal Constitucional procura escudriñar la mente del constituyente en el año 1978, cuando se redactó el art. $32 \mathrm{CE}$. Reconoce que en ese momento el matrimonio era entendido mayoritariamente como matrimonio entre personas de distinto sexo, pero que el objetivo de dicho precepto no era referirse a la orientación sexual de las personas que lo celebrasen sino desligar el matrimonio y la familia, de proclamar la igualdad de los cónyuges en el seno de la institución, y de constitucionalizar la separación y la disolución. Luego de únicamente mencionarlas se refiere en exclusivo a la igualdad de hombres y mujeres al interior y exterior del matrimonio, y ello es importante porque de esta manera el principio de igualdad entra a justificar el cambio de la heterosexualidad por la homosexualidad. El centro son las personas que celebran el matrimonio, una visión personalista del mismo, que duda cabe, o mejor dicho individualista, pero desligada de la institución que conforman. El parangón mujer, homosexual, alude a discriminación, lo cual es a todas luces combatido por el artículo 14 de la CE.

Pero, tal cual se ha señalado anteriormente, para un sector de la doctrina, la idea según la cual el constituyente, al concretar la titularidad del derecho a contraer matrimonio, hizo que ésta recayese textualmente en el hombre y la mujer como sujetos del derecho a contraer matrimonio entre sí, una fórmula que habría resultado a estos efectos como incompatible con el matrimonio homose$\mathrm{xual}^{269}$.

Aún cuando en rigor, estamos ante una interpretación meramente literalista que no se ajusta de inicio a los parámetros de la hermenéutica constitucional, cabe hacer notar que, incluso este mismo plano argumentativo, el contrapunto a esta pretensión surge inmediatamente del enunciado de los restantes derechos constitucionales en el propio Capítulo II. Puede allí constatarse que el Constituyente, para el reconocimiento de la titularidad de dichos derechos, empleó diversas fórmulas todas ellas genéricas: todos (arts 15 y 27); todos los españoles (art. 29). Incluso, en ocasiones, no se especifica formalmente el sujeto titular del derecho proclamado, que simplemente se reconoce por la norma fundamental (arts. 20 a 22). Así pues el hecho de que precisamente se haga mención al hombre y la mujer en el artículo 32, en tanto ello puede ser interpretado como una excepción deliberada a las restantes titularidades genéricas y, por lo tanto, como una explicitación del requisito de la dis-

269 En este sentido, por ejemplo, SAURA MARTÍNEZ, L. F. "Uniones libres y la configuración del nuevo Derecho de familia", Ed. Tirant Lo Blanch, Valencia, año 1995, página 58; PÉREZ CANOVAS, N. "Homosexualidad, homosexuales y uniones homosexuales en el Derecho español", Ed. Comares, Granada, año 1996, página 119; GIMENEZ GLUCK, D. “Juicio de Igualdad y Tribunal Constitucional”, Ed. Bosch, Barcelona, año 2004, página 251. 
tinción sexual de los cónyuges, abonaría la tesis de la adopción constitucional del presupuesto de la heterosexualidad en el matrimonio ${ }^{270}$.

Desde una óptica que, por lo general, termina siendo en la práctica sólo aparentemente menos formal (o formalista) que la que se acaba de exponer, otro de los planteamientos recurrentes, acaso el más utilizado, en defensa de la aceptación implícita por parte del constituyente del matrimonio entre personas del mismo sexo, es el que, incidiendo en la necesidad de interpretar el art. 32 en clave sistemática, adecuadamente contextualizado en el marco constitucional y, por ello, a la luz de los restantes principios y valores que del mismo se derivan, concede un papel decisivo a la vigencia de los principios constitucionales de igualdad y de libre desarrollo de la personalidad. Este planteamiento, además como sea visto, ocupa un lugar privilegiado en el ámbito de la exposición, por parte del legislador, de los motivos que inspiran su reforma.

Por otra parte el Tribunal Constitucional en reiteradas ocasiones se refiere a la Carta Magna como un “árbol vivo”, basándose en las alegaciones del Abogado del Estado, el que a su vez se remite a la expresión de la sentencia Privy Council, Edwards c. Attorney General for Canada de 1930 retomada por la Corte Suprema de Canadá en la sentencia de 9 de diciembre de 2004 sobre el matrimonio entre personas del mismo sexo. Alude en este punto a la denominada interpretación evolutiva, la cual es la acomodación del Código político a las realidades de la vida moderna, de tal manera de asegurar su relevancia y legitimidad ${ }^{271}$.

Tal aseguramiento será en primer lugar por medio de grandes principios, los cuales pueden aplicarse a supuestos cuyos redactores no imaginaron siquiera que podrían acaecer, la aplicación provendrá de los propios poderes públicos, y particularmente el legislador, ante ello el propio Tribunal Constitucional velará por que dichas actualizaciones sean ajustes plenamente constitucionales, es decir, el contenido de los preceptos que conforman el texto constitucional deben leerse a la luz de los problemas contemporáneos, y de las exigencias de la sociedad actual.

Esta interpretación evolutiva tiene relación con la formación social de la cultura jurídica, mediante una observación de los fenómenos jurídicamente relevantes, esta observación implica la observancia de los estudios, dictámenes, así como las diversas resoluciones emanadas de los operadores del Derecho, ya sea internos o externos.

Inmediatamente resalta el hecho que amparado en la interpretación evolutiva el matrimonio sigue siendo reconocido como tal por la ciudadanía, alude por ello a su carácter de comunión afecti-

270 Este aspecto es destacado por la Dirección General de los Registros y del Notariado, en su resolución de 21 de enero de 1988.

271 STC 198/2012.,... op. cit., página 24. 
va, y tal comunión se relaciona con el igualdad de los cónyuges, la libertad de voluntad para contraerlo o disolverlo, mediante el seguimiento de ciertas formalidades. La interpretación evolutiva a que nos referimos facilita la respuesta a la cuestión de si el matrimonio, tal y como resulta de la regulación impugnada, sigue siendo reconocible en el contexto sociojurídico actual como tal.

Tras las reformas introducidas en el Código Civil por la Ley 13/2005, de 1 de julio, la institución matrimonial se mantiene en términos perfectamente reconocibles para la imagen que, tras una evidente evolución, se tiene en la sociedad española actual del matrimonio, como comunidad de afecto que genera un vínculo, o sociedad de ayuda mutua entre dos personas que poseen idéntica posición en el seno de esta institución, y que voluntariamente deciden unirse en un proyecto de vida familiar común, prestando su consentimiento respecto de los derechos y deberes que conforman la institución y manifestándolo expresamente mediante las formalidades establecidas en el ordenamiento $^{272}$.

Sobre este punto, la sentencia concluye afirmando que desde el punto de vista de la garantía institucional del matrimonio no cabe tacharlo de inconstitucional porque, amparándose en el propio artículo 32, el matrimonio entre personas del mismo sexo es una opción no excluida por el propio constituyente y su noción es cada vez más aceptada por la sociedad española e internacional ${ }^{273}$.

Ahora bien, qué sucede respecto al matrimonio considerado como derecho fundamental, ya de entrada a mi juicio existe un error de conceptualización, por cuanto debiese hablarse en términos más correctos del "derecho a contraer matrimonio", haciendo esta distinción puede argumentarse que tal derecho es dueño de un denominado "corazón”, dicho corazón es su contenido esencial. Frente a este, es necesario una aproximación, lo cual a juicio del Tribunal Constitucional, se puede

272 STC 198/2012., ...op. cit., página 24.

273 Voto particular concurrente que formula el Magistrado don Manuel Aragón Reyes respecto de la Sentencia dictada en el recurso de inconstitucionalidad núm. 6864-2005 : "En segundo lugar tampoco se subraya otro dato importante: que la interpretación que el Tribunal Constitucional fue dando al art. 32.1 CE era inequívoca: el matrimonio como unión entre un hombre y una mujer. Y ello lo hizo el Tribunal en múltiples resoluciones, y no sólo en el ATC 11/1994 (RTC 1994, 222 AUTO), que la Sentencia cita dotándolo de una relatividad que, a mi juicio, no tenía. Por eso es claro, y la Sentencia debía de haberlo constatado, que la regulación legal del matrimonio anterior a la reforma recurrida no había vivido en la inconstitucionalidad. Por último, en la Sentencia (F. 11) se contiene una valoración positiva en términos constitucionales de la apertura del matrimonio a las parejas del mismo sexo que no me parece propia del tipo de enjuiciamiento que el Tribunal debe hacer e incluso contradictoria con otros pasajes de la Sentencia en los que se admite que no se incurriría en inconstitucionalidad si el legislador hubiera optado por otra solución distinta a la del matrimonio para garantizar la unión estable de ese tipo de parejas, como ha sucedido en diversos ordenamientos extranjeros próximos al nuestro, habiendo sido esta alternativa considerada no contraria al Convenio de Roma por el TEDH. Me refiero a dos párrafos en los que el Tribunal considera que la opción tomada por el legislador español «da un paso en la garantía de la dignidad de la persona y el libre desarrollo de la personalidad» y que tal opción está en consonancia con el «mandato que el constituyente integró en el art. $9.2 \mathrm{CE}$, de promover las condiciones para que la libertad y la igualdad del individuo y de los grupos en que se integra sean reales y efectivas, apoyándose en la interpretación que ya ha hecho este Tribunal de la cláusula antidiscriminatoria del art. 14 CE, en la que hemos incluido la discriminación por razón de orientación sexual". 
efectuar por medio de dos caminos complementarios. Sólo aborda el primero que tiene intrínseca relación con la naturaleza jurídica o el modo de concebir o de configurar cada derecho.

El Tribunal define el contenido esencial de un derecho subjetivo como aquellas facultades o posibilidades de actuación necesarias para que el derecho sea reconocible como pertinente al tipo descrito y sin las cuales deja de pertenecer a ese tipo y tiene que pasar a quedar comprendido en otro desnaturalizándose, por decirlo así. Todo ello referido al momento histórico de que en cada caso se trata y a las condiciones inherentes en las sociedades democráticas, cuando se trate de derechos constitucionales ${ }^{274}$.

Nuevamente empieza a fundar su decisión procurando interpretar el artículo 32.1 CE bajo el prisma del principio de igualdad ${ }^{275}$, debido que dicho derecho si bien presenta una titularidad indi-

274 Voto particular que que formula el Magistrado Ramón Rodríguez Arribas respecto a la Sentencia del Pleno de fecha 6 de noviembre de 2012 dictada en el R.I. 6864/2005 "Para sostener que la garantía institucional del matrimonio puede verse alterada por el legislador sin vulnerarla, dentro de una amplia libertad de configuración, se recurre a la evolución de la cultura jurídica, en la que se integran el derecho comparado, el internacional, la doctrina cientifica y la realidad social, aportando abundantes datos estadísticos y demoscópicos, para concluir que la imagen de la institución matrimonial ha evolucionado hasta hacerla compatible con que la contraigan personas del mismo sexo, aunque se reconoce que ello no es un elemento determinante para valorar la constitucionalidad de la Ley y que entre los estudiosos del derecho «no existe una posición unánime», ni tampoco «sea unánimemente aceptada» en la sociedad internacional. Por el contrario, entiendo que el núcleo, la imagen maestra, de una garantía institucional no puede someterse a los avatares de la cultura jurídica a lo largo del tiempo. Precisamente para evitar que el legislador ordinario, atendiendo al supuesto clamor de la calle, las estadísticas y los estudios de opinión, pueda vulnerar la Constitución, se crearon los Tribunales Constitucionales. De otro lado resulta muy peligroso sentar el principio de que las normas pueden no decir lo que dicen, sino lo que se quiere que digan. Es más, los argumentos sociológicos, estadísticos, de conveniencia práctica, de derecho comparado e internacional y hasta de justicia efectiva, suelen eludir el verdadero problema jurídico-constitucional, sobre el que hay que operar con conceptos y argumentos de derecho, sin que los que pueden llamarse «meta-jurídicos» tengan otra función que la de reforzar, en su caso, la solución a que se llegue, pero no para fundarla o condicionarla."

275 STC, Pleno, núm. 39/2002, de 14 de febrero, RTC 2002/39: «a) El art. 14 CE contiene en su primer inciso una cláusula general de igualdad de todos los españoles ante la Ley, habiendo sido configurado este principio general de igualdad, por una conocida doctrina constitucional, como un derecho subjetivo de los ciudadanos a obtener un trato igual, que obliga y limita a los poderes públicos a respetarlo y que exige que los supuestos de hecho iguales sean tratados idénticamente en sus consecuencias jurídicas y que, para introducir diferencias entre ellos, tenga que existir una suficiente justificación de tal diferencia, que aparezca al mismo tiempo como fundada y razonable, de acuerdo con criterios y juicios de valor generalmente aceptados, y cuyas consecuencias no resulten, en todo caso, desproporcionadas- Como tiene declarado este Tribunal....., recogiendo al respecto la doctrina del Tribunal Europeo de Derechos Humanos en relación con el art. 14 el principio de igualdad no implica en todos los casos un tratamiento legal igual con abstracción de cualquier elemento diferenciador de relevancia jurídica, de manera que no toda desigualdad de trato normativo respecto a la regulación de una determinada materia supone una infracción del mandato contenido en el art. 14 CE, sino tan sólo las que introduzcan una diferencia entre situaciones que puedan considerarse iguales, sin que se ofrezca y posea una justificación objetiva y razonable para ello, pues, como regla general, el principio de igualdad exige que a iguales supuestos de hecho se apliquen iguales consecuencias jurídicas y, en consecuencia, veda la utilización de elementos de diferenciación que quepa calificar de arbitrarios o carentes de una justificación razonable. Lo que prohíbe el principio de igualdad son, en suma, las desigualdades que resulten artificiosas o injustificadas por no venir fundadas en criterios objetivos y razonables, según criterios o juicios de valor generalmente aceptados. También es necesario, para que sea constitucionalmente lícita la diferencia de trato, que las consecuencias jurídicas que se deriven de tal distinción sean proporcionadas a la finalidad perseguida, de suerte que se eviten resultados excesivamente gravosos o desmedidos. En resumen, el principio de igualdad, no sólo exige que la diferencia de trato resulte objetivamente justificada, sino también que supere un juicio de proporcionalidad en sede constitucional sobre la 
vidual, su ejercicio no lo es, debido a que no hay matrimonio sin consentimiento ${ }^{276}$, y que al manifestarse este consentimiento se generalizan una serie de derechos y obligaciones que dan lugar al vínculo en cuestión.

El Tribunal, asimismo, se refiere a que además del derecho a contraer matrimonio se puede extraer la libertad de no contraerlo. El derecho a contraer matrimonio, o a no contraerlo no garantiza que ambas acepciones gocen de los mismos efectos, porque sin perjuicio de la identidad de los sujetos titulares de la libertad, el contenido de la misma no tiene porque ser homogéneo y que por ello el legislador ordinario puede atribuir consecuencias a una y a otra manifestación ${ }^{277}$ de manera que la primera se constituya en un auténtico derecho subjetivo, mientras que la segunda no sea más que una mera libertad jurídica, integrada en el mismo derecho fundamental, y cuyo contenido se ciñe a la posibilidad de optar a la existencia de una alternativa de acción ${ }^{278}$.

relación existente entre la medida adoptada, el resultado producido y la finalidad pretendida (SSTC 22/1981, de 2 de julio, $F$. 3... b) La virtualidad del art. 14 CE no se agota, sin embargo, en la cláusula general de igualdad con la que se inicia su contenido, sino que a continuación el precepto constitucional se refiere a la prohibición de una serie de motivos o razones concretos de discriminación. Esta referencia expresa a tales motivos o razones de discriminación no implica el establecimiento de una lista cerrada de supuestos de discriminación..., F. 6), pero sí representa una explícita interdicción de determinadas diferencias históricamente muy arraigadas y que han situado, tanto por la acción de los poderes públicos como por la práctica social, a sectores de la población en posiciones, no sólo desventajosas, sino contrarias a la dignidad de la persona que reconoce el art. 10.1 CE...”

276 STC, Pleno, núm. 51/2011, de 14 de abril, RTC 2011/51: “En el caso que nos ocupa, la demandante de amparo, en el legítimo ejercicio de su derecho a la libre elección de cónyuge, contrajo matrimonio civil con persona cuyo estado civil era el de divorciado. No ha existido, pues, obstáculo alguno para que la demandante ejerciese su derecho constitucional a contraer matrimonio en condiciones de plena libertad e igualdad (arts. 14 y 32.1 CE), derecho que, como también hemos tenido ocasión de precisar... «no es ... un derecho de ejercicio individual, pues no hay matrimonio sin consentimiento mutuo (art. 45 del Código Civil)». Ahora bien, lo que aquí se discute no es, claro está, que la demandante haya podido ejercer libremente su ius connubii, sino si la reacción del Obispado de Almería al ejercicio por parte de la demandante de su derecho a contraer matrimonio con la persona elegida (reacción que ha determinado a la postre la pérdida de su puesto de trabajo como profesora de religión y moral católicas) puede entenderse lesiva de los derechos fundamentales de aquélla. “

277 STC 198/2012., ...op. cit., página 29.

278 ATC, Sala segunda, núm. 204/2003, de 16 de junio, RTC 2003/204 auto: "Si bien es cierto que doctrinalmente cabe extraer del art. 32.1 CE el derecho a no casarse, no sólo como derecho de libertad negativa, en cuanto exige a los poderes públicos su no proscripción y que no sea directamente impedido, sino también como libertad positiva, es decir, que los poderes públicos estarían obligados a promover las condiciones necesarias para su efectivo ejercicio, lo cierto es que tal solución contrasta con la doctrina constitucional existente, hasta el momento, en este punto. En este sentido... «el matrimonio es una institución social garantizada por la Constitución, y el derecho del hombre y de la mujer a contraerlo es un derecho constitucional (art. 32.1), cuyo régimen jurídico corresponde a la Ley por mandato constitucional (art. 32.2). Nada de ello ocurre con la unión de hecho «more uxorio», que ni es una institución jurídicamente garantizada ni hay un derecho constitucional expreso a su establecimiento». En suma, el contenido de la libertad de contraer (o no contraer) matrimonio se limita a asegurar la capacidad de elección, a impedir el mandato o la imposibilidad absoluta, pero no a asegurar a quien la ejercita en un determinado sentido los mismos efectos que se atribuyen a quien lo hace en otro. Ello explica que, pese a la identidad de los sujetos titulares de la libertad, el contenido de la libertad positiva y negativa no tenga por qué ser homogéneo, y que el legislador ordinario pueda atribuir, como es el caso, consecuencias a una y a otra manifestación, y hasta que la primera se constituya en un auténtico derecho subjetivo, mientras que la segunda no sea más que una mera libertad jurídica, integrada en el mismo derecho fundamental, y cuyo contenido se ciñe a la posibilidad de optar o a la existencia de una alternativa de acción. “ 
Al asumir la existencia de dos regímenes diferenciados por voluntad del legislador, el del matrimonio y el de la convivencia more uxorio, los cuales son reflejo de la capacidad de elección de las personas respecto del ejercicio de su derecho a contraer matrimonio, reconoce que las relaciones de convivencia more uxorio no son una institución ni está jurídicamente garantizada, tampoco existe un derecho constitucional expreso para su establecimiento ${ }^{279}$.

Sobre ello quiero enunciar que sólo cuatro Comunidades Autónomas no tienen leyes sobre parejas de hecho: La Rioja, Murcia, Castilla-La Mancha y Castilla y León. Los ejecutivos que aprobaron las leyes de las Comunidades en las que existen tienen como base ideológica bastantes diferencias, sin perjuicio de esto también de conformidad a sus distintas competencias se reconocen diversos derechos a dichas parejas. La primera ley en aprobarse fue la catalana, seguida de la aragonesa. Navarra, a su vez fue la primera que permitió la adopción de las mismas formadas por homosexuales

Prosiguiendo con la sentencia en estudio, el punto que a continuación se enuncia me parece de peculiar importancia por tal motivo estimo mejor citarlo de manera textual: "Para determinar si la reforma objeto de este recurso vulnera el derecho a contraer matrimonio, ha de partirse de la certeza de que la misma ha introducido importantes matices respecto del derecho constitucional. Decíamos anteriormente, evocando nuestra jurisprudencia previa, que siendo un derecho de titularidad individual no lo es de ejercicio individual, puesto que exige de otra persona para realizarse y del consentimiento mutuo libremente expresado por los contrayentes dentro de los límites que se deriven de la configuración legal que realiza el Código Civil (...) de los requisitos para contraer matrimonio. Dejando de lado el debate sobre si las personas homosexuales gozaban ya del derecho a contraer matrimonio antes de la reforma legal aqui analizada, resulta evidente que la nueva redacción del Código Civil que introduce la Ley 13/2005(...) permite que el ejercicio del derecho se concrete con una persona del mismo sexo. No estamos, pues ante una cuestión relativa a la ampliación del elenco de titulares del derecho individual, sino ante una modificación de las formas de su ejercicio. Por tanto, es preciso determinar si la citada modificación supone un ataque al contenido esencial del derecho fundamental. "280

A continuación de dicha exposición se prosigue aludiendo al matrimonio como garantía institucional, dejando atrás su análisis como derecho fundamental sin justificar por que sucede este abrupto cambio, aludiendo a que la garantía institucional "coincide substancialmente con la dimensión objetiva del derecho constitucional al matrimonio, puesto que ambas nociones, contenido es-

280 STC 198/2012., ibídem, páginas 29 y 30. 
encial y garantía institucional, se solapan al definir el matrimonio, aunque dogmáticamente su naturaleza sea diferente. Por eso, una vez establecido que la garantía institucional del matrimonio permanece intacta con la nueva regulación legal, ello nos conduce a entender que también la dimensión objetiva del derecho permanece inalterada, debiendo dirigir nuestra reflexión exclusivamente hacia la dimensión subjetiva del mismo, que impone al legislador, que debe preservarla, la obligación negativa de no lesionar la esfera de libertad que contiene el derecho..." ${ }^{281}$. Bajo este prisma la aprobación de la Ley 13/2005 no supone tanto una limitación del derecho al matrimonio como una modificación de las condiciones de ejercicio. Ahora bien, debemos frente al cuestionamiento de si la regulación impugnada impide el ejercicio del derecho por parte de las personas heterosexuales, en las mismas condiciones en que anteriormente lo ejercían, afectando por tanto al contenido esencial de ese derecho, y la respuesta a esta cuestión ha de ser negativa: "El reconocimiento del derecho al matrimonio a todas las personas, independientemente de su orientación sexual, implica la posibilidad para cada individuo de contraer matrimonio con personas de su mismo sexo o de diferente sexo, de manera que ese ejercicio reconozca plenamente la orientación sexual de cada uno. Ello no afecta al contenido esencial del derecho, porque el que puedan contraer matrimonio entre sí personas del mismo sexo ni lo desnaturaliza, ni lo convierte en otro derecho, ni impide a las parejas heterosexuales casarse libremente, o no casarse. Las personas heterosexuales no han visto reducida la esfera de libertad que antes de la reforma tenían reconocida como titulares del derecho al matrimonio, puesto que con la regulación actual y con la anterior, gozan del derecho a contraer matrimonio sin más limitaciones que las que se deriven de la configuración legal de los requisitos para contraer matrimonio que realiza el Código Civil. Sin embargo, las personas homosexuales gozan ahora de la opción, inexistente antes de la reforma legal, de contraer matrimonio con personas del mismo sexo, de tal modo que el respeto a su orientación sexual encuentra reflejo en el diseño de la institución matrimonial, y por tanto su derecho individual a contraer matrimonio integra también el respeto a la propia orientación sexual. De este modo se da un paso en la garantía de la dignidad de la persona y el libre desarrollo de la personalidad"

281 STC 198/2012., ibídem, página 30.

282 STC, Pleno, núm. 212/2005, de 21 de julio, 2005/212: "De la legislación orgánica aludida se desprende que el sistema de becas constituye un instrumento esencial para hacer realidad el modelo de «Estado social y democrático de derecho» que nuestra Constitución impone (art. 1.1), determinando en consecuencia que los poderes públicos aseguren que la igualdad de los individuos sea real y efectiva (art. 9.2 CE). De este modo se garantizan también la dignidad de la persona y el libre desarrollo de la personalidad (art. 10.1 CE) que suponen la base de nuestro sistema de derechos fundamentales. “ 
Lo anterior permite adentrarse en una esencial conclusión cual es que el Legislador, a juicio del Tribunal simplemente esta regularizando dentro de los márgenes de configuración que la propia Constitución le establece cómo límites ${ }^{283}$.

Frente a esta afirmación no estoy de acuerdo, por cuanto el Legislador no puede evitar al legislar hacer una reflexión profunda, de cariz antropológico, no se trata simplemente de regular e interpretar que si la Carta Marga no prohíbe expresamente algo, entonces lo permite, por cuanto estamos en los recintos del Derecho Público, es necesario un mandato claro y si no lo es entonces debiese buscarse reformar el Código político.

Expresa en un voto particular OLLERO TASARA que toda actividad jurídica no es sino filosofía práctica. Evoca a un imperio de radicalismo individualista que resulta contraproducente y que por lo demás “dificulta la adecuada articulación entre instituciones jurídicas, rebosantes de exigencias sociales, y derechos individuales, haciendo que los segundos conviertan en irrelevantes a las primeras. No me parece acertado tratar a determinadas instituciones jurídicas como si fueran mero corolario de los derechos y no más bien razón de su fundamento, abocando a una contraposición simplista entre limitación o ampliación de derechos individuales. Esta deriva individualista instrumenta hoy una nueva versión de uso alternativo del derecho. El indiscutible imperativo del artículo 14 CE se convertiría en fuente de nuevos derechos destinados a eliminar las discriminaciones más arraigadas. El intento de reconocer el carácter heterosexual del matrimonio, «ex» artículo 32 CE, y un derecho constitucional a contraer uno homosexual alternativo, ex artículo 14 CE, no ha dejado huella en la Sentencia por no encontrar apoyo significativo durante su deliberación. La Sentencia no deja sin embargo de dibujar un recorrido al que sería absurdo plantear objeción alguna: partiendo de unas relaciones homosexuales criminalizadas (F. 11), que ninguna de las partes ha defendido, se supera su mera conversión en un no prohibido agere licere, para elevarlas a fuente de derechos, capaces de desvirtuar a su servicio una milenaria institución social. El radicalismo individualista lleva esta instrumentalización, no reconociendo al matrimonio función más importante que la de otorgar reconocimiento social a conductas injustamente discriminadas. Comparto integramente la legítima aspiración a erradicar la injusta discriminación de las personas que suscriben una orientación homosexual. Lo que nunca suscribiré es que el fin justifique los medios, im-

283 Voto particular que formula el Magistrado D. Andrés Ollero Tassara respecto a la Sentencia del Pleno de fecha 6 de noviembre de 2012 dictada en el Recurso de Inconstitucionalidad núm. 6864/2005, página 41: “Resulta llamativo que se afirme en la Sentencia con toda rotundidad que la heterosexualidad reflejada en el artículo 32 CE no excluye la homosexualidad, aun apuntando que esto «no significa que implícitamente acogiera el matrimonio entre personas del mismo sexo, si nos limitamos a realizar una interpretación literal y sistemática, pero tampoco significa que lo excluyera» (F. 8). Se busca para ello amparo en que no todo lo que la Constitución no contempla es necesariamente inconstitucional; pero es claro que lo será lo que prive de todo sentido a lo que sí contempla”. 
perativo obligado de cualquier versión de uso alternativo del derecho. El respeto a una determinada orientación sexual, que lleva a mantener unas relaciones ajenas al matrimonio, no obliga a reconocer la posibilidad de contraerlo"284.

Sin embargo, el Tribunal estima que la ley al modificar el régimen de ejercicio del derecho constitucional al matrimonio sin afectar a su contenido, ni menoscabar el derecho al matrimonio de las personas heterosexuales, habida cuenta de que la Ley recurrida no introduce ninguna modificación material en las disposiciones legales que rigen los requisitos y efectos del matrimonio civil de personas de sexo diferente, y sin que la opción adoptada suponga denegar a cualquier persona o restringir el derecho constitucional a contraer o a no contraer matrimonio.

\section{3 ¿Qué se entiende en la actualidad por matrimonio?, especial referencia a la relación entre el art. 12 del Convenio Europeo de Derechos Humanos y la actualidad española. La intervención social del mismo}

Antes de analizar el matrimonio propiamente, me gustaría referirme al derecho al matrimonio, si existe realmente tal derecho, y por ello empezaré con una visión más global del mismo a nivel europeo. El Convenio Europeo de Derechos garantiza en su artículo 12 el derecho a contraer matrimonio $^{285}$. Asimismo en el ámbito convencional debe mencionarse el art. 5 del Protocolo núm. 7 al Convenio, el cual también prescribe la igualdad entre los esposos. Para dar forma a este derecho el Tribunal de Estrasburgo se ha servido de numerosos asuntos que plantearon problemas relativos a su titularidad, respecto a la edad exigible, como a la sujeción especial de ciertas personas, como los presos o circunstancias relativas a su orientación sexual, como los transexuales.

El TEDH se ha referido, como ya se manifestó anteriormente al derecho a contraer matrimonio en algunas sentencias en las que también el demandante sostuvo que la medida estatal en litigio afectaba a su vida familiar. Posiblemente sean en lo referente a que si tal derecho puede extenderse a los transexuales, incluso cuando uno de los dos se ha sometido a un tratamiento hormonal y/o quirúrgico, con lo que se busca es adquirir la características propias del otro sexo. Este punto resulta bastante contradictorio en la línea jurisprudencial, porque no ha existido una línea de pensamiento común sino más bien incertidumbre, no existía al interior del Consejo de Europa una obligación general de permitir el matrimonio de transexuales operados. En sentencias tales como la STEDH,

284 OLLERO TASSARA, A. loc. cit, página 39.

285 Cfr. ARRESE IRIONDO, Mª N. "Artículo 12. Derecho a contraer matrimonio", en LASAGABASTER HERRARTE, I. (Dir.), “Convenio Europeo de Derechos Humanos. Comentario sistemático”, Ed. Thomson CivitasGobierno Vasco, Madrid, año 2004, páginas 488 y siguientes; TORRES GUTIERREZ, A. "El derecho a contraer matrimonio (art. 12 CEDH)", en GARCÍA ROCA, J y SANTOLAYA, P. "La Europa de los Derechos. El Convenio Europeo de Derechos Humanos”, CEPCO, Madrid, año 2005, páginas 621 y siguientes. 
Gran Sala, Coster contra Reino Unido, de 18 enero 2001. TEDH 2001/4; STEDH, Sheffield y Horshamcontra Reino Unido, de 30 julio. TEDH 1998/34, el Tribunal ha justificado tales decisiones amparándose en aspectos médicos en virtud de los cuales se afirma que la persona transexual no adquiere plenamente todas las características de quien forman parte del sexo contrario al cual se orienta, ante lo cual no se trata de dos personas de distinto sexo tal cual se dejaba en el articulo 12 antes mencionado.

Pero no acabó aquí el asunto, como bien se sabe, hasta el año 2002 el Tribunal consideraba que en realidad los transexuales gozaban del derecho a contraer matrimonio, porque siempre podrían contraerlo con una persona de su mismo sexo aparente. En la STEDH, Gran Sala, Caso I contra Reino Unido. Sentencia de 11 julio 2002. TEDH 2002/45, declaró que el Estado parte incumple el Convenio Europeo de Derechos Humanos al permitir que una persona se someta a una operación de cambio de sexo y posteriormente le impide cambiar en el Registro Civil los datos relativos al mismo y en tal sentido le niega la posibilidad de contraer matrimonio con una persona del mismo sexo a aquel con el cual el transexual nació, se les negaría sin más a a ejercer el derecho manifestado en el art. 12 de la Convención.

Detrás de tal razonamiento existe el ánimo de sancionar la incoherencia de algunos Estados que consienten operaciones de cambio de sexo, incluso bajo el amparo del presupuesto público y le otorgan un tratamiento psicológico y hormonal para luego negarse a aceptar todas las consecuencias jurídicas que dicho cambio provoca, como son la corrección registral en su identificación personal y la aceptación de su derecho a casarse y fundar una familia con una persona de sexo opuesto a aquél que el transexual siente como propio. Finalmente destaco la STEDH, Sección $4^{\mathrm{a}}$, Caso Grant contra Reino Unido. Sentencia de 23 mayo 2006. TEDH 2006/39, en donde manifiesta: “ El Tribunal recuerda que ya ha tratado una serie de asuntos relativos a la posición de los transexuales en el Reino Unido ( Rees c. El Reino Unido, sentencia de 17 de octubre de 1986 [ TEDH 1986, 11] , Serie A núm. 106, Coosey c. El Reino Unido, sentencia de 27 de septiembre de 1990 [ TEDH 1990, 22] , Serie A núm. 184, X., Y. y Z. c. El Reino Unido sentencia de 22 de abril de 1997 [ TJCE 1997, 24] , Repertorio de Sentencias y Decisiones 1997-II, Sheffield y Horsham c. El Reino Unido, sentencia de 30 de julio de 1998 [ TEDH 1998, 34] , Repertorio 1998-V, pg. 2011, la más reciente y ya mencionada Christine Goodwin c. El Reino Unido [JUR 2002, 181176] , así como I. c. El Reino Unido [GS], núm. 25680/94, 11 de julio 2002 [ TEDH 2002, 45] ). En los asuntos más antiguos, sostuvo que la negativa del Gobierno del Reino Unido a alterar el registro de nacimientos o de emitir certificados de nacimiento cuyo contenido y naturaleza relativa al sexo del in- 
dividuo difiriera del original, no podía ser considerada como una injerencia con relación al derecho de respeto a la vida privada (la ya mencionada, Rees, pg. 14, ap. 35 y Coosey, ap. 36; Sheffield y Horsham, ap. 59). Sin embargo, al mismo tiempo, el Tribunal era consciente de los serios problemas a los que se enfrentan los transexuales, y en todas y cada una de las ocasiones, subrayó la necesidad de someter a revisión las medidas legales apropiadas sobre el tema (véase Rees ap. 47; Coosey, ap. 42 y Sheffield y Horsham, ap. 60). En los últimos asuntos, tuvo expresamente en cuenta la situación dentro y fuera de los Estados Contratantes para establecer «a la vista de las condiciones de hoy en día» lo que resultaba más conveniente en la interpretación y aplicación del Convenio ( Christine Goodwin, ap. 75). Tras el examen de las circunstancias personales de los demandantes como transexuales, las actuales consideraciones médicas y cientificas, el estado del consenso Europeo e internacional, el impacto en el registro de nacimientos y en los desarrollos sociales y legislativos domésticos, el Tribunal consideró que el Gobierno demandado no podía seguir afirmando que ese asunto correspondia al ámbito de su margen de apreciación, excepto en lo que concierne a los medios apropiados para alcanzar el reconocimiento de los derechos protegidos por el Convenio. Dado que no existían factores significativos de interés público que esgrimir en contra del interés de dichos demandantes individuales por obtener un reconocimiento legal de su nueva condición de género, llegó a la conclusión de que el justo equilibro inherente al Convenio, se decantaba ahora de forma decisiva a favor de los demandantes y que por tanto, se habia producido la vulneración de su derecho a ver respetada su vida privada, violando con ello el artículo 8 del Convenio ( RCL 1999, 1190, 1572).”

Prosiguiendo con el derecho a contraer matrimonio, sin duda que el primer requisito que debe cumplir cualquier persona que quiera ejercer este derecho es el de gozar de una edad mínima, lo que comúnmente se denomina edad núbil, tal exigencia tiene relación con una determinada capacidad que se presume con el cumplimiento de un determinado número de años, esto en consideración a la formación y evolución de la psicología propia del menor como a su autodeterminación.

Este derecho también protege a los presos, es contrario al art. 12 del Convenio Europeo de Derechos Humanos, las restricciones que les impidan su ejercicio, ya sea impidiendo que se celebran matrimonios en las cárceles, ya sea impidiendo que puedan salir para la celebración de los mismos. Si bien no se exige a los Estados que organicen las visitas conyugales, es una constancia que en varios países europeos se han regulado, por cuanto son un ejercicio de la intimidad de la perso$\mathrm{na}^{286}$.

286 STEDH, Sección 4a, Caso Aliev contra Ucrania. Sentencia de 29 abril 2003. JUR 2003/69271. 
En relación al matrimonio de las personas homosexuales el Tribunal Europeo de Derechos humanos ha manifestado que mediante el art. 12 se encuentra garantizado el derecho fundamental para un hombre y una mujer a casarse y fundar una familia, sin embargo el segundo aspecto no es una condición del primero y la incapacidad para una pareja de concebir o criar un hijo no puede ser causa de privación del derecho tal cual lo señala la primera parte. Esta alude al derecho a casarse, por persona de ambos sexos. Pero no esta seguro de que en la actualidad el sexo deba ser determinado únicamente por aspectos biológicos. Con el Convenio, el matrimonio se ha transformado, asimismo la ciencia y los adelantos, especialmente en las ciencias de la salud, han provocado el reconocimiento del cambio de sexo, el cual puede ser registrado, sin perjuicio que el art. 9 de la Carta de los Derecho Humanos de la Unión Europea se aparte del art. 12 ya antes señalado.

El hecho de que se permita registrar el cambio no provoca la obligación de reconocer el derecho a contraer matrimonio por parte de una persona transexual, ni tampoco el fundamento a privarles de tal posibilidad, sí o sí.

Un análisis similar puede inferirse respecto al matrimonio de las personas homosexuales, no se protege tal derecho en al art. 12, pero tampoco se prohíbe, en palabras de Praesidium de la Convención Europea en relación con el art. correspondiente en la Carta, "este artículo ni prohíbe ni impone el que se conceda estatuto matrimonial a la unión de personas del mismo sexo", es decir, dependerá de las legislaciones internas el que un matrimonio lo puedan contraer únicamente personas de sexo contrario o del mismo (Casos de Países Bajos desde el año 2000, Bélgica desde el 2003, España dese el 2005, Noruega desde el 2009, Portugal desde el 2010, Francia desde el 2011). Lo anterior, a mi juicio, resulta importante para interpretar el art. 32.1 de la CE, en tal sentido GAVIDIA SÁNCHEZ ha manifestado que dicho artículo a la luz del Convenio obliga a inferir que lo convencional y constitucionalmente garantizado es el matrimonio entre dos personas sean o no del mismo $\operatorname{sexo}^{287}$.

Finalmente el TEDH ha precisado que para el ejercicio del derecho a contraer matrimonio habrá de estarse a las limitaciones previstas en las leyes nacionales que lo disciplinan, si bien no pueden restringirlo o reducirlo de una forma o hasta un punto que lo vulneren en su sustancia misma ${ }^{288}$. En los Estados miembros de la UE estas limitaciones son sin duda condiciones que se manifiestan en normas ya sea de fondo como de forma, las de forma se refieren a la publicidad y a la solemni-

287 GAVIDIA SÁNCHEZ, J. “Uniones homosexuales y concepto constitucional de matrimonio”, Revista Española de Derecho Constitucional, núm. 61, Madrid, página 49 y 50.

288 STEDH, caso Rees contra Reino Unido. Sentencia de 17 octubre 1986. TEDH 1986/11; STEDH, Sección 4a, Caso Grant contra Reino Unido. Sentencia de 23 mayo 2006. TEDH 2006/39. 
dad del matrimonio, mientras que las de fondo tienen relación con la capacidad, así como con el consentimiento y ciertos impedimientos ${ }^{289}$.

Por otra parte, y en relación al derecho a contraer matrimonio y a la naturaleza misma de lo que actualmente se entiende por matrimonio, el fenómeno de las uniones de hecho ha puesto de relieve una cierta línea evolutiva (acaso cabría decir más bien involutiva) que, como rechazo del proceso de rígida formalización del contrato matrimonial, nos devuelve paulatinamente a la concepción del matrimonio en el Derecho romano clásico, allí donde aquel fue concebido como un mero hecho social (convivencia presidida por la voluntad marital) eventualmente productor de efectos jurídicos. Aún así, la exigencia de la voluntad marital (afectio maritalis) como rasgo distintivo del matrimonio (aun no concretada formalmente en un momento inicial), y no la mera convivencia, sigue estando presente en ese modelo histórico y constituye precisamente el dato que permite diferenciar al matrimonio del concubinato ${ }^{290}$.

La cuestión se traslada entonces a la determinación de lo que efectivamente haya de entenderse por voluntad conyugal y, desde ese punto de vista, el proceso de vaciamiento institucional que ha venido experimentando el contrato matrimonial resulta de excepcional importancia.

En el contexto de esa progresiva pérdida del contenido genuinamente matrimonial, el papel preponderante que otrora ocupase la procreación como fin del matrimonio parece sin embargo ha-

289 STEDH, Caso F.contra Suiza. Sentencia de 18 diciembre 1987. TEDH 1987/3. "El artículo 12 asegura el derecho fundamental de un hombre y de una mujer a contraer matrimonio y a fundar una familia. El ejercicio de este derecho da lugar a consecuencias personales, sociales y legales. Obedece las leyes nacionales de los Estados Contratantes", pero "las limitaciones así introducidas no deben restringir ni reducir el derecho en tal sentido o hasta el punto de que la esencia del derecho sea perjudicada". En todos los Estados miembros del Consejo de Europa, estas "limitaciones" aparecen como condiciones y se encarnan en normas tanto de forma como de fondo. Las primeras afectan principalmente a la publicidad y solemnidad del matrimonio; los segundos a la capacidad, consentimiento y ciertos impedimentos.”; STEDH, Sección 4a, Caso Jaremowicz contra Polonia. Sentencia de 5 enero 2010. TEDH 2010/1. "Las instituciones del Convenio aceptaron que las limitaciones sobe el derecho a contraer matrimonio establecidas por las legislaciones internas podían incluir normas relativas a la publicidad y celebración del matrimonio. También podían incluir disposiciones sustantivas basadas en consideraciones reconocidas de interés público, en concreto, relativas a la capacidad, consentimiento, prohibición de grados de afinidad o prevención de la bigamia. En el contexto de las Leyes de inmigración y por razones justificadas, los Estados pueden tener derecho a impedir matrimonios de conveniencia, celebrados con el único propósito de obtener ventajas para el inmigrante. Sin embargo, las Leyes aplicables -que también deben cumplir los criterios de accesibilidad y claridad exigidos por el Convenio- no pueden privar a una persona o grupo de personas con plena capacidad legal del derecho a contraer matrimonio con la persona de su elección..."

290 DOMinguEZ LOZANO, P. “La unión de personas del mismo sexo y sus implicaciones jurídicas”, Revista de Derecho Privado y Constitución, núm. 20, enero-diciembre 2006, Centro español de Estudios Constitucionales, Madrid, página 188. Si el matrimonio se define como una comunidad afectiva y material de vida, y no por su función social, si su finalidad esencial ya no es la reproductora sino el contribuir a la realización personal y al desarrollo de la personalidad, si su contenido constitucional tiene relación directa con los derechos y libertades fundamentales de carácter individual, si el ius connubium se predica en principio en reacción a cualquier persona, sobre exigencias de igualdad y libertad, y si la regulación jurídica del matrimonio y las relaciones entre los cónyuges a vivido un giro hacia el Derecho de las obligaciones., es difícil no admitir dentro del ordenamiento la unión de parejas del mismo sexo. 
ber sido sustituido, en la vigente legislación española, por la mera relación de convivencia amorosa o de afectividad, lo cual también puede ser visto en el concepto que del matrimonio proclama la STC 198/2012, lo que implica en definitiva, que el matrimonio ya no se contempla en su condición tradicional de núcleo reproductivo, sino desde la perspectiva, ahora preeminente, de la comunidad vital creada entre los esposos ${ }^{291}$.

De este modo, se ha podido hablar con justeza de la relajación del componente sexual en el matrimonio y de su desplazamiento fuera de la definición del instituto legal ${ }^{292}$, al tiempo que se ha detectado la presencia, cada vez más notable, en sede judicial y pese a la ausencia de estricto apoyo legal, del reconocimiento del cese del afecto conyugal como origen de la crisis jurídica del matrimonio, tal como lo analiza ARCOS VIEIRA ${ }^{293}$.

La desaparición de aquella dimensión generativa del ámbito de los requisitos esenciales de la unión marital en nuestra vigente legislación, dimensión de la que era fiel reflejo, con anterioridad a la reforma de 1981, la configuración de la impotencia sexual como un impedimento para contraer matrimonio en el art. 83.3 del Código Civil, implica, por si misma, un cambio notable en el concepto jurídico de matrimonio y, en este sentido, plantea la necesidad de redefinir lo que deba entenderse por tal a efectos de la legislación civil ${ }^{294}$, circunstancia que debe además interpretarse en un contexto general de revisión, puesto que el vaciamiento de contenidos institucionales del matrimonio se ha detectado también respecto de la práctica totalidad de los aspectos de la institución, dando origen a lo que se ha designado como una grave crisis de identidad del concepto civil de matrimonio ${ }^{295}$.

A partir de ahí, quedaría teóricamente expedito el camino hacia la admisibilidad del matrimonio homosexual, desprovisto de la expectativa de generación de la prole pero perfectamente acorde a la idea de la relación de convivencia amorosa o afectiva ${ }^{296}$. Esta argumentación, por lo demás no

291 LUNA, A. "La reforma de la legislación matrimonial", en LACRUZ BERDEJO, J. L. (Coord.), "Matrimonio y Divorcio. Comentarios al Título IV del Libro primero del Código civil", Ed. Civitas, Madrid, año 1994, página 15.

292 MARTI, J. M. "Comunidad política e institución del matrimonio" en CASTRO, A (Ed), "Derecho de familia y libertad de conciencia en los paises de la Unión Europea y el Derecho comparado", Universidad del País Vasco, San Sebastián, año 2001, página 558.

293 El fenómeno ha sido ampliamente estudiado por ARCOS VIEIRA, M. L. en "La Desaparición de la Affectio Maritalis como Causa de Separación y Divorcio", Ed. Aranzadi, Cizur Menor, año 2000.

294 ROCA I TRIAS, E. "El matrimonio", en VV. AA., "Derecho de familia", Ed. Tirant Lo Blanch, Valencia, año 1997 , página 52 a 55.

295 REINA, V y MARTINELL, J. M. "Las uniones matrimoniales de hecho”, Ed. Marcial Pons, Madrid, año 1996, página 27.

296 Así lo hace notar, por ejemplo, LLEBARÍA SAMPER, S, "Hacia la familia no matrimonial (Presente y futuro en Derecho civil catalán)", Cedecs Ed., S.L., Barcelona, año 1997, páginas 44 y 45; relaciona también ambos aspectos MONTESINOS SÁNCHEZ, A. M.. "La conflictividad jurídica de las uniones homosexuales", en XVIII Jornadas de la Asociación Española de Canonistas, Salamanca, año 1999, página 367. 
carece de lógica interna y en ese sentido resulta convincente. Ahora bien, si se analiza el tema en su más honda repercusión nos enfrenta a una interrogante que se vincula al origen mismo de la consideración del matrimonio como institución reconocida y tutelada por el Derecho.

En esta materia, la intervención social, a través del Derecho y, sus mecanismos protectores, ha encontrado tradicionalmente su justificación en la consideración de la trascendencia social del matrimonio, en su relevancia para la comunidad política en tanto que ámbito de realización de la expectativa de generación y crianza de nuevos miembros de la comunidad y, por consiguiente, como una garantía del necesario relevo generacional. Siguiendo en este punto a CABEZUELO ARENAS, aunque de entrada es indudable que la misma o muy similar relevancia social puede atribuirse a la unión de hecho heterosexual, no lo es tanto, sin embargo, el que dicha atribución pueda hacerse en relación con las uniones homosexuales, siendo entonces cuando cobra un especial relieve la idea del declive de la dimensión procreativa, la cual ahora ya no resulta del todo necesaria en la conformación del núcleo del matrimonio. Hoy por hoy lo esencial en la legislación estatal, es la primacía de la convivencia afectiva o amorosa, ella es la causa origen del matrimonio y también puede de ser la causa de su extinción ${ }^{297}$, permitiendo todo ello residenciar el fundamento de la intervención social, elemento cuya presencia en las uniones homosexuales no admite discusión.

La Constitución española contempla el matrimonio en el art. 32 como objeto de un derecho (ius connibii). La determinación de su rango y naturaleza jurídica, su adscripción o no a la categoría de los derechos fundamentales, es cuestión discutida doctrinalmente. Las razones de esta discusión se deben en parte a la ubicación sistemática del precepto en el seno de la norma fundamental (Sección segunda del Capítulo $2^{\circ}$ del Título I), lo cual trae aparejado la consiguiente ausencia del mecanismo de protección reforzada de que gozan los derechos de la Sección primera. La critica que recibe tal opinión se debe al nominalismo que presenta, sin perjuicio de ser una cuestión casi exclusivamente formal. Frente a ello está la manifestación del mismo derecho en varios textos internacionales formalmente consagrados al reconocimiento de los derechos fundamentales. De todas maneras la discusión acerca de la clasificación de los derechos constitucionales y su adscripción a una u otra categoría formal, de entre las muchas que se pueden extraer del propio Derecho positivo o del ámbito de la construcción dogmática, no deja de tener valor relativo, a menudo de muy escasa operatividad $^{298}$, pero tal discusión tampoco es el objetivo del presente trabajo.

297 "La cesación de la "affectio maritalis" como causa de separación en la práctica judicial. Un exponente de la interpretación sociológica de la norma”, Ed. Aranzadi, Aranzadi Civil, Tomo 10, Volumen 3, Revista Doctrinal, Cizur Menor, año 2001, página 2269 a 2284.

298 POLO SABAU, J. R. “Matrimonio y Constitución ante la Reforma del Derecho de Familia”, Ed. Thomson Civitas, Cuadernos Civitas, Cizur Menor, año 2006, página 47. El citado autor expone que : "Puede destacarse, inicialmente, el recurso ocasional, por parte de un sector de la doctrina, a la idea según la cual el constituyente, al 
Lo anterior es sin perjuicio de que existe un consenso doctrinal respecto a que del contenido del art. 32 se desprende la garantía constitucional de la institución del matrimonio y, en ese sentido, es posible hablar de la existencia aquí de una garantía institucional, tal cual se mencionó anteriormente, con la que básicamente se predetermina la dimensión objetiva del derecho y se dota a este de sustancial intangibilidad, al imponerse desde la Constitución una estructura normativa o institucional objetiva que no puede estar ausente del ordenamiento jurídico ${ }^{299}$. Aunque tal no poder estar ausente es sin perjuicio de la reinterpretación que puede sufrir, en aras de la evolución social que lo enmarca, el punto es, si tal evolución dirigida por este elemento sociológico puede llevar al extremo de que tal garantía institucional quede vaciada de contenido.

Según esta idea, el constituyente habría asumido la noción del matrimonio como una de las instituciones básicas de la vida social, “institución social garantizada por la Constitución”, dirá la STC 184/1990 300 , constituyendo ese carácter institucional su rasgo propiamente distintivo respecto de otro tipo de uniones libres o no juridificadas ${ }^{301}$. Merced al amplio reconocimiento del derecho que se lleva a cabo, la Constitución garantiza de entrada la exclusión de cualquier tipo de limitación impuesta a su ejercicio por causas ajenas al matrimonio mismo, pero no así la de aquellos condicionamientos que, previstos en atención al concepto de matrimonio asumido por el constituyente, se entienden como una garantía de la institución. Dicho de otro modo, como una consecuencia del reconocimiento constitucional, las condiciones del ejercicio del derecho sólo podrán fundarse en lo que desde la propia Constitución pueda considerarse como la esencia del matrimonio ${ }^{302}$.

concretar la titularidad del derecho a contraer matrimonio, hizo que ésta recayese textualmente en el hombre y la mujer, y no, como podía haber sido el caso, en el hombre y la mujer como sujetos del derecho a contraer matrimonio entre sí, una formula que habría resultado a estos efectos inequívocamente incompatible con el matrimonio homosexual".

299 Cfr. VILLAVERDE MENÉNDEZ, I. “Concepto, contenido, objeto y límites de los derechos fundamentales”, en "La democracia. Estudios en homenaje al profesor Francisco Rubio Llorente”, Centro de estudios Políticos y Constitucionales, Madrid, año 2002, páginas 317 a 360.

300 STC, Pleno, núm. 184/1990, de 15 de noviembre, RTC 1990/184: “Es claro que en la Constitución Española de 1978 el matrimonio y la convivencia extramatrimonial no son realidades equivalentes. El matrimonio es una institución social garantizada por la Constitución, y el derecho del hombre y de la mujer a contraerlo es un derecho constitucional (art. 32.1) cuyo régimen jurídico corresponde a la Ley por mandato constitucional (art. 32.2). Nada de ello ocurre con la unión de hecho more uxorio , que ni es una institución jurídicamente garantizada ni hay un derecho constitucional expreso a su establecimiento. El vínculo matrimonial genera ope legis en la mujer y el marido una pluralidad de derechos y deberes que no se produce de modo jurídicamente necesario entre el hombre y la mujer que mantienen una unidad de convivencia estable no basada en el matrimonio. Tales diferencias constitucionales entre matrimonio y unión de hecho pueden ser legitimamente tomadas en consideración por el legislador a la hora de regular las pensiones de supervivencia. ". Cfr. STS Madrid, Sala de lo social, sección 4a, núm. 784/2010, de 10 diciembre, AS 2011/152; STS Madrid, Sala de lo social, sección $4^{\text {a }}$, núm.207/2010, de 29 de abril, AS 2010/147.

301 DIEZ-PICAZO PONCE DE LÉON, L y GULLÓN BALLESTEROS, A. “Instituciones de Derecho Civil, II”, Ed. Tecnos, año 1995, Madrid, página 433.

302 ESPIN CANOVAS, D. “Artículo 32. Derecho al matrimonio”, en ALZAGA, O (Dir.) “Comentarios a la Constitucional española de 1978”, Tomo III, Ed. Edersa, Madrid, año 1996, página 454. 
Tal vez sea oportuno precisar que el empleo de esta terminología, en todo caso, no debe ser aquí entendido, como una apelación a una noción esencialista, de signo metajurídico, del matrimonio en la Constitución, sino que, por referencia siempre al contenido normativo de la ley fundamental, nos remite más bien a la existencia de un núcleo básico de la institución que, de hecho en términos de su efectiva protección constitucional, no es sustancialmente distinto de la categoría del contenido esencial aplicable a los derechos fundamentales, tal como lo manifiesta la STC $26 / 1987^{303}$.

A este respecto, un sector de la doctrina científica ha subrayado que, al margen de la discusión acerca del distinto perfil teórico de las dos categorías (derecho fundamental y garantía institucional), en ambos supuestos esa suerte de núcleo duro responde básicamente la misma idea rectora, hasta el punto de que las definiciones que del mismo hace el Tribunal Constitucional en cada caso resultan perfectamente intercambiables en opinión de BAÑO LEÓN ${ }^{304}$; algo a lo que, por otra parte, desde el punto de vista conceptual, no es ajeno al eco que ha encontrado en la doctrina del alto Tribunal la teoría institucional en la interpretación de los derechos fundamentales, en la que el contenido esencial se concibe, precisamente, como una garantía institucional del núcleo objetivo conformado por los fines que determinan el sentido, alcance y condiciones de ejercicio de cada derecho ${ }^{305}$.

En el caso de la garantía institucional que representa el derecho constitucional en el art. 32, existe sin duda un contenido esencial que se ofrece como límite al legislador, puesto que, aunque se haya podido discutir su condición de derecho fundamental, su reconocimiento constitucional lo excluye de la protección reforzada que depara a algunos derechos fundamentales el art. 53.2, pero no así de la garantía del respeto a su contenido esencial en el marco de la regulación legislativa de su

303 STC, Pleno, núm. 26/1987, de 27 de febrero, RTC 1987/26. "Hay, pues, un "contenido esencial" de la autonomía universitaria que está formado por todos los elementos necesarios para el aseguramiento de la libertad académica. En el art. 3.2 de la L. R. U. se enumeran las potestades que comprende y que, en términos generales, coinciden con las habitualmente asignadas a la autonomía universitaria. Por tanto, y dado que lo impugnado por supuesta vulneración del "contenido esencial"de dicha autonomía se dirige a preceptos concretos y no a la descripción general que recoge la Ley, habrá de ser en el análisis de cada precepto impugnado por esta razón donde se examine si se da o no la infracción denunciada. Conviene, sin embargo, dejar fijado desde este momento un criterio fundamental para el enjuiciamiento de los preceptos impugnados por este motivo. El art. 27.10 de la Constitución reconoce la autonomía universitaria «en los términos que la ley establezca». La ley regulará, por tanto, la autonomía universitaria en la forma que el legislador estime más conveniente, dentro del marco de la Constitución y del respeto a su "contenido esencial" en particular, y al analizar la impugnación de un precepto desde este punto de vista, lo que habrá de determinarse primordialmente es si se invade o no ese contenido esencial, sin que sea necesario justificar la competencia del legislador."

304 "La distinción entre derecho fundamental y garantía institucional en la Constitución española", en Revista Española de Derecho Constitucional, núm. 24, Madrid, año 1988, página 169.

305 PEREZ LUÑO, A. E. "Derechos Humanos, Estado de Derecho y Constitución”, Ed. Tecnos, Madrid, año 2003, página 311 y 312 . 
ejercicio, instaurada por el art. 53.1, con lo que, en esta ocasión, como ocurre con los demás preceptos de la Sección segunda del Capítulo segundo y a diferencia de otras instituciones garantizadas en otros Títulos de la Constitución, no tiene especial incidencia el debate genérico acerca de la distinta resistencia frente al legislador del contenido esencial en el derecho fundamental y en la garantía institucional, sigo en este punto a GALLEGO ANABITARTE ${ }^{306}$.

Lo que acaso si tenga ahora cierto interés respecto de la determinación de la noción del núcleo esencial o reducto indisponible de la garantía institucional, en aquellos supuestos, como es el caso del que nos ocupa, en los que el instituto garantizado es al mismo tiempo objeto de un derecho fundamental, es la posibilidad de percibir el contenido esencial del derecho y el núcleo objetivo de la institución como dos realidades diferenciadas, aunque íntimamente conexas. En estos casos, el instituto garantizado, dotado de su propio núcleo esencial que lo define como institución jurídica, se integra en el derecho fundamental como su objeto de protección $\mathrm{y}$, en ese sentido, lo delimita, de modo que en este ámbito, el de la adecuada delimitación del derecho, puede resultar conveniente distinguir ambos aspectos, pero no debe olvidarse, por lo que ahora más concretamente nos interesa, que en cualquier caso la intangibilidad de ambos frente al legislador esta igualmente garantizada, de tal manera lo expresa JIMENEZ CAMPO ${ }^{307}$.

De todo ello cabe presuponer que existe un particular concepto y contenido del matrimonio constitucionalmente garantizados en el art. 32, al que expresamente remite el apartado 2 de esta norma para la instauración del régimen jurídico matrimonial, sin perjuicio del adecuado entendimiento de su ámbito propio de competencia en el que ha lugar a las diversas opciones de política legislativa (STC 11/1981) $)^{308}$, se vería obligado en todo caso a respetar dicho contenido constitucional (TC $32 / 1981)^{309}$. No hay razón, por tanto, para no considerar paralelamente aplicable a la institución del

306 "Derechos fundamentales y garantías institucionales: análisis doctrinal y jurisprudencial (derecho a la educación; autonomía local; opinión pública)”, Ed. Civitas, Madrid, año 1994, página 83 y siguientes.

307 “Derechos fundamentales, concepto y garantías”, Ed. Trotta, Madrid, año 1999, páginas 67 y 68.

308 STC, Pleno, núm. 11/1981, de 8 de abril, RTC 1981/11: “Aunque admitiéramos que el Real Decreto-ley 17/1977 pudiera considerarse como restrictivo, sería ésta una calificación derivada de un enjuiciamiento político. No es posible calificar jurídicamente el artículo 28 de la Constitución como más liberal o más avanzado o más generoso. La Constitución lo que hace es reconocer el derecho de huelga, consagrarlo como tal derecho, otorgarle rango constitucional y atribuirle las necesarias garantías. Corresponde, por ello, al legislador ordinario, que es el representante en cada momento histórico de la soberanía popular, confeccionar una regulación de las condiciones de ejercicio del derecho, que serán más restrictivas o abiertas, de acuerdo con las directrices políticas que le impulsen, siempre que no pase más allá de los límites impuestos por las normas constitucionales concretas y del límite genérico del artículo 53. De este modo, la afirmación del recurrente en punto al carácter restrictivo es un juicio de valor político muy respetable y acaso compartible. Desde el punto de vista jurídico-constitucional lo único que hay que cuestionar es si sobrepasa o no el contenido esencial del derecho."

309 STC, Pleno, núm. 32/1981, de 28 de julio, RTC 1981/32: “El orden jurídico-político establecido por la Constitución asegura la existencia de determinadas instituciones, a las que se considera como componentes esenciales y cuya preservación se juzga indispensable para asegurar los principios constitucionales, estableciendo en ellas un núcleo o reducto indisponible por el legislador. Las instituciones garantizadas son elementos arquitecturales indispensables del orden constitucio- 
matrimonio una afirmación general como la de que cualquier norma que incida sobre la vida de la familia debe ser respetuosa con la concepción de esta que se alienta en la Constitución en palabras de FERNÁNDEZ-CORONADO GONZÁLEZ ${ }^{310}$. De hecho, como se ha visto, es la propia Ley 13/2005 la que, en su Exposición de Motivos, alude intencionalmente al mantenimiento en su integridad de los efectos del matrimonio "respetando la configuración objetiva de la institución”.

Partiendo, pues, de la existencia de un contenido objetivo de la institución matrimonial en la Constitución, inmune en cuanto tal a una eventual intervención configuradora del legislador que pudiera desvirtuarlo, la pregunta a la que hay que tratar de dar respuesta es la de si es constitutivo de dicho contenido el presupuesto de la heterosexualidad. Para responder tal cuestionamiento deben de entrar en juego, el principio del libre desarrollo de la personalidad, así como el principio de igualdad.

En relación con la vigencia del principio de igualdad, el reconocimiento del derecho del hombre y la mujer a contraer matrimonio con plena igualdad jurídica, según reza el art. 32.1, constituiría, para quienes así lo entienden, la prueba evidente de que el constituyente pretendió impedir toda posible discriminación en el acceso al matrimonio por razón de la condición sexual de los cónyuges, debiendo en consecuencia ser interpretada dicha referencia en el sentido de que tanto los hombres como las mujeres tienen derecho a contraer matrimonio con plena igualdad jurídica ${ }^{311}$. Esta tesis, además, parece venir apoyada por la idea de que, de otro modo, la vigencia general del principio consagrado en el art. 14 hubiera hecho innecesaria una mención específica a la igualdad en materia matrimonial.

Este enfoque de la cuestión, sin embargo, tampoco resulta satisfactorio. Antes bien, la doctrina científica, por lo común, tiende a considerar que la referida mención específica a la igualdad en el art. 32 no es más que la manifestación concreta del principio general de igualdad en la esfera intra-

nal y las normaciones que las protegen son, sin duda, normaciones organizativas, pero a diferencia de lo que sucede con las instituciones supremas del Estado, cuya regulación orgánica se hace en el propio texto constitucional, en éstas la configuración institucional concreta se defiere al legislador ordinario al que no se fija más límite que el del reducto indisponible o núcleo esencial de la institución que la Constitución garantiza. Por definición, en consecuencia, la garantía institucional no asegura un contenido concreto o un ámbito competencial determinado y fijado de una vez por todas, sino la preservación de una institución en términos recognoscibles para la imagen que de la misma tiene la conciencia social en cada tiempo y lugar. Dicha garantía es desconocida cuando la institución es limitada de tal modo que se le priva prácticamente de sus posibilidades de existencia real como institución para convertirse en un simple nombre. Tales son los límites para su determinación por las normas que la regulan y por la aplicación que se haga de estas. En definitiva, la única interdicción claramente discernible es la de la ruptura clara y neta con esa imagen comúnmente aceptada de la institución que, en cuanto formación jurídica, viene determinada en buena parte por las normas que en cada momento la regulan y la aplicación que de las mismas se hace."

310 "La evolución jurídica del sistema matrimonial español desde la Constitución de 19878 a la admisión del matrimonio homosexual”, Revista Foro, núm. 3/2006, Facultad de Derecho Universidad Complutense de Madrid, páginas 93 a 112.

311 Cfr. GOMEZ SÁNCHEZ, Y. “Familia y matrimonio en la Constitución española de 1978”, Organismos oficiales de la Administración, Madrid, año 1990, página189. 
matrimonial, esto es, el reconocimiento solemne del principio de igualdad entre los cónyuges. En nada obstaculiza a esta idea, el hecho de que pueda entonces considerarse esa manifestación como reiterativa e, incluso, innecesaria a la luz del enunciado del art. 14, puesto que éste es un fenómeno de reiteración apreciable en otro sectores de la ordenación constitucional, como consecuencia de la voluntad de remarcar deliberadamente determinados rasgos del sistema democrático y ausentes del régimen precedente, si que de todo ello se deban extraer mayores repercusiones hermenéuticas.

Resulta esclarecedor, a estos efectos, el ejemplo de la solemne proclamación del pluralismo político en el artículo 1 de la Constitución, aparentemente innecesario a partir del pleno reconocimiento de las libertades públicas en general, y del derecho de asociación en particular, de los que el pluralismo es una consecuencia natural, y cuya justificación reside precisamente en la necesidad de subrayar la relevancia del sistema de partidos en el nuevo ordenamiento democrático, pese a que, incurriendo en un manifiesto exceso formalista sin fundamento sistemático, se haya podido sostener en alguna ocasión, a partir de aquella proclamación que la Constitución ampara sólo el pluralismo político y no religioso ${ }^{312}$. En este marco general de reflexión, por lo tanto, la consagración explícita del principio de igualdad, intramarital, adquiere su más plena significación, precisamente, como superación de una tradicional discriminación de la mujer frente a los derechos reconocidos al marido, lo que, por lo demás, suele ser destacado en sede doctrinal.

Consecuentemente, en nuestro criterio, el intento de hacer derivar del principio de igualdad específicamente consagrado en el art. 32.1 la no exigencia del requisito de la heterosexualidad en el matrimonio no resiste un análisis sistemático del precepto, en contra de lo que algún autor plantea como hipótesis ${ }^{313}$, no puede ser en ningún caso considerada como una interpretación equivocada de la misma. El carácter estructuralmente abstracto y abierto, propio de las normas que enuncian dere-

312 MARTÍN SÁNCHEZ, M. "Matrimonio homosexual y Constitución”, Ed. Tirant Lo Blanch, Monografías, núm. 589. Valencia, año 2008, página 42. "Ante todo, la igualdad está consagrada por nuestro Texto Constitucional como uno de los valores superiores de nuestro ordenamiento -artículo $1.1^{a} \mathrm{CE}$ - de este modo un sector importante de la doctrina española, al conectar el precepto de la igualdad con los valores superiores el art. 1.1 CE, introduce un concepto de igualdad conectado con la realidad social que amplía su eficacia jurídica. Esto supone dar un peso mayor al criterio interpretativo igualitario que a otros derivados de otro tipos de intereses inferiores a los especificamente primarios reconocidos en el art. 1. $1^{a} \mathrm{CE}$. Asi lo ha interpretado el Tribunal Constitucional. No obstante no hay que obviar un importante dato, cual es que el Legislador tiene cuasi plena potestad ponderadora a la hora de sopesar cuál de los valores en juego tiene mayor peso en sectores concretos del ordenamiento -en caso de entrar varios de ellos en conflicto-, ya que, en principio aunque la igualdad parecería ser el de mayor relevancia para no incurrir en trato discriminatorio , nuestra Carta Magna permite al legislador establecer diferencias de trato ante ciertos supuestos, sin que estos lleguen a considerarse discriminatorios ni rompan el principio de igualdad. El legislador tiene potestad para ponderar y establecer diferenciaciones, aunque respetando en todo caso ciertos límites constitucionales, ya que de no ser admisibles constitucionalmente, dichas diferenciaciones se convertirían en arbitrarias"

313 IBAN, C. L. “El matrimonio en la Constitución”, en Revista de Derecho Privado, octubre, Madrid, año 1980, página 139. 
chos constitucionales (repárese, en un contexto cercano, en la conocida idea de derecho fundamental como garantía de posibilidades ${ }^{314}$ ), ampara la validez de diversas posibles concreciones de las mismas, lo que no autoriza, sin embargo, a violentar el sentido de la norma más allá del que pretendió conferirle el constituyente ${ }^{315}$.

En caso de adoptar el criterio de que la heterosexualidad forma parte integrante del reducto esencial del matrimonio, la inadmisión del matrimonio homosexual no constituiría violación del principio de igualdad pero no cabría decir lo mismo de la negación a un ciudadano homosexual, precisamente en atención a su calidad de tal, de su derecho a contraer matrimonio con una persona de distinto sexo.

Paralelamente, la asunción de la heterosexualidad como parte del núcleo esencial de la institución impediría entender que la falta de reconocimiento del matrimonio homosexual conlleva un menoscabo del principio de libre desarrollo de la personalidad, puesto que lo que en tal caso reclamaría la vigencia de ese principio no es sino la prohibición de establecer restricciones arbitrarias o injustificadas a la libertad matrimonial ${ }^{316}$.

El proceso de vaciamiento institucional del matrimonio civil en el Derecho español, la pérdida de buena parte de los caracteres que tradicionalmente poseía como consecuencia del influjo de las construcciones canónicas en la paulatina conformación histórica del modelo, es hoy, y lo viene siendo desde hace algún tiempo, un hecho incontrovertible, que justifica plenamente el que se haya podido hablar, como se ha visto, de una grave crisis de identidad del concepto civil de matrimonio.

La doctrina científica más perspicaz ha estudiado el proceso en sus diversas manifestaciones e implicaciones y, como consecuencia de ello, ha podido identificar las líneas de fuerza que revelan, en efecto, de un modo bastante evidente, la existencia de esa profunda crisis, que lo es además, no tanto del matrimonio como instrumento de ordenación de un ámbito concreto de la convivencia so-

314 DE OTTO Y PARDO, I. "Derecho Constitucional. Sistemas de fuentes”. Ed. Ariel, Barcelona, año 1995, página 41.

315 MARTÍN SÁNCHEZ, M. "Matrimonio homosexual y Constitución”, ...op. cit., página 124. "El punto de partida, por lo tanto, sería la proclamación constitucional de un concepto de matrimonio heterosexual, por lo que resulta de crucial importancia la determinación de la naturaleza del elemento heterosexual. Esto es, determinar si elemento heterosexual del matrimonio proclamado en el articulo 32.1 de nuestro Texto Constitucional, ha de considerarse elemento subyacente de la noción constitucional de matrimonio, prescindible para el legislador, llegado el caso, por exigencias constitucionales de mayor índole capaces de superar un juicio de proporcionalidad; o si por el contrario ha de considerarse elemento definidor, perteneciente a la esencia misma del matrimonio, por lo que su eliminación, desnaturalizaría la idea del matrimonio."

316 DE VERDA Y BEAMONTE, J. R. "Principio de libre desarrollo de la personalidad y ius connubii (A propósito del Auto del Tribunal Constitucional 222/1994)", en Revista de Derecho Privado, octubre, Madrid, año 1998, páginas 725 y 726 . 
cial, sino de una determinada concepción jurídica del mismo conforme a unos patrones que se estiman obsoletos.

En este sentido, y pese a la paulatina e inexorable merma de sus contenidos institucionales, el matrimonio desempeña todavía una importante función instrumental que se manifiesta muy singularmente en su dimensión operativa, conformando su régimen jurídico un sistema de garantías y presunciones en el marco del Derecho de familia, cuya aptitud para servir a la protección de los intereses familiares o para subvenir a las exigencias del principio de seguridad jurídica conserva hoy su pleno significado, el mismo con el que históricamente se gestó y fue desarrollándose el proceso de juridificación del matrimonio.

El matrimonio, pues, como cauce de ordenación de las relaciones personales que se generan en el entorno familiar, así como de los efectos ad extra que de tales relaciones se derivan, aparentemente goza aún de buena salud, y su validez, como tal instrumento de ordenación, vendría básicamente respaldada por el dato de que es precisamente el acceso al régimen matrimonial y su extensión a las llamadas uniones de hecho, también a las de carácter homosexual, lo que se ha venido reivindicando en los últimos años. Por lo que ahora más directamente nos interesa, uno de los fenómenos más sobresalientes, en el contexto del referido decaimiento del contenido tradicional del matrimonio, reside en la supresión de dicho contenido de la dimensión procreativa, expresada históricamente, siguiendo la concepción canónica de la ordenación del matrimonio, en la preservación de la generación, crianza y educación de los hijos como una de las finalidades institucionales del matrimonio.

En el nivel constitucional, aunque ello pudiera tal vez discutirse sobre la base de lo que pueda implicar la exigencia de diferenciación de sexo biológico en la jurisprudencia del tribunal de Estrasburgo, no es ni mucho menos claro que los datos normativos avalen la opinión de que la faceta procreativa es inherente a la actual configuración del matrimonio en el art. 32 317 , en opinión de MARTÍNEZ LÓPEZ-MUÑIZ. Justo es reconocer que los síntomas de la extinción de esta vertiente procreativa admiten poca discusión, siendo la eliminación del impedimento que su carencia provocaba su manifestación más palmaria. Paralelamente, en el ámbito registral civil, la Dirección General de los Registros y del Notariado, al reconocer finalmente el derecho a contraer matrimonio a las personas transexuales que hayan obtenido el cambio de sexo registral, consolidó la visión de apartar como una de las finalidades más importantes del matrimonio la procreación ${ }^{318}$.

317 En este sentido, por ejemplo, MARTINEZ LOPEZ-MUÑIZ, J. L., "La familia en la Constitución española”, Revista Española de Derecho Constitucional, núm. 58, año 2000, páginas 30 a 31.

318 Sobre este punto puede analizarse la opinión de LOPEZ-GALIACHO PERONA, J. “Reflexiones en torno a las resoluciones de la Dirección General de los Registros y del Notariado de 8 y 31 de enero de 2001 sobre el dere- 
En este aspecto, opina ALKORTA IDIAREZ, esgrimen algunos, radicaba primordialmente, además, el fundamento de la intervención social, de carácter tutelar y promotor, sobre el matrimonio, como garantía del relevo generacional, ya que de otro modo, sin esa dimensión generativa, el matrimonio no dejaría ser un pacto entre particulares sin una especial trascendencia al ámbito de la comunidad política $^{319}$. Se agrega que en poco o nada se diferenciaría el pacto conyugal de cualquier otra relación interpersonal de base contractual o asociativa protegida por el ordenamiento en tanto que manifestación de la libertad y autonomía individuales, pero no por ello merecedora de un tratamiento privilegiado o más beneficioso.

Respecto de esto quisiera manifestar mi opinión contraria a lo recientemente manifestado, si bien estoy de acuerdo en que justamente la voluntad e interés de generar una prole están entre los anhelos que la mayoría de la personas que van a contraer matrimonio expresan, existe algo más, hay una elección del otro, generar un vínculo íntimo y personal que no existe en otros tipos de contrato, una elección de compartir un destino juntos, que sin duda el Derecho implícitamente ha resguardado, sin perjuicio de que los lazos patrimoniales que se gestan al interior del matrimonio son tantos y tan importantes que el sistema jurídico regula la seguridad que ellos denotan de una manera notoria. cho al matrimonio transexual", en Revista del Poder Judicial, núm. 63, año 2001.

319 "Nuevos límites del derecho a procrear" en Revista de Derecho Privado y Constitución, núm. 20, enero-diciembre, Madrid, año 2006, páginas 9 a 12. "El ordenamiento jurídico internacional, v. gr. La Convención Europea de Derechos Humanos de 1950 o el Pacto Internacional de Derechos Civiles y Políticos de 1966, reconoce de forma solemne el derecho de todo ser humano a fundar una familia, $y$, por tanto, de forma implícita, el derecho a tener descendencia propia 8así como también de adoptar). La tutela de la libertad procreativa, en su dimensión biológica, se entendía reconocida en los artículos relativos a la protección de la intimidad personal y familiar de los propios Convenios. Teniendo en cuenta la distinción habitual en materia de derechos humanos entre derechos positivos y negativos, la libertad de procrear se configuraba como un derecho de carácter defensivo -derecho negativo- más que como un derecho positivo frente al Estado. El hombre o la mujer deben ser protegidos frente a las injerencias de las autoridades públicas que interfieran sin su consentimiento en el proceso de reproducción.- Según dicta una doctrina consolidada, para ser legítima, cualquier interferencia en la esfera privada de la persona, en realidad, cualquier restricción de los derechos fundamentales, debe reunir una serie de condiciones especificas: debe estar dirigida a la consecución de un fin legítimos (como por ejemplo la protección de otro derecho fundamental), debe constituir una medida necesaria social justificada), las medidas restrictivas deben ser proporcionales a los fines perseguidos, y la injerencia de que se trate debe estar prevista en una norma con rango de ley..- En suma, hasta hace poco el derecho a procrear se entendía comprendido en la protección de la familia como lugar privilegiado en cuyo seno el individuo afirmaba y desarrollaba su personalidad. Se configuraba además como un derecho negativo: el Estado no debía inmiscuirse en la libertad de procrear de las personas. Más recientemente, la necesidad de tutelar a la persona por sí y en sí, prescindiendo de su inserción familiar o social ha llevado a la necesidad de reconocer explícitamente el derecho a la reproducción. Hoy más que en el pasado, la centralidad de la tutela del individuo y de sus derechos empieza a configurar nuevos derechos en las codificaciones nacionales e internacionales. En concreto, el derecho a procrear emerge con fuerza como vertiente fundamental del derecho a la toma de decisiones sobre la propia existencia vital. El reconocimiento de un derecho subjetivo de procrear parece últimamente confirmado por las recientes decisiones de comités de ética, organismos internacionales y legislaciones sectoriales de numerosos países europeos en torno a las implicaciones morales y jurídicas de los descubrimientos cientificos sobre la vida humana, cuestiones que modernamente se conocen como decisiones relativas a la propia vida, de las cuales no puede excluirse la vertiente reproductiva... estas codificaciones recientes de derechos bioéticos tienden a considerar la procreación como un asunto individual y de pareja, en el cual no es lícito inmiscuirse si no es en el plano de consecuencias, relacionadas, sobre todo, con la seguridad de los tratamientos médicos o con la protección del nacido." 
Sin duda que nos adentramos a lo "metajurídico", y fundamental. La posibilidad de constituir un matrimonio y una comunidad familiar no es una posibilidad extraña al ser personal, sino que surge de su misma entraña ontológica.

Realizar la propia vida con otro y con otros no es una posibilidad añadida y opcional para la persona, sino que está inscrita en su misma realidad. Aquí arranca el análisis de cómo la conyugalidad arraiga en el mismo ser personal, en su posibilidad de apertura real a otro, en su orientación al otro y en su capacidad de encuentro con el otro. A su vez esta apertura intencional que permite el encuentro es lo que posibilitará la fundamentación de la misma persona haciéndose tal ${ }^{320}$, así lo expresa DOMÍNGUEZ PRIETO, pero sin duda tal ámbito es más profundo que lo netamente afectivo.

Sin perjuicio, volviendo al análisis de los autores que ven en la procreación la principal finalidad del matrimonio que debe ser resguardada por el Derecho, adquiere su verdadera dimensión la pregunta que se han formulado en el sentido de cuál es el fundamento por el que se debe seguir manteniendo, por parte de la comunidad política y a través de su Derecho, un tratamiento singular, privilegiado, del matrimonio, habiendo perdido este la connotación que le confería una trascendencia social, más allá del ámbito de los intereses particulares.

Es posiblemente una cuestión de fondo, verdaderamente esencial, y a la que, además, habría necesariamente que dar una respuesta con carácter previo a cualquier otro debate relativo, ya sea a la equiparación de las uniones de hecho al matrimonio, o bien al reconocimiento del derecho a contraerlo por parte de personas del mismo sexo, aunque no se efectúo, como bien se sabe, en tal sentido en España. Una respuesta a este interrogante en el sentido de propugnar la pérdida del fundamento en cuya virtud se justifica la intervención social, obviamente, haría sencillamente innecesaria la discusión acerca de esas otras cuestiones. En toda su simplicidad que es sólo aparente, la pregunta de “¿Cuál es la razón por la que la sociedad está obligada a proteger específicamente los sentimientos de los ciudadanos y las relaciones que pueden derivarse de los mismos?", incide con fino sentido jurídico, en el auténtico corazón del problema, y su respuesta, que atañe antes que nada al matrimonio mismo en tanto que desprovisto de los elementos que le otorgan relevancia política, en buena lógica, es previa a cualquier planteamiento de homologación o extensión del régimen matrimonial a otras realidades sociales ${ }^{321}$.

320 "Antropología de la familia. Persona, matrimonio y familia". Ed. Biblioteca de autores cristianos, serie Filosofía y ciencia, Madrid, año 2007, página 55.

321 NOVALES ALQUÉZAR, Ma "Las obligaciones personales del matrimonio en el Derecho Comparado", Tomo II, Colegio de Registradores de la Propiedad y Mercantiles de España, Madrid, año 2008, página 1750 . Esta autora sostiene que para dejar justificada la importancia del amor en el planteamiento de esete estudio (las obligaciones personales del matrimonio), "...nada mejor que las palabras de Von Hildebrand en su tratado de impronta fenomenológica sobre la esencia del amor, acerca de la existencia de prejuicios de índole filosófica general, y 
A mi juicio, la razón de ser es que no existe otro contrato, pacto o institución llámese como se llame donde el ser humano deposite tal esperanza, donde su persona, su personalidad y su integridad sea tan expuesta, es decir, se trata al fin y al cabo del anhelo de felicidad y trascendencia que cuan semilla está sembrado en el corazón del Hombre. Puede que esta reflexión no sea de ribetes jurídicos, pero al fin y al cabo lo más importante de la existencia humana sin duda está más allá del Derecho.

Pese a todo, este diagnóstico del que sin duda constituye el principal problema de fondo que subyace, en sede jurídica, a la más reciente evolución del Derecho matrimonial, no ha calado aun como debiera en el debate científico, con excepciones como la sindicadas, ni mucho menos en el debate social, la falta de una reflexión más extensa acerca de las consecuencias de este abordaje teórico del problema, y la consiguiente ausencia de un criterio firme y unánimemente aceptado en el que asentar el fundamento de la intervención social en el matrimonio, ha generado además, como era previsible, algunas paradojas y ciertos equívocos, sobre los que merece la pena detenerse ahora, siquiera sea por lo que tienen de revelador junto con su carácter meramente anecdótico.

El cambio de perspectiva en la imagen que la sociedad tiene de la institución del matrimonio de su rostro histórico, es perfectamente posible y, de hecho, como evidencia la ya mencionada pérdida de contenidos tradicionales del matrimonio civil, se detectan signos de ese cambio que constituye un alejamiento de ciertos parámetros de moralidad inherentes a la tradicional concepción de la institución, de inspiración religiosa, y es el fruto del proceso de secularización que viene experimentando la sociedad de forma palpable en los últimos años, esto último será tratado en el último capítulo, por cuanto tiene directa relación con el principio del libre desarrollo de la personalidad.

Esta posibilidad, referida ahora a la supresión del presupuesto de la heterosexualidad, sugiere a su vez la apertura de dos problemas fundamentales. De un lado, de llegar a consolidarse ese cambio de perspectiva en la sociedad española, nada obsta a que se pueda plantear la necesidad de refor-

en concreto acerca de la desconfianza infundada hacia el acto personal del amor, que dificultan el entendimiento de la esencia del amor: a) perjuicio del deslizamiento desde lo metafísico a lo psicológico, que también debería ser aplicable al analisis del conocimiento o de la voluntad; b) idea errónea de que el ser impersonal es de algún modo más objetivo que el personal y, en el caso del amor, que análogo a la tendencia al autodespliegue y al pleno perfeccionamiento, frente al acto personal de amor a otro que se nos da inequívoca e inmediatamente; c) prejuicio de desvalorización y simbolización de lo dado, es decir, desconfianza funesta hacia lo dado inmediato y creencia de que lo mas propio y valioso hay que buscarlo "detrás", prejuicio que conduce a sustituir el analisis de la esencia por la "explicacion"; d) prejuicio de que el amor es un síntoma de unidad, una manifestación subjetiva de la unidad (v. gr.: afirmación de que la parte ama al todo), especial error "cuyo origen está en no haber tomado completamente en serio los actos personales y espirituales (y también la vivencia de estos) para hallar su sentido y valor en sí mismos; e) el peligro de conformarnos, frente a la evidencia de lo dado: el misterio del amor, con una plausibilidad razonable que hace al objeto aparentemente inteligible; f) prejuicio, muy extendido en la filosofía de todos los tiempos, de que para entender lo superior es preciso subir de lo ontológicamente inferior." 
mar la Constitución para adaptarla en este punto a la nueva imagen institucional del matrimonio (dicho sea sin prejuzgar por el momento si en ese caso tendría o no sentido seguir denominándolo así), pero de lo que no hay duda es de la necesidad de la reforma No bastaría con recurrir a la idea de que la interpretación constitucional del núcleo objetivo garantizado acorde con la evolución de la sociedad, atenta al devenir de la concepción social dominante de la institución y de la ordenación legislativa de la misma en cada momento, en tanto que expresión esta última de esa misma elaboración dogmática.

Sin duda este punto ya ha sido asumido por la jurisprudencia constitucional, dando cuenta que la ruptura abrupta que ese cambio propone respecto del núcleo esencial del matrimonio que el constituyente pretendió sin duda garantizar, no deja otro camino posible que el de la reforma del art. 32 de la Constitución. La dinámica que el principio de historicidad impone a la determinación evolutiva del contenido de la garantía institucional como técnica de protección constitucional tiene sus límites infranqueables, y, como ha quedado sentado, el mantenimiento en el ordenamiento jurídico de los caracteres mínimos estructuralmente definitorios del instituto en la Constitución constituye uno de ellos.

Reitero ha llegado la ocasión de plantear la necesidad de reformar la Constitución para dar cabida en ella a una nueva imagen institucional del matrimonio, otro asunto es que el mecanismo de reforma constitucional, sea extremadamente costoso y aparatoso, como a mi juicio lo es. Se debiesen satisfacer las exigencias del art. $167 \mathrm{CE}$, con ello se hace necesario rescatar el alcance de la propia Constitución en su papel de control del poder legislativo al ceder la iniciativa al Legislador y realizar a renglón seguido desde el Tribunal Constitucional interpretaciones del texto constitucional conformes con tal punto de partida. Esto permite afirmar que se está invirtiendo el mecanismo de control de constitucionalidad, sustituido por otro de control legislativo de la Constitución, al ignorarse el art. 167. Sin duda que la sociedad española no puede conceder a determinado legislador un salvoconducto que lo libere de su responsabilidad de suscitar una reforma de la Constitución por la vía del artículo $167 \mathrm{CE}$, cuando sus proyectos legislativos así lo exijan.

Habrá de adquirir por tanto un especial relieve el tema de la finalidad protectora de la norma, aspecto este que, desde la Teoría general de los derechos fundamentales, constituye un componente esencial en la delimitación del alcance efectivo de la garantía institucional reconocida de un modo abstracto en la Constitución.

Así, estando implícita en la noción de la garantía institucional la idea de la asignación a determinadas instituciones de una función social relevante y esencial en el marco del sistema de convi- 
vencia diseñado por la Constitución, será preciso determinar si el nuevo modelo de matrimonio desempeña de algún modo dicha función, o si, por el contrario, ha quedado definitivamente certificada su paulatina pérdida de trascendencia comunitaria y su consiguiente reconducción al ámbito de los intereses meramente privados, quedando allí al amparo del sistema de libertades que garantiza la vigencia del principio de autonomía de la voluntad, pero no sujeto a un régimen privilegiado respecto de otros tipos de relación entre particulares. De llegarse a esta última conclusión, como es natural, carecería de un especial fundamento la mención constitucional del matrimonio, reducido a la condición de ser uno más de los negocios jurídicos entre particulares, y cuya regulación podría entonces dejarse a la ley ordinaria, si bien se nos antoja igualmente innecesaria la declaración en ese caso de un “derecho genérico a la determinación libre de las relaciones personales y sociales”, también denominado "derecho genérico a la afectividad como expresión de unas relaciones personales li-

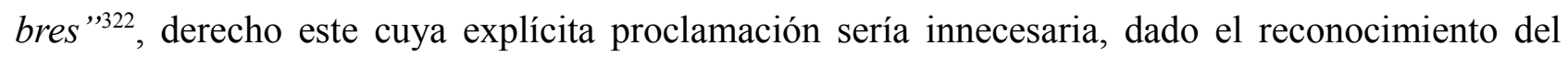
principio de libre desarrollo de la personalidad y, en general, el régimen común de los derechos fundamentales garantizado en la Constitución.

\subsection{El principio de igualdad como criterio rector en materia de efectos personales del matrimonio. El deber de socorro mutuo}

La regulación del matrimonio es y ha sido siempre reflejo de la situación social, moral y económica de una determinada época histórica, tal cual se ha intentado reflejar antes, de manera que los cambios en tal situación se han traducido normalmente de forma más o menos inmediata, en modificaciones de la configuración matrimonial. Esta realidad es la que justifica que la regulación de los efectos personales del matrimonio haya sufrido de forma paulatina una profunda transformación en el último siglo, que ha llevado esa materia hasta su configuración actual ${ }^{323}$.

322 Vid. TORRES DEL MORAL, A. "Principios de Derecho Constitucional español”, Volumen 1, Universidad Complutense de Madrid, Facultad de Derecho, Madrid, año 1992, páginas 398 y 399.

323 Interesante es la exposición que sobre esta materia da a conocer LÓPEZ DE LA CRUZ, L. "La incidencia del principio de igualdad en la distribución de las responsabilidades domésticas y familiares. (La nueva redacción del artículo 68 del Código Civil tras la reforma operada por la Ley 15/2005, de 8 de julio)", en Revista de Derecho Privado, Ed. Reus S.A., marzo-abril 2007, Madrid, año 2007, página 11. Sostiene que: "Si nos centramos en las relaciones paterno-filiales, un gran paso de la democracia ha sido sin duda el de atribuir la patria potestad a ambos progenitores, reconociéndoles idénticas facultades e iguales deberes para con sus hijos menores de edad. Desde el punto de vista legal parece que, tras la nueva redacción dada a los artículos 154 y siguientes por la Ley 11/1981, de 1 de mayo, se impone la equiparación en lo que a la relación con sus hijos se refiere: los hijos menores están bajo la potestad del padre y de la madre y ambos han de ponerse de acuerdo respecto a todas las decisiones sobre su educación y crianza... La participación del padre en e cuidado de los hijos es muy inferior a la de la madre con la consiguiente merma para ella de oportunidades laborales, además de las limitaciones que pueda suponer para la evolución de su vida personal. Por tanto no se trata sólo de equiparar a los progenitores en un plano jurídico, sino también de redistribuir las cargas familiares a fin de proporcionar a ambos cónyuges las mismas posibilidades de desarrollo personal y profesional." 
De hecho, el punto de partida en la regulación de los efectos personales del matrimonio distaba mucho del estado en que se encuentra en estos momentos. Tradicionalmente, el Derecho de Familia y el matrimonio recogido en la redacción originaria del Código Civil de 1889, en la misma línea en que se regulaban en otros países del entorno español, se estructuró en torno al modelo de la familia patriarcal, vestigio más o menos modificado del modelo de familia romana, en el que el padre-marido ocupaba una posición jerárquicamente superior al resto de los miembros de la misma y reunía en sí los poderes de dirección y organización del grupo familiar.

Correspondientemente, la madre-esposa quedaba sometida a su consorte, en una serie de cuestiones que impedían su libre actuación en el tráfico y que aproximaban su situación personal a la de los incapacitados. Concretamente, esta posición subordinada de la mujer casada se manifestaba, fundamentalmente, en tres aspectos de los que derivaban, a su vez, otras limitaciones a su actuación: por un lado el deber de obediencia al esposo, que ostentaba la autoridad marital, con su correlativo poder de protección (art. $57 \mathrm{CC}$ ); por otro, la limitación de su capacidad de obrar reflejada a través de la licencia marital (art. 60 a 62 del CC) y finalmente, la titularidad del marido de la patria potestad sobre los hijos (art. $154 \mathrm{CC}$ ). De estos tres grandes ámbitos de sometimiento de la mujer al marido derivaban el resto de las manifestaciones de este principio que se imponían a la mujer casada.

Así, como consecuencia del deber de obediencia, la mujer estaba también obligada a seguir al marido, tanto en cuanto a su residencia, como en sus hipotéticos sucesivos cambios de nacionalidad, con lo que la desigualdad proclamada entre cónyuges llegaba a afectar incluso a la ley personal aplicable a la mujer casada. Por otro lado como consecuencia de la falta de capacidad de obrar de la mujer, ésta quedaba sometida al régimen de la licencia marital de su marido, por lo cual su actuación en el tráfico jurídico quedaba condicionada a la aprobación o sanción de sus actos por parte de su consorte, si ése no actuaba junto con ella o en representación de la misma (poder de representación que se le atribuía automáticamente al marido por el hecho del matrimonio). Del mismo modo, siendo el marido el que gozaba de capacidad de obrar, a él se atribuía la administración de los bienes del matrimonio con el régimen de la sociedad de gananciales ${ }^{324}$.

Por tales motivos, los movimientos sufragistas primero y feministas después que reivindicaban una equiparación en los derechos civiles y políticos, fueron sentando las bases para un cambio primero ideológico y luego social y sin lugar a dudas jurídico.

324 MACÍA MORILLO, A. "Los efectos personales del matrimonio", DIEZ-PICAZO GIMÉNEZ, G (Coordinadora). "Derecho de familia", Capítulo VII, Ed. Civitas Thomson Reuters, Cizur Menor, año 2012, página 466 
SÁNCHEZ ROMÁN opinaba que "resulta evidente la insuficiencia individual, atendida la dualidad de los sexos y la natural forma de solución de ese motivo de diferencia sexual. Esa misma insuficiencia individual, que tiene su origen en una distinción de la naturaleza, hace necesaria y fundamental la idea del auxilio, que no significa otra cosa sino aumento, suplemento de condiciones que no se tienen, ó complemento de las deficientes, más aún que en la mera noción genérica de asistencia; y como la deficiencia individual de un sexo, tiene su natural complemento en el otro, la fórmula perfecta de vida total de la especie, exige que ese auxilio sea recíproco, mutuo, y respectivamente, complementario. Las variedades del auxilio humano, que toman las formas de la caridad moral, de la asistencia social ó de la prestación jurídica, son muy distintas del mutuo auxilio conyugal que nace del matrimonio, porque además de lo específico, á la vez que lo complejo de sus fines, éste se caracteriza por tener su fundamento en la naturaleza, ya física. Ya psíquica. Por ello se ha dicho que en los diversos órdenes afectivos de la asistencia humana, en unos hay amistad sin naturaleza, paternales y parentales y en el matrimonio hay amistad y naturaleza, en cuanto a las relaciones conyugales son hijas de un afecto y de una necesidad moral y fisica de mutuo auxilio, fundada en la natural y distinta condición de los sexos. El mutuo auxilio conyugal es de carácter integral a la vida de la especie humana en cada uno de los individuos de los dos sexos, mientras que las demás formas de auxilio son más accidentales, de índole parcial, y, sobre todo, de eficacia meramente externa y de condición variable y contingente [...] por algunos se asigna un nuevo fin al matrimonio, que el de moralizar las relaciones sexuales: el resultado es cierto, pero no nos parece un nuevo fin distinto del complementario de la insuficiencia individual por razón del sexo, que sintetiza el mutuo auxilio; fuera de que el admitir como fin especial lo que se llama en lenguaje figurado la moralización del amor, y en realidad se refiere a las relaciones naturales de los sexos, no deja de ofrecer cierto repugnante aspecto de impudor preconcebido y de referirse también á hipótesis, que no siempre subsisten, y menos de manera permanente, en el matrimonio". ${ }^{25}$

Así desde finales del siglo XIX y comienzos del XX en la mayoría de los países occidentales comienza a erosionarse esa imagen de la familia patriarcal y se dan los primeros pasos hacia un modelo familiar basado en la igualdad entre los esposos.

En Alemania, por ejemplo, la Constitución de Weimar pone bajo la protección especial de la Constitución a la familia, que entra a formar parte del universo jurídico de las figuras jurídicas que han de tener lugar en los Textos Fundamentales, hasta en la actualidad, se asume en tal sentido por

325 Vid. SÁNCHEZ ROMÁN, "Derecho Civil”, Reimp. de la edición. de Madrid, Sucesores de Rivadeneyra, Madrid, año 1912. página 388 y 389; Cfr. MARÍN GARCÍA DE LEONARDO, T. "Remedios indemnizatorios en el ámbito de las relaciones conyugales", DE VERDA Y BEAMONTE, J. R. (Coord). "Daños en el Derecho de Familia", Ed. Thomson Aranzadi, Cizur Menor, año 2006, página 151. 
el Constituyente un compromiso con tal realidad, buscando su permanencia en el ordenamiento jurídico, lo que se conoce como garantía institucional. VALPUESTA FERNÁNDEZ ${ }^{326}$, ha expresado, que dicha iniciativa se debía a que se la quería proteger de los embates marxistas o bolcheviques que la ven como un medio para destruir justamente los valores que quieren desterrar. Disolver a la familia se ve como un peligro serio.

España, no permanece ajena a esta corriente, sino que ya desde un primer momento, específicamente dese la Constitución republicana de 1931, se proclama en el art. 43.1 la igualdad de sexos al interior del matrimonio. No obstante este enunciado se queda prácticamente en una mera declaración, en vista del escaso desarrollo legislativo que recibió. De hecho, pese a la promulgación constitucional, la ley de Matrimonio civil de 28 de junio de 1932 no modifica el matrimonio en lo esencial, en materia de relaciones personales entre los cónyuges. Derrocada la II República y derogada su Constitución hay que esperar hasta 1958 a que se produzca el siguiente impulso, concretamente parece darlo la Ley 24 de abril de 1958, que establece las bases para lograr la plena capacidad de las mujeres solteras y deroga ciertas normas limitaban la capacidad de la mujer, pero se trata de una reforma que no afecta en lo esencial al rol que cumple la mujer casada.

Mayor trascendencia tiene, a finales del régimen franquista, la Ley 14/1975, de 2 de mayo, sobre reforma de determinados artículos en materia de situación jurídica de la mujer casada y deberes de los cónyuges. Constatando el hecho de que la mujer sufre serias limitaciones en su capacidad de obrar que han perdido su razón de ser, tal como se indica en la Exposición de Motivos de la Ley, se parte de la idea de que reconocer a la mujer un ámbito de libertad y de capacidad es consustancial con la dignidad misma de la persona, proclamada en las leyes fundamentales, y se pretende equiparar a los cónyuges en el seno de la relación de la relación matrimonial. A partir de ahí, a raíz de la norma, se modifica la redacción de los antiguos artículos 57 y 58 del Código Civil y se eliminan de manera expresa el deber de obediencia y la idea de la autoridad marital, las licencias maritales para la actuación de la mujer casada y la representación de la mujer casada y la representación legal de ella por el marido, al tiempo que se proclama de forma expresa, en el artículo 62 del Código Civil, una de las principales manifestaciones del principio de igualdad: la igual capacidad de obrar del marido y la mujer.

Con todo, la reforma es parcial, y de nuevo la eficacia de esta norma es más formal que real, pues no se eliminan por completo las diferencias entre ambos cónyuges, al mantener la subsistencia de las limitaciones de la mujer en materia de patria potestad sobre los hijos comunes y de adminis-

326 VALPUESTA FERNÁNDEZ, R. “La disciplina constitucional de la familia en la experiencia europea”,... op. cit., páginas 129 y siguientes. 
tración de la sociedad de gananciales. Por lo tanto permanecen algunas de las grandes diferencias entre los cónyuges.

El cambio definitivo se da con la entrada en vigor de la Constitución de 1978 y de su proclamación de la igualdad entre sexos en el artículo 14, confirmada y trasladada al seno del matrimonio en virtud del artículo 32.1 CE, reiteración ésta que no carece en absoluto de relevancia, con respecto de esto cabe citar la STC 241/1988, de 19 de diciembre ${ }^{327}$, en la cual se señala la idea de que el Legislador intenta llevar a este campo las exigencias de la libertad individual y de solidaridad; de ahí

327 STC, Sala segunda, núm. 241/1988, de 19 de diciembre, RTC 1988/241: "Ese alcance discriminatorio se deduce, en primer lugar, de los escritos o declaraciones de las partes pues, frente a la alegación de trato discriminatorio efectuada por la demandante, la Empresa -a la que, según las reglas de prueba en materia de derechos fundamentales, correspondería probar lo contrario- no ha aportado datos ni argumentos para destruir esa imputación. Es más, en el escrito de 5 de julio de 1982, el Consejo General, si bien reconoce que «actualmente no existe discriminación entre el personal masculino y femenino», añade que «únicamente si se constituye en alguna ocasión en cabeza de familia podrá, previa demostración fehaciente de tal situación solicitar nuevamente (la actora) el reingreso en la plantilla de personal de la Organización Médica Colegial», y posteriormente concreta el significado del término en cuestión en escrito de 6 de noviembre, por el que contesta a una nueva solicitud de reingreso afirmando que «si objetivamente no existe una imposibilidad (fisica o psíquica) o incapacidad legal en el sujeto o persona de su marido por la que no pueda atender a su familia, hay que mantener que él es el cabeza de familia», y añadiendo que "no se puede atender al criterio subjetivo, al menos de una forma determinante, del deseo de la señora R.M., altamente elogiable y por supuesto digno del mayor respeto, de querer mejorar la calidad y condiciones de vida de su familia con el complemento que pudieran suponer sus ingresos, pero es claro que este deseo no la convierta objetivamente en cabeza de familia». Concebida asi tal condición, resultaba únicamente aplicable a la mujer; de aqui que en modo alguno conste, ni se deduzca por la Empresa, que el varón pudiera acceder o hubiera accedido efectivamente a la situación de excedencia en tales condiciones, haciendo depender su reingreso igualmente de la adquisición de la cualidad de «cabeza de familia», ya que, sólo por el hecho de ser tal, se le consideraba titular de la misma. -Esta concepción responde, por otra parte, al contexto social y normativo en el que la demandante accedió a la excedencia. En efecto, el concepto de cabeza de familia vigente en aquella época no era otro que el consagrado más tarde por la Ley 25/1971, de 19 de junio... de Protección a las Familias Numerosas, en la que tal cualidad se atribuía expresamente al padre, y sólo en defecto del mismo podría ser transferida a la madre.- Esa atribución originaria de la condición de cabeza de familia al consorte de sexo masculino, que implícitamente estaba presente también en todas aquellas Reglamentaciones de Trabajo que disponían la excedencia forzosa de la mujer por razón de matrimonio -entre ellas, la que fue aplicada a la actual demandante de amparo-, se correspondía con el papel asignado a cada uno de los cónyuges por las normas anteriores a la Constitución, en las que el marido o padre seguía apareciendo, pese a las reformas de los últimos años, como administrador de la sociedad conyugal y de gananciales y como titular en primer término de la patria potestad sobre los hijos (arts. 59, 154 y 1412 del Código Civil en su redacción anterior) y en las que, lejos de ver en la actividad laboral de la mujer, libremente elegida, un medio de expresión y desarrollo de su propia condición humana, se reducía arbitrariamente el ámbito de dicha actividad y se proclamaba como un objetivo del Estado «liberar» a la mujer casada «del taller y de la fábrica» (ap. II. 1 del Fuero del Trabajo) .... Es cierto, por lo que aqui concretamente interesa, que a partir de la Ley 56/1961, de 22 de julio, el matrimonio dejó de ser causa de excedencia forzosa, pero las reglas sustitutivas de esa compulsión legal -que otorgaban la posibilidad de continuar la actividad laboral, extinguir el contrato o pasar voluntariamente a la situación de excedencia-, aunque en apariencia más favorables para la mujer, seguían en realidad estimulándola, a diferencia del varón, al abandono del trabajo y a su dedicación a las labores caseras, como claramente se advierte en el art. 2 del Decreto 258/1962, en el que esa triple posibilidad se ofrecía «en defensa del hogar familiar». En definitiva, pues, si a las alegaciones de la demandante se añaden los datos extraídos de las actuaciones previas y del contexto normativo y social en que tuvo lugar el acuerdo controvertido, no cabe duda de que éste puede ser calificado justamente de discriminatorio, en virtud de las profundas transformaciones experimentadas por la sociedad y plasmadas en nuestro ordenamiento jurídico actual. Es evidente que los presupuestos en que se sustentaba la anterior concepción resultan hoy en día inadmisibles, una vez que para poner fin a la tradicional postergación de la mujer borrando aquellas diferencias que históricamente la han colocado en situación de inferioridad en la vida jurídica y social -STC 128/1987, de 16 de julio... se ha consagrado en nuestra Constitu- 
que insista en la igualdad en el artículo 32. Poco después de este mandato constitucional, la igualdad entre cónyuges se establece material y formalmente en el Código Civil a través de la reforma introducida por las Leyes 11/1981, de 13 de mayo, por la que se modifican determinados artículos en materia de filiación, patria potestad y régimen económico del matrimonio, y 30/1981, de 7 de julio, por la que se modifica la regulación del matrimonio y se determina el procedimiento a seguir en las causas de nulidad, separación o divorcio. Especialmente con la segunda de ellas se produce la expresa consagración de la evolución de esta materia, mediante la proclamación en el artículo 66 de Código Civil de la igualdad de marido y mujer en derechos y deberes.

Actualmente, tras la reforma de la Ley 15/2005, la igualdad de los cónyuges, se incluye concretamente encabezando la lista de tales derechos y deberes conyugales, lo que es muestra de su carácter inspirador del sistema. Ahora bien, las reformas de 1981 no se quedan en una mera declaración de intenciones, sino que se completan con la derogación y modificación de la mayor parte de los preceptos que aún contenían restos de desigualdad de trato entre marido o mujer.

Por último, como colofón y remate final de este cambio, los últimos residuos de discriminación de la mujer casada se eliminan con las reformas posteriores de 13 de julio de 1982, en materia de nacionalidad, de 24 de octubre de 1983, en materia de tutela y de 15 de octubre de 1990, entre otras, en materia de vecindad civil. Con ello, desaparece definitivamente todo rastro de distinción entre cónyuges por razón del matrimonio y se completa el modelo familiar basado en la equivalencia entre ambos cónyuges. Por lo tanto, no es que la situación matrimonial no afecte a los casados y que su situación sea la misma antes y después del matrimonio sino que el matrimonio afecta a ambos cónyuges en iguales condiciones. Tal es la situación actual: la igualdad rige como principio inspirador e integrador del matrimonio de toda la regulación sobre los efectos personales entre los cónyuges. Las posibles cautelas, frente a tal afirmación que efectuaba parte de la doctrina tras las reformas de 1981 luego de veinte años de implantación del actual sistema ya no tienen asidero.

Mucha ha sido la evolución jurídica, política y social, como para poder afirmar hoy que, actualmente, no hay discriminación legal de la mujer casada en el seno del matrimonio, menos aún

ción el principio de igualdad y no discriminación por razón de sexo, con la consiguiente proclamación de la igualdad jurídica de marido y mujer en el matrimonio y en las responsabilidades familiares (arts. 14 y 32 C. E. y art. 66 del C.C.), consagración que ha quedado reforzada con la incorporación de nuestro país a la Comunidad Económica Europea, que mantiene entre sus principios básicos la igualdad entre ambos sexos -art. 119 del Tratado constitutivo de la CEE... y Directivas 75/117, 76/207 y 79/7-. La incompatibilidad con tales principios puede constatarse claramente en la norma reglamentaria que se aplicó en el presente caso y en las decisiones que se apoyaron en ella para denegar el reingreso en la Empresa a la actual demandante de amparo, puesto que una y otras parten de que únicamente tras la desaparición o incapacidad laboral o legal del marido podría la mujer casada constituirse en cabeza de familia, sin tener en cuenta que tras la entrada en vigor de la Constitución esa condición corresponde, en todo caso, a ambos cónyuges por igual." Cfr. STC, Sala segunda, núm. 70/1993, de 1 de marzo, RTC 1993/70. 
tras la reforma de la Ley 15/2005. Aún así, con todo el anunciado del artículo 66 del Código Civil sigue cumpliendo un importante papel de recordatorio al mismo tiempo de su preferencia actual frente al sistema ya superado ${ }^{328}$ y sobre todo de guía de interpretación de los artículos que regulan los poderes públicos y la autonomía de la voluntad de los particulares. De hecho, sigue siendo especialmente relevante su papel de criterio rector en la interpretación de las normas sobre matrimonio, porque impide el recurso a criterios de supra y subordinación entre los cónyuges en el establecimiento de su relación, en cualquiera de sus facetas, al tiempo que limita la actuación del legislador en la configuración misma de la relación matrimonial. En este segundo caso, la limitación se manifiesta, concretamente, en la inconstitucionalidad de las normas que vulneren la igualdad entre los cónyuges por ir en contra del principio general proclamado en los artículos 14 y $32.1 \mathrm{CE}$, en la medida en que no respondan a un fundamento racional y plausible, es decir existe la posibilidad de que se puedan admitir diferencias puntuales entre los cónyuges justificadas en la tutela de intereses dignos de protección o en la propia distinción física entre ambos, cuando son de distinto sexo. Pues bien, proclamado y consolidado así este principio, resta por ver qué significado concreto proyecta sobre el matrimonio y las relaciones personales entre los cónyuges.

En esta línea, partiendo de una primera aproximación general, la igualdad supone que la Ley no toma partido por uno u otro cónyuge, identifica roles o funciones que primen unos sobre otros ${ }^{329}$. Esto es particularmente significativo en relación con el papel que va a desempeñar cada uno de los esposos en la comunidad familiar, que no está legalmente predeterminado. El reparto de papeles y funciones en el marco de la comunidad de vida establecida se debe dejar por tanto a la autonomía de la voluntad en el seno de cada pareja, partiéndose de la base de que a la hora del reparto, ambos cónyuges están en pie de igualdad y ninguno queda subordinado a la voluntad del otro, tal cual lo menciona RAGEL SÁNCHEZ ${ }^{330}$. Esta idea de igualdad en el desarrollo de la relación matrimonial ha sido sostenida también desde hace tiempo por el Tribunal Constitucional (STC 159/1989, de 6 de octubre $^{331}$ ), que pone de relieve que la igualdad entre marido y mujer en el matrimonio debe predi-

328 Me decanto aquí por la interpretación que afirma la utilidad del precepto, por ejemplo, PUIG BRUTEAU, J. "Fundamentos de Derecho Civil”, IV, Ed. Bosch S.A., Barcelona, año 1985, página 38.

329 Es muy interesante el tratamiento que hace de los deberes personales entre los cónyuges Cfr. NOVALES ALQUEZAR, Mª . A., "Los deberes personales entres los cónyuges ayer y hoy", Ed. Comares, Granada, año 2007.

330 RAGEL SÁNCHEZ, L. F. "Los deberes conyugales", en Anuario de la Facultad de Derecho de Cáceres, números 14 y 15, año 1998, página 267.

331 STC, Sala primera, núm. 159/1989, RTC 1989/159: "En la actualidad, el referido principio de igualdad ha sido instaurado en nuestra legislación ordinaria por obra de sucesivas reformas del Código Civil -alguna de ellas preconstitucionales, como es el caso de la Ley de 2 de mayo de 1975... de entre las que cabe señalar las operadas por las Leyes 11 y 30 de 1981, fruto de las cuales es la proclamación de la igualdad jurídica entre marido y mujer (arts. 66 y 1328) y, en general, la desaparición de los vínculos patriarcales y autoritarios, así como la configuración de un nuevo grupo familiar de base asociativa.- No fue éste, sin embargo, el régimen normativo 
carse no sólo en el momento de la creación de la unión matrimonial, sino también en lo que se refiere a su desarrollo y extinción.

Por tanto, la proclamación de igualdad entre cónyuges constituye uno de los más importantes principios que informan la regulación del matrimonio, con una plasmación directa en todos los ámbitos relativos al mismo: personal, familiar y patrimonial de los cónyuges; en otras palabras, en todas estas esferas, la regulación se ve fuertemente influida por la igualdad que preside las relaciones entre los esposos.

Por lo que respecta a la esfera personal de los cónyuges la igualdad se manifiesta en todos los efectos personales derivados del matrimonio, justificando su configuración actual. Así, en primer lugar, la igualdad se establece como criterio que debe determinar la valoración de los derechos y deberes que nacen de la relación personal de los cónyuges. Concretamente la igualdad supone que estos derechos y deberes que se les atribuyen por razón de matrimonio son iguales en entidad y contenido, sea cual sea el sexo de un cónyuge y el de su consorte. Por lo tanto la igualdad otorga a cada uno de los esposos el derecho a no recibir un trato discriminatorio o diferente en la distribución de cargas por razón de su sexo y, correlativamente, le impone un deber de respetar la esfera personal

del derecho de familia existente tras la promulgación de la L.A.U. de 1964, que, antes al contrario, estaba caracterizado por la situación de preeminencia del marido y sumisión a él de la mujer. Múltiples eran las limitaciones a la capacidad de obrar de la mujer casada (que la relegaban a una mera "potestad de las llaves»), de entre las que, en nuestro caso, interesa destacar la atribución al marido de la facultad de administrar los bienes de la sociedad conyugal (antiguos arts. 59 y 1412) y, por tanto, la de detentar exclusivamente la capacidad para ser único titular formal de la relación arrendaticia. Dicha facultad de administración se extendía incluso con posterioridad a la separación judicial si ésta hubiera sido acordada a su instancia (antiguo art. 1435), y, si no lo hubiere sido, la conservaría la mujer (antiguo 1436.2. ${ }^{\circ}$ ), pero con una capacidad de obrar limitada (antiguo art. 1441.4. ${ }^{\circ}$ ) y sometida a intervención judicial cuando se tratase de enajenar o gravar los bienes inmuebles cuya titularidad dominical o administración se le hubiese transferido (antiguo art. 1444); régimen legal, en suma, que consagraba una situación de discriminación por razón de sexo, hoy proscrita por el art. 14 de la Constitución. En el anterior contexto normativo era, pues, prácticamente imposible que el legislador arrendaticio pudiera prever una excepción al régimen común del traspaso del local de negocio en base a una sucesión inter vivos de los derechos del arrendatario por causa de separación judicial de la esposa (ni muchos menos que ésta, por sí sola, pudiera sacar a pública subasta los derechos de traspaso o «transigir» sobre los bienes gananciales). Por esta razón, tan sólo pudo el legislador material contemplar la sucesión mortis causa del arrendatario del local de negocio (art. 60.1 y L.A.U.), y por la misma, el art. 31.1. ${ }^{\circ}$ L.A.U. exonera del traspaso la asociación que, exclusivamente entre sí, realicen los hijos del titular arrendatario del local de negocio que hubiere fallecido, aunque formen parte de ella el cónyuge sobreviviente. - Pero en el actual derecho de familia no sólo se ha pasado a un régimen general de cogestión de la Sociedad de gananciales (lo que obliga a replantearse si la titularidad de la relación arrendaticia corresponde exclusivamente al marido), sino que la mujer ha recuperado su plena capacidad de obrar no sólo sobre los bienes adjudicados por separación judicial, sino sobre los propios bienes adjudicados por separación judicial, sino sobre los propios bienes gananciales (e incluso los pendientes de liquidación), de entre los que hay que entender incluidos los derechos arrendaticios, con los que se hace obligado dilucidar si la interpretación restrictiva del art. 31.1. ${ }^{\circ}$ L.A.U. que efectúa la Audiencia conculca o no el principio de igualdad o, dicho en otras palabras, ¿goza de algún género de justificación objetiva y razonable la inaplicación del art. 31.1. ${ }^{\circ}$ L.A.U. a los supuestos de sucesión de la relación arrendaticia a los hijos y esposa como consecuencia de una separación legal?.” Cfr. SAP, Valladolid, núm. 12/1994, de 21 de enero, AC 1994/12. 
del otro cónyuge y la paridad de derechos y obligaciones entre ambos, sin realizar alteraciones arbitrarias o irrazonables.

Tal punto de partida no supone, sin embargo, que el resultado final conlleve necesariamente a una absoluta paridad o identidad en la concreción de los efectos personales en cada matrimonio, pues habrá circunstancias personales, sociales o económicas que puedan influir de manera notoria en la concreta medida de estos efectos en cada caso $^{332}$. Por poner un ejemplo: el deber de ayuda o socorro mutuo que proclaman los artículos 67 y 68 del Código Civil depende en su concreción de las necesidades y circunstancias de cada uno de los cónyuges, lo que puede llevar a que en un matrimonio concreto, uno sea siempre deudor y el otro acreedor; la igualdad lo que supone, por tanto, es que ambos son potenciales deudores o potenciales acreedores, de tales efectos personales en igual medida.

Del mismo modo, el principio de igualdad no impide que los cónyuges puedan acordar la concreción de los efectos personales del matrimonio, siempre que no esté absolutamente excluida cualquier modalización o disposición sobre los mismos (como es el caso de los efectos relativos a la emancipación o, con ciertos matices, a la nacionalidad y vecindad civil).

Estos papeles o roles familiares, en la medida en que no están predeterminados legalmente pueden ser asumidos en la relación conyugal por cualquiera de los cónyuges, conforme a las circunstancias que afecten al matrimonio, haciendo recaer sobre ellos en mayor o menor medida el ejercicio de los deberes conyugales ${ }^{333}$. Sobre esto último puede argumentarse que a futuro el rol de-

332 Me parece sin embargo un error pensar en aplicar una igualdad a raja tabla, por ello en el nuevo art. 57 ya no se establecen deberes respectivos para cónyuge, sino que se completan los deberes recíprocos establecidos en el artículo 56 Cfr. LACRUZ BERDEJO, J. L. “El nuevo Derecho Civil de la mujer casada”, Ed. Civitas, Madrid, año 1975, página 34, “...por ello sería más bien un complemento de dicha artículo, lo cual se debe, o mejor dicho puede ser, a la intención de no querer afectar la enumeración de los preceptos.. Este deber de protección recíproco puede confundirse con el de mutuo socorro.. Antes por ejemplo cuando la obligación recaía en el marido, en lo referente a la protección de la mujer, esto se debía en parte a que se presumía su mayor fortaleza física, pero en la actualidad eso se pasa por alto, no le importa al legislador dichas características que diferencian al uno y al otro., anteriormente se presumía una diversa participación y rol en la economía doméstica, no en la actualidad, , ahora bien, el igualar no implica equiparar que es justamente el objetivo de las políticas actuales, existe una diferencia de grado en cuanto al análisis de la situación concreta. La redacción del Código, en su artículo 57, puede interpretarse como una afán de entender que los cónyuges tienen la misma fuerza y las mismas expectativas de ganancias, pero la realidad no demuestra que ello no es así. Esto trae como consecuencia la necesidad de interpretar el precepto en el sentido de una superioridad concreta ya sea de uno u otro cónyuge en una situación dada lo que conlleva que este cónyuge deba proteger al otro."; Cfr. SANCHO REBULLIDA, F. y FUENMAYOR, AMADEO DE. "Comentario al Código Civil y Compilaciones Forales”, en ALBALADEJO, M.. (Dir.), Tomo II, arts. 42 a 107, Ed. Edersa, Jaén, año 1978, páginas 128 a 129.

333 Antes de la última reforma se entendía por la doctrina que tal deber mutuo, aunque impuestos a ambos esposos por igual no supone igualdad, necesariamente en sus concretas aplicaciones; asi, en particular, para la mujer supone la obligación de asistir y atender al marido, gobernar la casa y atender a los hijos menores, conforme a sus necesidades y a la situación económica concreta de la familia, no imponiéndole el deber de trabajar de modo habitual, Cfr. SANCHO REBUlliDA, F., en "Comentario al Código Civil y Compilaciones Forales”, ...op. cit., página 123 y siguientes. Después de la reforma podría estimarse que la interpretación ya no es válida, depende exclusivamente de la autonomía de la voluntad de los cónyuges, asimismo es necesario analizar la situación bajo 
sempeñado por uno de ellos, en especial aquel que desempeña tareas domésticas, podría ser objeto de determinación de pensión compensatoria ${ }^{334}$. Pues bien, en este punto, lo que impide el principio de igualdad proclamado en el artículo $66 \mathrm{CC}$, limitando en este sentido la autonomía de la voluntad de los esposos, es que se elimine de facto la igualdad entre los cónyuges, al establecerse un reparto que no resulte equitativo, que subordine constantemente a uno de los cónyuges o que favorezca a uno de los esposos en perjuicio del otro, sin que exista para ello un motivo razonable y plausible que lo justifique, en palabras de LÓPEZ DE LA CRUZ ${ }^{335}$. Conforme a lo indicado anteriormente

el prisma del régimen económico con que viven los esposos. Cfr. GARCÍA CANTERO, G. “Comentarios al Código Civil y Compilaciones forales” ALBALADEJO, M (Dir.). Tomo II, Artículos 42 a 107 del Código Civil, Ed. Edersa, 2a edición, Madrid, año 1982, páginas 190 y 191.

334 STS, Sala de lo civil, Sección $1^{\text {a }}$, núm. 534/2011, de 14 de julio, RJ 2011/5122 “Infracción del Art. 1438 CC. Se articula el presente motivo confrontando dos sentencias de la Audiencia Provincial de Toledo con dos de la Audiencia Provincial de Madrid. El núcleo central de la discusión lo constituye la respuesta a la pregunta sobre si es necesaria o no la existencia de un incremento patrimonial a favor del cónyuge deudor como consecuencia del trabajo realizado en el hogar por el cónyuge acreedor para obtener la compensación del Art. 1438 CC. O si bien es suficiente la dedicación pasada a la familia por parte del solicitante, que ha impedido la propia proyección personal y ha servido de base y ayuda, liberándose al otro cónyuge, que puede ejercer su carrera profesional. Se han producido dos líneas de resolución en las sentencias: una objetiva, de modo que el derecho a la compensación surge únicamente cuando el cónyuge se dedica a las tareas del hogar, con fundamento en la pérdida de expectativas laborales o profesionales. Frente a esta tendencia, otra línea interpretativa entiende que debe tenerse en cuenta el incremento o enriquecimiento en el patrimonio del esposo.". Cfr. SAP, Valladolid, Sección $1^{\mathrm{a}}$, núm. 191/2012, de 7 mayo. JUR 2012/210236 “... entiende esta Sala que al igual que acontece con el formulado por la otra parte litigante merece ser desestimado, debiendo ser confirmada la resolución recurrida en lo relativo a este concreto pronunciamiento, y ello porque pese al interesado análisis que se hace en el recurso de las cuentas que aporta al procedimiento el ahora apelante para concluir que se le ha impuesto, por causa de una errónea valoración de la prueba, una pensión compensatoria por desequilibrio que representa un excesivo $44,15 \%$ de sus ingresos netos, lo cierto es que de lo actuado y probado puede concluirse que, como ya lo entiende la Juez de Instancia, los ingresos que por todos los conceptos percibe el apelante son superiores a los que expresamente admite y reconoce, como lo pone de manifiesto además que de forma voluntaria venía entregando hasta la fecha a $D^{a}$ Carmen una suma superior incluso a la que se le ha fijado en concepto de pensión compensatoria. Debe por tanto mantenerse el montante indicado en la resolución recurrida, puesto que se entiende que es correcta y proporcionada a las posibilidades económicas del apelante la suma fijada al objeto de corregir el desequilibrio económico que causa la ruptura de la convivencia familiar y conyugal... Con respecto a la pretendida temporalización de la pensión compensatoria, que en la contestación a la demanda se cifraba en tan solo un año y que ahora en el recurso se amplía a un abanico de uno a tres años, lo cierto es que pese a consideraciones generales sobre la posibilidad de adopción de tal medida, lo cual no solo se consagra en la doctrina jurisprudencial indicada... no aporta el recurso argumento alguno que permita desvirtuar los acertados razonamientos de la Juez de Instancia para rechazar la fijación "ex ante" de un plazo predeterminado de vigencia de la medida en cuestión, pues nos encontramos en el caso examinado ante un matrimonio de muy larga duración -contraído el 23 de diciembre de 1.981-, con amplia, y no discutida dedicación prácticamente exclusiva de la sra. Carmen a la familia, carencia de recursos propios, escasas posibilidades de acceso a ocupación laboral alguna dada la edad -55 años-, inexperiencia por no desempeño hasta la fecha de ocupación laboral y situación del mercado de trabajo."

335 LÓPEZ DE LA CRUZ, L., en "Libertades personales y deberes entre cónyuges. La influencia de los comportamientos de las mujeres en la configuración actual de los deberes matrimoniales”, ...op. cit., páginas 571 y siguientes. La autora en cuestión estima que : "La nueva redacción del art. 68 del Código Civil impone por tanto el reparto entre los cónyuges de las responsabilidades domésticas y familiares, como manifestación de un genérico deber de ayuda entre ambos. La cuestión que ahora nos planteamos es la admisibilidad de un pacto entre cónyuges por el que se altere el reparto legal de las cargas familiares... La opinión de la doctrina fluctúa entre aquellos que insisten en que la imperatividad de los preceptos que regulan el contenido personal del matrimonio (art. 66 y ss. C. C.) deriva de su carácter de orden púbico y or consiguiente niegan la posibilidad de que los cón- 
respecto a la proyección del principio de igualdad sobre el matrimonio, hay que afirmar que este pacto será nulo, al igual que cualquier actuación de los cónyuges que vulnere la igualdad que se predica entre ellos, por ser contrario no sólo al artículo $66 \mathrm{CC}$, que se establece como norma imperativa, sino también el derecho fundamental de igualdad que proclama el artículo 14 de la Constitución.

En segundo lugar, dentro de la esfera personal de los esposos, la igualdad se demuestra en la posición de ambos cónyuges en el tráfico jurídico. De acuerdo con el principio programático ya enunciado por la Ley 14/1975, la igualdad supone que ambos cónyuges gozan de igual capacidad de obrar o, dicho de otra forma, que el matrimonio no altera o restringe tal capacidad a ninguno de los miembros de la pareja. Son paradigmáticas en tal sentido las palabras de la STS, Sala de lo Civil, de 20 de enero de 1989, RJ 1989/109, que proclama que "el matrimonio no limita la capacidad jurídica de los esposos, que ambos pueden obligarse individualmente y responder con su respectivos bienes".

Ahora bien, este principio no es contradictorio con el hecho de que en ocasiones sea necesario el concurso de ambos esposos para la adopción de determinados actos -especialmente, en materia de régimen económico matrimonial-, pues viene justificado por los intereses de la unión que puedan estar en juego.

Antes de la Ley 14/1975, el marido debía protección a su esposa y ésta obediencia a aquél. Esta ley dio nueva redacción al art. 57, señalando: "El marido y la mujer se deben respeto y protección recíprocos y actuarán siempre en interés de la familia”.

La redacción originaria del art. 57 del Código Civil implicaba, por definición, que el deber recíproco de los cónyuges de socorrerse mutuamente del antiguo art. 56 resultaba agravado para el marido en relación a la mujer porque a este correspondía "no sólo el deber de protección en sentido estricto, sino, además, el de amparo y asistencia de todo orden, proporcionándole todo aquello que sea necesario para la vida, tanto de orden material como de carácter moral”. De todas maneras la autoridad marital no debía ser despótica sino un poder de protección.

La Ley 30/1981 de 7 de julio dio al art. 67 nueva redacción: "El marido y la mujer deben respetarse y ayudarse mutuamente y actuar en interés de la familia”. En efecto, se comprueba que,

yuges negocien un distinto modelo de convivencia, y aquéllos que admiten un cierto margen de autonomía que les permita adoptar acuerdos que concreten la forma de su ejercicio”; Cfr. SALVADOR CODERCH,. "Comentario al art. 45 CC.", en VV. AA., “Comentarios a las reformas del Derecho de familia”, Volumen I, Enciclopedia Jurídica Básica, Ed. Civitas, Madrid, año 1995, página 135 y siguientes ; Vid. DE LA CÁMARA ÁLVAREZ, M. "La autonomía de la autonomía en el actual Derecho español sobre la familia”, Boletín de Información de la Academia Granadina del Notariado, núm. 9, Ilustre Colegio Notarial de Granada, Mayo, año 1986, páginas 9 y siguientes. 
tras la reforma de 1981 se alude al deber de ayuda mutua por duplicado pues socorrerse es lo mismo que ayudarse, de tal manera lo ha entendido ESPÍN CÁNOVAS ${ }^{336}$.

La Ley 14/1975 de 2 de mayo, sobre reforma de determinados artículos del Código Civil y del Código de Comercio sobre la situación jurídica de la mujer casada y los derechos y deberes de los cónyuges, pretendió incluir en el Derecho de Familia el principio de igualdad jurídica de estos. Esta ley dio la siguiente redacción al art. 57: "El marido y la mujer se deben respeto y protección recíprocos, y actuarán siempre en interés de la familia”. Esta reforma borró, de modo absoluto, al cambiar el texto del art. 57, el deber de obediencia, con lo cual la esposa podía ejercitar su libertad en la misma medida que el marido, de hecho en la Exposición de Motivos de la ley de 2 de mayo se decía que: "en el art. 57 resulta suprimida la fórmula discriminatoria en la protección como atributo del marido y la obediencia como obligación de la mujer, para decir en términos de absoluta reciprocidad que marido y mujer deben protegerse mutuamente, añadiendo que habrán de actuar siempre en interés de la familia, con lo que ésta, como institución más general que engloba el matrimonio y le dota de un sentido trascendente y transindividual, recibe el refrendo legislativo que se echaba en falta en la anterior ordenación. Previamente, con referencia a este artículo y al 58 (respecto de los que observa su dificil sanción jurídica, precisamente por sus acusados presupuestos éticos y sociales se afirma que ha sido preciso conformarlos de acuerdo con la general finalidad perseguida de equiparar en lo posible a los cónyuges".

El problema que surge, a mi juicio reside en que el legislador se inmiscuye en algo tan íntimo como es la organización interna del hogar familiar, aunque se sostenga el estandarte de la igualdad absoluta y se intenten equiparar todos los roles. Esto se deja entrever de la sola lectura del contenido del nuevo inciso agregado al art. 68 por la Ley 13/2005, de 1 de julio, que obliga a los cónyuges a compartir las responsabilidades domésticas y de atención y cuidado de terceros. No está demás afir-

336 “Manual de derecho Civil español”, volumen IV, Familia, Ed. Reus, S. A., séptima edición, Madrid, año 1982, página 217: "el auxilio económico, especialmente los alimentos, e incluso el auxilio espiritual, la ayuda debe encaminarse hacia otras situaciones, como podrían ser las de asesoramiento y consejo, aceptación del mandato y de la representación que voluntariamente le confiera el otro cónyuge, en interés especial del mandante o poder dante, e incluso la gestión sin mandatos de asuntos del otro cónyuge impedido o ausente”; Cfr. GETE-ALON$\mathrm{SO}, \mathrm{M}$ del C. "Comentarios a los artículos 67 a 71 del Código Civil”, en la obra colectiva "Comentarios a las reformas del Derecho de familia”, Volúmen I, Madrid, año 1984, páginas 320 y siguientes. Para este autor la ayuda de la que trata el art. 67 prescinde de todo lo que tradicionalmente se ha entendido como socorro mutuo. Mientras que este se circunscribe al marco de las necesidades económicas o materiales, la ayuda comprende el aspecto personal, fundamentalmente de índole intelectual y psíquico; MORENO MOZO, F. “ Cargas del matrimonio y alimentos”, Ed. Comares, Granada, año 2008, página 41. Sin embargo la mayoría de la doctrina, considera que son deberes idénticos, siendo redundantes, por tanto, en este aspecto los dos preceptos citados . Realmente no hay argumentos para distinguir a uno de otro, ni tampoco como consecuencia de esta reforma restringir el de socorro mutuo a lo estrictamente material. De conformidad con lo expuesto, según nuestra doctrina, el deber de socorro mutuo, o si se quiere de ayuda mutua, aunque a veces suele confundirse con la más estricta e im periosa necesidad de mantenimiento, es un deber más amplio. 
mar que en la práctica las mujeres trabajan más fuera de casa que los hombres dentro de ella, por lo que hay muchas labores no remuneradas que queda desatendidas.

En relación con esto al parecer los ordenamientos jurídicos occidentales muestran muchas dificultades en reconocer en concreto la autoridad de las mujeres. Parece ser que los postulados ilustrados dejaron algo en el camino que se desconoce. De ahí la importancia de que la Ciencia Jurídica incluya en sus reflexiones los resultados epistemológicos obtenidos de la crítica al período ilustra$\mathrm{do}^{337}$.

Es de justicia reconocer que hombres y mujeres necesitan tipos de protección diferentes. La protección que necesitan las mujeres, que es de tipo moral, más que físico, derivaría de la calidad espiritual de las mismas más que de una supuesta inferioridad o subordinación. De esto último se ha hecho eco el Derecho Canónico mucho más que el Derecho Civil. Precisamente, las peculiaridades de la naturaleza, espíritu y psicología son argumentos utilizados contra la disolubilidad del vínculo matrimonial, en relación con las profundas situaciones de injusticia que crea para las mujeres que, en un porcentaje elevado, realizan con el matrimonio una apuesta personal más fuerte que los hombres. La mayoría de las mujeres tienden a cifrar su realización personal en el amor o la familia. La mayoría de los hombres en el trabajo.

Sin perjuicio del carácter novedoso de este planteamiento en una época caracterizada por la defensa de feminismos de la igualdad con argumentos pretendidamente incontestables, se observa también el panorama ético-social, que no en las normas jurídicas, es necesario afianzar el respeto, si no reconocimiento, de abnegadas madres de familia y de las actividades aglutinadoras de ésta.

El fundamento del problema de todo esto radica en que la sociedad ha recibido de buena gana el salario que representa el trabajo extradoméstico de las mujeres, pero los hombres no se han incorporado a los trabajos domésticos del mismo grado. Por ello, conviene no olvidar que varones y mujeres tienen necesidades diferentes lo que implica que cada cónyuge ha de hacer el esfuerzo de comprender y ponerse en el lugar del otro.

Con la obligación de ayuda y socorro mutuos se garantiza la necesidad de que los cónyuges desplieguen una actividad en plan de igualdad que no debe de ser entendida en términos absolutos sino relativos, valorando las posibilidades de cada cual y las necesidades respectivas que en particular se dan en cada persona ${ }^{338}$.

337 NOVALES ALQUEZAR, M. . . "Derecho Antidiscriminatorio y Género: Las premisas invisibles”, Fondo de Desarrollo de las Naciones Unidas para la Mujer: Universidad Central de Chile, Gobierno de Chile, Santiago de Chile, año 2004.

338 A modo de ejemplo, Código de Derecho Foral de Aragón, Decreto Legislativo 1/2011, artículo 187: "Satisfacción de las necesidades familiares.1. Ambos cónyuges tienen el deber de contribuir a la satisfacción de las necesidades familiares con la atención directa al hogar y a los hijos, la dedicación de sus bienes al uso familiar, la 
Existe la necesidad de reconocer legalmente, de modo explícito, la contribución moral y afectiva de los cónyuges a las cargas del matrimonio y la exigencia de la justicia de dignificar los trabajos hasta ahora denominados "no remunerados" porque, si no se lleva a cabo tal reconocimiento, un elevado número de tareas, trabajos y actitudes, absolutamente necesarias para el buen funcionamiento de las familias, matrimonios y parejas de hecho permanecen en la sombra, casi siempre contra las mujeres, a la hora de evaluar las consecuencias jurídicas de las crisis matrimoniales ${ }^{339}$ : pensiones alimenticias, pensiones por desequilibrio económico, etc, y lo anterior, además de acarrear mucha infelicidad, trae consigo, la imposibilidad de construir sociedades democráticas sanas, justas, cohesionadas y desarrolladas social y económicamente ${ }^{340}$.

remuneración de su trabajo, los rendimientos de sus capitales y otros ingresos y, en último término, con su patrimonio. 2. En defecto de pacto, para determinar la contribución de cada cónyuge se tendrán en cuenta los medios económicos de cada uno, así como sus aptitudes para el trabajo y para la atención al hogar y los hijos. 3. Los hijos, cualquiera que sea su edad y mientras convivan con sus padres, deben contribuir equitativamente a la satisfacción de las necesidades familiares conforme a lo previsto en los artículos 66, 67 y 70."

339 LÓPEZ DE LA CRUZ, L. "El resarcimiento del daño moral ocasionado por el incumplimiento de los deberes conyugales", INDRET, Revista para el análisis del Derecho, Facultad de Derecho, Universidad Pablo de Olavide, núm. 4, Barcelona, año 2010. "Desde hace algunos años, es una cuestión debatida en la doctrina y en la jurisprudencia si los perjuicios ocasionados por el incumplimiento de los deberes que nacen del matrimonio (arts. 67 y 68 C.C.) pueden ser objeto de resarcimiento conforme a las reglas generales del Derecho de daños. En principio, la tendencia general ha sido la de rechazar, o cuanto menos limitar, lo que se ha llamado la injerencia del Derecho patrimonial en el Derecho de familial, y en particular, se ha cuestionado el margen de aplicación que se debe otorgar a los mecanismos resarcitorios característicos de la responsabilidad extracontractual en el ámbito propio del matrimonio.- Cierto es que la especial naturaleza de la relación matrimonial, sustentada en vínculos afectivos y de confianza, implica que no sean frecuentes los litigios de este tipo entre los cónyuges, salvo que se trate de conductas tipificadas como delito, o de daños de una cierta cuantía en los que, la más de las veces, entran en juego las compañias aseguradoras (accidentes caseros, siniestros automovilísticos, etc.). Además, es también un dato a tener en cuenta el interés de los cónyuges en mantener el vínculo matrimonial, pues no cabe duda de que la exigencia del resarcimiento del daño, además de la existencia del daño en sí mismo, va a suponer una importante quiebra de la estabilidad de la pareja2. Y la propia organización económica de la familia será determinante a la hora de decidir si incoar o no el correspondiente procedimiento judicial. Será mucho más factible que un cónyuge proceda contra el otro en los supuestos en que el régimen económico del matrimonio sea el de separación de bienes, que en el caso de gananciales, pues aunque el art. 1346, $6^{\circ}$ C.C. establece la naturaleza privativa de la indemnización por "daños inferidos a la persona de uno de los cónyuges o a sus bienes privativos", lo cierto es que el cónyuge condenado al resarcimiento debe hacer frente al mismo con sus propios bienes privativos, pero si carece de ellos, será a cuenta de los gananciales, cierto, limitado a la parte que le correspondería en el reparto, pero en la práctica ello se traduciría en que a un cónyuge se le indemniza "con su propio patrimonio".

340 Entre otros, DE BAUVOIR, I y PEREZ DEL RIO, T: "Los derechos de conciliación en la Ley 39/99: Interrupción o reducción de la actividad laboral para atender responsabilidades familiares”, Revista Aequalitas, $\mathrm{n}^{\circ} 4$, Zaragoza, mayo, año 2000; MARI-KLOSE, M, y NOS COLOM, A, “Itinerarios vitales: educación, trabajo y fecundidad de las mujeres” en “Opiniones y actitudes”, Centro de Investigaciones sociológicas, Madrid, año 1999; HAALAND MATLARY, J. "Ser mujer en términos de mujer: Desafios paras las mujeres de Occidente: Una perspectiva católica” en "La mujer en el umbral del siglo XXI”, Ed. Complutense, $1^{\text {a }}$ edición, Madrid, año 1998; MARIAS AGUILERA, J. "La mujer en el siglo XX”, Ed. Alianza, Madrid, año 1990; DURAN HERAS, Ma A. “La jornada interminable”, Ed. Icaria, Barcelona, año 1986, página 54; GARCIA SERRANO, F, “Notas sobre el trabajo doméstico (Apropósito de los artículos 1.319 y 1438 CC)”, Anuario de Derecho Civil, T XXXVIII, Madrid, año 1985; DE LOS MOZOS y DE LOS MOZOS, J. L. “La igualdad de los cónyuges y la organización y ejercicio de las potestades domésticas" en Documentación Jurídica (Volumen monográfico dedicado a la reforma española del Derecho de Familia de 1981), volumen 1 (núms. 33 a 36), Enero-Diciembre, año 1982, Madrid, página 103 y siguientes; DEL CAMPO URBANO, S, “Análisis sociológico de la familia española”, Ministerio 
Concluyendo este punto quisiera manifestar que Naciones Unidas ha intentado por todos los medios concienciar sobre la injusticia de la estructura interna patriarcal familiar, ante ello ha procurado variar la visión de los Estados sobre tal aspecto induciendo a reformas. Entre tales documentos destaca la Convención sobre la Eliminación de todas las Formas de Discriminación contra la mujer de 18 de diciembre de 1979, en las que se busca que se adopten medidas medidas encaminadas a eliminar la discriminación de la mujer en el matrimonio, por ejemplo mediante la garantía de la libre elección del cónyuge, la elección del trabajo, de los apellidos de la familia. A nivel Europeo las instituciones judiciales de la Unión, no han disfrutado de demasiadas oportunidades para pronunciarse sobre el derecho a un trato igualitario y al goce de unos mismos derechos por parte de los esposos, así lo estima SANZ CABALLERO ${ }^{341}$. En realidad, la escasez de jurisprudencia en la materia va aparejada con la ausencia de competencias cedidas a las Comunidades Europeas en cuanto a la reglamentación de las relaciones internas de los cónyuges. Estamos sin duda frente a un aspecto de derecho interno.

Aunque indirectamente abarcan el punto que se ha tratado en el presente destaco la Directiva 79/7/CEE de 19 de diciembre de 1978 relativa a la aplicación progresiva del principio de la igualdad de trato entre hombres y mujeres en materia de seguridad social, así como la Directiva 2006/54/CE, relativa a la aplicación del principio de igualdad de oportunidades e igualdad de trato entre hombres y mujeres en asuntos de empleo y ocupación, asimismo la STJCE, Sala $1^{\text {a }}$, Caso Jutta Johannes contra Hartmut Johannes. Sentencia de 10 junio 1999. TJCE 1999/124, en la cual se manifiesta: "El Gobierno alemán y la Comisión recuerdan que de una jurisprudencia constante se desprende que el artículo 6 del Tratado (LCEur 1986, 8) sólo es aplicable en las situaciones comprendidas dentro del ámbito de aplicación del Derecho comunitario. A su juicio, no sucede así en el presente caso, ya que las disposiciones relativas a la compensación de los derechos a pensión son disposiciones de Derecho civil que no son competencia del legislador comunitario, sino que siguen incumbiendo a los Estados miembros. La diferencia de situaciones a que alude el Sr. Johannes es el resultado de la aplicación de Derechos nacionales diferentes. La nacionalidad de las partes del litigio sólo se toma en cuenta como factor de conexión sobre el cual se basan las normas de Derecho internacional privado que permiten determinar el derecho material nacional aplicable a efectos del divorcio."

de Cultura, Madrid, año 1982; BERCOVITZ y RODRIGUEZ-CANO, R. "Derecho de la persona", Ed. Montecorvo, $1^{\mathrm{a}}$ edición, Madrid, año 1976.

341 "La familia en perspectiva internacional y europea", Ed. Tirant Lo Blanch, monografías, núm. 384, Valencia, año 2006, páginas 272 y 273. 


\subsection{El principio de igualdad entre los progenitores en la guarda y custodia compartida}

En la mayoría de los países cuyas legislaciones contemplan la guarda compartida ${ }^{342}$, el establecimiento de la misma ha estado sujeto a un importante debate social y jurídico en torno a la igualdad real o material entre los progenitores y, si bien en Europa la recepción legal de la custodia conjunta no ha sido acompañada siempre de una declaración fuerte que refuerce la igualdad de los roles parentales, claro está que ha sido una de las directrices informadoras ${ }^{343}$. En otros países, sin embargo, se ha consagrado positivamente el deber de considerar a ambos padres en pie de igualdad para la

342 SAP Barcelona, sección 12a , núm. 181/2012, de 9 de marzo, JUR 2007/120665, este fallo define en parte el concepto en cuestión: "En cuanto a la guarda y custodia compartida que solicita el recurrente respecto de las hijas comunes, debe tenerse en cuenta que, tal como ha dicho esta Sala en diversas sentencias, es una modalidad de ejercicio de la responsabilidad parental, tras la crisis de la pareja, en la que tanto el padre como la madre están capacitados para establecer una relación viable entre ellos, basada en el respeto y en la colaboración, con el objeto de facilitar a los hijos comunes la mas frecuente y equitativa comunicación con ambos progenitores, y de distribuir de forma justa y proporcional la atención de las necesidades materiales de los hijos, con la previsión de un sistema ágil para la resolución de los desacuerdos que puedan surgir en el futuro.- La Ley 15/2005 de 8 de julio, en su art. 92, 7 establece que no procederá la guarda conjunta cuando existan indicios fundados de violencia doméstica y en el caso de autos el recurrente, Sr. Jaime ha sido condenado por dos delitos de malos tratos en el ámbito familiar por sentencia de la Sección $8^{a}$ de fecha 26 de septiembre de 2005 , por lo que este motivo excluye por si solo, la posibilidad de acordar la guarda y custodia compartida que solicitaba.

343 La SAP, Madrid, Sección 24으, núm. 482/2007 de 11 de abril de 2007, JUR 2007/313755, falla anulando la de instancia que la atribuía a la madre, y la atribuye sólo al padre por entender que : "No deben tenerse en cuenta otros informes periciales existentes en autos que tienden a una guarda y custodia compartida que, en puridad jurídica, es un contrasentido con la medida nuclear solicitada y concedida de separación física de cuerpos y rompimiento del vínculo matrimonial; y no debe tenerse en cuenta la guarda y custodia para las partes por periodos alternativos que según constante doctrina jurisprudencial es altamente perjudicial para los hijos por el continuo cambio de domicilio, o de costumbre dentro del domicilio familiar si quienes cambian son los padres; y no debe, finalmente, tenerse en cuenta la edad de la hija para concedérsela a la madre o al padre, pues es tema ampliamente superado". Cfr. SAP Valencia, Sección 10, núm. 232/2006 de 5 de abril de 2006, JUR 2006/254405: "Por lo que se refiere a la custodia compartida solicitada por el padre debe decirse que es criterio de esta Sala, salvo supuestos puntuales, que pudieran presentarse, que pudiesen aconsejarla, la no concesión a los padres en situaciones de separación o divorcio, de la guarda y custodia compartida de los hijos, criterio antedicho coincidente con el de la generalidad de las otras Audiencias Provinciales, cabiendo citar a título de ejemplo, la Sentencia de la A.P. de Madrid de 31 de octubre de 1995 , que considera: "Se plantea por la parte recurrente una solución de guarda compartida, medida que dentro del Derecho de Familia español podría calificarse de excepcional; tanto es así que el propio legislador, sin prohibirla expresamente, no ha contemplado tal posibilidad, y así el artículo 92 del Código Civil, concretamente en su párrafo tercero, alude a la decisión que tomará el Juez acerca de cuál de los progenitores tendrá a su cuidado los hijos menores, sin que esto sea óbice para que el ejercicio de la patria potestad sea compartida en orden a tomar decisiones de cierta trascendencia que, afectando a los hijos puedan adoptarse de común acuerdo, sin que el progenitor que no convive con los hijos se vea privado del conocimiento de aquéllas, debiendo valorarse en igual medida sus opiniones que la de aquel que los tenga en su compañía.-Mas la guarda y custodia no tiene su contenido en la adopción de medidas de tanta trascendencia, sin que ello suponga restarle valor a tan importante función, sino que la misma se desenvuelve en un quehacer más cotidiano y doméstico, que sin lugar a dudas también contribuiría a la formación integral del hijo y que difícilmente podrían compartirse por quienes no viven juntos, lo que supondría de admitirse otra tesis, una invasión de la esfera privada de un progenitor en la del otro, o en otro caso un continuo peregrinaje de los hijos de un hogar al otro, siendo, entonces, más correctamente denominarla en este supuesto, custodia periódicamente alternativa".; y SAP, Barcelona, Sección 12º, núm. 617/2006, de 7 de noviembre de 2006, JUR 2007/113747. 
determinación de los derechos y responsabilidades parentales, sin conceder preferencia a uno de los progenitores respecto del otro debido a su sexo, edad, estado civil o sexo del hijo ${ }^{344}$.

Por otra parte, es posible observar que no sólo existe una consagración y promoción directa del principio de igualdad a favor de los progenitores, alcanzan también a los mayores bajo cuyo cuidado se encuentran. De ello da cuenta la particular visión que subyace en la Convención de los derechos del niño en materia de igualdad.

344 La SAP Toledo, Sección $1^{\circ}$, núm. 200/2008 de 16 mayo. JUR 2008/330924, es de las pocas resoluciones que aplica la excepcionalidad del párrafo 3 del artículo 93 del CC: “...debe comentarse destacando que concurren todos y cada uno de los exigidos y exigibles, en ambos progenitores, para que se les concediera individualmente la custodia del hijo menor a uno de ellos sin detrimento del otro y viceversa; como también el informe favorable del Ministerio Fiscal y, sobre todo el análisis y valoración de la pericia psicológica de ambos progenitores, en sí mismos considerados y en relación con el menor -y sin perjuicio de ulteriores variaciones por el interés del hijo común-, hacen que en el momento actual se pueda estimar como muy favorable el establecimiento del régimen de custodia compartida. Es más, la propia madre, a la que se apunta tal posibilidad, asevera que se acomodaría a la misma en el interés superior del niño. Además, en régimen de cambio de custodia se entiende ponderado a los intereses del menor y a que el cambio de custodia se lleve cabo respetando el interés del niño, en periodo vacacional y a fin de que se acostumbre al cambio ; finalmente y siempre a salvo de los acuerdos que fijen los padres, se establece un régimen de visitas supletorio muy amplio, siempre en beneficio del menor"; SAP Girona, núm. 408/2006 de 3 noviembre. JUR 2007/105329, en virtud de la cual el Tribunal impone la custodia compartida, existiendo además un desacuerdo entre los padres, argumentando de la siguiente forma su decisión: " la Sala se inclina también por establecer establecer el régimen de custodia compartida por considerarlo adecuado al interés de los menores, pues la similitud de los estilos educativos de los progenitores podrá paliar los pretendidos inconvenientes derivados de la falta de comunicación fluida y contenida con uno sólo de los progenitores, que por otro lado son inherentes a toda crisis matrimonial contenciosa; se estima en consecuencia que se dan las circunstancias necesarias, requeridas por el artículo 92 del Código Civil, redactado conforme a la reforma llevada a cabo por la Ley 15/2005, de 8 de julio, para el establecimiento de este sistema de guarda, incluido el informe favorable del Fiscal que ha pedido la confirmación de la sentencia de guarda, incluido el informe favorable del Ministerio Fiscal, que ha pedido la confirmación de la sentencia"; SAP Barcelona, núm. 102/2007 de 20 febrero, JUR 2007/101427: "Llegados a este extremo, es de concluir afirmando que, en el supuesto de autos, habiendo el Ministerio Fiscal informado en el acto de la vista de la apelación a favor de la custodia compartida, se cumple el presupuesto procesal, de pertinente aplicación, previsto en el artículo 92, 8. del Código Civil, y, por tanto, el Tribunal estima que debe acordarse la guarda y custodia compartida de los des hijos de los progenitores hoy en litigio a favor de éstos, en el bien entendido que sólo de esta forma se protege adecuadamente el interés superior, tanto de Lorenzo -cuyo deseo es palmario-, como de Laura, pues, aparte de que debe procurarse no separar a los hermanos, lo que el sistema de custodia compartida potencia que así sea, dada la convivencia conjunta de cada uno de ellos en las estancias ya sea con uno o con otro progenitor, para la niña -que cuenta en la actualidad con 7 años y casi 9 meses de edad-su hermano mayor, Lorenzo -de 13 años y casi 4 meses de edad- es un referente importante en todos los aspectos de su vida.- En definitiva, se accede a la solicitud de guarda y custodia compartida de ambos hijos con cada uno de sus progenitores, si bien el Tribunal, atendida a la edad de Laura y a lo expresado con sumo detalle por el hijo Lorenzo en la prueba de exploración judicial, considera que no es conveniente ni aconsejable estimar la petición del Ministerio Fiscal de que se fije aquélla por semanas alternas, si no por días de la semana y partiendo la misma, ya que asi se asegura una regularidad en la vida de los niños de forma que determinadas actividades las vincularán con las estancias en casa del padre o en casa de la madre, creando referencias fijas y, eso sí, alternándose los fines de semana. Por ello se establece el siguiente régimen de custodia compartida: lunes y martes con la madre, y miércoles y jueves con el padre, siempre con pernocta en casa de cada uno de los progenitores, el cual deberá acompañar a la mañana siguiente a los niños al colegio en donde cursan sus estudios, así como los fines de semana-que abarcarán desde el viernes a la salida de la escuela hasta el lunes a la entrada de la misma- con la debida alternancia, o sea, un fin de semana con cada progenitor -y por ello la recogida de los niños el viernes y su llevanza el lunes al colegio, deberá realizarse por quien de los dos le corresponda el concreto fin de semana-. Asimismo se mantiene el pronunciamiento concerniente a que las vacaciones escolares de los hijos, en los periodos de Navidad, Semana Santa y 
En efecto, este instrumento internacional contempla uno de los conceptos más omnicomprensivos del principio de "no discriminación" ya que no sólo prohíbe efectuar diferencias arbitrarias en contra del menor sino también respecto de sus padres y representantes legales. Su artículo 2.1 establece que: “los Estados Partes respetarán los derechos enunciados en la presente Convención y asegurarán su aplicación a cada niño sujeto a su jurisdicción, sin distinción alguna, independientemente de la raza, el color, el sexo, el idioma, la religión, la opinión política o de otra índole, el origen nacional, étnico o social, la posición económica, los impedimentos, el nacimiento o cualquier otra condición del niño, de sus padres o de sus representantes legales". Y aunque la citada Convención no ha establecido que entiende por “discriminación”, el Comité de Derechos Humanos, que es el órgano de Naciones Unidas encargado de vigilar el cumplimiento de las normas del Pacto Internacional de los Derechos Civiles y Políticos de 1966 e interpretar su contenido, ha señalado que la no discriminación junto con la igualdad ante la ley y la igual protección de la ley, constituye un principio básico y general relativo a la protección de los Derechos Humanos; agregando en cuanto a la discriminación en contra de los niños y niñas, el Pacto dispone que todo niño, sin discriminación alguna, tiene derecho a las medidas que su condición de menor requiere, tanto por parte de su familia como de la sociedad y del Estado ${ }^{345}$. En particular, el Comité de Derechos Humanos destaca que, en ciertos casos, dicho Pacto exige expresamente a los Estados Partes que adopten medidas que garanticen la igualdad de derechos de las personas de que se trate. Así, el párrafo cuarto del art. 23 estipula que deben efectuarse acciones apropiadas para asegurar la igualdad de derechos y de responsabilidades de ambos esposos en cuanto al matrimonio, durante, así como en caso de disolución del mismo ${ }^{346}$.

En España, la Ley 15/2005 suscitó un interesante debate social en torno al principio de igualdad entre progenitores. En efecto, su establecimiento ha sido impulsado, principalmente, por asociaciones de padres (varones) separados y divorciados que, reivindicando su papel en la formación integral de sus hijos sobre la base del principio de igualdad, demandaron al Estado el reconocimiento legal de un mayor protagonismo en el desarrollo de las funciones de convivencia con los mismos ${ }^{347}$,

verano sean disfrutadas por mitad entre ambos progenitores, correspondiendo, salvo acuerdo en otro sentido, a la madre elegir el período en que los niños estén en su compañía, en los años pares, y al padre, en los años impares."

345 Cfr. COMITÉ DE DERCHOS HUMANOS: Observación General, número 18, año 1989, “No discriminación”, Ginebra, Naciones Unidas. HRI/GEN/1/Rev. 7 at 168, 1. ${ }^{\circ}$ de noviembre de 1989, páginas 1 y 5.

346 Cfr. COMITE DE DERECHOS HUMANOS. ibídem, pág. 5.

347 Un primer paso jurisprudencial lo conformaron los pronunciamientos judiciales que sin reconocer expresamente la custodia compartida establecían un amplio régimen de visitas para el cónyuge no custodio. De esa forma se optó por un modelo entre el sistema tradicional y la custodia compartida partiendo de la buena relación existente entre padre e hijo y admitiendo la bondad y comunicación de su relación con el menor. 
sin perjuicio se estimaba que era beneficioso para el menor, debido a que procuraba mantener los lazos de cercanía y confianza que deben de fundar toda relación paterno filial ${ }^{348}$. De esta forma, entre las ventajas que este instituto presenta frente a la custodia unilateral, se manifiesta que fortalece la igualdad de roles entre hombres y mujeres, padres y madres, y su progresiva y equitativa responsabilidad en la educación de sus hijos ${ }^{349}$, quienes serán beneficiados al crecer en un ambiente donde los valores de la igualdad y respeto quedan mejor protegidos ${ }^{350}$, que en el actual sistema patriarcal y sexista $^{351}$.

348 CAMPUZANO TOMÉ, H. "La custodia compartida. Doctrina jurisprudencial de las Audiencias Provinciales", Ed. Aranzadi S.A. Aranzadi Civil-Mercantil, núm. 22/2004, parte Estudio, Pamplona, año 2005, BIB 2005/563. Sostiene la autora que la vía que abre la reforma adquiere notable trascendencia, y ello considerando variadas decisiones jurisprudenciales que han negado la atribución de la custodia compartida, incluso en supuestos en los que resultaba clara su bondad, han encontrado refugio en la circunstancia de que en el Código Civil únicamente contemplara como opción expresa su otorgamiento a uno u otro progenitor sin mención alguna al posible ejercicio alternativo por ambos. Prosigue opinando que la nueva normativa no impone en modo alguno la modalidad de custodia compartida, sino que simplemente abre al Juzgador y a los propios progenitores formas nuevas y di ferentes de repartir el tiempo de permanencia de los hijos comunes con ambos padres. Ahora bien, no debe olvidarse que dicha opción puede resultar ventajosa en determinados supuestos y bajo circunstancias concretas. En cualquier caso merece ser analizada y examinada su oportunidad frente al esquema tradicional derivado de la atribución exclusiva a uno solo de los progenitores. Sin embargo al equipararla con la atribución individual de la custodia a uno de sus progenitores, la custodia compartida ofrece importantes ventajas y beneficios para el menor. Su fundamento teórico reside en la idea de que la separación o el divorcio ponen fin al matrimonio pero no a los vínculos familiares; ello supone que los derechos y las responsabilidades de cada uno de los padres con respecto a sus hijos comunes, una vez sobrevenida la crisis conyugal, deben ser iguales a los derechos y responsabilidades que tenían con anterioridad. En la práctica este esquema exige la fijación por parte del Juez de medidas que permitan al hijo disfrutar de una mayor presencia física de ambos progenitores una vez decretada la separación y el divorcio.

349 GUARRIGA GORINA, M. "El criterio de la continuidad frente a la guarda conjunta", INDRET, Revista para el análisis del Derecho, Facultad de Derecho, Universitat Pompeu Fabra, núm. 3, año 2008, http://www.indret.com/pdf/562 es.pdf "La propuesta de una regulación que favorezca que los progenitores que no conviven compartan los tiempos de convivencia con los hijos es coherente con la afirmación según la cual la mejor solución para los hijos es mantener relaciones con ambos progenitores y también con el ideal de alcanzar soluciones que sean justas en términos de relación entre los progenitores. Además, a nivel simbólico, la preferencia por la guarda conjunta demuestra el compromiso del Estado con la promoción de la participación de hombres y mujeres en el cuidado de la descendencia. Pero el objetivo de las iniciativas de reforma en esta materia es también incidir en la realidad actual en que la guarda se atribuye de forma mayoritaria a las madres, pues exis te la percepción de que ello no encaja con la mayor implicación de los hombres en las tareas de cuidado de los hijos ni refleja los cambios que se han producido en la organización de las familias por efecto de la mayor tasa de actividad laboral femenina"

350 SAP Madrid, Sección 22a , núm. 660/2005, de 7 de octubre, JUR 2005/252353: "Dicho lo anterior, y reafirmando dicho vínculo afectivo, y puesto que existe una permanente y fluida relación entre el menor y el padre, pues nunca ha existido obstáculo alguno para este último para comunicar con su hijo casi a diario, es lo cierto que con el amplio régimen de visitas que viene señalado en la sentencia apelada se asegura la permanencia del lazo afectivo y familiar, y también material, entre el menor y su padre, pues no se olvide que las visitas se han establecido, en fines de semanas, de viernes a lunes, y además de las vacaciones de Navidad, verano y semana Santa, también se incluyen dos tardes semanales, todo lo cual permite afirmar que, en realidad, en el devenir diario de la vida del menor, existe casi una custodia compartida entre ambos progenitores; por todo lo anterior, debe confirmarse la resolución apelada en este apartado. “

351 Resulta interesante revisar una encuesta realizada por la "Asociación SOS papá" poco antes de la entrada en vigor de esta controvertida ley. Arrojaba los siguientes resultados. A la pregunta "iestá usted a favor o en contra de que, tras un divorcio, los hijos puedan continuar relacionándose por igual con ambos progenitores?”, el $90 \%$ de los entrevistados se manifestó a favor; el 3\% en contra, y el 7\% no supo o no contestó. A la pregunta "cuando no 
A la igualdad jurídica entre hombre y mujer se refiere la Exposición de Motivos de la Ley $15 / 2005$, al establecer que esta reforma legislativa también ha de ocuparse de determinadas cuestiones que afectan al ejercicio de la patria potestad y la guarda y custodia de los hijos menores e incapacitados, cuyo objeto es procurar la mejor realización de su beneficio e interés, y hacer que ambos progenitores perciban que su responsabilidad para con ellos continúa, a pesar de la separación o el divorcio, y que la nueva situación les exige, incluso, un mayor grado de diligencia en el ejercicio de la potestad.

Esta reforma buscaba la más plena igualdad de derechos y oportunidades de la mujer. Se trataba de desterrar la concepción que tradicionalmente le es asignada en el cuidado familiar (binomio maternidad-hogar), mediante la creciente asunción de roles compartidos por ambos progenitores en lo que respecta a la guarda y custodia de los hijos; agregando que, para que la mujer participe en condiciones de equidad en la vida pública, debe garantizarse que pueda hacerlo también en su vida privada.

En este orden de ideas, se estima que no puede desconocerse la existencia de ciertos condicionamientos sociales que han alterado los tradicionales criterios de atribución de la guarda y custodia de los hijos. Así, desde hace algunos años, se advierte un proceso de revisión de dichas pautas que es, en definitiva, lo que ha pretendido reflejar la referida reforma legal ${ }^{352}$. Entre dichos factores de cambio social se encuentran la lucha progresiva por la igualdad jurídica y material entre hombre y mujer; la incorporación femenina normalizada al mundo del trabajo; la reivindicación de la igualdad económica, social y familiar, que ha implicado el surgimiento de conflictos de intereses hasta ahora desconocidos; y el ejercicio de la libertad sexual de hombres y mujeres en un plano de igualdad, que ha significado la consolación de una nueva conciencia social, con nuevos hábitos y pautas de com-

hay acuerdo entre los ex cónyuges respecto a la custodia de los hijos, ¿está usted a favor o en contra de una ley de custodia compartida?", el 83,6\% de los encuestados contestó que estaba a favor; el 4,8\% en contra, y el 11,6\% no supo o no contestó. Por último, a la pregunta “¿considera honesta o deshonesta la actitud de los políticos que están a favor de la igualdad pero en contra de la custodia compartida señaló que la consideraba honesta, y el 64,3\%, deshonesta. Intergallup, S.A (Grupo Gallup España), Encuesta sobre Custodia Compartida, Referencia 050110, abril de 2005 (www.custodiacompartida.org/content/view/124/). La ficha técnica de este estudio es la siguiente. Universo: Población española de 18 y más años. Ámbito geográfico: Nacional, exceptuando Canarias, Ceuta y Melilla. Tamaño muestral: 964 n. Entrevistas: Telefónicas mediante sistema CATI en el hogar de los entrevistados. Fecha del trabajo de campo: del 25 al 29 de abril de 2005.

352 Así lo demuestra la SAP Barcelona, Sección 18º, núm. 23/2006 de 12 enero. JUR 2006/84815, al afirmar que "se han de modificar en definitiva los parámetros conforme a los cuales se vienen resolviendo estos problemas y adecuarlos a las condiciones actuales de cada familia. El art. 3 del Código Civil indica claramente que la normas deben interpretarse conforme a la realidad social del tiempo que han de ser aplicadas y es un hecho notorio, que el funcionamiento interno de las familias, en cuanto a distribución de roles entre el padre y la madre, ha evolucionado hacia una mayor participación del padre en la tarea del cuidado de los menores, convirtiéndose en una figura presente que ha asumido la función cuidadora”. Cfr. SAP Córdoba núm. 103/2006 de 24 abril. JUR 2006/230967. 
portamiento. Esto, que duda cabe, se ha trasladado a la conformación de una igualdad de roles que ambos progenitores deben desempeñar en el ejercicio de la corresponsabilidad parental ${ }^{353}$.

Lo que hay detrás de las aspiraciones que se han suscitado con la regulación de la custodia compartida es el ideal de que tanto padres como madres se impliquen en las tareas que conlleva el cuidado parental. Sin duda es imposible que tal implicación sea de manera igual al cien por cien, pero el conseguir que pese a la situación de ruptura la responsabilidad frente al hijo(s) sigue siendo la misma, es decir, compartida, porque un hijo(s) es compartido, es sin duda uno de los mayores éxitos que puede conseguir la ley y su implantación ${ }^{354}$.

Además, sobre la base del principio de igualdad entre hombre y mujer, la custodia conjunta contribuiría a desterrar la asignación de los roles que tradicionalmente le son asignados: de provisión y seguridad económica y el cumplimiento de labores domésticas, respectivamente ${ }^{355}$.

353 GONZALEZ GONZALEZ, C. “Guarda y custodia compartida: conflictividad y protección del menor” en Revista Aranzadi Doctrina, núm. 4/2012, parte Fichas de Jurisprudencia, Ed. Aranzadi S.A., Pamplona, año 2012, BIB 2012/1189. El autor sostiene que el TS en relación a la sentencia de dictada el 29 de septiembre de 2009 por la Audiencia Provincial de Alicante, Sección 4JUR 1010/65075 desestimó el recurso, rechazando la guarda y custodia compartida porque reinterpretó el art. 92 del CC señalando que el juez puede acordar la guarda y custodia si la solicitan ambos progenitores o cuando, a pesar de no existir acuerdo, lo considere procedente para proteger el interés del menor de forma más eficaz y que ello implica una amplia facultad en torno los magistrados para decidir cuál debe ser la solución adecuada a la vista de las pruebas, de modo que en los procedimientos judiciales sobre menores no rige el principio dispositivo. Al mismo tiempo el juez debe valorar las alegaciones de las partes, la prueba practicada y la relación que los padres mantengan entre sí y con sus hijos para determinar su idoneidad con el régimen de guarda.- Prosigue poniendo énfasis en el hecho de que Código español no contiene una lista de criterios que permitan al juez determinar en cada caso qué circunstancias deben ser tenidas en cuenta para justificar el interés del menor en supuestos en que existen discrepancias entre los progenitores, que no impiden tomar la decisión sobre la guarda conjunta, del estudio del derecho comparado se llega a la conclusión de que se pueden utilizar, entre otros, criterios tales como la práctica anterior de los progenitores en sus relaciones con el menor y sus aptitudes personales; los deseos de los menores y el número de hijos; el cumplimiento por los progenitores de su deberes en relación con los hijos y el respeto mutuo en sus relaciones; los acuerdos adoptados; la ubicación de sus respectivos domicilios, horarios y actividades; el resultado de los informes exigidos legalmente $\mathrm{y}$, en definitiva, cualquier otro que permita a los menores una vida adecuada en una convivencia que forzosamente deberá ser más compleja que la que se lleva a cabo cuando los progenitores conviven juntos. Estos criterios deben atender siempre a la protección del interés del menor.

354 Cfr. GARCÍA RUBIO M. P. y OTERO CRESPO, M. "Apuntes sobre la referencia expresa al ejercicio compartido de la guarda y custodia de los hijos en la Ley 15/2005", Revista Jurídica de Castilla y León, Ed. Junta de Castilla y León, Valladolid, año 2006.

355 SAP Las Palmas, Sección $5^{\text {a }}$, núm. 327/2004 de 15 abril. JUR 2004/152448: "De el puede deducirse que en la actualidad las relaciones entre los progenitores se encuentran plenamente normalizadas, lo que constituye un hecho esencial para la progresiva aceptación por los hijos de la situación que en estos provoca la ruptura conyugal. También que el menor, pese a estar sufriendo en estos momentos aún las consecuencias derivadas de la falta de aceptación de la ruptura conyugal y el abandono al que se vio expuesto por la actitud de los padres, que lejos de evitar que ello afectará en la menor medida posible a su hijo menor, potenciaron la asunción por éste de tendencias auto-culpabilizadoras frente a los conflictos parentales, se encuentra en una situación que podría calificarse de mejoría. De la misma forma, cabe deducir de dicho informe que tanto el padre como la madre se encuentran en condiciones adecuadas de prestar al menor la necesaria asistencia moral para su correcto desarrollo, y que las condiciones en las que habitan uno y otro permiten ofrecer a su hijo menor un habitad conforme a sus necesidades. - Como punto de partida el principio básico reconocido en el art. 39 de la Constitución Española, en la Declaración de los Derechos del Niño proclamada por la Asamblea General Naciones Unidas de 2011-89 ratificada por España (BOE 31-12-90), en numerosos preceptos recogidos a lo largo del articulado del Código Civil, y en la Ley Orgánica 1/96 de 15 de enero de Protección jurídica del menor, de la necesaria protec- 
GUILARTE MARTÍN-CALERO, ha planteado en torno a este tema, de manera muy clara y precisa, el vínculo existente entre el compartir los roles y tareas domésticas antes de la ruptura y la situación surgida por el acaecer de esta y que repercute en el establecimiento de la guarda y custodia compartida. La autora manifiesta que si constante convivencia existió un modelo organizativo familiar basado en la igualdad y en la corresponsabilidad en todos y cada uno de los ámbitos relevantes, sobrevenida la ruptura aquel modelo organizativo debe pervivir, adaptado a la falta de convivencia que produce aquella. En este sentido la custodia compartida debe ser contemplada como una oportunidad profesional para las mujeres que antes de la crisis organizaron su convivencia sobre los principios de igualdad y corresponsabilidad, mientras que luego de aquella anhelan seguir su vida personal, familiar y laboral de acuerdo con aquellos mismos principios ${ }^{356}$.

Ahora bien, dentro del feminismo, no todas las voces que se escuchan están contestes en torno a la custodia compartida ${ }^{357}$. Puede tildarse contradictoria la posición de tales movimientos debido a que una de sus banderas de lucha de siempre ha sido la igualdad de género y que por lo tanto vean con perplejidad el establecimiento de un modelo compartido de cuidado personal de los hijos que, teóricamente, promovería la desaparición del papel históricamente asignado a la mujer en el seno familiar $^{358}$. De hecho, también existen posturas que defienden la custodia conjunta como sistema

ción del derecho del que son titulares los menores a su propio desarrollo, educación y formación, lo que se traduce en la materia que nos ocupa, en sede de relaciones paterno filiales, en que el conflicto surgido acerca de todo lo relativo a su guarda y custodia deba resolverse por prescripción legal, jurisprudencial y justas razones, atendiendo primordialmente al beneficio e interés del menor- Pues bien, no cabe duda que en casos como el presente el interés del menor se concreta, por un lado, en la consideración, a la vista del informe aportado, de que sería contraproducente la separación del mismo de su núcleo familiar, y de otro en la búsqueda de cuál de entre las posibles soluciones es la correcta para la atribución de la guarda y custodia, puesto que ambos progenitores solicitan que la misma sea compartida, manteniéndose la situación que hasta este momento se está llevando a cabo de hecho. Cierto es que a la hora de fijar la guarda y custodia, conforme al art. 90 A) del Código civil deberá indicarse la persona a cuyo cuidado deban quedarse los hijos sujetos a patria potestad, siendo por lo tanto normal que se designe a uno de los progenitores, y no a los dos. Por lo tanto es innegable que ha de ser excepcional el compartimiento de tal tarea, generalmente y por lo que la experiencia enseña tan excepcional como la buena relación entre los cónyuges, que es lo que permite la observancia del régimen, entre quienes son capaces de postergar su desencuentro personal, por el beneficio del hijo/a común. Cabe excepcionalmente entonces y siempre que las circunstancias objetivas lo propicien el compartimiento de la custodia, y sin perder de vista naturalmente el principio rector en la materia, el bonnum fillii."

356 GUILARTE MARTÍN -CALERO, C. "La regulación de la custodia compartida: una oportunidad para la consolidación de la carrera profesional de las mujeres”, en VV. AA. "Mujeres, contratos y empresa desde la igualdad de género”, Ed. Tirant Lo Blanch, Valencia, año 2013, páginas 689 a 802.

357 Cfr. GUILARTE MARTÍN-CALERO, C. "Comentarios del nuevo artículo 92 del Código Civil” en GUILARTE GUTIERREZ, V. (Dir.) “Comentarios a la reforma de separación y divorcio, Ley 15/2005, de 8 de julio”, Ed. Lex Nova, Valladolid, año 2005, página 120 a 122.

358 GONZÁLEZ MORENO, B. "El principio de igualdad en el ámbito del Derecho de familia: La custodia compartida”, en GONZÁLEZ MORENO, B (Coord.) en "Principios de igualdad y derechos fundamentales", Ed. Tirant Lo Blanch, monografías, núm. 655, Valencia, año 2009, páginas 342 y 343. "En cambio, un significativo sector de las asociaciones de mujeres separadas y divorciadas se muestran contrario a la figura de la custodia compartida, señalando que en ningún caso contribuye a la igualdad entre mujeres y hombres, y que la experiencia demuestra que la implicación de las madres en el cuidado y atención de los hijos menores es siempre muy superior 
que permite balancear efectivamente el cumplimiento de los roles domésticos y de cuidado de los hijos, sin perjuicio, tal cual se acaba de mencionar hay corrientes de opinión que la rechazan al atribuirle la desventaja de perpetuar la asignación de las funciones tradicionalmente asociadas a la mu$\mathrm{jer}^{359}$.

Tal cual se puede verificar, la defensa del principio de igualdad genera argumentos, tanto para promover como para descartar la custodia compartida ${ }^{360}$. Ello explica la gran polémica levantada en torno a su implementación jurídica y social, y el abundante debate existente al respecto en las más variadas disciplinas dedicadas al estudio de la familia, desde luego, en el Derecho y en la Psicología. En suma, es posible advertir que diversos grupos sociales conformados, generalmente, únicamente por padres y madres, en su caso, tienen como bastión de lucha la consecución del principio de igualdad sobre la base de intereses diametralmente opuestos ${ }^{361}$.

En el primer caso, se persigue ejercer la custodia de los hijos en condiciones de paridad junto a las progenitoras, tradicionalmente consideradas más aptas para ejercer las labores de cuidado y crianza de los hijos comunes, invocando además el derecho del hijo a seguir gozando de relaciones directas y regulares con sus dos padres. En el segundo caso, se reivindica el principio de igualdad señalando que la custodia compartida puede generar situaciones abusivas dada la desigualdad real existente aún en la sociedad española, injusticias que, en definitiva, pueden acarrear que las madres accedan al establecimiento de la custodia conjunta frente a las presiones económicas de sus ex cónyuges -que continúan estando en condiciones de superioridad para negociar estos aspectos-, a cambio de continuar gozando de un nivel de vida que les permita seguir desenvolviéndose con cierta estabilidad patrimonial y al cual no han podido acceder o no podrían acceder en situación de paridad junto al sexo opuesto precisamente por esa profunda y arraigada diferencia enunciada. Debe pensarse, por ejemplo, en la brecha salarial existente y en las dificultades de la mujer para reincorporarse al mundo laboral tras años de renuncia a cualquier clase de promoción y calificación profesional.

a la de los padres, aunque en los casos de reparto de la tareas familiares, se señala, además, que el marco de colaboración doméstica que se da en situaciones normales de convivencia es muy difícil de reproducir tras una ruptura y que el grado de conflictividad entre los padres debe valorarse para constituir el régimen más idóneo."

359 LATHROP GÓMEZ, F. “Custodia compartida de los hijos”, Ed. La Ley, Madrid, año 2008, página 373.

360 Se sabe que el parámetro de toda resolución judicial sobre este punto es el interés del menor, concepto jurídico que tal cual se estudiará resulta indeterminado cuya concresión a resultado a menudo problemática. Resulta evidente una tendencia jurisprudencial a subsumir el interés del menor en la satisfacción de necesidades de tipo material, ya en lo referente a la cobertura económica de los alimentos o la atención referida a cuidados puramente externos, lo que ha consolidado la tendencia a atribuir la custodia a la madre por entenderla más capacitada para resolver las necesidades de los menores en las cuestiones relativas asu crianza, atribuyendo al adre una asistencia meramente económica mediante el pago de la pensión alimenticia.

361 LATHROP GÓMEZ, F. “Custodia compartida de los hijos”. ...op. cit., página 374. 
Al respecto, algunos sectores han cuestionado el discurso tradicional de igualdad de género que subyace en la defensa de la custodia compartida, pues la reforma llevada a cabo conduciría más bien hacia la igualdad formal y no material ${ }^{362}$, llegando incluso a sostenerse que la instauración de la custodia compartida crearía una desigualdad en el resultado ${ }^{363}$. Ello se produciría debido a que el mayor grado de poder contractual de los padres, fruto de esta cultura igualitaria, se vería reforzado ante la imposición judicial de esta modalidad de cuidado personal de los hijos ${ }^{364}$. Así, si bien se experimentarían algunas transformaciones en los roles que tradicionalmente le son asignados al hombre y a la mujer, el reparto del trabajo doméstico y las prácticas reales del cuidado de los menores continuarían radicadas primordialmente entre las mujeres.

Por otra parte, se ha afirmado que la custodia conjunta perjudica a las mujeres al potenciar las posibilidades de que sea el padre quien la solicite y obtenga. Esta situación crearía un efecto perverso, puesto que “como la madre valora casi siempre mucho más que el padre la custodia de los hijos, acabará estando dispuesta a renunciar a todo (pensión, alimentos, bienes matrimoniales)",365.

Al respecto, se estima que el juez debe garantizar que el establecimiento de la guarda y custodia compartida y las cuestiones patrimoniales conexas a ellas, se acuerden en conformidad al principio de protección del cónyuge más débil, de manera que la negociación se lleve a cabo en paridad de condiciones y las transacciones que se efectúen se mantengan ajenas a presiones y concesiones ilegítimas. En tal sentido no podemos desconocer que, en muchos casos, es el marido quien continúa ejerciendo la posición económica más ventajosa, lo cual provoca que en el juicio de divorcio la mujer sufra intimidaciones con respecto a la custodia de los hijos. Sin embargo, el legislador español prevé ciertos remedios frente a esta distorsión, como la norma conforme a la cual el juez debe velar por el interés del cónyuge más débil (párrafo antepenúltimo del art. 90 del CC) y que, aplicada

362 GOIRIENA LEKUE, A. "La Custodia compartida, el interés del menor y la neutralidad de género", Revista Aequalitas, núm. 16 enero-junio, año 2005, página 57.

363 En efecto, sectores feministas han criticado la doctrina de la custodia alternada calificándola como una vía que otorga poder a los padres como colectivo, debilitando a su vez, el poder individual de las madres. Cfr. HUAITA ALEGRE, M., "Derecho de custodia, neutralidad de género, derechos humanos de la mujer e interés superior del niño o niña". Ediciones LOM, Santiago de Chile, año 1999, páginas 558.

364 Desde el Derecho civil ha predominado en general la opinión de que el Derecho de Familia es diferente al resto del ordenamiento civilista, de una u otra forma nos encontramos ante una rama con carácter más moral que jurídico, lo que se traduce en sus normas, fundadas sobre elementos metajurídicos, sean afectivos, psicológicos o puramente sociales, lo que implica en muchos casos la existencia de preceptos sin sanción y obligaciones incoercibles; el fondo etico de sus instituciones o el predominio de las relaciones estrictamente personales sobre las patrimoniales. Sin embargo, las relaciones familiares han experimentado en el ultimo tiempo una marcada evolución y profundos cambios sociales que han debilitado algunos de esos rasgos tradicionales de sus normas regula doras. Son dos principalmente las lineas de fuera que han tenido una mayor incidencia en la evolucion de las normas de Derecho de familia. Cfr. CASTÁN VÁZQUEZ, J. M. "Derecho civil, común y foral", Tomo V, Vol. 1, Ed. Reus, S.A., Madrid, año 1983, paginas 50 a 54.

365 Vid. CARRASCO PERERA, A., "Custodia compartida”, Actualidad Jurídica Aranzadi, número 648, Parte Tribuna, Ed. Aranzadi, Pamplona, año 2004, BIB 2004/1707, página 1. 
con prudencia, puede llegar a constituir una herramienta de gran utilidad en la consecución de dicha igualdad material.

En todo caso, el legislador ha intentado poner límites a esta desigualdad real en el seno familiar a través de la modificación del artículo 68 del Código Civil, ubicado en el Capítulo IV, relativo a los derechos y deberes de los cónyuges, del Título II del libro I del Código Civil, agregando a los tradicionales deberes de vivir juntos, guardarse fidelidad y socorrerse mutuamente, los de compartir las responsabilidades domésticas y el cuidado y atención de ascendientes y descendientes y otras personas dependientes a su cargo. Al parecer, mediante este precepto ubicado fuera de la reglamentación de los efectos comunes a la nulidad, separación y divorcio del Capítulo IX del Título IV del Código Civil, donde se regula la custodia compartida, el legislador ha pretendido establecer un soporte normativo de esta figura.

Se ha intentado, concretar el principio de corresponsabilidad parental reforzando la vigencia del principio de igualdad jurídica ${ }^{366}$, para que hombre y mujer, padre y madre, puedan reconstruir sus relaciones de familia en paridad de condiciones ${ }^{367}$.

Frente a la realidad descrita en los epígrafes anteriores, podría sostenerse que la reforma de 2005 se ha apresurado al implementar la modalidad de custodia compartida. La negativa inicial a legislar en la materia por parte de diversos colectivos de mujeres separadas y ciertos condicionamientos posteriores exigidos para la implementación de la misma, responden a la idea de que aún no están dadas totalmente las condiciones sociales suficientes y adecuadas para la instauración de un régimen de custodia que requiere idealmente, no sólo un mínimo de entendimiento y colaboración entre los progenitores, como a menudo suele señalarse en el plano doctrinal, sino también una igualdad material entre hombre y mujer ${ }^{368}$.

En este orden de ideas es donde, a nuestro juicio, cobra importancia la Ley Orgánica 3/2007, de 22 de marzo, "para la igualdad efectiva de mujeres y hombres", pues ella sienta las bases sobre las cuales la Ley 15/2005 puede desarrollar su función promocional de la igualdad parental al interior y exterior de la familia ${ }^{369}$. La nueva Ley reconoce y dispone una serie de elementos esenciales

366 LATHROP GÓMEZ, F. "Custodia compartida y corresponsabilidad parental. Aproximaciones jurídicas y sociológicas”, Diario La Ley núm. 7206/2009, año XXX parte Doctrina. La Ley - Actualidad, Las Rozas, año 2009.

367 RODRIGUEZ CHACON, R. Considera que estos nuevos extremos son al igual que los demás deberes contenidos en los artículos 67 y 68 del Código Civil, infectivos e inexigibles jurídicamente. En "Matrimonio, separación y divorcio en España: nueva regulación: estudio sistemático de las leyes 13/2005, de 1 de julio, y 15/2005, de 8 de julio”. Ed. Experiencia, Barcelona, año 2005, páginas 74 y 75.

368 LATHROP GÓMEZ, F. “Custodia compartida de los hijos”, ...op. cit., página 377.

369 Sin embargo, la Ley Orgánica 3/2007 que contiene 31 disposiciones adicionales que modifican una gran cantidad de artículos de otras normas, y que justifica previsiones adicionales dirigidas a conciliar la vida laboral con determinadas situaciones personales y familiares como la paternidad, la maternidad, el período post-parto, la lactan- 
para el desarrollo de los principios de corresponsabilidad parental y conciliación de la vida familiar y laboral y, en este sentido, podría contribuir a llenar ese "vacío" que impide la justa aplicación de diversas expresiones del principio de corresponsabilidad, como la custodia compartida.

Esta Ley transpone la Directiva comunitaria 2002/73/CE, relativa a la igualdad de trato entre hombres y mujeres, pretende hacer efectivo el principio de igualdad y eliminar toda discriminación contra la mujer. Para ello, contempla un conjunto de medidas transversales en todos los órdenes de la vida política, jurídica y social. Como lo señala su Exposición de Motivos, el carácter horizontal que reviste el principio de igualdad se ve reflejado en la estructura de esta Ley, que efectúa una proyección general de esta directriz en diversos ámbitos normativos, de forma que su vocación es erigirse como una "ley-código de la igualdad entre hombres y mujeres" "370.

Esta Ley ha reconocido el derecho a la conciliación de la vida personal y laboral y el fomento de una mayor corresponsabilidad entre mujeres y hombres en la asunción de las obligaciones familiares. Establece la representación equilibrada entre los mismos en todos los ámbitos de las Administraciones Públicas y de los Consejos de Administración de las empresas; fijando, además, la composición equilibrada de hombres y mujeres en las listas electorales.

En lo que respecta a la custodia compartida, aunque escasa, se puede señalar que la Ley tiene incidencia en los aspectos relativos a la corresponsabilidad familiar y, fundamentalmente, en el reforzamiento de las políticas de conciliación de la vida familiar y laboral, así como en la creación e implementación de otras nuevas.

Ciertamente no existen hasta la fecha leyes por las que se puedan deducir que el reparto del tiempo de convivencia de los hijos con el progenitor no custodio deba ser el que de una forma estándar y con carácter genérico u ordinario se ha venido imponiendo en la práctica, de fines de semana alternos y la mitad de las vacaciones escolares. El legislador no ha dado criterios para determinar el tiempo de reparto necesario con los hijos. Se podría optar por la supresión de la figura de la custodia y le régimen de visitas como hasta la fecha está establecido, en vez de ellos podría hablarse de

cia, los riesgos durante el embarazo, las adopciones o acogimientos que se produzcan o constituyan después de su entrada en vigor, la atención y el cuidado de las personas dependientes, y se regulan los permisos, las prestaciones y subsidios vinculados a estas situaciones. Ni una sola vez se menciona en esta prolija norma la custodia compartida como exponente del principio de corresponsabilidad con los hijos que debe existir entre progenitores, sean hombres o mujeres, y como cauce de igualdad efectiva en las relaciones parentales cuando no existe convivencia entre el padre y la madre. Esto es importante no tan sólo porque esta Ley que procuró la igualdad efectiva de mujeres y hombres se dicto casi dos años después que la reforma del Código Civil que introdujo la custodia compartida sino porque contiene numerosa normativa que puede tacharse de teórica.

370 Vid. LATHROP GÓMEZ, F. “Custodia compartida y corresponsabilidad parental. Aproximaciones jurídicas y sociológicas ”, ... op. cit., página 377. 
sistemas de reparto de tiempo de convivencia de los hijos ${ }^{371}$. La guarda y custodia compartida instaurada en la Ley 15/2005 es una alternativa, y lo fundamental de ella es que ha dejado de tener un carácter de excepcional y más bien consensuada ${ }^{372}$, porque ya no depende del informe favorable del

fiscal, sino que de conformidad a la valoración que efectúe el juez dicha medida se adecue al interés del menor.

Es esencial entender que tal modelo empieza a no ser ajeno al desarrollo social sobre la base de la igualdad de los progenitores en el ejercicio de las responsabilidades que deben asumir con la

371 PÉREZ MARTíN, A. J. "Los hijos menores de edad en situación de crisis familiar”, Ed. Dykinson, Madrid, año 2002, página 100 a $114 .$.

372 STS, Sala 1a, Sección primera, núm. 257/2013 de 29 abril. RJ 201313269 ; SOLA PASCUAL, S. "La custodia compartida no es una medida excepcional, sino que debe considerarse normal e incluso deseable.", Revista Aranzadi Doctrinal ,num. 4/2013. BIB 2013/1422. La autora menciona que el : "TS estudia pormenorizadamente el sistema legal de guardia y custodia. La primacía debe ser de aquel régimen que se adapte mejor al menor y a su interés, no al interés de sus progenitores, pues el sistema está concebido como una forma de protección del interés de los menores cuando sus progenitores no conviven, no como un sistema de premio o castigo al cónyuge por su actitud en el ejercicio de la guarda. La interpretación de los artículos 92, 5, 6 y 7 CC (LEG 1889, 27) debe estar fundada en el interés de los menores que van a quedar afectados por la medida que se deba tomar, que se acordará cuando concurran criterios tales como la práctica anterior de los progenitores en sus relaciones con el menor y sus aptitudes personales; los deseos manifestados por los menores competentes; el número de hijos; el cumplimiento por parte de los progenitores de sus deberes en relación con los hijos y el respeto mutuo en sus relaciones personales; el resultado de los informes exigidos legalmente, $y$, en definitiva, cualquier otro que permita a los menores una vida adecuada, aunque en la práctica pueda ser más compleja que la que se lleva a cabo cuando los progenitores conviven. La redacción del artículo 92 no permite concluir que se trate de una medida excepcional, sino que al contrario, habrá de considerarse normal e incluso deseable, porque permite que sea efectivo el derecho que los hijos tienen a relacionarse con ambos progenitores, aun en situaciones de crisis, siempre que ello sea posible y en tanto en cuanto lo sea"; FERNÁNDEZ MARTÍNEZ, J. M., "La guarda y custodia compartida", Revista Aranzadi Doctrinal, num. 4/2013 parte Comentario, Ed. Aranzadi, SA, Pamplona, BIB 2013/1426: “Como ya ha quedado reflejado líneas atrás, la custodia compartida precisa que sea solicitada por los progenitores, bien conjuntamente, en cuyo caso será de aplicación el apartado 5 del artículo 92 CC (LEG 1889, 27), bien por uno de ellos, supuesto del apartado 8. El problema deriva de que dicho punto octavo comienza señalando que excepcionalmente ...5. Acerca de cómo ha de entenderse la aludida excepcionalidad, señala la STS de 22 de julio de 2011 (RJ 2011, 5676) 6 que "La excepcionalidad a que se refiere el inicio del párrafo 8, debe interpretarse, pues, en relación con el párrafo cinco del propio artículo que admite que se acuerde la guarda y custodia compartida cuando asi lo soliciten ambos progenitores o uno con el acuerdo del otro. Si no hay acuerdo, el Art. 92.8 CC no excluye esta posibilidad, pero en este caso, debe el Juez acordarla "fundamentándola en que solo de esta forma se protege adecuadamente el interés superior del menor". De aquí que no resulta necesario concretar el significado de la "excepcionalidad", a que se refiere el Art. 92.8 CC, ya que en la redacción del artículo aparece claramente que viene referida a la falta de acuerdo entre los cónyuges sobre la guarda compartida, no a que existan circunstancias especificas para acordarla»; STS, Sala de lo Civil, Sección1a, núm. 496/2011, 7 julio, RJ 2011/5008 "La interpretación del art. 92 CC . En cambio, debe estimarse el segundo motivo, basado en la necesidad de interpretar una norma, el Art. 92 CC, con menos de cinco años de vigencia, dada la reforma que dicho artículo experimentó en 2005.- Esta Sala ha venido ya recogiendo una serie de criterios relativos a la interpretación de lo que significa "el interés del menor", que deben tenerse en cuenta en los litigios sobre guarda y custodia compartida.- La STS 623/2009, que anuló la anterior de la Audiencia Provincial de Alicante, sección $6^{a}$, decía que del examen del derecho comparado se deducía que se utilizaban "criterios tales como la práctica anterior de los progenitores en sus relaciones con el menor y sus aptitudes personales; los deseos manifestados por los menores competentes; el número de hijos; el cumplimiento por parte de los progenitores de sus deberes en relación con los hijos y el respeto mutuo en sus relaciones personales; el resultado de los informes exigidos legalmente, y, en definitiva, cualquier otro que permita a los menores una vida adecuada en una convivencia que forzosamente deberá ser más compleja que la que se lleva a cabo cuando los progenitores conviven". Estos criterios se utilizan también en las SSTS de 10 (RJ 2010, 2329) y 
prole $^{373}$, modelo que requiere en gran medida de un esfuerzo mayor de cada operador jurídico, lo cual puede ser visto como una oportunidad para que la mediación esté presente durante todo el proceso conflictivo ${ }^{374}$.

La custodia conjunta posibilita el desarrollo más normalizado de las relaciones paterno-filiales con los dos progenitores, evitando que los hijos menores sean privados de la compañía habitual de cualquiera de ambos. Sin embargo la custodia conjunta no es específicamente productiva ni perjudicial, dependerá en gran medida de la conciliación de ambos padres para su ejercicio, así como de sus circunstancias ${ }^{375}$.

A nivel autonómico me gustaría destacar la Ley 25/2010, de 29 de julio, del Libro Segundo del Código Civil de Cataluña, relativo a la persona y familia que entró en vigor el 1 de enero de 2011, la Ley 2/2010, de 26 de mayo, de igualdad en las relaciones familiares ante la ruptura de la convivencia de los padres. Asimismo el Decreto Legislativo 1/2011, de 22 de marzo, del Gobierno de Aragón, por el que se aprueba el Texto Refundido de las Leyes Civiles Aragonesas ${ }^{376}$. Finalmen-

11 marzo 2010 (RJ 2010, 2340).- Por ello la interpretación del Art. 92, 5, 6 y 7 CC debe estar fundada en el interés de los menores que van a quedar afectados por la medida que se deba tomar, que se acordará cuando concurran alguno de los criterios antes explicitados y que la redacción de dicho artículo no permite concluir que se trate de una medida excepcional, sino que al contrario, debería considerarse la más normal, porque permite que sea efectivo el derecho que los hijos tienen a relacionarse con ambos progenitores, aun en situaciones de crisis, siempre que ello sea posible y en tanto en cuanto lo sea."

373 IVARS RUIZ, J. "Guarda y custodia compartida. Aspectos procesales y sustantivos. Doctrina y jurisprudencia”, Ed. Tirant Lo Blanch, monografías, núm. 577, Valencia, año 2008, página 217.

374 CAMPO IZQUIERDO, A. L. "La conflictividad y los procesos matrimoniales”, Boletín de Derecho de Familia, El Derecho núm. 59 EDB 2006/102528, Julio 2006. Cfr. VIVES MARTÍNEZ, G. "Custodia compartida, valoración de la prueba y victimización de los menores. Una visión objetiva desde la Magistratura y la experiencia”. Economist \& Iurist, Noviembre, Madrid, año 2007.

375 IVARS RUIZ, J, “Guarda y custodia compartida. Aspectos procesales y sustantivos. Doctrina y jurisprudencia”... op. cit., página 222; Cfr. ALSACIO CARRASCO, L y MARÍN GARCÍA, I. “Juntos pero no revueltos: la custodia compartida en el nuevo artículo 92 CC”, INDRET, Revista para el análisis del Derecho. 3/2007, Barcelona, Julio de 2007, páginas 17 y 18; GUARRIGA GORINA, M. "El criterio de la continuidad frente a la guarda conjunta”,...op. cit., página 13. "La regulación de los criterios legales de atribución de la guarda puede señalar la preferencia política por un sistema de organización familiar más o menos igualitario, pero no va a modificar los roles de género. Es por ello que la idea del approximation es adaptar la distribución de la guarda de los hijos a la dinámica de cada familia y evitar imponer a todas ellas unos mismos modelos de funcionamiento. La finalidad es lograr soluciones realizables, respetuosas con las preferencias de cada familia, que permitan la continuidad de las relaciones de los hijos con sus padres tras el divorcio y que mitiguen el carácter enfrentado de las relaciones entre ellos."

376 Decreto Legislativo núm. 1/2011 y Texto Refundido que aprueba, con el título de "Código del Derecho Foral de Aragón”, el Texto Refundido de las Leyes civiles aragonesas. En ella se manifiesta que la presente regulación, respondiendo a una importante demanda social, supone un cambio del esquema tradicional, al configurar la custodia compartida frente a la individual como norma preferente en los supuestos de ruptura de la convivencia entre los padres y en ausencia de pacto de relaciones familiares. Con este cambio se pretende favorecer el mejor interés de los hijos y promover la igualdad entre los progenitores. La finalidad de la custodia compartida es un reparto efectivo de los derechos y responsabilidades de los padres, fomentando las relaciones afectivas y continuadas de convivencia con los hijos y la participación directa en su desarrollo y educación. La custodia compartida, tal y como se configura en esta Sección, no implica necesariamente una alternancia de la residencia de los hijos con sus progenitores en periodos iguales, pero sí en un tiempo adecuado para el cumplimiento de la finalidad de la custodia compartida. 
te, la Generalitat valenciana siguiendo el camino abierto por las Comunidades recién mencionadas, ha dictado la Ley 5/2011, de relaciones familiares de los hijos e hijas cuyos progenitores no convi$\operatorname{ven}^{377}$, esta norma tiene por finalidad la regulación del régimen de guarda y custodia compartida como mecanismo idóneo para cumplir con las diversas obligaciones que nacen de la patria potestad, amparándose en el principio de coparentalidad, provocando que ambos progenitores participen igual en la toma de decisiones que afectan a los intereses de sus hijos menores.

Este grupo de leyes autonómicas se alinean en la postura que hace primar la guarda y custodia compartida, a diferencia de la Ley Navarra, Ley Foral 3/2011, de 17 de marzo, sobre custodia de los hijos en caso de ruptura de la convivencia de los padres, la cual de una u otra manera atribuye mas discrecionalidad al juez para determinar el modo de ejercicio de la guarda y custodia de los hijos menores.

\subsection{Especial referencia a la maternidad, paternidad y familia. Comentarios a propósito de la Ley orgánica para la igualdad efectiva de mujeres y hombres.}

El concepto de conciliación denota conflicto $^{378}$ : ¿Por qué conciliar?, ¿para qué?, conciliamos algo porque ha provocado enfrentamientos, problemas, entre distintas partes con intereses contrapuestos. La mayoría de los casos que tratan de la conciliación familiar y laboral son vistos desde una perspectiva feminista, partidista, en la que se trabaja en contra de la discriminación que todavía sufre la mujer hoy día en todo el planeta, y concretamente en el caso que nos concierne en España. La acepción de conciliación que se emplea en este trabajo es aquella que la entiende como una situación de "pluripresencia" (laboral, familiar, personal) que cualquier persona intenta afrontar a lo largo de su vida, para compaginar lo mejor posible los distintos aspectos que consiguen dotarla de identidad personal, familiar y social, tal cual lo deja ver VALPUESTA FERNÁNDEZ ${ }^{379}$.

377 Esta norma ha sido recurrida de inconstitucionalidad mediante el recurso de inconstitucionalidad núm. 3859/2011. El Pleno del Tribunal Constitucional por providencia de 19 de julio de 2011 lo acogió a trámite. Este recurso invoca el art. 16.2 de la CE, lo que produce la suspensión de la vigencia y aplicación de los preceptos impugnados desde la fecha de interposición del recurso.

378 El Derecho a conciliar la vida laboral y familiar o personal presenta un contenido indefinido, abierto, moldeable, lo que permite cuestionar la admisibilidad de derechos atípicos de conciliación. Desde el punto de vista teórico, según la previsión legal del derecho y la regulación de su contenido, cabe distinguir entre derecho típicos y atípicos de conciliación. Loa atípicos pueden entenderse según el artículo 44 de la Ley 3/2007: "se reconocerán en forma que fomenten la asunción equilibrada de responsabilidades familiares, evitando toda discriminación basada en su ejercicio". Esto se funda en el carácter abierto, dinámico, evolutivo y actualizable del derecho de conciliación, existe, sin lugar a dudas, una necesidad de renovarlo ante el eventual fracaso o infrautilización de los previstos legalmente. Asimismo, la configuración legal de la conciliación como derecho dispositivo cuyo contenido se diseña a través de los planes de igualdad y convenios colectivos, permite considerar priori este derecho como atípico.

379 Vid. VALPUESTA FERNÁNDEZ, Ma " El Derecho de Familia desde una perspectiva de género", en NAVAS NAVARRO, S. (Dir.), “Iguales y diferentes ante el Derecho Privado”, Ed. Tirant Lo Blanch, Homenajes y Congresos, Valencia, año 2012, página 343. "Como hemos dicho, la exigencia constitucional contenida en el art. 14 
RUIZ-RICO RUIZ, a su vez, estima que el recurso al término conciliación como definitorio de la dicotomía actual existente entre ambas, y con esto se refiere a las esferas laboral y familiar o personal, se fundamenta en la deficiente respuesta del Derecho a la problemática derivada de la confluencia de ambas responsabilidades. En efecto, el binomio trabajo-familia se ha forjado principalmente por la ausencia de mecanismos jurídicos amortiguadores de los efectos negativos que la superposición de roles produce en el acceso al trabajo, la promoción y el desarrollo de las relaciones laborales y profesionales ${ }^{380}$.

Debe aclararse que la noción de conciliación fue introducida en el ordenamiento español por la Ley 39/1999. de 5 de noviembre, cuya aprobación vino condicionada por la Directiva 96/34/CE, de 3 de junio de 1996, sobre el permiso parental que supuso un cambio de orientación en el enfoque de la materia. Desde esta perspectiva con la nueva Ley empieza a prestarse atención a la problemática de la conciliación de la vida familiar y laboral, lo cual deja de importar únicamente al ámbito privado, para ser también de una importancia pública, por lo cual el legislador debe prestarle atención $^{381}$.

La sociedad moderna actual exige a sus miembros (hombres y mujeres) una respuesta a las demandas que se suscitan desde muy diferentes campos, al mismo tiempo que la compresión de que la igualdad es compañera de la solidaridad y el respeto, por ello estimo ya arcaico el pensamiento en torno a que sólo el trabajo remunerado es trabajo, porque posiblemente dejamos fuera a

$C E$, de no discriminación por razón de sexo, se ha impuesto al Derecho de familia tradicional, hasta el punto de modificar todas aquellas disposiciones que excluian a las mujeres de las decisiones sobre la familia.- Pero el género es algo más que la mera diferencia sexual, es la sublimación de esa diversidad hasta el punto de asignar roles diferentes a las mujeres y a los hombres, unos roles que si bien se sustentan en última instancia en el sexo de uno u otro, responden a de aptitudes y capacidades especificas que han de traducirse en una distinta posición en el seno de las relaciones familiares y, muy especialmente en lo que concierne al cuidado y atención de los hijos.- Prueba de ello es la maternidad, pues evidente que sólo las mujeres pueden tener esta experiencia, y también podemos convenir que la presencia de la madre, sin ser indispensable, es muy importante para los hijos en su temprana edad; de ahi la relevancia de las normas laborales que regulan los permisos de maternidad, las licencias por lactancia y otras disposiciones que se refieren al riesgo durante el embarazo. Ahora bien, de lo anterior no podemos extraer como conclusión que el desarrollo de los hijos y su formación atrae a las madres en mayor medida que los padres, pues esta aseveración no tiene que ver con la biología, sino con la construcción social que de tales roles se ha hecho, asta el punto de dispensar un dispar tratamiento a los padres, por el simple hecho de que no han dado a luz a los hijos. Crítica que cobra aún más fuerza en los supuestos en los que la relación paterno filial tiene su origen en la adopción. Y en este punto hay que afirmar que las normas que regulan las consecuencias de la maternidad en todos los órdenes aún reflejan la fuerza del género." Cfr. VALPUESTA FERNÁNDEZ, Ma " "La Ley Orgánica para la Igualdad efectiva de Mujeres y Hombres", en Teoría y Derecho, Revista de Pensamiento Jurídico, núm. 1/2007, página 265 y siguientes.

380 "El derecho constitucional a conciliar la vida laboral, familiar y personal", Ed. Tirant Lo Blanch, Monografías, núm. 802, Valencia, año 2012, página 15.

381 MOLERO MARAÑÓN, Ma. L. "Derechos de conciliación: Derechos de Adaptación y, Reducción del Tiempo de Trabajo. Suspensión por Paternidad y Excedencias familiares", en "Igualdad de Género y Relaciones Laborales", VALDÉS DAL-RÉ y QUINTANILLA NAVARRO, B (Dirs.), Ministerio del Trabajo e Inmigración-Fundación Largo Caballero, Madrid, año 2008, página 211. 
una buena parte de la población que desempeña labores domésticas que requieren una responsabilidad y compromiso quizás aún mayor y más personal, crítica ya manifestada con anterioridad.

En ese contexto socio-cultural las tareas relacionadas con el entorno doméstico se vuelven invisibles y por ello quedan al margen de valoración alguna y, es más, responden a un menor reconocimiento y prestigio social. Ha sido a raíz de la incorporación de la mujer al mercado de trabajo, fenómeno que va en crecimiento, cuando la sociedad comienza a valorar sus aportaciones tanto al seno familiar como al conjunto de la sociedad ${ }^{382}$.

Se ha hecho necesario una transformación de la cultura laboral y empresarial para hacer posible la compatibilidad del trabajo y de la vida familiar, no sólo para las mujeres, sino también para los hombres, que han de incorporarse en mayor medida a responsabilidades domésticas y de cuidado familiar ${ }^{383}$. Para lograr esta transformación se han de cambiar las mentalidades de todos.

Cambiar de mentalidad, sin duda, es el único camino para hacer realidad esa igualdad de derechos entre las mujeres y los hombres ${ }^{384}$. Se sabe que la redistribución de roles sociales entre ambos sexos se encuentra muy condicionada por el papel que históricamente han ocupado el hombre y la mujer a lo largo de la historia, por ello hoy en día constituye un paso pendiente la incorporación de los hombres en la vida familiar, compartiendo con la mujer las responsabilidades del hogar, la familia y los hijos. La consecución de tal objetivo constituye una medida eficaz y efectiva para que la mujer se incorpore plenamente en el mercado de trabajo, por ello los poderes públicos deben de fomentar el cambio y la modificación del rol de los hombres, no en sentido de desvirtuar la personalidad de que goza el sexo masculino, sino haciendo énfasis en la colaboración de las tareas ${ }^{385}$.

382 Respecto de los conflictos entre límites del derecho a conciliar la vida laboral y familiar o personal, destaca el riesgo de colisión de la protección de la familia y la libertad de empresa. En principio, no cabe alegar la primacía del derecho constitucional a la libertad empresarial sobre la tutela de la familia, menores o mayores. En particu lar, la protección de la familia como principio rector de las políticas ha alcanzado la consideración de principio general del Derecho, informador del ordenamiento jurídico, y por tanto, valor de fuente del derecho. La transversalidad de este principio jurídico permite incluso su anteposición a la libertad de empresa cuando al ponderar el conflicto no es posible la armonización entre ambos, sobre todo cuando se trata de obligaciones familiares que pueden generar responsabilidades y que por tanto resultan inexcusables o bien calificables como de fuerza mayor, su relevancia jurídica de tal modo es capaz de limitar la libertad empresarial.

383 En este sentido, la indiferencia inicial del Derecho en torno a la compatibilidad de la vida laboral y familiar reflejaba una prolongación del desinterés social y empresarial sobre la necesidad de armonizar ambas realidades; sin que tampoco la política haya actuado como eje vertebrador de una conciencia social y jurídica en éste ámbito hasta fechas recientes. Por esta razón, la incultura social y política de la conciliación ha obstruido el desarrollo mismo de la función jurídica en esta materia, acomodando el Derecho a la realidad en vez de recurrir a su virtua lidad transformadora para cambiar la rígida organización laboral.

384 Por tal motivo, la buena fe de todos los agentes sociales con una actitud proclive a facilitar y flexibilizar la vida laboral y familiar, promueve la implantación de este derecho. Sin perjuicio existe un tarea no menos importante y aún previa, el desterrar las suspicacias de fraude y de incumplimiento contractual asociadas al ejercicio del derecho de conciliación, obstaculizadoras de su natural desenvolvimiento. Cfr. RUIZ-RICO RUIZ, C. "El derecho constitucional a conciliar la vida laboral, familiar y personal”, ... op. cit. página 25.

385 Exposición de Motivos de la Ley 3/2007, de 22 de marzo, para la igualdad efectiva de mujeres y hombres. 
Si bien es una realidad ya aceptada en el ámbito legal ${ }^{386}$ y el político, todavía no se encuentra extendida en el ámbito socio económico, por todos los ciudadanos, hombres y mujeres. Las claves, a su vez, que ayudan a explicar el trasfondo de las dificultades actuales por las que atraviesa la conciliación de la vida laboral, familiar y las políticas implicadas, se encuentran en la fuerza de las pautas y valores sociales asumidos por hombres y mujeres en torno a dicho contrato social y a dicho modelo. La reivindicación por la igualdad entre los sexos y el aumento del empleo femenino se ha convertido en un fenómeno universal, pero las consecuencias de tales tendencias en los conflictos entre la vida laboral y familiar dependen no sólo de las políticas estatales sino también de la diferente persistencia del arraigo de las normas tradicionales relativas al género en lo que respecta a la división del trabajo y de los roles familiares ${ }^{387}$.

Nuestra civilización, tal cual se ha dicho anteriormente ha consagrado la igualdad entre el hombre y la mujer, lo que es una conquista relativamente reciente. Ejemplo de lo anterior son las luchas de las sufragistas en las calles exigiendo el derecho a votar en las elecciones públicas, antiguamente la expresión cabeza de familia, que solía coincidir normalmente con la figura del marido y padre, nos remitía al viejo pater familia romano, hace no muy poco era el marido quien decidía la elección del domicilio familiar, ejercitaba por sí sólo la patria potestad sobre los hijos, y llevaba a cabo en solitario la administración y disposición de los bienes conyugales, ¿Qué ha quedado de ello? Es más, era el marido quien representaba legalmente a la mujer. En 1969 juristas como DE LA CÁMARA ÁLVAREZ consideraba la primacía del varón dentro de la esfera familiar como un

386 Ejemplos de ello son la Ley 3/2011, de apoyo a la familia y la convivencia en Galicia. art. 6, 2 b): "Principio de igualdad. $1^{\circ}$ ) Se reconocerá y respetará la igual dignidad de hombres y mujeres, la igualdad de sus derechos y su corresponsabilidad en la vida familiar, particularmente en el mantenimiento, cuidado y educación de los hijos e hijas, ascendientes y personas a su cargo. $2^{\circ}$ ) Se promoverá la igualdad de oportunidades de los hombres y las mujeres en el acceso al mundo laboral y en la asunción de las tareas familiares, mediante actuaciones que procuren la conciliación de la vida personal, familiar y laboral. $3^{\circ}$ ) Se reconocerá a los niños, niñas y adolescentes su dignidad y se promoverá el ejercicio pleno de los derechos y responsabilidades que tienen reconocidos en las convenciones internacionales y en nuestro ordenamiento jurídico."

387 STSJ, Castilla-La Mancha, Sala de lo Social, Sección 1º, núm. 174/2011 de 15 febrero. AS 2011/103 “Aplicando lo expuesto al presente supuesto, y partiendo de que no existe la obligación de no trabajar durante la excedencia para cuidado de hijos, es de ver que, además, existen motivos razonables y lógicos para entender que las circunstancias y condiciones en que se desarrolla el trabajo en el SESCAM, especialmente el horario, de 8 a 15 horas, coincidente con el de la guardería que atiende al hijo menor, que no abre por las tardes, permite a la actora conciliar la vida laboral con la familiar de mejor manera que el trabajo para la empresa demandada, en el que tenía que prestar servicios también por las tardes. Así pues, la opción de la actora por situarse en excedencia en la empresa demandada para trabajar en el SESCAM es absolutamente razonable, por lo que no puede considerarse realizada en fraude de ley." 
principio inmutable por ser de derecho natural, así lo expresa RAGEL SÁNCHEZ ${ }^{388}$. ¿Qué ha pasado?

Las sucesivas reformas legislativas de 1958, 1975, 1981, 1990 y 2005 han desembocado en una plena igualdad de los cónyuges ante la ley. Ya no existe ningún precepto legal, que establezca una diferencia de trato para hombre y mujer y actualmente, tal como ya se ha analizado, una persona se puede casar con otra de su mismo sexo ${ }^{389}$. Debido a ello la ley les llama ahora cónyuges y les concede uso de derechos que son ejercitables indistintamente por uno u otro. La igualdad ante la ley significa igualdad de oportunidades y de posibilidades jurídicas, es decir, un trato legal exactamente igual a las personas que se hallen en la misma situación legal, en este caso los cónyuges. Para la STC 45/1989 de 20 de febrero (RTC 1989, 45) 390 $^{39}$ la ley debe asegurar la plena igualdad de los cónyuges. Por esa razón, pensamos que es totalmente acertada la supresión que efectúo la Ley 11/1990, de 15 de octubre, de la preferencia de que gozaba anteriormente la madre para vivir en compañía de los hijos menores de siete años, en caso de separación de los progenitores.

La igualdad de los cónyuges ante la ley es la situación más deseable. Es también una clara manifestación del pleno reconocimiento de la dignidad de la persona como fundamento esencial de

388 YZQUIERDO TOLSADA, M y CUENA CASAS, M. (Dir). "Derecho de familia y Derecho de la familia. La relación jurídico-familiar. El matrimonio y su celebración” en "Tratado de Derecho de familia”, Volumen I,, Ed. Thomson Reuters, año 2011, Pamplona. RAGEL SÁNCHEZ, L.F. Capítulo 6, "Efectos personales matrimonio”, página 675 cita a DE LA CÁMARA ÁLVAREZ, M. "La separación de hecho y la sociedad de gananciales”, Anuario de Derecho Civil, año 1969, páginas 3 y siguientes.

389 LÓPEZ DE LA CRUZ, L., "La incidencia del principio de igualdad en la distribución de las responsabilidades domésticas y familiares. (La nueva redacción del artículo 68 del Código Civil tras la reforma operada por la Ley 15/2005, de 8 de julio)", ...op., cit. página 11. "No obstante aún queda tambien mucho camino por recorrer para la equiparación entre hombres y mujeres en el plano legal. Póngase como ejemplo el Proyecto de Ley orgánica para la igualdad efectiva de mujeres y hombres, que como medida para favorecer la conciliación de la vida familiar y laboral de los trabajadores amplía el permiso por paternidad a ocho días, y comparémoslo con las dieciséis semanas que corresponden a la madre (disposición Adicional 11). La diferencia cuantitativa repercute tanto en el marco laboral, a la hora e acceder a un puesto de trabajo con mayor o menor facilidad, como en el aspecto familiar, en cuanto a la participación real y efectiva del padre en la atención y el cuidado de sus hijos recien nacidos".

390 STC, Pleno, núm. 45/1989 de 20 febrero. RTC 1989/45. “Esta es, en el apartado primero del art. 39 C. E. la familia, una institución cuya trascendencia social no necesita ponderación y cuya definición exacta desde el punto de vista constitucional no es problema que ahora deba ocuparnos. Sea cual fuere, en efecto, el concepto constitucionalmente adecuado de familia, no es discutible que tal concepto incluya sin duda la familia que se origina en el matrimonio, que es en todo caso la que especialmente toman en consideración tanto la Declaración Universal de Derechos Humanos aprobada por las Naciones Unidas en 1948 (ApNDL 3626) (art. 16.1), como los Tratados sobre Derechos Fundamentales suscritos por España [así el Convenio de Roma -art. 12 ..., el Pacto Internacional de Derechos Civiles y Politicos -art. 23... y el Pacto Internacional de Derechos Económicos, Sociales y Culturales -art. 10.1... El régimen del matrimonio está diferido por la Constitución (art. 32) a la Ley, con la importante precisión de que ésta ha de asegurar, en todo caso, la plena igualdad jurídica de los cónyuges, un mandato éste del que se deduce naturalmente la necesidad de que el legislador, teniendo siempre en cuenta la realidad objeto de regulación, no condicione o determine la situación de los cónyuges de manera que ésta no sea efectivamente igual en el ejercicio de los derechos, por ejemplo, y por la inmediata relación que guarda con el tema que ahora nos ocupa, en el ejercicio del derecho al trabajo y a la libre elección de profesión u oficio. “ 
nuestra sociedad ${ }^{391}$, así como de la vigencia e imperio del principio del libre desarrollo de la personalidad.

No puede desconocerse, que la aprobación de la denominada Ley de Igualdad, “...por sus ambiciosos objetivos, por las múltiples reformas legislativas que conlleva y por la implicación de muchos y variados sujetos, públicos y privados, en la consecución de sus fines”, ha protagonizado un nuevo planteamiento respecto a la igualdad. ¿De qué manera se ha producido este nuevo planteamiento?

Sin lugar a dudas esta Ley ha querido influir en la sociedad, incluso en el ámbito privado. Proclamada como Ley transversal ${ }^{392}$, opera con un instrumento o concepto, la transversalidad “nacido en el área de la sociología organizativa y que pronto se ha introducido en el lenguaje jurídico" ${ }^{\text {"393. }}$.

En lo que interesa y prescindiendo de otras muchas y relevantes novedades que afectan a las esferas civil, económica, laboral, etc ${ }^{394}$, la Ley de la Igualdad, eleva las políticas de conciliación de la vida personal, familiar y laboral a pilar básico de las políticas de igualdad entre hombres y mujeres, considerando además que aquellas son una finalidad prioritaria de la protección social de la familia. Desde esta perspectiva, en la medida en que la maternidad coloca a la mujer en un plano de dificultad para realizar su actividad laboral, la norma incorpora sustanciales mejoras en su tratamiento como causa de suspensión del contrato y en las correspondientes prestaciones del Sistema de Seguridad Social. Así, además de dotar de mayor flexibilidad al hecho que justifica la suspensión de la misma, amplía su duración en ciertos casos y admite su simultaneidad con la nueva situación suspensiva de paternidad, para algunos la auténtica medida estrella de la iniciativa legal.

Con éstas y otras medidas, que contribuyen a un reparto más equilibrado en los ámbitos familiar y laboral se ha intentado influir para que la sociedad adopte una serie de buenos hábitos cívicos para consolidar su relevante papel en la aceptación de la igualdad de trato entre hombres y mujeres

391 RAGEL SÁNCHEZ, L.F. Capítulo 6, “Efectos personales matrimonio” YZQUIERDO TOLSADA, M y CUENA CASAS, M. (Dir), “Derecho de familia ”, ... op. cit., página 676.

392 Vid. LOUSADA AROCHENA, J. F. "El principio de transversalidad y el Derecho de la Seguridad Social”, Civitas Revista española de Derecho del Trabajo, núm.106/2001 parte Estudios, Ed. Civitas S.A., Madrid. 2001.

393 GONZALEZ-POSADA MARTÍNEZ, E y ROBLES CIFUENTES, H. “Los aspectos laborales de la Ley Orgánica para la Igualdad Efectiva de Mujeres y Hombres”, Ed. Aranzadi, Pamplona, año 2007, página 13.

394 VARgas GAllego, A. I. "Título II. Políticas públicas para la igualdad. Capítulo Primero. Principios generales”. En ROMÁN GARCÍA, F. (Dir.) “Análisis de la Ley Orgánica 3/2007, de 22 de marzo, para la igualdad efectiva de mujeres y hombres”, El Derecho Editores, Madrid, año 2007, página 51. “La transversalidad del principio de igualdad, en tanto que supone inyectar este principio en todos los ámbitos de funcionamiento de los poderes públicos, ve su necesario complemento en la consideración de la igualdad como principio informador del ordenamiento jurídico, que se ha de integrar y observar en la interpretación y aplicación de las normas, carácter que le otorga expresamente el art. 4 de la LOIMH que establece que la igualdad de trato y de oportunidades entre mujeres y hombres mujeres es un principio informador del ordenamiento jurídico y, como tal, se integrará y observará en la interpretación y aplicación de las normas jurídicas." 
y la progresiva asunción por los primeros de responsabilidades tradicionalmente asumidas en exclusiva por las segundas, como elemento normal de convivencia. Con todo, aún teniendo en cuenta que el propósito igualador de la Ley de Igualdad se desenvuelve en el ámbito de la erradicación de la discriminación entre sexos, de algunas de las medidas articuladas pueden derivarse otras diferencias de trato, igualmente intolerables, si bien por razón de la filiación. Aunque es laboral la norma que contempla y daría cobertura a las eventuales desigualdades, no pasa desapercibida su implicación constitucional $^{395}$, situándose también de lleno en el campo del Derecho de familia y en la protección dispensada a la institución familiar.

Entre ellas cabe referirse a las potenciales desigualdades resultantes de una diferente filiación, biológica o por adopción, o, desde la perspectiva de los progenitores, referidas a la maternidad y paternidad consiguientes en ambos casos y al ejercicio por aquéllos de ciertos derechos. Sobre tales diferencias de trato -o, mejor incoherencias en el trato- convendría hacer una reflexión, si bien algunas quizás tengan su razón de ser en la propia técnica legislativa de la Ley de Igualdad que, como es sabido contiene dos niveles diferenciados de regulación, sumando a su articulado un total de treinta y una disposiciones adicionales que modifican un amplio elenco de leyes vigentes.

$\mathrm{Al}$ proceder de este modo es posible que el legislador no reparase en los resultados de las puntuales modificaciones operadas y su falta de sintonía con preceptos que debieron ser igualmente objeto de nueva redacción, pero lamentablemente es una carencia del hacer legislativa, una falta de rigor que España no debiera permitirse, pero lo ha hecho hasta el punto de afirmar que ya forma parte de cómo se dictan leyes en el Derecho de familia actual. Otras, por el contrario, traen causa en la pretendida protección de la salud y recuperación de la madre tras el parto y, en consecuencia, de la maternidad como hecho biológico lo que, siendo teóricamente plausible, parece casar mal con el reconocimiento y dinámica de otros permisos que, en la actualidad, no quedan circunscritos al vínculo estrictamente maternal por tener una dimensión familiar ${ }^{396}$.

Es el caso, por citar algún ejemplo, de la titularidad del derecho a suspender el contrato de trabajo por maternidad ${ }^{397}$-que, en caso de parto, será de la madre trabajadora, quien puede o no ceder-

395 Conforme al art. 39.1 CE los poderes públicos aseguran, asimismo la protección integral de los hijos, iguales éstos ante la ley con independencia de su filiación, y de las madres, cualquiera sea su estado civil.

396 Es el caso del permiso de lactancia de un hijo menor de nueve meses que, aunque reconocido a las trabajadoras en el art. 37.4 el Estatuto de los Trabajadores (Texto Refundido aprobado por el Real Decreto Legislativo 1/95, de 24 de marzo) puede ser disfrutado por la madre o el padre en caso de que ambos trabajen confirmándose con ello que es el interés del menor y los cuidados familiares los que dan sentido a la medida.

397 Prestación que, en cualquier caso, es de maternidad, según dispone el Capítulo IV BIS de la Ley General de la Seguridad Social (Texto Refundido aprobado por Real Decreto Legislativo 1/94, de 20 de junio) cuyo art. 133 bis contempla, como situaciones protegidas, tanto la maternidad como la adopción y el acogimiento, pudiendo beneficiarse del subsidio, conforme al art. 133 ter. los trabajadores por cuenta ajena, cualquiera que sea su sexo. 
lo al padre, no siendo así en caso de adopción o acogimiento en los que cualquiera de los dos adoptantes o acogedores ostenta la titularidad. En términos similares, a mi juicio, se contempla el derecho de suspensión del contrato de trabajo por paternidad que, en el supuesto de parto, corresponde en exclusiva al otro progenitor, mientras que, en caso de adopción o acogimiento, es reconocido sólo a uno de los progenitores, a elección de los interesados. Ha de reseñarse, igualmente, la desigualdad resultante de mantener el permiso de dos días por nacimiento del hijo -lo que, evidentemente, sólo alcanza a los biológicos-, dándose continuidad a una diferencia de trato respecto a la filiación adoptiva, que tampoco ha sido corregida. Por citar, un último ejemplo, éste sí de reciente existencia, puede hacerse referencia a la nueva versión o modalidad no contributiva de la prestación por maternidad de las que únicamente podrán ser beneficiarias las madres biológicas no así las adoptantes- que reúnan todos los requisitos para causar derecho al subsidio, salvo el período previo de cotización.

Estimo que si bien el fundamento de igualdad que ha inspirado la ley es del todo loable, el sistema empleado, una ley de transversalidad, no ha sido el idóneo por cuanto ha dejado bastantes aspectos del ordenamiento jurídico de manera inconexa.

A nivel europeo, el art. 23 de la Carta de los Derechos Fundamentales de la Unión Europea que obviamente ha influido en la Ley recién reseñada, expresa: “Igualdad entre mujeres y hombres. La igualdad entre mujeres y hombres deberá garantizarse en todos los ámbitos, inclusive en materia de empleo, trabajo y retribución.

El principio de igualdad no impide el mantenimiento o la adopción de medidas que supongan ventajas concretas en favor del sexo menos representado”. En relación a este artículo se encuentra la Directiva 2006/54, refundición, de 26 de julio de 2006, sobre la aplicación del principio de igualdad de oportunidades e igualdad de trato entre mujeres y hombres en asuntos de empleo y ocupación, así como la Directiva 2010/41, de 7 de julio de 2010, sobre la igualdad de trabajo autónomo, esta última ha permitido que los países de la Unión Europea puedan adoptar medidas de acción positiva, así la Directiva 2010/18, sobre el permiso parental por motivo de nacimiento o adopción de un hijo. Según esta modificación de las Directivas 96/34 y 97/75, los trabajadores han de tener el derecho a un permiso parental por motivo de nacimiento o adopción de un hijo, añadiendo que dicho permiso puede tomarse hasta que el niño alcance una edad determinada que las legislaciones nacionales o los convenios colectivos definen, puede ser de hasta ocho años. Además la Directiva se aplica por igual a todos los trabajadores, ya sean hombres o mujeres e independientemente de su tipo de contrato (indefinido, temporal, a tiempo parcial o interinidad). En el mismo sentido ha cam- 
biado su duración mínima que es de cuatro meses. En principio, el permiso debe poder ser utilizado plenamente por cada trabajador, sin que tenga por tanto que transferirse de un progenitor al otro, sin perjuicio este tipo de transferencia se puede autorizar siempre que cada progenitor conserve al menos uno de los cuatro meses de permiso.

MONEREO ATIENZA ${ }^{398}$, explica que los Estados de la Unión Europea o los interlocutores sociales pueden: adaptar el permiso a las necesidades de los trabajadores y de los empresarios, acordando un permiso a tiempo completo o parcial de manera fragmentada o conforme a un sistema de crédito de tiempo, subordinar dicho derecho a un período de antigüedad, que no puede ser superior a un año; autorizar un aplazamiento del permiso por el empleador, por razones justificables vinculadas a la empresa; autorizar acuerdos particulares para garantizar el buen funcionamiento de las pequeñas empresas.

Aparte de estas Directivas, para concluir este punto, a nivel europeo existen multitud de Comunicaciones, Recomendaciones y Resoluciones, así como Informes que promueven la igualdad entre mujeres y hombres en varios ámbitos. Cabe destacar la Carta de la Mujer, esto es, la Comunicación de la Comisión de 5 de marzo de 2010 titulada "Un compromiso reforzado en favor de la igualdad entre mujeres y hombres-Una Carta de la Mujer: Declaración de la Comisión Europea con Motivo del Día Internacional de la Mujer 2010 en conmemoración del 15º aniversario de la adopción de la Declaración y la Plataforma de Acción de la Conferencia Mundial de las Naciones Unidas sobre la Mujer celebrada en Pekín, y del $30^{\circ}$ aniversario de la Convención de las Naciones Unidas sobre la Eliminación de todas las Formas de Discriminación contra la Mujer” (COM 201078 final), no publicada en el Diario Oficial.

\section{4 | Igualdad de género y Derecho civil. La situación de la mujer. Una relación que se intenta armonizar vía reformas legislativas y jurisprudencialmente}

La palabra "sexo" generalmente se usa para hacer alusión a las diferencias biológicas relacionadas con la reproducción y otros rasgos físicos y fisiológicos entre los seres humanos. El sexo, como parámetro para crear categorías, distingue entre hombres y mujeres, entre machos y hembras de la especie humana. "Género" se refiere sin embargo a las personas de uno u otro sexo, implicando diferencias por tanto de origen social, educativo, cultural etc. En síntesis se podría definir como la construcción socio-cultural de esa diferencia. Los atributos de género son, entonces, femeninos o

398 "Artículo 23. Igualdad entre mujeres y hombres" en MONEREO ATIENZA, C y MONEREO PÉREZ, J. L. (Dirs.) "La Europa de los Derechos. Estudio Sistemático de la Carta de los Derechos Fundamentales de la Unión Europea”, Ed. Comares, Granada, año 2012, páginas 504 a 509. 
Capitulo II El Principio de igualdad y el Derecho de Familia - Igualdad de género y Derecho civil. La situación de la mujer. Una relación que se intenta armonizar vía reformas legislativas y jurisprudencialmente

masculinos, y esa construcción del género no es inocente ni natural, obedece a unos determinados intereses estructurales según SÁNCHEZ DÍAZ ${ }^{399}$.

En tal sentido se tienden ha considerar atributos de la mujer, los comportamientos sensibles y delicados, el afán de tranquilidad y paz en la conducta, los gestos de cuidado hacia los otros, la inclinación por las tareas domésticas y manuales, la menor capacidad de abstracción, etc. Mientras que para los hombres, se han considerado a lo largo de la historia, en oposición a los comportamientos antes detallados, la brusquedad en las actuaciones, la violencia, el egoísmo, la competitividad, una mayor capacidad de abstracción, etc. De esta manera una cosa son las diferencias biológicamente dadas y otra la significación que culturalmente se asigna a esas diferencias, sobre esto último destaco el estudio propiciado por ELOSEGUI ITXASO ${ }^{400}$.

Ante la pregunta de cuándo ha tenido su origen "masivo" el concepto de género, debe responderse que éste se ha introducido en la teoría feminista en los años setenta ${ }^{401}$, y se destaca por cuanto ha sido empleado principalmente por dichos movimientos como ideología base en sus reivindicaciones, de diverso tipo, sobre todo en el ámbito político, sin embargo profesionales de otras áreas, tales

399 “El trabajo en RENFE: un análisis de género”. Sociología del trabajo, núm. 50, años 2003/2004, página 61.

400 Se ha propuesto al respecto, tres modelos: 1) El primero consistiría en la identidad sexo y género (el cual consi dera falso y superado) consistente en la interpretación de que a cada sexo le correspondería por necesidades bi ológicas unas funciones sociales, invariables a lo largo de la historia. A esto se añadiría la justificación biológica y cultural de la subordinación de la mujer al hombre; 2) el segundo modelo lo denomina "independencia entre sexo y género". Equiparación asimilacionista que surge a raíz de las reivindicaciones de los primeros movimientos feministas de los sesenta. Reclamaban la independencia de la mujer con respecto al varón, entendiéndose ahora su situación como la de igualdad sin diferencia. Ser iguales significaba ocupar los lugares que en el mundo público sólo habían pertenecido a los hombres, es decir, suplantarles adoptando sus maneras, imitando lo modos masculinos (como se apreciaba incluso en la moda unisex).Se produce así una paradoja, la mujer imita al hombre, queriendo a su vez liberarse del ámbito propiamente femenino. La igualdad se entiende en términos de una equiparación hombre-mujer, en términos asimilacionistas, significaba homogeneidad, y la legislación no debía hacer ninguna diferencia basada en el sexo; 3) El tercer modelo consistiría en la relación género y sexo pero no en su identidad. Interdependencia - corresponsabilidad, donde se entiende que la perspectiva de género es adecuada para descubrir los aspectos culturales que rodean a la construcción de las funciones del hombre y la mujer en el contexto social. Si los sexos son necesariamente varón o mujer, afirma la autora, las funciones atribuidas culturalmente a cada sexo pueden ser en algunos aspectos intercambiables. El género en ciertas de sus dimensiones se fundamenta en el sexo biológico, pero otras muchas de las funciones o del reparto de las tareas consideradas en una época $u$ otra son algo absolutamente aleatorio y no tiene ninguna base biológica. Dependen en este caso de los estereotipos formados por el grupo social, por las costumbres o por la educación. Este tercer modelo propugna la interdependencia entre los distintos sexos: una igualdad por la diferencia. Reivindica que los dos sexos deben estar simultáneamente presentes en el mundo de lo privado y lo público. Cfr. ELOSEGUI ITXASO, M. "Diez temas de género. Hombre y mujer ante los derechos productivos y reproductivos". Ediciones Internacionales Universitarias (EIUNSA), Madrid, año 2002, páginas 43 a 92 y ELOSEGUI ITXASO, M. "Las acciones positivas para la igualdad de oportunidades laborales entre mujeres y hombres", en "Un análisis de la legislación alemana y la Directiva 76/207/CEE desde la teoría de la argumentación de Robert Alexy”, Centro de estudios Políticos y Constitucionales y Universidad de Zaragoza, Madrid, año 2003, páginas 23 a 32 . También se han propuesto numerosos modelos o tipologías de feminismo que no son coincidentes en todos los autores. A título ejemplificativo: SUAREZ LLANOS Ma L. "Teoría feminista, Política y Derecho”, Ed. Dykinson, Madrid, año 2002, especialmente páginas 63 a10; AMOROS, C. "Historia de la Teoría feminista”, Comunidad de Madrid, año 1994; AMOROS, C. “Teoría feminista de la Ilustración a la globalización”, Ed. Minerva, Madrid, año 2005.

401 TUBERT, S. “Del sexo al género. Los equívocos de un concepto”, Ed. Cátedra, Madrid, año 2003, página 7. 
Capitulo II El Principio de igualdad y el Derecho de Familia - Igualdad de género y Derecho civil. La situación de la mujer. Una relación que se intenta armonizar vía reformas legislativas y jurisprudencialmente

como sexólogos, psicólogos y médicos, principalmente de Estados Unidos, habían hecho uso de él con el afán de distinguir el denominado sexo anatómico del género social, el motivo era procurar dar solución a las diversas realidades que se fundaban en los intersexos, transexuales y homosexuales, cuyo sexo biológico era ambiguo al nacimiento o no coincidía con su identidad sexual deseada u orientación sexual. Crucial resulta ser la opinión de autores como DE BEAUVOIR, para quien “no se nace, sino que se deviene mujer”, expresión de 1949 en su clásica obra titulada "El segundo sexo" ${ }^{402}$. Al respecto puedo afirmar mi desacuerdo con esta opinión, estimo que un hombre o una mujer nacen como tales y luego se hacen, es decir se reafirma o no lo que la naturaleza ya ha hecho, en parte esta idea es distante a las opiniones que denomino "voluntaristas", es decir, que de una u otra manera estiman que la voluntad humana puede crear o cambiar prácticamente todo, no es así para quien escribe el presente trabajo, sin duda de que el hombre puede modificar sus circunstancias, pero es limitado, sus creaciones, entre ellas el Derecho, también lo son.

En la relación Género y Derecho, especialmente en el Derecho Civil, destaco el interesante aporte de VALPUESTA FERNÁNDEZ ${ }^{403}$, aunque seguramente discreparía de la opinión recientemente comentada.

Género no es sinónimo de sexo, no es sinónimo de mujer. Incluso en ocasiones existen dudas acerca de la utilización de la expresión “discriminación por razón de sexo o de género" en determinados contextos. Quizás uno de los ejemplos más significativos lo constituyó el anuncio por parte de Gobierno español, de la época, de que iba a presentar un Proyecto de Ley Integral contra la violencia de género, la actual Ley Orgánica 1/2004, de 28 de diciembre de medidas de protección integral contra la violencia de género. El título propuesto en el anteproyecto de ley, se llevó a la Real Academia Española, la cual elaboró un informe aprobado en la sesión plenaria académica celebrada el día 13 de mayo de 2004 sobre el aspecto lingüístico de la denominación "violencia de género", incorporada ya entonces de manera equivalente en las leyes 30/2003 y 50/1997 al hablar de "impacto por razón de género".

402 STOLKE, V. “La mujer es puro cuento: la cultura del género”, en Estudios Feministas, Florianópolis, 12 (2), maio-agosto/2004, páginas. $77,84,85$ y 86 . Esta autora señala que tomó prestado este irónico título precisamente de los libros de la antropóloga y linguista nicaragüense Milagros Palma titulado "La mujer es puro cuento", una recopilación de mitos que son una muestra clara de la forma de perpetuarse el poder masculino a través de la transmisión de valores e imágenes que hacen de ella una creación puramente arbitraria.

403 Entre sus obras a considerar para el presenta trabajo se encuentran: "El Derecho de familia desde una perspectiva de género”, en NAVAS NAVARRO, S (Dir.), ... op. cit., páginas 321 a 357; VALPUESTA FERNÁNDEZ, Mª "Diversidad y ciudadanía: una reflexión desde el feminismo" en PERIÑÁN GOMEZ, B (Coord.), "Derecho, persona y ciudadanía: una experiencia jurídica comparada”, Madrid-Barcelona-Buenos Aires, año 2010, página 475 y siguientes; VALPUESTA FERNÁNDEZ, “El impulso de las mujeres en la transformación del Derecho de familia” en GARCÍA RUBIO, M. y VALPUESTA FERNÁNDEZ, M. a, “El levantamiento del velo: las mujeres en el Derecho Privado”, Ed. Tirant Lo Blanch, Homenajes y Congresos, Valencia, año 2011, páginas 475 y siguientes. 
Capítulo II El Principio de igualdad y el Derecho de Familia - Igualdad de género y Derecho civil. La situación de la

Lo anterior no es un dato inocuo, es más, de hecho la expresión "violencia de género" es según la Real Academia Española de la Lengua, la traducción del inglés gender-based violence o gender violence, expresiones difundidas a raíz del Congreso sobre la Mujer celebrado en Pekín en 1995 bajo los auspicios de la ONU. Con ella se identifica la violencia, tanto física como psicológica, que se ejercen contra las mujeres por razón de su sexo, como consecuencia de su tradicional situación de sometimiento al varón en las sociedades de estructura patriarcal. Lo que aquí se planteaba era la pregunta de si esa expresión era adecuada en español desde el punto de vista lingüístico, y si existían alternativas que permitiesen sustituirla con ventaja y de acuerdo con otras fórmulas de denominación legal adoptadas por países pertenecientes al área linguística románica, y con el uso mayoritario de los países hispano parlantes.

La palabra género, tiene, según la misma, los sentidos generales de conjunto de seres establecido en función de "características comunes" y "clase o tipo". En la gramática castellana significa "propiedad de los sustantivos y de algunos pronombres por la cual se clasifican en masculinos, femeninos y, en algunas lenguas, también en neutros”. Para designar la condición orgánica, biológica, por la cual los seres vivos son masculinos o femeninos, según la Real Academia, debe emplearse el termino sexo, y concluía afirmando que las palabras tienen género (y no sexo), mientras que los seres vivos tienen sexo (y no género), y que en español no existe tradición de uso de la palabra género como sinónimo de sexo. Asimismo realiza una pequeña estadística acerca de las expresiones usadas en español para expresar el concepto y concluye señalando que la expresión "violencia doméstica" es la más utilizada con bastante diferencia en el ámbito hispánico, doblando a la expresión violencia intrafamiliar muy frecuente en Hispanoamérica junto con "violencia familiar" o "violencia contra las mujeres".

Sobre este punto surge la duda, sobre si con el nombre violencia doméstica sólo se refiere a la violencia ejercida entre familiares dentro de un hogar, pero no comprende a los miembros de una pareja, por ejemplo, con aquellos que viven juntos, y no son familiares, en fin, son situaciones que traen aparejadas dudas.

Por todo ello, y de cara a la "Ley integral" que en ese momento era un Anteproyecto de ley, expresa que la expresión "violencia doméstica", tan arraigada en el uso por su claridad de referencia, tiene precisamente la ventaja de aludir, entre otras cosas a los trastornos y consecuencias que esa violencia causa no sólo en la persona de la mujer, sino el hogar en su conjunto, aspecto este último al que esa ley específica quería atender y subvenir con criterios de transversalidad. Y para que la Ley incluyese en su denominación la referencia a los casos de violencia contra la mujer ejercida por 
parte del novio o compañero sentimental con el que no conviva, podría añadirse, propone, "o por razón de sexo". Con lo que, la denominación completa y según los mismos ajustada sería la de "Ley integral contra la violencia doméstica o por razón de sexo”. En la misma línea, y por ser consecuentes y coherentes, entendieron que debería en adelante sustituirse la expresión "impacto por razón de género" por la de "impacto por razón de sexo", en línea con lo que la constitución establece en su artículo 14 al hablar de la no discriminación "por razón de nacimiento, raza, sexo...”, opción que en su opinión sería recomendarle que considerase el Gobierno. Finalmente, esta Ley Orgánica 1/2004, de 28 de diciembre se ha denominado "Ley Orgánica de medidas de protección integral contra la violencia de género".

Es cierto que siguen apreciándose ciertos problemas terminológicos, debido a que el término género erróneamente se traduce en muchas ocasiones como sinónimo de sexo, pero también como sinónimo de mujeres. No obstante, igual o más importante me resulta el hecho de que incluso teorías como las del feminismo de la diferencia se han convertido en el feminismo de la uniformidad: decir que las mujeres difieren de los hombres en tales y cuales aspectos equivale a afirmar que las mujeres son de tal y cual modo. Inevitablemente, una caracterización de la naturaleza o la esencia de las mujeres, aun cuando se las describa como naturaleza o esencia construida, tiende a reflejar la perspectiva de quien realiza la caracterización ${ }^{404}$. Por ello no debe querer eliminarse el término género generalizándolo y sustituyéndolo con el de sexo. En tal sentido, algún autor ha señalado que es necesario luchar contra todo tipo de discriminación sexista, cuyo origen sería el dualismo entendido como si el varón fuese res cogitans, y la mujer tan sólo res extensa. Hoy se sabe que el género no procede directamente del sexo $0^{405}$.

De otro modo se nacería con un sexo y se crecería con un género, o existiría una nueva masculinidad y feminidad dependiente de la sociedad en la que se vive. Es más, podríamos incluso comprobar que muchos médicos y científicos como MARAÑON en España, FREUD etc, partiendo del sexo habían creado estereotipos que definían mejor a la mujer como proveedora de unas cualidades, mejor dicho caracteres diferenciados del hombre, hoy plenamente rebatidos por la ciencia. Quizás para ello tenga razón BUTTLER cuando efectúa una reconstrucción de la dicotomía sexo/género, mostrando cómo el sexo es ya de por sí una construcción social que, por tanto ha sido género todo el tiempo ${ }^{406}$.

404 TUBER, S (Edit.) “Del sexo al género. Los equívocos de un concepto”. Ed. Cátedra, Madrid, año 2003, página 20.

405 BALLESTEROS LLOMPART, J. “Ecologismo personalista”, Ed. Tecnos, Madrid, año 1995, página 103.

406 BUTTLER, J. “El género en disputa. El feminismo y la subversión de la identidad”. Ed. Paídos, México, año 2001. 
Capitulo II El Principio de igualdad y el Derecho de Familia - Igualdad de género y Derecho civil. La situación de la mujer. Una relación que se intenta armonizar vía reformas legislativas y jurisprudencialmente

Sin duda, el lector a estas alturas podría preguntarse cuál es la relación que existe entre este interesante debate género/sexo y el Derecho Civil. Ha decir verdad la relación es basta, por cuanto a nivel de familia el género no sólo implica un rol que se vierte en diversas funciones, sino que determina un cosmovisión singular que sin duda influirá en los menores que crezcan en dicha familia, es decir, el sexo influye de sobre manera en la visión que pueda tener una persona sobre la realidad, por consiguiente conforma en gran medida su manera de vivir el género, pero lo que es aún más importante, los términos padre, madre, trascienden esta nomenclatura, constituyendo el eje formativo de los niños.

Sin perjuicio de ello el debate recién aludido presente notoriedad en el tema que a continuación se abordará.

El principio de igualdad de trato encuentra su mejor encuadre en el primer inciso del artículo $14 \mathrm{CE}$, en donde se establece que los españoles son iguales ante la ley. A continuación, podríamos situar el principio de no discriminación cuando afirma que ello ha de ser así "sin que pueda prevalecer discriminación alguna por razón de nacimiento, raza, sexo, religión, opinión o cualquier otra condición o circunstancia personal o social”, enumerando estas especiales causas por considerar que las mismas constituyen factores especialmente odiosos en los que basan la mayoría de las discriminaciones. En este sentido el Tribunal Constitucional declaró expresamente que la referencia al sexo del artículo 14 implica la decisión de inferioridad atribuida a la mujer, pero tal como veremos más adelante el debate ha ido más allá procurando que dicha inferioridad no quede reducida únicamente a la mujer sino que incluso abarque la homosexualidad.

La igualdad tiene un carácter dinámico, como derecho y como valor, esto se ampara no tan sólo en el artículo 14 sino que también en el 9.2 de la Constitución, tal como manifiesta CORCHETE MARTIN $^{407}$. En relación a ello se afirma que sin duda la mujer ha sido un colectivo marginado durante la historia, lo cual ha sido parcialmente modificado en los últimos años, empleando el término parcial por intentar contemplar la situación universal, en España aún existen sectores en donde se da la discriminación sobre ella. No obstante, la reciente integración social, en el sentido más amplio de la palabra, no es indicio de ser suficiente.

Ante la realidad será el legislador quien deba determinar en primer lugar la normativa constitucional y luego las del resto del ordenamiento pretendiendo ampararse siempre en una clima de consenso, porque tal consenso es el que configura las razones que facilitan la cultura democrática,

407 "Algunos apuntes sobre la igualdad en la constitución española y su situación sobre la mujer" en GONZÁLEZ BUSTOS, $\mathrm{M}^{\mathrm{a}}$. A. (Coord.) “La mujer ante el ordenamiento jurídico: soluciones a realidades de género", Ed. Atelier, Barcelona, año 2009, página 58. 
Capitulo II El Principio de igualdad y el Derecho de Familia - Igualdad de género y Derecho civil. La situación de la mujer. Una relación que se intenta armonizar vía reformas legislativas y jurisprudencialmente

el consenso resulta de ser una justificación de propuestas constitucionales y legislativas acerca de cuestiones básicas de la estructura social, estás son las denominadas razones públicas ${ }^{408}$.

Cuando se emplea el término marginar se debe asociar a la palabra discriminar, el legislador no puede tratar de manera diferente a las personas que se encuentren en una misma situación, y el juzgador tiene que aplicar sí o sí de manera igual la ley a todas las personas que se encuentren en la situación por ella regulada. Es sin duda resultado del cumplimiento del art. 9.3 de la Constitución española en torno al concepto de la seguridad jurídica ${ }^{409}$.

Cuando existe marginación existe una desigualdad jurídica de trato, y cuando esta se ampara en uno de los criterios anteriormente mencionados, la igualdad se transforma en un juicio muy riguroso, y por ello, es aplicable la doctrina de la clasificación sospechosa. Según REY MARTÍNEZ, existe una presunción de inconstitucionalidad contra las leyes que emplean esos rasgos definitorios aludidos (doctrina de la clasificación sospechosa -suspect classification-) y en consecuencia los tribunales deben examinarlas con un juicio más estricto ${ }^{410}$. Esta doctrina es de origen norteamericano, y según el autor antes citado está comprendida en el artículo 14 de la Constitución española.

Como afirma la mayoría de la doctrina, entre los que destaco a BARRÉRE UNZUETA, el "Derecho Antidiscriminatorio" se origina en los Estados Unidos de Norteamérica tras la finalizar la Segunda Guerra Mundial, con el fin de afrontar las revueltas protagonizadas fundamentalmente por las personas de raza negra. Sin embargo aunque este sea el motivo o factor que le da origen, a partir

408 Cfr. FERRERES COMELLA, V. “Justicia constitucional y democracia”, Centro de Estudios Políticos Constitucionales, Madrid, año 1997, páginas 134 a 135.

409 STSJ Extremadura, Sala de lo Contencioso-Administrativo, Sec. 1. a, núm. 175/2012, de 18 de septiembre, Recurso 181/2012. Este fallo declara :"La sentencia de esta Sala de Justicia de fecha 11-5-2010, dictada en el recurso de apelación número 49/2010, anulaba la Resolución que revocaba la anterior Resolución del Servicio Extremeño de Salud de 3-42007, que reconocía a la actora el nivel I de carrera profesional debido a que no se habia seguido el procedimiento adminis trativo legalmente previsto. Anteriormente, la Administración habia utilizado el mecanismo de rectificación de errores previs to en el artículo 105 de la Ley 30/1992, de 26 de noviembre, de Régimen Jurídico de las Administraciones Públicas y del Procedimiento Administrativo Común, que no era procedente pues no se trataba de una mera rectificación de errores materiales o de hecho que pudieran ser corregidos por la Administración sino de una verdadera revisión de oficio que debia tramitarse por el cauce procedimental establecido. Es por ello que la actuación administrativa ahora impugnada lo que hace precisamente es cumplir con la sentencia de este Tribunal, al proceder a utilizar el procedimiento de revisión de oficio de actos nulos en relación a la Resolución de fecha 3-4-2007. Al utilizar el procedimiento adecuado, la Administración está dando cumplimiento a los principios de seguridad jurídica y legalidad, por lo que no existe vulneración de los mismos. La sentencia que acabamos de mencionar se limitó a anular la actuación administrativa por infracción de norma procedimental, lo que ahora ha sido corregido por la Administración al encuadrar el supuesto en el procedimiento procedente. Todo lo anterior conduce a la Sala a desestimar integramente el recurso de apelación, confirmando la sentencia de instancia.”. Cfr. IBAÑEZ GARCÍA, I. “¿Quo vadis, Tribunal Supremo? En defensa del garante de la seguridad jurídica en un mundo de leyes desbocadas?”, Ed. Sepín, septiembre, Madrid, año 2012.

410 REY MARTINEZ no coincide, a diferencia de otros autores como RODRIGUEZ-PIÑEIRO y M.F. FERNÁNDEZ, en la separación radical entre el principio de igualdad y la prohibición de discriminación. La base de esta contraposición, según este autor, se halla la identificación de una concepción de la igualdad (liberal-individualista) con el concepto de igualdad. La igualdad del artículo $14 \mathrm{CE}$, afirma, es la igualdad del Estado social y democrático de Derecho; tiene también 1 significado de prohibición de discriminación ante ciertos criterios de diferenciación. REY MARTÍNEZ, F. “El derecho fundamental a no ser discriminado por razón de sexo”. Ed. McGrawHill, Madrid, año 1995, página 59. 
Capítulo II El Principio de igualdad y el Derecho de Familia - Igualdad de género y Derecho civil. La situación de la mujer. Una relación que se intenta armonizar vía reformas legislativas y jurisprudencialmente

de los años sesenta la cobertura del Derecho antidiscriminatorio irá más allá, incluyendo también el sexo y la religión, etc., tales términos son coincidentes con los rasgos típicos señalados en el citado artículo, a los que se le sumarán otros ${ }^{411}$. Este hecho es debido al último inciso del mismo en el que se expresa "o cualquier otra condición o circunstancia personal o social". Es decir, los que sin estar tipificados en él, el Tribunal Constitucional vaya distinguiendo como desigualdades que merezcan la consideración como discriminatorias.

Siguiendo a esta autora, cabe sin embargo realizar una puntualización, y es que es necesario hacerle perder a dicho término, su significado neutral de simple diferenciación, adquiriendo únicamente el significado peyorativo de diferenciación injusta y arbitraria (y no diferenciaciones tales como las acciones positivas), considerando únicamente como significado el relativo a la desigualdad de trato grupal o entre individuos que pertenecen a grupos con distinto status o poder social, precisamente por pertenecer al mismo. Y ello a pesar de la dificultad que a priori pueda ser reconocido, pues es difícil cambiar los usos lingüísticos dominantes también en la cultura jurídica y especialmente cuando, como en este caso, la ambigüedad favorece intereses inmovilistas. ${ }^{412}$

Entrando ya en la diferenciación entre sexo y género debemos observar que siempre ha sido el hombre el que tradicionalmente había establecido los criterios de normatividad política, jurídica, moral e incluso podríamos decir "doméstica". Al respecto ha de apuntarse la escasa participación de la mujer en su elaboración, a diferencia de lo ocurrido en la elaboración de la Constitución de 1931 en la que, al menos una mujer, CLARA CAMPOAMOR, formó parte de la ponencia constitucional, y también, además de los artículos sobre la Corona y los títulos nobiliarios, por la dicción de gran parte de su articulado.

411 BARRÉRE UNZUETA, Ma. A. "Discriminación, Derecho antidiscriminatorio y acción positiva a favor de las mujeres”, Ed. Civitas, Madrid, año 1997, páginas 34 y 35.

412 BARRÉRE UNZUETA, M.A. "Igualdad y discriminación positiva: un esbozo de análisis teórico-conceptual, en Género y Derechos Humanos". Mira Editores, Zaragoza, año 2002, página 23. Sin embargo conforme a la interpretación conjunta del artículo $14 \mathrm{CE}$ y del art. 9.2 CE, las medidas de acción positiva supondrían un mecanismo corrector de las desigualdades existentes por razón de género. Pero conviene hacer referencia a que junto a las medidas de acción positiva, existen las llamadas medidas de discriminación positiva, también denominada discriminación inversa. El objetivo es el mismo, la equiparación entre los grupos históricamente discriminados y marginados. Pero mientras las medidas de acción positiva resultan más fáciles de justificar por beneficiar a personas que sufren desigualdades, la discriminación positiva trata de privilegiar para la igualdad, estableciendo una ventaja concreta, de ahí que su aplicación sea restrictiva y temporal. De hecho las acciones positivas favorecen a las mujeres sin que, por ello perjudiquen a los hombres. En cambio la discriminación positiva o inversa, sí que perjudica a los valores que se encuentren en una situación similar, sujetándose por ello a determinadas condiciones. Este es uno de los problemas que se plantean en relación a la Ley orgánica 3/2007, de 22 de marzo para la igualdad efectiva de hombres y mujeres, en tal sentido véase STC, Pleno, núm. 4069/2007, de 22 de marzo, RTC $2007 / 5653$. 
Capitulo II El Principio de igualdad y el Derecho de Familia - Igualdad de género y Derecho civil. La situación de la mujer. Una relación que se intenta armonizar vía reformas legislativas y jurisprudencialmente

De este modo, resulta curioso que, a pesar de que en apariencia el texto constitucional no hace diferencias entre hombres y mujeres por poner un ejemplo, donde dice todos, españoles, trabajadores y ciudadanos, hay que entender hombres y mujeres, es decir, en el masculino plural ha de integrarse también a la mujer. Sin embargo, en los artículos 32.1 CE y 35.1 CE, se reitera la voluntad igualatoria, pues en éste último caso, tras establecer "todos los españoles" (a los que va dirigida la dicción del precipitado artículo), acto seguido recalca la idea de que el contenido del mismo ha de llevarse a cabo "sin que pueda hacerse discriminación por razón de sexo". PECES-BARBA ya ha hecho referencia a la pluralidad de términos usados para identificar a los titulares de los derechos en la Constitución. Según este autor, hubiera sido más adecuado unificar todos los términos y elegir uno solo entre ellos, para no dar la sensación de confusión, y para ello, uno de los propuestos es "todas las personas" 413 .

Tal cual se mencionó con anterioridad la Ley 3/2007, en su Exposición de motivos, incorpora dos Directivas en materia de igualdad de trato: la Directiva 2002/73/CE de reforma de la Directiva 76/2007 CEE, relativa a la aplicación del principio de igualdad de trato entre hombres y mujeres en lo que se refiere al acceso al empleo, la formación y la promoción profesional, asimismo las condiciones de trabajo, también la Directiva 2004/113/CE ${ }^{414}$, sobre el principio de igualdad de trato entre

413 PECES-BARBA, G. "Derecho y derechos fundamentales", Centro de Estudios Constitucionales, Madrid, año 1993, página 193. En dicha obra plantea que el término persona se ha presentado en la Constitución acompañado de determinantes del tipo "toda" (art. 17), "todas" (art. 21), y en ocasiones se ha convertido en pronombre (arts. $15,27,28 \ldots)$. Sin duda su matización es importante especialmente en artículos que se garantizan derechos tales como la vida. En otros artículos, el ámbito denotativo de persona tiene que restringirse y aparecerá, en su lugar, el término españoles (arts 11, 12, 14,19,...). En relación al art. 14 admitida la enmienda 466 del Congreso (Grupo mixto) se suprime el determinante "todos" (en “todos los españoles”) que aparecerá en el Anteproyecto. También, el texto que presente el Congreso al Senado frece una reordenación de las razones de discriminación. Con la enmienda 8 del Senado (PSI) se elimina la preposición “de” delante de cada una de dichas razones. Prosiguiendo con lo expuesto anteriormente, ha de señalarse que aunque el artículo de nuestra Constitución parece restringir esta igualdad a "los españoles", sujeto del texto, si lo relacionamos con el art. 13.1 donde se postula que "todos los extranjeros gozarán de las libertades públicas del presente Título”, vemos que no existe tal pretensión restrictiva. Es más no puede hablarse de restricciones en un artículo que predica la igualdad absoluta en cualquier caso y sin tener en cuenta "cualquier circunstancia personal o social".

414 STJUE, Gran Sala, Caso Association Belge des Consommateurs Test-Achats ASBLYann van VugtCharles Basselier contra Conseil de .... TJCE 2011/31. "Es incontrovertido que el objetivo de la Directiva 2004/113 ( LCEur 2004, 3568) en el sector de los seguros consiste, tal y como se desprende de su artículo 5, apartado 1, en la aplicación de la norma de primas y prestaciones independientes del sexo. El decimoctavo considerando de dicha Directiva señala expresamente que, a fin de garantizar la igualdad de trato entre hombres y mujeres, la utilización del sexo como factor actuarial no deberá dar lugar a diferencias en las primas y las prestaciones de las personas individuales. El decimonoveno considerando de dicha Directiva define la facultad concedida a los Estados miembros para no aplicar la norma de primas y prestaciones independientes del sexo como una «excepción». Por consiguiente, la Directiva 2004/113 parte de la premisa de que, en aras de la aplicación del principio de igualdad de trato entre mujeres y hombres consagrado en los artículos 21 y 23 de la Carta (LCEur 2000, 3480) , las situaciones en que se encuentran respectivamente las mujeres y los hombres a efectos de las primas y prestaciones de seguros que contratan son comparables.- Dadas las circunstancias, existe un riesgo de que el Derecho de la Unión permita indefinidamente la excepción a la igualdad de trato entre mujeres y hombres prevista en el artículo 5 , apartado 2, de la Directiva 2004/113 (LCEur 2004, 3568) .- Dicho precepto, que permite a los Estados miem - 
Capitulo II El Principio de igualdad y el Derecho de Familia - Igualdad de género y Derecho civil. La situación de la mujer. Una relación que se intenta armonizar vía reformas legislativas y jurisprudencialmente

hombres y mujeres en lo que se refiere al acceso a los bienes y servicios y su suministro, destaco que respecto de esta Directiva, el Tribunal de Justicia de la Unión Europea invalidó por medio de la sentencia C-236/09 la excepción a la igualdad de trato entre mujeres y hombres prevista en el artículo 5, apartado 2, de dicha Directiva, por consiguiente, la L.O. 3/2007 ha devenido inaplicable en este punto. También sobre ámbitos en los que la mujer parte con una situación de desventaja como son la violencia de género, la discriminación salarial, la discriminación en las pensiones de viudedad, el mayor desempleo femenino, la escasa presencia de las mujeres en puestos de representación política, social, cultural y económica, la conciliación entre la vida personal, laboral y familiar. Este afán de igualdad podría analizarse desde el punto de vista de los diversos órdenes jurisdiccionales, ya sea constitucional ${ }^{415}$, penal ${ }^{416}$, laboral ${ }^{417}$, administrativo y $\operatorname{civil}^{418}$.

En el orden jurisdiccional civil, la mayor parte de las sentencias reconocen la igualdad de las mujeres en lo referente al estatus matrimonial, de filiación y de contratación.

En relación con el estatus matrimonial, el Tribunal Constitucional ha mantenido una posición variable en cuanto a la exigencia de la formalidad del matrimonio en relación con las uniones de hecho, y de apoyo institucional al matrimonio en relación con situaciones jurídicas derivadas de él ${ }^{419}$.

bros afectados mantener de modo ilimitado en el tiempo una excepción a la norma de primas y prestaciones independientes del sexo, es contrario a la consecución del objetivo de igualdad de trato entre mujeres y hombres marcado por la Directiva 2004/113 ( LCEur 2004, 3568) y resulta incompatible con los artículos 21 y 23 de la Carta ( LCEur 2000, 3480).- Por consiguiente, dicho precepto ha de considerarse inválido tras la expiración un período transitorio adecuado."

415 ABRIL STOFFELS, R y URIBE OTAROLA, A. "Mujer, derecho y sociedad en el siglo XXI", Ed. Tirant Lo Blanch, monografías, núm. 677, Valencia, año 2010, páginas 15 a 21.

416 Cfr. SANZ MULAS, N. "Luces y sombras en la regulación penal de la violencia sobre la mujer en el ámbito familiar.” en GONZÁLEZ BUSTOS, $\mathrm{M}^{\mathrm{a}}$. A. (Coord.),... op. cit., página 201 y siguientes; QUINTERO OLIVARES, G., (Dir.), “Comentarios al nuevo Código Penal”, Ed. Aranzadi, 7ª edición, Pamplona, año 2008.

417 MARTÍN HERNÁNDEZ, Ma . L. "La protección de la seguridad y la salud en el trabajo de las mujeres trabajadoras. Un presupuesto de la igualdad efectiva de mujeres y hombres en el ámbito laboral"; MAYA FRADES, V. "Igualdad de oportunidades en el medio rural. ¿Es una realidad social?”; VEDAO FERNÁNDEZ, Ma. J. "La trabajadora víctima de la violencia de género". FIGUERUELO BURRIEZA, A. (Edit.), "Estudios interdisciplinares sobre la igualdad y violencia de género", Ed. Comares, Granada, año 2008, páginas 301 a 410.

418 ESTÉVEZ GONZÁLEZ, C y MESA MARRERO, C. "Tratamiento y protección de la familia en una realidad cambiante: una aproximación desde la perspectiva del principio de igualdad" en NAVAS NAVARRO, S (Dir.), ... op. cit., páginas 377 a 391; MARTÍNEZ DE AGUIRRE Y ALDAZ., "El Derecho de familia en nuestro pais se ha visto afectado por numerosas reformas legales, ocurridas básicamente en el último cuarto del siglo $X X$ ”, en MARTÍNEZ DE AGUIRRE Y ALDAZ, C. (Coord.), DE PABLO CONTRERAS, P y PÉREZ ÁLVAREZ, M. A., "Curso de de Derecho Civil (IV) Derecho de familia", Ed. Colex, $2^{\mathrm{a}}$ edición, Madrid, año 2008

419 STC, Pleno, núm. 222/1992, de 11 de diciembre, TRC 1992/222. "Nuestra Constitución no ha identificado a la familia a la que manda proteger con la que tiene su origen en el matrimonio, conclusión que se impone no sólo por la regulación bien diferenciada de una institución y otra (arts. 32 y 399, sino también junto a ello, por el mismo sentido amparador o tuitivo con el que la norma fundamental considera siempre a la familia y, en especial, en el repetido art. 39, protección que responde a imperativos ligados al carácter, "social" de nuestro Estado (arts. 1.1 y 9.2) y a la atención, por consiguiente, de la realidad efectiva de los modos de convivencia que en la sociedad se expresen... Sin duda que la garantía constitucional del matrimonio entraña, además de su existencia necesaria en el ordenamiento, la justificación de la existencia de su específico régimen civil, esto es, del con- 
Capitulo II El Principio de igualdad y el Derecho de Familia - Igualdad de género y Derecho civil. La situación de la mujer. Una relación que se intenta armonizar vía reformas legislativas y jurisprudencialmente

Estamos ante una desigualdad de trato por condición de matrimonio, justificada por la protección que el art. 39.1 otorga a la familia, que debe ser asegurada por los poderes públicos, lo que justifica que estos favorezcan el deber de convivencia a que se refiere el art. $68 \mathrm{CC}$. Lo que es suficiente para alterar el criterio general de antigüedad en orden a la prelación de los derechos ${ }^{420}$.

En materia de filiación la jurisprudencia ha ido eliminando del Código Civil todos aquellos vestigios que representaban de forma directa o indirecta una discriminación para las mujeres. Algunas de estas decisiones han permitido reformas importantes en la legislación civil sin necesidad de legislar ${ }^{421}$.

La STC 126/1997 por la que el Tribunal Constitucional desestima una cuestión de inconstitucionalidad acerca del orden de sucesión a los títulos nobiliarios es un paradigma al respecto ${ }^{422}$. Esta sentencia representa una excepción a una situación generalizada en la que el Tribunal ha abierto soluciones de igualdad de los cónyuges. Sin perjuicio de ello, en el Código Civil, han pervivido numerosas normas basadas en la inercia histórica de una visión patriarcal de la sociedad. También cito la

junto de derechos, obligaciones y expectativas jurídicas que nacen a raíz de haberse contraído matrimonio. Cuestión ya distinta es, sin embargo, si el matrimonio, más allá de esta regulación civil que le es propia, puede constituirse en supuesto de hecho de otras normas juridicas que, en sectores distintos del ordenamiento, atribuyan derechos o, en general, situaciones de ventaja”; Cfr. STS, Sala de lo Civil, Sección 1a , núm. 1048/2006, de 19 de octubre, $\mathrm{RJ} / 2006 / 8976$.

420 El Tribunal hace aquí una referencia importante a la distinta fuerza con que opera el art. 23 de la Constitución en el momento de acceso a la función pública, y al momento de permanencia, siendo este último momento de menor "rigor e intensidad", dando a entender que este criterio, el de entender a otros bienes o derechos (familia), no podría operar en el acceso a la función pública, pero sí como en este caso a los traslados. (STC 192/1991).

421 La STC 138/2005 conoce de una cuestión de inconstitucionalidad planteada por un Juzgado de Primera Instancia de Madrid respecto del art. 136 del Código Civil que se refiere al plazo de caducidad de un año para la impugna ción de la paternidad matrimonial, estableciendo como plazo desde la fecha de inscripción en el Registro Civil, con independencia de cuando se haya tenido conocimiento de la verdad material de la paternidad. Se alegaba una discriminación entre el ejercicio de la acción para a impugnación de la paternidad, y la de la reclamación de la paternidad, no sujeta a plazo alguno. No resuelve el Tribunal aplicando el art. 14, sino los arts. 24 y 39 CE. Se trata de una sentencia interpretativa solamente de inconstitucionalidad pero no de nulidad. Pero sólo desde el entendimiento de un agravio comparativo entre madres dentro o fuera del matrimonio, tiene sentido esta declaración de inconstitucionalidad del precepto, porque salvo por esta razón, ninguna otra se puede oponer al sistema de plazos. En todas las acciones de caducidad se puede producir una indefensión, esto es claro. Lo que es aquí de relieve constitucional es que hay otros supuestos en los que la acción es imprescriptible. La estimación de la inconstitucionalidad en el fondo sólo puede estar ocasionada porque hay otras diferentes posibilidades de acciones procesales ejercitadas por otros sujetos, de cuya cobertura no dispone el padre dentro del matrimonio. En caso contrario, no se hubiera suscitado la duda, luego el derecho a la jurisdicción no resultaría conculcado si antes no se hubiera considerado que había una discriminación entre sujetos sometidos o no a la relación matrimonial.

422 La desestimación de la cuestión se basó en la consideración de que los títulos nobiliarios no tienen un contenido económico, y en su pretendida consideración honorífica, que privarían prácticamente de contenido tal discriminación. Los votos particulares dejan en evidencia una resolución que debió ser a todas luces de estimación de la cuestión. El Tribunal ya se había venido pronunciando con cierta irregularidad respecto de este tema. Las SSTC 27/1982 y 114/1995 habían conocido sobre igualdad y títulos nobiliarios, pero el Tribunal no entró directamente a conocer por razones de forma. Con posterioridad, se ha regulado el derecho de igualdad en la transmisión de los títulos nobiliarios, por ejemplo en la Ley 33/2006, de 30 de octubre, sobre igualdad de hombre y mujer en el orden de sucesión a los títulos nobiliarios. Cfr. STS, Sala Primera, de lo Civil, núm. 661/2009, de 22 de octubre, RJ 1794/2006; 
STC 144/2003, por la que el Tribunal ha de recordar a la jurisdicción ordinaria la reforma de la Ley 11/1990, para la aplicación de la no discriminación por razón de sexo, que derogó el antiguo art. 159 CC por el que en caso de divorcio, la mujer quedaba a cargo de los hijos menores de siete años. Igual suerte corrió el art. 9.2 CC, referente a la preferencia injustificada de la nacionalidad del marido en el matrimonio, la STC 39/2002 declaró el precepto inconstitucional.

En materia de filiación el Tribunal Constitucional ha llegado a producir importantes conflictos con la jurisdicción ordinaria en un intento de garantizar el ámbito material del derecho. La STC 7/1994 declaró directamente la paternidad a un demandado que se negó a realizar las pruebas de paternidad, dando valor de certeza a una mera presunción. El importante conflicto en que derivó la atribución directa de la paternidad al demandado que se negó a realizar la prueba biológica, matizó la jurisprudencia posterior, en la que se devuelven los autos a las instancias para el dictado de la sentencia ${ }^{423}$. Igualmente, materias en que la atribución al padre había sido mimética, como el primer apellido o la patria potestad, se revisan en el sentido igualitario ${ }^{424}$.

Respecto a lo planteado en la Carta Europea de Derechos Humanos, la búsqueda por la igualdad entre hombres y mujeres tiene sus raíces en la noción de ser humano igual, siempre y cuando se entienda la igualdad de manera compleja, vale decir como una igualdad en la diferencia, la que procura dilucidar una esencia común a todos los sujetos a la vez que respetuosa con las diferencias individuales.

La igualdad, tal cual ya se manifestó en su momento, aparece como valor, principio y derecho. La Carta Europea de Derechos Fundamentales menciona la igualdad como valor estructural en su Preámbulo, afirmando que "Consciente de su patrimonio espiritual y moral, la Unión está fundada sobre los valores indivisibles y universales de la dignidad humana, la libertad. la igualdad y la solidaridad, y se basa en los principios de la democracia y el Estado de Derecho”.

423 Pero sin merma de las garantías sobre la investigación de la paternidad. La STC 3/2005 estima el amparo a una señora que solicito la prueba biológica a un presunto padre fallecido y le fue denegada por el juez de instancia. $\mathrm{O}$ la STC 118/2006, para que se motiven suficientemente los motivos de denegación de esta prueba. Todas estas resoluciones se desenvuelven ya en sede de derecho de tutela, no de igualdad, como la STC 177/2007, que estima el amparo en un supuesto de paternidad en la que el demandado solicita que no se practique la prueba, el juez no la acuerda, y atribuye directamente la paternidad. El Tribunal razonará sobre la necesidad de que antes de la atribución directa, se ordene la práctica de la prueba, a pesar de las manifestaciones de la parte. De esta forma se matiza la STC 7/1994 en cuanto a la atribución automática de paternidad en ausencia de prueba biológica, y la necesidad de otras pruebas indiciarias de paternidad (Auto 371/2003 y STC 29/2005).

424 Así, en materias que venían atribuidas de manera unilateral a los padres. Como en la STC 241/1988, reingreso por excedencia denegado por el CGM. Supeditado a que sea cabeza de familia. Estima en lo que se refiere a la extensión de los derechos de los hijos naturales a los adoptados, STC 200/2001, que resuelve la inconstitucionalidad del art. 41.2 de la Ley de Clases Pasivas del Estado de 1987, que exigía la supervivencia de dos años, del adoptante sobre el adoptado, para tener derecho a una pensión de orfandad. 
Aunque la mención de este valor en la Carta se hace en el Preámbulo y no en el articulado esto no puede restarle fuerza jurídica a la mención. El hecho de que la Carta aluda a la igualdad como valor común de todos los Estados de la Unión tiene gran relevancia para la definición de la propia Unión, puesto que, indudablemente, se trata de un valor perteneciente a una Moral históricamente incorporada en los ordenamientos jurídicos europeos, que se han configurado como Estados sociales y democráticos de Derecho.

Según MONEREO ATIENZA ${ }^{425}$ los valores de libertad, igualdad y solidaridad no son inmutables, para ella no pertenecen a una moral objetiva, sino a la historia concreta, en este caso, occidental, lo cual provoca que sean flexibles y abiertos, para interactuar en el diálogo intercultural. Prosigue aludiendo al hecho de que el valor de la igualdad, como el de la libertad, no podría cumplir su finalidad sin añadirle su dimensión social, es decir la libertad formal requiere de una libertad real, y la igualdad formal, a su vez, necesita de una igualdad sustancial.

La igualdad sustancial debe interpretarse entonces como igualdad en los resultados o igualdad en el punto de llegada. Esta igualdad requiere de diversas medidas, que son bastante abundantes, medidas que por lo demás implican la solidaridad hacia las mujeres, la solidaridad es descubrir el nosotros bajo el prisma de la justicia social. Esta es la idea básica que está detrás de las políticas de la Unión, es decir, la búsqueda de la igualdad en base a la dimensión no sólo formal sino también material de la igualdad y la conexión de este concepto con el resto de los valores fundamentales. Para la autora recién citada, existe todavía un desajuste conceptual entre la cultura jurídica tradicional y el feminismo jurídico en este punto, porque la primera entiende la igualdad en términos de lucha contra la discriminación, ya sea directa o indirecta. Por su parte, el segundo, entiende la igualdad como lucha contra una discriminación estructural, esto es, como lucha frente a la existencia de estructura desiguales de poder social, erigidas por el sistema sexo-género y ancladas en la división público-privado, que no repercuten en hombres y mujeres por igual. Los términos normativos de la cultura tradicional se asientan en las formulas de prohibición de la discriminación. Así sucede en el artículo 14 de la Constitución española y en las Directivas europeas sobre la igualdad de trato entre hombres y mujeres, sobre las que se han construido los conceptos del Derecho antidiscriminatorio. Aunque, por ejemplo, en la Directiva 2006/54 se ha incorporado un principio de igualdad de oportunidades.

En la Unión Europea mediante la mainstreaming o transversalidad se han incoado una serie de estrategias ambiciosas que resultan más ambiciosas que las políticas de la igualdad de oportunida-

425 "Igualdad entre hombres y mujeres", ... op. cit., página 516 y 517. 
des y las acciones positivas. Existen dos versiones, la primera propone ampliar el ámbito de actuación institucional del Estado o de la Comunidad en materia de políticas de igualdad de oportunidades. La segunda, a su vez, busca una herramienta para profundizar en la implementación de políticas más allá de la mera transversalidad institucional. Dichas estrategias consideran que todas las relaciones entre hombres y mujeres y su participación social están condicionada por el sistema de género, ante esto se procura que toda política sea analizada en términos del impacto diferente que tendrá en el colectivo femenino y masculino.

Concluyendo, el mainstreaming de género es la organización o reorganización, la mejora, el desarrollo y la evaluación de los procesos políticos, de modo que una perspectiva de igualdad de género se incorpore en todas las políticas, a todos los niveles y en todas las etapas por los actores normalmente involucrados en la adopción de medidas políticas. Ejemplo de lo anterior es la Directiva 2006/54, especialmente el art. 29 en donde se manifiesta que: “Los Estados miembros tendrán en cuenta de manera activa el objetivo de la igualdad entre hombres y mujeres al elaborar y aplicar disposiciones legales, reglamentarias y administrativas, así como políticas y actividades, en los ámbitos contemplados en la presente Directiva".

\section{5 | El principio de igualdad que inspira las relaciones patrimoniales en el matrimonio}

El principio de igualdad no sólo aparece en el artículo 1328 del Código Civil como límite a la libertad de estipulación capitular. También se encuentra en el artículo 66 del mismo cuerpo legal, en términos más generales, los que tienen que ver con los derechos y deberes entre los cónyuges. Y lo que es más importante, es un principio constitucional recogido con carácter general en el art. $14 \mathrm{CE}$ y con carácter especial en el art. 32.1 CE, específicamente relativo al derecho de los cónyuges a contraer matrimonio con plena igualdad jurídica. Estas afirmaciones ya han sido señaladas con anterioridad, pero revisten gran importancia en el presente título.

La diversidad, aunque pudiera parecer otra cosa, da lugar a bastantes puntos comunes, existe una razón lógica detrás de esta afirmación, una aplicación en la presente materia, pueden existir diversos regímenes patrimoniales, pero asimismo detrás de estas diferencias se esconde una razón que procura su unidad, existen diversos pero en ellos hay un matrimonio, y aunque ya me he remitido al tema, este matrimonio o comunidad de vida, a nivel personal, a nivel afectivo es también obviamente a nivel patrimonial. Su capacidad para gestionar sus bienes se verá modificada aunque exista una 
separación de bienes casi absoluta que procure mantener la situación anterior a que se hubiere contraído matrimonio, ello tiene una razón de ser, existe un interés que está por sobre el interés particular de los cónyuges, este interés es el familiar ${ }^{426}$. Esto debe coordinarse con el principio de igualdad. Lo anterior justifica la existencia de normas imperativas. Sin duda, la libertad y la igualdad son compatibles con la idea de que cada cónyuge esté obligado a contribuir a las cargas del matrimonio y que por ello sufran importantes limitaciones en la disposición de determinados bienes privativos como la vivienda familiar.

La idea del interés de la familia y comunidad de bienes es esencial para entender por que existen situaciones similares al matrimonio, me refiero especialmente a las parejas de hecho, las que pueden dar lugar a familias y que merecen la misma protección que las fundadas en el matrimonio. Una de las razones de tal analogía estriba en la intención de conformar tal comunidad de vida.

El artículo 1328 se expresa de manera incorrecta cuando habla de la igualdad que corresponda a cada cónyuge, como si no les correspondiera la misma. Evidentemente, en palabras de CLEMENTE MEORO $^{427}$ se trata de un error gramatical pues no puede ser que no le correspondan los mismos derechos y obligaciones, que es lo que establece el art. 66 del Código Civil. Me parece obvio la afirmación precedente, obviedad que no merece mayor aclaración.

Como se ha visto, el principio de igualdad opera como límite de la libertad de estipulación capitular en el art. 1328, lo que hay que poner en relación con algunas manifestaciones de esa misma libertad. Así, en el art. 1375 del Código Civil se permite a los cónyuges que pacten en capitulaciones la gestión o disposición de bienes, en el art. 1429 pueden pactar la participación que les ha de corresponder en el régimen de participación y en el art. 1438 respecto a su contribución al sostenimiento de las cargas del matrimonio. En efecto, en estos y otros preceptos los cónyuges pueden establecer un régimen distinto del legal más lo que no pueden es pactar de manera que se quiebre el principio de igualdad, es decir, discriminando a un cónyuge respecto del otro. Es lo que expresamente dispone el art. 1429 cuando dice que puede pactarse una participación distinta de la que establecen los arts. 1427 y 1428, que es por mitad, “pero deberá regir por igual y en la misma proporción respecto de ambos patrimonios y a favor de ambos cónyuges".

426 PRETE SERRANO, J. J. "Prologo" en GIMENO Y GÓMEZ-LAFUENTE, J. L. y RAJOY BREY, E. (Coords), "Regímenes económicos y sucesiones. Derecho Común, Foral y Especial". Tomo I. Centro de Estudios Registrales de Aragón, Ed. Thomson-Civitas, Cizur Menor, año 2008, página 12.

427 "Los efectos patrimoniales del matrimonio" en DIEZ-PICAZO GIMÉNEZ, G (Coord.). "Derecho de familia", Capítulo VII, Ed. Civitas Thomson Reuters, Pamplona, año 2012, página 544. 
Por el contrario no vulnera el principio de igualdad el pacto por el que, en un régimen de separación de bienes, se conceden recíprocamente los cónyuges facultades de disposición de todos los bienes, tal cual lo dispone la sentencia del Tribunal Supremo del 8 de junio de $1993^{428}$.

El legislador con la Ley 11/1981, de 13 de mayo procuró seguir fiel al sistema económico matrimonial anterior y mantuvo que la sociedad de gananciales será el régimen económico matrimonial a falta de capitulaciones o cuando estas sean ineficaces, art. 1316 CC describiéndola después en el art. 1344 CC (Ley 13/2005).

Ahora bien, dos cuestiones previas deben precisarse:

Una referente a qué matrimonio acompañará este régimen económico vía art. 1315 y 1316 CC.

La otra en su ámbito de aplicación. La respuesta tiene su apoyo en el propio texto constitucional arts. 10.1, 14 y 32.1 CE y su reflejo en el art. 66 CC (Ley 13/2005) "Los cónyuges son iguales en derechos y deberes" siendo el principio de igualdad el que debe presidir la interpretación del derecho matrimonial en todas sus esferas - personal, familiar y patrimonial- (STC, Sala primera, núm. 159/1989, 6 de octubre de 1989 (RTC 1989/159)) por lo que con independencia de la forma matrimonial por la que se opte, ya sea esta religiosa arts. 59 y $50 \mathrm{CC}$ o civil art. $49.1^{\circ} \mathrm{CC}$ en sus diversas variantes, el régimen económico será según el citado art. 1315 CC el establecido; generalidad que se extiende a todo matrimonio en cuanto que el art. $44.2 \mathrm{CC}$ recogiendo el matrimonio celebrado entre personas del mismo sexo dice expresamente que "tendrá los mismos requisitos y efectos cuando ambos contrayentes sean del mismo o diferente sexo" (Ley 13/2005) y uno de éstos, sin duda es, el aspecto patrimonial.

428 STS, Sala de lo civil, núm. 570/1993 de 8 junio. RJ 1993/4466 "El motivo C, último de los planteados, denuncia por el cauce del núm 4. ${ }^{\circ}$ del art. 1692 (querrá decir el núm. 5. vigente a la sazón) infracción de normas del ordenamiento jurídico aplicables a la cuestión objeto del debate. Como normas cita en el mismo motivo los arts. 66, 71, 1326, 1320, 1322 y 1715 del Código Civil, los arts. 9 y 11 del Código de Comercio, y el 138 de la Ley Hipotecaria... Cita tan abundante de preceptos, no todos homogéneos, podría ser ya causa de desestimación, pero es que, como sucintamente se dice a continuación, ninguno de tales preceptos ha sido infringido. - El art. 66 del Código Civil proclama efectivamente que el marido y la mujer son iguales en derechos y en deberes, pero tan paladina declaración no ha sido conculcada en autos puesto que ninguna mengua de derechos de la mujer se ha producido. Basta para comprobarlo leer el contenido de las capitulaciones matrimoniales, reparto de bienes en ella contenido, así como el otorgamiento absolutamente recíproco de amplios poderes de disposición .- El art. 71 tampoco se ha infringido puesto que la representación expresamente conferida cumple cabalmente la norma . No violan el art. 1326 los cónyuges que otorgan libremente capitulaciones matrimoniales cambiando en ellas su régimen patrimonial, que al atribuir a la esposa la propiedad de la casa no impide que ésta autorice al esposo que pueda disponer de la misma aunque constituyere vivienda habitual de la familia, que como se ha dicho no se ha probado en autos, por lo que tampoco cabe pensar en la infracción del art. 1320, que como es sabido prohibe el ejercicio de todo derecho que suponga atentar bajo cualquier forma contra el goce pacífico del alojamiento familiar, pero que como todo precepto de carácter limitativo exige una interpretación restrictiva y no es de aplicar al caso de autos en que, además de no estar probada la residencia en ese lugar, existía un poder de disposición perfectamente utilizable mientras no fuere revocado." 
Una vez que el legislador opta por mantener como régimen legal supletorio, el de gananciales, no hay otra solución que consagrar la igualdad como principio base de los poderes conyugales que aunque en el ámbito personal ${ }^{429}$, fue la Ley 2 mayo 1975 la que lo plasma, además fue uno de los objetivos de la Ley 11/1981 el extenderla al ámbito patrimonial y una consecuencia de ello es, el principio de cogestión que se dibuja en este artículo $1375 \mathrm{CC}$. Este principio puede ser hecho efectivo de dos maneras, o bien consagrando un sistema en el que la administración y disposición sea solidaria, esto es cada una de las actuaciones puede ser realizada por uno sólo de los cónyuges con total validez o bien un sistema de actuación conjunta en virtud del cual los cónyuges deben gestionar y disponer conjuntamente, de suerte que lo realizado por cada uno de ellos individualmente no es válido, lo que supuso la excepción al sistema de una serie de casos en los que se atribuye a uno u otro cónyuge individualmente no sólo la facultad de administrar sino también de disponer, la consecuencia de ello es paradigmática, pues en la práctica numerosas son las excepciones que en el Código Civil se contienen al principio de la cogestión, lo cual desencadena que sea la excepción frente a éste, la regla general.

Sin embargo uno de los temas que se planteó desde la propia regulación fue el carácter subsidiario que a tenor de la normativa presenta este principio de libertad de los cónyuges siempre que éste se contenga en capitulaciones, lo que origina sin duda una tensión por las consecuencias que pueden derivarse entre la libertad de $\operatorname{pactar}^{430}$, en defecto de pacto según art. 1375 CC y la igualdad

429 TORRES GARCIA, T. “De la administración de la sociedad de gananciales” en DIEZ-PICAZO GIMENEZ, G. (Coord), "Derecho de Familia”, Ed. Thomson Reuters, Cizur Menor, año 2012, páginas 1099 a 1101

430 STS, Sala de lo civil, sección primera, núm. 370/2012 de 18 junio. RJ 2012/6853 “La causa en las capitulaciones matrimoniales.- Las capitulaciones matrimoniales son un contrato entre cónyuges relativo a bienes, celebrado sobre el supuesto de la existencia de una economía común del matrimonio. El contenido de los capítulos incluye la regulación total o parcial de esa economía. El matrimonio constituye la base del negocio jurídico de capitulaciones, pero no es su causa en sentido técnico; en definitiva, es un presupuesto de eficacia, porque sin matrimonio, las capitulaciones no tienen sentido. Y ello, porque los negocios de derecho de familia tienen unas peculiaridades que no permiten utilizar el concepto general de causa, en el sentido del art. 1261 del CC. , aunque las capitulaciones deban considerarse como contratos, como lo demuestra el art. 1335 CC.- El principal pacto capitular lo constituye, según el art. 1325 CC, la estipulación, modificación o sustitución del régimen económico del matrimonio. La modificación, o sustitución del régimen es el objeto y la causa de las capitulaciones, por lo que si falta, de acuerdo con el art. 1325 CC, faltará a su vez el objeto y la causa de los capítulos. La doctrina ha discutido si este pacto tiene naturaleza onerosa o gratuita, lo que se plantea más directamente cuando la modificación se produce constante matrimonio. La conclusión más general es la que entiende que los capítulos no tienen abstractamente naturaleza onerosa o naturaleza gratuita, sino que, dado el contenido complejo de las mismas, habrá que estar a la naturaleza propia de cada pacto, por lo que no puede aplicarse la distinción a las determinaciones normativas que regulan el establecimiento, la modificación o la sustitución del régimen económico matrimonial... $2^{a}$ Las capitulaciones en sí mismas y el negocio que incluyen relativo al cambio de régimen, no tienen causa onerosa o gratuita, en el sentido que los arts. 1261 y 1274 CC otorgan a la causa. Pero al darse la circunstancia, que se ha declarado probada, de la falsedad de la declaración en relación a la existencia de bienes en el régimen que se disolvía, se deduce la concurrencia de falsedad de la causa en el otorgamiento de las capitulaciones, puesto que se expresan unas razones para el pacto de separación de bienes -la no existencia gananciales- que no coinciden con la realidad patrimonial de los cónyuges." 
que corresponde conjuntamente a los cónyuges, esto de conformidad al mismo artículo. Estás ideas introductorias intentarán ser desarrolladas a continuación, dando lugar a la reflexión de que sin duda el motor de tales reformas devenidas en esta materia ha sido el papel protagonista que actualmente desempeña la mujer, no tan solo a nivel familiar, sino también, económico, es decir, social.

Los beneficios en torno al establecimiento de relaciones más igualitarias fruto de la mayor incorporación de la mujer en el mundo laboral han influido en varios aspectos, entre ellos el Derecho económico matrimonial, y aunque no será motivo de estudio en el presente trabajo, si puede argumentarse una razón o acontecimiento histórico que ha sido importante en el posterior devenir de los tiempos, sin duda que tal importancia deba concederse al Congreso Internacional de Derecho comparado de Budapest, de 1968, por su incidencia en las medidas de protección patrimoniales en favor de las mujeres en las crisis matrimoniales.

Diez años después, aquí, en España, la aún núbil constitución de 1978 sirvió de antecedente e impulsor de la Ley 11 de mayo de 1981, que procuró intentar paliar las diferencias entre mujeres y hombres en los ámbitos económico y patrimonial, aunque aún quedaba (y queda) mucho trabajo por hacer $^{431}$. Esta Ley procuró implantar la igualdad legal, en tal sentido derogó el régimen dotal ${ }^{432}$. De la misma manera, en los casos que no se hubiera pactado en las capitulaciones matrimoniales un régimen diverso el supletorio sería la sociedad legal de gananciales, que hasta el 8 de junio de 1981 contempló como único administrador al marido, para posteriormente estipularse la administración conjunta $^{433}$.

Como bien se sabe el artículo 1315 determina que el régimen económico del matrimonio será el que los cónyuges estipulen ex voluntate en capitulaciones matrimoniales, en caso de no haberlas

431 VALPUESTA FERNÁNDEZ, Ma . del R. “El impulso de las mujeres en la transformación del Derecho de Familia” en LÓPEZ DE LA CRUZ, L y OTERO CRESPO, M. (Coords.) "El levantamiento del velo: La mujeres en el Derecho Privado”, Ed. Tirant Lo Blanch, Homenajes y Congresos, Valencia, año 2010, página 365. “ Los cambios legislativos que se han sucedido en el Derecho de Familia contemporáneo se han contado y justificado, casi exclusivamente, como iniciativas del legislador que, se dice, ha ido acomodando el régimen jurídico de la familia a las transformaciones sociales, sin que se haya entrado a especificar con detenimiento quiens realmente han propiciado y protagonizado las reformas; sólo en casos muy concretos se ha hecho alusión a las mujeres, más como destinatarias que como impulsoras de las mismas. Si, por el contrario, reparamos más detenidamente en las causas reales que levaron a modificar las normas que regulan las relaciones jurídicas que se dan en el seno de la familia podemos comprobar como las mujeres -están en el origen del nuevo rostro de esta disciplina que se ha ido perfilando con más intensidad en la segunda mitad del S. XX, sin que podamos afirmar al día de hoy que está definitivamente terminado, dado que aquellas están inmersas en u n proceso de transformación que se nos antoja inacabado."

432 Primaba el poder del marido en el Código sobre los bienes de la mujer, restringiendo la capacidad de obrar de esta. El marido, desde luego, administraba el patrimonio conyugal, representaba a la mujer y debía permitir a esta su actuación en tráfico jurídico, ya sea civil o mercantil. Muestra de este papel secundario de la esposa se en cuentra con la dote a través de la que, se decía, la mujer ha de comprar al marido que se obliga a alimentarla.

433 Cfr. RIVERA FERNÁNDEZ, M. "Recorrido práctico sobre el activo de la sociedad legal de gananciales”, Revista de Derecho de Familia, núm. 40, julio-septiembre 2008, Ed. Lex Nova, Valladolid, páginas 23 a 125. 
el artículo 1316 declara el régimen legal de supletorio de la sociedad legal de gananciales, y en aquellos supuestos en que las partes hubiesen otorgado capitulaciones con la finalidad de excluir el régimen de gananciales pero no hubieran mencionado nada al respecto debe aplicarse el artículo $1435.2^{\circ}$, el que dispone que entra a regir el de separación de bienes. Ahora bien, en relación con lo anterior, sin perjuicio del régimen que las partes declaren los artículos 1318 a 1324 contienen el denominado Régimen económico primario, que se aplicará a todos, tienen carácter imperativo.

El artículo 1315 del CC es sin duda manifestación expresa del principio de la libre autonomía de la voluntad en el ámbito del Derecho de Familia, lo que permitirá estipular el régimen que se quiera, y que tal régimen podrá modificarse e incluso sustituirse por otro, ello en conformidad al art. $1325 \mathrm{CC}$, el momento en que puede decretarse será antes o después de contraer matrimonio según el art. 1326.

El artículo 1318 es importante porque se refiere a una igualdad de deberes entre los cónyuges, señalando que los bienes de ambos cónyuges están sujetos al levantamiento de las cargas del matrimonio. El art. 1319, por su parte, regula la denominada "potestad doméstica" que proviene de la denominada "potestad de la llave alemana" ${ }^{\text {"34 }}$ que se introdujo en el Código Civil para ampliar una esfera de legitimación muy restringida de la mujer casada ${ }^{435}$. El art. 1320, por su parte, reconoce un derecho básico que procura afianzar la estabilidad familiar, al exigir el consentimiento de ambas partes para cualquier actos referidos a la disposición en relación con la vivienda habitual o el ajuar, sin perjuicio de quien sea el cónyuge titular de derechos sobre los mismos, permitiéndose que en caso de discrepancias se solicite autorización judicial, aún en aquellos supuestos en que la propiedad corresponda a un sólo cónyuge, sin duda que este artículo resulta fundamental para entender y dilucidar la toma de decisiones importantes al interior del núcleo familiar, muchas de estas decisiones, sin perjuicio de ser afectivas, son también decisiones de interés y poder. En tal sentido el artículo $1322 \mathrm{CC}$ refuerza el régimen de cogestión en la administración y disposición de los bienes de los cónyuges, por lo que ambos actúan de acuerdo con el principio de igualdad, dejando a un lado situaciones injustas como las que se daban con anterioridad, además da a conocer la posibilidad de que marido y mujer puedan celebrar actos y contratos entre sí, tal como lo dispone el art. 1323 del CC. La plena capacidad de los cónyuges y el principio de igualdad hace que hoy no puedan existir res-

434 Vid. HERRERO GARCÍA, M. J. "Comentario al artículo 1319" en "Comentarios al Código civil", Tomo II, Ediciones del Ministerio de Justicia, Madrid, año 1991, página 583.

435 La antigua redacción del artículo 62 exceptuaba de la sanción de nulidad de los actos realizados por la mujer casada sin que tuviese la licencia marital, aquellos celebrados para obtener bienes o servicios para el consumo ordinario de la familia. 
tricciones a las posibilidades de actuación tanto en la esfera personal como en la esfera patrimonial en las relaciones conyugales.

En lo referente a las capitulaciones matrimoniales ${ }^{436}$, estas aparecen reguladas entre los artículos 1325 a 1335, y en ellas puede concebirse estipular, modificar o sustituir el régimen económico de su matrimonio o cualesquiera otras disposiciones por razón del mismo, estando siempre presente el principio de igualdad entre los cónyuges ${ }^{437}$. Este principio, asimismo, actúa como límite a la autonomía de la voluntad que figura en las capitulaciones ${ }^{438}$. Existe una relación muy estrecha entre el art. 1328 del CC y los artículo 14 y $39.1^{\circ}$ de la CE, estas tres disposiciones más el artículo 66 permiten vislumbrar el imperio de la igualdad entre los cónyuges en todos los ámbitos de la vida fami$\operatorname{liar}^{439}$. Puede estimarse asimismo que existe una conexión en la aplicación de este artículo con los actuales 67 y 68 del CC y en concreto en lo que concierne a la asignación equitativa de las tareas domésticas, señalan que cualquier acuerdo que puedan adoptar los cónyuges respecto a la forma de organizar la convivencia tiene como límite insoslayable la dignidad de la persona y sus derechos fundamentales por lo que, en definitiva, los cónyuges pueden establecer un modo de contribución al trabajo doméstico no proporcional, e incluso exonerar a uno de ellos de participar en las obligaciones domésticas y familiares, siempre y cuando ello no genere una relación de dependencia de uno respecto del otro o suponga una merma de sus derechos ${ }^{440}$. Aunque efectivamente deben primar los pactos y estipulaciones, siempre y cuando no sean contrarios a la leyes o a las buenas costumbres,

436 Cfr. PÉREZ MARTÍN, A. J., "La determinación del régimen económico matrimonial”, Revista de Derecho de Familia, núm. 38, enero-marzo de 2008, Ed. Lex Nova, Valladolid, página 29 a 61.

437 Cfr. DE LOS MOZOS Y DE LOS MOZOS J.L. En ALBALADEJO, M (Dir.), “Comentarios al Código Civil y Compilaciones forales”, , Tomo XVIII-I, Ed. Edersa, Madrid, año 1984, páginas 206 y siguientes.

438 STS, Sala de lo Civil, núm. 570/1993, de 8 de junio, RJ 1993/4466: “El art. 66 del Código Civil proclama efectivamente que el marido y la mujer son iguales en derechos y en deberes, pero tan paladina declaración no ha sido conculcada en autos puesto que ninguna mengua de derechos de la mujer se ha producido. Basta para comprobarlo leer el contenido de las capitulaciones matrimoniales, reparto de bienes en ella contenido, así como el otorgamiento absolutamente recíproco de amplios poderes de disposición." En el artículo 1328 se fija -ya a propósito de las capitulaciones generales- una primera limitación al poder de regulación autónoma convencional del sistema económico patrimonial por lo propios cónyuges, declarándose «... nula cualquier estipulación contraria a las leyes o a las buenas costumbres o limitativa de la igualdad de derechos que corresponda a cada cónyuge ...". "А unque a primera vista pudiera interpretarse que este limitación actúa únicamente en materia de régimen económico matrimonial, está muy generalizada la opinión que entiende que ha de abarcar aquellas otras disposiciones de otra naturaleza, como pudieran ser las relacionadas con los deberes de fidelidad, ayuda, socorro mutuo o cualquier otro de los que dan contenido moral y ético al matrimonio, o con el contenido de los poderes y funciones, derechos y deberes que integran el contenido de la patria potestad o la tutela. Los pactos capitulares contrarios a esos principios generales imperativos serán nulos, en la mayoría de las ocasiones no sólo por expresa disposición del artículo 1328, sino como consecuencia de las normas propias que regulan cada una de estas instituciones. Por diferentes vías, se estarían aplicando los límites que a la autonomía contractual se ponen en el artículo 1255, a saber, la ley, la moral y el orden público.” Cfr. SAP HUELVA, Sección $1^{\mathrm{a}}$, núm. 242/2010 de 26 de noviembre AC 2011/1708.

439 Vid. CABANILlAS SÁNCHEZ, A. “Comentario al artículo 1328” en "Comentario al Código civil”, Tomo II, Ministerio de Justicia, Madrid, año 1991, página 606 y siguientes. 
lo cierto es que al hablar de relaciones de pareja, no debemos olvidar las consecuencias que se pueden ocasionar derivados de los desequilibrios en poderes históricamente atribuidos entre hombres y mujeres, tal como aprecia LÓPEZ Y LÓPEZ ${ }^{441}$.

En lo referente a los regímenes matrimoniales, el primero de ellos denominado régimen de gananciales contempla la existencia de tres patrimonios, entre tales se dan relaciones de crédito y débito, así como de titularidad, vale decir, los dos privativos de cada cónyuge y el común y ganancial, lo que presenta una ventaja en cuanto que es un régimen equitativo en el supuesto de la existencia de un desequilibrio económico entre ambos cónyuges, máxime como ya se ha comentado, considerando el rol tradicional asignado a la mujer, es decir, el privado, reproductivo y doméstico, no lleva implícito ningún reconocimiento económico. Esta sociedad está conformada por un conjunto de elementos patrimoniales, activos y pasivos y aunque la ley utiliza el término de sociedad, sería más idóneo hablar de una comunidad ganancial, teniendo el conjunto de elementos que componen la misma como fin primordial el mantenimiento de la familia.

Existen varios artículos que inciden en la igualdad entre los sexos en relación con el régimen mancomunado o de gananciales. Destacan los relativos a frutos y ganancias derivados de los bienes privativos, de hecho, en el artículo 1381 se expresa la pertenencia al haber de la sociedad ganancial aunque, no obstante como administradores de sus propios patrimonios, cada uno de los cuales puede disponer, de éste sólo efecto, de los frutos y productos de sus bienes. En sentido tal, como se puede inferir del propio artículo 1381, inciso último, cada cónyuge como administrador de su patrimonio privativo puede, al sólo efecto de administrarlo, disponer de los frutos y productos de sus bienes, si bien se puede alegar en contra de esta apreciación que, por una parte son de cargo de la sociedad de gananciales, los gastos originados por la administración ordinaria de los bienes privativos de un cónyuge, como se contempla en el artículo $1362.3^{\circ}$ y, por otra, que el artículo 1382 parte de la calificación ganancial del numerario obtenido por un cónyuge con su profesión o con sus bienes privativos, así lo expresó en su momento GARRIDO DE PALMA ${ }^{442}$. El artículo 1375 CC señala que en defecto de pacto, la gestión y disposiciones de los bienes gananciales corresponde a ambos cónyuges en conjunto, es decir, a contrario sensu, existe un permiso explícito para que los cónyuges pue-

440 LÓPEZ DE LA CRUZ, L. "Incidencia del principio de igualdad en la distribución de las responsabilidades domésticas y familiares (La nueva redacción del artículo 688 del Código Civil tras la reforma operada por la Ley 15/2005, de 8 de julio), ...op. cit., página 32.

441 LÓPEZ Y LÓPEZ, A. “Diversidad, feminismo y principio de igualdad”, en LÓPEZ DE LA CRUZ, L y OTERO CRESPO, M. (Coords.) “El levantamiento del velo: La mujeres en el Derecho Privado”, Ed. Tirant Lo Blanch, Homenajes y Congresos, Valencia, año 2010, página 17.

442 GARRIDO DE PALMA, V. M. “El matrimonio y su régimen económico” en "El nuevo derecho de familia español”, Ed. Reus, Madrid, año 1982, páginas 170 y siguientes. 
dan pactar por medio de capitulaciones matrimoniales un sistema diverso a la cogestión, en lo referente a la administración y disposición de los gananciales. Esto resulta importante para entender que es una situación proclive a facilitar la igualdad entre hombres y mujeres en este ámbito, y así la confrontación entre la libertad de estipulación de los cónyuges y la igualdad entre ambos es posible en esta materia, sobre todo en cuanto el pacto capitular consiste en atribuir a uno sólo la gestión plena de los gananciales ${ }^{443}$. De la lectura concienzuda de tal precepto puede inferirse un principio general, el de la gestión y disposición, unas excepciones a dicho principio y aquellos aspectos que inciden en la gestión y disposición de los gananciales en las actividades de comercio.

En lo referido al principio de igualdad de actuación conjunta, su origen puede hallarse en el principio de igualdad conyugal recogido en la Constitución española, aunque, como se ha reconocido, su estricta aplicación conlleva inconvenientes como la ralentización de las actuaciones relativas a la economía conyugal, la inseguridad de los terceros que entran en relación con algunos de los cónyuges, por citar sólo algunos ejemplos.

Respecto a la administración y disposición de los bienes gananciales en el ejercicio mercantil, el Código de Comercio contempla una regulación específica sobre las facultades de disposición del cónyuge comerciante, independiente de que el negocio sea ganancial o privativo, en la que se permite disponer libremente de sus bienes propios y de los gananciales adquiridos con las resultas del ejercicio del comercio, frente a esto hay que decir que se pueden enajenar tanto unos como otros ${ }^{444}$.

Por su parte el art. 1376 del mismo cuerpo legal también prevé la igualdad en el ámbito económico al contemplar que: "Cuando en la realización de actos de administración fuere necesario al consentimiento de ambos cónyuges y uno se hallare impedido para prestarlo, o se negare injustificadamente a ello, podrá el juez suplirlo si encontrare fundada la petición”. En el contenido de este artículo se desprende que la necesidad de que la actuación sea conjunta ha obligado al legislador a establecer un mecanismo intermedio en los supuestos en que siendo necesario el consentimiento de ambos y uno de ellos no se aviniera a prestarlo, se debe de solicitar la autorización judicial supletoria, en sustitución del consentimiento no prestado.

443 La doctrina está dividida dado que un sector considera que tal pacto ha de considerarse nulo por atentar contra la igualdad de los cónyuges, consagrada, no sólo en el artículo $1328 \mathrm{CC}$, sino también en el art. $32 \mathrm{CE}$; O tros por su parte consideran que dicho pacto entra las atribuciones concedidas por el art. 1375, siempre que no se produzca una situación abusiva. Cfr. RIVERA FERNÁNDEZ, M. "Del régimen económico matrimonial: Art. 1315 CC" en ALBIEZ DOHRMANN, K y LÓPEZ FRÍAS, A. (Coords) "Jurisprudencia Civil comentada, Código Civil", Tomo II, Ed. Comares, Granada, año 2000, página 2343.

444 La diferencia de regulaciones entre Código Civil y el Código de Comercio respecto a las facultades de disposición ha llevado a un sector de la doctrina a entender derogada la regulación mercantil de 1975 por la reforma del CC de 1981, puesto que ésta exige la actuación conjunta en relación a los actos dispositivos de los bienes gananciales. 
Este precepto también hace referencia a los actos de administración y su interconexión o distinción, según los distintos criterios, a los actos de disposición y, al respecto, la jurisprudencia no establece unos criterios que se decanten por una u otra opción ${ }^{445}$. Lo anterior sin perjuicio del artículo 1377 del Código Civil. a efectos de requerir, en primera instancia, el consentimiento de ambos cónyuges para la realización de actos de disposición a título oneroso sobre bienes gananciales ${ }^{446}$. La nulidad de los actos a título gratuito en aquellos supuestos en que no concurra el consentimiento de ambos cónyuges se contempla en el artículo 1378, si bien no se prevé que tanto el marido como la mujer puedan realizar liberalidades de uso con los bienes gananciales e igualmente el artículo 1412 del Código Civil modificó, mediante la ley de 1981, aspectos sustanciales en relación con el régimen de participación al plasmar que a cada cónyuge le corresponde la administración, el disfrute y la libre disposición, tanto de los bienes que le pertenecían en el momento de contraer matrimonio, como de los que pueda adquirir después de cualquier título ${ }^{447}$.

Sin embargo debe aclararse que los primeros efectos acaecidos tras alcanzar en 1981 la igualdad legal con relación a la administración y disposición de los bienes gananciales seguían siendo dispares en relación con las mujeres, puesto que había una general desinformación al respecto, en parte a la educación sexista de la época.

Toca ahora referirse suscintamente al régimen de participación en los gananciales, el cual durante su vigencia funciona como régimen de separación pero una vez disuelto se liquida como un régimen de comunidad. Detrás de este régimen se concibe una idea de igualdad e independencia de la mujer y el marido en el plano jurídico ${ }^{448}$. Posiblemente al no ser supletorio e intentar conjuntar la

445 STS, Sala primera, de lo civil, de 20 enero 1989. RJ 1989/109 : "El motivo 40, denuncia infracción del artículo 1322 en relación con el 1376 y 1377 del Código Civil y de la Jurisprudencia, al amparo de la causa $5^{a}$ del artículo 1692 de la L. E. C. Los recurrentes arguyen que al no haber firmado sus esposas, desconocedoras del documento privado de 30-9-1981, en el que se comprometieron a devolver el préstamo y cancelar la hipoteca, se ha dispuesto de bienes gananciales sin su consentimiento. Si no fuesen suficientes los argumentos de las sentencias de instancia en que se rebate parecida objeción a la demanda, habrá que recordar que el matrimonio no limita la capacidad jurídica de los esposos, que ambos pueden obligarse individualmente y responder con sus respectivos bienes; que el documento no contiene ningún acto de disposición de los gananciales y que siempre tendrán los cónyuges la posibilidad de ejercitar la facultad del artículo 1373, si se dirige apremio contra tales bienes. “

446 El art. 1377 establece que: "Para realizar actos de disposición a título oneroso sobre bienes gananciales se requerirá el consentimiento de ambos cónyuges, si uno lo negare o estuviere impedido para prestarlo podrá el juez, previa información sumaria, autorizar uno o varios actos dispositivos cuando lo considere de interés para la familia. Excepcionalmente acordará las limitaciones o cautelas que estime conveniente".

447 En el mismo sentido otros artículos como los arts. 1320, 1322, 1375, 1390 y 1395 CC, permiten reflexionar y reconocer que fruto de la Ley de 13 de mayo de 1981 en lo referente a la igualdad matrimonial dentro del ámbito económico, ambos ostentan tanto de manera individual como mancomunadamente, idénticas facultades de gestión y disposición sobre los bienes gananciales, dando cumplimiento al contenido del artículo 66 del mismo códi go, reafirmando la igualdad de derechos y deberes entre los cónyuges.

448 "Del régimen de participación” en RAMS ALBESA, J y MORENO ÁLVAREZ, J. A. (Coords.) "El régimen económico del matrimonio. Comentarios al Código civil: especial consideración de la doctrina 
ventaja de la separación absoluta de bienes es decir de titularidades y responsabilidades, con los comunes o gananciales y por consiguiente la solidaridad en los resultados comerciales que conlleva una comunidad de vida, en opinión de ALGARRA PRATS ${ }^{449}$, por cuanto cada cónyuge adquiere el derecho a participar en las ganancias obtenidas por su consorte durante el tiempo de vigencia del mismo, si bien la participación per se no se produce en las ganancias, sino en las diferencias entre las ganancias de uno y las del otro cónyuge, esto provoca que claramente existan dos etapas, la primera acaece con la separación de bienes, y la segunda cuando se produce la extinción del régimen en la que se lleva a cabo la participación en las ganancias obtenidas por la otra parte, lo que revierte en que cada una de ellas comparte cuestiones de índole económica, sin duda esto implica un avance para la plena igualdad de los cónyuges.

Sin embargo, su aplicación genera ciertas dudas y temores, en lo referente por ejemplo, a la composición del patrimonio, tanto el inicial como el final, y sobre todo si la valoración de los bienes es real y justa. También puede generar dudas respecto a si se pacta una participación distinta a la del 50\%, por cuanto debe de ser la misma proporción en ambos patrimonios, por ejemplo en caso de no haber descendientes. De tal manera que podría llegar a tener efectos positivos en el cónyuge que obtiene ingresos menos favorables que en los supuestos en que el régimen aplicable sea el de separación de bienes. Puede opinarse tan sólo cuando la mujer adquiera una efectiva igualdad en relación con los hombres en todos los aspectos que conforman la vida civil, ya sea laborales o familiares, etc, propiciando la conciliación de ambos, puede que en tal caso su acogida sea mas positiva, dando lugar a un equilibrio entre autonomía de la voluntad e igualdad.

jurisprudencial”, Ed. Dykinson S.L., Madrid, año 2006, páginas 721 a 814 . La autora manifiesta que no se encuentran antecedentes históricos respecto de España, pero sus precedentes se encuentran en los mismos regímenes de comunidad de ganancias, pues los autores clásicos decían que, durante la vigencia de la sociedad, el marido era el dueño in acto de los bienes gananciales y que la mujer tenía sólo una expectativa de participación; extinguida la sociedad, la cotitularidad era plena, y por lo tanto, mucho mas consistente que la que proporciona actualmente el régimen de anticipación”.

449 TAMAYO HAYA, S. "La posición jurídica de la mujer a través de las reformas del Derecho de familia” en en LÓPEZ DE LA CRUZ, L y OTERO CRESPO, M. (Coords.) "El levantamiento del velo: La mujeres en el Derecho Privado”, Ed. Tirant Lo Blanch, Homenajes y Congresos, Valencia, año 2010, páginas 788 y 789. “Igualmente se contempla en los textos la posibilidad de optar por el régimen de participación, en todo caso convencional, y que se configura como un instrumento interesante en la consolidación de la solidaridad e igualdad de los cónyuges. Y ello porque combina ventajas tanto de la sociedad de gananciales (solidaridad económica entre ellos y compensación al trabajo prestado en el hogar ya que al extinguirse el régimen se participa en el mayor beneficio o ganancia conseguido por el otro, lo cual desde un punto de vista de la solidaridad conyugal de compartir al máximo cada esposo el destino del otro en lo económico, resulta muy ventajoso), como del régimen de separación (independencia de los cónyuges como si fueran solteros). Se conjuga de este modo el principio de solidaridad familiar que ha de inspirar el régimen patrimonial del matrimonio con la autonomía y libertad de actuación de cada cónyuge en la gestión de sus bienes propios como expresión de la autonomía de la voluntad en este ámbito." 
Finalmente el régimen de separación de bienes, en cierta manera parece sencillo de entender por cuanto se trata en definitiva que los bienes que cada cónyuge posee o por cualquier título obtiene son de su propiedad ${ }^{450}$. Puede estimarse que con el transcurso de los años los bienes se confundan, sobre todos los de naturaleza mueble. Estos son difícilmente demostrables, aunque existe la regla enunciada en el artículo 1441, la cual se refiera a los supuestos en que no es posible acreditar la pertenencia de algún bien, entonces les corresponde a ambos por mitad. En tal sentido, para facilitar la titularidad dominical son frecuentes las cláusulas que presumen la misma y que pretenden, principalmente, que el hecho de que un bien aparezca a nombre de uno de los cónyuges determine que se le atribuye el dominio o la titularidad del derecho que se trate y únicamente, cuando ello no sea posible, es de aplicación el art. 1444 del Código Civil.

Me parece interesante que, respecto a la plena igualdad entre hombres y mujeres, en el ámbito de los regímenes económicos se deba analizar el ya citado artículo 1438, que al regular las consecuencias ordinarias del régimen de separación de bienes contempla la justa valoración del trabajo de uno de los esposos en su dedicación a la familia y al hogar, estableciendo el derecho a obtener una compensación en el momento de extinguirse el régimen de separación, pero de una manera proporcional a los respectivos recursos económicos en caso de que hayan contribuido al mantenimiento de las cargas familiares, pero no a la posibilidad de atribuir dominio alguno sobre los bienes y por tanto de convertir en comunes aquellos bienes que sean privativos de un cónyuge $\mathrm{e}^{451}$. De todas maneras la posibilidad para obtener una compensación económica es bastante escueta en el Código Civil, a diferencia de lo dispuesto en otras legislaciones autonómicas.

Un ejemplo de lo anterior lo constituye la Ley Valenciana de Régimen Económico Matrimonial, Ley 10/2007, de 20 de marzo, dicha ley no parte de un supuesto de incumplimiento de ningún deber conyugal, sino de una justa compensación por un trabajo realizado en el hogar, por lo que el efecto moral y social pasa a un segundo plano para reconocer la existencia de una norma de carácter

450 RIBERA BLANES, B. "La contribución a las cargas en el matrimonio en el régimen de separación de bienes", Ed. Tirant Lo Blanch, Valencia, año 2004. Esta autora es de la opinión que el régimen de separación de bienes tiene su origen en el sistema romano de separación combinada con la dote, propio del matrimonio sine manu. El sistema matrimonial romano penetro en la tradición jurídica castellana por medio de Las Partidas, aunque el peso adquirido por la comunidad de gananciales es en el Derecho territorial castellano y su compatibilidad con la dote hicieron que nunca existiese un régimen de separación puro. En todo caso podría esgrimirse que existía el régimen de separación de separación cundo la mujer ejercitaba la facultad de renunciar al régimen de sociedad conyugal prevista en la Ley 60 de Toro.

451 GARRIDO DE PALMA, V. M. “El matrimonio y sus regímenes económicos”, II Congreso Internacional del Derecho Familiar, Madrid y Salamanca, 2 al 6 de octubre de 1978 (Ponencia) 
liquidatorio, consecuencia de valorar la contribución al levantamiento de las cargas del matrimonio $^{452}$.

El CCCat le otorga amplia libertad a los cónyuges, ejemplarmente en el art. 231-19.1 se parte de la libre determinación del contenido de los capítulos que en caso de celebrarse regulan las relaciones económicas de los mismos, en tales capítulos se incluyen las estipulaciones y pactos que tengan por convenientes, eso si, siempre que sean lícitos, ahora bien, lo anterior no obsta a que necesariamente se encuentren limitados por el principio de igualdad, art. 231-2.2. Es más, desde la Ley 13/2005 sobre el derecho a contraer matrimonio, ese objetivo de igualdad entre los cónyuges ha de referirse indistintamente en las uniones conyugales heterosexuales y homosexuales, por lo tanto ya no es únicamente evitar alguna discriminación que se funde en su orientación sexual. Ello se infiere de los artículos 41 y 42 de la antigua Ley 9/1998, de 15 de julio, precedentes del art. 232 del Código Civil de Cataluña ${ }^{453}$. En dicha Comunidad, el régimen supletorio lo constituye el de separación, pero de su normativa se concluye que en el caso de que acaeciese la compensación o indemnización se realizará una comparación entre los patrimonios de ambos cónyuges, buscando su igualdad de conformidad a lo sucedido en el matrimonio de tal manera que al existir disparidad se intenta corregir el empobrecimiento a causa del trabajo gratuito y no reconocido de uno de ellos. Por tal motivo lo que se compara es la situación durante el divorcio y cual es la real tras el divorcio ${ }^{454}$. Doctrinalmente existió cierta polémica, y no me refiero únicamente al ámbito catalán sino que más allá, a ni-

452 El principio de igualdad entre cónyuges es una exigencia constitucional (arts. 14 y $32 \mathrm{CE}$ ) recogida en el art. 3 como fundamento del régimen económico matrimonial valenciano, añadiéndose a continuación que "se define por la más absoluta libetad civil" entre los c'nyuges. Sin embargo la plena igualdad de compadece mal con la más absoluta libertad civil. Al parecer la ley pretende que en los casos de violencia de género y para proteger a los hijos menores y discapacitados y a las personas mayores o en situación de dependencia, como ya hemos señalado, la ley puede establecer reglas que quiebren el principio de igualdad jurídica de los cónyuges o que limiten su libertad civil. Sin embargo de conformidad al art. 3 LREMV, es nulo cualquier pacto que vulnere la igualdad de derechos que corresponde a cada cónyuge. Asimismo la igualdad se presenta de manera muy precisa en el acto jurídico capitular, es de hecho un límite a la libertad capitular de los cónyuges. Dicha exigencia tiene su origen constitucional en los arts. 14 y 32 , pero se reitera en los arts. 3 y 25 LREMV. La formula legal contenida en el art. 25 de la citada Ley evoca la formulación general de la autonomía de la voluntad contenida en el art. 1255 CC.

453 TAMAYO HAYA, S. "La posición jurídica de la mujer a través de las reformas del Derecho de familia” , ...op. cit., páginas 788 y 789 . "En esta línea más justa y equilibrada parece la solución ofrecida por el C. de Familia catalán que en su art. 41 reconoce una compensación económica por razón de trabajo: "En los casos de separación judicial, divorcio o nulidad, el cónyuge que, sin retribución o con una retribución insuficiente, ha trabajado para la casa o para el otro cónyuge tiene derecho a recibir de éste un compensación económica, en caso de que se haya generado, por este motivo, una situación de desigualdad entre el patrimonio de los dos que implique un enriquecimiento injusto". A pesar de que no establece criterios precisos sobre la determinación de la cuantía (cuestión que queda ya solventada por el artículo $232.5^{\circ}$ y $6^{\circ}$ del Proyecto de Ley del Libro Segundo del CC de Cataluña, tiende a corregir los resultados perversos que el régimen de separación de bienes puede comportar para alguno de los cónyuges y constituye una regla especil de liquidación cuando la extinción del régimen venga motivada por la separación, la nulidad o el divorcio entre las partes.

454 El artículo 84 del Código de Familia Catalán es un equivalente al artículo 97 del Código civil. 
vel general, por cuanto para autores como LASARTE y VALPUESTA ${ }^{455}$, así como PÉREZ MARTÍN ${ }^{456}$, opinaban que eran compatibles la pensión compensatoria y la compensación. Mientras que autores como DE LOS MOZOS, MARTÍNEZ CALCARREDA y LACRUZ BERDEJO, aún reconociendo que el cónyuge que trabaja en el hogar y pese a tener un derecho a que se valore su trabajo como aportación y contribución a las cargas del matrimonio, tal aporte se medía en función de la retribución del servicio doméstico o en caso de no acordarse debía ser resuelto por autoridad judi$\operatorname{cial}^{457}$.

También como ejemplo, expreso que el principio de igualdad se encuentra recogido en el art. 3 de la Ley 10/2007, de Régimen Económico Matrimonial Valenciano, aunque también enfatiza la más absoluta libertad civil. Esto sin duda plantea dudas, por cuanto se sabe que la plena igualdad puede resultar contradictoria con la plena libertad civil, pero ante ello la interpretación que despeja las interrogantes de este punto es la que afirma que es nulo cualquier pacto que vulnere la igualdad de derechos que corresponde a cada cónyuge. Asimismo en la determinación voluntaria del régimen económico, la igualdad aparece como fundamento al mismo y como límite a la libertad capitular de los cónyuges. Dicha exigencia tiene origen constitucional en los arts. 14 y 32 de la Constitución, pero es reiterada en los arts. 3 y 25 de la Ley recién citada. El planteamiento general se encuentra en el art. 25 al establecer como límite a la libertad capitular "lo que establece esta Ley, lo que resulte de las buenas costumbres y lo que imponga la absoluta igualdad derechos y obligaciones entre los consortes dentro de su matrimonio”, resalta que dicha disposición no establece el tipo de ineficacia del pacto capitular que lo incumple. Se debe ir al caso concreto para saber si se infringe una norma imperativa común a todo régimen matrimonial o la propia de cada uno. El principio de igualdad en el presente caso se manifiesta en este punto concreto como limitación a la autonomía de la voluntad, e impide pactos limitativos de dicha igualdad, pero este principio es operativo en todo el Derecho de Familia y constituye criterio rector del sistema económico matrimonial.

Analizados los tres regímenes que en la actualidad se contemplan en el Derecho español, en condiciones donde exista plena igualdad de oportunidades entre hombres y mujeres al mercado laboral, sin duda es el régimen de separación de bienes el que más acorde puede estar conforme a aquel principio, de esta manera puede que el rol históricamente asignado a las mujeres cambie, aun-

455 LACRUZ BERDEJO, J. L. "El nuevo contractualismo en el Derecho de familia", Revista La Ley, núm. 3, Madrid, año 1982, página 729.

456 PÉREZ MARTÍN, A. J. "El procedimiento contencioso de separación y divorcio", en VV. AA. "Derecho de Familia", Ed. Lex Nova, 2 edición, Valladolid, año 1998.

457 GARRIDO DE PALMA, V. M. El matrimonio y sus regímenes económicos”, ....op. cit, página 193. 
que traiga aparejada una doble carga, el trabajo doméstico y el extra doméstico, situación que ya fue contemplada en la reforma de 1981 en cuanto a valorar el trabajo no remunerado que se realiza al interior del hogar, pero tan sólo en lo que afecta a los regímenes de separación de bienes y participación en los gananciales, pero tal reconocimiento no está contemplado para el régimen mayoritario en el Derecho común como lo es la sociedad de gananciales, debido a que no es frecuente la separación de bienes cuando sólo de uno de los cónyuges trabaja.

\section{6 | Igualdad y Filiación, en relación al Derecho a la identidad}

\subsection{La filiación como institución del Derecho de familia: La convergencia de factores biológicos y legales}

La filiación comienza con el nacimiento y posee una dimensión meta natural, esta es jurídica, cultural y ética, que la transforma en una institución que trasciende lo meramente legal. La pregunta sobre por qué se ha de privilegiar el principio de verdad material o biológica, u otro factor ajeno a la biología, en la determinación de la filiación, en aras de procurar el mejor interés del menor, encuentra su respuesta en que la relación paterno-filial no es un fin en sí, sino un medio para tutelar los derechos del hijo.

La determinación de la filiación cuando se hace en base a un criterio material permite a los hijos conocer su origen biológico y su identidad, por ello ante la pregunta ¿quién soy?, sin duda la respuesta de que, soy en parte lo que son mis padres es muy acertada ${ }^{458}$. Por otro lado, al determinarse la filiación se obliga a que los progenitores asuman sus deberes frente a sus hijos. Sin embargo, el interés del menor aconseja en algunos supuestos o bien no establecer un lazo legal entre hijos y progenitores, o bien interrumpirlo para evitar males psicológicos, y aun físicos, en la persona en formación ${ }^{459}$.

458 BUSTO LAGO, J. M., "Precisiones constitucionales sobre la investigación de la paternidad. La valoración de la prueba biológica (A propósito de la STC 29/2005, de 14 de febrero. La doctrina jurisprudencial y constitucional “ortodoxa”), Revista de Derecho Privado y Constitución., núm. 19, Madrid, año 2005, páginas 7 a 54.

459 PULIDO QUECEDO, M. “De nuevo sobre las pruebas de investigación a la paternidad”, BIB 2007/1315, Repertorio Aranzadi del Tribunal Constitucional num.12/2007 parte Tribuna, Ed. Aranzadi, SA, Pamplona. Año 2007, BIB 2007/1315. "No hace mucho prestábamos atención a la , enlazando su comentario con la consideración del Constituyente por proteger de forma igual a los hijos, sea cual fuere su filiación, lo que propició que el Alto TrSTC 29/2005, de 14 de febrero (RTC 2005, 29) ibunal se pronunciase sobre el alcance de la investigación de la paternidad. Lo hizo en la STC 7/1994, de 17 de enero (RTC 1994,7).- Allí fijó el alcance y límites de la prueba de investigación de la paternidad, que como recuerda la STC 177/2007 (RTC 2007, 177)_, han encontrado eco en el art. 767.4 de la LECiv ( Ley 1/2000 [ RCL 2000, 34, 962 y RCL 2001, 1892]_). En primer lugar, aclaró que la finalidad de permitir la práctica de las pruebas biológicas no es otra que la defensa de los intereses del hijo, tanto en el orden material como en el moral. No obstante, precisó que en la tensión entre derechos fundamentales, los invocados derechos a la integridad y la intimidad, el constituyente hizo prevalecer el in- 
La familia es una realidad en la que lo natural, lo social y lo legal convergen, los actos jurídicos y los vínculos relacionados con ellas se encuentran en mutua interacción. Sobre la base de dos pilares fundamentalmente, el matrimonio o una relación análoga al mismo y la filiación, se estructura el conjunto de normas que conocemos como Derecho de Familia. La familia como institución está compuesta por un complejo de relaciones de sustrato sociológico y cobertura normativa: legalmente una familia implica la interacción de personas, hechos, comunicación de lazos de vida, si acaso somos seres en permanente relación, sin duda la familia es el más íntimo de todos ellos ${ }^{460}$. Todo este conjunto tiene su origen en dos fuentes principales: la relación afectiva, que en la mayoría de los casos constituirá un matrimonio y la generación. El primero consiste en el pacto o contrato celebrado entre dos personas núbiles y que implica una comunidad de derechos patrimoniales y extrapatrimoniales. El segundo se refiere al vínculo, surgido a partir de un hecho, acto o negocio jurídico según el caso, que coloca a dos individuos en una situación única de mutua interdependencia patrimonial y extrapatrimonial.

En el régimen de filiación encontramos una suerte de espejo de la concepción social vigente de lo que es la familia y del valor del matrimonio como fundamento jurídico de la misma. En relación y proporción con el valor, trascendencia y situación social, económica y jurídica del matrimonio, ha primado uno u otro principio o criterio en materia de filiación. Los dos ejes o círculos que integran la familia, la relación entre los progenitores ${ }^{461}$, en caso de haberlos y la relación paterno-fi-

terés social y de orden público que subyace en las declaraciones de paternidad, si bien la práctica de la prueba queda sometida a determinadas garantías y límites.- Por ello consideró necesario, rodear la práctica de la prueba de un conjunto de garantías -al tratarse de una intervención corporal y pese a su alto grado de fiabilidad, absoluto, según la ciencia médica, para determinar la paternidad negativa y cercana al 99\% cuando es positivapara alcanzar los fines constitucionales protegidos.- Con esta finalidad -se señaló- que no siempre la prueba de paternidad es obligatoria, sobre todo cuando es posible obtener evidencias sobre la paternidad a través de otros medios menos lesivos para la integridad fisica. De tal suerte -señaló- que en tal caso el órgano judicial no está autorizado para disponer la práctica obligatoria de los análisis sanguíneos- En cuanto a los límites estableció uno de alcance absoluto consistente en no poder acordarse su práctica cuando supone un quebranto para la salud de quien la debe soportar y precisó, además, que debía estar sometida siempre a una adecuada proporción entre los derechos a la intimidad e integridad y la finalidad a la que sirve. - Esta doctrina, en lo que constituye su nervio y sustancia ha sido aplicada por los tribunales ordinarios, más allá de la puntual queja corporativa de algunos magistrados ejercientes en el orden civil."

460 O’CALlaghan MUÑOZ, X., “Compendio de Derecho Civil”, Tomo IV, Ed. Edersa, 5a, edición, Madrid, año 2001, página 62 a 64.

461 TAMAYO HAYA, S. "De la paternidad biológica a la paternidad social" en BLASCO, F y Otros (Coords.) "Estudios jurídicos en homenaje a Vicente L. Montés Penadés". Tomo II, Ed. Tirant Lo Blanch, Homenajes y Congresos, Valencia, año 2011,páginas 2557 y 2558. "Estos cambios sociales traen como consecuencia que aparezcan con fuerza nuevos sujetos que se sitúan al lado de aquellos familiares que tradicionalmente se han hecho cargo del menor. Resulta así que, tanto el aumento del número de divorcios como las nuevas configuraciones familiares, conducen al niño a verse rodeado de terceros, padres o no: abuelos, tíos, padrastros, hermanastros..., los cuales pueden intervenir en su desarrollo o incluso compartir su vida diaria y establecer con él vínculos estrechos y duraderos.- La consecuencia fundamental será una voluntad de redifinir el lugar y la figura del tercero y su reconocimiento como titular de la responsabilidad parental, con el fin de, respetando a los pa- 
lial. Ambos son el objeto de estudio del Derecho de Familia y su existencia puede ser simultánea y conjunta o separada y aislada, con convergencias en algunos supuestos. Como es evidente, estos dos ejes del Derecho de familia, filiación y matrimonio o la relación análoga del mismo, pueden discurrir de forma conjunta, lo cual tiene su asidero en el supuesto de concurrir un vínculo matrimonial y uno o más vínculos paterno filiales (como ser un grupo familiar compuesto por dos cónyuges y su progenie) o separada, en la filiación extramatrimonial (en la que se verifica un vínculo progenitor-hijo, sin existir vínculo conyugal con el otro progenitor). Las causas, vínculos y efectos de uno y otro eje son, en principio, independientes; sin embargo existen puntos de intersección que han fluctuado con el devenir histórico de las instituciones. Matrimonio, concepciones culturales y sociales, y filiación, se entrecruzan en cuestiones como las disposiciones y prohibiciones matrimoniales; legitimidad de la descendencia; parentesco; transmisión de nombre; propiedad; rango y dignidades; tutela y alimentos sobre la progenie y la autoridad parenta ${ }^{462}$.

Los factores naturales y, en especial, sociales, que confluyen en el tratamiento legal de las relaciones familiares, han fluctuado con el devenir histórico de las normas. Es así como la familia y la filiación han adoptado diversas formas legales según costumbres, creencias y usos sociales, en cada época. Algunos cambios han sido muy pronunciados a partir de la segunda mitad del Siglo XX.

El objeto de estudio del presente título es la filiación, pero ¿qué es y qué la compone?, de entrada me remitiré a la segunda pregunta, la componen la biología y la norma, el vínculo y la ley, pero ambos términos son como una pareja de enamorados, no siempre van de la mano. La posibilidad de disociar ambos permite que la filiación no necesariamente se asiente sobre un hecho natural de relevancia jurídica. Aún más, con la introducción de las Técnicas de Reproducción Humana Asistida (TRHA), la posibilidad de prescindir del dato biológico en la filiación ha aumentado en las últimas décadas. El Derecho se inclina a favorecer, en algunas situaciones, ciertos factores socioculturales, cuestión relacionada con la concepción actual del rol y funciones de la familia.

dres, facilitar su intervención en la vida del niño.- A la hora de concretar quienes son estos titulares de la responsabilidad parental, los Estados Miembros no mantienen una postura unánime. Son muchas las disparidades existentes en materias como la regulación de las parejas de hecho, inscritas o no, o la orientación sexual de cualquiera de sus miembros, y en particular, el reconocimiento del matrimonio entre homosexuales... La diferencia entre titularidad y ejercicio de la responsabilidad parental conduce a interpretar "cualquier titular" como todo sujeto que ejerce dicha responsabilidad, pudiendo recaer sobre un gran número de personas dependiendo de la amplitud concedida en cada ordenamiento, mientras que la atribución de la titularidad suele ser más estricta al corresponder, por lo general, a los padres desde el nacimiento del niño (estén o no casados) o la madre en solitario, dependiendo de las legislaciones".

462 KONIG, R., "La familia en nuestro tiempo. Una comparación intercultural”, Ed. Siglo XXI ediciones, $2^{\mathrm{a}}$ edición, Madrid, año 1994, páginas 6 a 18. 
La filiación es un concepto artificial, eminentemente jurídico. Establecer que una persona tiene por progenitor a otra, implica otorgarle un determinado estado civil, darle una posición dentro del sistema jurídico, situación que conlleva un nombre, el de hijo o hija de una persona particular. Históricamente, ese estado civil se diferenció en status filii y status familiae. El criterio de tal distinción radicó en alcance de las obligaciones y derechos entre padres e hijos, y la posibilidad de extenderlos a los parientes de ulterior grado. En el actual Derecho español, ambos status coinciden en un único estado civil ${ }^{463}$.

La relación de filiación es primordialmente jurídica puesto que, aun cuando el Derecho escoge como regla general al dato biológico de quién ha generado a quién para establecerla, en ocasiones impide que este dato actúe plenamente. El interés de la familia exige un cierto margen de apreciación entre familia biológica y familia legal. Hay situaciones en las que conviene que el Derecho no se apegue estrictamente a la Biología, en salvaguarda de otro valor fundamental ${ }^{464}$.

Así es como la Ley incluso llega a prescindir del hecho natural, construyendo la filiación sobre la relación adoptiva, a modo de ficción jurídica, el Legislador amparándose en la autonomía de la voluntad crea el vínculo bajo dos premisas, la primera, el interés superior del menor y la segunda de los futuros padres (puede ser uno) de poder educar y cuidar a un niño. Concluyendo esta reflexión precedente, el Derecho concede este estado civil en tres situaciones: cuando verifica la relación de generación natural (siempre que no existan circunstancias que hagan desaconsejable la consolidación legal de la relación generativa, así los artículos 124 y $125 \mathrm{CC}$ ); cuando se produce el acto jurídico atributivo de una relación de familia, mediante el recurso de la adopción; y a través del negocio jurídico en las TRHA. Puede, por ende, existir un estado de filiación apoyado en la generación y otro estado de filiación que no se apoye en ella ${ }^{465}$. También en la actualidad cabe la posibilidad de

463 La filiación no es un hecho que comienza con la gestación y acabe con el parto, sino que es una realidad que se prolonga durante toda la vida del individuo. Esta realidad que se prolonga durante toda la vida del individuo posee una cobertura legal o marco jurídico: el estado civil o status. El estado civil es uno de los conceptos más antiguos y permanentes de la ciencia jurídica: el Derecho Civil, el Canónico y el Penal hacen aplicación de esta circunstancia en materia de sucesiones, impedimentos matrimoniales y agravantes de ciertos delitos. Desde que se presume la posibilidad de la existencia de una persona, un conjunto de variables que incluyen la edad, el sexo y el nacimiento (entre otros) determinan una posición en la vida jurídica que es la caducidad relativa de los derechos.

464 HERRERA CAMPOS, R. "La filiación no matrimonial tras la reforma del Código Civil de 13 de mayo 1981 ”, Revista de Derecho Privado, Madrid, año 1983, página 24.

465 Se puede agregar que la filiación no es un hecho que comienza con la gestación y acabe con el parto, es más que esto, es una realidad que se prolonga durante toda la vida del individuo. Esta realidad posee una cobertura legal o marco jurídico: el estado civil o status. El estado civil es uno de los conceptos más antiguos y permanentes de la ciencia jurídica: el Derecho Civil, el Canónico y el Penal hacen aplicación de esta circunstancias en materia de sucesiones, impedimentos matrimoniales y agravantes de ciertos delitos. Desde que se presume la posibilidad de la existencia de una persona, un conjunto de variables que incluyen la edad, el sexo y el nacimiento (entre otros) determinan una posición en la vida jurídica que es la capacidad relativa de los derechos. 
Capítulo II El Principio de igualdad y el Derecho de Familia - Igualdad y Filiación, en relación al Derecho a la identidad

la simple generación sin estado de filiación, tal es el caso de los hijos habidos por TRHA con participación de donante anónimo.

Antes de la transformación del Derecho de filiación, acaecida a partir de la segunda mitad del Siglo XX, existía una tercera posibilidad; aquellos hijos frutos de relaciones prohibidas por el Derecho (incesto, adulterio, sacrilegio) que carecían de estado de filiación. Estos hijos tenían progenitores pero carecían de padres. Dentro de la filiación por naturaleza, los dos tipos de filiación que actualmente se reconocen, matrimonial y no matrimonial, poseen la misma causa ${ }^{466}$, pero siguen existiendo diferencias en los modos de determinación de uno y otro.

En relación con esto cabe afirmar que el Derecho de Familia, por sus especiales características, posee puntos de encuentro con el Derecho Público y diversas instituciones familiares son alcan-

466 STC, Pleno, núm. 273/2005 de 27 octubre. RTC 2005/273. " Aclarado el anterior extremo, podemos proceder ya al análisis de la primera infracción constitucional que se atribuye al art. 133, párrafo primero, del Código Civil. En el Auto de planteamiento de la cuestión se aduce que el precepto colisiona con el derecho a la igualdad ante la Ley en un doble sentido: por una parte, porque consagra una diferenciación de trato, en los supuestos de falta de posesión de estado, según el origen matrimonial o no de la filiación que, a juicio del órgano judicial, no puede ser considerado como elemento diferenciador que justifique la disimilitud de supuestos ni, por consiguiente, de soluciones jurídicas en cuanto a las oportunidades para acceder al proceso en que se discute la propia existencia de la relación paterno-filial. Por otra parte, por la desigualdad que produce entre los progenitores, al favorecer al que primero determina la filiación por medio del reconocimiento. - El art. 14 CE, al proclamar el principio general de que «los españoles son iguales ante la Ley», establece un derecho subjetivo a obtener un trato igual, e impone a los poderes públicos la obligación de llevar a cabo ese trato igual, al mismo tiempo que limita al poder legislativo y a los poderes de los órganos encargados de la aplicación de las normas jurídicas ( STC 49/1982, sw 14 de julio de 1982 , F. 2). Ahora bien, como tenemos declarado desde la STC 22/1981, de 2 de julio ( RTC 1981, 22) , recogiendo al respecto la doctrina del Tribunal Europeo de Derechos Humanos en relación con el art. 14 del Convenio Europeo de Derechos Humanos (CEDH), el principio de igualdad no implica en todos los casos un tratamiento legal igual con abstracción de cualquier elemento diferenciador de relevancia jurídica, de manera que no toda desigualdad de trato normativo respecto a la regulación de una determinada materia supone una infracción del mandato contenido en el art. 14 CE, sino tan sólo las que introduzcan una diferencia entre situaciones que puedan considerarse iguales, careciendo de una justificación objetiva y razonable para ello. Por tanto, como regla general, lo que exige el principio de igualdad es que a iguales supuestos de hecho se apliquen iguales consecuencias jurídicas y, por consiguiente, veda la utilización de elementos de diferenciación que quepa calificar de arbitrarios o carentes de una justificación razonable. De este modo, lo que prohibe el principio de igualdad son las desigualdades que resulten artificiosas o injustificadas por no venir fundadas en criterios objetivos y razonables, según criterios o juicios de valor generalmente aceptados. Por lo demás, también es necesario, para que sea constitucionalmente lícita la diferencia de trato, que las consecuencias jurídicas que se deriven de tal distinción sean proporcionadas a la finalidad perseguida, de suerte que se eviten resultados excesivamente gravosos o desmedidos. En resumen, el principio de igualdad, no sólo exige que la diferencia de trato resulte objetivamente justificada, sino también que supere un juicio de proporcionalidad desde una óptica constitucional sobre la relación existente entre la medida adoptada, el resultado producido y la finalidad pretendida [por todas, SSTC 152/2003, de 17 de julio, F. 5 c); STC 255/2004, de 22 de diciembre, F. 4; y STC 10/2005, de 20 de enero de 2005 F. 5].- Así pues, el presupuesto esencial para proceder a un enjuiciamiento desde la perspectiva del art. 14 CE es que las situaciones subjetivas que quieran traerse a la comparación sean, efectivamente, equiparables ( STC 76/1986, de 9 de junio, F. 3), y ello entraña la necesidad de que el término de comparación no resulte arbitrario o caprichoso (STC 148/1986, de 25 de noviembre, F. 6). Dicho de otro modo, el juicio de igualdad ha de constatarse siempre mediante un criterio de carácter relacional que, cuando se proyecta sobre el legislador, requiere la comprobación de que la norma de que se trate atribuye consecuencias juridicas diversificadoras a grupos o categorías de personas creadas o determinadas por él mismo...). 
zadas por disposiciones de orden público. Elementos como el estado civil de las personas, la nacionalidad y vecindad civil -todas ellas íntimamente ligadas a la filiación- trascienden la esfera del Derecho Privado. A su vez, a partir de la Segunda Guerra Mundial, han proliferado las cartas internacionales de derechos humanos cuyo campo de protección precisa ser plasmado en normas de Derecho interno. En ocasiones, el respeto por un derecho o libertad reconocido en un tratado internacional de derechos humanos exige la legislación civil del Estado que adhiere el tratado sea modificada. Esto explica, en parte, la preocupación mundial suscitada alrededor de ciertos ámbitos del Derecho de familia a partir de la segunda mitad del Siglo XX.

La figura del menor ha cobrado una relevancia especial, que se extiende a prácticamente todas las ramas del Derecho Civil. La autonomía de los particulares queda sumamente restringida, y la regulación de la filiación se ve influida por normas constitucionales e instrumentos internacionales, que en el caso de España, también incluyen normativa de la Unión Europea ${ }^{467}$.

La injerencia del Derecho Público en el régimen de la filiación comenzó en el ámbito internacional, para luego trasladarse a la esfera nacional a través de la normativa constitucional primero, y la legislación de menor rango después. En el plano internacional y global, la evolución que comenzó con el reconocimiento de la titularidad de los derechos humanos sin distinciones, culminó con el reconocimiento de los derechos del niño, como sujeto que goza de un status particular. La minoría de edad es protegida en virtud del proceso evolutivo que comprende: la personalidad va evolucionando hacia una autonomía y afirmación del yo, evolución paulatina pero de trascendencia para el ordenamiento jurídico. Se ha configurado un estatuto jurídico especial para la figura del niño, basándose en los principios de igualdad y primacía del interés del menor ${ }^{468}$.

467 Como consecuencia de esto, el Derecho de filiación ha sufrido transformaciones desde el interior, debido a los cambios experimentados por la sociedad, y desde el exterior. Esto último se explica por la trascendencia pública de ciertas instituciones de familia. Los efectos de la filiación, el régimen procesal especial para cuestiones en las que estén involucrados menores, la intervención de órganos estatales para velar por el interés del menor, son ex presiones del relativamente limitado campo de la autonomía de la voluntad en esta materia.

468 A su vez el Estado español ha adquirido un conjunto de compromisos supranacionales y regionales dentro del marco de la Unión Europea y del Consejo de Europa. En cumplimiento del objetivo de libre circulación de personas, pilar de la Unión Europea, ha sido necesario unificar legislaciones internas, incluido lo relativo a los menores, la filiación sus efectos. La apertura ad extra del ordenamiento permite y obliga a la incorporación de derechos reconocidos al amparo de normas internacionales y supranacionales. La tendencia en Europa es la unificación de criterios comunes en el Derecho privado. Si bien esta unificación atañe, fundamentalmente, a todo lo relacionado con el tráfico de bienes y servicios, puede alcanzar a ciertos aspectos relativos a la filiación y su régimen de ser necesario para garantizar la libre circulación de personas o la protección de los derechos humanos. Sin embargo, persisten diferencias en los ordenamientos de cada uno de los estados miembros. Estas normas inciden sobre la protección de los menores, generando nuevos derechos y obligaciones. Es por ello que no puede estudiarse el Derecho Civil aislado de estas normas. 
En el ámbito europeo, el Consejo de Europa, de acuerdo con su estatuto fundacional, tiene plena competencia en materia de Derecho de Familia y política familiar. Al igual que lo sucedido en otras áreas del Derecho Comunitario, el desarrollo y expansión hacia la unificación de esta rama, ha quedado en manos del Tribunal Europeo de Derechos Humanos (TEDH). El artículo 8 del Convenio de Roma, o Carta Europea de Derechos Humanos y Libertades Fundamentales (CEDH), protege el derecho fundamental de toda persona a la vida familiar ${ }^{469}$, tema al cual ya me he referido con anterioridad.

En tal sentido puede hablarse de un derecho a fundar una familia y relacionarlo con el derecho a la intimidad, por ello la Convención Europea de Derechos Humanos de 1950 o el Pacto de Derechos Civiles y Políticos de 1966, reconoce el derecho de todo ser humano a fundar una familia y de manera implícita el derecho a tener descendencia propia, ello implica también el adoptar.

ALKORTA IDIAKEZ ${ }^{470}$ entiende que la tutela de la libertad procreativa, en tal sentido, en su dimensión biológica, está configurada y defendida en los artículos relativos a la protección de la intimidad personal y familiar en los propios convenios. Argumenta dicha autora que teniendo en cuenta la distinción habitual en materia de derechos humanos entre derechos positivos y negativos, la libertad de procrear se comprende como un derecho de carácter defensivo, es decir negativo, más que como un derecho positivo frente al Estado. Hasta no hace mucho que el hombre y la mujer debían ser protegidos frente a las injerencias de las autoridades públicas que interfieran sin su consentimiento en el proceso de reproducción ${ }^{471}$. Siguiendo esta línea argumentativa el derecho a procrear se entendía comprendido en la protección de la familia como lugar privilegiado en cuyo seno el individuo afirmaba y desarrollaba su personalidad, y cuando se menciona el término procrear puede perfectamente englobarse el de adoptar. Se configuraba además como un derecho negativo: el Estado no debía inmiscuirse en la libertad de procrear de las personas, ni tampoco de adoptar. Recientemente, la necesidad de tutelar a la persona por sí y en sí, prescindiendo de su inserción familiar o social ha llevado a la necesidad de reconocer explícitamente el derecho a la reproducción. Hoy más que en el pasado la centralidad de la tutela del individuo y de sus derechos empieza a configurar

469 TAMAYO HAYA, S. "Las uniones de hecho y las relaciones paterno-filiales en el derecho europeo”, Revista de Derecho de Familia, núm. 42, enero-marzo 2009, Ed. Lex Nova, Valladolid, páginas 59 a 101.

470 ALKORTA IDIAKEZ, I. "Nuevos límites del derecho a procrear", Revista de Derecho Privado y Constitución, núm. 20, Madrid, Enero-Diciembre, año 2006, páginas 9 a 61.

471 HALE, L. J. "From the test tube to the Coffin: Choice and Regulation in Private Life", Stevens/Sweet and Maxwell, London, 1996, página 5. “...The rights set out in the Artiles 8 to 12 of the European Convention on Human Rights form a coherent and related group, the right to respect for privte and family life, home and correspondence; the right to freedom of expression; the right right ti freedom of peaceful assembly and free association, and the right to marry and found a family. These are very essentials of a free-thinking and freespeaking society". 
nuevos derechos en las codificaciones nacionales e internacionales ${ }^{472}$, en tal sentido puede entenderse que el derecho a procrear es una vertiente fundamental del derecho a la toma de decisiones sobre la propia existencia vital.

El reconocimiento de un derecho subjetivo de procrear parece últimamente confirmado por las recientes decisiones de ética, propiciadas por organismos internacionales y legislaciones sectoriales de numerosos países europeos en torno a las implicaciones morales y jurídicas de los descubrimientos científicos sobre la vida humana, cuestiones que modernamente se conocen como decisiones relativas a la propia vida, de las cuales no puede excluirse la vertiente reproductiva. Sin duda la filiación, no es propiamente una decisión, pero en su origen sí que lo es, es un vínculo legal y afectivo siendo de los más esenciales de la existencia de cada persona

Los cambios en el régimen legal de la filiación se han operado desde el nivel político, con la introducción, o reelaboración, de dos principios fundamentales, el principio del interés superior del menor, y el de verdad biológica ${ }^{473}$.

Respecto a que debemos entender por filiación, JOSSERAND ${ }^{474}$, entendía la existencia de dos acepciones del término. La primera es amplia, y se refiere a la concatenación que une a una persona con sus antepasados hasta el más remoto. La segunda, de alcance más restringido y más usualmente

472 Cfr. Convenio de Asturias de Bioética de 1997 en cuyo artículo $2^{\circ}$ se declara que: "Primacía del ser humano. El interés y el bienestar del ser humano deberán prevalecer sobre el interés exclusivo de la sociedad o de la ciencia".

473 STS, Sala de lo civil, Sección $1^{\text {o }}$, núm. 915/2008 de 3 octubre. RJ 2008/5672 : “En esta misma línea, el Tribunal Constitucional destaca la necesidad de que el principio de libre investigación de la paternidad se compatibilice con las exigencias derivadas del principio de seguridad jurídica, al concurrir derechos e intereses legítimos dignos de protección que derivan de las relaciones paterno filiales que refleja el Registro Civil. "Por ello-se dice en el Fundamento de Derecho Cuarto de la Sentencia 138/2005- el establecimiento de un plazo de caducidad para el ejercicio de la acción de impugnación de la paternidad matrimonial, además de presentar una conexión evidente con el reconocimiento tácito (tacens consentit si contradicendo impedire poterat), tiende a preservar un valor o principio constitucional, como es el de la seguridad jurídica en las relaciones familiares y la estabilidad del estado civil de las personas, así como a proteger a los intereses de los hijos (art. 39.1 y 2 CE). Así lo impone la primacía del interés de los menores que recoge el art. 2 de la Ley Orgánica 1/1996, de 15 de enero (RCL 1996, 145)_, de Protección Jurídica del Menor, recordando los principios inspiradores de instrumentos internacionales en los que España es parte, a los que resulta obligado remitirse con arreglo a lo dispuesto en el art. 39.4 CE, especialmente a la Convención de Derechos del Niño, de Naciones Unidas, de 20 de noviembre de 1989, ratificada por España el 30 de noviembre de 1990 (RCL 1990, 2712), o también, en el marco de la Unión Europea, la Carta Europea de los Derechos del Niño, aprobada por Resolución A 3-0172/92, del Parlamento Europeo y el art. 24 de la Carta de los Derechos Fundamentales de la Unión Europea, aprobada en Niza el 7 de diciembre de 2001 (LCEur 2000, 3480), y cuyo contenido (aun sin fuerza jurídica vinculante) se ha incorporado al Tratado por el que se establece una Constitución para Europa (Título II). En el mismo sentido el Tribunal Europeo de Derechos Humanos ha declarado que no vulnera el art. 14 (prohibición de discriminación), en relación con los arts. 6 y 8 (derecho a un proceso equitativo y derecho al respeto de la vida privada y familiar) del Convenio Europeo de Derechos Humanos, la institución de plazos para entablar una acción de investigación de la paternidad, institución que se justifica por el deseo de garantizar la seguridad jurídica y proteger los intereses del niño (STEDH de 28 de noviembre de 1984 , caso Rasmussen c. Dinamarca, § 41)".

474 “Derecho Civil”, Tomo I, Volumen II, CUNCHILLA Y MANTEROLA, S (Trad.), Ed. Bosch, Buenos Aires, año 1950 , página 213. 
utilizada, indica el lazo entre el hijo y sus progenitores. Esta relación posee dos nombres según la perspectiva desde la que se considere: filiación, si es desde el punto de vista de la criatura, y maternidad o paternidad si es considerada según los progenitores. Los términos de la relación paterno-filial son padre o madre e hijo, ambos términos son tales en relación al otro ${ }^{475}$.

Sin duda, la generación es un hecho biológico con trascendencia legal, diferente de la institución jurídica de la filiación. Generación es un concepto biológico mientras que la filiación es una construcción normativa. De lo anterior se desprende que en la filiación hay dos elementos: el físico, procreación, y el legal, atribución de la progenitura a uno o dos sujetos que pueden o no estar unidos en matrimonio entre sí, que no siempre se corresponden ${ }^{476}$. Nadie es hijo, en términos de generación, sin tener un padre y una madre; realidad biológica que puede resultar a veces ignorada por el Derecho, y que permite la existencia de más de una clase de filiación. No obstante que la filiación, es su aspecto generativo o natural, se da siempre en todas las personas, ya que todo individuo es siempre hijo de un hombre y una mujer, aunque no siempre se pueda verificar la filiación como un hecho jurídico ${ }^{477}$. El hecho de la generación origina un vínculo de sangre, que existe con independencia del vínculo jurídico.

La relación natural en el plano jurídico se traduce en un estado, es decir, una posición particular ante el orden jurídico, integrada por un complejo de relaciones jurídicas de las que se derivan derechos y obligaciones, en este caso entre generador y generado. Algunas de estas relaciones abarcan también a miembros de la familia externa.

Por tratarse de un estado civil sus reglas, principios, efectos y causas están delimitados por normas de orden público. Incluso puede haber relación filial con ausencia total de vínculo biológico; así los casos de adopción, la presunción de paternidad del marido que no podía ser rebatida, y, actualmente los TRHA, tal cual lo entiende ROYO MARTÍNEZ ${ }^{478}$.

475 HERRERA CAMPOS, R. "La investigación de la paternidad y la filiación no matrimonial”, Ed. Comares, Granada, año 1987, páginas 28 a 33.

476 SCAEVOLA, Q. M. "Código Civil comentado y concordado”, Tomo III, arts. 108 a 198, Ed. Reus S.A., $5^{\text {a edi- }}$ ción, Madrid, año 1942, páginas 285 a 287.

477 CICU, A.. “La filiación”, Revista de Derecho Privado, Madrid, 1930, páginas 16.

478 "Derecho de familia”, Sevilla, año 1949, página 228. "(si bien) la Biología sabe que no puede existir un ser humano sin padre o madre (...), el Derecho, para trabar entre dos personas concretas la relación de filiación, plena de pretensiones reciprocas, ha de exigir de determinados presupuestos que, de faltar, hacen imposible el establecimiento del vínculo de parentesco, y entrañan, como consecuencia, que no es para el derecho un absurdo la existencia de un ser humano sin padre e, incluso, sin madre, porque ello no quiere decir que biológicamente carezca de ellos, sino que significa que, simplemente, ningún varón o mujer, tienen respecto de dicho menor los derechos y deberes que al padreo a la madre, corresponden por imperativo y concepción de la norma jurídica". 
La Ley y la sociedad no siempre han considerado que la unión entre lazo biológico y lazo legal fuera necesaria e imprescindible ${ }^{479}$. El Derecho a su vez, no crea el vínculo biológico, es decir no crea per se la relación jurídica. La norma configura el contenido del vínculo legal, y construye los conceptos de padre e hijo, que pueden o no coincidir con el hecho natural de ser generador y generado.

El meollo de la cuestión yace en que en el Derecho no hay relación de necesaria correspondencia entre la realidad biológica y el hecho jurídico, puesto que deben ser consideradas una multiplicidad de circunstancias ajenas a lo genético, y de naturaleza psicosocial ${ }^{480}$. Los conceptos de padre o madre y el de progenitor ya no tienen necesidad de coincidir desde el punto de vista legal. Biológicamente, progenitor es aquél o aquélla que han tenido autoría en la procreación de un individuo, han participado aportando su material genético. Jurídicamente, padre y madre son aquellas personas que cumplen con el conjunto de deberes y se benefician de los correlativos derechos de la cultura, la sociedad y el ordenamiento jurídico imponen. Progenitor es un término biológico; padre es una categoría jurídica ${ }^{481}$.

Sobre este punto, me parece relevante el estudio efectuado por TAMAYO HAYA ${ }^{482}$. Dicha autora analiza de manera concienzuda la figura del "padrastro" amparándose en la realidad, dolorosa en la mayoría de los casos, de la disgregaciones de las familias dando lugar a las denominadas "familias recompuestas", "reconstituidas", "ensambladas", "segundas familias", "superpuestas”, etc.

Estos conjuntos se caracterizan por el grupo formado por un progenitor, su cónyuge o pareja, los hijos por lo menos de uno de ellos y si los hay los hijos comunes ${ }^{483}$. Varias son las situaciones que pueden dar origen a dichos modelos, una de tales situaciones vendría a ser los casos de filiación determinada sólo respecto de unos de los progenitores. Esta reconstrucción puede ampararse en el matrimonio o no, y puede incluir hijos menores de anteriores lazos, de uno sólo de los miembros, de

479 D’ORS Y PÉREZ-PEIX, A. “Derecho Privado Romano”, Ed. EUNSA, 3ª edición, Pamplona, año 1977, páginas 263 a 265. En Roma, la palabra pater se refería a quien ostentaba un determinado poder, más que e hecho biológico de haber engendrado. El nacimiento y el lazo físico no eran constitutivo de la familia; la generación era menos importante que la voluntad del pater en admitir al niño como filius familiae. El Derecho civil romano ni si quiera exigía una rigurosa certeza sobre la generación, bastaba con la presunción pater is est quam nuptiae demostrant. Por eso, un niño huérfano era pater pues no estaba sometido a poder de nadie, aún sin tener descendencia.

480 ENGEL, M. "Familias ensambladas en todo el mundo. Análisis comparativo de los enfoques legales en paises seleccionados", Fundación Familias S. XX1, http://www.familiassiglo21.org, año 2004.

481 DIEZ-PICAZO PONCE DE LEÓN, L. y GULLÓN BALLESTEROS, A. "Sistema de Derecho Civil", Volúmen IV, Tomo 1, Ed. Tecnos, $11^{\text {a }}$ edición, Madrid, año 2012, página 233.

482 "El statuto jurídico de los padrastros. Nuevas perspectivas jurídicas". Colección Scientia Iurídica, Ed. Reus S. A., Madrid, año 2009.

483 TAMAYO HAYA, S. ibídem, páginas 17 y 18. 
ambos y también los hijos comunes. Esta necesidad, de reconocer jurídicamente las relaciones entre una persona y los niños de su cónyuge o concubino, para la ciencia jurídica no es nueva, al contrario.

Actualmente sin duda la introducción y sucesiva liberalización del divorcio ha sido el elemento que ha propiciado la difusión de la convivencia more uxorio y de las familias monoparentales, ha contribuido a un ensanchamiento de los hechos que pueden comportar su creación y constituir un campo propicio para la formación de estas nuevas familias ${ }^{484}$. Antes estas nuevas realidades, lo que nos enseña el día a día es que cada vez son más los niños que viven con la pareja de su madre o padre, incluso esta realidad se encuentra recogida en ciertas disposiciones legales, como por ejemplo el art. 85 del Código Foral de Aragón. Sin duda que se está ante una relación que obviamente no hace parientes a los que no lo son, pero convierte en familiares a los que no lo eran ${ }^{485}$. La hipótesis por consiguiente es que uno de los dos adultos presente en el hogar, no es el padre biológico de uno de los niños del otro; de ahí que se deba reflexionar sobre la relación que mantienen el menor con el adulto, y si tal relación o vínculo debe ampararse en el Derecho.

La respuesta a mi juicio debiese ser afirmativa, en primer lugar por el principal interés de menor pero demás porque en caso de no hacerlo se estaría propiciando una desigualdad en el tratamiento de estos nuevos modelos de familia. Estos niños, que en caso de separación o divorcio, estarán bajo la custodia de sus padres de sangre, si bien han convivido periódicamente o de manera preferente con uno de los padres y con la nueva pareja o cónyuge de éste último. ¿Jurídicamente cuál será la relación entre el tercero con el niño? ¿y si luego deja de convivir con el progenitor de dicho niño, habrá lugar a un derecho de contacto? ${ }^{486}$. La autora en cuestión se refiere a una paternidad social, como una figura jurídica con más sentido, propicia que el progenitor deja de definirse

484 Existe un sector integrado por las parejas homosexuales que conviven con hijos de uno de sus miembros, ya sean fruto de una precedente unión heterosexual, concebidos de técnicas de reproducción asistida o adoptados por uno de ellos (homoparentalidad).

485 DÍAZ ALABART, S. "EL pseudo estatus familiae en el Código Civil. Una nueva relación familiar", Anuario de Derecho Civil, tomo LVIII, fascículo II, Madrid, abril-junio de 2005, página 856.

486 TAMAYO HAYA, S. “El statuto jurídico de los padrastros. Nuevas perspectivas jurídicas”... op. cit., páginas 22 y 23. La autora citando a Murat se refiere a los términos "parenté" y "parentalité". "A este respecto resultan interesantes las siguientes reflexiones de Murat esbozando una distinción de conceptos que sirvan de base a construcciones jurídicas concretas o a la recomposición de instituciones ya existentes. Contrapone el autor francés los términos "parenté" y "parentalité": la pertenencia a uan parenté es un estado que inscribe al individuo en su genealogía: une a una familia utilizando la filiación como vector y resulta fundamental el papel de los sexos. Por el contrario la parentalité es una función: aquella que cumplen algunos adultos aportando al niño medios materiales, educativos y afectivos; ésta no pasa por la filiación y no viene, así pues, marcada por la diferencia de sexos. En las familias recompuestas, donde los padrastros, que son jurídicamente extraños en relación al niño, ocupan funciones de apretalité, ambos términos aparecen disociados. Aquí, la ausencia actual de reglas apropiadas pone de manifiesto la inconsistencia en derecho de esta noción." 
por atributos consanguíneos, de respeto debido, de amor naturalizado, haciendo referencia a una conquista de la paternidad, de esta manera se disociarían lo consanguíneo con las funciones paternales, lo biológico y lo social, e incluso con una valoración con más peso de lo social. Todavía requiere una respuesta concreta del ordenamiento ante tal realidad, más allá de la armonización de diversas normas.

En relación con lo anterior, puede efectuarse un somero análisis de lo que ocurre en otros ordenamientos semejantes al español, como pueden ser el francés o el italiano o que se encuentran en la órbita europea, ya sea el inglés, el alemán, etc.

Diversos ordenamientos europeos tienen normas relativas a las relaciones del padrastro y el menor, ahora bien las respuesta que reflejan son diversas ${ }^{487}$.

En el ordenamiento francés ${ }^{488}$ padrastro que es aquel que resulta ser el nuevo cónyuge o conviviente del progenitor no goza de ningún derecho ni contrae ningún deber respecto del hijo de su cónyuge o persona con la que viva. Sin embargo existe la denominada délégation volontaire, en virtud de la cual este puede ejercer total o parcialmente la patria potestad sobre el menor y otra que le permite participar en el ejercicio de la patria potestad junto con uno o los dos progenitores y se denomina dálégation-partage. Sin duda los últimos años ha habido una notable multiplicación de las denominadas familias recompuestas, lo que ha provocado reflexiones sobre la posición jurídica de ese nuevo cónyuge o conviviente del progenitor. De tal manera el Rapport annuel du Défenseur des enfants, de $2006^{489}$ trató pormenorizadamente el papel del tercero en la vida del menor y en relación a su principal interés, para lo cual incluso propuso crear un acuerdo para el ejercicio de la patria potestad judicialmente homologado ${ }^{490}$.

En el Reino Unido a partir de la Ley de 1989 Children Act 1989, cuya vigencia fue posterior, en 1991, la figura del stepfather o padrastro puede al igual que cualquier tercero, dirigirse al juez

487 Cfr. MATEO Y VILLA, I. "Estatuto del cónyuge del progenitor. Legislación europea”, Revista de Derecho de Familia, núm. 52, $3^{\circ}$ trimestre año 2011, Ed. Lex Nova, Valladolid, página 81 y siguientes.

488 Cfr. GOUTTENOIRE-CORNUT, A y MURAT, P. " $L$ ' intervention d' un tiers dans l vie d l'enfant”, Droit de la familie, janvier 2003, page 4 et à la suite; GOUTTENERE-CORNUT, A. "La loi du mars 2002 relative à l' autorité parentale", Dossier, Actualit'Juridique Famille, avril 2002, page 124 à la suite; FULCHIRON, H. "Autorité parentale et familles recomposée” en VV. AA. "Mélanges à la mémoire de D. Huet-Weiller: Droit des personnes et de la famille, liber amicorum”, Paris, année1994; FULCHIRON, H. "L'autorité parentale rénovée”, Defrénois, núm. 15, 37580. année 2002.

489 L' enfant au coeur des nouvelles parentalités Pour un stand des tiers qui partagent our ont partagé la vie d'un enfant et ont des liens affectifs forts avec lui. http://lesrapports.ladocumentationfrancaise.fr.

490 JO Sénat 12 de marzo 2009. En 2008 se elaboró un anteproyecto de ley relativo a la patria potestad y a los derechos de terceros y, conforme a la réponse del Ministerio de Justicia, ese texto distingue la participación en el ejercicio de la patria potestad de la delegación de la misma, y prvé que la participación podrá llevarse a cabo por medio de acuerdo homologado por el juez de familia, que verifcará su conformidad con el interés del menor. Por contra, la delegación siempre sólo podrá establecerse en sentencia. 
para solicitar que le sea adjudicada conjuntamente con los progenitores, la patria potestad o parental responsability sobre el menor, mediante la declaración de que la vivienda del padrastro es la habitual al menor. Tal atribución de la patria potestad es automática y beneficia al padrastro en sentido amplio, independiente de su estatuto y de su orientación sexual. Por otra parte existe la The Adoption Act 2002, en ella se permite al padrastro la adquisición de la patria potestad sobre el menor en el caso de parejas reconstituidas homosexuales y siempre que exista su inscripción en el registro correspondiente. Para ello, el padrastro deberá llegar a un acuerdo con los titulares de la patria potestad sobre el menor y aprobado por el juez. Frente al supuesto anterior, se refiere al padrastro stricto sensu, quedando descartado el supuesto de padrastros que no tengan una relación jurídica formalizada con el cónyuge progenitor, aunque lo que se denomina como relación formalizada no sea necesariamente un matrimonio sino también una pareja de hecho inscrita. Es decir puede darse el caso de que la patria potestad sea ejercida por tres personas ${ }^{491}$.

En Alemania desde el año 2001 la ley otorga al padrastro una forma limitada de patria potestad. La Ley relativa a la pareja de hecho registrada que entró en vigor el 1 de agosto de 2001, concede al padrastro que constituya pareja de hecho registrada, la patria potestad reducida sobre el menor, siempre que el progenitor que forme pareja con él sea el único titular de la patria potestad. El padrastro en tal sentido no puede ser titular de la patria potestad reducida en dos casos. El primero, cuando no está casado con el cónyuge progenitor, vinculado a este por una pareja de hecho registrada, o el segundo caso, si la filiación del menor estuviera fijada respecto de ambos padres. La patria potestad reducida le permite al padrastro decidir sobre las cuestiones ordinarias en la vida del menor, cuando ocurra alguna emergencia, el padrastro también podrá actuar pero deberá informar de inmediato al progenitor. Todo esto bajo el prisma del interés del menor.

Finalmente en Italia, se sigue con el régimen por el cual los progenitores aunque vivan separados, ejercerán conjuntamente la patria potestad y en defecto de uno lo hará otro. Esto no obstante, el matrimonio entre el progenitor y su cónyuge crea una alianza entre éste último y el menor que supone que no podrán contraer matrimonio entre sí mientras el vínculo jurídico persista. La adopción constituye la única posibilidad de que el cónyuge del progenitor, en este caso adoptante, pueda formalizar una relación jurídica con el adoptado.

491 Cfr. MASSON, J. "Old Families into New: a Status for Step-Parents”, en State, Law and the Family, de. M. Freeman, London, Tavistock, year 1989; Commencement number 9, Order 2005. 


\subsection{La Dignidad Humana y el Derecho a la Identidad}

Los tres grandes problemas que se suscitan al estudiar la filiación son, en primer lugar su determinación; en segundo lugar los medios admisibles para lograrla; y en tercero sus consecuencias legales.

La determinación se refiere a que el ordenamiento jurídico considere a una persona como hija de otros individuos concretos y determinados, según FERNÁNDEZ GONZÁLEZ ${ }^{492}$, lo anterior no es una mera cuestión de prueba dado que, a veces, probada la filiación ésta queda sin efectos como en el caso de la filiación incestuosa. También, en ocasiones, se impide la prueba de la relación de generación en atención a otros intereses que el legislador considera que deben primar (en el caso de las TRHA con donación de gametos). Existen otros supuestos en los que se permite atacar la filiación ya determinada por no coincidir ésta con la realidad de la generación.

Los medios de determinación de la filiación han adquirido renovada importancia a partir de la introducción de las pruebas heredobiológicas. Los avances científicos en el área de la investigación genética han traído consigo mayor certeza para determinar la paternidad biológica. En esta cuestión probatoria, se ven implicadas consideraciones sobre derechos fundamentales, como el derecho a la intimidad e integridad física. Asimismo, el valor de la negativa a someterse a pruebas de ADN es discutido en la jurisprudencia ${ }^{493}$.

492 “El reconocimiento de los hijos no matrimoniales”, Ed. Dykinson, Madrid, año 1998, páginas 35 a 39.

493 SAP Asturias, núm. 369/2000 de 13 julio. AC 2000/1543. "Por tales razones, este Tribunal ha declarado ya en ocasiones anteriores que cuando un órgano judicial, valorando la negativa del interesado a someterse a las pruebas biológicas, en conjunción con el resto de los elementos fácticos acreditados a lo largo del procedimiento, llega a la conclusión de que existe la relación de paternidad negada por quien no posibilitó la práctica de la prueba biológica, nos hallamos ante un supuesto de determinación de la filiación, permitido por el art. 135, «in fine», el Código Civil, que no resulta contrario al derecho a la tutela judicial efectiva del art. 24.1 CE.. . Precisamente esta doctrina constitucional hace totalmente inviable el recurso de apelación interpuesto por la parte demandada contra el auto de fecha 17-9-1999 que denegó la incineración pretendida del cadáver del demandado, pues en casos como el presente es evidente que con tal acto se impediría sin duda la tutela constitucionalmente protegida.- En el caso sometido a la consideración de la Sala, además de que varios de los testigos propuestos relatan con firmeza tanto las circunstancias del trabajo, convivencia incluida, de la madre de la actora en el caserio familiar del demandado, como las relaciones entre los mismos en la época de la concepción, y aun durante años, sin contradicciones ni sombra de duda acerca de su veracidad, con afirmaciones que además no son de pura referencia, sino de vivencia directa; al haberse producido el fallecimiento de aquél, se acordó y fue practicada en esta instancia la prueba pericial biológica por el Instituto Nacional de Toxicología, mediante el examen comparativo de los polimorfismos del ADN. Respecto de esta prueba, dice ... que «la probanza biológica de la paternidad que autoriza el artículo 39.2 de la Constitución y 127 del Código Civil, en relación con el 135, constituye una prueba directa, pero no plena y absoluta, no obstante ha de atribuírsele valor de casi total aproximación a la verdad, sobre todo, cuando sucede, como en la presente controversia, que dicho informe pericial ha sido emitido por un órgano técnico oficial, dotado de medio y eficacia, para su elaboración más exacta, cual es el Instituto Nacional de Toxicología, dependiente del Ministerio de Justicia... En consecuencia con la doctrina constitucional y jurisprudencial, habiendo arrojado el informe pericial practicado, respecto del que las partes no formularon reparo alguno en el traslado que se les dio para instrucción, un índice de probabilidad a favor de la paternidad del demandado del 99,95\%, y valorada dicha prueba en unión del resto de lo actuado, según se expresó, unido a la actitud del actor negándose a la práctica de la prueba hematológica de manera injus- 
En la tercera de las cuestiones suscitadas por la filiación -las consecuencias de su determinación- radica el significado, en términos legales, del ser hijo y del ser padre. Fijar que un individuo es hijo de otro, no es una cuestión de pura índole patrimonial ya que afecta aspectos personales del individuo. Es por este motivo que la filiación no es una relación de estricto Derecho privado, puesto que su alcance constituye interés público. La filiación está íntimamente ligada a la estructura sociológica de la familia. La generación per se, es decir independientemente de la situación legal existente entre los progenitores, coloca al hijo en una posición legalmente determinada.

Entre las consecuencias de la filiación sobresale por su trascendencia la atribución de la patria potestad. En este instituto se resumen los derechos y obligaciones que recaen en el progenitor y en el hijo. El primer derecho que asiste al hijo es el de que su filiación quede establecida o determinada oficialmente, y es por ello que se establece el permiso de investigar la paternidad ${ }^{494}$. Éste es el primer paso necesario para hacer efectivos todos los demás derechos que, a partir de la Constitución de 1978, son iguales para todos los hijos.

El conocimiento de la verdad biológica acerca de la generación de una persona responde a intereses privados y públicos y es fuente de tensión entre derechos e intereses que, en ocasiones, aparecen como contrapuestos. Los intereses privados que confluyen en el acceso a los datos sobre la generación son, en primer lugar, los del hijo que desea obtener información sobre su origen y, en segundo lugar, los de los progenitores biológicos que desean permanecer en el anonimato.

En cuanto a los intereses públicos, cabe destacar el interés del Estado en la fijación del estado civil y la determinación de la patria potestad, con su función tuitiva moral y patrimonial. Asimismo,

tificada, lo que supone un obstruccionismo ilegitimo que debe tomarse como indicio revelador de la realidad de la filiación, permite inferir la evidencia indudable del mantenimiento de relaciones intimas con el rigor exigible para alcanzar el efecto pretendido y declarar la paternidad solicitada.".

STS, Sala de los Civil, sección $1^{\circ}$, núm. 729/2004 de 16 julio. RJ 2004/6789 "Finalmente, cabe añadir los siguientes argumentos para la compulsión de la prueba biológica sobre los causahabientes del progenitor premuerto y su relevancia jurídica en caso de negativa: $1^{\circ}$ ) Que en el plano de la formalidad decisoria, la práctica de esa prueba, responde a un principio de proporcionalidad en pos del objetivo acreditativo de progenie, sobre todo, cuando existen, en plenitud, otros elementos probatorios - primer sumando-. $2^{\circ}$ ) Que el cientifismo del ADN y su inmisión corporal, permite la obtención de los citados Predicados de Hummel. $3^{\circ}$ ) Que no es defendible una negativa de los deudos -en su bastardía de irrelevancia- porque haya premuerto el progenitor demandado, porque: a) su cualidad sucesoria, no les atribuye, en puridad, defensas de la intimidad/integridad del premuerto.- b) porque, en buena lid, impeditiva de conductas elusivas o de fraude, han de colaborar con la Justicia en pos del repetido objetivo...- $4^{\circ}$ ) Y, sobre todo, que esa negativa -si es que se sostiene su irrelevancia en el «onus» probatorio- determinaría consecuencias tan absurdas como las siguiente: a) Que su voluntarismo de rechazo, equivaldría a un cierre del principal instrumento probatorio, con lo que quedaría indefenso el actor. - b) Provocar una peor situación en estos litigios, porque, si vive el progenitor su negativa equivaldría, junto con las demás pruebas, a la imposición de la paternidad y, si fallece el mismo, la negativa de sus deudos, produciría el citado cierre o imposibilidad de averiguar la verdad biológica, y con ello la elusión del art. 39.

494 Cfr. DE LA CÁMARA ÁLVAREZ.. "Los hijos no matrimoniales y la Constitución de 1978", Actualidad Civil, año 1981, II, páginas 16 a 21 . 
el afianzamiento del Estado de Derecho que se logra mediante el respeto de los distintos derechos fundamentales involucrados en el conocimiento del propio origen. Esta última razón es especialmente importante en aquellos supuestos en los que del conocimiento de la ascendencia biológica no se sigue la determinación de la paternidad o maternidad ni, tampoco, la fijación de la patria potestad en cabeza del progenitor. Este ha sido, principalmente, el caso del acceso por los menores adoptados a los datos sobre su filiación y, cada vez con mayor frecuencia, el de los hijos habidos mediante TRHA como donación de gametos ${ }^{495}$.

Si se repasa la jurisprudencia española y comparada más reciente, puede vislumbrarse una tendencia a respetar, con intensidad y extensión creciente, el derecho e intereses de las personas a saber y conocer quiénes son sus progenitores, debido en gran medida a la profundidad de tan importante anhelo que yace en el corazón de cualquier persona.

Los tribunales han hecho suya la consideración de que la ocultación de la verdad biológica, y la consiguiente consagración de vínculos legales carentes de este sustrato, es contraria al mejor interés del niño. Asimismo el Derecho de familia actual (del que el Derecho español no es excepción) pone su acento primordialmente en la tutela del niño, o en el respeto del principio de mejor interés del menor que, en materia de filiación se concreta en el criterio de favor filii. Incluso cuando en la filiación adoptiva se establece un parentesco legal que no se corresponde con la generación, la finalidad buscada es la salvaguarda del mejor interés del hijo ${ }^{496}$. A partir de estos dos principios es que se avanza, jurisprudencial, doctrinaria y legislativamente, en la consagración de un derecho a conocer el propio origen genético y biológico como afirmación del derecho a la identidad.

Sin duda a partir del año 1989, en que se redactó la Convención de Derechos del Niño, la doctrina se refiere al derecho a la identidad como justificación de la búsqueda de los propios orígenes en situaciones diversas a las contempladas tradicionalmente por las acciones de reclamación e impugnación de la maternidad y paternidad. Se hace especial referencia a este derecho a la identidad en los casos de hijos habidos por TRHA con donación de gametos, y por la adopción nacional e internacional ${ }^{497}$.

Sin perjuicio de lo anterior aunque la denominación de derecho a la identidad es de reciente cuño, el objeto de protección de este derecho no es nuevo y ha encontrado protección bajo otros ins-

495 ALES URÍA ACEVEDO, M. "El derecho a la identidad en la filiación”, Ed. Tirant Lo Blanch, Monografías núm. 787, Valencia, año 2012, página 381.

496 Es distinto lo acontecido en la excepción legalmente consagrada a los principios de verdad biológica e interés del menor que se encuentra en ciertas figuras de las TRHA, en las que se privilegia al denominado favor genitoris.

497 ALES URÍA ACEVEDO, M. “El derecho a la identidad en la filiación”, ...op. cit., página 382. 
titutos del Derecho. Lo anterior puede implicarse con el estrecho vínculo que existe entre el nombre y su configuración como derecho de la personalidad ${ }^{498}$, lo cual implica su defensa en tal aspecto ya sea doctrinal como jurisprudencial.

El responder a la pregunta de si, en particular un niño, tiene derecho a conocer sus orígenes biológicos y genéticos, resulta ser la formulación de uno de los desafíos más importantes del Derecho de las últimas dos décadas.

Hoy en día se acepta que todos aquellos menores cuya filiación se encuentra dividida entre biológica, o genética, y social, poseen un interés vital en identificar a todos los elementos de su ascendencia. Este es el caso de las personas adoptadas y de quienes fueron concebidos mediante TRHA con donación de gametos. Incluso en algunos supuestos de filiación por naturaleza en los que los hijos a raíz de las relaciones de sus progenitores desconocen la identidad de quienes los han engendrado. Tales situaciones no tienen un común denominador en la vida real, por cuanto no es idéntica la relación entre un hijo adoptado y sus adoptantes, que la de un hijo concebido mediante TRHA heterólogas con el padre o madre no genético ni el de un hijo no matrimonial con el padre que no lo ha reconocido o la madre que se acogió al parto anónimo al momento de dar a luz. Se da en tales supuestos un conflicto, una batalla entre diversos intereses, en tales situaciones, el derecho del hijo a conocer su origen puede entrar en conflicto con los derechos de otras personas a la preservación de su intimidad y vida privada familiar, así lo analiza detalladamente ALES URÍA ACEVE$\mathrm{DO}^{499}$.

El derecho a la identidad es, en última instancia, uno de los motivos o razones que justifican la búsqueda de la paternidad y maternidad y también el amparo legal a la indagación para el conocimiento de las circunstancias y elementos de la propia generación, aun cuando la Ley no permita establecer un lazo de parentesco ${ }^{500}$. El conocimiento de quiénes son los progenitores es un elemento en la conformación de la individualidad del ser un "yo" único, un ser en el mundo. A su vez, la protección del derecho a la identidad se funda en la valoración de la dignidad humana: porque todo hombre, en cuanto persona, es digno, y por ello se exige el respeto a su identidad ${ }^{501}$.

498 Se sabe que el apellido como componente del nombre sirvió históricamente para identificar al individuo con una familia, un padre y una madre determinados y una red de parentesco. Esto como signo evidente y externo de aquella parte del yo que se conforma por ser "hijo de", "miembro de una familia", en otras palabras, por saber cuáles son las propias raíces. El apellido es el concepto jurídico que indica la pertenencia a un linaje y señala la historia de una persona incluso antes de su nacimiento.

499 "El derecho a la identidad en la filiación”, ...op. cit.,página 383

500 Cfr. SUÁREZ ESPINO, M. L. "El derecho a la intimidad genética”, Ed. Marcial Pons, Madrid, año 2008.

501 PRIETO ALVÁREZ, T. "La dignidad de la persona. Núcleo de la moralidad y el orden públicos, límite al ejercicio de libertades públicas", Ed. Thomson Civitas, página 164 y 165. El autor estima que al hacerse la pregunta ¿Y qué es la dignidad humana? Podría argumentarse que es la posesión de derechos. Ciertamente dicha vincula- 
La identidad está conformada, en parte, por el cómo empezó nuestra existencia, y esta aseveración provoca el que se ampare la búsqueda de la filiación biológica tanto paterna como materna, es una búsqueda cuya finalidad más que encontrar a otros sea encontrarse a sí mismo, completar hacia atrás el rompecabezas de la historia personal. Para el hombre y la mujer, como seres humanos, el conocimiento de su propia identidad biológica es esencial. Por eso, el conocimiento o incertidumbre, las dudas y certezas sobre el origen genético influyen de manera trascendental sobre el desarrollo de la personalidad ${ }^{502}$.

La existencia de límites al derecho a la identidad no sólo ha sido reconocida por el TEDH, sino que figura en instrumentos internacionales de derechos humanos y en las legislaciones internas. Un claro ejemplo puede leerse en los artículos 2, 6, 7, 9 y 11 de la Convención sobre los Derechos del Niño que dan sustento al derecho a la identidad pero que precisan de una aclaración a partir de la provisión específicamente incorporada por los Estados signatarios en el artículo 8:

“...los Estados Partes se comprometen a respetar el derecho del niño a preservar su identidad (...) y las relaciones familiares de conformidad con la ley sin injerencia ilícitas (...) Cuando un niño sea privado ilegalmente de algunos de los elementos de su identidad o de todos ellos, los Estados partes deberán prestar la asistencia y protección apropiadas con miras a restablecer rápidamente su identidad..."

Se debe poner énfasis en esta disposición en los términos "ilícita" e "ilegalmente", debido a que pueden acaecer situaciones en las que el niño sea privado de algunos de los componentes que hacen posible la determinación de su identidad -así en los supuestos de adopción en los que el menor pierde los lazos jurídicos con su familia biológica- pero a través de mecanismos legítimos y legales.

Pero, tal como afirma ALES URÍA ACEVEDO, más allá de la colisión de derechos, en la actualidad se admite la existencia del derecho a conocer el propio origen como elemento conformador de la identidad, aunque su extensión y alcance estén discutidos. Ejemplos de esta poca claridad son

ción es indudable. Ello sin perjuicio de las pretensiones de identificación, como la doctrina alemana, inducida por la sistemática de su texto constitucional, el capítulo primero de la Ley Fundamental de Bonn, que se inicia recogiendo la intangibilidad de la dignidad de la persona y que lleva por rúbrica de los derechos fundamentales., se ha considerado a la dignidad como un derecho fundamental más, pero no como fundamento de los mismos. Sin embargo ontológicamente no sería así, según parecer de FERNÁNDEZ SEGADO y HERNÁNDEZ GIL, para los cuales la dignidad se encuentra en un plano superior. A la vista de tal relación causa y efecto, fundamento y consecuencia, entre dignidad y derechos (entre ellos el derecho a conocer el origen propio), no sería necesario plantear una relación jerarquizada entre os primeros y los segundos, de todas maneras si la dignidad del ser humano es fundamento de los derechos fundamentales, este principio no sería efectivo sin ellos.

502 Cfr. VV. AA. "El derecho del adoptado a conocer sus orígenes en España y en el Derecho comparado", Observatorio de la infancia, Ministerio del Trabajo y Asuntos Sociales, Madrid, año 2006. 
los extremos que representan dos legislaciones europeas, por una parte la sueca y por otra la francesa, la primera presenta el anonimato del donante en cuanto a la TRHA, mientras que la segunda permite a las mujeres solicitar que su nombre no figure en el parte médico así como en la inscripción de nacimiento. El derecho a conocer el propio origen, como elemento conformador de la propia identidad, no es absoluto y debe ser ponderado en cada caso concreto cuando entre en colisión con otros derechos también fundamentales ${ }^{503}$.

La CE de 1978 consagró como fundamento del orden público y la paz social el libre desarrollo de la personalidad humana y la dignidad de la persona. Pero la CE no se ha limitado a un reconocimiento formal, sino que este artículo exige que los Poderes públicos empleen todos los mecanismos necesarios para satisfacerlo. En opinión de MARTÍN BERNAL, el constituyente consideró suficiente la referencia abstracta a estos valores para basar en ellos la totalidad de derechos que quiere reconocer, garantizando así los atributos de la personalidad ${ }^{504}$.

El TC se ha referido a la dignidad humana en varias sentencias que pueden perfectamente proclamarse como paradigmáticas, pero aquí se destacarán sólo algunas de ellas, por ser posiblemente las más representativas del tema ${ }^{505}$. Sentencia de 24 de mayo de $1982^{506}$ y de 11 de abril de $1985^{507}$.

503 “El derecho a la identidad en la filiación”, .... op. cit. página 384 y 385. "Es necesario distinguir el derecho a la identidad del principio de verdad biológica. El segundo (...) es un criterio rector de ajustamiento entre la paternidad formal y la real. Es una directriz que orienta a la investigación de la paternidad e informa a la legislación y al actuar de los poderes del estado al momento de establecer el vínculo legal entre padres e hijos. Por el contrario, el derecho a la identidad es una potestad jurídica reconocida a cada individuo y posee un campo de protección mucho más amplio y que se encuentra delimitado por la propia naturaleza de su objeto: aquello que conforma la identidad de una persona. En él encuentran cabida tanto los elementos biológicos como culturales que convergen en la individualidad de cada ser humano, haciéndolo único e irrepetible."

504 MARTÍN BERNAL, J.M., "Los derechos de la personalidad en la Constitución Española”, Revista General de Legislación y Jurisprudencia, Madrid, año 1979, página 13.

505 ALES URÍA ACEVEDO, M. “El derecho a la identidad en la filiación”, ...op. cit., página 396.

506 STC, Sala segunda, núm. 27/1982 de 24 mayo. RTC 1982/27. "El casar o no con persona noble no puede afectar en modo alguno a la dignidad de las personas, ni tiene sentido en nuestro tiempo y bajo la Constitución de 1978 afirmar, como se hace en la condición de 1733, que quien no casa con persona notoriamente noble es o está «mal casado». La mentalidad nobiliaria no puede mantener hoy su axiología como un sistema referencial socialmente dominante, pues ya no lo es, ni en todo caso compatible con la Constitución, pues aseveraciones como esa van contra la idea de igualdad, proclamada por el artículo 1 de nuestra Constitución como uno de los valores superiores del ordenamiento. No se es más o menos bueno o malo, digno o indigno por el hecho de casar con noble, siendo como son igualmente dignas todas las personas (artículo 10 de la CE)."

507 STC, Pleno, núm. 53/1985 de 11 abril. RTC 1985/53 "Junto al valor de la vida humana y sustancialmente relacionado con la dimensión moral de ésta, nuestra Constitución ha elevado también a valor jurídico fundamental la dignidad de la persona, que, sin perjuicio de los derechos que le son inherentes, se halla intimamente vinculada con el libre desarrollo de la personalidad (art. 10) y los derechos a la integridad fisica y moral (art. 15), a la libertad de ideas y creencias (art. 16), al honor, a la intimidad personal y familiar y a la propia imagen (art. 18.1). Del sentido de estos preceptos puede deducirse que la dignidad es un valor espiritual y moral inherente a la persona, que se manifiesta singularmente en la autodeterminación consciente y responsable de la propia vida y que lleva consigo la pretensión al respecto por parte de los demás. - La dignidad está reconocida a todas las personas con carácter general, pero cuando el intérprete constitucional trata de concretar este principio no puede ignorar el hecho obvio de la especialidad de la condición femenina y la concreción de los mencionados dere- 
Ambas al referirse al término dignidad la han conceptualizado como un valor espiritual y moral inherente a todas las personas, un mínimo que debe preservarse de las vulneraciones por parte de los poderes públicos y los particulares. Tal dignidad se manifiesta en la autodeterminación consciente y responsable de la propia vida, en la autonomía individual y constituye el punto de partida para la existencia y especificidad de los demás derechos fundamentales.

El respeto a la dignidad humana implica el reconocimiento de la persona como ser independiente y, con ello, el respeto de su personalidad e identidad. Por identidad se entiende el derecho a ser uno mismo incluyendo todas las facetas en las que el ser se manifiesta, desde las individuales hasta las sociales, religiosas, culturales, lingüísticas, sentimentales y políticas entre otras, así lo ha manifestado de manera fehaciente y concisa LARA AGUADO ${ }^{508}$.

Los valores de libertad e igualdad sobre los que asienta la primacía de los derechos fundamentales de un Estado de Derecho aparecen vinculados a la consideración de la persona como perso$\mathrm{na}^{509}$. Esto se traduce en la supremacía del valor de la dignidad humana como elemento central en la Constitución. Este reconocimiento de la dignidad esencial o inherente de todo ser humano implica su derecho a ser tratado de forma igual y sin discriminaciones. No obstante ello, se presenta una realidad evidente que es el deseo humano de proyectarse como individuo, lo cual implica diferenciación de los otros. Esta diferenciación es la afirmación de la propia personalidad y tienen proyección en lo jurídico. Todo ser humano necesita poder afirmar su propia individualidad con el fin de poder realizar y garantizar el pleno desarrollo de la personalidad ${ }^{510}$.

Ante la pregunta de cómo puede potenciarse el libre desarrollo de la personalidad, la respuesta es, se potencia y alcanza haciendo valer los derechos inviolables e inherentes a la persona que menciona el art. 10.1 $\mathrm{CE}^{511}$. Estos derechos, más allá de la denominación que se les otorgue, son mani-

chos en el ámbito de la maternidad, derechos que el Estado debe respetar y a cuya efectividad debe contribuir, dentro de los límites impuestos por la existencia de otros derechos y bienes asimismo reconocidos por la Constitución."

508 “El nombre en Derecho Internacional Privado", Ed. Comares, Granada, año 1998, páginas 76 y 77.

509 SALVADOR GUTIÉRREZ, S., "Derecho a la Identidad”, Actualidad Civil, año 1999-IV, Madrid, página 1469.

510 OEHLING DE LOS REYES, A. "La dignidad de la persona. Evolución histórico-filosófica, concepto, recepción constitucional y relación con los valores y derechos fundamentales.", Ed. Dykinson, S. L., Madrid, año 2010, página 384. "La educación se comprende como un proceso no sólo dirigido al desarrollo de la libre personalidad, sino como acción para la perfección de la persona también en las relaciones humanas,; por otro lado, presupone la elaboración de políticas educactivas de interacción de alumnos con problemas de aprendizaje o con otro tipo de problemáticas".

511 RUIZ-RICO RUIZ, G. "Derechos de la personalidad como elementos de articulación de la Constitución política y la Constitución Civil" en RUIZ-RICO RUIZ, G; MORENO-TORRES HERRERA, Ma L; PÉREZ SOLA, N (Coords.) "Principios y derechos constitucionales de la personalidad. Su proyección en la legislación civil", Ed. Tirant Lo Blanch, Monografías, núm. 698, Valencia, año 2010, página 18. "Desde el plano de las categorías conceptuales se pueden reconocer asimismo principios fundamentales de estos sectores del ordenamiento que se 
festaciones concretas del bien personalidad. Debe entenderse que el ordenamiento jurídico es uno, tanto en sus normas de Derecho Público como en las de Derecho Privado, y en su globalidad debe proteger eficazmente a la persona ${ }^{512}$. Los derechos fundamentales, en definitiva, garantizan al sujeto su señorío sobre alguna parte esencial de su propia persona y el ejercicio concreto de las proyecciones materiales y espirituales de las diversas caras del todo integral que es la persona humana ${ }^{513}$.

La Sección Primera del Título Primero de la Constitución incluye los derechos tutelados mayormente por el ordenamiento español y que por tales gozan de las más amplias garantías. Entre ellos están el derecho a la integridad física y moral, el derecho a la intimidad y a la tutela judicial efectiva. En la Sección Tercera del mismo Capítulo se encuentran los principios rectores de la política social y económica que también reconocen algunos derechos pero regulan, más específicamente, la actuación de los poderes públicos frente a la promoción de ciertas políticas. En el artículo 53, la CE precisa el nivel de garantías en el texto que corresponde a cada grupo de derechos contemplados en el texto. Esto no modifica su naturaleza pero sí su posición en el sistema de garantías normativas, jurisdiccionales e institucionales ${ }^{514}$.

Los derechos son llamados constitucionales cuando son reconocidos en la propia Constitución. Esta denominación sólo indica que están expresados en el Texto Fundamental pero no señala nada respecto a su alcance y garantías. Entre ellos se encuentran los derechos fundamentales, tal nombre designa un grupo específico de derechos constitucionales que la $\mathrm{CE}$ recoge en la sección Primera, Capítulo Segundo del Título Primero (arts.15 a 29) cuyo desarrollo requiere de un Ley Orgánica (art. 81.1) y que gozan de las máximas garantías normativas, institucionales y jurisdiccionales (artículos 53 y 54), ante esto me remito a la opinión de PECES BARBA ${ }^{515}$. El derecho constitu-

encuentran estrechamente relacionadas. En el caso de la CE de 1978 el concepto clave se menciona en su art. 10-1 ${ }^{\circ}$ (el libre desarrollo de la personalidad), mientras que en el contexto del derecho privado el principio básico en el cual se sintetiza aquella conexión sería el de la autonomía de la voluntad (o autonomía privada). La relación entre ambos principios no se tiene porque plantear en términos jerárquicos ni de eventual incompatibilidad. Al contrario, el desarrollo personal sólo se puede quedar garantizado mediante el presupuesto de la libertad individual. Y al mismo tiempo, el fundamento constitucional de la autonomía privada radica en esa misma realización de la persona conforme a las libertades y derechos que se otorgan en la norma fundamental".

512 QUESADA GONZÁLEZ, M.C., "El Derecho (¿Constitucional?) a conocer el Propio Origen Biológico”, Anuario de Derecho Civil, T. I, enero-junio, Madrid, año 1994, página 248 a 252.

513 DIEZ DÍAZ, J, “¿Derechos de la personalidad o Bienes de la Persona?”, Revista General de Legislación y Jurisprudencia, Madrid, año 1963, página 877 y página 890.

514 ALES URÍA ACEVEDO, M. "El derecho a la identidad en la filiación”, ... op. cit., páginas 397 y 398; También lo menciona en el mismo sentido GÓMEZ SÁNCHEZ, Y. "Derecho Constitucional Europeo". Ed. Sanz y Torres, Madrid, año 2005.

515 Cfr. PECES BARBA, G. "Derechos Fundamentales", Ed. Guadiana, Madrid, año 1976, página 21. Cabe advertir que algunos autores utilizan esta expresión como sinónimo de derechos Humanos. La terminología de derechos legales se utiliza para hacer referencia al desarrollo legislativo de los derechos constitucionales También son legales los derechos que son configurados y regulados por la Ley. Este es el caso de los derechos reconocidos en 
cional es un reconocimiento de una esfera de autonomía del sujeto, y el derecho fundamental es un concreto derecho constitucional, diferenciado dentro del ordenamiento jurídico en virtud de su materia y de las garantías de protección que ostenta. Los derechos fundamentales corresponden a la categoría de los derechos subjetivos en cuanto garantizan un ámbito de existencia con una libertad determinada. Son el núcleo esencial e inviolable de los derechos, derivados de su misma naturaleza, que nadie ni nada debe cohibir y que el Estado debe ayudar a preservar, prestando las condiciones necesarias para su realización. Vale decir, deben ser respetados por los poderes políticos y también por las actividades humanas, por ello están intrínsecamente relacionados con el Derecho Privado.

Los derechos fundamentales poseen la nota de ser reconocidos como tales a través de un determinado ordenamiento jurídico estimado en su totalidad normativa. En el ámbito político, sin embargo, se denomina derechos fundamentales a los que la Constitución enuncia como tales y dota de especiales garantías. Como corolario, los derechos humanos o del hombre, son derechos que el hombre posee por su naturaleza de tal y la dignidad que le es propia. No obstante, mientras que una sociedad política no los reconozca como parte de su derecho positivo, no se puede hablar de derechos en término jurídico estricto puesto que no podrán ser alegados frente a los tribunales en caso de violación. La función principal de la lucha por reconocer y consagrar jurídicamente una serie de derechos a favor del individuo y exigibles frente al Estado y los poderes públicos ha sido la de configurar y proteger una esfera de libertad individual en la que cada persona puede decidir con plena autonomía y conformar sus opciones vitales ${ }^{516}$.

Estos derechos, más allá de la denominación que se les otorgue, son manifestaciones concretas del valor de la personalidad y por consiguiente del valor libertad que la impregna ${ }^{517}$. Debe entenderse que el ordenamiento jurídico es uno, vuelvo a enfatizar esto, tanto en sus normas de Derecho Público como en las de Derecho Privado, y en su globalidad debe proteger eficazmente a la persona. Los derechos fundamentales son concreciones del valor de la dignidad y ésta, a su vez, goza de pleno respeto y eficacia cuando los derechos son respetados. Los derechos fundamentales, en definitiva, garantizan al sujeto su señorío sobre alguna parte esencial de su propia persona y el ejercicio concreto de las proyecciones materiales y espirituales de diversas caras del todo integral que es la persona humana ${ }^{518}$.

Tratados internacionales que, en España, poseen fuerza de Ley.

516 Cfr. VV. AA., "Los derechos fundamentales y su protección constitucional", Ed. Colex, Madrid, año 2007.

517 TUR AUSINA, R. "Garantía de Derechos y Jurisdicción Constitucional. Efectividad del amparo tras la sentencia estimatoria”, Ed. Tirant Lo Blanch, Monografías, núm. 525, Valencia, año 2008, páginas 109 y siguientes.

518 CASTÁN TOBEÑAS, J., "Los derechos del hombre”, Ed. Reus S.A., $2^{a}$ edición, Madrid, año 1976, página 12 a 15. El Estado de Derecho, es decir, el Estado sometido al ordenamiento jurídico, implica un elenco de derechos 
Debido a lo diverso que puede manifestarse el derecho al libre desarrollo de la personalidad, y la multiplicidad de situaciones en las que la dignidad humana puede exigir su respeto y promoción, es que no puede ni debe estipularse una lista cerrada que enumere taxativamente los derechos fundamentales $^{519}$.

La dignidad de la persona es constitutiva de su esencia e implica nociones antropológicas en cuanto diferencia al hombre de otros seres y es la base de su individualidad. Sin perjuicio de estos criterios antropológicos, la dignidad, posee elementos biológicos puesto que el ser humano, individualmente considerado, se diferencia de otros por su estructura genética y particular carga de caracteres cromosómicos, sin duda ellas son sellos de individualidad.

sobre los cuales existe un consenso generalizado puesto que se estiman necesarios para la existencia de una democracia. Es usual hablar de generaciones de derechos de acuerdo a la época en que cada grupo fue reivindicado y de cuyas ideas se nutrió. Así, tenemos una primera generación que se correspondía con el Estado liberal de Derecho y que consistió, esencialmente, en limitar jurídicamente al poder para garantizar la libertad individual. Esta primera generación está presentada por os derechos individuales más básicos: vida, libertad, propiedad, seguridad, participación política limitada. Es una libertad que resiste los embates del poder pero que no exige un desarrollo y promoción de aspiraciones. La segunda generación se corresponde con la Estado Liberal Cercado e incorpora el sufrago, aunque sólo para los hombres y ciertas libertades grupales como el derecho de asociación. La tercera generación es la que nace al amparo del Estado Social de Derecho o Wellfare State en el que se da una fuerte interacción entre el Estado y los particulares. Supone la integración de los derechos económicos y sociales y los derechos de prestación, es decir, la acción positiva del Estado para lograr una igualdad real por sobre la formal. El Estado está obligado a crear y mantener las condiciones materiales para el desenvolvimiento de determi nados derechos como la educación, la tutela judicial, la vivienda, etc. Finalmente, se menciona en doctrina la cuarta generación de derechos que han tenido acogida tanto en los Textos Fundamentales de las naciones como en los Instrumentos Internacionales. No responde a un quiebre sustancial en el modelo de Estado Social de Derecho sino en la evolución de este debido, mayormente, a las reivindicaciones de grupos de ciudadanos y a las transformaciones científicas y técnicas aplicadas a la vida cotidiana. En grandes líneas, puede subdividirse a esta cuarta generación en tres grandes bloques de derechos, algunos de ellos derivaciones de otros ya anteriormente reconocidos y otros nacidos a partir de situaciones sin precedente. En un primer bloque se encuentran los derechos relativos a la protección del ecosistema y medioambiente así como el patrimonio de la humanidad tangible e intangible. En el segundo bloque están los derechos relativos a un nuevo estatuto jurídico de la vida humana y en el tercero los derivados de las nuevas tecnologías de la comunicación y la información. Especial atención merecen los del segundo bloque, entre los que destacan y son relevantes al derecho a la identidad, los que defienden la integridad psicológica y moral del individuo, el derecho a la identidad genética y a recibir información sobre ella y el derecho a la reproducción humana. Cfr. GÓMEZ SÁNCHEZ, Y., "Derecho Constitucional Europeo", Ed. Sanz y Torres, Madrid, año 2005, página 60 a 68.

519 En el ordenamiento constitucional español, el artículo 10.1 CE actúa como una cláusula de reintegración que permite adaptar la lectura de las garantías constitucionales a la luz de los hechos y el devenir social con sus nuevas exigencias y desafíos. Serán, por supuesto, los tribunales quienes tendrán a su cargo la labor interpretativa integradora y expansiva de este precepto No obstante, la dificultad se debe como es el caso con los estándares jurídicos abiertos en procurar definir que se entiende por dignidad, debido a que ningún texto legal lo define y queda en el prudente entender y la intuición del intérprete en develar cuáles son sus exigencias en cada caso concreto. Por ello mismo, el cuadro axiológico que elaboró el constituyente queda abierto a ser llenado con diversos contenidos pues, proclamada abstractamente, la dignidad no dice nada en términos legales per se refiere a todos los derechos del Título Primero de la CE. 
La historia particular de cada uno comienza con su generación, con la unión de los gametos de sus progenitores. En razón de ello, al hombre le resulta esencial reflexionar sobre su propia historia individual a partir de su filiación, es decir a partir del comienzo de su existencia ${ }^{520}$.

Existe una relación intrínseca entre los conceptos de dignidad y el del libre desarrollo de la personalidad, por cuanto la personalidad es el aspecto dinámico de la dignidad humana, es dinámico por cuanto se va haciendo en el tiempo, se tiene por el sólo hecho de ser persona pero requiere de un reconocimiento y de un tratamiento proveniente del ambiente donde la persona se desenvuelva.

El libre desarrollo de la personalidad se alcanza mediante la plena realización de las potencialidades humanas y el ejercicio de los derechos, especialmente los fundamentales. El reconocimiento y respeto de los derechos fundamentales se asienta, a su vez, en el reconocimiento y respeto de la dignidad. Es decir, la dignidad es el valor del cual derivan los derechos fundamentales y el ejercicio de estos derechos implica el desarrollo de la personalidad. Esto provoca el que se entienda la personalidad como la faceta dinámica de la dignidad, asimismo, la dignidad contiene, en potencia, aquello que se despliega, en acto, con el proceso de perfeccionamiento y desenvolvimiento de la personalidad $^{521}$.

En el Derecho español, una parte importante de la doctrina se ha pronunciado a favor de considerar el derecho a conocer la verdadera filiación como un derecho de la personalidad ${ }^{522}$. El derecho a la identidad hace el conjunto de caracteres por los cuales un individuo define su personalidad propia y se distingue de sus semejantes. Privarle de conocer uno de los elementos de su origen im-

520 La dignidad del hombre se despliega y manifiesta en diversos niveles. Para empezar, la dignidad de la persona humana en cuanto ser racional con capacidad de volición y autodeterminación h sido una constante en la filosofía occidental. En segundo lugar, la dignidad se despliega en la pregunta por el origen y la finalidad de la propia existencia. Otra tercera manifestación de la dignidad humana es la dimensión moral o ética del hombre y de la mujer en cuanto a la valoración de los propios actos y sus consecuencias en relación a sí mismos y a terceros. En cuarto lugar, a dignidad se estima en la vida de relación y social de los individuos, en todo lo relacionado con su consideración y honor.

521 En el lenguaje usual la personalidad puede entenderse como la diferencia individual que constituye a cada persona y la distingue de otra. El texto constitucional apunta al despliegue de las potencialidades psíquicas, morales, culturales económicas y sociales de cada persona. En definitiva, alcanzar su modelo de ser humano o ideal de vida. Este modelo o ideal se plasma a través de la concreción, en el actuar de cada uno, de cada derecho fundamental reconocido por la Constitución. La fuerza impulsora del cambio subjetivo y personal, en relación dialéctica con el cambio social, es el motor que encierra la fórmula del "libre desarrollo de la personalidad" y que otorga dinamismo a la interpretación constitucional.

522 Cfr. SÁNCHEZ ROMAN, F. "Estudios de Derecho Civil, Historia General de la Legislación española”, Tomo IV, Ed. Analecta, Ediciones y Libros, Pamplona, año 2008; RIVERO HERNÁNDEZ, F. "La investigación de la mera relación biológica en la filiación derivada de técnicas de fecundación artificial”, La filiación a finales del siglo XX, II Congreso Mundial Vasco, Vitoria, año 1987, página 157 ROCA I TRÍAS, E. "Adopción y datos biogenéticos: el proyecto "genoma humano" como auxiliar de las técnicas del desarrollo de la personalidad”, Reunión internacional sobre el Derecho ante el proyecto genoma humano, Bilbao, 24 a 26 de mayo de 1993, página 17; Cfr. VILLANUEVA Y CASTELLANO, "La investigación de la paternidad ante la perspectiva constitucional”, III Congreso de Medicina Legal y Social, Madrid, año 1979. 
plica impedir el total desarrollo de la personalidad, para saber quién soy y dónde voy, se requiere saber de dónde provengo. Además, su integridad física y psíquica puede resultar vulnerada por carecer de datos relacionados con sus antecedentes, por cuanto provoca contemplar vacíos importantes en la historia personal. El derecho a investigar la paternidad tiene rango constitucional $^{523}$, y como motivo fundante de esto se encuentra el interés superior del niño. Tal derecho de la persona a conocer su verdadera filiación afecta a su dignidad y al libre desarrollo de la personalidad y deben interpretarse como que la contienen de manera implícita, en el caso de los menores ello se acentúa. El artículo 10.1 CE no es un resumen de los derechos sino una cláusula de reintegración que permite adaptar la CE a las nuevas necesidades sociales. Por la interpretación más favorecedora de la libertad, sumado a la importancia del respeto por la dignidad humana y el libre desarrollo de la personalidad, se extiende la protección constitucional a derechos no enumerados pero implícitos dentro de los fundamentos del orden constitucional. Vale para ilustrar este punto la STC de 25 de abril de $1994^{524}$. Al analizar el núcleo duro del derecho al honor, intimidad personal y propia imagen, el Alto Tribunal expresó que:

"El derecho a la propia imagen, reconocido por el artículo 18.1 de la Constitución a la par de los del honor y la intimidad personal, forma parte de los derechos de la personalidad y como tal, garantiza el ámbito de libertad de una persona respecto de sus atributos más característicos, propios e inmediatos, como son la imagen física, la voz o el nombre, cualidades definitorias del ser propio y atribuidas como posesión inherente e irreductible de toda persona. En la medida en que la libertad de ésta se manifiesta en el mundo físico por medio de la actuación de su cuerpo y las cualidades del mismo, es evidente que con la protección de la imagen se salvaguarda el ámbito de la

523 RUBIO TORRANO, E. “Inconstitucionalidad del Art. 133, párrafo 1º, del Código Civil ( LEG 1889, 27)” Aranzadi Civil-Mercantil num. 17/2005 parte Tribuna, Ed. Aranzadi, S.A., Pamplona, año 2005, BIB 2005/2546: “A mi juicio, la aspiración de lograr la verdad biológica posibilitando para ello la investigación de la paternidad es un objetivo en la medida en que con ello se logra una mayor protección del hijo; es decir, la previsión constitucional de investigar la paternidad se ofrece como instrumento al servicio del principio de igualdad y no discriminación de la filiación, no tanto como un derecho fundamental del progenitor. La consecución de la verdad, sea o no biológica, no es un desiderátum o aspiración constitucional, sí lo es, en cambio, la igualdad. Por cierto, las aspiraciones del progenitor, en el supuesto que nos ocupa, pueden verse satisfechas a través de otro mecanismo ofrecido por el Código Civil, cual es el reconocimiento. Éste permite a todo progenitor no matrimonial, exista o no posesión de estado respecto del hijo, determinar la filiación mediante una declaración unilateral de voluntad, no necesitada de aceptación para su validez. De los tres votos particulares que acompañan a la sentencia comentada -el primero, firmado por tres magistrados; el segundo, por dos (ente ellos, la ponente); y el tercero, por un magistrado que se adhiere al segundo de los votos emitidos-, el segundo hace especial hincapié en el reconocimiento como otra vía para la determinación de la filiación no matrimonial. Finalmente, no se debe descartar a priori que en ocasiones la determinación de la paternidad no matrimonial persiga intereses ocultos como, por ejemplo, la obtención por parte del padre de alimentos del hijo pretendido."

524 STC, Sala 2a , núm. 117/1994 de 25 abril. RTC 1994/117; Cfr. STS, Sala de lo civil, núm. 905/1997 de 21 octubre. RJ 1997/7176. 
intimidad y, al tiempo, el poder de decisión sobre los fines a los que haya de aplicarse las manifestaciones de la persona a través de su imagen, su identidad o su voz (...) Estos derechos, como expresión de la persona misma, disfrutan de la más alta protección en nuestra Constitución y constituyen un ámbito exento capaz de impedir o limitar la intervención de terceros contra la voluntad del titular."

Si se protegen las manifestaciones de la persona en el mundo físico, también se salvaguarda aquello que se manifiesta, esto es la identidad única, la personalidad de cada individuo y los elementos que la componen. Es decir, que si la expresión del propio yo es objeto de protección constitucional, tanto más lo es la conformación de ese yo. Por ello cabe entender que la salvaguarda de los derechos fundamentales a la intimidad y vida privada (art. $18 \mathrm{CE}$ ) y a la libertad de culto (art. 16 CE) y de expresión (art. $20 \mathrm{CE}$ ), entre otros, lleva implícita la protección de ese sustrato sobre el cual todas estas manifestaciones se asientan y que es la identidad.

\section{3 ¿Qué puede entenderse por Derecho a la identidad?}

Si bien es cierto que la identidad oficial o administrativa existe o es reconocida del alguna forma desde hace mucho tiempo, y se fundamenta en las estadísticas y censos de población que hicieron los gobiernos europeos desde finales del siglo XVII, la identidad personal, como se entiende hoy día, es un concepto más reciente y adquiere importancia únicamente a partir de la Segunda Guerra Mundial.

Para GÓMEZ BENGOECHEA perfectamente puede decirse que a partir de los años 50 la idea de que necesitamos tener y desarrollar una identidad propia empieza a formar parte del pensamiento de los publicistas y los investigadores del mercado, especialmente en Estados Unidos, y a principios de los sesenta el concepto de "identidad", aunque vago, estaba firmemente asentado en gran parte del pensamiento académico y profesional. Los cambios políticos y cultuales de los años sesenta lo llevaron a una posición aún más preeminente y pasó a formar parte del vocabulario de gran parte de grupos y causas, incluyendo feministas, gays, "black" militantes, campañas para la reforma de prisiones e instituciones de salud mental, etc., difundiéndose de tal manera que, en la actualidad se ha convertido en parte del lenguaje popular habitual. Por último el auge de la psicología en nuestra cultura, terminó de dar contenido y relevancia a este concepto, convirtiéndose en uno de los aspectos claves del estudio de la persona y su salud mental ${ }^{525}$.

525 "Derecho a la identidad y filiación. Búsqueda de orígenes en adopción y en otros supuestos de filiación transfronteriza". Colección Monografías de Derecho Civil, Persona y Familia. Ed. Dykinson S.L., Madrid, año 2007, páginas 28 y 29. 
La identidad antes de comprenderse desde el punto de vista jurídico debe analizarse desde una perspectiva psicológica. Pero desde esta última faceta es una cuestión difícil de definir teóricamente y con múltiples dimensiones, significados y funciones. Se puede enfatizar que tiene que ver con cómo la persona responde a la triple pregunta de quién es, de dónde viene y a dónde se dirige.

Existe lo que podría denominarse un desarrollo evolutivo de la identidad que ha jugado un papel realmente importante en el estudio y la popularización de tal concepto.

Importante resulta comprender que la identidad vendría a ser en tales términos la habilidad para experimentarse a uno mismo como algo que tiene continuidad y consonancia y de actuar en consecuencia, unidad consciente que permanece en el tiempo. Desarrollar una identidad personal adecuada implica ser consciente de uno mismo como alguien separado y distinto de los demás, en una experiencia de continuidad con el pasado, desde un presente con sentido y con una perspectiva de futuro, a través de los cambios personales, físicos y psicológicos, y los cambios contextuales y de función social que se dan a lo largo del tiempo. Saberse como alguien único e imprescindible.

En relación al concepto de uno mismo, RICHARDS plantea que puede esgrimirse que la identidad en primer lugar está formada por la percepción más o menos estable que la persona tiene de sí misma y de las cualidades, los defectos y los recursos que le son particulares como alguien único y diferente de todos los demás, tal como se mencionó recientemente. Un autogobierno global que caracteriza a la persona en todos los ámbitos de su desarrollo como tal, físico, intelectual, afectivo, sexual, relacional y que no sólo está formado por la autopercepción del sujeto en un momento dado, sino que es el resultado de las relaciones únicas y las experiencias que esa persona ha tenido durante su crecimiento, que serán absolutamente personales y distintas incluso en el caso de dos individuos pertenecientes a una misma familia ${ }^{526}$. Estas relaciones y experiencias se inician con el contexto familiar pero se van extendiendo a sectores sociales más amplios a medida que el sujeto va creciendo y ampliando a sus relaciones con su entorno. En este sentido, la experiencia que el individuo tiene del mundo exterior y de cómo es visto por los demás, especialmente por las personas cercanas más significativas condicionará fuertemente la concepción que tenga de sí mismo y la formación de su identidad ${ }^{527}$.

526 RICHARDS, B. “¿What is identity?”, en GABER, I. y ALDRIDGE, J., “Culture, identity and transracial adoption, in the best interest of the child", Free Association Books Ltd., London, año 1994, páginas 80 a 84.

527 GÓMEZ BENGOECHEA, B. "Derecho a la identidad y filiación. Búsqueda de orígenes en adopción y en otros supuestos de filiación transfronteriza", ...op. cit., página 31. Este autor cita en este punto la obra de STRIBANE, U. "El desarrollo del sentimiento de identidad desde una perspectiva psíquica infantil", Infancia y Sociedad, Ministerio de Asuntos Sociales, año 1991 (Nov-Dic), página 84. 
La identidad, por lo demás, tiene una vertiente social, que es el conocimiento del propio lugar en el entorno social. Se sabe que todo individuo, en virtud de sus características personales cumple con distintos roles en el entorno social a través de su historia y forma parte de un determinado grupo social, lo cual también es personalizado por el sujeto, de tal manera que esos roles y grupos parecen determinar quién es y cómo es. Se es uno y sus circunstancias, dentro de ellas su entorno social resulta ser muy importante. Este proceso implica identificarse con las personas que le rodean, ser consciente de lo que se tiene en común con los otros y compartir con ellos experiencias, desarrollando sentimientos de pertenencia a diversos grupos en función de lo que se comparte con ellos. De este modo, tener una identidad propia es también ser capaz de relacionarse con los demás no sólo desde lo que te diferencia sino que también desde lo que te iguala a los demás ${ }^{528}$. Este componente de la identidad ayuda a conocer la posición que uno tiene con respecto a los otros, el lugar del individuo concreto en la sociedad, y las expectativas que los demás depositan sobre $\mathrm{el}^{529}$

Uno de los aspectos centrales de la identidad es el desarrollo de la conciencia de que uno es uno mismo y siempre el mismo a través de los múltiples cambios físicos, psíquicos, relacionales y contextuales que se viven a lo largo de la vida. La pregunta que entonces se formula es: ¿Cómo tiene lugar esto? Pues bien, este sentimiento de continuidad es posible gracias a la creación de una estructura narrativa, a juicio de GOMÉZ BENGOECHEA, que permita integrar las distintas experiencias de la vida como pertenecientes a uno mismo y organizarlas con sentido. Es necesario que esta conciencia combine estabilidad y dinamismo, que incorpore las nuevas experiencias en una narración continua y con sentido sobre la vida de la propia persona. Al ser las relaciones y experiencias personales parte importante de la identidad personal hasta la vejez, su desarrollo es especialmente importante durante la adolescencia, momento en el cual los cambios físicos y cognitivos y las expectativas empujan a la persona a revisar su historia para proyectarse en el futuro ${ }^{530}$.

528 Cfr. ADROHER BIOSCA, S. "Desafios del derecho de familia en una sociedad intercultural” y BERÁSTEGUI PEDRO-VIEJO, A, “La adopción intercultural: diferencias étnico-culturales en el seno de la familia”, ambos en "Familia e interculturalidad", Colección Estudios Familiares, núm.13, Universidad Pontificia de Salamanca, año 2003.

529 Encontrado en http://www.corteidh.or.cr/tesauro/tr1875.cfm: "El derecho a la identidad personal se desdobla en derecho a la propia herencia genética y derecho al habitat natural que como ser humano le es propio. Todo individuo tiene derecho a su identidad personal, que es el núcleo o esencia especifica de lo humano. La identidad de un individuo la constituye el genoma en diálogo con el ambiente, porque son los estímulos y respuestas del habitat quienes descifran el mensaje genético. La biología, proporciona las estructuras que interactúan recíprocamente con el mundo cultural. Éste transmite por instrucciones y aprendizaje, no sólo formas de vida, sino también los elementos que descodifican el mensaje genético."

530 GÓMEZ BENGOECHEA, B. "Derecho a la identidad y filiación. Búsqueda de orígenes en adopción y en otros supuestos de filiación transfronteriza”, ....op. cit., página 31. 
La identidad, para DE LA HERRÁN GASCÓN no es una característica que únicamente tenga relación con un autoconocerse sino que además implica un saber valorarse y quererse, es decir tiene una dimensión valorativa y emocional. Tal dimensión puede ser negativa o positiva. Una identidad sana o positiva incluiría un sentimiento de estar a gusto en el propio cuerpo, con la psicología individual, un sentimiento de saber a dónde se va y una seguridad interior relativa a que será uno reconocido y estimado por aquellos que tienen importancia para cada uno. ${ }^{531}$

El sentimiento de identidad también está formado por la dirección, el propósito y el significado que uno le da a su propia historia y a su futuro. El sentido de la vida, la congruencia en la narración de la propia existencia y de las características, potencialidades y roles con las aspiraciones, deseos y objetivos, en definitiva, le aporta al sujeto un saber de dónde viene y dónde se dirige.

Dado el carácter multifacético de la identidad que se acaba de exponer, algunos autores han optado por definirla como integración coherente y estable en su dinamismo por las múltiples identidades o fuentes de identidad de toda persona: amparada en circunstancias personales, sociales, genealógicas, raciales o étnicas ${ }^{532}$.

A pesar de las dificultades que existen para su definición, los psicólogos coinciden al afirmar que la adquisición y el desarrollo de la misma es una necesidad básica y fundamental para el ser hu-

531 DE LA HERRÁN GASCÓN, A. "El Autoconocimiento como Eje de la Formación". Revista Complutense de Educación, 15 (1), Madrid, año 2004, páginas 11 a 50. El autor expone que el autoconocimiento es la raíz de todo conocimiento, quizás esta idea es antigua como la filosofía occidental. Este conocerse permite una unicidad que interesa a la razón. Esto trae aparejado una primera conclusión, al ser el ser humano racional, debería motivarle el cultivo de su pensamiento, "pero sobre todo de su tramo radical, tanto más cuanto mayor sea el porte de lo que sobresale, cuanto más próxima nos quede la cornisa, cuanto más incierta sea la deambulante trayectoria humana". Desde la práctica didáctica, el autoconocimiento es un tema simultáneamente transversal y radical a cualquier otro ámbito que se pueda aprender, investigar o comunicar. De tal manera que una una enseñanza de la que pueda obtenerse dominio cognoscitivo tenga una eficacia mayor; "una educación que favorezca la realización de aprendizajes significativos y creativos es sin duda fértil”; pero debe irse más allá en el sentido de buscar "una Didáctica que adopte al autoconocimiento como referente formativo" esta "siempre puede ser más útil para conocer y ser mejor”. Socioeducativamente más allá del contenido estaría el conocimiento, más allá de la información estaría la comunicación, la investigación, la indagación de la educación y la transformación. El autor reflexiona que: “...esto no es suficiente: Más allá de la educación (en valores casi siempre predeterminados y ofrecidos como parte de programaciones mentales colectivas asociadas a ismos de todos los gustos y colores) y la transformación está el pensamiento propio o fuerte (autocrítico, indagador, dialéctico, etc.), la complejidad-conciencia y la (auto)transformación evolutiva, centrada en lo que los ancestros llamaban virtudes. Pero hasta esta cota cabe trascenderse, porque más allá o quizá más acá de las virtudes está su centro o su eje. El autoconocimiento o autoconciencia de sí podría comprenderse como este eje o ese centro, aunque no parezca tal por encontrarse ausente, tergiversado, desnaturalizado o tapado. Por parecer tan cubierto, diríase que no cuenta para la vida cotidiana. Análogamente, pudiera sostenerse la idea de que el centro de la circunferencia no existe. Pero es precisamente su posición lo que la sitúa y concentra, de modo que sus puntos necesariamente orbitan en torno a sí. En síntesis, si el pensamiento propio o la capacidad de soberanía personal pudiera entenderse como el qué del para qué de la (auto)formación y educación en valores, el autoconocimiento equivaldría al para qué de ese qué primero.”; Cfr. POPPER, K. R. y ECLESS, J. “El yo y su cerebro”.'Ed. Tecnos, Madrid, año 1989.

532 TRISELIOTIS, J., "Identity formation and the adopted person revisited”, en KANTZ, I y TREACHER A, (eds), The Dynamics of Adoption: Social and personal perspectives, Jessica Kingsley, London, año 2000, página 90. 
mano. La identidad es tan importante como la comida, la seguridad personal, y la satisfacción sexual, posiblemente tenga una relación muy estrecha con la denominada autoestima. Por ello en épocas de crisis, de reestructuración social, ese replegarse en sí mismo, el adentrarse en el lirismo del yo, puede cobrar un sentido dramático pero que si es bien conducido tendrá efectos positivos refundadores. El desarrollo adecuado de la misma es fundamental para la salud mental de las personas de manera que la construcción de una identidad negativa o a falta de integración entre los diversos aspectos de la identidad puede derivar en diversas patologías psíquicas y sociales.

Se han mencionado ya cómo la identidad se desarrolla a través de un proceso dinámico y complejo de autodefinición basado en dos mecanismos psicológicos básicos: la identificación con los otros y la diferenciación, el anclarse en la percepción de que se es único e imprescindible, tal como se manifestó con anterioridad, no debido a un inadecuado orgullo, sino en la consideración de un valor que contribuye a la construcción de la propia historia y la de los demás. En este sentido, su edificación implica, por una parte, la conciencia personal de quién es uno mismo, de las características y cualidades personales que nos hacen seres únicos y, por otro lado, la relación con el entorno y la aceptación de las influencias sociales, emocionales y culturales. Es por tanto el resultado del equilibrio entre el sentimiento de semejanza y pertinencia y el de diferencia e individualidad ${ }^{533}$.

Este proceso dura la vida misma, sus inicios son el propio nacimiento, sin embargo, como ya hemos señalado, es en la adolescencia cuando el sujeto configura de manera consciente y autónoma lo que será el núcleo de su identidad por lo que es la etapa a la que más atención se ha prestado, debido a las mayores dificultades que puede presentar.

Entre los factores que contribuyen al desarrollo de la identidad se han mencionado la calidad de las relaciones del niño con su familia, especialmente las primeras relaciones que entabla y la calidad y estabilidad de los cuidados que le proporcionan las personas responsables de su atención más temprana. Por ello el conocimiento y la comprensión del pasado y de la genealogía en especial de los casos de los niños separados de su familia biológica resultan trascendentales y no solamente por cuestiones afectivas sino incluso por su propia salud ${ }^{534}$. La relación con los padres es, por lo tan-

533 GÓMEZ BENGOECHEA, B. "Derecho a la identidad y filiación. Búsqueda de orígenes en adopción y en otros supuestos de filiación transfronteriza”, ...op. cit., página 32.

534 GARCIA RUIZ, Y. "El origen biológico en la reproducción asistida: Nuevas tendencias normativas para una era global”, Fundación Centro de Estudios Andaluces, Consejería de la Presidencia, núm. 9, mayo 2010. “La incidencia de la genética en la salud y en la propensión a padecer determinadas enfermedades está poniendo en cuestión el mantenimiento del anonimato de los donantes en el ámbito de la reproducción asistida. Cada vez son más los Estados que están reconociendo, en sus leyes, el derecho a conocer el origen biológico de los hijos nacidos de donantes, por su incidencia médica y porque resulta decisivo para el desarrollo de la personalidad. Dicha tendencia normativa podría afectar a España, en un futuro próximo. Para ello, sólo es necesario que los afectados empiecen a reclamar judicialmente sus derechos, tal y como ha sucedido en algún país de nuestro en- 
to, fundamental para la formación de la identidad de las personas, y el conocimiento del origen biológico puede ser una parte importante del desarrollo de la propia identidad.

Los estudios sobre la importancia psicológica del conocimiento del origen biológico se han centrado especialmente en los casos de adopción y, más recientemente en los niños nacidos a raíz del empleo de técnicas de reproducción asistida. Sin embargo el tener la posibilidad de establecer una conexión con el propio origen familiar, tanto genético como social es una cuestión que afecta a todas las personas, independiente de su filiación, aunque no se encuentren en los dos casos anteriores, lo que se acentúa en una situación de desconocimiento de quien es su padre o madre biológicos. En este grupo se encuentran los niños que fueron abandonados al nacer y que no han sido adoptados después, los hijos de madres solteras y los que siendo concebidos extramatrimonialmente viven después como hijos legales del marido de sus madres o las esposas de sus padres, con quienes no tienen vínculos genéticos.

La identidad a la que hace referencia el discurso contemporáneo de los derechos humanos es muy distinta del concepto de identidad oficial o administrativa que históricamente se empleó para identificar a hombres y mujeres en cuanto ciudadanos o componentes personales de una sociedad ${ }^{535}$. A partir de la década de 1950, las reivindicaciones de algunos colectivos hasta entonces marginados, como las mujeres y las personas de color, comenzó a conformarse lo que hoy en día se entiende por este concepto. Las luchas feministas y de defensa de las etnias minoritarias llevaron a concebir una idea de identidad como rasgo distintivo que primero fue de un grupo y luego comenzó a predicarse de cada individuo.

Si bien la discusión sobre el derecho a la identidad, bajo otras denominaciones y referida a elementos sectorizados de éste, es de larga data en el Derecho, su precisión ha sido reciente asimismo su elaboración doctrinaria y jurisprudencial ${ }^{536}$.

torno. El presente trabajo aboga por el reconocimiento del derecho a conocer el origen biológico de los hijos de donantes y plantea la necesidad urgente de acometer reformas legislativas nacionales y autonómicas en relación con el establecimiento de Registros de Donantes."

535 Cfr. DE ASIS, R., "La apertura constitucional: la dignidad de la persona y el libre desarrollo de la personalidad como fundamentos del orden político y de la paz social”, en VV. AA. "Comentarios a la Constitución Socioeconómica Española”, Ed. Comares, Granada, año 2002, página 153.

536 STS, Sala de lo Civil, Sección primera, núm. 208/2012 de 11 abril. RJ 2012/5745 “Los demandados apelaron la anterior sentencia. La SAP, sección segunda de Córdoba, de 3 de diciembre de 2010... confirmó la sentencia recurrida, con los siguientes argumentos:a) no puede estimarse la excepción de litisconsorcio pasivo necesario, porque lo que se reclamó fue la filiación paterna, no siendo cuestionada la materna y la madre, Sra. María Luisa , fue oída como testigo, por lo que la alegación de los recurrentes sobre la infracción del Art. 766 LEC... "carece de fundamento y debe ser rechazada por considerar que lo que estos pretenden es ampararse en formalismos enervantes para impedir que se entre en el fondo de la cuestión debatida" ; b) de los actos de la Sra. María Luisa , madre de la demandante, "se deduce con meridiana claridad estar conforme con la pretensión deducida por la hija" ; c) las pruebas no dejan lugar a dudas y la valoración efectuada no incurre en ningún error, arbi- 
Se ha precisado que es un derecho de la personalidad a través del cual se proyectan socialmente las características que contribuyen a distinguir a la persona y que incluyen su patrimonio cultural, político, ideológico, sentimental, social y todo lo que hace a su modo de ser complejo y que constituye el denominado estilo de vida. En este concepto de identidad se engloban el honor, la imagen, la privacidad, la nacionalidad, la filiación y todo lo que contribuye a hacer a una persona reconocible en la sociedad como sujeto individual.

Lo que hoy en día se entiende como identidad individual puede resumirse en la respuesta a tres preguntas ¿quién soy?, ¿de dónde vengo?, ¿a dónde voy? La psicología coincide en que es tan necesario para el sujeto el desarrollo de su propia identidad como lo es alimentarse. La identidad que resulta de la respuesta a esos interrogantes estaría compuesta de dos niveles o círculos de personalidad. El primero, el más íntimo y nuclear, es esa dimensión que se conforma de tres elementos: la percepción que el individuo tiene de sí, la mirada y la consideración de los terceros y un conjunto de vivencias que se prolongan a lo largo del tiempo. Es decir, el núcleo más íntimo de la identidad consiste en la idea de sí, resultado de la propia percepción y de la mirada del entorno, y la propia experiencia vital. Un segundo círculo de identidad es el resultado de la interacción social a través de los diversos roles que la persona ocupa a lo largo de su historia: padre, hijo, hermano, esposo, profesional, miembro de una etnia, de una nación. La vivencia de cada uno de estos elementos coadyuva a conformar una identidad ya que la persona busca en esta interacción la diferenciación y también aquello que lo iguala y que le brinda la sensación de pertenencia. Es lo que se denomina identidad cultural y es de gran importancia para aquellos que, por diversas circunstancias (adopción internacional, emigración, etc) han experimentado una separación entre sus raíces y su entorno so$\operatorname{cial}^{537}$.

Un aspecto central de la identidad es el desarrollo de la conciencia de que uno es uno mismo y siempre el mismo a través de los múltiples cambios que se viven a lo largo de la vida. Es necesario que aquí se combinen estabilidad y dinamismo. Esto es especialmente crítico en la adolescencia en que los cambios físicos son también muy marcados. Es fundamental el sentimiento de uno mismo

trariedad, insuficiencia, incongruencia o contradicción; d) no está justificada la negativa de los recurrentes a la prueba biológica en el hecho de que la actora actuaba de mala fe, puesto que ésta no se ha probado; e) la actitud obstruccionista a la prueba biológica produce infracción del Art. 118 CE..., puesto que "[...] en los supuestos de filiación prevalece el interés social y de orden público que subyace en las declaraciones de paternidad, de acuerdo con la jurisprudencia del TS "; f) la acción de reclamación de la filiación puede ser ejercitada por el hijo durante toda su vida y en este caso, se ejercitó 7 meses después del fallecimiento del padre biológico, lo que es suficiente para desestimar la alegación de que la demandante actuó de mala fe, y g) "no es aplicable la doctrina del retraso desleal al presente supuesto, ni por tanto ha quedado acreditado que la actora actuara contraviniendo el principio de buena fe".

537 ALES URÍA ACEVEDO, M. "El derecho a la identidad en la filiación”, ...op. cit., página 408. 
como ser valioso: el sentimiento de ser capaz de auto dirigirse, de coherencia en la narración y desarrollo de la propia historia vital. Desde el nacimiento hasta su vejez y que unifica las características y potencialidades con los roles y aspiraciones ${ }^{538}$.

El hombre se percibe a sí mismo como alguien más que biología pura y experimenta en muchas ocasiones la necesidad psicológica de acceder a la información sobre su propio origen o al menos ser capaz de buscarla. La falta de información acarrea consecuencias negativas como baja autoestima, inseguridad y ansiedad que pueden degenerar en patologías. Incluso los niños muy pequeños acusan la necesidad de saber quiénes son sus padres biológicos y conocer todo el entorno social y la historia familiar de donde provienen. En el caso del niño es fundamental para la conformación de la identidad la calidad de las relaciones con su familia, los cuidados y estabilidad que recibe, el conocimiento y comprensión de su pasado y genealogía y la actitud de la comunidad para con él.

En el desarrollo de la conciencia sobre la necesidad de proteger el proceso de conformación de la propia identidad y la búsqueda de los orígenes ha tenido gran relevancia el tratamiento que se ha dado a este tema en materia de adopción.

Los estudios psicológicos sobre la maduración de los hijos adoptados y su integración con las nuevas familias llamaron la atención sobre la incidencia del deseo de conocer los orígenes biológicos en la conformación de la personalidad. Para las personas en esa situación, sin embargo, el pleno desarrollo de la personalidad se ve obstaculizado puesto que el acceso a la información sobre sus orígenes es, en muchas ocasiones, muy difícil ${ }^{539}$. La persona adoptada que suele sentir culpa por haber sido abandonada y quiere saber el por qué, de todas manera el dilema entre el derecho a conocer la identidad y la adopción se analiza más adelante ${ }^{540}$.

538 Cfr. LÓPEZ QUINTÁS, A. "Descubrir la grandeza de la vida: Una vida de ascenso a la madurez personal”, Ed. Deescle De Brower, Madrid, año 2009; ALMACELLAS, M. A. "Camino hacia la madurez persona: Plan de acción tutorial para la educación secundaria obligatoria y bachillerato”, Ed. Deescle De Brower, Madrid, año 2009.

539 STS, Sala de lo civil, sección 1a , núm. 208/2012 de 11 abril. RJ 2012/5745: “En ningún caso puede acusarse a la sentencia recurrida recurrida de haber vulnerado el principio constitucional de la presunción de inocencia. Es también doctrina reiterada de esta Sala que la presunción de inocencia tiene su proyección en el derecho penal, no en el derecho civil (SSTS 192/2002, de 8 de marzo; 634 (sic)/2002 de 28 febrero; 870/2006, de 21 de septiembre y 187/2008 de 28 febrero, entre muchas otras) y más en este caso, en que lo que se discute es la determinación de la paternidad, cuya identificación no puede constituir nunca una sanción, al afectar al derecho de la personalidad del nacido, derecho protegido por medio del Art. 10 CE y del art. 39.2 CE, que permitió en su día la libre investigación de la paternidad de acuerdo con la protección de la personalidad."

540 VIDALPRADO,C.www.academia.edu/826479/El derecho a conocer la filiacion biologica. "El derecho a conocer la filiación biológica (Con especial atención a la filiación materna)” : "Lo dispuesto en el art. 22 se refiere a la posibilidad de conocer el propio hecho de la adopción. Es decir, si se es o no hijo adoptivo. Pero no se establece el derecho a conocer también quiénes son los padres biológicos-al menos, uno de ellos, si es el único cognoscible-de esa persona mayor de 18 años. En otras palabras, no se determina el derecho a conocer la filia- 


\subsection{El libre desarrollo de la personalidad y la libre investigación de la paternidad}

El constituyente puso especial interés en formular como fundamento del sistema constitucional, los derechos a la dignidad humana y el libre desarrollo de la personalidad, aunque también plasmó en el texto de la CE la posibilidad de conflictos entre derechos y la existencia de límites ${ }^{541}$.

Decir que los derechos son limitados no implica que toda restricción esté justificada sino que estas restricciones deben enmarcarse dentro del propio ordenamiento, lo cual equivale a que deben protegerse otros intereses, derechos y libertades tutelados por la CE. La limitación de un derecho apelando la seguridad jurídica o la paz social sólo tiene sentido cuando detrás de estos referentes están los derechos y otros bienes constitucionales. Para reforzar esta idea, es doctrina del TC que los límites deben ser interpretados en sentido restrictivo y de la forma más favorable a la eficacia y esencia de tales derechos. Al afirmar que las restricciones de los derechos fundamentales deben ser in-

ción biológica o natural, cuando esto en principio no plantearía problemas jurídicos - a efectos de sucesión hereditaria, por ejemplo-, porque, en cualquier caso, la filiación biológica o natural «no afecta a la adopción» (art. 177 Código Civil). De modo que, en mi opinión, podría sostenerse que no se llega a garantizar totalmente lo dispuesto por la Constitución, puesto que no se garantiza plenamente el derecho a conocer el origen biológico por parte de cualquier persona. No obstante, soy consciente de que el problema debe plantearse más bien en términos de política legislativa. Es decir, que si se potencia la institución de la adopción, no es lógico que se facilite simultáneamente la posibilidad de que el hijo mayor de 18 años pueda conocer su verdadera filiación biológica, puesto que este elemento retraería a muchos posibles adoptantes. Podría interpretarse que, en este caso, no se vulnera lo dispuesto en el art. 39.2 de la Constitución, puesto que no se trata de investigar la paternidad-que puede ser conocida y estar registrada-, sino de desvelarla. El art. 178, párrafos 3 y 4 del Código Civil dice: «El adoptado, aunque constare su filiación, ostentará como únicos apellidos los de su adoptante o adoptantes. Al adoptado no le serán exigibles deberes por razón de parentesco con sus ascendientes o colaterales por naturaleza». Lógicamente, se está suponiendo que, en muchos casos, la filiación natural sí consta en el Registro, e incluso se puede haber consentido la adopción por los padres naturales. Por eso afirmo que se trataría de desvelar esos datos, y no de investigar (término que se utiliza en el art. 39.2 de la Constitución), pues no es necesario hacerlo. Los problemas que plantea la adopción van más allá, por tanto, de la mera investigación de la paternidad. El derecho a conocer el propio padre o madre se plantea, más que como acceso a la realidad natural, como acceso al Registro donde consta o puede constar quiénes son sus padres. Al producirse una «novación» de filiaciones -extinción de una por creación de otra- el peligro estriba en la resistencia de la filiación natural que consta en el Registro. Sin embargo, a pesar de los riesgos que pudiera suponer con respecto a la institución de la adopción, pienso que hay que afrontar el problema, asumir el riesgo de la disminución del número de adopciones, y reconocer el derecho de los hijos adoptados a conocer su origen biológico, puesto que, como se explicará más adelante, es éste un derecho de la personalidad, que tiene su fundamento en la propia dignidad humana y su desarrollo. Hallamos un problema parecido en el caso de la Ley de Reproducción asistida. Lo que se discute es el derecho subjetivo del hijo a conocer una realidad que puede afectarle de modo importante: su procedencia biológica 12 . Veamos qué ocurre en la citada Ley."

541 TORRES DEL MORAL, A., "Principios de Derecho Constitucional Español”, Tomo I, Ed. Atomo, $2^{\mathrm{a}}$ edición, Madrid, año 1988, página 215. Se puede acotar que el límite de los derechos es un tema clásico de Derecho constitucional, cuyo contenido viene dado, en parte, por el mismo artículo $10.1 \mathrm{CE}$ en cuanto establece que deben respetarse la Ley y los derechos de terceros en el ejercicio de los propios. Esta formulación constitucional lleva implícitos dos presupuestos, el primero es que los derechos, si bien de titularidad de cada persona, no son concebidos desde una óptica filosófica individualista, sino en el seno de una comunidad organizada políticamente bajo un Estado de Derecho, y el segundo es que existen conflictos de derechos y tensiones entre intereses contrapuestos pero tutelados por la Constitución. En el marco de estas tensiones, son los poderes públicos, en especial los tribunales, quienes deberán lograr un equilibrio que maximice el goce de los derechos sin menoscabar las bases del Estado de Derecho. 
terpretadas de manera restrictiva, el TCE hace suyo el principio de in dubio pro libertate que prefiere la presunción general de que, en todo Estado de Derecho, debe favorecerse siempre la interpretación que haga primar la libertad del individuo ${ }^{542}$.

Corolario del principio in dubio pro libertate es el postulado favor libertatis que significa que la interpretación y hermenéutica constitucional, por parte de todos los poderes públicos, debe ser concebida como un trabajo tendiente a maximizar y optimizar la fuerza expansiva de los derechos fundamentales en su conjunto. Es decir, siguiendo al STC núm. 21/1981 de 15 junio. RTC 1981/21 que: "La extensión de los derechos fundamentales a todos los ciudadanos como derechos inherentes a la propia personalidad, exige que las limitaciones a su ejercicio (...) sólo sean admisibles en la medida en que resulten estrictamente indispensables”.

Las limitaciones son aceptables solamente cuando son justificadas en pro de la defensa de otros derechos fundamentales reconocidos explícita o implícitamente en el ordenamiento o cuando esas restricciones sean necesarias para salvaguardar el orden objetivo de la comunidad y la subsistencia del Estado democrático ${ }^{543}$. Para los supuestos de colisión la prevalencia en cada caso de uno u otro, deberá atender al respeto del contenido esencial, es decir, aquellas facultades o posibilidades de actuación necesarias para que el derecho sea reconocible como perteneciente al tipo descrito y sin las cuales quedaría desnaturalizado. Estas cualidades se aprecian en cada momento histórico y de acuerdo con las exigencias de un sistema democrático. Es decir, el contenido esencial del derecho se ve afectado cuando el derecho queda sometido a condiciones o limitaciones que lo hacen impracticable. Cuando la restricción se efectúa en función de otro derecho, no es dable crear reglas absolutas sino que debe ponderarse en cada caso concreto cuál de los derechos enfrentados habrá de prevalecer. El intérprete deberá armonizar, maximizando las posibilidades de cada derecho, y precisar las condiciones bajo las cuales un derecho habrá de tener prepondrancia sobre otro pero sin permitir jamás que se afecte el contenido esencial de los derechos en conflicto. Esto es así porque la

542 PÉREZ LUÑO, E.A., "Derechos Humanos, Estado de Derecho y Constitución”, 9a edición, Ed. Tecnos, Madrid, año 2005, página 321. En su papel como intérprete del Texto Fundamental, el TCE ha afirmado que los derechos son limitados y que sus límites se encuentran en el ejercicio de otros derechos o en la protección de otros bienes constitucionales. Asimismo los límites de los derechos deben ser interpretados, con todo, de forma restringida puesto que todo derecho fundamental posee una fuerza expansiva que restringe los límites que puedan serle impuestos. Los límites son tanto intrínsecos como extrínsecos: los primeros derivan de su propio objeto, mientras que los segundos lo hacen de la sociedad y los derechos de terceros. El límite interno viene dado por el objeto y por la conducta del titular que debe enmarcarse en el ámbito de la buena fe y del ejercicio no abusivo del derecho. Entre los límites externos hay que tener en consideración los derechos ajenos, la moral vigente y el bien común.

543 STCE de 14 de julio de 1981. También la Sentencia del TCE de 7 de noviembre de 1983 afirmó que “... los derechos fundamentales reconocidos en la Constitución, y entre ellos el de reunión, no son derechos ilimitados, sino que encuentran sus límites en el derecho de los demás (artículo 10 de la Constitución) y, en general, en otros bienes y derechos constitucionalmente protegidos". 
plena vigencia y eficacia de los derechos y libertades es un requisito de la plena vigencia del Ordenamiento, de una manera u otra garantizar los derechos fundamentales es garantizar el Ordenamiento mismo $^{544}$.

El artículo $53 \mathrm{CE}$ exige que la ley regule el ejercicio de los derechos y libertades, es decir que se respete la reserva de ley, y que, en todo caso la regulación legal y la interpretación judicial "deberá respetar su contenido esencial". Esta garantía del contenido esencial se ha vinculado con la dimensión institucional de los derechos fundamentales puestos o institucionalizados por la Constitución y en función de los cuales se reconocen los derechos y libertades de las personas.

El TC ha defendido que deben seguirse dos caminos interpretativos a la hora de definir el contenido esencial de un derecho. En un primer paso deberá preguntarse por la naturaleza jurídica de éste y la concepción generalizada que de él tienen los juristas. Desde este ángulo, el contenido esencial serían aquellas facultades o posibilidades de actuación que lo hacen reconocible como tal o sin las cuales quedaría desnaturalizado. Es decir, debe indagarse en abstracto lo que los especialistas entienden por el derecho que se cuestiona en el caso concreto. Todo ello con referencia al momento histórico de que se trate y a las condiciones inherentes a la vida de una sociedad democrática. En una segunda etapa interpretativa deberá verificarse que la limitación impuesta al derecho no sea de tal entidad que su ejercicio se convierta en impracticable, más difícil de lo razonable o se lo despoje de la necesaria protección. Estos métodos no son alternativos, sino que deben utilizarse conjuntamente para llegar a los resultados más justos ${ }^{545}$.

En resumen, la libertad es la regla en un Estado de Derecho, por ello su limitación es la excepción y debe estar sólidamente justificada y respetar el contenido esencial de la libertad o derecho en cuestión ${ }^{546}$.

544 DÍEZ-PICAZO, L. M. “Sistema de Derechos Fundamentos”, Serie Derechos Fundamentales y Libertades Públicas, Ed. Thomson Civitas, Cizur Menor, año 2008, página 79. Para el citado autor la expresión "garantías de los derechos fundamentales" carece de un significado técnico-jurídico preciso. Hace referencia al conjunto de medios que el ordenamiento prevé para la protección, tutela o salvaguardia de los derechos fundamentales. Se trata de un conjunto heterogéneo, pues abarca tanto procedimientos de distinta índole como requisitos sustantivos, cuyo rasgo común es precisamente estar dirigidos a asegurar la observancia y la efectividad de los derechos fundamentales. Sin embargo, la citada expresión puede inducir a confusión, dada su proximidad linguística con los términos "garantía institucional" y "garantía del contenido esencial"; términos que en cambio, si poseen un significado técnico jurídico preciso.

545 Vid. CARMONA Y CHOUSSAT, J. F., “Constituciones: Interpretación histórica y sentimiento constitucional. Cuatro ensayos sobre la organización política”, Ed. Thomson Civitas, Cizur Menor, año 2004.

546 Cuando se trata de derechos constitucionalmente reconocidos, se exige un especial justificación y explicitación de los hechos que se invocan como justificación. Los preceptos reconocedores de derechos deben ser interpretados extensivamente y los que los limitan de forma restrictiva. La legalidad debe ser interpretada de forma más favorable a la plena efectividad de los derechos y la maximización de su contenido para que no se desnaturalicen las mismas bases del Estado de Derecho. La finalidad de esta interpretación es no imponer a las personas otras li mitaciones en el ejercicio de sus derechos fundamentales que las que exijan el bien común y el respeto de los de- 
En torno a la verdad biológica, la Constitución de 1978 recoge el precepto fuente de la libre búsqueda de la verdad biológica en el ordenamiento jurídico español desde la doble vertiente de la incorporación de elementos como el artículo 7 de la Convención de los Derechos del Niño (art. 96.1 CE), y del reconocimiento en el artículo $39 \mathrm{CE}$ de la libre investigación de la paternidad y obligación de proteger integralmente a los hijos. Siguiendo estas directrices, tanto el Derecho común, mediante las correspondientes artículos del Código Civil, como el foral han reconocido el campo de acción de las personas para lograr la correcta determinación de su filiación a patre y a matre $e^{547}$.

Una definición bastante exacta de la investigación de la paternidad sería aquella que la considera como el conjunto de actividades tendientes a averiguar la existencia o inexistencia del nexo biológico de generación entre dos personas. CASTAN TOBEÑAS la definía como la facultad concedida a los hijos ilegítimos de, en ciertos casos y bajo ciertas condiciones procesales y probatorias, acudir a los tribunales para aportar pruebas relativas a la filiación a fin de que ésta fuese declarada y así se les impusiera a los padres las obligaciones derivadas de la generación. En otras palabras, se trata de un procedimiento que tiende a lograr la cobertura legal y social de un vínculo biológico y que normalmente se encauza por la vía judicial aunque pueden arbitrarse medios extrajudiciales de obtener el mismo resultado ${ }^{548}$.

La normativa internacional suscripta le exige al estado español la creación de mecanismos eficaces y reales para lograr el conocimiento por parte del menor de sus verdaderos progenitores ${ }^{549}$. Por otro lado, el artículo $39 \mathrm{CE}$ es un principio rector de política social y económica. No se trata de un derecho directamente invocable ante los tribunales para indagar en todo caso, la paternidad o maternidad, sino de un principio cuya articulación progresiva, tal como reza el artículo 53.3 CE, deben lograr los poderes públicos dándole una configuración concreta ${ }^{550}$.

rechos de los demás.

547 SILLERO CROVETTO, B. y ASENCIO SÁNCHEZ, C. "La investigación de la paternidad: principio y derecho en nuestro ordenamiento jurídico", Actualidad Civil, Madrid, año 1998, página 1084.

548 "Derecho Civil español común y foral", Tomo V, Volumen II, Ed. Reus S. A., 8 a edición., Madrid, año 1966, página 65.

549 Cfr. ALONSO GARCÍA, R. y SARMIENTO, D. "La carta de los Derechos Fundamentales de la Unión Europea. Explicaciones, concordancias y jurisprudencia”, Ed. Thomson Civitas, Cizur Menor, año 2006.

550 STS Sala de lo civil, sección 1a , núm. 453/2004 de 27 mayo. RJ 2004/4265 "Está dedicado el segundo motivo, que es el decisivo, a denunciar haberse infringido los artículos 140 y 141, en relación al 127 y 138 del Código Civil , debiendo advertirse cuanto antes que el recurrente amparó en el artículo 140 del Código Civil la acción que promovió a efectos de que judicialmente se declarase la nulidad del reconocimiento que efectuó de su paternidad biológica respecto al hijo de la demandada, por tratarse de reconocimiento de complacencia y sin que para nada se citase en la demanda el artículo 141, que sólo se alude de pasada para sostener que el reconocimiento de paternidad estaba viciado por habérselo impuesto al recurrente la demandada como condición para contraer matrimonio, sin que la acción ejercitada se apoye en alguno de los supuestos que contempla el artículo 141, para alcanzar la conclusión de que no hubo vicios en el consentimiento del recurrente y en todo caso la ac- 
El principio o directriz de verdad biológica persigue la adecuación del vínculo paterno y materno filial, tal como aparece en el Registro Civil y es reconocido por la Ley, al hecho natural de la filiación. Es decir, el primer paso es el permiso legal para perseguir la determinación de la filiación, que es un vínculo netamente formal y jurídico, y el segundo es que este vínculo responda a su vez, a la realidad de la generación. La obligación del legislador es arbitrar los medios adecuados para que esto suceda ${ }^{551}$. Una forma de encauzar el principio de verdad biológica en las relaciones paterno filiales es la investigación de la paternidad cuya finalidad es averiguar la existencia o inexistencia del nexo de generación entre dos personas: podremos decir que hay apego a la verdad biológica cuando no sólo se permita al hijo indagar sobre la mujer y el hombre que lo han engendrado, sino que la Ley en sí busca adecuar el parentesco legal a la materialidad de la procreación. Lo que se busca es la adecuación del hecho natural de la generación con el efecto jurídico creado por el nexo de filiación.

El principio de igualdad ante la Ley, recogido en el artículo $14 \mathrm{CE}$, guiado por la directriz constitucional del artículo 39.2 de supremacía del interés del menor lleva a que todo aquél que haya engendrado un hijo, en principio, deba hacerse cargo de su existencia y necesidades. Aquí surge el principio de libre investigación de la filiación como medio para evitar la discriminación entre hijos en base a las condiciones personales y deseos de sus progenitores, por lo tanto asegura la igualdad de los hijos independiente de su origen. Es decir, que toda criatura tiene el derecho a que las perso-

ción había caducado por haber transcurrido el plazo de un año que el precepto establece. Es claro que se ha aplicado indebidamente el artículo 141 que no afecta a la exactitud o inexactitud de la verdad biológica de la filiación, dejándose de aplicar el 140, que ha sido el alegado y conforma el debate jurídico procesal, por lo que la cuestión en esta vía casacional ha de concretarse a resolver si procede aplicar en sentido afirmativo o negativo el referido artículo 140 .... En el caso presente resulta incuestionable que la verdad biológica no coincide con la que representa el reconocimiento de paternidad que llevó a cabo el recurrente respecto al menor Carlos Ramón y se plantea la cuestión si ha de tenerse por prevalente la declaración formal registral. Aunque queda dicho, no ha de olvidarse que el artículo 140 reconoce legitimación activa a quien aparece como progenitor y es precepto no equiparable sino distinto del 119 que determina que la filiación adquiere el carácter de matrimonial desde la fecha del matrimonio de los progenitores, dando a entender que se trata de padre y madre reales y que se casan con posterioridad al nacimiento del hijo o de los hijos habidos de una unión extramatrimonial precedente y siempre que el hecho de la filiación quede determinado en forma legal, por lo que junto a los nacidos constante el matrimonio (matrimonios originarios) se colocan los nacidos con anterioridad no estando los padres casados (hijos matrimoniales anticipados).. La imperatividad del artículo 39 de la Constitución , que exige la protección de los hijos, clama contra la inexactitud en la determinación de la paternidad, con la anomalía de atribuir potestad sobre los mismos a quien no es su padre biológico y la aplicación de un formalismo riguroso vendría a potenciar una situación injusta y hasta en línea de fraude, por lo que se impone la adecuada interpretación de la norma en la línea que marca el artículo tres del Código Civil. Esta doctrina se reitera en la sentencia del 15 de septiembre de 2003, al otorgar toda eficacia decisiva al hecho de que el padre que impugnó no era padre biológico, pues la paternidad real, en otro caso, resultaría clamorosamente inexacta si se atribuyera a quien ha probado que no engendró el hijo y solo se limitó a reconocerle como acto de complacencia y, aún más, se llegaría a proteger situaciones de indefensión, que violentan el artículo 24 de la Constitución...da inicial.."

551 GASPAR LERA, S. "La investigación de la paternidad” en VV. AA., "El Derecho español a 200 años del Código Napoleón”, Ed. Porrúa, Universidad Nacional Autónoma de México, año 2005, páginas 253 a 271. 
nas que la han engendrado se responsabilicen por su bienestar y cumplan con los deberes que impone la patria potestad, siempre que esto sea conducente a alcanzar el mejor bien del niño. Esta averiguación, a raíz del artículo 39.2 CE presenta el carácter de principio del ordenamiento jurídico, y rige la actividad política, social y económica. Además, es directamente invocable ante los tribunales y ha de informar toda la paternidad de manera imperativa.

La verdad biológica, por lo demás, es el criterio necesario para ajustar la forma legal y la verdad material. La primacía de esta directriz es que coincida el padre legal con el progenitor biológico y titular de la patria potestad. A partir del principio de libre investigación de la paternidad y maternidad, guiado por la búsqueda de la verdad biológica, se llega al derecho a conocer el propio origen. La doctrina más reciente postula la raigambre fundamental de este derecho, dada su íntima conexión con la construcción de la propia identidad. Las discusiones en torno a su titularidad determinan quiénes y bajo que requisitos podrán accionar judicialmente para lograr el conocimiento de las auténticas relaciones de generación ${ }^{552}$.

El conocimiento de la filiación biológica se asocia directamente con los derechos al honor y desarrollo de la personalidad y de la identidad ${ }^{553}$. El concepto de identidad está en la base del reconocimiento social y jurídico de la existencia de un ser humano como persona, titular de derechos y obligaciones. Al niño se lo identifica a partir de su conexión con sus padres y con ello tiene según la ley, parientes, un apellido familiar y una nacionalidad. La identidad es un derecho que se adquiere con el nacimiento pero que debe ser protegido durante toda la vida, tal como lo recoge el artículo 8.1 de la $\mathrm{CDN}^{554}$. Este derecho se concreta en el deber de registrar a los niños inmediatamente después de su nacimiento como medio efectivo de protección del vínculo con la familia de sangre y en el principio de que el asiento registral del nacimiento debe reflejar la verdad material de la paternidad y maternidad.

De lo anterior se desprende la influencia de ciertos criterios guías, al momento de elaboración del régimen de averiguación de la paternidad que sin duda se relacionan completamente con la búsqueda de la verdad biológica, aunque se permitan ciertas limitaciones en aras a proteger otros intereses constitucionales.

552 GARCÍA VICENTE, J. R. "Los principios del Derecho de las Acciones de filiación", en ABRIL-CAMPOY, J. M. y AMAT LLARI, E. (Coords) "Homenaje al Profesor Puig i Ferriol, L". Tomo II, Ed. Tirant lo Blanch, Congresos y Homenajes, Valencia, año 2006, página 1423 a 1425.

553 SSTS, Sentencia núm. 185/1992 de 1 marzo. RJ 1994/1634; Sentencia de 13 diciembre 1994. RJ 1994/10494.

554 Esta disposición se originó a partir del requerimiento de la República Argentina, tras una dura experiencia nacio nal de supresión ilegal de la identidad de menores secuestrados. En cumplimiento de ésta, la República Argentina por Ley 23.511 creo el Banco Nacional de Datos Genéticos n 1987 para la realización gratuita de pruebas biológicas tendientes a clarificar el parentesco cuando existan disputas sobre el origen de un menor. 
En cuanto al interés del menor, la línea jurisprudencial dominante parece identificarlo con el conocimiento de su origen biológico, ya sea que se trate del conocimiento en sí mismo o que a través de él se pretenda responsabilizar a quienes han traído al mundo a un nuevo ser humano, aunque se admiten ciertas limitaciones. La Sentencia de 28 de mayo de 1997 del TS, declaró que, si bien la protección del menor está atribuida en primer lugar a sus progenitores "no es verdad (...) entender que el bien del menor está en la obtención de una declaración de filiación materna y paterna" ${ }^{555}$. La búsqueda de la verdad biológica y la determinación de la paternidad en consecuencia debe realizarse de manera tal que mejor procure el cumplimiento de los derechos de los cuales los hijos son acreedores. De este razonamiento es válido entender que en algunas circunstancias se pondrán en juego intereses y derechos que puedan postergar el que se ajuste la filiación formal con la generación material.

\subsection{El reconocimiento jurídico del Derecho a la identidad}

Una de las cuestiones que caracteriza el derecho a la identidad es su tradicional falta de positivización como un derecho autónomo con sustantividad propia, tanto en el plano internacional como en el derecho interno ${ }^{556}$. En tal sentido si bien la protección de los diferentes elementos que configuran la identidad personal y a través de los cuales ésta se manifiesta, tales como el nombre, la nacionalidad y especialmente la filiación, ha sido más frecuente, la protección expresa y autónoma de este derecho es relativamente reciente, y es en los últimos años cuando empieza a aparecer mencionado tanto en el ámbito internacional como en el Derecho interno de los distintos países. Se trata, además de un derecho que aparece siempre vinculado a la filiación, su determinación y el derecho a conocer el origen biológico, por ser la identidad biológica un elemento especialmente importante del mismo, siendo muchas las veces difícil desligar la protección de la identidad, en general, de la que se hace de esta manifestación concreta de la misma.

Es más, es cierto que la identidad personal aparece con mucha frecuencia indisolublemente unida a la filiación, y, concretamente, a la posibilidad de conocer el origen biológico. La protección que del derecho a la identidad se hace en el ámbito internacional no es ajena a esta situación, ni a la dificultad de desligar la protección de la identidad en general de la protección de la determinación y conocimiento de la filiación como manifestación de ésta.

555 STS núm. 451/1997 de 28 mayo. RJ 1997/4326; Cfr. STS núm. 65/2002 de 1 febrero. RJ 2002/1585 ; SAP Baleares, Sección $5^{\text {a }}$, núm. 229/2004 de 7 junio. JUR 2004/192717

556 GÓMEZ BENGOCHEA, B. "Derecho a la identidad y filiación. Búsqueda de orígenes en adopción y en otros supuestos de filiación transfronteriza”, ...op. cit., página 49 
Tal como se afirmó precedentemente, el reconocimiento del derecho a la identidad en general es escaso en el Derecho convencional y relativamente reciente en el tiempo. El texto que contiene el primer reconocimiento expreso del derecho a la identidad personal es la Convención de Naciones Unidas sobre los Derechos del niño, de 20 de noviembre de 1989, que en su artículo 8 se pronuncia en los siguientes términos:

“1. Los Estados Partes se comprometen respetar el derecho del niño, preservar su identidad, incluidos la nacionalidad, nombre y relaciones familiares de conformidad con la ley sin injerencias ilícitas. 2. Cuando un niño sea privado ilegalmente de alguno de los elementos de su identidad o de todos ellos, los Estados Partes deberán prestar la asistencia y protección adecuadas con miras a restablecer rápidamente su identidad" ${ }^{\text {"557. }}$

En relación con esto la Convención reconoce, expresamente, en el artículo 7, el derecho del niño a la transcripción de su nacimiento, al nombre, la nacionalidad y "en la medida de lo posible a conocer a sus padres y a ser cuidado por ellos", y la obligación de los Estados de velar “por la aplicación de estos derechos de conformidad con su legislación nacional y las obligaciones que se hayan contraído en virtud de instrumentos internacionales pertinentes en esta esfera, sobre todo cuando el niño resultara de otro modo apátrida”.

Sin duda la redacción originaria del artículo 7 reconocía de un modo bastante más explícito el derecho de los niños a la identidad y recogía en su apartado primero el derecho al nombre, al registro y a adquirir una nacionalidad desde el momento del nacimiento, y en el segundo, el derecho del niño a "que se respete su identidad y dignidad humanas, raciales, nacionales y culturales, con la obligación correspondientes de respetar la identidad y la dignidad humanas, raciales, nacionales y culturales de los demás",558.

Dentro de las sesiones del Grupo de Trabajo, Argelia, Egipto, Irak, Libia, Jordania, Kuwait, Marruecos, Omán, Pakistán y Túnez propusieron que se incluyera en el párrafo primero el derecho del niño a conocer y pertenecer a sus padres, reforzándose aún más la protección de la identidad de los menores, especialmente en aquello que tiene que ver con la filiación y con el origen biológico.

557 El texto originario del artículo 8 (artículo 9 bis en la primera redacción de la Convención), era prácticamente igual al texto definitivo y apenas se propusieron enmiendas en este artículo. Cabe destacar la intervención en el Grupo de Trabajo del representante de México, que declaró que deberían formularse en términos más explícitos los compromisos que los Estados asumirían en virtud del párrafo 1, y que se deberían incluir también los elementos biológicos de la identidad. NACIONES UNIDAS, CONSEJO ECONÓMICO Y SOCIAL, COMISION DE DERECHOS HUMANOS, Informe del Grupo de Trabajo acerca de un proyecto de convención sobre derechos del niño, E/CN.4/1989/48, 2 de marzo de 1989, página 55 a 54.

558 Artículo 72 en la primera versión sobre la que se discutió el Grupo de Trabajo de Naciones Unidas acerca de un proyecto de Convención sobre los derechos del niño. NACIONES UNIDAS, CONSEJO ECONÓMICO Y SOCIAL, COMISIÓN DE DERECHOS HUMANOS, Informe del Grupo de Trabajo..., op. cit. Página 16 a 20. 
Se intentaba así asegurar la estabilidad psicológica del niño, manifestando que se trataba de una cuestión de gran importancia para su crecimiento físico y mental y para la formación de su identidad. Frente a esta propuesta, la República Democrática Alemana, la Unión de Repúblicas Socialistas Soviéticas y los Estados Unidos, hicieron referencia a la posibilidad existente en las legislaciones de que se dieran adopciones secretas (en las que el niño adoptado no tenía derecho a conocer a sus padres naturales) manifestando que, por este motivo, el "derecho a conocer a sus padres" no podía aplicarse en todos los lugares.

Las discusiones sobre la redacción de este artículo dieron lugar a que se tuviera en cuenta todas las aportaciones hechas en el grupo de trabajo hasta el momento. El grupo en tal sentido propuso la siguiente redacción: "1. El niño tendrá derecho desde su nacimiento a un nombre y registro y a adquirir una nacionalidad y, en la medida de lo posible, a conocer a sus padres y a ser cuidado por ellos. 2. Los estados partes velarán por la aplicación de estos derechos de conformidad con su legislación nacional y las obligaciones que hayan contraido en virtud de los instrumentos internacionales pertinentes en esta esfera, sobre todo cuando el niño resulta de otro modo apátrida”. Se discutió sobre si la expresión "en la medida de lo posible” era la más adecuada, y sobre la necesidad de recoger que la inscripción en el registro debía realizarse inmediatamente después del nacimiento, porque así lo establecía el Pacto Internacional de Derechos Civiles y Políticos, y finalmente el Grupo de Trabajo aprobó el texto definitivo.

GOMEZ BENGOCHEA ${ }^{559}$ plantea que es posible aseverar que si la redacción del artículo se modificó en lo referente a la posibilidad de conocer a los padres ello se debe a que las legislaciones de algunos países permitían el secreto con respecto a estas cuestiones, por ello lo que se pretendió con la redacción final fue, precisamente no proteger el derecho al conocimiento de los orígenes, que queda desdibujado a través del uso de expresiones imprecisas que pueden dar lugar a distintas interpretaciones. Así la expresión "en la medida de lo posible" puede entenderse referida a la posibilidad legal, es decir, podrá conocer a sus padres y ser cuidado por ellos siempre que no existan impedimentos prácticos para ello, como por ejemplo la ausencia de datos sobre su identidad. Parece que esta segunda interpretación carece de sentido si se conocen los antecedentes del texto que ya se han mencionado ${ }^{560}$.

559 "Derecho a la identidad y filiación. Búsqueda de orígenes en adopción y en otros supuestos de filiación trans fronteriza”, ... op. cit., página 52.

560 GARRIGA GORINA, M. "La adopción y el derecho a conocer la filiación de origen. Un estudio legislativo y jurisprudencial. ”, Ed. Aranzadi, Pamplona, año 2000, páginas 216 a 218; Cfr. MAGALDI, N. "Derecho a saber, filiación biológica y administración pública”, Ed. Marcial Pons, Madrid, año 2004. 
La manera de cómo estos artículos están redactados manifiesta la aparición del derecho a la identidad con contenido propio, como derecho sustantivo e independiente de los demás. Pero, en nuestra opinión, deja un margen de actuación tan amplio a los Estados en la regulación de la cuestión (margen que, además, se ha visto se dejó voluntariamente para evitar proteger la identidad de los menores más explícitamente) que caben en él hasta las legislaciones más restrictivas en esta materia, así opina la autora recién citada. Aunque se reconozca el derecho a la identidad y se haga en un instrumento que cuenta con medios para controlar su cumplimiento, se trata de una protección bastante ineficaz porque, por los términos que utiliza, caben en ella incluso las legislaciones que prohíben la investigación. Es, a mi juicio, un reconocimiento puramente formal, más bien vacío y demasiado respetuoso con la diversidad.

La Carta Europea de Derechos del Niño, aprobada por el Parlamento Europeo el 8 de julio de 1992 reconoce también la existencia del derecho a la protección de la identidad, partiendo de una concepción esencialmente biológica del mismo y estableciendo que "todo niño tiene derecho a la protección de su identidad y, dado el caso, deberá poder conocer ciertas circunstancias relativas a sus orígenes biológicos, con las limitaciones que impongan las legislaciones nacionales para la protección de los derechos de terceras personas. Se deberán determinar las condiciones bajo las cuales se otorgarán al niño las informaciones relativas a sus orígenes biológicos así como las condiciones necesarias para proteger al niño de la divulgación de dichas informaciones por terceros".

Menciona también expresamente la protección de algunos otros elementos de los que conforman la identidad de la personas, tales como el derecho al registro de nacimiento, conciencia y religión y el derecho a gozar de su propia cultura, a practicar su propia religión o creencias y a emplear su propia lengua.

Además de la alusión que realiza el artículo 7 de la Convención de las Naciones Unidas al derecho a la inscripción, al nombre, a la nacionalidad y a conocer y ser cuidado por los propios padres y de lo recogido en la Carta Europea de Derechos del Niño, existen, en otros instrumentos internacionales, la mención de algunos de los medios a través de los cuales se protege la identidad de la persona.

Así, los derechos al nombre y a la inscripción de los niños en el Registro Civil inmediatamente después del nacimiento están también expresamente recogidos en el Pacto Internacional de los Derechos Civiles y Políticos, de Nueva York, de 16 de diciembre de 1966, que establece además la protección del derecho a la intimidad familiar. 
La posibilidad de conocer la filiación biológica se menciona en la Resolución A3-314/91, de 31 de diciembre de 1991 del Parlamento Europeo sobre los diversos problemas de los niños en la en ese entonces denominada Comunidad Europea, en la que se señala que todos los niños deben tener derecho a conocer su filiación biológica y a ser informados de cualquier deficiencia genética y de las posibilidades de heredarla.

El Convenio-marco para la Protección de las Minorías Nacionales, $\mathrm{n}^{\circ}$ 157, hecho en Estrasburgo, en el seno del Consejo de Europa, el 1 de febrero de 1995, protege la vertiente del derecho a la identidad relacionada con la cultura, haciendo referencia en sus artículos 5 y 12 a la necesidad de permitir a las personas pertenecientes a minorías nacionales preservar su religión, lengua, tradicionales y patrimonio cultural, así como el compromiso de los Estados partes de reconocer a estas personas el derecho a utilizar su apellido y nombre de pila en la lengua minoritaria, y a reconocerlos oficialmente según modalidades previstas en su ordenamiento jurídico. Y aún cuando el Convenio Europeo para la Protección de los Derechos Humanos y de las Libertades Fundamentales, firmado en Roma el 4 de noviembre de 1950 no hace mención expresa a la identidad ${ }^{561}$.

Asimismo jurisprudencialmente, a nivel europeo destaco la STEDH, Sección 1 ${ }^{\mathrm{a}}$, Caso Mikulic contra Croacia, de 7 febrero 2002. JUR 2002/78019, en donde se declara la violación de este derecho a la libre investigación de paternidad no en lo referente a la negativa de someterse, en este caso por parte del supuesto padre a las pruebas de ADN, sino que por cuanto no existe en el ordenamiento jurídico en cuestión otro medio legal alternativo que aplicar frente a tal negativa ${ }^{562}$.

561 STEDH, Gran Sala, Caso S. y Marper contra Reino Unido. Sentencia de 4 diciembre 2008. TEDH 2008/104. "La combinación particular de los alelos en un perfil de ADN puede utilizarse, además, para evaluar el origen étnico más probable del donante. Es posible deducir el origen étnico a partir de los perfiles de ADN puesto que la «apariencia étnica» individual se consigna siempre en la base de datos: cuando extraen las muestras biológicas, los policías clasifican sistemáticamente a los sospechosos en una de las siete categorías de «apariencia étnica». Por tanto, los exámenes de origen étnico efectuados en la base de datos pueden proporcionar, por deducción informaciones útiles en las investigaciones policiales, por ejemplo para ayudar a reducir el número de sospechosos y jerarquizar las prioridades de la policía. El informe indica que los factores sociales y las prácticas policiales conducen a que un número desproporcionado de miembros de la población negra y de grupos étnicos minoritarios sean interpelados, cacheados y detenidos por la policía y que, en consecuencia, quede registrado su perfil de ADN. De ahi el temor, expresado en el informe, de que la posibilidad de deducir la identidad étnica a partir de muestras biológicas, lleve a que se refuercen las teorías racistas en lo que respecta a la propensión a cometer delitos."; Caso Coster contra Reino Unido. Sentencia de 18 enero 2001. TEDH 2001/44. “"Hay que subrayar que la elección del modo de vida, nómada, seminómada o sedentario, como sobre otros as pectos de la identidad étnica, debería ser únicamente personal. Las políticas seguidas en ciertos Estados de la OSCE han infringido a veces este principio, bien fijando para un grupo un modo de vida que no corresponde a la elección de los miembros del grupo, bien actuando de manera que sea prácticamente imposible a los individuos seguir el modo de vida que expresa su identidad de grupo...".

562 STEDH, Sección 1a, Caso Mikulic contra Croacia, de 7 febrero 2002. JUR 2002/78019. "En opinión del Tribunal, las personas en la situación de la demandante tienen un interés vital, protegido por el Convenio, de recibir la información necesaria para descubrir la verdad sobre un aspecto importante de su identidad personal. Por otro lado, se debe tener en cuenta, que la protección de terceras personas puede imposibilitar que sean obligadas a estar disponibles para cualquier examen médico de cualquier tipo, incluyendo el examen de ADN.- Los Es- 
Volviendo al ordenamiento jurídico español, en este no se menciona expresamente el derecho a la identidad, pero si hace referencia a algunos de sus elementos o manifestaciones, especialmente a la posibilidad de investigar la paternidad.

Aún así, la protección que recibe este derecho y la categoría en la que podría enmarcarse son cuestiones confusas en la legislación española.

En primer lugar, existen convenios internacionales ratificados por España que hacen mención al derecho a la identidad en general y/o a algunas de sus manifestaciones, que vinculan a los poderes públicos y que forman parte del ordenamiento jurídico español.

En segundo lugar la CE recoge, en su artículo 39, entre los principios rectores de la política social y económica, el más importante principio informador en materia de filiación de nuestro ordenamiento. Introduce la protección a la familia, y concretamente la protección a los hijos independientemente de su filiación y a las madres independientemente de su estado civil, mencionando también la obligación de los padres de prestar asistencia a sus hijos nacidos dentro o fuera del matrimonio y haciendo reconocimiento expreso de la posibilidad de investigar la paternidad, estableciendo que la ley "posibilitará la investigación de la paternidad”, sin que tampoco quede muy claro cuál es el valor de tal reconocimiento.

El TS y parte de la doctrina han interpretado el uso del término "posibilitará" entendiendo que el derecho a investigar la paternidad es un derecho que nace limitado y que, el legislador, puede regular los requisitos que es preciso reunir y los casos en los que ésta será posible, teniendo en cuenta que este derecho entra en conflicto con frecuencia con otros considerados fundamentales. De manera que no se trata de un derecho absoluto, sino que admite ciertas matizaciones ${ }^{563}$.

GUZMÁN ZAPATER entiende, siguiendo un criterio sistemático, que al tratarse de un precepto que se encuentra ubicado tras los derechos y libertades fundamentales, en el Capítulo III del

tados Contratantes del Convenio tienen distintas soluciones al problema que surge cuando un supuesto padre se niega a cumplir con las órdenes judiciales sobre los exámenes que son necesarios para establecer los hechos. En algunos Estados, los tribunales pueden multar o encarcelar a la persona en cuestión. En otros, la falta de cumplimiento de una orden judicial puede crear una presunción de paternidad o constituir desacato al Tribunal, lo que puede llevar a un procesamiento penal.- Un sistema como el croata, que no tiene medios para obligar a un supuesto padre a cumplir las órdenes judiciales para que se someta a la prueba del ADN, en principio, puede ser considerado compatible con las obligaciones derivadas del artículo 8, teniendo en cuenta el margen de apreciación del Estado. Sin embargo, el Tribunal considera que en tal sistema, deben asegurarse los intereses de la persona que busca el esclarecimiento de la paternidad cuando dicha paternidad no puede establecerse por medio del examen de ADN. La falta de medida procesal para obligar al supuesto padre a cumplir con las órdenes judiciales únicamente está en conformidad con el principio de proporcionalidad si dispone de un medio alternativo que posibilite a una autoridad independiente a decidir sobre una demanda de paternidad rápidamente. Ningún procedimiento como este estuvo disponible en el presente caso".

563 GUZMÁN ZAPATER, M. "El derecho a la investigación de la paternidad (En el proceso con elemento extranjero)”, Ed. Civitas, Madrid, año 1996, páginas 37 y 38; STS 116/1999, de 17 de junio. RTC 1999/116 
Título I, recoge los principios rectores de la política social y económica. Parece que la existencia de la investigación de la paternidad sí implica "un programa de acción estatal en aras de la satisfacción de objetivos diversos", de manera que aunque el Estado sí queda obligado por la norma, la conducta en ella enunciada no puede ser exigida por los ciudadanos si no existe una ley que la desarrolle ${ }^{564}$.

Pero el conocimiento de la filiación biológica es una cuestión que va más allá de la investigación de la paternidad tal y como está enunciada en el artículo 39 CE y puede, además relacionarse con otros artículos del texto constitucional que no lo mencionan expresamente. Así ocurre con el artículo $15 \mathrm{CE}$, en el que se enuncia el derecho a la integridad física y moral, y con el artículo 10, que recoge el principio del libre desarrollo de la personalidad.

Admitir la relación del derecho a conocer el propio origen biológico con el derecho a la integridad supondría reconocer que se trata de un derecho fundamental de las personas. Aunque la mayoría de los comentarios sobre esta cuestión están referidos a la vinculación de la investigación de la paternidad con el artículo $10 \mathrm{CE}$, sin duda existen casos en los que el nexo entre el conocimiento del origen biológico y la integridad física y moral también está claramente presentes.

Con respecto a la relación que tiene esta cuestión con el artículo $10 \mathrm{CE}$, parte de la doctrina y la jurisprudencia del TS ha vinculado en reiteradas ocasiones el derecho a la investigación de la filiación con el derecho al libre desarrollo de la personalidad, llegando a considerar algunos autores, principalmente civilistas que, precisamente por la existencia de esta vinculación, además de por la ya comentada con el artículo $15 \mathrm{CE}$, se trata de un derecho fundamental de la persona ${ }^{565}$.

El derecho a conocer la verdadera filiación debiera ser considerado un derecho de la personalidad, y que va más allá de la libre investigación de la paternidad contemplado en el artículo 39 de la Constitución Política, trascendiendo el límite de lo puramente familiar para convertirse en un derecho fundamental de la persona. De tal manera que el origen biológico forma parte de la identidad del individuo porque lo individualiza y lo distingue de otros seres humanos, contribuyendo a su definición biológica y sociojurídica, es la base de la propia estima y del sentido que cada uno tiene de

564 GUZMÁN ZAPATER, M., ibídem, páginas 40 a 42. La autora recién citada misma entiende que este argumento decaería en el caso de que se superara la idea de que no hay más derechos fundamentales que los enunciados en el Capítulo II del Título I, aunque la imposibilidad de ejercitar un recurso de amparo para proteger este derecho de la que hablaremos más adelante, desactiva este argumento.

565 Esta situación se da también en Alemania, donde aunque la Ley Fundamental no menciona expresamente la cuestión, la jurisprudencia considera desde hace tiempo el derecho a conocer la propia filiación como un derecho de la personalidad, vinculado a la inviolabilidad de la dignidad de la persona. VIDAL MARTÍNEZ, "La figura del anonimato del donante en la regulación de las técnicas de reproducción asistida", Revista General del Derecho, septiembre 1994, página 9526; PÉREZ MONGE, "La filiación derivada de técnicas de reproducción asistida", Centro de Estudios Registrales, Madrid, año 2002, página 227 y 228. 
la dignidad personal y constituye el punto de partida desde el cual comienza la historia que cada uno tiene y que por ello es presupuesto de todos los demás derechos incluidos los denominados fundamentales.

El poder conocerlo, el acceder a la estructura profunda (causal) de la propia personalidad y a los datos que conforman esa parte de la identidad de cada uno, muchos de los cuales, físicos y psíquicos, se transmiten hereditariamente, guardan una íntima relación con la dignidad de la persona y contribuye al libre desarrollo de la personalidad y es una cuestión que entronca directamente con los artículos 10 y 18 de la Carta Fundamental ${ }^{566}$.

Así se entiende la importancia psicológica de conocer las circunstancias relacionadas con el propio origen y con la identidad de los padres biológicos para el adecuado desarrollo de la personalidad y así lo entiende también parte de la jurisprudencia, que ha hecho referencia a esta relación entre el conocimiento de la filiación de origen y la dignidad de la persona y el libre desarrollo de la personalidad. En este sentido, el TS, en Sentencia de 21 de septiembre de 1999, declara la inconstitucionalidad sobrevenida de los artículos de la legislación registral que permitían que la identidad de la madre biológica no constara desde el momento del parto, por considerar que permitir que el registro de la maternidad quede a voluntad de la madre vulnera, además de los artículos 39.2 y 14 $\mathrm{CE}$, el artículo 10 "al afectar a la misma dignidad de madre e hijo, a sus derechos inviolables inherentes a ella, y el libre desarrollo de la personalidad" ${ }^{\prime 57}$.

En el mismo sentido y en sentencia de 26 de enero de 1993 había afirmado ya, en relación con la práctica de la prueba biológica dentro de un proceso de reclamación de filiación que "debe tenerse presente que se está debatiendo sobre el derecho de la persona a conocer su verdadera filiación, lo que afecta a su dignidad y al desarrollo de su personalidad, derechos ambos fundamentales reconocidos en el Art. 10.1 CE”. También se pronuncian sobre la cuestión empleando los mismos ar- 
Capítulo II El Principio de igualdad y el Derecho de Familia - Igualdad y Filiación, en relación al Derecho a la identidad

gumentos las SSTS de 15 de marzo de $1989^{568}$ y18 de mayo de $1994^{569}$, entre otras. El artículo 10 está situado al inicio del Título I de la CE, "De los derechos y deberes fundamentales", a modo de introducción o principio general antes del inicio del Capítulo I, y está redactado más bien como una norma programática.

Sin embargo, a pesar del estilo en el que el texto está redactado, su lectura en profundidad y

su ubicación, dentro de los dos primeros Títulos de la Constitución y como pórtico de los derechos

568 STS, Sala de lo civil, de 15 marzo 1989. RJ 1989/2054 "El sentido iusprivatista del derecho de familia ha evolucionado en los últimos años hasta el punto de romper los estrechos moldes en que se encontraba enmarcado para pasar a integrarse en el ius cogens y en el ámbito del derecho público. Esta nueva naturaleza ha marcado las instituciones que la componen y transido los procesos de principios que han sustituido a los arcaicos y tradicionales. Así, en los procesos de filiación y de investigación de la paternidad se ha ido pasando del principio de verdad formal al de verdad material en aras del derecho de la personalidad consagrado en las leyes Constitucionales. 2. Sin embargo, el principio de verdad material aplicado al proceso civil, en trance casacional, requiere ciertas matizaciones para no convertir la casación en una tercera instancia. Es decir, el principio absoluto de verdad material, representado por la obligación impuesta a los órganos jurisdiccionales para averiguar la verdad ha de extraerse de la apreciación que se hubiere hecho de las pruebas practicadas por los Tribunales inferiores para deducir aquella verdad material que como instrumento básico fue utilizado en el proceso. 3. Estas premisas resultan aplicables al caso de autos si se tienen en cuenta las distintas apreciaciones llevadas a cabo por los órganos de la instancia, y quizá sea ocasión propicia para poner de relieve y destacar el valor que pueda representar el voto particular formulado en el Tribunal colegiado en la elaboración de la sentencia disidente, y en la redacción de la mayoritaria, y aquella otra de Primera Instancia donde, el principio de inmediación en la práctica de las pruebas, y la actitud de las partes e intervinientes en el proceso adquieren el máximo protagonis mo. Así, en el caso de autos son de destacar, de una parte, la sentencia de primera instancia y el voto particular en los que, con fundamentaciones paralelas se llegan a conclusiones idénticas, cuales son, de una parte, la posibilidad de la fecundación de la mujer y, de otra, la negativa obstruccionista por parte del padre para someterse a las pruebas biológicas y que es analizada con mesura y acierto por el voto particular."

569 STS, Sala de lo civil núm. 478/1994 de 18 mayo. RJ 1994/4092 "Inadmitido el primer motivo del recurso, queda su fundamento reducido al formulado como segundo al amparo del núm. 5. ${ }^{\circ}$ del art. 1692 de la Ley de Enjuiciamiento Civil en su redacción anterior a la Reforma de 30 abril 1992. Se acusa en este motivo infracción de los arts. 127 y 135 del Código Civil y 15, 18 y 39.2 de la Constitución, debiendo advertirse, en principio, que el hoy recurrente, don José M. ${ }^{a}$ de S. y G. L., parte en sus alegaciones de «la falta de consistencia de la declaración realizada por el Tribunal de instancia»-se refiere a la filiación de Francisco Javier $R$. D. cuya paternidad se le atribuye como hijo habido de doña M. ${ }^{a}$ José R. D.-, que se trata de inferir de los documentos sobre que trata el motivo primero deduciendo asi que se produjo «el error en la instancia», por lo que, al haberse inadmitido aquel motivo, la argumentación del recurrente ha devenido en gran parte inoperante. En cualquier caso, lo cierto es que la sentencia recurrida no infringe ninguno de los preceptos invocados por el señor de $S$. y, en cuanto a la valoración de su negativa a someterse a la prueba biológica sobre su paternidad-cuestión básicamente planteada en este motivo-, la Audiencia se atuvo a la doctrina jurisprudencial interpretativa de los arts. 127 y 135 del CC, según la cual la negativa a someterse a la prueba biológica, aun no constituyendo «ficta confessio», ha de relacionarse con los restantes elementos probatorios y es un dato de gran valor cuando va unida a otras pruebas o indicios que revelan la razonable posibilidad de la unión carnal, sobre la que no debe esperarse una prueba plena y directa [Sentencias de 5 y 17 marzo 1992, 17 junio del mismo año y 26 enero y 28 abril 1993 , como es el caso y fue certeramente apreciado por el Tribunal «a quo». En lo relativo al derecho constitucional «del presunto padre a su intimidad, integridad y honor», que invoca el recurrente, sólo ha de recordarse que «se está debatiendo sobre el derecho de la persona a conocer su verdadera filiación [Sentencia de 15 marzo 1989, lo que afecta a su dignidad y al desarrollo de la personalidad, derechos ambos fundamentales reconocidos en el art. 10.1 de la Constitución» [Sentencia de 26 enero $1993 y$ la doctrina jurisprudencial antes reseñada en absoluto conduce a violación alguna de los derechos del recurrente, pues las pruebas biológicas no afectan a la integridad física y moral de la persona ni mucho menos implican intromisión en su intimidad u honor, sino que constituyen un me- 
y deberes fundamentales, ha llevado a algunos a concluir que se trata de una norma vinculante y con mayor potencialidad de la que cabría pensar en un primer momento.

En relación con el libre desarrollo de la personalidad, principio que será de todas maneras discutido en el último capítulo del presente trabajo, es necesario por ahora afirmar que el artículo 10 CE garantiza un derecho subjetivo de contenido genérico, relacionado con la libertad de acción, que puede ser invocado tanto en vía de recurso de inconstitucionalidad contra una ley que lo conculque, como en cualquier otra vía judicial, ya que la Constitución vincula a todos los poderes públicos (art. 9.1) que, por tanto, están obligados a respetar también este derecho. Es por tanto, posible su tutela por los procedimientos ordinarios que existen para proteger cualquier derecho subjetivo ${ }^{570}$. En relación con esto, se afirma que, está configurado como uno los fundamentos del orden establecido. De manera que a su tenor literal y su colocación han permitido, a juicio de algunos autores, calificarlo de principio constitucional fundamental, que dota de sentido al resto de los preceptos del Título Primero, que recoge los derechos y deberes fundamentales ${ }^{571}$.

El Tribunal Constitucional ha manifestado que los principios generales plasmados en la Constitución, informadores de todo el ordenamiento jurídico, tienen valor aplicativo y no meramente programático, de modo que también lo tienen los valores y principios recogidos en el artículo 10, que quedan protegidos por el sistema especial de tutela establecido en el artículo $53.2 \mathrm{CE}^{572}$. Sin embargo, ha señalado también que un recurso de amparo no puede basarse directamente en la lesión del derecho al desarrollo de la libre personalidad ${ }^{573}$. Sin perjuicio de esto servirá como criterio de interpretación para la aplicación de los derechos y libertades públicas pero con la señalada limitación ${ }^{574}$. De manera que, tanto los civilistas como el TS, defienden la relación entre la investigación

dio de prueba legítimo en el proceso sobre investigación de la paternidad.

570 GÓMEZ BENGOCHEA, B. "Derecho a la identidad y filiación. Búsqueda de orígenes en adopción y en otros supuestos de filiación transfronteriza"...op. cit. 68 y 69; Cfr. DURÁN RIVACOBA, R. "El anonimato del progenitor", Aranzadi Civil-Mercantil num. 3/2004 parte Estudio, Ed. Aranzadi, SA, Pamplona. 2004, BIB 2004/332.

571 ROBLES MORCHÓN, G. "El libre desarrollo de la personalidad (Artículo 10.1 de la CE)", en GARCÍA SAN MIGUEL, L (Coord.) "El libre desarrollo de la personalidad. Artículo 10 de la Constitución", Universidad de Alcalá, Madrid, año 1995, página 52.

572 AlZAGA VILlamiL, O (Dir) "Comentarios a las leyes Politicas. CE de 1978”, Tomo II, arts. 10 a 23, Revista de Derecho Público, Ed. Revista de Derecho Privado, Madrid, año 1984, páginas 102 a 105.

573 SSTC, Sala segunda, núm. 57/1994, de 28 febrero. RTC 1994/57 y 233/1993.

574 La imposibilidad de utilizar el recurso de amparo, que resulta ser el gran instrumento que existe en el Derecho español para proteger los derechos fundamentales, no explica a juicio de algunos la reticencia del TC a aplicar los derechos recogidos en el artículo $10.1 \mathrm{CE}$, ya que el recurso de inconstitucionalidad y la cuestión de inconstitu cionalidad si son vías procesales adecuadas para la defensa de los derechos individuales, y en estos procesos sí son invocables y aplicables todos los preceptos constitucionales, incluido el 10.1, En estos casos tampoco ha sido habitual el uso de este precepto como ratio decidendi de las sentencias. Nuestro TC prefiere la aplicación de normas concretas que la de principios generales, a pesar de que la aplicación de estos principios podría permitir abrir más las normas jurídicas a las necesidades de nuestro tiempo, y hacer más flexible el sistema. LATORRE, A., 
de la paternidad y el libre desarrollo de la personalidad, y califican a la posibilidad de conocer el propio origen de derecho fundamental, pero el TC y los constitucionalistas no se refieren a esta relación, y establecen que la protección que le corresponde al artículo 10 no incluye la posibilidad del recurso de amparo, de modo que, aun considerando que la relación entre la investigación y el desarrollo de la personalidad existe, no le correspondería a tal derecho la misma protección que el resto de los derechos fundamentales reconocidos por la CE.

La posibilidad de investigar la filiación y el libre desarrollo de la personalidad están indudablemente relacionados, baste recordar lo ya dicho en relación con la importancia psicológica del conocimiento del propio origen, y es necesario, sino urgente, que tanto el Tribunal Constitucional como la doctrina constitucionalista se pronuncien sobres esta cuestión, y al menos conveniente que la dignidad de la persona humana y el libre desarrollo de la personalidad empiecen a ser más utilizados y citados, aunque sea en vías diferentes al amparo constitucional, como principios generales fundamentadores de decisiones judiciales, así lo señala ALES URÍA ACEVEDO ${ }^{575}$.

Finalmente para terminar este apartado y a modo de conclusión se debe reflexionar sobre la importancia de la dignidad humana en las instituciones de Derecho Civil, por cuanto éstas han tratado, de una u otra manera, de articular la convivencia humana sobre postulados de justicia traduciendo al plano concreto de la realidad valores tales como la libertad y la igualdad, operando sobre parámetros contingentes de la más variada procedencia para garantizar a los seres humanos un espacio habitable. El hilo conductor para guiar la organización de la convivencia humana es el principio del libre desarrollo de la personalidad ${ }^{576}$. Ahora bien, de qué manera estos adelantos "globalizados" de índole tecnológica han influido en las relaciones familiares, es sin duda, un punto importante a analizar, que por lo demás trasciende las fronteras del presente estudio, pero se vislumbran sus efectos en la filiación, ya sea mediante la institución de la adopción, especialmente la internacional, haciéndola más expedita así como en las TRHA.

"El libre desarrollo de la personalidad en la jurisprudencia del TC" en GARCÍA SAN MIGUEL, L. (Coord.), "El libre desarrollo de la personalidad. Artículo 10 de la Constitución", Publicaciones de la Universidad de Alcalá, Madrid, año 1995, páginas 79 a 81.

575 Cfr. ALES URÍA ACEVEDO, $\mathrm{M}^{\mathrm{a}}$. "El derecho a la identidad en la filiación”, ...op. cit., páginas 381 y siguientes.

576 Cfr. VIDAL MARTíNEZ, J. "Acerca del valor permanente del Derecho Civil como Derecho de la persona en la era de la globalización" en "Estudios jurídicos en homenaje a Vicente Montés Penadés", Tomo II, Ed. Tirant Lo Blanch, Homenajes y Congresos, Valencia, año 2011, página 2857. 


\subsection{Verdad biológica y autonomía, en relación con la determinación de la filiación}

Así como el principio de protección del interés del menor preside todo el campo del actual Derecho de Familia, puede afirmarse que en el campo de la determinación de la filiación el criterio rector, desde hace casi tres décadas es el de libre investigación de la paternidad. Es también cierto que, en innumerables ocasiones, la doctrina y los tribunales han identificado al principio de libre investigación de la paternidad como una concreción, en el específico campo de la filiación, del principio de protección y salvaguarda del mejor interés del niño.

RIVERO HERNÁNDEZ plantea que la fuerza vinculante de ambas directrices es innegable, pero su eficacia real es más fuerte en la vía judicial de determinación de la maternidad y paternidad que en el ámbito extra judicial en donde priman todavía concepciones voluntaristas que permiten dejar el estado civil librado, en gran medida, a la decisión de los particulares sin consulta sobre la verdad material de las relaciones ni sobre la convivencia para los menores de la fijación legal de algunos vínculos ${ }^{577}$.

El régimen de las acciones de filiación -y la jurisprudencia que lo afecta y modifica- señala la efectiva vigencia y alcance del principio de libre investigación de la paternidad, que no es absoluto y que puede entrar en conflicto con otros intereses ${ }^{578}$. Entre estos intereses son dignos de mencionar la protección del mejor interés del menor, la verdad sociológica manifestada en la posición de estado y la estabilidad del estado civil. La regulación de las acciones de filiación es un instrumento que sirve para aplicar mandatos constitucionales y que precisa ser interpretado de acuerdo con la teleología de la filiación y los principios de razonabilidad y proporcionalidad. El régimen de filiación vigente fue elaborado en un contexto de amplio debate y ruptura radical con los postulados del sistema de filiación, desigualdad de los hijos, prohibición de investigación de la paternidad y prevalencia de la verdad sociológica por encima de la biología, tal cual ha sostenido GARCÍA VICENTE $^{579}$.

La regulación de cómo ha de determinarse la filiación es el primer extremo que el legislador precisa establecer puesto que, si bien todo hijo posee un padre y una madre, este hecho no adquiere relevancia erga omnes a menos que sea constatado por el sistema jurídico. Mientras maternidad y

577 RIVERO HERNÁNDEZ, F. “Acerca de cierta jurisprudencia relativa a acciones de filiación”, Revista del Poder Judicial, núm. 75, año 2004, páginas 57 a 114.

578 STS, Sala de lo civil, núm. 371/2002 de 25 abril. RJ 2002/4160

579 "Los principios del Derecho de las Acciones de filiación", en ABRIL-CAMPOY, J.M., y AMAT LLARI, M.E. (coords.), "Homenaje al Profesor Luis Puig i Ferriol", V. II, Ed. Tirant Lo Blanch, Valencia, año 2006 páginas 1414 a 1417. 
paternidad no consten por las vías legalmente dispuestas, no surtirán los efectos que la Ley les reconozca como propios.

Además, existen hipótesis en las que el Derecho estima conveniente ocultar ciertas relaciones de parentesco, tales como las surgidas del incesto, o evalúa que el mejor interés del menor se encuentra cubierto por la asunción de la patria potestad por personas que no son responsables de la generación ${ }^{580}$. En ocasiones, la determinación de la maternidad o paternidad serán contrarias al pleno desarrollo de la persona del hijo. En razón de la minoridad y desprotección natural del hijo es que a los padres se les impone la patria potestad como deber y función y es que se legitima más ampliamente al hijo para ejercer todas las acciones tendientes a averiguar su procedencia biológica.

El nuevo marco regulatorio de la filiación se embandera en el principio de verdad biológica y considera que el beneficio de la legitimidad cede frente a la necesidad de averiguar quiénes son los verdaderos progenitores del menor. Relacionado con esto encontramos la derogación del principio de jerarquía de las filiaciones y la eliminación de diferencias de los efectos de la filiación: tan sólo pervive un diverso régimen de determinación de acuerdo a la matrimonialidad o extramatrimonialidad de la relación de generación ${ }^{581}$.

El principio de la libre investigación de la paternidad y maternidad está muy ligado al criterio rector del ajustamiento de la filiación a la verdad biológica o realidad material de la generación ${ }^{582}$. En la doctrina más reciente se entronca este criterio rector con un pregonado derecho a la identidad en su vertiente de acceso al conocimiento del propio origen, elemento que vendría a construir parte esencial del respeto a la dignidad humana (artículo 10.1 CE). Su validez es indiscutible en el ámbito del proceso de filiación pero posee una relativa eficacia fuera del ámbito judicial. Sin embargo, las reglas imperativas del estado civil deben perseguir que la filiación determinada extrajudicialmente se corresponda con la realidad material. Mientras este ideal no se alcance, la normativa vigente per-

580 DE LA CÁMARA ÁlVAREZ, M., “El nuevo régimen jurídico de la filiación”, en VV. AA., "La Reforma del Derecho de Familia”, Ed. Edersa, Sevilla, año 1982, páginas 239 a 269.

581 DE LA CÁMARA ÁLVAREZ, M., ibidem, páginas 242 a 251.

582 En Cataluña, la Ley 25/2010, Libro II del CCcat, en lo relativo a la persona y a la familia, trata la maternidad derivada regulándola y amparándola en la fuente que implica el mero consentimiento para la procreación asistida de la esposa o compañera, esta no es una maternidad biológica, por naturaleza, sino una relación jurídica puramente legal. Sin embargo, eso no es ninguna novedad en el ordenamiento jurídico catalán. Se da en la paternidad del hombre, casado o no, que presta el consentimiento para la procreación asistida de su esposa o pareja estable. Por ello se incorporó una nueva categoría jurídica para este tipo de filiación y se optó por asimilarla, en cuanto al tratamiento legal, a la paternidad del hombre que consiente la fecundación asistida, dado que en ambas el título de atribución es el consentimiento, y no la relación biológica. La posibilidad de que la maternidad de la esposa o compañera que consiente la fecundación asistida de la que será la madre biológica se determine directamente trae como consecuencia que se afecten los medios de determinación de la filiación, ante esto se añadió el consentimiento para la procreación asistida a la lista de títulos de atribución de la filiación. 
mitirá la existencia de puntos de fuga, lagunas y antinomias en el sistema de determinación de la filiación. Estos puntos de fuga y antinomias resultan de la supervivencia de situaciones anómalas como los reconocimientos de complacencia.

También encontramos en el régimen de la filiación un equilibrio muy precario entre los principios de autonomía de la voluntad y control público por el Estado que organiza ciertas dimensiones de las acciones y controla de forma muy limitada, la determinación extrajudicial de la maternidad y paternidad. La autonomía de la voluntad encuentra un cauce en las presunciones de paternidad débiles (en las que el marido puede refutar la paternidad del hijo de su esposa o asumirla aún cuando no sea el causante de la generación, todo según su deseo) y en los institutos del reconocimiento e impugnación de la filiación.

Por último vale destacar el principio de igualdad que, en ocasiones, resulta de difícil concreción en el régimen de determinación de la filiación según los progenitores estén casados entre sí o no. En tal sentido, las restricciones para establecer la filiación pueden referirse a la paternidad o a la maternidad según cada estado en cuestión, puesto que en los dos supuestos, el establecimiento de un vínculo legal y formal con el hijo en la vía extrajudicial está sometido a cierto grado de discrecionalidad que, sin embargo, no se reparte proporcionalmente entre el hombre y la mujer a la hora de solicitar la determinación del parentesco y al momento de atacar un vínculo que no se condice con la verdad de los hechos.

En cuanto a la maternidad, la dificultad estará dada, básicamente en la noción de que el nombre de la madre no figure en el parte médico o en el certificado de nacimiento o bien que la mujer pueda desconocer al hijo alumbrado por ella. De estas dos formas no podrá probarse el hecho de que cierta mujer parió a un niño o niña y la regla mater semper certa est será inoperante. Si bien el hijo puede con posterioridad, reclamar su filiación materna, esta acción será infructuosa sino se prueba la identidad de la supuesta madre. En estos casos el padre, si bien en teoría, podría reclamar su paternidad dada la divisibilidad de la filiación no matrimonial, en la práctica la falta de mención de la madre en el certificado de nacimiento hará virtualmente imposible la identificación del menor $^{583}$. Usualmente, el progenitor masculino no casado con la madre posee una potestad muy limitada de actuación para promover el establecimiento del vínculo paterno filial. En muchas ocasiones, al no estar determinada la filiación materna, no podrá identificar legalmente al niño ni podrá accio-

583 FRANK, R., “The Establishment and Consequences of Maternal and Paternal Affiliation”, XXVIIth Colloquy on European Law Foundation for International Studies, Valletta, Septiembre 15 a 17, año 1997, páginas 83 a 105. 
nar para que se establezca la paternidad por vía judicial, al carecer de la correspondiente posesión de estado.

\subsection{El derecho a la identidad y la libre investigación de la paternidad en el caso de la adopción}

Sin duda el hombre es más que un cuerpo biológico y como ser humano necesita acceder por motivos estrictamente psicológicos a la información que existe sobre su propio origen o por lo menos la posibilidad de buscarla. La importancia de tal cuestión no parece clara desde el punto de vista psicológico. Es cierto que el conocimiento del origen biológico y de la familia de origen constituyen sólo una pequeña parte de la propia identidad, conformada también por otros factores emocionales, sociales y culturales que ayudan a tomar conciencia de quien es cada uno. Sin embargo parece que esta faceta del derecho es especialmente trascendente.

La relevancia de este conocimiento radica, entre otras cuestiones, en que la conciencia de las propias raíces forma parte del desarrollo de la personalidad como una fase más en el proceso de maduración personal por este motivo es una cuestión que afecta a todos y no sólo a las personas adoptadas, si bien en ellas cobra una especial importancia por la dificultad que tienen para acceder a las informaciones acerca de su pasado familiar.

El interés por conocer el propio origen no es tanto por una cuestión que podría tildarse anormal, al contrario son intentos serios por lograr cierta normalidad, de procurarla al menos. Contribuye a la formación de la identidad personal, tanto física como psicológica, en las que se apoyan y fundamentan la autoestima y el sentido de la dignidad personal, el desarrollo personal y la satisfacción de la curiosidad y la falta de información en este sentido puede generar una fuerte inseguridad e inquietud, sentimientos de vergüenza y baja autoestima, así como problemas personales, psiquiátricos, así como de formación y desarrollo de la personalidad ${ }^{584}$.

Se debe considerar que el sentimiento de pérdida es muy importante en las personas adoptadas, y que, como es evidente, puede constituir un importante trauma y una importante causa de estrés en las adopciones tardías en las que los niños muchas veces tienen recuerdos de sus progenitores o hermanos; sin embargo este sentimiento existe incluso en aquellos que fueron separados de sus familias biológicas siendo muy pequeños. En estos casos la pérdida es menos traumática pero puede influir de forma decisiva en la personalidad del niño, del desarrollo de esta. No es sólo que

584 Cfr. GARCIA VILLALUENGA, L y LINACERO DE LA FUENTE, M. "El derecho del adoptado a conocer sus orígenes en España y en el Derecho Comparado", Colección Observatorio Infancia, núm.1, Ministerio del Trabajo y Asuntos Sociales, Madrid, año 2006. 
echen de menos a unos padres que nunca conocieron, sino que acusan la falta de los demás aspectos de sí mismos que han perdido en la adopción: sus orígenes (especialmente el origen racial y/o cultural en los casos de adopciones internacionales), la continuidad genealógica; en definitiva, el completo sentido de los mismos, sentido que resulta antagónico al anonimato ${ }^{585}$.

Una persona que vive con una familia biológica dispone de más información para iniciar y realizar la búsqueda de sí mismo y de su propia personalidad. Puede ver en sus padres su propio fu turo reflejado, partes de su propia personalidad en sus hermanos y hermanas. Sin embargo, un hijo adoptado tiene más dificultades en este camino, y el desarrollo de una identidad personal propia resulta más complicado porque buena parte de su historia personal se encuentra al otro lado de la barrera de la adopción.

Los adoptados hablan a menudo de los cortes de su propia historia, de sus padres, de su familia extensa, su herencia genética, sus orígenes raciales, su aspecto físico. Se preguntan con frecuencia por su imagen corporal, porque no saben a quién deben su talla, el color de su pelo, ni tienen en quien fijarse para saber cómo serán físicamente cuando pasen los años. Se cuestionan también sobre su predisposición genética para contraer determinadas enfermedades, su carácter, sus aptitudes intelectuales, etc ${ }^{586}$.

Esta necesidad de saber y de buscar suele hacerse especialmente presente en la adolescencia, que marca el inicio de la denominada búsqueda activa ${ }^{587}$. Cuando los hijos adoptivos se deciden a iniciar las averiguaciones sobre sus orígenes no siempre pretenden encontrarse con sus padres biológicos. A menudo tras la búsqueda no hay tanto un deseo de encontrar a la madre o al padre biológico sino que es un modo de encontrarse con sí mismos; en muchas ocasiones desean sólo obtener información sobre su pasado, sobre las circunstancias que rodearon su concepción, nacimiento y abandono, los motivos de este, su genealogía. Buscan datos que transmitir a sus hijos, o información sobre cuestiones prácticas tales como las genéticas y de salud. Otras veces quieren conocer la identidad de la madre biológica, la existencia de hermanos así como la posibilidad de contactar con ellos y la situación en que se encuentra su familia de origen. Muchas veces el contacto con la madre

585 Cfr. Ilustrativo de esta posición que aboga contra el anonimato, es la apasionada exposición de KEMELMAJER DE CARLUCCI, A. "El derecho humano a conocer el origen biológico y el derecho a establecer vínculos de filiación. A propósito de la decisión del Tribunal Europeo de Derechos Humanos del 13/02/2003 en el caso "Odiève c/ France" en www.jus.mendoza.gov.ar.

586 RIVERO FERNÁNDEZ, F. "La constitucionaidad del anonimato de gametos y el dereho de la persona al conocimiento de su oridgen biológico de la STC. 116/1999, de 17 de junio, al affaire odiève”. Familia, Revista di diritto della famiglia e delle successioni in Europa. Giuffré Editore, marzo-abril-2004, páginas 342.

587 AMORÓS, P. Y OTROS. “La búsqueda de los orígenes en la adopción”; Anuario de Psicología, núm. 71, año 1996, Facultad de Psicología, Universidad de Barcelona, página 108. 
biológica es la única manera de acceder al resto de la información que se anhela, que no podrían ser obtenidas de otro modo, posiblemente esto esta situación se haga más verosímil debido a la no necesidad del asentimiento de los padres biológicos en el procedimiento de adopción de un menor cuando éstos se encuentran incursos en causa de privación de la patria potestad, estos datos han sido estudiados de forma veraz por CASADO CASADO ${ }^{588}$.

No siempre, en todo caso es necesario un encuentro personal para satisfacer las necesidades del hijo adoptado, debido a que tales datos pueden serles transmitidos por un tercero. Generalmente la búsqueda no supone la intención de sustituir a la familia adoptiva ni se debe al descontento con ella, por ello, los padres adoptivos no deben temer nada al respecto, se trata de explorar la propia identidad, rellenar los huecos existentes en la propia historia ${ }^{589}$.

El primer punto sobre el que es necesario detenerse es que el acceso a la información que existe sobre su origen es para el adoptado siempre un derecho y nunca una obligación, es decir está en su mano el ejercitarlo o no.

En España la adopción es cada vez más una realidad abiertamente reconocida fuera de los hogares adoptivos; para dejar de ser un asunto privado que la familia vivía como secreto ${ }^{590}$. Este cambio sociológico se ha plasmado en las Leyes 21/1987 y 1/1996 que sentaron las bases de una concepción y procedimientos en el ordenamiento español sobre adopciones. Hace pocos años, la última Ley 54/2007 ha dado una regulación integral al fenómeno social y legal de la adopción internacional.

La adopción en España en los últimos años ha experimentado un visible cambio adquiriendo matiz internacional y público: ya no es un acuerdo privado entre partes destinado, exclusivamente, a paliar la esterilidad de parejas casadas mediante la adopción de infantes sin problemas. En la actua-

588 Cfr. CASADO CASADO, B. "El asentimiento de los padres biológicos en el procedimiento de adopción de menores”, Revista de Derecho de Familia, núm. 35, abril-junio 2007, Ed. Lex Nova, Valladolid, páginas 51 a 64.

589 Según un estudio señalado por el Observatorio de la Infancia, op. cit., paginas 15 y siguientes. Los motivos para iniciar la búsqueda son comunes a todos los adoptados, con independencia del lugar de donde procedan; asimis mo, los procesos tienen un "iter" similar, más allá de las fronteras. Se trata, por tanto, de valores universalmente compartidos. Los adoptados comienzan el proceso de búsqueda una vez que han superado una interpretación errónea el sentimiento de lealtad hacia los adoptantes, en muchas ocasiones el adoptado siente que si busca su origen no es leal a sus padres adoptantes, cuando lo que se trata no es ir contra ellos, sino que avanzar en el conocimiento de uno mismo. Asimismo influye el miedo que produce el rechazo de la persona buscada lo que supondría un segundo abandono. Sin perjuicio de lo anteriormente citado, son importantes también las etapas de la vida en que el adoptado inicia esta acción, pues suelen coincidir con hecho tales como; contraer matrimonio, el nacimiento de un hijo, alguna enfermedad provoca la preocupación por la propia salud, la muerte de un padre adoptivo, es decir, los sentimientos de perdida y vacío que origina. En definitiva la necesidad de saber más el origen y las causas del abandono, o tener un espejo biológico, cada ser humano necesita mirarse en los ojos de la persona que le dio la vida, en el fondo se trata de construir un sentido de identidad mas completo, más pleno.

590 PALACIOS, J. SÁNCHEZ-SANDOVAL, Y. \& LEÓN, E., “Adopción internacional en España”, Estudios del Ministerio del Trabajo y Asuntos Sociales, núm. 49, año 2005, páginas 17 a 22. 
lidad, las familias pueden verse ampliadas por la adopción de niños como hermanos de hijos biológicos ya habidos en la pareja o por la integración de niños mayores y con necesidades especiales. Esto puede traer problemas de adaptación adicionales a los frecuentes entre hermanos, sumados a las cuestiones relativas a las preguntas e interrogantes sobre el origen de los diversos niños.

Hoy en día no sólo pueden adoptar parejas casadas, según la estructura tradicional, sino también parejas de hecho o personas solas o incluso parejas del mismo sexo. Junto con estos cambios en el perfil de adoptantes y adoptados se verifica socialmente un cambio de actitud ambiental y familiar en torno a la adopción y el secreto de la misma. Las familias aceptan la identidad adoptada como una posibilidad más y comparten esa información con la familia extensa.

Históricamente, al menos en la práctica de las naciones occidentales, los niños adoptivos eran bebes sin problemas; cuando un niño o niña superaba una cierta edad o presentaba problemas importantes era catalogado como no adoptable. Hoy en día, a nivel español, los infantes abandonados al nacer son una excepción en los índices de adopción nacional; con creciente intensidad las adopciones de los españoles tratan sobre menores sobre los que se ha dictado una situación de desamparo, a raíz de las condiciones negativas para vivir en que se encontraban y que cuentan con edades superiores al año y en ocasiones han experimentado diversos tipos de maltratos.

Hoy en día no hay para la ley niños que no puedan ser adoptados debido a que se entiende que todos los menores tienen un derecho a crecer en un ambiente familiar sano con independencia de sus características de salud física o psíquica.

Otro cambio fundamental que se ha verificado en la adopción es la diversidad de nacionalidades de los menores adoptados que se debe en parte a la escasez de niños y niñas españoles de corta edad y sin problemas o necesidades especiales y en parte por los largos tiempos de espera asociados a la adopción nacional así como también a una sensibilidad desarrollada respecto a los niños y niñas de países con enormes dificultades especiales ${ }^{591}$.

En la adopción internacional existe un doble proceso de adaptación, puesto que no sólo deben padres e hijos adaptarse entre sí, sino que el hijo deberá adaptarse a la nueva cultura del país donde está inmerso ${ }^{592}$. Así cuanto mayor sea la brecha cultural entre el país de origen y el de recepción, mayores serán los retos, esto justifica la necesidad de la cooperación internacional entre las diversas

591 Véase Ministerio de Justicia para datos actualizados al año en curso.

592 GÓMEZ CAMPELO, E. "La Ley 54/2007 de adopción internacional: Un texto para el debate”, Ed. Reus S.A., Familia y Derecho, Madrid, año 2009; ARANZAZU CALZADILLA MEDINA, Ma " "La adopción internacional en el derecho español”, Ed. Dykinson, Colección Monografías de Derecho Civil. I Persona y Familia. Madrid, año 2004. 
autoridades $^{593}$. Entre los procesos internos que experimenta el niño adoptado, el más destacado es el del desarrollo de una identidad cultural doble, particularmente cuando el adoptado ha estado más inmerso e integrado en la cultura de su país debido a su edad ${ }^{594}$.

A medida que el niño crece con la conciencia de la pertenencia a una cultura por su origen y a otra por su adopción, la problemática de la búsqueda de los orígenes tan característica de los hijos adoptivos, puede adquirir rasgos más notables ${ }^{595}$. De esta forma, lo más probable es que la búsqueda se oriente mucho más al conocimiento de la cultura de origen que a la búsqueda de la familia biológica $^{596}$. Otro cambio esencial se refiere a la naturaleza del proceso y acto de constitución de la adopción que ha pasado a ser nuevamente público. Hoy en día se enfatiza el dar prioridad a las necesidades del niño y en exigir la supervisión de un órgano judicial, así como en establecer un régimen igual para todas las adopciones, confiriendo derechos dentro de la familia y un auténtico status familiae para el hijo adoptado.

España no ha evolucionado de manera solitaria en materia de adopción, en otros países pertenecientes a la tradición del Derecho Continental la adopción ha experimentado modificaciones radicales en materia de capacidad para adoptar, valoración del interés del adoptado y derecho a conocer los datos relativos a la filiación originaria. En el mundo del Common Law es importante destacar la evolución de la legislación británica y sus elaboraciones, así como las nuevas modalidades de adopción que se iniciaron en Nueva Zelanda, y el acceso a los datos registrales sobre el propio origen en EE.UU ${ }^{597}$.

593 PÉREZ MILLA, J. "Matching y función pública autonómica en la adopción internacional: Los casos "Berta”", Revista de Derecho de Familia, núm. 36, julio-septiembre 2007, Ed. Lex Nova, Valladolid, páginas 65 a 88.

594 PALACIOS, J., SÁNCHEZ-SANDOVAL, Y., \& LEÓN, E., “Adopción internacional en España: un nuevo país, una nueva vida"..., op. cit., páginas 27 y 28.

595 GÓMEZ BENGOECHEA, B. "El Derecho a la búsqueda de orígenes” en GARCÍA GÓMEZ, M. E. (Coord.) "El camino a casa. Los derechos del niño en la adopción internacional", ACEBO Colección, Grupo 5, Madrid, año 2010. Las personas adoptadas que se deciden a iniciar una búsqueda activa de la de información sobre sus orígenes no siempre llegan a los mismos resultados. En este sentido se distinguen varias etapas diferentes: La primera de ellas es el hecho de conocer que se ha sido adoptado, esto en términos clínicos se denomina la revelación del hecho adoptivo. Luego en el momento en que se es conciente de tal hecho y lo que significa surge la conciencia de que para ser adoptado hubo que ser previamente abandonado, y empiezan a surgir multitud de preguntas que pueden llevar al segundo paso: el conocimiento de las circunstancias que rodearon el propio nacimiento y la posterior adopción, la causa o causas del abandono y la manera como se vivía antes de la adopción, y con ello nos referimos a la cultura, a las condiciones de vida. Finalmente nos encontramos con el conocimiento de la familia biológica, los datos no identificativos tales como aquella cuestiones relativa a la salud, forma de vida, etc.

596 TRISEL OTIS, J., "Intercountry Adoption: Global Trade or Global Gift", 24 Adoption and Fostering 48, año 2000, página 48.

597 En el año 2004 en el Reino Unido se implementó la Adoption and Children Act (ACA 2002) que fuera elaborada en 2002 y que reemplazó a la anterior Act de 1976 pues era evidente que la normativa elaborada hacía más de dos décadas era insuficiente para resolver la nueva problemática de la adopción hacia finales del siglo XX. Así es que, en sus orígenes, la legislación había concebido al instituto de la adopción como lo que podría denominarse un trasplante legal (legal trasplant) o una ruptura limpia (clean break). Y es por esto que uno de los desarrollos 
En materia de adopción, tanto en la nacional como en la internacional, debe respetarse escrupulosamente el principio de subsidariedad de la familia de origen. El instituto no debe ser utilizado como un elemento más para solucionar un problema existente entre el menor y su familia biológica, sino que debe ser la última ratio a la que acudir para salvaguardar el interés pleno del niño cuando las demás medidas de protección fallen ${ }^{598}$. De la conjunción del principio de subsidariedad de la adopción con la restringida actuación de la familia biológica en el proceso, es que resulta imprescindible agotar todos los elementos al alcance para que el niño o niña pueda crecer entre sus progenito$\operatorname{res}^{599}$.

A modo de conclusión cabe destacar la relación existente entre el derecho del menor adoptado a conocer sus orígenes y algunos artículos de la Constitución española que enuncian derechos fundamentales, así ocurre con los artículos 15 y 10 en los que se recoge el derecho a la integridad física y moral, así como el derecho al libre desarrollo de la personalidad. Aunque existen casos en los que el nexo entre el conocimiento del origen biológico y la integridad física y moral está claramente presente, enfermedades genéticas, necesidad de donantes compatibles, etc, la mayoría de los comentarios sobre esta cuestión están referidos a la vinculación de la investigación de la paternidad con el artículo 10 de la Constitución ${ }^{600}$, ya que parte de la doctrina y la jurisprudencia del Tribunal Supre-

más recientes y radicales en materia de adopción en el ámbito anglosajón ha sido el cambio desde el corte absoluto de vínculos legales hacia una nueva forma de adopción llamada abierta en la cual, si las circunstancias del caso son apropiadas, se mantiene el contacto entre el niño y su familia de nacimiento y se formaliza el derecho del niño no sólo a conocer la identidad de sus progenitores, sino también a mantener el contacto con ellos y la familia extensa.

598 CAlZADILla MEDINA, M. A. “La adopción internacional en el Derecho Español”, Ed. Dykison, Madrid, año 2004, página 53.

599 El ejemplo ensayado por las legislaciones neozelandesa, británica y en alguno de los estados de EE.UU., es un interesante ejemplo de la posibilidad de contemplar la desigualdad inherente a los niños y niñas adoptados con respecto a los hijos biológicos, en materia de integración en la nueva familia y pleno desarrollo de la identidad. Frente a las nuevas realidades sociales en materia de adopción de niños mayores y de niños de diferentes nacionalidad y etnia, en los países anglosajones se ha empezado a ensayar un tipo de adopción abierta (open adoption) en la que se mantiene la relación con la familia de origen sin que ello suponga mantener lazos jurídicos de filiación. Sin embargo, en la actualidad, la mayoría de los casos continúan siendo situaciones análogas a la adopción plena con la ruptura total de los lazos con el origen biológico.- En el Reino Unido el énfasis se ha colocado en rehabilitar la relación familiar de los menores, puesto que también ha cambiado el perfil de los niños adoptados. La mayoría de los niños británicos adoptados son menores que han estado al cuidado de los servicios sociales del estado, en su mayoría mayores de dos años, vulnerables y con antecedentes familiares de conflicto. La adopción de niños que se encuentran dentro de este grupo implica que se tengan en cuenta una serie de necesidades especiales, entre ellas la realidad de que muchos de ellos han convivido y estado en contacto con uno o más miembros de su familia de origen biológico. Este último dato proviene de HARRIS-SHORT, S. \& MILES, J., "Family Law: text, cases and a materials”, Oxford University Press, Oxford, año 2007, páginas 992 a 999.

600 VIDAL MARTÍNEZ, J. "La figura del anonimato del donante en la regulación de las técnicas de reproducción asistida”, Revista General del Derecho, septiembre, Madrid, año 1994, página 9526; PÉREZ MONGE, “La filiación derivada de técnicas de reproducción asistida”, Centro de Estudios Registrales, Madrid, año 2002, página 227 a 228; RIVERO HERNÁNDEZ, F., "La constitucionalidad del anonimato del donante de gametos y el derecho de la persona al conocimiento de su origen biológico (de la STC 116/1999, de 17 de junio al affaire 
mo ha relacionado en reiteradas ocasiones el derecho a la investigación de la filiación con el derecho al libre desarrollo de la personalidad (principalmente civilistas) que, precisamente por la existencia de esta vinculación, se trata de un derecho fundamental de la persona, y que tiene que ser protegido como tal. Tal como se ha repetido en varias ocasiones, sin duda el origen biológico forma parte de la identidad del individuo, porque lo individualiza y los distingue de otros seres humanos, contribuye a su definición biológica y socio-jurídica, es la base de la propia estima y del sentido que cada uno tiene de la dignidad personal, y constituye el punto de partida desde el cual comienza la historia de cada uno y desde el que se inicia el desarrollo de la personalidad, y que, por ese motivo, es presupuesto de todos los demás derechos, incluidos los más fundamentales ${ }^{601}$.

El poder conocer el origen permite acceder a la estructura profunda causal de la propia personalidad y a los datos que conforman esa parte de la identidad de cada uno, muchos de los cuales físicos y psíquicos se transmiten hereditariamente, guarda una íntima relación con la dignidad de la persona, contribuye al desarrollo de la personalidad, siendo una cuestión intrínsecamente relacionada ya con el artículo 1 de la CE, ya con el artículo $18^{602}$, asimismo lo han entendido nuestra juris-

Odievre)”, Revista Jurídica de Cataluña (Legislación), volumen 103, núm. 1, año 2004, página 113 a 114.

601 LACRUZ BERDEJO, J. L; ;ANCHO REBULLIDA, F; LUNA SERRANO, A; RIVERO FERNÁNDEZ, F; RAMS ALBESA, J en "Elementos de Derecho Civil IV. Derecho de Familia”. Ed. Bosch S.A., Barcelona, año 1997, páginas 339 a 340; SALVADOR GUTIÉRREZ, S. "Derechos Registrales del Menor” en RODRIGUEZ TORRENTE, J (Ed.), "El menor y la Familia, Conflictos e Implicaciones”, Universidad Pontificia de Comillas, Madrid, año 1998; RIVERO FERNÁNDEZ, F . “Mater semper certa est?, Problemas de determinación de la maternidad en el ordenamiento español”, Anuario de Derecho Civil, 1997-1, Madrid, página 23; RIVERO FERNANDEZ, F. “La filiación en el umbral del Siglo XXI”, Revista de la Facultad de Derecho de la Universidad de Granada, núm. 4, año 2001, página 111.

602 STS, Sala de lo Civil, de 26 enero 1993. RJ 1993/364. "Se alega sustancialmente en el motivo primero que «la sentencia de la Audiencia establece que la negativa a practicar determinada prueba biológica solicitada por la parte demandante constituye un indicio valioso para declarar la paternidad, con lo que de la negativa se hace derivar el mismo efecto que de un resultado positivo de la práctica de la prueba», pero sucede que no es cierto que dicha negativa se infiera -ni en la sentencia de apelación ni en la de primera instancia cuya fundamentación acepta aquélla- el efecto de declararse la paternidad del hoy recurrente, don Rafael $V$. C., sino que expresamente reconoce la Sala que la conducta procesal del demandado, no obstante calificarla como absolutamente obstruccionista, no constituye «ficta confessio» y, por tanto, ha de relacionarse con los restantes elementos probatorios, lo cual es del todo correcto y ajustado a la reiterada doctrina jurisprudencial [SS. 28-5-1990, 25 abril y 28 junio 1991 y 5 marzo y 17 junio 1992, entre otras]; es claro, por otra parte, que valorar, no como exclusivamente determinante de la declaración de paternidad, la negativa a someterse a una prueba biológica -por lo demás inocua- en modo alguno implica inconstitucionalidad [S. 18-2-1992 ], pues no se trata de hacer depender el resultado del litigio de tal negativa sino de que, existentes otras pruebas de cualquier clase (art. 127-1. ${ }^{\circ}$ del CC), muy significativamente la de presunciones, la actitud del demandado reafirma la conclusión probatoria favorable a la realidad de la paternidad, sin que ello suponga equiparar resultado positivo de la prueba biológica y negativa a su práctica, y, en definitiva, debe tenerse presente que se está debatiendo sobre el derecho de la persona a conocer su verdadera filiación [S. 15-3-1989 ], lo que afecta a su dignidad y al desarrollo de la personalidad, derechos ambos fundamentales reconocidos en el art. 10-1 de la Constitución. Ha de advertirse, por último, que para hacer la valoración discutida no es precisa una "prolongada convivencia entre el demandado y la madre», como pretende el recurrente, pues de lo que obviamente es de verificar la paternidad en cualesquiera circunstancias -así, S. 17-3-1992 -; debe decaer, por tanto, el motivo examinado.”; Cfr. STS, Sala de lo Civil, núm. 776/1999 de 21 septiembre. RJ 1999/694. 
prudencia. Es decir, puede vislumbrarse que la búsqueda de la identidad es requisito para un desarrollo armónico de la personalidad, jurídicamente podría argumentarse que es esta personalidad la que de una u otra manera se encuentra amparada mediante la igualdad de las filiaciones, su sostén es, que duda cabe, fundamento de una real y efectiva protección de la dignidad humana. 
Capítulo III

Autonomía de la

voluntad y Derecho de

Familia 


\section{1| Consideraciones previas}

Qué debe entenderse por autonomía de la voluntad?, Qué relación guarda con el Derecho de Familia?. Se intentará dar respuesta a estas interrogantes y otras que sin duda aparecerán a lo largo del presente capítulo.

Según KANT la autonomía de la voluntad será la constitución de la voluntad por la cual ella es para sí misma una ley ${ }^{603}$. En otras palabras, la autonomía de la voluntad es la cualidad de la voluntad en cuya virtud el hombre tiene la facultad de autodeterminarse y autorresponsabilizarse, conforme a los dictados de su conciencia, sin más límites que las idénticas y concurrentes facultades de otros hombres ${ }^{604}$. En el concepto propuesto encontramos un antecedente y un consecuente. El antecedente está dado por la libertad (autodeterminación), sin la cual no hay ni siquiera voluntad; el consecuente por la fuerza vinculante (autorresponsabilidad), que emana de la propia voluntad como ley de sí misma.

Tanto la doctrina como la jurisprudencia suelen identificar a la autonomía de la voluntad con la libertad de actuar, pero aquella es más amplia que ésta, pues no sólo comprende a la libertad como su presupuesto esencial sino que también es el fundamento de la fuerza obligatoria de los actos humanos. Aunque la autonomía como atributo inmanente de la voluntad del hombre es una realidad latente desde que éste existe, corresponde a KANT el mérito de haber acuñado la expresión al postular a la voluntad de todo ser racional como voluntad legisladora universal, y luego sostener: "Llamaré a este principio el de la autonomía de la voluntad, en oposición a cualquier otro, que, por lo mismo, calificaré de heteronomía" ${ }^{\prime 65}$. En otras palabras la voluntad es autónoma cuando se gobierna a sí misma, y es heterónoma cuando está dirigida desde fuera.

En la autonomía de la voluntad radica asimismo la dignidad humana, aunque no únicamente en ella, tal cual lo asegura KANT. Para este, la autonomía de la voluntad, es el único principio de todas las leyes morales y de los deberes conforme a ellas; toda heteronomía del albedrío, en cambio, no sólo no funda obligación alguna, sino que más bien es contraria al principio de la misma y de la moralidad de la voluntad.

603 KANT, E. "Fundamentación de la metafísica de las costumbres", en "Fundamentación de la metafísica de las costumbres-Crítica de la razón práctica-La paz perpetua”, Capítulo 2, GARCIA MORENTE, M (Trad.), Ed. Porrúa- Universidad Autónoma de México, año 1998, página 52.

604 MOISA, B. "La autonomía de la voluntad y la predisposición contractual”, Zavalia Editor, Córdoba, Argentina, año 2004, página 62.

605 Vid. KANT, E. Fundamentación de la metafísica de las costumbres”. ...op. cit., página 46. 
Ahora bien, algunos autores desde una óptica normativista, prefieren hablar de autonomía pri$\operatorname{vada}^{606}$. Contrariamente podría manifestarse que el fundamento de la obligatoriedad de los actos jurídicos es la voluntad de las partes, limitándose el ordenamiento a reconocer tales efectos. En relación a esto cito a STOLFI, para quien los negocios jurídicos son generalmente cumplidos, aunque hayan sido concertados contra legem, pues el interesado se considera obligado a ello por haberlo así querido. $^{607}$

No obstante, no hay inconveniente alguno en el empleo indistinto de las expresiones autonomía de la voluntad y autonomía privada o, en el ámbito de los contratos, autonomía contractual; siempre que se tenga bien en cuenta que los negocios obligan porque las partes así lo quieren, incluso cuando no siempre gocen de la protección de la ley positiva.

La autonomía de la voluntad opera en dos momentos, reconoce un antes y un después de la celebración del acto. Un antecedente y un consecuente que dan lugar a dos sub-principios: el de autodeterminación y el de autorresponsabilidad. Las personas son libres de obligarse o no, pero una vez que se han autobligado deben cumplir o responder por la obligación contraída. Así, lo que primero fue libre decisión, luego es constreñimiento (quod prius est libertatis postea fit necessitatis), tal cual lo entiende TRABUCCHI ${ }^{608}$. Es tan natural y lógica la relación entre la libertad previa y la obligación posterior, que puede decirse que esa correspondencia está en la naturaleza misma del vínculo y siempre se le ha reconocido así.

Toca entonces responder:¿Qué es para el Derecho la autonomía de la voluntad?. El interrogante exige su repuesta desde una doble perspectiva: la del derecho natural y la del derecho positivo, esto es, la del derecho justo y la del derecho legal, la del derecho que debe ser y la del derecho que es.

Desde el punto de vista del derecho natural, universal y atemporal, la autonomía de la voluntad es un principio general del derecho. Es un principio porque como verdad fundamental no reconoce otro sustento más que la naturaleza misma del hombre, es decir, que su fundamento primero se

606 MOISA, B. "La autonomía de la voluntad y la predisposición contractual", ...op. cit., página 62.; FERRI, E. "La autonomía privada", Ed. Comares, Granada, año 2001.

607 STOLFI, G. "Teoría del negocio jurídico”, SANTOS BRIZ, J (Trad.), en Revista de Derecho Privado, Madrid, año 1969 , página $25 .$.

608 Vid. TRABUCCHI, A. "Instituciones de Derecho Civil”, MARTíNEZ-CALCERRADA (Trad.), en Revista de Derecho Privado, Madrid, año 1967, Tomo II, núm. 277, página 164. Asimismo puede citarse a los emperadores DIOCLECIANO y MAXIMIANO, Ed. Codex, IV, X, 5: "Así como en un principio tiene cada cual libre facultad para celebrar o no celebrar un contrato, así también, nadie puede renunciar a una obligación una vez ya constituida, no consintiéndolo el adversario. Por lo cual debéis tener entendido que, una vez sujetos vosotros a una obligación voluntaria, no podéis en manera ninguna separaros de ella, no consintiéndolo la otra parte, de la que hicisteis mención en las súplicas” 
encuentra en la dignidad de la persona humana ${ }^{609}$, es general porque domina todo el derecho, a tal punto que, como lo señala SAVIGNY, "puede definirse la relación de derecho, diciendo que es el dominio de la voluntad libre ${ }^{" 610} \mathrm{y}$, finalmente, es jurídico porque excediendo lo moral y subjetivo, su campo de acción comprende esencialmente lo intersubjetivo.

Desde el punto de vista del derecho positivo, del derecho vigente en un lugar y tiempo dados, la autonomía de la voluntad también es un principio general del derecho, en aquellas legislaciones que al igual que la española se inspiraron en el ideario liberal del Código de Napoleón.

Como argumento destinado a convencer de la exactitud de cuanto precede se debe recordar que el principio de la autonomía de la voluntad fue delineado por los iusnaturalistas alemanes hacia fines del siglo XVIII y recogido a continuación por los pandectistas, aún después de surgir la escuela histórica; sin duda que los iusnaturalistas y pandectistas vivieron en uno de los períodos más brillantes del pensamiento humano, así mientras los primeros opusieron, incluso en el campo del derecho, la omnipotencia de la voluntad individual a la prepotencia del príncipe; los segundos, remontándose a la doctrina justinianea de que los efectos de los actos humanos dependen de la voluntad individual, terminaron por crear un sistema de derecho privado fundado en la libertad de los particulares, poniendo en el centro del mismo al negocio jurídico.

Familia y autonomía de la voluntad tienen una relación intrínseca, por cuanto se han personalizado hasta tal punto las relaciones jurídicas en el marco familiar, amparadas en los afectos, ejemplo claro de esto es el matrimonio, que sin duda constituyen no sólo un límite para legitimar los diversos negocios jurídicos sino que garantizan su existencia, son en definitiva una condición sine qua non de ellos. Enfatizo este punto, la relación autonomía de la voluntad y los afectos, porque al confundirse, tal cual se argumentará, la libertad con la autonomía, se han desdibujado las limitaciones para actuar de los particulares en el ámbito familiar, hasta tal punto que muchas veces puede

609 SAVIGNY, F. C. DE. "Sistema de Derecho Romano actual", Tomo I, Capítulo LIII, procedencia del original: GONGORA, F. Biblioteca de Catalunya, digitalizado el 18 de mayo de 2009, página 225: "Desde luego no puede desconocerse que el hombre dispone lícitamente de sí mismo y de sus facultades; y hay más, todo derecho verdadero tiene por base e implica necesariamente este poder: as', por ejemplo, la propiedad y las obligaciones no tienen otro sentido y valor que el de una extensión artificial de nuestra fuerza personal, son nuevos órganos que el arte añade a nuestra primitiva naturaleza; pero esta posesión de nosotros mismos no tiene en modo al guno necesidad de ser reconocida y definida por el derecho positivo, y confundir este poder natural con sus extensiones artificiales poniéndolas al mismo nivel y tratándolo de igual manera, es un error que no tiene justificación alguna"

610 SAVIGNY, F.C. DE. "Sistema de Derecho Romano actual”, ... ibídem., página 224, a lo que agrega: "La voluntad puede obrar sobre la persona misma del individuo; y también moverse fuera de su propia persona, es decir, sobre el mundo que le es exterior: tal es la más alta generalización de los diferentes modos de acción de la voluntad. En el mundo exterior se comprende la naturaleza no libre, y además voluntades libres como la nuestra, esto es, personas extrañas a nuestra personalidad; y mirada así lógicamente la cuestión, nos encontramos con tres clases de objetos sobre los cuales puede obrar la voluntad humana y que parecen constituir tres géneros principales de relaciones de derecho a saber: la persona propia, la naturaleza no libre y las personas extrañas". 
confundirse interés con sentimientos y estos con libertad. Soy lo que quiero y mientras quiera puedo.

\section{2 | Autonomía y libertad}

En el ámbito filosófico, autonomía y libertad no son lo mismo a pesar de la equivocidad del término, los distintos significados que ha tenido y tiene el concepto de autonomía en el terreno de la antropología filosófica podrían resumirse en una idea básica, subyacente a todos ellos. Autonomía sería: la limitada pero real capacidad de autodeterminación del actuar que asiste al ser humano, relativa y contingente capacidad de autogobierno para tomar decisiones, para elegir opciones. La autonomía se traduce, ya en el campo de la ética, en la capacidad de elección moral ${ }^{611}$.

Debe identificarse, pues, la autonomía con la ausencia relativa de condicionantes determinativos del obrar moral del hombre, esto es, con la capacidad de elección o libre arbitrio, que es condición necesaria, aunque no suficiente de la libertad en sentido moral ${ }^{612}$.

Conviene ahora recordar que la autonomía moral de la que goza el ser humano cuando alcanza cierta madurez psicológica personal no significa "absoluta capacidad para determinar o establecer lo que es bueno o justo”. Esto último es la base del llamado autonomismo moral, versión posmoderna del escepticismo y subjetivismo moral que se remonta a MONTAIGNE ${ }^{613}$. Creer que cada persona define, en cada momento de modo total y absolutamente autónomo -independiente-, el bien moral, de acuerdo con mi razón (racionalismo), con mis circunstancias (situacionismo-relativismo) o con mis sentimientos del momento (emotivismo), supone excluir la posibilidad de que exista un bien objetivo y, en última instancia, desechar a priori la posibilidad de existencia de una verdad sobre el hombre y las cosas que le vinculen, lo cual sin duda influye en mis decisiones particulares con trascendencia ética ${ }^{614}$.

611 La "autonomía de la voluntad" según la RAE, http://ema.rae.es/drae/?val=autonomía, es el "Poder que el derecho confiere a las personas para definir el contenido de sus relaciones jurídicas conforme a sus intereses, sin otros límites que los derivados de las leyes imperativas, de la moral y del orden público".

612 ABELLAN SALORT, J.C., "Autonomía, dependencia y vida social”, en LACALLE, M (Coord.), "Cuestiones disputadas de la vida en sociedad", Ed. Voz de Papel, Madrid, año 2006, página 101 y siguientes.

613 Cfr. COMTE-SPONVILLE, A. "Montaigne y la filosofia”, Ed. Paídos, Barcelona, año 2012.

614 CAMPS, V. "Un marco ético para la bioética", en PALACIOS, M (Coord) "Bioética 2000", Ed. Nobel, Oviedo, año 2000. El otro peligro vendrá a ser el de la judicialización de nuestras actuaciones y prácticas. Cuando nadie quiere asumir la responsabilidad de las decisiones, es finalmente un juez quien se define sobre la cuestión. La responsabilidad profesional queda, así, reducida a responsabilidad penal. Una dinámica tan nefasta para la buena salud profesional, como para esa autonomía que Kant insistió en atribuir al individuo emancipado. ¿Cómo puede denominarse autónomo el individuo que no está dispuesto a responder de lo que hace? Responsabilidad y autonomía son dos conceptos inseparables. En la unión de ambos está el misterio de una ética personal y libre pero no relativista porque se instala en la dialéctica entre lo universal y lo singular. 
Si bien tal cual se ha manifestado no son lo mismo autonomía y libertad generalmente ambos conceptos son empleados indistintamente.

La creencia y la consiguiente afirmación de la libertad del hombre no son nuevas, desde PLATÓN, pasando por la Edad Media, hasta el pensamiento moderno -HUME, KANT, SCHELLING-, y contemporáneo -MARX, SARTRE- y en los teóricos del liberalismo, el hombre no es sólo consciente de poseer esta facultad, sino que se enorgullece de ella. Y discurriendo y teorizando acerca de ella, desde diversas perspectivas llega también a distintas conclusiones ${ }^{615}$.

En el contexto de la filosofía cristiana, el libre albedrío se percibe como uno de los más importantes de los dones del Creador a su criatura, de Dios a los hombres, siendo la libertad una de las claves de la historia de la salvación de los hombres en su devenir terrenal, esto es, la condición necesaria que posibilita el obrar moral, y por tanto el pecado y la necesaria salvación ${ }^{616}$.

En mi opinión el proceso de secularización conduce a la absolutización de la libertad. Esto es, excluyéndose la relación de la liberta humana con su fuente -Dios- el hombre moderno llega a elevar a la máxima dignidad el "querer del hombre", su poder y su libertad.

Así, en KANT, el hombre libre es el que se realiza a sí mismo, el que elige el camino más arduo, más ambicioso, el del individualismo. Cuando la ley moral, regida por el imperativo categórico, estipula la rigurosa observancia de la ley, en vista de un beneficio o recompensa, que es el respeto por la misma ley, la moral no sólo se formaliza, sino que se vacía de cualquier otro fundamento objetivo que no sea el cumplimiento del deber.

Entonces, el obrar moral del hombre se hace más que libre, autónomo. Cuando se identifica el concepto de la libertad con el poder de hacer el bien o el mal, estamos ante un mero "querer", autonomía absoluta para obrar. La libertad es "creadora de nuevos valores", para un SARTRE para el que cada uno debe crearse y elegir su propia moral, su propia ocasión y destino, con una libertad que se identifica con el mismo hombre ${ }^{617}$. Excluido el Ser Supremo -Dios- el hombre es el árbitro de su destino, no tiene que justificar ante nadie el fundamento de sus actos a menos que tales conductas estén proscritas en el ordenamiento jurídico. El hombre es moral, pero regido por su moral autónoma, sin otro referente que su querer. El hombre afirma su individualidad y toda trascendencia

615 BERROCAL LANZAROT, A y ABELLAN SALORT, J. “Autonomía, libertad y testamentos vitales. Régimen jurídico y publicidad”. Colección Monografías de Derecho Civil.; I. Persona y familia. Ed. Dykinson, S.L., Madrid, año 2009, página 12.

616 VV. AA., “San Agustín”, Ed. Gredos, Madrid, año 2012.

617 Cfr. MARTÍNEZ CONTRERAS, J. "Sartre. La filosofia de un hombre”, Ed. Siglo XXI de Comunicación, Madrid, año 2005. 
queda excluida mientras la convivencia -de seres encerrados en sí mismos- se convierte en un infierno. El hombre aparece "condenado" al ejercicio de la libertad.

La antropología filosófica que dominó el pensamiento sobre la libertad hasta el siglo XVI, salvo algunos momentos de "autonomismo", se fundaba en que aquélla no es total independencia de acción o juicio, sino capacidad otorgada a la persona humana por el Creador para actuar el bien que es conforme a su naturaleza. La referencia a una Ley Natural, inscrita en el corazón humano, cognoscible por el hombre y reflejo o participación de una Ley Eterna, con la que Dios ordena y gobierna el cosmos, supuso durante siglos un límite objetivo a cualquier pretensión autonomista.

El hombre podía y debía acomodar su conducta moralmente relevante a unos fines naturales, que brotan de su naturaleza y cuya realización es garantía del respeto a su dignidad y condición de posibilidad de su propia y plena felicidad. Ello no significa que no pudiera desobedecer esa ley, contrariando sus inclinaciones o sus tendencias naturales; pero cuando su voluntad libre actúa conforme a la Ley Natural, universal e inmutable, el ser humano se dignifica y perfecciona. Por otra parte, el conjunto de bienes y derechos que brotan y se fundan en las exigencias nacidas de esa naturaleza humana es lo que el iusnaturalismo clásico entendía por Derecho Natural ${ }^{618}$.

Esta moral naturalista, fundada en una ontología y en una trascendencia entró en crisis con el advenimiento de la Modernidad, de modo que la libertad se tornó en atributo inmanente e ilimitado y los derechos naturales se concibieron como el fruto de una convención o pacto al que se llegó para vivir en sociedad. A ello se sumo la fuerte crítica recibida por la moral naturalista desde las filas del empirismo, especialmente HUME, y sobre todo, más recientemente, desde la filosofía analítica, quienes la rechazaban por encubrir una falacia, la "falacia naturalista", por implicar, acusaban ellos, un tránsito ilegítimo entre los ámbitos del ser y del deber ser.

La filosofía moral de base realista ha respondido a esta tesis muy extendida en la modernidad, explicando cómo sí es posible extraer conclusiones (y obligaciones) para el obrar moral (deber ser), a partir de una antropología que reconoce en la naturaleza humana y en la Ley natural, exigencias o factores de un débito ético, que ya están -ontológicamente- presentes en el ser, en forma de tendencias naturales (fines) y que, por tanto, no existe tránsito falaz, ni desde el punto de vista lógico ni desde el ontológico tal como asegura HERVADA XIBERTA ${ }^{619}$.

Sin duda es esta postura la que combina de mejor manera los elementos fundamentales del tránsito "naturalista" a la "modernidad", de tal manera de fundarse en el ser para conformar los ele-

618 FERNANDEZ GALIANO, A. y DE CASTRO, B. "Lecciones de Teoría del Derecho y Derecho Natural”, Ed. Universtas, Madrid, año 2000, página 282.

619 “Lecciones propedéuticas de Filosofía del Derecho”, Ed. EUNSA, 4a edición, Pamplona, año 2008, páginas 62 y siguientes. 
mentos componedores del deber ser, es la posición realista la que intenta entender la integridad del hombre. Lo que es y lo que está llamado a ser.

Prosiguiendo con esta reflexión, desde la modernidad, el concepto autonomista de la libertad ha pasado al pensamiento postmoderno en nuestros días. Frente al libre albedrío o frente a la libertad concebida no como un acto sino como una facultad, accidente, condición necesaria del acto libre, en nuestros días se afirma la autonomía. No se cree, realmente, en la existencia de la libertad, sino que se defiende una libertad que realmente es autonomía, tal como señala MILLÁN PUE$\operatorname{LLES}^{620}$.

El problema principal, sin duda, es esta reducción de la libertad a la autonomía, porque de una u otra manera limita demasiado su trascendencia, minimizándola únicamente al acto de elegir, sin el por qué de esta elección, su para qué. Pero libertad es más que elegir, es una faceta del ser que no se agota en ella.

La filosofía moral de la postmodernidad, reacia a aceptar absolutos morales, escéptica de que exista una verdad fundante del acto moral, es una ética de la autonomía. Heredera del formalismo kantiano, y de los excesos de los diversos liberalismos, secularizada y liberada de cualquier vinculación a código o conjunto axiológico universable alguno, es una moral del individuo de la subjetividad. Cada uno crea su propia moral, su norma ética. La autonomía es el aspecto dominante de la ética. Pero lejos de la exigencia del rigorismo kantiano, el subjetivismo moral de nuestra época rechaza cualquier deber que me venga impuesto desde fuera, rechaza cualquier código moral objetivo que me obligue desde el exterior ${ }^{621}$.

Ello no nos impide reconocer que, en último término, cada decisión moral es "autónoma", en la medida en que siempre se funda en un juicio íntimo y personal de mi conciencia respecto del sentido de mi acción. Sin embargo, comprender que toda elección moral es subjetiva no implica necesariamente caer en el subjetivismo de creer que yo "decido lo que está bien", desde la constatación de que lo bueno y lo justo no lo crea o establece el hombre en cada momento o circunstancia, sino que la voluntad libre del hombre está llamada a satisfacer las exigencias de bien y de justicia que derivan de su propia naturaleza y dignidad.

620 Cfr. MILLÁN PUELLES, A., “El valor de la libertad”, Ed. Rialp, Madrid, año 1995. El discurso moral dominante afirma -, frecuentemente exalta- la libre elección (el "choice" de los anglosajones), que no es sino una limitada capacidad de autodeterminación, y esto es lo que propiamente puede denominarse "autonomía". Acerca de los otros tipos de libertad,

621 Tal como ha formulado KELSEN, la libertad como oposición a todo vínculo se convierte así en la libertad del vínculo consentido, en la libertad de la autodeterminación. KELSEN, H. "Justicia y Derecho Natural”, en la obra colectiva: “Crítica del Derecho Natural”, DÍAZ, E. (Trad.), Madrid, Ed. Taurus, año 1966. 
Volviendo a la identificación libertad y autonomía, ya se sabe, la mayoría de los pensadores contemporáneos identifican la libertad con la autonomía, tal cual ya se manifestó, entendiendo por libertad la mera capacidad de elección. Pero además, la libertad-autonomía de la que se creen investidos de manera inalienable no es la simple capacidad de elección. Creer esto solo sería una penosa reducción de la libertad al choice. El problema del individualismo nihilista imperante en Occidente es que "absolutiza" esa capacidad de elección que se convierte en la total y omnímoda facultad de elegir. No teniendo límites, la autonomía que se predica del hombre postmoderno es más bien una autarquía, es decir, una falsa y soberbia pretensión de independencia ${ }^{622}$.

Ya en las Institutas de IUSTINIANO, con perenne vigencia, se lee: "Libertad, de la que viene la denominación de libres, es la natural facultad de cada cual para hacer lo que le plazca, a no ser que por la fuerza o por la ley se le prohiba”. Varios siglos después, KANT entiende a la libertad como la propiedad de la voluntad por la cual puede ser eficiente, independientemente de causas extrañas que la determinen. ${ }^{623}$

Sin duda que esta libertad constituye una de las piedras angulares del Derecho Civil, el cual es sin duda el más personal de los derechos. El hombre, es el centro de ordenamiento civil, el hombre entendido como un ente inteligente y libre y no una tabla rasa en que el legislador construye codificaciones arbitrarias. La libertad civil viene a ser la libertad de acción, y tanto se la restringe prohibiéndose actos que sin la prohibición sería posible practicar como exigiéndose actos que sin la ley imperativa podrían dejarse de practicar. Deben excluirse las relaciones de los individuos con el Estado, pues los derechos civiles corresponden al hombre con independencia de su nacionalidad y de sus derechos políticos.

El Derecho civil se basa en la opinión de que el orden más adecuado para las relaciones jurídicas de los individuos es el que ellos mismos establecen y, por tanto, en este sentido da amplia facultad a los interesados.

Para que un acto sea libre, y por lo tanto voluntario, no basta con que el ordenamiento jurídico garantice una libertad en abstracto (libertad formal o jurídica), sino que es necesario que provea los medios idóneos para que tal libertad se traduzca en los hechos concretos (libertad material o fáctica), es decir, para que la persona pueda ejercer efectivamente la libertad que la ley le reconoce con independencia de influencias extrañas (heterónomas) que determinen su voluntad. Esta problemática así planteada presenta a los principios de libertad y de igualdad, tanto en lo formal como en

622 BERROCAL LANZAROT, A y ABELLAN SALORT, J. “Autonomía, libertad y testamentos vitales. Régimen jurídico y publicidad”, ...op. cit., páginas 14 y 15.

623 Vid. KANT, E. “Fundamentación de la metafísica de las costumbres”, ...op. cit., , página 55. 
lo material, indisolublemente unidos, a tal punto que no resulta concebible el primero sin el segundo. En efecto, el desequilibrio en el poder negocial de las partes conduce, casi inexorablemente, al aprovechamiento de quien detenta una posición dominante y al sometimiento del débil a sus designios.

No son suficientes los principios consagrados por los códigos decimonónicos, pensados para una comunidad de pequeños comerciantes y artesanos, para regular la complejidad de la sociedad actual, caracterizada por un tráfico negocial masivo y por las grandes diferencias en el poder de negociación de las partes ${ }^{624}$. Los códigos del siglo XIX se encuentran a mitad de camino, pero no por su filosofía que no es otra que la de la dignidad humana, sino por no haber podido percibir debido a su contemporaneidad los cambios y desequilibrios socio-económico-culturales que produciría la Revolución Industrial. Por lo tanto, deben ser la base sobre la que se estructure cualquier nuevo orden privado patrimonial, pasando las transformaciones por una visión renovada de los principios romanos contenidos en ellos con miras a las exigencias actuales, la que debe ser complementada con la instrumentación de modernas herramientas de equilibrio, cuidando en todo momento de no provocar ni posibilitar un desequilibrio inverso.

Tal cual se infiere de lo mencionado anteriormente acerca de la reducción de lo que se entiende por libertad, en ciertos ambientes modernos, es mejor referirse a ella como el sub-principio antecedente de la autonomía de la voluntad, presupuesto indispensable para que el hombre pueda actuar (autodeterminarse) en procura de la satisfacción de sus necesidades. Reconoce como únicos límites inmanentes los derechos de los demás, considerados individual o colectivamente (orden público). Sin perjuicio de ello, la libertad de las acciones está sujeta a limitaciones o restricciones heterónomas, impuestas por el Estado o por otros particulares, las que excepcionalmente pueden encontrar justificación en orden a exigencias circunstanciales de la realidad.

El principal efecto de todo acto jurídico es su fuerza vinculante, consecuencia de la virtualidad de la voluntad para establecer entre las personas relaciones jurídicas (art. 994, Código Civil). A su vez, la condición de persona es lo que distingue al hombre de los demás seres vivientes. Por ello, el hombre, de acuerdo con su peculiar naturaleza y destino, está constituido para configurar libre y responsablemente su existencia y su entorno, para proponerse objetivos e imponerse a si mismo límites en su actuación, límites algunos que no son consecuencia inmediata de la convivencia social sino son derivación mediata de su naturaleza. Asimismo, la esencial limitación de la libertad del hombre es un dato filosófico, además de una evidencia empírica: "Yo no puedo hacer todo lo que

624 BALLESTEROS GARRIDO, J. A. "Las condiciones generales de los contratos y el principio de autonomía de la voluntad”, Ed. J.M. Bosch, Barcelona, año 1999, página 51 y siguientes. 
quiero", por ejemplo, "no puedo volar", por mucho que mi voluntad lo desee. Un ser limitado y contingente como el ser humano no podría ser titular de un atributo de carácter absoluto. Solo Dios es absolutamente libre. Claro que para compartir esta noción es necesario participar de esta concepción antropológica y teológica ${ }^{625}$.

Pero junto con esa limitación fáctica y ontológica, la vida en sociedad impone regular la libertad individual, cuyo desenvolvimiento puede entrar en conflicto con otros bienes, puede colisionar con el libre arbitrio de los otros individuos. Esto siempre se tuvo claro en el mundo del Derecho. La Filosofía del Derecho y el mismo Derecho positivo han entendido que éste suponía un orden normativo de la conducta libre del hombre, en la vida social, desde el punto de que se ha definido el Derecho como un orden coactivo capaz de hacer posible la coexistencia del arbitrio de las personas. En tal sentido, el Derecho parte de la constatación de la autonomía de los sujetos individuales que persiguen la realización de sus propios fines, que buscan actuar mediante su libertad. El dato fáctico inicial es la presencia de voluntades autónomas, cuya coexistencia hay que organizar. Como ha escrito LISSER, comentando el planteamiento kantiano de la libertad, en la búsqueda de una delimitación de las libertades concurrentes en una determinada sociedad, "la voluntad del legislador, al igual que toda voluntad en general, tiene por condición aceptar la autonomía del hombre" ${ }^{\text {626. }}$.

Cada individuo tiene unos límites en el ejercicio de la autonomía de su voluntad que no debe sobrepasar si no quiere romper el equilibrio formal de un determinado sistema jurídico. Al Derecho correspondería, por tanto, articular las relaciones sociales, las relaciones entre individuos libres, pero también regular la actividad pública. Debe ordenar jurídicamente el ejercicio del poder político; debe constituir, regular, sostener, limitar y encauzar el sistema de organización política que la sociedad se ha dado, esto es el Estado. En efecto, uno de los fines por excelencia del Derecho, el cual hoy en día no se concibe sino íntimamente vinculado al Estado, es organizar y legitimar la proyección del poder, de modo que garantice la justicia y la seguridad jurídica, al tiempo que permita el despliegue de la libertad de sus ciudadanos ${ }^{627}$.

625 BERLIN, I. "Los conceptos de libertad”, en "Cuatro ensayos sobre la libertad”, Ed. Alianza, Madrid, año 2000, página 235. “...Esto demuestra (si es que se necesita demostración para una verdad tan evidente) que las concepciones que se tengan de la libertad se derivan directamente de las ideas que se tengan sobre lo que constituye el yo, la persona, el hombre. Se pueden hacer suficientes manipulaciones con las definiciones de hombre y de libertad para que signifiquen todo lo que quiera el manipulador". La historia reciente ha puesto muy en claro que esta cuestión no es meramente académica".

626 LISSER, K., "El concepto del Derecho en Kant”, Cuadernos del Centro de Estudios Filosóficos, Universidad Autónoma de México, año 1959, página 27.

627 BERROCAL LANZAROT, A y ABELLAN SALORT, J. “Autonomía, libertad y testamentos vitales. Régimen jurídico y publicidad", ...op. cit., pagina 18. 
Esta teoría de las relaciones del individuo con el Estado desde el siglo XVIII se concibe como una teoría de la libertad, al definir el espacio de acción y de participación conferido a los miembros de una comunidad política, en relación con la acción del poder público del Estado. De hecho, las diversas teorías sobre la dialéctica Estado-persona ha dado lugar a diversos regímenes políticos que difieren precisamente en su concepto, fundamento y garantía de la libertad.

El modelo de organización política estatal que mejor ha sabido coordinar las libertades y derechos individuales con el bien común, equilibrando el impulso del poder y de la libertad, es el Estado de Derecho. El Estado de Derecho es, sin duda, el que mejor sirve a los valores éticos del Derecho de ser garante de la libertad y seguridad de las personas.

En todo caso, y como ha manifestado GARCIA MAYNEZ, “conviene, desde luego, distinguir la libertad como atributo de la voluntad humana, de la libertad como derecho. Aquélla es generalmente concebida como poder o facultad natural de autodeterminación Podría definirse diciendo que es la aptitud de obrar por sí, o sea, sin obedecer a ninguna fuerza o motivo determinante. Es, como diría Kant, una causalidad cuyo primer momento es sólo causa, no efecto de otra causa" ${ }^{628}$.

Entre los valores centrales de todo ordenamiento jurídico, sin duda destacan la libertad y la igualdad. El artículo 1.1 de nuestra Constitución asume de forma expresa estos valores. Sin embargo, la libertad, en cuanto valor, no tiene un significado unívoco ni en la doctrina ni en todas las épocas, tal como ya se ha analizado recientemente.

La libertad puede entenderse como exención de una necesidad de obrar, es decir, la liberación de cualquier tipo de coacción a la propia voluntad. Es también un poder hacer efectivo, porque se dispone de los medios adecuados para hacer efectiva nuestra decisión. Este sentido añade algo a la independencia o ausencia de coacción, asimismo puede entenderse como autonomía de elección y tal autonomía significa muy específicamente participación en las decisiones colectivas.

Es clásica también la diferenciación entre libertad positiva y negativa, en el ámbito de la ciencia jurídica. En sentido negativo, la libertad es invocada como inhibición de los poderes públicos respecto de la esfera individual que engloba la capacidad de iniciativa, creación etc. La libertad es ausencia de interferencias y un ámbito en el que uno es su propio dueño dependiendo de las posibilidades que se le brindan para ello socialmente. La libertad positiva sería, por el contrario, "libertad para", esto es, una libertad que en el ámbito personal se equipararía con la autorrealización y, en el colectivo, con la participación política.

Al principio de su famoso ensayo "Dos conceptos de la libertad”, BERLIN explica su significado: "El primero de estos sentidos que tienen en política las palabras freedom o liberty (libertad)

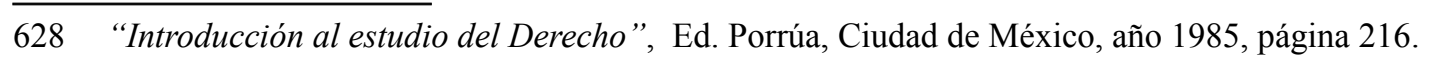


-que emplearé con el mismo significado- y que, siguiendo muchos precedentes, llamaré su sentido “negativo", es el que está implicado en la respuesta que contesta a la pregunta cuál es el ámbito en que al sujeto -una persona o un grupo de personas- se le deja o se le debe dejar hacer o ser lo que es capaz de ser o hacer, sin que en ello interfieran otras personas. El segundo sentido, que llamaré positivo, es el que está implicado en la respuesta a la pregunta de qué o quién es la causa de control o interferencia que puede determinar que alguien haga o sea una cosa u otra.

Ser libre, en sentido negativo significa, pues, que otros no se interpongan en mi actividad. Cuanto más extenso sea el ámbito de esta ausencia de interposición, más amplia es mi libertad. Esto es lo que querían decir los filósofos políticos ingleses clásicos cuando usaban esta palabra (...) El sentido positivo de la palabra "libertad" se deriva del deseo por parte del individuo de ser su propio dueño. Quiero que mi vida y mis decisiones dependan de mi mismo y no de fuerzas exteriores, sean del tipo que sean. Quiero ser el instrumento de mi mismo y no de los actos de voluntad de otros hombres" $" 629$.

La libertad que consiste en ser dueño de sí mismo y la libertad que consiste en que otros hombres no me impidan decidir como quiera -dice BERLIN-, pueden parecer conceptos que lógicamente no distan mucho uno del otro y que no son más que las formas negativa y positiva de decir la misma cosa. Sin embargo, explica el autor recién citado, las ideas "positiva" y "negativa" de libertad se desarrollaron históricamente en direcciones divergentes, no siempre por pasos lógicamente aceptables, hasta que al finalmente entraron en conflicto directo la una con la otra.

Para BOBBIO, esta forma de libertad "positiva" se llama también "autodeterminación" o, de manera más apropiada, "autonomía", dice el autor italiano que "es positiva porque indica la presencia de algo, a saber, de un atributo especifico de la voluntad, que es la capacidad de moverse hacia un objetivo sin ser movido. Teniendo en cuenta que se suele llamar "libertad" también a esta situación, que podría llamarse de forma más apropiada “autonomía”, en la medida en que en la definición se hace referencia no tanto a lo que hay cuanto a lo que falta. Como cuando se dice que autodeterminarse significa no estar determinados por otros, no depender para las propias decisiones de otros, o determinarse sin ser determinados. Llevando hasta sus extremas consecuencias esta observación, habría que decir inmediatamente que, siendo "libertad" un término que indica, en la multiplicidad de las propias acepciones, carencia de algo, la expresión "libertad positiva” es contradictoria" ${ }^{630}$.

629 Vid. BERLIN, I. "Los conceptos de libertad",... op. cit., páginas 220 y siguientes.

630 BOBBIO, N. “Igualdad y Libertad”, Ed. Paidós, Barcelona, año 1993, página 100 y 101. 
La aspiración de la libertad como fin esencia del hombre, no es, sin embargo, la única finalidad existencial de éste, sino que la libertad, aun siendo un valor irrenunciable, tiene que buscar vías de realización efectivas compatibles con otros valores y fines humanos.

"El mundo con el que nos encontramos en nuestra experiencia ordinaria es un mundo en el que tenemos que elegir entre fines igualmente últimos y pretensiones igualmente absolutas, la realización de algunos de los cuales tiene que implicar inevitablemente el sacrificio de otros (...). El grado de libertad que goce un hombre, o un pueblo, para elegir vivir como quiera tiene que estar medido por contraste con lo que pretendan significar otros valores, de los cuales quizá sean los ejemplos más evidentes la igualdad, la justicia, la felicidad, la seguridad o el orden público. Por esta razón, la libertad no puede ser ilimitada" ${ }^{631}$.

La conclusión de BERLIN no puede ser más ilustrativa de nuestro argumento principal: La libertad individual, en el sentido del libre arbitrio, debe cohonestarse con otros valores, por un lado, pero también con el arbitrio de los demás.

"El pluralismo, con el grado de libertad "negativa" que lleva consigo, me parece un ideal más verdadero y más humano que los fines de aquellos que buscan en las grandes estructuras autoritarias y disciplinadas el ideal del autodominio "positivo" de las clases sociales, de los pueblos o de toda la humanidad. Es más verdadero porque, por lo menos, reconoce que los fines humanos son múltiples, no todos ellos conmesurables, y están en perpetua rivalidad unos con otros" ${ }^{632}$.

BERLIN, sin embargo, tiene grandes dificultades para admitir un criterio objetivo que permita rechazar unos fines (por ir en contra del hombre por ejemplo), así como para jerarquizar u ordenar aquellos otros que sí son válidos, ya que para él, los hombres elegimos entre diferentes valores últimos, según categorías y sistemas de valores últimos o conceptos morales fundamentales, a veces distintos, pero que son en todo caso, lo que nos hace "humanos". Ferviente defensor de que las personas se rijan por principios, aun conscientes de su relativa validez, no puede evitar caer en un cierto relativismo, confundiendo acaso pluralismo con relativismo, como si el primero tuviera que llevar necesariamente al segundo.

Pero, dicho esto, la lucha por la libertad, como la lucha por la justicia, la autonomía de la voluntad frente a la autonomía de las demás voluntades, es el punto de partida para organizar racional y jurídicamente la vida en sociedad, y por consiguiente, de su célula básica, la familia. Así, la libertad en el derecho, es no solo la condición necesaria de la existencia de éste, como orden normativo que se dirige a regular la conducta libre del hombre, sin que, al tiempo, ha sido reconocida y confi-

631 Vid. BERLIN, I. “Los conceptos de libertad”, ...op. cit., página 278.

632 Vid. BERLIN, I. “Los conceptos de libertad”, ...op. cit., página 279. 
gurada como un valor superior del ordenamiento. Por ello, podemos decir que la autonomía, es decir, la capacidad de autodeterminación y elección individual supone un dato antropológico subyacente y básico de todo Derecho y se convierte en el presupuesto de la libertad, un bien jurídico que debe ser protegido por ser considerado generalizadamente como valioso ${ }^{633}$.

Prosiguiendo con el presente análisis, según PECES-BARBA ${ }^{634}$, la idea actual de libertad hay que observarla en dos fases o momentos:

1. Libertad inicial (Psicológica), que remite a la idea de autonomía personal, y se traduce en la libertad de elección (dimensión fáctica de la libertad que nos distingue de los animales);

2. Libertad moral, que se constituye alrededor de la idea de autonomía moral (dimensión moral de la libertad).

Para PECES-BARBA, la libertad moral sin la inicial conduce a la toma decisiones dogmáticas que desvirtúan la propia idea de libertad; y la libertad de elección sin la libertad de autonomía moral, nos puede llevar al subjetivismo ético radical y al escepticismo.

Sin duda, tal cual se puede concluir por lo detallado en el presente título, cada vez más nos encontramos con una concepción de la libertad reducida a lo que nosotros entendemos que es, más bien, la autonomía. La posibilidad de desplegar esa capacidad de hacer u omitir una acción no es la libertad, como ya se ha argumentado más arriba, sino autonomía, que en Derecho queda restringida a los actos potestativos, como no podía ser de otra manera. De modo que lo que, frecuentemente, es denominado y regulado como "libertad", en realidad solo es una faceta o nivel de ésta, que es lo que llamamos autonomía.

"La libertad es el gran valor por el que el Derecho adquiere su más noble sentido. El Derecho no existe solo para que sobrevivamos, para evitar el "bellum ómnium contra omnes", sino para que podamos vivir en libertad" ${ }^{635}$.

La libertad como valor jurídico genérico se refiere a la autonomía individual y de los grupos que los individuos constituyen. El Derecho ha de servir para hacer posible, según dijo KANT, la “coexistencia de libertades", no trata de eliminar la libertad sino de remover los obstáculos que se oponen a la libertad. El Derecho procura ordenar libertades, establecer límites a las libertades para que al menos las más fundamentales puedan sobrevivir ${ }^{636}$. Las libertades absolutas son en realidad,

633 Cfr., VV. AA. "La praxis del consentimiento informado en la relación sanitaria. Aspectos biojurídicos", Cuadernos Prácticos, Ed. Difusión Jurídica, Madrid, año 2007, página 20 y siguientes.

634 PECES-BARBA, G. En VV. AA. “Introducción a la Teoría del Derecho”, Ed. Tirant lo Blanch, 3ª edición, Valencia, año 1997, páginas 316 a 318.

635 LOPEZ CALERA, N. M . “Filosofía del Derecho” (Volumen II), Ed. Comares, Granada, año 1998, página 168.

636 Ejemplo de como intentar mantener un equilibrio entre las diversas libertades, entre ellas la ideológica y la de contratación lo constituye la STC, Pleno, núm. 51/2011 de 14 abril. RTC 2011/51 “La facultad reconocida a las 
una negación de la libertad y negación de un sistema de convivencia en igualdad, ya que solo unos pocos podrán ser libres o autónomos. En realidad, la libertad, en abstracto, no existiría, sino que lo que existen son libertades concretas que son muchas porque son muchos los objetivos y los fines que pueden ser elegidos para conformar la vida y el destino de un sujeto.

Esta diversidad de sujetos y de libertades engendra conflictos que pueden ser entre libertades de igual o de distinto contenido o quizás entre sujetos distintos. El Derecho ha de procurar interferir lo mínimo posible en el ejercicio de las libertades, hasta el punto de que el fin genérico del derecho vendría a ser, precisamente, salvar el valor de la libertad.

Conviene ahora advertir que esta autonomía no se puede identificar directamente con lo que el Derecho, sobre todo el Privado, ha conocido como "autonomía de la voluntad". Como veremos enseguida un poco más extensamente, la autonomía de la voluntad consiste en una cierta capacidad reconocida por los ordenamientos jurídicos al sujeto individual, a la persona, para constituir relaciones jurídicas, para celebrar negocios jurídicos, entre ellos los negocios jurídicos comprendidos en el Derecho de familia. Es una capacidad pues negocial, limitada a unas categorías negociales predeterminadas (nominados) a los que, confirmada su validez, se reconoce plenitud de efectos jurídicos, exactamente igual que a una ley o a cualquier otra fuente de obligaciones jurídicas ${ }^{637}$.

La relación de la autonomía de la voluntad negocial del Derecho Civil o Mercantil, con la autonomía de la persona no es de identidad, sino de subordinación y dependencia de la primera en relación a la segunda. La capacidad para contratar se basa, en el nivel del fundamento último, en la autonomía del hombre, una autonomía que perfectamente se puede calificar de fundamento, de esa otra capacidad reconocida por el Derecho positivo con ciertos límites, que es la autonomía de la voluntad para generar negocios jurídicos. El Derecho no podría otorgar esta última capacidad, si la persona no gozara de la autonomía fundamental, por ineptitud o radical incapacidad ontológica ${ }^{638}$.

autoridades eclesiásticas para determinar quiénes sean las personas cualificadas para la enseñanza de su credo religioso constituye una garantía de libertad de las Iglesias para la impartición de su doctrina sin injerencias del poder público [...] En efecto, a partir del reconocimiento de la garantía del derecho de libertad religiosa de los individuos y las comunidades del art. 16.1 CE no resultaría imaginable que las Administraciones públicas educativas pudieran encomendar la impartición de la enseñanza religiosa en los centros educativos a personas que no sean consideradas idóneas por las respectivas autoridades religiosas para ello. Son únicamente las Iglesias, y no el Estado, las que pueden determinar el contenido de la enseñanza religiosa a impartir y los requisitos de las personas capacitadas para impartirla dentro de la observancia, como hemos dicho, de los derechos fundamentales y libertades públicas y del sistema de valores y principios constitucionales. En consecuencia, si el Estado, en ejecución de la obligación de cooperación establecida en el art. 16.3 CE, acuerda con las correspondientes comunidades religiosas impartir dicha enseñanza en los centros educativos, deberá hacerlo con los contenidos que las autoridades religiosas determinen y de entre las personas habilitadas por ellas al efecto dentro del necesario respeto a la Constitución que venimos señalando".

637 STC, Pleno, núm. 97/2002 de 11 febrero. RJ 2002/3107

638 Cfr. OURLIAC, P. Et DE MALAFOSSE, J. “Histoire du Droit privé”, 2ème édition, Presses, Universitaires de France, Paris, 1969, página 114 
Pero si desde el punto de vista ontológico la subordinación es clara, desde el punto de vista práctico, operacional, también existe subordinación. Si la persona tuviese anulada o limitada su autonomía como tal, su autonomía de la voluntad quedaría seriamente comprometida. La autonomía no sólo es la base de la autonomía de la voluntad del Derecho Privado, sino ante todo, la condición necesaria aunque no suficiente de la Libertad, que es el valor que el Derecho quiere garantizar de modo prioritario en la vida social.

Del mismo modo, la autonomía es el fundamento de una "libertad" muy importante para cualquier persona y que sólo puede ser limitada jurídicamente, como es la libertad ambulatoria, entendiendo por tal la capacidad de trasladarse o desplazarse físicamente de un lugar a otro, de determinar, en cada momento y sin más límites que los establecidos por las leyes, el lugar físico donde se quiere estar ${ }^{639}$. La libertad para circular o viajar pude ser suspendida en su ejercicio por una condena o pena privativa de libertad.

Sin embargo, esta ausencia de constricción física para moverse, que llamamos libertad ambulatoria y que vemos que como cualquier otro atributo humano no es absoluta ${ }^{640}$; es, en realidad, autonomía ambulatoria, puesto que es una relativa capacidad autodeterminativa (una autonomía) y no otra cosa lo que se protege. Atendiendo al bien jurídico protegido, no es la libertad o "una libertad" lo que se garantiza y eventualmente, se limita con una sanción penal, sino la autonomía de movimientos del sujeto.

Tras lo que parece un mero problema terminológico, que no merecería toda esta disquisición filosófica-jurídica, se oculta una confusión conceptual de extraordinaria importancia: la de concebir como libertades o como libertad en general, como atribución básica del hombre, lo que en realidad no es sino la "base" o la condición fundante de los actos libres, el fundamento de la libertad como valor jurídico fundamental del Derecho ${ }^{641}$.

Se da la paradójica circunstancia de que los ordenamientos jurídicos propugnan la libertad como valor supremo, cuando, en realidad lo que se está regulando son aspectos de la autonomía. Y no de la llamada "autonomía de la voluntad", sino de la autonomía fundante de los actos lícitos, que es algo bastante más amplio y conceptual.

639 GOIZUETA VÉRTIZ, J. “El Derecho de entrada y circulación”, en AJA, E. (Coord.), “Los derechos de los inmigrantes en España”, Ed. Tirant Lo Blanch, Institut de Dret Públic, núm. 12, Novedades de Derecho Público, Valencia, año 2009, paginas 91 a 119. El asunto en cuestión ha sido muy discutido, sobre todo por los extranjeros irregulares. Cfr. MOYA ESCUDERO, M. "La libertad de circulación en Europa: los nuevos estatutos personales”, Ed. Tirant Lo Blanch, Homenajes y Congresos, Valencia, año 2012, páginas 661 a 675.

640 Sobre la libertad ambulatoria como manifestación de la libertad personal, vid., BANACLOCHE PALAO, J. “La libertad personal y sus limitaciones”, Ed. Mc. Graw-Hill, Madrid, año 1996, páginas 3 y siguientes.

641 Cfr. CREMADES, I. y GUTIÉRREZ-MASSON, L., "El proyecto de un código civil y la revolución”, en PORTALIS, J. E. M., “Discurso preliminar al Código Civil francés”, Ed. Civitas, Madrid, 1997. 
La razón de este "desajuste" formal y sustantivo, pudiera encontrarse en la ausencia de un concepto claro de lo que es la libertad. Los legisladores constitucionales quisieron introducir en las secciones dogmáticas de nuestras Constituciones, una serie de contenidos axiológicos, en orden a procurar la garantía de unos valores humanos, en forma de libertades, sin saberse ni explicitarse muy bien en qué consistían ni cuál era su fundamento. Si se observan las legislaciones europeas, incluida la española, particularmente si se fija uno en sus constituciones, los estados modernos y contemporáneos procuran enunciar y proteger eficazmente no ya sólo la libertad en general, sino una serie de dimensiones de ella (libertades), que se configuran como derechos fundamentales.

Estas libertades o derechos son catalogados como tales en las Declaraciones internacionales y, en la medida en que se recogen en las legislaciones internas de los Estados, serán mayores sus posibilidades de vigencia efectiva respecto de las personas.

Para que el Derecho pudiera regular algo más que la autonomía que es lo único que se puede hacer mientras se siga concibiendo la libertad como autonomía, sería necesario, además retirar definitivamente de la mentalidad de nuestros legisladores el prejuicio moderno que separa o, más bien, pretende separar, la Moral del Derecho. Ambos son órdenes distintos pero no separables no independientes, en efecto el Derecho y la autonomía de la voluntad en él implícito son limitados no tan sólo respecto de los particulares sino también en relación al Estado, y tal limitación no se entiende únicamente en cuanto ley sino también en cuanto orden metajurídica, en cuanto orden moral ${ }^{642}$. El Derecho busca -o debería buscar-, como fin fundamental, la realización de la justicia. Además intenta, que valores como la libertad, la seguridad, el pluralismo, la solidaridad o el bien común se materialicen a través de sus normas y regulaciones. De modo que estos valores, que no son sino valores morales generalmente compartidos por la comunidad política, son los que orientan y presiden el desarrollo del Derecho en sus momentos creativo y aplicativo. ¿Cómo puede decirse entonces

642 En efecto, ALONSO MARTÍNEZ, citado por DIEZ-PICAZO Y PONCE DE LEÓN, L., "Fundamentos de Derecho Civil Patrimonial", Tomo I, Ed. Civitas, $4^{a}$ edición, Madrid, 1993, página 127. en su obra El Código Civil en sus relaciones con las legislaciones forales escribiría lo siguiente: "He condenado siempre con energía el empeño de aprisionar la libertad humana en unas cuantas reglas preestablecidas en la Ley. Son válidas y dignas de respeto cuantas combinaciones invente el interés privado con tal que no sean contrarias a la moral y buenas costumbres, quepan o no en las clasificaciones siempre estrechas e insuficientes del legislador. Lo de menos es que los pactos y estipulaciones de los ciudadanos estén de antemano clasificados y tengan un nombre técnico en el Código. No hay quien pueda prever todas las combinaciones que es capaz de crear el ingenio humano estimulado por el aguijón de la necesidad y del interés. En nuestro tiempo se han descubierto formas de asociación antes desconocidas, contratos mercantiles y manifestaciones del crédito ignoradas de nuestros abuelos y aun de nuestros padres. ¿Y hemos de rechazarlos porque en los Códigos les falte el nombre de bautismo o porque no se acomoden a sus clasificaciones artificiosas, interventoras y arbitrarias? No. La tutela del Estado no puede llegar hasta obligar a los ciudadanos a que en sus convenciones no se salgan del patrón que les ofrezca la Ley. En buena hora que ésta modere los contratos ya conocidos y estudiados, pero respetando siempre las modificaciones que libremente pacten los contratantes, así como las nuevas combinaciones que su razón les sugiera, siempre que en su esencia sean lícitas y honestas" 
que el Derecho es -o debiera ser- aséptico, ajeno a los valores morales? Es una evidencia empírica palmaria que lo moral está presente en el ámbito jurídico y que el Derecho es un orden ético.

Entonces, comprendido el Derecho como una ordenación racional y ética de la libertad, ¿cómo desligar la libertad de esos bienes que están en el hombre y que dan sentido a esa libertad?. El legislador moderno y contemporáneo, que concibe el Derecho como un orden desvinculado del bien moral del hombre y concibe la libertad como la autonomía para realizar dicho bien, puede reducir el Derecho a un orden coactivo, no de la libertad, sino de las voluntades autónomas de los individuos.

El Derecho ha dejado de verse como una regulación racional de la conducta libre del hombre encaminada a la justicia, a la consecución del orden justo. Desde la modernidad, no es sino una creación cultural, un artificio de naturaleza convencional, regulativo de la autonomía de los individuos integrantes del grupo social, en orden a garantizar la coexistencia pacífica.

El empobrecimiento de la noción de la libertad, ha conducido a una visión también empobrecida, miope del Derecho. Descreídos o radicalmente escépticos de la Justicia absoluta ${ }^{643}$, denostado o ignorado el Derecho Natural, los fines del Derecho han sido subvertidos y la libertad cuyo desenvolvimiento se pretende arbitrar solo puede ser una forma de autonomía cuyos límites son establecidos por consenso ${ }^{644}$.

Como conclusión se afirma que lo único que aspira a regular el Derecho es la autonomía, aunque lo llame o diga proteger las libertades, porque la libertad no se sabe lo que es, ideológicamente se ha mutilado, su esencia y finalidad navegan a la deriva.

\section{3 | Aspectos jurídicos en torno a la idea de voluntad}

Se sabe por KANT que la autonomía de la voluntad, tal cual ya se indicó es la constitución de la voluntad por la cual ella es para sí misma una ley, razones lógicas y metodológicas imponen la previa necesidad de indagar acerca del substrato del principio, es decir, sobre el soporte o asiento que le sirve de base para desplegar toda su virtualidad, esto es la voluntad.

643 Cfr. MARTINEZ-SICLUNA, C. "Legalidad y legitimidad. La teoría del poder”, Ed. Actas, Madrid, año 1991

644 ABELLAN SALORT, J. C., "El Derecho hoy: Entre el reto de la globalización y la pérdida de la realidad”, en VV. AA. ABELLAN SALORT, J. C., (Edit.), "Derecho y Realismo. Introducción a la filosofía jurídica de M. VILLEY”, Universidad Francisco de Vitoria, Biblioteca de Derecho, Madrid, año 2005. 
Entonces la pregunta que surge es: ¿Qué es la voluntad?. Es la potencia del alma que mueve al hombre a hacer o no hacer alguna cosa, es libre albedrío o libre determinación. ${ }^{645}$ Según KANT “Es una especie de causalidad de los seres vivos en cuanto que son racionales ${ }^{\text {"646. }}$.

El hombre como ser racional, a diferencia de los animales, tiene la facultad de autodeterminarse y autorresponsabilizarse. Así la voluntad viene a ser requisito esencial de todo acto y por ende del contrato. Tan importante es la voluntad que los hechos involuntarios no generan civilmente ninguna obligación. Toda la vida consciente del hombre está dominada por la voluntad; pero para el Derecho esto no basta, sino que además debe ser exteriorizada.

\subsection{Elementos constitutivos del acto jurídico. Voluntad y manifestación}

Para la existencia de un hecho voluntario, un acto, es imprescindible la concurrencia de dos elementos: uno material y otro moral. Sin el elemento material y aunque exista el elemento moral, hay puramente un hecho interior que nadie puede conocer, mientras no se traduzca en signos sensibles y tal como recién se ha hecho referencia para el Derecho no basta. Si bien tenemos el elemento material, se requiere además el elemento moral. En otras palabras, dos elementos deben concurrir para la existencia de un acto relevante para el Derecho: el interno, la voluntad; y en otro externo: su manifestación.

Para la existencia de voluntad son necesario tres requisitos: discernimiento, intención y libertad, entendidos como condiciones del espíritu humano para comprender, querer y poder ejecutar o no un determinado acto.

El discernimiento es la aptitud intelectual para comprender los alcances de un acto, es decir, para distinguir lo bueno de lo malo (moral), lo justo de lo injusto (derecho) y, en definitiva, para valorar la conveniencia o inconveniencia de las acciones. Es así como el discernimiento es determinante de la capacidad de las personas. Sin perjuicio de lo anterior, el discernimiento también tendría causas obstativas tales como la inmadurez y la falta de sanidad mental del sujeto.

La intención consiste en, previa deliberación, querer realizar el acto. Es la tendencia o dirección de la voluntad esclarecida por el discernimiento para practicar el acto, es, sin duda, la decisión.

645 Cfr. REAL ACADEMIA ESPAÑOLA, Diccionario de la lengua española. $1^{\text {o }}$ y $4^{\mathrm{o}}$ acepciones. 21 ${ }^{\mathrm{a}}$ ed. (1992), en Internet: $\underline{\text { www.rae.es, }}$, sitio en el que se pueden consultar todas las ediciones de los diccionarios de la Academia. Si bien se advierte que la $22^{\mathrm{a}}$ edición (2001) del Diccionario de la lengua ha modificado la $1^{\mathrm{a}}$ acepción("Potencia de alma, que mueve a hacer o no hacer una cosa") del vocablo "voluntad" que traía la $21^{a}$ edición, en el concepto que se propone se ha decidido mantener la paráfrasis de la antigua redacción por ajustarse mejor a los fines del presente estudio. En la $22^{\mathrm{a}}$ edición la $1^{\mathrm{a}}$ acepción de la palabra "voluntad" dice: "Facultad de decidir y ordenar la propia conducta", lo que nos parece aproximarse más a la noción de "autonomía de la voluntad".

646 Vid. KANT, E. “Fundamentación de la metafísica de las costumbres”, ...op. cit., página 55. 
Finalmente la libertad, aunque se ha analizado antes, es la facultad o poder del hombre de obrar de una determinada manera, o de no obrar, una vez cumplidos los pasos previos del proceso volitivo (deliberación y decisión) que corresponden a los otros dos elementos de la voluntad.

En suma, como factores constitutivos de la voluntad, por un lado, el discernimiento y la intención conforman la conciencia de sí; mientras que, por otro, la libertad implica el imperio de si, adquiriendo particular relevancia esta última, pues no sólo participa el proceso volitivo interno al igual que el discernimiento y la intención, sino que determina además su exteriorización, indispensable para la existencia del acto.

Mientras la voluntad no se exteriorice se mantiene dentro de los dominios de la Moral al margen del imperio del Derecho. Sin perjuicio de la exigencias formales que el Derecho civil exige para esta manifestación, ella puede ser expresa, tácita o presumida por la ley.

No hay problema si la voluntad es coincidente con su manifestación, lo cual suele ser lo normal, pero ¿qué sucede si voluntad real y voluntad declarada son divergentes? Históricamente, la cuestión ha motivado una ardua polémica sobre si debe prevalecer la voluntad o, por el contrario, si debe primar la declaración. En este sentido, el antiguo Derecho Romano e igualmente el antiguo Derecho Alemán, atendiendo a lo sensiblemente perceptible y dominados por las formas, consideraron suficiente la declaración formal. En cambio, el Derecho Clásico, en su afán de responder de la mejor manera a los múltiples requerimientos de la vida, dio prioridad a la verdadera voluntad ${ }^{647}$.

RIEG sostiene que desde el siglo XIX el dogma de la autonomía de la voluntad fue considerado como una tradición nacional y verdaderamente francesa. Frente a él, una parte de la doctrina alemana se levantó en busca de la manera de conciliar la voluntad individual y la seguridad ${ }^{648}$. A partir de entonces los autores, según sus puntos de vista coincidentes con una u otra postura, comenzaron a enrolarse en las denominadas teorías de la voluntad y de la declaración ${ }^{649}$.

647 VON THUR, A. “Derecho civil. Teoría general del derecho civil alemán.” RAVÁ DEPALMA, T. (Trad.), Tomo 3, Volumen III, Ed. Marcial Pons, Madrid, año 2005. En esta obra el autor manifiesta un aspecto fundamental bastante clarificador en términos jurídicos, sobre la interioridad y exterioridad de los actos, por cuanto la vida interior del hombre no siempre produce efectos directamente sobre el mundo externo. De ello deriva que mucho de los hechos que la integran carecen de importancia para el Derecho. De tal manera la voluntad sólo producirá efectos para la vida jurídica en forma de acto.

648 RIEG, A. "Le rôle de la volonté dans l'acte juridique en droit civil francais et allemand”. Librairie générale de droit y de jurisprudence. Paris, año 1961, página 7.

649 RIEG, A, “Le rôle de la volonté dans l’acte juridique en droit civil francais et allemand”, ibídem, página 7. Este autor señala que es la voluntad interna la que debe triunfar siempre, esto exclamaron los partidarios de la teoría de la voluntad: la voluntad es el soporte de la declaración; si ella está ausente, el acto jurídico todo entero lo estará. Mejor aún, sólo la voluntad tiene valor jurídico, la declaración no es sino el procedimiento para hacerla aparente a los terceros. En sentido contrario se manifiesta que el papel capital en el acto jurídico corresponde a la declaración; la seguridad en las transacciones exige que su autor sea obligado por el sentido normal de las expresiones empleadas, sin que pueda argüir una intención divergente. 
La intercalación entre ambos extremos de una tercera categoría que agrupe a las doctrinas intermedias ofrece el reparto de que, en la práctica, nadie sigue en forma pura la teoría de la voluntad ni la de la declaración, sino que todos navegan por aguas eclécticas, por lo cual esta, de tercera, se convierte en única categoría. Sin embargo, es necesario señalar el punto de partida de cada posición, debido a que no es lo mismo inclinarse hacia el lado individual que hacia el social, con lo cual la disputa entre la doctrina de la voluntad y la de la declaración supera lo meramente académico, incluso hasta hace no mucho se amparaba en el ámbito de las ideologías.

Sin duda, la manifestación de la voluntad como unidad inescindible entre el querer y el declarar se debe complementar con los principios de responsabilidad y de confianza en perfecta coordinación como límites impuestos en protección de los terceros. Por el principio de responsabilidad, el agente debe obrar con diligencia y prudencia, como lo haría un hombre de negocios de tipo medio de acuerdo a las circunstancias de tiempo y lugar; por el principio de confianza, los terceros deben haber adquirido, obrando con la misma diligencia y prudencia, una razonable convicción acerca de los reales alcances del acto. Es decir que, en caso de discordancia entre la voluntad y la declaración, la sola apariencia de un negocio normal no basta para generar el correspondiente vínculo jurídico, sino que además es necesario que se haya debido al obrar culpable del declarante y que haya dado lugar a una razonable confianza por parte del destinatario de la declaración.

En palabras de FERRARA: “El principio de responsabilidad, cuando se combina con el de la confianza, ilumina y domina incluso éste; una confianza culpable, irrazonable, no puede admitirse. La prevalencia de la voluntad está, pues, limitada. Pero la limitación se halla condicionada, de un lado, por la responsabilidad del sujeto; por otro, por la razonable confianza con los demás" . ${ }^{550}$ Desde otra perspectiva RIEG observa que: "El nacimiento del acto reposa todo entero sobre la voluntad de su autor. Él no existe como acto jurídico sin consentimiento, y el Derecho positivo debe pues proteger ante todo el nacimiento de esta voluntad. No solamente acordará al declarante toda amplitud en la expresión de su intención, sino que también velará porque el consentimiento expresado sea de calidad, porque el agente no se obligue a la ligera y sin motivos válidos. En una palabra, la etapa del nacimiento del acto supone la protección, por el ordenamiento, de la autonomía individual. Se concluye que, durante esta etapa, el respeto de la voluntad prima sobre la estabilidad. Pero una vez que el acto está creado, que ha tomado lugar en la vida jurídica y se ha integrado en el medio social, el problema de la seguridad deviene más imperativo. Todo contratante debe

650 CARIOTA FERRARA, L. "El negocio jurídico”, ALBALADEJO, M. (Trad.), Ed. Aguilar, Madrid, año 1956, página 54 . 
poder contar con la ejecución de sus obligaciones por el otro contratante, y este último no debe poder desligarse unilateralmente del vínculo contractual ${ }^{\prime 651}$.

Es decir que, mientras en la génesis del acto predomina la voluntad, una vez creado, en sus efectos, tiene mayor importancia la declaración. De inmediato me asalta la duda de si tal idea tiene aplicación actualmente en el matrimonio, en España, la respuesta es claramente negativa, lo declarado sólo importa mientras no declare lo contrario mi "libertad"-"autonomía" afectiva.

\section{El principio de autonomía de la voluntad en la Constitución española de} 1978

No es tema del presente trabajo, la autonomía en su significación política aunque en el Derecho español presente mucha relevancia debido a que España es un Estado que se organiza en torno a las comunidades autónomas, con esa relativa capacidad de autogobierno y de legislación en el ámbito de las competencias que les han sido conferidas por la Constitución española y las leyes que la desarrollan. Sin embargo, reiteramos que, aun conscientes de su interés jurídico, no es ésta la autonomía de la que nos ocupamos aquí, aunque aquella se funde, precisamente en la que sí tratamos.

Conviene recordar, por otra parte, que en el mundo jurídico occidental, desde la época romana, está vigente con mayor o menor alcance, el principio de la autonomía de la voluntad, de especial importancia en el Derecho Civil.

La acepción predominante del término autonomía en la Constitución española de 1978 es la de la autonomía como capacidad de autogobierno de las regiones y nacionalidades constituidas en Comunidades Autónomas (artículo $2 \mathrm{CE}$ ), como cuando regula, en el Título VII, todo el marco competencial autonómico (artículo 148-150), definiendo España como un Estado descentralizado administrativamente (artículos 137 y 143) cuando se refiere a las relaciones entre ellas (artículo 145), de aquellas con el Estado central (artículos 138, 139, 153-155), su financiación (artículos 13, 156-158) transferencia de competencias (artículo 150), capacidad normativa o legislativa, etc.

Además de las anteriores, que son acaso las más importantes, todas las referencias que encontramos a la autonomía política, es decir, con la autonomía de gestión, gobierno o legislación de las Comunidades Autónomas.

La Constitución no emplea el término autonomía en la significación filosófica-moral con la que se utiliza en el contexto ético y jurídico. La Carta Magna española emplea siempre la palabra li-

651 RIEG, A. "Le rôle de la volonté dans l' acte juridique en droit civil francais et allemand”, ...op. cit., página $10 \mathrm{y}$ siguientes. 
bertad (aunque lo haga con contenidos no siempre iguales), fruto de la tradición humanista y del espíritu democrático que inspiraron su redacción ${ }^{652}$.

En este sentido, la libertad se recoge en el texto constitucional como valor jurídico fundamental, valor superior del ordenamiento jurídico (artículo 1).

La referencia del artículo 1 nos da idea de la importancia fundamental que para los ponentes constitucionales tiene la libertad, como valor superior de nuestro Derecho, precediendo incluso a los otros tres valores superiores; la justicia, la igualdad y el pluralismo político.

Para una sociedad como la española, que salía de un régimen político de carácter autoritario, la afirmación de la libertad era primordial y de primer orden frente a cualquier otra demanda, intentando afianzar los fundamentos de un nuevo orden democrático ${ }^{653}$.

Acaso sea ésta la razón de la configuración de la libertad como un valor superior, lo que significa su primacía frente a cualquier otro imperativo moral, político o social ${ }^{654}$; su conversión en el eje o punto básico del resto de las reglas de convivencia social; su enunciación como signo de identidad de la España que se construía política, legislativa y socialmente como un Estado de Derecho, y, por todo lo anterior, la idea clave de un sistema garantista de una serie de bienes jurídicos básicos, personales y sociales, que se quiere proteger, que se llaman libertades o derechos fundamentales y que, desde ahora, se consideran inalienables y universales ${ }^{655}$.

La Constitución de 1978, pues habla, ante todo, de libertad, y no de autonomía (a excepción del uso político-administrativo-territorial del término que ya hemos mencionado que sí es frecuente). Por tanto, debemos entender que el valor fundamental de la libertad, ya sea entendida como ausencia de intromisión, coacción o interferencia por parte del Estado, respecto de determinadas facetas de la vida individual, ya sea entendiéndola como capacidad para ejercitar, desplegar, desarrollar ciertos bienes o derechos ${ }^{656}$.

La matriz liberal e individualista de las constituciones de nuestro entorno cultural y político internacional hace que las libertades sean preconizadas y protegidas, frente a limitaciones ilegítimas

652 Cfr. BELMONTE GARCÍA, O. "Pensar la violencia, la justicia y la libertad”, Pontificia Universidad de Comillas, Madrid, año 2012; ROSADO VILLAVERDE, C. "La regulación estatutaria de los derechos y libertades”, Ed. Dykinson, S.L., Madrid, año 2012.

653 FIGUEROA GARCIA HERRERO, N. “Libertad y virtud. Un ensayo a propósito de Jean Jacques Rousseau”, Universidad de Los Andes, Bogotá, año 2009.

654 SÁNCHEZ DE LA TORRE, A. "El Derecho en la aventura europea de la libertad”, Ed. Reus, Madrid, año 1987.

655 DAMM ARNAL, A. “El punto sobre la I. Ideas en torno a la libertad individual, la responsabilidad personal y la propiedad privada.”, Unión Ed. S.A. Biblioteca de la libertad, Formato menor, Madrid, año 2012.

656 Cfr. ÁlVAREZ CONDE, E. "Curso de Derecho Constitucional, Volumen I. El Estado constitucional. El sistema de fuentes. Los derechos y libertades”, Ed. Tecnos, S. A., Madrid, año 2008. 
de poder o del resto de los individuos, como espacios de realización de la personalidad, pero, con frecuencia sin una definición mínima o básica del contenido, alcance y limitaciones de esas libertades.

Se suelen incluir en catálogos o elencos de derechos, de forma genérica, remitiéndose a leyes específicas para su desarrollo y explicitación de sus diversos aspectos. Normalmente, la necesidad de aparecer como un texto de consenso político y social, como un marco para la convivencia, provoca su redacción genérica y abstracta, insertándose las diversas libertades, sin hacer referencia alguna a su fundamentación, al porqué, ni él hasta dónde de su protección ${ }^{657}$.

En buena medida eso es lo que ocurre con la manera de explicitar la libertad que hace la Constitución española en su artículo primero. No dice en qué consiste esa "libertad", sólo esclarece su carácter fundamentador del orden jurídico político español.

Sin embargo, su carácter "valioso" y fundamental (de valor superior) se deriva de su arraigo en la persona, por lo que hay que conectar este enunciado primero, con lo prescrito por el artículo 10, cuando se refiere a que: "La dignidad de la persona, los derechos inviolables que le son inherentes, el libre desarrollo de la personalidad, el respeto a la ley y a los derechos de los demás son el fundamento del orden político y de la paz social”. Hay que vincular esa noción de la libertad como valor, con estos Principios Generales del Derecho, sobre todo entendiendo que la libertad es constitutiva y radica en la dignidad de la persona, lo cual sin duda también será analizado en el capítulo pertinente al principio del libre desarrollo de la personalidad. Pero se puede adelantar que sólo comprendiendo que no es una mera convención para entrar en un nuevo régimen, sino que la libertad se deriva de la dignidad ontológica de todo ser humano, la libertad podrá ser defendida como valor inviolable. Decir que el desarrollo de la personalidad ha de ser libre, implícitamente indica el reconocimiento de la personalidad como un factum un dato inherente a todo ser humano, que se debe permitir desarrollar libremente.

En este punto se hace necesario enfatizar la relevancia de que la Constitución diga "libremente" y no emplee el término "autónomamente", aludiendo a la necesidad de que el desarrollo de la personalidad no sufra de restricciones externas, goce de autonomía. La Constitución quiere que sea "libre", o sea, que todo individuo pueda realizar y "actuar" sus derechos, intereses y potencialidades personales para alcanzar los fines que le son propios o inherentes. Desarrollar la personalidad no significa hacer de uno mismo "lo que se quiera", sin restricción alguna - esto sería desarrollarlo autónomamente-, sino que el texto constitucional protege un desarrollo libre, lo que entendemos inclu-

657 LÓPEZ BARJA DE QUIROGA, J. “Los límites de la vida y la libertad de la persona”, Ed. Tirant Lo Blanch, Valencia, año 2011. 
ye la autonomía, pero no sólo eso, sino que está implicando una teleología, una orientación a los fines de cada sujeto conforme a su ser personal. Lo contrario significaría la necesidad de admitir pretensiones aberrantes de un individuo so pretexto de que la Constitución reconoce a todos el desarrollo de su personalidad ${ }^{658}$.

El valor superior es la libertad, que lógicamente, tiene ese primer nivel de autonomía, que comentábamos antes, es "básico" respecto de la misma, la cual, sin embargo no se agota en los límites de aquella. La lectura sistemática del texto nos obliga a tener en cuenta que el contenido de la libertad en la Constitución está determinado por estas referencias a la dignidad de la persona y a esos bienes que protege como inherentes a ella. Además, es necesario interpretar estas referencias a las libertades “...de conformidad con la Declaración Universal de Derechos Humanos y los tratados y acuerdos internacionales suscritos por España”, tal cual dispone el art. 10.2 de la Constitución Española.

Un breve comentario crítico merece, sin embargo, la ordenación en que aparecen en el artículo 1 de la Constitución Española estos valores superiores, encabezados por la libertad.

En primer lugar, es necesario advertir la dificultad que tiene intentar separar los valores de la libertad y la igualdad. La Modernidad ha concebido como básico el principio de la igual-libertad, es decir, el principio igualitario respecto del ejercicio de las libertades. Desde este punto de vista, puede parecer lógico que la libertad, como valor, preceda a la igualdad, puesto que la igualdad a la que se refiere, fundamentalmente en el artículo 14, es la igualdad jurídica ${ }^{659}$. Sin embargo, como bien ha explicado HERVADA XIBERTA, la igualdad ante la ley encuentra su asiento y condición de posibilidad en el nivel metafísico, en la llamada igualdad fundante ${ }^{660}$. Hay una igualdad subyacente, que es la igualdad en tanto que personas, poseedoras de una idéntica naturaleza y dignidad ${ }^{661}$. Desde esta última perspectiva, en cambio, no es tan clara la prelación entre los dos valores. Más bien, debemos entender que van de la mano, que hay un nexo filosófico, social y político entre ellos ${ }^{662}$.

658 SUAREZ CORTINA, M. "Libertad, armonía y tolerancia. La cultura constitucionalista en la España contemporánea”, Ed. Tecnos S.A., Madrid, año 2011; MARTINELL SEMPERE, L. (Coord.). "Cultura y desarrollo. Un compromiso para la libertad y el bienestar", Ed. Alkal S.A., Madrid, año 2010.

659 El artículo 14 de la Constitución Española dice: "Los españoles son iguales ante la ley, sin que pueda prevalecer discriminación alguna por razón de nacimiento, raza, sexo, religión, opinión o cualquier otra condición o circunstancia personal o social".

660 HERVADA XIBERTA, J. “Lecciones propedéuticas de Filosofia del Derecho”, Ed. EUNSA, $4^{\mathrm{a}}$ edición, Pamplona, año 2008, páginas 210 y 211.

661 Cfr. CODINA BLASCO, M. "Donde vive la libertad. Una lectura de Romano Guardini", Ed. Biblioteca Nueva S.L., Madrid, año 2011.

662 Cfr., BOBBIO, N. "Igualdad y libertad”, Ed. Paídos, Barcelona, año 1993, páginas 56 y siguientes. 
En cuanto al pluralismo político, en buena medida depende en su existencia de que se haya conseguido un grado razonable de vigencia real de la libertad y la igualdad. En muchos casos, la materialización del valor del pluralismo político requiere, como condición necesaria el reconocimiento de las libertades políticas sin cuya previa garantía, el pluralismo político no pasa de ser una utopía deseable. En todo caso, la defensa del pluralismo suele concurrir, indisolublemente, con la de la libertad y la igualdad.

Tiene interés la formulación dada al artículo 9, en que la libertad y la igualdad son caracterizadas según el concepto negativo, ausencia de constricción para su ejercicio, que debe ser promovida, garantizada por los poderes públicos. Reza así, el número 2: “Corresponde a los poderes públicos promover las condiciones para que la libertad e igualdad del individuo y de los grupos en que se integra sean reales y efectivas; remover los obstáculos que impidan o dificulten su plenitud y facilitar la participación de todos los ciudadanos en la vida política económica, cultural y social”.

En primer lugar el artículo habla de individuo, no de persona, además hace también la referencia a los grupos, entre ellos se alude asimismo a la familia, obligando, sin distinción, a los poderes públicos a garantizar que, tanto para uno como para otro, se den las condiciones para el efectivo disfrute de la libertad e igualdad, de tal manera se quiere que ambas tengan el carácter de reales. Esto es, se intenta garantizar la operatividad de esos valores, que no se vean obstaculizados, es decir, se dice que el Estado debe garantizar que se den las condiciones de no restricción (autonomía). Enunciadas pues en sentido "negativo", se está protegiendo, sin decirlo, la autonomía, no necesariamente la libertad, en el sentido que se vienen diferenciando ambos conceptos.

Otro problema distinto se plantea con la relación entre la libertad y la justicia. Porque, puede existir la pregunta: ¿Puede haber verdadera libertad si no hay justicia? Y, al revés, ¿podemos hablar de justicia, si no se respeta la libertad? La Constitución antepone la libertad. No es lugar para profundizar en tan grave asunto, debido a que en primer lugar habría que dilucidar claramente no ya qué es la justicia y qué es la libertad, sino además intentar averiguar con qué sentido los utiliza la Constitución. Excediendo el ámbito de la presente tesis una mínima fundamentación de lo que se podría discutir al respecto, solo diremos que, en una clásica concepción de la justicia (por tanto, superando los límites de la Justicia Social), este, y no otro, es el valor por excelencia del Derecho y del orden político, en el que deben apoyarse todos los demás. La subversión en el orden de los valores o de los fines del Derecho, imputable a la Modernidad, es la consecuencia lógica del prejuicio positivista que escéptico de la posibilidad de una justicia absoluta, como el fin primordial del Dere- 
cho, la sustituye por los llamados "valores jurídicos fundamentales", ciertamente vacíos de contenido, empobrecidos cuando se les ha disociado de la justicia ${ }^{663}$.

Todos los restantes artículos en los que se utiliza el término "libertad" remarcan diversas facetas (derechos) de la personalidad, formulándose como libertad de participación política (artículo 6), de sindicación laboral (artículos 7 y 28), libertad ideológica y religiosa (artículo 16), libertad física, ambulatoria (artículo 17 y 25), libertad de residencia y circulación (artículo 19), libertad de expresión (artículo 20), libertad de enseñanza (artículo 27), libertad de elección de oficio o profesión (artículo 35), libertad de empresa (artículo 38), libertad de participación para la juventud (artículo 48). Además en el artículo 53 la Constitución obliga a tutelar y garantizar esas libertades y en el artículo 13, extiende su titularidad a los extranjeros en España.

Antes de finalizar este título puede expresarse que aunque no se mencione expresamente, la Constitución, que no define la libertad, y que promueve como valor superior, está intentando en realidad garantizar la autonomía de las personas en diversos aspectos de su personalidad. Para el constituyente, lo que denomina "libertades" o derechos fundamentales, presentan las siguientes características:

a) Se garantizan universalmente, procurando la remoción de todo obstáculo a su legítimo ejercicio;

b) Se protegen como bienes limitados, no absolutos (esto es patente en el caso de la propiedad);

c) No se fundamenta ni se propone un telos para estas atribuciones;

d) Sólo contemplándolas en relación con la referencia a la dignidad de la persona, como valores que le son inherentes, se pueden interpretar razonablemente.

En esta línea entra en juego la denominada Constitución económica que sería el conjunto de principios, valores y reglas de la Constitución en materia económica. Debemos entonces hacer referencia, aunque sea sumariamente a ella, pues nos suministrará las posibilidades de autorregulación de intereses por los particulares. El conjunto de dichos intereses se conoce en Derecho Civil por el nombre de "autonomía de la voluntad" o también autonomía privada o autonomía de los particulares, todas las expresiones indican lo mismo.

La Constitución económica española puede venir identificada a través de una serie de principios normativos que sucintamente se enuncian a continuación.

663 MARTINEZ-SICLUNA, C. "Del poder y la justicia”, Ed. Actas, Madrid, año 1993, página 169; Cfr. HERRÁN ALONSO, J. C. "El orden jurídico de la libertad. La aportación de F. A. Hayek al estudio del Derecho.", Unión Ed. S.A., Madrid, año 2010; LEONI, B. “La libertad y la ley”, Unión Ed. S.A., Madrid, año 2010. 
1. Reconocimiento y garantía en los términos del artículo 53 del derecho de propiedad: La transmisión y adquisición de la misma como consecuencia del fallecimiento de su titular (herencia) (artículo 33.1); Propiedad que comporta deberes sociales (artículo 33.2); La llamada "función social”, y de la que sólo puede ser privado el particular con indemnización y de acuerdo con lo establecido por la leyes (artículo 33.3); Se reconoce también la existencia de la propiedad pública, con carácter instrumental para el desempeño de las funciones públicas (artículo 131.1). De todos modos "toda la riqueza del país en sus distintas formas y sea cual fuere su titularidad está subordinada al interés general” (artículo 128.1).

2. Reconocimiento (y garantía en los términos del artículo 53.1) de la libre iniciativa económica de los particulares, a la que se llama "libertad de empresa en el marco de la economía de mercado" (artículo 38). La referencia al mercado, que no es sino un instrumento de autoconcierto de los intereses económicos particulares, subraya de modo especialmente intenso que una manifestación de primer orden de esta libertad es la llamada, de acuerdo con la presente nomenclatura, "la autonomía privada". Se ha de observar empero que esta libertad no es una libertad económica ilimitada, sino que los poderes públicos la protegerán “de acuerdo con las exigencias de la economía general y, en su caso, de la planificación”.

3. Reconocimiento de la iniciativa pública en la actividad económica. Pero el monopolio público de actividades únicamente puede producirse para recursos o servicios esenciales, y mediante ley. Ley que se pide asimismo para la intervención de empresas privadas si lo exigiere el interés general (artículo 128.2).

4. Reconocimiento de la potestad planificadora del Estado, mediante la ley, "para atender a las necesidades colectivas, equilibrar y armonizar el desarrollo regional y sectorial y estimular el crecimiento de la renta y de la riqueza y su más justa distribución” (artículo 131.1).

Las anteriores normas configuran una "Constitución económica" en la que el protagonismo de los particulares está fuertemente acentuado y protegido.

Finalmente, aunque no siempre sea del todo claro, la problemática de la autonomía de la voluntad tiene una importante relación con el Derecho de familia, y no tan sólo en materia patrimonial. 


\section{5 | La autonomía de la voluntad y el Derecho de familia}

\subsection{Antecedentes}

Cuando en el ámbito del Derecho se menciona el término autonomía, resulta forzoso referirse a la fuente por excelencia de creación del Derecho, que no es otra que el principio de autonomía de la voluntad $^{664}$.

Si se habla de fuentes "materiales" del Derecho, es decir, de instancias creadoras de normas con carácter jurídico, en la actualidad dichas fuentes se concentran en las instituciones estatales. Es la Ley o la Constitución la que suele establecer en el Estado, en algunos o varios de sus "poderes", la titularidad de la capacidad de creación de normas jurídicas, acaparando dichos poderes estatales la condición de fuentes materiales del Derecho ${ }^{665}$. Sin embargo, no debe olvidarse que la facultad

664 DÍEZ-PICAZO Y PONCE DE LEÓN, L, “A vueltas con la autonomía privada en materia jurídica”, Diario La Ley, No 7765, Sección Tribuna, 29 Dic. 2011, Año XXXII, Ref. D-485, La Ley 21915/2011 . "Tras todo lo dicho para introducirnos hoy en el tema de la autonomía privada, reconociendo que no resulta fácil arrancar en esta disertación, he pensado llevar a cabo el cotejo de tres expresiones que no son, por supuesto, radicalmente distintas, pero en las que un análisis detenido permite advertir en ellas diferencias de matices. Estoy hablando de la utilización de los términos «autonomía de la voluntad», «autonomía privada» y «libertad de contratar». Habrá que admitir que el espiritu y el sustrato intelectual que tras estos términos se esconde son muy parecidos. No puede perderse de vista un dato que parece especialmente importante. Toda la cultura de la Europa Occidental y de América se encuentra presidida por la idea de que existe iniciativa privada en la actividad económica y que, además, es bueno que esta iniciativa privada exista. Es la existencia y la amplitud de esta iniciativa privada lo que permite hablar de un libre mercado, de manera tal que es absolutamente imposible dentro de esa cultura tratar de sostener otros principios diferentes, pues cuando llegan los planes quinquenales y la economía totalmente organizada desde oficinas estatales o cuasi estatales, todo condujo decididamente al fracaso. Lo que seguramente ocurre es que situado frente a un sustrato cultural como el descrito, caben dos posturas muy diferentes: la de admitirla en la forma más extensa posible o la de admitir algún tipo de distinciones que permitan algún intervencionismo en la economía justificándolo, tal vez como coartada, en el intento de realización de políticas sociales."

665 DIEZ- PICAZO, L., ibidem, página 11. Este autor cree que no puede discutirse que es un principio general del Derecho y que por eso se habla del principio de la autonomía de la voluntad o de la autonomía privada o incluso con otros nombres. Al ser los principios normas que expresan las ideas cardinales de una comunidad respecto de su propia organización, necesiten después o no un proceso de concreción o concretización que los haga aplicables a los supuestos particulares, aunque no hay ningún inconveniente en que los principios estén también expresados no solo en normas constitucionales, sino en normas de orden legal, y en ese sentido, existe un esbozo de reconocimiento de la autonomía privada como principio en el art. $1255 \mathrm{CC}$. Distinto es el problema relativo a si el producto de la autonomía privada y, por consiguiente, la norma o preceptos emanados de ella deben encontrar un puesto en la enumeración y clasificación de las fuentes del Derecho. "Respecto de ello mi respuesta es también deudora de las enseñanzas de F. DE CASTRO, quien distinguía unas normas que aparecen con la pretensión de tener lo que llamaba una "eficacia social de organización» y otras que carecen de tal pretensión y de tal eficacia. La primera pretensión de eficacia y de organización debe reconocerse a la mayor parte de las normas legales y a un buen número de normas consuetudinarias. Lugar distinto en la ordenación merecen aquellas que carecen de tal eficacia, aunque no pueda negárseles la condición de preceptos por llamarlos de una forma quizá suave. Las reglas son contenidos de Derecho y las obligaciones emanadas de la autonomía privada son, en mi opinión, indudablemente "preceptos», y en ese sentido se puede hablar de preceptos de la autonomía privada. Seguramente no merecen el calificativo de normas porque no hay en ellas una eficacia social de organización y su eficacia de organización tiende a restringirse a muy pocas personas: las que hayan sido parte en la creación del precepto o su destinatario inmediato de acuerdo con la Ley. Por eso no hay que buscar ningún puesto en el orden de las fuentes del Derecho ni modificar éste. “ 
creadora de normas que posee el Estado tiene su origen en una instancia anterior, lógica y cronológicamente, al orden político estatal, en cualquiera de sus modalidades. Al margen de algunas posiciones propias del positivismo estatista, suele convenirse en que la capacidad normativa del Estado, como la de cualquier institución u organización con capacidad reguladora de las relaciones humanas, se funda, en última instancia, en la capacidad normativa de cada ser humano, en su racionalidad y en su libertad ${ }^{666}$.

La realidad jurídica no se agota con las normas (generales y singulares) producidas desde el Estado. Existen otros ámbitos -igualmente jurídicos- en la realidad jurídica, tales como el Derecho Natural, el derecho consuetudinario y, sobre todo, como ejemplo de Derecho para-estatal, el que es fruto de la autonomía individual, cuyos ejemplos paradigmáticos y más frecuentes y numerosos son el contrato privado y el convenio colectivo.

En este sentido, ha de aclararse, en primer lugar, que el negocio jurídico, como fruto directo de la autonomía de la voluntad, como fuente normativa, se funda sobre el presupuesto de que no todo el Derecho es expresión de la voluntad general o de la voluntad de la comunidad ${ }^{667}$. Contra la noción roussoniana y hegeliana, ha de partirse de una concepción más amplia del Derecho, que admitiría que un negocio jurídico rubricado por unos particulares contiene o puede contener auténtico derecho.

La autonomía de la voluntad es, igual que el poder legislativo estatal, fuente material del Derecho, a mi juicio constituye la fuente esencial básica, ya sea para constituir el pacto político social como para fundar una familia. Esta tiene su fundamento así como su justificación en la capacidad natural de toda persona, como sujeto, para adquirir obligaciones de tinte jurídico, generando una realidad de tal naturaleza que a su vez pueda dar pie al nacimiento de derechos y de su otra cara, a veces demasiado olvidada, los deberes.

Es, por tanto, la más importante instancia de producción de relaciones jurídicas, en primer lugar, en el aspecto cuantitativo. En segundo lugar, la autonomía de la voluntad, en sentido amplio, considerándola como poder de disposición normativo que excede al ámbito de la capacidad, a juicio de CAPILLA RONCERO, es previa y fundamentadora de cualquier capacidad o competencia legislativa o normativa de alcance general. Si la persona no contara con la capacidad ontológica para lo jurídico, y, en concreto, con capacidad autónoma de "normativizar" -gracias a su racionalidad-, sus relaciones sociales, no sería posible ningún Derecho "legislado" o "legal", en el sentido de produci-

666 VILLAVERDE MENÉNDEZ, I. "Igualdad en la diversidad. Formas de Estado y Derecho fundamentales", Centro de estudios Políticos y Constitucionales, Madrid, año 2012.

667 Cfr. CIFUENTES, S. "Negocio jurídico”, Ed. Astrea, Buenos Aires, año 2004. 
do por una autoridad pública legítima y de obligado cumplimiento por sus conciudadanos, la autonomía privada tiene un carácter personal, personalista más bien, y relacional, porque implica una toma de decisión en el ámbito interno pero en relación a los demás ${ }^{668}$.

Por otra parte, existe una primera limitación de la autonomía de la voluntad, que tiene que ver con su incapacidad o incompetencia para constituir o modificar derechos personalísimos, los derechos de la personalidad, que no pueden originarse ni perderse por causa de una voluntad autónoma, ni privada, ni estatal.

En cualquier caso, el tema de la autonomía de la voluntad nos remite a la consideración del hombre como sujeto de derecho, como sui juris, esto es, como sujeto en el orden social y jurídico con una connatural capacidad de autodeterminación o autogobierno, a nivel personal pero también familiar. El ser humano posee tal plenitud de ser que es ontológicamente capaz de gobernarse a sí mismo, porque se "posee a sí mismo" y no puede ser objeto de posesión de nadie. En su máxima dignidad ontológica, con poder de gobernarse a sí mismo, radica su autonomía. Por esto LORCA NAVARRETE afirma: "Y este poder -comprensivo de los derechos, obligaciones, relaciones, etc.,-

668 CAPILLA RONCERO, F. “Autonomía de la voluntad y Derecho de la persona; o la autonomía personal en el Derecho privado”, Diario La Ley, No 7675, Sección Tribuna, , Año XXXII, Ref. D-302, La Ley 13920/2011, páginas 1 y 2. "La categoría de la autonomía de la voluntad, de profuso empleo por los juristas y en especial por los iusprivatistas, ha sido tradicionalmente estudiada en el ámbito de las relaciones patrimoniales, para aludir a la capacidad de los particulares de crear reglas jurídicamente vinculantes sobre la base de su voluntad, materializándose fundamentalmente, como es bien sabido, en los instrumentos identificados con los conceptos de contrato y testamento. Presupuesto de esa autonomía es la libertad de decidir y su marco viene dado por el margen que el sistema jurídico habilita para que los particulares configuren el desenvolvimiento de sus relaciones jurídicas en el ejercicio de esa libertad.- El campo propio del Derecho de la persona, tal cual se entiende éste en la sectorización habitual (savigniana) del Derecho privado, ha permanecido ajeno durante mucho tiempo al enfoque que pivota sobre esa noción de autonomía de la voluntad. Las razones son variadas y merecen una mínima.consideración, para poner de relieve cómo paulatinamente se ha ido ampliando la relevancia jurídica de la libertad de configuración del estatuto jurídico de la persona, que ha pasado desde las orillas del foco proyectado por el Derecho privado a ocupar un papel central destacado. Enunciados de forma sucinta, los factores para provocar ese cambio pueden identificarse con los siguientes: de una parte, el ámbito personal se ha «iusprivatizado», esto es, ha dejado de estar extramuros del Derecho privado; de otra, el Derecho privado ha asumido los valores personalistas que con anterioridad eran sólo presupuesto, pero no objeto, del sistema jurídico codificado, apareciendo ámbitos de libertad de decisión (por ende, derechos) impensables poco tiempo atrás; también, la «privatización» del régimen jurídico de la autonomía personal ha precisado de técnicas con anterioridad ajenas a su campo, como los "consentimientos informados», las autorizaciones, las determinaciones unipersonales vinculantes, etc.; en fin, el desarrollo cientifico-técnico ha ampliado aceleradamente las posibilidades de decidir sobre asuntos que hasta hace poco estaban al margen de la libertad del individuo o que, en su caso, sólo se contemplaban jurídicamente como posible ilícitos penales.- Estos fenómenos, al menos en el Derecho general español, no han ido acompañados de la debida actualización de los textos legales básicos, sino que hemos cultivado hasta extremos indeseables la "especialidad legislativa», de suerte que las respuestas de nuestro sistema se des granan en infinidad de textos legales de la más diversa laya y calidad (a menudo, ausente de modo absoluto), con la consiguiente necesidad de desarrollar un esfuerzo de reconstrucción del conjunto del sistema. Para tal tarea desempeña un papel capital la centralidad de la Constitución; pero no es suficiente, pues el texto constitucional ni está diseñado ni tiene por función detallar el régimen específico y detallado de todas estas cuestiones, siendo pues necesario que se acometa un ambicioso proyecto de actualización normativa mediante una reelaboración sobre todo de nuestro Código Civil (como por demás nos muestran los ejemplos de algunos de los paises de nuestro entorno)." 
se desdobla en principio en un poder de constitución de las relaciones jurídicas así como en el poder de regular el contenido de dichas relaciones jurídicas ${ }^{\prime 669}$.

Es claro, pues que, para situar adecuadamente la autonomía, hay que volver a la teoría de la persona. Sólo es predicable la autonomía de la voluntad, como fuente creadora de Derecho, en el ámbito ontológico de lo personal, del único y verdadero sujeto de relaciones jurídicas que es la persona, y por supuesto en el ámbito personal, ámbito donde resulta fundamental el rol de la familia ${ }^{670}$.

La autonomía de la voluntad se materializa en la libertad civil de contratación, de disposición testamentaria, etc., de las personas físicas, pero también se proyecta respecto de las personas jurídicas, colectivas o morales. Éstas (asociaciones, empresas, fundaciones y corporaciones), poseen una relativa autonomía, que trae origen en la de las personas físicas que las integran y que se sitúa sobre todo, en la de sus órganos representativos y de gobierno, para realizar negocios jurídicos de toda índole, aunque con mayores limitaciones, estas se encuentran establecidas en sus estatutos y normas de régimen interno.

Como ha fundamentado FERRI en su estudio ya clásico y ya citado antes, sobre la autonomía privada “... En esta concepción debe verse la base más segura y la confirmación más clara de la utilidad de la categoría dogmática del negocio jurídico, cuya esencia es esencia normativa. En ella se condensa y se expresa la naturaleza de la autonomía privada y del negocio jurídico en su aspecto formal. Si la autonomía privada es poder que incumbe a los particulares de crear normas jurídicas, con ello queda perfectamente ilustrada la correlación entre los dos términos "autonomía privada" y "negocio jurídico", el segundo como manifestación de la primera" ${ }^{671}$.

Si el negocio jurídico es fuente normativa, y en esto sigo al autor recién mencionado, es porque contiene normas jurídicas, lo que hace que la autonomía de la voluntad deba ser considerada como un poder, atribuido por la ley a los particulares, de crear derecho, es decir, de establecer nor-

669 Vid. LORCA NAVARRETE, J. F., “Temas de Teoría y Filosofía del Derecho”, Ed. Pirámide, Madrid, año 1998, página 94.

670 El ser humano vivo (capaz de ser titular de derechos y deberes) en el Código era contemplado casi en exclusiva desde la óptica del eficaz, personal y confiable (en tutela de los terceros) ejercicio de sus derechos (y cumplimiento de sus deberes) a que obedece la categoría de la capacidad de obrar, medida en función de la madurez y equilibrio mental. De ahí la existencia de los estados civiles de mayor o menor edad de mayor y menor edad, y de incapacitación. Acompañados por otros, singularmente los familiares, que escondían la radical desigualdad con que se trataba a los componentes del grupo familiar, en cuya reglamentación interna apenas si entraba el Derecho, pues se articulaba su funcionamiento sobre la primacía del varón y padre: la mujer casada y los hijos menores quedaban bajo las potestades marital y paterna, sin apenas interferencias por parte del Derecho privado, como garantía de la predicada «autonomía» (mejor, infra o parajuridicidad) de las relaciones desenvueltas en el seno del grupo familiar, con la salvedad de las patrimoniales que sí eran atendidas por el Derecho privado, aunque también sobre la base de los principios de «autonomía» y jefatura paterno-marital.

Vid. FERRI, L. “La autonomía privada”, ...op. cit., páginas 36 y 37. 
mas jurídicas. El negocio, pues, es algo más que el resultado del ejercicio de un poder o de una potestad. Y la autonomía privada se identifica con este poder o potestad.

La autonomía de la voluntad, con gran desarrollo sobre todo en el campo del Derecho Privado, se ha visto progresivamente limitada por imperativos diversos. Estas limitaciones han de existir pero no debiesen ser demasiado amplias, de todas maneras debe evitarse otorgar al individuo una libertad desmesurada, con la consiguiente perturbación del orden, ni tampoco debe llegarse a suprimir la propia autonomía según LÓPEZ PINA ${ }^{672}$.

Los límites a la autonomía de la voluntad vienen impuestos por el respeto a los derechos fundamentales, que representan en la actualidad el sistema de valores que inspira diversos ordenamientos jurídicos en el mundo, entre ellos el español. Entre tales limitaciones puede afirmarse que los principios constitucionales consagrados en los arts. 1 y 10 de la Constitución (la libertad, la justicia y la igualdad como valores superiores del ordenamiento jurídico; la dignidad de la persona y el libre desarrollo de la personalidad como fundamento del orden político y la paz social), lo son, pero a su vez permiten inclinar, en la duda, la balanza a favor del respeto a la autonomía de la voluntad, que sin perjuicio de ser punta de lanza de la codificación y de sus cuerpos legales ahora revista una esencialidad por su trato en la carta fundamental, para ello recordamos la denominada constitución económica ${ }^{673}$.

672 LÓPEZ PINA, A. "La autonomía privada y los derechos fundamentales. Los intereses generales. Mandato constitucional.",UNED. Teoría y Realidad Constitucional, núm. 20, 2007, páginas 145 a 173. Dice el autor que: "Al respecto, tengo para mí que nuestra arquitectura constitucional arranca, en primer lugar, de la autonomía privada, de la que son elementos esenciales la propiedad privada y la libertad empresarial. Ahora bien, para que la libertad de cada uno sea conciliable con las de los demás, deberá ser limitada, plegándola a la primacía de los intereses generales. Y, así, el texto constitucional levanta como barreras a la autonomía privada, de un lado, la vertiente objetiva de los derechos fundamentales y los principios rectores de la política social y económica (arts. 39-52 CE). De otro, como cláusula constitucional específica, el postulado de la subordinación de la riqueza al interés general (art. 128 CE). En conjunto, alzan los intereses generales como clave de bóveda del orden jurídico."

673 PRATS ALBENTOSA, L. "La autonomía de la voluntad en el siglo XXI: objeto del 11. ${ }^{\circ}$ Congreso Notarial Español, conmemorativo del 150 Aniversario de la Ley del Notariado", Diario La Ley, No 7646, Sección Tribuna, 7 Junio2011, Año XXXII, Ref. D-235, La Ley 12094/2011, página 3. "La atención hacia la regulación de las relaciones entre particulares ha sido circunstancial y episódica, generalmente motivada por la necesidad de desarrollar un precepto constitucional, amparado en una demanda social ineludible, o en la inaplazable atención a exigencias derivadas, directamente, de intereses generales. Lo que ha dado lugar a la modificación de algunos preceptos de los referidos Códigos y Leyes decimonónicas; modificaciones que se han insertado en ellas como cuerpos extraños, cuando la realidad es justo la contraria: estas venerables normas son, en sí, cuerpos extraños en el Ordenamiento jurídico constitucional actual, que intenta paliar incompatibilidades extremas y realizar un loable esfuerzo de reinterpretación a fin de apuntalar su vigencia, casi formal, en un una sociedad que ya las ha sobrepasado. El aforismo «las Constituciones pasan, los Códigos permanecen» ha de ser superado. Nuestra Norma Fundamental ha de ser testigo de la sustitución de tales Códigos y Leyes de la España del pasado. Para lo que es preciso que el Legislador sea consciente de que ya es momento de atender a la regulación conjunta, ordenada y coherente de los derechos de los particulares. De articular la sociedad de los ciudadanos de acuerdo con normas que respondan a las necesidades y valores comunes de nuestra era. A este fin, no sólo es precisa la «voluntad política», también lo es la implicación de los agentes sociales, para que la impulsen y la asistan, tanto 
Ahora bien, en relación, a la de idea de que los actos emanados de la autonomía de la voluntad deben gozar de eficacia frente a terceros, y por lo tanto constituir pactos, en especial por las consecuencias que se derivan de la titularidad de los bienes y de la responsabilidad frente a terceros por las deudas contraídas, el problema no debe ser abordado tanto como una cuestión de validez sino de oponibilidad, de eficacia frente a terceros, conectado con los principios de seguridad jurídica y tutela del crédito.

En la práctica se presentan como especialmente conflictivos los pactos que incluyen renuncias anticipadas a derechos, como la prestación compensatoria o la compensación para el trabajo doméstico prevista en algunos sistemas para el régimen de separación, pero también para las parejas que conviven. En el mismo sentido parece razonable admitir la validez de todos aquellos pactos sobre derechos futuros que no tengan función alimenticia, porque sobre los alimentos futuros no cabe renuncia. Es preciso garantizar adecuadamente que el consentimiento se emite debidamente formado, descartando presiones y vicios de la voluntad ${ }^{674}$. En estas condiciones es posible la "renuncia" de un derecho que todavía no ha ingresado en el patrimonio.

en el proceso previo, como en el de la toma de la decisión y en el de su ejecución y puesta en práctica."

674 DE ÁNGEL YAGÜE, R. "La autonomía de la voluntad y la evolución de las formas de prestar el consentimiento”, Diario La Ley, No 7800, Sección Tribuna, 17 Feb. 2012, Año XXXIII, Ref. D-74, La Ley 2021/2012, páginas 2 y 3. "Consentimiento es palabra que, ciertamente, puede aplicarse a cualquier voluntad humana. Según el Diccionario de la Real Academia, la primera acepción es acción y efecto de consentir. A su vez, según la misma autoridad, consentir, acepción 5 (que es precisamente la que se indica en el Diccionario como específica del Derecho), se identifica con «otorgar», «obligarse». Y estos dos últimos verbos conducen a la idea del acto por el que una persona adopta por sí misma, es decir, unilateralmente, una decisión.- No obstante, consentimiento, desde el punto de vista etimológico y en una estricta perspectiva jurídica, mueve a una idea de, por lo menos, bilateralidad; es decir, lo que una persona expresa, no a otra o a otras, sino con otra o con otras. Cosa que no su cede en el caso de la palabra voluntad, que significa, sin más, libre albedrío o libre determinación. En este sentido es significativo que esa palabra (voluntad), presente desde luego en diversos lugares de nuestro Código Civil, sea, con mucha diferencia, la más utilizada en materia sucesoria, es decir, en los arts. 657 a 1087. - Decía que el Diccionario atribuye a consentimiento el significado de «acción y efecto de consentir», primera acepción. Pero la segunda, precedida de la observación de que es la propia del Derecho, dice que consentimiento es «conformidad de voluntades entre los contratantes, o sea entre la oferta y su aceptación, que es el principal requisito de los contratos». Lo cual, por cierto, concuerda con lo que nos dice el recurso al latín. - Por todo ello he querido entender, y asi se me ha permitido, que cuando el título de la ponencia habla de prestar el consentimiento, quiere decirse (...) declarar la voluntad. Dicho de otro modo, es a la declaración de voluntad, tan habitual en nuestro particular lenguaje, a la que he entendido que debía referirme.- La expresión declaración de voluntad, presente en los más tempranos pandectistas, se ha convertido en una de las principales de la terminología jurídica. Se encuentra ya en autores anteriores a Savigny, pero habia de ser éste el que la convirtiera en concepto medular de su brillantísima «construcción» del Derecho romano estudiado y aplicado en su época. Me refiero a la palabra alemana Willenserklärung, que en los diccionarios histórico-jurídicos se pone explícitamente en relación con la expresión latina declaratio voluntatis. El hecho es que la locución declaración de voluntad vino a ser luego aceptada, sin vacilación y con rara unanimidad, en los diferentes idiomas, por toda la doctrina europea. Me refiero, desde luego, a la continental, porque el mundo jurídico anglosajón refractario en general a los conceptos acuñados por la pandectística siguió expresándose con su propia terminología.- La declaración de voluntad vino, así, a dar nombre a uno de los «elementos» del concepto que probablemente ha sido objeto de una mayor elaboración por la ciencia del Derecho. Me refiero, desde luego, al negocio jurídico. Hasta tal punto es así, que para no pocos autores, el negocio jurídico es la declaración de voluntad. Por ejemplo, en Ennecerus; y, entre nosotros, en Albaladejo." 
Con independencia de que deba calificarse o no como auténtica renuncia (acto unilateral, de un derecho ya adquirido...) puede ser perfectamente lícita siempre que se respeten los límites que el ordenamiento impone a la autonomía de la voluntad. Desde este punto de vista, resultan excesivas las normas autonómicas que extienden las normas imperativas de protección de la vivienda familiar previstas para el matrimonio a las parejas, tanto durante la convivencia como al producirse su extinción, o las que imponen un deber legal de alimentos en caso de ruptura, o imponen una asignación compensatoria entre quienes tienen un hijo en común, aunque nunca hayan sido pareja. Frente a normas semejantes el debate debe centrarse en la idea de que el respeto al principio de igualdad y a la libertad aconseja establecer para las situaciones no formalizadas un régimen dispositivo, lo que dotaría de previsibilidad a los conflictos planteados, pero respetaría al mismo tiempo la voluntad de las partes ${ }^{675}$. Admitir la preferencia de la voluntad de las partes no es incompatible, por lo demás, con la consideración de otros correctivos, en particular con el juego de la cláusula rebus sic standi-

bus, cuya aplicación permitiría de modo absolutamente excepcional un contraste entre las conse-

675 DE LA TORRE OLID, F. En su estudio denominado "El contrato de mediación familiar. Aspectos relevantes desde su positivización por la Ley Balear 18/2006”, Diario La Ley, No 6765, Sección Doctrina, 25 Jul. 2007, Año XXVIII, Ref. D-180, La Ley 2758/2007, páginas 1 a 3. Propone que la conflictividad que se puede originar en el seno de la familia y entre personas que componen esta unidad se debe superar pacificando el enfrentamiento y solucionando el problema que lo desencadenara, o que lo ha desencadenado, aunque lo ideal es la actuación preventiva, mediadora. El Derecho debe prestar una solución, por cuanto la familia es una institución que ha de ser protegida por imperativo constitucional y su protección pasa por su estabilidad en cuanto en ésta reside la garantía de servir de sede natural e idónea de desenvolvimiento de la personalidad, al desarrollo de la misma, tal cual está garantizado por la Carta fundamental en el art. 10.1. Efectivamente, la función pacificadora del Derecho encuentra una oportuna y necesaria proyección en el ámbito familiar por razón de la institución misma, por cuanto por su propia naturaleza requiera de estabilidad, y siempre que los intereses de sus miembros sean de consideración jurídica con cierta relevancia. Siguiendo la política de estímulo de la solución extrajudicial de conflictos, antes que perseverar en la idea de entender que la tutela ha de ser judicial efectiva (Cfr. art. $24 \mathrm{CE}$ ), se confía en el mecanismo de la mediación familiar, instrumento donde existe un alto grado de actuación de la autonomía de los particulares envueltos en el conflicto. Y con el mismo se está confiando, a ultranza, en la solución autónoma, antes que el recurso a la heteronomía pública (judicial o administrativa) o privada (arbitral). Aunque, por ser la familiar una esfera de mayor privacidad y de, al tiempo, mayor preocupación desde el orden público, el protagonismo de la voluntad de los miembros de la familia que mantengan el conflicto se armoniza con la ordenación de la persona mediadora, un profesional instruido y formado para lidiar con esta clase de intimidades problemáticas, pero el cual está revestido de una naturaleza pública, de un connotación de confianza, por un necesario buen hacer que represente un papel activo (antes que el de un mero y más pasivo conciliador). Prosigue el autor afirmando que : "Como también, el desenvolvimiento de la privada composición, se encuadra en la esfera de lo público con la regulación de un procedimiento (en el marco de un contrato) dispuesto por ley y ofertado y disciplinado en su impulso, desarrollo y ejecución por la Administración (por lo que en sus principios se ha de completar la actividad de oficio con el principio dispositivo). Hablamos del contrato de mediación porque el protagonismo de la voluntad privada de los particulares-familiares en conflicto se traduce en una fuerza de tipo negocial en cuanto constituye (efecto constituyente) y preside el tratamiento (efecto informante) y la solución (efecto determinante), en su caso, del conflicto. Y es concurrente la voluntad de ese colectivo con la del mediador, entrelazándose en un vínculum iuris negocial y contractual desde la suma de la nota de bilateralidad con la de patrimonialidad. Pues bien, es este contrato el que nos ocupa, desde su tipificación que acuña el nomen iuris y que, además, añade el concepto que es descriptivo en cuanto se completa con la relación de unos caracteres definidores. Todo ello ya es una novedad que merece ser destacada y que, en cuanto manifestación de esa apuesta por ampliar y generalizar el cuadro de soluciones extrajudiciales de los conflictos, debemos contribuir a divulgar la figura para su conocimiento e implantación." 
cuencias pactadas y lo que podría exigirse en defecto de pacto. De esta forma, lo pactado sería válido pero ineficaz si en el momento de cumplirlo las circunstancias hubieran variado de modo imprevisible y extraordinario. Este planteamiento es coherente tanto con la consideración de la familia como elemento del complejo Estado social de Derecho proclamado por la Constitución como con la protección constitucional de la familia encomendada a los poderes públicos.

\subsection{La autonomía de la voluntad en materia familiar}

Seguramente tras la conciencia del individuo, la familia será el reducto donde pueda existir más autonomía, todo en ella se debe en parte a ese decidir pensando en el otro, y a veces y sobre todo en situaciones de crisis, no necesariamente en el bien de ese otro. La familia, su éxito o fracaso, aparece como el resultado de un juego de azar entre las diversas voluntades que la conforman. Voluntades autónomas, pero inmersas en un océano de intimidad.

Este mar de afecto, a veces calmo a veces violento, tiene olas de pasiones y esperanzas, que nacen y mueren ${ }^{676}$. Subsumir tales movimientos del corazón humano al entramado jurídico resulta una quimera, los mandatos del Derecho, sus fórmulas, soluciones, son como malecones que nada pueden hacer frente a la danza de tal océano, autónomo, humano, y por ende, inesperado. Los marineros que navegan estas aguas, los verdaderos actores, los que personalmente triunfan o fracasan, pese a que en ello les va la mayor parte de su vida o, más exactamente, la parte de la vida que más estiman, suelen quedar voluntariamente excluidos.

A la autonomía de la voluntad, la que estudiamos, casi exclusivamente, centrada en torno a la figura del contrato, se evita todo lo posible en las sucesiones y se convertía antes en un instrumento menor en materias sujetas al Derecho de Familia.

Las inevitables contradicciones internas que se manifiestan en la acuñación de nuevos valores y, sobre todo, en la circulación social de los mismos ha propiciado que algunas posiciones inicialmente muy minoritarias incidan sobre los rasgos sociales de ciertas instituciones familiares que permiten concebir normas en un determinado y concreto sentido después de leerlas, interpretarlas y aplicarlas en otro bien distinto sin que se evidencie ningún sentido de contradicción interna.

676 MARÍN GARCÍA DE LEONARDO, M. T., “Es indemnizable la infidelidad?”, Revista de Derecho de Familia, núm. 47, abril-junio 2010, Ed. Lex Nova, Valladolid, página 31. "Desde la perspectiva actual cada vez se aprecia más cómo en el Derecho de familia se concede una mayor relevancia a la autonomía individual de los integrantes, reforzando sus derechos individuales y la igualdad entre los cónyuges, por lo que se puede afirmar que existe un abandono progresivo de los privilegios de inmunidad en los daños entre ellos. Por el hecho de estar casados, los cónyuges no pueden alegar situaciones de privilegio, de supremacía o de vínculos de sujeción, sino considerarse particular y singularmente libres, iguales y completamente responsables, los unos frente a los otros y frente a terceros". 
La crisis matrimonial y familiar no puede contemplarse como una cuestión que se puede o se debe atajar, cerrando los ojos sobre la realidad, sino como una bien presente y que desde el Derecho se puede coadyuvar a la tarea de favorecer la aparición de soluciones, tanto por la vía de la cons trucción e interpretación doctrinales, como la de la pulcritud de la legislación esforzándose en el papel de neutralidad del Estado en el encauzamiento de problemas, asimismo por la aplicación exquisita de la ley en las intervenciones jurisdiccionales en vez de añadir más leña al fuego fomentado el decisionismo judicial, forma de actuación no prevista en el ordenamiento jurídico español tanto tradicional como constitucional ${ }^{677}$.

Estas soluciones, sin duda posibles, no se encontrarán, si se quiere generalizarlas, al contrario siempre debe considerarse que cada individuo es, lo sepa o no el sujeto, un mundo y cada relación, asimismo otro mundo más complejo que el anterior. Es preciso fomentar conductas racionales en materia de vivencia de las instituciones familiares, que eviten las confrontaciones, por ejemplo, en períodos de crisis de las mismas ${ }^{678}$.

677 PARRA LUCÁN, M. A., “Autonomía de la voluntad y derecho de familia”, Diario La Ley, No 7675, Sección Tribuna, , Año XXXII, Ref. D-304, La Ley no 13922/2011. "Las transformaciones de la familia y de las normas del Derecho de familia apuntan a un nuevo escenario en el que prevalecen los intereses individuales y aumenta la libertad personal. Resulta por ello imprescindible una revisión de los conceptos jurídicos claves utilizados para explicar el Derecho de familia, en particular, de los llamados «estados familiares» y de los «negocios jurídicos familiares», con el fin de profundizar en el ámbito en el que puede jugar la autonomía de la voluntad y sus límites. Los «estados familiares», tradicionalmente considerados materia de orden público, por entender que asi lo exigía el interés general de la organización social, han perdido gran parte de su significado. El viejo concepto de orden público se identifica hoy con las normas constitucionales que regulan los derechos fundamentales, en cuanto expresión del sistema de valores imprescindible en nuestro ordenamiento. Ello explica la posibilidad de acuerdos sobre muchas materias del Derecho de familia sobre las que hace años hubiera resultado impensable pactar (acuerdo sobre apellidos de los hijos, sobre la guarda y custodia, sobre la educación de los hijos, sobre la liquidación del régimen económico, pactos que modifican los derechos y deberes de los cónyuges...)."

678 REBOLLEDO VARELA, A. L. "Belicosidad derivada de la elección del régimen económico matrimonial (I y II) ’. Publicación: Aranzadi Civil-Mercantil num. 15/2003 parte Estudio. Ed. Aranzadi, SA, Pamplona. 2003. BIB 2003/1362. "Estas cuestiones son resueltas por el ordenamiento jurídico, tanto estatal como autonómico, partiendo de la admisión de un amplio juego del principio de autonomía de la voluntad de los cónyuges, o futuros cónyuges, en la determinación del contenido de sus relaciones patrimoniales a través del otorgamiento de capitulaciones matrimoniales -complementado con un sistema de publicidad registral para conocimiento de terceros-, y el establecimiento de un régimen legal o supletorio que oscilando entre los clásicos regímenes separatistas y de comunidad parcial según la legislación aplicable de que se trate, les da respuestas muy diversas, con consecuencias muy distintas, y que con frecuencia es necesario afrontar aun en la disolución y liquidación del régimen económico no contenciosas pues, como mínimo, la concreción de las titularidades está íntimamente relacionada, más bien vinculada, a actuaciones previas de determinación del haber hereditario del cónyuge premuerto con repercusión en los aspectos tributarios o en la futura partición.- Pero si tenemos en cuenta las situaciones conflictivas, la problemática derivada del régimen económico matrimonial puede plantearse frecuentemente durante la propia vigencia del régimen en las relaciones externas de los cónyuges con los terceros, bien actuando conjunta o separadamente, tanto en el ámbito de la administración y disposición de bienes como en la responsabilidad patrimonial por las deudas contraídas, cuestiones ambas a las que aparece unida inexorablemente la propia titularidad de los bienes. Pero igualmente se plantea entre los propios cónyuges, también en ocasiones durante la vigencia del régimen económico - en último término, del matrimonio-y, sobre todo, a su conclusión, con una especial fuerza en las crisis matrimoniales dentro de los procedimientos de separación $y$ divorcio, cuando el patrimonio conyugal alcanza un cierto nivel económico, en los que el grado de enfrenta- 
En primer lugar debe reflexionarse en torno a la autonomía de la voluntad y su ámbito concerniente a los regímenes económicos matrimoniales ${ }^{679}$. Este puede agruparse en dos direcciones, según palabras de RAMS ALBESA ${ }^{680}$.

La primera tiene lugar en el espectro de la libre elección de régimen prevista en el artículo 1.315 del Código Civil.

La voluntad efectiva es la manifestada por los contrayentes en la fase de formalización del expediente matrimonial, o en el caso de las parejas de hecho en los denominados pactos de conviven$\mathrm{cia}^{681}$, bien por la celebración de formales capítulos matrimoniales conforme a las previsiones actuales del Código para acordar un régimen distinto a los previstos sustitutivamente ante el silencio de los contrayentes, o bien sin necesidad de capitular, pero con manifestación expresa por acuerdo de consuno efectuada por los contrayentes ante el encargado de la instrucción del expediente matrimo-

miento de la pareja tiene una repercusión directa en la liquidación del régimen matrimonial, en la práctica casi siempre de corte comunitario fuera de los ámbitos territoriales en los que el régimen de separación de bienes es supletorio. Ello se refleja en el propio título del tema que me fue propuesto por la organización del X Encuentro de la Asociación Española de Abogados de Familia: ni siquiera «conflictividad» en relación con el régimen económico como indica el título general del Encuentro sino directamente «belicosidad», término que bien puede calificarse un tanto extraño en el ámbito jurídico civil pero claramente descriptible y perceptible en el ámbito del Derecho de Familia."

679 EIRANOVA ENCINAS, E. "El nuevo Derecho de Familia como sistema funcional”, Revista de Derecho de Familia, núm. 27, Ed. Lex Nova, Valladolid, año 2005, página 24. "La idea "institucional” del matrimonio y la familia era el presupuesto general que hasta hace poco determinaba y explicaba el régimen económico matrimonial. Desde el momento que la Constitución garantiza la libertad ideológica (art. 16 CE), dogmáticamente el régimen económico matrimonial tiene una dimensión diferente que lo sustituye: el régimen económico de las clases de familia... En terminología Hegeliana se diría que la "idea" del matrimonio. Lo que se "quiere" se ha impuesto a lo que se "debía" (Ius in causa positum: D.8, 2, 52, 2). De ahi que sean convenientes rectificaciones dogmáticas desde las que explicar el "matrimonio", la "familia” y su "régimen económico" en la actualidad.Entre los autores cada vez tienen más acogida las propuestas que optan por una perspectiva de examen estrictamente "contractual". De ella, se usan criterios eficientes para resolver los problemas (sobre todo, aunque no exclusivamente, los referidos al régimen económico de la familia) que se suscitan en las relaciones familiares. En estas propuestas el Derecho de Familia dejaría de estar presidido por criterios prácticos de finalidad (del matrimonio y la familia), para interpretarse a través de la función de "ajuste” en el entorno social en el que está."

680 RAMS ALBESA, J. “Autonomía de la voluntad y negocios jurídicos de familia”, Ed. Dykinson S.L., Madrid, año 2009, página 75.

681 REBOLLEDO VARELA, A. L., "El contrato de unión civil: la regulación de su contenido y efectos”, Revista de Derecho de Familia, núm. 43, abril-junio 2009, Ed. Lex Nova, Valladolid, páginas 23 a 54. El autor sostiene en relación al tema tratado que: “(...) no presenta mayor controversia que los efectos jurídicos que la unión estable de pareja deba producir entre los convivientes, especialmente en sus aspectos patrimoniales, deben ser voluntariamente convenidos en los llamados "pactos de convivencia". Ahora bien, no tiene mayor interés solucionar los problemas prácticos de esta realidad social a través de un genérico reconocimiento del valor del principio de autonomía de la voluntad pues, superados planteamientos de moral y orden público, la validez de éstos ya hace mucho tiempo que ha sido reconocida por la jurisprudencia. La cuestión reside, aparte de analizar el contenido de los pactos, en determinar cuál sería el régimen jurídico y los efectos que deberían producir en defecto de convenio entre los convivientes -lo que se trata a continuación- y si, en todo caso, determinados efectos de contenido económico deberían producirse necesariamente superponiéndose incluso a la voluntad de las partes." 
nial en el registro civil manifestando que opta por uno de los tres regímenes que regula, el Código civil en el Título III del Libro IV.

Para alcanzar una solución conveniente, según palabras del propio RAMS, bastaría una mínima reforma de los artículos 1315 y 1316 del Código Civil ${ }^{682}$.

La segunda dirección se orienta a la derogación sin más del art. 1328 del Código Civil, debido a que no añade ni una sola idea jurídica distinta de las que adornan al art. 1255 y sólo sirve para confundir cualquier interpretación racional de la igualdad pues este derecho viene impuesto por la ley.

El artículo 1328 del Código Civil es muy similar a su precedente el art. 1316 en su versión original de $1889^{683}$.

Posiblemente con tales ajustes se abriría una vía de racionalización en la celebración del matrimonio, que en nuestra sociedad actual, se conforma con entender que este contenido está subsumido en el consentimiento matrimonial. De esta manera se quiere entender que en él se incluyen todas las reglas, así como todos y cada uno de los derechos y deberes de los cónyuges.

En relación a la interpretación de los pactos que inciden en los regímenes económicos, se debieran abrir otras vías de interpretación e integración de normas encaminadas a respetar el sentido dispositivo de muchas de las reglas de los regímenes tipificados.

En el régimen de gananciales deberían entenderse modificables por acuerdo capitular algunas de las fuentes de ganancialidad que fueron pensados en términos de justicia despersonalizada y abstracta $^{684}$ como el que hace referencia a los establecimientos abiertos constantes de la sociedad pero a partir de una empresa privativa a las que se hace referencia en el artículo $1347.5^{\circ}$ del Código Civil; a las reglas sobre pago con precio aplazado en los artículos 1354 y 1357; a la llamada accesión económica del inciso segundo del artículo 1359 y a la del artículo 1360; a las reglas de inclusión y exclusión en la alimentación de hijos de uno sólo de los cónyuges del art. 1362.1 a inciso segundo; la aclaración y simplificación de las potenciales interpretaciones contrarias entre los artículos 1362 y 1365 (responsabilidades definitiva y provisional de la masa común); la admisión de gestiones especiales encargadas o pactadas fuera de capitulaciones matrimoniales, pero acordadas en documento público; las ineficaces e inútiles reglas de imposición de la cogestión y el inevitable y paralelo exce-

682 RAMS ALBESA, J. “Autonomía de la voluntad y negocios jurídicos de familia”...., op. cit., página 76.

683 La antigua redacción era de la manera que sigue: "En los contratos a que se refiere el artículo anterior (capitulaciones) no podrán los otorgantes estipular nada que fuere contrario a las leyes o a las buenas costumbres, ni depresivo de la autoridad que respectivamente corresponda en la familia a los futuros cónyuges"

684 Cfr. VV. AA., "Problemática jurídica de los bienes y deudas que no se incluyeron en el inventario de la sociedad de gananciales", Revista de Derecho de Familia, núm. 40, julio-septiembre 2008, Ed. Lex Nova, Valladolid, páginas 301 a 304. 
so de previsiones de intervención de los jueces, convirtiendo las discrepancias en conflictos jurídicos abiertos; simplificación de la liquidación de la sociedad y previsión de que ésta se pueda efectuar sin necesidad de disolución ni del matrimonio ni del régimen; y, por último, facilitar la liquidación y partición de la sociedad con atribuciones preferentes, así como posibilidad de ampliar éstas ${ }^{685}$.

Para el régimen de separación se debería poder interpretar libérrimamente el artículo 1438 sobre la participación en el levantamiento de cargas donde se impone cada vez más un intervencionismo absolutamente injustificado; en el art. 1440, inciso segundo, no se tiene en cuenta que el artículo 1319 fue redactado pensando en la sociedad de gananciales y naturalmente no casa con el propósito práctico de la separación de bienes; para la interpretación de la presunción se debe tener en cuenta que incluso en Cataluña es un cuerpo extraño introducido a mediados del siglo pasado, muy a pesar de los fundamentos romanos, tal cual lo deja entrever RAMS ALBESA ${ }^{686}$.

Pero y ¿qué sucede con los pactos previos sobre las relaciones conyugales y su extinción, incluso los que pueden celebrarse al interior de los more uxorio?, se pregunta SALAS CARCELLER $^{687}$. Bajo las reglas de indisolubilidad del matrimonio e incluso con las del divorcio-remedio, debiendo incurrir uno de los cónyuges en una de las causas tipificadas para ello, era una lógica consecuencia entender que la vida matrimonial debía regirse por una serie de convicciones y conductas previstas, el matrimonio tenía que vivirse conforme a las reglas específicas de una moral matrimonial.

En la perspectiva actual, coincidente con la Roma clásica, de que el matrimonio nace y persiste en tanto que entre los cónyuges se mantenga la personal y subjetiva affectio matrimonialis, no puede sostenerse, amparados en el Derecho positivo los derechos y deberes matrimoniales son y deben ser universales y objetivos.

El mundo occidental está asistiendo a una subjetivación de la institución matrimonial, por lo que ésta obedecerá y responderá a las ideas, convicciones y acuerdos que los cónyuges establezcan,

685 RAMS ALBESA, J. “Autonomía de la voluntad y negocios jurídicos de familia”, .....op. cit., página 79.

686 RAMS ALBESA, J. "Autonomía de la voluntad y negocios jurídicos de familia”, ... op. cit., página 79.

687 "Uniones de hecho y premios económicos", Revista Aranzadi Doctrinal num.. 2/2010, parte Comentario, Ed. Aranzadi, SA, Pamplona. 2010 "Desde luego el hecho de no contraer matrimonio apunta claramente hacia una voluntad común de seguir un régimen jurídico patrimonial de absoluta separación de bienes, salvo aquellos supuestos especialmente queridos en que se proceda a la adquisición conjunta o en comunidad pro indiviso por ambos convivientes. La realidad es que en el ámbito de tales relaciones personales y, singularmente, en sus inicios en que está presente la ilusión por la convivencia, existe un desinterés por los temas patrimoniales que suele acompañar a la «ceguera» que impide contemplar la posibilidad de una posterior ruptura -incluso traumática, como tantas veces ocurre-e incluso parece como una muestra de indeseable desconfianza el hecho de que se propongan pactos previos de contenido patrimonial que, incluso para los supuestos de celebración de matrimonio, ya son frecuentes en varis países, singularmente en Estados Unidos." 
si bien solo tendrán trascendencia en la medida en que esas se plasmen en estipulaciones capitulares; de lo contrario habrá que conformarse con las recomendaciones sin acciones jurídicas, para hacerlas efectivas, de los paupérrimos artículos 67 y 68 del Código Civil, pues su incumplimiento y desatención no son ni siquiera causa de separación o de divorcio, como mucho se podrá ver en ellos y en caso de controversia meras motivaciones psicológicas que puedan dar lugar a la aparición de la desaffectio. Claro está que la affectio puede desaparecer cumpliendo generosamente con el contenido material y formal de estos dos artículos ${ }^{688}$.

Los pactos prematrimoniales pueden versar sobre múltiples cuestiones, que van desde dar contenido explícito a los conceptos jurídicos indeterminados el "respetarse" , "ayudarse mutuamente", de "guardarse fidelidad" o el "vivir juntos", a asegurar los contenidos con fijación económica del daño que su incumplimiento genere, hasta fijar criterios de colaboración ante la desaparición de la affectio matrimonialis previendo el sometimiento de los cónyuges a arbitraje sobre los efectos de la ruptura o la fijación previa del montante de las compensaciones.

El estudio de la incidencia de la autonomía de los sujetos en materia de Derecho de familia se dice "está de moda" 689 , calificándose recientemente como el tema estrella dentro de esta rama del ordenamiento. Son muchas las manifestaciones de este principio en el ámbito de las relaciones familiares, especialmente entre los cónyuges o las parejas, no porque se trate de un tema nuevo que no lo es, sino porque se intenta buscar en la libertad de regulación de los sujetos la posible solución a los problemas que les incumben, para los que no siempre parecen adecuadas ni las reglas del ordenamiento, ni la intervención de los tribunales cuando intentan resolver problemas que podrían no haber surgido con una mínima previsión por parte de los interesados ${ }^{690}$.

Parece tratarse de un movimiento general que trasciende a las meras relaciones personales y patrimoniales, implica una alternativa a los modelos de protección de los intereses de las personas, dirigidos desde los Poderes públicos o desde las diversas instancias del Estado. Estos asumen su propia inoperancia para la adecuada solución y tratamiento de muchas de las cuestiones que afectan

688 RAMS ALBESA, J., “Autonomía de la voluntad y negocios jurídicos de familia”, ...op., cit., página 82 y 83.

689 Vid. ROCA I TRIAS, E. “Autonomía, crisis matrimoniales y contratos con ocasión de la crisis”, ABRIL CAMPOY, J.M. y AMAT LLARI, M. ${ }^{a}$ E. (Coords), "Homenaje al profesor Lluis Puig I Ferriol”, Ed. Tirant lo Blanch, Valencia, año 2006, página 2108, valorando el crecimiento constatado en el otorgamiento de capitulaciones matrimoniales.

690 LACRUZ BERDEJO J.L. “El nuevo contractualismo en el Derecho de familia”, La Ley, año 1982, n 3, página 729. El autor trata sobre los nuevos espacios que se ofrecían a la libertad de pacto, como el ejercicio de la patria potestad, la fijación del domicilio o del nivel de vida de la familia o las condiciones en que van a quedar los anti guos integrantes de la familia tras 1 separación o el divorcio. 
a los particulares. Los modelos excesivamente protectores o tuitivos de los individuos en algunas ocasiones resultan ser poco adecuados al libre desarrollo de la personalidad ${ }^{691}$.

En materia de relaciones entre los cónyuges, en especial las de carácter económico, con ocasión de la reforma del Código civil de 1981 y el novedoso reflejo de los principios plasmados en la Constitución, se observó claramente una tendencia interpretativa dirigida a la consecución de la igualdad entre los esposos y la ausencia de tratamiento discriminatorio.

La radical transformación entre la posición del marido y la mujer antes de la reforma de 1981 esencialmente en el régimen de gananciales y la instauración de reglas que determinan la gestión y administración conjunta, o la contribución por igual y sin distinciones al levantamiento de las cargas han puesto el acento, en más ocasiones de las debidas ${ }^{692}$, en la consecución de la igualdad como

691 DE AMUNATEGUI RODRIGUEZ. C. "La libertad de pacto en el régimen de separación de bienes" en "Autonomía de la voluntad y negocios jurídicos de familia", (V.V.A.A.), Ed. Dykinson, S.L., Madrid, año 2009, página 122. Esta autora se refiere al movimiento de encorsetamiento, que hoy también tendría lugar en la regulación de las parejas estables, que sin mayor justificación, lleva un camino paralelo. El legislador, o mejor, los legisladores han decidido tomar partido por la defensa de los intereses de las parejas, con reglas tuitivas, en algunas casos indisponibles, fuera de la autonomía de los interesados, para proteger el modelo de unión que cada uno considera merecedor de su tutela, con un exagerado e innecesario proteccionismo que está limitando la libertad de los interesados. "Se puede observar así la paradoja de que es mayor la protección que dispensa el legislador para algunas parejas respecto del tratamiento más liberal, que dispone para las relaciones conyugales. Es lo que sucede en el Derecho Balear donde se llega al proceder de atribuir a los integrantes de las uniones de hecho derechos que no se reconocen a los matrimonios baleares casados en régimen de separación, configurando tradicionalmente como un modelo de libertad e independencia entre los esposos (por ejemplo, en cuanto a reconocimiento de posibles pensiones o compensaciones que concede el art. 9 de la Ley 18/2001 de Parejas Estables que no se atribuyen por la Compilación de Derecho Civil de las Islas Baleares a los cónyuges). No se trata de hablar de constitucionalidad o no en base al distinto tratamiento dispensado, sino tan sólo de señalar el absurdo quehacer de un legislador autonómico que debería ser mucho más sensible a la idiosincrasia o realidad sociológica que impera en su ordenamiento, mostrándose por el contrario inconsecuente con los principios que inspiran el Derecho balear de los que se prescinde sin justificación posible. No obstante y curiosamente el legislador balear ha vuelto a retomar la cuestión de las parejas copiando, lamentablemente, el poco ortodoxo, y que por tanto no debía ser adoptado como modelo, modo de proceder del legislador estatal de aprovechar la publicación de una ley para, en contra de la más elemental sistemática colar algunas disposiciones sobre cuestiones ajenas al título o finalidad de la norma. En concreto, en la Ley 3/2009, de27 de abril, del Parlamento Balear, sobre causas de indignidad sucesoria y desheredamiento, se ha incluido una Disposición Adicional, por la que se modifica la Ley 18/2001, de 19 de diciembre, de Parejas estables, añadiendo un apartado cinco al artículo 5 de la Ley, relativo al régimen económico de la pareja, con el siguiente tenor: "En todas las relaciones patrimoniales, si consta convivencia, será de aplicación supletoria el artículo 4 de la Compilación de Derecho Civil de Illes Balears" (...) Las dificultades de entendimiento de esta nueva previsión en el contexto de la inscripción constitutiva que requiere la ley balear de parejas a los integrantes de la pareja para que sean aplicables sus disposiciones contrasta con la extensión a los simples "convivientes" de las reglas que disciplinan el régimen económico matrimonial. Parece que algunos legisladores ya han advertido la presencia del peculiar fenómeno descrito anteriormente intentando retroceder en el tratamiento de la cuestión como claramente se pone de manifiesto al consultar el Proyecto de Ley de Libro II del Código civil de Catalunya."

692 Existen reglas como el artículo 1373 del Código Civil que se consideran erráticamente como una aplicación del principio de igualdad entre los esposos, cuando en la práctica se han desarrollado en ámbitos completamente ex traños a esa inspiración formando parte, más bien, de los comportamientos acordados entre los esposos para in tentar poner a salvo parte de sus patrimonios. Ver sobre la cuestión las consideraciones de GUILARTE GUTIERREZ, V., "La sociedad de gananciales: desde la comunidad germánica al caos liquidatorio", en "Estudios jurídicos en Homenaje al profesor Luis Díez-Picazo," Tomo III, Ed. Thomson Civitas, Madrid, año 2003, páginas 4692 y siguientes. 
equivalente a la presencia conjunta de los esposos en todos y cada uno de aquellos pactos en los que uno pudiera ostentar una postura distinta al otro ${ }^{693}$.

Pero, tal cual pregona la doctrina, la esencia y el adecuado entendimiento de la igualdad debería suponer la posibilidad de cada cónyuge de gestionar directamente, sin intermediación del otro, todos sus bienes y derechos privativos y ejercer su profesión u oficio con entera libertad sin requerir licencia o aquiescencia del otro cónyuge y sin poder oponer éste prohibición alguna.

Por otra parte, en numerosas ocasiones puede observarse igualmente una cierta confusión pues se tiende a identificar la autonomía patrimonial, en el sentido de existencia de patrimonios independientes en cuanto a responsabilidad frente a terceros, con la autonomía en la gestión y administración de los mismos, cuando se trata de situaciones diferentes ${ }^{694}$. Por eso suele ser frecuente afirmar reconocer una mayor presencia de autonomía en el régimen de separación de bienes, lo que no es del todo exacto, pues de lo que se trata no es de que en los regímenes separacionistas los cónyuges dispongan de una mayor libertad de contratación, sino de que sus actos responsabilizarán, en la gran mayoría de los casos y por disposición de la ley, su patrimonio propio, y no el común o incluso el del otro como puede ocurrir en la sociedad de gananciales.

Pero con independencia de las consecuencias patrimoniales de su actuación los cónyuges pueden, tengan el régimen que tengan, realizar todo tipo de negocios y contratos entre ellos ${ }^{695}$, entre es-

693 La confusión entre la igualdad entre los cónyuges y la necesidad de evitar para el futuro la posición preeminente del marido se observa especialmente en la consagración de la gestión conjunta de los gananciales cuando el establecimiento de la gestión indistinta, recogida en otros ordenamientos, en nada afecta la igualdad. Sobre el parti cular consultar GUILARTE GUTIERREZ, V., "La sociedad de gananciales caducidad de un modelo", Propiedad y Derecho civil, Centro de Estudios Registrales, Madrid, 2006, página $42 \mathrm{y}$, extensamente, recogiendo distintas tendencias doctrinales sobre la libertad de pacto respecto de la gestión en RAMS ALBESA, J., "La sociedad de gananciales”, Ed. Tecnos, año 1992, página 195 y siguientes.

694 Precisamente DE LOS MOZOS, J.L. en "Comentarios al Código Civil y a las Compilaciones Forales", ALBALADEJO GARCIA, M. (Dir), T. XVIII, vol. 1. ${ }^{\circ}$ (arts. 1315 a 1343), Ed. Edersa, $2^{\text {a }}$ edición, Madrid, año 1982 hablando de los principios inspiradores de la reforma de 1981 destaca el principio de "individualidad" de la res ponsabilidad, que se corresponde con los de igualdad y libertad, "principio que se desenvuelve como una exigencia de la lógica de las cosas, claramente presente, hasta ahora en los régimenes separacionistas".

695 STS, Sala de lo civil, Sección 1a, núm. 162/2009 de 10 marzo. RJ 2009/1637 "Contra esta sentencia se alza en casación el marido por vía de interés casacional en la modalidad de oposición a la Jurisprudencia de esta Sala, -recurso que fue admitido por auto de esta Sala de 17 de enero de 2006, al haberse justificado el presupuesto de recurribilidad previsto en el artículo 477.2, $3^{\circ}$ de la Ley de Enjuiciamiento Civil 1/2000 y concurrir los requisitos legalmente exigidos-, aduciendo que la Audiencia ha resuelto la cuestión objeto de debate reconociendo a la esposa el derecho a pensión compensatoria transgrediendo así, por inaplicación, tanto la doctrina de los actos propios como la formulada por esta Sala en torno a los artículos 1091 y 1258 del Código Civil, incurriendo también en interpretación errónea y aplicación indebida del artículo 97 del mismo cuerpo legal y de la doctrina sobre los presupuestos que han de concurrir para la concesión de la pensión por desequilibrio. En particular, y por lo que se refiere a la infracción de la doctrina de los actos propios, expone el recurrente que, siendo éstos expresión del consentimiento y vinculantes para a su autor por causar estado y definir unilateralmente la situación jurídica del mismo, como tal acto propio de la esposa, vinculante para la misma a la hora de impedirle reclamar pensión por desequilibrio, debe entenderse el Pacto IV de las Capitulaciones de 24 de marzo de 1998 , toda vez que en dichas capitulaciones los cónyuges, además de modificar el régimen económico matrimonial adoptando el de separación de bienes, acordaron en el Pacto IV que "los gastos de cada uno de los cónyuges, 
tos se contemplan también las capitulaciones matrimoniales, incluso alterando las iniciales posiciones de "pretendida igualdad" previstas en el Código Civil ${ }^{696}$. Aunque pueda parecer, como ya ha quedado expuesto, que en el régimen de separación existe más libertad para los cónyuges. Lo cierto es que el ámbito al que se extiende la autonomía de la voluntad de los sujetos en la práctica se presenta más reducido. Por así decirlo, es un régimen más propicio para pactar, pero en el que el pacto resulta más innecesario. Por el contrario, es el régimen de gananciales el que, en la actualidad, presenta mayores disfunciones exigiendo cada vez más de una cierta modalización para adecuarse a la satisfacción de las necesidades concretas y específicas de cada matrimonio.

Todos los pactos que intenten introducir elementos separacionistas en el régimen de gananciales, o comunitarios en el de separación no pueden atentar o contravenir el principio de igualdad, sin más, tampoco el límite de las reglas imperativas, y menos alterar la materia de orden público ${ }^{697}$. Es el propio legislador el que nos ofrece poder optar por el modelo contrario, luego no puede predicarse la existencia de límite alguno en la medida en que los esposos adopten medidas de tipo intermedio. Por ejemplo, someter a especiales reglas de gestión ciertos ingresos en el régimen de ganancia-

de cualquier tipo y en cualquier circunstancia, serán a cargo exclusivo del que los produjere, sin posibilidad de repercusión alguna frente al otro y sus bienes ", dejando así patente la voluntad de ambos esposos de desvincularse totalmente del otro a nivel económico, lo que, en suma, suponía una renuncia de la esposa, y un impedimento a la hora de reclamar la pensión que, pese a ello, le ha sido reconocida. En torno a la segunda infracción, por inaplicación de los artículos 1091 y 1258 del Código Civil, se argumenta que el citado pacto IV de las Capitulaciones, por tratarse de una estipulación de carácter contractual, genera obligaciones que tienen fuerza de ley entre las partes (artículo 1091 CC; pacta sunt servanda), añadiéndose que dichas obligaciones contractuales comprenden además (artículo 1258 del Código Civil) las consecuencias derivadas de la buena fe, del uso y de la ley, habiendo incurrido la demandada en mala fe desde el momento en que actuó contra sus propios actos al reclamar pensión pese a admitir su independencia económica. Finalmente, para fundamentar la pretendida interpretación errónea y aplicación indebida del artículo 97 del Código Civil y la doctrina de esta Sala contenida en las Sentencias que cita, se alega que la pensión compensatoria no está concebida para compensar una posible lesión derivada de la liquidación del régimen económico matrimonial, de modo que como la liquidación de la sociedad de gananciales supuso una "equiparación cuantitativa de los cónyuges”, no puede hablarse de desequilibrio que justifique la concesión de pensión compensatoria a favor de la esposa y a cargo del marido."

696 Otra cosa será que el régimen de gananciales, por su compleja naturaleza, dificulte la realización de algunos desplazamientos patrimoniales entre los esposos, tema independiente de la igualdad o no entre los cónyuges y de la libertad de contratación entre ellos.

697 RDGRN (Propiedad), de 16 abril 2003. RJ 2003/4035 “El carácter mudable del régimen económico del matrimonio como consecuencia de la libertad de convención que sobre el mismo se concede a los cónyuges (cfr. artículos 1315, 1325 ó 1326 del Codigo Civil puede dar lugar a supuestos tan poco frecuentes como el que ha alumbrado el presente recurso en que, pacta inicialmente la separación de bienes entre los cónyuges, se pasa después, constante matrimonio, al régimen de comunidad de la sociedad de gananciales pero con una importante matización, la pretensión de hacer comunes, a través de un sistema cuya falta de claridad es lo que ha suscitado el recurso, los bienes adquiridos y las deudas contraidas por cualquiera de ellos desde el momento de la celebración del matrimonio o sea, mientras rigió entre ellos la separación de bienes. Y todo para culminar en un momento en que disuelta la sociedad de gananciales por divorcio aunque pendiente de liquidación según se dice, se pretende por uno de ellos inscribir como un bien que habia adquirido el otro en la fase inicial del matrimonio, aquellas en las que regía el régimen de separación de bienes, acudiendo a tal fin a un negocio de aportación del bien a la sociedad de gananciales en el que, junto con su consentimiento, presta el de una antigüedad esposa haciendo uso de las facultades que reciprocamente se había conferido a tal fin en la escritura que recogía el citado cambio de régimen (sic)." 
les ( los que provienen del ejercicio profesional o empresarial de un cónyuge), o de determinados grupos de bienes no puede contravenir el principio de igualdad, pues el propio Código pone a disposición de los particulares un régimen -el de separación- en el que esa es la regla general, o, por el contrario, establecer, en el arco de separación, que sólo se contribuya al levantamiento de las cargas con los ingresos de la actividad profesional o empresarial de uno de los esposos y no con el capital mobiliario o inmobiliario del otro no puede decirse que infringe preceptos constitucionales cuando esa es la consecuencia que se sigue en muchas ocasiones de estar casado en régimen de gananciales. Podrán en ocasiones conculcarse otros límites -como el respeto a las reglas imperativas o al principio de legalidad- pero no la igualdad entre los esposos, tal cual afirma DE AMUNATEGUI RODRIGUEZ $^{698}$.

En este sentido resulta cuanto menos llamativo que no se suela plantear, por aquellos que defienden la radical igualdad en todos los ámbitos y aspectos del régimen de gananciales- proscribiendo los pactos por los que pudieran sustraerse ciertos bienes del control, la administración y la gestión del otro, qué sucede con aquellas previsiones que, introduciendo aspectos comunitarios en regímenes de separación, conllevan en la práctica que uno de los esposos vea disminuida su capacidad de libre disposición sobre sus propios bienes. En ese caso no parece observarse ninguna infracción a la igualdad, a pesar de autolimitarse un cónyuge perdiendo parte de las facultades que le asistían inicialmente, pero si resulta anómalo el no permitir en el régimen de gananciales que uno de los esposos interfiera en la gestión empresarial del otro.

Por tanto, pasado un tiempo de reflexión desde la reforma de 1981, sin atisbo de duda en cuanto a qué deba significar la igualdad entre los esposos y su posición dentro del matrimonio, deben afrontarse las relaciones entre los cónyuges con una cierta perspectiva favorable al reconocimiento de una mayor libertad y respeto del ámbito de responsabilidad de los sujetos para permitir que puedan decidir sobre algo tan privado como sus relaciones personales o patrimoniales, ajustándolas a sus necesidades concretas y reales, con la adecuada dispensa a la protección de terceros, y aprovechando las importantes posibilidades de actuación para la voluntad de los esposos que ofrece el texto de la ley debidamente interpretado.

698 "La libertad de pacto en el régimen de separación de bienes”, ...op. cit.., página 126. En ella la autora expone que no comparte por ello la opinión expresada por GARCIA RUBIO, M. a P. en "Alimentos entre cónyuges y entre convivientes de hecho”, Ed. Civitas, Madrid, año 1995, página 48, cuando afirma categóricamente la nulidad de cualquier pacto que pretendiera establecer una regla de contribución a las cargas que no fuera la de la proporcionalidad, manifestando que "solo esa proporcionalidad respeta escrupulosamente la imperativa igualdad de derechos y deberes entre el marido y la mujer”. En mi opinión la proporcionalidad no existe como principio en el régimen de gananciales, pues los gananciales como una regla inderogable en el de separación pudiendo existir pactos sobre el particular que no tienen porqué considerarse contrarios a la igualdad, aunque volveré sobre esto más adelante. 


\subsection{Modificaciones en el concepto de la familia que pudieran haber influido en la autonomía de la voluntad}

Puede afirmarse que, en el momento presente, el marco de las relaciones familiares, y muy especialmente de las conyugales, demanda revisiones y reformas constantes, pues el modelo tan minuciosamente regulado y previsto por el legislador en 1981 está sometido a constantes transformaciones. Sin duda los textos y los ideales de la reforma han envejecido mucho más rápidamente de lo que cabría esperar al ser superados por la velocidad del cambio operado en la sociedad española, en el seno de las familias y en los roles en ella asignados a los distintos componentes, así como en la mentalidad y valores morales de los individuos de quienes, en definitiva, dependen las estabilidades y los cambios $^{699}$. Para describir las transformaciones experimentadas se habla insistentemente de una desregulación de modelos familiares, de una subjetivación del derecho de familia, o de una mayor contractualización o privatización del mismo. No puede negarse la veracidad de todas estas afirmaciones que, lejos de poder considerarse como apreciaciones personales o meras reflexiones sociológicas, describen a la perfección la modificación de un aspecto de la realidad al que no terminan de ajustarse las reglas rígidas, impuestas con carácter general o sustraídas al ámbito de la regulación de los particulares invocando inadecuadamente exigencias constitucionales de igualdad ${ }^{700}$.

Parece que el modelo tuitivo, proteccionista o intervencionista de las relaciones entre los cónyuges no es el más adecuado para resolver las exigencias que demanda el funcionamiento económico de las familias en la realidad diaria, ni resulta igualmente que la solución a los problemas que presenta la gestión cotidiana de la economía familiar tenga que alejarse de los parámetros que reglamentan otras relaciones patrimoniales ${ }^{701}$. Más bien al contrario, serán los esposos los que conozcan cuál sea la situación concreta y específica que presenta su familia y en consecuencia deberán adaptar las reglas del ordenamiento, dispositivas claro está, a sus exigencias particulares estableciendo un régimen personalizado que tan sólo puede modalizarse mediante el reconocimiento de su poder de autorregulación.

No puede cuestionarse en el momento presente que las normas que disciplinan el régimen económico del matrimonio responden a las exigencias de un modelo que cada vez coincide menos

699 Cfr. ALONSO PÉREZ, M. "La Familia entre el pasado y la modernidad. Reflexiones a la luz del Derecho civil”. Actualidad Civil, La Ley 2338/2001, Sección Doctrina, Madrid, año 1988.

700 RAMS ALBESA, J. En VV. AA. “Autonomía de la voluntad y negocios jurídicos de familia”, ... op. cit., página 127.

701 https://buleria.unileon.es/bitstream/handle/10612/1505/Hum8 art8.pdf?sequence=1. HERNÁNDEZ CORROCHANO, E. "Modelos de familias en España: Entre la permanencia y el cambio. El caso concreto de Castilla y León". 
con el estándar de familia que se establece en España, muy alejado de aquel que inspiró a legislador de los ochenta ${ }^{702}$.

Ciertamente es algo sobradamente conocido pero la incorporación de la mujer al trabajo, el descenso del número de hijos, o la inestabilidad matrimonial actual, con la consiguiente formación de nuevos y sucesivos núcleos familiares, proyectan un patrón de convivencia sustancialmente diferente del presente hace casi treinta años.

Esas transformaciones están siendo tenidas en cuenta por el legislador cuando aborda la reforma puntual de algunas instituciones en particular, como puede ser el radical cambio operado por las leyes $13 / 2005$ y 15/2005 en materia de matrimonio y divorcio ${ }^{703}$. El establecimiento de una ruptura unilateral del matrimonio con un divorcio que más que objetivo puede calificarse de sin causa, teniendo en cuenta el tratamiento que en la práctica diaria de los tribunales se está dispensando al mismo, determinará en un plazo más o menos próximo que los esposos, mediante acuerdos prematrimoniales, intenten remediar las consecuencias que presente el divorcio en su caso concreto procediendo a valorar circunstancias personales que antes eran objeto de valoración judicial. En relación a esto último cito los denominados planes de parentalidad que se manifiestan en el Libro Segundo del Código Civil de Cataluña, los cuales expresan la forma concreta en que ambos progenitores ejercerán sus responsabilidades parentales, estos serán analizados más adelante.

Lo anterior permite reflexionar sobre si el actual entendimiento del matrimonio como una unión en la que cada vez se acentúa con más fuerza la igualdad entre los cónyuges lleva a potenciar la libertad de actuación de cada uno de ellos y con ello desaparece el sentido proteccionista del más débil. En estos planteamientos subyacen ciertas ideas de tintes feministas que postulan un modelo de mujer autosuficiente desde el punto de vista económico gracias a su incorporación en el mercado laboral y una consiguiente reducción de su dedicación al cuidado del hogar y de los hijos. Se potencia además la idea de que estas tareas deben ser asumidas por igual por ambos cónyuges, y en este sentido se introduce un nuevo deber conyugal dirigido al reparto de las responsabilidades domésti-

702 Los regímenes de comunidad están pensados y ordenados teniendo en mente el legislador familias estables, personal y económicamente ordenadas y que, además, gastan menos de lo que ingresan, es decir que tienen el ahorro como una de las virtudes familiares.

703 Cfr. DOMINGUEZ LUELMO, A., “El matrimonio y su naturaleza tras la ley 15/2005: consecuencias jurídicas de la supresión de las causas de separación y divorcio”, en Estudios de Derecho de Familia y de Sucesiones, ÁlVAREZ GONZALEZ, S. (Ed.), Santiago de Compostela, año 2009, páginas 91 y siguientes. Resultan también interesantes las reflexiones de GUILARTE GUTIERREZ, V. En "Comentarios a la reforma de la separación y el divorcio (Ley 15/2005, de 8 de julio)”, Ed. Lex Nova, Valladolid, año 2005, página 88, en las que, citando a PEREZ MARTIN se plantea el gran problema que traerá la nueva regulación en relación con los matrimonios de conveniencia entre inmigrantes pues "un inmigrante que ha obtenido la nacionalidad es en potencia una fuente interminable para obtener legalizaciones si cada año se casa y divorcia” 
cas y cuidado de personas dependientes y la posibilidad de establecer una custodia compartida ${ }^{704}$ tras la separación y el divorcio, como expresión de que ni unas tareas son más propias del marido, ni otras de la mujer ${ }^{705}$.

En coherencia con este contexto de desacralización del matrimonio frente a anteriores concepciones más proclives al mantenimiento de la unión conyugal, se facilita la disolución del vínculo y desaparece toda injerencia del Derecho civil en el aspecto personal de la relación, que queda relegado a la esfera íntima de la pareja. Por ello, aunque continúan reconociéndose determinados deberes conyugales de carácter personal, deja de tener trascendencia jurídica su cumplimiento. Es interesante lo anteriormente mencionado, al aligerarse las consecuencias de la ruptura del matrimonio, que se concibe como una decisión amparada por la libertad de la persona y no puede encontrar trabas, según los planteamientos actuales, todo se reduce a la intimidad familiar. Sin duda estas transformaciones parecen relajar el vínculo entre los esposos en aras de una mayor libertad individual, y como presupuesto para el libre desarrollo de la personalidad ${ }^{706}$.

La actual configuración del matrimonio, tanto desde el punto de vista jurídico como social, hace más real la igualdad de los cónyuges, pero al mismo tiempo fomenta la autonomía de cada uno de ellos en detrimento de la tradicional interdependencia, lo que previsiblemente podría reducir el juego de la compensación por desequilibrio en el caso de ruptura. Por otra parte, tal vez esta situación de igualdad, que da por extinguidas las antiguas estructuras jerárquicas, a cuya cabeza se situaba el padre de familia, podría fundamentar la defensa de la naturaleza contractual del matrimonio ${ }^{707}$ frente a otros planteamientos en los cuales la unión conyugal y el compromiso que denota es más valorado que la autonomía individual.

El hecho de que uno de los cónyuges no pueda de ninguna manera oponerse a la decisión de otro de poner fin a su matrimonio incidirá, probablemente cuando la sociedad esté más preparada para ello, en que aquel que se considere perjudicado por la posible ruptura intente paliar las conse-

704 Cfr. GUILARTE MARTÍN-CALERO, C. "La custodia compartida alternativa”, INDRET, Revista para el análisis del Derecho, núm. 2, año 2008; “Criterios de atribución de la custodia compartida”, INDRET, Revista para el análisis del Derecho, núm. 3, Barcelona, año 2010.

705 MARTÍNEZ ESCRIBANO, C. “Pactos prematrimoniales”, Ed. Tecnos, Madrid, año 2011, página 33 y 34.

706 Desde los poderes públicos ya no se protege férreamente a quien se dedica plenamente a su familia, porque en la coyuntura de la elección entre la familia basada en el vínculo matrimonial o el individuo, se opta por este último como valor superior.

707 A favor de la configuración del matrimonio como contrato se pronuncian entre otros, SALVADOR CODERCH, P. “Comentario al artículo 1 CF”, en EGEA FERNÁNDEZ Y FERRER I RIBA, J. (Dir.) "Comentaris al Codi de familia, a la Llei d' unions estables de parella i a la Llei de situacions convivencials d' ajuda mútua”, Ed. Tecnos, Madrid, año 2000, página 56; REQUERO IBAÑEZ, J. L., "Reformas del Código Civil al servicio de una empresa ideológica”, Actualidad Jurídica Aranzadi, núm. 655, Madrid, año 2005, páginas 1 a 7; AGUILAR RUIZ, L y HORNERO MÉNDEZ, C. "Los pactos conyugales de renuncia a la pensión compensatoria: autonomía de la voluntad y control judicial”, Revista Jurídica del Notariado, núm. 57, Madrid, año 2006, página 35. 
cuencias desfavorables de la misma mediante el establecimiento de prestaciones económicas que le compensen de alguna manera del divorcio no deseado, y que puedan sustituir las apreciaciones particulares del juez, evitadas por el legislador, en cada ruptura particular ${ }^{708}$.

Por otra, aunque resulte contradictorio con la afirmación anterior, a partir de la consagración de un divorcio absolutamente libre surge la reflexión en torno a si será posible, por vía de pacto, el establecimiento de fuertes penalizaciones que limiten o dificulten la salida y al libre desarrollo de la personalidad, inspirador de la nueva regulación que recoge en repetidas ocasiones la Exposición de motivos de la Ley 15/2005, de 8 de julio, de reforma de la separación y el divorcio.

Será necesario por tanto que los futuros o presentes cónyuges obren con cautela y con precisión a la hora de pactar las consecuencias de la ruptura, así como en la elección del vehículo adecuado para ello, evitando la posible intervención judicial tanto en el sentido de no aprobar sus previsiones (con una evidente falta de respeto a la voluntad de los interesados en parcelas o ámbitos que

708 El intento de llevar las obligaciones entre los esposos y su posible incumplimiento al campo de las relaciones contractuales o extracontractuales es un tema controvertido no sólo en el seno de la doctrina, sino también en los escasos pronunciamientos que han recaído sobre la materia. Con ocasión de la reforma de separación y divorcio el profesor LACRUZ BERDEJO, J. L. "Matrimonio y Divorcio. Comentarios al título IV del Libro Primero del Código Civil, Comentario al artículo 68”, Ed. Civitas, 2a edición, Madrid año 1994, revisado por RAMS ALBESA, J. y DELGADO ECHEVERRIA, J. Páginas 662 y siguientes. Se planteaba si la supresión de la culpabilidad como criterio de fijación de la pensión compensatoria determinaría, en los casos de infracción de obligaciones recíprocas, "la posibilidad de una acción de daños del cónyuge ofendido frente al ofensor". En su opinión, tratando de los deberes de los cónyuges -y disculpando la extensión de la cita que reproduzco textualmente por su interés y su vigencia actual- si la convivencia y la fidelidad "son obligaciones jurídicas, el obligado no puede faltar a ellas sin quedar sujeto al resarcimiento de los daños que cauce”, considerando que el hecho de no ser coercibles no les priva de su juridicidad, sino que, "al contrario, hace tanto más urgente arbitrar los medios precisos para mantenerlas en pie en esa consideración suya plenamente jurídica. Medios que habrán de consistir en la sanción del incumplimiento: se trata de deberes concretos impuestos por una norma, que no podrían tener consideración o trato inferior a los impuestos mediante un contrato, obligaciones legales sin carácter patrimonial, pero cuya infracción produce a veces consecuencias económicas y en todo caso un daño moral resarcible, ya ellas habremos de aplicar las reglas generales sobre el incumplimiento de las obligaciones -las de la llamad “culpa contractual”, pero que no sólo se aplican al incumplimiento de las obligaciones contractuales-y en último término las reglas relativas al ilícito civil. Sin que valga alegar la presencia de unas limitadas sanciones especificas para castigar la infidelidad, el abandono (desheredación, causa de separación), bien la idea general del legislador de prescindir de la declaración de culpabilidad en tema de divorcio o la eficacia de éstas en la separación, motivo que no es suficiente para suprimir la vigencia de las normas sobre daños y resarcimiento". 
deben de quedar fuera del control judicial) ${ }^{709}$, bien en el mejor de los casos, mediante la moderación de aquellas indemnizaciones que pudieran interpretarse como cláusulas penales ${ }^{710}$.

Ciertamente en algunos casos los efectos descritos en cuanto a la transformación del modelo familiar han sido valorados por el propio legislador, como por ejemplo en el supuesto de la reforma de la posible temporalidad de la pensión compensatoria, o de su sustitución por una prestación única, potenciando además el carácter subsidiario de la regulación legal, si bien la influencia de estas reformas se traducen mucho más allá de lo previsto ${ }^{711}$.

$\mathrm{Si}$, estando totalmente de acuerdo con este planteamiento, se dice que la forma de salir del matrimonio incide claramente en la decisión de entrada en el mismo, ello puede predicarse en cuanto al régimen económico que debe acompañar a la pareja. No parece que en un sistema que facilita la ruptura matrimonial hasta esos límites, incidiendo en una inestabilidad matrimonial patente, justifique la complejidad de un régimen como el de gananciales, especialmente en lo referente a su disolución y liquidación, ideado por el legislador como subsidiario de primer grado en el ámbito del Código Civil, sin duda que hasta hace quizás un par de décadas esto era comprensible, no así en la actualidad.

No se trata de hacer valoraciones personales sobre si el matrimonio debe ser o no una institución de carácter más o menos estable, sino de poner de manifiesto que en la realidad social española del momento presente, la inestabilidad matrimonial y la duración de los matrimonios difiere sensi-

709 Resulta bastante sorprendente que en la práctica los tribunales, a pesar de que los jueces evitan inmiscuirse en materias como la disolución de los gananciales, de índole estrictamente patrimonial, intenten controlar las previsiones contractuales o indemnizatorias que pudieron haber previsto los cónyuges. Poco interesan a los tribunales la liquidación posterior del régimen económico matrimonial cuando inciden directamente en las proporcionalidad, equilibrio o justicia de las medidas definitivas adoptadas, liquidaciones que se retrasan habitualmente a tramitaciones procesales posteriores. Tal desinterés contrasta notablemente con la clara intención en los jueces de intentar cercenar cualesquiera iniciativas de los esposos en el convenio regulador cuando no se ajusten exactamente al contenido típico del convenio (sobre alguno de los aspectos comentados ver RAMS ALBESA, J. en RAMS ALBESA. J. L y MORENO FLOREZ, R. Ma. (Coords.) "Comentarios al Código Civil”, Tomo II, Volumen 1, Ed. J. M. Bosch, Barcelona, año 2000.

710 Cláusulas penales que se admiten sin inconveniente en la STS de 17 de octubre de 2007 (RJ 2007/7307) si bien garantizar 1 cumplimiento de algunas de las obligaciones pactadas por los cónyuges. Sentencia, igualmente, en la que se considera aplicable el art. $1124 \mathrm{CC}$ al incumplimiento de as obligaciones surgidas de capitulaciones o previstas en convenio regulador, pues o pueden calificarse como recíprocas o interdependientes, pero que no impide su alegación en el caso de otros pactos entre cónyuges, siempre -lógicamente- que tengan presencia los requisitos que se exigen para su aplicación.

711 Por ejemplo en la regulación de la pensión de viudedad donde la mera presencia o existencia del matrimonio no es suficiente para ser acreedor de la pensión en el caso de divorciados, exigiéndose que en el momento del fallecimiento (aparte de otros requisitos) el reclamante fuese acreedor de una pensión compensatoria que quede extinguida por la muerte del deudor, lo que influye, sin duda, en sustituciones por prestaciones únicas, temporalidades o renuncias (Ley 40/2007, de 4 de diciembre, modificadora del art. 174 de la LGSS, en el que, entre otras cosas se dice que: "el derecho a pensión de viudedad de las personas divorciadas o separadas judicialmente quedará condicionado, en todo caso, a que siendo acreedoras de la pensión compensatoria a que se refiere e art. 97 del $\mathrm{CC}$, ésta quedara extinguida por el fallecimiento del causante"). 
blemente de la situación que en su día inspiró al legislador al reformar toda la materia en 1981. Tampoco el reparto de posibles tareas, competencias o funciones dentro de la pareja es la misma que tuvo presente la importante reforma llevada entonces a término, fundamentalmente por la incorporación de las mujeres al trabajo fuera de casa, pero también por la toma de postura y participación de la misma en el ámbito de decisión de la familia.

Todas estas circunstancias, unidas a otras como la evolución de la economía y el desarrollo de actividades por los cónyuges, alejadas del modelo eminentemente rural del que parte la regulación del Código, han ido poniendo de manifiesto la inoperancia y falta de funcionalidad de la regulación de algunos aspectos del régimen económico matrimonial. La necesidad de cambio se ha hecho notar especialmente en el tratamiento de algunas actividades de los cónyuges para los que el régimen de gananciales se ha mostrado inoperante y distorsionador, por ejemplo, al tratamiento de la empresa familiar, a las ineficientes consecuencias del planteamiento de ciertas actividades de los cónyuges, esto en palabras de AMUNATEGUI RODRÍGUEZ ${ }^{712}$.

Cuando en la reforma del Código de 1981 se introdujo en el mismo el actual artículo 1323 consagrando el principio de libertad de contratación entre los esposos fue considerado superfluo por algunos. Acostumbrados a la anterior prohibición de contratar entre los esposos casados bajo el régimen de gananciales y con la supresión de la mismo, no parecía necesario que el Código advirtiera de la posibilidad de que los cónyuges celebraran entre ellos todo tipo de contratos o se transmitieran bienes por cualquier título: resultaba más bien obvio.

No obstante, y a pesar de que el legislador no tiene por qué establecer las cosas que pueden hacer los particulares pues en principio podrán hacer todo aquello que no les esté prohibido, la norma se ha revelado como fundamental a la hora de constatar y consagrar la autonomía de los cónyuges mucho más allá de lo que inicialmente pudiera pensarse, sirviendo además de contrapunto a las posibles interpretaciones restrictivas en cuanto a la libertad que asiste a los contratantes.

712 Vid. DE AMUNATEGUI RODRIGUEZ, “La libertad de pacto en el régimen de separación de bienes” en VV. AA. “Autonomía de la voluntad y negocios jurídicos de familia”, Ed. Dykinson S. L. Madrid, año 2009, página 134, plantea tres caminos para solucionar esto:

a. En primer lugar, en una hipotética reforma del Código, que no parece presente en la mente del legislador en este momento.

b. En segundo lugar en la mayor utilización por los contrayentes de la posibilidad de elegir regímenes diferentes al de gananciales, especialmente el de separación de bienes, mediante el otorgamiento de las correspondientes capitulaciones, régimen al que se referirá especialmente peste trabajo.

c. Finalmente, y continuando con el ejercicio de la posibilidad de autorregulación de los interesados, alterando aquellos aspectos de la regulación legal que no se adecuen a la satisfacción de sus intereses desarrollando al máximo las posibilidades que ya ofrece el ordenamiento para hacer efectiva la voluntad de los esposos, junto con una adecuada posición de respeto a tales previsiones por parte de los tribunales. 
Puede afirmarse en este sentido que el artículo 1323 es la norma que legitima todo tipo de acuerdos o pactos entre los esposos, tanto en relación con su régimen económico matrimonial como en cuanto a la adopción de las previsiones que pudieran acompañar a la ruptura de la pareja; además, y por supuesto, avala, aunque innecesariamente, la celebración de contratos entre los esposos (fundamentalmente donaciones, compraventas, constitución de sociedades o mandatos) que deberán regirse por las disciplinas generales de cada uno de ellos.

La regla, aplicable a todos los regímenes económicos matrimoniales y que en el sentir de algunos, debería haberse recogido dentro de los deberes y derechos de los cónyuges en sede de regulación del matrimonio, presenta, evidentemente, mayores dificultades de conjunción con los de comunidad que con los de separación. La cercanía entre la posición jurídica de los casados en régimen de separación con la que ostentarían dos extraños facilita en gran manera la realización de todo tipo de contratos entre ellos, a tenor de las reglas generales; mientras que, por el contrario, la existencia de la sociedad de gananciales (o cualquier otro régimen comunitario) determina en ocasiones importantes problemas de configuración jurídica por la peculiar naturaleza de la misma y por las complejas reglas que determinan su gestión.

\subsection{Acerca de los límites generales a la autonomía de la voluntad en el ámbito de las relaciones conyugales}

Sin duda alguna los límites a la libertad de los cónyuges, más allá de lo que dispone el Código Civil, los marcan los preceptos constitucionales. Norma superior que constituye la barrera al poder de determinación de los sujetos por encima del Código Civil y de cualquier texto de derecho autonómico que regule, con las competencias adecuadas para ello, cuestiones de régimen económico matrimonial, funcionando como un techo común y general ${ }^{713}$.

Es cierto que la Constitución proscribe cualquier tratamiento legal discriminatorio en el artículo 14, o que el artículo 32 reconoce el derecho a contraer matrimonio con plena igualdad. Ambas normas se consideraron como uno de los principales criterios inspiradores de las reformas llevadas a

713 Como es sabido, no todos los derechos autonómicos son iguales, pudiendo calificarse en algunos -los que tienen las competencias para ello- como autointegrados en el sentido de que no se podrá acudir a la regulación corres pondiente del Código Civil para solucionar los problemas de ausencia de regulación o como cauce o criterio de interpretación, ni, por supuesto, a los límites previsto en el Código civil en materia de régimen económico matri monial primario o disposiciones generales sobre el mismo. En más ocasiones de las deseables se asiste al error por parte de algunos autores y no pocas resoluciones de los tribunales, por ejemplo, que las reglas consagradas en los artículos 1315 y siguientes del Código civil son de aplicación a todos los españoles, constituyendo además un importante freno a la libertad de disposición al tratarse de reglas imperativas. Ambas apreciaciones son incorrectas, por una parte porque tales reglas no forman parte de los ordenamientos autointegrados (como el catalán, el balear, el aragonés, el navarro, el vasco o el gallego) que tan sólo tendrán las reglas imperativas que sus propias fuentes determinen - que las tienen- y no las del Código civil; y, en segundo lugar, porque la pretendida imperati vidad de tales reglas no es tal como se deduce en muchos casos del propio articulado del Código. 
cabo en el Código en $1981^{714}$. No obstante, reconociendo su carácter de límite tanto a la actuación del legislador como a los particulares, se trata de límites que afectan especialmente a todo el contenido de derechos y deberes que ligan a los esposos en sus relaciones de carácter personal -familiarbuena prueba de ello es lo dispuesto en los artículos 66 y siguientes del Código Civil ${ }^{715}$, son difíciles de conculcar en el marco de las relaciones estrictamente económicas de los esposos, y de manera aún más acusada en el ámbito de gestión y administración de sus bienes como tantas veces se mantiene $e^{716}$.

Entre las distintas relaciones que surgen del matrimonio habría que distinguir por tanto entre las que ligan a los esposos (de tipo horizontal) sean personales o patrimoniales, destacando la presencia de libertad de una manera más acusada en las últimas; y las que relacionan a los padres con los hijos (de tipo vertical) en las que las limitaciones, constitucionales o no, son mayores al verse concernidas otras personas a las que el ordenamiento dispensa especial protección.

Si el enfoque se centra en los aspectos patrimoniales, no pueden considerarse reducidos o suprimidos los derechos constitucionales mencionados en el supuesto concreto y particular de que un cónyuge delegue en el otro las facultades de gestión del consorcio o porque decidan atender al levantamiento de las cargas familiares con el sueldo del uno y no del otro, por mencionar algunos

714 Aún en el caso de los derechos y deberes entre los cónyuges recogidos en el ámbito de las relaciones personales entre los cónyuges se plantea la doctrina la posible admisibilidad de ciertos pactos que alteren o sirvan para modalizar el cumplimiento de los mismos.

715 En cuanto a las relaciones de los tribunales pueden encontrarse algunos pronunciamientos sobre el particular, como la SAP de Almería de 17 de febrero de 2003 (AC 2003/623), en la que se considera nulo por contrario a los derechos fundamentales de los cónyuges -en concreto contra la igualdad- el pacto por el que se fijan indemnizaciones por el tiempo de convivencia de los cónyuges. En tal sentido la sentencia dispone que "la igualdad se perdería desde el momento en que la convivencia conyugal se condiciona en cuanto a su cese, por medio de una clausula penal que por el transcurso del tiempo puede hacer muy gravoso o de casi imposible cumplimiento el abono de la indemnización contractual". En mi opinión no está tan claro que las posibles indemnizaciones premiando los años de convivencia conculquen el principio de igualdad (si acaso sería el d la liberad), ni tampoco que puedan considerarse como una penalización por ruptura, sino más bien como un incentivo a la convivencia, lo que se conoce como una "premial" que ha sido admitida en algunos ordenamientos. Cfr. NOVALES ALQUÉZAR, M ${ }^{a}$ A., "Las obligaciones personales del matrimonio en el Derecho comparado", ...op., cit., páginas 57 y siguientes.

716 La lectura del Preámbulo y en especial del artículo 3 de la Ley 10/2007, de 20 de marzo, de Régimen Económico Matrimonial Valenciano parece no entender el significado de todo esto, recordando constantemente que el principio de igualdad es el fundamento del régimen económico matrimonial, mezclando la libertad en este ámbito con la protección integral de menores e incapacitados, mayores en situación de dependencia, o situaciones de violencia de género, lo que no guarda ninguna relación con la libertad de pacto respecto de las cuestiones económicas de los esposos. Más bien se trataría de reglas que disciplinan la regulación de la familia, extrañas a una norma cuyo único contenido es el campo patrimonial. Ver, todavía sobre el Proyecto, las apreciaciones sobre la ley formuladas por BLASCO GASCÓ, F., "Despropósitos de la Proposición de Ley de Régimen económico matrimonial valenciano", Revista Jurídica de la Comunidad Valenciana, $n .{ }^{\circ} 21 /$ enero 2007, página 5 y siguientes. La Ley ha sido ya objeto de reforma preventiva, para evitar claros aspectos de inconstitucionalidad, por la Ley 8/2009, de 4 de noviembre, derogatoria de algunos preceptos y modificatoria de otras, mostrando, una vez más, el absurdo y precipitado proceder de los legisladores de este país, en claro detrimento de la seguridad jurídica de los ciudadanos. 
ejemplos controvertidos, sin duda son situaciones perfectamente acorde con la legalidad. No me parece adecuado mezclar en la justificación o proscripción de este tipo de conductas con frenos que implican relativizar en exceso los trascendentes e inalterables límites constitucionales. Sin duda quedarían comprometidos si, en base a los pactos adoptados, se anulara totalmente la capacidad de uno de los cónyuges, o no se atendiere por los progenitores al sustento de los hijos, o se colocase a uno de los esposos bajo el dominio permanente del otro sujetándole a su poder de decisión, o se limitase su salida del domicilio o del lugar de residencia, o se estableciera que uno de los esposos no disfrutará del nivel de vida que posibilita y permite el nivel del otro; pero desde luego no deben traerse tales límites a colación por el hecho de atribuir por pacto la administración de un cónyuge al otro de los bienes comunes, o de los propios del administrado, o por alterar la regla de proporcionalidad en la contribución al levantamiento de las cargas familiares en el régimen de separación de bienes en opinión de MORENO-TORRES HERRERA ${ }^{717}$. Pero es que además parece que tales derechos y límites, para los que prefieren relacionarlos continuamente con las relaciones patrimoniales entre esposos, quedan atenuados por la aplicación del artículo 10 de la Constitución y la consagración del libre desarrollo de la personalidad como principio rector de los comportamientos de los particulares.

El propio legislador de un tiempo a esta parte está considerando tal principio, con más o menos acierto o criterio, como inspirador de buena parte de las reformas operadas en el Derecho de Familia, especialmente en las llevadas a cabo en el año 2005 como se infiere de la exposición de motivos de la Ley 15/2005.

Resulta de esta manera que los límites al poder de autorregulación en aspectos concretos habrá que buscarlos en lo dispuesto en el Código Civil, para el ámbito de aplicación del propio Código. Limites que no sólo derivan de lo dispuesto en el artículo 1255 (ley, moral, orden público), sino de la especificación de los mismos que surge del artículo 1328: "será nula cualquier estipulación contraria a las Leyes o a las buenas costumbres o limitativa de la igualdad de derechos que corresponda a cada cónyuge", o incluso del contenido del artículo 1315: "El régimen económico del matrimonio será el que los cónyuges estipulen en capitulaciones matrimoniales, sin otras limitaciones que las establecidas en este Código".

Dejando aparte la frontera de las "buenas costumbres" o la "moral", limitaciones peligrosas, que tienden a confundirse con el modelo de familia del intérprete, y que, en principio, parecen más

717 MORENO-TORRES HERRERA, M L . "La pensión compensatoria”, en "La reforma del matrimonio (leyes 13 y 15/2005)”, Ed. Marcial Pons, Madrid, año 2007, página 133 y 134. La autora en cuestión se manifiesta contraria a la opinión de que la derogación de la regla de igualdad sea contraria a los límites del artículo 1328 y al principio de igualdad recogido en los artículos 14 y 32 de la Constitución. 
propias de las convenciones sobre aspectos personales que las referentes a aspectos patrimoniales, en cuyo ámbito, habría que centrarse en dos tipos de barreras: las leyes y, nuevamente, la igualdad entre los cónyuges.

La segunda parte del art. 1328 sanciona con la nulidad cualquier pacto restrictivo de la igualdad que corresponda a cada cónyuge, lo cual denota una supraordinación entre la autonomía de la voluntad y el principio de igualdad, con claro predominio del segundo. Sin duda se trata de una norma de complejo entendimiento y pésima redacción pues la igualdad que corresponda a una persona es sencillamente toda y a la vez ninguna, ya que la igualdad requiere de una comparación y sólo puede medirse en la coincidencia de situaciones jurídicas, derechos subjetivos y facultades que en su ejercicio ordinario entren en colisión directa, puede que en relación a esto deba indicarse en abstracto que la igualdad tiene un contenido demasiado pobre y desdibujado por ello resulta tan moldeable por quien lo emplee. Este precepto, pese a su grandilocuencia pensada para todo lo contrario, no permite deducir que los pactos entre los esposos no puedan conculcar la igualdad que "corresponda" entre los mismos, recalcando, una vez más la importancia que reviste tal principio a lo largo de toda la regulación del régimen económico matrimonial.

Debe asignarse al límite de la igualdad una visión relativista, de forma que sólo se considere conculcado cuando los acuerdos entre los cónyuges coloquen a uno de los esposos en una posición de dependencia o sumisión respecto del otro; o cuando se prive, con carácter definitivo y sin posibilidad de revisión o alteración, de las posibilidades que la ley reconoce en cuanto a la gestión, disposición o administración de sus propios bienes o de los comunes; así como cuando se le impida cualquier intervención en la marcha o desarrollo de la economía familiar; o cuando determinados acuerdos rompan con la igualdad, con la regla de reciprocidad.

Teniendo en cuenta además la proclamada libertad de contratación entre los esposos deberán interpretarse los pactos o convenios dudosos a favor de su admisibilidad ${ }^{718}$, debiendo rechazarse tan

718 SAP Madrid, Sección 24a ,núm. 241/2008, de 27 Feb. 2008, RJ. 22/2008 “Conocida ya la razón de ser de la presente alzada, en la extensión y términos antes dichos por la expresión de los motivos que llevaron al apelante a recurrir la resolución de instancia, es llegado el momento de dar respuesta concreta a las anunciadas pretensiones a la luz de legalidad vigente, doctrina jurisprudencial y circunstancias concurrentes. Ahora bien, del estudio de las actuaciones, cabe decir que la solución a dar para resolver el presente recurso de apelación es sencilla, de simple entendimiento, y por ello y por compartirse el criterio y argumentación del órgano "a quo" no es necesario que nos extendamos en argumentaciones jurídicas para confirmar la sentencia de fecha 24 de septiembre de 2007 . En efecto, no habiendo cambiado las circunstancias, y aún en el presente proceso de divorcio donde pueden y deben analizarse "ex novo" las circunstancias concurrentes; no es correcto aprovecharse de un nuevo proceso para operar un cambio brusco que cambie lo pactado hace poco tiempo cuando dicha pactación es dada por las partes con ánimo de permanencia y con miras de futuro. Es doctrina jurisprudencial emanada de nuestro Tribunal Supremo al interpretar y aplicar el artículo 1091 del C.C . que: "este artículo contiene una norma sancionadora del principio de autonomía de la voluntad y respeto y obediencia a los pactos" (vid: SS.T.S de 9-julio- 1986 y 15-octubre-1986); este precepto obliga a cumplir lo pactado (vid: S.T.S. de 8-febrero-1989). En efecto, este artículo sienta la regla básica de la contratación (el pacta sunt servanda), dentro de los límites de 
sólo aquellos en los que con tal claridad se quiebre la igualdad entre ellos; todo ello, por otra parte, en el contexto individual de cada matrimonio y de las posibles particularidades y exigencias de su economía y de su actividad económica o profesional. No se trata de erradicar decisiones que en determinados casos darían lugar a hipotéticas desigualdades, sino de declarar nulas las que los desigualen como personas y como cónyuges, generando una jerarquización que el ordenamiento declara contraria al mismo.

Es cierto que existe también una compleja relación entre lo que supone una estipulación o pacto capitular, que consista en una alteración del régimen económico matrimonial, y como tal irrevocable, en principio, si no lo es por un nuevo acuerdo entre las partes, y la posibilidad que, en capítulos, o fuera de ellos, los esposos celebren todo tipo de negocios sin someterlos a las rígidas reglas que disciplinan las modificaciones del régimen ${ }^{719}$.

En relación a la Ley como límite al poder de disposición, como principio de legalidad y como derecho imperativo, se trataría de impedir todas aquellas previsiones o pactos que sirvieran para desvirtuar las reglas esenciales que determinan la configuración de un régimen económico matrimonial, y que se encuentran amparadas bajo el ordenamiento jurídico, lo que podríamos calificar también como reglas estatutarias, cuya presencia deriva del artículo 1315 del Código Civil. Por ello, puede argumentarse que existen, dentro de cada régimen, especialmente en el de gananciales, una serie de aspectos que configuran el modelo no formando parte del poder de disposición de los interesados, incluso puede estimarse normas de orden público, de modo que, so pena de crear un régimen económico atípico con las dificultades correspondientes que comporta, no pueden ser cambiadas por los particulares hasta el extremo de desfigurar los caracteres esenciales del mismo, estarían desvirtuando la esencia del régimen. Ejemplo de tales reglas son aquellas normas que definen las reglas de responsabilidad de los bienes de los cónyuges o de composición de los patrimonios de los esposos, o de atribución de la titularidad de los bienes conforme al principio de subrogación real o

autonomía de la voluntad marcado por los artículos 1255 y 1258 del C.C. Se insiste, no es acertado pretender cambiar una pactación reciente, cuando no hay cambio de circunstancias, como así aprecia correctamente el órgano de instancia, y menos de carácter sustancial, con aprovechamiento de un proceso en el que se pretende cambiar el estado civil; luego, se debe mantener la cuantía de la pensión de alimentos de la hija fijada por las partes en el convenio regulador de la separación; y se debe mantener este convenio por todo lo que se lleva dicho, en lugar de cambiarlo por el que pretende ahora el apelante."

719 REYES LOPEZ, Ma J. “Economía del matrimonio y empresa familiar”, en REYES LOPEZ, M J. (Coord.) “La empresa familiar: encrucijada de intereses personales y empresariales”, Ed. Thomson Aranzadi, Cizur Menor, año 2004, página 97 y siguientes. Dicha autora considera por ejemplo, contrario al principio de igualdad y a las normas que lo amparan el establecimiento de un pacto expreso de administración por uno de los intereses del otro con carácter irrevocable. En mi opinión, tal pacto no sería en principio admisible dentro de unas capitulaciones, pero podría considerarse válido fuera de ellas entendido como mandato irrevocable entre extraños; o incluso admisible en el marco de capitulaciones si de las mismas se desprende la posibilidad de su revocación al no constituir un pacto capitular relativo a la configuración del régimen económico matrimonial. 
de titularidad según los casos, etc. Reglas que no es que tengan necesariamente el carácter de indisponibles, sino que lo serán dentro de cada uno de los regímenes y que, en caso de ser sustituidas por otras, normalmente determinarán el establecimiento de un régimen singular, más o menos atípico.

En el régimen de separación, mucho más simple en su funcionamiento objeto de menor atención comparativamente y en consecuencia poco regulado por el Código, son escasas las reglas de esta índole, sin embargo debe argumentarse que no parece adecuado expulsar del régimen de separación o el de gananciales algunos pactos para, a continuación, propugnar su plena admisibilidad como régimen matrimonial atípico, o el anunciar el carácter imperativo e inderogable de ciertas reglas y después admitir sin ninguna dificultad la posibilidad de acogerse a cualquiera de los regímenes económicos que se regulan dentro del país en ejercicio de la autonomía de la voluntad y que pueden no contener la norma a cuya aplicación no podía sustraerse los interesados, especialmente cuando no se encuentran comprometidos los intereses de terceros.

En el supuesto de considerarse reglas absolutamente inderogables como se las califica en ocasiones podría parecer constitutivo de un fraude de ley el hecho de poder evitar su aplicación pactando otro régimen económico distinto; es más aceptable por ello propugnar una interpretación adecuada del precepto que podría dirigirse a no mantener su indisponibilidad bajo ningún concepto, pudiendo modalizarse el contenido de la norma conforme al principio de autonomía de la voluntad, pues, sin duda, se trata de una regla de régimen económico matrimonial. Entonces, ¿Se trata de un conflicto entre autonomía de la voluntad y orden público?. No, no se trata de ello, se trata de que quizás los regímenes matrimoniales sea uno de los aspectos más privatistas del Derecho de Familia.

Pese a que, como se ha dicho, en el régimen de separación los límites de carácter estatutario revistan menor presencia e intensidad, no quiere decir que no existan y que deban ser respetados por los cónyuges so pena de desvirtuar totalmente el régimen. Por ello es que no sería admisible que pudieran incluirse previsiones que dificultaran hasta tal punto la independencia en la gestión patrimonial de cada uno que pudieran considerarse contrarias a la lógica del sistema e hicieran no reconducible el régimen previsto a los esquemas generales de la separación.

Puede argumentarse perfectamente que la independencia en la gestión y la responsabilidad se constituyen en principios rectores del régimen de separación de bienes, afectando directamente a la protección de la seguridad jurídica y de los intereses de los acreedores de cada uno de los esposos, que no podrían verse en dificultades por haber previsto los esposos un entramado de pactos capitulares que excluyeran totalmente la separación de patrimonios, impidiendo las reclamaciones de los terceros cuando se trate de deudas de las que deba responder el patrimonio de cada uno de los espo- 
sos. No sería posible por tanto que, a través de las estipulaciones de los cónyuges, se desvirtuaran las reglas del régimen, estableciendo por ejemplo, la necesidad de consentimientos recíprocos para sus respectivas actuaciones en contra de las reglas de independencia propias de la separación., porque en tal caso se estaría afectando la esencia de tal régimen matrimonial.

Siguiendo con el régimen de separación de bienes, se hace igualmente necesario proceder a una interpretación de las posibles previsiones de los casados, así como de las escasas normas que disciplinan el régimen, conforme a los principios que inspiran la separación de bienes, y no en sentido contrario o divergente.

La línea del derecho imperativo tampoco se presenta especialmente definida, ni siquiera en aquellos ordenamientos en los que el legislador tiene la previsión de señalar las normas que revisten tal cualidad ${ }^{720}$. En el marco del Código Civil no existe acuerdo en la doctrina sobre qué o cuáles normas participan de imperatividad asignándose tal condición en un mayor número de preceptos de los que realmente lo son.

Sin duda alguna es imperativa la regla que disciplina que las modificaciones del régimen económico deben constar en capitulaciones, así como la posible elección de un régimen diferente al supletorio en cada caso, careciendo de eficacia las posibles configuraciones que no hubiesen cumplido con la forma exigida. No obstante eso no impide que determinados acuerdos entre los esposos, por ejemplo los dirigidos a operar el reparto de las cargas familiares o el modo de proceder a las mismas puede establecerse fuera de capítulos, e incluso verbalmente. En algunos supuestos podrán surgir problemas sobre si alguna estipulación reviste o no naturaleza capitular, cuestión que deberá examinarse en la práctica caso por caso.

Suele ser frecuente la afirmación del carácter imperativo de las disposiciones generales sobre régimen económico matrimonial recogidas en los artículos 1315 y siguientes del Código, aseveración que no siempre es rigurosa, pues de un análisis detallado o de la propia regulación del texto en otras sedes se deduce en numerosas ocasiones lo contrario, especialmente respecto del contenido de los artículos 1318 y siguientes que, al ser desarrollados en el marco de cada régimen económico por ejemplo por el art. 1438 del Código Civil presentan un mayor campo de actuación para la autonomía de los esposos de lo que aparentemente pueda resultar.

720 Es lo que sucede con el Derecho aragonés en el art. 3 LREMV en el que se mencionan expresamente las reglas imperativas dentro de las disposiciones generales, si bien, en sentir de la doctrina existen más normas con este carácter que las señaladas, al constituir un desarrollo de las mismas. Así MARTINEZ-CORTES GIMENOS, J., "La gestión del consorcio en la Ley 2/2003, de 12 de febrero", El Justicia de Aragón, Zaragoza, año 2007, páginas 25 y 26. 
Resulta de esta manera que en ocasiones se predica la imperatividad de normas sin más, sin detenerse a desentrañar las propias posibilidades que, en otras sedes, ofrece el mismo Código a la autonomía de los sujetos, si no para suprimirlas, si para modalizarlas o matizarlas. Ciertamente, por adelantar algún supuesto práctico, los bienes de ambos esposos están sujetos al levantamiento de las cargas familiares, pero en la forma real y concreta del cumplimiento de esa obligación puede llegar a modalizarse notablemente, ofreciendo un enorme campo de actuación a la autonomía de los esposos para adecuarlas a sus necesidades, y todo ello sin forzar en ningún caso la interpretación de las reglas previstas por el propio Código. Lo mismo sucede con las reglas de administración y gestión de los bienes, en uno u otro régimen, que permiten alteraciones en el sentido de acercar el régimen de separación al de gananciales con la finalidad de corregir algunos de sus aspectos calificados como injustos; o por el contrario, introducir en el de gananciales mayores parcelas de autonomía en la gestión y administración de algunos bienes, tal como ha planteado la jurisprudencia en alguna ocasión $^{721}$.

\subsection{Autonomía de la voluntad y crisis matrimoniales}

Recapitulando algunas de las ideas manifestadas en este capítulo, no cabe duda de que en las últimas décadas se ha producido una importante transformación en relación con el papel que ha venido jugando la mujer, y por consiguiente el rol de su autonomía de la voluntad, en la sociedad y que tales cambios se han visto impulsados una veces, y seguidos otras, de una serie de modificaciones legales. Por lo que se refiere al ámbito del Derecho de familia, tales cambios se iniciaron en 1975 al ponerse fin a las limitaciones en relación a la capacidad de obrar de la esposa, continuando con la reforma del Código Civil de 1981 que equipara en derechos y deberes a ambos cónyuges (artículo 66) en consonancia con los postulados constitucionales. Pero esta igualdad jurídica predicada abiertamente desde 1981 no puede considerarse una igualdad absoluta del hombre y la mujer si sus circunstancias sociales y económicas son dispares. Al inicio de la década de los 80 todavía eran muchos los hogares en los que el reparto de funciones entre los esposos se ajustaba al patrón

721 SAP Castellón, Sección 2a, núm. 147/2008, de 11 Dic. 2008, RJ.. 40/2008“El art. 1255 del Código Civil consagra el principio de autonomía de la voluntad de las partes en materia de contratación, siempre que lo pactado no sea contrario a la ley, orden público o a la moral, razón por la cual lo convenido entre ambos litigantes tiene fuerza de ley entre los mismos, sin perjuicio obviamente de que frente al acreedor, el BBVA, responden ambos del pago de la deuda así como sus obligados solidarios a saber, los padres del Sr. Juan Antonio , por no poder perjudicar ni ser oponible dicho pacto frente a terceros. Partiendo de ello el motivo del recurso no puede ser estimado pues el Sr. Juan Antonio que asumió el pago de la deuda no puede exigir a la Sra. Sofí el $50 \%$ del pago de las cuotas que vayan venciendo, sin perjuicio de que llegado el momento en su caso de proceder a la liquidación de la sociedad de gananciales se resuelva conforme a derecho pues si el préstamo personal de carácter ganancial fue por importe de 18.435,58 euros y la vendedora reintegró 7.888,92 que se destinaron a amortizar la deuda resta todavía una cantidad cuyo destino se desconoce, lo que habrá de determinarse." 
tradicional, según el cual las tareas domésticas son asumidas en su integridad por la esposa mientras que el marido realiza un trabajo remunerado fuera de casa, lo cual en la actualidad se ha modificado e inclusive ha influido por ejemplo en la guarda y custodia compartida, tal cual lo manifiesta GUILARTE MARTÍN-CALERO ${ }^{722}$.

Ante tal estado de cosas, era lógico y casi una exigencia basada en razones de equidad, que las crisis matrimoniales adoptarán una regulación tendente a la protección de la mujer para paliar las desastrosas consecuencias, sobre todo económicas, que se derivarían para ella al ponerse fin al modelo de convivencia diseñado con el matrimonio, con su específica asignación de roles entre los cónyuges. Pero el tiempo, sin duda el mejor escultor de la realidad, fue a poco a poco cambiando el orden de los factores, de tal manera que paulatinamente comienza a ser superior el número de parejas en el que ambos esposos desempeñan un trabajo remunerado que les permita disfrutar de una cierta independencia económica. La igualdad va siendo entonces más real, aunque continúan existiendo matrimonios anclados en el modelo tradicional.

Como consecuencia de estos cambios, se van abriendo camino las interpretaciones flexibles de la ley que buscan la adecuación a las nuevas circunstancias de unas normas paternalistas respecto de la mujer ${ }^{723}$. En este sentido, por ejemplo, comienza a imponerse la temporalidad de la pensión compensatoria, no reconocida expresamente en el artículo 97 del Código Civil según la redacción de 1981, pero tampoco prohibida. Y así se llega hasta la reforma de 2005, que trata de dotar de un mayor protagonismo a la libertad de los cónyuges en relación con las crisis matrimoniales en consonancia con ese contexto de igualdad de los esposos que proporciona las condiciones adecuadas para

722 "La regulación de la custodia compartida: una oportunidad para la consolidación de la carrera profesional de las mujeres”.... op. cit., página 796. "En los primeros comentarios a la ley de 2005, de forma optimista, mantuve que la custodia compartida alternativa, constituiría, con el paso del tiempo, el modelo principal de guarda y custodia, pues es el que mejor responde a las necesidades de una sociedad moderna, en la que hombre y mujer comparten durante la vida en común, funciones y responsabilidad, de suerte que, producida la ruptura, la vida común, funciones y responsabilidad, de suerte que, producida la ruptura, estas funciones y esta responsabilidad deben alcanzar por igual. Han pasado cinco años desde entonces y las cosas van cambiando muy poco a poco, lentitud debida fundamentalmente a la regulación nefasta que el legislador de 2005 dio a la custodia compartida en el artículo 92; ahora bien, se observa un importante movimiento legislativo en algunas comunidades autónomas que han optado por apartarse del modelo codicial y han regulado la custodia compartida como modelo compartido de custodia, convertir en modelo prioritario un modelo que no lo es ni siquiera en situaciones de normalidad convivencial me parece legislar a espaldas de la realidad que debe regularse..."

723 Durante el período de codificación europea, la concepción que se tenía de la familia era la de un cuerpo unitario, la de una unión de los cónyuges, que se encontraba sujeto al gobierno de familia, por ende la mujer en cierta medida perdía su personalidad; este último, el pater, ejercía la autoridad y el poder de disciplinar a los demás miembros, sobre quienes pesaba el deber de obediencia, la familia, por lo tanto era considerada una célula de la socie dad, la cual internamente, se encontraba jerárquicamente organizada, constituyendo el medio para que sus miembros pudieran participar en la vida social y gozar del estatus de pertenecer a un determinado grupo social., conforme a esto el interés que primaba durante dicho período en el interior de la familia era de carácter familiar, superior al fin individual de sus miembros y en el cual el interés familiar supraindividual se justificaba en el orden necesario para el adecuado mantenimiento, educación y asistencia de sus miembros incapaces o imposibilitados de valerse por si mismos. 
que sean ellos quienes tomen sus propias decisiones sobre lo que estimen más adecuado en el marco de la convivencia y para poner fin a esta ${ }^{724}$.

El convencimiento del Legislador era patente sobre la conveniencia de fomentar las libres decisiones de los esposos en el marco de su relación frente a la imposición de normas imperativas, que como ha quedado demostrado con la experiencia, fracasan en su cometido. Sin embargo, la ley quizás es escueta con el propósito de abrir el paso a las libres decisiones de los cónyuges en marco de la crisis matrimonial. Seguramente el Legislador ha tenido muy presente que en un buen número de casos, cuando acaece una crisis matrimonial, las partes se enzarzan en negociaciones complicadas muchas veces cegadas por rencillas afectivas, heridas abiertas que trascienden el marco jurídico.

Ciertamente, se introduce en la ley una libertad prácticamente absoluta para instar el divorcio, incluso sin separación previa cuando así se desee, y se introduce la figura de la mediación como modo alternativo de solucionar el conflicto frente a la imposición de una decisión judicial ${ }^{725}$. Todo ello parece estar propiciado por la cada vez más real igualdad de los esposos en el matrimonio anhelando una mejor solución para evitar que el conflicto se perpetúe.

En tal sentido, los artículos 90 y siguientes del Código Civil van directamente dirigidos a dotar del adecuado marco normativo a las medidas de carácter personal y patrimonial que van a regir en lo sucesivo la nueva situación existente tras la crisis de la pareja, y van dirigidas a determinar en interés de los hijos con cuál de los cónyuges quedarán estos, régimen de comunicaciones del proge-

724 La Exposición de motivos de la Ley 15/2005, insiste en esta idea: "La reforma que se acomete pretende que la libertad, como valor superior de nuestro ordenamiento jurídico, tenga su más adecuado reflejo en el matrimonio (...) esta ley persigue ampliar el ámbito de libertad d los cónyuges en lo relativo al ejercicio de la facultad de solicitar la disolución de la relación matrimonial.- Con este propósito, se estima que el respeto al libre desarrollo de la personalidad, garantizado por el artículo 10.1 de la CE, justifica reconocer mayor trascendencia a la voluntad de la persona cuando ya o desea seguir vinculando con su cónyuge."

En definitiva se considera que los cónyuges han de poder decidir libremente sobre estos extremos, porque la imposición de unos rígidos esquemas legales conduce a resultados insatisfactorios. En este mismo sentido, la misma Exposición de Motivos apunta: "El evidente cambio en el modo de concebir las relaciones de pareja en nuestra sociedad ha privado paulatinamente a estas normas de sus condicionantes originales. - Los tribunales de justicia, sensibles esta evolución, han aplicado en muchos casos la ley y han evitado, de un lado, la inconveniencia de perpetuar el conflicto entre los cónyuges, cuando en el curso del proceso se hacía patente tanto la quiebra de la convivencia como la voluntad de ambos de continuar su matrimonio, y de otro, la inutilidad de sacrificar la voluntad de los individuos demorando la disolución de la relación jurídica por razones inaprensibles".

725 RONDON GARCÍA, L. M. “Bases para la mediación familiar”, Políticas de Bienestar Social, Ed. Tirant Lo Blanch, Valencia, año 2012, página 52 y 53. Un proceso de mediación basado en sólidos principios éticos: “ $L a$ persona mediadora y las partes han de mantener el deber de confidencialidad en relación con la información de que se trate. Esto también implica la protección de los datos que se manipulen en el servicio. Según la Recomendación $N^{o} R$ (98) 1 el mediador no puede revelar ninguna información que haya obtenido durante el procedimiento o con ocasión del mismo a menos que obtenga el consentimiento expreso de las partes, o así lo requiere la legislación natural.... Se indica también que el mediador no puede ser obligado a redactar informes que reflejen los contenidos de las conversaciones que se lleven a cabo en el proceso..el deber de los mediadores de actuar con profesionalidad y respetar el secreto tanto durante el procedimiento como en caso de no llegarse a un acuerdo... Se acude voluntariamente a la mediación. Es una actuación extrajudicial, y se requiere la voluntad de todas las partes para proceder a la mediación." 
nitor no custodio con los hijos menores o incapacitados, contribución de cada progenitor para satisfacer los alimentos, atribución del uso de la vivienda familiar y, en su caso, pensión compensatoria que deba establecerse en favor del cónyuge a quien la ruptura produzca un desequilibrio económico. Los cónyuges, con fundamento en su autonomía de la voluntad, pueden pactar los efectos que producirá su separación, su divorcio o la nulidad de su matrimonio, pues nada se opone a la validez de los acuerdos a que puedan llegar privadamente estos en orden a regular los efectos de la ruptura matrimonial en el ejercicio de su libertad negocial (art. 1255 del Código Civil), cuando concurran los requisitos mínimos imprescindibles (art. 1261 del Código Civil.) y entre los cuales no se encuentra ninguno específico relativo a la forma (art. 1278 del Código Civil en relación con el art. 1280 del mismo cuerpo legal).

La igualdad de los cónyuges, no sólo legal, sino efectivamente real, propiciada por la cada vez más frecuente independencia económica de la mujer, sienta las bases para permitir todo tipo de pactos sobre la relación conyugal y su ruptura -sin necesidad de imponer un régimen imperativo que proteja especialmente, con carácter general, a uno de los esposos por estimar que se encuentra más necesitado de protección. El legislador catalán, sin embargo, ha ido más allá que el legislador estatal reconociendo en el art. 15.1 de su Código de familia que: "en los capítulos matrimoniales, puede determinarse el régimen económico matrimonial, convenir heredamientos, realizar donaciones y establecer las estipulaciones y pactos lícitos que se consideren convenientes, incluso en previsión de una ruptura matrimonial". La posibilidad de celebrar tales acuerdos patrimoniales, no está reconocida expresamente en la ley estatal, pero tampoco se encuentra prohibida ${ }^{726}$.

El poder prever antes de la celebración del matrimonio la suscripción de un pacto de los futuros contrayentes en el que establezcan algunas de las consecuencias que se derivarían en caso de separación o divorcio es una idea que puede generar, en principio, cierto rechazo. Si la sola posibilidad de plantear un régimen económico matrimonial de separación de bienes puede interpretarse en algunas parejas como un síntoma de falta de afecto o desconfianza hacia la otra persona, desde el entendimiento de que el amor incondicional en que se basa su unión ha de estar por encima de esas cuestiones patrimoniales, más aún lo supondría un pacto por el que se tratan de prefijar las consecuencias que se producirían con la eventual crisis matrimonial. Sin duda de que el período inmediatamente anterior a la celebración del matrimonio no es el más idóneo para tratar estas cuestiones y si alguno de los miembros de la pareja sugiere algún acuerdo de esta naturaleza despertaría en el

726 MARTINEZ ESCRIBANO, C. "Consecuencias de la crisis matrimonial y autonomía de la voluntad", en GUILARTE MARTÍN-CALERO, C. "Aspectos civiles y penales de las crisis matrimoniales”, Ed. Lex Nova, Valladolid, año 2009, página 103. 
otro un sentimiento desconfianza respecto a sus expectativas en el futuro matrimonio tal como asegura MARTÍNEZ ESCRIBANO ${ }^{727}$.

Sin perjuicio de lo anterior, puede también inferirse que cuando el pacto en cuestión beneficie claramente a uno de los cónyuges en caso de la disolución del citado matrimonio, entonces, en caso de crisis, malos entendidos, problemas, discusiones, ¿por qué no instar al divorcio si seguramente se saldrá beneficiado patrimonialmente? Ahora bien, para una buena parte de la población y específicamente de los cónyuges en situación de crisis matrimonial no todo es dinero, pero cuando no se vislumbra la salida, quizás optar por el fin y su secuela económica favorable puede resultar la opción más viable. También sería posible el caso contrario, en el que se negase todo derecho económico por ejemplo a la esposa para el caso de crisis matrimonial. Ningún óbice encontraría entonces el esposo para poner fin a la unión cuando así lo desee, mientras que la esposa podría encontrar un importante freno para instar el divorcio, particularmente si carece de ingresos económicos propios. Es decir, se podría llegar incluso a pretender una utilización instrumental del matrimonio con el fin de conseguir una compensación.

Sin embargo, también es cierto que el pacto prenupcial permite una mejor previsión del futuro y la posibilidad de planificar la convivencia de manera acorde con lo pactado, evitando que se produzcan consecuencias negativas de forma inesperada para alguno de los esposos, porque todo habrá sido previsto de antemano en palabras de PINTO ANDRADE ${ }^{728}$. El tratamiento de estas cuestiones antes de contraer matrimonio permite aclarar lo que cada uno de los esposos pretende dar y recibir en el marco de la relación conyugal y enfocar la convivencia de un modo racional; antes de realizar una renuncia o sacrificio en el plano profesional. Por ejemplo, cada uno de los esposos sabrá si se verá compensado o no en el plano profesional. Y en definitiva, los pactos prematrimoniales permiten que cada pareja diseñe su relación conyugal de la manera que estime más adecuada de acuerdo con sus circunstancias personales, su ideología, creencias y su libre voluntad, de tal modo que podría llegar a mitigar, quizá, las tensiones que se producen en la crisis matrimonial por cuestiones de índole económica.

Este enfoque, por otra parte, encaja mejor con la idea antes anunciada del matrimonio en el que ambos cónyuges se encuentran en una situación de igualdad, no sólo jurídica, sino real, y pueden adoptar sus propias decisiones, maduros e independientes, sobre el modo en que quieren afrontar su relación y en una sociedad cada vez más plural como es la sociedad española, estos pactos

727 "Consecuencias de la crisis matrimonial y autonomía de la voluntad”, ...op. cit., página 104.

728 PINTO ANDRADE, C. "Pactos matrimoniales en previsión de ruptura”, Ed. Bosch S. A., Barcelona, año 2010. 
pueden ser el instrumento adecuado para acomodar cada matrimonio a las convicciones de los cónyuges.

Pese a las ventajas apuntadas no debiese predicarse una validez absoluta y general de los acuerdos prenupciales. Al contrario, parece conveniente establecer ciertos límites y cautelas con relación a estos pactos para evitar consecuencias injustas que lleguen a atentar contra el orden público, o que se produzcan abusos de uno de los esposos frente al otro en los términos anteriormente apuntados con relación a posibles comportamientos oportunistas.

Respetando esos límites, los pactos prematrimoniales serían un instrumento útil al servicio de los esposos como vía para diseñar cada matrimonio de la manera más acorde con las circunstancias y la voluntad de los miembros de la unión ${ }^{729}$. Cuando se trata de atribuir la guarda y custodia, la norma cardinal será el acuerdo de los padres, el cual es materializado en el convenio regulador y en observancia del interés del hijo. La posibilidad de autorregulación a la que nos estamos refiriendo es expresión del principio de autonomía de la voluntad reconocida a los cónyuges en materia familiar. Libertad que se encuentra limitada por tratarse de una materia indisponible, gobernada por el favor filii. De ahí que el ordenamiento jurídico conciba la intervención judicial como una herramienta de control público y garantía de dicho interés ${ }^{730}$. Se aclara que dicho interés será objeto principal de estudio en el próximo capítulo.

En este sentido, existe un debate relativo al papel del juez frente a las determinaciones que los padres hayan efectuado en el convenio regulador. Se entiende que el legislador ha querido incorporar expresamente una nueva modalidad en el ejercicio de la guarda y custodia de los hijos, ampliando el poder de decisión de los progenitores en la esfera personal de las relaciones filiales, con las consiguientes repercusiones en el plano económico que ello conlleva, por ejemplo, en lo que respecta a la atribución del uso de la vivienda familiar y la pensión de alimentos

Adelantamos que la Ley 15/2005 permite incluso que en caso de no existir acuerdo, el juez a instancia de una de las partes y con informe favorable del Ministerio Fiscal, el cual en todo caso ya no es obligatorio, acuerde la guarda y custodia compartida fundamentándola en que sólo de esta for-

729 MARTINEZ ESCRIBANO, C. Consecuencias de la crisis matrimonial y autonomía de la voluntad”, ...op. cit., página 105.

730 GARCIA PASTOR, M. "La situación jurídica de los hijos cuyos padres no conviven: Aspectos personales", Ed. McGraw-hill, Madrid, año 1997, página 63 y 110. No escapa a esta afirmación la situación de separación de hecho de los padres. En este caso, los acuerdos respecto de sus relaciones de convivencia y las de carácter paternofilial, están sujetos a la misma comprobación judicial prevista para el caso del convenio regulador. Debemos tener presente que, a falta de acuerdo entre los progenitores separados de hecho, conforme al artículo 159 del Código Civil, es el juez quien decide, en interés del hijo, la atribución de la guarda y custodia. Esta decisión pue de materializarse en u acuerdo general plasmado por escrito (así sucede en STS de 21 de julio de 1993, el cual es homologable mediante un expediente de jurisdicción voluntaria. 
ma se protege adecuadamente el interés superior del menor (párrafo octavo del artículo 92 del Código Civil). Cabe así la posibilidad de que se determine la guarda y custodia compartida aun contra la voluntad de uno de los cónyuges, cuestión que ha sido ampliamente discutida en el Derecho comparado, y frente a la cual la doctrina nacional se ha pronunciado en diversos sentidos, según ya se analizó antes ${ }^{731}$.

Pues bien, se puede decir que, dependiendo de la relevancia que se le concede a la autonomía de la voluntad de los cónyuges en la regulación de los efectos de su crisis matrimonial, el papel del juez frente a la homologación u aprobación del convenio pertinente se posiciona más o menos de manera protagonista. Los principios de autonomía de la voluntad e intervención judicial concurren de tal forma, que es posible advertir una interdependencia vital entre ellos; la labor del juez asume, en ciertas ocasiones, rasgos de control de lo acordado por los cónyuges y, en otras situaciones, funciones sustitutivas o quizás complementarias. En este sentido, al amplio reconocimiento de la autonomía privada de los cónyuges para regular los efectos de la ruptura conyugal favorece la redacción del convenio regulador, pues, atendiendo el dinamismo que reviste toda crisis matrimonial, es conveniente considerar que el acuerdo que se logre debe ser capaz de dar solución a cuantas vicisitudes se produzcan con posterioridad.

731 LATHROP, F. “Custodia compartida y corresponsabilidad parental. Aproximaciones jurídicas y sociológicas ”, Diario La Ley, No 7206, Sección Doctrina, 29 Jun. 2009, Año XXX, Ref. D-231. La Ley 12921/2009. “Así, el reconocimiento progresivo de la autonomía individual de los cónyuges se ve reflejado, por una parte, en la tendencia a reducir las exigencias legales previstas para el pronunciamiento del divorcio y, por otra, en la denominada cultura jurídica de la autorregulación, manifestada en la introducción de la mediación como un sistema que pretende eliminar los procedimientos contenciosos para ceder lugar al tratamiento de la conflictividad matrimonial sobre la base de los acuerdos de los ex cónyuges, y que ha sido crecientemente aceptada en Europa (2) - Esta libertad conllevaría un ámbito de disposición de las partes en las materias relativas a su situación conyugal pero no así, en cambio, respecto de la esfera paterno-filial que permanece prácticamente inalterada y férreamente protegida por la intervención judicial a través de la realización del interés superior del hijo. - La reforma española en materia de separación y divorcio es, en parte, ejemplo de esta evolución. El legislador ha avanzado hacia el reconocimiento de una mayor capacidad de los cónyuges para autorregular el conflicto familiar; la L 15/2005 ha suprimido las causas de separación y divorcio, equiparando prácticamente ambas figuras. En efecto, se ha señalado que con la derogación de los arts. 2, 86 y 87 y la modificación del art. 81 Código Civil (CC), el legislador ha optado por introducir un sistema de absoluto consensualismo en la relación matrimonial, no únicamente al momento de contraer el vínculo sino también al extinguirse (3). Sin embargo, en cuanto a las relaciones parentales, el CC continúa exigiendo la presentación de un convenio regulador de las relaciones personales y económicas entre las partes y respecto de los hijos y, por otra parte, ha sometido la ordenación y aplicación de la custodia compartida a un fuerte control judicial. Así, si bien conforme al párrafo quinto del art. 92 CC (LA LEY 1/1889), son los padres quienes proponen, en principio, dicha modalidad de cuidado, es el juez quien, en definitiva, pondera su procedencia adoptando las cautelas que estime convenientes, recabando Informe del Ministerio Fiscal, oyendo, si corresponde, al menor, y valorando tanto las alegaciones de las partes vertidas en la comparecencia y la prueba practicada en ella, como la relación que los padres mantienen entre sí y con sus hijos. Sin considerar que, además, puede determinar su ejercicio contra la voluntad de uno de los padres, de manera excepcional y siempre que concurran los requisitos establecidos en el párrafo octavo del mencionado artículo. De esta forma, a mi juicio, el legislador de 2005 ha reforzado el papel decisorio del juez a través de la ampliación de sus poderes discrecionales, inspirado por una indudable lógica de paternalismo judicial." 
Tal como se puede comprobar la autodeterminación de los cónyuges no es absoluta, pues se encuentra sometida al control judicial. En este sentido, sobre la base de su naturaleza de negocio jurídico de Derecho de familia, el convenio regulador ha sido considerado como un estatuto conyugal o un negocio o pacto jurídico familiar en el que predomina la autonomía de la voluntad ${ }^{732}$; aunque en el ejercicio de esta libertad, los cónyuges deben observar las limitaciones generales propias de todos los contratos, la prohibición de amparar situaciones abusivas, evitar un ejercicio antisocial del derecho y no efectuar renuncias de derechos de orden público ${ }^{733}$. Otras limitaciones específicas son las contenidas en el párrafo segundo del artículo 90 del Código Civil, que dispone que los acuerdos de los cónyuges adoptados para regular las consecuencias de la nulidad, separación o divorcio serán aprobados por el juez, salvo si son dañosos para los hijos o gravemente perjudiciales para uno de los cónyuges. De esta forma, a pesar de ser, como todo negocio jurídico, expresión de la autonomía de la voluntad concorde, no es por sí solo suficiente para generar consecuencias jurídicas: la aproba-

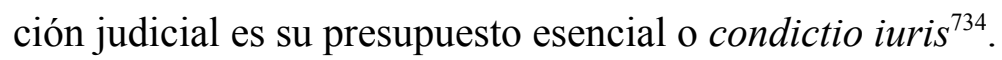

Pues bien, dadas estas cortapisas que el ordenamiento jurídico impone a la autonomía de la voluntad en este ámbito del Derecho de familia, cabe preguntarse si la autorregulación de los efectos de la crisis matrimonial se ve o no disminuida. En este sentido, por una parte, resulta claro que

732 Cfr. LLAMAS POMBO, E. “Los efectos de las crisis matrimoniales a revisión” en "Nuevos conflictos en el Derecho de Familia", Ed. La ley, Madrid, año 2009.

733 El convenio regulador es el estatuto jurídico negocial de los cónyuges separados o divorciados y de los efectos inherentes a estas situaciones familiares. No es un contrato, ya que no crea, modifica o extingue solamente relaciones patrimoniales; es más bien un acuerdo o convención que regula una múltiple situación familiar o un enrevesado de relaciones jurídicas de carácter familiar o un enrevesado de relaciones jurídicas de carácter familiar. Cfr. ALONSO PEREZ, M. "La familia entre el pasado y la modernidad. Reflexiones a la luz del Derecho Civil”, Actualidad Civil, año 1998-1, Madrid, página 25. STS, Sala Primera, de lo Civil, núm. 1187/2003, de 10 Dic. 2003, RJ. 3788/1997. “ La naturaleza de los Convenios Reguladores viene representada por constituir un efectivo negocio de naturaleza mixta, al intervenir en su perfección y consolidación la autoridad judicial que no elimina ni desplaza su naturaleza esencial de tipo contractual privada, ya que su elaboración dimana de la voluntad de los otorgantes que se expresa en el acto material de llevar a cabo la división y adjudicación del haber ganancial.

734 ÁlVAREZ ALARCÓN, A.; BLANDINO GARRIDO, M A.; SÁNCHEZ MARTÍN; P. "Las crisis matrimoniales. Nulidad, separación y divorcio”. Ed. Tirant Lo Blanch, Valencia, año 2010, páginas 175 y 176. “Sin embargo la autonomía de la voluntad juega un papel secundario en la elección de las soluciones para estos casos comprendidos en el artículo 90, puesto que, en primer lugar, los efectos de la nulidad, la separación y el divorcio vienen establecidos por la Ley, en una intervención decisiva del Poder público y, además, esta misma Ley impone un único modelo para aquellas crisis que el establecido en los artículos 90 a 101 del Citado Código Civil, en cuya confección se han tenido en cuenta los principios constitucionales de igualdad y protección de los hijos establecidos en los artículos $32.1^{\circ}$ y 39 de la Constitución; por ello se impone un control judicial de los convenios reguladores, cuyo resultado final consistirá en su homologación si se ajustan a los mencionados principios o, su denegación, si son contrarios a los mismos; de ahí que, si bien la estructuración de la dinámica interna del grupo familiar y, en en este caso, de las relaciones efecto de la crisis, corresponde a los particulares, la libertad de pactos viene condicionada por los principios constitucionales y para su salvaguardia se prevé la intervención judicial; y esto se traduce en que la autonomía de la voluntad de los cónyuges implique que puedan regular de lamenra que más convenga a su situación el contenido de los efectos previstos en la Ley, pero no puedan excluir sin razones ninguno de los efectos que se producirían con independencia de su voluntad y por decisión de esa Ley, siendo entonces objeto de una decisión judicial complementaria o modificatoria del convenio." 
la naturaleza del negocio jurídico del acuerdo regulador permanece aunque el papel que se le otorgue al juez sea la homologación, esto es, calificación y comprobación de los requisitos legales. Sin embargo, por otra parte, es igualmente cierto que, de acuerdo con el artículo 90 del Código Civil, el juez puede llegar a ser extraordinariamente activo, de tal modo que la aprobación del convenio puede llegar a convertirse en un juicio sobre su conveniencia.

Los procesos relativos al ámbito privado de las personas están sometidos al principio de disponibilidad, lo cual impide que el juez decida en contra de lo solicitado por la partes o que se pronuncie sobre un aspecto no sometido a su conocimiento. Sin embargo, como se ha señalado, determinadas cuestiones referidas a las crisis matrimoniales afectan a bienes, valores e intereses disponibles, regidos por normas y principios de ius cogens, a los que se adecuan mal los principios de rogación y de congruencia, que normalmente son los que rigen el proceso civil. Al respecto aunque nada diga el Legislador, la doctrina ${ }^{735}$ y la Jurisprudencia ${ }^{736}$ han distinguido dos grandes grupos de efectos derivados de la nulidad, separación o divorcio matrimonial.

Así, la guarda de los hijos menores, el ejercicio de la patria potestad, el derecho de comunicación y relaciones personales con el padre o madre con quien han de convivir los hijos, la contribución de cada progenitor para satisfacer los alimentos debidos a los hijos sujetos a patria potestad, y la atribución de la vivienda familiar en el caso de existir hijos, son instituciones todas de carácter indisponible respecto de las cuales debe decidir el juez ineludiblemente, aunque los cónyuges nada hayan solicitado, pudiendo recabar e investigar de oficio los datos no suministrados por las partes ${ }^{737}$. En cambio, la pensión compensatoria, la indemnización del artículo 98 del Código Civil prevista

735 Cfr. RIVERO HERNÁNDEZ, F. “Comentarios al art. 91”, en “Matrimonio y Divorcio. Comentarios al nuevo título IV del libro I del Código Civil”, LACRUZ BERDEJO, J.L. (Coord.), Ed. Civitas, Madrid, $2^{\circ}$ edición, año 1994, páginas 995 a 999.

736 El Tribunal Constitucional ha señalado en STC, Sala 2a , núm. 120/1984 de 10 diciembre. RTC 1984/120, que: "La dimensión de los efectos económicos de la sentencia estimatoria del divorcio en encuentra, más o menos extensamente tratada, en los escritos de ambas parte, por lo que la afirmación del recurrente es, en este punto, inexacta. Pero es que aunque la parte demandante en el proceso matrimonial no hubiera suscitado en modo alguno estos problemas, no por ello el juez se hubiera visto obligado a silenciarlo en su sentencia o a considerar como una reconvención la petición de contenido económico formulado por la parte demandada. No es ocioso traer a colación aquí alguna somera reflexión en orden al carácter de todo proceso matrimonial, en el que se dan procesos no dispositivos, sino de ius cogens, precisamente por derivar y ser un instrumento al servicio del Derecho de familia. No se puede transitar por él y ampararse en sus peculiaridades para olvidarse de ellas a la hora de los efectos de la sentencia que ponga fin a la relación conyugal, apelando, entonces, a los principios dispositivo y rogatorio del proceso civil español”. En este sentido, vid. STC, Sala 2a, núm. 4/2001 de 15 enero. RTC 2001/4 .

737 El art. 90 C.C., cuando establece el contenido mínimo de los convenios reguladores, dispone que éstos deben ser aprobados judicialmente, siempre que se respeten los límites que en la propia norma se prevén. Coherente con esto, el art. 777 de la Ley de Enjuiciamiento Civil, en el que se regulan las peticiones de separación o divorcio presentada de mutuo acuerdo por ambos cónyuges o por uno de ellos con el consentimiento del otro, en su número dos establece que a la petición deberá acompañarse la propuesta no de cualquier convenio regulador, sino del convenio redactado conforme a lo establecido en la legislación civil. De este modo, al juez compete en esta fase verificar que el convenio contiene la regulación mínima indicada en el art. 90 del Código Civil. 
para el caso de nulidad, los alimentos debidos a los hijos mayores y entre cónyuges, la liquidación del régimen económico del matrimonio, y la atribución de la vivienda familiar no habiendo hijos, son materias que se rigen por el principio dispositivo y rogatorio; por ende, el juez nada debe ni puede conceder ni resolver sin mediar solicitud de parte ${ }^{738}$.

$\mathrm{Al}$ respecto, cabe efectuar una breve referencia a una situación que puede presentarse en materia de custodia de los hijos en relación con el control público: la concesión judicial de la guarda de los hijos al padre o madre que no la haya solicitado, o bien, a un tercero no propuesto por los cónyuges.

Por una parte, aplicando a rajatabla el principio de la autonomía de la voluntad que gobierna el poder de decisión de los padres sobre sus cuestiones familiares, debería descartarse de plano un pronunciamiento judicial en tal sentido. Además, un argumento legal podía apoyar esta postura. La regulación de la guarda y custodia de los hijos no matrimoniales se encuentra en el artículo 159 del Código Civil, norma que establece que el juez decidirá sobre la guarda y custodia de los hijos en los casos en que los padres no lo hayan efectuado de común acuerdo, sin exigir que dicho pacto se exprese de determinada manera. De ello se desprende que el juez debe respetar lo acordado expresa o tácitamente por los padres en cuanto al cuidado de sus hijos no matrimoniales. Cuestión que resulta aplicable a las situaciones de nulidad, separación y divorcio, pues la dualidad de regulaciones (sobre hijos matrimoniales y no matrimoniales) debe resolverse descartando cualquier interpretación discriminatoria, como lo sería en este caso, afirmar que el juez sí puede decidir contra la voluntad de los progenitores en el marco de las crisis matrimonial y no así, en cambio, ante la ausencia de dicho vínculo.

Sin embargo, atendiendo el aludido carácter de ius cogens de las materias relativas a la custodia de los hijos, debemos concluir que, aunque en principio cabe rechazar la posibilidad de que el juez atribuya la guarda y custodia de los hijos a una persona que no la ha solicitado, existen situaciones excepcionales que pueden justificar una decisión en tal sentido, como sería el caso de atribución a terceros mediante resolución fundada en que ninguno de los padres es idóneo para ejercer dicho derecho-función ${ }^{739}$. En definitiva, la única limitación que respaldaría una decisión judicial de

738 A diferencia de lo que ocurre en otros ámbitos sometidos a la voluntad de las partes, en este ámbito de la regulación de las consecuencias de las rupturas matrimoniales el control judicial se ha impuesto de modo previo. La razón de esta regulación tiene que ver con la existencia de ciertas cuestiones bajo las que subyace un interés público y sobre las que necesariamente debe establecerse alguna regulación. Así pues, el control judicial se dirige a verificar que nos e deja huérfana de regulación alguna de las materias que la Ley (art. 90 C.C.) señala como ne cesaria y que el interés público concurrente no es desprotegido.

739 En este mismo sentido, GARCIA PASTOR, M., "La situación jurídica de los hijos cuyos padres no conviven: Aspectos personales", ... op. cit., páginas 111 a 113. En la jurisprudencia, la SAP de Navarra de 27 de enero de 1993 (rollo de apelación número. 270/1992) afirma que no existe incongruencia en la decisión judicial que atri- 
esta clase es que el perjuicio causado al hijo por el acuerdo previsto por las partes vulnere su interés supremo.

Pese a que la relación no varía en función de cual sea el status jurídico de pareja de los padres o los cambios que en él pudieren producirse, hay un elemento fundamental que, sin alterar el contenido de las relaciones paternofiliales, obliga a establecer una forma distinta de desarrollo y ejecución de las mismas: la ausencia de convivencia continuada, no sólo de forma esporádica, de ambos progenitores con sus hijos. De hecho, una de los elementos comunes en las situaciones de crisis familiares es justamente esta falta de convivencia, lo cual no es a todas luces un factor negativo sino más bien necesario cuando la situación de permanencia juntos puede acarrear a la pareja entrar en una escalada de inestabilidad que por supuesto afectará a los menores que junto con ellos residan.

Ante una situación de ausencia de convivencia el Legislador interviene, estableciendo cuáles son aquellas cuestiones relativas a los hijos sobre los que ha adoptarse una decisión, esta puede provenir del mutuo acuerdo por ambos progenitores, donde intervendría, aunque limitada por el visto bueno del juez por parte del juez (arts. 90, 91 y 159 del Código Civil), su autonomía de la voluntad.

Se indica que, a excepción de lo previsto en los artículos 156 y 159, el resto de las disposiciones del Código Civil que hacen referencia a las relaciones paternofiliales cuando no hay convivencia se encuentran en la regulación de los efectos de la separación, nulidad o divorcio ${ }^{740}$. Resulta ciertamente extraño que, a pesar de que el Código Civil establece los mismos derechos y obligaciones en todas las relaciones paternofiliales, con independencia de la situación jurídica de pareja de los progenitores, el tratamiento de dichas relaciones en caso de ausencia de convivencia se limita a los casos de separación, nulidad y divorcio, máxime cuando fueron dos leyes del año 1981, las que reformaron el Código Civil en materia de filiación, patria potestad, separación y divorcio ${ }^{741}$.

De todas maneras, la importancia práctica de tal laguna legal es mínima toda vez que dado que todos los hijos, con independencia de que su filiación sea matrimonial o no matrimonial, son iguales ante la ley y tienen los mismos derechos, la doctrina jurisprudencial consolidada ha estable-

buye al padre el cuidado de los hijos aunque este no lo haya solicitado expresamente. Asimismo la SAP de Valencia de 8 de abril de 1993 (rollo de apelación número 627/1991) señala que no existe incongruencia si no habien do sido solicitada por ninguna parte en la apelación, se atribuye la custodia del hijos a la abuela materna. Por último, la SAP de Palma de Mallorca de 13 de diciembre de 1990 (RGD 1992, enero-febrero, páginas 758-759) consideró congruente atribuir la custodia de los dos hijos del matrimonio al padre que sólo solicitó la custodia de uno de ellos.

740 SAINZ TORRES, M. “Los menores en el Derecho español”, LÁZARO GONZÁLEZ, I (Coord.). Ed. Tecnos, Madrid, año 2002, página 214.

741 La LEC, como bien se sabrá, contempla una regulación específica en ella para los procedimientos de guarda, cus todia y alimentos, al margen de los de separación, nulidad y divorcio. No puede estimarse, en relación con esto, que no existe regulación específica sustantiva, la hay y habrá que acudir a ella cuando el procedimiento afecte a menores que no se someten al procedimiento de separación, nulidad o divorcio. 
cido la aplicación analógica de las normas relativas a los hijos en casos de separación, nulidad y divorcio a los casos en que los progenitores no están casados entre sí $^{742}$.

Los padres son los primeros llamados a procurar, ante la crisis de la pareja o su inexistencia, las soluciones más adecuadas para sus hijos, ya que son quienes, en palabras de ZARRALUQUI ${ }^{743}$ “conocen, con infinita ventaja, la realidad de las características de su familia y de los miembros de ella, dentro de la enorme variedad de situaciones, planteamientos, conductas, personalidades, hábitos y creencias que se dan en nuestra sociedad". En el Código Civil también se entiende así, al limitar la intervención judicial al caso de que no exista acuerdo entre progenitores o que el convenio presentado por éstos no fuera aprobado por el juez, art. $91 \mathrm{CC}^{744}$.

Sin embargo, la facultad de decidir que se atribuye a los padres no es total y absoluta, pues los pactos alcanzados han de ser sometidos a la aprobación judicial.

El alcance y efectos de la intervención judicial en relación con el convenio presentado para su aprobación, sólo en supuestos de mutuo acuerdo, es materia ciertamente discutida. Por lo que se refiere a los acuerdos relativos a los hijos, el tenor literal del artículo 91 es claro al disponer que el Juez necesariamente ha de aprobar el convenio ("serán aprobados"), y sólo si considera que alguna o varias de las medidas pactadas es perjudicial para los hijos pueden denegar la aprobación, en cuyo caso, se solicitará de los progenitores que presenten un nuevo acuerdo respecto de los puntos conflictivos (art. 90 CC). El problema que se plantea al poner en práctica el art. 90 del $\mathrm{CC}^{745}$, que es fiel

742 En tal sentido se puede reflexionar de esta manera, tal como expresa TORRERO MUÑOZ, M. "Las Crisis Familiares en la Jurisprudencia, Criterios para una mediación familiar”. Ed. práctica de Derecho S.L. Valencia, Año 1999.

743 ZARRALUQUI SANCHEZ-EZNARRIAGA, L. "El convenio regulador y su aprobación judicial”, Boletín del Ilustre Colegio de Abogados de Madrid, núm. 8, 3 Epoca, año 1997.Página 63.

744 MARÍN LÓPEZ, M, expresa que: "Este precepto reproducido casi literalmente en el art. 774.4 LECiv, prevé que sea el juez quien establezca las medidas definitivas que han de regir tras la sentencia de nulidad, separación o divorcio. La intervención del juez tiene carácter subsidiario: sólo procederá cuando no exista un convenio regulador judicialmente homologado. En particular, el juez deberá ordenar las medidas definitivas en dos hipótesis: cuando los cónyuges no han presentado un convenio regulador, por no estar obligados a ello (demandas contenciosas de separación o divorcio, demandas de nulidad), y cuando habiendo presentado un convenio, alguno o algunos puntos del mismo no han sido aprobados por el juez. Estas medidas sustituyen, desde el momento de su otorgamiento, a las medidas provisionales (art. 103) que hayan estado vigentes durante la tramitación del procedimiento judicial. La adopción de medidas definitivas puede producirse, no sólo en el proceso declarativo en el que se dicta la oportuna sentencia, sino también en el proceso de ejecución... Cada parte podrá solicitar al tribunal, en la demanda y en la reconvención, la adopción de las medidas a que se refiere el artículo 91, debiendo aportar cada uno los documentos en que funde su derecho: todos aquellos documentos de que dispongan que permitan al juez evaluar la situación económica de los cónyuges y, en su caso, de los hijos-declaraciones tributarias, nóminas, certificaciones bancarias-(art. 770.1 LECiv). En la vista, o dentro del plazo que el tribunal señale a tal efecto, se practicarán las pruebas solicitadas por las partes y las que de oficio acuerde el juez. Además, el juez oirá siempre a los hijos mayores de doce años y a los menores de esa edad o incapacitados, si tienen juicio suficiente (art. 770.4 LECiv)...". En BERCOVITZ RODRÍGUEZ-CANO (Coord.), “Comentarios al Código Civil”, Ed. Thomson Aranzadi, Madrid, año 2006, página 213.

745 O'CALLAGHAN MUÑOZ, X indica, comentando este artículo que: “Además de los efectos que son propios de la nulidad, separación o divorcio, hay una serie de efectos comunes a todos y otros efectos que son comunes, no 
al principio del interés superior del menor, es que, al presentar ante el juez el convenio para su aprobación, no se le expone con claridad y certeza, en la mayoría de los casos, la situación concreta de la familia sobre la que versa el convenio, ni los motivos que han llevado a los progenitores a alcanzar un determinado pacto, en resumidas cuentas, no se le aportan los elementos de juicio necesarios, que sí tiene en el proceso contencioso, para juzgar correctamente los acuerdos alcanzados ${ }^{746}$. Sólo en el caso de que el juez lo considere indispensable se practicará la prueba que estime oportuna para apreciar la procedencia o no de aprobar el referido convenio (art. 777.4 LEC).

Lo anterior es importante, y no tan sólo desde el punto de vista de la conveniencia o no de una resolución judicial, sino también debido a que generalmente, la decisión judicial se adoptará desde el desconocimiento de las circunstancias particulares del caso, aún a pesar de que por parte del Juez se haya acordado la práctica de alguna prueba, pues ésta no va a ser suficiente para trasladar al juez la complejidad de cada situación familiar, aquellos detalles que condujeron a los progenitores a adoptar un acuerdo y que sin duda son esenciales para una buena decisión.

Es precisamente por tal motivo, que autores como ZARRALUQUI, se pronuncian a favor del "principio de mínima intervención judicial”. Este autor participa de la idea de que se respeten al máximo los pactos válidos de los progenitores (si no se da intervención al Juez, más que muy excepcionalmente, cuando la familia está unida y se consideran suficientemente protegidos, los intereses de los menores por la actuación de sus padres, no parece existir razón para darle mayor intervención cuando cesa la convivencia) y "Sólo muy excepcionalmente y, desde luego, en razón del evidente perjuicio de menores e incapacitados, debería el órgano judicial incidir en un convenio..., ${ }^{, 747}$.

Quizás, basándose en tal planteamiento podrían evitarse aquellas situaciones en que los jueces no admiten ciertos acuerdos, pero amparándose en circunstancias distintas a que los mismos constituyan un daño para los hijos. Contra tales decisiones cabe, desde el punto de vista teórico, el recurso de apelación contra la resolución judicial. Pero, desde la perspectiva práctica su eficacia es relativa, ya que implica hacer perdurar en el tiempo una situación de inestabilidad que los interesados desean

de la sentencia de nulidad, separación o divorcio, sino del proceso en trámite. Son: Primero. Las medidas previas a la interposición de la demanda... Segundo Las medidas definitivas, durante la sustanciación del proceso. Tercero. Los efectos o medidas definitivas, comunes a la sentencia de nulidad, divorcio o separación Todas las medidas anteriores tienen, esencialmente, la misma sistemática: las referencias a los hijos, la vivienda y ajuar doméstico, a la contribución a las cargas familiares y alimentos, al régimen económico matrimonial y a la pensión de uno u otro de los cónyuges. La separación consensual lleva consigo la necesidad de presentar el convenio regulador al formular la demanda (tal como exige el $n^{\circ} 1$ del art. 81)...". "Código Civil comentado y con jurisprudencia", Ed. La Ley, año 2004, página 145 y 146.

746 SAINZ TORRES, M. “Los menores en el Derecho español”, ...op. cit., página 219.

747 ZARRALUQUI SÁNCHEZ-EZNARRIAGA. "El convenio regulador y su aprobación judicial”, ....op. cit., página 85 . 
que concluya lo antes posible, lo que suele traer como consecuencia o bien que los progenitores admitan, a veces sólo formalmente, lo propuesto o resuelto por el Juez, o bien que se rompan los acuerdos alcanzados y haya de acudirse a la vía contenciosa ${ }^{748}$.

Cuando no exista acuerdo entre los progenitores sobre la manera en que han de regularse las relaciones entre ellos y con sus hijos, tras la ruptura, cualquiera de éstos puede solicitar al Juez que adopte las medidas que considere oportunas conforme a lo establecido en los artículos 92 y siguientes CC. En el curso del proceso, el Juzgador oirá a las partes, así como a los hijos menores si tuvieran suficiente juicio y siempre si fueren mayores de doce años, y se les expondrán los fundamentos en que cada uno se apoye para justificar sus pretensiones. La resolución judicial, en lo que se refiere a las medidas en relación a los hijos, no ha de atenerse a lo solicitado por las partes. La actuación judicial deberá ser discrecional por tratarse de una materia de ius cogens, no rigiendo los principios dispositivo y de rogación. Por tanto, las medidas acordadas por el juez pueden ser distintas de las contenidas en el petitum de las partes.

El Ministerio Fiscal, si bien no goza de las facultades decisorias que la Ley atribuye a progenitores y Jueces, sí tiene una intervención notable en los procedimientos matrimoniales y de menores, tanto de mutuo acuerdo como contenciosos, en cuanto ha de ser oído en todos ellos, siempre que intervengan o estén afectados menores o incapacitados, en ejercicio de su función de velar por los intereses de éstos ${ }^{749}$.

748 SAINZ TORRES, M. "Los menores en el Derecho español”, ... op. cit., página 220.

749 El mismo ZARRALUQUI, "El interés del menor en los casos de nulidad, separación y divorcio", en "El menor en la legislación actual", Fundación Antonio Nebrija, año 2002, página 93. El autor señala que: "la D.A. $8^{a}$ de la Ley 30/1981 dispone, con carácter general, que "en todos los procesos a que se refieren las normas anteriores será parte el Ministerio Fiscal, siempre que alguno de los cónyuges o sus hijos sean menores, incapacitados o ausentes." Aunque la afirmación se extiende a todos los procesos regulados en las D.A. de la Ley 30/1981, sin embargo la D.A. $\sigma^{a}$, que contiene la normativa procesal de los mutuos acuerdos, también realiza una mención especifica al señalar que si hubiera hijos menores o incapacitados (D.A. $6^{a}$. 6), "el juez dará audiencia por cinco días al Ministerio Fiscal sobre los términos del convenio relativo a los hijos." ¿Quiere esto decir que en los procesos de la D.A. $6^{a}$ el fiscal no es parte como dice la D.A. $8^{a}$, sino que sólo debe informar? Evidentemente, no se debe confundir el ser parte-que comprende la facultad de oponerse a la demanda, promover excepciones, proponer pruebas, interponer recursos, etc-, con la simple función de informar ¿Se debe ello a la naturaleza no contenciosa del proceso de mutuo acuerdo, donde no cabe que el fiscal realmente sea parte? Seguramente. Pero, entonces, la mención de la D.A. $8^{a}$ debería contener la excepción de este proceso para intentar ser clara.

También las D.A. de la Ley 30/1981 contienen una referencia más al Ministerio Fiscal y su participación en estas materias, cuando existan hijos menores o incapacitados. Se trata del punto 11 de la D.A. $6^{a}$. En el se previene que el fiscal, habiendo hijos menores o incapacitados "podrá solicitar la aprobación de un nuevo convenio (...) en el supuesto que hayan variado sustancialmente las circunstancias tenidas en cuenta con anterioridad." Esta posibilidad de proponer reformas de lo convenido por cambios de circunstancias, a cuyo conocimiento y procedencia pudiera-aunque nos sorprenda-tener acceso y conocimiento y conocimiento a través de la denuncia de terceros o de los propios hijos, sino de presentar a la homologación judicial un nuevo convenio, que por definición tiene que ser suscrito por los cónyuges. Si lo han firmado éstos, ellos presentarán a aprobación judicial o lo cumplirán. Y si no lo han suscrito, no existe convenio que el fiscal pueda presentar a nadie." 
El mutuo acuerdo de los padres es, sin lugar a dudas, el modo más ventajoso en que pueden establecerse las consecuencias que se derivan de la ruptura de la pareja y el cese de la convivencia de todos los miembros de la familia. El mayor y mejor conocimiento de la realidad familiar que tienen los progenitores, que por cierto es bastante compleja, les habilita para buscar mejores formas de consenso, considerando además que, en la gran mayoría de los casos, ninguno de ellos desea perjudicar a sus hijos, su autonomía de la voluntad, la manifestación de ella, debiera ser primordial.

También existe el acuerdo sin homologación judicial, este tiene lugar cuando los progenitores pactan las medidas pero no someten los acuerdos alcanzados a la aprobación judicial, ya sea porque, tratándose de una pareja casada, los cónyuges no solicitan que se declare judicialmente la separación o divorcio de su matrimonio, bien porque los progenitores no casados simplemente omiten iniciar el procedimiento judicial para la aprobación de los pactos o también porque iniciados tales trámites el acuerdo no es aprobado judicialmente. Es cierto que, en algunos casos, se produce el cese de la convivencia sin que se pacte nada respecto de las medidas, con la inseguridad jurídica que de ello se deriva ${ }^{750}$. Por lo demás, ésta es una forma en que los progenitores pueden convenir las medidas derivadas de la ruptura de la familia. Tales acuerdos tienen una eficacia limitada ya que sólo son eficaces entre las partes pero no frente a terceros. Este tipo de acuerdo difiere del convenio regulador no aprobado por vía judicial, fundamentalmente, en que su cumplimiento no es exigible por tal

750 El caso que aquí se trata es el de los pactos de los cónyuges que no tienen reconocimiento judicial. En todos estos casos, estamos ante acuerdos conyugales que, o bien no se han presentando como convenios reguladores en un proceso matrimonial, o bien, aportados al correspondiente jucio, no han sido objetos de aprobación judicial. Se trata entonces de dos supuestos distintos. El primero se refiere a un acuerdo conyugal no aprobado judicialmente, convenio regulador en el procedimiento de mutuo acuerdo o acuerdo en el procedimiento contencioso que no obtiene la aprobación judicial, aunque sin duda el juez habrá resuelto lo que a su parecer sea más procedente. El se gundo caso se trata del acuerdo en el que se prevean los efectos de una eventual separación o que se adopte este acuerdo una vez acaecida la crisis cónyugal, pero sin proceder a presentar el acuerdo alcanzado como tal convenio regulador en el correspondiente proceso matrimonial. 
vía $^{751} \mathrm{y}$, en consecuencia su efectividad sólo tendrá lugar en la medida en que las partes voluntariamente cumplan lo pactado ${ }^{752}$.

Sin considerar los acuerdos que se refieran exclusivamente a las relaciones patrimoniales de parejas no casadas, cuyo tratamiento es distinto, en el resto de los supuestos se requiere una resolución judicial que establezca unas medidas (bien sea mediante la aprobación del convenio o por adoptarlas el juez a falta de acuerdo entre los progenitores) para que el cumplimiento de las mismas pueda ser exigido a los tribunales, de lo contrario se tornarán ineficaces en tal aspecto. En relación con esto es relevante y ya clásica la STS de 22 de abril de $1997^{753}$ que señala: "La cuestión jurídica

751 SAP Teruel, núm. 52/2009, Sentencia de 27 Feb. 2009, rec. 249/2008. "Se plantea, por lo tanto, en esta alzada el tema relativo a la determinación del alcance que debe tener un convenio de separación no ratificado judicialmente. Tuvo ocasión de pronunciarse esta Sala sobre este extremo en la sentencia dictada en grado de apelación en el rollo de apelación núm. 89/2007 incoado para la resolución del recurso interpuesto contra la sentencia dictada por el Juzgado de Primera Instancia núm. 2 de Alcañiz en el procedimiento de disolución del matrimonio núm. 323/06 seguido a instancia de don Florian contra doña Soledad, resolución en la que se recogía la jurisprudencia del Tribunal Supremo, plasmada, entre otras sentencias, en las de 22/4/97 y 27/1/98, que ha sostenido que en cualquier caso los convenios reguladores no homologados tienen la misma validez que cualesquiera otros negocios jurídicos, que deben encontrar su límite genérico en el art. 1.255 del Código Penal y en ese sentido son perfectamente vinculantes para las partes y deben tener un peso específico trascendental en un ulterior proceso contencioso en cuanto a lo autorregulado entre partes con carácter inmediato. También en este sentido la sentencia del Tribunal Supremo de 10 de diciembre de 2003 (RJ 2003/8648) dice que "la naturaleza de los convenios reguladores viene representada por constituir un efectivo negocio de naturaleza mixta, al intervenir en su perfección y consolidación la autoridad judicial que no elimina ni desplaza su naturaleza esencial de tipo contractual privado, ya que su elaboración dimana de la voluntad de los otorgantes que se expresa en el acto material de llevar a cabo la división y adjudicación del haber ganancial". Es decir, que el convenio regulador aceptado por los cónyuges no se ve privado de su naturaleza de contrato privado por el mero hecho de que haya sido aprobado judicialmente".

752 STS, Sala primera, de lo Civil, núm. 1822/1993, de 22 de abril de 1993, RJ. 1822/1993. "La cuestión jurídica esencial que se plantea es la naturaleza jurídica del convenio regulador, en las situaciones de crisis matrimonial, contemplado y previsto su contenido mínimo en el artículo 90 del Código Civil, que no ha obtenido la aprobación judicial. En principio, debe ser considerado como un negocio jurídico de derecho de familia, expresión del principio de autonomía privada que, como tal convenio regulador, requiere la aprobación judicial, como conditio iuris, determinante de su eficacia jurídica. Deben, por ello, distinguirse tres supuestos: en primer lugar, el convenio, en principio y en abstracto, es un negocio jurídico de derecho de familia; en segundo lugar, el convenio regulador aprobado judicialmente queda integrado en la resolución judicial, con toda la eficacia procesal que ello conlleva; en tercer lugar, el convenio que no ha llegado a ser aprobado judicialmente, tiene la eficacia correspondiente a todo negocio jurídico, tanto más si contiene una parte ajena al contenido mínimo que prevé el artículo 90 del Código Civil. La sentencia de 25 de junio de 1987 declara expresamente que se atribuye trascendencia normativa a los pactos de regulación de las relaciones económicas entre los cónyuges, para los tiempos posteriores a la separación matrimonial; la de 26 de enero de 1993 añade que la aprobación judicial del convenio regulador no despoja a éste del carácter de negocio jurídico que tiene, como manifestación del modo de autoregulación de sus intereses querido por las partes."

753 STS, Sala de lo Civil, núm.325/1997, de 22 de abril de 1997, RJ 1997/3251: "Respecto a la naturaleza jurídica del convenio regulador, se cita la sentencia del TS de 15 de febrero de 2002, que señala que "los cónyuges, en contemplación de las situaciones de crisis matrimonial (separación, o divorcio), en ejercicio de su autonomía privada (art. 1255 CC), pueden celebrar convenios sobre cuestiones susceptibles de libre disposición, entre las que se encuentran las económicas o patrimoniales. Estos acuerdos, auténtico negocios jurídicos de derecho de familia ( S. 22 de abril 1997 ), tienen carácter contractual, por lo que para su validez han de concurrir los requisitos estructurales establecidos por la Ley con carácter general (art. 1261 CC), además del cumplimiento de las formalidades especiales exigidas por la Ley con carácter "ad solemnitatem" o "ad sustantiam" para determinados actos de disposición. Se trata de una manifestación del libre ejercicio de la facultad de autorregulación de las relaciones privadas, reconocida por la Jurisprudencia (Sentencias, entre otras, de 26 de enero 1993,7 mar- 
esencial que se plantea es la naturaleza jurídica del convenio regulador, en las situaciones de crisis matrimonial, contemplado y previsto su contenido mínimo en el artículo 90 del Código Civil, que no ha obtenido la aprobación judicial. En principio, debe ser considerado como un negocio jurídico del derecho de familia, expresión del principio de autonomía privada que, como convenio regulador, requiere la aprobación judicial, como conditio iuris, determinante de su eficacia jurídica. Deben, por ello, distinguirse tres supuestos: en primer lugar, el convenio, en principio y en abstracto, es un negocio jurídico de derecho de familia, en segundo lugar, el convenio regulador aprobado judicialmente queda integrado en la resolución judicial, con toda la eficacia procesal que ello conlleva; en tercer lugar, el convenio que no ha llegado a ser aprobado judicialmente, tiene la eficacia correspondiente a todo negocio jurídico, tanto más si contiene una parte ajena al contenido mínimo que prevé el artículo 90 del Código Civil”. La sentencia de 25 de junio de $1987^{754}$ declara expresamente que "se atribuye trascendencia normativa a los pactos de regulación de las relaciones económicas entre los cónyuges, para los tiempos posteriores a la separación matrimonial”; la de 26 de enero $1993^{755}$ “añade que la aprobación judicial del convenio regulador no despoja a este

zo 1995 , 22 de abril y 19 diciembre 1997 y 27 enero y 21 diciembre 1998) y la doctrina registral (Resoluciones de la DGRN de 31 de marzo y 10 de noviembre de 1995 y 1 de septiembre de 1998), que no está condicionada en su validez y fuerza vinculante Inter-partes a la aprobación y homologación judicial." Desde el punto de vista sustantivo, una vez expresado el consentimiento por los esposos, quedan estos vinculados, (artículo 1258 del Código Civil) sin que quepa el desistimiento unilateral, produciendo efectos el convenio, incluso aunque no se presente a aprobación judicial Atendiendo a lo anterior, si en la firma y ratificación judicial posterior se ha producido algún vicio del consentimiento que pudiera conducir a su nulidad, procede valorar dicha cuestión en un procedimiento declarativo posterior, en el que se garantiza el principio de igualdad procesal de ambas partes."

754 STS, Sala de lo Civil, de 25 junio 1987. RJ 1987/4553, expresa en sus fundamentos de derecho: "Si bien es cierto que su validez se halla legalmente condicionada a su aprobación judicial, aprobación que se prevé en el curso del procedimiento de separación matrimonial que regulan las disposiciones adicionales de la Ley de 7 de julio de 1981, producido el reconocimiento de la validez en el curso de un juicio de mayor cuantía, en el que están presentes ambas partes, ha de entenderse suficientemente cumplido el requisito de la intervención judicial a que el artículo 103 del Código Civil subordina la efectividad entre partes de los aludidos Convenios reguladores... Junto con el cumplimiento en sentido estricto, cabe un cumplimiento por equivalencia de la condición. El T. S. (Sala $1^{a}$ ), sentencia de 25 de junio de 1987... El Juzgado dictó sentencia declarando "perfecto y válido el pacto $7^{\circ}$ del Convenio conyugal celebrado entre ambos litigantes el día 6 de marzo de 1981, así como que el mismo vincula al demandado, pero que su efectividad está suspensivamente condicionada a la declaración, por autoridad civil o canónica, de la invalidez o la disolución del vínculo conyugal que une a ambos, condenando al demandado a entregar a la demandante "los bienes que en el referido pacto se detallan, libres de toda carga o gravamen, si se cumple aquella condición". La Audiencia confirmó el fallo del Juzgado, desestimando el recurso del demandado. El T. S. desestima, a su vez, el recurso de casación interpuesto por el mismo demandado. El T. S. desestima, a su vez, el recurso de casación interpuesto por el mismo demandado.".

755 STS, Sala de lo Civil, núm. 4/1993 de 26 enero de 1993. RJ 1993/365; STS, Sala de lo Civil, Sección 1ª núm. 775/2006 de 11 julio. RJ 2006/4975. "El tercero de los motivos del recurso, también amparado en el artículo $1692-4^{\circ}$ de la Ley de Enjuiciamiento Civil, afirma que se ha infringido el artículo 90 del Código Civil al reconocerse validez a la propuesta de convenio regulador de separación de fecha 13 de mayo de 1986, pese a que no fue ratificada por el esposo demandante ante el Juzgado que conoció del proceso matrimonial (autos de separación $n^{\circ}$ 236/86).- Sin embargo, la Audiencia no reconoce validez ni carácter vinculante para las partes a la propuesta de convenio regulador referida, sino que tiene en cuenta que en el mismo, formulado por la esposa hoy recurrente, se insistía en el carácter común de la vivienda y en la obligación que la misma asumía de que, en caso de venderse, habría de entregar la mitad del precio obtenido al actor previa deducción de la mitad de una 
del carácter de negocio jurídico que tiene, como manifestación del modo de autorregulación de sus intereses querido por las partes...en virtud de lo dispuesto en el artículo 1256 del Código Civil las partes deben cumplir el negocio jurídico, concertado según el principio de la autonomía de la voluntad que proclama el artículo 1255 y está reconocido en las sentencias de esta Sala antes citadas de 25 de junio de 1987 y de 26 de enero 1993”. Por su parte, la sentencia del Tribunal Supremo de 21 de diciembre de $1998^{756}$ aclara aún más la validez del convenio no homologado judicialmente, ya que califica la aprobación judicial que establece el artículo $90 \mathrm{CC}$ de "requisito o conditio iuris de eficacia del convenio regulador, no de su validez, y atributiva de fuerza ejecutiva al quedar integrado en la sentencia".

El principal problema que plantea, desde un punto de vista práctico en lo referente al convenio no aprobado, es precisamente su falta de fuerza ejecutiva y la inseguridad para las partes y el menor, que de ello se deriva, tal como se señaló anteriormente. Por tal motivo, ante el incumplimiento de alguno de los progenitores, en cuyo caso es evidente que no será factible la vía del procedimiento de mutuo acuerdo, al otro sólo le cabe iniciar un procedimiento contencioso solicitando del Juez, la adopción de las medidas que estime oportunas, y sólo cuando se produzca una resolución judicial que las acuerde, éstas podrán ser objeto de ejecución.

En el proceso contencioso pueden ser aportados como prueba los acuerdos alcanzados entre los progenitores, más es preciso tener en cuenta que en defecto de "concreta norma valorativa de prueba”, el sistema que rige el ordenamiento español está basado en el principio de la apreciación libre de la prueba ${ }^{757}$, por lo que convenido por las partes no vincula al Juez, quien valorará libremente la totalidad de la prueba aportada.

serie de gastos asumidos por la parte vendedora -lo que resulta lógico con independencia de que se hubiera o no reflejado en la propuesta de convenio-y de las cantidades que el actor adeudara por pensiones alimenticias. Lo sucedido en el caso presente es que el propio demandante al reclamar su derecho a percibir la mitad del precio obtenido por la venta acepta que del mismo se detraigan las referidas cantidades, por lo que así lo aceptó la Audiencia respetando el principio dispositivo propio del proceso civil; sin que ello, se reitera, supusiera reconocer eficacia vinculante al convenio que, por otra parte, según jurisprudencia de esta Sala presenta carácter de negocio de Derecho de Familia capaz de generar ciertos efectos aunque no haya sido objeto finalmente de aprobación judicial ( sentencias de 22 de abril y 19 de diciembre de 1997 y 21 de diciembre de 1998, entre otras)."

756 STS, Sala de lo Civil, núm. 1183/1998 de 21 diciembre. RJ 1998/9649

757 STS, de 21 de junio de 1990, RJ 1990/10581. Este principio de libre apreciación de la prueba se acentúa en los procesos especiales sobre capacidad, filiación, matrimonio y menores regulados en el Título I del Libro IV de la LEC. Especialmente significativo es el punto segundo del artículo 752 de la citada ley: "La conformidad de las partes sobre los hechos no vinculará al Tribunal, ni podrá éste decidir la cuestión litigiosa basándose exclusivamente en dicha conformidad o en el silencio o respuestas evasivas sobre los hechos alegados por la parte contraria. Tampoco estará el Tribunal vinculado, en los procesos a que se refiere este Título, a las disposiciones de esta ley en materia de fuerza probatoria del interrogatorio de las partes, de los documentos públicos y de los documentos privados reconocidos" 
El juez no está vinculado por los acuerdos de los progenitores en lo relativo a los hijos menores, por mucho que los mismos hayan quedado aprobados en el curso de sus personales negociaciones. En todo caso, no sucede del mismo modo respecto a los pactos de índole estrictamente patrimonial que afecten exclusivamente a los cónyuges y que hayan tenido lugar dentro de los parámetros del principio de la autonomía de la voluntad. Por tal razón la deseable seguridad jurídica de las partes exige que, cuando no se desea por los motivos que sean, someter los convenios a la aprobación judicial, los mismos consten por escrito, siendo preferible el documento notarial por la acreditación fehaciente de fechas e identidad de los firmantes que éste otorga.

En lo que toca el convenio regulador propiamente tal, si se quiere exponer un concepto sobre él, se puede expresar que es el documento en el que los cónyuges reflejan los acuerdos que han alcanzado sobre la forma en que se van a desarrollar las relaciones personales y patrimoniales entre ellos y respecto de sus hijos ${ }^{758}$, a fin de presentarlo para su aprobación por parte de la autoridad judicial $^{759}$. En su naturaleza jurídica se entremezclan pactos de contenido patrimonial con otros de ín-

758 ECHARTE FELIU, A. "Patria potestad en situaciones de crisis matrimonial”, Ed. Comares, Granada, año 2000, Páginas 13 y 14. Este autos menciona en lo referente a las influencias de la intervención judicial en la autonomía de los cónyuges, que: "Una de las más importantes novedades de la reforma de 1981 ha consistido en otorgar a los cónyuges un protagonismo fundamental en cuanto a la regulación de su propia situación en los casos de separación, nulidad y divorcio, sin más limitación que el daño de los hijos o el grave perjuicio de uno de los cónyuges apreciables por el Juez. Vista la voluntad de las partes, el juzgador podrá aceptarla o rechazarla, pero, en principio, aquella voluntad prima sobre la de Jueces o Fiscales, quienes, aun con buena intención, son desconocedores de las circunstancias y problemas existentes en el caso."

759 Sin embargo, esta autonomía de la voluntad de los esposos para dar solución a los problemas derivados de su crisis matrimonial encuentra un límite incuestionable: la intervención del Juez. Así, pues, el convenio, aunque realizado de común acuerdo por ambos cónyuges, no es eficaz sin la posterior homologación judicial. Esta homologación, como más adelante se verá, debe ceñirse a dos cuestiones principales: La existencia de extremos dañosos para los hijos y las estipulaciones gravemente perjudiciales para uno de los cónyuges. Si alguno de estos puntos resultara descuidado en el convenio, debe procederse a su denegación, la cual deberá ser motivada, atendiendo lo preceptuado en el artículo 90.2 del C.C.

La cuestión que cabe plantearse a la luz de las ideas expuestas es si esta intervención judicial ciertamente supone una merma para libertad de los otorgantes del convenio o en que medida la supone. Es decir, cuál es el alcance de la resolución del Juez.

Según un sector de la doctrina, la homologación judicial constituye una condición iuris del convenio desde la celebración del matrimonio, si los cónyuges están de acuerdo en separarse, y si los puntos del convenio no perjudican a uno de los esposos o a los hijos. El juez, según estos autores, ni evita la ruptura, ni complementa a los cónyuges en su decisión. La libertad de los esposos no queda coartada por el juzgador, quien lleva a cabo un cometido mínimo, dejando las facultades decisorias en última instancia en manos de aquellos.

Según otra opinión doctrinal, tanto el consentimiento de los cónyuges establecido en el convenio como la posterior aprobación judicial constituyen elementos necesarios del convenio, no pudiéndose reconocer más valor a uno que a otro. Es decir, se sitúan en planos similares.

Por último, se ha defendido también la posición preeminente de la homologación judicial con respecto al consentimiento de los cónyuges.

Esta postura, mantenida por parte de la doctrina, pero fundamentalmente por la Jurisprudencia, entiende que el Juez puede no sólo aprobar o denegar el convenio, sino también modificar los pactos acordados por los esposos". Esta autora se adhiere a la primera postura, es decir, entiende que las facultades del Juez son de mera homologación, desprendiéndose de esta manera por el tenor literal del artículo 90. Además expresa que lo que ocurre es que la autonomía de los cónyuges es un principio informador del Derecho de familia español, y como tal no es 
dole estrictamente personal, y se requiere, además, la aprobación judicial para que surta plenos efectos $^{760}$.

El convenio regulador ha de ser presentado ante el juzgado junto a la solicitud de adopción de medidas relativas a los hijos o de modificación de medidas adoptadas con anterioridad, debiendo los progenitores ratificarlo en presencia del juez. Una vez dictada sentencia que apruebe el convenio regulador, éste goza de la total fuerza ejecutiva de que están dotadas las resoluciones judiciales, es un equivalente jurisdiccional, como lo es la transacción.

Respecto a las materias a que el convenio regulador debe referirse, el art. 90, señala las mínimas que debe contener cualquiera de ellos. Este contenido mínimo del convenio no impide que en el mismo se puedan incluir pactos sobre cuestiones relacionadas con la pareja y los hijos comunes. Por el propio tenor literal del precepto, "al menos", ha de entenderse que la enumeración que en el mismo se hace no es cerrada sino abierta y que, por tanto, es factible presentar para la aprobación judicial, un convenio cuyo contenido exceda el mínimo permitido ${ }^{761}$.

El art. 90 del CC, como se ha visto, establece sólo el mínimo, dejando la puerta abierta a la inclusión en el convenio de cualesquiera otros pactos que las partes consideren necesarios y que deseen incluir. En todo caso, se puede afirmar, que cualquiera otros pactos que dentro de los límites de lo disponible alcancen los progenitores al margen del convenio, al tiempo de suscribir éste o después, serán válidos y eficaces entre ellos, sin perjuicio de que no podrán ser ejecutados en vía judicial al no estar homologados ${ }^{762}$.

absoluto, sino que debe ser atemperado por el juego de otros principios, en el presente caso, por el favor filii y la atención al miembro más débil de la relación conyugal, es decir, una consideración absoluta de la libertad de los esposos pasaría por encima de los anteriores principios. Esta opinión se desprende en su obra.

760 STS, Sala de lo Civil, núm. 4/1993 de 26 enero de 1993. RJ 1993/365, ya citada: “La aprobación judicial del convenio regulador no despoja a éste del carácter de negocio jurídico que tiene, como manifestación del modo de autorregulación de sus intereses querido por las partes; se limita a homologarlo después de que se comprueba que no es gravemente perjudicial para uno de los cónyuges o para los hijos (apartado E del art. 90 del Código Civil), pero de ninguna manera examina la corrección contable y valorativa de las operaciones liquidatorias ni mucho menos la ausencia de vicios de la voluntad en el consentimiento prestado a las mismas por los cónyuges".

761 LLOPIS GINER, J. M. (Coord.) “El contenido del Convenio Regulador. Sus diferentes aspectos”. Fundación Registral, Madrid, año 2006.

762 El mismo DIEZ-PICAZO Y PONCE DE LEÓN, L. “Derecho y familia”, Ed. Civitas, año 1984, Madrid, página 93. El autor señala que: "Por lo que al convenio regulador propiamente se refiere, hay que señalar que el poder que se reconoce a la voluntad de las partes no es consecuencia de un desinterés o de un abandono de las situaciones reguladas por parte del legislador. Lejos de ello, nos parece que se trata simplemente de reconocer que los que están más cerca de los problemas pueden regularlos mejor que aquellos otros que, distanciados, sólo podrán formular un juicio demasiado abstracto. Lo que no debe olvidarse, en el concreto punto en que nos movemos es que la opción aquí no es entre la ley y el negocio, entre la lex publica y la lex privata. Me parece que es una opción distinta. Es la elección entre la reglamentación imperativa del juez y la consentida por las partes. Esto significa, ante todo, que el convenio presenta una doble limitación. - En primer lugar, el convenio es una vía de ejecución de la ley y no de sustitución de la ley. Se trata de proveer de un estatuto a la situación de crisis matrimonial $y$, por hipótesis, de un estatuto que sea en términos generales conforme con los caracteres singulares 
A continuación me referiré a como este tema está tratado, a nivel patrimonial, en los diversos ordenamientos autonómicos.

En Cataluña en los arts. 23119 y ss del Código Civil de Cataluña se trata los denominados capítulos matrimoniales, los cuales son documentos necesariamente en escritura pública, de contenido múltiple, tendencialmente interdependientes o recíprocos que en contemplación de un determinado matrimonio o para la eventualidad de su ruptura otorgan entre sí, antes o después de contraerlo, los contrayentes o cónyuges. Estos capítulos constituyen la principal manifestación de la autonomía de la voluntad o poder autorregulador, que ha reconocido a contrayentes y cónyuges el Derecho Civil catalán, en contraste con las restricciones que, hasta la Ley 14/1975, de 2 de mayo existieron en el ámbito del Código Civil español, así lo menciona YZQUIERDO TOLSADA ${ }^{763}$. En Cataluña esa libre determinación es inherente a la propia tradición jurídica catalana y, por lo tanto, anterior e independiente de la codificación del propio Derecho. Esta libertad consistía de una parte en la posibili-

de la propia situación.- $\quad$ En segundo lugar, creo que también está en juego, en este lugar, el tema de los límites generales de la autonomía privada, entre los cuales se encuentra la frontera de lo indisponible, por pertenecer a lo que se ha llamado, en la técnica del Derecho Civil, "el orden público", pues, a mi juicio, orden público y ámbito de indisponibilidad son conceptos sinónimos. - En este sentido se podría cuestionar si puede hablarse de un orden público familiar de la misma manera que puede hablarse de un orden público económico. En mi opinión la respuesta al interrogante anterior es afirmativa. Hay un orden público familiar, es indispensable y queda más allá de las posibilidades de actuación de la autonomía privada. Lo que ocurre, probablemente, es que, tras la Constitución, el orden público familiar no cubre el mismo terreno que con anterioridad cubría. Sin embargo, sí creo que se pueden extraer ciertas conclusiones. Sobre todo la de que la Nación, al organizarse, ha reconocido el fenómeno familiar como un elemento básico. Resulta así del artículo 39.1 de la Constitución (...) Esta conclusión -el fundamento constitucional de la familia como elemento básico de nuestro modelo de sociedad- ha de iluminar el estudio del convenio, aun en el supuesto de que lo inscribamos en el ámbito de autonomía privada, como una manifestación de la misma y como un tipo de negocio jurídico familiar". Asimismo se destaca la SAP Cuenca, núm. 132/2010, de 30 Jun. 2010, rec. 21/2010. "El recurso de apelación no merece acogimiento por parte de este Tribunal que hace suyas las conclusiones jurídicas contenidas en la resolución recurrida.- En efecto, dos son las circunstancias que impiden que prospere la demanda rectora y, consecuentemente, el presente recurso de apelación. Así, siendo hecho indiscutido que entre las partes se formó una propuesta de convenio regulador en fecha 11 de julio de 2006 (doc. $n^{\circ} 4$ de los acompañados a la demanda) en el mismo se pactó ( $\left.8^{a}\right)$ los efectos de este convenio vincularán desde su firma y las partes se comprometen a ratificarlo en el Juzgado en el día y hora que se señale, sin que conste acreditado que el mismo hubiese sido aprobado judicialmente, esto es, previa la ratificación de los firmantes. Por otro lado, y esto es lo fundamental, tratándose de un convenio no sancionado judicialmente, debe señalarse que el principio de la autonomía de la voluntad contractual alcanza aquéllas materias sobre las que las partes pueden disponer libremente sin cortapisa alguna, como acontece con los pactos de contenido meramente económico o matrimonial, como asi ha sido sostenido por el Tribunal Supremo en sentencia de fecha 15 de febrero de 2002 , entre otras muchas. En cambio, como señala la Sentencia de la Audiencia Provincial de Lleida de fecha 23/07/2003 (Sección $1^{a}$ ) en tesis que es plenamente compartida poro este Tribunal, "... sin embargo carecen de eficacia los acuerdos alcanzados respecto de aquéllas otras cuestiones relativas al ámbito de la personalidad, en especial, las referidas a los menores de edad, cuando no hubieren contado con la necesaria y preceptiva homologación judicial, como así acontece en el presente supuesto en relación con la pensión alimenticia convenida para atender a las necesidades de las hijas menores de edad habidas en el matrimonio". Quiere ello decir, que si el convenio no ha sido ratificado judicialmente, debe al parte instar el correspondiente procedimiento sobre guarda, custodia y alimentos, con intervención del Ministerio Fiscal al existir menores de edad, para obtener el correspondiente pronunciamiento sobre, entre otras materias, los alimentos para las menores.

763 YZQUIERDO TOLSADA, M. y CUENA CASAS, M. “Tratado de Derecho de la Familia”, Volumen VII, La familia en los distintos Derechos forales, Ed. Thomson Reuters, Cizur Menor, año 2012, página 182 y 183. 
dad de otorgar antes o después de celebrado el matrimonio los capítulos matrimoniales, con la posibilidad de alterar el régimen económico matrimonial que hubiera quedado establecido, ya fuese por acuerdo anterior o por falta de aquel, por aplicación del régimen legal supletorio de separación de bienes, en esto se incluye la amplitud de su contenido. Hoy en día la regulación del Código Civil Catalán ha truncado la indisoluble asociación entre capítulos y pacto sucesorio universal, hay que pensar que el objetivo principalmente perseguido al otorgar capítulos va a seguir siendo mitigar los efectos de la separación de bienes antes que determinar cuál es el régimen económico matrimonial. Actualmente se suma la posible situación de una crisis familiar, admitiéndose que sean los propios interesados quienes se anticipen a aquel escenario y puedan regular sus efectos, ya sea por medio de unos capítulos prenupciales o conyugales, con ello se ha buscado desjudicializar lo más posible los conflictos familiares y favorecer su resolución dentro del propio ámbito familiar, son los denominados pactos en previsión de ruptura regulados en el art. 23120.

El CCCat pretende la libre determinación del contenido de los capítulos para su otorgamiento, permitiéndoles incluir en ellos estipulaciones y pactos que tengan por conveniente siempre que sean lícitos. Esta apelación de licitud implica el respeto a los límites institucionales de la autonomía de la voluntad, pero también el respeto a la igualdad de derechos y deberes entre los cónyuges o entre los contrayentes que contratan en contemplación de su futura condición conyugal.

En relación a las situaciones de ruptura familiar la Ley 25/2010 ha promovido las propuestas de los progenitores denominadas planes de parentalidad, estos son un instrumento para concretar la forma en que ambos progenitores piensan ejercer las responsabilidades parentales, en el que se detallan los compromisos que asumen respecto a la guarda, el cuidado y la educación de los hijos. Sin imponer una modalidad concreta de organización, alienta a los progenitores, tanto si el proceso es de mutuo acuerdo como si es contencioso, a organizar por sí mismos y responsablemente el cuidado de los hijos en ocasión de la ruptura, de modo que deben anticipar los criterios de resolución de los problemas más importantes que les afecten. En esta línea, se facilita la colaboración entre los abogados de cada una de las partes y con psicólogos, psiquiatras, educadores y trabajadores sociales independientes, para que realicen una intervención focalizada en los aspectos relacionados con la ruptura antes de presentar la demanda. Quiere favorecerse así la concreción de los acuerdos, la transparencia para ambas partes y el cumplimiento de los compromisos conseguidos ${ }^{764}$.

764 LAUROBA LACASA, E. "Los planes de planes de parentalidad en el Libro segundo del Código civil de Cataluña”, Revista Jurídica de Cataluña, núm. 4, Barcelona, año 2012, página 12 y 13. "En definitiva, la ruptura no tiene que dar lugar a la "adscripción” del menor a uno de sus progenitores, con la correlativa disminución de la presencia del otro. Diversas investigaciones avalan cómo un porcentaje significativo de menores crecen sin la presencia de los dos progenitores tras la crisis de pareja, pese a los probados beneficios en el desarrollo de su personalidad de la implicación de ambos. Atribuir la guarda con carácter compartido puede facilitar esa desea- 
En el Derecho Civil de Baleares el sistema capitular fue importante mientras imperaba un sentido de la familia en términos de amplitud. Hoy al imponerse un concepto nuclear de familia, en la que la determinación de los efectos patrimoniales del matrimonio se deja en muchas ocasiones a lo establecido con carácter supletorio por el Código de Derecho Civil Balear ${ }^{765}$. El art. 3 CDCB, aplicable en Mallorca y en Menorca, exige que las capitulaciones matrimoniales se formalicen en escritura pública, asi como el art. 66 del CDCB, aplicable a Ibiza y Formentera, para los espolits, o señalan como requisito de forma ad solemnitaten. Sus estipulaciones de carácter-económico familiar no se refieren al régimen económico matrimonial sino al régimen económico familiar, y es consecuencia de la idea de familia tradicional que engloba varias generaciones.

En lo referente al Derecho Civil Navarro me parece muy interesante destacar lo referente a la guarda y custodia de los hijos en los casos de ruptura de la convivencia de los padres, es la Ley Foral 3/2011, de 17 de marzo. Esta ley ha pretendido introducir un régimen propio de atribución de la guarda y custodia de los hijos ante la no cohabitación de sus padres, se aplica así tanto en los supuestos de crisis matrimonial como en el cese de convivencia de parejas no casadas, con ello se persigue evitar la aplicación del art. 92 del CC. Tal como señala su Exposición de motivos es esencial lo que hayan acordado los padres, y de hecho frente a la falta de tal acuerdo puede instaurarse el régimen de custodia compartida de los hijos. La citada Exposición anuncia en todo caso que no implanta un régimen de custodia compartida preferente en defecto de acuerdo de los padres, tal como se señala en la Ley aragonesa 2/2010, de 26 de mayo de igualdad en las relaciones familiares ante la ruptura de la convivencia de los padres. Si los padres no alcanzan un acuerdo y sólo unos de ellos solicita la custodia compartida-supuesto que en principio es el que motiva la aprobación de la Ley Foral, el Juez seguirá decidiendo cual es la modalidad más conveniente para los hijos, pero existe una importante diferencia con el régimen codificado del art. 92. En el régimen navarro basta con oir al Ministerio Fiscal, no es preceptivo el informe favorable de dicho órgano y hay que considerar

da colaboración, siempre que, más allá de las declaraciones entusiastas, exista el reconocimiento mutuo y la voluntad de priorizar el interés de los hijos comunes."... "Pero ¿en qué consiste exactamente un Plan P? El Preámbulo de la ley 25/2010... tras resaltar su carácter novedoso, lo define así: (e) s un instrumento para concretar la forma en que ambos progenitores piensan ejercer las responsabilidades parentales, en el que se detallan los compromisos que asumen respecto a la guarda, el cuidado y la educación de los hijos. Sin imponer una modalidad concreta de organización, alienta a los progenitores, tanto si el proceso es de mutuo acuerdo como si es contencioso, a organizar por sí mismos y responsablemente el cuidado de los hijos en ocasión de la ruptura, de modo que deben anticipar los criterios de resolución de los problemas más importantes que les afecten. En esta línea, se facilita la colaboración entre los abogados de cada una de las partes y con psicólogos, psiquiatras, educadores y trabajadores sociales independientes, para que realicen una intervención focalizada en los aspectos relacionados con la ruptura antes de presentar la demanda. Quiere favorecerse así la concreción de los acuerdos, la transparencia para ambas partes y el cumplimiento de los compromisos conseguidos."

765 Vid., en este sentido, FERRER VANRELL, P., "Lecciones de Derecho Civil Balear", $2^{\mathrm{a}}$ edición, Universitat de les Illes Balears, Palma de Mallorca, año 2003, páginas 165 y siguientes. 
múltiples factores que ordena tomar en cuenta el art. 3. Con lo cual se asemeja a las soluciones adoptadas por el Libro Segundo del Código Civil de Cataluña relativo a la persona y la familia, aprobado por Ley 25/2010, de 29 de julio ${ }^{766}$.

La Ley aragonesa, Código de Derecho de Familia aragonés, otorga prioridad en la regulación de las relaciones familiares a lo acordado por los padres en el denominado pacto de relaciones familiares $^{767}$. El pacto de relaciones familiares regula las cuestiones principales que se deriven de la ruptura de convivencia tanto en su relación personal con sus hijos como en el orden económico. Este concretará los acuerdos sobre los siguientes extremos relacionados con la vida familiar. En primer lugar, el régimen de convivencia o de visitas con los hijos. En segundo lugar, el régimen de relación de los hijos con sus hermanos, abuelos, parientes y otras personas allegadas. En tercer lugar, el destino de la vivienda y el ajuar familiar. En cuarto lugar, la participación de cada progenitor en el sufragio de los gastos ordinarios de los hijos, también se fijará la previsión de los gastos extraordinarios y la aportación de cada progenitor los mismos. En quinto lugar, la liquidación, cuando proceda, del régimen económico matrimonial. Finalmente la asignación familiar compensatoria.

En el Derecho valenciano existen los denominados pactos de convivencia familiar, estos serían los posibles pactos, acuerdos o convenios que pudieran establecer los progenitores con su hijos debido a la imposibilidad de una convivencia simultánea hijos-padres. El pacto sin embargo no ordena la convivencia de la familia, sino la de los menores con sus progenitores no convivientes y con el resto de la familia. El contenido del pacto recuerda al art. 90 del CC.

\subsection{Principios generales de la mediación familiar, fruto de la autonomía de la voluntad, en el ámbito de las crisis familiares}

Es ampliamente reconocido entre los profesionales de la salud, sociólogos y juristas ${ }^{768}$, que la ruptura matrimonial o de pareja da lugar a un proceso conflictivo doloroso que ocasiona prolongadas e

766 Cfr. FERNÁNDEZ URZAINQUI, F. J., "Apuntes sobre la reforma de la patria potestad en el Fuero Nuevo", Revista Jurídica de Navarra, núm. 9, año 1990, páginas 61 a 85.

767 MARTÍNEZ DE AGUIRRE Y ALDAZ, C. "Las líneas básicas de la reciente legislación aragonesa en Derecho de familia", en NAVARRO VIÑUALES, J. M. "El nuevo derecho de familia: modificaciones legislativas y tendencias doctrinales". Seminario organizado por el Consejo General del Notariado en la UIMP, agosto de 2005, Ed. Civitas, Madrid, año 2006, páginas 27 a 48.

768 IGLESIAS MIRANDA, F. "Las emociones en el proceso de mediación”, en MARTíN DIZ. F. (Coord.). "La mediación en materia de familia y Derecho Penal", Ed. Andariva, Santiago de Compostela, año 2011. Este autor es de la opinión que: "El tratamiento de las emociones en los procesos de mediación es fundamental para que estos sean exitosos, pero si mediar no es hacer terapia: ¿qué se entiende por tratamiento de las emociones en mediación?. Por un lado dar a conocer las partes los procesos emocionales propios de la ruptura de pareja y los efectos que tienen, de manera que con su identificación intervengan lo menos posible en la toma de decisiones, pero si tener como objetivo el avance en los procesos personales de adaptación a los cambios vitales, éste sería un fin terapeútico, por otro lado el conocimiento y manejo de las propias emociones del mediador con el fin de facilitar el contexto imparcial característico del proceso" 
intensas tormentas emocionales y genera niveles muy perjudiciales de ansiedad, situación que no afecta únicamente a la pareja, la familia también se ve implicada de diversas maneras, sobre todo son los hijos los más desfavorecidos por el impacto emocional que generan tales situaciones ${ }^{769}$. La implantación de la mediación en Europa ${ }^{770}$ ha constituido un proceso imparable que puede constatarse fácilmente, sin embargo esto contrasta con el escaso conocimiento que en los círculos judiciales de España tenía la figura. La podemos situar en los diversos sistemas alternativos al proceso contencioso para la solución de conflictos Alternative Dispute Resolution, ADR, en una muy extendida denominación inglesa, junto a la conciliación y al arbitraje, pero con diferencias muy marcadas. La mediación familiar en palabras de VERDÚN, supone cuestionar el modelo tradicional y legal vigente, aplicable en los casos de separación o divorcio, el cual tiene su base en la dinámica ataque - defensa, se gana o se pierde ${ }^{771}$.

En el contexto de la mediación se pretende facilitar las vías de diálogo y restablecer la comunicación con el objetivo de llegar a acuerdos, ya sean estos totales o parciales, en que ninguno de los intervinientes sea perdedor. En efecto nadie va imponer su voluntad, pero para llegar a esta instancia se hace necesario acceder voluntariamente. La solución será fruto de mutuas concesiones, de una elaboración conjunta, es el resultado de un esfuerzo y colaboración, nadie decide por los mediados en asuntos donde la intimidad presenta tanta importancia, sobre todo cuando está o puede estar en juego la guarda y custodia del menor, incluso la posibilidad de que esta sea compartida ${ }^{772}$.

769 GARCÍA GARCÍA, L. "Mediación familiar. Prevención alternativa al litigio en los conflictos familiares", Ed. Dykinson, Madrid, año 2003, página 17; VERDÚN, J. “La mediación familiar en España y en Inglaterra”, Revista de Treball Social, núm. 154, juny, any 1999, página 86; UTRERA GUTIERREZ, J. L. "El marco jurídico de los puntos de encuentro familiar", Revista de Derecho de familia, número 9, octubre 2000, Ed. Lex Nova, Valadolid, página 271.

770 Afirma MARÍN LOPEZ, J. J "Prólogo de Legislación sobre mediación familiar”, ...op. cit., página 10 y siguientes, que aunque la mediación familiar es cosa nueva entre los europeos, el fenómeno reviste en lares varios años. Es en algunos estados norteamericanos y en el Quebec canadiense donde la mediación familia hace su aparición a finales de la década de los sesenta, en espacios culturales dados más al diálogo y a la negociación, como modo de solución a los conflictos humanos. Detrás de ello existe una constante y creciente desconfianza hacia los procesos judiciales como de resolución de las diversas controversias. El documento fundacional de la mediación en Europa es la Recomendación número R (98), sobre Mediación Familiar, aprobada por los Ministros del Consejo de Europa, el 21 de enero de 1998, en la 616 reunión de los Delegados de los Ministros, recomendación que ha influido de sobre manera en la legislación aprobada desde esa fecha en la presente materia.

771 Se puede estimar que al no ser un sistema adversarial de resolución de disputas, no se reproduce el esquema ganador-perdedor. Eso sí, de todas maneras reivindicar la desjudialización como medio alternativo a la solución de este tipo de conflictos, no significa que se plantee la manera de eludir la decisión judicial. No corresponde al agente mediador ejercer la función judicial. El agente mediador es el encargado de conducir la contienda a los justos causes donde prevalezca el interés familiar y en especial el principio del favor filii.

772 SAP, Zaragoza, Sección 2a núm. 622/2011, de 2 Dic. 2011, rec. 514/2011 "En cuanto a la guarda y custodia debe indicarse que esta Sala tiene declarado que el Código del Derecho Foral de Aragón aprobado por Decreto legislativo 1/2011 de 22 de Marzo (LA LEY 5705/2011) del Gobierno de Aragón en su subsección $4^{a}$ (Arto .79 y ss) al regular las relaciones familiares tras la ruptura de la convivencia de los padres, a falta de pacto de relación familiar, establece una serie de normas entre las cuales ha establecido como preferencia legal la custodia compartida, al considerar que esta forma de custodia es más beneficiosa para el interés del menor y más respe- 
Por otra parte, es un hecho constatable que el margen de la autonomía de la voluntad, en el Derecho de Familia, se incrementa en el día a día ${ }^{773}$. Así se declara en la Exposición de Motivos de la Ley 15 de 2005, de 8 de julio por la que se modifica el Código Civil y la Ley de enjuiciamiento civil en materia de separación y divorcio que "la reforma que se acomete pretende que la libertad como valor superior del, ordenamiento jurídico español, tenga su más adecuado reflejo en el matrimonio. El reconocimiento de la Constitución de esta institución jurídica posee una innegable trascendencia en cuanto que contribuye al orden público y la paz social, y es cauce a través del cual los ciudadanos pueden desarrollar su personalidad y con el fin de reducir las consecuencias derivadas de una separación y divorcio para todos los miembros de la familia, mantener la comunicación y el diálogo, y en especial garantizar la protección del interés superior del menor, se establece la mediación como un recurso voluntario alternativo de solución de los litigios familiares por vía de mutuo acuerdo con la intervención de un mediador; imparcial y neutral”.

La Recomendación 1/98 del Comité de Ministros del Consejo de Europa destaca que "la mediación no debería en principio ser obligatoria”. Y es que la mediación familiar se fundamenta en el principio de voluntariedad el cual constituye su esencia ${ }^{774}$ y determina que las partes, no sólo sean

tuosa con los derechos de los progenitores, lo que implica que al estar configurada como regla general, el juez podrá optar por la individual cuando sea más conveniente para el menor, justificando adecuadamente esta opción, ello no implica que la custodia compartida opere de manera automática, sino que en caso de solicitarse por uno de los progenitores la custodia individual deberá realizarse el necesario estudio de los factores que señala la propia normativa y con máximo respeto al principio básico o fundamental e inspirador de la norma que es el beneficio e interés de los hijos menores de edad, tal como indica el Art ${ }^{o} .76 .2$ del Código del Derecho Foral en línea con lo proclamado igualmente por el Art ${ }^{\circ} 39$ CE (LA LEY 2500/1978). L.O. 1/1996 de 15 de enero (LA LEY 167/1996) sobre Protección Jurídica del Menor, Convención de los Derechos del Niño de 1989, Carta Europea de los Derechos del Parlamento de Europa, Ley Aragonesa de la Adolescencia e Infancia y STC 114/1992 (LA LEY 1975-TC/1993) , 143/1990 (LA LEY 1550-TC/1990) y 141/2000 (LA LEY 8805/2000) entre otras.Igualmente en la Sentencia del T.S.J.A. de 13/7/2011 se indica expresamente que el legislador aragonés, al promulgar la Ley 2/2010, de 26 de mayo (LA LEY 11829/2010), ha modificado sustancialmente el régimen legal antes existente para los casos de ruptura de la convivencia de los padres, para establecer, de modo preferente, el sistema de custodia compartida respecto de los menores. Así resulta del propio Preámbulo de la Ley 2/2010, del conjunto de sus normas y,especialmente, de los preceptos hoy contenidos en los Arts. 75.2 y 76 y 80.2 del Código del Derecho Foral de Aragón (en lo sucesivo, CFA). - Pretende, en primer lugar, propiciar un acuerdo entre los progenitores, mediante una regulación que fomenta el "El pacto de relaciones familiares", inspirado en el respeto a la libertad de pacto del Derecho Foral aragonés, de modo que se atribuye prioridad de la regulación de las relaciones familiares a lo acordado por los padres. Se fomenta este acuerdo, así como la solución del litigio si llegare a producirse, mediante la mediación familiar, que constituye, como expone el mismo Preámbulo, "un instrumento fundamental para favorecer el acuerdo entre los progenitores, evitar la litigiosidad en las rupturas y fomentar el ejercicio consensuado de las responsabilidades parentales tras la ruptura".

773 "Se trata de mediar en materias de derecho dispositivo, con pleno respeto a la voluntad de las partes, que con capacidad de decisión sobre situaciones jurídicas propias, pueden canalizar y determinar de común acuerdo la resolución de sus conflictos. Las partes buscan un instrumento válido y eficaz que les permita, con la ayuda de una tercera persona, resolver sus conflictos de menare inmediata y con el menor coste posible”, así lo expresa MUÑOZ GARCÍA, C. “Aspectos jurídicos de la mediación familiar”, Revista de Derecho Privado, marzo-abril, Madrid, año 2003, página 260.

774 Sobre esta cuestión afirma MARÍN LÓPEZ, J. J. que la mediación familiar debe ser siempre y absolutamente voluntaria y que está sobradamente demostrado que una mediación obligatoria no sólo es incoherente con el propio 
libres de someterse o no, sino también de desistir en cualquier momento. Asimismo el mediador puede dar por terminado el procedimiento cuando aprecie en alguna de las partes la falta de colaboración, que no se respeten las normas establecidas o porque considere que el proceso, atendidas las circunstancias del caso, resulta inútil para la finalidad perseguida ${ }^{775}$.

Como pone de manifiesto GARCÍA GARCÍA, algunos autores plantearon sería dudas acerca de la conveniencia de la institucionalización de este sistema. Se aduce que no parece muy conveniente que la mediación se formalice y pase a formar parte del sistema judicial, imponiéndose de manera forzosa como paso previo al juicio. Se considera que el éxito de la mediación depende justamente de que las partes hayan acudido voluntariamente, por su propia convicción ${ }^{776}$. Si lo que se pretende es alcanzar acuerdos voluntarios, no parece lógico imponer a los implicados que se sometan al procedimiento. En la misma línea que la Recomendación 1798, la Ley 1/2001, de 15 de marzo, de Mediación Familiar de la Generalitat de Cataluña, establece en su artículo 11 que "la mediación familiar está basada en el principio de voluntariedad"777. La voluntariedad, como principio de la mediación, sin duda, entraña la más íntima esencia de la institución mediadora, definiendo claramente su perfil, lo cual en todo caso no la asemeja a un negocio jurídico propio del Derecho de familia como puede ser el convenio regulador ${ }^{778}$.

significado de la institución como mecanismo extrajudicial de solución de la diferencia sino que proporciona re sultados insatisfactorios. En este sentido el art. 79.2 del Código de Familia de Cataluña, en cuanto permite que sea el Juez el que remita a las partes a la mediación, no resulta excesivamente conforme con dicho principio, por lo menos el precepto se interpreta en sus términos literales. En "Prólogo de Legislación sobre mediación familiar", ... op. cit. página 15 y siguientes.

775 GARCÍA GARCÍA, L., “Aspectos jurídicos de la mediación familiar”, ...op. cit., página 136. La voluntariedad constituye uno de los rasgos más significativos, tanto en su inicio como en su desarrollo carácter que no sólo cabe afirmarlo de las partes en conflicto, sino también del mediador.

776 MARTÍNEZ DE MURGUIA, B., "Mediación y resolución de conflictos", Ed. Paídos, Barcelona, año 1999, página 58; GUILARTE GUTIERREZ, V, "La mediación familiar: panacea cuestionable”, Revista de Derecho de Familia, núm. 6, Ed. Lex Nova, Valladolid, enero 2000, página 33.

777 No obstante lo anterior el art. 22 alude a la "mediación realizada por indicación de la autoridad judicial", lo que armonía con lo establecido en el artículo 79.2 del Código de Familia. Preceptos de los que podría interpretarse que al realizar la indicación la autoridad judicial, no hubiera de tenerse en cuenta la voluntad de los implicados.

778 SAP, Barcelona, Sección 12a, núm. 132/2011, de 21 Feb. 2007, rec. 455/2006 “Destaca la doctrina civilista que no puede equipararse el acuerdo de mediación, cuya naturaleza jurídica es singular y típica, con ninguna categoría contractual, ni tampoco -mucho menos-, con el convenio regulador, que es un instrumento procesal específico del procedimiento de familia consensuado. Incurre en error la parte recurrente cuando fundamenta su argumentación en este intento de asimilar la mediación a los paradigmas y a las categorías contractuales consolidadas en el derecho civil.- El derecho comparado pone de relieve que la mediación, como metodología, es en gran parte ajena al derecho, con importantes elementos incorporados de otras ciencias sociales, como la psicología y la teoría social de la gestión positiva de los conflictos, por lo que los acuerdos que se generan y que son producto de esta metodología, también son de una naturaleza mixta, puesto que en la mayor parte de los casos pueden contener una gran parte de elementos extrajurídicos que los distinguen de cualquier régimen contractual.- Respecto a su naturaleza, es esencial la impronta que les imprime la intervención del mediador, que confiere al acuerdo una serie de características singulares. En relación con los contratos privados, en la mediación la igualdad y equilibrio entre de las partes ha sido garantizada de forma más efectiva por la intervención del mediador neutral e imparcial, por lo que cabe presumir que el análisis de los conflictos abordados y las so- 
Este parece ser el sentir del de Ley 5/2012, de 6 de julio, de mediación en asuntos civiles y mercantiles, que al dar el concepto de esta figura hace referencia expresa a la "voluntariedad" en el artículo 1. La voluntariedad ha sido sancionada plenamente en los instrumentos internacionales dictados en la materia, tales como la Recomendación (98)1 del Comité de Ministros a los Estados miembros ${ }^{779}$ o El Libro Verde sobre modalidades alternativas de solución de conflictos en el ámbito del derecho civil y mercantil. Sin embargo, hemos de hacer especial referencia al Código de Conducta Europeo para los Mediadores de 6 de abril de 2004, que vincula la voluntariedad con el derecho a permanecer o separarse del proceso, tanto de las partes, que podrán retirarse del mismo "sin

luciones alcanzadas han sido asumidas como ventajosas por las dos partes. En cuanto a la libertad de forma que es consustancial al proceso de mediación, es consustancial con el proceso de racionalización que caracteriza todo acuerdo de este tipo, que su eficacia quede condicionada por un periodo de revocabilidad que las propias partes suelen pactar, dentro del cual los intervinientes en el acuerdo tienen la oportunidad de sopesar todas las circunstancias concurrentes, principalmente las de trascendencia jurídica, que deben ser objeto de asesoramiento específico por los abogados de las partes, como condición necesaria para la garantía de sus derechos.Junto a los anteriores elementos, el acuerdo de mediación puede contener manifestaciones de voluntad, expresiones de propósitos, menciones o intervenciones de terceras personas (como acontece en el caso de autos cuando se pacta que la sociedad mercantil destinataria de la inversión que se prevé que realice la esposa tendrá como gerente, con facultades mancomunadas, a un hijo de los litigantes). También el acuerdo puede referirse a una gran variedad de negocios jurídicos posteriores que no se perfeccionan con el acuerdo de mediación, sino que deberán ser objeto de puntual contratación o concertación posterior, incluso con la intervención de terceros o las actuaciones en entidades mercantiles, con personalidad jurídica diferenciada. En definitiva, que tales pactos o acuerdos de mediación son del todo punto extraños a los instrumentos jurídicos clásicos. - De lo hasta ahora analizado resulta que no puede confundirse el acuerdo de mediación alcanzado por las partes, con el Convenio Regulador del artículo 90 del Código Civil, ni con la propuesta a la que se refiere el artículo 77 del Código de Familia de Cataluña . Este es un instrumento definido en sede procesal, propio del procedimiento matrimonial de mutuo acuerdo, bien sea con carácter originario o sobrevenido, y su alcance viene determinado en su sentido jurídico, por un específico contenido legal de carácter obligatorio, suscrito siempre por los cónyuges, y exclusivamente por ellos, respecto del cual cualquier adición, declaración, intervención de tercera persona o condición, es extraña al mismo.- El acuerdo de mediación, a diferencia del Convenio Regulador, no es un instituto procesal y tampoco está vinculado a los procedimientos del artículo 777 de la Ley de Enjuiciamiento Civil . Puede ser anterior a la judicialización del litigio, posterior al mismo, puede referirse únicamente a aspectos parciales del litigio o insertarse en un proceso contencioso, sin que sea obstáculo para que, respecto al resto de las cuestiones a resolver en una crisis matrimonial, se mantenga la controversia judicial contenciosa.- Es importante resaltar que en la práctica de la mediación en conflictos familiares los mediadores, aun cuando posean una formación especifica respecto de las instituciones jurídicas objeto de negociación, su función no es la de asesorar (tarea reservada a los abogados de las partes). De hecho pueden proceder de otras licenciaturas o dis ciplinas, y no obstante ser excelentes profesionales que pueden ayudar a las partes a alcanzar acuerdos muy positivos para sus vidas y la de sus hijos. Mas en lo que se refiere a los aspectos jurídicos, tanto sustantivos, como en el caso de autos es la previsión de la cesión de un inmueble a una sociedad mercantil, como formales o fiscales, el mediador no es un asesor legal, por lo que no puede garantizar que la redacción de los pactos sea la idónea. Esta es la razón por la que acuerdo de mediación y Convenio Regulador son cosas distintas. Aquél es mucho más amplio, puede que mucho más genérico o más específico, pero desde luego, no puede asimilarse su régimen jurídico al del convenio regulador."

779 RODRIGUEZ LLAMAS, S. “La mediación familiar en España”, Ed. Tirant Lo Blanch, Monografías, núm. 678, Valencia, año 2010, página 64. "Es comúnmente aceptado por los analistas del movimiento de los sistemas alternativos de resolución de conflictos (ADR), que el auge principal de dicho fenómeno se produce como consecuencia de la situación que en la actualidad atraviesa el sistema judicial tradicional caracterizado por la dilación de los procesos, así como por el colapso de los Tribunales. No obstante con independencia de que este motivo posea cierto peso, tanto la anterior Recomendación 98/257/CE, como a propia Directiva que se analiza, ponen de mayor énfasis en que el principal objetivo que se pretende cumplir es el de mejorar la calidad de la justicia..." 
dar explicación alguna" (ex art. 3.3.), como del mediador, al que se le reconoce la facultad de poner fin a la mediación si el acuerdo al que se va a llegar le parece ilegal o de imposible cumplimiento, teniendo en cuenta las circunstancias del caso, o si estima poco probable que continuar con la mediación permita llegar a un acuerdo (ex art. 3.2.), cuestión, por lo demás, criticable.

La Directiva 2008/52/CE del Parlamento Europeo y del Consejo, sobre ciertos aspectos de la mediación en asuntos civiles y mercantiles de 21 de mayo de 2008, contempla la voluntariedad expresamente en la exposición de motivos, destacándola, y la incluye también entre los principios de la mediación, sin dejar fuera la posibilidad de la mediación preceptiva, en la que el órgano jurisdiccional tiene la potestad de remitir a las partes a mediación. Puede, por tanto, proponer el tribunal a los involucrados el uso de la mediación para solucionar el litigio, así como requerirlas para que asistan a una sesión informativa al respecto ${ }^{780}$.

En efecto, la voluntariedad, a tenor de la Directiva 2008/52/CE, parece ceñirse más al desarrollo del proceso y a la permanencia en el mismo que a su inicio, ya que admite la posibilidad de que una legislación nacional conste el uso obligatorio de la mediación o que la someta a incentivos o sanciones, siempre que tal legislación no impida a las partes el ejercicio de su derecho de acceso al sistema judicial.

Lo importante parece ser, por tanto, que no se prive a las partes de su derecho a acceder a la justicia (a la vía jurisdiccional) cuando lo deseen. Sin embargo, junto a la posibilidad del Juez de “invitar" a utilizar el recurso de la mediación o a acudir a la sesión informativa previa (donde la voluntariedad de las partes consideramos que no se conculca), destaca el hecho de que la mediación, si así lo disponen los Estados, pueda ser, y en esto prefiero no emplear el término "obligatoria" sino el de "necesaria", presentando este mismo carácter, si su utilización conlleva "incentivos o sanciones". Por tanto, la derivación preceptiva por el órgano judicial puede constreñir en parte la voluntariedad de esta institución, aunque lo esencial sigue siendo que las partes quieran permanecer en ella una vez iniciada y no prefieran optar por métodos más tradicionales de resolución de conflictos.

780 ORTUÑO MUÑOZ, P. "El proyecto de Directiva Europea sobre la mediación", en "Mediación y protección de menores en Derecho de Familia", Consejo General del Poder Judicial, Escuela Judicial, Cuadernos de Derecho Judicial, Madrid, año 2005, página 262. "Uno de los grandes problemas de la ejecución de las resoluciones judiciales es que para el cumplimiento de las mismas se ha de desplegar una actividad coercitiva muy costosa en la fase de ejecución forzosa de las sentencias. La esencia de la mediación, por el contrario, es que la finalización al conflicto es pactada y asumida por ambas partes como la mejor posible para ambas, no como el mal menor del famoso dicho de que vale más un mal arreglo que un buen pleito. Se habla por tanto de "solución" y no de "decisión". Esta es impuesta, mientras que la primera es libremente aceptada. La consecuencia de ello es que la actividad en la fase de ejecución va a ser mínima, en todo caso muy reducida respecto a la resolución judicial. En un contexto internacional o transfronterizo este valor es de enorme importancia tanto si es en el ámbito de relaciones personales como económicas." 
El lev motiv de la Ley de mediación española, en este punto, siguiendo el camino abierto por la Directiva citada, afirma, en su artículo 6 la voluntariedad y libre disposición de la misma. Por tanto, parece claro que se desprende de la citada Ley la esencia de la voluntariedad, al igual que se proponía en la Directiva, de la permanencia o no de las partes en el proceso y, fundamentalmente, del hecho de que son libres para acordar o no y, por tanto, para suscribir un pacto total o parcial, a pesar de que el inicio del proceso de mediación no haya sido elegido inicialmente por ellas ${ }^{781}$.

Por otro lado, el hecho de que haya de tenerse por intentada la mediación y cumplida la obligación legal justificando la asistencia, puede hacer pensar más en una primera sesión donde las partes inician sus narraciones y los mediadores comienzan planeando sobre los temas y estructurando el proceso, pero no es así, la voluntariedad se presenta siempre durante todo el mismo.

Del modo en que se reconoce la voluntariedad en la distinta normativa expuesta, podemos colegir la trascendencia que el legislador atribuye a este principio. En todo caso, la voluntariedad se puede valorar teniendo en cuenta distintos factores combinables, por un lado, las distintas fases del proceso en que ha de ser reconocida, y por otro, los sujetos que tienen derecho a ella.

Respecto de la primera cuestión, como hemos apuntado, no ha de ponerse en tela de juicio la voluntariedad del proceso por el hecho de que se derive a las partes a una sesión en que puedan ser informados de la existencia, principios y ventajas de esta institución o por el hecho de que la autoridad judicial les sugiera este recurso a los posibles destinatarios ${ }^{782}$. En cuanto a las partes, ambas conjuntamente, o una a instancia de la otra, suelen ser en la mayoría de los casos las que solicitan entrar en un proceso de mediación, predicándose por tanto su voluntariedad desde el inicio. Ello puede tener lugar tanto antes de comenzar un procedimiento judicial, como en el transcurso del mis$\mathrm{mo}^{783}$.

781 RODRIGUEZ LLAMAS, S. “La mediación familiar en España”, ... op. cit., página 145. “No obstante, creo que la inserción de la mediación familiar como un instrumento de ayuda a las familias en situaciones de crisis, tal y como se está configurando a través de las leyes autonómicas constituye un paso adelante en la configuración moderna del Derecho de Familia, en el que la autonomía de la voluntad de los cónyuges va desplazando progresivamente a las normas prohibitivas de orden público o de derecho necesario, lo que por otro lado no debe ser obstáculo para que el Estado asegure la protección social, económica y jurídica de la familia, tanto en su conjunto como individualmente, a los miembros más necesitados de protección como son los hijos."

782 GARCÍA PRESAS, I. "La mediación familiar. Una alternativa en el proceso judicial de separación y divorcio", Ed. La Ley, Madrid, año 2009, página 162. "Si es evidente que la voluntariedad ha de estar en el principio mismo de la actividad mediadora, resulta fundamenta que se mantenga en todo el desarrollo de la misma.". Cfr. GARCÍA VILLALUENGA, L. "Mediación en conflictos familiares. Una construcción desde el Derecho de la familia”, Ed. Reus S. A., Zaragoza, año 2006, página 385.

783 RONDÓN GARCÍA, L. M., “Bases para la mediación familiar”, Temas de Bienestar Social, Ed. Tirant Lo Blanch, Valencia, año 2012, página 217. "El contacto entre las partes y la mediación, puede realizarse a partir de la iniciativa de las partes, cuando la comunicación no se ha interrumpido y se conoce la posibilidad de la mediación. Otra forma de contacto es a partir de una derivación de los tribunales por entender los organismos judiciales que el asunto puede ser tratado a través de la mediación. También puede ser a partir del mediador o del servicio en que se encuentre el mediador. En este caso la dificultad se centra tanto en enganchar a ambas partes 
También cabría que las partes quisieran acceder a la mediación una vez concluido el proceso, sin que a este respecto pueda hacerse objeción alguna. La posible renuencia a proponer la mediación en los conflictos, en tanto que se generalice este proceso, por el temor a que se interprete como una debilidad en la posición negociadora, puede contrarrestarse previendo la mediación en los contratos, sometiéndose las partes a una cláusula de estas características que les remita a mediación en caso de discrepancias en la interpretación o en el cumplimiento del mismo; puede incluso establecerse quién será el mediador, o identificar a un tercero que tendrá la responsabilidad de nombrarlo. En estos casos, la voluntariedad no quedaría cuestionada, pues el compromiso es asistir a una primera reunión con el mediador, pudiendo desistir del proceso en cualquier momento posterior.

Como se ha señalado, el proceso de mediación debe necesariamente basarse en la buena fe, y se sostiene principalmente porque hay voluntad de las partes de intervenir y trabajar seriamente para tratar de resolver el conflicto que las mantiene enfrentadas y lograr un acuerdo viable. Por eso, hay que tener en cuenta que en el desarrollo del proceso de mediación pueden sobrevenir circunstancias que modifiquen la situación o el interés de las partes, debiendo predicarse la voluntariedad respecto de ellas, a lo largo de todo el tiempo, pudiendo abandonar la mediación, si ésta ya no responde a su interés. El hecho de que sea el mediador quien guíe y organice el proceso, o la necesaria suscripción del acuerdo en que las partes que desean someterse a mediación asumen unas reglas, no disminuye en modo alguno la autonomía de la voluntad de las partes, sino que sirve de garantía para el buen funcionamiento de la mediación.

Finalmente, este principio ha de acompañar a las partes hasta la conclusión de la mediación, puesto que ha de extenderse necesariamente a la adopción o no de los acuerdos, afectando esencialmente a todo su contenido, esta es, precisamente, la diferencia fundamental con los procesos heterocompositivos. Por ello, entendemos que la libre decisión de las partes a la que se encuentra sometido el acuerdo de mediación, es la manifestación amplia del principio de voluntariedad, que ha de regir para toda la institución mediadora y sus efectos. En resumen, si bien en las tres fases señaladas (comienzo del proceso de mediación, negociaciones a lo largo del proceso y toma de decisiones) se ha de reconocer la voluntariedad a las partes, en su inicio, puede venir "condicionada" a propuesta de un órgano judicial, o por sumisión previa de los actores en una cláusula ad hoc a este proceso, pero, en cualquier caso, no podrá comunicarse esta situación a etapas posteriores del proceso.

En cuanto al mediador, hay que señalar que el hecho de que alguna Ley le atribuya expresamente la potestad de no iniciar el proceso en ciertos supuestos, no es baladí, ya que puede ocurrir

como a transmitir la idea de imparcialidad y generar una primera confianza. La habilidad para convocar forma parte del mismo proceso de mediación." 
que el mediador tenga la convicción, por las circunstancias que concurran en el caso, de que el proceso no será efectivo y, por tanto, su intervención y la puesta en marcha del proceso resultarían inútiles, pudiendo dar lugar a que se desvirtúe su esencia, cuestión que puede evitarse con la referida denuncia del mediador.

En el desarrollo del proceso, está claro que la voluntariedad del mediador ha de valorarse como esencial para su buena marcha, permitiéndosele dar por terminada la mediación, en el momento en que aprecie la falta de la colaboración necesaria de alguna de las partes para continuarla, o cuando valore que no se dan las circunstancias idóneas para proseguir atendiendo a la finalidad y principios de la mediación.

Tal como se advirtió, en la Exposición de Motivos de la Ley 15/2005, de 8 de julio por la que se modifica el Código Civil y la Ley de Enjuiciamiento Civil en materia de separación y divorcio, se establece la mediación como un recurso voluntario alternativo de solución de los litigios familiares por vía de mutuo acuerdo. En este sentido se introduce una nueva regla $7^{\mathrm{a}}$ al artículo 770 de la LEC con la consiguiente redacción: "Las partes de común acuerdo podrán solicitar la suspensión del proceso de conformidad con lo previsto en el art. 19.4 de esta Ley, para someterse a mediación”.

Se puede concluir afirmando que en la sociedad civil, la familia constituye el núcleo originario y básico para el desarrollo personal de sus miembros. La estabilidad familiar constituye el índice más significativo de paz social; al contrario, los conflictos familiares comportan dolorosas secuelas para los miembros de la misma, que frecuentemente conlleva dolorosas secuelas, y por ende en su entorno social. En suma está claro que los conflictos familiares deben ser remediados de la manera más efectiva posible mediante la búsqueda de mecanismos que coadyuven a la estabilidad familiar, o al menos que alivien las tensiones que surjan.

El modo habitual para resolver estos conflictos es acudir a los tribunales, sin embargo, y por muy diversos motivos, este método ha demostrado o ser el medio más adecuado para resolver o aliviar los conflictos familiares. Es por ello que debe ser bien recibido cualquier instrumento o medida que ayude a gestionar la resolución efectiva de las crisis familiares, sobre todo cuando dicho instrumento es fruto de la responsable autonomía de las partes, o mejor dicho, cuando dicha autonomía de ambas voluntades, es conciliada, por un tercero profesional, neutral e imparcial, el cual no juzga en ningún caso, media. 
La mediación familiar supone, una fórmula para resolver conflictos familiares, recomponiendo la propia familia desde dentro, en un clima de cooperación y respeto mutuo ${ }^{784}$; para ese fin, los miembros de la familia en conflicto solicitan y aceptan la intervención confidencial de una tercera persona, ajena, esta trabajará con y para la consecución de un acuerdo justo, duradero y aceptable para los familiares en conflicto, en el sentido de mantener las responsabilidades de cada miembro de la familia, y especialmente con los más dignos de protección, cuales son los hijos, teniendo presente el carácter familiar de la persona y el libre desarrollo de su personalidad ${ }^{785}$.

784 La Ley 1/2001 de 15 de marzo de Mediación Familiar de Cataluña no dedica ningún artículo a definir la media ción familiar. No obstante si se recoge en su Preámbulo un concepto de mediación familiar, según la cual esta institución consiste en un método de resolución de conflictos, que se caracteriza por la intervención de una tercera persona imparcial y experta, sea a iniciativa propia de las partes, sea a indicación de una autoridad judicial, que tiene como objeto ayudar a las partes y facilitarles la obtención, por ellas mismas de un acuerdo satisfactorio. Sin embargo la Ley 15/2009, de 22 de julio de Mediación de Derecho Privado de Cataluña si dedica el art. $1^{\circ}$ de la misma para definir el concepto y la finalidad que se le asigna a la mediación: "A los efectos de la presente Ley, se entiende por mediación el procedimiento no jurisdiccional de carácter voluntario y confidencial que se dirige a facilitar la comunicación entre las personas, para que gestionen por ellas mismas una solución a los conflictos que les afecten, con la asistencia de una persona mediadora que actúa de modo imparcial y neutral". El art. 2 de la Ley 4/2001 de 31 de mayo de Galicia de Mediación Familiar define la mediación regulada en la Ley como: “ (...) la intervención de los profesionales especializados requeridos voluntariamente y aceptados en todo caso por las partes en condición de mediador. Estos serán expertos en actuaciones psico-socio-familiares que actuarán en funciones de cooperación y auxilio a aquellas personas que tienen o han tenido una relación familiar, para ofrecerles una solución pactada, a su problemática matrimonial o de pareja". Ley 7/2001 de 26 de noviembre de la Comunidad Autónoma Valenciana de Mediación Familiar, en su art. $1^{\circ}$ la define: "La mediación familiar es un procedimiento voluntario que persigue la solución extrajudicial de los conflictos surgidos en su seno, en el cual uno o más profesionales cualificados imparciales y sin capacidad para tomar decisiones por las partes asiste a los miembros de una familia en conflicto con la finalidad de....". La Ley 15/2003, de 8 de abril que regula la mediación familiar en la Comunidad Autónoma de Canarias dedica su art. 2 a definir y configurar la finalidad de la misma. La Ley 4/2005, relativa a la Mediación Familiar, de 24 de mayo, de Castilla-La Mancha no dedica un precepto específico a regular el concepto de mediación familiar y es en su art. 1, en relación al objeto de la Ley, donde se incluye lo que debe entenderse por tal. Finalmente, aunque podría explayarme mucho más, destaco la Ley 1/2006, de Mediación Familiar, de 6 de abril de la Comunidad de Castilla y León se vincula lo que puede entenderse como concepto de mediación familiar con el contenido del art. 1: "Es objeto de la presente Ley regular la mediación familiar que se desarrolle en el ámbito de la Comunidad de Castilla y León. Se entiende, en este sentido, por mediación familiar la intervención profesional realizada en los conflictos familiares señalados en esta Ley, por una persona mediadora cualificada, neutral e imparcial, con el fin de crear las partes en conflicto un marco de comunicación que les facilite gestionar sus problemas de forma no contenciosa".

785 SAP, Sevilla, Sección 6a, núm. 440/2005, de 21 Nov. 2005, rec. 4491/2005 "El hombre es un ser social por naturaleza, y más fundamentalmente familiar, y necesita de ese núcleo familiar para formarse, desarrollarse e integrarse en la comunidad que forma parte de un estado. Los abuelos como la cabeza de familia, aunque no estuviesen de acuerdo con la mujer de su hijo y la atacasen injustamente, han comprendido que fue un error, y necesitan tener de nuevo contacto con sus hijos y nietos, porque sin ellos su personalidad quedaba mermada, debiendo comprender los demandados que la actuación anterior de los demandantes ha sido un error, y la petición de tener contacto con sus nietos supone el reconocer que quieren que los lazos familiares que estuvieron anulados anteriormente vuelvan a la normalidad de una familia, por el bien de los propios menores, que sin la presencia de sus abuelos y tíos paternos, quedaría disminuido su entorno familiar y con ello el desarrollo de su personalidad. Entendemos pues, que no existe infracción del artículo 160 del C.Civil y que las relaciones de los abuelos con sus nietos dará lugar a que las relaciones con sus hijos vuelva a la normalidad después de esa rup tura. ...La parte apelante afirma en su recurso que la sentencia de instancia es incongruente, pues se excede en los pedimentos de la demanda, pues en la misma se solicita que las visitas de los abuelos con sus nietos se desarrollen en presencia de los padres de los menores, y la sentencia no acuerda que las visitas se desarrollen en presencia del padre, no habiendo podido defenderse de esta medida, visitas sin presencia de los padres de los 
Finalmente, quiero destacar brevemente la invitación que formuló el Consejo de Europa para promover la mediación el en marco de una resolución específicamente dedicada al secuestro internacional de menores, esta es la Resolución 1291 (2002), de 26 de junio de 2002, la razón fundamental es que cuando los miembros de una pareja con hijos deciden poner fin a su convivencia y organizan los derechos de guarda y custodia y de visita por medio de un acuerdo logrado a través de la mediación, lo hacen con la flexibilidad necesaria y las garantías precisas de manera que, en función del momento en el que se encuentre el conflicto pueden cumplir dos importantes funciones ${ }^{786}$. La primera es de prevención, un empleo exitoso de la mediación permitiría alcanzar acuerdos que son acatados de forma voluntaria la mayoría de las veces, debido a que satisfacen la mayoría de las veces los intereses de todos los implicados. De ahí que, empleada en el momento en que la pareja entra en conflicto, la mediación serviría para impedir que los menores fuesen trasladados o retenidos de manera ilícita. Mientras que la segunda función es la de instrumento útil para resolver la problemática cuando se ha producido el secuestro. Por lo motivos recién explicados no debe resultar extraño que el valor de la mediación para resolver situaciones de traslado o retención ilícitos aparezca reflejado, implícitamente o de forma expresa, en los instrumentos de cooperación internacional ${ }^{787}$.

menores... Observando el suplico de la demanda, se entiende que la parte demandante solicite en un principio por un periodo de tres meses, dado el nulo contacto de los abuelos paternos con sus nietos, que estas visitas se desarrollen en presencia del padre de los menores; pero en el tercer párrafo se solicita que estas visitas se desarrollen sin la presencia del padre de los menores, es por lo que no existe sentencia incongruente, ni se ha limitado la defensa de la parte demandada... Tampoco es cierta esta afirmación, pues no es prioritario, como alega la parte apelante, que en el informe pericial se diga que las partes procesales acudan a un Servicio Especializado en Mediación Familiar antes de que se otorgue el derecho de visitas, sino por el contrario de forma clara y contundente se informe que no existe ningún impedimento para que los demandantes puedan mantener un régimen de visitas con sus nietos, estimando necesario que las partes acudan a un Servicio Especializado de Mediación Familiar, para que puedan recomponer y establecer unos mínimos cauces de comunicación hoy inexistentes. En tanto no se produzca el cambio, no se considera adecuado que los menores no pernocten con sus abuelos paternos."

786 Vid. OREJUDO PRIETO DE LOS MOZOS, P. “El empleo de la mediación en situaciones de secuestro internacional de menores”, en ALDECOA LUZÁRRAGA, F y FORNER DELAYGUA, J. “La protección de los niños en el Derecho Internacional y en las Relaciones Internacionales”, Ed. Marcial Pons, Madrid, año 2010, páginas 369 a 373.

787 A los instrumentos que a continuación se citan habría que añadir el Convenio de La Haya de 19 de octubre de 1996, relativo a la competencia, la ley aplicable, el reconocimiento, la ejecución y la cooperación en materia de responsabilidad parental y de medidas de protección de los niños. En tal sentido Cfr. BORRAS, A y GONZÁLEZ CAMPOS, J. D. en http://www.hcch.net/index.es.php?act=conventions.pdf\&cid=70. Este convenio prevé en su art. 31 que la Autoridad Central de un Estado contratante tomará, ya sea directamente o con la cooperación de autoridades públicas o de otros organismos, todas las medidas apropiadas para facilitar la mediación, la conciliación o cualquier otro procedimiento análogo, acuerdos amistosos para la protección de la persona o de los bienes del niño, en las situaciones a las que se aplica. 


\section{6 | La autonomía de la voluntad del menor}

¿Quién puede saber lo que es bueno para un niño?. Por ejemplo, un menor inmigrante, o mejor dicho proveniente de una familia inmigrante: ¿Qué sucede con los menores nacidos en familias emigrantes con una cultura y costumbres religiosas marcadamente diferenciadas?, ¿acaso este menor quedará afectado por las tensiones existentes entre la sociedad de acogida y la originaria?, ¿qué papel juega la autonomía de la voluntad en este tipo de situaciones?

Las necesidades básicas del niño son semejantes sea cual sea su ámbito cultural, se trata de objetivizar tales necesidades para luego llevarlas al plano concreto y lograr su adecuada satisfacción. Si se efectúa la pregunta si existen necesidades diferentes para el menor por vivir en culturas distintas, en el fondo se cuestiona sobre, hasta qué punto puede condicionar al menor el haber nacido en una familia de una cultura particular cuando tiene que vivir en una sociedad cultural distinta. Autores como DE TORRES PEREA, J. M. opinan que las necesidades son las mismas ${ }^{788}$.

Ello implica que una vez satisfechas éstas, no debe limitarse al menor condicionando su desarrollo mediante unos criterios culturales, los de la sociedad originaria de los padres que le puedan dificultar severamente su integración en el ámbito cultural distinto ${ }^{789}$. Y esto es sólo un ejemplo de la basta problemática que existe en torno a la persona del menor y su personalidad en vías de madurez. Se trata, en definitiva de respetar los principios básicos del Derecho del menor ${ }^{790}$, de garantizar que se le proporcione el afecto, cariño y condiciones mínimas que contribuyan a su desarrollo, aunque la minoría de edad no sea siempre fácil de determinar, y sin perjuicio de su carácter evolutivo gradual. Es decir, contribuir a que el menor desarrolle una consciencia que le permita ver su lugar en el mundo, para lo cual es fundamental fomentar el autocontrol, pues sólo controlando sus impul-

788 DE TORRES PEREA, J.M. “Interés del menor y Derecho de familia. Una perspectiva Multidisciplinar”. Ediciones Iustel, Madrid, año 2009, página 37.

789 OCHOTORENA, J DE P. "Situaciones de desprotección infantil. Definiciones de desprotección y maltrato infantil. Importancia de la detección. Objetivos de los servicios de protección infantil”, en el Curso sobre Menores y Familias en riesgo social organizado por la Universidad de Málaga y la Diputación Provincial de Málaga, 16 de marzo de 2006.

790 VALLÉS, A. (Dir.) “La protección del menor”, Ed. Tirant Lo Blanch, Valencia, año 2009, página 10. “...las circunstancias culturales, etnográficas, económicas e incluso geográficas pueden condicionar la existencia de diferentes criterios a la hora de difinir en cada sociedad cuando comienza la mayoría de edad, cuestión que es necesario fijar con carácter general por exigencias jurídicas evidentes, como la aplicación del principio de igualdad ante la ley, pese a que el factor individual no se acomoda con facilidad a esta unificación general. Por ello, las legislaciones más evolucionadas compensan la rigidez del criterio uniforme de la mayoría de edad general, en cuanto causa legitimadora de la titularidad potencial para el ejercicio de los derechos propios de las personas adultas, así como para las exigencia de las obligaciones y responsabilidades exigibles en su caso a éstas, con el reconocimiento de diferentes edades para el ejercicio efectivo, personal y directo por el menor, de determinados derechos y obligaciones" 
sos se llega a la autoestima, debiendo procurarse igualmente potenciar su inteligencia emocional desde una primera edad ${ }^{791}$.

En tal sentido, la familia se nos presenta no sólo como fuente de apoyo material y afectivo, sino también como cauce para la socialización, tal cauce, tal camino, se define como un proceso mediante el cual la persona adquiere valores, creencias, normas y formas de conducta apropiados en la sociedad a que pertenece, siendo fundamental en el período de niñez y adolescencia. Se espera que los padres sean capaces de enseñar a los hijos a controlar sus impulsos para poder vivir en sociedad con otros seres humanos ${ }^{792}$. Sin duda son el principal espejo que puede tener el menor, espejo que jamás será impoluto pero que hay que evitar que esté tan sucio o quebrado que le provoque al menor una distorsión de su propia imagen, de lo contrario esa distorsión crecerá con él, se hará un adulto.

Debido a ello el ambiente en que la personalidad del menor se desenvuelva, es esencial, asimismo los márgenes de libertad en que dicha personalidad se manifieste también lo son, de tal manera que permitan de manera gradual, paulatina, su desarrollo, por ello una metáfora que explica bastante bien este ambiente y libertad es la de un jardín donde existen árboles adultos y otros incipientes. Los primeros con su sombra y sus raíces contribuyen al fortalecimiento de los más núbiles, el abono que se empleará para su consolidación será el alimento para la madurez de los aún incipientes árboles. Todo el jardín constituye en ecosistema donde todo importa, esos pequeños árboles tienen una personalidad propia y sin duda, asimismo, necesidades individuales ${ }^{793}$.

791 No puede olvidarse que el centro de gravedad es el propio menor, debe procurarse que pueda desarrollarse plenamente en la sociedad en la que va a crecer, no limitando sus posibilidades de adaptación. No obstante para poder adecuar el acervo cultural de los mayores a las exigencias de la sociedad resulta importante, no sólo que éste no vea limitados sus recursos de adaptación, sino también hacer responsable al menor para que pueda tener un criterio propio, especialmente en determinadas etapas de su madurez. Por tanto resulta imprescindible promover la propia autorregulación del menor, si bien ésta ha de aprenderse. Se trata, sin dudas, de un difícil proceso de aprendizaje en el que se han de ir creando las condiciones necesarias para que el menor poco a poco pueda alcanzar su autonomía, su identidad.

792 Predomina en nuestra doctrina y se impone progresivamente la idea de que la familia no es tanto una institución preeminente, cuyo interés deba primar frente al de sus componentes, sino que, aun sin desconocer su valor tras cendente, no pasa de ser un medio y un marco idóneo, pero sólo instrumental, respecto de la persona de sus miembros y los derechos fundamentales de éstos, de forma que estos últimos son más valiosos y deben triunfar cuando entran en conflicto con los intereses del grupo familiar.

793 VILLAGRASA ALCAIDE, C. "Las reivindicaciones de los movimientos internacionales de infancia y adolescencia en el vigésimo aniversario de la Convención sobre los Derechos del Niño" en ADELCOA LUZÁRRAGA, F y FORNER DELAYGUA, J. (Dirs.) en "La protección de los niños en el Derecho Internacional y en las relaciones internacionales.", Jornadas en conmemoración del 50 aniversario de la Declaración Universal de los Derechos del Niño y del 20 aniversario del Convenio de Nueva York sobre los Derechos del Niño, Colegio de Notaris de Catalunya, Marcial Pons, Barcelona, año 2010, página 415. "Siendo indiscutible la vigencia de la Convención sobre los Derechos del Niño en su vigésimo aniversario, su aplicación efectiva debe superar los obstáculos de cada contexto nacional, a partir de tres vias: del reforzamiento de los derechos de la infancia y de la adolescencia como derechos humanos, del cumplimiento de los compromisos asumidos a través de los tratados internacionales y sus protocolos facultativos, y de la respuesta a las reivindicaciones de la propia infancia y 
Consecuentemente con este propósito la LO 1/1996 señala que "el conocimiento científico actual permite concluir que no existe una diferencia tajante ente las necesidades de protección y las necesidades relacionadas con la autonomía del sujeto, sino que la mejor forma de garantizar social y jurídicamente la protección a la infancia es promover su autonomía como sujetos De esta manera podrán ir construyendo progresivamente una percepción de control acerca de su situación personal y de su proyección de futuro. Este es el punto crítico de todos los sistemas de protección a la infancia en la actualidad"

Precisamente por ello el Ordenamiento español reconoce al menor capacidad de decisión cuando acredite tener una madurez suficiente ${ }^{794}$. Dicha capacidad natural lo habilita para poder realizar por si mismo los actos relativos a los derechos de la personalidad según dispone el art. 162.1 del Código Civil. Debe tenerse en cuenta que la capacidad natural se alcanzará a distinta edad por cada persona, y que un mismo menor puede tener madurez suficiente para decidir sobre determinadas materias y carecer de ella para decidir otras.

Esta capacidad de decisión, tal cual se puede ir conociendo, intuyendo, es gradual ${ }^{795}$. Porque sin duda, hoy en día, el menor desde el punto de vista de vista del Derecho es analizado como una personalidad en desarrollo más que como un incapaz, por ello se hace necesario considerar su creciente autonomía, debido a que resulta ser un elemento fundamental para fundar tal personalidad, y ejercer sus derechos fundamentales ${ }^{796}$.

adolescencia expuesta a través del ejercicio de su derecho de participación. En este contexto, debe sustituirse el enfoque de necesidades por el enfoque de derechos humanos.- El gran desafio actual de la Convención sobre los Derechos del Niño es el reconocimiento de los niños, niñas y adolescentes, como sujetos de pleno derecho, con personalidad propia y necesidades individuales, y con derecho a tomar parte en las decisiones que le conciernen. Se trata de una respuesta global, que supere iniciativa sectoriales, identificadas con derechos concretos, que se lleven a cabo desde la perspectiva asistencial de cubrir necesidades."

794 SÁNCHEZ HERNÁNDEZ, C. "Capacidad natural e interés del menor maduro como fundamentos del libre ejercicio de los derechos de la personalidad”, en "Estudios Jurídicos en Homenaje al profesor Luis Díez-Picazo”, Tomo I, Semblanzas, Derecho Civil, Parte General, Ed. Thomson Civitas, Madrid, año 2003, página 956. Se expone que la capacidad jurídica es la aptitud o idoneidad para ser sujeto de derechos y obligaciones, es una cualidad esencial de la persona que ostenta por el mero hecho de serlo, no admitiendo grados. Los problemas que puede plantear derivan de la verificación del cumplimiento de los requisitos de los artículos 29 y 30 del Código Civil determinantes de su adquisición. Por el contrario, la capacidad de obrar es la aptitud o idoneidad para realizar eficazmente actos jurídicos. Su contenido y posible dependencia o no del estado civil de la persona ha generado diversas formulaciones, al ser determinada la capacidad de obrar por la natural es susceptible de graduación, no siendo igual y homogénea para todos los hombres.

795 SÁNCHEZ HERNÁNDEZ, C. ibídem, página 956. “En concreto, la capacidad de obrar del menor de edad ha progresado y va a seguir haciéndolo, ya que son cada vez más los actos para cuya realización solamente se le exige capacidad natural cuando demuestra tener la suficiente aptitud psíquica para la válida prestación del consentimiento necesario en el ejercicio del derecho y las consecuencias que para el ejercicio de su libertad futura tiene la disposición de ese derecho. En consecuencia, el menor debe tener voluntad para emitir el consentimiento y conocimiento de los efectos jurídicos derivados del mismo."

796 STC, Pleno, núm. 154/2002 de 18 julio. RTC 2002/154 en relación a SANTOS MORON, M". J "Sobre la capacidad del menor para el ejercicio de sus derechos fundamentales. Comentario a la TC S 154/2002 de 18 de julio (1)”. Diario La Ley, No 5675, Sección Doctrina, 12 Diciembre 2002, Año XXIII, página 1632, tomo 7, Madrid. 
La autonomía del menor, incipiente en edades tempranas, se va desarrollando luego al relacionarse con otras personas, lo que le da seguridad y autoafirmación de su personalidad, le permite el desarrollo de la misma, principio rector de nuestro ordenamiento, aunque como bien se sabe no fue siempre así a los ojos del Derecho ${ }^{797}$. En una sociedad liberal y democrática que concibe la educación como dirigida al pleno desarrollo de la personalidad en el respeto a los principios y derechos fundamentales (art. 27.2 CE), el ordenamiento está obligado a promover la autonomía de toda persona, obligación que compete en particular a los encargados de dirigir su vida y formar su personalidad, como también a los poderes públicos ${ }^{798}$.

Es interesante dilucidar la edad a partir de la que puede serle concedida tal autonomía y el alcance de esta, que dependerá de su preparación personal para asumirla. En relación con la edad es muy difícil establecer una edad o edades fijas por debajo de la mayoría de edad a partir de los cuales pueda reconocerse capacidad para ciertos actos al menor, debido a que el desarrollo psíquico de un niño y adolescente puede ser muy distinto con la misma edad. Por ello, salvo para aquellos casos en que la ley lo determina expresamente (por ejemplo, los doce años para consentir su adopción; o los dieciséis años para el consentimiento para actos médicos, de la ley 41/2002), parece más razonable vincular la concesión al menor de la autonomía de referencia a su madurez y juicio, a su discernimiento, es decir la aptitud psíquica (intelectiva y volitiva) para comprender el alcance y conse-

797 ALÁEZ CORRAL, B. "Minoría de edad y Derechos fundamentales", Ed. Tecnos, 2003, pág. 31. Plantea este autor que hasta bien entrado el siglo XX los menores no han sido contemplados jurídicamente como sujetos de derechos subjetivos. El menor era tratado como un individuo disminuido y no como un ser que está en desarrollo durante toda su vida, aunque durante la minoría de edad este desarrollo sea cualitativa y cuantitativamente más intenso. El menor de edad era objeto de la protección de los padres o del Estado y no un auténtico sujeto de derechos subjetivos, porque la minoría de edad era considerada como un status del individuo, semejante al género o al estado civil, durante el cual primaba el aspecto de imperfección de la personalidad. Los derechos legales del menor aparecen como auténticos derechos reflejos del interés paterno o social en dicha protección y no del interés del propio menor en desarrollar su autonomía.

798 SAP, Sección 7", Alicante, núm. 41/2003 de 29 enero. AC 2003/694. "Por otra parte, no debemos desconocer la finalidad teleológica, el espíritu de la tan citada exigencia, que no es otra que la de poder conocer los deseos, motivaciones y aspiraciones del menor en aras a su protección. Y partiendo de esta premisa, habremos de concluir que sin caer en la falta de sensibilidad del drama familiar que toda separación o divorcio conlleva, el simple hecho de "oír al menor» no es de por sí mismo negativo o algo que no convenga al interés del mismo. Podrá serlo o no, en función del modo en que se practique dicha audiencia, y así, el interés del menor exigirá, además de la evidente colaboración de los progenitores, que el Juzgador despliegue de una serie de habilidades, que le permitan cumplir la finalidad del precepto, aprobando o no el convenio que los progenitores le someten, sin perjudicar al menor y en interés del mismo.- Y más, dejando al margen la cuestión relativa a la exigencia de oír al menor, habría que preguntarse cómo puede el Juzgador conocer que el convenio que someten a su aprobación, ambos progenitores, lesiona o quebranta el interés de los menores o que existen o no intereses contrapuestos entre los menores y sus progenitores, en supuestos en los que no les ha oído, y en un proceso en el que no existe más prueba que la documental y la ratificación de los progenitores por separado. La experiencia parece estar demostrando, en la actualidad, que existen algunos casos en los que bajo la apariencia de un mutuo acuerdo, subyacen situaciones de violencia, conflictividad emocional, dependencia económica, y otras circunstancias que pueden determinar un régimen de guarda y custodia y de visitas, no movido por criterios de interés del menor, sino por otras razones. Tal vez, éstos o similares argumentos son los que han llevado al Legislador a imponer que los Jueces oigan a los menores con 12 años o más." 
cuencia de sus actos, con el autocontrol de su voluntad suficiente para asumir o desistir de la decisión correspondiente en cada caso concreto, según su apreciación de las consecuencias ${ }^{799}$.

Esa capacidad de discernimiento viene a coincidir con la llamada capacidad natural. En este orden cabe citar aquí el art. 31 de la aragonesa ley 13/2006 que tras presumir la capacidad de la persona que ha cumplido 14 años, no incapacitada, añade: "2. Se presume también su aptitud de entender y querer para un acto concreto mientras no se demuestre lo contrario".

Si la capacidad natural, o discernimiento, considerada en general y en abstracto, puede calificarse como categoría jurídica general, ha de ir referida a cada caso concreto, y en relación con el acto o derecho de que se trata, cuya dificultad o importancia pueden determinar que le menor no esté en condiciones de comprender las consecuencias y alcance de su decisión, o de controlar su voluntad $^{800}$.

El dar una amplia participación al menor en la determinación de cuál es su propio interés no quiere decir que se decline o delegue en él la toma de decisiones, sin duda que se vela por el desarrollo de su personalidad, ya sea en el presente y también en el futuro, pero aún no se le considera el principal responsable para si ${ }^{801}$. Cabe pensar en no pocas objeciones a ello, no sólo porque muchas veces no reúne los mínimos intelectuales y volitivos (discernimiento) para optar en una disyuntiva y decidir consciente y libremente, o por falta de experiencia de vida (particularmente importante en estas situaciones vivenciales, donde no todo es inteligencia y voluntad), sino, sobre todo, en los ca-

799 Interesante es el estudio propiciado en torno a la capacidad natural en materia de consentimiento matrimonial, vid. el estudio de TOLDRA ROCA, M". D. "Capacidad natural y capacidad matrimonial. La transexualidad. (Estudio de la capacidad en el matrimonio civil. Problemática jurídica de la persona transexualizada)”, Ed. Cedecs, Barcelona, año 2000, páginas 97 y siguientes.

800 De la interpretación conjunta de los arts. 162 y 322 del CC (32) se deduce, señala LACRUZ BERDEJO, J. L. “Elementos de Derecho Civil”. Tomo IV. Familia, Ed. Dykinson, Madrid, año 2002, página 425, la incapacidad de obrar es la regla general aplicable a los menores de edad no emancipados, de modo que necesitan actuar a través de representante legal.- Sin embargo, tal regla general debe ser atemperada tras la promulgación de la LO 1/1996, de 15 de enero, de Protección Jurídica del Menor, con el mandato expreso contenido en el art. 2 de la ci tada Ley, en su párrafo segundo, consistente en que las limitaciones a la capacidad de obrar de los menores se in terpretarán de forma restrictiva.- Así las cosas, la cláusula general contenida en el art. 154 del CC y desarrollada en el art. 162 del mismo código coexiste ahora con el principio básico que reconoce el art. 2 de la referida Ley. Junto al citado precepto-cabeza del CC aparece, ahora, otro precepto capital. El niño debe hacer y decidir él todo y en todo lo que pueda, según sus aptitudes psíquicas y discernimiento, y que no hagan otros lo que él pueda decidir o hacer por y para sí: se trata de hacer realidad la idea de la determinación consciente y responsable de la propia vida.

801 Como afirma ALÁEZ CORRAL, B. “Minoría de edad y Derechos fundamentales”, ... op. cit., páginas 156 y 157 , los arts. 12 y 39.2 y 3 de la CE diseñan la minoría de edad como un periodo vital durante el cual el individuo no se basta para la tutela de sus derechos e intereses y precisa la adopción de instrumentos de heteroprotección. Dado que el menor pasa la mayor parte de su tiempo en el seno del hogar familiar o por lo menos bajo la dependencia personal y patrimonial de la familia y como disfruta la mayor parte del tiempo efectivo de su vida en el ámbito familiar bajo la dependencia de sus padres, de forma decreciente a medida que se aproxima a la mayoría de edad, los padres son los primeros destinatarios del mandato constitucional de protección del menor. En este sentido, la cláusula general del art. 154 del CC constituye un claro ejemplo de la habilitación legislativa para incidir sobre los derechos fundamentales del menor. 
sos en que los menores se ven implicados en conflictos con personas muy próximas: estos son muy vulnerables a presiones de los adultos para decidir a favor de alguno de éstos; corren el riesgo de sentirse culpables del resultado de su opción. Un ejemplo claro es la situación de crisis matrimonial de sus padres y de sufrir la enemistad de aquél contra quien han decidido y con quien habrán de convivir o relacionarse de otro modo. Sin duda, es a veces muy difícil interpretar correctamente el verdadero deseo o elección del menor, que para ser calificada como tal deberá ir precedida de una correcta información de los hechos en que deba fundarse y las opciones posibles que maneja, la cual puede ser influida por el interés o perjuicios del informador y por la dificultad de transmitirle la posibilidad de alternativas y naturaleza de aquél. A su vez, la opción o decisión del menor está muy influenciada por su edad, por sus apetencias, deseos frustrados, mal que mal se trata de alguien que cuenta con una visión de la vida y sus conflictos muy diferente a la que puede tener un adulto, por ello la forma de averiguar tal visión no podrá efectuarse de idéntica manera como se realiza para conocer la de este.

Es decir no se trata sólo de arrancar decisiones del menor, sino de establecer el entorno más propicio para él y que así pueda desarrollar su personalidad en transformación y por ese conducto, con su propia participación, modelar los resultados ulteriores referidos a él mismo, se le protege de manera externa, pero también amparándose en elementos propios del mismo menor, sus aficiones, sus necesidades individuales, etc ${ }^{802}$. Es deber del mundo adulto conformar razonablemente ese entorno, hacerlo realidad ${ }^{803}$.

802 ÁlVAREZ CORRAL, B. "Minoría de edad y Derechos fundamentales", ...op. cit., página 41, opina que la consideración de la minoría de edad como un status natural en el que el menor ha de ser objeto de protección, consideración que fue una constante en nuestro ordenamiento hasta la entrada en vigor de la Constitución de 1978, la situación jurídica del menor de edad ha experimentado un largo proceso evolutivo encaminado fundamentalmente a variar la naturaleza jurídica de las instituciones jurídicas bajo las que se encuentra, tales como la patria potes tad o la tutela y convertirlas en instituciones sirvientes de las necesidades de protección del menor. Según el citado autor, la consideración del menor como un bien objeto de protección ha dado paso a un sistema mixto de protección: heteroprotección y autoprotección, desarrolladas ambas durante la minoría de edad.

803 SAP, Sección 1a, Tarragona, de 13 abril de 2005, rec. 99/2004. "En el caso de autos todos los informes emitidos en los mismos acreditan la conveniencia del mantenimiento de una situación que se estima favorable y amparadora de la menor, situación que no cabe alterarse por los buenos deseos o aspiraciones del recurrente cuando las circunstancias fisicas y socio-familiares que en él concurre no le permiten hacerse cargo de unos deberes que requieren de unas capacidades y disponibilidades que no concurren en su caso, al encontrarse limitado por la enfermedad que padece de poder actuar con la autonomía y libertad que la atención de una menor recomienda, máxime si esas limitaciones en lugar de inducirle a una superación le llevan a una dependencia de terceros o a una pasividad a la espera de poder ser el mismo atendido, situación comprensible y lógica pero que no constituye la más adecuada para quien pretende hacerse plenamente cargo de la educación y formación de una menor atendiéndola en todos los órdenes de la vida, máxime si el ámbito familiar en el que habita está ya sobrecargado por la presencia de cuatro adultos más y supone ya por ello importantes restricciones de espacio y atención. De todo ello se deriva que no se trata de una falta de sensibilidad el oponerse a una asunción de facultades y dedicaciones siempre gravosas y dificiles, ni de que una situación física disminuida implique una incapacidad de cumplirla, sino que se trata de ver suficientemente garantizado la adecuada cobertura a la menor, garantía que no se ve en el caso de su padre que, prácticamente, se pasa el día viendo la TV no presenta otra actividad que la de salir a tomar unas copas, al tiempo que aporta un escaso poder económico, consecuencia de su situación, ga- 
Los deseos y sentimientos del menor no deben ser infravalorados, pueden ser un dato o factor significativo en su decisión, son parte importante en la conformación de su autonomía. Pero en atención a la dificultad de una correcta formación del primero e interpretación de tales sentimientos y deseos, las afirmaciones de los menores ante los jueces, abogados y demás, pueden carecer de fundamento suficiente para dar relevancia a una decisión. Incluso puede suceder que un especialista, por ejemplo un psicólogo, lea mejor en la personalidad del menor, sus deseos y anhelos, tal valoración aclararía la estabilidad y consistencia del proceso interno de formación y manifestación del parecer de tal menor.

Una pregunta que surge en el presente análisis es sobre el consentimiento del menor, sobre todo en aquellos actos que afectan de manera especial sus derechos de la personalidad, actos que puede realizar el menor por sí mismo de conformidad con sus condiciones de madurez, tal cual lo preceptúa el art. 162. $1^{\circ}$ del Código Civil. Este precepto es acorde con la antes aludida concesión al menor de una creciente autonomía en la decisión de asuntos vinculados directamente a su perso$\mathrm{na}^{804}$. Más su interpretación no deja de plantear problemas: desde la cuestión de si procede la distinción entre la capacidad jurídica y capacidad de obrar en este ámbito, en tanto que el goce de aquellos derechos no requiere especial capacidad y que los "actos" a que alude el artículo $162.1^{\circ}$ no son tanto de disposición o creadores de obligaciones cuanto de mero goce de los derechos.

Sin duda, si el menor tiene discernimiento suficiente (capacidad natural), sólo él puede dar el consentimiento para los actos de referencia, en particular en su relación con terceros. En el caso de que el menor no la tenga, y deba dar su "consentimiento" su representante legal, no se trata, en todo caso, de una declaración de voluntad de estos que vendría a sustituir la del menor, debido a que el consentimiento de éste es personalísimo para esos actos e insustituible; sino que se emite como expresión de un deber en el ejercicio de la función pertinente y, en tal concepto, deberá ser acorde con el beneficio del menor. Este beneficio o interés es lo esencial, no una voluntad negocial.

Es momento de entrar a analizar el concepto de capacidad, resulta importante y necesario, sin duda, ¿por qué?, porque la primera medida de protección al menor, de cara a cuidar su interés, se ha

rantías que requieren algo más que deseos y palabras."

804 Sin perjuicio de ello en la mayoría de las sociedades occidentales está aumentando una peligrosa dicotomía e incongruencia entre la maduración biológica y relacional de la juventud y los ritmos y pasos hacia la sociedad adulta. Al tiempo que los desarrollos biosociales son más precoces, los procesos de emancipación concluyen más tardíamente. Se van anticipando tránsitos y se van posponiendo otros. Se van adelantando hacia la adolescencia, e incluso la infancia, comportamientos y experiencias que antaño se vivían a partir de los 18 años (se adelantan la iniciación afectiva y sexual, la libertad de decisión sobre el tiempo libre, y también la iniciativa sobre el destino del gasto del dinero que ganan o reciben de la familia; esa capacidad lleva incluido el autocontrol para consumir o no productos que generan riesgos).Y por otra parte, se van desplazando hacia los últimos años de la juventud, e incluso hacia después, iniciaciones existenciales que aún se tienen por logros característicos y propios de edades juveniles. La inserción en la edad adulta se alarga, la adquisición de la autonomía se aplaza. 
hecho limitando y restringiendo su capacidad de obrar .En tal sentido en muchos de los códigos de inspiración napoleónica, cuando se trataba la capacidad de obrar era cuando primeramente se hacía referencia a los menores, no en cuanto a persona con la autonomía propia de la misma en plena evolución sino que en lo referente a su capacidad limitada en el trato jurídico. En la nomenclatura jurídica de entonces se empleaban los términos de impúberes o púberes dentro de los menores de dieciocho años. Eran los primeros incapaces absolutos (sin jamás poder celebrar actos jurídicos por si mismos) y los segundos incapaces relativos, es decir, gozaban de la posibilidad de celebrar ciertos actos ya sea de manera personal pero autorizados por su representante legal o representados por aquel $^{805}$.

Las limitaciones de la capacidad de obrar no son a simple vista una merma en la personalidad del menor, como un estudio simplista puede concluir, ni tampoco son una medida de protección acaecida por la falta de madurez de tales menores que impliquen un complemento del desarrollo de su autonomía. Son más bien el reconocimiento de que sus capacidades intelectuales y emocionales están desarrollándose, son pinceladas del desarrollo de tal personalidad ${ }^{806}$, que implican un dejar hacer gradual, un obrar paulatino en el mundo de los negocios jurídicos, pero más aún, son el antecedente básico del derecho del menor a ser oído. Pues, si se le permite expresar su opinión y que ésta sea considerada en un proceso determinado, no es tan sólo por su carácter de víctima en dicho proceso, sino, en gran parte, porque que goza de la suficiente capacidad, ya sea sustantiva como proce-

805 Vid. GUILLÓ JIMENEZ, J. "La participación del menor en la sociedad”, en POUS DE LA FLOR, M. P. (Coord.), "La capacidad de obrar del menor: Nuevas perspectivas jurídicas.”, Exlibris Ediciones, SL, Madrid, año 2009, páginas 171 a 174 . Sostiene que "La imagen social de la niñez, el modo de comprender la infancia y la adolescencia varía con el tiempo y cambia según consideremos distintas partes del mundo.- La comprensión de las necesidades de los menores para optimizar su desarrollo, la elección de los ambientes que satisfacen más eficientemente sus necesidades o qué tipo de protección son adecuados a cada edad específica, depende de la mirada que las sociedades hacen sobre los menores."

806 SANCHO CASAJUS, C. "Los derechos de la personalidad de los menores en Aragón”, página 69, en http://www.eljusticiadearagon.com/gestor/ficheros/ n004368 LOS\%20DERECHOS\%20DE\%20LA

\%20PERSONALIDAD\%20DE\%20LOS\%20MENORES\%20EN.pdf. "En la doctrina civilística moderna se considera que el menor de edad no es un incapaz, sino simplemente que tiene limitada su capacidad de obrar en la medida en que sus capacidades intelectuales y emocionales están todavía en desarrollo y no han alcanzado su plenitud. Por lo tanto si un menor de edad tiene capacidad natural en el sentido de madurez, discernimiento, capacidad de entender y querer, tendrá capacidad de obrar para realizar el acto jurídico concreto. En definitiva si hay capacidad natural en el menor debe tener capacidad de obrar. De lo contrario se vulneraria su derecho al libre desarrollo de la personalidad. Este criterio de capacidad natural como sinónimo de capacidad de obrar se propugna tanto en el ámbito de la patrimonial como en el ámbito de la personalidad del menor. Lo que ocurre es que en el ámbito de los derechos de la personalidad, como afectan a intereses existenciales del menor, la apreciación de la existencia de la madurez necesaria debe hacerse de forma rigurosa ya que en definitiva están en juego la libertad y la igualdad de las personas. En el aspecto patrimonial, por el contrario, no quedan tan directamente afectados los derechos de la personalidad del menor al no recaer sobre cualidades directas del individuo; y además en el ámbito patrimonial no solo están afectados los derechos de los interesados sino también los derechos de terceros lo que implica que para garantizar la seguridad económica debe saber con exactitud dicho tercero con quien tiene que contratar y como tiene que contratar (de ahí la representación legal del menor en el ámbito patrimonial)". 
sal, para manifestar una opinión que reconduzca la situación en la que actualmente se encuentra inmerso $^{807}$.

Por estas dos justificaciones resulta interesante entrar en un análisis de la capacidad del menor, en materia civil, capacidad distinta a la de un adulto pero que lo prepara a su plenitud jurídica.

En relación con esto, el tránsito desde la personalidad, como cualidad o naturaleza jurídica del hombre, a la capacidad, como figura instrumental enmarcada en las grandes instituciones del Derecho privado general (patrimonio, familia, sucesiones) supone un proceso de tecnificación necesario y problemático ${ }^{808}$.

Resulta imprescindible para intentar entender bien este concepto, y además por la relación directa e íntima con el concepto de personalidad, que reviste un fundamento más moral que jurídico, comprender que la aplicación del término en cada campo necesita de una terminología adecuada. En relación al contenido del término capacidad, la noción de personalidad presenta al ser humano ante el Derecho como una existencia individual y unitaria pero también dinámica y evolutiva, cuya presencia como sujeto en las relaciones y los actos va a depender no sólo de su naturaleza última, sino, además de sus relaciones concretas en el ejercicio de la libertad psicológica o autogobierno ${ }^{809}$.

LACRUZ, expresa que la cualidad de persona, formalmente, no presupone la titularidad actual de derecho alguno, si bien toda persona física, aún recién nacida, además de los derechos de la personalidad, tendrá al menos una pretensión de alimentos frente a sus progenitores y otros parientes, o bien, subsidiariamente, un derecho similar frente al Estado. Lo que exige necesariamente la cualidad de persona es la aptitud genérica para ser titular de derechos. Para ello no es necesario que

807 La formación-evolución que se espera del menor atañe muy directamente a su conciencia. Ésta, siendo el rasgo común y definitorio de la persona - estrechamente vinculado a su identidad-, no se nos da ya hecha sino que ex perimenta un proceso de formación descrito por la Psicología evolutiva, si bien se carece por completo del sentido de la propia identidad, se puede ir construyéndola porque se dispone del material suficiente para ello. Velar por este proceso es una exigencia de la protección del menor. En este sentido concuerdo con lo planteado por MARTÍ, J. M. en "La situación jurídica del menor y su formación”, artículo que se encuentra en la obra SANTIAGO CATALÁ RUBIO (Coord.) “Evolución del Derecho de familia”, Colección Estudios, Ediciones de la Universidad de Castilla-La Mancha, Cuenca, año 2006, página 201.

808 RAMOS CHAPARRO, E. “La persona y su capacidad civil”. Ed. Tecnos, Madrid, año 1995, página 175.

809 DE LAMA AYMÁ, A. "La Protección de los Derechos de la Personalidad del Menor de edad”, Ed. Tirant lo Blanch, Valencia, año 2006, página 45 y siguientes: "las situaciones jurídicas abstractas son categorías jurídicas generales que engloban en su seno la figura del derecho subjetivo, el bien jurídico y el interés legitimo, entre otras, como manifestaciones de la personalidad y la dignidad del individuo. La personalidad como valor se manifiesta en una serie de bienes jurídicos de la personalidad, es decir, conceptos inherentes a la existencia humana que el ordenamiento jurídico considera merecedores de una protección cualificada. Por ello la tutela de los bienes jurídicos de la personalidad debe considerarse una cuestión de interés general pues la sociedad considera necesario que estos queden garantizados en su seno. El concepto de bien jurídico encuentra su origen en la doctrina penalista pues es la idea de protección del bien jurídico donde esta el fundamento de la sanción penal"; pero desde el derecho civil también se ha hecho uso de el "como un valor beneficioso, aprovechable y positivo de una realidad personal, social y material", 
la persona física tenga uso de razón, ni menos voluntad e inteligencia plenamente desarrollada: es por su mera condición de ser humano por lo que el Derecho natural y el positivo le consideran con capacidad para servir de soporte a derechos y obligaciones, lo cual no incluye el poder de gobernar la propia esfera jurídica, que puede tenerse en un grado mayor o menor, o del que se puede care$\operatorname{cer}^{810}$.

Como bien es sabido la capacidad jurídica estándar, es decir, la que in abstracto corresponde a toda persona, comprende, en hipótesis, la aptitud para ser, genéricamente, titular de derechos y deberes, el poder para ser parte en todos los actos o negocios, salvo aquellos que requieran una aptitud especial: poder que, faltándole capacidad de obrar, podrá ejercer en los negocios no personalísimos mediante su representante legal. Esto último en el caso de los menores es patente y notorio.

Al concepto de capacidad jurídica suele contraponerse el de capacidad de obrar, que se refiere a un concreto acto o negocio, significa que una persona es capaz de realizarlo por sí, que no precisa en lugar suyo la intervención del representante legal ni la cooperación de otra persona. La capacidad de obrar, siguiendo a LACRUZ, recién citado, no es igual en todas las personas, pero esta desigualdad no puede ser arbitraria. El Derecho atiende hoy, para reconocerla a la aptitud de cada uno para regir su persona y bienes; nula en el recién nacido, creciente con la edad hasta el pleno juicio, disminuida o anulada por las enfermedades mentales.

El objeto de esto es adaptar la capacidad de obrar (legal) a la situación concreta, es decir a la aptitud o capacidad para querer y entender de cada uno.

ALBALADEJO ${ }^{811}$, menciona que la capacidad jurídica la tiene todo hombre, comienza con su personalidad y acaba con ella. La capacidad jurídica que el Derecho español reconoce, consiste, general e indeterminadamente, en una capacidad abstracta y uniforme para todos.

Como todas las grandes construcciones jurídicas teóricas, la distinción clásica de la capacidad aparece aquejada de su crisis particular. Para una exposición de los principales ataques doctrinales que ha recibido, se podría hablar de dos "frentes" que representan motivaciones, planteamientos e incluso épocas diversas y sucesivas. El primero y más antiguo, formado sobre todo por autores alemanes, centra sus críticas en la figura de la capacidad jurídica, mientras el segundo, contemporáneo, localizado principalmente en la doctrina italiana, dirige las suyas contra la capacidad de obrar legal o abstracta $^{812}$.

810 LACRUZ BERDEJO, J. L. y OTROS. "Elementos de Derecho Civil”, Parte General, Volumen Segundo, Ed. Dykinson, $2^{\mathrm{a}}$ edición, Madrid, año 2000, páginas 3 y 4.

811 AlBALADEJO, M. "Derecho Civil. Introducción y parte general", Volumen 1, Ed. J. M. Bosch Editor S.A., Barcelona, $12^{\mathrm{a}}$ edición, año 2006, página 229.

812 DE CASTRO Y BRAVO, F. “Derecho Civil de España”, Ed. Civitas, Madrid, año 1984, páginas 40 a 44. 
En ambos, con fines contrarios, de una u otra forma, se impugna básicamente el criterio de la distinción tradicional, utilizando argumentos técnicos que intentan demostrar la inutilidad de las categorías resultantes del mismo, al menos, en sectores concretos de la normativa civil.

Estas posiciones han perturbado el planteamiento fácil del binomio clásico, demostrando su relatividad histórica como instrumento de la técnica jurídica. Se debe creer que la distinción clásica está llamada a superar su crisis y a sobrevivir largo tiempo en la doctrina, dado que su misma evolución la ha relativizado históricamente, poniéndola, cada vez más, al servicio de los principios derivados de la construcción realista de la persona. De todas maneras gran parte de las críticas que ha recibido han servido para perfeccionarla y ninguna hasta ahora ha proporcionado una alternativa técnica que sea capaz de reconstruir, enteramente desde otras bases, el régimen jurídico de la persona sujeto.

El régimen de la capacidad de obrar del menor está contenido fundamentalmente en el Código Civil, si bien de forma dispersa y con carácter fragmentario, y además es el sedimento de varios aportes legislativos, la más importante es la Ley 1/1996. Dicha Ley sorprendentemente no abordó la regulación de la capacidad de obrar del menor, salvo la previsión contenida en el párrafo $2^{\circ}$ del art. 2.

En efecto, aunque han proliferado las normas especiales, cuyo objeto son determinadas clases de actos jurídicos, para los cuales se reconoce capacidad de obrar al menor de cierta edad, siguiendo el criterio objetivo, o su suficiente madurez personal (acogiendo el criterio subjetivo), todavía la norma más general del mismo sigue siendo la recogida en el artículo $1263.1^{\circ} \mathrm{CC}^{813}$.

Esta interpretación también explica que se hayan denominado capacidades especiales a las concretas posibilidades de actuar que las leyes reconocen a los menores, y aunque el artículo 1263 $1^{\circ} \mathrm{CC}$ está en sede de contratos (actos patrimoniales), se ha considerado aplicable supletoriamente a todo tipo de actos jurídicos, pues en el Derecho privado español, al desconocerse legalmente la categoría de negocio jurídico, las insuficiencias normativas en el régimen legal de los actos jurídicos

813 BERCOVITZ RODRIGUEZ-CANO, expresa que, en relación al artículo 1263: "La norma comentada se refiere con valor fundamentalmente programático o de regla base, a la capacidad general de contratar, que no concurre en principio ni en los casos de minoría de edad sin emancipación ni en los de incapacitación legal. La posibilidad en el caso concreto habrá que considerarla según la regulación especifica que puede aumentar este principio, aumentado o reduciendo las exigencias de capacidad (art. 1264). Aunque hay quien alude literalmente a que la norma se refiere a la incapacidad de consentir, en realidad tal como señala la doctrina mayoritaria y la jurisprudencia, se está aludiendo a la incapacidad para contratar, o de forma más amplia a la incapacidad de obrar... El hecho jurídico de la minoría de edad no hace que se considere inexistente, puesto que el artículo debe interpretarse conjuntamente con los artículos 1301 y 1302, se tratará en principio de contratos no nulos sino que anulables...", en la obra de BERCOVITZ RODRÍGUEZ-CANO, R y OTROS, "Comentarios al Código Civil", Ed. Thomson Aranzadi, año 2006, páginas 1513 y 1514. 
unilaterales se han colmado mediante la aplicación analógica de los criterios generales de los contratos, justificada a fortiori en el artículo $1090 \mathrm{CC}^{814}$.

DE CASTRO ${ }^{815}$ era partidario de que al menor no se le podía considerar un incapaz absoluto en función de la edad, salvo las excepciones legales, más bien un protegido por el Derecho. Esto se justificaba expresando que el menor sólo es incapaz cuando carece de capacidad natural, lo que conlleva a la nulidad de sus actos, pero cuando goce de capacidad natural, el menor puede actuar, si bien sus actos son anulables por ser objeto de protección jurídica y estar sometido a patria potestad o tutela. Esta postura descansa, en último término, en la distinta técnica jurídica de tratamiento de los actos realizados por el menor, vale decir, si goza o no de capacidad natural suficiente. Y su único alcance práctico consiste en que, a falta de norma expresa, al menor con capacidad natural suficiente no le podrán impedir actuar, salvo sus representantes legales.

JORDANO FRAGA ${ }^{816}$, por su parte, ha manifestado que: "en este artículo (se refiera al art. 162.1) se encuentran elementos suficientes para construir jurídicamente la capacidad general del menor dentro del ámbito limitado y variable de sus aptitudes naturales”. Si esto fuera así, tal precepto aportaría fundamento legal bastante para reconocer al menor una capacidad de obrar general acorde con su capacidad natural, lo que implicaría superar definitivamente las insuficiencias señaladas del régimen legal del menor.

Sobre la base de esta interpretación, el mismo autor, defiende que el menor, atendiendo a sus crecientes condiciones de madurez, pueda realizar por si mismo aquellos actos relativos a los derechos de la personalidad u otros, por ejemplo patrimoniales, cuya trascendencia social sea acorde con la madurez alcanzada. Se logra con ello la flexibilización definitiva del régimen jurídico de la capacidad de obrar del menor, pues se le reconoce un ámbito de tal capacidad, delimitada por dos vectores, primero, las condiciones de madurez del menor o, lo que es igual, su capacidad natural; segundo, la trascendencia socio-jurídica del acto de que se trate, salvo disposición legal expresa que establezca otra cosa.

Sin embargo, tal interpretación del art. $162.1^{\circ}$ ofrece dificultades que parecen difíciles de responder. Daría lugar a la consagración total del criterio subjetivo para determinar la capacidad de obrar del menor, lo que no se compadece con el límite legal de los dieciocho años de edad, ni con la

814 Para la tesis tradicional, CASTÁN TOBEÑAS, Derecho Civil español, común y foral, I, 2º, Ed. Reus, $14^{\mathrm{a}}$ edición, Madrid, año 1984, páginas 179 a 180, y MANRESA Y NAVARRO, "Comentarios al Código Civil español”, VIII, Ed. Reus, 4 edición, Madrid, año 1929, páginas 584 a 585.

815 DE CASTRO, F. “Derecho Civil de España”, Ed. Civitas, Madrid, año 1984, páginas 173 a 193

816 Vid. JORDANO FRAGA, F. "La capacidad general del menor”, Revista de Derecho Privado, Tomo LXVIII, enero-diciembre, Madrid, año 1984, página 892. 
existencia de otras normas relativas a las potestades tuitivas a las que está sometido el menor, que acogen el criterio objetivo (art. 164.2.3 ${ }^{\circ}$ ).

Aparte de esta explicación fallida, se pueden barajar distintas explicaciones para dar cobertura jurídica a los contratos que el menor realiza en la vida corriente, desde la compra de chocolates a la adquisición de ropa o pequeños equipos musicales, que no parece puedan ser impugnados. Por ejemplo puede existir una autorización tácita del guardador; o producirse una renuncia tácita de la impugnación; o en realidad, el menor está cumpliendo una obligación de los padres, o los actos son impugnables según las circunstancias del menor por estar amparados por los usos sociales, con base en un fundamento consuetudinario. En general, todas las explicaciones presentan dificultades, en los casos de autorización o renuncia tácita, no es fácil determinar cuando se producen ${ }^{817}$.

Paulatinamente, se abre una vía para reconocer al menor más amplias posibilidades de actuación de las que se derivan expresamente de las normas legales. ¿Qué consecuencias se deducen de ello?. En primer lugar, bastante inseguridad jurídica, porque la pluralidad de medios de integración del Derecho recogidos en los citados artículos del Código Civil y la proliferación de las normas especiales de capacidad del menor en aquellos medios en que pueda apoyarse, dejarán al juzgador una gran capacidad de decisión, y en gran medida la determinación concreta de la capacidad de obrar del menor se deja al arbitrio judicial. Además, dada la primacía en el Derecho español de las normas de protección del menor, es previsible que lo que haga el menor más allá de los casos previstos, se juzgará plenamente eficaz si le beneficia e ineficaz si le perjudica.

En conclusión, de conformidad con los principios constitucionales sobre la materia y aquellos otros principios que puedan inducirse del conjunto de normas especiales sobre la capacidad de obrar de los menores, no deja de ser insatisfactoria la caracterización general de todo el sistema por las dudas que se suscita, dada la falta de criterios claros y flexibles, lo que lo deja completamente abierto $^{818}$.

817 El poder de representación que indica el art. 162.1 del CC nace directamente de la Ley, que tales representantes serán el padre y la madre salvo que alguno de ellos esté privado de su ejercicio, en tal caso sólo aquel que la ejerce es quien goza de tal representación.

818 Asimismo, cuando el conflicto se suscita entre la voluntad del menor al que se le reconoce suficiente capacidad de juicio y discernimiento y la de sus padres, la voluntad del menor debe prevalecer sobre cualquier otra medida cuando nos movamos dentro del ámbito de aplicación de artículo 162.2.1 CC, siempre que dicha voluntad se manifieste en beneficio de su interés. Del mismo modo en beneficio del menor debe ser interpretada la intervención del Ministerio Fiscal y, en su caso del Juez, en los supuestos en los que el consentimiento debe ser prestado por sus representantes, en aras no sólo a contemplar su falta de capacidad natural, sino también como mecanismo de control ante una posible manipulación de la voluntad de la persona del menor 


\subsection{Autonomía del menor en el ámbito sanitario: el consentimiento informado}

En primer lugar debe señalarse que el Convenio de Oviedo, se remite a la ley nacional para determinar cuándo el menor puede otorgar consentimiento. No obstante, señala en su art. 6.2, segundo párrafo, que "La opinión del menor será tomada en consideración como un factor que será más de-

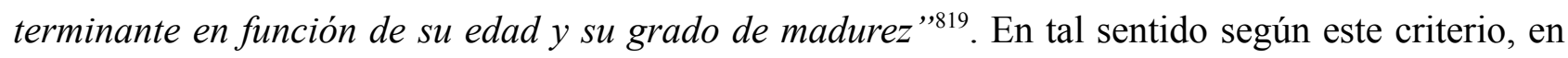
algunas ocasiones el consentimiento del menor debe ser necesario o suficiente, vale decir, es imperativo.

En el desarrollo del Convenio en España y, comenzando por la Ley estatal, el art. 8 sienta el principio del respeto de la autonomía del paciente a través del consentimiento informado ${ }^{820}$. El concepto legal del mismo lo encontramos en el art. 3, que lo define como "la conformidad libre, voluntaria y consciente de un paciente, manifestada en el pleno uso de sus facultades después de recibir la información adecuada, para que tenga lugar una actuación que afecta a su salud”. Por lo tanto, según se deduce del texto, el paciente es la persona que es destinataria de la "información" previa a la prestación del consentimiento (art. 5) y es, igualmente, el sujeto activo del consentimiento (art. 8). Esto es, el titular de ambos derechos es siempre el paciente, sujeto que sufrirá el tratamiento terapéutico o procedimiento invasivo; por eso, sólo ante la imposibilidad o incapacidad la Ley prevé que el mencionado consentimiento se dé por representación ${ }^{821}$.

Uno de esos supuestos es el de minoría de edad del paciente. Al respecto la Ley señala que se otorgará el consentimiento por representación, "Cuando el paciente menor de edad no sea capaz intelectual ni emocionalmente de comprender el alcance de la intervención. En este caso, el consentimiento lo dará el representante legal del menor después de haber escuchado su opinión si tiene doce años cumplidos. Cuando se trate de menores no incapaces ni incapacitados, pero emanci-

819 RODRIGUEZ GONZÁLEZ, J. I. "La autonomía del menor: su capacidad para otorgar el documento de instrucciones previas". Diario La Ley, N 6197, Sección Doctrina, 24 Feb. 2005, Año XXV, Madrid. Este trabajo ha sido expuesto en el X Congreso Nacional de Derecho Sanitario que tuvo lugar en Madrid, los días 23, 24 y 25 de octubre de 2003, y es resultado del Proyecto de Investigación «El testamento vital y los bienes y derechos de la personalidad», financiado por la Universidad de Alcalá con número UAH2002/003

820 CERVILLA GARZÓN, Ma. D. "Comentario a la Ley 41/2002, de 14 de noviembre, básica reguladora de la autonomía del paciente y de derechos y obligaciones en materia de información y documentación clínica”, Actualidad Civil, núm. 12, del 17 al 23 de marzo, Madrid, año 2003, página 320.

821 En particular la Ley señala lo siguiente: cuando el paciente no sea capaz de tomar decisiones, o su estado fisico o psíquico no le permita hacerse cargo de la situación, cuando está incapacitado legalmente y respecto de los menores de edad.- La legislación autonómica sigue los mismos parámetros de reconocimiento de la autonomía de los menores respecto de los derechos de información y consentimiento en el ámbito sanitario que la legislación estatal, si bien, con alguna deficiencia técnica, como ocurre con la Ley de Derechos e Información al Paciente de la Comunidad Valenciana, Ley 1/2003, que obligará, sin duda, a un esfuerzo interpretativo, y que ya ha sido objeto de crítica por la doctrina (Vid. DOLZ LAGO, M.J., “¿Inconstitucionalidad de la Ley 1/2003, de 28 de enero, de la Generalitat, de derechos e información al paciente de la Comunidad Valenciana en relación con los menores de edad?”, en Diario La Ley, núm. 5744, de 21 de marzo de 2003, Madrid, página 3.) 
pados o con dieciséis años cumplidos, no cabe prestar el consentimiento por representación. Sin embargo, en caso de actuación de grave riesgo, según el criterio del facultativo, los padres serán informados y su opinión será tenida en cuenta para la toma de la decisión correspondiente”, así lo dispone el art. $9.3 \mathrm{c})$.

El primer aserto de la norma no aporta en realidad ninguna excepción respecto del caso de pacientes mayores de edad, dado que en la letra anterior del artículo también prevé el consentimiento por representación de los mayores de edad cuando no sean capaz de tomar decisiones, a criterio del médico responsable de la asistencia, o su estado físico o psíquico no le permita hacerse cargo de su situación. Respecto del segundo aserto, distingue varias clases de menores. En primer lugar se encuentran los menores incapaces. Comprende aquellos menores que no tienen desarrolladas, por su corta edad, las cualidades cognoscitivas y volitivas suficientemente, por lo que carecen de autonomía personal. En segundo lugar se hallan los menores incapacitados. El supuesto está previsto en el art. $201 \mathrm{CC}$, respecto de los menores en quienes concurran en ellos causa de incapacitación y se prevea razonablemente que la misma persistirá después de la mayoría de edad. Tampoco los mayores de edad incapacitados pueden prestar el consentimiento informado. Finalmente nos encontramos con los menores emancipados o con dieciséis años cumplidos. Esta clase de menores coincide con los denominados menores maduros o menores mayores. Respecto de ellos, la norma es terminante: no cabe prestar el consentimiento por representación. Son, por tanto, estos menores los únicos legitimados para prestar el consentimiento informado ${ }^{822}$.

El precepto prevé el supuesto de "actuación de grave riesgo" según el criterio del facultativo. En ese caso, "los padres serán informados y su opinión será tenida en cuenta para la toma de la decisión correspondiente". Esta previsión es confusa y contradictoria con la autonomía del menor maduro en el ámbito sanitario que postula la Ley. Sin duda es razonable que la norma no pretenda una afirmación en sí misma. Esto es, no quiere decir que la opinión de los padres será seguida necesariamente en la decisión final, sino sólo tenida en cuenta, en condicional. Sin perjuicio de ello, la norma se refiere al supuesto ordinario de hijo de familia. Pero no es el único supuesto que puede darse. Así, en caso de que el menor emancipado lo sea por matrimonio (art. 316 CC), se plantea el caso de quién será el consultado, los padres o el cónyuge. A mi juicio, debiese ser el cónyuge, en caso de que fuese mayor de edad, el porque de esto último estriba en que es él quien ejerce la curatela y no los padres. Es lógico que sea así, dado que el menor, con el matrimonio, se desgaja del nú-

822 CERVILlA GARZÓN, M". D. "Comentario a la Ley 41/2002, de 14 de noviembre, básica reguladora de la autonomía del paciente y de derechos y obligaciones en materia de información y documentación clínica”, Actualidad Civil, núm. 12, del 17 al 23 de marzo, Madrid, año 2003, página 320. 
cleo familiar para constituir otro, creando una proximidad parental que sustituye las relaciones filiales. No, en cambio, si el cónyuge del menor es también menor, porque en ese supuesto, la curatela se ejerce por los padres. En el caso de que se trate de un menor que ostenta el beneficio de la mayor de edad, por haber estado sometido a tutela, en vez de a la patria potestad, la opinión debe recabarse de su curador, que según el art. 292 CC será quien hubiese sido su tutor, a menos que el Juez dis ponga otra $\operatorname{cosa}^{823}$.

Sin perjuicio de todo ello, si se acude a la legislación autonómica se tienen varias soluciones. A modo de ejemplo cito la Ley Foral 11/2002, de la Comunidad Navarra, señala, como sujetos que deben otorgar el consentimiento por sustitución, las personas a él vinculadas por razones familiares o de hecho, dándose preferencia al cónyuge o persona vinculada al enfermo por análoga relación de afectividad, y, en su defecto, a los familiares de grado más próximo y dentro del mismo grado a los de mayor edad (art. 8 ). Puede asimismo reflexionarse en torno a cierta confusión del precepto porque al parecer pudiera existir la posibilidad de que la decisión final fuera contraria al consentimiento del menor si, oídos los padres, el médico optara por otra distinta. Esto es, es el facultativo quien decide el tratamiento que aplicará al menor, bien con el consentimiento informado del mismo y oído a los padres. Aunque su opinión será tenida en cuenta, podrá decidirse en contra de su consentimiento, también oído a los padres.

Estimo que en este último caso el facultativo no puede hacer imperar su decisión porque en tal caso se hablaría de la autonomía del médico y no del paciente. Podría eso si recabar la autorización judicial para aplicar el tratamiento ${ }^{824}$. El menor en tal caso goza del pleno reconocimiento del derecho de autodeterminación en estas materias siempre que tenga suficiente madurez personal. Ahora bien el facultativo puede optar por el tratamiento consentido por el menor en contra de la opinión de los padres. De tal manera se cumpliría el contenido propio de los deseos del titular y se respetaría su autonomía personal. En este caso, a los padres les quedaría la posibilidad de acudir al Juez a fin de que la decisión final fuera distinta, aun en contra de la opinión del médico y del paciente. Pero queda una situación aún más polémica, cuando el médico debe actuar en contra de la opinión del menor y por supuesto en beneficio de él pero con el respaldo de los padres, este supuesto debe ser excepcional, y así es tratado en la norma que comentamos, en relación con el art. 2, segundo párrafo de la

823 Cfr. RUIZ JIMÉNEZ, J. “La capacidad del menor en el ámbito sanitario” en POUS DE LA FLOR, Ma. P., "La capacidad de obrar del menor: nuevas perspectivas jurídicas”, Exlibris Ediciones SL, Madrid, año 2009, páginas 77 a 89.

824 Cfr. SANTOS MORÓN, M. J. "Sobre la capacidad del menor para el ejercicio de sus derechos fundamentales. Comentario a la STC 154/2002, de 18 de julio” Diario La Ley, núm. 5675, de 12 de diciembre de 2002, Madrid; STC, Pleno, núm. 154/2002 de 18 julio. RTC 2002/154. 
LO 1/1996, que afirma que las limitaciones a la capacidad de obrar de los menores se interpretarán de forma restrictiva.

Concluyendo, deben relacionarse y emplearse como instrumento principal de interpretación las normas sobre la capacidad de obrar de los menores en general con la que les reconoce la Ley respecto del consentimiento informado. Del empleo de ambas puede estimarse en términos generales que los menores se consideran con un juicio maduro cuando logran gozar de un desarrollo psíquico y emocional suficiente, en tal caso la Ley lo presume cuando se alcanzan los 16 años o se logra la emancipación.

La autonomía alcanzada bajo estas circunstancias, y que por supuesto se centra en su ámbito personal les permitirá otorgar competentemente el consentimiento informado en el ámbito de la salud, de tal manera ejercerían sus derechos personales. Tal como ha opinado RODRIGUEZ GONZÁLEZ puede hablarse de coincidencia entre la capacidad general de los menores, tanto en el ámbito patrimonial como personal y la requerida para el consentimiento informado, hasta tal punto de que no es tanto un problema de edad sino de madurez lo que determina su capacidad de obrar, subrayando además la existencia de una presunción legal de madurez a partir de los 16 años cumpli$\operatorname{dos}^{825}$.

825 RODRIGUEZ GONZÁLEZ, J. I., "La autonomía del menor: su capacidad para otorgar el documento de instrucciones previas", op. cit., páginas 10 y 11; Asimismo GONZALEZ MIRASOL, P. en "Autonomía sanitaria del menor y responsabilidad médica", Diario La Ley, № 6326, Sección Doctrina, 26 Sep. 2005, Ref. D-213, La Ley, $\mathrm{N}^{\circ}$ 6327, 27 Sep. 2005, Madrid, ha opinado que: "La configuración constitucional de la patria potestad, modulada por el principio del interés superior del niño y una nueva concepción de la relación clínica, obligan a respetar la autonomía sanitaria del menor a partir de los dieciséis años, a respetar hasta esa edad las facultades paternas en el cuidado sanitario de los hijos y a rechazar el uso alternativo del inseguro criterio de una pretendida madurez del paciente menor, cambiante según la concreta atención médica solicitada y la opinión del facultativo interviniente." 
Capítulo IV

El Principio del interés superior del menor y el Derecho de Familia 


\section{1| Consideraciones previas}

La identificación de cuál sea el interés del hijo menor edad como criterio prevalente exige, como premisa necesaria, una referencia al criterio de protección integral del niño. Consagrado como principio general informador del sistema jurídico, de manera singular en los ámbitos del Derecho de la Persona y del Derecho de Familia ${ }^{826}$.

La actual potenciación de los valores individuales de la persona, propiciada por variadas razones de índole sociocultural y económica, que en el orden jurídico encuentra reflejo en la revalorización de los derechos de la personalidad, ha contribuido a reforzar la protección conferida por el Derecho a la infancia, configurada no sin razón desde la Psicología como etapa vital esencial en la formación de la personalidad del individuo y en la consolidación de su propia identidad, a esto ya se aludió cuando se trató sobre naturaleza y su autonomía ${ }^{827}$.

Ante esta perspectiva el denominado "interés superior" es un concepto de suma importancia que transformó sustancialmente el enfoque tradicional que informaba el tratamiento de los menores de edad, de manera total y absoluta para ser categórico. En el pasado, el menor era considerado “menos que los demás” y, por consiguiente, su intervención y participación, en la vida jurídica (salvo algunos actos en que podía intervenir mediante representante) y, en la gran mayoría de situaciones que lo afectaban, prácticamente era inexistente o muy reducida.

Desde tal consideración se justifica la mayor atención prestada a las necesidades de la persona del menor, sin duda valorada forzosamente en su propia dimensión pero también sin desatender su notoria proyección de adulto en formación, sometido por consiguiente a un mayor grado de vulnerabilidad en especial por parte de agentes y circunstancias externas.

No obstante, justificado su sentido y predeterminado su alcance como valor superior, la concreción del interés del menor no es tarea fácil. La utilización por parte del legislador de un “concepto jurídico relativamente indeterminado", impone al sujeto obligado a aplicarlo, un complementario proceso de valoración en el que deberán ser ponderadas todas y cada una de las particulares

826 CARBONELL BENITO, G. "El interés del menor: criterios para su concreción y defensa a través de las figuras del Defensor del Menor y del Ministerio Fiscal”, en VALLÉS, A. (Dir.) “La protección del menor”, Ed. Tirant Lo Blanch, Valencia, año 2009, página 131. En la actualidad la importancia que ha adquirido el tema del interés del menor y su correlativa eclosión legislativa no es gratuita. Se está en presencia de una potenciación social de los valores personales genéricos y en concreto, de los valores pertenecientes al niño o menor. Se trata de una revalorización del menor en su calidad de persona.

827 La potenciación de los valores individuales de la persona y del menor emerge, como no podrá ser de otro modo, a partir de 1978 cuando a través de la Carta Magna española, ascienden al plano jurídico nuevos valores ideológicos y éticos sociales entre los que se encuentran la protección de la infancia desde dos perspectivas que, lejos de ser excluyentes, se muestran como complementarias: la protección directa del niño a causa de su debilidad psicológica y de su inexperiencia y, de otro lado, la tendencia que propugna la liberación del menor respecto del status de persona dependiente que hasta entonces caracterizaba su situación jurídica. 
circunstancias concurrentes a fin de conseguir determinar in concreto y de una manera efectiva cuál sea el interés del menor en la específica situación que se pretende resolver, y cuando se menciona al sujeto obligado de aplicarlo se hace referencia básicamente a jueces y magistrados ${ }^{828}$. A lo que cabe añadir la amplitud del arco cronológico que jurídicamente enmarca el estado de minoría de edad, determinante de una insoluble dificultad en la pretensión de sistematizar situaciones caracterizadas por su evidente heterogeneidad, porque tal cual se hizo referencia aunque la Ley establece mínimos, como por ejemplo los 16 años, hay que observar a la persona en concreto y su situación psicológica, física, así como sus circunstancias para vislumbrar o esclarecer la aplicación legal del caso concreto.

Es por lo que resulta imposible el establecimiento de pautas de solución válidas para todos los supuestos, ni siquiera para aquéllos que pudieran presentarse con engañosa apariencia de semejanza, pues la necesaria operación de discernimiento en la búsqueda del beneficio del menor siempre presupondrá la misión de descubrir su personalidad, y la identidad de cada persona -por supuesto también la del menor- sin duda ofrece un paisaje único e irrepetible.

Del interés del menor o del favor minoris como también se le llama no hace mucho que se habla en el Derecho Privado español y en general en el mundo jurídico occidental y en el europeo continental, en particular, en el sentido del presente estudio, tal como afirma RIVERO HERNÁNDEZ ${ }^{829}$. El término era usado antes en el Derecho de familia con tintes éticos, en unos casos (favor legitimitatis, en la determinación de la filiación) o de tipo social o familiar en otros (el favor filii, frente a interés del o de los padres, cuando la patria potestad fue siendo considerada un officium más que un

828 TORRES PEREA, J. M., “Tratamiento del interés del menor en el Derecho alemán”, Revista Anuario de Derecho Civil, núm. LIX-2, abril, Madrid, año 2006, página 2. El autor señala que la doctrina alemana, incluso, considera temerario todo intento definitorio en materia de interés del menor por lo que la ciencia jurídica alemana no sólo no aporta ninguna definición de lo que pudiera entenderse por interés del menor sino que, además, entiende que se trata de un concepto que no debería siquiera intentar ser definido por la especial naturaleza que le acompaña., en tal sentido se habla de un principio de contenido indeterminado sujeto a la comprensión y extensión propios de cada sociedad y momento particular.

829 Vid. RIVERO HERNÁNDEZ, F. “El interés de menor”, Ed. Dykinson, Madrid, año 2007, página 27, el autor señala que: "El interés del menor está presente en todos los sistemas jurídicos modernos; en algunos, bajo presión de las grandes Declaraciones de Derechos y Convenios Internacionales aludidos; en otros, por una evolución social y jurídica natural y semejante a la habida en nuestro país. Sobre la especial atención que se ha prestado al interés del menor en la doctrina y praxis jurídica de algunos países, véase M. DOGLIOTTI, "Che cosa è l interesse del minore”, Il Dir. Fam. E Pers., 1992-4, página 1093, que dice que en Italia se empezó a hablar del interés del menor a partir de la Ley de Adopción de 1967; SM. CRETNEY-MASSON, J.M., Principles of Family Law, $5^{a}$ ed., Londres (Sweet and Maxwell), año 1990, página 468 (para quien el interés del menor en el Reino Unido aumenta en los años 70); GOLDSTEIN-FREUD, A-SOLNIT, A.J., "Before the best interest of the Child", New York 8The Free Press), año 1979, página 9 y RUBELLIN-DEVICH, J, "The best interest principle in Fench Law and Practice, en Ph. Alston (coord.), The best interests of child, Oxford (Clarendon Presss), año 1994, páginas 260 y siguientes." 
beneficium), y con perspectiva y aplicación limitada; en todo caso, con planteamiento y alcance diferente.

Hoy, aquí y allá, la cuestión es distinta. Por un lado, frente a una concepción tradicional, que concedía al menor un estatus de persona meramente protegida, una concepción moderna, actual, le confiere, sobre todo a partir de cierto momento de su vida (la adolescencia), el status de persona (tendencialmente) autónoma; desde esta perspectiva, el interés del menor consiste en adquirir progresivamente mayor autonomía y una identidad de adulto que le habilite para ejercer él directamente derechos y libertades indeclinables, aunque ya se volverá sobre esta apreciación, es de capital importancia entender y manejar la idea del desarrollo evolutivo de la personalidad, una especie de apreciación in crescendo de la autonomía del sujeto ${ }^{830}$. Tal proceso dependerá en gran medida de las propias cualidades pero también del ambiente en el cual se viva, ambiente familiar podría agregarse.

Por otra parte, el interés del menor es uno de los principios y valores emergentes del moderno Derecho de la persona y de la familia, que irradia energía jurídica y alcanza a otras partes del ordenamiento jurídico. Razones ideológicas, sociológicas y jurídicas están detrás de la aparición y auge actual del interés del menor, no sólo en los ordenamientos internos sino en Convenios, Tratados y Pactos internacionales, en Declaraciones Universales, que han penetrado toda la normativa y consideración o proyección jurídica de los menores ${ }^{831}$.

Conocida es la relevancia que en el Derecho como en otras disciplinas extrajurídicas relativas a la persona se ha dado la infancia y a los menores en años recientes, como resultado de estudios de Psicología (sobre todo) y expresión de una sensibilidad nueva de la sociedad en esta época, que en el orden jurídico se ha traducido en una potenciación de los valores personales y especialmente en el niño ${ }^{832}$, en contraste con lo que ocurrió en otros tiempos no tan lejanos. Se trata de una verdadera revalorización del menor en su calidad de persona. Ciertamente, no podía de ser de otro modo en el

830 El menor como persona, ya no sólo en su dimensión jurídica sino también en su dimensión humana necesitara de la salvaguarda de sus derechos fundamentales, los que le atañen. Y, no menos importante, tendrá derecho a que su felicidad quede suficientemente preservada. Es decir, no bastará para determinar el interés de los menores reparar en su dignidad como persona, en los derechos fundamentales que le son inherentes y en el libre desarrollo de la personalidad, sino que más allá del plano formal deberá atenderse también, aunque sea mínimamente, a su felicidad inmediata y a su bienestar personal.

831 RIVERO HERNÁNDEZ, F. “El interés de menor”, ...op. cit., páginas 30 y siguientes.

832 “El ordenamiento jurídico, y esta Ley en particular -dice la Exp. Motivos de la L.O. 1/1996-, va reflejando progresivamente una concepción de las personas menores de edad como sujetos activos, participativos y creativos, con capacidad de modificar su propio medio personal y social; de participar en la búsqueda y satisfacción de sus necesidades y en la satisfacción de las necesidades de los demás.- El conocimiento cientifico actual nos permite concluir que no existe una diferenciación tajante entre las necesidades de protección y las necesidades relacionadas con la autonomía del sujeto, sino que la mejor forma de garantizar social y jurídicamente la protección a la infancia es promover su autonomía como sujetos. De esta manera podrán ir construyendo progresivamente una percepción de control acerca de la situación personal y su proyección de futuro" 
ordenamiento jurídico a partir de 1978, en que la Constitución no sólo garantiza, junto a otros bienes y valores (la dignidad de la persona, los derechos inviolables que le son inherentes, el libre desarrollo de la personalidad), la protección integral de los hijos y obliga a los padres a prestarles asistencia de todo orden (art. 39.2 y 3), sino que afirma que "los niños gozarán de la protección prevista en los acuerdos internacionales que velan por sus derechos" (art. 39.4 C.E.), lo que ha obligado a trasladar a estos mandatos constitucionales y los de los Convenios internacionales a las leyes ordinarias en varios ámbitos jurídicos, en forma de normas. Ahora bien, surge la pregunta de si este traslado ha sido armónico, sabiendo que justamente es en el Derecho de familia donde muchas veces el Legislador cae en diversas contradicciones. Sin perjuicio de esta reflexión hay otra que tiene mucha relación con ella, si se trata del menor, la ley suele tener el doble de cuidado, el legislador no sólo vela por la familia, ni siquiera por el Estado de Derecho, vela por ambos y por alguien más, vela por el futuro, por el menor.

Es evidente que, entre otros cambios habidos en nuestra sociedad en las dos últimas décadas (múltiples razones sociales y económicas, crisis de un sistema de valores que la informó durante mucho tiempo), no es menor el de la quiebra de modelo jurídico y una mayor y mejor ponderación de los valores personales, entre ellos el de la posición del menor, tanto en la familia como en la sociedad, cuyo papel participativo en su propia maduración y formación y en las decisiones y opciones vitales es reconocido hoy por especialistas de las más diversas disciplinas, lo cual constituye un fundamento de las mismas y principio rector de la Legislación ${ }^{833}$.

El ascenso general en el mundo occidental (especialmente) de los derechos de la personalidad, en particular el derecho fundamental a la libertad, unido a causas socioeconómicas varias, han hecho cambiar la vida del hombre y obligado a valorar de forma especial ciertas etapas de la vida, sobre todo las más decisivas en la formación de su propia personalidad e identidad. Los valores individuales tales como la libertad, la dignidad, el respeto de la persona, la autonomía de cada ciudadano para dirigir su propia vida y ejercer sus opciones más trascendentes según su voluntad y sin coacciones exteriores eran incompatibles con una mentalidad y normas que primaban antes, la existencia de una autoridad fuerte anulaba en buena medida la personalidad de los sometidos, en

833 Cfr. ALONSO PÉREZ, M. "La situación jurídica del menor en la Ley Orgánica 1/1996 de 15 de enero de Protección jurídica del Menor, de modificación del Código Civil y de la Ley de Enjuiciamiento Civil: luces y sombras", Revista Actualidad Civil, núm. 1, Madrid, año 1997, páginas 17 a 40 . El autor sostiene que como principio rector, como principio de carácter general se revela en la propia Ley 1/1996 de Protección Jurídica del Menor en la que se afirma que el centro de gravedad de esta norma lo constituye precisamente el principio general que supone y es el interés de los menores. 
particular de los hijos in potestate ${ }^{834}$. Todo esto ha cambiado, en tal sentido puede hablarse de una personalización del Derecho ${ }^{835}$.

Expresa RIVERO HERNÁNDEZ que esa incompatibilidad y la superación del autoritarismo paternalista en la familia ha contribuido a que las funciones de los miembros de la familia se redistribuyan y se rediseñen los roles individuales y familiares en un nuevo orden familiar y, consecuentemente, también en el social, llevando la igualdad de los cónyuges y la cotitularidad de la patria potestad a la vida familiar y a cambiar drásticamente la concepción de dicha potestad y el papel y personalidad del hijo (menor) en la familia. Por repercusión inevitable, esa pequeña "revolución familiar" ha trascendido a la sociedad toda, la cual ha prestado más atención a las necesidades de toda índole del niño sencillamente como persona y, en particular, en cuanto personalidad vulnerable y en formación y adulto futuro. En ese marco ideológico y social de fondo ( a lo largo del cambio habido y como resultado de una evolución ideológica y social) aparece con fuerza el denominado interés del menor, el cual nunca fue del todo desconocido para el Derecho, sobre todo a nivel jurisprudencial, simplemente que en la actualidad ha superado los márgenes del ámbito familiar para ser elevado al rango de principio general informante del actual sistema jurídico. Esto se puede catalogar como un avance, sin duda, y uno con mayúsculas, pero resulta interesante en analizar en cómo el cambio en la familia provoca un cambio mayor en la sociedad, o quizás sea al revés, como los cambios sociales son trasladados el ámbito familiar, de tal manera que quizás se pueda alterar el desarrollo del grupo familiar.

Es decir, si la sociedad tiene sus tiempos, si cada sociedad los tiene, cada familia, la familia en términos generales también. Posiblemente algunos cambios pueden tildarse drásticos, sobre todo por la forma de volcarse en las diversas personas, hasta tal punto de volverse artificiales. Quizás en ese momento el Derecho esté transformándose en un vehículo de la Ingeniería social, ¿es este uno de sus fines? Puede que no sea este el ámbito ni el estudio que deba responder tal pregunta, pero a veces se echa en falta un poco de filosofía del Derecho Civil. La ley no basta, porque el Derecho se crea y se ejerce pensando, no copiando ni menos aún experimentando.

Sin perjuicio de haber tratado al menor recientemente en el tema concerniente a su autonomía de la voluntad, se estima que es más idóneo tratarlo en los referente a su superior interés, debido a que tal como se verá en las páginas que a continuación se detallan, es en lo referente a este principio cuando su figura, su persona adquiere un total protagonismo. Por tal motivo se considera necesario

834 RIVERO HERNÁNDEZ, F. “El interés de menor”, ...op. cit., página 39 y 40.

835 Se hace referencia en ocasiones a la interpretación demasiado personalidad del interés superior del menor, así lo plantea BORRAS RODRIGUEZ en “El interés del menor como factor de progreso y unificación”, Revista Jurídica de Catalunya, Vol. IV, Barcelona, año 1994, página 107. 
profundizar aquí la relación entre el menor y el Derecho, el menor y su protección amparada por el ordenamiento jurídico, en cuanto su interés preponderante es fundamental en tal ordenamiento.

Antes de abordar la problema del interés en cuestión en España, me referiré brevemente a su acontecer europeo.

Como no podía ser de otra forma la Carta de los Derechos Fundamentales de la Unión Europea, establece, siguiendo la Convención de 1989, que la norma guía de toda actuación relacionada con la infancia es el denominado "interés superior del niño" (art. 3 de la Convención de las Naciones Unidas y art. 24.2 de la Carta). Ciertamente, es una noción subjetiva y actúa fundamentalmente en el campo de la tutela judicial. El interés superior del niño es un concepto amplio que hace referencia a su desarrollo físico, mental, espiritual, moral y social. La Carta pone también cierto énfasis en la libre opinión de los niños y en la conveniencia de tomarla en cuenta en función de su edad y madurez, tal cual preceptúa el párrafo primero del art. 24. En relación con este punto, sin duda las denominadas Reglas de Beijing significaron un gran avance técnico. En el marco relativo a los litigios que afectan a la infancia, los niños deben ser informados y oídos y, en función de las circunstancias pueden pedir la designación de un representante legal en caso de conflicto con los intereses de quienes asumen la patria potestad y la tutela legal. En esta materia la norma de referencia general son las Reglas de Beijing antes mencionadas y un Convenio europeo en el marco del Consejo de Europa, sobre el ejercicio de los derechos de los niños. Asimismo en el ámbito comunitario hay que aplicar la Decisión marco 2001/220/JAI del Consejo, de 15 de marzo de 2001, relativa al estatuto de la víctima en el proceso penal.

En materia jurisprudencial, sin duda se vislumbra la estrecha relación entre el interés superior del menor y cualquiera de las fórmulas que determinan la existencia de una vida familiar, esta cobra una relevancia especial el objetivo de procurar la integración del menor en su familia desde el momento mismo del nacimiento. Ya en la primera ocasión en la que el TEDH se enfrentó a la necesidad de precisar el significado de palabras tales como "el respeto a su vida familiar" (asunto Marckx contra Bélgica, de 13 de junio de 1979), manifestó que “el respeto a la vida familiar implica concretamente, según la opinión del Tribunal, la existencia en el ordenamiento jurídico interno de cada Estado de ciertas garantías legales que permitan la integración del menor en su familia desde el momento mismo de su nacimiento" ${ }^{836}$. Y es que una vez que se haya establecido una relación fa-

836 STEDH, Caso Marckx contra Bélgica. Sentencia de 13 junio 1979. TEDH 1979/2 . Asimismo afirma el Tribunal que "Con esta finalidad, el Tribunal tendrá en cuenta el hecho de que la concepción que se tiene del carácter oportuno de una intervención de las autoridades públicas en los cuidados que hay que procurar a un niño varía de un Estado a otro en función de elementos como las tradiciones relativas al papel de la familia y a la intervención del Estado en los asuntos familiares, así como los recursos que se pueden dedicar a medidas públicas en ese campo concreto. El interés superior del niño reviste en cada caso una importancia decisiva. No hay que per- 
miliar con un menor, el Estado debe actuar de manera que procure su desarrollo, acordando la protección jurídica que haga posible desde el nacimiento su integración en la familia (asuntos Keegan c. Irlanda, de 26 de mayo de 1994, y Kroon con Los Países Bajos, de 27 de octubre de 1994).

El objetivo de la integración se condicionará a que sea lo más adecuado para la garantía del interés superior del menor, hasta el punto que "cuando ha pasado un periodo de tiempo considerable desde que el niño ha sido colocado por primera vez bajo asistencia (de los servicios sociales), el interés por que el niño no vea que su situación familiar de facto vuelve a cambiar de nuevo puede ser más importante que el interés de los padres en el reagrupamiento de la familia” (asunto Kutzner con Alemania, de 26 de febrero de 2002) ${ }^{837}$. De esta manera se constata que el Tribunal Europeo de Derechos Humanos ha construido un derecho de familia que, de manera gráfica, ha sido calificado de "pedocéntrico", a pesar de que dicho interés no aparece mencionado en el Convenio Europeo de Derechos Humanos, a pesar de que si consta en el art. 24 de la Carta de los Derechos Fundamentales de la Unión Europea. Invocando este derecho, el Tribunal de Justicia de las Comunidades Europeas ha procurado recordar que la Carta en su art. 7, reconoce el mismo derecho al respeto a la vida privada o familiar. Esta disposición debe ponerse en relación con la obligación de tener en cuenta el interés superior del menor, reconocido en el art. 24, apartado 2, de dicha Carta, y tomar en consideración la necesidad del menor de mantener de forma periódica relaciones personales y contactos directos con su padre y con su madre, expresada en el apartado 3 del citado art. $24^{838}$.

Por su parte, el TEDH recuerda que el Convenio no debe ser interpretado independientemente y debe aplicarse de acuerdo con los principios de derecho internacional. Y, en el aspecto concreto que nos ocupa, ha señalado en fecha reciente (asunto Maumousseau y Washington contra Francia, de 6 de diciembre de 2007), de 20 de noviembre de 1989, "el interés superior del menor" en cualquier materia que le concierna, es el objetivo central de la protección del menor, buscando la plenitud del niño en el ámbito familiar, constituyendo la familia "la unidad fundamental de la sociedad y el medio natural para su crecimiento y bienestar", según los términos del preámbulo de esta Con-

der de vista que las autoridades nacionales tienen el beneficio de relaciones directas con todos los interesados (Sentencia Olsson [núm. 2] anteriormente citada, ap. 90), a menudo desde el momento en el que se contemplan las medidas de colocación o inmediatamente después de que sean puestas en práctica. De ello se deriva que el Tribunal no tiene como tarea el sustituir a las autoridades internas en el ejercicio de sus responsabilidades en materia de regulación de las cuestiones relativas a la toma a su cargo por parte de las autoridades públicas y de los derechos de los padres cuyos hijos han sido así colocados, sino la de controlar desde el punto de vista del Convenio las resoluciones que éstas han dictado en el ejercicio de su poder de apreciación (véase, por ejemplo, Sentencia Hokkanen de 23 septiembre 1994, serie A, núm. 299-A, ap. 55, Sentencia Johansen anteriormente citada, ap. 64 y Sentencia K. y T. contra Finlandia anteriormente citada, ap. 154). “

837 STEDH, Sección 4a, Caso Kutzner contra Alemania, de 26 febrero 2002. JUR 2002/90046

838 El art. 24 de la Carta ha sido invocado también en la Sentencia del Tribunal de Justicia (Sala Tercera) de 14 de febrero de 2008 (petición de decisión prejudicial planteada por el Landgericht Koblenz-Alemania)- Dynamic Medien Vertriebs GmbH/Avides Media AG (Asunto C-244/06). 
vención. Como ya ha estipulado el Tribunal, esta consideración primordial puede suponer varios aspectos. El Tribunal suscribe en su totalidad a la filosofía subyacente de esta Convención" 839 .

Así pues, la regla que ha venido presidiendo la labor jurisprudencial del Tribunal Europeo de Derechos Humanos es la de que "la preocupación por el interés superior del menor reviste en cada caso una importancia decisiva" (asunto K.T. Contra Finlandia, sentencia de la Gran Sala de 12 de julio de 2001) ${ }^{840}$, lo que obligará a los Estados parte a adoptar medidas positivas, cuya inexistencia o incumplimiento llevará aparejada una infracción del Convenio.

La búsqueda del mejor interés para el menor se debe promover tanto en los supuestos de parentesco biológico como en los de parentesco jurídico, sin olvidar los casos de ausencia de parentesco pero con efectivas relaciones de parentesco de facto. Habrá que estar a las circunstancias del caso para decir que es lo mejor para el menor, lo que por otra parte provoca una disparidad en la sentencias, tal cual lo ha manifestado PRESNO LINERA ${ }^{841}$. El autor en cuestión denota tres criterios: a)Debe primar la efectividad y apariencia de familia, a pesar de la ausencia de parentesco jurídico y biológico; b) Atender el parentesco biológico o jurídico si la ausencia de relación efectiva se ha producido en contra de la voluntad del progenitor; c) elegir entre la filiación biológica o la adoptiva en los supuestos en que ambas puedan coincidir.

\section{2 | El desarrollo de la persona y el ordenamiento jurídico}

El concepto de menor de edad, es necesariamente jurídico ${ }^{842}$. Se basa en un dato cronológico-biológico, como es la edad de una persona, sólo tienen sentido en el ámbito jurídico. Se determina un estatuto especial hasta la mayoría de edad y el surgimiento de una nueva situación jurídica una vez alcanzada ésta ${ }^{843}$.

839 STEDH, Sección $3^{\text {a }}$, Caso Maumousseau y Washington contra Francia . Sentencia de 6 diciembre 2007. TEDH 2007/88 ; STEDH, Sección 2a , Caso Ilker Ensar Uyanik contra Turquia. Sentencia de 3 mayo 2012. TEDH 2012/43.

840 STEDH, Gran Sala, Caso K. y T. contra Finlandia. Sentencia de 12 julio 2001. TEDH 2001/467

841 Vid. PRESNO LINERA, M. A. "El Derecho Europeo de Familia”, Ed. Thomson Aranzadi, Cizur Menor, año 2008, páginas 43 y siguientes.

842 HERNÁNDEZ GALILEA, JESÚS MIGUEL y otros. "El Sistema español de Justicia Juvenil”, Ed. Dykinson, Madrid, año 2002, página 23.

843 Vid. VÁZQUEZ- PASTOR JIMENEZ, L. “La construcción de la ciudadanía del menor de edad”, Ed. Tirant Lo Blanch, Monografías 619, Valencia, año 2009, página 40. Debido a que la minoría de edad es un concepto relacionado con varias disciplinas y puede ampararse perfectamente en el concepto de ciudadanía entendida esta como la plena dotación de los derechos civiles, políticos económicos, sociales y culturales que se extienden y cobran carta de naturaleza con la universalización de los servicios públicos y el Estado de bienestar. Dicha acepción sustantiva implica asimismo el efectivo disfrute de los mencionados derechos por las personas que integran una comunidad organizada, de tal manera que la participación real y efectiva del ciudadano en la colectividad exige la realización de todas sus posibilidades en lo concerniente al ejercicio de los derechos que le son constitucionalmente reconocidos. Asimismo la ciudadanía del menor supone la posibilidad de que el mismo pueda ejercitar 
La mayoría y minoría de edad surgen como una consecuencia de que el ordenamiento jurídico tome en cuenta el desarrollo humano, no es que antes no hubiese tenido importancia para este ordenamiento, sino que tenía una importancia menor, valga la redundancia. A primera vista, tal consideración, parece excesivamente simplificada, pues sólo toma en consideración la etapa infantil y la etapa adulta. En este sentido el ordenamiento al parecer olvida que el desarrollo humano lejos de ser estático es dinámico ${ }^{844}$. Sin perjuicio de ello el ordenamiento ofrece ciertas precisiones que clarifican este concepto.

Existe una perspectiva desde la que puede considerarse el desarrollo humano en el ámbito jurídico. La primera que es quizás la más llamativa, la que se utiliza casi intuitivamente cuando se habla del menor de edad y se refiere a la teoría de los actos jurídicos. Desde esta perspectiva se considera el desarrollo humano en sí mismo como situación que puede generar, y de hecho genera, unos derechos y obligaciones peculiares.

El desarrollo humano desde la perspectiva de la teoría de los actos jurídicos tiene en la capacidad de obrar uno de sus principales elementos ${ }^{845}$. Se recuerda que ya se analizó, en parte la capacidad de obrar cuando se trató la autonomía de la voluntad en la persona del menor.

El derecho regula el comportamiento humano en su vertiente social según criterios de justicia. Para ello emplea normas de dos tipos, por una parte se encuentran las normas de prohibición, y por otra, las normas formales. Las primeras prohíben determinados comportamientos bajo la amenaza de una sanción. Las segundas establecen una serie de efectos de los actos humanos pero condicionados al cumplimiento de unos requisitos: uno de ellos es la capacidad. Pero tal como se acaba de decir, es importante considerar que uno de sus aspectos principales es considerar que tienen supeditadas el cumplimiento de sus efectos a la reunión de una serie de requisitos. Porque, también a diferencia del resto de los actos humanos externos, sus efectos no son efectos derivados directamente del acto sino que del ordenamiento que toma en consideración ese acto.

aquellos derechos que le permiten el libre y armónico desarrollo de su personalidad, así como los que facilitan su participación social y el desarrollo de su autonomía.

844 Cfr. LAUROBA LACASA, E... op. cit., página 908 "El apartado final del art. 233-9 señala que los PlanP pueden prever "la conveniencia de modificar el contenido para adaptarlo a las necesidades de las diversas etapas de la vida de los hijos. Esta prescripción debe cohonestarse la DA 9. , que confía al departamento de Justicia la elaboración de modelos de PlanP “atendiendo a las diferentes etapas de la vida de los menores” ¿qué se pide exactamente?"

845 DÍEZ-PICAZO Y PONCE DE LEÓN, L y GULLÓN BALLESTEROS, A., "Sistema de Derecho Civil, Vol. I, Introducción. Derecho de la persona. Autonomía privada. Persona jurídica”, Ed. Tecnos, Madrid, año 2002, página 212; VALPUESTA FERNÁNDEZ, R., en LÓPEZ Y LÓPEZ, A. M., MONTES PENEDÉS, V. L., ROCA I TRÍAS, E. (Edit.), “Derecho Civil. Parte General. Derecho de la persona.”, Ed. Tirant Lo Blanch, Valencia, año 2003, páginas 202 a 204; DELGADO ECHEVERRÍA, J., en LACRUZ BERDEJO, J.L. Et al., "Elementos de Derecho Civil. Parte General, I, vol. 2º Personas”, Ed. Dykinson, Madrid, año 2004 páginas 4 y 5. 
El acto humano tiene características propias, se considera como tal acto al consciente y libre, el acto en el que interviene la voluntad. La libertad y voluntariedad de los actos exigen un cierto desarrollo intelectual y una cierta madurez, por lo que el ordenamiento no puede tomar en consideración los actos de cualquier sujeto, que posea una capacidad independiente para querer y comprender lo que hace. Asimismo, tampoco puede limitarse la actuación de los ciudadanos con referencia a criterios oscuros y variables que puedan dar lugar a una arbitraria restricción de su capacidad.

En cualquier ordenamiento jurídico se establece una edad a partir de la cual se presume que el ciudadano tiene plena capacidad de actuar libre y voluntariamente. Una edad que determina automáticamente el pleno ejercicio de sus derechos civiles. Y cuando, a pesar de la mayoría de edad, el sujeto no tiene capacidad de actuación libre y voluntaria o la ha perdido, es el propio ordenamiento quien establece una serie de limitaciones para que se desencadenen totalmente los actos o produzcan sus efectos de manera ilimitada.

Además existe otra perspectiva distinta de la teoría de los actos jurídicos, que debe utilizarse para la consideración de la minoría edad. Una perspectiva que, aunque menos aparente, menos inmediata, está en la base de esa limitación de la capacidad: la del propio desarrollo humano como fundamento de unos derechos específicos y una singular protección. Porque tiene su capacidad de obrar limitada es porque el menor merece, entre otras consideraciones, una especial protección ${ }^{846}$. Una protección que no puede equipararse ni por la causa ni por los efectos, con la que el ordenamiento otorga a los incapaces. Es más, puede decirse que en la situación actual la limitación ha pasado a un plano secundario adquiriendo un mayor protagonismo el contenido de singular protección que debe tener toda la normativa referida a los menores.

Desde que en 1924 la Declaración sobre los derechos del Niño de Ginebra recordara en su preámbulo que el niño por su madurez física y mental, necesita protección y cuidado especial, así como la debida protección social, tanto antes como después del nacimiento, han sido diversos los documentos y acuerdos internacionales que han insistido en este aspecto protector. Entre ellos cabe destacar, como ya se afirmó con anterioridad, las Reglas de Beijing ${ }^{847}$ que en su exposición de motivos dicen: "Reconociendo que la juventud por constituir una etapa inicial del desarrollo humano, requiere particular atención y asistencia para su desarrollo físico, mental y social y necesita pro-

846 MARTÍNEZ DE AGUIRRE ALDAZ, C. en MARTÍNEZ DE AGUIRRE, C., DE PABLO CONTRERAS, P., PÉREZ ÁlVAREZ, M. A., PARRA LUCAN, M. A., "Curso de Derecho Civil, tomo I, Parte General y Derecho de la Persona", Ed. Colex, Madrid, año 2003, páginas 171 y 172; LETE DEL RÍO, J. M., "Derecho de la persona", Ed. Tecnos, Madrid, año 1996, páginas 26 a 29.

847 Estas son reglas mínimas, de las Naciones Unidas, para la administración de la justicia de menores conocidas como Reglas de Beijing. Resolución 40/33 de 29 de noviembre de 1985 de la Asamblea General de Naciones Unidas. 
tección jurídica en condiciones de paz, libertad, dignidad y seguridad”. La Convención sobre los Derechos del Niño, adoptada por las Naciones Unidas el 20 Noviembre 1989, e incorporada al ordenamiento español, vuelve a insistir en el tema reproduciendo en su preámbulo las palabras de la Declaración de Ginebra.

El nuevo enfoque se produce de una manera dual, al situar las limitaciones en el plano de los medios y la protección en el plano de los fines. Ello no es un invento de la Convención de los Derechos del Niño, sino que recoge el sentir de los diversos países que en sus legislaciones han ido acentuando este carácter protector, con importantes innovaciones. Además, este nuevo enfoque, dota a la protección del menor de una mayor consistencia, pues permite entender la minoría de edad como una situación especial de la que surgen unos derechos peculiares ${ }^{848}$.

Menor de edad es la persona que, por la fase de desarrollo en que se encuentra, es objeto de una especial protección por el ordenamiento, que le reconoce unos derechos específicos que perderá al alcanzar la mayoría de edad. Se trata de unos derechos que tienen diversas posibilidades de fundamentación constitucional y que se reconocen con rotundidad en la ya citada Convención. Acentuando el carácter de obligación que tiene para el Estado la garantía de esa protección y no considerándola como humanitaria.

Junto con los derechos inherentes a toda persona humana, a la vida, a la integridad física, etc, en todas estas normas internacionales se han venido reconociendo explícitamente diversos derechos peculiares de los menores. Derechos de los que surgen obligaciones para diversos sujetos: los padres, en primer lugar -ya desde antiguo se ha positivizado una evidente obligación natural de cuidado, de protección, de educación - pero también para el Estado que viene obligado a garantizar que se cumplen esas obligaciones por parte de los padres - sancionando los incumplimientos graves- y a proporcionar los medios para que puedan llevarlas a cabo; en su caso, a suplir el incumplimiento, estableciendo los mecanismos para que el menor pueda desarrollarse plenamente, ejemplo de esto lo constituye el acogimiento ${ }^{849}$.

848 En la actualidad, las transformaciones sociales y culturales operadas en nuestra sociedad han provocado un gran cambio en la consideración de la infancia por la colectividad, lo que ha tenido un reflejo en el status jurídico delos niños que han pasado de ser considerados meros incapaces a verse reconocidos como auténticos titulares de derechos con una capacidad progresiva para ejercerlos. De esta forma, se abre paso a una concepción de los menores de edad como sujetos activos, participativos y creativos, con capacidad de modificar su propio medio personal y social, con el objeto de satisfacer sus propias necesidades. En consecuencia, la protección de la infancia aparece ahora ligada a la necesidad de promover la autonomía de los menores como sujetos, en cuanto no debe existir una diferencia tajante entre las necesidades de protección y la progresiva autonomía personal del niño. Cfr. BENITO ALONSO, F., "Actuaciones frente a situaciones de riesgo y desamparo de menores: tutela por ministerio de ley y guarda”, Ed. La Ley, Madrid, año 1997, página 1728.

849 GONZÁLEZ PILLADO, E y GRANDE SERRA, P. “Aspectos procesales civiles de la protección del menor”, Ed. Tirant Lo Blanch, Monografías núm. 321, Valencia, año 2006. 
Todos estos derechos, establecidos en normas de diverso rango, han venido configurando un estatuto del menor claramente identificable que aumenta su consistencia y exigibilidad situándolos más allá de una mera actitud humanitaria. Sin embargo, al ser una regulación asistemática resulta difícil extraer con claridad las implicaciones y consecuencias, simplemente debe concluirse que la minoría de edad es una etapa del desarrollo humano que exige una singular protección de la que surgen unos peculiares derechos. Derechos de los que es titular el menor, pero de los que en función del menor, son titulares los padres o quienes tienen encomendada su custodia. En todo caso, de la minoría de edad corresponde tratar a continuación.

\section{3 | La minoría de edad}

Desde antiguo el Derecho ha prestado atención particular a la condición de los seres humanos en los estadios iniciales de su vida, dotándoles de un especial régimen jurídico adaptado a sus específicas características vitales. La especie humana destaca, respecto de otras especies de seres vivos, por la intensa necesidad de sus individuos recién nacidos, cuyo crecimiento y desarrollo dependen de la atención y cuidados prestados por los individuos adultos durante largo tiempo, es la etapa de niñez en sentido amplio. Su longitud no es ajena a la peculiar condición de la especie humana, caracterizada por su enorme capacidad de adaptación al medio y su creciente poder de transformación del mismo, mediante la sociabilidad y la cultura, ello exige un largo período de aprendizaje ${ }^{850}$. Por supuesto, mucho más largo que otras especies.

Los diversos ordenamientos jurídicos, habitualmente han organizado, en general, el tratamiento jurídico de la niñez atendiendo tanto a la inserción familiar del niño, como a sus posibilidades reales de valerse por si mismo, según el grado de madurez alcanzado.

El Derecho ha considerado la edad, por gozar de un carácter objetivo, como criterio para determinar la aplicabilidad del régimen jurídico previsto ad hoc (o de las normas jurídicas particulares) a los individuos en la niñez. La razón de ello se funda en que la edad corresponde al tiempo de existencia de un individuo transcurrido desde su nacimiento hasta el momento en que se computa y teniendo en cuenta que en una sociedad dada, con sus propios rasgos históricos, los individuos adquieren los diversos niveles de madurez a edades semejantes en términos normales ${ }^{851}$.

850 Cfr. LAZARO GONZÁLEZ, I. (Coord.), "Los menores en el Derecho español”, Ed. Tecnos, Madrid, año 2002, página 33.

851 Se pueden considerar para el análisis de los antecedentes históricos y comparados las opiniones de ALBALADEJO, M. "Comentarios al Código Civil y Compilaciones Forales", IV, Ed. Edersa, $10^{\mathrm{a}}$ edición, Madrid, año 2005, páginas 504 a 508; DE CASTRO BRAVO, F, "Derecho Civil de España", edición facsimilar de la 2 $2^{\mathrm{a}}$ de 1952, Ed. Cívitas, Madrid, año 1986, páginas 149 a 151 y las páginas 156 a 164. 
De la generalización de la edad como criterio estructurador de la regulación de esta materia surgen los conceptos de minoría de edad, y su opuesto, la mayoría de edad, también el de menor emancipado. En una primera aproximación, se les puede caracterizar de la siguiente manera, la minoría de edad denota la condición de quien puede valerse por si mismo, por su parte el menor emancipado, aquel a quien siendo menor de edad, se le habilita como si fuese mayor de edad, es más bien una situación excepcional ${ }^{852}$.

La fijación de la edad, que determina el paso de la menor a la mayor edad, es fruto de un juicio de oportunidad, en función de las circunstancias de lugar y tiempo en que se manifiestan diversos factores (alimentación, educación, configuración de la familia, sistema social de valores y creencias) de los que depende la madurez física, sicológica y social de los individuos ${ }^{853}$. Cada ordenamiento jurídico debe tomar una decisión al respecto. El sentido de la evolución histórica ha sido disminuir la edad requerida para alcanzar la mayoría de edad, por un lado, y por otro, fijar la edad

852 HERNÁNDEZ IBÁÑEZ, C. Expresa que: "No obstante y a pesar de todo lo expuesto hasta ahora, creo que estas leyes (se refiere a las leyes relativas al acogimiento) no deberán ser de aplicación a los menores emancipados, tampoco a las personas que se les ha concedido el beneficio de la mayor edad, ni a los hijos mayores de dieciséis años, que con el consentimiento de los padres vivieran independientemente, pues estos últimos están a todos los efectos emancipados. Y ello porque las leyes hacen referencia, no sólo a que las personas sean menores de edad, sino que también exige el requisito de que éstos se encuentren en una situación de desprotección y desamparo.- Para ello me baso, en primer lugar, en que el artículo 323 del Código Civil indica que la emancipación habilita al menor para regir su persona y bienes como si fuera mayor, a pesar de que señala unos supuestos en los que el emancipado necesita del consentimiento de sus padres, y a falta de éste el de su curador, pero únicamente para determinados actos puramente patrimoniales que son: tomar dinero a préstamo, gravar o enajenar bienes inmuebles y establecimientos mercantiles o industriales u objetos de extraordinario valor. Lo mismo se ha de aplicar al menor que ha obtenido judicialmente el beneficio de la mayor edad, artículo 323 párrafo último del Código Civil, y al que vive independientemente, artículo 319 del mismo texto legal.- $\quad$ En segundo lugar, los menores emancipados no están sujetos a la patria potestad, ya que esta se extingue por la emancipación, artículo 169 no2 del Código Civil. Idéntico criterio hay que aplicar en este último caso cuando los padres pueden revocar su consentimiento, lo que daría lugar a que ya no se les considere como emancipados si esto ocurriera. Y los menores que hubieran obtenido el beneficio de la mayor edad dejan de estar sometidos a tutela, artículo $276 n^{\circ} 4$.- Por tanto, si los menores emancipados y los que hayan obtenido el beneficio de la mayor edad no están sometidos a patria potestad y tutela, y pueden regir su persona y bienes como si fueran mayores, excep to en unos determinados supuestos, significa que estas leyes no se les debe de aplicar a ellos, ya que es dificil que puedan llegarse a encontrar en situación de desamparo y por consiguiente ser protegidos a través de algunas de las instituciones que desarrollan estas normas.- Como consecuencia, considero que únicamente deben de aplicarse a los menores no emancipados, aunque en la inmensa mayoría de los casos, estos son los menores de dieciocho años. Y no hay por qué alegar, desde mi punto de vista, que ello ocasione un perjuicio para los meno res emancipados que pudieran quedar desprotegidos, ya que la inmensa mayoría de los derechos que se recogen en estas leyes vienen ya regulados en otras leyes, y por tanto se aplican a todas las personas, lo que implica también a esto". "Destinatarios de las leyes autonómicas" en "La protección de los menores. Derechos y recursos para su atención”. Ed. Civitas, Madrid, año 1998, página 17 y siguientes.

853 La madurez psicológica del menor para la toma de decisiones, y por lo tanto, su autonomía evolutiva, esta claramente expuesto por ROLDÁN FRANCO, Ma . En "El papel del consumo en la formación psicológica del niño y de la familia", en LÁZARO GONZÁLEZ, I., e MAYORAL NARROS, I (Coords.) "Infancia, publicidad y consumo", Jornadas sobre Derecho de los menores, en Documentos de trabajo de la Facultad de Derecho de la Pontificia Universidad de Comillas, Madrid, año 2005, páginas 87 y siguientes. 
de forma unitaria para todos los individuos de la comunidad jurídica, en virtud del principio de la igualdad jurídica.

En el entorno occidental en el que el ordenamiento jurídico español se inserta, la tendencia general ha sido adoptar la edad de dieciocho años como determinante de la mayoría de edad.

Partiendo de estas premisas, desde el punto de vista formal del Derecho español, la minoría edad es un estado civil en que se encuentra el ser humano desde que nace hasta que cumple dieciocho años, siempre y cuando no sea emancipado. Debe, por tal motivo, considerarse que la formalidad de la definición obliga a excluir de su ámbito a los menores emancipados, en cuanto a que la situación de éstos constituye otro estado civil, aunque cabe pensar en normas jurídicas cuyos destinatarios sean genéricamente los menores, y en tales casos habría de determinarse, mediante la interpretación, si se incluye también a los menores emancipados ${ }^{854}$. Estimo que en caso de ser una norma que les beneficie, entonces bajo el principio de protección eficaz de su interés, tal norma debería ser aplicada a los menores emancipados, aunque ya no sean considerados propiamente menores, por el ordenamiento jurídico.

Es decir, en los ordenamientos jurídicos modernos que tengan consagrados constitucionalmente los principios del libre desarrollo de la personalidad ${ }^{855}$ y de no discriminación, como es el caso del español, el fundamento de la minoría de edad radica en las condiciones de inmadurez física, sicológica y social de quien es menor de edad y que le imposibilitan valerse por si mismo; y su finalidad no es otra que dotar a quien se encuentra en ella de la necesaria protección que le permita su desarrollo personal hasta alcanzar la madurez ${ }^{856}$. Entre los preceptos que resulta necesario citar

854 SERRANO ALONSO, L. "El menor en el Derecho. Sistema normativo y principios rectores del Derecho de menores” en LÁZARO GONZÁLEZ (Coord.) “Los menores en el Derecho español”, Ed. Tecnos, Madrid, , año 2002, página 34 .

855 En relación con este principio DIEZ-PICAZO, ha manifestado que al estudiar las opiniones de los que pretenden la separación total entre Familia y Derecho hay que situar, por último la pretensión de los radicales a favor de una completa deslegalización del Derecho de familia, que supondría la pura y simple desaparición de este derecho. Dejar a la familia fuera del Derecho, con el fin de que se rija a merced de sus impulsos espontáneos. Este modo de pensar, que algunos seguramente calificarán como ácrata, podrá encontrar su fundamento en la idea de que la familia es una institución represiva y fuente de frustraciones. La completa libertad individual lleva a la libertad de establecer relaciones intersexuales. Podría encontrar algún fundamento en lo que el art. 10 de la Constitución española denomina ambiguamente "el libre desarrollo de la personalidad". Que la personalidad y la persona se desarrollen libre y espontáneamente y, por consiguiente, sin ningún tipo de ataduras y de represiones. Significa que no haya Derecho de Familia. Expresa el autor, que el principio de libre desarrollo de la personalidad del art. 10 de la Constitución es evidente que no puede ser atendido en un sentido tan amplio. La Constitución española contiene normas que señalan la necesidad de mantener el Derecho de Familia. Así resulta del art. 32 que regula el ius connubi y del art. 39 que habla de una protección social, económica y jurídica de la familia. Se destaca la protección jurídica de la familia, por ende, la necesidad de un Derecho que la regule." Opinión vertida en "Familia y Derecho”, Ed. Civitas, primera edición, Madrid, año 1984, página 27.

856 Se puede analizar en este sentido el texto de GORDILLO CAÑAS, A. "Capacidad, incapacidades y estabilidad de los contratos”, Ed. Tecnos, Madrid, año 1986, página 1450 y siguientes. En cuanto a la evolución histórica también se puede analizar la exposición de DE CASTRO, F en su obra “Derecho Civil de España I", Ed. Edersa, Madrid, año 1985, página 169 a 171, así como la evolución en el Derecho Romano, destaca aquí la exposición 
aquí, correspondientes a la Constitución de 1978, están los art. 10, art 12, art. 14, art. 20 nº 4, art. 39 $n^{0} 1$.

Del concepto de la minoría edad propuesto, destaca su consideración de estado civil de la persona $^{857}$. Ello plantea dos cuestiones: la primera, ¿cuál es el significado y el alcance actual del concepto de estado civil?; la segunda, ¿cuál es el régimen jurídico aplicable a la menor edad como tal estado civil?.

Respecto a la primera cuestión, significado y alcance actual del estado civil, no es procedente formular en este apartado una reconstrucción completa de la teoría del estado civil, cuyo concepto ha sido revisado críticamente en la doctrina española reciente, pues tal no es el objetivo del presente estudio, sin perjuicio cito los estudios ya clásicos sobre el tema escritos por COSSIO, DE CASTRO, SANCHO REBULLIDA y GORDILLO CAÑAS ${ }^{858}$.

de ARIAS RAMOS, J y ARIAS BONET, J. A en su “Derecho Romano II”, Obligaciones, Familia, Sucesiones, Revista de Derecho Privado, Madrid, año 1979, páginas 703 a 712.

857 También la minoría de edad es tratada como un estado civil, por SERRANO MOLINA, A. "El menor en el Derecho. Sistema normativo y principios rectores del Derecho de menores"en LÁZARO GONZÁLEZ, I (Coord.) “Los menores en el Derecho español”, Ed. Tecnos, primera edición, Madrid, año 2002, páginas 37 a 40.

858 Si se remonta al pensamiento ilustrado, y su relativa puesta en práctica durante la Revolución francesa que pro clamó la igualdad de todos los hombres, se destaca que los estados del Antiguo Régimen derivados de los viejos status romanos -libertatis, civitatis y familiae-, pierden su significado originario de determinar la capacidad jurídica de los individuos que los ostentan. Se produce entonces una desgaste del concepto, derivándose hacia las circunstancias modificativas de la capacidad de obrar y se duda de cuál es su alcance y su significado y de qué situaciones del individuo merecen la calificación de estados civiles. "Así llega a apuntarse la perfecta inutilidad de semejante construcción, reducida a una mera categoría escolástica (COSSIO, A, "El moderno concepto de personalidad y la teoría de los estados en el Derecho Civil", Revista de Derecho Privado, Madrid, año 1943, página 11). DE CASTRO intenta, no obstante, una reconstrucción del estado civil sobre la base de la capacidad de obrar, en efecto, el estado civil es aquella cualidad del individuo, por su especial situación en la organización jurídica que determina su capacidad de obrar, caracterizándola cada estado civil según su especialidad, según ello "ha de advertirse que en la persona concurren normalmente varios estados civiles y que para averiguar la capacidad de obrar de una persona (....) hay que estar al resultado que produzca la posible concurrencia de los estados" (DE CASTRO, "Derecho Civil de España I",...op. cit., páginas 58 a 74). SANCHO REBULLIDA recorre el camino propugnado por DE CASTRO y, admitiendo su relación directa con la capacidad de obrar, propone una enumeración de los estados civiles que todavía es dominante en la doctrina española -estados civiles relativos a la familia (matrimonio y filiación), relativos a la pertenencia de la comunidad jurídica (nación y vecindad civil), relativos a la capacidad de obrar (menor, menor emancipado, mayor de edad, incapacitado parcial y total, declarado pródigo), SANCHO REBULLIDA, F. "El concepto de estado civil, Estudios en homenajes al profesor Serrano, I". Valladolid, año 1965, páginas 742 a 840. Ahora bien, la teoría del profesor DE CASTRO entra en crisis, puesto que algunos de los estados civiles comúnmente admitidos como tales (por ejemplo, los relativos a la pertenencia a la comunidad jurídica o los relativos a la familia) no afectan a la capacidad de obrar, más aún des pués de la consagración del principio del libre desarrollo de la personalidad y de no discriminación, como pone de manifiesto GORDILLO CAÑAS, analizando particularmente la situación de la mujer casada; para el citado autor, el estado civil "sin ser ya determinante de la capacidad de obrar, quedará relegado a indicador de situaciones de carácter personal, estables y especialmente significativas, atractivas, por ello, del estatuto jurídico básico de las personas en función de tales situaciones", constituyendo su unidad conceptual "su valor definitorio de la situación jurídica básica de la persona en la sociedad" (GORDILLO CAÑAS, A. "Capacidad, incapacidades y estabilidad de los contratos", Ed. Tecnos, Madrid, año 1986, páginas 54 y 56 respectivamente, el desarrollo entero de la cuestión, páginas 48 a 56). Como consecuencia de ello, otro sector de la doctrina ha desplaza do el centro de gravedad del concepto de estado civil, sin cuestionar la enumeración propuestas de estados civiles, al aspecto meramente adjetivo: La legislación vigente emplea la locución "estado civil", en un sentido, al parecer, bastante preciso, para calificar una pluralidad de relaciones jurídicas, a las que cabe aplicar un tratamien- 
En torno a la segunda cuestión planteada, es decir, el régimen jurídico aplicable a la minoría de edad como tal estado civil, esta se inserta dentro de un régimen jurídico homogéneo de tutela y garantía de los estados civiles ${ }^{859}$, si bien con la singularidad de que está determinada, salvo en caso de emancipación, por el dato objetivo de la edad, lo que implica que las facultades y acciones de estado, con sus peculiaridades (carácter personalísimo, orden público, carácter imperativo de las normas, intervención del Ministerio fiscal, eficacia ergo omnes, necesidad de seguridad, estabilidad y permanencia) sólo entrarían en juego en relación con la concesión de la emancipación; por otra parte, la prueba de la minoría de edad de un individuo resulta de su inscripción de nacimiento en el Registro Civil, que da fe de la fecha y hora del mismo.

\subsection{Alcance y extensión de la minoría de edad}

Tanto las legislaciones antiguas, a excepción del Derecho romano, como las modernas, para resolver el problema jurídico de la edad adoptaban un mismo sistema: valerse de reglas de carácter general, que se estudiarán a continuación, aunque en determinados casos el legislador atendía a circunstancias individuales.

En Roma se distinguían una pluralidad de edades: 1) Infantes, hasta los siete años, eran incapaces de realizar actos jurídicos, 2) Impúberes infantia maiore, entre los siete y catorce o doce años, según se tratase de hombre o mujer, a los que se les reconocía un mínimo de capacidad para realizar aquellos actos que le reportase un beneficio patrimonial; 3) Púberes, a los catorce y doce años res-

to homogéneo. "El interés práctico del concepto de estado civil reside precisamente en esta posibilidad de aplicar un mismo régimen jurídico -por más de que la ley nos proporcione sólo de una forma desproporcionada y desordenada- a los diversos casos incluidos, en particular por lo que se refiere a la prueba y a las acciones de estado. Por ello a podido decirse que son en buena parte los aspectos judiciales los que han impuesto la noción de estado civil al legislador y a la doctrina”. (DELGADO ECHEVERRIA, J en LACRUZ BERDEJO, J. L. “Elementos de Derecho Civil, I.”, Ed. J. M. Bosch editor, 2 a edición, Barcelona, año 1993). Más recientemente, se ha sustentado una tesis estricta sobre el estado civil, en virtud de la cual sólo deben de considerarse por tales los estados de ciudadanía (nacionalidad y vecindad civil) y de familia (matrimonio y filiación), quedando el estado civil definitivamente de la capacidad de obrar y reducido a denotar la dimensión de la sociabilidad esencial del ser humano: su integración en la comunidad y la familia (vid. RAMOS CHAPARRO, E. "Ciudadanía y Familia: los estados civiles de la persona”, Ed. Cedecs, Barcelona, año 1999, páginas. 131 a 136, si bien toda la monografía es un desarrollo de la tesis ya expuesta).

859 Atendiendo a la perspectiva que adopta el ordenamiento jurídico español de las instituciones de protección, cabe distinguir dos modelos o sistemas de protección en torno a los menores; el institucional y el funcional. El modelo institucional, está formado por un conjunto de instituciones, relacionadas entre sí, atendiendo a los criterios de supletoriedad y complementariedad, de modo que se prevén, desde un punto de vista formal, todas las posibles situaciones, en las que se establecen tres niveles. En este modelo se incluye la protección prestada por los padres, la protección prestada por el tutor ordinario (ya sea familiar, ya sea la autoridad) y la protección prestada por el defensor judicial. Lo decisivo en tal modelo es la perspectiva institucional, es decir al menor se le contempla como individuo en situación de protección bajo una de las instituciones de guarda legal. El modelo funcional, por otra parte, enfatiza la situación real del menor, su situación de desamparo, cuando no cumplen su función protectora eficazmente las instituciones del modelo anterior, así en caso de desamparo, el modelo institucional es desplazado por el funcional, mediante la asunción de la tutela o la guarda administrativa, por las entidades públicas de protección al menor, con los mecanismos previstos. 
pectivamente, los cuales eran plenamente capaces para contraer matrimonio y para testar; 4) Mayores de veinticinco años, con plena capacidad de obrar, aunque esta mayoría de edad se encontraba supeditada a la situación familiar.

Así se distinguían dos tipos de hijos, los sui iuris, y los alienni iuris. Los primeros eran plenamente capaces pero los segundos quedaban sometidos al pater familias, carecían de independencia jurídica y su capacidad se encontraba totalmente restringida. La patria potestas romana duraba toda la vida, independientemente de la edad de los filii.

Posteriormente, antes de que entrase en vigor el Código Civil, en las Partidas, asimismo en la Novísima Recopilación, en la Ley de Matrimonio Civil, en la Ley de Enjuiciamiento civil, etc., los individuos recibían diferentes nombres según la edad que ostentaban. Así se clasificaban en mayores y menores, según tuviesen o no veinticinco años. Estos se subdividían a su vez en impúberes y púberes, los primeros eran los menores de doce y catorce años, según fuesen mujeres o varones, y los segundos los mayores de esas edades. Los impúberes se clasificaban a su vez en infantes y simplementes impúberes, según estuviesen dentro de los siete años o superasen esa edad. Los simplementes impúberes se dividían en próximos a la infancia y próximos a la pubertad, según fuesen mayores o menores de los diez años y medio (varones) y nueve y medio (mujeres).

Como se puede observar, en la etapa anterior a la Codificación civil, la capacidad de obrar de la persona, su autonomía personal y patrimonial en el tráfico jurídico venía determinada a través de dos datos: la existencia de capacidad natural y la consideración jurídica dependiente o independiente, (alienni iuris o sui juris respectivamente) ${ }^{860}$.

HIERRO ${ }^{861}$ ha manifestado sobre este punto que fue la Codificación con su método racionalista la que sustituyó un sistema gradual por uno más simple, de menor y mayor edad. La mayor edad es equivalente a plena capacidad jurídica y de obrar; la menor edad es, con alguna excepción puntual para algún acto jurídico determinado, una incapacidad general de obrar.

La concepción del hombre subyacente al individualismo liberal racionalista es la concepción de un hombre abstracto cuya dignidad moral deriva de la autonomía de su voluntad. Y ese hombre autónomo abstracto sólo se concreta adecuadamente en el cabeza de la familia, varón propietario adulto, pero esto no implica un desconocimiento de la personalidad. Tal como lo explica el autor re-

860 ARAMBURU Y MACHADO, M. "La capacidad civil. Estudio de las causas que determinan, modifican y extinguen, según la filosofía del derecho, la historia de la legislación y el Derecho vigente en España”. Madrid, , año 1931, páginas 95 a 105.

861 HIERRO SÁNCHEZ-PESCADOR, L, “Los derechos humanos del niño”. Separata del libro editado por ANTONIO MARZAL “Derechos humanos del niño, de los trabajadores de las minorías y complejidad del sujeto”, Ed. Bosch-ESADE, Barcelona, año 1999, páginas 15 a 32. 
cién citado, al Derecho liberal le interesaba no tanto el niño en cuanto niño, sino el propietario en cuanto niño. Por ello la Codificación protege principalmente al niño como titular de unos derechos de propiedad que pueda ostentar aunque no puede ejercer por sí mismo. Mientras que el Derecho privado reconoce al menor como sujeto de Derecho, aunque con una general incapacidad de obrar, el Derecho Público, por su parte, no reconoce al niño como ciudadano porque la participación (la libertad positiva) supone un ejercicio de la libertad y el menor carece de la madurez suficiente como para acceder a su disfrute.

En la etapa codificadora, específicamente en el Proyecto de 1851, es cuando se fijan las bases del sistema de la minoría de edad: 1) Se describe la situación de la minoría de edad con carácter general, sin distinguir entre hijos de familia y pupilo (el art. 142 del Proyecto en cuestión considera menores de edad a todas aquellas personas sin distinción de sexo que no hubiesen cumplido los veinte años); 2) La mayoría de edad extingue la patria potestad; 3) Se suprime la distinción entre el sui iuris y el alieni iuris. Es aquí cuando la división de la capacidad de la persona se fija conforme a una edad límite.

El esquema seguido por el Código civil de 1889 bastante similar al propugnado por el del Proyecto de 1851 y el de 1882 , por una parte elimina las edades basadas en la presunción de capacidad a partir de la pubertad con alguna excepción (art. 83.11. derogado; 663. 11; 1245 y 1246.3 también derogados, del Código Civil) y distingue dos etapas diferenciadas, la mayoría y la minoría, estableciendo una edad límite, en segundo lugar califica la minoría de edad como uno de los supuestos de restricción de la personalidad (art. 32.11 hoy derogado) ${ }^{862}$, en tercer lugar abandona la distinción entre el sui iuris y el alieni iuris, estando el menor de edad sometido, por su situación de tener restringida la personalidad, a una potestad ajena como es la patria potestad o la tutela ${ }^{863}$. Sobre esto MONTON GARCÍA afirma que hasta ese momento el menor se encontraba sometido al denominado régimen tutelar ${ }^{864}$.

Destaco que cuando el legislador español reformó la mayoría de edad, lo hizo estando ad portas la votación para la aprobación de la Constitución de 1978, de tal manera que, al incluir dentro de

862 Sobre estos aspectos históricos y generales de la edad civil Vid. por ejemplo: CASTÁN TOBEÑAS, J: "Derecho civil español, común y foral”, Tomo I, Introducción y Parte General Vol. $2^{\circ}$ (Teoría de la relación jurídica), Ed. Reus, Madrid, año 1952, páginas 133 y siguientes; LACRUZ BERDEJO, J. L. y otros, "Elementos de Derecho Civil, I. ”, ... op. cit., página 102.

863 LÓPEZ SAN LUIS, R. “La capacidad contractual del menor”, Ed. Dykinson, Madrid, año 2003, página 41.

864 MONTÓN GARCÍA, M. "Derechos y garantías de los menores en el ámbito civil, su protección procesal en la Ley orgánica 1996 de 15 de enero", Universidad Complutense Facultad de Derecho, Servicios de Publicaciones, Madrid, año 2003, página 16. 
los sufragantes a las personas que se encontrasen en ese rango de edad, se pensaba obtener la mayoría necesaria para su aprobación.

Concluyendo, sobre el alcance y extensión de la minoría de edad, en primer lugar debe conocerse durante cuánto tiempo cronológico se considera a una persona menor de edad y, por tanto, merecedora de ese tratamiento diferenciado en relación con los mayores. En este momento, el tiempo ha quedado constitucionalmente señalado en los dieciocho años y ello se proyecta en todo tipo de actuaciones, aunque en el Derecho civil esto siempre ha presentado atenuaciones ${ }^{865}$.

En segundo lugar el factor de la edad ha sido una variable durante mucho tiempo que se ha visto influenciada incluso por factores sexistas, conforme a los cuales en determinados ámbitos o situaciones se diferenciaba en cuanto al tratamiento específico que había que dar a las mujeres ${ }^{866}$.

En tercer lugar, en cuanto a la legislación vigente, excepcionalmente por razones que se fundan en el bonum filii, se reconocen o limitan derechos y obligaciones y se gradúan responsabilidades.

Así, los preceptos que contemplan edades de la "minoría" (3, 12, 16 años etc.) encierran el propósito de tutelar en el orden económico, moral o incluso físico, a quienes no tienen por su infancia, puericia o pubertad, el desarrollo que se estima necesario para que puedan decidir correctamente, valerse o protegerse por sí mismos. Y aquellos otros que reparan en edades de la "mayoría" (18, 45, 60 años etc.) son válidos, por lo general, para afirmar la plena capacidad de la persona, para reconocerle unos determinados derechos, para fijar el momento en que esos $u$ otros derechos se extinguen, o bien, para eximirle del cumplimiento de determinadas obligaciones.

LÓPEZ SAN LUIS ${ }^{867}$ se refiere a la importancia jurídica que reviste la edad “...con sólo considerar que la edad es una causa de carácter general y universal, a la que se hallan sujetos todos los hombres, y que ésta decide el momento en que pueden hacerse efectivos los derechos de más trascendencia, tanto más difícil de fijar cuanto que al hacerlo se impone como necesaria la referen-

865 En tal sentido lo expresa MONTÓN GARCÍA MAR, quien menciona que: "Hasta la reforma de la Ley 30/1981 de 30 de julio no podían contraer matrimonio civil los varones menores de catorce años, ni las hembras menores de doce, tal como lo preceptuaba el antiguo artículo 83 del Código Civil. Los menores de catorce años, con independencia de su sexo, no podían ni pueden otorgar testamento (Art. 663.1 Código Civil). Ni los menores de dieciséis años ser testigos en el otorgamiento de testamento abierto sin la presencia de Notario, en caso de epidemia (Art. 701 Código Civil). En el mismo sentido, la condición de testigo se excluía absolutamente para los menores de catorce años, por "incapacidad natural", en las causas civiles conforme al artículo 1.246 del Código Civil. Este precepto (y en general todos los reguladores de la prueba en éste Código) se derogan por la ley de Enjuiciamiento Civil 1/2000, pero se mantiene la idoneidad de los testigos menores de catorce años, aún cuando ahora no de forma absoluta sino condicionada a que "posean el discernimiento necesario para conocer y para declarar verazmente” (Art. 361, párrafo segundo). Ibídem, página 14

866 MONTÓN GARCÍA, M., ibidem, página 15.

867 Vid. LÓPEZ SAN LUIS, R. “La capacidad contractual del menor”, ...op. cit., página 39. 
cia a actos en que juegan toda clase de intereses y que agitan todo género de pasiones". Sí, es cierto, fijar la mayoría de edad no ha sido una tarea fácil, pero sin duda ha sido necesario.

\section{4| El menor como sujeto de derechos}

Según OCHAÍTA y ESPINOSA ${ }^{868}$ se han elaborado definiciones "por negación” de las que pueden vislumbrarse necesidades universales básicas, definiéndolas como aquellos objetivos sin cuya consecución no es posible para los hombres y mujeres integrarse de forma satisfactoria en su grupo social. Por tal motivo, volviendo al tema de las necesidades, se propone que la salud física y la autonomía son las necesidades básicas de todas las personas en todos los entornos culturales. Se puede incluir a los niños, niñas y adolescentes como individuos que tienden a conseguir, desde su nacimiento, los niveles máximos de salud y autonomía.

Puede pensarse que proponer necesidades diferentes para los niños y para los adultos no viene al caso, pero ello no obsta a tener en cuenta que la manifestación de dichas necesidades -de la salud física y la autonomía- es diferente en las distintas etapas evolutivas de todo ser humano, como resulta lógico.

En todo caso, la idea de considerar salud física y autonomía como elementos necesarios para el desarrollo personal, es una constante manifestada a través de la historia evolutiva del pensamiento, que sin duda se ha acrecentado desde el siglo XVIII en adelante ${ }^{869}$.

La concepción del ser humano como individuo libre, presente ya en los filósofos griegos y latinos, exponen OCHAÍTA y ESPINOZA, fue retomada por los pensadores ilustrados, y constituye la base de las primeras declaraciones de derechos humanos. Sin embargo fue la Ilustración alemana y específicamente KANT quien, junto con el concepto de libertad negativa o de defensa de los ciudadanos contra el Estado, introduce el concepto de libertad positiva o libertad como capacidad de autodeterminación en cuanto base moral de los derechos humanos ${ }^{870}$.

868 OCHAÍTA, E y ESPINOZA M‥ A., en MARTÍN LÓPEZ, Mª T. (Coord.), "La protección de los menores. Derechos y recursos para su atención". , Ed. Civitas. Madrid, año 2002, páginas 33 y siguientes.

869 MARTÍ, J. M., indica que: "Las nuevas categorías mentales también van a impregnar el Derecho Privado moderno a través de las codificaciones legislativas. La legislación se muestra partidaria de una apuesta por la libertad como esfera de autodeterminación -que presupone la autonomía de la voluntad-con un sentido eminentemente formalista e individualista. Esto provoca un cambio en la función jurídico-social del status familiae ." . Así lo manifiesta en "La situación jurídica del menor y su formación", que puede encontrarse en el texto "Evolución del Derecho de Familia en Occidente", CATALÁ RUBIO, S. (Coord.), Colección estudios, Ediciones de la Universidad de Castilla-La Mancha, Cuenca, año 2007, página 194.

870 Según HIERRO SÁNCHEZ-PESCADOR, se supone que los derechos del menor son una parte de la tercera generación de los derechos humanos. Pues se suelen explicar los derechos humanos como el producto de tres partos históricos. El primer parto se produce a finales del siglo XVIII y da lugar a una generación de derechos que se denominan "derechos civiles y políticos". El segundo parto se produce a principios del siglo XX y da lugar a una 
Es necesario preservar la salud y el desarrollo biológico de la infancia, pero es necesario que también se acepte la autonomía, como una necesidad fundamental del ser humano desde su nacimiento. Pero esto puede presentar dudas, porque, en primer lugar, se entiende autonomía como libertad en el sentido adulto, como la capacidad de decidir por uno mismo sus propias opciones personales, lo que obviamente no puede hacerse extensivo a los niños, y menos aún en las primeras etapas de la vida. En segundo lugar, en estrecha relación con lo anterior, debido a que se entiende la autonomía como un estado final y no como una meta. Por último, debido a que es necesario recurrir a los conceptos teóricos que proporciona la Psicología del Desarrollo para explicar la tendencia constante del ser humano desde su nacimiento a construir su propio desarrollo y a integrarse de forma satisfactoria en su necesidad ${ }^{871}$.

En efecto, la capacidad de autoidentificación social y de libre desarrollo de la personalidad convierte al menor en sujeto capaz de ser titular de los derechos fundamentales reconocidos genéricamente a la persona ${ }^{872}$. Por tanto, también el menor está dotado de dignidad desde su nacimiento hasta la mayoría de edad, incluso, es probable que, durante ese período temporal, el desarrollo de su personalidad sea más intenso que posteriormente, durante la madurez, por lo que el reconocimiento del disfrute de los derechos y libertades constitucionalmente garantizados se hace más necesario ${ }^{873}$.

segunda generación de derechos que se suelen denominar "derechos económicos, sociales y culturales". El tercer parto se produce en la era actual, es un parto sin dolor, sin el dolor de la violencia revolucionaria que implicaron los dos partos anteriores, dando lugar a una tercera generación de derechos que, según estos mismos autores se caracterizarían por ser específicos en razón del sujeto (derechos de las mujeres, de los niños, de los minusválidos), o específico en razón del objeto (derechos medioambientales, derechos sobre el código genético, derechos informáticos, etc.). Esto aparece en su artículo denominado "Los Derechos Humanos del niño", separata del libro editado por MARZAL A. "Derechos humanos del niño, de los trabajadores, de las minorías y complejidad del sujeto". Ed. J. M. Bosch-ESADE, Barcelona, año 1999, páginas 15 a 32.

871 Aparte de esas dos necesidades humanas básicas, se deben considerar otras necesidades más concretas, denominadas satisfacciones universales o necesidades intermedias. Estos satisfactores universales son considerados requisitos imprescindibles para favorecer el desarrollo de la salud física y de la autonomía de todos los individuos en todas las culturas. Vendrían a significar un enlace entre las necesidades universales y los satisfactores culturales y pueden servir como indicadores de evaluación de necesidades.

Las relaciones entre las necesidades y los derechos humanos adultos han sido tratados de manera profusa y rigurosamente por muchos estudiosos de la Filosofía del Derecho. Pero a pesar de aquello, son muy escasos los autores que se han preocupado de focalizarlos en la infancia. Esto, probablemente se deba a la dificultad ya sabida de justificar la existencia de derechos en las personas menores de edad que, desde el punto de vista legal no tienen la capacidad de ejercerlos. Pero justamente las necesidades son las que permiten justificarlo. Las necesidades son las mismas, pero se manifiestan de una manera distinta.

872 Vid. VÁZQUEZ-PASTOR JIMÉNEZ, L. "La construcción de la ciudadanía del menor de edad", Ed. Tirant Lo Blanch, Monografías, núm. 619, Valencia, año 2009.

873 TAMAYO HAYA, S. "El interés del menor como criterio de atribución de la custodia", Revista de Derecho de familia, , núm. 41, octubre-diciembre de 2008, Ed. Lex Nova, Valladolid, página 39. "Afloran ahora nuevos valores (libre desarrollo de la personalidad, dignidad de la persona, autonomia, ...) que otorgan mayor relevancia a su personalidad: se considera el núcleo familia como un ámbito protector dentro del cual el menor pueda desarrollar su propia personalidad. El menor se ha vuelto persona, con la atribución del derecho a una tutela privilegiada de sus intereses, según una perspectiva que es fácil reconducir al proceso de ampliación de los derechos fundamentales a categorías siempre más amplias y en general al proceso de afirmación de los derechos huma- 
Así, por ejemplo, cuál sea la extensión del ámbito dentro del cual el individuo adulto manifiesta su necesidad de contacto social, sea éste de carácter expresivo (libertad de expresión), asociativo (libertad de reunión y de asociación) o participativo (derechos de participación), expresa su identidad personal como sistema psíquico mediante la posesión de una conciencia propia (libertad ideológica y religiosa, derecho a la intimidad, honor y propia imagen), y como sistema biológico mediante el dominio del propio sistema y de su medio físico (libertad personal, derecho a la vida y a la integridad física y moral, etc.), no son aspectos que se determinen en un único acto, una vez alcanzada la mayoría de edad, sino que exigen que el propio individuo, en evolución desde su nacimiento, pueda ir configurándolos gradualmente en su propio interés -por sí mismo o a través de un tercero- mediante el ejercicio de los ámbitos de libertad constitucionalmente reconocidos ${ }^{874}$.

Quiénes sean sujetos de derecho y, por tanto, se les pueda atribuir la titularidad de los derechos fundamentales, es una cuestión que el ordenamiento jurídico determina mediante la definición legal de personalidad, esto es, mediante la definición de quiénes se convierten en agentes con capacidad comunicativa dentro del sistema social en general, y del sistema jurídico de persona, al establecer, por un lado, su dignidad y el libre desarrollo de la personalidad como marco definitorio de nos que va envolviendo al mundo entero."

874 Para BARRACA MAIRAL, J., debe de captarse en primer lugar la especial relevancia de las relaciones entre el Derecho y el niño, y además actuar en consecuencia adecuadamente según su situación. Pero lo más difícil, probablemente, no consista en advertir estos incontestables hechos, sino en saber reaccionar de modo adecuado ante ellos. Para poder actuar de forma conveniente, tanto a nivel científico como técnico, en el campo del Derecho respecto a la infancia, lo primero es captar "la estructura fundamental" de esta relación, su organización natural. Así para introducir a la forma básica de esta relación basta con partir de un hecho originario: "el niño tiene derecho a ser niño”. Este hecho complejo, unidad de múltiples aspectos, presenta connotaciones éticas y jurídicas, al mismo tiempo. Ahora bien, tener derecho a ser niño implica ante todo: "tener derecho a ser una persona humana no madura, en proceso de desarrollo hacia la madurez, en crecimiento físico y psíquico”... La primera concierne a los llamados derechos fundamentales de la persona, los Derechos Humanos, en los que el niño participa por el hecho de ser persona humana. Ejemplos de estos derechos de los niños son el derecho a la vida, que impli ca el derecho a nacer o venir a la luz una vez concebido, el derecho a la integridad física y psíquica, el derecho a la igualdad ante la ley, etc. El segundo campo de estas relaciones tiene que ver con la necesidad por parte del Derecho de considerar que el niño no tiene la madurez del adulto. De aquí derivan innumerables consecuencias jurídicas para el niño, como son todas las cuestiones que afectan a su responsabilidad antes sus propios actos. Por ejemplo, sus limitaciones civiles, su especialísimo tratamiento penal, la patria potestad, la tutela, la adopción, etc. En tercer lugar, nos encontramos con todo el campo jurídico que hace referencia al desarrollo del niño, a su crecimiento psíquico y físico, a su progreso. Es importante que seamos conscientes a este respecto de un punto clave, y es que el niño tiene derecho a ser siempre niño, en el sentido pleno del término; o, desde otro punto de vista, el niño tiene el derecho a que los adultos, colaboren con él y le ayuden a desarrollarse y madurar. Además, se trata de madurar "en todos los sentidos" (el derecho de la Constitución y del CC a la formación "integral": intelectual, moral, religiosa, etc.). Este hecho tiene una importancia vital, porque supone la garantía del progreso del niño. Debido a ello, tal autor considera que el derecho a la educación y a la formación constituye probablemente la clave de bóveda de toda consideración y prácticas jurídicas de la infancia. La educación, con todo lo que ello conlleva; este es el gran reto, la cuestión decisiva que plantea siempre la infancia. Esto se expresa en su artículo sobre la articulación fundamental de las relaciones entre el Derecho y el niño. "El Derecho y el niño: principios éticos y jurídicos fundamentales", en "El menor en la legislación actual”, varios autores, U. Antonio de Nebrija, Madrid, año 2002, páginas 37 a 39. 
la dogmática de los derechos fundamentales, y, por otro, un catálogo de derechos fundamentales que dotan de contenido a esa dignidad, sin necesidad de acudir a ninguna pre comprensión metafísico - valorativa, de ésta ${ }^{875}$.

Sin embargo, la determinación del momento temporal a partir del cual se puede vincular ese conjunto normativo a cada uno de los sujetos es una cuestión que casi todas las constituciones -y la española de 1978 así lo ha hecho- relegan tácitamente al legislador, en particular, aunque no de forma exclusiva, al Código Civil. El artículo 29 del Código Civil español, siguiendo lo anteriormente mencionado, colma esta falta de previsión constitucional y establece el inicio de la personalidad con el nacimiento, realizándose este último, de conformidad con el artículo 30 del mismo cuerpo legal, cuando el feto haya sobrevivido 24 horas desprendido del seno materno, es decir, cuando se haya probado mínimamente la viabilidad de su existencia psico - física independiente. Es a partir de ese momento cuando cabe afirmar jurídicamente la existencia civil de la persona ${ }^{876}$.

En el ordenamiento español el menor se convierte, por voluntad constitucional, en titular de los derechos fundamentales que la Constitución reconoce a toda persona y de aquellos otros que reconoce al nacional español cuando ostente la condición de tal. Pero con ello no se dice, ni mucho menos, que pueda ejercerlos en todo caso en las mismas condiciones y circunstancias que durante la mayoría de edad.

Aunque será analizado en el siguiente capítulo, quizás sea menester, expresar algunas ideas en torno al libre desarrollo de la personalidad, en este punto, principio vertido sobre las aguas constitucionales y civiles y que baña las playas del Derecho del menor.

Para hablar de la personalidad debemos empezar refiriéndonos a la dignidad de la persona y entenderla como su valor en sí misma, independiente de cualquier circunstancia o cualidad interna o externa. Por tanto, independientemente de su raza, credo, ideología, sexo, clase social, nacionalidad, y lo que para este estudio resulta más importante, la edad.

La idea de dignidad humana es la traducción al lenguaje secularizado de la idea cristiana de que todos los hombres, independiente de cualquier condición o circunstancia, son hijos de Dios. Con el cristianismo el hombre adquiere un valor supremo. Al ser hecho a imagen y semejanza de

875 Cfr. DÍEZ-PICAZO Y PONCE DE LEÓN, L. "El principio de protección integral de los hijos ("Tout pour l' enfant")", en "La tutela de los derechos del menor", $1^{\circ}$ Congreso Nacional de Derecho civil, dirigida por GONZÁLEZ PORRAS, J. M, Córdoba, año 1984, páginas 127 a 131; ELÍAS MÉNDEZ, C., "La protección del menor inmigrante desde una perspectiva constitucional", Ed. Tirant Lo Blanch, Valencia, año 2002.

876 Vid. NAVAS NAVARRO, S. "El bienestar y el interés del menor desde una perspectiva comparada" en "Estudios jurídicos en homenaje al profesor Luis Díez-Picazo", Tomo I, Ed. Civitas, Madrid, año 2003, páginas 687 a 713; PASCUAL MEDRANO, $\mathrm{M}^{\mathrm{a}}$. A., "Los derechos fundamentales y la Ley de Protección del Menor", Revista Jurídica de Navarra, núm. 22, año 1996, páginas 249 a 264. 
Dios y al estar destinado por El a la eterna bienaventuranza, se sitúa por encima de cualquier voluntad humana. El ser humano deja de ser un medio para transformarse en un fin en sí mismo. Esto es precisamente lo que significa "dignidad": cualidad de ser fin en sí mismo, no susceptible de rebajarse a la categoría de medio bajo ninguno circunstancia, ni siquiera de carácter excepcional ${ }^{877}$.

La dignidad de la persona excluye toda consideración utilitarista de la misma, esto es, la concepción que aceptaría verla no como un fin en sí misma, sino como un posible medio para satisfacer cualesquiera fines ajenos o propios. La dignidad del ser humano se manifiesta en su intagibilidad o indisponibilidad. Que la dignidad es intangible quiere decir que no puede aceptarse nada que le afecte en su integridad, siendo tarea de los poderes públicos (aunque no sólo de ellos) el protegerla. La indisponibilidad se refiere a que nadie puede disponer del valor dignidad, ni siquiera el propio sujeto.

El artículo 10 de la Constitución española vincula la dignidad de la persona a los derechos inviolables que le son inherentes y al libre desarrollo de la personalidad. La dignidad se canaliza a través de dichos derechos y a través del libre desarrollo de la personalidad, donde la familia también juega un decisivo papel, pues es generalmente el marco donde este desarrollo se desenvuelve, en lo referente al menor ${ }^{878}$.

Debe entenderse que el texto constitucional apunta al despliegue de las potencialidades psíquicas, morales culturales, económicas y sociales de cada persona humana, la conquista de los valores que le satisfagan y de los ideales que le atraigan; el alcance, en suma, hacia su "modelo" de "ser humano" y de miembro activo, protagonista, en una sociedad determinada y dentro de un orden político y jurídico concreto, en este caso de España, pero abierto a la comunidad universal de todos los pueblos $^{879}$.

877 ROBLES MORCHÓN, G. "El libre desarrollo de la personalidad (Art. 10.1 de la C.E.)” en GARCIA SAN MIGUEL, L. (Coord.) “El libre desarrollo de la personalidad”, Servicio de Publicaciones de la Universidad de Alcalá, Madrid, año 1995, página 45.

878 STC, Pleno, núm. 53/1985, de 11, RTC 1985/53. “Junto al valor de la vida humana y sustancialmente relacionado con la dimensión moral de ésta, nuestra Constitución ha elevado también a valor jurídico fundamental la dignidad de la persona, que sin perjuicio de los derechos que le son inherentes, se halla intimamente vinculada con el libre desarrollo de la personalidad (art. 10) y los derechos a la integridad física y moral (art. 15), a la libertad de ideas y creencias (art. 16), al honor, a la intimidad personal y familiar y a la propia imagen (art. 18.1)”". Asimismo cito STC, sala Segunda, núm.a 1993/47, de 8 de febrero, RTC 1993/47, donde expresa: “...en correspondencia con el pluralismo de opciones personales existentes en la sociedad española y la preeminencia que posee el libre desarrollo de la personalidad (art. 10.1 C.E.), la Constitución no sólo protege a la familia que se constituye mediante el matrimonio (aunque a esta la proteja especialmente), sino también a la familia como realidad social, entendida por tal la que se constituye voluntariamente mediante la unión de hecho, afectiva y estable, de una pareja”.

879 RUIZ-GIMÉNEZ CORTÉS, J., con la colaboración de RUIZ-GIMÉNEZ ARRIETA, I., en “Comentarios a la Constitución española de 1978”, tomo II, dirigidos por OSCAR ALZAGA VILLAAMIL, Cortes Generales, Eds. de Derecho reunidas, Madrid, año 1996, página 73. 
Los derechos constituyen el aspecto estático de la dignidad humana, y se tienen por el mero hecho de ser persona. Este haz de derechos, son recogidos en los artículos 22 a 55, aunque el tratamiento jurídico que efectúa la Constitución española, a cada uno, es muy diverso. Sólo los derechos dotados de la protección especial a la que se refiere el artículo 53.2 pueden ser considerados derechos fundamentales, siendo sin embargo los demás también derechos inherentes a la persona, incluidos por supuestos los menores ${ }^{880}$.

Como los derechos inherentes a la persona delimitan esferas de acción que el individuo ha de hacer propias dotándolas de contenido, puede decirse que el libre desarrollo de la personalidad constituye el aspecto dinámico de los mismos y, a la vez, de la dignidad humana, pues ésta sólo puede realizarse en la medida en que el individuo ponga en marcha libremente dicha cualidad que le es intrínseca, para así concretarla en su vida.

Llama la atención, en primer lugar, la diversidad terminológica. El precepto habla de dignidad “de la persona" y de libre desarrollo "de la personalidad”. La diferenciación no es casual ni caprichosa. Pues en el primer caso se trata de una cualidad: por el mero hecho de ser humano, se es portador del valor dignidad mientras que en el caso de la personalidad se trata de una conquista, cada cual ha de hacerse la suya propia: se es persona, pero se tiene personalidad. Me parece relevante este punto, pues el menor gozará de personalidad desde su nacimiento, pero el ejercicio de sus atribuciones lo podrá efectuar en la medida de que avance en madurez $z^{881}$.

La palabra "persona" no podemos entenderla en el contexto del art. 10.1 en el sentido jurídico habitual, esto es, como ser sujeto de derechos y deberes, lo que haría que tendríamos que incluir bajo dicho concepto a las personas jurídicas, y por tanto, también al Estado, pero no es el caso, la dignidad de la persona quiere decir dignidad del ser humano. Persona, considerada desde este punto

880 Cfr. ROGEL VIDE, C. “Bienes de la personalidad, derechos fundamentales y libertades públicas”, Bolonia, año 1985; RAMOS CHAPARRO, E. "Niños y jóvenes en el Derecho Civil Constitucional” Revista de Derecho Privado y Constitución, núm. 7, septiembre-diciembre de 1995, páginas 167 a 230.

881 GARAY G., J. Y MIREN GARAY, D. Han formulado que: "En cuanto al libre desarrollo de la personalidad, éste es un tema que afecta a la infancia y la adolescencia e implica una cuestión educativa. Por ejemplo: ¿Hasta que punto puede un padre obligar al hijo a estudiar una carrera o elegir un oficio? Los casos en que el padre decide son cada vez menos comunes. Antiguamente nadie ponía en duda el derecho del padre a exigir al hijo que siguiera en su mismo oficio y no digamos si era el dueño de un taller y quería conservarlo después de su retiro. Y si nos remontamos a un par de siglos más, siendo el padre de una clase adinerada, el marido de la hija lo elegía él, a fin de sumar patrimonios. Y si la hija rehusaba podía ingresarla en un convento. Hoy día, habiendo disminuido la autoridad del padre sobre el hijo o hija, se ha abierto el campo del libre (y no impuesto) desarrollo de la personalidad del hijo (a). Creemos que en este sentido que hay que interpretar la frase de la Constitución sobre el libre desarrollo de la personalidad. Estimamos necesario comentar algunas situaciones históricamente para que se vea que en muchas cosas hemos humanizado a la sociedad y liberado las costumbres en comparación con las de antaño”. "Constitución Española Explicada”, Ed. Londonbil S.L., Madrid, año 2006, página 43 y 44 . 
de vista, no es un concepto jurídico sino que un concepto moral, que hay que identificar con ser humano, independientemente de sus condiciones concretas de existencia biológica, social y política: por lo tanto, independientemente del momento de su formación biológica. Tanto el anciano en el lecho de muerte como el feto en el útero de su madre son seres humanos dotados de dignidad a los cuales hay que aplicar por consiguiente los artículos 10 y ss. de la Constitución española, asimismo a un niño de 5,8 o 14 años ${ }^{882}$.

El "ser persona", en este sentido moral, se concreta en la "personalidad" que no es sino la configuración concreta que la persona va adquiriendo a lo largo de su vida. La personalidad es aquí también un concepto moral, y no jurídico, puesto que se refiere a todas las diversas modalidades de acción y de pensamiento que la persona hace suyas y que constituyen la manifestación de su existencia, de su ser en el mundo como individualidad personal. La personalidad es algo que no se da de una vez por todas, como sucede con la persona, sino que se desencadena en un proceso de desarro1lo. Es una realidad sometida a continua revisión y decisión del ser humano. De ahí que la libertad sea su condición primera y necesaria. De esta manera la dignidad se manifiesta en el aspecto dinámico de la libertad de acción y de pensamiento que conlleva el libre desarrollo de la personalidad.

El libre desarrollo de la personalidad implica por consiguiente que el individuo es dueño de su propio proyecto vital, también puede expresarse algo similar hablando de autonomía del individuo o de autodeterminación de éste. La libertad constituye la esencia de la personalidad moral, no pudiéndose construir ésta sino desde la libre elección. Pero al ser el concepto de "personalidad" un concepto moral, la libertad que es su punto de partida no podrá tener cualquier contenido sino sólo aquéllos que efectivamente conduzcan al desarrollo de la personalidad moral que el ser humano, el niño por ejemplo, como libre sujeto agente, se propone. De todas maneras, la autonomía, que se deriva de este concepto, puede presentar dudas al considerarla una meta no un estado final, tal cual se analizará más adelante.

La cláusula del "libre desarrollo de la personalidad" del artículo 10.1 establece un derecho de libertad individual de carácter general. Es el individuo el que tiene el derecho a decidir libremente su proyecto vital, así como a cambiarlo cuantas veces quiera, incluso a no tenerlo propiamente, es la libertad general de acción el contenido del libre desarrollo de la personalidad.

En todo caso agrega ROBLES MORCHÓN, “es el propio sistema constitucional quien establece en otros preceptos todo un elenco de derechos del individuo, que son la expresión de libertades concretas que el ordenamiento jurídico reconoce y sitúa al máximo nivel de jerarquía normati-

882 Vid. ROBLES MORCHÓN, G. "El libre desarrollo de la personalidad (Art. 10.1 de la C.E.)”, ... op. cit., página 48 y 49. 
va, hay que convenir también en que el libre desarrollo de la personalidad constituye al menos uno de los fundamentos axiológico - normativos de esa pluralidad de derechos que reconoce la Constitución, y que vendrían a ser la expresión concreta de aspectos parciales de la libertad general de acción." 883

\subsection{Las necesidades de la infancia, la respuesta familiar formulada ${ }^{884}$}

Al emplear el término de necesidad, se quiere decir que el niño o la niña se desarrollarán de una determinada manera, es decir, se trata de un proyecto que paulatinamente se está cumpliendo, y por tal motivo requiere de determinadas condiciones. Tales necesidades son principalmente de naturaleza biológica, social, y tienen directa relación con las características de la especie humana ${ }^{885}$.

Explican OCHAÍTA y ESPINOZA ${ }^{886}$ una idea que sin duda se encuentra en el subconsciente de la humanidad pero que lamentablemente se olvida, es que toda persona tiene una manera individual de ser hombre, y que tal manera sólo puede desarrollarse, eficazmente, bajo ciertas circunstancias.

Los adultos tienen el deber de responder a las necesidades de los menores, pues ellos no tienen la misma capacidad de autoprotección, son mucho más vulnerables, constatación por todos conocida. Pero el niño no es simplemente un receptor pasivo de la satisfacción de sus necesidades, sino que por el contrario, los niños son agentes activos en las decisiones que les afecten y en todas las actividades de interacción con los demás. Desde pequeños se deben considerar sus peticiones, hacerles partícipes de las decisiones que les afecten, y conseguir que tenga un rol más activo que contribuya eficazmente a satisfacer sus propias necesidades y de los demás.

Las autoras antes citadas hacen una distinción, entre las necesidades de carácter fisico - biológico, las cognitivas y las necesidades emocionales y sociales.

Las necesidades biológicas son claramente aceptadas por todos, entre ellas están: La alimentación, que debe ser suficiente, variada, estar bien secuenciada en el tiempo y adaptada en la edad, por ejemplo la necesidad de la lactancia materna en los tres primeros meses. La temperatura adecuada

883 ROBLES MORCHÓN, G., ibídem, página 48 y 49; Cfr. CABEDO MALLOL, V., quien con su estudio denominado "Marco Constitucional de la protección de menores", editado por el Instituto de Iberoamérica y el Mediterraneo, Valencia, año 2006, páginas 17 y siguientes, analiza este tema en referencia al menor. Asimismo es interesante la obra de CENZANO BARTOLOMÉ, J., “Derechos fundamentales y libertades públicas”, Ed. Tirant Lo Blanch, Valencia, año 2003, páginas 73 a 82.

884 Este título está basado en un artículo aparecido en la Revista Infancia y Sociedad, de ESPERANZA OCHAÍTA y MARÍA ÁNGELES ESPINOZA, núm. 30, Madrid, año 1995, página 15.

885 Cfr. LÓPEZ SÁNCHEZ, F. “Necesidades en la infancia y en la adolescencia. Respuesta familiar, escolar y social.”, Ed. Pirámide, Madrid, año 2008.

886 OCHAÍTA y ESPINOZA. “Las necesidades de la infancia, la respuesta familia formulada”, ... op. cit., página 15 y siguientes. 
debe ser garantizada con apropiadas condiciones de vivienda y vestido. La higiene corporal, de la alimentación, del vestido, de la vivienda y del entorno ambiental, es muy necesaria para el desarrollo saludable de los niños, muchas de las enfermedades que se propagan por causa de una deficitaria higiene, ello es sobre todo patente en los países del tercer mundo. La necesidad de dormir, el suficiente tiempo, y en condiciones ambientales adecuadas es también fundamental para el desarrollo. Los lugares demasiados ruidosos, fríos, poco higiénicos no ofrecen condiciones adecuadas para la salud. Los horarios de sueño deben ser regulares y amplios. La necesidad de actividad corporal, es imprescindible para que tengan lugar los procesos madurativos y el adecuado desarrollo motor. Los niños deben ser lo suficientemente libres y disponer de un hábitat apropiado, a ser posible con amplios espacios de tiempo al aire libre y en contacto con los elementos naturales (agua, tierra, vegetación, animales, etc) para llevar a cabo una variada actividad.

Las necesidades cognitivas se presentan de diversa manera. Por ejemplo, la necesidad de estimulación es hoy ampliamente reconocida por todos los especialistas y se sabe que tiene directa relación con el proceso del aprendizaje, vital para lo que hoy se conoce como la sociedad del conocimiento. Los niños nacen con capacidades sensoriales bastante desarrolladas y estructuradas desde el punto de vista auditivo, visual y táctil. Nacen también con gran capacidad de aprendizaje físico y social, estableciendo asociaciones desde los primeros días de vida y haciendo muy pronto aprendizajes complejos.

Es importante entender que para que los sentidos y la capacidad motoras se desarrollen es necesario que los niños sean estimulados de forma amplia y que ellos, por sí mismos, puedan interactuar con un entorno físico y social rico en cantidad de estímulos, variable, en cuanto a las características de éstos y contingentes con su propia actividad, para que establezcan relaciones entre sus acciones y lo que sucede en el entorno.

Las necesidades emocionales y sociales, son de muy diferente tipo, sólo pueden ser satisfechas por quienes ejercen la función de padres, otros familiares y adultos, los iguales y compañeros, las asociaciones y la comunidad donde viven, los educadores o educadoras, etc.

Sin perjuicio de que ambos sean también instrumentos educativos, ¿cuántos programas de este tipo pueden verse en España?, ¿existiendo una entrada tan fácil a Internet, no es acaso aconsejable mejorar el control de acceso a direcciones en ella?, pues son muchos los niños que lo hacen para ver contenido violento o pornográfico que luego son comentados por sus amigos, quienes también ingresan a los mismos sitios, y mutuamente se "educan". 
De entre las necesidades emocionales la más primaria es la de seguridad emocional. Es sentida subjetivamente como necesidad de sentirse querido, aceptado, apoyado, acompañado y protegido, etc. Su insatisfacción es vivida como abandono, soledad, marginación, rechazo, aislamiento, inseguridad, miedo, ansiedad, etc.

El vínculo que satisface esta necesidad es fundamentalmente el del apego, que es el único que en su propia naturaleza, conlleva la incondicionalidad de la aceptación. Disponer de varias figuras de apego adecuadas es, por consiguiente, fundamental desde este punto de vista. Tener, al menos, una figura de apego es una condición imprescindible, de esta manera se puede lograr un adecuado desarrollo de la infancia.

Esta seguridad emocional es la base adecuada para que se construya un sentimiento de identidad personal, así mismo, para lograr forjar la autoestima. La autoestima sólo se desarrollará en la persona que se sabe querida, tal como es. Esta incondicionalidad es la base de aquella y la mejor forma de ser aceptado en su diversidad o identidad personal ${ }^{887}$.

El riesgo en este caso es la ausencia de figuras de apego y las diferentes deficiencias de éstas que condenan al niño a la carencia de vínculos incondicionales o a la formación de patrones de apego ansioso. Entre éstos están la separación de los padres por hospitalización u otros motivos, la ausencia de figuras de apego capaces de fortalecer su desarrollo.

Está claro que para el individuo no le es suficiente con disponer de una o varias figuras de apego, sino también la necesidad de ampliar sus relaciones con los iguales y con la comunidad en que vive en general. El individuo y la familia nuclear no pueden vivir aislados socialmente. Estas relaciones satisfacen la necesidad de sentirse perteneciendo a un grupo y a una comunidad. Este asociarse es fundamental.

Existe una necesidad denominada de participación y autonomía progresiva. Los niños son actores dentro del sistema familiar pero también del educativo. Tienen el derecho y la necesidad de participar en las decisiones y situaciones en las que estén implicados en la medida de sus posibilidades. La necesidad de jugar está presente en todas las especies cercanas a la nuestra, pero en el caso de los seres humanos es muy clara. El juego les proporciona a las personas la capacidad de gozar de

887 Expresa PIEPER, J. "El Amor”, Ed. Rialp S.A., Madrid, página 54: "Y por muy sorprendente que parezca, esta realidad está confirmada por la más elemental experiencia, por lo que cada día experimenta y vive cada una de esas personas. Se oye decir: esa persona "florece" cuando se siente querida. Sólo en ese momento parece que está en su propio ser, empieza para él una nueva vida, y otras expresiones análogas. Par el niño, y sobre todo para el que todavía está por nacer, el ser amado por su madre es rigurosamente la condición indispensable de su crecimiento. Y no es preciso siquiera que este amor maternal se "materialice" forzosamente en determinados comportamientos de signo benéfico; lo importante es siempre aquella inclinación y entrega que brota del centro existencial y vital mismo de la madre amante; podemos tranquilamente decirlo: la que sale del corazón y que se dirige también literalmente al corazón del niño: eso que suele llamarse "amor" verdadero". 
la vida, de divertirse y de compartir. El juego puede neutralizar el estrés, el decaimiento. Además sirve para fomentar las relaciones sociales, les enseña a los más pequeños el deber de compartir.

Una vez vistas, a grandes rasgos, la teoría de las necesidades del menor, resulta lógico que surja la pregunta ¿Cómo la familia puede satisfacer estas necesidades?.

En primer lugar debe decirse que la familia está llamada a satisfacer las necesidades fundamentales del niño, por sí misma o como mediadora, con el apoyo de otras instituciones sanitarias y educativas. Si la familia no ejerce bien esta función, el resto de los servicios sociales suelen tardar en detectar estas carencias, en el caso de las necesidades emocionales, la capacidad de respuesta, de apoyo social es especialmente limitada, salvo en los casos en que pueda tomarse la medida de adopción. La familia es fuente de información y transmisión de valores. La presencia constante de los miembros adultos de la familia, las conversaciones y las conductas permiten a los niños adquirir informaciones básicas que les permiten interpretar la realidad física y social, así como asimilar las creencias básicas de su cultura ${ }^{888}$.

La familia actúa como grupo de control, vale decir, enseña y obliga a sus miembros a comportarse de forma socialmente deseable. Continuamente juzga la conducta del niño, la premia o castiga. Estos juicios, castigos y premios se refieren a todo tipo de conductas, incluidas las manifestaciones emocionales. La familia ofrece modelos de imitación e identificación a los niños. Estos tienen la oportunidad de conocer la forma concreta de actuar, ya sea de sus padres o de otros familiares y aprender sin necesidad de experiencias personales directas sobre multitud de aspectos de la vida ${ }^{889}$.

La familia ayuda y enseña como debe reaccionar y actuar en las situaciones estresantes. Cuando un miembro de la familia tiene una dificultad, toda la familia la comparte con él, le ayuda a buscar respuestas adecuadas, comparte sus emociones, busca ayuda externa, etc. Lo cual se acentúa en el caso de quien sufra un problema sea un menor.

La familia es el núcleo social que sirve de descanso y lugar para recuperarse de esfuerzos, tensiones o problemas que hayan supuesto costos para el individuo. En ella puede descansar tranquilo, pues sabe que es aceptado en su dificultad.

La familia es un lugar de participación activa del niño; en ella participa en las decisiones que le afectan, se entrena en la relaciones grupales, es ayudado, ayuda, etc.

La familia, en definitiva, es la institución que satisface las necesidades básicas de los niños, por sí misma o con ayuda de otras instituciones, le apoya cuando tiene dificultades y le permite des-

888 Cfr. BRAZELTON, T. B. "Necesidades básicas de la infancia. Lo que cada niño o niña precisa para vivir, crecer y aprender.", Ed. Grao, Barcelona, año 2005.

889 OCHAÍTA, E. y ESPINOZA. Ma . A. "Las necesidades de la infancia, la respuesta familia formulada", ... op. cit., páginas 209 y siguientes. 
cansar, con las espaldas cubiertas, sabiendo que dentro de ella no tiene ninguna batalla que ganar, porque es el lugar de aceptación incondicional.

\section{Algunas consideraciones en torno al interés del menor y la Carta Europea de Derechos Fundamentales}

Ya se ha hecho mención de este tema anteriormente, pero posiblemente sea este el momento oportuno para profundizar más en el mismo.

La interpretación que se ha efectuado de los dos pilares básicos del sistema actual de reconocimiento y protección de los derechos de los niños, contemplados en los dos primeros párrafos del art. 24 de la Carta, es decir, la protección del derecho del niño a participar en la toma de decisiones que se hagan en todos los asuntos que le afecten y de su interés superior como consideración primordial a la hora de llevar a cabo los actos que le conciernen al menor, han sido fundamentales en la progresiva construcción del ordenamiento jurídico de la Unión Europea. Entre los principales textos legales que se han dictado sobre esta materia cabe destacar, las Resoluciones del Parlamento Europeo A-3314/91 sobre los problemas de los niños en la Comunidad Europea (DO C 13/05 de 20.1.1992, 534), A3-0172/92 sobre una Carta Europea de Derechos del Niño (DO C 241/03 de 21.9.1992, 67) y A4-0393/96 sobre medidas de protección de menores en la Unión Europea (DO C 20/04 de 20.01.1997, 170). Resoluciones que habría que situar dentro de una creciente preocupación por definir y proteger los derechos de los niños, impulsada por la Convención de 1989, y en las que, como la posterior Resolución del Consejo y de los Ministros responsables de la Juventud reunidos en el seno del Consejo, de 8 de febrero de 1999, relativa a la participación de los jóvenes (DO C 42/01 de 17.2.1999, 1), se atiende tanto a la protección del interés superior del niño, cuanto a su derecho a participar en la toma de decisiones en aquellos asuntos que les afecten.

En este sentido, hay que recordar que el Parlamento Europeo adoptó el 12 de julio de de 1990, una Resolución en la que invitaba a los Estados miembros a que ratificasen la Convención de las Naciones Unidas, teniendo también la Comisión el encargo de elaborar una Carta Europea sobre los Derechos del Niño en la que se adaptasen las disposiciones de la Convención a la realidad de los niños en Europa. Destaco que la Resolución A3-0172/92 del Parlamento Europeo sobre una Carta Europea de los Derechos del Niño, basada en el informe Bandrés, respondía a la petición que se hacía en el punto 2 de la Resolución A3-314/91, cual pretenda instaurar "una Carta Europea de los Derechos del Niño con carácter vinculante" una carta en que se habrían de garantizar y adaptar a los ni- 
ños en el ámbito universal. De hecho en el punto 1, el Parlamento Europeo recordaba que "en las resoluciones citadas de 12 de julio de 1990 y de 13 de Diciembre de 1991, solicitó a los Estados miembros que adhirieran sin reservas al Convenio de las Naciones Unidas de 1989, sobre Derechos del Niño, afrontaran los problemas esenciales inherentes a la integración europea de los menores, para los que no existen disposiciones en la legislación de los Estados miembros" (DO C 241/03 DE 21.9.1992, 68).

Así respecto al interés superior del niño", la Resolución A3-314/91 establecía expresamente en el apartado N, que "La protección del niño debe basarse en el interés superior del niño"; la Resolución A3-0172/92, en el punto 8.14, que "toda decisión familiar, administrativa o judicial, en lo que se refiere al niño, deberá tener por objeto prioritario la defensa y salvaguarda de sus intereses", la Resolución A4-0393/96, en el punto 14: "Desea que la Comisión, al preparar las iniciativas legislativas que afecten directa o indirectamente a los niños, dé prioridad a los intereses de éstos garantizando la efectividad de los instrumentos jurídicos ya existentes"; y en la Resolución de 8 de febrero de 1999, se invita a la Comisión a "centrarse en los intereses de los jóvenes como principio rector de las acciones, aplicable a todos los ámbitos de las políticas correspondientes y, en su caso, a evaluar los efectos potenciales de las medidas que se hayan de iniciar a nivel comunitario sobre las condiciones de vida de los jóvenes y a mostrar las vías y medios para tener en cuenta los intereses de los jóvenes" ${ }^{990}$.

Y en cuanto al derecho del niño a participar en la toma de decisiones que se hagan respecto a todos los asuntos que le afecten, si bien la Resolución A3-314/91 sólo señalaba, en el apartado C, que "los derechos más fundamentales del niño deben estar protegidos por la Comunidad Europea, con el fin de que cada niño pueda vivir su infancia en dignidad y alegría y alcanzar el libre desarrollo de la personalidad confiando en sí mismo y en los demás; que sólo así puede prepararse a tomar parte en la futura sociedad con sentido de responsabilidad, solidaridad y esperanza que son condiciones para una vida plena"; la Resolución A3-0172/92 ya establece claramente, en su punto 8.14, que "siempre que ello no implique un riesgo o perjuicio para algún niño, este deberá ser oído desde el momento en que su madurez y edad lo permitan en todas las decisiones que le afecten". Aspectos que completará adecuadamente la Resolución A4-0393/96, al pedir a los Estados miembros, en sus puntos 23 y 24, respectivamente, que "fomenten la participación política de los niños, en particular en la formación de parlamentos juveniles representativos a nivel local, regional y nacional, y la par-

890 CAMPOY CERVERA, I. “Artículo 24. Derechos del niño”, en MONEREO ATIENZA, C y MONEREO PÉREZ, J. L. (Dirs.), "La Europa de los Derechos. Estudio sistemático de la Carta de los Derechos Fundamentales de la Unión Europea”, Ed. Comares, Granada, año 2012, página 541. 
Capitulo IV El Principio del interés superior del menor y el Derecho de Familia - Algunas consideraciones en torno al interés del menor y la Carta Europea de Derechos Fundamentales

ticipación de los niños en organizaciones y asociaciones regidas democráticamente" y que, "fomenten la participación social de los niños, en particular mediante la designación de representantes de los niños, siguiendo el ejemplo de Noruega u otros modelos ya experimentados", en este sentido es importante que existan instituciones u organismos que, de forma independiente e imparcial, supervisen efectivamente el respeto a la legalidad vigente y los derechos de los niños y de las niñas. En relación con esto la Resolución de 8 de febrero de 1999 invita a la Comisión a "promover la participación de los jóvenes a nivel comunitario mediante el aprovechamiento del interés que los jóvenes tienen en conformar la Europa de hoy y de mañana".

Hay un aspecto que vale la pena destacar, la indeterminación del contenido de los principios tiene un nuevo aspecto en la redacción del primer párrafo del art. 24 de la Carta. Pues si en el mismo está claro que se está reconociendo el derecho del niño a participar en todos los asuntos que le afectan, reproduciendo casi literalmente en sus dos últimas frases el art. 12.1 de la Convención; sin embargo, la primera frase: "Los niños tienen derecho a la protección y a los cuidados necesarios para su bienestar", no se corresponde de manera directa con el derecho de participación del menor, sino en lo referente a la consideración de su interés superior. Quizás el sentido del legislador era establecer un principio general respecto de los derechos de los niños, un principio que implicaría a tener en cuenta respecto de los derechos de los niños la protección y cuidado de los mismos ${ }^{891}$.

De todas maneras destaco que aquí entran en juego dos ámbitos muy relacionados y que forman parte del presente trabajo. El primero, tratado en lo referente a la autonomía de la voluntad del menor, es decir, su participación en la toma de decisiones de asuntos que le conciernen de manera importante y la segunda, que es el tema el presente capítulo, el interés superior del menor.

Puede estimarse que ambos principios responden a realidades diferentes que no resultan del todo compatibles. La protección del interés superior del menor parece derivar de un pensamiento paternalista, en cuanto la defensa de su interés se efectuará no sólo respecto de las acciones u omisiones de terceros sino también respecto a lo que el propio niño puede efectuar de conformidad a sus incapacidades. Mientras que la participación del menor en la toma de decisión en asuntos que le conciernen es un aspecto que se funda en su libertad, o mejor dicho, autonomía.

891 STJUE, Sala 3 ${ }^{\text {a }}$, Caso Jasna Deticek contra Maurizio Sgueglia. Sentencia de 23 diciembre 2009. TJCE 2009/399. "Por lo tanto, procede considerar que una medida que obstaculiza que se mantengan de forma periódica relaciones personales y dificulta el contacto directo con ambos progenitores sólo podría estar justificada por otro interés del menor de tal entidad que primara sobre el protegido por el mencionado derecho fundamental. - Sin embargo, una apreciación equilibrada y razonable de todos los intereses en juego, que debe basarse en consideraciones objetivas sobre la persona del menor y su entorno social, debe efectuarse, en principio, en el marco de un procedimiento ante el órgano jurisdiccional competente para conocer del fondo con arreglo a las disposiciones del Reglamento núm. 2201/2003 (LCEur 2003, 4396)." 
De conformidad al intento por hacer compatibles ambos principios, debe entenderse, desde una óptica de proteccionismo renovado, el que la participación del niño es necesaria para determinar cual es su interés superior y cómo satisfacerlo, pero que también el propio respeto por la participación del niño tiene su límite en la protección del interés superior, de tal manera que su participación permite hacer eficaz la defensa de su interés. Conforme a este planteamiento, la construcción de la Carta y la interpretación que en general se le ha dado desde las instancias europeas dan una preferencia al principio de la protección del interés superior respecto a la de la participación real y efectiva de los niños en la toma de decisiones que les afecten. De tal manera se entiende que es el principio del interés superior lo que finalmente primará, el que se garantizará siempre, el que regirá todas las medidas que se adopten, sin perjuicio de considerar su opinión, de conformidad a su edad y madurez.

La existencia de tal linea de pensamiento viene de bastante lejos. El punto 8.14 de la Resolución A3-0172/92 sobre una Carta Europea de Derechos del Niño, en la que el Parlamento Europeo, pedía a la Comisión que tuviese en cuenta que: "Toda decisión familiar, administrativa o judicial en lo que se refiere al niño, deberá tener por objeto prioritario la defensa y salvaguarda de sus intereses. A tales efectos, y siempre que ello no implique riesgo o perjuicio alguno para el niño, éste deberá ser oído desde el momento en que su madurez y edad lo permitan en todas las decisiones que le afecten Con objeto de ayudar a tomar una decisión a las personas competentes, el niño deberá ser oído, especialmente en todos aquellos procedimientos y decisiones que impliquen la modificación del ejercicio de la patria potestad..." ${ }^{» 92}$. La misma sigue presente en la interpretación que la Comisión Europea ha hecho de los principios contenidos en el art. 24 de la Carta. Así en su Informe de 2010, señalaba explícitamente que el principio del interés superior del niño incluye: "el derecho a expresar su opinión libremente y a que esta se tenga en cuenta en los asuntos que les afecten. Un principio importante de la Carta es que cuando se tomen decisiones buscando el interés superior del menor, este tenga la oportunidad de expresar su opinión y que esta se tenga en cuenta".

Concluyendo este título puede afirmarse que las políticas de la UE que afectan directa o indirectamente a los niños deben concebirse, aplicarse y controlarse teniendo en cuenta el principio del interés superior del niño, tal cual se vislumbra en la Carta de los Derechos Fundamentales de la Unión Europea y en la Convención de los Derechos del Niño.

CAMPOY CERVERA ${ }^{893}$ opina que estas ideas básicas no son compatibles con la construcción de un sistemas de reconocimiento y protección de los derechos de los niños que se encuadre en el

892 DO C 241/03 de 21 de septiembre de 1992, 70.

893 CAMPOY CERVERA, I. “Artículo 24. Derechos del niño”... op. cit., página 546. 
actual modelo de los derechos humanos. Y no lo son, según este autor, en la medida en que no se da una adecuada solución a la necesidad de compatibilizar, por un lado, la consideración del niño como persona de la que es predicable su igual dignidad, a la que se ha de respetar, pues en igualdad de condiciones, la posibilidad de diseñar sus propios planes de vida y actuar para su efectiva consecución, y por otra, la adopción de medidas paternalistas justificadas que, finalmente implican negar un vínculo jurídico a la voluntad manifestada por el niño de tomar un determinado curso de acción. Conforme a dichas ideas, pese a la gran trascendencia que se pueda reconocer y proporcionar a la participación del niño en la toma de decisiones en todos aquellos asuntos que le afecten, así como también en la determinación de cual es su verdadero interés y de cual es la manera para satisfacerlo, es sin duda la voluntad de otros, la de los padres fundamentalmente, las tenidas principalmente en consideración para las correspondientes decisiones sobre sus vidas. A mi juicio, en ciertos casos puede resultar justificado y necesario, y con ello no quiero avalar una posición paternalista, sino que por el contrario, dar margen al hecho de que la voluntad del menor requiere un constante indagar evolutivo, no puede soportar todas las consecuencias que implica la voluntad de los adultos porque los efectos no son los mismos, en el fondo estimo que menor y adulto, ambos en su calidad de personas, tienen igual dignidad, pero la debida protección difiere, en el primer caso debe acentuarse, y puede que ello sea optimizar su principal interés antes que el imperio de su verdadera voluntad, tal cual se estima que es.

Sin perjuicio, la sociedad y por supuestos las autoridades, deben procurar que se logre respetar la posibilidad de que todas las personas, incluso los niños puedan diseñar los propios planes de vida y actuar para su efectiva consecución, a fin de conseguir el libre desarrollo de sus propias personalidades, esto implica el respeto por el ejercicio de cualquier persona de sus derechos fundamentales conforme a lo que se considera su voluntad, sin duda esto es su interés superior, pero siempre y cuando se considere el caso concreto de que se trate, con sus específicas circunstancias, por ejemplo, su edad y madurez ${ }^{894}$.

894 STJUE, Sala $1^{\text {a }}$, Caso Joseba Andoni Aguirre Zarraga contra Simone . Sentencia de 22 diciembre.... TJCE 2010/41. "En efecto, por un lado, dicho artículo 24, en su apartado 1, exige que los menores puedan expresar su opinión libremente y que esta opinión sea tenida en cuenta para los asuntos que les afecten, únicamente «en función de su edad y madurez», y, en su apartado 2, obliga a tener en cuenta, en todos los actos relativos a un menor, el interés superior de éste, interés que, por tanto, puede justificar que no se dé audiencia al menor. Por otro lado, dicho artículo 42, apartado 2, párrafo primero, letra a), obliga a dar al menor posibilidad de audiencia, «a menos que esto no se hubiere considerado conveniente habida cuenta de su edad o grado de madurez". 

jurídico indeterminado

\section{6 | El interés del menor como concepto jurídico indeterminado}

El interés como categoría jurídica es uno de los conceptos fundamentales en la consideración instrumental del Derecho, como medio para la satisfacción de los fines esenciales de la persona, de intereses vitales de ésta. El interés comprende tanto los bienes materiales, patrimoniales, como los espirituales o ideales, todos aquellos a los que la persona considera subjetivamente valiosos; y afecta a la persona como una especie de "energía latente" en sus aspiraciones humanas, del tipo que fueren, materiales o ideales (éticas, religiosas, estéticas), nobles e innobles; afecta también a todos los sectores vitales, en todos los ámbitos individuales y sociales de la persona ${ }^{895}$.

Es necesario destacar la apertura o amplitud de la idea de interés en sentido jurídico, y como comprende, junto a los bienes y valores relevantes en el ámbito de la consciencia, lo inteligible y dominable por la voluntad, los que son objeto de impulsos inconscientes, las aspiraciones humanas sentidas o ideales, de todos los sectores vitales, incluidos los no racionales (los sentimientos afectivos, religiosos, estéticos y otros). Merece la pena subrayar este último dato (por su infrecuente consideración por los juristas): cómo son también relevantes para el Derecho y se integran en el concepto de interés jurídicamente protegible estos valores no racionales, esos sentimientos de variada índole que participan de manera importante en la vida de la persona y que contribuyen a su felicidad o infelicidad, tales fines de la persona deben ser servidos por el Derecho que no deja de ser un instrumento al servicio de la misma.

Es más, sin duda que en el caso de un menor, sus apreciaciones sensibles, afectivas, "irracionales", tendrán más cobertura que otras, debido a lo incipiente de su personalidad, de su madurez, por ello el Derecho debe también apoyarse en ellas, no para necesariamente resolver un asunto conforme a ella sino que para evaluar de manera más completa, más integral la realidad que aspira resolver ${ }^{896}$.

Sin lugar a dudas todas éstas son pautas muy generales del interés de cualquier persona, y como tal vale también para la persona menor de edad, aunque debido a lo incipiente de su desarrollo, de su personalidad que poco a poco va formándose es necesario poner acento en los bienes y va-

895 Cfr. RODRIGUEZ JIMÉNEZ, S y GONZÁLEZ MARTÍN, N. “El interés superior del menor en el marco de la adopción y tráfico internacional. Contexto mexicano. ”, UNAM, México, año 2011.

896 El fomento y fortalecimiento de la posición del menor obligan a considerarlo como un ser humano con creciente madurez intelectual que, cuando por tener capacidad natural consiga tomar decisiones racionales, ha de poder decidir por si mismo. El respeto a su personalidad exige que se le reconozca un papel activo dentro de la familia, otorgándole un señalado protagonismo en la determinación de su propio devenir, al tiempo que posibilita el establecimiento de límites de actuación de las potestades paternas. Carece por ello de sentido la representación del menor y ejercicio de actos en su nombre cundo éste tiene discernimiento y condiciones de madurez suficientes para actuar y tomar decisiones. Se hace preciso reconocerle un ámbito decisional en proporción a su edad y madurez. 
lores no racionales, tal como se acaba de manifestar, en los afectos, aspiraciones, impulsos inconscientes, debido a que tales bienes y valores llenan en proporción considerable sus necesidades y comportamientos.

Para intentar descifrar qué es el interés del menor se han empleado dos técnicas legislativas muy diferentes, que se analizarán un poco más adelante, la primera es la preponderante en el sistema español, es la que apela a las clausulas generales, la otra, opta por la concreción de situaciones que considera que redundan en interés del menor, esto en palabras de RIVERO HERNÁNDEZ ${ }^{897}$.

Si bien es cierto que el principio del interés superior de niño se presenta como un concepto indeterminado, el cual requiere ser concretado en cada situación concreta, con tal técnica la Ley se refiere a una esfera de realidad cuyos límites no aparecen bien precisados en su enunciado no obstante lo que está claro es que intenta delimitar un supuesto concreto que admite ser precisado en el momento de su aplicación. En otras palabras, en estos supuestos la norma no nos ofrece la solución directa de cada caso, de tal modo que ésta debe ser buscada acudiendo a criterios de valor o de experiencia, según se trate la naturaleza del concepto. Tales criterios deben buscarse por ejemplo a nivel jurisprudencial, asimismo en otras disciplinas que sirven de apoyo a la labor de los tribunales, por ejemplo, la psicología, la sociología, etc.

Esta técnica puede comprender la introducción de cláusulas generales en un Ordenamiento Jurídico lo cual tiene sus ventajas e inconvenientes; entre los aspectos positivos podemos citar la posibilidad de que el intérprete adapte las soluciones a los criterios de conciencia social (art. 3.1 del Código Civil) que han de prevalecer en cada momento en la aplicación de una materia tan cambiante como es el derecho de familia, derecho que por lo demás se encuentra en constante evolución. Dicho de otra manera, permite la adaptación del mandato legal a cada supuesto concreto, atendiendo la diversidad de sujetos y circunstancias que puedan presentarse, así como el mantenimiento de su validez a lo largo de un amplio período de tiempo gracias a la posibilidad de ser interpretada de manera acorde con la evolución social y jurídica que se vaya produciendo. Entre los aspectos negativos que puede presentar una legislación que incluya este tipo de cláusulas se encuentra, sin duda, el problema que plantea la interpretación extremadamente subjetiva, que puede acarrear desviaciones notables sobre aquello que la conciencia social considera aceptable en un momento determinado.

Para delimitar con precisión el ámbito de aplicación de los conceptos jurídicos indeterminados resulta capital, según GARCIA DE ENTERRÍA, distinguirlos del supuesto de aplicación de la libertad estimativa que comporta la discrecionalidad ${ }^{898}$.

897 RIVERO HERNÁNDEZ F. “El interés del menor”, ...op. cit., página 69. 
Si lo propio de todo concepto jurídico indeterminado, en cualquier sector del ordenamiento jurídico $^{899}$, es que la determinación de su indeterminación, de su enunciado, no se traduce en una indeterminación de las aplicaciones del mismo, es decir, que su aplicación sólo permite una única solución justa, a la que se llega mediante una actividad de cognición, objetable por tanto, y no de volición, ello en cambio no es así en el ejercicio de una actividad discrecional, que permite, por el contrario, una pluralidad de soluciones justas, o, en otros términos, optar entre alternativas que son igualmente equitativas desde la perspectiva del Derecho, a juicio de GONZÁLEZ ALONSO ${ }^{900}$.

La discrecionalidad como se acaba de enunciar es esencialmente una facultad de elección entre varias opciones igualmente justas, porque la decisión se fundamenta normalmente en criterios extrajurídicos de oportunidad, económicos, no incluídos en la Ley y remitidos al juicio subjetivo de la Administración. Por el contrario la aplicación de conceptos jurídicos indeterminados es un caso de aplicación de la Ley, puesto que se trata de subsumir en una categoría legal (configurada eso sí de una manera amplia y flexible) unas circunstancias reales indeterminadas, vale decir, se trata de un proceso reglado. De conformidad a ello, el concepto jurídico del interés superior del menor se configura de tal forma en el Ordenamiento jurídico que sólo provoca la existencia de una solución justa en la concreción del mismo en cada una de las circunstancias de hecho en que se aplique. El encargado de precisar dicho interés, progenitores, jueces, administración, no va a ser libre para decidir a través de un proceso volitivo de discrecionalidad, entre varios posibles "intereses", sino que tendrá que precisar el "interés" que real y efectivamente sea el verdadero y adecuado en cada supuesto, tal como sostiene FERNÁNDEZ GARCÍA ${ }^{901}$.

898 "Curso de Derecho Administrativo I”, Ed. Civitas, décima edición, Madrid, año 2000, página 457 . "La confusión de ambas técnicas ha supuesto en la historia del Derecho Administrativo un gravísimo peso, que sólo recientemente ha comenzado a liberarse. Es un mérito de la doctrina alemana contemporánea del Derecho Público haber llevado esta distinción hasta sus últimas consecuencias". El mismo autor se había pronunciado años antes en los siguientes términos: "Estos conceptos jurídicos indeterminados, o que se contienen en lo que también se laman las normas flexibles, son consustanciales a toda la técnica jurídica y no constituye una particularidad del Derecho Público". GARCIA DE ENTERRÍA, E. "La lucha contra las inmunidades del poder en el Derecho Administrativo” en Revista de Administración Pública, n. ${ }^{\circ}$ 38, mayo-agosto 1962, página 171.

899 Vid. GARCIA DE ENTERRÍA, E y FERNÁNDEZ, T., ibídem, página 458. El citado autor reflexiona en torno a que la técnica de los conceptos jurídicos indeterminados se da en todas las ramas del Derecho. En el Derecho Civil (buena fe, diligencia del buen padre de familia, negligencia, interés superior del menor, interés de la familia, entre otros); en el Penal (nocturnidad, alevosía, abusos deshonestos, por citar algunos); en el Procesal (dividir la continencia de la causa, conexión directa, pertenencia y relevancia de las pruebas, medidas adecuadas para promover la ejecución, perjuicio de la reparación imposible o difícil y más); en el Mercantil (interés social, diligen cia del buen comerciante, sobreseimiento general en los pagos, entre los muchos existentes).

900 "La discrecionalidad y su control. Diferenciación con la arbitrariedad y con los conceptos jurídicos indeterminados”, Revista práctica de Derecho ,Comentarios y casos prácticos, CEFLEGAL, Centro de estudios financieros, junio 2009, Madrid, página 133 a 142.

901 FERNÁNDEZ GARCÍA, Ma . Y. "El concepto jurídico indeterminado de servicio esencial en la Constitución española”, Revista de Administración pública, núm. 170, mayo-agosto 2006, Madrid, páginas 325 a 338.; Asimismo, Ley 3/2011, de Apoyo a la familia y a la convivencia en Galicia, artículo 38: “.Principios rectores. Serán 
La legislación no define el concepto de interés del menor, sino que se limita a dar una primera aproximación del mismo, configurándolo como un auténtico principio general del Derecho inspirador de toda actuación, tanto a nivel público como privado que se siga en relación con el menor y que, además, constituye un auténtico principio interpretativo de las normas cuando existan menores. Se trata, por tanto, de un concepto jurídico indeterminado que, como tal, plantea un problema fundamental: el de su concreción, es decir, su determinación en relación con algo o alguien ${ }^{902}$.

A partir de las ideas esbozadas anteriormente se puede deducir que existen dos sistemas de determinación del interés del menor: el primero, el sistema de cláusula general, y el segundo, el sistema de lista.

En el primero de los sistemas, el interés del menor actúa como una cláusula general, en virtud del cual toda actuación, tanto pública como privada, en relación con el menor debe perseguir dicho interés, constituyendo un principio general en los ordenamientos continentales. En este sistema, en caso de conflicto, corresponderá a los operadores jurídicos fijar el interés en cada caso concreto. En el segundo de los sistemas se establece una lista de situaciones que se entienden en interés del menor, es el sistema inglés de la Children Act de $1989^{903}$.

La técnica de la cláusula general presenta al mismo tiempo ventajas e inconvenientes. Tiene la ventaja de su flexibilidad y adaptabilidad a la realidad social, permitiendo a los operadores jurídicos un amplio arbitrio en su aplicación. Esta ventaja, al mismo tiempo, se torna en inconveniente porque, por tratarse de un concepto jurídico indeterminado, puede ser fuente de inseguridad jurídica ${ }^{904}$.

El ordenamiento español sigue el sistema de cláusula general de los ordenamientos continentales, configurando el interés del menor como un concepto indeterminado que corresponde determi-

principios rectores de la actuación de los poderes públicos de Galicia en el ejercicio de las funciones de atención y protección a la infancia y la adolescencia: a) La primacía del interés de la o el menor sobre cualquier otro interés que inspirase las actuaciones públicas o privadas de quien se encargue de su protección por legítimo que este fuera. Para la determinación de ese interés se atenderá en primer término a las necesidades y derechos de los niños, niñas y adolescentes, se tendrán en cuenta sus opiniones y deseos manifestados con juicio suficiente y se considerará su individualidad en el marco familiar y social.".

902 ASENSIO SÁNCHEZ, M. A. , “La patria potestad y la libertad de conciencia del menor”, Ed. Tecnos, Madrid, año 2006, página 64.

903 La sección 105 de la Children Act establece que los tribunales están obligados a procurar el interés del menor. Se identifica el bienestar a través de una check list que incluye los contrastados derechos del niño, considerando: su edad y su capacidad natural las necesidades físicas, emocionales y educativas; los probables efectos del cambio de circunstancias; su edad, sexo y entorno, etc.

904 Cfr. DELGADO ECHEVERRÍA, J. "La transformación del Derecho de familia y la formación del jurista”, en LACRUZ BERDEJO, J. L. (Coord.), “El nuevo régimen de la filiación. 1. Matrimonio y divorcio”, Madrid, año 1982, páginas 16 a 18; ROCA I TRÍAS, E. “Familia y cambio social..,”, Ed. Civitas, Madrid, año 1999, página 211; RIVERO HERNÁNDEZ, F. “El interés del menor”, Ed. Dykinson S.L., Madrid, año 2007, página 101 y siguientes. 
nar, en su alcance y en su aplicación, a los operadores jurídicos. Aquí la técnica de caso a caso se presenta especialmente útil ${ }^{905}$.

Sólo existen un par de artículos en el Código Civil que definen, de forma más o menos certera que se puede entender por interés del menor. El artículo 234 del Código Civil en relación con el nombramiento del tutor dice: "se considera beneficioso para el menor la integración en la vida familiar del tutor”; y, en parecido sentido, el art. 172.4 CC sitúa el interés del menor bajo acogimiento familiar en "su inserción en la propia familia y que la guarda de sus hermanos se confíe a una misma institución o persona”.

El fenómeno de la creciente preponderancia del interés del menor ha tenido lugar de forma paralela en todo el mundo occidental (y más allá); y la preocupación por los menores se ha producido desde dos perspectivas: una que ha tendido a la protección directa del niño, en razón de su debilidad e inexperiencia; y otra a la liberación respecto de sus status de dependencia. A veces excesiva. En el ámbito anglosajón hay en ese orden, desde hace treinta o cuarenta años, cierto antagonismo y tensión entre los que ponen el acento en el bienestar del niño ${ }^{906}$ y los que ponen el acento en sus derechos $^{907}$. De todas maneras en muchas ocasiones el concepto del interés superior del menor y bienestar del niño se analizan como sinónimos. En tal sentido NAVAS NAVARRO, que los diferencia, ha planteado que existe la dificultad de dar una definición de bienestar del menor porque hay que conjugar un factor abstracto y otro concreto. Y al igual que el interés del menor, se trata de un concepto jurídico indeterminado que requiere concreción, dependiendo de la edad del menor y de las circunstancias socioeconómicas, culturales y morales en las que vive ${ }^{908}$. Definiéndolo como el óptimo desarrollo de su personalidad a través del ejercicio de los derechos fundamentales de los que es titular. Este óptimo desarrollo de la personalidad del menor se da en diversos ámbitos de los que las legislaciones analizadas sólo destacan el físico, el psíquico y el moral ${ }^{909}$.

Entre otros cambios habidos en nuestra sociedad en las dos últimas décadas (múltiples razones sociales y económicas, crisis de un sistema de valores que la informó durante mucho tiempo, no

905 ASENSIO SÁNCHEZ, M. A. “La patria potestad y la libertad de conciencia del menor”, ...op. cit., página 65.

906 La primera cuestión que conviene destacar es la confusión terminológica que en torno al concepto de bienestar del menor reina. Esta confusión se manifiesta también en las diversas traducciones que presenta el vocablo "interés” del artículo 3 de la Convención de la ONU sobre los Derechos del Niño de 20 de noviembre de 1989. En efecto en el mundo anglosajón esta expresión ha sido traducida como "the best interest of the child"; en Francia como "le bien de l'enfant"; en Alemania se ha traducido por "Besten des Kindes"; en Suiza por "Kindeswohl” y en España por "interés del menor”.

907 RIVERO HERNANDEZ, F. “El interés del menor”, ...op. cit., página 38.

908 NAVAS NAVARRO, S. "El bienestar y el interés del menor desde una perspectiva comparada” en "Estudios Jurídicos en Homenaje al Profesor Luis Diez-Picazo”, Tomo I, Semblanzas, Derecho Civil, Parte General, Ed. Thomson Civitas, Madrid, año 2003, página 693.

909 NAVAS NAVARRO, S., ibídem, página 693. 
es menor el de la quiebra del modelo jerárquico de la familia y una mayor y mejor ponderación de los valores personales, entre ellos el de la posición del menor tanto en la familia como en la sociedad, cuyo papel participativo en su propia maduración y formación y en las decisiones y opciones vitales es reconocido hoy por psicólogos, sociólogos y juristas. En tal sentido ha opinado EEKELAAR que existe un doble elemento que permite la estructuración de los derechos de los menores, a nivel personal, por un lado, su independencia, es decir, de como influye en el resultado de las actuaciones que le conciernen y por otro lado, un elemento dinámico, en que se consideran las diversas situaciones que vive el menor mientras avanza en edad ${ }^{910}$.

El ascenso general en el mundo occidental de los derechos de la personalidad, en particular el derecho fundamental a la libertad o autonomía personal, unido a causas socioeconómicas aludidas, han hecho cambiar la vida del hombre y obligado a valorar de forma especial ciertas etapas de su vida, sobre todo las más decisivas en la definición de su propia identidad y personalidad futura.

Las normas que aluden al interés del menor lo hacen en la adopción de diferentes medidas o en la regulación de instituciones que de una u otra manera afectan a los menores, y estas prevalecen para garantizar su bienestar, es decir, el óptimo desarrollo de su personalidad mediante el ejercicio de sus derechos fundamentales.

En tal sentido el menor ha salido de la crisálida en que antes era custodiado, y está ya colocado en situación de adquirir las primeras reacciones, de identificar más rápidamente su propio status, de encaminarse a una formación más rápida y más consolidada para afrontar los problemas de la mayoría de edad ${ }^{911}$. Los valores individuales (la libertad, la dignidad y el respeto de la persona), la autonomía de cada ciudadano para dirigir su propia vida y ejercer sus opciones más trascendentes según su voluntad y sin coerciones exteriores, eran incompatibles con una mentalidad y normas en que primaba una autoridad fuerte y anulaban en buena medida la personalidad de los sometidos, en particular, de los hijos in potestate ${ }^{912}$.

De una u otra manera puede asegurarse que el niño se ha vuelto protagonista, pero su protagonismo es incipiente en el sentido de que debe poco a poco cimentarse en lo paulatino de su desarro-

910 EEKELAAR, J. "The interest of the child and the Child's Wishes: the role of dynamic self-determinism” en "The best interest of the child. Reconciling Culture an Human Rights”, Alston, P., Unicef, Oxford, año 1994, páginas 47 y siguientes.

911 RIVERO HERNÁNDEZ, F. “El interés del menor”, ...op. cit., página 39.

912 Esa incompatibilidad y la superación del autoritarismo en la familia ha obligado a redistribuir las funciones de sus miembros y rediseñado los roles individuales y familiares en un nuevo orden familiar y por consiguiente en lo social, llevando la igualdad de los cónyuges y la cotitularidad de la patria potestad a la vida familiar y a cambiar drásticamente la concepción de dicha potestad y el papel y personalidad del hijo (menor) en la familia. Esto ha tenido una repercusión inevitable en la sociedad, la que ha estado mucho más atenta a las necesidades de toda índole del niño sencillamente como persona y sobre todo en cuanto a personalidad vulnerable y en formación y adulto futuro. 
$1 \mathrm{l}^{913}$. Posiblemente tampoco esta etapa de con la solución, pero significa un avance notorio. Ante ello, me pregunto si ¿Es necesario el protagonismo únicamente del menor?. En mi opinión, los protagonistas deben ser las personas, no el niño, no el padre, la familia, las personas, todos.

En ese marco ideológico y social de fondo aparece con fuerza el denominado interés superior del menor, el cual, si bien nunca pasó totalmente desapercibido para el Derecho, destaca ahora por la nueva valoración que de él se hace más allá del ámbito familiar. Tal interés implica una energía nueva y provoca múltiples proyecciones, sobre todo, el haber sido elevado al rango de principio general informante de sistema jurídico español, con múltiples consecuencias.

Todo ello se ha trasladado en primer lugar a normas recientes que han tenido que reconsiderar los nuevos componentes e intereses existentes en las relaciones familiares y, en general, en todas las relaciones interpersonales en las que participan los menores. Se deben abordar de otra manera los conflictos de intereses bajo la bandera de la primacía del interés del menor. Pero ello ha ocurrido no tan sólo en el orden legislativo, sino también en el ámbito judicial, donde además de la aplicación estricta y correcta de las leyes correspondientes que lo encarnan, es un principio general, recogido en diferentes normas de los cap. II y III, título I, de la Constitución, por lo que vincula a todos los poderes públicos (art. 53.2 C.E., respecto de las del cap. II) e informa la práctica judicial (art. 53.3). Paralelamente, una nueva jurisprudencia, más sensible a ese principio e interés ha surgido en las últimas décadas, en distinto ámbitos y respecto de varias instituciones, que han adquirido de esa forma nuevas dimensiones y matices que es necesario considerar ${ }^{914}$.

El interés del menor constituye, en efecto, en nuestro sistema jurídico y en otros, un concepto jurídico indeterminado, por medio del cual la ley se refiere a una realidad cuyos límites no precisa con exactitud, pero con lo que intenta definir o delimitar un supuesto concreto que permite que sea precisado luego en el momento de su aplicación ${ }^{915}$. Se trata, en este caso como en otros en que el

913 El interés del menor no sólo debe verse desde el presente sino sobre todo desde su futuro, desde una proyección como adulto que formará parte de una sociedad determinada.

914 RIVERO HERNÁNDEZ, F. “El interés del menor”, ...op. cit., página 41.

915 SAP, Sevilla, Sección $5^{a}$, de 1 febrero 2001. AC 2001/429. "La propia naturaleza de la declaración de menores de edad, máxime cuando han de prestar un consentimiento, como en el caso de Sandra, hace completamente inconveniente la presencia en el acto de cualquier persona, pues su sola asistencia podría mediatizar, influir o limitar la libertad y espontaneidad de sus declaraciones y expresiones de voluntad. El menor debe sentirse libre, distendido y con la confianza suficiente para expresar al Juez sus sentimientos, voluntad, deseos y vivencias, y la presencia de otras personas en el acto no ayuda a conseguir ese ambiente de relajación, confianza y libertad necesarios. Así pues, la decisión de la Juez «a quo» en cuanto a la forma en que practicó el acto de prestación de consentimiento de Sandra y de audiencia de David es conforme con la legalidad procesal, además de razonable y conveniente en atención al superior interés de los menores, siempre preferente a cualquier otro interés legítimo que pudiera concurrir (art. 2 de la Ley 1/1996). Y no ha generado una real y afectiva indefensión al apelante, pues tales actos no tienen la naturaleza de medios probatorios que generen el derecho de la parte a intervenir en su práctica, sino que son actos de realización del derecho del mayor de 12 años a prestar su consentimiento y del menor de esa edad a ser oído, el apelante ha tenido conocimiento de su contenido, y la imposibilidad de es- 
Legislador recurre a estos standars o conceptos indeterminados tales como la buena fe, la negligencia, la diligencia de un buen padre de familia, de conceptos de valor o de experiencia referidos a realidades que inicialmente no permiten una mayor precisión o concreción, pero que, trasladadas a situaciones específicas, a supuestos determinados, su aplicación conduce a una solución y no otras $^{916}$ : así, el poseedor actúa de buena fe o no. El hallazgo de esa solución, la única adecuada, sólo es posible al trasladar el concepto indeterminado, en la aplicación de la ley, a la realidad y circunstancia concretas del caso.

Considerar el interés del menor o el interés de cualquier persona requiere plantear su tratamiento en dos planos diferenciados: por un lado, el interés en el ámbito jurídico y, por otro, el interés en el ámbito normativo. Antes de pasar a la expresión normativa del interés del menor y con ello a los modelos en los que se incorpora, una breve aproximación a la doctrina del interés nos conduce a IHERING. El acentúa la protección de los intereses considerándolos como el fin de la ley, de manera que cada precepto jurídico decide un conflicto de intereses a la vez que la protección de un interés se realiza siempre a costa de otros intereses ${ }^{917}$. El concepto de interés en IHERING es muy amplio $^{918}$, el Derecho se centra en servir o satisfacer dichos intereses. Pero no sólo los legisladores delimitan los intereses en juego en una norma y resuelven los conflictos, sino que los órganos judiciales tienen una labor decisiva al respecto en la medida en que la normativa no es perfecta y éstos han de decidir conforme a los intereses en juego.

Tras una breve aproximación el concepto jurídico de interés, el reflejo de éste en la norma y en lo que nos afecta en particular a la incorporación del interés del menor, no se ha realizado de igual modo en todos los ordenamientos. La diferencia fundamental se produce entre los ordenamientos que incorporan el citado interés como cláusula general -latinos y germánicos-, y aquellos que, huyendo de la falta de concreción de la primera técnica apuntada, se inclinan por incorporar una lista de criterios explícitos en los que se recogen los datos que el intérprete ha de tener en cuen-

tar presente tiene una razón justificativa en el preponderante y preferente interés de los menores."

916 STS, Sala de lo Civil, Sección 1a, núm. 776/2004 de 16 julio. RJ 2004/4382. "Y así es, pues en la sentencia recurrida de una manera lógica y racional se determina y acogiendo lo dicho en la sentencia de primera instancia en el fundamento jurídico cuanto que afirma «...que interésdel menor debe señalarse un régimen de visitas a favor del mismo, ya que de las pruebas practicadas y, en concreto, la exploración de F., ha puesto de manifiesto de un régimen de visitas que se dirá en el fallo de la presente resolución”.

917 Cfr. HECK, P. “Jurisprudencia de intereses”, Ed. Comares, Granada, año 2011; GROSSI, P. "Mitología jurídica de la modernidad”, Ed. Trotta, Madrid, año 2003.

918 Sobre el mismo, vid. RUIZ RESA, J. D.: “El concepto de interés en Ihering”, Revista de la Facultad de Derecho de la Universidad de Granada, número 3, año 2000. En el citado trabajo destaca a siguiente concepción sobre el interés: "El interés en el sentido subjetivo, designa el sentimiento que se tiene de las condiciones de vida. Si me intereso por una persona, por un objeto o por una situación es que yo siento que dependo de ella desde el punto de vista de mi existencia o de mi bienestar, de mi satisfacción o de mi felicidad. Los intereses son pues las condiciones de la vida en sentido lato”, página 345. 
ta para decidir en interés del menor, y con ello me refiero principalmente a los ordenamientos de la órbita del common law.

El empleo de las cláusulas generales en los distintos ordenamientos es cada vez más frecuente. Su incorporación sobre todo en el derecho de familia es una realidad constatada. Para justificar su incremento se ha apuntado la dificultad de una determinación más precisa de la realidad a la que se refiere la norma. Este argumento ha servido, a su vez, para fomentar tanto las ventajas como las desventajas que la doctrina ha vertido sobre la incorporación de las cláusulas generales en los ordenamientos jurídicos. El margen de discrecionalidad que se deja al intérprete del interés del menor no debería desvirtuar su utilidad práctica ${ }^{919}$; en efecto, la valoración racional de los datos fácticos y jurídicos ha de conducir a una decisión acorde con el respeto a los derechos fundamentales del menor, por el hecho no tan sólo de ser menor, sino porque es persona, y requiere un cuidado más acentuado del libre desarrollo de su personalidad ${ }^{920}$.

De igual forma y con el objetivo de no transgredir el principio de seguridad jurídica, es necesario situar la interpretación de interés del menor o de cualquier otra cláusula general en función de la finalidad de la ley en la que se incluye ${ }^{921}$. Por tanto, la cuestión más sugestiva, y a la vez polémica de la incorporación del interés del menor como cláusula general se sitúa en el juicio de concreción que realiza el intérprete con el fin de situar su contenido, juicio que en el peor de los casos puede ser tildado de arbitrario. En este orden de consideraciones, y como ha sostenido la doctrina, la concreción supone "el proceso que llega desde el texto a la regla del caso",922.

Si bien el resultado de la concreción encuentra un límite lógico en el propio texto del que surge la regla, éste confiere a la intervención del órgano judicial como intérprete una dimensión significativa, en efecto, se asiste a un movimiento creciente en la flexibilización, en el que el órgano judicial asume un mayor papel en la regulación de las situaciones que llegan a su conocimiento.

El empleo de cláusulas generales y conceptos jurídicos indeterminados es frecuente en todos los ámbitos jurídicos, esto se debe, en parte, a que la realidad jurídica que se refieren difícilmente admiten una determinación más precisa.

919 CALVO CABELLO, J. L., "Discrecionalidad y arbitrariedad en la fijación del derecho y régimen de visitas. Análisis de diversos casos prácticos, en Derecho de visita. Teoría y praxis", Ed. EUNSA, Pamplona, año 1982, página 333. "Obrar discrecionalmente quiere decir, en definitiva, regirse por criterios generales de los que, en conjunción con las peculiaridades de cada caso, se obtienen as consecuencias que permiten establecer la solución más adecuada y justa para el supuesto de hecho individual”.

920 SALAZAR BORT, S. "La tutela especial de los hijos en la atribución del uso de la vivienda familiar en las crisis matrimoniales: el interés protegido”, Ed. Tirant Lo Blanch, Valencia, año 2000.

921 MIQUEL GONZALEZ, J. M. “Cláusulas generales y desarrollo judicial del Derecho” en "La vinculación del juez a la ley”, Anuario de la Facultad de Derecho de la Universidad Autónoma de Madrid, año 1997, número 1, página 313.

922 Vid. NIETO GARCÍA, A. “El arbitrio judicial”, Ed. Ariel, Barcelona, año 2000, página 130. 
Pero la elección de esa técnica legislativa tiene importantes consecuencias, porque requerirá una forma especial de aplicación de la norma que incorpora tales conceptos, lo cual exige una doble labor: precisar el significado y contenido del concepto, y luego, comprobar en qué situación y circunstancias concretas de las posibles se da el valor que ha pretendido captar la norma ${ }^{923}$. Se le critica porque conlleva ciertas dosis de subjetivismo, que incorpora siempre las convicciones y experiencias personales de quien hace la valoración, todo lo cual comporta inevitablemente, no poca inseguridad jurídica para el ciudadano y para el justiciable, lo que es contrario a principios constitucionales (art. 9.3 C.E.) y peligroso social y jurídicamente.

Dicho en otros términos: esa técnica legislativa de la cláusula general se traduce, en la realidad jurídica, en la necesidad de trasladar a cada caso específico de la vida corriente, la determinación en concreto del interés en cuestión, para cada menor; en cada supuesto de separación de los padres, o discusión sobre su educación u opción en materia de religión, o de salud, etc. De cuál es o en qué consiste su mejor interés, lo que más le conviene (variable, a su vez según el momento vital del menor, que está, además, en continuo cambio y evolución), en ello concuerdo con lo manifestado en torno al concepto de bienestar del menor por EEKELAAR ${ }^{924}$.

Y no sólo eso, que en principio es razonable e inevitable, sino que tal determinación y concreción la van a hacer, con el mismo abanico de hipótesis, de valoraciones y de respuesta, distintas personas (en última instancia, jueces, que a veces pueden ser más de uno para el mismo caso, verosímilmente con diferentes criterios personales de valoración, que dependerán de sus respectivas ideologías, sensibilidades, concepción del mundo y de la vida, etc), y que se traducirán en decisiones probablemente muy variables y, lo que es peor, sin garantía de un trato igualitario, en detrimento del principio de igualdad ante la ley y en la aplicación de la ley: una veces, con soluciones distintas para supuestos de hecho idénticos; otras, con respuestas iguales para casos y datos diferentes. Son los conocidos riesgos, a veces inevitables, ciertamente del arbitrio judicial, aquí multiplicados por todas aquellas circunstancias ${ }^{925}$.

923 Lo que más conviene a un niño en particular, y sobre todo, va a dar relevancia inusitada a los datos y circunstan cias del caso concreto porque éstos son los que van a permitir encontrar la solución dentro del ámbito de apreciación o zona de variabilidad del concepto jurídico indeterminado. La principal ventaja radica en la generalidad de su enunciado a modo de principio multicomprensivo que permite, ante la dificultad general y objetiva de determinación del valor que pretende captar la norma, una inicialmente sencilla definición del concepto, que responde a valores de justicia y razonabilidad referidas a situaciones empíricas, con remisión, para su determinación efecti$\mathrm{va}$, al momento y persona en que se deba aplicar la norma y el concepto, con la correspondiente (y no exclusiva de este caso) adecuación del mandato legal a cada supuesto concreto, a la amplia variedad de personas implicadas y situaciones que pueden presentarse, el abanico de posibilidades y realidades sociales es amplísimo, y valido tanto en el momento de su enunciado como en el futuro, tras la correspondiente evolución social y jurídica.

924 "The interest of the child and the Child's Wishes: the role of dynamic self-determinism" en "The best interest of the child. Reconciling Culture an Human Rights", ... op. cit., páginas 47 y siguientes.

925 RIVERO HERNÁNDEZ, F. “Interés del menor”, ... op. cit., página 59. 
En relación a la técnica legislativa de la concreción del interés del menor según criterios normativos preestablecidos. Esta es lo antagónico del método de la cláusula general que se acaba de criticar y se presenta en cuanto técnica legislativa, como una reacción frente a la falta de concreción de las normas abiertas y cláusulas generales y a los riesgos de inseguridad e injusticia que crea el arbitrio judicial que aquella indeterminación exige, es decir su principal justificación es el principio de seguridad jurídica y la defensa frente a posibles arbitrariedades que puedan cometerse por los poderes públicos, en especial el Poder Judicial, con las clausulas generales ${ }^{926}$. Y no es exclusiva de este campo del Derecho, sino que en otros ámbitos tiene parecidas manifestaciones. Esta técnica de la concreción, en una u otra forma del interés del menor, es propia de los ordenamientos anglosajones, tal cual se manifestó, bastantes más pragmáticos que los latinos, donde convive con enunciados del tipo cláusula general también, con distintas presentaciones legales ${ }^{927}$.

\section{7| El interés del menor en la doctrina española}

Aunque este tema ha sido tratado, en parte, al inicio del presente capítulo, será ahora cuando se enfatice su tratamiento en España, específicamente por varios de los autores españoles que han trabajado este tema.

El concepto de interés del menor y de su problemática jurídica subyacente es una cuestión que, a diferencia de otros países, sólo en años más bien recientes ha despertado el interés de cierta parte de la doctrina. Se trata de dilucidar que se quiere decir cuando se alude al interés del menor y, por lo tanto lo que significa dicho interés en abstracto, como paso lógico-formal previo y necesario a su ulterior determinación in concreto en relación con otros derechos.

Se ha indagado sobre el modo de concebir el interés superior del menor. Es necesario aportar elementos que ayuden a configurar su contenido. Del análisis doctrinal se puede inferir que el "interés superior del menor" o favor filii es un principio jurídico de carácter general establecido en el Derecho español, como tantos otros conceptos jurídicos indeterminados: la buena fe, la diligencia de un buen comerciante o un buen padre de familia, le negligencia, etc., cuya determinación se logrará analizándolo en cada supuesto de hecho donde se plantee ${ }^{928}$.

926 Esta material es de especial relevancia en el ámbito del Derecho de Consumo y del Derecho de extranjería. ES TEVE GARCÍA, F. "Las cláusulas generales antidiscriminatorias: ámbito de aplicación y efectos jurídicos”, en AJA, E (Coord.) "Los derechos de los inmigrantes en España”, Ed. Tirant Lo Blanch, Valencia, año 2009.

927 NAVAS NAVARRO, S. “El bienestar y el interés del menor desde una perspectiva comparada”, ... op. cit., páginas 689 a 713.

928 Para LINACERO DE LA FUENTE, M. a, “Protección jurídica del menor”, ... ob. cit., pág. 63, la noción jurídica del "interés superior del menor" habrá que concretarla con los derechos fundamentales del niño consagrados en la Convención de 1989 (derecho a la salud; derecho a la educación; derecho a la libertad de pensamiento, con- 
Es difícil precisar sus límites. Todo concepto indeterminado cabe estructurarlo en varias zonas según DE PALMA. Una primera "zona de certeza positiva”, que contiene el presupuesto necesario o la condición inicial mínima. Una segunda "zona de certeza negativa”, a partir de la cual nos hallamos fuera del concepto indeterminado. En tercer y último lugar la denominada "zona intermedia” más amplia por su ambigüedad o incertidumbre, donde cabe tomar varias decisiones. En la “zona intermedia” para determinar cuál es el interés del menor es necesario precisar los hechos y las circunstancias que lo envuelven. En esta zona podemos observar como el interés del menor no es siempre el mismo, ni siquiera con carácter general para todos los hijos, va mudando en relación con las circunstancias personales y familiares. Además, dicha zona se amplía cuando se pasa en la indeterminación del concepto del plano jurídico al cultural o también entendido como menos técni$\mathrm{co}^{929}$.

El Derecho positivo no puede precisar con exactitud los límites del "interés superior del menor", para cada supuesto de hecho planteado. Son los operadores jurídicos quienes han determinado moviéndose en la "zona intermedia", haciendo uso de valores racionales y de justicia. Sin embargo, cabe reconocer a la indeterminación de los conceptos jurídicos y a su contenido abierto, una mayor movilidad interpretativa del Ordenamiento jurídico, o que permite adaptar las normas jurídicas para resolver las cuestiones que se planteen, mediante un análisis axiológico ${ }^{930}$.

ciencia y religión; derecho a ser oído; derecho a la protección contra toda forma de prejuicio, abuso físico o men tal, descuido o trato negligente, malos tratos o explotación, derecho a no ser separado de sus padres, salvo que sea necesario al interés del menor; derecho del niño impedido física o mentalmente a recibir cuidados especiales...). Por su parte LATHROP GÓMEZ, F., ob. cit., páginas 115 y 116, amparándose en la opinión vertida por el Comité de la Convención Internacional de los Derechos del Niño de 20 de noviembre de 1989 estima que la no discriminación, la máxima supervivencia y desarrollo, y el respeto a la opinión del niño o adolescente, son directrices relevantes para dar un concepto de interés superior del menor. En definitiva, la legislación actual se refiere al interés del menor pero sin entrar en su concepto. Es la técnica denominada "cláusula general”, en cuya virtud los conceptos no se definen en la Ley, sino que se refieren a las realidades indeterminadas, llevados a situaciones concretas donde se obtiene una solución específica. Sin desdeñar lo anteriormente apuntado, estoy de acuerdo con lo expresado por quienes concretan el interés del menor en cada tiempo y lugar, sin duda la indeterminación es consecuencia de que el interés del menor deberá ser apreciado en cada supuesto de hecho que se plantee, ya que para su concreción habrá que tener en cuenta la personalidad del menor, las circunstancias que le rodean, el momento concreto en que surja, sin olvidar su evolución futura En definitiva la dificultad para conocer el interés del menor no está tanto en el concepto abstracto que lo envuelve, sino en la indeterminación de lo que en cada caso este exija.

929 DE PALMA DEL TESO, A. “Administración pública y protección de la infancia. En especial, estudio de la tutela administrativa de los menores desamparados”, INAP, Madrid, año 2006.

930 Sin duda, a priori, esto puede provocar cierta inseguridad jurídica en el justiciable, que ve cómo el contenido del interés del menor dependerá de la concepción y la aplicación que los operadores jurídicos le atribuyan en cada caso concreto, por tal motivo resulta importante acudir a los usos sociales para completarlo. Debido a que se trata de un concepto sometido a la evolución de la sociedad a través del tiempo, los usos sociales pueden generalizar u objetivar el beneficio del interés del menor equiparándolo a una posición similar o parecida a los demás, fundamentándolo en la idea de igualdad. Sin embargo, en otro apartado del presente estudio ya se mencionó que no la concreción del interés en cuestión no es fruto de la discrecionalidad del operador jurídico, ni tampoco un asunto por resolver dejado a su entero arbitrio, sino que es una situación de tratamiento jurídico perfectamente reglada. 
La denominada jurisprudencia de intereses o de valoración ${ }^{931}$, ha sido utilizada como criterio relevante para determinar el contenido del interés del menor. Nos indica que es la práctica jurídica diaria (y dentro de ella la judicial), la que establecerá cuál es el interés del menor o el interés familiar más necesitado de protección. Tradicionalmente la jurisprudencia ha hecho hincapié en el bienestar físico y emocional del menor, para así atribuir a la madre la guarda y custodia exclusiva de los hijos. Continuando con la idea de aportar elementos para conformar el contenido del "interés superior de los hijos" y poder elegir el régimen idóneo de convivencia tras la ruptura matrimonial, se ha de apuntar el bienestar del hijo menor de edad, recordemos que autores como NAVAS NAVARRO distingue entre ambos términos, distinguiendo dentro de él un aspecto moral y otro material. El primero viene relacionado con la formación espiritual, educativa e intelectual del menor, y el segundo que lo completa, se refiere a la situación económica de los progenitores ${ }^{932}$.

El bienestar físico se identifica con el bienestar material (procurar a los hijos el derecho de alimento, vestido, habitación), en función de los medios económicos disponibles para proporcionar un hogar agradable, que les asegure una buena salud y un nivel de vida confortable. Este bienestar viene añadido al bienestar emocional (el afecto de los progenitores hacia los hijos), de mayor importancia por cuanto procura estabilidad y seguridad a la persona del hijo menor de edad, mediante la comprensión, el cariño y el cuidado que el progenitor/progenitores le proporcionen durante la guarda y custodia, y hagan que se sientan satisfechos de sí mismos. Lo que permitirá el adecuado desarrollo de la personalidad del hijo. Por consiguiente el progenitor que esté dispuesto a satisfacer ese bienestar físico y emocional del hijo, deberá ser quien se haga cargo de la guarda y custodia del menor.

Otro elemento a valorar, e integrado en el concepto del "interés superior de los hijos", es la convivencia o el contacto frecuente continuado del hijo menor de edad con ambos progenitores ${ }^{933}$.

931 SANTOS BRIZ, J, "Criterios Judiciales en la adjudicación del uso de la vivienda y ajuar familiares. Su aplicación en los distintos supuestos procesales”, en VILADRICH, P. J. (Coord.) “El hogar y el ajuar de la familia en las crisis matrimoniales, Bases conceptuales y criterios judiciales”, EUNSA, Universidad de Navarra, Pamplona, 1986, páginas 227 y 228, emplea el criterio de la jurisprudencia de intereses o de valoración, cuando haya que determinar el interés familiar más necesitado de protección.

932 LATHROP GÓMEZ, F., ...ob. cit., páginas 118 y 119, puntualiza el contenido de interés superior del menor de edad o favor filii con el interés moral y el interés material, y aunque lo ideal es conciliar ambos intereses, reconoce la prevalencia de aquel sobre éste. El interés material lo identifica con la posibilidad de contar con la asistencia adecuada y los cuidados necesarios para cada etapa y eventualidades de la vida, y gozar de todo aquello que la haga más cómoda. Aunque también reconoce que el interés material no debe quedar limitado a los aspectos ampulosos y se debe acercar a los problemas y a las decisiones dolorosas de la vida. Efectivamente, el aspecto espiritual es el elemento enriquecedor primordial en el desarrollo de la personalidad, poco valorado en la adolescencia, pero muy gratificante en la edad adulta.

933 CAMPUZANO TOMÉ, H. "La Custodia compartida. Doctrina Jurisprudencial de las Audiencias Provinciales", Aranzadi Civil-Mercantil, núm. 22/2004, parte Estudio, Pamplona, año 2005, BIB 2005/563. Reflexionando so- 
Efectivamente, es el modo idóneo de cultivar el amor paterno-filial. La Convención sobre los Derechos del Niño adoptada por la Asamblea General en Resolución 44/25, de 20 de noviembre de 1989, en su art. 9.3 requiere a los Estados Partes para que respeten "el derecho del niño que esté separado de uno o de ambos padres mantener relaciones personales y contacto directo con ambos padres de modo regular, salvo si ello es contrario al interés superior del niño”. El límite al interés del menor es que la relación familiar con ambos progenitores sea perjudicial al desarrollo de su personalidad.

El motivo de que tal concepto jurídico indeterminado se muestre cambiante, tiene relación con las fases evolutivas de la persona. En edades tempranas el interés del menor viene potenciado con el afecto, en la adolescencia la libertad es el elemento más valorado en el desarrollo de la personalidad. Por ello el interés superior del menor está en función de su futuro, es decir, prioriza obtener el adecuado desarrollo, a través de un equilibrio entre el bienestar espiritual y material, aunque con predominio de aquel sobre éste, que le permita llegar a ser una persona adulta capacitada para vivir en sociedad.

Para entender la aplicación de estos elementos apuntados que ayudan a concretar "el interés superior del menor" en la relación entre la dualidad de regímenes de convivencia (custodia exclusiva unilateral y custodia compartida), es necesario ver la evolución histórica-jurídica sufrida por la función de la guarda y custodia de los hijos ${ }^{934}$. Fundamentalmente en Estados Unidos se han desarrollado varias teorías, que han influido en la doctrina de autores y en la legislación vigente, hasta la llegada de la custodia compartida con la Ley 15/2005, de 8 de julio.

La preponderancia de la esfera personal y de los derechos de la persona constituye, tal y como se ha señalado, una nota característica de la reforma de 1981 que se manifiesta a lo largo de los preceptos del Código Civil y tiene su continuación en la Ley del Menor. Este respeto a la personalidad del hijo tiene relación con el interés del menor y, por tanto, con el ejercicio autónomo de sus derechos y libertades fundamentales dentro del seno de la familia que, de este modo, aparece como una institución cuya función, entre otras, sería la formación en su seno de ciudadanos. Asimismo, influye en la patria potestad, que deberá ejercerse con arreglo a ella, para lo que se deberá tener en cuen-

bre ambas formas de bienestar del hijo, estima que tras la ruptura matrimonial sería ideal para los hijos, mantener con ambos progenitores una relación cotidiana y habitual, que le proporcionara una estabilidad tanto afectiva como física. En caso de necesidad de sacrificar una de ellas, el Juez ha de adoptar las medidas en las que se dé prioridad a la estabilidad emocional.

934 ESPINOSA CALABUIG, "Custodia y visita de menores en el espacio judicial europeo", Ed. Marcial Pons, año 2007; CASTILLO MARTÍNEZ, C. C. “El Interés del menor como Criterio Prevalente en la Mediación Familiar”,http://www.monografias.com/trabajos30/menores-criterio-prevalente-mediacion-

familiar/menores/criterio/prevalente-madiación-familiar.shtml 
ta la edad, ya que a mayor edad será precisa más autonomía del menor y, por tanto, su personalidad como límite al ejercicio de la patria potestad se acentuará ${ }^{935}$.

Tal respeto a la personalidad, tradicional en las instituciones jurídico-privadas españolas se ve reforzado en relación con el menor en la LOPJM sobre la consideración de que la mejor forma de garantizar su protección y adecuada inserción socio familiar es promoviendo su autonomía como sujeto, porque tal como pregona la Exposición de Motivos de la Ley antes citada el conocimiento científico de ésta época permite concluir que no existe una diferencia tajante entre las necesidades de protección y las necesidades relacionadas con la autonomía del sujeto, sino que la forma de garantizar social y jurídicamente la protección a la infancia es promover su autonomía como sujetos. De esta manera podrán ir construyendo progresivamente una percepción de control acerca de su situación personal y su proyección de futuro, el cual consiste en el punto crítico de todos los sistemas de protección a la infancia en la actualidad. Sobre esto ya se hizo mención cuando se analizó la persona del menor como sujeto protagonista del interés en estudio.

Sin perjuicio de lo recién expuesto, en la regulación que el Código Civil hace de la patria potestad, si bien no alude directa y expresamente a la autonomía del menor, si, en cambio, contiene diversos preceptos tendentes a promover el libre desarrollo de la personalidad con la finalidad última de garantizar su autonomía como individuo, bien mediante su participación en la toma de decisiones que le afecten, bien mediante su decisión exclusiva cuando tenga las suficientes condiciones de madurez. Tales manifestaciones vendrían siendo: $1^{\mathrm{a}}$. En el ejercicio de la patria potestad se deberá tener en cuenta las condiciones individuales y subjetivas de los hijos. 2. ${ }^{\text {a }}$ No se le puede impedir la relación con los parientes y allegados (art. 160 del Código Civil). 3. ${ }^{a}$ Se requiere su previo consentimiento, si tuviere suficiente juicio, para celebrar contratos que le obliguen a la realización de prestaciones personales (art. 162 del Código Civil, párrafo último). 4. ${ }^{\mathrm{a}}$ Las restricciones a la capacidad de obrar del menor se interpretarán restrictivamente (párr. 2. ${ }^{\circ}$ del art. 2 LOPJM). 5. ${ }^{a}$ El derecho de audiencia del menor en los asuntos que le conciernen, recogido en el Código Civil ${ }^{936}$ y en el artículo 9 LOPJM. El fundamento de este derecho sería el libre desarrollo de la personalidad y el interés del

935 TOLDRÀ ROCA, Ma . D. en PADIAL ALBÁS, A y TOLDRÁ ROCA, Ma , D. "Estudios jurídicos sobre la protección de la infancia y la adolescencia”, Ed. Tirant Lo Blanch, Valencia, año 2007. Por consiguiente existe una imposición constitucional a los padres y a los poderes públicos en el deber de dispensar una protección especial a quienes por razones de edad, no están en condiciones de valerse por si mismos o de procurar su autogobierno, aunque paulatinamente se encaminen hacia ello y es la patria potestad la institución que les protege por excelencia y que está fundada en el vínculo de filiación.

936 Son múltiples los supuestos que regula el Código en los que se contempla la audiencia al menor: El artículo 92, relativo a los supuestos de crisis matrimonial; En la patria potestad: artículos 154, 156 y 162; En materia de adopción y de instituciones de protección: artículos 172, 173, 177, 231, 237, 248 y 273. 
menor. El derecho de audiencia aparece configurado en la Ley del Menor con un carácter mucho más amplio que en el Código Civil, ya que no se limita por razón de edad salvo que concurran carencias en cuanto a la capacidad de expresión y comunicación, pues no se fija una edad mínima, ni siquiera la de los doce años que establece el Código Civil ${ }^{937}$. De aquí se infiere una profundización por la Ley del Menor en la protección de la personalidad de los menores potenciando su papel en la toma de decisiones que les afecten. 6. ${ }^{\mathrm{a}}$ Los derechos de la personalidad quedan exceptuados en la representación legal según se infiere del artículo 162.1 del Código Civil ${ }^{938}$.

Este respeto por el legislador de la personalidad del menor no es sino manifestación de la dignidad de la persona y del libre desarrollo de la personalidad del artículo 10.1 de la Constitución. Es precisamente el libre desarrollo de la personalidad y los principios constitucionales de la protección de los menores y de los hijos del artículo 39.3 y 4 CE lo que nos permite interpretar el interés del menor como referido a la protección de sus derechos y libertades fundamentales, lo cual a su vez se manifestó en relación a la interpretación del art. 24 de la Carta Europea de Derechos Fundamentales y, dado que la finalidad última de la protección es garantizar el libre desarrollo de la personalidad, aparecerán por esta vía, identificados, interés del menor y libre desarrollo de la personalidad. Este es el criterio que sigue de forma unánime la doctrina española ${ }^{939}$. No obstante, el interés del menor puede tener carácter patrimonial y puede no coincidir con el interés de la familia ${ }^{940}$.

937 CASO SEÑAL, M. "La audiencia del menor en los procedimientos de familia: Guía de recomendaciones para la práctica de la exploración judicial”, en Familia y sucesiones, núm. 91, Ed. Sepín, mayo-junio 2010, Madrid, página 24 a 28; CASTIELLA RODRÍGUEZ, J. J. “La vulnerabilidad del menor”, $2^{\circ}$ parte, Revista jurídica del notariado, núm. 73, enero-marzo 2010, Madrid, páginas 163 a 242.

938 ASENSIO SÁNCHEZ, M. A. “La patria potestad y la libertad de conciencia del menor”, ...op. cit., pagina 69.

939 Es este sentido el que tiene el concepto de interés del menor para la doctrina que se ha preocupado del tema. Ejemplo, ROCA I TRÍAS, E. "Familia y cambio social”, ...op. cit. Páginas 212 a 213; de la misma autora puede leerse "El interés del menor como factor de progreso y unificación del Derecho Internacional Privado (Contestació al Discurs d'ingrés en la Academía de Jurisprudéncia i Legislació de Catalunya de A. Borras)”, Revista Jurídica de Catalunya, año 1994-4, páginas 107 a 110; ALONSO PÉREZ, M. "La situación jurídica del menor en la Ley Orgánica 1/1996, de 15 de enero, de Protección Jurídica del Menor”, Actualidad Civil $n^{\circ} 2$, Madrid, año 1997, página 24; BO JANÉ, M y CABALLERO RIBERA, M. "El nuevo derecho del menor a ser oído: ¿sujeto activo en la determinación de su interés?”, Ed. La Ley, tomo 6, Madrid, año 1996, página 1487; DÍEZPICAZO, L. “El principio de protección integral de los hijos ("Tout pour l'enfant”)", en "La Tutela de los derechos del menor”, ...op. cit., página 131.

940 Cfr. DE PRADA GONZÁLEZ, J. M., “La patria potestad tras la reforma del Código Civil”, Anales de la Academia Matritense del Notariado, T. XXV, año 1982, página 361. Sobre el interés familiar puede verse asimismo DORAL GARCÍA. A. "El interés de la familia”, Documentación Jurídica, Monográfico dedicado a la reforma española del Derecho de familia, Volumen I, Madrid, año 1982, página 5 a 21. Esta reflexión sobre el interés del menor hay que extrapolarla al derecho a la libertad de conciencia, en el que, por tratarse e un ser en devenir, cobra especial importancia el derecho a la libre formación en cuanto precipitado lógico-formal. Por esta vía, interés del menor, libre desarrollo de la personalidad y derecho a la libre formación de la conciencia se identificarían. 
El interés del menor, de este modo se configura como un concepto jurídico indeterminado que cumpliría dos funciones ambivalentes en relación con la patria potestad ${ }^{941}$ :

a) Una legitimadora de la actuación de los titulares de la misma, y

b) Otra, limitadora de su ejercicio, de suerte que los actos realizados por los padres que no sean en interés del menor se consideran como un supuesto de extralimitación en la facultad de representación legal de los hijos que les atribuye el artículo 162 del Código Civil ${ }^{942}$.

También en relación a esta materia es interesante establecer a quien corresponde la determinación del interés del menor, debido a que es un concepto jurídico indeterminado. En primer lugar correspondería al propio menor determinar su interés siempre que tenga capacidad natural de obrar, que es capacidad suficiente para el ejercicio autónomo de los derechos fundamentales. Tratándose de un menor que carezca de capacidad natural, corresponde la determinación a los denominados "garantes del menor" (titulares de la patria potestad, padres no titulares, tutores, parientes, Administración, jueces y fiscales, en general, cualquier pariente, en virtud del art. 158 del Código Civil).

Para un adecuado desarrollo de la patria potestad y de su ejercicio hay que entender que, en un primer momento, su determinación correspondería a los titulares de la potestad de guarda y que existe una presunción iuris tantum de que los titulares de la patria potestad actúan en interés del hijo $^{943}$. Sobre esta última reflexión cabe inferir que uno de los problemas que plantea la determinación del interés del menor, y más concretamente en los derechos relacionados con la libertad de conciencia, es el de cuál sea el papel del menor que carece de capacidad natural en la determinación de su interés ${ }^{944}$. Es claro, el menor debe ser oído si sus circunstancias personales lo aconsejan y

941 El interés del menor, además de la unción modalizadora de la patria potestad, cumpliría las siguientes funciones: En primer lugar será criterio de solución de los conflictos interconyugales (arts. 90 a 92, 103.1 y 156.5 CC). En segundo lugar será un factor determinante en las decisiones que se tomen en relación con el menor (arts. 125, 161, 170, 173 bis -introducido por la Ley del Menor-, 176 y 224 CC). Mientras que en tercer lugar tendrá una función social que otorga la ley a la patria potestad y a los actos de ejercicio de la misma, que tienen en dicho interés el menor su causa: cfr. DIEZ-PICAZO, L., “El principio de protección integral de los hijos...”, ...op. cit., páginas 120 a 130.

942 Cfr. SUÁREZ SÁNCHEZ-VENTURA, J. Ma., y MARTÍNEZ MARTÍNEZ, F. “El principio de protección integral de los hijos", ...op. cit. páginas 129 a 130.

943 VALERO HEREDIA, A. “La libertad de conciencia del menor de edad... ”, ...op. cit., página 59. Este autor participa de la idea de que la concepción del menor de edad como sujeto pleno de derechos fundamentales y el des pliegue de su autonomía ha conllevado una modulación inevitable de las características que tradicionalmente definían la institución de la patria potestad. Las facultades y deberes atribuidos a los padres respectos de los hijos han dejado de ser concebidos como un asunto estrictamente privado para convertirse en instrumentos dirigidos al cumplimiento de un mandato constitucional, aquel que les exige prestar a los menores una asistencia de todo orden que atiende a todas las esferas de su existencia.

944 ROMERO COLOMA, A. Ma . "Libertad religiosa del progenitor frente al beneficio del hijo menor", Revista de Derecho de familia, núm. 33, Ed. Lex Nova, Valladolid, octubre-diciembre 2006, página 297. En este teme sin duda se verifica el influjo de la Constitución sobre el Derecho Civil, este ha transitado diversos ámbitos, que tienen que ver, la mayoría de las veces, con los derechos de la personalidad y con el principio de igualdad. Pero 
siempre si tiene doce años cumplidos. Cosa distinta es determinar la relevancia que hay que darle a su opinión. Un sector de la doctrina de autores ${ }^{945}$ y algunas resoluciones judiciales ${ }^{946}$, han cuestionado el valor preponderante del favor filii, cuando entra en conflicto con otros intereses legítimos.

Efectivamente en el terreno de los principios y en el ámbito familiar cabe un trato de igualdad para los intereses legítimos. Sin embargo, en las crisis familiares, el interés legítimo más débil, y por tanto más necesitado de protección, es el de los hijos. Es importante en tal sentido entender cómo se conjuga el interés del menor dentro del entorno familiar, y para ello se observa su preponderancia que se pone de manifiesto durante el ejercicio de la patria potestad, en situación de crisis familiar, en esos casos el interés de los padres debe entenderse como instrumental y destinado al desarrollo de la personalidad de los hijos, por ello cuando existe conflicto de intereses es necesario, en los supuestos del art. 163 y 299 y siguientes del Código Civil, el nombramiento de un defensor judicial. Es importante reflexionar en torno al hecho de que en pos de la convivencia familiar, el interés familiar no es supraindividual, contrapuesto al de cada uno de los miembros de la familia, sino la suma de los intereses de los integrantes del grupo. Por ello el Ordenamiento jurídico y los operadores jurídicos han de ubicar dicho interés en un lugar destacado, fuera de las amenazas y ataques que pueda sufrir durante la relación que mantenga con los demás miembros de la familia, parientes y allegados.

Una posición doctrinal menos radical propugna un equilibrio de intereses y admite que la prevalencia del interés del menor no conlleva arrinconar los demás intereses y derechos de los progenitores $^{947}$. En tal sentido el Tribunal Constitucional viene estableciendo doctrina consolidada en mate-

donde más se ha percibido la influencia de la Constitución sobre el Derecho Privado es en la parcela o área del Derecho de Familia. Efectivamente la sentencia

945 LINACERO DE LA FUENTE, M" “, “La protección del menor”, ...ob. cit., página 64. La autora se refiere a que el interés del menor debe ser admitido en un plano de igualdad, ya que hacerlo solo desde la perspectiva del interés de menor, da una visión parcial y sesgada del mismo. Se trata de un interés mutuo, en el que no cabe plantear que el interés de uno de los sujetos sea de mejor categoría que el del otro. Ambos sujetos dan y obtienen beneficios personales de esa relación, y desarrollan su personalidad. La existencia del interés del menor no supone la ignorancia de los demás intereses en la vida del menor. Debe por tanto coordinarse con los demás intereses del grupo donde se inserte, por lo que no siempre en términos absolutos podrá tener un valor prioritario.

946 No es uniforme la jurisprudencia menor hallada. En ese sentido cabe apuntar la SAP Granada, Sección $3^{\mathrm{a}}$, núm. 33/2003 de 20 enero. JUR 2003/109199 y la SAP Madrid Sección 24a núm. 676/2006 de 8 junio. JUR 2006/288053. Sin embargo otras resoluciones reconocen el valor preponderante del interés del menor sobre cualquier otro. Así se ve en la SAP Baleares Sección 3a, núm. 332/2005 de 14 julio. JUR 2005/185641, en ella se declara que: “(...) En consecuencia es el interés de los hijos el que debe ser tomado en cuenta para establecer el régimen de guarda y custodia y de visitas del menor con prevalencia sobre el deseo de los progenitores de tenerlos consigo (...)”; idéntica importancia le atribuye la SAP A Coruña Sección 4a , núm. 7/2007 de 24 enero. JUR $2007 / 81314$.

947 SALANOVA VILLANUEVA, M. “El derecho del menor a no ser separado de sus padres”, Revista de Derecho Privado y Constitución, núm. 7, septiembre - diciembre, Madrid, año 1995, páginas 239 y 286, en relación al: “Derecho del menor a ser separado de sus padres?. Nota a la Sentencia del Tribunal Europeo de Derechos 
ria de relaciones paterno-filiales y así lo expresa en la STC, Sala 1ª núm. 176/2008 de 22 diciembre. RTC 2008/176, donde se manifiesta que: “(...) el criterio que ha de presidir la decisión que en cada caso corresponde adoptar al juez, a la vista de las circunstancias concretas, debe ser necesariamente el del interés prevalente del menor, ponderándolo con el de sus progenitores, que aún siendo de menor rango, no por ello resulta desdeñable (...)”.

Aunque reconoce el Alto Tribunal: "Cuando el ejercicio de alguno de los derechos inherentes a los progenitores afecta al desenvolvimiento de sus relaciones filiales, y puede repercutir de un modo negativo en el desarrollo de la personalidad del hijo menor, el interés de los progenitores deberá ceder frente al interés de éste".

De las opiniones analizadas se puede colegir que el modo de obtener el interés superior del menor -concepto jurídico indeterminado y abstracto-, es enfrentándolo a otros intereses legítimos, especialmente durante el ejercicio de la patria potestad. Lo habitual es que el hijo menor de edad se halle integrado en la unidad familiar, cuando lo que se pretenda restaurar en la medida de lo posible es el orden familiar alterado por la situación de crisis, a través del convenio regulador o de las medidas judiciales. Determinar cuál es el interés familiar más necesitado de protección, puede dar lugar a elegir entre los intereses de los padres y los de los hijos. El enfrentamiento se ha de solventar favoreciendo el interés más débil o necesitado de protección, es decir el interés superior del menor.

\section{8 | El interés del menor tras la Constitución de 1978}

La evolución ideológica y social aflora en la Constitución de 1978, y se traduce en normas, primero constitucionales, y luego pasan al Código civil con motivo de las leyes de reforma de 1981 que modificaron profundamente el Derecho de la persona y de familia (en particular, la de 13 de mayo y 7 julio de 1981); en términos semejantes, a los ordenamientos civiles autonómicos.

El artículo 39, en sus apartados 3 y 4 no es el único precepto constitucional que está implicado aquí, detrás de las novedades habidas en materia de protección de menores. Han influido los grandes principios del art. 10.1 (la dignidad de la persona, los derechos inviolables que le son inheren-

Humanos de 10 de mayo de 2001 (TEDH 2001/332), Caso Z y otros V. Reino Unido.”, Aranzadi Civil, núm. 2, año 2001, páginas 2371 a 2391. Esta autora pone de manifiesto el valor de los intereses legítimos de los progenitores. La autora mantiene que para determinar su interés habrá que sopesar los intereses en juego -el derecho de los padres a educar a sus hijos, a mantener una vida familiar-, y apurar todas las probabilidades de conexión, de manera que únicamente cuando no pueda haberla entre el derecho de los progenitores y el interés del menor, habrá que llevar a cabo la separación entre progenitor o progenitores y los hijos. En sentido similar se pronuncia LATHROP GOMEZ, F. “Custodia compartida de los hijos”, Ed. La Ley Wolters Kluwer, Madrid, año 2008, página 381, sobre la necesidad de equilibrio de intereses de los hijos y de los progenitores. Este equilibrio podemos apreciarlo tras la ruptura matrimonial, con la necesidad de conciliar el ejercicio de la guarda y custodia de los hijos con una nueva relación de pareja, como expresión de respeto a la vida privada de los progenitores. 
tes, el libre desarrollo de la personalidad) y algunas de sus concretas proyecciones (art. 27.2 C.E.: “la educación tendrá por objeto el pleno desarrollo de la personalidad humana...”), que son el exponente de una ideología que ha exaltado los grandes valores de la persona y de la familia y ha influido de manera notable en el ámbito de Derecho. Con todas las normas constitucionales la situación jurídica del menor ha pasado de ser considerada como garantía institucional con las consecuencias pertinentes ${ }^{948}$.

El principio del libre desarrollo de la personalidad es fundamental para la concreción del interés del menor, si bien tal derecho no está incluido como principio fundamental en el artículo 15 y siguientes de la Constitución. Eso sí, está incluido en el artículo 10.1, junto a la dignidad de la persona y los derechos inviolables que le son inherentes, como fundamento del orden político y de la paz social. Por su función de fundamento del orden político y jurídico y por su relación con la dignidad de la persona y otros valores constitucionales del art. 10.1 CE, este principio deberá ser tenido en cuenta en la interpretación y aplicación de las normas atinentes a otros derechos y libertades, de los que es un prius lógico y ontológico. Este principio implica una proyección hermenéutica amplia que autoriza para incluir en tal desarrollo los cambios físicos de forma del ser humano, aunque seguramente es más esclarecedor referirse a las denominadas condiciones de madurez ${ }^{949}$. Esto implica sostener su valor informante de sistema jurídico y su proyección en la interpretación y aplicación de normas y derechos, entre ellas las relativas al interés del menor.

El interés del menor y su protección jurídica no se presenta ya como una discriminación positiva como podría considerase o pensarse si se le considerara como ser en situación de inferioridad, al modo de cómo se produce el art. 49 CE ni se supone un preconcebido trato de favor compensatorio de un previo e injusto desequilibrio adverso para él, pues aquel principio no afecta sólo a los menores desamparados, maltratados o desafortunados, sino que es aplicable a todos los menores ${ }^{950}$. Se trata, sencillamente, de hacerle justicia en su vertiente existencial y de garantizarle su status de persona y los bienes y derechos fundamentales de la misma que por su mera calidad de persona le corresponden, si bien adecuados todos ellos a su situación de menor de edad (sus derechos de libertad

948 ALÁEZ CORRAL, B. "Minoría de edad y derechos fundamentales”, Madrid, Ed. Tecnos, año 2003, página 21.

949 GARCÍA GARNICA, Ma DEL C. "El ejercicio de los derechos de la personalidad del menor no emancipado”, Ed. Thomson Aranzadi, Cizur Menor, año 2004. página 77. Este autora trata de manera bastante detallada las condiciones de madurez como criterio determinante de la capacidad para ejercitar los derechos de la personalidad.

950 DE TORRES PEREA, J. M. “Interés del menor y Derecho de Familia. Una perspectiva multidiscilinar”, Ed. Iustel, Madrid, año 2009, página 33, esta nueva perspectiva es la que conforma el llamado interés superior del menor...como un conjunto de condiciones necesarias que contribuyen a paliar las necesidades esenciales de este así como proveer al menor de un marco vital suficiente en el que pueda desarrollar sus capacidades y cualidades necesarias para su progresivo crecimiento personal. 
ideológica, religiosa o de expresión, o a su intimidad, no funcionan ni pueden ser ejercitadas por él al igual que un adulto), no apto todavía para ejercitarlos a ciertas edades y necesitados, sin embargo, de particular protección para que su propia entidad e identidad personal no se frustre, y llegue a ser mañana un ciudadano activo bien integrado en la sociedad.

Sin duda que cuando la Constitución proclama nuevos valores personales exige que las normas subconstitucionales respeten y regulen aquellos valores y este principio. En el Código Civil postconstitucional, secundado por otras normas, ha habido un profundo cambio de todo el Derecho de la persona y de familia, por mor de esos nuevos valores y principios constitucionales. Entre otras repercusiones ha tenido particular importancia la nueva concepción de la patria potestad, fruto de la crisis del autoritarismo ya aludido, pero también de una nueva valoración de la personalidad del menor sobre la que se ejerce.

Preceptos tan importantes como los arts. 154. 2 156 y 158 del Código Civil, en forma paralela, arts. 133 y 134 del Código de Familia de Cataluña, sobre todo, revelan la voluntad del legislador de dar un giro copernicano en cuanto a la idea y el régimen de la institución que gira ahora alrededor de la protección del menor y salvaguarda de sus intereses en los términos recién indicados. Esas normas no únicas pero si las más notorias y cuya calidad de orden público ya ha subrayado el Tribunal Constitucional en cuanto limitan la autoridad de los padres y modalizan muy señaladamente su ejercicio y función, han de ejercerse siempre en beneficio de los hijos, de acuerdo con su personalidad, tales normas revelan como subyacente un principio de carácter general, nuevo e innovador, que destaca el interés del menor como centro de gravedad de la institución y eje central en la organización del grupo en el nuevo orden familiar, al que queda sometida la potestad paterna que no puede forzar inmotivadamente la personalidad del menor.

La contemplación y particular relevancia dada por la ley al interés del menor y el especial juego que hoy tiene social y jurídicamente, se ha traducido, en la interpretación finalista de ciertas instituciones clásicas tales como la patria potestad y tutela, asimiladas, más que en la necesidad de crear otras nuevas, acentuando su contenido personalista, donde el menor adquiere importancia y protagonismo destacados, y aquellas instituciones el valor de medios jurídicos aptos para alcanzar ciertos fines constitucionales (los de los arts. 10, 27.2, 39 CE.).

En forma paralela y semejante al cambio de concepción y régimen de la patria potestad en el Código Civil a partir de 1981 por influjo de una nueva valoración de la personalidad del menor y lo mismo cabría decir de las instituciones tutelares: art. 216. $2^{\circ}$ del Código Civil, han aparecido otras importantes leyes postconstitucionales que toman en consideración de forma especial el interés del 
menor, en el sentido ya apuntado, a la hora de regular instituciones o desarrollar derechos fundamentales. Así por ejemplo:

a) La L.O. 1/1982, de mayo, de protección civil del derecho al honor, a la intimidad y a la propia imagen, cuyo art. 3 regula el consentimiento de los menores e incapaces, para que deje ser intromisión ilegítima, que podrán prestar ellos mismos si sus condiciones de madurez lo permiten, con regulación y protección específica en otro caso. Por otro lado, la defensa de esos derechos de los menores, la L.O. 1/1996 concede legitimación al Ministerio Fiscal en interés de los mismos.

b) La L.O. 1/1985, de 3 de julio, reguladora del derecho a la educación (LODE): aun respetando el derecho de los padres "para que sus hijos reciban la formación religiosa y moral que esté de acuerdo con sus propias convicciones" (art. 27.3 C.E.), garantiza también el derecho de los menores (alumnos) "a recibir una formación que asegure el pleno desarrollo de su personalidad”, el "derecho a que su libertad de conciencia sea respetada, así como sus convicciones religiosas y morales de acuerdo con la Constitución” y el "derecho a que se respete su integridad y dignidad personales" (art. 6, apart. a, c y d).

c) La Ley de 21 de noviembre de 1987, de Adopción, reguló de nueva planta el acogimiento y la adopción, presididas en todo momento por la idea del principio del interés del menor, cuyo consentimiento para la adopción es necesaria a partir de los doce años, y deberá "ser oído" por debajo de esa edad “si tuviere suficiente juicio”. Las Leyes 1/1996 y 13/2005, de 1 de julio, han modificado (la primera) y afectado (la segunda por el matrimonio homosexual) al régimen de la adopción, pero procurando salvaguardar dicho interés.

d) La L.O.1/1996, de Protección Jurídica del menor, que introdujo modificaciones en el régimen de acogimiento y adopción, además de implementar un sistema de protección a los derechos del menor así como pautas para el ejercicio de los mismos, sin perjuicio de instaurar los principios rectores de la acción administrativa de tales derechos.

e) La Ley de Enjuiciamiento Civil del año 2000, toma en consideración el interés del menor al tratar los procesos especiales sobre todo el arts. 749.2, art. 775.1, art. 777.5 y art. 777.8 (posibilidad de recurrir la sentencia o auto en que se apruebe la propuesta de convenio "sólo... en interés de los hijos menores o incapacitados, por el Ministerio Fiscal”).

Respecto de otros aspectos debe precisarse que el emergente interés del menor y el principio correspondiente no sólo han motivado reformas legislativas sino que se han convertido en tanto que principio general del Derecho español -de lo cual ya se ha hecho mención y que se tratará con ma- 
yor profundad cuando se estudie este principio juntamente con otros- con carácter informador del ordenamiento jurídico ${ }^{951}$, tal cual lo manifiesta el art. 1.4 del Código Civil, en criterio hermenéutico de rango finalista (protector de los menores) y sociológico, sobre todo, de muy amplio espectro: a) Por un lado, de las normas e instituciones en que ese interés aparece tipificado; y b) en las situaciones y relaciones de la vida corriente afectadas, tanto para detectar conflictos como en la solución de problemas en que resulta implicado ese interés, con lo que su influencia llega muy lejos, prácticamente a todos los ámbitos jurídicos donde se halle comprometido el interés de los menores ${ }^{952}$.

En el aspecto teórico o dogmático ha repercutido asimismo en el nuevo enfoque de muchas cuestiones relativas al Derecho y derechos de la persona, en la reconsideración de perspectivas de estudio y comprensión de casi todo lo que afecte al menor, en particular en lo que atañe a sus derechos fundamentales, a la patria potestad y la injerencia de los poderes públicos en todo lo que concierne al mismo, sobretodo en situaciones de ruptura familiar, sobre este tema cito el estudio propiciado a nivel de la Comunidad Foral de Navarra, por parte de NANCLARES VALLES ${ }^{953}$.

951 El interés del menor, como bien se sabe, se ha introducido en la legislación española como unacláusula general, es decir, se expresa normativamente por medio de un concepto jurídico indeterminado, pero está referida a supuestos de hecho muy generale y abstractos.

952 ROCA I TRIAS, E. "Contestación: El interés del menor como factor de progreso y unificación del Derecho internacional privado", Revista Jurídica de Cataluña, Barcelona, año 1994-4, página 975. La inclusión del interés del menor como una cláusula general ha supuesto ventajas y desventajas. Ventajas porque permite que el intérprete adapte las soluciones a los criterios de la conciencia social, siempre en evolución; y desventajas porque precisamente el amplio abanico de interpretaciones posibles puede dar lugar a desviaciones notables respecto a lo que puede considerarse aceptable en una realidad social en un momento dado.

953 "La custodia de los hijos en el derecho civil de Navarra", Publicación:Aranzadi Civil-Mercantil num. 1/2012 parte Estudio, Editorial Aranzadi, SA, Pamplona. 2012, BIB 2011/1379. "En los últimos años, el notable incremento en el número de rupturas matrimoniales 2 y las no menos frecuentes rupturas en el seno de las parejas de convivientes more uxorio han realzado el importante papel que juega en nuestro Derecho civil la normativa destinada a la protección de los hijos menores de edad ante tales crisis familiares. Guiados por el principio del favor filii, los Tribunales españoles han utilizado las herramientas legales a su disposición para dispensar a los hijos la mayor tutela posible en aquellos casos en los que las desavenencias de sus progenitores derivaban en una quiebra de la estabilidad familiar y en una desintegración del núcleo familiar.- En el año 2010 el número de divorcios ascendió a 119.554 (de ellos, 70.932 consensuados), mientras que el número de separaciones fue de 7.962 (de las cuales 5.233 fueron de muto acuerdo), quedándose en 166 las nulidades declaradas. En la Comunidad Foral de Navarra se produjeron 1282 divorcios (892 consensuados), frente a 79 separaciones (59 de mutuo acuerdo) y tan solo 3 nulidades matrimoniales. Véase el Informe de la Sección de Estadística Judicial del Consejo General del Poder Judicial publicado el 6 de junio de 2011 y titulado «La Justicia Dato a Dato. Año 2010», p. 62. - Ciertamente, los datos globales son similares, e incluso ligeramente inferiores a los registrados en 2004, cuando el número de divorcios era de 52.591, frente a las entonces mayoritarias separaciones, que ascendían a 82.340, datos a los que cabía añadir 190 nulidades (vid el Informe «La Justicia Dato a Dato. Año 2004», Sección de Estadística del Consejo General del Poder Judicial, publicado el 1 de junio de 2005), pero en todo caso el número de crisis matrimoniales es muy superior al registrado a principios de la década de los 80, pudiendo tomarse como referencia el año 1982, en el que el número de divorcios ascendió a 21.463, mientras que el de separaciones llegó a 17.445. Una visión general de este progresivo incremento en el número de rupturas matrimoniales puede verse en "La Ruptura Familiar en España», Boletín Mensual Monográfico $n^{\circ}$ 3, Julio-Agosto 2009, Instituto de Política Familiar, www.ipfe.org, p. 6.- Sin embargo, los cambios sociales relevantes en esta materia iban más allá de la estadística judicial y del declive del modelo matrimonial. La masiva incorporación de la mujer al mercado laboral y la mayor implicación de los varones en las actividades domésticas 
Capítulo IV El Principio del interés superior del menor y el Derecho de Familia - El interés del menor y la interpretación restrictiva de las limitaciones a la capacidad de obrar de los menores en la Ley Orgánica 1/1996, de 15 de enero, de protección jurídica del menor

\section{9| El interés del menor y la interpretación restrictiva de las limitaciones a la capacidad de obrar de los menores en la Ley Orgánica 1/1996, de 15 de} enero, de protección jurídica del menor

Tal como se ha esgrimido en varias ocasiones, desde hace ya algunos años puede constatarse una creciente preocupación por dotar a los menores de un marco jurídico que garantice su adecuada protección social, económica y jurídica.

Consecuencia de lo anterior es el importante proceso de renovación del ordenamiento jurídico español en la materia, iniciado por la Ley 11/1981, de modificación de la filiación, patria potestad y régimen económico del matrimonio, a la que siguen otras muchas, pudiendo destacarse, entre ellas, la Ley 13/1983, de 24 de octubre, sobre la tutela; la Ley 21/1987, de 11 de noviembre, por la que se modifican determinados artículos del Código Civil y de la Ley de Enjuiciamiento Civil en materia de adopción; la Ley Orgánica 1/1996, de 15 de enero, de Protección Jurídica del Menor, de modificación parcial del Código Civil y de la Ley de Enjuiciamiento Civil; la Ley 1/2000, de 7 de enero, de Enjuiciamiento Civil, y la Lay 41/2003, de 18 de noviembre, de protección patrimonial de las personas con discapacidad y de modificación del Código Civil, de la Ley de Enjuiciamiento Civil y de la Normativa Tributaria con esta finalidad ${ }^{954}$.

Este conjunto normativo ha reformado en profundidad las tradicionales instituciones de protección de los menores reguladas en el Código Civil, intentando establecer un equilibrio entre la necesidad de protección de esas personas, imprescindible por la especial situación en la que se encuentran, y las necesidades relacionadas con su propia autonomía, indispensable para promover el libre desarrollo de su personalidad (art.10 CE) $)^{955}$.

(cuya constatación convertía en aún más superflua la modificación del artículo 68 CC [ LEG 1889, 27] motivada por la Ley 15/2005, de 8 de julio [RCL 2005, 1471] ) suponían una ruptura de la tradicional asignación de roles familiares: ni la mujer era inhábil para trabajar ni el varón carecía de suyo de capacidad para afrontar el cuidado de un hijo."

954 SANCHEZ-CALERO ARRIBAS, B. "El interés superior del menor y la interpretación restrictiva de las limitaciones a la capacidad de obrar de los menores en la Ley Orgánica 1/1996, de 15 de enero, de protección jurídica del menor", en HERRERA CAMPOS, R y BARRIENTOS RUÍZ, M.A. (Coords.) "Derecho y familia en el siglo XXI”, Volumen II, , Ed. Universidad de Almería, año 2011, página 847.

955 ORTUÑO MUÑOZ, P. “Prólogo” en GARCÍA GARNICA, Ma DEL C. “Aspectos actuales de la Protección Jurídica del Menor”, Ed. Thomson Aranzadi, Cizur Menor, año 2008, página 14. Sostiene el citado autor que es cierto que en el ámbito jurídico se ha producido un cambio importante en e enfoque de la problemática del menor. Se recuerda que la problemática de la filiación ha tenido hasta hace muy pocos años como ejes la protección de la legitimidad de la descendencia; que la adopción permaneció hasta hace muy pocos años en la esfera de lo privado, especialmente vinculada a la transmisión de las herencias, y que las únicas constituciones judiciales de tutelas que se realizaban tenían como finalidad administrar el patrimonio de los menores, sin que se haya formalizado ningún consejo de familia para proteger al menor si éste no era titular de un patrimonio que administrar. El cambio operado ha sido en el terreno de los principios, puesto que desde la perspectiva de la dignidad de la per- 
Capitulo IV El Principio del interés superior del menor y el Derecho de Familia - El interés del menor y la interpretación restrictiva de las limitaciones a la capacidad de obrar de los menores en la Ley Orgánica 1/1996, de 15 de enero, de protección jurídica del menor

El instrumento de que se sirve el Derecho para conseguir una adecuada protección de los menores es la representación legal, concebida como una potestad vinculada en su ejercicio a dicha finalidad $^{956}$. La existencia de la representación legal no es incompatible con el reconocimiento de un ámbito de capacidad propio del menor que favorezca su desarrollo como persona. La finalidad de tal reconocimiento es, por tanto, buscar el mayor beneficio del menor ${ }^{957}$, el cual se configura como uno de los principios básicos que ha presidido la reforma en materia de patria potestad y tutela. Al citado beneficio hacen referencia varios preceptos legales provenientes del Código Civil, además de hallarse enunciado como un principio general, en relación a los menores en la Ley Orgánica 1/1996, de 15 de enero, de Protección Jurídica del Menor, de modificación parcial del Código Civil y de la Ley de Enjuiciamiento Civil, junto con el de interpretación restrictiva de las limitaciones a la capacidad de obrar de los menores.

El artículo 2 de dicha Ley manifiesta: “En la aplicación de la presente Ley primará el interés superior de los menores sobre cualquier otro interés legítimo que pudiera concurrir. Asimismo, cuantas medidas se adopten al amparo de la presente Ley deberán tener carácter educativo.

Las limitaciones a la capacidad de obrar de los menores se interpretarán de forma restricti$v a ”$.

Se ha esgrimido que aún cuando se diga en el referido artículo : "En la aplicación de la presente Ley ... ”, su vocación de generalidad hace que debamos ponderar el favor minoris en todos los cuerpos normativos sea cual fuere su naturaleza penal, civil, procesal o laboral en los que esté en juego, se afecten, o disciplinen de algún modo los derechos de los menores, las actuaciones de todo orden en situaciones de desprotección social y las instituciones de protección de menores. A ello obliga la interpretación sistemática que se viene proponiendo que lleve a extender el ámbito del artículo 2 a las materias normativas a que se refieren los títulos I y II de la Ley. Por otra parte, debe puntualizarse que el mencionado precepto establece la primacía "del interés superior de los menores sobre cualquier otro interés legítimo que pudiera concurrir" ${ }^{\prime 958}$.

sona y la interdicción de la discriminación por razón de edad, la línea básica es la de implantar un principio jurí dico nuevo, el del "interés del menor", que debe influir en toda la actividad legislativa administrativa y judicial, tanto a nivel nacional como internacional.

956 Vid. SÁNCHEZ-CALERO ARRIBAS, B. “La actuación de los representantes legales en la esfera personal de los menores e incapacitados”, Ed. Tirant Lo Blanch, Valencia, año 2005; y “La intervención judicial en la gestión del patrimonio de los menores e incapacitados”, Ed. Tirant Lo Blanch, Valencia, año 2006.

957 Tal cual se expresó con anterioridad hay autores que distinguen los términos beneficio del menor e interés del mismos. Vid. NAVAS NAVARRO, S. "El bienestar y el interés del menor desde una perspectiva comparada” en Estudios jurídicos en homenaje al profesor Luis Díez-Picazo, ...op. cit., páginas 687 a 713

958 VARGAS CABRERA, B., "El Ministerio Fiscal y el principio del interés del menor”, en "La desprotección social de los menores y las instituciones de amparo reguladas e la Ley Orgánica de protección del menor”, Jorna- 
Capitulo IV El Principio del interés superior del menor y el Derecho de Familia - El interés del menor y la interpretación restrictiva de las limitaciones a la capacidad de obrar de los menores en la Ley Orgánica 1/1996, de 15 de enero, de protección jurídica del menor

En tal sentido, el principio del interés superior del menor no es algo nuevo, puesto que, aparece recogido en algunos preceptos del Código civil tras la reforma de 1981 (por ejemplo, arts. 154, $156.4,159,161,170.2,216,224$, etc.) y en diferentes textos internacionales, tales como la Declaración de los Derechos del Niño de 1959, Principios $2^{\circ}$ y $7^{\circ}$; Convención de los Derechos del Niño de 1989, arts. 3.1 $\left.{ }^{959}, 9.1,18.1,20.1,21,37 . c\right)$ y 40.2 ). iii); Resolución del Parlamento Europeo sobre una Carta Europea de los Derechos del Niño de 1992, punto 8.14; Resolución del Parlamento Europeo sobre medidas de protección de menores en la Unión Europea de 1996, etc.

Con carácter general, el artículo 154 del Código Civil establece que: "la patria potestad se ejercerá siempre en beneficio de los hijos, de acuerdo con su personalidad, y comprende los siguientes deberes y facultades (...)”, y el artículo 216 del mismo Texto legal dice que "las funciones tutelares constituyen un deber, se ejercerán en beneficio del tutelado y estarán bajo la salvaguarda de la autoridad judicial”.

El problema consiste en determinar qué se entiende por “interés superior del menor". Para ALONSO PÉREZ, dicho interés: "debe referirse al desenvolvimiento libre e integral de su personalidad (art. 10 CE; art. 5 Ley de Cataluña 8/1995), a la supremacía de todo lo que le beneficie más allá de las apetencias personales de sus padres, tutores, curadores o administraciones públicas, en orden a su desarrollo físico, ético y cultural. La salud corporal y mental, su perfeccionamiento educativo, el sentido de la convivencia, la tolerancia y la solidaridad con los demás sin discriminación de sexo, raza, etc., la tutela frente a las situaciones que degradan la dignidad humana (droga, alcoholismo, fundamentalismos, sectas, etc) son otros tantos aspectos que configuran el concepto más vivencial que racional del interés del menor. Por encima de todo, el interés del menor se respeta en la medida en que las funciones familiares o parafamiliares fomentan equilibradamente la libertad del menor y el sentido de la responsabilidad, en armonía inescindible entre derecho y deber",960.

Similares eran las apreciaciones que hacía DIEZ-PICAZO, antes de la Ley Orgánica 1/1996, en relación a la idea del "beneficio de los niños", al que consideraba como un criterio de selección entre las diferentes y eventuales opciones que en relación con ellos se pueden adoptar: elegirá el re-

das de Derecho Civil en Homenaje a Estanislao de Aranzadi, Servicio de publicaciones, Universidad de Coruña, año 1999, página 14.

959 Dice tal precepto: "En todas las medidas concernientes a los niños que tomen las instituciones públicas o privadas de bienestar social, los tribunales, las autoridades administrativas o los órganos legislativos, una consideración primordial a que se atenderá será el interés superior del niño".

960 ALONSO PÉREZ, M. "La situación jurídica del menor en la LO 1/1996, de 15 de enero, de protección jurídica del menor, de modificación del Código Civil y de la Ley de Enjuiciamiento Civil: luces y sombras", Actualidad Civil, núm. 1, enero, Madrid, año 1997, página 24. 
Capitulo IV El Principio del interés superior del menor y el Derecho de Familia - El interés del menor y la interpretación restrictiva de las limitaciones a la capacidad de obrar de los menores en la Ley Orgánica 1/1996, de 15 de enero, de protección jurídica del menor

presentante legal, o en su caso el Juez, la que resulte o considere razonablemente que puede resultar la más beneficiosa para los menores.

Tratándose de una fórmula de gran ambigüedad, sólo la casuística puede perfilar sus contornos, aunque se puede avanzar que lo más beneficioso no es subjetivamente lo que el padre entiende, sino que en algunos casos se permite que sea decisivo el criterio subjetivo del padre, lo que ocurre en el art. 27 de la Constitución que faculta a los padres para exigir una educación de los hijos que sea conforme con sus creencias y sus convicciones. No son decisivas las creencias de los órganos jurisdiccionales, aunque de facto son las que se imponen. Por consiguiente, serán las convicciones generales de la sociedad o del grupo humano en donde se encuentra inmerso el menor las que determinarán que es lo más beneficioso para el mismo. Sin perjuicio de ello, tratándose de personas de corta edad, ha de preponderar el beneficio futuro por encima del presente beneficio, equilibrándose la connotación económica que posee la idea del beneficio con su connotación pedagógica. Por último, en relación al fundamento del "beneficio de los niños" y al "principio del libre desarrollo de la personalidad" se encuentra la idea de igualdad, o que el beneficio de cada uno consiste en disfrutar de una posición similar o parecida a la de los demás ${ }^{961}$.

Existe un punto que es determinante en este asunto, es la consideración del menor como persona, si desde un punto de vista jurídico-formal puede bastar inicialmente el identificar el interés del menor con el de la dignidad de la persona, los derechos inviolables que le son inherentes y el libre desarrollo de su personalidad, desde un punto de vista personal y humano, especialmente relevante aquí tratándose de un niño, parece que no puede prescindirse de alguna referencia a una mínima felicidad, incluso inmediata y bienestar personal de ese menor (exento de tensiones y problemas que le exceden), al equilibrio personal, al equilibrio emocional y afectivo, que tanto pueden influir ya sea de manera positiva o negativa en el desarrollo de su personalidad, identificar el interés del menor es en definitiva identificar los aspectos más favorables para el desarrollo de su personalidad ${ }^{962}$. Sin duda el menor es una realidad humana en devenir, lo que resulta esencial para que los agentes sociales se fijen más en el futuro del menor que en su presente y en tal sentido es importante cono-

961 DIEZ-PICAZO, L. “El principio de protección integral de los hijos (“Tout pour l'enfant”)” en GONZÁLEZ PORRAS, J. (Coord.) "La tutela de los derechos del menor”, $1^{\circ}$ Congreso Nacional de Derecho Civil, dirigido por. Junta de Andalucía, Córdoba, año 1984, páginas 130 y 131.

962 Cfr. DE LA RASILLA, M. “El valor de la identificación en la determinación del interés superior del menor”, en VV. AA., “Aproximación a la protección Internacional de los menores no acompañados en España”, Ed. La Merced Migraciones, Madrid, año 2010, páginas 89 a 110. 
Capitulo IV El Principio del interés superior del menor y el Derecho de Familia - El interés del menor y la interpretación restrictiva de las limitaciones a la capacidad de obrar de los menores en la Ley Orgánica 1/1996, de 15 de enero, de protección jurídica del menor

cer qué es lo que piensa, cuáles son sus anhelos, sus sentimientos, es decir fundarse en la persona integral de tal menor ${ }^{963}$.

El interés del menor, es en primer lugar un criterio de control, es decir el instrumento que permite controlar la patria potestad sin poner en cuestión la existencia de los derechos de los padres. Así en la familia unida, el interés presumido del niño ha de tenerse en cuenta por el padre y la madre, o quien ejerza la tutela, pero en caso de abuso o mal uso de tal prerrogativa por cualquiera de ellos provocará que se despoje o se controle de mayor manera la prerrogativa.

Este principio rector del Derecho de Familia ha de ser aplicado por todos los que teniendo poder de decisión en el ámbito público o privado, actúen en materias relativas a los menores, con una primordial consideración en todos $\operatorname{los} \operatorname{casos}^{964}$. Así se deduce del artículo 11 de la Ley Orgánica del Menor 1/1996, titulado "Principios rectores de la acción administrativa", que en su número 2 establece: "Serán principios rectores de la actuación de los poderes públicos, los siguientes: a) la supremacía del interés del menor" y del punto 2 de la Exposición de Motivos, cuando dice que el contenido de la Ley "vincula a todos los Poderes Públicos, a las instituciones específicamente relacionadas con los menores, a los padres y familiares y a los ciudadanos en general”.

RIVERA FERNÁNDEZ ha manifestado que le resulta sorprendente el carácter absoluto con el que se enuncia: “absoluta superioridad del interés del menor sobre cualquier otro interés legítimo”. Esta primacía se debe a que el "interés del menor" es un concepto indeterminado referido a aquello que proporciona un mayor beneficio al mismo en relación a todos los ámbitos; por tanto, no puede plantearse una ponderación entre el interés del menor y su integridad física porque, si se estima que en un determinado caso ha de prestarse atención a la integridad física, es precisamente porque eso es lo más beneficioso para el menor; en definitiva, estaría primando el interés del menor ${ }^{965}$.

963 Vid. DAL VIGIL, E. "Los derechos en la Convención de Derecho del Niño y en la Constitución española”, en BALADO, M y GARCÍA REGUEIRO, J. A. (Dir.) "La Constitución española de 1978 en su XXV aniversario”, Ed. J. M. Bosch S. A., Barcelona, año 2003; REQUENA HUERTAS, M. "La protección jurídica del menor en el ámbito del Consejo de Europa: el Convenio Europeo sobre el ejercicio de los derechos del niño" en CALVO GARCÍA, M. y FERNÁNDEZ SOLA, N. (Coord.) "Los derechos de la infancia y de la Adolescencia”, Mira Editores, Zaragoza, año 2000.

964 FERNÁNDEZ CASADO, Ma . D. “Una aproximación al principio del interés superior del menor”, en "Protección jurídica del menor”, Ed. Comares, Granada, año 1997, página 249. En el mismo sentido, VARELA GARCÍA, C. "Comentarios a la Ley Orgánica 1/1996, de 15 de enero, de protección jurídica del menor: principios programáticos y normas de conflicto”, Actualidad Civil, número 12, marzo, Madrid, año 1997, página 264; ALONSO SUÁREZ, C y DE LAMA AYMÁ, A. "La protección civil de personas sometidas a manipulación mental”, Ed. Tirant lo Blanch, Valencia , año 2003, página 218.

965 RIVERA FERNÁNDEZ, M., “Anotaciones a la Ley 1/1996, de 15 de enero, de protección jurídica del menor”, Revista General de Derecho, Ed. Iustel, junio, Madrid año 1996, página 6503. 
Capitulo IV El Principio del interés superior del menor y el Derecho de Familia - El interés del menor y la interpretación restrictiva de las limitaciones a la capacidad de obrar de los menores en la Ley Orgánica 1/1996, de 15 de enero, de protección jurídica del menor

Sin duda, decidir en una situación jurídica determinada, de acuerdo con el interés eminente del menor, supone unas veces (sin conflicto con otro derecho o persona), inclinarse por una opción determinada entre varias posibles en el ejercicio de un derecho del menor. El problema reside ahora en cómo, en qué sentido debe resolverse el conflicto, porque no siempre podrá o ha de imponerse el interés del menor: ello dependerá de los términos en que la norma aplicable regule el conflicto y especifique la prevalencia del interés del menor. En general, se impondrá éste cuando en el conflicto haya cierto equilibrio de intereses (relativamente) equiparables, más o menos igualmente valiosos, y cuando el legislador diga directamente cuál es para él preponderante y que debe triunfar; porque habrá ocasiones en que el propio legislador los ha valorado desigualmente y determinado cuál debe imponerse por estar legalmente más protegido. Entonces estamos ante una situación distinta a la que aquí nos ocupa: se impone directamente el interés superior, el legalmente más valioso. Sea el del menor u otro. En tal hipótesis, pues es posible (aunque excepcionalmente, si así lo dispone el legislador) que deba ceder el interés del menor.

LINANCERO DE LA FUENTE indica, respecto a la aplicación de este principio por los órganos jurisdiccionales que "en todo caso, aunque la valoración judicial del "interés del menor" sea discrecional, ello no justifica resoluciones arbitrarias. La discrecionalidad del juzgador debe tener como límite: "la racionalidad en la apreciación de los hechos; b) evitar todo perjuicio para el bienestar espiritual y material del menor; y c) la protección de los derechos del niño plasmados en la legislación nacional e internacional"966. Además del principio del interés superior del menor, el artículo 2 de la Ley Orgánica 1/1996, en el párrafo segundo, reconoce el principio de interpretación restrictiva de las limitaciones a la capacidad de obrar de los menores, por ello se plantea la duda de si el legislador ha pretendido establecer el principio de la capacidad de obrar del menor, excepto para los actos y negocios en los que la norma legal la limite o simplemente que tal norma, cuando exista, deba ser sometida a una interpretación restrictiva. GULLÓN BALLESTEROS sostiene que "la interpretación restrictiva de las limitaciones de la capacidad de obrar del menor ha sido siempre, desde la promulgación del Código Civil, un principio rector de la interpretación y aplicación de las normas restrictivas de la capacidad, no sólo del menor sino de cualquier persona, como corresponde a su dignidad. Mucho más importante hubiera sido regular la capacidad de obrar del

966 Vid. LINACERO DE LA FUENTE, Ma, “Protección jurídica del menor”,Ed. Montecorvo, Madrid, año 2001, páginas 61 a 65. SANTOS URBANEJA, F., “QQué significa el interés del menor?”, Revista de Derecho de Familia, núm. 15, Ed. Lex Nova, Valladolid, Abril, año 2002, páginas 271 y siguientes. Para tratar de acercarse al significado del "interés del menor", propone preguntar a los menores y a los padres cuál es su interés y finalmente, analizar el interés que el Estado tiene en los menores, que no es otro que la Educación (art. $27 \mathrm{CE}$; Decla ración de las Naciones Unidas sobre derechos del niño de 20 de noviembre de 1989; LO 1/196, de 15 de enero, de Protección Jurídica). 
Capitulo IV El Principio del interés superior del menor y el Derecho de Familia - El interés del menor y la interpretación restrictiva de las limitaciones a la capacidad de obrar de los menores en la Ley Orgánica 1/1996, de 15 de enero, de protección jurídica del menor

menor con carácter general, acabando con la consideración fragmentaria e incompleta que en el Código Civil recibe la materia ${ }^{\circ 967 .}$

Las limitaciones a la capacidad de obrar del menor tienen su fundamento en el principio de protección del menor consagrado constitucionalmente en el artículo 39, dicho principio tiene directa relación el principio consagrado en el artículo 10 de la $\mathrm{CE}$, "el libre de desarrollo de la personalidad", tal como se ha mencionado en repetidas ocasiones, así se indicará cuando se analice el principio ya citado. Ambos principios se complementan y a la vez se limitan mutuamente, determinando el equilibrio que debe encontrar la regulación civil en este punto, la cual no debe ser demasiado restringida hasta tal punto de hacer referencia a una sobreprotección del menor más que una protección propiamente tal o tan amplia que la protección en cuestión sea tildada de insuficiente ${ }^{968}$.

Sin duda es un desafío, porque hay que compatibilizar dos exigencias que aparentemente son contrapuestas y que responden a la naturaleza de la protección del menor. Por una parte el potenciamiento de su autónoma personalidad, de su iniciativa personal propia (protección de la personalidad de menor desde el mismo) y la indiscutible necesidad de la existencia de potestades de control, vigilancia y defensa que suplan las carencias inherentes a la propia personalidad del menor (protección de la personalidad del menor desde fuera ${ }^{969}$.

En tal sentido, la Exposición de Motivos de la Ley Orgánica 1/1996 hace referencia a una reformulación de la estructura del derecho a la protección de la infancia en base al reconocimiento pleno de la titularidad de derechos en los menores de edad y de una capacidad progresiva para ejercerlos, y más adelante hace mención de que no existe una diferencia tajante entre las necesidades de protección y las necesidades relacionadas con la autonomía del sujeto, sino que la mejor forma de garantizar social y jurídicamente la protección de la infancia es promover su autonomía como sujetos.

\section{Análisis del interés del menor como principio general}

Tal como se ha mencionado al interés del menor aluden múltiples normas civiles (Derecho común y autonómicos) y otras, ya mencionadas ${ }^{970}$. De ellas se pude inducir un principio general de Derecho por vía de generalización. Pero al propio tiempo aquellas normas y ese principio son consecuencia

967 Vid. GULLÓN BALLESTEROS, A., “Sobre la Ley 1/1996, de protección del menor”, Revista La Ley, 8 de febrero de 1996, Madrid, página 2.

968 MARTÍNEZ DE AGUIRRE, C. “La protección jurídico-civil de la persona por razón de la menor edad”. Anuario de Derecho Civil, octubre-diciembre, año 1992, página 1396.

969 JORDANO FRAGA, F. “La capacidad general del menor”, Revista de Derecho Privado, T. LXVIII, enero-diciembre, Madrid, año 1984, página 892. 
próxima de otras normas constitucionales: el precepto constitucional más directa y profundamente implicado en aquel interés es el art.39 CE, que explicita, a su vez, el principio de protección integral de los hijos menores de edad (números 2 y 3 ) y de la infancia (número 4); también, indirectamente, el art. 10.1. Las normas civiles ( y otras, insisto) que hablan del interés (superior) del menor o beneficio del hijo son sólo una instrumentalización o desarrollo del terminante mandato constitucional de art. 39 como ha dicho en más de una ocasión el Tribunal Constitucional, según sentencia 273/2005, de 27 de octubre ${ }^{971}$, como más reciente, y en relación con una de sus manifestaciones ${ }^{972}$.

Resulta así, que el del interés del menor, además de principio general de Derecho privado, constituye per se un principio constitucional, uno de los principios rectores, incluidos en los artículos 39 a 52 de la Constitución, caracterizados por enunciar unos objetivos de la acción del Poder, para cuyo cumplimiento tiene éste amplia libertad en cuanto medios y forma de concretarlos. Son mandatos de optimización, susceptibles de cumplimiento en diferentes grados ${ }^{973}$. Como constitucional que es el principio del interés del menor, le ha dotado la Constitucionalidad de la superioridad normativa formal que ella misma implica, sin dejar de ser un principio general de Derecho Privado, además el principio del interés del menor, por su ubicación en la Constitución y como otros de su misma clase vincula a todos los poderes públicos, no en el sentido del art. 53.1 C.E., sino en el que da a conocer el art. 53.3, su reconocimiento, respeto y protección informará la legislación, práctica judicial y actuación de los poderes públicos ${ }^{974}$.

970 Las legislaciones autonómicas- concretamente de Andalucía, Aragón, Asturias, Extremadura, Cantabria, CastillaLa Mancha, Cataluña, Galicia, Islas Baleares, La Rioja, Navarra, Madrid, Región de Murcia- recogen diversos Principios Rectores. Toman como pilar la prevalencia del interés del menor sobre cualquier otro concurrente. Además tienen en consideración otros principios básicos como la defensa de los derechos constitucionales del menor y de los reconocidos por acuerdos internacionales. Se reconocen derechos específicos de los menores en distintas Comunidades Autónomas. En el Principado de Asturias los menores tienen los siguientes derechos: a ser informado acerca de la actuación protectora; a ser oído y a expresar su opinión; de conciencia y religión; al honor, a la intimidad personal y familiar y a la propia imagen; y a la garantía y defensa de los derechos. En la Región de Murcia tienen los derechos siguientes: de la infancia ; a la identidad; a la intimidad y a la propia imagen; en materia de atención integral de salud. En la CA de Madrid se reconocen particularmente los derechos a la protección de la salud y a la educación. En la CA de La Rioja se reconocen los derechos: a la protección y a la promoción de la salud y a la atención sanitaria. En la CA Castilla-La Mancha se conceden los derechos: a la identidad; a la prevención y atención ante los malos tratos y explotación; al honor, intimidad y a la propia imagen; a la información; a la libertad ideológica; a la participación y asociación; a ser oído; a la educación; a la protección de la salud; a la cultura y el ocio; al medio ambiente; a la integración social. En la CA de Cantabria tienen derecho: al honor, a la intimidad personal y familiar y a la propia imagen, a la información; a la libertad ideológica, a la participación, asociación y reunión; a la libertad de expresión; a ser oído; a la educación; al juego y al desarrollo de actividades culturales y deportivas; a una estancia saludable; a la protección de la explotación económica, laboral y social; a la salud.

971 STC, Pleno, núm. 273/2005 de 27 octubre. RTC 2005/273

972 RIVERO HERNÁNDEZ, F. “El interés del menor”, ...op. cit., página 81.

973 Cfr ALEXY, R. "Teoría de los derechos fundamentales”, Centro de estudios Políticos y Constitucionales, Madrid, año 1993, páginas 8 y siguientes.

RIVERO HERNÁNDEZ, F. “El interés del menor”, ...op. cit., página 82. 
El del interés del menor, como principio general de Derecho privado, es concreción en este último terreno de ese mandato y principio constitucional, con clara visión finalista (de protección de los niños $)^{975}$. La realización del interés del menor es una forma específica de su protección y cumplimiento del mandato de optimización del art. 39.2, 3 y 4 CE. Dicho principio deviene, así, instrumento normativo del principio constitucional, confluyendo ambos en idéntico sujeto destinatario. Es, pues, una norma jurídica, no un mero criterio orientador o interpretativo, sin dejar de ser eso también.

Cuando se habla de principio general es porque así lo dan a conocer ciertas normas, por ejemplo el art. 2 de la L.O. 1/1996, de Protección Jurídica del Menor, que lo incluye entre los principios generales; asimismo su Exposición de motivos lo menciona ${ }^{976}$. En el mismo sentido la Ley catalana 8/1995, de atención y protección de los niños y adolescentes, cuyo art. 3 dice que "el interés superior del niño y del adolescente será el principio inspirador de las actuaciones públicas y de las decisiones y actuaciones que les conciernen adoptadas (...)”. Aun no explicitado como principio general, actúa en esa calidad en la Convención de Derechos del Niño (1989), art. 3 (y en todo su articulado, véase también su Preámbulo). Igualmente en la jurisprudencia, que también habla del principio del interés superior del menor ${ }^{977}$.

En cuanto principio general, el del interés del menor, no hace excepción a lo esencial de esa categoría jurídica: es la expresión de unas convicciones y valoraciones ético-sociales, de una sensi-

975 Vid. ZUMAQUERO GIL, L. "El interés del menor en los tribunales españoles" en "La protección de los niños en el Derecho Internacional y en las relaciones internacionales", Jornadas en Conmemoración del 50 aniversario de la Declaración Universal de los Derechos del Niño y del 20 aniversario del Convenio de Nueva York sobre los Derechos del Niño, Colegi de Notaris de Catalunya, Ed. Marcial Pons, año 2010, Madrid, páginas 41 y 42. "Aunque como hemos apuntado no existe en nuestra legislación ningún precepto que concrete qué debe entenderse por interés del menor, sino que únicamente se hace referencia a la necesidad de buscar el beneficio del menor o de actuar en interés, sí es unánime la doctrina al señalar del menor como un principio general del Derecho, presentándolo como un concepto jurídico indeterminado, cuyo alcance es necesario determinar en el caso concreto."

976 "Esta es la razón -dice la Exposición de Motivos.- por la que, además de establecerse como principio general, el que en toda actuación habrá de tener fundamentalmente en cuenta el interés del menor y no interferir (...)".

977 STSJ, Cataluña, Sala de lo Civil y Penal, núm. 9/2010 de 3 Marzo, rec. 152/2008. "Así resulta también del art. 82.2 en relación con el art. 76, ambos del Codi de Família de Cataluña aprobado por la Llei 9/1998, de 15 de julio, y del art. 3 de la Llei 8/1995, de 27 de julio, de Atención y Protección a la Infancia y la Adolescencia, de manera congruente con lo dispuesto en el art. 752.2 LEC sobre la facultad de los tribunales de decidir en este punto lo más adecuado para los menores al margen de las concretas pretensiones de las partes del procedimiento.- Así lo ha señalado nuestro Tribunal Constitucional, según el cual constituye "un estatuto jurídico indisponible de los menores de edad dentro del territorio nacional" (STC 141/2000 de 29 may) y un "criterio básico y preferente" en los procedimientos en materia de familia (ATC 127/1986 de 12 feb.), que "debe inspirar la actuación jurisdiccional" (STC 217/2009 de 14 dic.) y que, en consecuencia, faculta al tribunal para resolver incluso "ex officio" sobre todo lo concerniente a los menores (STC 4/2001 de 15 ene.). - Así lo ha declarado el Tribunal Supremo, para el que debe prevalecer "incluso por encima del de sus progenitores" (STS 1 ${ }^{a}$ 719/2003 de 9 jul.) y cuyas características de orden público lo convierten en un principio de necesaria observancia por jueces y tribunales (STS $1^{a} 614 / 2009$ de 28 sep.)." 
bilidad y de juicios de valor, de que hablaba DE CASTRO $^{978}$, y la condensación de los grandes valores jurídicos materiales básicos del ordenamiento jurídico, positivización, según lo manifestado por otros autores tales como LACRUZ BERDEJO y DELGADO ECHEVERRIA ${ }^{979}$, de los valores y aspiraciones ideales sociales de la comunidad. Por ello se transforma en norma jurídica de carácter básico en la organización social, que expresa un sistema de valores que la funda, asimismo un criterio de valoración jurídica en un sector de la realidad social y de ciertos conflictos de intereses, con otras consecuencias normativas ${ }^{980}$.

Por ello en el ordenamiento jurídico español el interés del menor no sólo está presente en normas concretas y en su aplicación en los supuestos de hecho previstos, sino que es un principio que desborda su estricta tipificación, de modo que además de criterio hermenéutico para otros supuestos y normas, cuando está en juego un interés del menor deberá imponerse sobre cualquier otra solución, a menos que razones suficientes aconsejen o exijan otra cosa, lo que habrá de justificar cumplidamente, amén de demostrar la necesidad e idoneidad de la medida restrictiva del derecho o interés del menor y de ser proporcionada al caso.

En esa calidad de principio general, reforzado por su elevación a constitucional, además de ser garantía para los ciudadanos y vincular a los poderes públicos (art.53.3. C.E.), a cuya actuación pone límites, el interés del menor actúa como instrumento informador de instituciones que afectan a las personas que se pretende proteger, ya sea la patria potestad, la tutela, el desamparo, el acogimiento y la adopción, para lo que entrega directrices para la consecución de fines constitucionales como la protección de los menores ${ }^{981}$. Asimismo otorga criterios para interpretar la normativa que regulan a los menores, procediendo a contribuir a la integración del ordenamiento. Al tener un imperio constitucional se extiende a otros ámbitos del sistema ${ }^{982}$.

978 DE CASTRO Y BRAVO, F. "Derecho civil de España”, Instituto de Estudios Políticos, Madrid, año 1955, páginas 460 y 461.

979 LACRUZ BERDEJO, J. L. y DELGADO ECHEVERRIA, J. “Elementos de Derecho Civil”, Ed. Dykinson, Madrid, año 2006, páginas 169 y siguientes.

980 RIVERO HERNÁNDEZ, F. "El interés del menor", ... op. cit., página 84.

981 Cfr. BORRAS RODRÍGUEZ, A. "El interés del menor como factor de progreso y unificación del Derecho Internacional Privado", Discurs d'ingrés en la Academia de la Jurisprudéncia I Legislació de Catalunya, RJC, núm. 4, Barcelona, año 1994, página 923.

982 RIVERO HERNÁNDEZ se refiere a las normas específicas de protección de los menores en materia penal (Código penal; L.O. 5/2000, de 12 de enero), de Seguridad Social, de educación (cfr. L.O. 8/1985, de 3 de julio, y L.O. 1/1990, de 3 de octubre), o en relación con el internamiento en instituciones penales o administrativas. "El interés del menor", ... op. cit., página 85. 
En cuanto al juez, su protección y delimitación del interés del menor la realiza por medios de sus resoluciones y, formalmente, con la motivación de las mismas, en particular en cuanto concierne a los límites de aquel y en la justificación de la restricción concreta, cuando proceda.

Se estima que el principio constitucional de protección integral como el principio civil del interés del menor no son absolutos, sino que limitados, deben ceder ante intereses jurídicamente más relevantes, siempre que la restricción o recorte del interés del menor sea estrictamente necesario para lograr el fin legítimo previsto y proporcionado para alcanzarlo, todo ello ponderando los valores en juego, es decir que haya una relación razonable de proporcionalidad entre los medios empleados y el fin perseguido. En tal sentido la delimitación del alcance del principio del interés superior del menor en aquellas situaciones que no está tipificadas o explicitadas legalmente, en principio compete al Legislador señalar los límites funcionales de su control, el criterio fundamental es el del principio de proporcionalidad.

De todas maneras, en la aplicación del interés del menor y en su enfrentamiento con otros intereses ya no basta el criterio de razonabilidad que se invocara otrora al ponderarlos en el marco del conflicto, sino es necesario también analizar la proporcionalidad ${ }^{983}$, es decir, que no exista otra mejor solución o más adecuada para la situación concreta, vale decir, una ausencia de otra solución más moderada para la consecución del propósito con igual eficacia y adecuación o proporcionalidad stricto sensu, o sea, que la medida sea proporcionada o equilibrada por derivarse de la misma más beneficios y ventajas para el interés general, más beneficios y ventajas para el menor ${ }^{984}$.

\section{1 | Interés del menor y derechos fundamentales}

En primer lugar, en esta materia, hay que intentar dilucidar que se entiende por derecho fundamental, este podría entenderse como toda exigencia básica derivada de la dignidad humana que es reconocida constitucionalmente, estando garantizada al máximo nivel, para poder predicar así su eficacia directa y su exigibilidad. Tal definición es clarificadora de la diferente óptica que del con-

983 STC, Sala 1a, núm. 176/2008 de 22 diciembre. RTC 2008/176. “El interés superior del niño como contrapeso de los derechos de cada progenitor obliga a la autoridad judicial a ponderar tanto la necesidad como la proporcionalidad de la medida reguladora de la guarda y custodia del menor. Cuando el ejercicio de alguno de los derechos inherentes a los progenitores afecta al desenvolvimiento de sus relaciones filiales, y puede repercutir de un modo negativo en el desarrollo de la personalidad del hijo menor, el interés de los progenitores deberá ceder frente al interés de este."

984 STS, Sala de lo Civil, Sección 1a , núm. 653/2004 de 12 julio. RJ 2004/437. En este caso el Supremo, tras señalar que la privación de la patria potestad de un progenitor no es consecuencia sólo de los deberes que integran el contenido de la patria potestad, sino que esta medida deberá ser adoptada en función de las circunstancias concurrentes en cada caso y siempre en beneficio del menor acordó la privación de la patria potestad respecto del padre. 
cepto de derecho fundamental puede encontrarse en la contraposición entre iusnaturalismo y positivismo jurídico ${ }^{985}$.

Para el iusnaturalismo la consideración de fundamental ha venido determinada por el hecho de que ese derecho se manifiesta como expresión de la dignidad humana, siendo el conjunto de derechos fundamentales reconocidos a la persona los que van a dar contenido a la misma. Esta consideración es bastante cercana a lo que comúnmente se denomina como "derechos humanos", siendo uno de los pilares del constitucionalismo originario en el que los derechos declarados y reconocidos eran por el mero hecho de ser persona ${ }^{986}$. El problema se plantea a la hora de determinar quien ha de señalar, establecer, regular y garantizar qué derechos son manifestación de la dignidad humana y cuáles no lo son.

En un estado constitucional fundamentado sobre una constitución normativa la respuesta es sencilla: en la Constitución. Así, como es obvio, desde una consideración normativista lo que hemos de entender por derecho fundamental no puede ser sino manifestación directa de las previsiones constitucionales. En nuestro ordenamiento jurídico el art. 53.2 de la Constitución se convierte en el precepto sobre el que pivotan estas consideraciones al establecer qué conjunto de derechos constitucionales son los que van a gozar de un máximo nivel de protección y exigibilidad. Esto resulta fundamental a la hora de estudiar la titularidad y ejercicio de los derechos fundamentales por parte del menor $^{987}$. Si la constitución recogiese todos y cada uno de los derechos que son manifestación de la dignidad humana y solamente a ellos dotase de ese máximo nivel sería muy difícil argumentar que un menor no pudiera ser titular de todos y cada uno de los derechos fundamentales. El concepto normativo de derecho fundamental hace pues necesario un análisis más detenido de esta cuestión ante la eventualidad de que un menor no pueda ser titular de todos los derechos fundamentales, al

985 MARTÍNEZ RUANO, P. "La capacidad iusfundamental del menor", en SÁINZ-CANTERO CAPARRÓS, Ma. B. (Edit.) "Políticas Jurídicas para el Menor", Ed. Comares, Granada, año 2009, página 86.

986 Declaración de Derechos del Buen Pueblo de Virginia, de 12 de junio de 1776. "Declaración de derechos hecha por los representantes del buen pueblo de Virginia, reunidos en convención plena y libres como derechos que pertenecen a ellos y a su posterioridad como base y fundamento de su gobierno. 1. Que todos los hombres son por naturaleza igualmente libres e independientes, y tienen ciertos derechos inherentes, de los cuales, cuando entran en un estado de sociedad, no pueden ser privados o postergados; en esencia, el gozo de la vida y la libertad, junto a los medios de adquirir y poseer propiedades, y la búsqueda y obtención de la felicidad y la seguridad".- Declaración de los Derechos del Hombre y del Ciudadano, adoptada por la Asamblea Constituyente francesa del 20 al 26 de agosto de 1789, aceptada por el Rey de Francia el 05 de octubre de 1789. "Los representantes del pueblo francés, que han formado una Asamblea Nacional, considerando que la ignorancia, la negligencia o el desprecio de los derechos humanos son las únicas causas de calamidades públicas y de la corrupción de los gobiernos, han resuelto exponer en una declaración solemne estos derechos naturales, imprescriptibles e inalienables;..."

987 NUÑEZ RIVERO, C. "La protección del menor desde un enfoque de Derecho Constitucional", Revista de Derecho, UNED, núm. 9, Madrid, año 2011, páginas 261 a 294. 
margen de las posibilidades efectivas de su ejercicio, de manera parecida a lo que sucede en relación a la titularidad y ejercicio de los derechos fundamentales por parte de los extranjeros ${ }^{988}$.

En este orden de ideas merece traer a colación la definición de FERRAJOLI ${ }^{989}$, quien entiende que los derechos fundamentales serían aquellos derechos que, en un ordenamiento dado, se reconocen a todas las personas, o en su caso a todos los ciudadanos, por el mero hecho de serlo. Se trataría de derechos inherentes a la condición de persona o ciudadano, tal como ésta es concebida en dicho ordenamiento; y por eso mismo serían derechos universales en el sentido de que corresponden a todos los miembros del grupo. Esta definición tiene la enorme ventaja de explicar los derechos fundamentales con independencia de las concretas características de cada ordenamiento, al menos en la tradición liberal-democrática. Lo esencial sería que hay derechos que se reconocen efectivamente a todas las personas o a todos los ciudadanos por el mero hecho de serlo; siendo accesorio el modo en el que están regulados o protegidos.

Esta definición presupone una concepción material de los derechos fundamentales, al sobreentender que lo verdaderamente peculiar de los derechos es su contenido. Frente a esta concepción se encontraría la formal, para la cual lo crucial no es su contenido, sino el rango de la norma que los reconoce.

Sin duda que los derechos fundamentales se encuentran muy relacionados con el régimen constitucional aplicable a la minoría de edad, el cual se encuentra básicamente en el Capítulo I del Título Primero ("De los españoles y extranjeros" arts. 11 a $13 \mathrm{CE}$ ), que tiene un sentido ante todo lógico, en primer lugar se regulan las condiciones de ejercicio de los derechos y libertades fundamentales, para pasar con posterioridad a enumerar las mismas. Así pues, hace referencia de modo especial a las circunstancias y situaciones que afectan al ejercicio y titularidad de los derechos fundamentales (nacionalidad, mayoría de edad), aunque en su contenido también se consagran algunos de los derechos (derecho de asilo, derecho a la nacionalidad $)^{990}$. Se regulan las condiciones de ejer-

988 MARTÍNEZ RUANO, P. “La capacidad iusfundamental del menor”, ... op. cit., página 87. También sobre este punto se puede analizar la STC, Sala 2a, núm. 107/1984 de 23 noviembre. RTC 1984/107.

989 FERRAJOLI, L. “Los fundamentos de los derecho fundamentales”, Ed. Trotta, Madrid, año 2002.

990 Cfr. ALÁEZ CORRAL, B. "Minoría de edad y derechos fundamentales”, Ed. Tecnos, Madrid, año 2003, página 57. Los derechos fundamentales son instrumentos a través de los cuales el individuo puede desarrollar su personalidad llegando, a través de su ejercicio evolutivo, a consolidar su propia identidad. De manera que, desde el nacimiento, todo individuo es sujeto pleno de los derechos fundamentales que son inherentes a su dignidad humana con independencia de su "nacimiento, raza, sexo, religión, opinión o cualquier otra condición personal o social", entre las que se halla la edad. Siguiendo en este punto a la doctrina, cabe sostener, que "es precisamente esta función instrumental de los derechos fundamentales 1 que les permite dar forma a la dignidad de la persona como su resultado, es decir, como vías para la identificación y libre desarrollo del individuo en su interrelación con otros.; FERRER RIBA, J. "Derechos del menor, relaciones familiares y potestades públicas para la protección de la infancia y de la adolescencia en Cataluña”, Derecho Privado y Constitución, núm. 7, septiembre-diciembre, año 
cicio por la razón de que los derechos fundamentales al ser derechos subjetivos están sometidos a determinadas prescripciones generales que se exigen para el ejercicio de estos. Esta regulación se complementa con lo establecido en las normas de Derecho Internacional Público y Privado, y con la legislación de desarrollo de cada uno de los derechos ${ }^{991}$.

Por ello, el contenido del Capítulo I del Título I se detiene de manera especial en dos puntos: la capacidad iusfundamental en relación a la nacionalidad, y la capacidad iusfundamental derivada de la edad. El contraste entre las categorías generales de la Ciencia Jurídica y la praxis jurídico constitucional tiene una importancia vital en la relación menor y derechos fundamentales. Así, desde una óptica clásica, por capacidad jurídica se entiende la aptitud que el ordenamiento exige para poder ser titular de un derecho subjetivo ${ }^{992}$.

Por lo general se es titular de tal derecho subjetivo por el mero hecho de ser persona, pero la capacidad puede ejercerse en función de la nacionalidad del sujeto ${ }^{993}$. Asimismo, debemos señalar que la personalidad jurídica no es un atributo predicable sólo de las personas físicas, pues también lo es de determinadas instituciones y corporaciones públicas y privadas (personas jurídicas). Una vez que se es titular de determinados derechos subjetivos (capacidad jurídica) lo que interesa es poder ejercitarlos y para ello se requiere de la capacidad de poder ejercerlos directamente, sin necesidad de ningún intermediario.

El artículo 12 CE establece la mayoría de edad en los 18 años, límite equivalente al de los ordenamientos similares, y asociado de manera particular a la participación política. En tal sentido la mayoría de edad es un requisito, una exigencia para el ejercicio total de los derechos ${ }^{994}$. Aunque se

1995, página 50. Señala que “...si el libre desarrollo de la personalidad es el fundamento de nuestro orden político -artículo 10.1 CE-, el ordenamiento debe legitimar a toda persona para ejercer por sí misma los derechos preordenados a esa maduración personal, en tanto ello sea compatible con su aptitud para el discernimiento".

991 La vinculación entre la idea de que el menor es titular por sí mismo de derechos fundamentales y los valores de dignidad y libre desarrollo de la personalidad ha sido puesta de manifiesto expresamente por la doctrina del Tri bunal Constitucional alemán: BverfGE24, 119. Asimismo, el Tribunal de Karlsruhe ha ampliado dicha reflexión al considerar el paulatino proceso de maduración psíquica del niño.

992 Cfr. RAMOS CHAPARRO, E. "Niños y jóvenes en el derecho civil y constitucional", Revista de Derecho Privado y Constitución, núm. 7, Madrid, año 1995, página 190.

993 TRIGUERO MARTÍNEZ, L. A. "Los derechos sociales fundamentales de los extranjeros en un escenario de reformas estructurales y perspectiva de futuro ante la Directiva de permiso único de residencia y trabajo.", Revista de Derecho Migratorio y Extranjería, núm. 30, Ed. Lex Nova, Valladolid, página 99 a 115.

994 Los avances que se han suscitado en el reforzamiento de la autonomía de los menores, no impidieron al constituyente español, sin embargo, y considerando que la capacidad iusfundamental no era áun plena, sancionar la protección jurídica de los niños como un principio rector de la política social y económica del Estado, principio que debe informar la legislación positiva, la práctica judicial y la actuación de los poderes públicos. Ello significa que la Norma Suprema no desconoce la condición de especial fragilidad en que se encuentra el individuo durante su minoría de edad, lo que convierte a ésta en una etapa del desarrollo de su personalidad constitucionalmente protegida. Cfr. MARTÍNEZ DE AGUIRRE, C. "La protección jurídico-civil por razón de la menor edad", Anuario de Derecho Civil, Madrid, año 1992, página 1450, el autor indica que: "En los ordenamientos jurídicos moder- 
debe distinguir, porque la CE lo único que hace es dar contenido al concepto "mayoría de edad" estableciéndolo en los 18 años, sin que ello prejuzgue la capacidad para poder ejercer plenamente derechos fundamentales sin que se haya alcanzado dicha edad ${ }^{995}$.

Por otra parte, la condición de beneficiario de un derecho fundamental se adquiere inicialmente con la titularidad del mismo. Antes de abordar la cuestión de cuándo se adquiere esa titularidad y a qué tipo de individuos corresponde, o la de cuáles son las condiciones constitucionalmente necesarias para su ejercicio, es preciso deslindar la titularidad de la capacidad jurídica iusfundamental. Esta última se refiere a una cualidad potencial a la que el ordenamiento jurídico atribuye relevancia, mientras que, por el contrario, la titularidad tiene por objeto una cualidad actual.

En efecto, la capacidad jurídica iusfundamental refleja la abstracta capacidad del individuo para ser sujeto de imputación de derechos y obligaciones fundamentales, esto es, para ser titular de ellos. Por su parte, la titularidad de los derechos fundamentales hace referencia a la concreta atribución de un derecho o un deber fundamental que el ordenamiento ha realizado a favor de un individuo, generando con ello las diversas posiciones jurídicas en las que éste se encuentra en relación con el poder público y con los demás particulares. De ahí que la capacidad jurídica iusfundamental no puede estar sujeta a condiciones o requisitos ni internos ni externos para el ejercicio de los derechos, pues su objeto no es el derecho mismo, sino la aptitud virtual para ser titular del mismo. Dichas condiciones y requisitos se aplicarían en su caso, a la titularidad o al ejercicio de los derechos fundamentales. La mera adquisición de la personalidad es, conforme al artículo 10.1 CE, el único requisito para la posesión de dignidad y para el disfrute de la capacidad jurídica iusfundamental a ella anudada, que, en ese sentido, vendría a identificarse con la capacidad para ser titular de los derechos inviolables que le son inherentes ${ }^{996}$.

Por ello, aunque el ordenamiento haya querido dispensar un trato desigual a los individuos y no convertirlos simultáneamente en titulares de todos los derechos, distinguiendo, por ejemplo, entre nacionales y extranjeros, sí ha decidido conferirles a todos la misma abstracta capacidad para alcanzar dicha titularidad desde el momento en que adquieren la personalidad. Todas las personas tie-

nos que tngan consagrados constitucionalmente los principios de libre desarrollo de la personalidad y de no discriminación, como es el caso del español, el fundamento de la menor edad reside en las condiciones de inmadurez -física, psicológica, social- de quien es menor de edad y que le imposibilitan valerse por si mismo; y su finalidad no es otra que dotar a quien se encuentra en ella de la necesaria protección que le permite su desarrollo personal hasta alcanzar la madurez”.

995 Cfr. ASENSIO SÁNCHEZ, M. A., "Minoría de edad y derechos fundamentales: su ejercicio por el menor de edad”, Revista General de Derecho Canónico y Derecho Eclesiástico del Estado, núm. 7, enero, Madrid, año 2005, página 7, www.iustel.com,

MARTÍNEZ RUANO, P. “La capacidad iusfundamental del menor”, ...op. cit., página 89. 
nen idéntica capacidad jurídica iusfundamental, en base a la dignidad y el libre desarrollo de la personalidad, como plasmación del principio democrático, se infiere del artículo 10.1 CE. Esa capacidad jurídica iusfundamental, y no el mero arbitrio interpretativo, explica que nuestro Tribunal Cons-

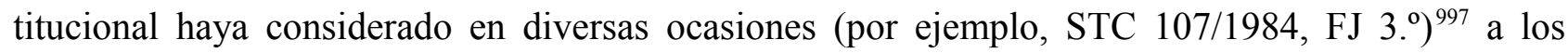
extranjeros titulares, -de derechos constitucionales de configuración legal y no de meros derechos legales- de aquellos que, aun inicialmente atribuidos sólo a los españoles, les venga extendidos por Tratado o por Ley conforme al artículo 13 CE. Pero también explica que el legislador no sea totalmente libre a la hora de determinar quién adquiere la nacionalidad española, pues, de serlo, podría configurarla de tal modo que determinadas personas quedasen para siempre totalmente excluidas, por su mero status de extranjeras, de la posibilidad de convertirse en españoles y, con ello, ser titulares del derecho de sufragio activo y pasivo en las elecciones a Cortes Generales o las Asambleas legislativas de las comunidades autónomas (único derecho no extensible a los extranjeros y reservado en exclusiva a los nacionales) $)^{998}$.

Este marco constitucional de la capacidad jurídica iusfundamental explica que los status del individuo se vean relativizados, en la medida en que no se trata de posiciones absolutas en las que se encuentre éste de forma necesaria a lo largo de determinados períodos de su existencia o como consecuencia de determinados rasgos naturales. Muy al contrario, la dignidad común a todas las

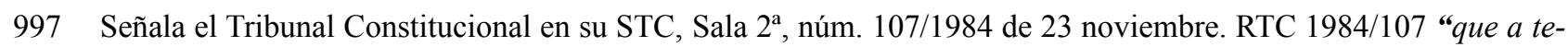
nor del art. 13 de la Constitución, "los extranjeros gozarán en España de las libertades públicas que garantiza el presente título en los términos que establezcan los tratados y la Ley”. Ello supone que el disfrute de los derechos y libertades -el término "libertades públicas" no tiene, obviamente, un significado restrictivo- reconocidos en el Título I de la Constitución se efectuará en la medida en que lo determinen los tratados internacionales y la Ley interna española, y de conformidad con las condiciones y el contenido previsto en tales normas, de modo que la igualdad o desigualdad en la titularidad y ejercicio de tales derechos y libertades dependerá, por propia previsión constitucional, de la libre voluntad del tratado o la Ley.

No supone, sin embargo, tal previsión que se haya querido descontitucionalizar la posición jurídica de los extranjeros relativa a los derechos y libertades públicas, pues la Constitución no dice que los extranjeros gozarán en España de las libertades que les atribuyan los tratados y la Ley, sino de las libertades "que garantiza el presente título en los términos que establezcan los tratados y la ley”, de modo que los derechos y libertades reconocidos a los extranjeros siguen siendo derechos constitucionales, por lo tanto, dotados -dentro de su especifica regulación- de la protección constitucional, pero son todos ellos sin excepción en cuanto a su contenido derechos de configuración legal. Esta configuración puede prescindir de tomar en consideración, como dato relevante para modular el ejercicio del derecho, la nacionalidad o ciudadanía del titular, produciéndose asi una completa igualdad entre españoles y extranjeros, como la que efectivamente se da respecto de aquellos derechos que pertenecen a la persona en cuanto tal y no como ciudadano, o, si se rehuye esta terminología ciertamente equívoca, de aquellos que son imprescindibles para la garantía de la dignidad humana que, conforme al art. 101 de nuestra Constitución, constituye fundamento del orden politico español. Derechos tales como el derecho a la vida, a la integridad física y moral, a la intimidad, a la libertad ideológica, etc., corresponden a los extranjeros por propio mandato constitucional y no resulta posible un tratamiento desigual respecto a ellos en relación a los españoles." También se cita, en el mismo sentido, STS, Madrid, Sala de lo contencioso-administrativo, Sección $5^{\text {a }}$, núm. 1348/2006 de 28 septiembre. JUR 2006/268516

998 MARTÍNEZ RUANO, P. “La capacidad iusfundamental del menor”, ... op. cit., página 91. 
personas por el hecho de serlo hace que todas puedan transitar en distintos momentos de su vida por varios de estos status ${ }^{999}$.

La condición jurídica de los menores ha ido evolucionando históricamente, se sabe y se ha pronunciado anteriormente ${ }^{1000}$. Los menores, los niños, se integraban como un elemento más, a la propiedad privada y al patrimonio de los padres ${ }^{1001}$ que estos administraban con potestad absoluta y sometimiento total. El abandono, la brutalidad, la violencia y el abuso fueron circunstancias por las que transitaron los menores a lo largo de la historia. Progresivamente y ante la variedad de abusos cometidos contra la infancia sobre todo en lo que se refiere al trabajo infantil, aflora su condición de sujetos desvalidos que merecen una protección y el reconocimiento de unos derechos. Pero aún no se les atribuía la posibilidad de defender tales derechos por sí mismos. Será muy tardíamente, tras la Segunda Guerra Mundial, cuando se considere al menor como un ser con autonomía y capacidad para afirmarse como sujeto de sus propios derechos. Ya han sido mencionadas en el presente trabajo pero nuevamente debe manifestarse la evolución que sobre este punto se ha venido manteniendo desde la Declaración Universal de los Derechos Humanos aprobada por la Asamblea General de las Naciones Unidas en diciembre de 1948 que incluía implícitamente las libertades y derechos de los niños hasta llegar a la Declaración Universal de los Derechos del Niño adoptada en 1959 por la Asamblea General de las Naciones Unidas ${ }^{1002}$.

Un paso decisivo lo constituye la Convención de Derechos del Niño de 1989, texto que recorriendo las diversas situaciones vitales en las que se puede encontrar un menor, le atribuye derechos que garanticen su protección en todas ellas. Esta Convención parte de un concepto de niño expresado en su artículo 1: "todo ser humano menor de dieciocho años de edad, salvo que, en virtud de la Ley que le sea aplicable, haya alcanzado antes la mayoría de edad”. Por tanto, todos los niños son

999 ENÉRIZ OLAECHE, F. “La protección de los derechos fundamentales y las libertades públicas en la Constitución Española”, Universidad Pública de Navarra, Pamplona, año 2007, página 117. "A pesar que el art. 14 CE proclama que los españoles son iguales ante la ley sin que pueda prevalerce discriminación por razón de nacimiento o cualquier otra condición o circunstancia social, la edad y la incapacidad introducen importantes diferencias jurídicas cuando no en la titularidad de los derechos, si en su ejercicio o capacidad de obrar...Las cues tiones más interesantes las plantea, precisamente, la edad, entendido este concepto de forma muy amplia. En efecto el devenir de la vida provoca que los derechos no sea iguales según se trate de un individuo concebido y no nacido (nasciturus), de un menor de edad o del cumplimiento o carencia de determinadas edades."

1000 WINTERSBERGER, H. “Infancia y ciudadanía: el orden generacional del Estado de Bienestar”, en Revista Política y Sociedad, volumen 43, número 1, Madrid, año 2006, páginas 81 a 83.

1001 TRINIDAD NUÑEZ, P. "La cara oscura de las relaciones familiares: la protección internacional del niño frente a los miembros de su propia familia” en Anuario de la Facultad de Derecho (Universidad de Extremadura) Volumen XXII, año 2004, páginas 133 a 158.

1002 GARCIA MEDINA, J. “Crisis matrimoniales y derechos de los menores”, en GUILARTE MARTÍN-CALERO, C. (Coord.) “Aspectos civiles y penales de las crisis matrimoniales”, Ed. Lex Nova, Valladolid, año 2009, página 241 . 
sujetos de ese conjunto de derechos y titulares acreedores de una efectiva protección y aplicación, sin distinción o discriminación alguna como señala el artículo 18. Están especialmente llamados a defender los derechos de los niños: padres, representantes legales, Estado e Instituciones públicas y privadas con capacidad para intervenir en interés del menor, y aquí radica la principal importancia de este punto, defender los derechos fundamentales de los menores es actuar en pro de su interés, que es superior, por su especial vulnerabilidad y fragilidad, psíquica, psicológica y física, es así como el derecho fundamental se concreta en el interés concreto de cada niño ${ }^{1003}$.

Los derechos del niño se fundamentan en la dignidad inherente a toda persona humana y en aquellos valores que la representan. En el propio preámbulo de la Convención se dice que: “Considerando que, de conformidad con los principios proclamados en la Carta de las Naciones Unidas, la libertad, la justicia y la paz en el mundo tienen por base el reconocimiento de la dignidad intrínseca y de los derechos fundamentales del hombre y en la dignidad y el valor de la persona humana, y su determinación de promover el progreso social y elevar el nivel de vida dentro de un concepto más amplio de libertad...". Sin embargo, la Convención pretende ser más concreta en su fundamentación y en su oferta de seguridad jurídica, al señalar en el preámbulo que "el niño, por su falta de madurez física y mental, necesita protección y cuidado especiales, incluso la debida protección legal, tanto antes como después del nacimiento”. El artículo 3.1 de esta Convención indica que "en todas las medidas concernientes a los niños que tomen las instituciones públicas o privadas de bienestar social, los Tribunales, las autoridades administrativas o los órganos legislativos, una consideración primordial a que se atenderá será el interés superior del menor”.

Los derechos que corresponden a los niños, a los efectos que aquí interesan serían entre otros $^{1004}$, resumidamente.

1003 Cfr. BARRERO ORTEGA, A. "Libertad religiosa y deber de garantizar la vida del hijo (A propósito de la STC 154/2002, de 18 de julio)”, Revista Española de Derecho Constitucional, núm. 75, septiembre-diciembre, Madrid, año 2005, página 335. Tiene relación también la STS, Sala de lo Contencioso-Administrativo, Sección 4a de 22 febrero 2011. RJ 2011/1260, pero el interés del menor en este caso es enfocado bajo el prisma del derecho de los padres para escoger la educación de sus hijos.

1004 Además la Convención reconoce como derechos: derecho a la vida (artículo 6): “1. Los Estados Partes reconocen que todo niño tiene el derecho intrínseco a la vida. 2. Los Estados Partes garantizarán en la máxima medida de lo posible la supervivencia y el desarrollo del niño”; derecho al nombre a la nacionalidad (artículo7): “1. El niño será registrado inmediatamente después de su nacimiento y tendrá derecho desde éste a un nombre, y a adquirir una nacionalidad”. El derecho a la información (artículos 13 y 17): Artículos 13.1: “El niño tendrá derecho a la libertad de expresión, ese derecho incluirá la libertad de buscar, recibir y difundir informaciones e ideas de todo tipo, sin consideración de fronteras, ya sea oralmente, por escrito o impresas, en forma artística o por cualquier otro medio elegido por el niño". Artículo 17: “Los Estados Partes reconocen la importante función que desempeñan los medios y velarán porque el niño tenga acceso a información y material procedente de diversas fuentes nacionales e internacionales, en especial la información y el material que tengan por finalidad promover su bienestar social, espiritual y moral y su salud física y mental”; derecho a la libertad de asociación y 
1. El derecho a la protección familiar (artículos 7, 18, 20 y 27):

1.1. Artículo 7.1: El derecho, en la medida de lo posible, a conocer a sus padres y a ser cuidado por ellos.

1.2. Artículo 18.1: Incumbirá a los padres o, en su caso, a los tutores, la responsabilidad primordial de la crianza y el desarrollo del niño. Su preocupación fundamental será el interés superior del niño.

1.3. Artículo 20: Los niños temporal o permanentemente privados de su medio familiar, o cuyo superior interés exija que no permanezcan en ese medio, tendrán derecho a la protección y asistencia especiales del Estado.

1.4. Artículo 27: 1. Los Estados Partes reconocen el derecho de todo niño a un nivel de vida adecuado para su desarrollo físico, mental, espiritual, moral y social. 2. A los padres u otras personas responsables por el niño les incube la responsabilidad primordial de proporcionar, dentro de sus posibilidades y medios económicos, las condiciones de vida que sean necesarias para el desarrollo del niño.

2. El derecho a la intimidad, (artículo 16):

2.1. Los Estados Partes reconocen el Derecho del niño a no ser objeto de injerencias arbitrarias o ilegales en su vida privada, su familia, su domicilio o su correspondencia...

2.2. El niño tiene derecho a la protección de la ley contra tales injerencias o ataques.

3. El derecho al honor (artículo 16):

3.1. Los Estados Partes reconocen el derecho del niño a no ser objeto de... ataques ilegales a su honra o a su reputación.

3.2. El niño tiene derecho a la protección de la Ley contra esas injerencias o ataques.

4. El derecho a la libertad de expresión (artículos 12 y 13):

a la libertad de reunión (artículo 15): “Los Estados Partes reconocen los derechos del niño a la libertad de asociación y a la libertad de celebrar reuniones pacíficas. No se opondrán restricciones al ejercicio de estos derechos distintas de las establecidas en conformidad de la ley que sean necesarias en una sociedad democrática, en interés de la seguridad nacional o pública, el orden público, la protección de la salud y la moral públicas o la protección de los derechos y libertades de terceros"; derecho a la salud (artículo 24); derecho a la asistencia sanitaria (artículo 25); derecho a la seguridad social (artículo 26); derecho a la educación (artículos 28 y 29); derecho a no ser discriminado en razón de su origen étnico, o por su pertenencia a una minoría racial o religiosa, o lingüística (artículo 30); derecho al descanso y al ocio (artículo 31.1); derecho a participar plenamente en la vida cultural (artículo 31.2); derecho a estar protegido contra la explotación económica (artículo 32); derecho a estar protegido contra todas las formas de explotación y abusos sexuales (artículo 34); derecho a la seguridad personal, previsto en el artículo contra la venta y trata de niños (artículo 35); derecho a la seguridad personal, frente a las torturas y los tratos o penas crueles, inhumanos o degradantes (artículo 37a); derecho a la libertad (artículo 37.b), c) y d); derecho a la protección de las normas de Derecho Humanitario (artículo 38); derecho a las garantías pro cesales (artículo 40). 
4.1. Artículo 12.1: Los Estados Partes en la presente Convención garantizarán al niño que esté en condiciones de formarse un juicio propio del derecho de expresar su opinión libremente en todos los asuntos que le afecten, teniéndose debidamente en cuenta sus opiniones, en función de su edad y de su madurez.

4.2. Artículo 13.1: El niño tendrá derecho a la libertad de expresión, ese derecho incluirá la libertad de buscar, recibir y difundir informaciones e ideas de todo tipo, sin consideración de fronteras, ya sea oralmente, por escrito o impresa.

5. El derecho a la libertad de pensamiento, de conciencia y de religión (artículo 14) ${ }^{1005}$.

De una u otra manera se puede vislumbrar que el menor es considerado, de conformidad a las características que su camino de madurez implica, plenamente titular de sus derechos fundamentales, es más, goza de especiales prerrogativas por cuanto requiere de una protección tal que no es necesaria en las personas adultas. Sin duda, el Derecho se preocupa por el menor no tanto ya como futuro propietario, sino que en su calidad de incipiente ciudadano, por ello la los ordenamientos jurídicos, tanto el español como aquellos de su misma raíz han abierto sus fronteras para que mediante diversos convenios se logre una más efectiva y plena tutela en todos los ámbitos que le conciernen al menor ${ }^{1006}$.

Tal como se afirmó antes, el interés superior del niño se afirma como uno de los principios rectores de la Ley Orgánica 1/1996 de Protección Jurídica del Menor, la cual en parte de su articulado también hace referencia a derechos fundamentales y debido a que en el artículo 2.a) se señala que: "en la aplicación de la presente Ley primará el interés superior de los menores sobre cualquier otro interés legítimo que pudiera concurrir", tales derechos deben ser aplicados e interpretados bajo ese prisma. Asimismo el artículo 3 de esta Ley indica que derechos corresponden a los menores y son los "que reconoce la Constitución y los Tratados Internacionales de los que España sea parte especialmente la Convención de los Derechos del Niño de Naciones Unidas y los demás

1005 GARCIA MEDINA, J. “Crisis matrimoniales y derechos de los menores”...op. cit. página 242

1006 Por ello pueden deducirse los parámetros constitucionales que definen la posición jurídica del menor de edad y que intentan reflejar pero también armonizar dos principios que son complementarios pero a veces contrapuestos. En primer lugar, el reconocimiento del menor como sujeto activo de los derechos fundamentales que la norma suprema atribuye a toda persona desde su nacimiento y, en segundo lugar, la estimación del niño como acreedor de un mandato de especial protección sobre el que se asienta la necesidad de tutelar el proceso evolutivo en que consiste la minoría de edad. Ambos indican, no está demás decirlo, el aspecto dinámico de la minoría de edad. Es generalmente admitido que no puede hablarse de una sola infancia habida cuenta que la presencia de diferentes franjas de edad en el seno de la misma es consustancial al carácter evolutivo del desarrollo físico y psíquico del ser humano. Dicho carácter dinámico incide inevitablemente en el régimen de ejercicio de los derechos fundamentales por parte del menor de edad en la medida que su capacidad natural va construyéndose y desarrollándose de forma progresiva. Cfr. VV. AA. "Teoría General de los Derechos Fundamentales en la Constitución española de 1978”, Ed. Tecnos, Madrid, año 2004, página 44. 
derechos garantizados en el ordenamiento jurídico”. Más específicamente el derecho al honor, a la intimidad y a la propia imagen (artículo 4); el derecho a la información (artículo 5); a la libertad ideológica (artículo 6); derecho de participación, asociación y reunión (artículo 7); derecho a la libertad de expresión (artículo 8); derecho a ser oído (artículo 9). Para la realización efectiva de estos derechos, la Ley hace una llamada explícita en estos artículos a los padres para que respeten, protejan, velen, cooperen y promuevan tales derechos ${ }^{1007}$.

En consecuencia, se sostiene que la Constitución de 1978 no tiene prevista una genérica incapacidad para el obrar iusfundamental de los menores, sino sólo la posibilidad de contemplar legalmente incapacidades específicas, derivadas de la conjunción entre el ejercicio del derecho fundamental y el mandato constitucional de protección del menor, acentuando el hecho de que el menor no goce de las condiciones suficientes de madurez ${ }^{1008}$. Será el Legislador el que estableciendo determinadas condiciones para el ejercicio de un derecho fundamental o cuando lo delimita, excluyendo del mismo determinadas conductas en aras de la protección del menor o de otros bienes o derechos fundamentales, justifique suficientemente la conformidad constitucional de esas limitaciones o delimitaciones $^{1009}$. De no existir debe presumirse la capacidad de obrar iusfundamental del sujeto menor $^{1010}$.

Al menor de edad debe reconocérsele, como principio general, una capacidad amplia para el ejercicio de sus derechos fundamentales que vendrá a sustanciarse en virtud de su capacidad natural, esto es de su discernimiento o grado de madurez, pues el libre desarrollo de la personalidad estipulado en el 10.1 CE así lo dispone.

1007 GARCIA MEDINA, J. “Crisis matrimoniales y derechos de los menores”, ...op. cit. página 243.

1008 GARCÍA GARNICA, M. C. "El Ejercicio de los Derechos de la Personalidad del Menor no Emancipado, Especial consideración al consentimiento y a los actos médicos y a las intromisiones en el honor, la intimidad y la propia imagen”, Ed. Thomson Aranzadi, Cizur Menor, año 2004, página 78. Corrobora esta tesis el hecho de que también en el ámbito iusprivatista el ejercicio de los llamados derechos de la personalidad, no se rige por la regla general de a capacidad de obrar, sino por la aptitud de su titular para comprender y querer el alcance de sus actos o por las condiciones de madurez de mismo, utilizando los términos que emplea el Legislador en el art. 162 del CC. En definitiva, por la capacidad natural del titular de estos derechos. Autores como DÍEZ-PICAZO y PONCE DE LEÓN, L. y GULLÓN BALLESTEROS, A., consideran que todos los derechos de la personalidad han sido elevado a fundamentales aunque defienden que no existe una equiparación total entre ambas categorías, véase tal postura en "Introducción. Derecho de la persona. Autonomía privada. Persona jurídica”, Sistema de Derecho Civil I, Ed. Tecnos, Madrid, año 2001, página 323; ORTI VALLEJO, A. "Derecho a la intimidad e informática (tutela de la persona por el uso de ficheros y tratamiento informático de datos personales. Particular atención a los ficheros de tipo privado”, Ed. Comares, Granada, año 1994, página 33. Este último autor sostiene la total correspondencia entre los derechos de la personalidad y los derechos fundamentales.

1009 VALERO HEREDIA, A. "La libertad de conciencia del menor de edad desde una perspectiva constitucional”, ...op. cit., página 52.

1010 ALÁEZ CORRAL, B. “Minoría de edad y derechos fundamentales”, ...op. cit., página 124. 
La consideración de la minoría de edad como una situación dinámica, marcada por lo que la Ley de Protección Jurídica del Menor ha denominado hecho evolutivo ${ }^{1011}$, condiciona el régimen de ejercicio de los derechos fundamentales de los que el menor es titular, siendo el estadio de madurez o grado de discernimiento alcanzado por éste el criterio jurídico más adecuado para graduar su ejercicio autónomo ${ }^{1012}$. Reconocer a los menores de edad un ámbito de capacidad general para el autoejercicio de sus derechos fundamentales, aunque limitado en función de su capacidad natural, implica reconocer que la potenciación de su autonomía es el instrumento más adecuado para favorecer el libre desarrollo de su personalidad sin desconocer la necesidad de ampararlo cuando su aptitud volitiva e intelectiva no hubiese alcanzado cuotas suficientes de madurez ${ }^{1013}$. Finalmente debe manifestarse que la asunción de un determinado grado de madurez puede ser suficiente para el ejercicio autónomo de un determinado derecho fundamental y no así para el ejercicio directo de otro. Sin duda las condiciones de madurez no pueden juzgarse por criterios generales y objetivos sino deben relacionarse con cada sujeto de Derecho concreto, es decir, con cada menor en particular.

\section{2 | Los significados del concepto de principio para comprender el interés del menor como tal}

Como se manifestó en la introducción del presente trabajo el término "principio" puede adoptar significados diversos. Los principios aparecen como normas de enunciado y consecuencias formuladas de modo general y abstracto. Lo cual contribuye a su vaguedad pues dado su alcance indeterminado es posible abarcar diversos casos.

Así, el principio del interés superior del menor reuniría muchos de los rasgos ya aludidos, con anterioridad, debido a que el ordenamiento jurídico ha querido elevar a fundamental la protección integral del menor y presentarlo como criterio prevalente de interpretación, si bien con las suficientes dosis de vaguedad de forma que quepan en él situaciones diversas y complejas. Puede entenderse que este principio es una expresión de lo establecido en el artículo 39 de la CE en la que insta a la

1011 SANTOS MORÓN, M. J. "Sobre la capacidad del menor para el ejercicio de los derechos fundamentales. Comentario a la STC 154/2002, de 18 de julio”, La Ley, Revista Jurídica Española de Doctrina, Jurisprudencia y Bibliografía, núm. 5675, Madrid, año 2002, página 1634.

1012 La autonomía del menor también viene ligada a la madurez del mismo tanto en la Convención Internacional de los Derechos del Niño de 1989 como en el Convenio Europeo sobre el ejercicio de los Derechos del Niño de enero de 1996 . Aunque el tema de la autonomía del menor fue tratado en el capítulo anterior y me remito a aquel.

1013 Vid. DELL'ANTONIO, V. A. M., “La partecipazione del minore alla sua tutela. Un diritto misconosciuto”, Giuffrè, Milán, año 2001, página 105. Este autor ha identificado este criterio con la capacidad del menor para distinguir la naturaleza y el valor de las cosas, para comprender aquello que le es útil y para decidir al respecto de manera autónoma y sin ser influenciado por la voluntad de terceros. 
protección integral de los hijos menores de edad, al menos así ha sido entendida por la ya citada STC, Pleno, núm. 273/2005 de 27 de octubre RTC 2005/273 ${ }^{1014}$. Es decir, este principio no sólo forma parte de los principios rectores de la política social y económica consagrados en los artículos 39 a 52 de la CE sino que también es un principio general del Derecho Privado, lo cual ya fue manifestado.

En este doble sentido el principio del interés jurídico superior del menor opera: “a) como instrumento informador de instituciones que afectan a las personas que se pretende proteger (patria potestad, tutela, desamparo y acogimiento, adopción) para lo que da directrices para la consecución de fines constitucionales (protección de los menores); b) proporciona criterios de interpretación (eminentemente teleológica) coherentes con ese principio y sistema de valores subyacentes, de normas directas o conexas que alcanzan a menores; y c) deviene norma supletoria de aplicación (artículo 1.4 del CC), cuando proceda a falta de otra norma especial, es decir, fuera de los casos tipificados (función de integración del ordenamiento)" ${ }^{1015}$. Este principio no tiene un carácter absoluto sino relativo, pero cuando haya que introducir límites se han de utilizar argumentos de razonabilidad y ponderación que atiendan a los beneficios y ventajas de la decisión a adoptar.

Junto con lo anterior es necesario averiguar en qué consiste el interés del menor y como procede a su concreción, y en el caso de vincularlo con otros derechos fundamentales cuales serían sus diversas implicaciones.

Cuando se toma una decisión judicial en los procesos de separación y divorcio que afecte a los menores se dice que ha de respetar el interés superior del menor, el cual opera como "regla de reconocimiento"1016 (fija el criterio último de validez que permite validar la pertenencia e idoneidad de una solución) dentro del modelo de protección jurídica de los menores articulado por el sistema legislativo. Dicho de otro modo, cuando surgen situaciones en las que se habla del interés del menor

1014 La sentencia expresa: “Así pues, resulta claro que, en la ponderación de los intereses en presencia, el legislador ha optado por otorgar prevalencia al del hijo, teniendo especialmente en cuenta el valor constitucional relevante de la protección integral de los hijos (artículo 39.2 de la CE), sin perder de vista, al mismo tiempo, la seguridad jurídica (artículo 9.3 de la CE), en el estado civil de las personas. "; Cfr. STS, Sala de lo Contencioso-Administrativo, Sección 3 $3^{\mathrm{a}}$, de 14 febrero 2011. RJ 2011/1388.

1015 Vid. RIVERO HERNÁNDEZ, F. “El interés del menor”, ...op. cit., páginas 84 y 85.

1016 Se toma la definición de HART de regla de reconocimiento, pero dándole un sentido distinto. Para HART, la regla (o reglas) de reconocimiento tienen como función establecer los criterios últimos de validez que permiten certificar la pertenecía de una norma a un ordenamiento jurídico. Vid. "Derecho y moral. Contribuciones a su análisis”,,(contiene tres ensayos de Hart: El positivismo jurídico la separación entre derecho y moral; ¿Hay derechos naturales? y Definición y teoría en la ciencia jurídica). ¿Existen Derechos Naturales? - revista Estudios Públicos del CEP, Santiago de Chile, año 1990 
materializado en la necesidad de protección de sus derechos (libertad, educación, salud, integridad, etc) la decisión que se tome habrá de estar presidida por este principio.

Es evidente que la determinación del interés del menor es muy compleja pues depende de variables a considerar en cada caso concreto: a) situaciones que afectan sólo al menor; situaciones de conflicto de intereses; situaciones de conflicto con los derechos de otros; b) circunstancias concretas en que se produce la crisis matrimonial; c) relaciones previas del menor con sus padres, abuelos, familiares; d) madurez del menor para entender y comprender la situación; e) disponibilidad de recursos económicos, etc ${ }^{1017}$.

Si se tiene en cuenta que la minoría de edad se extiende hasta los 18 años, la edad y la madurez del menor son elementos a considerar a la hora de tomar en cuenta las opiniones de los menores. El interés del menor es algo más que la manifestación de una opinión, para que ésta sea considerada ha de constatarse que es su propia opinión que entra dentro de lo razonable y de lo objetivamente valioso para el menor. En la concreción del interés del menor entran en liza las concretas circunstancias personales del menor y "los parámetros ideológicos y sociológicos del momento, las condiciones y la sensibilidad del grupo social en que esté o deba estar inserto el menor, con ayuda de datos y criterios sociológicos, psicológicos, éticos y demás (metajurídicos todos ellos)" ${ }^{1018}$. Apreciada la complejidad existente alrededor de esta cuestión, se ha de centrar la atención sobre la materialización del interés del menor desde la perspectiva jurídica. El menor es una persona en formación y por lo tanto como tal persona en desarrollo necesita esencialmente la garantía y protección especial de sus derechos fundamentales (así se aprecia en la LOPJM). A partir de ahí se podrán hacer las interpretaciones sobre el interés del menor que se quieran, pero siempre respetando el núcleo de sus derechos fundamentales y los derechos que de ellos se deriven. Dadas las múltiples dimensiones que contribuyen a formar la personalidad de un menor, no se puede desatender en las decisiones que

1017 FERNÁNDEZ CASADO, Ma . D. “Una aproximación al principio del interés superior del menor” en Asociación de letrados de la Junta de Andalucía, “La protección jurídica del menor”, Ed. Comares, Granada, año 1997, páginas 247 a 252. La autora sostiene que tal cual ya se ha mencionado el interés superior del niño ha sido consagrado por la Convención en su art. 3 como un concepto fundamental alrededor del cual deben articularse todos los derechos reconocidos al niño como sujeto de derecho. Para explorar el alcance de dicho principio es importante considerar: ¿Quién y cuando ha de aplicarlo?. Debe ser tratado como consideración primordial en todas las actuaciones concernientes a los niños en instituciones benéficas públicas o privadas, en los Tribunales de Justicia y en cuerpos legislativos y normas administrativas. Esta frase debe servir como guía para determinar cundo debe ser aplicado el principio. La referencia a todas las medidas concernientes a los niños indica que el principio debe aplicarse en su mayor amplitud. ¿Qué peso se debe dar al Principio?. Ha de tener un interés primordial en todas las actuaciones que le conciernen. La citada Convención establece que el Principio del superior interés del menor ha de ser aplicado por todos los que tienen poder de decisión, en el ámbito público y privado, que actúan en materias relativas a los niños, con primordial consideración en todos los casos.

1018 Vid. RIVERO HERNANDEZ, F. “El interés del menor”, op. cit., páginas 152-153. 
le afecten los aspectos materiales de subsistencia pero tampoco los aspectos afectivos que coadyuven a su felicidad.

Ha de combinarse en un justo equilibrio las necesidades presentes con las futuras, para conseguir una cobertura coherente de los actuales y futuros intereses del menor. Se trata, por tanto, de facilitar al menor todo lo necesario con el objetivo de conseguir desarrollar su personalidad e identidad propias.

El núcleo del interés del menor lo componen, como se ha señalado, los derechos fundamentales. Ahora bien, hay algunos derechos fundamentales que deben ser especialmente considerados en una situación de crisis matrimonial como se deduce cuando, por ejemplo, se observa el contenido bien de los convenios reguladores en caso de mutuo acuerdo, bien de las diferentes medidas judiciales, centrados esencialmente en cuestiones de custodia, régimen de visitas, ejercicio de la patria potestad, pensiones alimenticias, cuyo fin es proveer los medios para que los menores puedan ejercer con garantías tanto derechos fundamentales de primera generación (libertad, asociación, reunión, intimidad, etc.) como de segunda generación (derechos económicos y sociales: salud, asistencia sanitaria, educación). Pero el hecho de que se pacten o se regulen estos términos no impide que surjan disparidades que pueden dificultar el ejercicio de estos derechos.

\section{3 | Interferencias parentales e interés del menor}

En la delicada trama del proceso de divorcio se alude constantemente al interés del menor, como principio que primará sobre cualquier otro interés legítimo con el que pueda concurrir, especialmente, cuando se trate de adoptar cualquier medida que pueda afectarle, este superior interés en la generalidad de los casos impera bajo el mandato de igualdad entre los padres en lo concerniente a sus relaciones con el menor. A modo de ejemplo cito lo manifestado en el Decreto Legislativo 1/2011, de Derecho Foral de Aragón, en su Preámbulo, concerniente al Libro I: “La preocupación por la protección del menor y de la familia ha sido una constante en las democracias más desarrolladas. Este principio se reconoce en el artículo 39RCL 1978/2836 de la Constitución española y en el Estatuto de Autonomía de Aragón, cuyo artículo 24RCL 2007/822 impone a los poderes públicos aragoneses adoptar políticas que garanticen la protección de las relaciones familiares y la igualdad entre el hombre y la mujer. Igualmente, la Convención sobre los Derechos del Niño, proclamada por la Asamblea General de las Naciones Unidas el 20 de noviembre de 1989 y ratificada por España el 30 de noviembre de 1990, obliga a los Estados a respetar el derecho del niño a mantener relaciones 
personales y contacto directo con ambos padres de modo regular, salvo que fuera contrario al interés superior del niño" ${ }^{1019}$.

Tras la ruptura de la pareja y ante la manifiesta imposibilidad de que ambos progenitores convivan a la vez con los niños, el tema más trascendente y controvertido será decidir, en consonancia con aquel interés, las futuras relaciones que mantendrán los menores con sus padres. A nadie se le escapa que serán éstos quienes se encuentran en la mejor posición para determinar lo más beneficioso para los menores en lo que al divorcio se refiere, que aconseja el mejor interés del menor; y cuya propuesta solo será rechazada cuando se justifique que tal acuerdo pudiera resultarle perjudicial. A falta de acuerdo, será el Juez, actuando con el amplio margen de discrecionalidad que le otorga la legislación, quien determinará cuál de ellos ostentará la guarda y custodia, pudiéndola acordar -aún sin consenso- compartida y en caso contrario, quién ostentará el régimen de comunicación, estancia y visitas. Teniendo en cuenta que el interés implica en términos generales un amplio régimen de relación y contacto con ambos progenitores ${ }^{1020}$.

Relaciones que les permitirán continuar con los lazos de contacto y afectividad que devienen tan decisivos para la configuración de su carácter y joven personalidad en formación ${ }^{1021}$. Para la adopción de estas medidas, tanto en los supuestos de atribución inicial de la guarda y custodia, como en los de modificación de medidas, la legislación previene que el Juez pueda recabar la opinión del menor expresada por sí mismo o a través de especialistas.

1019 Decreto Legislativo núm. 1 de 2011 y el Texto Refundido que se aprueba con el título de "Código del Derecho Foral de Aragón", página 14 y 15.

1020 Entre otros instrumentos internacionales, así lo recoge, el art. 9 de la Convención de los Derechos del Niño de Naciones Unidas de 20 de noviembre de 1989 (ratificada por España el 30 de noviembre de 1990): "Los estados partes espetarán el derecho del niño que está separado de uno o de ambos padres a mantener relaciones personales y contacto directo con ambos padres de modo regular, salvo si ello es contrario al interés superior del niño”. El art. 14 de la Carta Europea de los Derechos del Niño aprobada por el Parlamento Europeo en Resolución de 18 de julio de 1992 señala que "En caso de separación de hecho, separación legal, divorcio de los padres o nulidad de matrimonio, el niño tiene derecho a mantener contacto directo y permanente con los dos padres, ambos con las mismas obligaciones, incluso si alguno de ellos viviese en otro país, salvo si el órgano competente de cada Estado miembro lo declarase incompatible con a salvaguardia de los intereses del niño". Asimismo el artículo 24.3 de la Carta de los Derechos Fundamentales de la Unión Europea (de 7 de diciembre de 2001 e incorporada al Tratado por el que se establece una Constitución para Europa) señala que "Todo niño tiene derecho a mantener de forma periódica relaciones personales y contactos directos con su padre y con su madre, salvo si ello es contrario a sus intereses".

1021 SECCIÓN PRÁCTICA, "Cambio de residencia del progenitor custodio en relación con la custodia de los hijos”, Revista de Derecho de Familia, núm. 35, Ed. Lex Nova, Valladolid, abril-junio de 2007, año 2007, página 255. "Antes de dar el paso y solicitar el cambio de guarda y custodia, es necesario sopesar si realmente ésa es la petición que exige el interés de los hijos, porque, en muchas ocasiones, las disfunciones que se producen en las relaciones del progenitor no custodio con los hijos, cuando estos cambian e residencia, quizás puedan tener solución adaptando el régimen de visitas a la nueva situación e incluso compartiendo los gastos que suponen el traslado tanto del progenitor no custodio como de los menores para el cumplimiento de las visitas". 
Una parte de la doctrina ${ }^{1022}$ veía en la guarda y custodia compartida el régimen de convivencia más adecuado para proteger el interés del menor, al permitir la continuidad de la relación familiar entre los hijos y los progenitores ${ }^{1023}$.

La Exposición de motivos de la ley que instauró el régimen de guarda y custodia compartida en estudio, Ley 15/2005, expresa que la reforma legislativa va encaminada -en cuestiones que afecten al ejercicio de la patria potestad y la guarda y custodia de los hijos menores o incapacitados-, a obtener el beneficio del interés del menor, y hacer ver a los progenitores que la responsabilidad con-

1022 GOIRIENA LEKUE, A. "La custodia compartida, el interés del menor y la neutralidad de género", Aequalitas: Revista jurídica de igualdad de oportunidades entre mujeres y hombres, núm. 16, Instituto aragonés de la mujer, Zaragoza, enero-junio 2005, página 52 y siguientes. Estima la custodia compartida como el régimen de convivencia más adecuado para proteger el interés del menor. En el mismo sentido se manifiesta CASTILLO MARTíNEZ C. C. "La determinación de la guarda y custodia de los menores en los supuestos de crisis matrimonial o convivencial de sus progenitores. Especial consideración de la guarda y custodia compartida tras la Ley 15/2005, de 8 de junio", Actualidad Civil, número 15, Primera quincena de septiembre de 2007, página 1750. Al apreciar la insuficiencia del régimen de custodia exclusiva en orden a la protección del interés del menor y al desarrollo de su personalidad, estima más conveniente una relación equitativa con ambos progenitores. El grupo de autores que a continuación están mencionados destacan que en la custodia compartida están presente los principios de igualdad de corresponsabilidad parental y de coparentalidad. Ello supone reconocer este modelo como el más idóneo de proteger el interés superior del menor. Para PINTO ANDRADE, C. "La custodia compartida", Ed. J. M" Bosch, Barcelona, año 2009, página 43. Lo característico de la custodia compartida es la ficción que se crea al procurar el mantenimiento de una normalidad de relación familiar, que realmente ha desaparecido, de los progenitores con los hijos; GODOY MORENO, A. "La guarda y custodia compartida. Guarda conjunta y guarda alternativa", en HERNÁNDEZ CATALÁN, G. y DE ANDRÉS IRAZAZÁBAL, C. (Coord.) "Diez años de Abogados de familia", Ed. La Ley-Actualidad, S.A., Madrid, año 2003, páginas 326 a 341. Destaca entre los argumentos favorables al sistema de guarda y custodia compartida el principio de igualdad de los progenitores y sería el sistema menos distorsionador para el normal coejercicio de la patria potestad y guarda del artículo 154 del Código Civil, ya que permite a los padres participar igualmente y sin discriminación en el desarrollo de los hijos.

1023 STS, Sala de lo civil, Sección 1a, núm. 961/2011 de 10 enero. RJ 2012/3642. "Esta Sala ha tenido ocasión de pronunciarse sobre el régimen de guarda y custodia compartida, en todos aquellos asuntos en los que se ha justificado el interés casacional. Así, en la sentencia de 28 septiembre 2009, RC núm. 200/2006, se interpretó el art. $92 \mathrm{CC}$ en el sentido siguiente: "[...] permite al juez acordarla en dos supuestos: a) cuando sea pedida por ambos progenitores (párrafo 5), y b) cuando a pesar de no existir esta circunstancia, se acuerde para proteger el interés del menor de forma más eficaz (párrafo 8). En cualquier caso, se debe recabar informe del Ministerio Fiscal, que debe ser favorable en el supuesto previsto en el pr. 8, se debe oir a los menores cuando tengan suficiente juicio, así como tener en cuenta el informe de los equipos técnicos relativos a «la idoneidad del modo de ejercicio de la patria potestad y del régimen de custodia» (artículo. 92.9 CC). Esta normativa debe completarse con lo establecido en el artículo 91 CC, que permite al Juez una amplia facultad para decidir cuál debe ser la solución adecuada a la vista de las pruebas que obran en su poder, de modo que en los procedimientos judiciales sobre menores no rige el principio dispositivo, tal como se afirma en la Exposición de Motivos de la vigente Ley de Enjuiciamiento Civil ... y regula el artículo 752.1 , 2 LECiv. Además en relación con la guarda y custodia compartida, el artículo 92.6 CC, establece que el juez debe «valorar las alegaciones de las partes vertidas en la comparecencia y la prueba practicada en ella, y la relación que los padres mantengan entre sí y con sus hijos para determinar su idoneidad con el régimen de guarda».- Los criterios que se deben de valorar en la atribución de la guarda y custodia compartida, también han sido analizados por esta Sala. Así en la sentencia de 8 octubre 2009, RC núm. 1471/2006, se señaló que " [...] el Código español no contiene una lista de criterios que permitan al Juez determinar en cada caso concreto qué circunstancias deben ser tenidas en cuenta para justificar el interés del menor en supuestos en que existen discrepancias entre los progenitores, que no impiden, sin embargo, tomar la decisión sobre la guarda conjunta. [...] Del estudio del derecho comparado se llega a la conclusión que se están utilizando criterios tales como la práctica anterior de los progenitores en sus relaciones con 
tinúa, a pesar de la separación o el divorcio. Reserva la intervención judicial cuando no sea posible el pacto entre los progenitores o éste sea contrario al interés del menor.

Sin embargo, la redacción del número 2 del artículo 92 del Código Civil no menciona el interés superior de los hijos, cuando el juez deba adoptar cualquiera medida sobre la custodia, el cuidado y la educación de los hijos menores. Únicamente está obligado a velar por el cumplimiento de su derecho a ser oídos. Ello parece un olvido del legislador, pues de las disposiciones establecidas sobre patria potestad en el mencionado artículo y de las normas que regulan la protección del menor en el Ordenamiento jurídico (arts. 2 y 11. 2 a) de la LO 1/1996 de Protección Jurídica del Menor y normas internacionales suscritas por España como el Convenio sobre los Derechos del Niño de 1989), no cabe descartar el interés superior del menor como principio inspirador de las medidas judiciales adoptadas en esta materia. Es "el interés superior de los hijos" la columna vertebral en la que engarza el modelo de guarda y custodia de los hijos, elegido tras la ruptura familiar ${ }^{1024}$, la decisión que asuman los tribunales deberá respaldarse en el, asimismo la petición de los progenitores.

Continuando con la búsqueda del contenido del "interés superior de los hijos" en las crisis familiares, nos preguntamos si la regulación de la guarda y custodia compartida de los hijos en el Código Civil, facilita algún elemento que nos ayude vislumbrar su concepto. Sin duda la reforma introducida por la Ley 15/2005, de 8 de julio, colabora poco en la determinación del contenido del favor filii. Así el núm. 4 del art. 92 del Código Civil se preocupa del interés superior del menor para deci-

el menor y sus aptitudes personales; los deseos manifestados por los menores competentes; el número de hijos; el cumplimiento por parte de los progenitores de sus deberes en relación con los hijos y el respeto mutuo en sus relaciones personales y con otras personas que convivan en el hogar familiar; los acuerdos adoptados por los progenitores; la ubicación de sus respectivos domicilios, horarios y actividades de unos y otros; el resultado de los informes exigidos legalmente, $y$, en definitiva, cualquier otro que permita a los menores una vida adecuada en una convivencia que forzosamente deberá ser más compleja que la que se lleva a cabo cuando los progenitores conviven".

1024 Para LÓPEZ ORDIALES, J. J. “Custodia compartida. Cuestiones procesales” en SARAVIA GONZALEZ, A. M. ${ }^{\mathrm{a}}$ y GARCIA CRIADO, J.J., (Dirs.) "La jurisdicción de familia: especialización. Ejecución de resoluciones y custodia compartida”, Consejo General del Poder Judicial, Estudios de Derecho Judicial, número 147-2007, Madrid, año 2008, página 260. La Ley 15/2005, de 8 de julio, ha consagrado al "bonum filii" como Principio Universal de Derecho, y así se desprende de cuantas disposiciones afectan a los hijos menores de edad. Incluso el principio de igualdad entre hombres y mujeres que incide sobre la guarda y custodia compartida de los hijos queda supeditado al interés superior del menor; SARAVIA GONZÁLEZ, A. M. ${ }^{a}$, ibidem, página 236. Estima que el interés superior del menor regulado en el art. 92 del Código Civil constituye el límite y el punto de referencia último de la institución jurídica de la guarda y custodia de los hijos.; Cfr. STS, Sala de lo Civil, Sección $1^{\mathrm{a}}$, núm. 229/2012 de 19 abril. RJ 2012/5909 "Motivo primero. Interés casacional en base al art. 477.2 , 3 LEC_. Vulneración de norma con menos de cinco años de vigencia, como es el art. 92 CC, en su redacción de 2005. Reproduce los requisitos para que el juez decrete la custodia compartida, que son que sea solicitada por uno solo de los progenitores, que el Ministerio Fiscal se pronuncie de forma favorable y que solo de este modo se proteja el interés del menor. Señala que no se han producido los supuestos en que debe negarse la custodia compartida. Dice que ésta fue solicitada, inicialmente, por ambos cónyuges, por lo que el juez venía obligado a concederla, aunque posteriormente la madre se desdijera solo en la fase de apelación. Con este sistema se protege el interés de los menores." 
dir el ejercicio de la patria potestad -adoptado en Convenio regulador o como medida judicial- atribuido total o parcialmente por uno de los cónyuges; y el Juez, tal cual se expresó con anterioridad podrá acordar el ejercicio de la guarda y custodia compartida si sólo de esta forma se protege adecuadamente el interés superior del menor, ya no tiene el carácter de excepcionalidad, así como tampoco resulta preceptivo el informe del fiscal ${ }^{1025}$. El resto de los apartados recogidos en el art. 92 del Código Civil referidos a la guarda y custodia de los hijos no expresa el interés del menor, aunque subyace este como elemento inspirador de las decisiones judiciales o de la actuación de los especialistas.

Sin duda de que existe un cambio en la jurisprudencia sobre esta materia. Es más, Se criticó el presente régimen por el peligro que para el bienestar emocional de los hijos supone un peregrinaje constante entre los domicilios de los progenitores, frente a ello se alza la situación de conflicto permanente entre los progenitores como la verdadera causa de la inestabilidad emocional del hijo menor de edad ${ }^{1026}$.

1025 STS, Sala 1 $1^{a}$, núm. 257/2013, de 29 de abril, RJ 2013/257. En esta sentencia la Sala Primera del Tribunal Supremo ha fijado doctrina en torno a la interpretación de los apartados 5, 6 y 7 del artículo 92 del Código Civil en lo relativo a los presupuestos que han de concurrir y valorarse para que pueda adoptarse, en interés del menor, el régimen de guarda y custodia compartida. En dicha sentencia $\mathrm{n}^{\circ} 257 / 2013$, de 29 de abril, del Tribunal Supremo, en unificación de doctrina, considera que la Audiencia Provincial que denegó el régimen de guarda compartida en el asunto que es objeto de casación, partió para tomar su decisión de que el régimen de guarda y custodia compartida es algo excepcional, mostrando una posición inicialmente contraria a este régimen y considerando "como problemas lo que son virtudes de este régimen como la exigencia de un alto grado de dedicación por parte de los padres y la necesidad de una gran disposición de éstos a colaborar en su ejecución". También reprocha a la sentencia recurrida que no fundara su decisión "en el interés del menor, al que no hace alusión alguna, y que debe tenerse necesariamente en cuenta en los litigios sobre guarda y custodia compartida". La Sala acude a la sentencia del Tribunal Constitucional 185/2002, de 17 de octubre, en la cual se establece que la adopción del régimen de guarda y custodia compartida ya no depende del informe favorable del Fiscal sino, únicamente, de la valoración que merezca al Juez la adecuación de dicha medida al interés del menor, siendo punto de partida que la guarda y custodia compartida no es lo excepcional sino que debe ser la regla general siempre que no resulte perjudicial para el menor, pues "el mantenimiento de la potestad conjunta resulta sin duda la mejor solución para el menor en cuanto le permite seguir relacionándose establemente con ambos padres". Sentados estos postulados, la Sala concluye que para la adopción de la medida de la guarda conjunta deben concurrir determinados requisitos, que el Tribunal concreta, expuestos con reiteración por la Sala de lo Civil del Tribunal Supremo y que nuevamente se afirman. Estos requisitos son los siguientes: 1) La práctica anterior de los progenitores en sus relaciones con el menor y sus aptitudes personales; 2) Los deseos manifestados por los menores competentes; 3) El número de hijos; 4) El cumplimiento por parte de los progenitores de sus deberes en relación con los hijos y el respeto mutuo en sus relaciones personales; 5) El resultado de los informes exigidos legalmente; 6) En definitiva, cualquier otro que permita a los menores una vida adecuada en una convivencia que forzosamente deberá ser más compleja que la que se lleva a cabo cuando los progenitores conviven, sin que la mera constatación de que el ré gimen de guarda y custodia se adapta mejor al interés de los progenitores resulte suficiente para deducir que se adapta mejor al interés del menor, que es el que debe primar.

1026 Es clara la uniformidad observada últimamente en las resoluciones judiciales de los juzgados y tribunales, a propósito del régimen de convivencia de la custodia compartida en los conflictos matrimoniales que desembocan en separaciones y divorcios - a través de la jurisprudencia por ejemplo- al exigir como presupuesto esencial en la búsqueda de la protección del interés del menor, que los padres tengan una actitud positiva para unir esfuerzos tendientes a la unificación de criterios educativos. Otros criterios que debieran considerarse sería la no separación de los hermanos, la proximidad del domicilio, la tenencia cada progenitor de viviendas adecuadas y horarios la- 
En la concepción actual el beneficio del interés del menor se logra con la inexistencia de conflicto entre los miembros de la pareja, lo cual también es entendido de la misma manera a nivel europeo $^{1027}$, lo que refleja la capacidad de los progenitores para ejercer la custodia compartida, a través de los principios de corresponsabiidad y coparentalidad ${ }^{1028}$, pues una pareja en conflicto permanente no tiene posibilidad real de establecerla ${ }^{1029}$. Ha sido, por lo demás, una lástima que el legislador no haya establecido en el Código Civil el modelo de la guarda y custodia compartida como regla general o régimen preferente de convivencia para el cuidado y la atención de los hijos, aunque tal cual se

borales que lo permitan.

1027 STEDH, núm. 2007/88, Caso Maumousseau y Washington contra Francia . Sentencia de 6 diciembre 2007. “El Tribunal estima que la noción de «interés superior» del menor es igualmente importante en el ámbito de los procedimientos dependientes de la Convención de La Haya. Entre sus elementos constitutivos figura el hecho para el menor de no estar lejos de uno de sus progenitores y retenido por el otro, es decir, por el que estima, con o sin razón, tener un derecho tan o más importante sobre su persona. En relación a esto, conviene recordar la Recomendación núm. 874 (1979) de la Asamblea Parlamentaria del Consejo de Europa, según la cual «los niños no serán considerados como propiedad de sus padres, sino como individuos con sus propios derechos y necesidades». El Tribunal subraya además, que en el preámbulo de la Convención de La Haya, las partes contratantes expresan su convicción de que «el interés del menor es de primordial importancia para cualquier cuestión relativa a su custodia» y subrayan su voluntad de "proteger al menor, en el plano internacional, contra los efectos dañinos de un traslado o una retención ilícitos y de establecer procedimientos con vistas a garantizar la restitución inmediata del menor al Estado de su residencia habitual, así como de asegurar la protección del derecho de visita». Se debe entender que estas estipulaciones constituyen el objetivo y el fin, en el sentido del artículo 31.1 de la Convención de Viena_ sobre el Derecho de los Tratados, de la Convención de La Haya (ver, en este sentido, Paradis contra Alemania, [déc], núm. 4783/03, de 15 mayo 2003). - El Tribunal suscribe en su totalidad a la filosofía subyacente de esta Convención. Inspirado en el deseo de proteger al menor considerado como la primera víctima del trauma causado por su traslado y retención, este instrumento pretende luchar contra la multiplicación de sustracciones internacionales de menores. Por tanto, una vez reunidas las condiciones de aplicación de la Convención de La Haya, se trata de volver lo antes posible al statu quo ante con la intención de evitar la consolidación jurídica de situaciones de hecho inicialmente ilícitas, y de dejar las cuestiones relativas al derecho de custodia y de patria potestad a la competencia de las autoridades judiciales del lugar de residencia habitual del menor, de conformidad con el artículo 19 de esta Convención..."

1028 STS, Cataluña, Sala de lo Civil y Penal, Sección 1'a núm. 29/2008 de 31 julio. RJ 2009/643. "Pues bien, abstracción hecha de las opiniones que desde planteamientos militantes se han emitido profusamente en los últimos tiempos, no cabe duda de que la llamada "custodia compartida" o conjunta por ambos progenitores presenta indudables ventajas para la evolución y desarrollo del niño en las situaciones de conflicto familiar producido por la ruptura matrimonial, en la medida en que evita la aparición de los "conflictos de lealtades" de los menores para con sus padres, favorece la comunicación de éstos entre sí, aunque no sirva para disminuir las diferencias entre ellos -tampoco puede afirmarse que las acentúe- $y$, en fin, coadyuva, por un lado, a visualizar la ruptura matrimonial como un conflicto en el que no existen vencedores y vencidos ni culpables e inocentes, y por otro, a concebir el reparto equilibrado de cargas derivadas de la relación paterno filial como algo consustancial y natural, y no como algo eventual o accidental, favoreciendo la implantación en los hijos de la idea de la igualdad de sexos."

1029 LATHROP GÓMEZ, F. op. cit., páginas 460, 461, 464 y 465. Tal como indica la autora, la regulación dada a la custodia compartida por la Ley 15/2005, de 8 de julio ayuda a concretar el interés superior del menor, a través de los principios de coparentalidad y de corresponsabilidad parental, que si bien no lo agotan si logran colaborar en su individualización ante cada ruptura familiar, sobre todo tras la entrada en vigor de la Ley 15/2005 y de la Ley Orgánica 3/2007, de 22 de marzo, esta ha definido el concepto jurídico indeterminado del interés superior del menor, en el sentido de permitir al hijo pese a la ruptura familiar continuar su relación con ambos progenitores. Ello se verá reflejado en cuestiones relacionadas con el cuidado y atención de los hijos, en cualquiera de los asuntos que les afecten. Por eso no se podrá rechazar la coparentalidad sobre la base de la conflictividad existente entre ellos, puesto que no solo es una reivindicación de los padres, sino además es un derecho de los hijos. Cual- 
acaba de enunciar el Tribunal Supremo le ha dado un carácter ya no excepcional. Del artículo 92 del Código Civil no se desprende la intención del legislador de dar prioridad con carácter general a este modelo de convivencia como el mejor modo de proteger el favor filii. Sin embargo, es inapropiado un sistema de presunción general de la guarda y custodia compartida tras la ruptura matrimonial o de pareja y dar uniformidad a cada situación familiar sometida al conocimiento familiar, sin atender las circunstancias concretas de la misma.

Que los términos "guarda y custodia” y "régimen de visitas, comunicación/estancia” de los hijos/as no deben ser más que "dos conceptos temporales de la función de tenerlos en su compañía”, es un dato que no debe admitir matices. Y es que, aunque la guarda y custodia exclusiva/unilateral implique la determinación de la persona a cuyo cuidado han de quedar los hijos, si los padres viven o están separados (arts. 159, 90, 92 apartados, 5 y 8 y $1031 .{ }^{\text {a }} \mathrm{CC}$ ), existe otro dato indiscutible que revela cómo, entre las funciones del progenitor custodio, están aquellas que vienen encaminadas a fomentar y potenciar la relación de los hijos con aquél que no los tienen en su compañía.

Desgraciadamente, por no ser las cosas así, nos encontramos con la otra cara de la guarda y custodia. Esto es, el tradicional y rígido mal llamado "régimen de visitas". Régimen restrictivo que ha supuesto en muchos casos, especialmente cuando persisten malas relaciones post-ruptura, que el menor pierda de forma progresiva los vínculos y lazos de afecto que lo unían al progenitor no custodio. E incluso, en situaciones extremas, que el menor identifique a aquél, como un ser ajeno o extraño a su círculo familiar más íntimo y lo asocie a contactos y estancias esporádicas y breves en las que prima la diversión o el entretenimiento. Tanto es así, que el paso del tiempo se ha ocupado de detectar estas disfunciones y la más moderna configuración del derecho de visitas, propicia en beneficio del menor el establecimiento de un amplio régimen de relación y contacto que comprende, tanto la comunicación flexible, como la estancia y pernocta de los hijos, con el progenitor que no vive habitualmente con ellos. Al respecto, un sector importante de la judicatura apunta "la posibilidad de establecer un reparto de tiempo de permanencia con los hijos menores, sin reconocer a ninguno de los padres la custodia, ni un determinado régimen de visitas" ${ }^{\prime 1030}$.

quier resolución judicial sobre un asunto determinado que no acoja la aplicación de ambos principios, deberá contener un razonamiento jurídico concreto al respecto.

1030 Vid. FORO ABIERTO. "Posibilidad de establecer un reparto del tiempo de permanencia con los hijos menores sin reconocer a ninguno de los padres la custodia ni un determinado régimen e visitas" en PRIETO FERNÁNDEZ-LAYOS J.M. ${ }^{a}$ (Coord.) en Boletín de Derecho de Familia, Año VIII, número 83, octubre 2008, página 1 a 7. 
En este sentido, tal como apunta MORENO VELASCO, de esta manera se desdibuja el concepto de guarda y custodia y aunque no se acuerde "formalmente" una custodia compartida, el reparto de tiempos de estancia y comunicación puede ser tan amplio que en opinión del autor, se da una "guarda y custodia compartida de facto" ${ }^{1031}$. Sin obviar de otra parte, que entre algunas de las desventajas ${ }^{1032}$ que se atribuyen a cada régimen de visitas, está aquella, reiterada por el TC, que revela cómo, "los sucesivos cambios del entorno afectivo y de convivencia del menor podrían causarle graves perjuicios en su personalidad en formación" ${ }^{1033}$. Sobre el particular y a propósito de la preferencia por el sistema de custodia exclusiva con un amplio régimen de visitas a favor del progenitor no custodio, se muestran partidarios jueces, abogados y psicólogos forenses consultados, según revela un estudio piloto ${ }^{1034}$ que recoge las valoraciones de estos profesionales que intervienen en los casos en los que se discute la custodia de un menor.

Sentado este precedente, puede colegiarse que, aún en el caso de que el interés del menor aconseje en el momento inicial de la ruptura, la atribución de la guarda y custodia de forma unilateral, que respondería al "principio de continuidad"1035, ello no obstará, sino que decididamente acon-

1031 Vid. MORENO VELASCO, V. "Hacia una adecuada comprensión del ejercicio de la patria potestad”, Diario la Ley, Año XXX, Número 7267. Jueves, 22 de octubre de 2009, página 2.

1032 A propósito de los problemas que plantea la custodia compartida en los procesos contenciosos puede consultarse ampliamente a MARÍN GARCÍA DE LEONARDO, M. T. "Problemas que genera la actual regulación de la guarda y custodia compartida en el proceso contencioso”, Abogados de Familia, número 50, Sección Tribuna Abierta, Cuarto trimestre de 2008. Diario La Ley, número 7105, Sección Doctrina, 2 de feb, 2009. Año XXX, Ref. D-29. (La Ley 40228/2008). La autora pone de manifiesto la necesidad de modificar otras materias conexas, como la vivienda familiar la prestación de alimentos.

1033 Sobre el particular puede verse la siguiente jurisprudencia: El Tribunal Constitucional (Sala Primera) en el Auto núm. 108/2005 de 14 de de marzo (JUR 2005/141729). En igual sentido, el auto de 18 de julio de 2007 (que a su vez cita, entre otros el Auto 21/2002, de 25 de febrero, el auto 148/2002, de 23 de julio, el Auto 273/2003, de 22 de julio, el Auto 198/2004, de 26 de mayo). Cfr. Auto del TC (Sala Segunda) Auto núm. 336/207 de 18 de julio (TC 2007/336).

1034 ARCH MARIN, M. y JARNE ESPARCIA, A. "Opinión y valoración de los diferentes sistema de guarda y custodia por psicólogos forenses y juristas españoles. Un estudio piloto”. Revista de Derecho de Familia, número 41, octubre-diciembre 2008, página 25 a 33.

1035 Este criterio de la continuidad (aproximation standard) propuesto por el American Law Institute en los Principles of the Law of Family Dissolution, consiste en atribuir la guarda a cada uno de los progenitores en la medida a su dedicación histórica a la atención y cuidado del menor antes de la ruptura, "teniendo en cuenta el ligamen emocional entre cada uno de los progenitores y el menor o las aptitudes de cada uno de ellos en relación con dicho cuidado". Así lo recoge la STS (Sala de lo Civil, Sección 1. a) de 8 de octubre de 2009. (RJ 2009/4606). Para ver un análisis exhaustivo de este criterio puede consultarse a GARRIGA GORINA, M. "El criterio de la continuidad frente a la guarda conjunta”. INDRET, Revista para el Análisis del Derecho, 3/2008 (www.indret.com) y TAMAYO HAYA, S., quien considera que este criterio permite basarse más en los hechos que en factores subjetivos, opina que "El fin es proporcionar un criterio objetivo basado en las circunstancias existentes antes de la separación lo cual hace mucho más dificil examinar el género y la orientación sexual a la hora de determinar su responsabilidad y al mismo tiempo limita las posibilidades del juez de insertar sus propios prejuicios culturales en el proceso". Cfr. TAMAYO HAYA, S. "El interés el menor como criterio de atribución de la custodia”. Revista de Derecho de Familia, núm. 41, octubre-diciembre de 2008, Ed. Lex Nova, Valladolid, página 57. También a propósito de la expresión "principio de continuidad", acuñado en el Derecho alemán, para referirse al derecho que tiene el menor a que se le garantice su continua relación y contacto con sus dos progenitores en los casos de 
sejará promover, un sistema progresivo adaptativo del contacto progenitor no custodio con los hijos, que permita acomodarse a la nueva situación que les ha tocado vivir. Incluyendo la posibilidad de que en un futuro, si las circunstancias así lo aconsejan poder acceder a la custodia compartida/alterna, cuando concurran, además de los requisitos legales (art. 92.5 y $8 \mathrm{CC}$ ) otros condicionantes ${ }^{1036}$ que habrán de ser ponderados por el Juez, al "no existir un modelo general que obligue a repartir la convivencia en períodos iguales con cada uno de los progenitores ${ }^{\prime 1037}$. Y es que, tal cual lo menciona CASTILLO MARTÍNEZ, la extensión del tiempo en la alternancia de la custodia compartida entre los progenitores admite la determinación de períodos temporales bastante amplios y la fijación de períodos de tiempo más cortos ${ }^{1038}$.

crisis matrimonial, puede verse a DE TORRES PEREA, J.M. "Interés del menor y Derecho de Familia. Una perspectiva multidisciplinar". ... op. cit., página 247 a 249.

1036 Condicionantes como por ejemplo que los progenitores no tengan capacidades parentales adecuadas que no sean capaces de reconocer los intereses y necesidades del menor, que la comunicación entre ellos no sea flexible o inexista, se aprecien estilos educativos y de vida muy diferentes, cercanía en los domicilios, así como un largo etcétera de factores que pueden desembocar en una situación que rompa la armonía constante e incidir negativamente en el desarrollo equilibrado del menor; Cfr. STS (Sala de lo Civil, Sección 1.a) de 8 octubre de 2009. (RJ 2009/4606).

1037 Así lo señala el TS a propósito de la falta de una lista de criterios que, en España no existen, a diferencia de otros ordenamientos jurídicos, donde si lo especifican. Vid., STS, Sala de lo Civil, Sección 1. a, núm. 623/2009, de 8 de octubre, RJ 2009/4606. El en el fallo en cuestión se expone que: “A diferencia de lo que ocurre en el derecho francés (Art.373-2-11 Code civil, modificado por la ley 2002-305, de 4 marzo 2002) o en la Children Act 1989 inglesa el Código español no contiene una lista de criterios que permitan al Juez determinar en cada caso concreto qué circunstancias deben ser tenidas en cuenta para justificar el interés del menor en supuestos en que existen discrepancias entre los progenitores, que no impiden, sin embargo, tomar la decisión sobre la guarda conjunta. Otros sistemas, como los American Law Institute Principles of the Law of Family Dissolution ha fundado en la dedicación de cada uno de los progenitores a la atención y cuidado del menor antes de la ruptura, teniendo en cuenta el ligamen emocional entre cada uno de los progenitores y el menor o las aptitudes de cada uno de ellos en relación con dicho cuidado. Del estudio del derecho comparado se llega a la conclusión que se están utilizando criterios tales como la práctica anterior de los progenitores en sus relaciones con el menor y sus aptitudes personales; los deseos manifestados por los menores competentes; el número de hijos; el cumplimiento por parte de los progenitores de sus deberes en relación con los hijos y el respeto mutuo en sus relaciones personales y con otras personas que convivan en el hogar familiar; los acuerdos adoptados por los progenitores; la ubicación de sus respectivos domicilios, horarios y actividades de unos y otros; el resultado de los informes exigidos legalmente, $y$, en definitiva, cualquier otro que permita a los menores una vida adecuada en una convivencia que forzosamente deberá ser más compleja que la que se lleva a cabo cuando los progenitores conviven."

1038 Períodos que pueden llegar a durar un semestre o incluso un año, hasta la práctica ordinariamente más frecuente por la que se fija la alternancia de uno o tres meses. Esta última posibilidad se viene estimando como la más adecuada a fin de garantizar la estabilidad emocional del menor. Pero también, en ocasiones nuestros tribunales acuerdan la fijación de períodos de tiempo más cortos, de duración semanal o quincenal, que por su propia esencia podrían permitir la exclusión de las visitas por parte del progenitor no custodio en cada tramo temporal, llegando alguna resolución a establecer incluso períodos de duración inferior a una semana. CASTILLO MARTÍNEZ, C. C. "La determinación en la guarda y custodia de los menores en los supuestos de crisis matrimonial o convivencial de sus progenitores. Especial consideración de la guarda y custodia compartida tras l Ley 15/2005, de 8 de julio". Actualidad Civil, número 15, Sección A Fondo, Quincena del 1 al 15 sep. 2007, página 1738, tomo 2. (La Ley 2911/2007). 
Para ello, y ante la indefinición del término custodia compartida será preciso concretar el tipo de guarda que merece este nombre, donde en opinión de CARRASCO PERERA ha sido el Tribunal Supremo quien en mayor medida ha solucionado el asunto ${ }^{1039}$.

Sentadas las anteriores premisas no es difícil situar la perspectiva en el cotidiano escenario, en el que tras la separación o divorcio uno de los progenitores, generalmente el no custodio, solicita una modificación de medidas en base a reiterados y graves incumplimientos respecto al régimen de visitas; que incluso le han podido llevar a perder definitivamente los lazos de afecto con su hijo. Se advierte cómo en estos procedimientos en los que están implicados los menores, el paso del tiempo tiene mucha importancia y puede aconsejar ese cambio o modificación de medidas en beneficio del menor. Modificación de medidas, cuyo criterio decisivo se contiene en el art. 776 LEC que bajo la rúbrica "Ejecución forzosa de los pronunciamientos sobre medidas" señala en su apartado 3 (modificado por la Ley 13/2009, de 3 de noviembre, de reforma de la legislación procesal para la implantación de la nueva Oficina Judicial) ${ }^{1040}$ que: "el incumplimiento reiterado del régimen de visitas, tanto por parte del progenitor guardador podrá dar lugar a la modificación "por el Tribunal” del régimen de guarda y visita”.

Sin embargo, para modificar una medida patrimonial o personal, convenida por los cónyuges o adoptada en previa resolución judicial, es preciso que concurra una alteración sustancial de las circunstancias. Así lo establece el penúltimo párrafo de art. $90 \mathrm{CC}$, para los procesos tramitados de mutuo acuerdo y el articulo $91 \mathrm{CC}$ in fine para los contenciosos. Y no todo cambio es relevante para justificar la pretensión de la modificación. Ese cambio ha de tener suficiente entidad, lo que exige que concurran los siguientes requisitos, que se infieren a partir de diversa jurisprudencia:

1. Que haya existido, y se acredite debidamente, una alteración de las circunstancias tenidas en cuenta por los cónyuges, o por el juez, para la adopción de medidas establecidas en el convenio regulador de la separación o divorcio, o en la correspondiente resolución

1039 Como señala CARRASCO, por primera vez el TS se enfrenta al reto de interpretar el régimen de custodia com partida. Al respecto, resulta interesante la reflexión del autor cuando considera que hay "un descarado tributo al formalismo procedimental”. En su opinión "será preciso concretarlo. El CC no lo dice, y caben variaciones de todo tipo. ¿Cuántos días del menor con el padre hacen tránsito a la custodia compartida? Es custodia compartida cualquier régimen de guarda que atribuya al padre un derecho de pernocta intrasemanal? (...). El juez de primera instancia así lo decretó, pero su decisión es equivocada, porque tomó una decisión de custodia compartida sin haber seguido un procedimiento de custodia compartida. Como se descubre, otro triunfo del formalismo. La noche intersemanal marca la diferencia". Vid. CARRASCO PERERA, A., "La custodia compartida llega al Tribunal Supremo”. Actualidad Jurídica Aranzadi, número 790/2009 (Tribuna).

1040 Publicada en el BOE número 266, Miércoles 4 de noviembre de 2009 y que entrará en vigor como dispone la Disposición Final Tercera, a los seis meses de su publicación en el Boletín Oficial del Estado, esto es, el 4 de marzo de 2010 . 
judicial de tal manera que las existentes al tiempo de solicitar la modificación de aquellas medidas sean distintas de las existentes al tiempo de su adopción.

2. Que dicha alteración de las circunstancias sea sustancial, es decir, de tal entidad, que haga suponer que, de haber existido tales circunstancias al momento de la separación o del divorcio, se hubieran adoptado medidas distintas.

3. Que tal alteración de circunstancias no sea esporádica o transitoria, sino que se presente con caracteres de estabilidad o permanencia en el tiempo.

4. Que la referida alteración no haya sido provocada o buscada voluntariamente a propósito para obtener una modificación de las medidas ya adoptadas, sustituyéndolas por otras que resulten más beneficiosas para el solicitante ${ }^{1041}$.

Desde estas consideraciones puede colegirse que la regla general es la estabilidad de las medidas acordadas, que como se ha visto, estas no pueden verse alteradas por cualquier coyuntura o hecho de nuevo, sino excepcionalmente, cuando tiene lugar la alteración sustancial de las circunstancias tenidas en consideración, en relación al interés superior del menor.

Ante la pregunta: ¿Qué interacción produce la modificación acordada y el interés del menor.?, en el caso que nos ocupa, la actitud obstativa que calificamos de "interferencia", puede haber comenzado con un entorpecimiento leve de la relación de los hijos con uno de sus progenitores, generalmente el no custodio; y como hemos visto, al no ser una alteración de suficiente entidad, en principio, no justificaba por si sola, la modificación de la guarda y custodia al poder preverse otras medidas correctivas o de apoyo a la familia en beneficio e interés del menor. Sin embargo, puede ocurrir, que la escalada de conflicto y la situación de hostilidad que mantienen los padres (de la que hacen partícipes a los niños, consciente o inconscientemente), haya alcanzado tal magnitud que el entorpecimiento de la relación sea tan grave y reiterado, que cree en ellos un grave conflicto de lealtad difícilmente superable, que terminará con la privación parental de uno de sus progenitores debido a un proceso de alineación, como señala SANTANA PÁEZ ${ }^{1042}$. Al respecto TOVAR ESCUDERO define la alineación parental como "una modalidad especifica y grave de interferencia en las legitimas y deseables relaciones paterno filiales, tras la ruptura de la convivencia de una pareja que, generalmente, afecta a las del progenitor sin la custodia"1043. Alineación parental que -aún por su similitud gramatical y síntomas asociados- no debe confundirse con la construcción del "Síndro-

\footnotetext{
1041 A propósito de estos requisitos pueden consultarse, entre otras, la SAP Salamanca, Sección 1ª núm. 192/2007 de 21 mayo. JUR 2007/328050; la SAP Barcelona, Seccíón 12a , de 20 marzo 2001. JUR 2001/161161 y la SAP

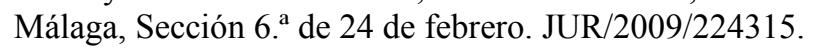

1042 SANTANA PÁEZ, E. En HIJAS FERNÁNDEZ, E. (Coord.) “Los procesos de familia: una visión judicial”, Ed. Colex, $2^{\circ}$ edición, Madrid, año 2009, página 885.
} 
me de Alineación Parental" más conocido como SAP, elaborada por GADNER, la cual está presente en numerosos estudios ${ }^{1044}$. En este caso, se habla de niños "programados" que presentan algún rechazo o se niegan rotundamente a tener relación con uno de los progenitores. Sentimiento que generalmente se ve venir motivado por el "odio visceral, fobia y resentimiento" que, hacia el otro progenitor, le transmite consciente e inconscientemente, el no custodio. Estos supuestos pueden perfectamente ser calificados de maltrato psicoemocional ${ }^{1045}$. Conductas que tendrían suficiente entidad para justificar, en su caso, y si el interés del menor lo aconseja, una modificación de medidas, pues, no ofrece dudas, el daño o el peligro potencial que esta actitud puede deparar en la integridad moral y de todo orden en el menor. Teniendo en cuenta, no obstante, que en la decisión a adoptar ha de primar el interés superior del menor, y es que, ambas relaciones, la paterno-filial y la materno-filial son necesarias para el desarrollo del niño.

Por ello, cabría someter a consideración si es adecuado en todos los casos en los que se alega el SAP, un pronunciamiento judicial de cambio automático de la guarda y custodia. Debido a que tal como señalan algunas resoluciones judiciales, esa modificación ha supuesto un "castigo severo" para el progenitor custodio, que irremediablemente incide en el menor un "fuerte correctivo" para el progenitor incumplidor que, en ocasiones, mal se compaginará con el interés del niño. Más aún, cuando después se ha revelado "no tener justificación suficiente" considerándose "una medida drástica (...) pues si bien es cierto que ha existido por parte de aquél un actuar negligente, pasivo y permisivo para con los deseos de la niña, no lo es menos que se le ha castigado con una dureza inusual" ${ }^{1046}$.Así el denominado SAP, en cuanto provoca reacciones negativas en los hijos, su concu-

1043 Vid. TOVAR ESCUDERO, C. “Manifestaciones y expresiones de los niños afectados por alineación parental

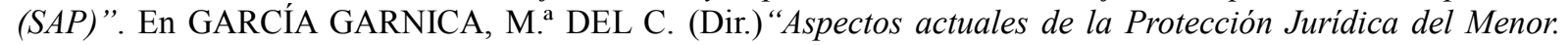
Una aproximación interdisciplinar”, Ed. Aranzadi, Cizur Menor, año 2008, página 119.

1044 AGUILAR CUENCA, J.M., “El uso de los hijos en los procesos de separación: el síndrome de alienación parental”, Revista de Derecho de Familia, núm. 29 octubre-diciembre, Ed. Lex Nova, Valladolid, año 2005, página 71 y siguientes; GÓMEZ MAGÁN, P., "Síndrome de Alienación Parental”. Revista de Derecho de Familia, núm. 38, enero-marzo, Ed. Lex Nova, Valladolid, año 2008, página 63 y siguientes; DE LOS RÍOS GONZÁLEZ, M., "Cambio de guarda y custodia. El Síndrome de Alienación Parental. Aspectos prácticos", Revista de Derecho de Familia, núm. 27, abril-junio, Ed. Lex Nova, Valladolid, año 2005, página 305 y siguientes; ESCUDERO, A., AGUILAR, L., DE LA CUZ, J. “La lógica del síndrome de alienación parental de Gadner (SAP): "terapia de la amenaza”. Revista de la Asociación española de Neuropsiquiatría, Año XXVIII, fascículo 2, Madrid, año 2008, número 102. Páginas 285 a 307; VACCARO, S y BAREA. PAYUETA, C. "El pretendido síndrome de Alienación Parental: Un instrumento que perpetúa el maltrato y la violencia”, Ed. Desclée de Brouwer. MAIOR. Bilbao, año 2009.

1045 El maltrato psicológico/emocional (según el glosario de términos de la web del Observatorio de la Infancia se entiende producido en el menor cuando "no se toman en consideración las necesidades psicológicas del niño o de la niña, particularmente las que tienen que ver con las relaciones interpersonales y con la autoestima.” Vid. “Menores de Edad en Andaluciá". Datos cuantitativos. Informe 2009, página 2009, página 56.

1046 Vid. SAP, Barcelona, Sección 18, núm. 272/2008 de 17 abril. AC 2008/1056 que resuelve el Recurso de apelación contra la sentencia del Juzgado de Primera Instancia e Instrucción de 4 de junio de 2007 (JUR/2007/209316) 
rrencia puede tener especial importancia en orden a resolver sobre su guarda y custodia. Pero precisamente por estas posibles repercusiones en la guarda de los menores, su concurrencia "ha de de resultar cumplidamente acreditada, no bastando con los meros indicios e hipótesis periciales que apuntan a tal posibilidad". Y es que la irrupción del fenómeno psico-legal denominado SAP, y su, a veces, "fácil" invocación ${ }^{1047}$ en los procesos matrimoniales, podría desembocar también, en daños irreparables para el menor.

Así, en algunas, se procede al cambio de guarda y custodia que se otorga al padre, aún reconociendo el Tribunal "por más que suponga un cierto shock para la niña" ${ }^{1048}$ el ser el único medio que garantiza relaciones normalizadas con el padre sin suponer ello una pérdida de la relación con la madre. En otra se recoge como "la menor lleva casi 10 meses sin ver a su madre y sólo últimamente empieza a mantener un muy breve contacto telefónico mensual, que se estima del todo punto insuficiente, y ello máxime cuando según los peritos judiciales "la niña solo se emociona cuando habla su madre, dado que teme no poderla ver" ${ }^{1049}$. En ocasiones, para que el menor pueda curarse de este síndrome, se requiere bastante tiempo, en ese sentido "los menores (de 16 y 14 años) llevan 3 años de internamiento como medida (acordada con carácter temporal "durante el tiempo necesario para su mejora”) para desactivar el SAP. Casi tres años después, el mismo equipo manifiesta que la intervención terapéutica que se está realizando con los menores aún no ha logrado el objetivo de que superen la alineación de que son objeto, aunque se les ha separado todo este tiempo de quien se dice es el causante del daño, salvo contactos esporádicos". El propio equipo califica esta tarea de difícil "dada la edad de los niños" donde "ya es difícil cambiar" ${ }^{1050}$. Otras resoluciones, en beneficio o interés del menor, no proceden a la modificación solicitada y mantienen la guarda y custodia.

que atribuyó la guarda y custodia de a hija menor al padre, modificando el régimen de guarda otorgada a la ma dre al acogerse a la pericial que entendía que la niña sufre el síndrome de alienación parental. Asimismo la sentencia declaró la suspensión del derecho de comunicación y visitas de la madre y familia materna con la menor por un período mínimo de seis meses.

1047 En este sentido UREÑA señala como el SAP en la actualidad es una coartada muy recurrente en los procedimientos contenciosos de rupturas de pareja, para conseguir la guarda y custodia del menor o una guarda compartida y así evitar el pago de la pensión de alimentos a los hijos y para defenderse un progenitor de la acusación vertida por el otro de malos tratos y/o abusos sexuales en el ámbito familia. UREÑA MARTÍNEZ, M. "Malos tratos a menores en el ámbito familiar”, este trabajo se ha realizado en el seno del Proyecto de Investigación "Conflictos, Rupturas y Negociaciones en Crisis Familiares", financiado por la Dirección General de Investigación del Minis terio de Educación y Ciencia (SEJ 2005-01390), cuyo investigador principal es el Prof. D. Ángel Carrasco Perera.

1048 Vid. SAP Madrid, Sección 24 ${ }^{\text {a }}$, de 23 de abril de 2009, JUR 2009/245393.

1049 Vid. SAP Barcelona, Sección $18^{\text {oa }}$, de 17 de abril de 2008 , AC/2008/1056.

1050 Vid., SAP Asturias de 17 de abril de 2009, JUR/2009/246099. 
Puede colegirse la dificultad que encierra adoptar decisiones de este tipo y por tanto, ante la incertidumbre es preferible adoptar medidas no tan drásticas, incluidas las de ayuda y apoyo a la familia, para que ambos progenitores tomen conciencia de que esa actitud beligerante, de entorpecimiento de las mutuas relaciones paternofiliales, puede generar daños irreparables en el menor. Prácticas de entorpecimiento, de victimización secundaria y manipulación de menores que recoge expresamente el art. 21.3 de la Ley del Menor Valenciana ${ }^{1051}$ y de las que también se han hecho eco la Memoria de la Fiscalía General del Estado. En concreto en el punto 14 bajo la rúbrica "Menores y crisis matrimoniales”, se expone como la Sección de Menores de la Fiscalía Provincial de Cáceres señala que con ocasión de los procesos originados por las crisis conyugales, se ha comprobado que en una pequeña proporción, el enfrentamiento entre la partes del proceso puede perjudicar seriamente a los hijos y su derecho a relacionarse con los padres cuya relación conyugal termina : “(...) Lo que ha llevado a trasladar a la Fiscalía de Menores aquellos casos en que la actitud de uno de los padres (normalmente el custodio) se sirve, voluntaria o inconscientemente de su mayor proximidad con el menor para perjudicar el vínculo del menor con el otro progenitor, causando una situación psicológica en el menor compatible con un maltrato o con un incumplimiento de los deberes derivados de la patria potestad (...) daño causado al menor y la suficiencia del mismo como lesión idónea para sustentar una acusación por maltrato o por incumplimiento de los deberes parentales ${ }^{\prime 1052}$.

\section{4 | Algunas conclusiones en torno al interés del menor}

La jurisprudencia no tiene señalada una línea general que delimite el contenido del interés del menor para cualquier supuesto de hecho planteado. Lo que tiene establecido el Tribunal Constitucional es la consideración del interés superior del niño como criterio básico y preferente a la hora de elegir el progenitor del menor encargado de la guarda y custodia de los hijos. Así lo indica el ATC núm. 127/1986, de 12 febrero RTC 1986/127 AUTO Sala Primera, Sección Segunda: “(...) el juez, en de-

1051 "Las conductas de victimización secundaria y de manipulación de los menores, especialmente en los procesos de crisis matrimoniales, serán tenidas en cuenta a fin de no causar un nuevo o mayor perjuicio para el menor. En los casos en los que alguno de los progenitores lleve a cabo prácticas de entorpecimiento de la relación de los hijos con el otro progenitor, el órgano judicial competente adoptará las medidas necesarias para proteger eficazmente a estos menores de los efectos de dichas conductas". Vid., Ley 12/2008, de 3 de julio de 2008, de la Generalitat, de Protección Integral de la Infancia y la Adolescencia de la Comunitat Valenciana. DOCV. Diari Oficial de a Comunitat Valenciana, 10 de julio 2008 (número 5.803).

1052 Vid. Memoria de la Fiscalía General del Estado 2009. Vol I. Cap. III. Actividad del Ministerio Fiscal, letra G) Fiscales de Sala Coordinadores y Delegados para Materias Específicas y Secciones o Delegaciones Territoriales Especializadas. 6. Fiscal de Sala Coordinador en materia de Menores. En concreto véase el punto 14 bajo la rúbrica “Menores y crisis matrimoniales”, Madrid, año 2009, página 876 y 877. 
fecto de acuerdo entre los cónyuges o en caso de no aprobación del convenio regulador, utilizando la amplia discrecionalidad que caracteriza los procedimientos en materia de familia y teniendo en cuenta como criterio básico y preferente el interés de los hijos, acordará a cuál de los cónyuges corresponde la guarda y custodia de estos, en razón de sus intereses morales y materiales, con independencia de cuáles hayan sido los motivos y causas productores de la situación de ruptura conyu$\operatorname{gal}(\ldots)$...

También ha planteado la jurisprudencia constitucional la importancia del interés superior del menor en la interpretación de los derechos y libertades constitucionales, marcando los límites de su ejercicio a favor de la autonomía del hijo. La STC núm. 141/2000 de 29 de mayo, RTC 2000/141, enfrenta el interés superior del menor con el derecho de libertad ideológica, religiosa y de culto, cuando las creencias afecten de forma negativa al desarrollo de su personalidad. Para el Tribunal Constitucional, en caso de conflicto, el "interés del menor" es el elemento decisorio en la valoración y alance del derecho recogido en el art. 16. 1 de la Constitución de 1978: “(...) frente a la libertad de creencias de sus progenitores y su derecho a hacer proselitismo de las mismas con sus hijos, se alza como limite, además de la intangibilidad de la integridad moral de estos últimos, aquella misma libertad de creencias que asiste a los menores de edad manifestada en su derecho a no compartir las convicciones de sus padres o a no sufrir sus actos de proselitismo, o más sencillamente a mantener creencias diversas a las de sus padres, máxime cuando las de estos pudieren afectar negativamente a su desarrollo personal, libertades y derechos de unos y otros que, de surgir el conflicto, deberán ser ponderados teniendo siempre presente el "interés superior" de los menores de edad (arts. 15 y 16.1 CE en relación con el art. 39 CE)".

El Tribunal Supremo se ha extendido más sobre aspectos específicos del contenido del "interés superior del menor". Este Tribunal ha establecido la edad y los derechos fundamentales constitucionalmente reconocidos, como valor seguro para determinar el contenido del interés del menor en relación con la capacidad para ejercer sus derechos, y construir de forma progresiva el control de su situación personal y la proyección del futuro; evitando con las medidas judiciales manipulaciones y logrando una formación integral, y su integración familiar y social. En definitiva, la protección del menor en términos jurídicos, persigue el fin expresado en la STS, Sala de lo Civil, Sección $1^{\mathrm{a}}$ núm. 3280/2011 de 12 mayo. RJ 2011/3280, en ella se estipula: “ (...) salvaguardar los derechos fundamentales de la persona, los derechos de su propia personalidad. En el fondo, no es otra cosa que asegurarle la protección que merece todo ciudadano en el reconocimiento de los derechos fundamentales del individuo como persona singular y como integrante de los grupos sociales en que se 
mueve, y en el deber de los poderes públicos de remover todo obstáculo que se oponga al completo y armónico desarrollo de su personalidad (...)”.

¿Cuáles son los criterios que ha de utilizar el juez para valorar y decidir el contenido del interés superior del menor? Sin duda el juez deberá tomar el pulso a la sociedad en la temática que le sea planteada, y para ello hará un uso adecuado de la discrecionalidad a la hora de adoptar decisiones. Discrecionalidad que no le autoriza a manejar de modo arbitrario la cuestión que se somete a su conocimiento. Así antes de establecer las medidas más convenientes al interés superior del menor, deberá ponderar los hechos, valorando los beneficios y riesgos asumidos en cada opción, decantándose por aquella que otorgue mayor protección a los derechos constitucionales del menor de edad. En definitiva, la valoración del juez sobre los datos aportados por las partes en el proceso se ha de llevar a cabo prescindiendo, en la medida de lo posible, de su ideología política, convicciones religiosas y educativas, que puedan incidir en la valoración de la familia, el matrimonio y los hijos ${ }^{1053}$.

Lo verdaderamente relevante a la hora de concretar en cada caso el interés del menor, es que los elementos utilizados por el juez en las medidas de carácter personal o patrimonial deben ser puntos de referencia universalmente aceptados. Con ello se evita una dispersión judicial de criterios, que nos llevan a tantas y diversas soluciones como jueces haya ${ }^{1054}$.

1053 RIVERO HERNÁNDEZ, F., “El derecho de visita”, Ed. J. Ma Bosch Editor, S.L., Barcelona, año 1996, página 162 a 164; GRACIA VICENTE, F., “19 de octubre de 1983: Patria Potestad. Suspensión del ejercicio de guarda y custodia. Ejemplo corruptores. Competencia de los Tribunales Tutelares de Menores. Competencia del Tribunal Supremo”, Cuadernos Civitas de Jurisprudencia Civil, número 3, septiembre-diciembre de 1983, Madrid, página 1007. La influencia externa sobre la resolución del Juez, a la hora de valorar el interés del menor, ha de estar movida por criterios sociológicos, psiquiátricos médicos y educacionales, convenientemente asesorado por especialistas, dejando los criterios éticos y religiosos, por muy respetables que sean para su fuero interno, sin que tengan una incidencia trascendente en la resolución judicial. A la vez SEIJAS QUINTANA, J. A., "Consecuencias de la separación y el divorcio: el interés del menor. Alimentos, guarda y custodia. Régimen de visitas. Aspectos internacionales. La vía convencional como medio de solución de conflictos. Especial referencia a los convenios de La Haya, Luxemburgo y Bruselas”, Actualidad Civil, número 29, 14 al 20 de julio de 1997, Madrid, páginas 642 y 643, indica otros actores externos que van a surgir a lo largo del proceso judicial, como las reglas de la ló gica y del sentido común, el conocimiento, la experiencia y a sensibilidad, junto a otros datos como la edad, sexo y personalidad de los menores, la capacidad de los progenitores para ejercer la guarda y custodia, la predisposi ción de estos a facilitar la relación de los hijos con el otro progenitor. Todos ellos deberán conformar en la mente del juzgador el contenido del interés del menor, para fundamentar la adopción de una determinada medida. También la opinión mantenida por SÁNCHEZ HERNÁNDEZ, C. "Un caso de secuestro internacional de menores por parte del titular de la guarda y custodia: el interés del menor como criterio de decisión”, Actualidad Civil, núm. 12, 22 al 28 de marzo de 1999, Madrid, página 308.

1054 Este planteamiento se aprecia a la hora de buscar presupuestos necesarios que han de concurrir para aplicar el régimen de convivencia de custodia compartida, como el mejor modo de proteger el interés superior del menor. La SAP Burgos, Sección 2a , núm. 00459/2006 de 14 de diciembre de 2006, plantea la exigencia de requisitos previos que han de concurrir necesariamente, en cualquier ruptura matrimonial, para establecer este régimen de convivencia. Capacidad del progenitor para participar en la guarda y custodia compartida; la tenencia de vivienda propia de cada progenitor; contar ambos con medios económicos suficientes, implicación directa de ambos progenitores en el cuidado y atención del hijo (recogidas sucesivas a la salida del colegio o de las actividades extraescolares, acudir ambos progenitores conjuntamente a las citas por el tutor de su clase del colegio; velar por el cuidado personal y la salud, comprando ropa y material escolar, acudir ambos progenitores a personas de con- 
Sin duda la jurisprudencia le atribuye un valor al "interés superior de los hijos", por ello el titular del órgano judicial al amparo de las normas jurídicas y del margen de discrecionalidad, establecerá las medidas que estime convenientes para proteger el interés superior de los hijos. Esto podrá llevarse a cabo empleando conceptos tales como los de "estabilidad emocional", "equilibrio psicológico", “formación integral”. El juez de oficio tendrá en cuenta, las declaraciones de los progenitores; la opinión del menor; el dictamen de especialistas, y adoptará la decisión oportuna, en función de las circunstancias personales y familiares de cada menor de edad. Ante esto los juzgados y tribunales deben valerse de instrumentos esenciales para la determinación del interés superior del menor en la elección del régimen de guarda y custodia más adecuado.

Por una parte se encuentra el valor teleológico. Las resoluciones judiciales muestran uniformidad en la prosecución de delimitar el contenido del interés superior del menor, amparándose en la obtención del desarrollo adecuado de la personalidad del hijo menor de edad, potenciando sus facultades físicas, intelectivas y morales ${ }^{1055}$.

Determinadas normas jurídicas sirven de guía a la actividad jurisdiccional en la elección del régimen de guarda y custodia, por el valor teleológico que muestran para la protección del interés del menor. En el Derecho Internacional se observa especialmente en algunos instrumentos jurídicos: La Convención de Naciones Unidas sobre los Derechos del Niño, de 20 de noviembre de 1989; la Carta Europea de los Derechos del Niño, aprobada por Resolución A 3-0172/92 del Parlamento Europeo. En el ámbito interno el art. 39.2 de la Constitución de 1978, la Ley Orgánica1/1996, de 15 de enero, de Protección Jurídica del Menor, y determinados artículos del Código Civil que lo recogen, como el 92.4 (el ejercicio de la patria potestad), el 103.1 ${ }^{\text {a }}$ (medidas provisionales sobre la atribución de la guarda y custodia), el 96 (atribución del uso de la vivienda familiar a los hijos), el 159 (qué progenitor quedará al cuidado de los hijos menores de edad).

Por otra parte está la aplicación de oficio, las resoluciones judiciales dictadas en el procedimiento matrimonial y de menores, medidas protectoras del interés superior del menor. Aunque en ocasiones tal como indica la SAP Las Palmas, Sección 3 $3^{\text {a }}$, núm. 329/2007 de 26 julio. JUR

fianza en las ocasiones en las que no podían ocuparse de su hijo, etc.).

1055 Por ello ha opinado LINACERO DE LA FUENTE, "Protección jurídica del menor", ...ob. cit. página 63, los tribunales de justicia, a la hora de buscar el interés superior de los hijos, podrán hacer uso de la discrecionalidad para tomar una decisión sobre varias alternativas igualmente válidas, sin arbitrariedad, que tendrá como límite: “a) la racionalidad en la apreciación de los hechos; b) Evitar todo perjuicio para el bienestar espiritual (...) y material del menor; y c) La protección de los derechos del niño plasmados en la legislación nacional e internacional". Vid. BERMÚDEZ BALLESTEROS, $\mathrm{M}^{\mathrm{a}}$. del S. "Criterios para la atribución y modificación de la guarda y custodia de los hijos en la práctica judicial”, Aranzadi Civil, Volumen I, Tomo X, año 2001, páginas 1864 y 1865. 
2007/346951, “una relación de convivencia impuesta judicialmente no es la más deseable para la satisfacción del interés del menor y es generadora de situaciones de inestabilidad emocional que repercuten en el ordenamiento escolar, en el desarrollo de la psique de niño o joven, de sus derechos de la personalidad, etc.”. En el mismo sentido destaco la SAP Valencia, Sección 10a núm. 476/2010 de 13 julio. JUR 2010/310592.

Sin duda los jueces en determinadas materias del Derecho de Familia no están vinculados por los acuerdos suscritos en el convenio regulador contrarios al interés del menor, ni tampoco rige el principio rogatorio y dispositivo propio del procedimiento civil en defecto de acuerdo. Como indica el art. 91 del Código Civil ante la presencia del favor filii, el juez de oficio adoptará las medidas de protección adecuadas para los hijos o en su lugar modificará las ya adoptadas, cuando sean alteradas las circunstancias que le sirvieron como base.

Dentro de las actuaciones de oficio está conocer cuál es el alcance del "interés superior del menor" frente a otros intereses legítimos, materia a la que ya hemos aludido con anterioridad. De todas maneras debe indicarse de que prácticamente es unánime la jurisprudencia del Tribunal Supremo que consagra la supremacía de aquel, por cuanto tiene un carácter de principio inspirador a tener presente por los operadores jurídicos de determinados preceptos del Código Civil y de aquellas otras disposiciones reguladoras de materias matrimoniales, paterno-filiales y de adopción, destacando la superioridad de dicho principio, en la valoración conjunta con otros intereses incluido el de los progenitores. Así lo recoge la Ley Orgánica 1/1996 que recoge el espíritu de la Convención de Naciones Unidas de 20 de noviembre de 1989, ratificada por Instrumento de 30 de noviembre de 1990 que vinculan a España. Dichas normas otorgan al Juez facultades discrecionales para adoptar medidas oportunas en beneficio del menor de edad, en concreto que favorezcan la educación, el cuidado, el desarrollo físico y mental así como la estabilidad emocional de aquél.

A los criterios fijados en la jurisprudencia española sobre la aplicación de "interés superior de los hijos", aparecen unidos otros más específicos y de gran utilidad para atribuir la función de guarda y custodia de los hijos. Así los tribunales tras la ruptura familiar deberán: atender a las necesidades (físicas, educativas y emocionales, relacionadas con la edad y el sexo) demandadas por los hijos en el desarrollo de su personalidad; tener en cuenta la capacidad (atención prestada a los hijos antes de la separación o divorcio, disponibilidad de una vivienda adecuada, horario laboral, etc.) que detenten los progenitores para satisfacerlo; conocer la voluntad del menor de edad conforme establece el núm. 2 de art. 92 del Código Civil, en la forma que prevé la regla $4^{\mathrm{a}}$ del art. 770 de la LEC, y apreciar la estabilidad que le proporciona el entorno familiar, escolar y social. Se cita la SAP Ma- 
Capítulo IV El Principio del interés superior del menor y el Derecho de Familia - Algunas conclusiones en torno al interés del menor

drid, Sección 24a núm. 754/2007 de 7 junio. JUR 2007/312426 : “(...) En estas circunstancias es evidente la convivencia y necesidad del cambio en la alternativa de guarda operado en la instancia, máxime cuando se ha informado que garantiza adecuadamente la estabilidad familiar, personal, social y de todo orden que precisa el hijo común”. Y la ya citada STS 257/2013, Sala 1', de 29 de abril, que declara la no excepcionalidad de la guarda y custodia compartida, y destaca aludiendo a la anterior STC 185/2012, de 17 de octubre, el carácter no preceptivo del informe del Ministerio Fiscal ${ }^{1056}$. Según esta sentencia los requisitos para la guarda y custodia compartida, y que reflejan su íntima relación con el interés superior del menor, serían son los siguientes:1) La práctica anterior de los progenitores en sus relaciones con el menor y sus aptitudes personales; 2) Los deseos manifestados por los menores competentes; 3) El número de hijos; 4) El cumplimiento por parte de los

1056 STS, Sala 1", Sección primera, núm. 257/2013 de 29 abril. RJ 2013\3269 . " El motivo se estima en lo que se refiere a los argumentos contenidos en la sentencia para denegar la medida de guarda y custodia compartida, que la Sala no comparte en absoluto, pues se justifica a partir de una posición inicialmente contraria a este régimen en la que plantea como problemas lo que son virtudes de este régimen como la exigencia de un alto grado de dedicación por parte de los padres y la necesidad de una gran disposición de éstos a colaborar en su ejecución, sin fundar la decisión en el interés del menor, al que no hace alusión alguna, y que debe tenerse necesariamente en cuenta en los litigios sobre guarda y custodia compartida.- Es cierto que la STC 185/2012, de 17 de octubre, ha declarado inconstitucional y nulo el inciso "favorable" del informe del Ministerio Fiscal contenido en el artículo 92.8 del Código civil, según redacción dada por la Ley 15/2005, de 8 de julio, de tal forma que corresponde exclusivamente al Juez o Tribunal verificar si concurren los requisitos legales para aplicar este régimen. Es por tanto al Juez al que, en el marco de la controversia existente entre los progenitores, corresponde valorar si debe o no adoptarse tal medida considerando cuál sea la situación más beneficiosa para el niño; y si bien se confiere a los progenitores la facultad de autorregular tal medida y el Ministerio Fiscal tiene el deber de velar por la protección de los menores en este tipo de procesos, sólo a aquel le corresponde la facultad de resolver el conflicto que se le plantea, pues exclusivamente él tiene encomendada constitucionalmente la función jurisdiccional, obligando a los progenitores a ejercerla conjuntamente sólo cuando quede demostrado que es beneficiosa para el menor- Lo dicho no es más que el corolario lógico de que la continuidad del cumplimiento de los deberes de los padres hacia sus hijos, con el consiguiente mantenimiento de la potestad conjunta, resulta sin duda la mejor solución para el menor por cuanto le permite seguir relacionándose del modo más razonable con cada uno de sus progenitores, siempre que ello no sea perjudicial para el hijo, desde la idea de que no se trata de una medida excepcional, sino que al contrario, debe considerarse la más normal, porque permite que sea efectivo el derecho que los hijos tienen a mantener dicha relación.- Pues bien, el artículo 92 CC -STS 19 de abril de 2012- establece dos posibilidades para que pueda acordarse la guarda y custodia compartida: la primera es la contenida en el párrafo 5, que la atribuye cuando se de la petición conjunta por ambos progenitores. La segunda se contiene en el párrafo 8 de esta misma norma, que permite "excepcionalmente y aun cuando no se den los supuestos del apartado cinco", acordar este tipo de guarda "a instancia de una de las partes", con los demás requisitos exigidos (sobre la interpretación de la expresión "excepcionalmente ", véase la STS 579/2011, de 27 julio). En ambos casos, un requisito esencial para acordar este régimen es la petición de uno, al menos de los progenitores: si la piden ambos, se aplicará el párrafo quinto, y si la pide uno solo y el juez considera que, a la vista de los informes exigidos en el párrafo octavo, resulta conveniente para el interés del niño, podrá establecerse este sistema de guarda. El Código civil, por tanto, exige siempre la petición de al menos uno de los progenitores, sin la cual no podrá acordarse.- No obsta a lo anterior, sigue diciendo, lo dicho en nuestra sentencia 614/2009, de 28 septiembre, porque si bien es cierto que, de acuerdo con lo establecido en el art. 91 CC, el Juez debe tomar las medidas que considere más convenientes en relación a los hijos, en el sistema del Código civil para acordar la guarda y custodia compartida debe concurrir esta petición. Este sistema está también recogido en el art. 80 del Código del Derecho foral de Aragón (Decreto Legislativo 1/2011, de 22 de marzo). Ciertamente existen otras soluciones legales, como la contemplada en el art. 5.1 y 2 de la Ley 5/2011, de 1 de abril, de la Generalitat Valenciana de Relaciones Familiares de los hijos e hijas cuyos progenitores no conviven, pero no es precisamente lo que determina el Código civil." 
progenitores de sus deberes en relación con los hijos y el respeto mutuo en sus relaciones personales; 5) El resultado de los informes exigidos legalmente; 6) En definitiva, cualquier otro que permita a los menores una vida adecuada en una convivencia que forzosamente deberá ser más compleja que la que se lleva a cabo cuando los progenitores conviven, sin que la mera constatación de que el régimen de guarda y custodia se adapta mejor al interés de los progenitores resulte suficiente para deducir que se adapta mejor al interés del menor, que es el que debe primar.

Concluyendo este tema quisiera manifestar que la división territorial legislativa en materia de Derecho de Familia ha hecho mella en el comportamiento del legislador español a la hora de fijar factores que colaboren a determinar el contenido del "interés superior del menor". En un principio el legislador español no fijaba en el Derecho positivo, factores que ayudaran a concretar este concepto jurídico indeterminado. Ello se observa en la reforma llevada a cabo en el Código Civil mediante la Ley 15/2005, de 8 de julio, señala determinados y escasos instrumentos en el número 6 del art. 92 del Código Civil que inciden sobre el interés superior del menor.

Por su parte el Código Civil de Cataluña aprobado por Ley 25/2010, de 29 de julio, en el art. 211- 6 aunque regula de forma expresa el interés superior del menor, y establece criterios objetivos para los operadores jurídicos, cuando haya que adoptar medidas que afecten a los hijos menores de edad, no aporta nada novedoso para la jurisprudencia menor. A su vez, el Decreto Legislativo 1/2001, de 22 de marzo, del Gobierno de Aragón, por el que se aprueba el denominado "Código de Derecho Foral de Aragón", como establecía la derogada Ley 2/2010, de 26 de mayo, de igualdad en las relaciones familiares ante la ruptura de convivencia de los padres, refuerza el principio de interés superior del menor, advirtiendo a los progenitores que sean conscientes de que la responsabilidad parental continúa, a pesar de la ruptura matrimonial e incluso la nueva situación exige, sin duda, mas diligencia y cuidado en su deber de padres.

Diferente es, por lo demás, la postura adoptada en las Legislaciones territoriales aplicables en las Comunidades Autónoma de Valencia y Navarra. La Ley 5/2011, de 1 de abril, de la Generalitat, de relaciones familiares de los hijos e hijas cuyos progenitores no conviven, antes de fijar el régimen de convivencia entre los hijos y los progenitores, exige a la autoridad judicial comprobar la concurrencia de determinados factores ${ }^{1057}$. Por su parte la Ley Foral 3/2011, de 17 de marzo, sobre

1057 El art. 5-3 de la Ley 5/2011, de 1 de abril, de la Generalitat, de Relaciones Familiares de los hijos e hijas cuyos progenitores no conviven, indica al juez determinados factores que les facilite la elección como medida judicial del régimen de convivencia entre progenitores e hijos: a) la edad de os hijos e hijas. En los casos de menores lactantes, se podrá establecer un régimen de convivencia provisional, de menor extensión, acorde con las necesidades del niño o de la niña, que deberá ser progresivamente ampliado a instancia de cualquiera de los progenitores. b) La opinión de los hijos e hijas menores cuando tuvieran la madurez suficiente y, en todo caso, cuando hayan cumplido doce años. c) La dedicación pasada a la familia, el tiempo dedicado a la crianza y educación de los hi - 
custodia de los hijos en caso de ruptura de la convivencia de los padres, aplicable en la Comunidad Autónoma de Navarra, de idéntico modo exige la concurrencia de determinados factores, antes de elegir el régimen de convivencia más conveniente ${ }^{1058}$.

jos e hijas menores y la capacidad de cada progenitor. d) Los informes sociales, médicos, psicológicos y demás que procedan. E) Los supuestos de especial arraigo social, escolar o familiar de los hijos e hijas menores. f) Las posibilidades de conciliación de la vida familiar y laboral de los progenitores. g) La disponibilidad de cada uno de ellos para mantener un trato directo con cada hijo o hija menor de edad. h) Cualquier otra circunstancia relevante a estos efectos.

1058 El art.3-3 de la Ley Foral 3/2011, de 17 de marzo, sobre custodia de los hijos en los casos de ruptura en la convivencia de los padres, establece como factores decisivos para la elección del régimen de convivencia los siguientes: a. La edad de los hijos. b. La relación existente entre los padres y, en especial, la actitud de cada uno de los progenitores para asumir sus deberes, respetar los derechos del otro y, en especial, cooperar entre sí y garantizar la relación de los hijos con ambos progenitores y sus familias extensas. c. El arraigo social y familiar de los hijos. d. La opinión de los hijos, siempre que tengan suficiente juicio y, en todo caso, si son mayores de doce años, con especial consideración a los mayores de catorce años. e. La aptitud y voluntad de los padres para asegurar la estabilidad de los hijos. f. Las posibilidades de conciliación de la vida familiar y laboral de los padres y que estos le hayan justificado. h. Cualquier otra circunstancia de especial relevancia para el régimen de convivencia. 


\section{Capítulo V}

El Principio del libre desarrollo de la personalidad y el Derecho de Familia. Su influencia el Principio de Igualdad, en la Autonomía de la voluntad y en el Interés superior del menor 
Capitulo V El Principio del libre desarrollo de la personalidad y el Derecho de Familia. Su influencia el Principio de Igualdad, en la Autonomía de la voluntad y en el Interés superior del menor - Consideraciones previas

\section{1| Consideraciones previas}

El Derecho y su importancia, el por qué y el para qué?, su fundamento sin duda es la persona, su justificación radica en servirle como instrumento de ordenación y defensa de si misma y de sus intereses. Cuando el ordenamiento reconoce un derecho, lo que procura es satisfacer unos fines, unas utilidades que considera dignos de protección. Debido a esto, a la existencia física, a la integridad moral y espiritual, a la necesidad de salvaguardar estas dimensiones en los sujetos de derecho, ha resultado esencial la construcción de los derechos humanos ${ }^{1059}$.

Si bien el principio en cuestión se denomina de libre desarrollo de la personalidad, será más bien entendido como desarrollo de la persona, lo cual es el reconocimiento pleno, teórico y práctico de la dignidad de la misma, en este caso en el ámbito civil.

De partida, debemos reflexionar sobre la persona, esta vendría a ser, en lenguaje corriente, la denominación genérica que se da a todos los individuos de la especie humana, iguales en naturaleza y dignidad. Es común afirmar que los seres humanos somos personas, somos hombres y mujeres, somos criaturas en las que se concentran tanto procesos vitales, como actividades espirituales ${ }^{1060}$.

1059 Los autores y la jurisprudencia tienen distintas acepciones y calificaciones para los derechos, por lo que es conveniente que ahora, consciente de su insuficiencia y sin perjuicio de su posterior desenvolvimiento, se depuren algunas de sus diferencias. Derechos humanos: denominación que se asigna a aquellos derechos que son inherentes a la persona por razón de su naturaleza humana, según la cual todos los hombres son titulares de ellos por igual. Para PÉREZ LUÑO, en "Derechos humanos. Estado de derecho y Constitución", Ed. Tecnos, $9^{\mathrm{a}}$ edición, Madrid, año 2005. Tales derechos constituyen el conjunto de facultades e instituciones que, en cada momento histórico, concretan las exigencias de la dignidad, la libertad y la igualdad humanas, las cuales deben ser reconocidas positivamente por los ordenamientos jurídicos a nivel nacional e internacional. La Declaración Universal de Derechos humanos de la Asamblea General de Naciones Unidas de 10 de diciembre de 1948, carece de fuerza normativa directa, aunque si indirecta por la influencia que pretende ejercer en las diferentes legislaciones nacionales. Los derechos humanos son beneficiosos y deseables para el conjunto de la sociedad porque buscan lo que justamente le ha de corresponder a cada persona, es decir, a todos los que pertenezcan al género humano Derechos individuales: es un concepto de raíz liberal, son los que gozan los hombres como particulares, como individuos y no pueden ser restringidos por los gobernantes, siendo inalienables, inmanentes e imprescriptibles. Derechos subjetivos: hacen referencia a un poder atribuido a un sujeto para que lo ejerza y defienda. Derechos naturales: son los inherentes al hombre desde su nacimiento. Derechos fundamentales: son los derechos humanos imprescindibles una vez que han sido positivizados, los cual les dota de un elenco de garantías que posibilitan al individuo su ejercicio real y efectivos, en principio esta noción sólo atañe a los particulares y al Estado. Son propiamente aquellos que se hayan reconocidos como tales en las Constituciones políticas que rigen las naciones. Derechos Constitucionales: son los derechos que se encuentran insertados dentro de la Constitución que les da constancia, contenidos y garantías.

1060 CASTÁN TOBEÑAS, J. "Los derechos del hombre", Ed. Reus, $4^{a}$ edición, Madrid, año 1992, páginas 58 y 59. Algún antecedente de la concepción del hombre con significación espiritual, ético-jurídica, encontramos ya en el concepto romano de la humanitas, forjado por la filosofía estoica, precursora de la concepción cristiana de la persona humana. Pero el verdadero y más propio encuentro de la persona como valor esencial, como fundamental concepto filosófico-jurídico, hay que buscarlo en el Cristianismo. Sin duda, la filosofía de la persona apareció en la confluencia de la filosofía antigua con la incipiente teología cristiana, es decir, con llamada filosofía patrística, la filosofía antigua, no obstante la preocupación socrática acerca de la esencia del hombre y la doctrina aristotélica de la individuación, desconoció completamente el problema de la persona. En el plano de la naturaleza, único ángulo de la visión de la filosofía antigua, el hombre no podía ser sino individuo. La persona es categoría espiritual. Nace cuando en el ente pisicofísico despierta la conciencia de si y de su destino exclusivo, intransferible. 
Capitulo V El Principio del libre desarrollo de la personalidad y el Derecho de Familia. Su influencia el Principio de

La persona humana trasciende, se hace eco en diversas actuaciones y el rastro que deja, la historia personal que se plasma en ellas, configura la personalidad. Esta, entonces deriva de la noción de persona y vendría a ser el conjunto de rasgos biológicos, sociológicos y psicológicos que caracterizan a un sujeto y si le falta alguno de ellos no puede imaginarse que exista. Presenta una gran riqueza de matices y una ilimitada variedad de concreciones que permiten afirmar que cada individuo tiene una única e irrepetible personalidad.

Desde la perspectiva filosófica y ética, se destacan como caracteres definitorios de la personalidad la autoconciencia, el autodominio, la subjetividad y la responsabilidad moral. El análisis sociológico, por su parte, centra la atención sobre el conjunto de papeles o funciones que desempeña el sujeto dentro de la comunidad. Así, la personalidad resulta modelada por agentes tales como el aprendizaje y la experiencia adquirida socialmente ${ }^{1061}$.

En relación al principio del libre desarrollo de la personalidad, este ha estado presente en las más importantes innovaciones que se han hecho en el Derecho de Familia. Por ejemplo ha estado presente en la Ley 30/1981, de 7 de julio, por la que se modificó la regulación del matrimonio en el Código Civil y se determinó el procedimiento a seguir en las causas de nulidad, separación y divorcio. De conformidad con los entonces nuevos principios, se procuró promover y proteger la dignidad de los cónyuges y sus derechos, logrando que mediante la relación jurídica se favoreciera el libre desarrollo de la personalidad de ambos. El derecho a contraer matrimonio se configuró como un derecho constitucional, cuyo ejercicio no podía afectar, ni desde luego, menoscabar la posición jurídica de ninguno de los esposos en el matrimonio, y por último, dio lugar a una relación jurídica di-

Fue así el Cristianismo el que infundió a la cultura oCcidental un espíritu nuevo. En efecto, el Cristianismo ha afirmado el valor del individuo como ser de fines absoluto; ha exaltado, desde sus primeros momentos, el sentimiento de la dignidad de la persona humana y ha proclamado y proclama enérgicamente hoy la necesidad de que la sociedad este organizada en forma tal que permita a la persona desenvolverse íntegramente, realizar su perfec ción y afirmar su personalidad, sin perjuicio del bien común y cooperando con él.

1061 Vid. BASTIDA FREIJEDO, F. J., VILLAVERDE MENÉNDEZ, I., REQUEJO RODRÍGUEZ, P,. PRESNO LINERA, M. A., ALÁEZ CORRAL, B., FERNÁNDEZ SARASOLA, I. "Teoría general de los Derechos fundamentales en la Constitución española de 1978”, Ed. Tecnos, Madrid, año 2004, página 87. "La titularidad en tanto concreción de la capacidad jurídica iusfundamental presupone la personalidad del sujeto en la que se basa ésta última. Ello plantea en primer término el problema del comienzo y fin de la personalidad, sobre todo de las personas físicas. Con independencia de cuál sea el concepto religioso, filosófico o biológico de la persona que se maneje y las implicaciones que del mismo se deriven para el momento en que se adquiere la personalidad, lo cierto es que el texto constitucional maneja un concepto de persona en la que ésta resulta ser un complejo de imputaciones jurídicas cuyo único aspecto valorativo es la dignidad que predica de la misma y que se concreta en los derechos y libertades constitucionalmente garantizados. Aunque la CE de 1978 ha guardado silencio en relación con el momento de adquisición de la personalidad y, por ello, la tarea de determinarlo ha quedado relegada al legislador, es posible deducir una serie de criterios en su construcción que le vinculan y a los que éste se ha atenido. Sin duda, el criterio más significativo es que la personalidad ya está en nuestro ordenamiento vinculada al hecho del nacimiento. La vida humana, entendida como un proceso biológico previo al nacimiento, es sólo un bien constitucionalmente protegido, pero su portador sea embrión o feto, no es titular de derechos fundamentales (STC 53/1985, FFJJ 5\%)." 
soluble, por las causas que la ley dispusiera. Que duda cabe, el respeto al libre desarrollo de la personalidad, garantizado por el artículo 10.1 de la Constitución, justificó reconocer mayor trascendencia a la voluntad de la persona.

Sin perjuicio de ello, si se considerase este principio como vivificador de las diversas instituciones provocaría aún más la consideración de que el Derecho Civil es el mejor aliado de la Constitución cuando se trata de poner a la persona como centro del ordenamiento jurídico, sin perjuicio de que la propia Carta Magna crease su propio estatuto constitucional de la misma ${ }^{1062}$.

El principio del libre desarrollo de la personalidad, tal cual se acaba de manifestar, impregna prácticamente todo el Derecho de la persona en el ámbito civil, y su relación más intrincada se da con el principio de la autonomía de la voluntad que sin duda es la manifestación más conocida del Derecho Civil. De alguna manera su historia es la trayectoria de su concreción en las más diversas realidades privadas ${ }^{1063}$.

La ubicación del principio de libre desarrollo de la personalidad en la CE a la cabeza del título destinado a la consagración de los “derechos fundamentales y de las libertades públicas", de "los derechos y deberes de los ciudadanos" y de "los principios rectores de la política social y económica" da una idea exacta de su importante significado, por cuanto este principio tiene su centro en la exigencia del respeto y primacía de la dignidad humana.

La manera en que esta autodeterminación consciente y responsable de la propia vida y de la propia dignidad se desenvuelve en el Derecho Civil, en relación a los derechos fundamentales, es lo que permite entender que se entiende por tal principio, y especialmente como tal puesta en práctica en el Derecho de Familia tiene lugar.

En esencia, lo que se busca al reflexionar sobre el principio del libre desarrollo de la personalidad y el Derecho de Familia es poner en el centro de la diana la dignidad humana a nivel del matrimonio, a nivel de la filiación, pero sobre todo en un ámbito que es bastante más amplio que los dos recién mencionados, a nivel de la familia y sus diversos modelos.

1062 Cfr. MARTÍNEZ VÁZQUEZ DE CASTRO, “El principio de libre desarrollo de la personalidad en el ámbito privado”, Ed. Thomson Reuters, Cizur Menor, año 2010.

1063 Así lo manifiesta MARTÍNEZ VÁZQUEZ DE CASTRO, El principio de libre desarrollo de la personalidad en el ámbito privado", ... op. cit. página 10, contrariamente a ello opina CARRASCO PEREA cuando afirma que "La proyección humana de la persona y su autorrealización constituye sin duda un objetivo no sólo laudable, sino exigido por la Constitución como una tarea a afrontar por el legislador Pero no constituye un objetivo del Derecho civil, en cuanto limitado al juego de las relaciones de derecho entre sujetos. Constituye una afirmación obvia que el derecho de las personas al desarrollo de su propia personalidad, siendo un evidente derecho politico, no expresa ninguna relación de Derecho privado, como tampoco la expresa el derecho al libre desarrollo de las facultades intelectuales o creativas". Cfr. CARRASCO PEREA, A. "El Derecho civil, señal, imágenes y paradojas", Ed. Tecnos, Madrid, año 1988, pagina 34. 
Capítulo V El Principio del libre desarrollo de la personalidad y el Derecho de Familia. Su influencia el Principio de Igualdad, en la Autonomía de la voluntad y en el Interés superior del menor - El fundamento del principio del libre desarrollo de la personalidad: la dignidad y la libertad del hombre

\section{2 | El fundamento del principio del libre desarrollo de la personalidad: la dignidad y la libertad del hombre}

Sin duda que cuando se hace referencia al libre desarrollo de la personalidad se hacer referencia a la dignidad de la persona. La dignidad humana constituye uno de los valores indivisibles y universales sobre los que descansa el ordenamiento jurídico español, así como su homónimo europeo, de hecho la Unión Europea está fundada en él, art. 2 TUE y Preámbulo de la Carta de los Derechos Humanos de la Unión Europea. En tal sentido la dignidad humana no es tan sólo la base del ordenamiento, por consiguiente fundamento de su Constitución, todo derecho fundamental deber referirse a ella, y por consiguiente al rol activo que constituye el libre desarrollo de la personalidad. La dignidad es la esencia de los derechos, así lo ha entendido la Carta de los Derechos Fundamentales de la Unión Europea, la cual tras el correspondiente Preámbulo, se inicia, precisamente con el Título Primero consagrado a la dignidad, cuya primera disposición, el art. 1 se refiere a la dignidad humana, con una redacción idéntica a la contenida en al art. 1 en la Carta de los Derechos Fundamentales adoptada en Niza en 2000. Y en esa redacción se encuentra un triple prisma que se funde en cada una de las normas del sistema, y por consiguiente constituyen un canon interpretativo del mismo, no sólo comunitario sino incluso a nivel nacional. La dignidad humana es inviolable, la dignidad humana será respetada, y por consiguiente será protegida.

Tal como se acaba de afirmar la dignidad humana es inviolable, no cabe atentar contra ella por cualquier motivo que sea, incluso, con la justificación de proteger alguno de los derechos fundamentales consignados en la Carta recién mencionada, ahora bien, el rol que desempeña en un ordenamiento jurídico depende en gran parte de la cultura jurídica en que se incluya al Estado de cuyo ordenamiento se trate ${ }^{1064}$. Es un principio absoluto e inderogable, es decir, permanente que implica

1064 TEDH, Sección 4", Caso P. y S contra Polonia. Sentencia de 30 octubre 2012. TEDH 2012/96. "Las cuestiones relativas a la definición legal de protección de la vida humana, la determinación de las condiciones para su terminación aceptable y la comprensión de la privacidad y la libertad de conciencia son cuestiones de importancia fundamental, profundamente arraigado en la cultura de cada sociedad. La definición de los límites temporales de la vida humana entra dentro del margen de apreciación de los Estados partes. No corresponde al Tribunal cuestionar las decisiones de las autoridades estatales y de los médicos sobre la aceptación del aborto. Ha sido reconocido en la jurisprudencia del Tribunal que la aceptación de la interrupción del embarazo debería dejarse a las decisiones de las autoridades nacionales elegidas democráticamente. Este enfoque se basa en los valores que sustentan el Convenio, como el respeto de la dignidad y la libertad individual. La comprensión de las nociones de vida y la paternidad está tan fuertemente vinculada a la dignidad y la libertad personal y también a los valores espirituales comunes a la nación, que su protección no puede quedar fuera de la esfera nacional. En el examen de cualquier caso el Tribunal también debería tomar en consideración la especificidad social y cultural de Polonia." 
Capítulo V El Principio del libre desarrollo de la personalidad y el Derecho de Familia. Su influencia el Principio de Igualdad, en la Autonomía de la voluntad y en el Interés superior del menor - El fundamento del principio del libre desarrollo de la personalidad: la dignidad y la libertad del hombre

que no puede justificarse el uso instrumental de un ser humano, nunca jamás, tal cual lo afirma SOBRINO HEREDIA ${ }^{1065}$.

La dignidad de la persona es, el rango de la persona como tal ${ }^{1066}$. Definir lo que es la dignidad humana se intuye especialmente complicado, sin embargo resulta ineludible. La dignidad se ha ido delimitando en una doble dirección. Resulta ser un límite a la actuación del Estado y de otros poderes. Constituye el fundamento de la prohibición de prácticas tales como la tortura o la esclavitud y aparece aparejada a términos tales como Estado de Derecho, Constitución, etc. Actualmente y sin perder esta primigenia dimensión fundamental, la dignidad se vincula particularmente al libre desarrollo de la personalidad y la vida privada ${ }^{1067}$. Por tal motivo la dignidad de la persona resulta invocada cuando se analizan temas de especial actualidad, en donde identidad y libertad, personalidad y privacidad, juegan un importante rol, constituyéndose en elementos configuradores de la misma, provocando un intervención mínima del Derecho, solo para eliminar los obstáculos que impiden su plena realización o para sancionar las incursiones estatales o de terceros en este ámbito. Se estima que la dignidad constituye el magma del que se alimentan los derechos, algunas de sus manifestaciones y límites. Por esta razón, la dignidad adquiere una dimensión personalista, independiente y autónoma que trasciende el contenido y alcance de los derechos humanos aunque tal cual se analizará están estrechamente vinculados. Puede apreciarse en palabras de OEHLING DE LOS RE$\mathrm{YES}^{1068}$ la pretensión de hacer ver, como habían insinuado tiempo antes autores tales como RECASENS SICHES ${ }^{1069}$, LEGAZ LACAMBRA ${ }^{1070}$, MILLÁN PUELLES ${ }^{1071}$ y otros ${ }^{1072}$, que la sociedad sólo se puede realizar a partir del recíproco reconocimiento de que cada hombre tiene dignidad intrínseca. Por lo tanto, cuando se gestaba la Constitución española, había que inculcar en ella la idea, la importancia de uno valores consistentes en percibir, en primer lugar la importancia de la dignidad

1065 SOBRINO HEREDIA, J. M. “Art. 1. Dignidad humana.” en MANGAS MARTÍN, A. (Dir.), “Carta de os Derechos Fundamentales de la Unión Europea. Comentario artículo por artículo”, Fundación BBVA, Bilbao, año 2008, página 107 y 108.

1066 GONZÁLEZ PÉREZ, J. “La dignidad de la persona”, Ed. Civitas, Madrid, año 1986, página 24.

1067 JIMENEZ GARCÍA, F., "El respeto a la dignidad humana”, en BENEYTO PÉREZ, J. M". "Tratado de Derecho y Políticas de la Unión Europea”, Tomo II, Derechos fundamentales, Ed. Aranzadi, Cizur Menor, año 2009, página 292.

1068 OEHLING DE LOS REYES, A. “La dignidad de la persona”, Ed. Dykinson S. L., Madrid, año 2010, página 274 y siguientes.

1069 RECASENS SICHES, L. "Vida humana, Sociedad y Derecho, fundamentación de la Filosofia del Derecho”, Fondo de Cultura Económica, México D. F., año 1945, página 251.

1070 LEGAL LACAMBRA, L. "La noción jurídica de la persona y los derechos del hombre”, en Revista de Estudios Públicos, XI, 55, IEP, Madrid, año 1951, páginas15 a 46.; el mismo autor en “Estado de Derecho" en Revista de Administración Pública, núm. 6, CEPEC, Madrid, año 1991, página 33.

1071 MILLÁN PUELLES, A. “Sobre el hombre y la sociedad”, Ed. Rialp, Madrid, año 1976, páginas 97 a 103.

1072 GIL ROBLES, J. M. “Por un Estado de Derecho”, Ed. Ariel, Barcelona, año 1969, páginas 83 y 84. 
Capítulo V El Principio del libre desarrollo de la personalidad y el Derecho de Familia. Su influencia el Principio de Igualdad, en la Autonomía de la voluntad y en el Interés superior del menor - El fundamento del principio del libre desarrollo de la personalidad: la dignidad y la libertad del hombre

de la persona y de los derechos que le son inherentes, por encima de cualquier otra circunstancia social o personal, como base previa para lograr una paz social que sostuviera el anhelado consenso que por entonces se buscaba con tanto afán ${ }^{1073}$. En tal sentido CISNEROS LABORDA es de la opinión de que la dignidad y su reconocimiento son la base del pacto de convivencia, como concepto necesario incluso para la propia existencia de la Constitución ${ }^{1074}$.

La dignidad de la persona quiere decir que ésta tiene un valor en sí misma, independiente de cualquier circunstancia o cualidad interna o externa. Por tanto, independientemente de su raza, credo ideología, sexo, clase social, nacionalidad, etc. También independiente de su conducta, se prescinde en este caso de un juicio valórico de carácter moral. En tal sentido, tal cual se ha afirmado antes en el presente trabajo, ROBLES MORCHÓN manifiesta que: "La idea de dignidad humana es la traducción al lenguaje secularizado de la idea cristiana de que todos los hombres, independientemente de cualquier condición o circunstancia, son hijos de Dios. Con el cristianismo el hombre adquiere el máximo valor posible. Al ser hecho a imagen y semejanza y al estar destinado por él a la eterna bienaventuranza se sitúa por encima de cualquier voluntad humana. El ser humano deja de ser un medio para transformarse en un fin en sí mismo, no susceptible de rebajarse a la categoría de medio bajo ninguna circunstancia, ni siquiera de carácter excepcional ${ }^{1075}$.

La dignidad de la persona es ejemplo del carácter institucional, fundacional y esencial de la persona, tiene sus propios fines que el Derecho debe proteger. Y ello implica precisamente que en la regulación jurídica todo hombre tiene capacidad de obrar, esto es lo que da su especial sentido a las

1073 FERNÁNDEZ SEGADO, F. “La dignidad de la persona en el ordenamiento constitucional español”, RVAP, núm. 43, año 1995 , página 68. Si bien la colocación de la dignidad en el frontipacio del título primero ("De los derechos y deberes fundamentales") podría inducir a considerarla como un derecho fundamental , esta conclusión quedada vedada por situarse aquella fuera de los capítulos que recogen los derechos y libertades; además, el art. 53, al contemplar las garantías de los derechos, se refiere únicamente a los derechos de los capítulos $2^{\circ}$ y $3^{\circ}$. En este sentido, Vid. MATEO PARDO, R. "La dignidad de la persona humana y su significación en la Constitución española de 1978 a través de la jurisprudencia del Tribunal Constitucional”, en Escritos jurídicos en memoria de Luis Mateo Rodríguez, Tomo I, Universidad de Cantabría- Facultad de Derecho, Santander, año 1993, página 350.

1074 CISNEROS LABORDA, G., “Balance y perspectiva de la Constitución” en Revista valenciana d' estudis autonòmics, núm. 39 y 40, Generalitat Valenciana, Valencia, año 2003, páginas 99 a 101.

1075 Añade ROBLES MORCHÓN, G.,"El libre desarrollo de la personalidad (Artículo 10 de la Constitución española)", ... op. cit., página 47: "La dignidad de la persona excluye toda consideración utilitarista de la misma, esto es, la concepción que aceptaría verla, no como un fin en sí misma, sino como un posible medo para satisfacer cualquiera fines ajenos o propios. La dignidad del ser humano se manifiesta en su intangibilidad o indisponibilidad. Que la dignidad es intangible, quiere decir que no puede aceptarse nada que le afecte en su integridad, siendo tarea de los poderes públicos (aunque no sólo de ellos) el protegerla. La indisponibilidad se refiere a que nadie puede disponer del valor dignidad, ni siquiera el propio sujeto, por ejemplo, vendiéndose como esclavo, o renunciando a los derechos que le son inherentes como persona". 
Capítulo V El Principio del libre desarrollo de la personalidad y el Derecho de Familia. Su influencia el Principio de Igualdad, en la Autonomía de la voluntad y en el Interés superior del menor - El fundamento del principio del libre desarrollo de la personalidad: la dignidad y la libertad del hombre

variadas formas del estado civil, marca el alcance de las reglas sobre el patrimonio, autonomía y ejercicio de los derechos de la personalidad y justifica el deber general de respeto a la persona ${ }^{1076}$.

Sin duda, el ya citado artículo 10.1 supone la visión constitucional de la persona y también la dimensión axiológica de la CE. Esta visión parece implicar mucho, por cuanto hace referencia a la concepción constitucional de los valores ${ }^{1077}$. Es más, se hace referencia a la influencia del personalismo en el citado texto. Se trata a la vez de una forma práctica de la noción de dignidad que se expande por otros derechos fundamentales ${ }^{1078}$ y sirve como pauta de base y complementación para la interpretación y desarrollo de otros conceptos jurídicos ${ }^{1079}$. De la misma manera lo manifiestan GARCÍA DE ENTERRÍA ${ }^{1080}$ y PÉREZ LUÑO ${ }^{1081}$. Es el propio Tribunal Constitucional quien ha reconocido que el artículo 10.1 de la CE parece describir determinada finalidad axiológica ${ }^{1082}$.

Dignidad de la persona que como valor constitucional implica según afirma DOMINGUEZ RODRIGO $^{1083}$, una exigencia positiva inmediata, el mantenimiento en todo tipo de relación jurídica de ese rango de la dignidad humana, sin ser admisible ninguna suerte de degradación de la misma, como ocurría con la tortura, o, en términos generales, la cosificación de ser humano ${ }^{1084}$. La dignidad de la persona expresa, junto con lo anterior, la idea de que se es dueño del propio proyecto vital, esto es, del libre desarrollo de la personalidad. También puede hablarse de algo similar hablando del individuo o de autodeterminación del mismo.

En tal sentido, la dignidad constituye la esencia de la personalidad moral, no pudiéndose construir ésta sino desde la libre elección. Pero al ser el concepto de "personalidad" un concepto moral,

1076 Es claro que la propia naturaleza de la persona informa toda regulación del Derecho de la Persona; pero, a la vez influye todas las instituciones del Derecho civil; la persona puede ser objeto de derechos como en el Derecho de familia, o quedar su conducta sometida a una voluntad ajena por el contrato; más al recaer el derecho sobre la misma persona la obligación funciona de un modo radicalmente distinto que cuando la vinculación está referida a una cosa, pues en el primer caso se ha de respetar siempre el valor y la dignidad de la persona y en lo posible su libertad.

1077 Cfr. MUÑOZ ARNAU, J. A. "Los limites de los derechos fundamentales en el Derecho Constitucional español”, Ed. Aranzadi, Pamplona, año 1998.

1078 PECES-BARBA, G. “Los valores superiores”, Ed. Tecnos, Madrid, año 1984.

1079 LUCAS VERDÚ, P. “Estimativa y políticas constitucionales”, Servicio de Publicaciones de la Universidad Complutense de Madrid, año 1984, páginas 123 y 124.

1080 GARCÍA DE ENTERRÍA, E. “Los fundamentos constitucionales del Estado”, en REDC, núm. 5, CEPC, Madrid, año 1998, páginas 20, 21 y 30.

1081 PÉREZ LUÑO, A., “Los Derechos Fundamentales”, Ed. Tecnos, Madrid, año 2004, páginas 58, 59,174 a 177.

1082 STC, Pleno, núm. 25/1981 de 14 julio. RTC 1981/25.

1083 DOMINGUEZ RODRIGO, L. M. "Los derechos procreativos como expresión del desarrollo al libre desarrollo de la personalidad en el seno de las unidades familiares no matrimoniales”. GOMEZ-FERRER MORANT, R. (Coord), Libro homenaje al profesor José Luis Villar Palasí., Ed. Civitas,Madrid, año 1989, página 352.

1084 Cfr. MARÍN CASTÁN, M. L., "Notas sobre la dignidad humana como fundamento del orden jurídico-político en la Constitución española y en la futura Constitución europea”, en BALADO, M. y GARCÍA REGUEIRO, J. A. (Dir.), “La Constitución española de 1978 en su XXV aniversario”, Ed. J. Mª Bosch, Barcelona, año 2003. 
Capitulo V El Principio del libre desarrollo de la personalidad y el Derecho de Familia. Su influencia el Principio de Igualdad, en la Autonomía de la voluntad y en el Interés superior del menor - El fundamento del principio del libre desarrollo de la personalidad: la dignidad y la libertad del hombre

la dignidad que es su punto de partida no podrá tener cualquier contenido sino sólo aquellos que efectivamente conduzcan al desarrollo de la personalidad moral que el ser humano como libre sujeto agente se propone.

Pero sin duda la noción de dignidad humana tiene también un sentido práctico, y este sentido se trasluce en diversas sentencias del Tribunal Constitucional ${ }^{1085}$. En tales casos la dignidad se manifiesta como "fundamento jurídico del ordenamiento jurídico entero"1086, "valor cardinal"1087,

1085 Cfr. OEHLING DE LOS REYES, A. “La dignidad de la persona”, ...op. cit., páginas 362 y siguientes.

1086 STC, Pleno, núm. 5/1981 de 13 febrero. RTC 1981/5.

1087 STC, Sala 1"a núm. 170/1994 de 7 junio. RTC 1994/170. "Es opinión pacifica de todos, jurisprudencia y autores, que el delito de injurias protege el honor de las personas, como pone de manifiesto el propio epígrafe del Título X del Código Penal, en el cual se encuadra con la calumnia como la otra de sus modalidades. En el texto y el contexto aqui enjuiciados desde una perspectiva estrictamente constitucional, se moteja a una de las víctimas como «titi», cuyo significado peyorativo, insultante en fin, es de sobra conocido y se hace en tono ostensiblemente despectivo, se inventa un propósito de abandono por parte del novio para conseguir un efecto burlesco, con un ataque frontal a la intimidad, y se imagina un futuro que sirve tan sólo para darse el gusto de calificar a la mujer «como una foca, coja, pero como una foca». El texto analizado, por otra parte, deja traslucir un concepto despreciativo respecto de la mujer como género de la especie humana, no sólo de esa mujer individualizada, con una clara actitud machista. Es evidente que todo ello nada tiene que ver con la sedicente desidia municita finalidad del comentario periodístico. Las expresiones entresacadas son exabruptos gratuitos e innecesarios, dictados por un claro animus iniurandi, el afán de «meterme con alguien» como confiesa el autor en las mismas páginas, días después, cuando tuvo la ocasión de rectificar, que desaprovechó para insistir en su agresión hiriente e innecesaria. Con tal manera de escribir se añade una vejación gratuita al infortunio sufrido por la víctima del accidente, manchando así su imagen social y atentando a su dignidad, valor cardinal especialmente proclamado en el art. 10.1 de nuestra Constitución, dignidad de la persona que es el núcleo irreductible del derecho al honor. Tal exceso, que no es admisible ni siquiera cuando el destinatario de los insultos es un personaje público, resulta notoriamente recusable si de particulares se trata. El autor se coloca así, él mismo, fuera del ámbito constitucionalmente protegido de la libertad de expresión por menoscabar la reputación y buena fama, sin que el sacrificio de este otro derecho se justifique por la defensa de ningún bien constitucionalmente protegido. En definitiva, la calificación de su conducta como delictiva y la pena impuesta como consecuencia, no han de reputarse atentatorias a libertad de expresión, ni a la de comunicar información veraz reconocida en el art. 20 de la Constitución (STC 105/1990). Por el contrario, la sentencia que, en apelación, absuelve al acusado de tal imputación vulnera con ello el derecho al honor contemplado desde la dignidad personal de los hoy demandantes (arts. 10.1 y 18 CE) por haber ponderado con error los derechos fundamentales en colisión." 
Capítulo V El Principio del libre desarrollo de la personalidad y el Derecho de Familia. Su influencia el Principio de Igualdad, en la Autonomía de la voluntad y en el Interés superior del menor - El fundamento del principio del libre desarrollo de la personalidad: la dignidad y la libertad del hombre

"principio constitucional""1088, "marco dentro del cual debe desarrollarse el ejercicio de los derechos fundamentales" 1089 .

Es importante mencionar que la noción de dignidad presenta a su vez una dimensión relacional con los valores superiores y los derechos fundamentales, estos sin duda la explican de manera más detallada ${ }^{1090}$. En orden a los valores constitucionales esa relación está tan incardinada que en muchas ocasiones resulta dificultoso mencionar la noción de dignidad sin hacer mención de principios tales como la libertad, la igualdad, la justicia y el pluralismo político, todos ellos recogidos en el artículo 1.1. de la $\mathrm{CE}^{1091}$. La garantía de la dignidad en el Estado constitucional, se corresponde

1088 STC, Pleno, núm. 215/1994 de 14 julio. RTC 1994/215 . "Los ejemplos de la historia reciente, conocidos y sufridos por la humanidad, ponen de relieve la desproporción jurídica de medidas de este tipo y el riesgo cierto que conllevan de relativización de los derechos fundamentales de la personalidad. Por lo pronto, una Ley autoriza, bajo ciertas condiciones, la lesión de la integridad fisica de los incapaces. Mas la ley no es ya ahora garantía suficiente para la defensa de los derechos fundamentales y por ello éstos han debido incluirse en las constituciones. La posibilidad de que las leyes, con diversos fundamentos, permitan en unos u otros casos su afección, los coloca en riesgo cierto de resultar degradados y alterados. Mas la garantía constitucional habrá resultado insuficiente si no se le reconoce toda la fuerza inherente a unos derechos que se fundan directamente en la dignidad del hombre. Porque ulteriores leyes podrán, una vez degradado el principio constitucional, extender la aplicación de la medida mediante la modificación de las condiciones exigibles: en cuanto a los fines, en cuanto a la persona del solicitante, en cuanto a los requisitos de la intervención judicial... y finalmente, incluyendo en la categoría «autorizable» a otros sujetos pasivos que se consideren parangonables a los deficientes psíquicos. Cuando se altera un derecho de esta naturaleza las consecuencias antijurídicas pueden llegar a ser desmesurada".

1089 STC, Pleno, núm. 235/2007 de 7 noviembre. RTC 2007/235. Manifiesta esta sentencia que: "De este modo, el reconocimiento constitucional de la dignidad humana configura el marco dentro del cual ha de desarrollarse el ejercicio de los derechos fundamentales y en su virtud carece de cobertura constitucional la apología de los verdugos, glorificando su imagen y justificando sus hechos cuando ello suponga una humillación de sus víctimas ( STC 176/1995). Igualmente, hemos reconocido que atentan también contra este núcleo irreductible de valores esenciales de nuestro sistema constitucional los juicios ofensivos contra el pueblo judio que, emitidos al hilo de posturas que niegan la evidencia del genocidio nazi, suponen una incitación racista ( SSTC 214/1991, de 11 de noviembre; 13/2001 de 29 de enero). Estos límites coinciden, en lo esencial, con los que ha reconocido el Tribunal Europeo de Derechos Humanos en aplicación del apartado segundo del art. 10 CEDH_. En concreto, viene considerando (por todas, Sentencia Ergogdu \& Ince c. Turquía, de 8 de julio de 1999) que la libertad de expresión no puede ofrecer cobertura al llamado «discurso del odio», esto es, a aquél desarrollado en términos que supongan una incitación directa a la violencia contra los ciudadanos en general o contra determinadas razas o creencias en particular. En este punto, sirve de referencia interpretativa del Convenio la Recomendación núm. $R$ (97) 20 del Comité de Ministros del Consejo de Europa, de 30 de octubre de 1997, que insta a los Estados a actuar contra todas las formas de expresión que propagan, incitan o promueven el odio racial, la xenofobia el antisemitismo u otras formas de odio basadas en la intolerancia (SSTEDH Gündüz c. Turquía de 4 de diciembre de 2003_, \$ 41; Erbakan c. Turquía de 6 de julio de 2006”.

1090 VILLAVERDE MENÉNDEZ, I. “Los límites de los derechos fundamentales”, en BASTIDA FREIJEDO, F. J. et al., "Teoría general de los derechos fundamentales en la Constitución Española de 1978”, Ed. Tecnos, Madrid, año 2004.

1091 http://www.tribunalconstitucional.es/actividades/artic046.html. JIMENEZ SÁNCHEZ e DE LA CUEVA ALEU, "La dignidad humana en la jurisprudencia constitucional española", septiembre-octubre 2007. Estiman que el Tribunal Constitucional se cuida de precisar que no existe una plena identificación entre derechos fundamentales y dignidad personal, o lo que es lo mismo, que ni la totalidad de los derechos fundamentales reconocidos son, por ese sólo hecho, inherentes a la persona en cuanto conectados con su dignidad, ni puede afirmarse que toda restricción de los derechos humanos de la persona suponga un ataque a su dignidad. A tal efecto citan la STC 120/1990, de 27 de junio, en la que se afirma que de acuerdo con este precepto, la dignidad de la persona y los derechos inviolables que le son inherentes sean, junto con el libre desarrollo de la personalidad, el respeto a la Ley y a los derechos de los demás, "fundamento del orden político y de la paz social”, no significa ni que todo el 
Capítulo V El Principio del libre desarrollo de la personalidad y el Derecho de Familia. Su influencia el Principio de Igualdad, en la Autonomía de la voluntad y en el Interés superior del menor - El fundamento del principio del libre desarrollo de la personalidad: la dignidad y la libertad del hombre

paralelamente así con el respeto a la libertad del individuo, la proscripción de la discriminación, la responsabilidad del individuo y la promoción de la participación del ciudadano en la vida social y viceversa $^{1092}$, de una u otra manera la relación del ciudadano y el Estado queda garantizada a través de la garantía de la dignidad, la cual presupone el respeto y protección de los derechos fundamentales y principios directrices estatales. Cuanto más logrados están estos objetivos y valores, tanto más se comprende de como un Estado de Derecho es respetuoso de tal dignidad, de como la fomenta.

Para el tema que nos ocupa es de vital relevancia entender el respeto a la dignidad de la persona presuponiendo el respeto a la libertad, por ello no puede justificarse sea cual sea el fundamento, emplear a otro como medio, como instrumento privándolo de su yo. En definitiva, coartando la posibilidad de vincularse a la idea del libre desarrollo de su personalidad. Esto, por cuanto el reconocimiento de la dignidad presupone la valoración y respeto de un margen de autonomía y desarrollo del individuo a través de su propia experiencia, por ello se intenta hacer del ciudadano el verdadero sujeto de su actuación ${ }^{1093}$.

El respeto a la dignidad de la persona presupone el respeto a la libertad del individuo, porque su recepción lleva implícito el reconocimiento que todo el ordenamiento estatal existe para y por el hombre, por ello debe dar cierta relevancia a la opción y experiencia vital que la persona estima para sín $^{1094}$. No se puede plantear un reconocimiento auténtico, pleno de la dignidad de la persona si el Estado, previamente, no reconoce, estima y protege, la autorrealización de la persona en libertad, en todas sus formas de manifestación, ya sea artística, religiosa, política, de expresión, etc, principalmente me refiero al modo de vida que se escoja, ámbito donde la persona se muestra tal cual $\mathrm{es}^{1095}$. Por ello se habla de un ámbito personal de libertad exento de cualquier intervención externa,

derecho le sea inherente y por ello inviolable ni que los que se califican de fundamentales sean condiciones imprescindibles para su efectiva incolumidad, de modo que de cualquier restricción que a su ejercicio se imponga devenga un estado de indignidad.

1092 OEHLING DE LOS REYES, A. "La dignidad de la persona”... op. cit., página 365..

1093 Si un Estado reconoce el concepto de dignidad, pero no parte de su conexión con la idea de libertad, la noción de de dignidad queda desvinculada de la idea de autodeterminación de la persona, de su posibilidad de desarrollarse como él quiera ser o como él realmente es y constituiría, quizás, un régimen que implementaría algunos aspectos sectoriales de reconocimiento de la idea de dignidad, pero quedaría apartado el deber del Estado de dar a la persona la importancia que se merece. Es muy difícil imaginar como se puede posibilitar el desarrollo pleno de la faceta individual si no hay un posicionamiento estatal de reconocimiento real de la capacidad de autorrealización independiente de la persona en libertad.

1094 Ciertamente no puede comprenderse la dignidad sin reconocer la libertad en sus diversos planos, artística, ideo lógica, religiosa, de expresión, política, etc. Esta conexión entre los derechos de libertad y los derechos fundamentales conforman un cierto status de libertad según HÄBERLE, P. en "La libertad fundamental en el Estado constitucional”, Ed. Comares, año 2003, páginas 29 a 67.

1095 Cfr. MURILLO DE LA CUEVA, P y CARMONA CUENCA, E. "La tutela jurisdiccional de los derechos fundamentales por los tribunales ordinarios”, Ed. Tirant Lo Blanch, Valencia, año 2008. 
Capítulo V El Principio del libre desarrollo de la personalidad y el Derecho de Familia. Su influencia el Principio de Igualdad, en la Autonomía de la voluntad y en el Interés superior del menor - El fundamento del principio del libre desarrollo de la personalidad: la dignidad y la libertad del hombre

el cual se encuentra protegido por medio del respeto a los derechos fundamentales, siendo únicamente el individuo quien puede decidir sobre el devenir de su propia existencia y actuar bajo su responsabilidad.

Esta posibilidad de elección y actuación responsable requiere de una promoción educacional por el Estado en su conexión con la idea de dignidad humana. Es decir, este poder de decisión requiere de la posibilidad de desarrollar la propia personalidad obteniendo una formación educacional sólida, para que así la persona tome conciencia verdadera de la realidad humana que le circunda, del sufrimiento y las necesidades de los demás en comparación con las suyas propias y de sus posibilidades personales desde el respeto a la sociedad en la que vive y la dignidad de los demás.

El libre desarrollo de la personalidad aporta una concepción dinámica del hombre y por ende de su dignidad, en la que se afirma que la libertad psicológica o autogobierno, implican que dicha personalidad se desenvuelve libremente a través de los actos, relaciones y negocios jurídicos de la persona-sujeto, y, en definitiva a través de todo el actuar o no actuar humanos, en este caso, en el ámbito jurídico.

El libre desarrollo de la personalidad del artículo 10.1 establece en definitiva un proyecto de libertad individual de carácter general. Es el individuo el que tiene el derecho a decidir libremente su proyecto vital, así como a cambiarlo cuantas veces quiera e incluso a no tenerlo propiamente. Es lo que la doctrina alemana denomina “una libertad general de acción”. Éste, según ROBLES ${ }^{1096}$, es el contenido propio del libre desarrollo de la personalidad.

CASTÁN TOBEÑAS ${ }^{1097}$ manifestaba que el porvenir del mundo depende, sobre todo, de la formación educativa de las jóvenes generaciones. Más que el Estado, es la sociedad la que tiene a su cargo esta función y la responsabilidad consiguiente. Aunque en la obra de reeducación de los hombres hayan de intervenir muchos factores y sean necesarias muchas colaboraciones, es de destacar el cometido primordial que con relación a ella corresponde a la familia. Ciertamente, y por suerte, las más modernas constituciones políticas, así como también las declaraciones de derechos humanos en el ámbito mundial, incluyen ya, entre los derechos sociales, los que afectan a la protección de la familia; pero no basta con salvaguardar la familia en sus implicaciones económicos-sociales; es im-

1096 ROBLES. MORCHON, G. "El libre desarrollo de la personalidad (Artículo 10 de la Constitución española)", ... op. cit. página 49

1097 CASTÁN TOBEÑAS, J. "Los derechos del hombre”, ... op. cit., página 244. El citado autor afirma que hay que aspirar dentro del Derecho de familia, a conseguir el mayor equilibrio posible entre los derechos propiamente individuales, basados en la idea de igualdad y en el principio fundamental del respeto debido a la dignidad humana, y los derechos de la familia como grupo social, célula básica de la sociedad y del Estado, que tiene a su cargo funciones tan importantes y necesarias para el desenvolvimiento de la propia personalidad individual de los seres que viven en ella y han obtener dentro de la misma su pleno desarrollo. 
Capítulo V El Principio del libre desarrollo de la personalidad y el Derecho de Familia. Su influencia el Principio de Igualdad, en la Autonomía de la voluntad y en el Interés superior del menor - El fundamento del principio del libre desarrollo de la personalidad: la dignidad y la libertad del hombre

prescindible también defender su régimen interno y la continuidad y estabilidad de la misma, como organismo natural con fines propios, puesto en peligro por muchas de esas mismas normas sociales y por otras de Derecho Privado poco favorables para la unidad y la permanencia del grupo familiar. Proteger la estabilidad de la familia de los fenómenos y fuerzas disociadoras que tienden a debilitar esta institución significa asegurar la dignidad del individuo, proporcionándole el medio natural para su desarrollo físico, moral y social ${ }^{1098}$.

Una vez expuesta la estrecha conexión entre libre desarrollo de la personalidad y dignidad humana, es necesario abordar la libertad y su intrínseca relación con el principio en cuestión. Es en este punto donde es muy notoria la función de este principio en el Derecho de familia.

La Constitución reconoce expresamente en su artículo 1.1 la libertad, como uno de los valores superiores del ordenamiento. Dicha disposición hace referencia a un principio general de libertad, lo cual implica la posibilidad de que los ciudadanos realicen todas las actividades que la Ley no prohíba, sabiendo que no se pueden imponer restricciones arbitrarias ${ }^{1099}$. Es más, denota la posibilidad de realizar una interpretación extensiva de los derechos fundamentales o incluso comprendiendo la posibilidad de creación de unos nuevos, todo ello bajo el amparo de acudir a la libertad ${ }^{1100}$.

Al existir un principio general de libertad se derivan, por consiguiente diversas manifestaciones concretas de libertades, las cuales se consideran derechos subjetivos, con distinto encuadre y naturaleza en relación al principio enunciado en al art. 1.1. de la $\mathrm{CE}^{1101}$. En relación con esto puede estimarse que únicamente constituyen derechos subjetivos de libertad los derechos reconocidos expresamente como derechos de libertad por la Constitución, en tal sentido sólo se justificarían desde el derecho de libertad las conductas subsumidas en cualquiera de tales derechos subjetivos o libertades, expresamente reconocidos constitucionalmente. Para MARTÍN SÁNCHEZ, debe entenderse que derivado del valor superior libertad, existe un derecho general de libertad implícito en el ordenamiento jurídico, por lo tanto, estarían protegidas tanto las concretas manifestaciones del principio general de libertad expresamente reconocidas constitucionalmente a través de los derechos

1098 GOICOCHEA, A “La idea democrática y la evolución hacia el Estado de Derecho (Discurso inaugural del Curso en la Academia Nacional de Jurisprudencia y Legislación”, Madrid, año 1932, páginas 90 y siguientes.

1099 STC, Pleno, núm. 83/1984 de 24 julio. RTC 1984/83; STS, Sala de lo contencioso-administrativo, Sección 6a, de 31 marzo 2004. RJ 2004/1958 .

1100 MARTÍN SÁNCHEZ, M. “Matrimonio Homosexual y Constitución”, Ed. Tirant Lo Blanch, Monografías, núm. 589, Valencia, año 2008, página 111.

1101 Vid. SÁNCHEZ FERRIS, R. “Estudios sobre las libertades”, Ed. Tirant Lo Blanch, 2a edición, Valencia, año 1995, página 42. 
Capítulo V El Principio del libre desarrollo de la personalidad y el Derecho de Familia. Su influencia el Principio de Igualdad, en la Autonomía de la voluntad y en el Interés superior del menor - El fundamento del principio del libre desarrollo de la personalidad: la dignidad y la libertad del hombre

subjetivos de libertad, así como cualquier manifestación de libertad aunque no esté reconocida de manera explícita en algún derecho subjetivo ${ }^{1102}$.

DÍAZ REVORIO ${ }^{1103}$ opina que el derecho de libertad del individuo se encuentra como norma de clausura en el art. 10.1 CE, en el principio del libre desarrollo de la personalidad, así tendría cabida cualquier manifestación de la "libertad a secas", como derecho de libre actuación del individuo. Por su parte, PRIETO SANCHÍS ${ }^{1104}$, es partidario de la tesis de la norma de clausura del sistema de libertades, situando dicha norma entre los derechos fundamentales, otorgándole así un carácter especial y una mayor protección constitucional. Concretamente la ubica en el art. 16.1 CE, vinculada al Derecho de libertad de conciencia, el cual está implícito en la libertad ideológica y religiosa del art. 16.1 CE, situando así la norma de clausura en un derecho fundamental, lo cual le reviste de mayor protección. Podría argumentarse esta opinión procurando entender el derecho de libertad de conciencia de una manera amplia, es decir, no situándolo únicamente a la libertad de creencias sino a la libertad de conducta humana, lo cual implica que un individuo pueda comportarse de acuerdo a sus propias convicciones.

Lo importante en todo caso es sostener la existencia de un derecho de libertad garantizado constitucionalmente para el individuo, que no es tan solo un principio que ordena el sistema, sino que resulta exigible en la medida que se refleje en alguna conducta del individuo.

Estimo que el derecho de libertad como una "libertad a secas", presenta mayor vinculación con el libre desarrollo de la personalidad y la dignidad humana, previsto en al art. 10.1 CE, por cuanto este es fundamento del orden político y de la paz social, que carecería de sentido sino se asocia a un derecho general de libertad que garantice su efectividad, de lo contrario no gozaría de contenido, más bien sería una enunciación programática. El libre desarrollo de la personalidad debe considerarse fundamento de la libertad general de acción, por ello se reconoce en la libertad del individuo $^{1105}$.

Ahora bien, ¿Es ilimitada esta libertad?, No, claro que no, no pueden admitirse todas las conductas del ser humano, argumentando su justificación en su derecho general de libertad fundado en el libre desarrollo de la personalidad, es necesario establecer límites y restricciones. Algunos de tales límites serían los derechos fundamentales, el resto de tales límites serían impuestos por el Legis-

1102 MARTÍN SÁNCHEZ, M. “Matrimonio Homosexual y Constitución”....op. cit., página 112.

1103 DÍAZ REVORIO, F. J. "Valores superiores e interpretación constitucional", Centro de estudios Políticos y Constitucionales, Madrid, año 1997, página 517.

1104 “Estudios sobre derechos fundamentales", Ed. Debate, Madrid, año 1990, página 162.

1105 Cfr. DÍAZ REVORIO, F. J. “Valores superiores e interpretación constitucional”, ...op. cit.,página 510. 
Capítulo V El Principio del libre desarrollo de la personalidad y el Derecho de Familia. Su influencia el Principio de Igualdad, en la Autonomía de la voluntad y en el Interés superior del menor - El fundamento del principio del libre desarrollo de la personalidad: la dignidad y la libertad del hombre

lador, respetando lo preceptuado en el Código político, ponderando las causas que permiten justificar estas restricciones, siempre que se considere asimismo el principio de proporcionalidad, es decir, la justificación de dichas restricciones sería la defensa de los valores y principios constituciona$\operatorname{les}^{1106}$.

Esto tiene una directa relación con el Derecho de Familia, y especialmente con la libertad de contraer matrimonio, por cuanto esta libertad se podría limitar a determinada categoría de personas, en razón de su orientación sexual, preservando de esta manera el orden público, entendido éste último como el conjunto de principios no disponibles para el sujeto, formado por: los imperativos y los pilares de carácter constitucional, entendiendo como tales los derechos fundamentales y los valores materiales.

Tal orden público permitirían restringir la libertad de elección, por ejemplo en el derecho a contraer matrimonio, en el derecho a adoptar, etc. La duda de tal restricción, sin embargo, debe fundamentarse en la ponderación ya aludida, restringir la libertad del individuo a contraer matrimonio, por ejemplo, para desarrollar así libremente su personalidad en su faceta personal y familiar, llevando a cabo su proyecto personal de vida no parece ser el medio adecuado para salvaguardar el orden público, además no presenta un carácter necesario, considerando que el respeto de dicha libertad sea constitutivo de una alteración del orden público de una sociedad como la española ${ }^{1107}$. En este caso, a mi juicio, sería más convincente el argumento de justificar la restricción del derecho a la libertad, bajo el prisma del libre desarrollo de la personalidad, porque su ejercicio desvirtúa el contenido esencial de una institución amparada en la Constitución, institución garante del orden social, como puede ser el matrimonio, aunque tal cual ya se explicó en otro capítulo no ha sido estimado de esta manera por el Tribunal Constitucional ${ }^{1108}$.

1106 MARTÍN SÁNCHEZ, M. “Matrimonio Homosexual y Constitución”.....op. cit., página 113, “Llevando todo esto al tema que centra nuestra atención observamos que, partiendo de la existencia de la libertad genérica como "libertad a secas", perteneciente al individuo y cristalizado en artículo 10.1 CE, limitar la libertad de actuación del individuo a través del no reconocimiento -como hasta hace muy poco en el caso de contraer matrimonio entre personas del mismo sexo- o a través de su omisión en la Ley-en este caso en las leyes que hasta hace poco venían regulando el matrimonio-, sólo tendría justificación si se argumentase que dicha limitación o restricción de la libertad obedece a la protección de algún valor, principio o bien constitucional tal que tras efectuar una ponderación de bienes en juego, sería conveniente establecer dicha limitación. Sin embargo, no parece existir ningún valor, principio o bien constitucional en riesgo, cuya protección necesite de tal restricción A este respecto, se hace preciso además tener presentes el resto de argumentos y fundamentos constitucionales ya apartados anteriormente, tales como la igualdad y la prohibición de discriminación, y la dignidad de la persona, además de este derecho genérico la libertad del individuo."

1107 REY MARTÍNEZ, F. “Homosexualidad y Constitución”, en Revista Española de Derecho Constitucional, núm. 73, Madrid, año 2005, página 131.

1108 STC, Pleno, núm. 198/2012, de 6 de noviembre, RTC 2012/198 
Capítulo V El Principio del libre desarrollo de la personalidad y el Derecho de Familia. Su influencia el Principio de Igualdad, en la Autonomía de la voluntad y en el Interés superior del menor - El fundamento del principio del libre desarrollo de la personalidad: la dignidad y la libertad del hombre

Es decir, no podría limitarse o restringirse arbitrariamente la libertad del individuo, sino que las limitaciones que se impongan a la libertad se tendrán que justificar en base a valores o bienes constitucionales, considerando la exigencia de ponderar y así evitar la imposición de restricciones abusivas que coarten injustificadamente la libertad del individuo, entendida tal libertad como partícipe del libre desarrollo de la personalidad, fundamento del orden político y de la paz social.

\section{3 | El principio del libre desarrollo de la personalidad y el Derecho de Familia}

Las Leyes 13/2005 de 1 de julio, y 15/2005, de 8 de julio, que han operado una profunda reforma del Derecho de Familia en el ordenamiento jurídico español, tienen un hilo conductor, consistente en la "personalización" del matrimonio, este es el núcleo de la tesis propugnada por DE VERDA Y BEDAMONTE $^{1109}$. Las referidas leyes hacen jugar al principio constitucional del libre desarrollo de la personalidad una importancia desconocida hasta ahora en el Derecho Civil, acentuando la función del matrimonio como un medio de desarrollo de la personalidad en detrimento de su carácter de institución social, lo que ha estado en estrecha relación con la conexión de una de las finalidades del matrimonio, la cual era, la procreación de los hijos y el cuidado de los mismos ${ }^{1110}$.

GAVIDIA SÁNCHEZ ${ }^{1111}$, sostiene que es necesario distinguir entre concepto y concepción. Por una parte hace referencia a la concepción de matrimonio que subyace en el Legislador y por otra al concepto que se enmarca en la Constitución. Este último podría admitir diversas concepciones, en función de la libertad de goce de que cuenta el Legislador. Para este autor no existen instituciones naturales, sino que intereses individuales, utilidades sociales, situaciones más o menos típicas, con connotación jurídica o moral, y que tales intereses pueden perfectamente ser analizados con afán crítico en relación a visión tradicional que ha tenido aquella situación, aquel interés. Si esta reflexión se aplicase al matrimonio podría entenderse el debate a que ha dado lugar.

Puede existir originariamente o generarse posteriormente una gran divergencia entre lo que la mayoría de los ciudadanos considera acerca de cuál debe ser el contenido y los perfiles básicos de una institución jurídica, como también puede suceder que en un determinado momento, el descontento acerca de la regulación del matrimonio sea mayor en algunos sectores o grupos sociales espe-

1109 “La personalización del matrimonio en las reformas de 2005”, en DE VERDA Y BEAMONTE, J. R. (Coord.), “Comentario a las Reformas de Derecho de Familia de 2005”, Thomson Aranzadi, Cizur Menor, página 17.

1110 Cfr. DE VERDA Y BEAMONTE, J. R., "Principio de libre desarrollo de la personalidad y ius connubi (a propósito del auto del Tribunal Constitucional 222/1994)”, en Revista de Derecho Privado, Octubre, año 1998, páginas 683 a 736.

1111 "La libertad de elegir como cónyuge a otra persona del mismo sexo y de optar entre el matrimonio y una unión libre (Análisis crítico de la constitucionalidad del matrimonio homosexual y del llamado "divorcio express")'” en “La Reforma del Matrimonio. Leyes 13 y 15/2005”, Ed. Marcial Pons, Madrid, año 2007, página 23 y siguientes. 
Capítulo V El Principio del libre desarrollo de la personalidad y el Derecho de Familia. Su influencia el Principio de Igualdad, en la Autonomía de la voluntad y en el Interés superior del menor - El principio del libre desarrollo de la personalidad y el Derecho de Familia

cialmente influyentes, pero no entre la generalidad de la sociedad. Ahora bien ¿es consciente la sociedad de estás innovaciones?, ¿existe un debate a la altura de lo que implica tal innovación? A mi juicio, ambas preguntas, se responden con un rotundo no.

Este principio, el de libre desarrollo de la personalidad, ha permitido justificar la supresión del requisito de la heterosexualidad, tal cual se deja entrever en la Exposición de Motivos de la Ley 13/2005, "la relación y convivencia de pareja, basada en el afecto, es expresión genuina de la naturaleza humana y constituye cauce destacado para el desarrollo de la personalidad, que nuestra Constitución establece como uno de los fundamentos del orden político y de la paz social”, así como "el establecimiento de un marco de realización personal que permita que aquellos que libremente adoptan una opción sexual y afectiva por personas de su mismo sexo puedan desarrollar su personalidad y sus derechos en condiciones de igualdad se ha convertido en exigencia de los ciudadanos de nuestro tiempo, una exigencia a la que esta Ley trata de dar respuesta" "1112.

En lo referente al divorcio este principio también juega un rol clave, pues justifica junto a la autonomía de la voluntad, el que no exista la necesidad de referirse a un motivo de culpabilidad, sino que "se estima que el respeto al libre desarrollo de la personalidad, garantizado por el art. 10.1 de la Constitución, justifica reconocer mayor trascendencia a la voluntad de la persona cuando ya no desea seguir vinculado a su cónyuge. Así el ejercicio de su derecho a no continuar casado no puede hacerse depender de la demostración de la concurrencia de causa alguna, pues la causa determinante no es más que el fin de esa voluntad expresada en su solicitud, ni, desde luego, de una previa e ineludible, situación de separación”.

A mi juicio, uno de las dificultades fundamentales estriba en amparar todos estos cambios en los afectos. Son importantes, claro, pero la personalidad es bastante más que lo meramente sentimental. Lo afectivo nos conforma, pero no nos forma únicamente.

Puede fundamentarse el matrimonio en el principio constitucional del libre desarrollo de la personalidad. Pero este principio tendrá límites, aunque esos límites no se desprendan de la regulación positiva del matrimonio en el Código Civil, es más, quizás uno de los límites más importantes sea la esencia misma de la institución matrimonial, pero si ni siquiera se sabe si es o no institución, si ni siquiera se sabe qué es un matrimonio, cuales son sus elementos fundamentales, salvo los afec-

1112 Cfr. LASARTE ÁLVAREZ, C. "Merecido adiós al sistema causalista en las crisis matrimoniales”, Actualidad Aranzadi, núm. 655, de 3 de febrero de 2005, páginas 10 y siguientes; CAÑETE QUESADA, A. "El anteproyecto de Ley por el que se modifica el Código Civil en materia de separación y divorcio”, Diario La Ley, núm. 6140, e 2 de diciembre de 2004, páginas 1 y siguientes; PASTOR VITA, F. J. "Algunas consideraciones sobre la ley de reforma del Código Civil en materia de separación y divorcio.”, Revista de Derecho de familia, núm. 28, julio-septiembre 2005, Ed. Lex Nova, Valladolid, páginas 25 a 56. 
Capítulo V El Principio del libre desarrollo de la personalidad y el Derecho de Familia. Su influencia el Principio de Igualdad, en la Autonomía de la voluntad y en el Interés superior del menor de la personalidad y el Derecho de Familia - El principio del libre desarrollo

tos, me temo que el libre desarrollo de la personalidad se vuelca en una total consideración de la libertad personal como único elemento válido de análisis. Pero en cuanto a en qué consiste el desarrollo, en qué consiste la personalidad, muy poco puede manifestarse.

En relación con esto, SERRANO ALONSO opina que el Legislador con esto ha querido dar un contenido claramente interesado a un derecho, el desarrollo de la propia personalidad, con infinitas posibilidades todas ellas de carácter subjetivo, y al menos es dudoso que el Legislador constitucional pensase en incluir el contraer matrimonio entre personas del mismo sexo, cuando el derecho a contraerlo viene constitucionalmente configurado en otros términos, a juicio de este autor. Sin contar que este derecho podría justificar otro tipo de uniones, como por ejemplo, la de hermanos ${ }^{1113}$.

La personalidad no debe tener sólo alcance personalista, es decir, personalidad se funda en la persona, y la fidelidad, la crianza y el cariño dispensado a los hijos, entre los cónyuges, si los hay, el superar los diversos problemas, auxiliarse mutuamente, por ejemplo, permiten mi perfección como persona $^{1114}$. El libre desarrollo de la personalidad es cauce de este camino de perfección no para hacer lo que mi voluntad quiera. El compromiso jurídico denota cumplir deberes y gozar de derechos, pero no todo es "derecho a", sino que, también debe velarse por el "en cumplimiento de”. ¿Puede el Derecho ampararse únicamente en los afectos?, ¿puede el compromiso jurídico afanarse de afectividad?, ¿puede un deber justificarse únicamente en los sentimientos? ${ }^{1115}$

MARTÍNEZ DE CASTRO, siguiendo en este punto a MARTÍNEZ DE AGUIRRE sostiene que "el matrimonio no se basa en el hecho de ser una forma institucionalizada de amistad y comunicación humana, sino en su condición de estado de vida estable que por su propia estructura, propiedad y finalidad, aceptadas libremente por los cónyuges, pero no establecidas por ellos mismos, desempeña una esencial y multiforme función a favor del bien común: sucesión de las generaciones, supervivencia de la sociedad, educación y socialización de los hijos, etc. Realidad objetiva, en función de la cual el ordenamiento jurídico establece los derechos y las obligaciones conyugales. Tal papel social de relevancia jurídica no es desempeñado, ni siquiera analógicamente, por las

1113 “El nuevo matrimonio civil”, Ed. Edisofer, Madrid, año 2005, página 23.

1114 VERDA Y BEAMONTE, J. R. "La personalización del matrimonio en las reformas de 2005”, op. cit., en relación al artículo del mismo autor, titulado el "Principio de libre desarrollo de la personalidad y ius connubi (a propósito del auto del Tribunal Constitucional 222/1994)”, ...op. cit.

1115 MARTÍNEZ VÁZQUEZ DE CASTRO, L. "El principio de libre desarrollo de la personalidad en el ámbito privado", Ed. Civitas Thomson Reuters, Cizur Menor, año 2010, página 210. "No es la afectividad la razón jurídica del compromiso, aunque pueda ser el motivo principal. De hecho, puede existir un matrimonio sin esa afectividad. Si esto no se ve así, aunque en la práctica pueda resultar costoso, como la experiencia nos lo hace ver día a día; si se considera que el matrimonio no es un compromiso jurídico, como sucede en la realidad positiva, no se ve por qué debe estar protegido constitucionalmente... la razón de que el Código Civil le siga dedicando tantos preceptos. Para vivir juntos no hace falta tanta normativa jurídica. Como mucho un pacto ante Notario para establecer alguna reglas de contenido patrimonial." 
Capítulo V El Principio del libre desarrollo de la personalidad y el Derecho de Familia. Su influencia el Principio de Igualdad, en la Autonomía de la voluntad y en el Interés superior del menor - El principio del libre desarrollo de la personalidad y el Derecho de Familia

uniones homosexuales que no se ve como podrían ser consideradas células fundamentales de la sociedad. Con ello no se está realizando ningún tipo de discriminación con respecto a los homosexuales. Lo que se está diciendo es que, a partir de datos naturales, como son el carácter sexuado del ser humano, que sólo lo es en cuanto hombre y mujer y que esta diferenciación sexual se dirige, también por su propia naturaleza, a la reproducción de la especie humana, el matrimonio aparece como una realidad propia del hombre y mujer y el ambiente propio para el desarrollo espiritual y material de los hijos" $" 1116$.

Sin duda, es importante la relación que acaece entre el matrimonio y el principio en cuestión, porque de inmediato salta a la palestra la contradicción existente en la mente del legislador actual, quien ha desplazado el centro de atención desde la institución colectiva a la persona individual, porque si bien el matrimonio aún es entendido como cauce idóneo para el libre desarrollo de la personalidad, no es propiamente tal lo que debe entenderse, porque lo importante no es el matrimonio, lo esencial son los afectos, es la personalidad afectiva la que a mi juicio, el legislador busca proteger.

Por otra parte, se debe reconocer que también ha habido un segundo traslado del centro de atención, fruto de la lucha continua por la reivindicación y la defensa de las competencias matrimoniales estatales frente al Derecho canónico. El Estado se ha afanado en centrar su propio cometido y desarrollar su concepción matrimonial de Estado personalista, que tiene en su punto de mira los derechos de sus ciudadanos derivados de su propia dignidad como personas, y necesarios para el libre desarrollo de la personalidad; cuestiones ambas, dignidad y libre desarrollo, que sustentan la libertad de conciencia individual de todos ellos.

Para FERNÁNDEZ-CORONADO este sin duda, es el punto clave, que marca no sólo la definitiva madurez del sistema, sino el inicio de lo que ha denominado derechos de secularización de segunda generación ${ }^{1117}$, que derivan directamente de esta toma de conciencia por parte del Estado de su exclusiva competencia legislativa y jurisdiccional, consecuencia de su plena soberanía y ajena a condicionamientos de cualquier signo. Este fenómeno, asimismo es lo que se ha denominado como secularización plena y que no se debe confundir con el secularismo, que supondría la prolongación del proceso secularizador más allá de sus debidos límites, en el sentido de negar a la religión el

1116 MARTÍNEZ VÁZQUEZ DE CASTRO, L. "Una posible concepción del matrimonio en el Código Civil . El es tado de la cuestión." en VV. AA. "Estudios en Homenaje al Profesor Manuel Amorós Guardiola”, Centro de Estudios, Colegio de Registradores de la Propiedad y Mercantiles de España, Madrid, año 2006, página 1673; Cfr. MARTÍNEZ DE AGUIRRE, C. “Diagnóstico sobre el Derecho de Familia”, Ed. Rialp, Madrid, año 1996, páginas 34 y siguientes.

1117 FERNÁNDEZ-CORONADO GONZÁLEZ, A. "La evolución jurídica del sistema matrimonial español desde la Constitución de 1978 a la admisión del matrimonio homosexual”, en Revista Foro, núm. 3, Facultad de Derecho, Universidad Computense de Madrid, año 2006, página 105. 
Capítulo V El Principio del libre desarrollo de la personalidad y el Derecho de Familia. Su influencia el Principio de Igualdad, en la Autonomía de la voluntad y en el Interés superior del menor de la personalidad y el Derecho de Familia - El principio del libre desarrollo

puesto que le corresponde, incluso en una sociedad plenamente secularizada, ya que en tal caso el Estado estaría actuando con la pretensión de invadir un campo que le corresponde a la fe, elevando un mundo desprovisto de todo valor religioso a la categoría de lo absoluto ${ }^{1118}$.

Por el contrario, la secularización lo que hace es permitir al legislador estatal profundizar en su obligación positiva de contribuir a la realización efectiva de los derechos en esta materia, adaptando las leyes a aquellas necesidades que la evolución de los valores de convivencia en las sociedades y la plenitud de desarrollo de los derechos fundamentales de sus ciudadanos puede exigir ${ }^{1119}$.

Son, precisamente, estos dos parámetros, en primer lugar, la realización de derechos fundamentales y, en segundo, la adecuación a la realidad o necesidad social del momento, lo que origina el nacimiento de estos derechos de secularización de segunda generación. Estos derechos de secularización en general pueden ser de muy diverso carácter y una parte de ellos, ha encontrado un importante campo de desarrollo en el ámbito de la bioética, cuestión íntimamente ligada a la libertad de conciencia y a la propia dignidad personal ${ }^{1120}$.

En materia matrimonial, el más claro exponente de estos derechos es, sin duda, la admisión al matrimonio de personas del mismo sexo, porque el ius connubii es un derecho inherente a la dignidad de la persona misma, pero la pregunta es ¿puede la orientación sexual, que sin duda tiene directa relación con la dignidad de la persona y lo que ha sido el matrimonio, justificar una transforma-

1118 MARRAMAO CATANZARO, G. “Poder y secularización”, Ed. Península, Barcelona, año 1989, página 28.

1119 OLLERO TASSARA, A. “España: ¿Un Estado Laico?. La libertad religiosa en perspectiva constitucional.”, Ed. Thomson Civitas, Cizur Menor, año 2005, páginas 17 y 18. "En realidad, para poder dar una respuesta al interrogante de si el español es o no hoy en día un Estado Laico habría que realizar un doble análisis. Por una parte, sin duda, ahondar en la concreta regulación de los derechos y libertades fundamentales en la Constitución de 1978; pero también determinar qué habríamos de entender por laico, ya que este socorrido calificativo puede reenviar a planteamientos tan diversos entre sí como la laicidad y el laicismo.- Por laicismo habría que entender el diseño del Estado como absolutamente ajeno al fenómeno religioso. Su centro de gravedad sería más una contaminación -marcada con atisbos de fundamentalismo, sino de abierta beligerancia- que la indiferencia o la auténtica neutralidad. Esa tajante separación, que reenvía toda convicción religiosa al ámbito íntimo de la conciencia individual, puede acabar resultando más que neutra, neutralizadora de su posible proyección sobre el ámbito público. Su versión más patológica llevaría incluso a generar una posible discriminación por razón de religión. Determinadas propuestas podrían acabar viéndose descalificadas como confesionales por el simple hecho de haber encontrado acogida en la doctrina o la moral de alguna de las religiones libremente practicadas por los ciudadanos. - Nada sin embargo, más opuesto a la laicidad que enclaustrar determinados problemas civiles, al considerar que la preocupación por ellos derivaría inevitablemente de una indebida injerencia de lo sagrado en el ámbito público. Así podría estar ocurriendo en la opinión pública española cuando se plantea la defensa de la vida humana prenatal, la libre elección de centros escolares o la protección de la familia monogámica o heterosexual. Esto puede explicar la sorprendente ruindad, gobierne quien gobierne, con que se han apoyado las políticas de apoyo a la familia; precisamente en un país que -en buena parte como reflejo paradójico de años de crisis interna en la Iglesia Católica- ofrece una de las tasas de natalidad más preocupantemente reducidas de Europa."

1120 MARTÍN SÁNCHEZ, I. (Coord.), “Bioética, religión y salud”, Consejería de Sanidad y Consumo,Dirección General de Aseguramiento y Atención al Paciente, Madrid, año 2005; MARTÍNEZ MORÁN, N. (Coord.), “Biotecnología, derecho y dignidad humana”,Ed. Comares, Granada, año 2003. 
Capítulo V El Principio del libre desarrollo de la personalidad y el Derecho de Familia. Su influencia el Principio de Igualdad, en la Autonomía de la voluntad y en el Interés superior del menor de la personalidad y el Derecho de Familia - El principio del libre desarrollo

ción del mismo hasta punto de contradecir uno de sus contenidos esenciales, la heterosexualidad?, ¿no hubiera sido mejor proteger esa dimensión de la dignidad humana y proteger al matrimonio mediante la conformación de otra figura jurídica?

Sin perjuicio de ello, la homosexualidad no influyó en el proceso de secularización del matrimonio en sí mismo considerado, porque surge como demanda social y como derecho ligado al libre desarrollo de la personalidad con posterioridad a ese proceso.

La heterosexualidad ya está presente en el matrimonio romano ${ }^{1121}$, que concibe el matrimonio como un acto único de naturaleza consensual sustentado en la affectio maritalis, frente a las fórmulas antiguas del matrimonio por etapas ${ }^{1122}$, y se integra en la cristianización del matrimonio como elemento esencial, ligado por el Derecho canónico al fin primario del mismo, constituido por la generación de la prole. Tampoco durante el proceso de secularización del matrimonio la heterosexualidad del mismo se pone en tela de juicio, se da por supuesta. La razón de ello es que el punto esen cial de la controversia no residía en la propia institución matrimonial. Se debatía si la unión civil era auténtico matrimonio o si sólo tenía tal carácter la unión canónica, siendo considerada la primera como simple consorcio para los que no pudiesen acceder al matrimonio canónico, por no profesar la religión católica ${ }^{1123}$.

Así y todo, es la plena secularización del matrimonio lo que produce la inversión de esa realidad y es por donde, en su momento adecuado, encuentra el resquicio de entrada el reconocimiento legal del matrimonio homosexual. Sin el proceso de secularización ello hubiera sido imposible. Produciendo una redimensión del mismo, despojándolo de contenidos dogmáticos y morales, haciendo desaparecer los criterios de culpabilidad para la disolución del vínculo y simplificando la propia desvinculación, admitiendo, incluso la simple voluntad unilateral para su consecución ${ }^{1124}$.

Sin duda, se puso sobre el tapete la necesidad de tomar en consideración el pleno desarrollo de los derechos inalienables de la persona en toda su dimensión como elementos determinantes para la configuración jurídica del vínculo, derechos entre los que se encuentra el de contraer matrimonio

1121 MURILlO, M. “Matrimonio y homosexualidad. La constitucionalidad de la Ley 13/2005, de modificación del Código civil español sobre derecho a contraer matrimonio entre personas del mismo sexo”, en Laicidades y Libertades. Escritos Jurídicos, núm. 5, año 2005, páginas 261 a 314, donde además se recoge un tratamiento pormenorizado y riguroso de la evolución del tratamiento de la homosexualidad, desde su denominación como enfermedad mental a su consideración como un rasgo que define la identidad personal.

1122 GAUDEMET, J. “El matrimonio en Occidente”, Ed. Taurus, Madrid, año 1993, páginas 37 y siguientes.

1123 En estos términos se refería al matrimonio civil el Preámbulo del Decreto de 9 de febrero de 1875 sobre el esta blecimiento de un sistema de matrimonio civil subsidiario.

1124 MARTINELL GUISPERT-SAUCH, J. M., "Tutela jurídica del libre desarrollo de la personalidad y juridificación de la vida afectiva de pareja en el Derecho español”, en Laicidad y Libertades, número 5, Madrid, año 2005, páginas 9 y siguientes. 
con independencia del sexo de las personas. Pero también hay que constatar que este impulso definitivo definitivo para su entrada en escena está estrechamente ligado a un momento previo: la toma en consideración por los Estados de los derechos humanos, tras la amarga experiencia de la Segunda Guerra Mundial. El desarrollo de los llamados derechos humanos primarios por el Estado laico (libertad, igualdad, dignidad humana, etc.) permitió el nacimiento y reconocimiento estatal de otros derechos humanos de segunda generación enraizados en los anteriores, donde ya se encontraba el libre desarrollo de la personalidad, aunque constitucionalmente en el ámbito español no sea enfoque tanto como un derecho propiamente tal, sino que, como principio.

Ya desde la última década del siglo XX se habían dejado sentir voces en el aspecto internacional sobre esta cuestión. En febrero de 1994, el Parlamento Europeo llamó la atención sobre la necesidad de que los Estados miembros de la Unión tomasen las medidas precisas para garantizar la igualdad de trato de sus ciudadanos con independencia de su orientación sexual, extremo que fue reiterado en abril de 2003, reseñando la discriminación que suponía la prohibición a los homosexuales de contraer matrimonio o de adoptar niños ${ }^{1125}$, y algunos Estados europeos incorporaron a su Derecho tempranamente el matrimonio sin discriminación por razón de sexo ${ }^{1126}$.

También la Constitución Europea de 1994 en su artículo 2, relativo a los valores de la Unión, establece el respeto a la dignidad humana como el principio de estos valores, junto a la libertad, la democracia, la igualdad, el Estado de Derecho y el respeto de los derechos humanos, valores que el propio artículo inserta en una sociedad caracterizada por el pluralismo, la tolerancia, la justicia, la solidaridad y la no discriminación. Si a esto se une que la Carta de los Derechos humanos de la Unión del año 2000, que integra la Segunda Parte de la mencionada Constitución, recoge expresamente el respeto, la protección y la inviolabilidad de la dignidad de la persona humana como primero de sus contenidos, e introduce por primera vez en un texto de ésta índole la prohibición de discriminación por razón de orientación sexual ${ }^{1127}$, parece claro que la evolución de los derechos fundamentales y su ahondamiento en la radical libertad del individuo, demandada por la sociedad actual, transforma la configuración clásica del matrimonio.

1125 Vid., respectivamente, Resolución A.3-0028/94, de 8 de febrero, sobre la igualdad de derechos de los homosexuales y las lesbianas en la Comunidad Europea, y Resolución A-.5-0281/2003, de 9 de abril, sobre la situación de los derechos fundamentales en la Unión Europea.

1126 Por ejemplo, Holanda, mediante la Ley de apertura del matrimonio de 21 de diciembre de 2000, o Bélgica, con la Ley de apertura del matrimonio para personas del mismo sexo de 13 de febrero de 2003.

1127 Vid. Art. II. 21 de la Constitución Europea. 
La Ley 30/2005, de 1 de julio, modifica el Código Civil en materia de derecho a contraer matrimonio, estableciendo que éste tendrá los mismos requisitos cuando ambos contrayentes sean del mismo o de diferente sexo, y hace derivar este derecho del propio artículo $32.1 \mathrm{CE}$, ya se ha dicho en varias oportunidades, pero debe resaltarse que el Constituyente no tuve en su mente al matrimonio homosexual.

Está claro que el Legislador interpreta esta norma conforme a dos parámetros esenciales, el primero es la convivencia en pareja como cauce adecuado al libre desarrollo de la personalidad en condiciones de igual libertad, y la adaptación a la realidad social del tiempo en que ha de aplicarse la norma. Según FERNÁNDEZ-CORONADO, es el propio carácter personalista que modela los derechos fundamentales de la persona en el texto constitucional lo que provoca esta interpretación ${ }^{1128}$. Lo anterior es consecuencia de la secularización matrimonial, debido a que sólo cuando el Legislador estima que se ha liberado de presupuestos ajenos y ahonda en la esencia constitucional que le es propia, es que está en condiciones de percibir la necesidad de cambiar algunas concepciones tradicionales cuando no se adecuen al desarrollo integral de los ciudadanos en el contexto social del momento, lo que impide el apoyo jurídico.

DE VERDA Y BEAMONTE es de la opinión que tal exégesis es inadecuada ${ }^{1129}$, para ello da a conocer las siguientes razones:

1.- Ante todo, el art. 32.1 CE, a diferencia de otros preceptos del Capítulo segundo del Título primer de la Constitución, refiere el derecho a contraer matrimonio, no a la persona humana in genere (no usa una fórmula del tipo "todos tienen derecho a contraer matrimonio”), sino específicamente al "hombre" y a la "mujer". La mención sexuada de los titulares de ius nubendi (que no aparece respecto de los restantes derechos fundamentales), sin duda debe ser interpretada en el sentido de que la Constitución refiere el derecho a contraer matrimonio, exclusivamente, a dos personas de distinto sexo ${ }^{1130}$.

2.- Por otro lado, la fórmula empleada por el art. 32.1 CE, al reconocer el derecho a contraer matrimonio, coincide con la de los principales textos legales internacionales en materia de derechos

1128 FERNÁNDEZ-CORONADO GONZÁLEZ, "La evolución jurídica del sistema matrimonial español desde la Constitución de 1978 a la admisión del matrimonio homosexual”, ...op. cit., página 110.

1129 DE VERDA Y BEAMONTE, J.R. "El libre desarrollo de la personalidad como principio inspirador de la Ley 13/2005, de 1 de julio, por la que se modifica el Código Civil en materia de derecho a contraer matrimonio”, en DE VERDA Y BEAMONTE, J. R. (Coord.), “Comentarios a las Reformas de Derecho de Familia de 2005”, Ed. Thomson Aranzadi, Cizur menor, año 2006, página 38.

1130 Cfr., POUS DE LA FLOR, M. P. “La institución familiar en las parejas del mismo sexo”, Ed .La Ley, T.3, Madrid, año 2005, páginas 1882 a 1895. 
Capitulo V El Principio del libre desarrollo de la personalidad y el Derecho de Familia. Su influencia el Principio de Igualdad, en la Autonomía de la voluntad y en el Interés superior del menor - El principio del libre desarrollo de la personalidad y el Derecho de Familia

humanos, que al consagrar el ius connubii, refieren dicho derecho al hombre y a la mujer, sin que utilicen la fórmula "entre si", lo cual no ha sido óbice para que siempre se haya considerado que dichos textos contemplan, exclusivamente, el matrimonio entre personas de sexo contrario ${ }^{1131}$.

Así, a tenor del art. 16.1 de la Declaración Universal de Derecho Humanos, de 10 de diciembre de 1948, "Los hombres y las mujeres, a partir de la edad núbil, tienen derecho, sin restricción alguna por motivos de raza, nacionalidad o religión a casarse y fundar una familia"; según el art. 12 del Convenio de Roma sobre protección de los derechos humanos y de las libertades fundamentales, de 4 de noviembre de 1950, “a partir de la edad núbil, el hombre y la mujer tienen derecho a casarse y a fundar una familia”; y conforme al art. 23.2 del Pacto Internacional de derechos civiles y políticos de Nueva York, de 18 de diciembre de 1966, "se reconoce el derecho del hombre y de la mujer a contraer matrimonio y a fundar una familia".

3.- Por último, el Tribunal Constitucional, en el auto 222/1994 ${ }^{1132}$, al enjuiciar la regulación del matrimonio del Código Civil, anterior a la reforma operada por la Ley 13/2005, ha afirmado "la plena constitucionalidad del principio heterosexual como calificador de matrimonio", declarando, además que "la unión entre personas del mismo sexo biológico no es una institución jurídicamente regulada, ni existe un derecho constitucional a su establecimiento: todo lo contrario al matrimonio entre un hombre y una mujer que es un derecho constitucional (art. 32.1) que genera ope legis una pluralidad de derechos y obligaciones".

Sobre esta última consideración no está de más decir que el parecer del Tribunal Constitucional evolucionará de conformidad a su composición, y por ende sus decisiones e interpretaciones podrán sufrir modificaciones.

Por lo tanto, el Tribunal, aparte de contraponer "el matrimonio entre un hombre y una mujer” a "la unión entre personas del mismo sexo biológico”, parece admitir que el art. 32 CE con-

1131 Cfr. HERNÁNDEZ IBÁÑEZ, C. "Cambio revolucionario en una institución milenaria : del matrimonio heterosexual al matrimonio homosexual”. La Ley, T. 3, Madrid, año 2006, páginas 1875 a 1884; CALVO CARAVACA, A y CARRASCOSA GONZÁLEZ, J. "Matrimonio entre personas del mismo sexo y Derecho internacional privado español”, Ed. La Ley, T. 1, Madrid, año 2006, páginas 1149 a1164.

1132 ATC, Sala Primera, Auto núm. 222/1994 de 11 julio. RTC 1994/222 AUTO . "En suma, se debe admitir la plena constitucionalidad del principio heterosexual como calificador del vínculo matrimonial, tal como prevé nuestro Código Civil; de tal manera que los poderes públicos pueden otorgar un trato de privilegio a la unión familiar constituida por hombre y mujer frente a una unión homosexual. Lo cual no excluye, que por el legislador se pueda establecer un sistema de equiparación por el que los convivientes homosexuales puedan llegar a beneficiarse de los plenos derechos y beneficios del matrimonio, tal como propugna el Parlamento Europeo." 
Capítulo V El Principio del libre desarrollo de la personalidad y el Derecho de Familia. Su influencia el Principio de Igualdad, en la Autonomía de la voluntad y en el Interés superior del menor - El principio del libre desarrollo de la personalidad y el Derecho de Familia

templa exclusivamente, "el concepto tradicional de matrimonio entre dos personas de distinto sexo" ${ }^{\prime 1133}$.

No hay pues duda que la lectura del precepto lleva a la clara conclusión de que el matrimonio protegido por la Constitución es la unión entre un hombre y una mujer, opina VERDA Y BEAMONTE ${ }^{1134}$.

Sin duda, el elemento teleológico es un criterio exegético, que ha de ser tenido en cuenta en la interpretación de las normas y por consiguiente en las constitucionales. No obstante su utilización ha de ser cautelosa, sobre todo considerando las recién indicadas reformas, porque, de lo contrario, se puede llegar a la más absoluta inseguridad jurídica, descartando de una manera más simplista los rígidos procedimientos previstos para la reforma constitucional. De conformidad a este razonamiento, debe presumirse que la letra de la Ley expresa la intención del legislador, de modo que hay que atenerse a ella, a no ser que su interpretación literal conduzca a atribuirle un sentido diverso del que corresponda a su razón de ser, es decir, a la finalidad que la norma se proponga alcanzar.

Mi opinión es que la ratio del art. 32.1 CE, no era establecer exclusivamente la igualdad entre cónyuges, amparándose en el libre desarrollo de la personalidad de cada uno de ellos, aunque desde luego, ésta era una de sus finalidades más destacadas, marcando, así, una directriz, que sería desarrollada por las reformas del Código Civil operadas por las Leyes 11/1981, de 13 de mayo , y 30/1981, de 7 de julio ${ }^{1135}$.

En la línea con las modernas constituciones y textos internacionales en materia de protección de derechos humanos, el art. 32.1 CE proclama expresamente la libertas matrimonialis, dentro de la cual se sitúa el ius nubendi, que constituye una de las máximas expresiones de libre desarrollo de la

1133 En este sentido se pronunció el Ministro de Justicia en eL debate de totalidad al defender el Proyecto de Ley (BOCG Congreso de los Diputados, serie A, número 18-1, de 21 de enero de 2005, página 3771), quien, a propósito del art. 32.1 CE, dice lo siguiente : "Afirma que el hombre y la mujer tienen derecho a contraer matrimonio con plena igualdad jurídica. Y creo poder decir que el sentido de esta redacción es el de reaccionar contra toda una historia de discriminación, sí, pero entre el hombre y la mujer"; más adelante añade: "Lo que establece el artículo 32 es una afirmación rotunda, la plena igualdad jurídica entre los contrayentes del matrimonio. No excluye la posibilidad de un matrimonio ente dos personas del mismo sexo".

1134 La mención al "hombre" y a la "mujer" aparecía ya en el art. 27 del Anteproyecto de Constitución (precedente del art. 32.1 CE); y durante la tramitación parlamentaria del precepto se rechazaron diversos votos particulares y enmiendas, que sin conseguirlo, pretendieron sustituir la referencia al hombre y a la mujer, por expresiones asexuadas como "contrayentes" o "cónyuges" sin duda, con la finalidad de evitar la constitucionalización de la nota de heterosexualidad del matrimonio.

1135 Ahora bien centrar, exclusivamente, la ratio legis en la constitucionalización del principio de igualdad entre Los cónyuges, me parece inadecuado, ya que, de este modo, no se contempla en su integridad de todo el significado jurídico que tiene la consagración del ius connubii como derecho fundamental: no desde luego en su aspecto axiológico u objetivo pero tampoco en su dimensión subjetiva y personal. 
Capitulo V El Principio del libre desarrollo de la personalidad y el Derecho de Familia. Su influencia el Principio de Igualdad, en la Autonomía de la voluntad y en el Interés superior del menor - El principio del libre desarrollo de la personalidad y el Derecho de Familia

personalidad en la medida en que tutela un interés fundamental de la persona a constituir una familia, en este caso matrimonial y a desenvolver en ella la propia personalidad ${ }^{1136}$.

En el precepto se subsume así la libertad nupcial positiva o derecho a contraer matrimonio de donde resulta que el ius connubii no puede ser desconocido ni menoscabado. Pero también la libertad nupcial negativa que comprende el derecho a no contraer matrimonio, o más exactamente, la libertad que tiene todo individuo de permanecer soltero ${ }^{1137}$.

El punto de conexión entre libertad nupcial y libre desarrollo de la personalidad es bastante claro, puesto que la libertad matrimonial, dentro de la cual se sitúa el ius nubendii, constituye una de las máximas expresiones del principio en cuestión, en la medida en que tutela un interés fundamental de la persona a constituir una familia fundada o no en el matrimonio y a desenvolver en ella la propia personalidad ${ }^{1138}$. En relación con esta idea, ROCA I TRÍAS ${ }^{1139}$, afirma que el principio del libre desarrollo de la personalidad, reconocido en el art. $10 \mathrm{CE}$, refuerza la base constitucional del divorcio. Así, cuando desaparece el consentimiento que sostiene el matrimonio, el interés individual en la disolución prevalece sobre el interés de la pareja en el mantenimiento del matrimonio, porque éste ha dejado de tener razón. De acuerdo, por tanto, con el principio del libre desarrollo de la per-

1136 MARTÍNEZ DE AGUIRRE Y DE ALDAZ, C. “A cada uno su familia, a cada familia su derecho (aproximación funcional a las nuevas formas de familia y elogio de la diversidad)". Nuevos modelos de familia en Teoría \& Derecho, núm. 2, Barcelona, año 2007, páginas 29 a 47.

1137 Cfr. MARTÍN SÁNCHEZ, I. "Derecho a convivir en pareja y libertad de conciencia”, en MORALES MORENO, A. M. y MIQUEL GONZÁLEZ, J. M. (Dirs.),’Derecho, sociedad y familia: cambio y continuidad.”, Servicios de Publicaciones, UAM, Madrid, año 2007, páginas 159 a 188.

1138 La libertad de opción entre estado civil de casado o de soltero es uno de los derechos fundamentales más íntimamente vinculados al libre desarrollo de la personalidad, considerado por la Constitución fundamento del orden político y de la paz social”; Cfr. STC, núm. 184/1990. "la posibilidad de optar entre el estado civil de casado o de soltero está íntimamente vinculada al libre desarrollo de la personalidad (art. 10.1 de la CE), de modo que el Estado no puede imponer un determinado estado civil”; ARECHEDERRA ARANZADI, L. I., "El consentimiento matrimonial (Comentario al art. 45 del Código civil)", Servicio de Publicaciones de la Universidad de Navarra, S.A., Pamplona, año 1989, páginas 29 y 30. El autor evidencia la consideración del matrimonio como un cauce idóneo para el desarrollo de la propia personalidad de los contrayentes. Para el autor, "el ius nubendi -derecho a casarse- se presenta como una proyección de la persona", que, "entre otras cosas, supone el modo común de resolver la propia intimidad". Y añade: "su catalogación como fundamental no desvirtúa (...) la estricta componente personalísima de este derecho a contraer que responde a un interés, por intimo, privado”; LUNA SERRANO, "La reforma de la legislación matrimonial”, en VV. AA., "Matrimonio y divorcio. Comentarios al nuevo Título IV del libro primero del Código civil”, LACRUZ BERDEJO, J. L. (Coord.), Ed. Civitas, $2^{\mathrm{a}}$ edición, Madrid, año 1994, páginas 15 a 17, considera el principio de libertad nupcial (consagrado en el art. 32.1 de la CE.), "una de las más significativas manifestaciones del libre desarrollo de la personalidad (...) por las connotaciones psicológicas y afectivas de la vida en común que se establece en el matrimonio”, estimando el autor que el principio constitucional del libre desarrollo de la personalidad ha inspirado la supresión de los impedimentos de impotencia y afinidad, así como la introducción al divorcio.

1139 "Familia, Formas familiares y Economía. Dos ensayos sobre metodología del derecho de familia” en ROCA I TRÍAS, E. y GUILARTE GUTIÉRREZ, V. "Patrimonio matrimonial en matrimonios indisolubles”, Fundación Coloquio Jurídico Europeo, Madrid, año 2010, Madrid, páginas 70 y 71. 
Capitulo V El Principio del libre desarrollo de la personalidad y el Derecho de Familia. Su influencia el Principio de Igualdad, en la Autonomía de la voluntad y en el Interés superior del menor - El principio del libre desarrollo de la personalidad y el Derecho de Familia

sonalidad, lo que se garantiza constitucionalmente es que el interés legítimo de los individuos quede protegido frente al inexistente interés de grupo. Esto ocurre con el del menor y con el de los individuos mayores de edad. Para la autora recién mencionada, decir que la familia matrimonial debe ser protegida contra los derechos fundamentales de sus miembros sería tanto como vulnerar el principio del libre desarrollo de la personalidad, que implica la protección de los derechos fundamentales de los individuos.

Desde esta perspectiva, la libertas matrimonialis alcanzaría especial significación en el concreto plano del consentimiento que, sin duda, constituye el elemento básico del negocio matrimonial (art. 45 CC). La institución del matrimonio está animada por el principio fundamental de absoluta libertad de los individuos, plena libertad (hasta la perfección del acto) incluso claro está para decidir no contraerlo. La libertad matrimonial exige que ninguna persona deba asumir el estado civil de casado y las consecuencias jurídicas, personales y patrimoniales, que conlleva, contra su voluntad. Quien contrae matrimonio debe ser plenamente consciente del acto que realiza y consentir con entera libertad en todas las consecuencias jurídicas que de dicho acto derivan. La solución contraria pugnaría con la concepción del matrimonio como cauce al servicio del libre desarrollo de la personalidad del ser humano: la naturaleza misma del matrimonio exige la espontaneidad y la libertad del querer ${ }^{1140}$.

Las normas que garantizan la libertad nupcial desde la perspectiva de la protección del consentimiento matrimonial son diversas ${ }^{1141}$.

La Ley 30/1981, de 7 de julio, estableció una normativa protectora del consentimiento, que confirma la calificación del matrimonio como un acto de autonomía privada encaminado a actuar

1140 Los convenios internacionales en materia de derechos humanos, los cuales deben ser tenidos en cuenta para in terpretar las normas relativas a los derechos fundamentales consagrados por la Constitución (art. 10.2 de la CE), no pueden ser más reveladores. El artículo 16.2 de la Declaración universal de derechos humanos de 10 de diciembre de 1948 dispone que "Sólo mediante libre y pleno consentimiento de los futuros esposos podrá contraerse el matrimonio". Análoga declaración encontramos en el art. 10.1, in fine del Pacto internacional de derechos económico, sociales y culturales de Nueva York de 16 de diciembre de 1966, a cuyo tenor, "el matrimonio debe contraerse con el libre consentimiento de los futuros cónyuges”, así como en el artículo 23.3 del Pacto internacional de derechos civiles y políticos de Nueva York de igual fecha, según el cual "el matrimonio no podrá celebrarse sin el libre y pleno consentimiento de los contrayentes”. Se da, además, la circunstancia de que dichas declaraciones aparecen en el mismo artículo inmediatamente después de la consagración del derecho de los hombres y mujeres a casarse y a fundar una familia, con lo que se confirma la consideración de las normas de protección del consentimiento matrimonial como normas de libertad.

1141 El art. 43 del Código Civil suscita la cuestión de determinar la naturaleza de la obligación, en cuya virtud el promitente, que incumple sin justa causa la promesa cierta del matrimonio, debe resarcir al promisario de los gastos hechos y de las obligaciones contraídas en atención al matrimonio proyectado. Dicha norma parece presentar problema de coordinación con la contenida en el art. 42 del Código Civil, que sanciona la incoercibilidad de la promesa de matrimonio, al establecer que los esponsales no son vinculantes en el plano jurídico considerarlos un verdadero negocio jurídico de Derecho de familia. 
por intereses personalísimos de los contrayentes, el cual es observado ya sea en la nulidad del instituto, por falta de consentimiento, artículos 45 y 73.1, ya sea en la separación, donde los cónyuges pueden evitar cumplir el deber de convivencia por un acuerdo privado, sin necesidad de sentencia judicial, artículo 82 en relación al 86 CC.

De tal manera que la consagración del ius connubii como derecho fundamental, art. $32 \mathrm{CE}$, constituye la garantía de que el matrimonio es un instituto al servicio de la persona lo cual potencia su carácter de vía para el desarrollo de la personalidad.

En el Derecho español, la homosexualidad, ha dejado de ser un elemento esencial para la constitución del consentimiento matrimonial, al desaparecer como trastorno psicológico que determina una incapacidad para contraer el vínculo, perdiendo asimismo el carácter de impedimiento matrimonial que le había otorgado la Ley 7 de julio de $1981^{1142}$, para insertarse en la propia dignidad de la persona, como derecho inherente a su libre desarrollo, eje sobre el que gravitan todos los derechos fundamentales del sistema.

Es la propia letra de la Constitución, al establecer que la dignidad de la persona humana, y el libre desarrollo de la personalidad a través de los derechos que le son inherentes constituyen el núcleo de los demás derechos fundamentales, lo que sin duda permite al Legislador encausar las reformas estudiadas en el Derecho matrimonial. Este es a mi juicio el fundamento que el propio Legislador ha estimado.

Esta dimensión individual como eje del Derecho positivo y su consideración en materia matrimonial ha consolidado la plena secularización del matrimonio, ya lograda brevemente durante la Segunda República, permitiendo afianzar al Estado en su legítima soberanía sobre el tema y, como consecuencia, acabar con la lucha por las competencias en materia matrimonial, largamente mantenida con el Derecho canónico.

1142 MURILLO, M., "Matrimonio y homosexualidad. La constitucionalidad de la Ley 13/2005, de modificación del Código Civil español sobre el derecho a contraer matrimonio entre personas del mismo sexo”...op. cit., página 261 a 314; Cfr. PÉREZ ÁLVAREZ, S. "La Incidencia de la Ley 13/2005 en el reconocimiento de los matrimonios entre personas del mismo sexo celebrados en el ámbito de la Unión Europea”, en Revista española de derecho internacional, Volumen 57, núm. 2, julio-diciembre año 2005, páginas 841 a 867; Por lo demás la Circular de la Dirección General de los Registros y del Notariado de 29 de julio de 2005, sobre matrimonio civiles entre personas del mismo sexo, señala que: "la identidad de sexos en la concepción legal ahora vigente, es elemento vinculado directamente con la propia naturaleza del derecho a contraer matrimonio y, por extensión, de la institución matrimonial y no necesariamente con la capacidad nupcial subjetivamente considerada”. 
En definitiva, el punto de atención se ha desplazado desde la institución a las personas de los cónyuges, colocando a aquella al servicio de los derechos fundamentales ${ }^{1143}$, pero sin duda se ha desvirtuado.

Concluyendo, podemos afirmar que mediante el principio del libre desarrollo de la personalidad se desenvuelve uno de los hilos conductores de la reforma del Código Civil operada por la Ley 30/1981 de 7 de julio, la cual aparece ya en la Ley 30/1981, de 7 de julio, como bien se sabrá, y que para autores como LUCAS SERRANO provocó una personalización del matrimonio ${ }^{1144}$.

Es más, la inserción de la dignidad de la persona y su libre desarrollo, en la evolución de la sociedad, ha permitido desplazar a la procreación como elemento sustentador de la heterosexualidad del matrimonio y sustituirlo por la afectividad, como base de la relación de pareja y como cauce adecuado de ese libre desarrollo. Esta afectividad mutua presente en el momento del matrimonio, unida a cierta vocación de estabilidad, es lo que constituye la esencia del matrimonio y esta afectividad se produce entre los cónyuges con independencia de cuál sea su orientación sexual.

La consecuencia directa es la admisión del matrimonio entre personas del mismo sexo, que constituye un derecho de secularización de segunda generación, en el lenguaje de FERNÁNDEZ-CORONADO, en tanto que lo anterior sólo es posible cuando el Estado ha logrado culminar su proceso secularizador con una autonomía jurídica plena, y puede comenzar a desplegar todo su contenido como protector y promotor de los derechos inherentes a la dignidad autónoma de la persona humana.

\section{El libre desarrollo de la personalidad y la transexualidad}

Debe anticiparse que los conceptos en torno a la transexualidad no están consensuados en modo alguno, lo cual implica incluso a la comunidad transexual, y debe también tenerse en cuenta que la condición de hombre o mujer no determina, per se, la aplicación de un régimen jurídico distinto ${ }^{1145}$.

En primer lugar hay que concretar si se entiende que para considerar a alguien transexual debe haber pasado por operaciones quirúrgicas de reconstrucción general, o al menos haber comenzado

1143 ROCA I TRÍAS, E. "Familia, Formas familiares y Economía. Dos ensayos sobre metodología del derecho de familia”... op. cit., páginas 11 y 12. “En trabajos anteriores dedicados a la materia relacionada con la familia intenté demostrar que el concepto de familia tradicional, ligado a la casa, había sido superado por el sistema consitucional, que al reconocer la efectividad de los derechos fundamentales en las relaciones familiares, desembocaba en un individualismo, en el que el papel "tradicional" de la familia tendía a quedar relegado."

1144 LUNA SERRANO, “Disolución del matrimonio”..., op. cit., página 224.

1145 Cfr. SÁNCHEZ GONZÁLEZ, Ma . P. “La intersexualidad como problema jurídico” en VV. AA. “Estudios jurídicos en homenaje al profesor Luis Díez-Picazo”, Ed. Thomson-Civitas, Madrid, año 2003, página 925. 
Capitulo VEl Principio del libre desarrollo de la personalidad y el Derecho de Familia. Su influencia el Principio de Igualdad, en la Autonomía de la voluntad y en el Interés superior del menor - El libre desarrollo de la personalidad y la transexualidad

la denominada terapia hormonal. Así se entendía por el Tribunal Supremo hasta el año 2007. La Ley 3/2007 de 15 de marzo, reguladora de la rectificación registral de la mención relativa al sexo de las personas, ha entendido un sentido a priori del término transexualidad, cuando en su Exposición de Motivos habla de que esta es "considerada como un cambio de la identidad de género", aunque de una lectura más sosegada se puede inferir otra opinión ${ }^{1146}$. Sin embargo, lo más común es que se considere "transexual" a la persona que simplemente encuentra una disconformidad entre su sexo psicológico y alguno o todos los demás caracteres sexuales, como se desprende de la Recomendación 1117/1989 del Consejo de Europa. El Tribunal Supremo, en la sentencia de 17 de septiembre de $2007^{1147}$, afirmó que se trata de un síndrome, un estado patológico que exige un tratamiento que

1146 En concreto se afirma que "la rectificación registral del sexo y el cambio del nombre se dirigen a constatar como un hecho cierto el cambio ya producido de la identidad de género".

1147 STS, Sala de lo civil, Sección Pleno, núm. 929/2007 de 17 septiembre. RJ 2007/4968 . Cfr. STS, Sala de lo civil, Sección $1^{a}$, núm. 465/2009 de 22 junio. RJ 2009/3408, esta última afirma que: “...que, desde esta perspectiva, se ha de preguntar, después de la vigencia de la Ley 3/2007, a la que se ha de dar valor como ampliación del ámbito de libre desarrollo de la personalidad, si la imposición de la intervención quirúrgica vulnera los derechos fundamentales a la intimidad privada y a la propia imagen que tutelan y amparan los artículos 18.1 y 10.1 CE . Pero hay que aceptar iuxta modo una respuesta positiva a esta cuestión. Ciertamente, la posición del TEDH, especialmente en las sentencias de 11 de julio de 2002 (I contra Reino Unido y C. Goodwin contra Reino Unido) y 23 de mayo de 2006 (Grant contra Reino Unido) acude al Tribunal al artículo 8 del Convenio de Roma, que declara la vulneración del derecho a la intimidad privada, que vincula a la dignidad de la persona, como la reiteradamente citada sentencia de 11 de octubre de 1978 , del Tribunal Constitucional alemán, que anclaba su decisión en la dignidad de la persona y en el libre desarrollo de la personalidad (artículos 1 y 2. 1 de la Ley Fundamental alemana), pero hay que señalar, en primer lugar, que el artículo 8 del Convenio de Roma impone al respeto a la vida privada y familiar y prohibe la injerencia de la autoridad pública en el ejercicio de este derecho, salvo que esté previsto en la ley y constituya una medida necesaria para determinados bienes o valores. Parece, pues, un derecho de contenido más amplio que el derecho a la intimidad personal y familiar que se tutela en el artículo 18.1 CE. Además, en los casos resueltos por el TEDH la infracción se produce porque, aún cuando se haya verificado la totalidad del tratamiento, incluida la intervención quirúrgica de reasignación de sexo, no se reconoce el cambio del sexo, porque el Estado demandado, aún así, hace primar el factor biológico y, con ello, desconoce el cambio. Pero, si bien se piensa, el resultado, de aceptar la posición que hasta ahora se ha venido sosteniendo en la jurisprudencia, sería el mismo: no aceptar el cambio por falta de la operación quirúrgica significa, en el fondo, hacer primar el factor fenotípico o cromosomático, que la operación, por otra parte, no puede corregir, con lo que no se da valor a las mutaciones psíquicas o los cambios en el rol socialmente asumido, no obstante hallarse el interesado en situación patológica ... haber sido diagnostico y haber sido sometido a tratamiento.- No hay, en puridad, continúa diciendo la Sentencia, una vulneración de los derechos a la intimidad o la propia imagen, pero hay un freno al libre desarrollo de la personalidad (artículo 10.1 CE) que se proyecta en una lesión de la dignidad humana, en una falta de tutela de la salud (artículo 43.1 CE ), al respeto, a la intimidad y a la propia imagen (artículo 18.1 CE) y a la protección de la integridad fisica y moral (artículo 15 $C E$ ), pues parece que el libre desarrollo de la personalidad (aceptado como soporte y justificación del cambio por las sentencias de esta Sala de 15 de julio de 1988, 3 de marzo de 1989, 19 de abril de 1991 y 6 de septiembre de 2002 ) implica, dada la prevalencia de los factores psico-sociales en la determinación del sexo, que han de primar en los supuestos de disforía de género, un derecho de sostener la identidad sexual como expresión de la identidad personal, que es un bien de la personalidad. - También dice que hay que reconocer al individuo que sufre la patología denominada disforía de género la facultad de conformar su identidad sexual de acuerdo con sus sentimientos profundos, con sus convicciones de pertenecer a otro sexo, pues de otro modo ni se protege su integridad, ni se le concede la protección de la salud, ni se trata adecuadamente el derecho a la imagen y a la intimidad familiar. Se trata, en una palabra, de dejar que el libre desarrollo de la personalidad se proyecte en su imagen y se desarrolle dentro de un ámbito de privacidad, sin invasiones ni injerencias.-" 
Capitulo V El Principio del libre desarrollo de la personalidad y el Derecho de Familia. Su influencia el Principio de Igualdad, en la Autonomía de la voluntad y en el Interés superior del menor - El libre desarrollo de la personalidad y la transexualidad

no se dirige a corregir la tendencia hacia el sexo fenotípico o genotípico, sino hacia el psíquico o anímico, tratando de aproximar el soma hacia la psique y no a la inversa. Un transexual es una persona cuya identidad sexual o de género es contraria a su sexo biológico, es decir, la identidad sexual está en conflicto con la anatomía sexual ${ }^{1148}$. El individuo se siente preso en el cuerpo equivocado, padeciendo el grado más extremo de trastorno de identidad sexual, en estas personas suele darse el deseo de modificar las características sexuales anatómicas que no corresponden con el sexo con el que se sienten identificados. Como consecuencia de ello, algunas suelen pasar por un proceso de reasignación de sexo, que puede incluir o no una cirugía de reconstrucción genital, conocida como "operación de cambio de sexo".

En definitiva, se trata de un problema en el libre desarrollo de su personalidad, reflejado en la identidad del sujeto, que se debe a la falta de correspondencia entre lo que es y lo que se siente ser, con todas las consecuencias que ello conlleva.

Respecto de la Ley 3/2007, puede argumentarse que lo habitual y, a la vez lo correcto técnicamente hablando, es comenzar una Ley definiendo el objeto de la misma. Sin embargo llama la atención que el primer precepto de la Ley recién citada se destine directamente a la legitimación del procedimiento registral regulado en esta norma y que sea únicamente la Exposición de Motivos la que haga referencia a ello $^{1149}$. Comienza afirmando que "tiene por objeto regular los requisitos necesarios para acceder al cambio de la inscripción relativa al sexo de una persona en el Registro Civil, cuando dicha inscripción no se corresponde con su verdadera identidad de género”. Sin expresarlo con claridad está reconociendo el denominado derecho a la identidad sexual o más recientemente el derecho a la identidad de género ${ }^{1150}$. Debía haberlo establecido explícitamente en el art. 1 de la Ley, como se solicitó en la tramitación parlamentaria.

El derecho a la identidad sexual es considerado expresión del libre desarrollo de la personalidad y de la dignidad humana, conforme al art. 10.1 $\mathrm{CE}^{1151}$. De tal manera se consagra en la Ley

1148 Artículo "Transexualidad”, siguiendo a CROOKS, R: “Nuestra Sexualidad”, International Thomson Editores, VII Edición, año 2003, páginas 56 y 57, en http://es.wikipedia.org/wiki/Transexualidad.

1149 Respecto al proyecto de Ley, declaraba DIAZ FRAILE que, de acuerdo con la Resolución de 28 de julio de 2005, de la Subsecretaría del Ministerio de la Presidencia, por la que se da publicidad al Acuerdo del Consejo de Ministros, de 22 de julio de 2005, en la que se aprueban las Directrices de técnica normativa, la falta de un primer artículo dedicado a definir el "objeto" del mismo, lo que resultaría conveniente desde el punto de vista de la técnica legislativa dado el citado Proyecto se configura sobre la base de articular un procedimiento de rectificación de lo asientos o inscripciones registrales, y no como una acción de estado civil encauzada a través de un verdadero procedimiento judicial.

1150 El concepto de género engloba el de sexo en as normas jurídicas de más reciente aprobación, como la Ley Orgá nica $1 / 2004$, de 28 de diciembre. 
Capitulo VEl Principio del libre desarrollo de la personalidad y el Derecho de Familia. Su influencia el Principio de Igualdad, en la Autonomía de la voluntad y en el Interés superior del menor - El libre desarrollo de la personalidad y la transexualidad

3/2007 $7^{1152}$, la Exposición de motivos de la misma declara que la respuesta del legislador tiene como finalidad garantizar el libre desarrollo de la personalidad y la dignidad de las personas cuya identidad de género no se corresponde con el sexo con que inicialmente fueron inscritas ${ }^{1153}$.

En España al carecerse de regulación civil que admitiese expresamente el cambio en la mención registral del sexo del transexual, al cumplir ciertos presupuestos se intento salvar dicho escollo mediante una interpretación de la Constitución, considerando dicha rectificación como expresión

1151 VALPUESTA FERNÁNDEZ, Ma . “Reflexiones sobre el Derecho de familia”, Teoría \& Derecho, núm. 2/2007, Ed. Tirant Lo Blanch, Valencia, páginas 84 y 85 . Dicha autora opina que se esta ante un cambio de mentalidad, más respetuosa con las opciones individuales y dispuesta a aceptar la diversidad social, un cambio que trasciende los valores que informan los derechos fundamentales siendo, así que éstos muestran su permeabilidad a las concepciones éticas y morales vigentes al tiempo en el que tienen que aplicarse, y no cabe duda que los transexuales encuentran en el derecho al libre desarrollo de su personalidad el fundamento constitucional para su reconocimiento.

1152 STS, Sala de lo Civil, Sección Pleno, núm. 929/2007 de 17 septiembre. RJ 2007/4968 . “Desde esta perspectiva, nos hemos de preguntar, después de la vigencia de la Ley 3/2007_, a la que se ha de dar valor como ampliación del ámbito de libre desarrollo de la personalidad, si la imposición de la intervención quirúrgica vulnera las derechos fundamentales a la intimidad privada y a la propia imagen que tutelan y amparan los artículos 18.1 y 10.1 C.E.. Pero hay que aceptar iuxta modo una respuesta positiva a esta cuestión. Ciertamente, la posición del TEDH, especialmente en las Sentencias, 11 de julio de 2002 y 23 de mayo de 2006 (Grant contra Reino Unido ) acude al Tribunal al artículo 8 del Convenio de Roma_, que declara la vulneración del derecho a la intimidad privada, que vincula a la dignidad de la persona, como la reiteradamente citada Sentencia de 11 de octubre de 1978, del Tribunal Constitucional alemán, que anclaba su decisión en la dignidad de la persona y en el libre desarrollo de la personalidad (artículos 1 y 2.1 de la Ley Fundamental alemana), pero hay que señalar, en primer lugar, que el artículo 8 del Convenio de Roma impone al respeto a la vida privada y familiar y prohíbe la injerencia de la autoridad pública en el ejercicio de este derecho, salvo que esté previsto en la Ley y constituya una medida necesaria para determinados bienes o valores. Parece, pues, un derecho de contenido más amplio que el derecho a la intimidad personal y familiar que se tutela en el artículo 18.1 CE.. Además, en los casos resueltos por el TEDH la infracción se produce porque, aún cuando se haya verificado la totalidad del tratamiento, incluida la intervención quirúrgica de reasignación de sexo, no se reconoce el cambio del sexo, porque el Es tado demandado, aún así, hace primar el factor biológico y, con ello, desconoce el cambio. Pero, si bien se piensa, el resultado, de aceptar la posición que hasta ahora se ha venido sosteniendo en la jurisprudencia, sería el mismo: no aceptar el cambio por falta de la operación quirúrgica significa, en el fondo, hacer primar el factor fenotípico o cromosomático, que la operación, por otra parte, no puede corregir, con lo que no se da valor a la mutaciones psíquicas o los cambios en el rol socialmente asumido, no obstante hallarse el interesado en situación patológica.. haber sido diagnóstico y haber sido sometido a tratamiento. No hay, en puridad, una vulneración de los derechos a la intimidad o la propia imagen, pero hay un freno al libre desarrollo de la personalidad (art. 10.1 CE) que se proyecta en una lesión de la dignidad humana, en una falta de tutela de la salud (art. $43.1 \mathrm{CE}$ ), al respeto a la intimidad y a la propia imagen (art. 18.1 CE) y a la protección de la integridad física y moral (artículo $15 \mathrm{CE}$ ), pues parece que el libre desarrollo de la personalidad (aceptado como soporte y justificación del cambio por las Sentencias de esta Sala de 15 de julio de 1988, 3 de marzo de 198919 de abril de 1991 y 6 de septiembre de 2002. Implica, dada la prevalencía de los factores psico-sociales en la determinación del sexo, que han de primar en los supuestos de disforía de género, un derecho de sostener la identidad sexual como expresión de la identidad personal, que es un bien de la personalidad.” STS, Sala de lo civil, Sección primera núm. 465/2009 de 22 junio. RJ 2009/3408.

1153 Exposición de motivos, Ley 3/2007, de 15 de marzo, reguladora de la rectificación registral de la mención relativa al sexo de las personas. Boletín Oficial del Estado, núm. 65 de 16 de marzo de 2007 "La presente Ley tiene por objeto regular los requisitos necesarios para acceder al cambio de la inscripción relativa al sexo de una persona en el Registro Civil, cuando dicha inscripción no se corresponde con su verdadera identidad de género. 
Capitulo V El Principio del libre desarrollo de la personalidad y el Derecho de Familia. Su influencia el Principio de Igualdad, en la Autonomía de la voluntad y en el Interés superior del menor - El libre desarrollo de la personalidad y la transexualidad

del libre desarrollo de la personalidad ${ }^{1154}$. Otros de los argumentos en que los autores se han basado para fundamentar el derecho transexual a ver reconocida su identidad de género son el derecho a la salud, ex art. 43.1 $\mathrm{CE}^{1155}$, a la integridad moral, art. $15 \mathrm{CE}^{1156}$, o a la intimidad personal y a la propia imagen, art. $18 \mathrm{CE}^{1157}$.

En el Título de la Ley 3/2007 puede leerse que esta es reguladora de la rectificación registral de la mención relativa al sexo de las personas. Esta rúbrica puede resultar confusa a priori. De una primera lectura del mismo y de gran parte de su articulado parece desprenderse un ámbito de aplicación mayor que el realmente comprendido, que no es otro que la transexualidad, dado que puede inicialmente entenderse que va afectar a cualquier rectificación registral que tenga mención relativa al sexo de las personas, lo que comprendería la disforía de género, la intersexualidad e indicación equivocada del sexo, como ocurre en el regular de los supuestos de publicidad restringida en el RRC (arts. 21 y 22), donde se habla, genéricamente, de rectificación de sexo.

Contempla también el cambio del nombre propio para que no resulte discordante con el sexo reclamado. - La transexualidad, considerada como un cambio de la identidad de género, ha sido ampliamente estudiada ya por la medicina y por la psicología. Se trata de una realidad social que requiere una respuesta del legislador, para que la inicial asignación registral del sexo y del nombre propio puedan ser modificadas, con la finalidad de garantizar el libre desarrollo de la personalidad y la dignidad de las personas cuya identidad de género no se corresponde con el sexo con el que inicialmente fueron inscritas. - De acuerdo con la regulación que se establece en esta Ley, la rectificación registral del sexo y el cambio del nombre se dirigen a constatar como un hecho cierto el cambio ya producido de la identidad de género, de manera que queden garantizadas la seguridad jurídica y las exigencias del interés general. Para ello, dicho cambio de identidad habrá de acreditarse debidamente, y la rectificación registral se llevará a cabo de acuerdo con la regulación de los expedientes gubernativos del Registro Civil.- Mediante esta Ley España se suma a aquellos países de nuestro entorno que cuentan con una legislación específica que da cobertura y seguridad jurídica a la necesidad de la persona transexual, adecuadamente diagnosticada, de ver corregida la inicial asignación registral de su sexo, asignación contradictoria con su identidad de género, así como a ostentar un nombre que no resulte discordante con su identidad.- Por último, se reforma mediante esta Ley el artículo 54 de la Ley del Registro Civil de 8 de junio de 1957. Para garantizar el derecho de las personas a la libre elección del nombre propio, se deroga la prohibición de inscribir como nombre propio los diminutivos o variantes familiares y coloquiales que no hayan alcanzado sustantividad.-"

1154 A favor de que el derecho a rectificar el sexo registral, en supuestos de transexualidad, pudiera encontrarse en el artículo 10.1 de la CE, LÓPEZ GALIACHO, P. “Problemática jurídica de la transexualidad”, Ed. McGraw Hill, Madrid, año 1998, páginas 110 y siguientes, seguido por CAMPOS, A. "La transexualidad y el derecho a la identidad sexual”, Valencia, año 2001, disponible en www.transexualitat.org/ página 26 y siguientes; ARROYO I AMAYUELAS, E. “El matrimonio del transexual (II) (El marco constitucional y conclusión)”, Revista de Derecho Privado, septiembre, Madrid, año 2002, páginas 649 a 679.

1155 VIDAL MARTÍNEZ, J. “ ¿Se incluye el “cambio de sexo” transexualidad, en el "libre desarrollo de la personalidad”, al que se refiere el artículo 10-1 de l Constitución Española? (Comentario a la sentencia del Tribunal Supremo Sala $1^{\circ}$ de 2 de julio de 1987)", Revista General de Derecho, Madrid, año 1989, página 1013; GORDILLO CAÑAS, A., también se lo plantea en "Comentario a la sentencia de 2 de julio de 1987 ” Cuadernos Civitas de Jurisprudencia Civil, núm. 370, Madrid, año 1987, página 4743.

1156 LÓPEZ-GALIACHO PERONA, recogiendo la opinión de FERNÁNDEZ SESSAREGO y de STANZIONE, "Problemática jurídica de la transexualidad”, ...op. cit., páginas 123 y 124.

1157 GÓMEZ LAPLAZA, C. “Transexualidad”, Aranzadi Civil, año 2004/1, Madrid, páginas 64 y siguientes. 
Ciertamente, dichas dudas preliminares quedan totalmente disipadas con la lectura de la Exposición de Motivos al precisar que la presente Ley tiene por objeto regular los requisitos necesarios para acceder al cambio de la inscripción relativa al sexo de una persona en el Registro Civil, cuando dicha inscripción no se corresponde con su verdadera identidad de género.

Asimismo, se observa fácilmente que las dificultades ya expuestas sobre el término adecuado para designar el síndrome de la transexualidad, desde el punto de vista médico y social, afloran a lo largo del contenido de la Ley 3/2007. La Exposición de Motivos habla de transexualidad y de cambio de la identidad de género, el art. 4 de diagnóstico de disforía de género.

El texto legal en estudio centra su objetivo en la regulación del procedimiento registral del cambio de la inscripción relativo al sexo y al nombre propio del transexual, pero, como parece claro y según veremos, no es sólo este su único fin.

En su articulado se encuentran contemplados otros aspectos conexos de carácter jurídico-civil, tales como los efectos derivados de dicha inscripción, la publicidad concerniente a la rectificación registral y diversas cuestiones administrativas relacionadas con la rectificación. Reflexionando en torno a la evolución de la jurisprudencia del Tribunal Supremo sobre este tema, ante la falta de regulación legal específica del transexualismo, que había antes de la Ley 3/2007, esta fue estableciendo una doctrina en la que aceptó el cambio de sexo y nombre masculino por otro femenino y la consiguiente rectificación de los que figuren en el acta de nacimiento del Registro Civil, accediendo a demandas de transexuales varones con cambios morfológicos externos a consecuencia de intervenciones quirúrgicas. Una síntesis de la doctrina del TS podría apreciarse a través de las siguientes vías: La primera es la aplicación a la situación del transexual de la teoría de la ficción jurídica. Mientras que la segunda es la aplicación al transexualismo de la vía de los derechos fundamentales reconocidos en la Constitución, entre ellos el de igualdad jurídica. Respecto a la teoría de la ficción jurídica, la primera de las sentencias dictadas sobre el fondo de la transexualidad por el TS el 2 de 
Capitulo VEl Principio del libre desarrollo de la personalidad y el Derecho de Familia. Su influencia el Principio de Igualdad, en la Autonomía de la voluntad y en el Interés superior del menor - El libre desarrollo de la personalidad y la transexualidad

julio de $1987^{1158}$, utilizó esta vía. El TS anuló la sentencia recurrida de la Audiencia y confirma la del JPI de Las Palmas sobre la base de esta doctrina:

a.- A diferencia de las leyes europeas que citó sobre el transexualismo, existía en el ordenamiento español un vacío legal aunque se tiene en cuenta la despenalización de la intervención quirúrgica del transexual por la Ley de 1983; pero ante la permanencia de las normas en el tiempo, se presentan cambios que demandan soluciones.

b.- Para el cambio de sexo la solución que se adoptó hubo de ser netamente jurídica pues la puramente biológica no puede aceptarse al no poder haber cambio biológico de sexo ya que continúan inmutables los cromosomas masculinos. Pero ante el cambio morfológico con caracteres similares a los femeninos, afirmó la sentencia, "será una ficción de hembra, si se quiere, pero el derecho también tiende su protección a las ficciones" porque la ficción desempeña en el derecho un

1158 STS, Sala de lo Civil, Sentencia de 2 julio 1987. RJ 1987/5045 : "Denuncia el motivo 4 la inaplicación del artículo 14 de la Constitución Española, por cuanto "al no reconocer el cambio de sexo» del actor «está cometiendo una discriminación basada en el sexo». Se alega en el desarrollo del motivo que "el sexo no tiene relevancia ninguna en nuestro ordenamiento jurídico, de forma que el varón y la mujer tienen los mismos derechos y las mismas obligaciones» por lo cual «el título legal de varón o hembra, como una circunstancia del estado civil de la persona, tampoco debe tener relevancia alguna».- Se trata de un razonamiento inatendible ya que lo que el precepto constitucional invocado proclama es la igualdad de derechos entre los individuos de los dos sexos, sin que pueda prevalecer discriminación alguna por causa de la diferencia de sexo; pero, obviamente, no establece criterio alguno para la atribución de uno u otro de los dos sexos conocidos por la naturaleza. - Por otra parte, en manera alguna es cierto que la atribución de uno u otro sexo carezca de toda relevancia en el orden jurídico ya que es uno de los datos caracterizadores o conformadores del estado civil. El recurso pretende desconocer la trascendencia jurídica del reconocimiento del cambio de sexo como hecho distinguible de la constatación de que el sexo se asignó erróneamente atribuyendo al sujeto otro que el sexo real. En otro lugar del recurso se atisba, sin embargo, no estar el recurrente ajeno a cuanto conllevará la tesis permisiva que la sentencia disentida comporta, pues, en efecto, abarca y comprende la adquisición de cuantas expectativas, facultades y derechos pudieran asistirle desde la sobrevenida condición de mujer. Se pugna así por ganar un nuevo «status» a partir del cual no podría menos que serle reconocido al actor calidad de mujer, el «ius nubendi», pues tal es la consecuencia más propia que se sigue del cambio de sexo que se alega y pretende. «Evidentemente (se lee en el desarrollo del motivo segundo) la sentencia está anclada en conceptos muy anticuados, pues hoy con el artículo 14 de la Constitución Española, entendemos que llegará a admitirse el matrimonio con otro varón»...No puede el sexo ser, dentro del estado civil, un dato proteico y cambiante.- Desde la óptica del motivo del recurso que se juzga, esto es, como se deja consignado en el comienzo, el de la irrelevancia del cambio de sexo y el principio de la igualdad entre ellos, ha de considerarse, por último, el fundamento de la sentencia disentida (sin trascendencia al fallo) de que no sobrevendrá (por efecto de la confirmada, emanada del Juzgado) «una equiparación absoluta» y que en el nuevo estado o con el nuevo sexo todavía para realizar determinados actos o negocios jurídicos "precisará la plena capacidad y aptitud en cada supuesto». Si la sentencia del Juzgado que se confirma, declara que el actor "por cambio ulterior, tiene en la actualidad el sexo femenino», dentro de tal declaración constitutiva no es viable introducir limitaciones, las cuales, en presencia del invocado precepto constitucional, habrían de ser tachadas de discriminatorias por razón de sexo: si, principalmente, se negara a la parte actora el derecho de contraer matrimonio con varón. Esta consecuencia, a juicio del presente voto, se contiene en el fallo del juzgado que la sentencia disentida confirma sin acudir a remediar consecuencia alguna. Más aún: sin posibilidad de preverlo ni de instalar, ni la especialmente considerada ni otras limitaciones que representarían, de hacerse, una desestimación parcial de la demanda y hasta vicio de incongruencia, dando otra cosa que la solicitada que es (dígase otra vez) el más pleno reconocimiento de la condición femenina en el orden del derecho." 
papel tan importante como la hipótesis en las ciencias exactas ${ }^{1159}$. Unas y otras son meras suposiciones que hay que admitir para lograr determinadas consecuencias en orden a la verdad científica o de la justicia social.

c.- Aplicando estos postulados al caso, afirma la sentencia, que el transexual operado no pasa a ser hembra sino que se le ha de tener por tal, por haber dejado de ser varón y presentar unos órganos sexuales similares a los femeninos y caracterologías psíquica y emocional propias de este sexo.

Estas apreciaciones llevan al TS a apreciar que el transexual "tiene un primigenio derecho a cambiar el nombre de varón por el de hembra pero sin que tal modificación registral suponga una equiparación absoluta con la del sexo femenino para realizar determinados actos o negocios jurídicos toda vez que cada uno de éstos exigiría la plena capacidad y aptitud en cada supuesto”. Sobre este punto hoy en día su importancia práctica ha decrecido de manera notable, debido que al permitirse el matrimonio entre personas del mismo sexo, no es inconveniente que el otro cónyuge sea cromosómicamente hombre o mujer.

En relación a la vía de los derechos fundamentales, es esencial destacar su importancia aquí por su íntima conexión con el principio del libre desarrollo de la personalidad . La segunda ocasión en que se pronuncia el TS sobre la transexualidad fue en la sentencia de la Sala de lo Civil de 15 de julio de 1988 que estimó el recurso de casación de un varón transexual al que se le había denegado la pretensión en ambas instancias a cambio de nombre y sexo, inscrito como varón en el Registro Civil $^{1160}$. Los hechos son similares a los de la primera sentencia; tras una intervención quirúrgica que provocó una transformación morfológica y psicológica acentuando los aspectos femeninos, actuando con esa apariencia y declarando que "se siente mujer". El TS acepta los hechos descritos en la sentencia de instancia pero les da una diversa valoración, invocó el art. 10.1 de la CE vigente de 1978, ¿Por qué?, porque una interpretación amplia de este derecho permite incluir los cambios físicos, de forma del ser humano, siempre que no constituyan delito ni ilícito civil, lo que no ocurre al estar despenalizada la intervención quirúrgica en el art. 428 CP ni estar prohibida por la norma sustantiva ni procesal civil.

Esta claro que el razonamiento del Tribunal no trataba de justificar el cambio de sexo, al ser genéticamente imposible, sino en resolver la cuestión humana y social planteada ante los Tribuna-

1159 Cfr. DE LA VALGOMA, Ma " "La ficción jurídica o porque el Derecho “miente” tanto” en VV. AA. "Estudios jurídicos en homenaje al profesor Luis Díez-Picazo”, Ed. Thomson-Civitas, Madrid, año 2003, páginas 1039 y siguientes.

1160 STS, Sala de lo civil, de 15 julio de 1988. RJ 1988/5722. 
les. Ante ello se ha intentado elaborar la traducción jurídica de un fenómeno empírico acudiendo a la interpretación extensiva del art. 10.1 CE.

La sentencia al fundarse en este principio valora el factor psicológico, a su juicio, el más importante de la personalidad a que atiende la norma constitucional ${ }^{1161}$.

Pero sin duda que mucho más recientemente se tienen varias sentencias que tratan este tema desde el punto de vista de los derechos fundamentales. Cito la STS, Sala de lo Civil, Sección Pleno, sentencia núm. 929/2007 de 17 septiembre. RJ 2007/4968. En dicho fallo se comenta que el Juzgado de Primera Instancia, después de señalar que la jurisprudencia del Tribunal Supremo había admitido el cambio social de sexo, estimando que viene exigido por el libre desarrollo de la personalidad (artículo 10.1 de la Constitución) en la medida en que nadie puede ser obligado a permanecer dentro de los márgenes de un sexo que psíquicamente no le corresponde, lo que debe tener su reflejo en la inscripción de nacimiento del interesado en el Registro Civil. Destaca que esa misma jurisprudencia viene exigiendo que para hacer constar, como sería en el caso, el sexo femenino en lugar del masculino, se haya producido la adecuación del sexo anatómico del interesado a su comportamiento sexual psíquico y social mediante la correspondiente intervención quirúrgica y el tratamiento hormonal subsiguiente.

El actor demostró que desde su infancia sus reacciones psíquicas y sentimentales fueron las propias del sexo femenino, y también probó que su comportamiento social presenta caracteres de índole femenina, se había sometido a tratamiento hormonal, su forma de expresión corporal era femenina, pero no se había sometido, por motivos económicos, a la intervención quirúrgica que la jurisprudencia exige para estimar la pretensión de cambio de sexo.

La Sala de Apelación, por su parte, puso de relieve en primer lugar, que el solicitante manifestó sentirse mujer desde la pubertad, aceptando esa condición y desarrollando las actividades de la vida siguiendo pautas conductuales femeninas, con sometimiento a tratamiento hormonal, si bien todavía no se sometió a intervención quirúrgica que propiciase su transformación sexual completa, manteniendo sus caracteres primarios, esto es, genitales externos masculinos, aunque los secundarios fuesen femeninos. En segundo lugar, se refería a la Sentencia del Tribunal Supremo, de 6 de junio de 2002, en la cual se amparaba la doctrina que "si bien el dato cromosómico no es decisivo para el reconocimiento de la identidad sexual de una persona, tampoco pueden considerarse sufi-

1161 Cfr. MEDINA GUERRERO, M “La vinculación negativa del legislador a los derechos fundamentales”, Ed. McGraw-Hill, Madrid, año 1996; DE OTTO Y PARDO, I "La regulación del ejercicio de los derechos fundamentales. La garantía de su contenido esencial en el artículo 53.1 de la Constitución", en MARTIN-RETORTILLO, L y DE OTTO Y PARDO, I “Derechos fundamentales y Constitución”, Ed. Civitas, Madrid, año 1988. 
Capitulo V El Principio del libre desarrollo de la personalidad y el Derecho de Familia. Su influencia el Principio de Igualdad, en la Autonomía de la voluntad y en el Interés superior del menor personalidad y la transexualidad - El libre desarrollo de la

cientes los factores puramente psicológicos para conceder relevancia jurídica a las demandas de admisión de cambio de sexo, resultando imprescindible que las personas transexuales que las formulan se hayan sometido a los tratamientos hormonales y quirúrgicos precisos para la supresión no solo de sus caracteres sexuales secundarios...sino también y fundamentalmente para la extirpación de los primarios y la dotación a los solicitantes de órganos sexuales semejantes, al menos en apariencia, a los correspondientes al sexo que emocionalmente sienten como propio" ${ }^{1162}$.

A modo de reflexión quiero destacar que la problemática de la transexualidad es una problemática antropológica, se refiere a la imagen misma que del hombre tenemos, y de ello surge una cuestionamiento evidentemente filosófico, debido a que hay filosofía cuando se considera que el saber cultural no es absolutamente válido ${ }^{1163}$. Es evidente que el saber cultural acerca de la sexualidad es todo menos pacífico, no parece evidente, merece duda, merece cuestionarse.

La cultura se define como un sistema de conocimientos bastante congruentes que versa sobre la totalidad de lo real, el mundo concreto y lo espiritual, ambos aspectos se erigen como guías de la conducta humana, como un saber respecto del todo que dirige la acción humana. La vivencia que en tal sentido ha ido realizando la humanidad dentro de la denominada cultura occidental sexual puede mostrar de un modo paradigmático como ha ido variando la relación del hombre con su naturaleza y consigo mismo a través de sus libres elecciones. El fenómeno de la transexualidad es un ejemplo de tales cambios. Desde una visión teocéntrica de la realidad, de acuerdo con la cual la persona reconocía un significado intrínseco a su realidad sexual, a su identidad sexual, que podía ser aceptado o rechazado y manifestar tal decisión en las conductas sociales y culturales que decidiera asumir, se ha pasado a una visión antropocéntrica, amparada en su autonomía de la voluntad, en la que el hombre actúa decidiendo la naturaleza o significado de su propia identidad sexual personal, desarrollando una antropología alternativa, la tecnología le permite elegir tal identidad, a juicio de CAMPS MER$\mathrm{LO}^{1164}$.

En tal sentido la libertad es el núcleo decisivo de la persona. La corporeidad, contrapuesta a la libertad, pierde su significado antropológico fuerte, y viene reducida a un aspecto biológico secundario, disponible al arbitrio de todas las manipulaciones y anhelos, la diferencia sexual inscrita

1162 Cfr. SAP Coruña, Sección 6a núm. 407/2007 de 14 noviembre. AC 2008/278; SAP Cádiz, Sección 6 ${ }^{\text {a }}$ (Ceuta), núm. 23/2005 de 20 abril. JUR 2005/143363.

1163 ARREGUI, V y CHOZA, J. “Filosofía del hombre. Una antropología de la intimidad”, Ed. Rialp, Madrid, año 1993, página 30.

1164 “Identidad sexual y Derecho. Estudio interdisciplinario del transexualismo”. Ed. EUNSA, Pamplona, año 2012, páginas 219 y siguientes; Cfr. BALLESTEROS, J. "Postmodernidad, decadencia o resistencia”, Ed. Tecnos, Madrid, año 1997. 
Capitulo V El Principio del libre desarrollo de la personalidad y el Derecho de Familia. Su influencia el Principio de Igualdad, en la Autonomía de la voluntad y en el Interés superior del menor - El libre desarrollo de la personalidad y la transexualidad

en el cuerpo deja estar reconocida como una dimensión de la identidad personal ${ }^{1165}$. Se ha optado por la identidad sexual psicológica o género y no por la identidad sexual biológica o sexo. Esto sin duda influye en cómo se interpretan los diversos preceptos constitucionales sobre el presente asunto, la proporcionalidad que debe de haber entre la igualdad y el libre desarrollo de la personali$\operatorname{dad}^{1166}$.

Pero entonces ¿Cuál sería la justa solución?. CAMPS MERLO opina que es inevitable aceptar que muchas dimensiones de nuestra existencia nos son dadas, no las hemos elegido, como por ejemplo las circunstancias históricas y sociales en las que estamos inmersos, hasta nuestro carácter, nuestras virtudes y defectos, nuestras características corporales, salud, sexo, incluso nuestro ser personal. Por otra parte, se debe reconocer que el hombre con cada decisión libre, se da a si mismo algo así como una segunda naturaleza que puede acabar siendo más fuerte que la recibida, esta es la dimensión moral del actuar de la persona o praxis aristotélica, las acciones que realiza en tal sentido son inmanentes, la cuestión estriba en determinar si aquellas dimensiones dadas son totalmente indiferentes para aquellas que el ser humano mismo construye o si, por el contrario, posee algún significado que pueda implicar que haya dimensiones personales que favorezcan o perjudiquen más a quien las toma ${ }^{1167}$. La respuesta jurídica es no buscar soluciones uniformes para situaciones diversas, no es lo mismo una persona que psicológicamente es mujer pero cromosomáticamente es hombre, que una que es mujer en ambos sentidos, y en el caso del varón lo mismo, pero lo esencial es que detrás de esa situación se encuentra una persona y debe ser protegida, independiente de su diversidad impera su misma dignidad ${ }^{168}$.

1165 Cfr. VÁZQUEZ-PASTOR JIMÉNEZ, L. “El transexualismo primario y su contemplación legal en el ordenamiento jurídico español”, en NAVAS NAVARRO, S. (Dir.), "Iguales y diferentes ante el Derecho Privado”, Ed. Tirant Lo Blanch, Homenajes y Congresos, Valencia, año 2012, páginas 703 a 730.

1166 BERNAL PULIDO, C. "El principio de proporcionalidad y los derechos fundamentales”, Centro de Estudios Políticos y Constitucionales, Madrid, año 2005; BERNAL PULIDO, C, "Tribunal Constitucional, legislador y principio de proporcionalidad. Una respuesta a Gloria Lopera", Revista Española de Derecho Constitucional núm. 74, Madrid, año 2005; LOPERA MESA, G.P, “El principio de proporcionalidad y legislador penal”, Centro de estudios Políticos y Constitucionales, Madrid, 2006 ; LOPERA MESA, G.P, "El principio de proporcionalidad y los dilemas del constitucionalismo", en "Comentario al libro de Carlos Bernal Pulido: El principio de proporcionalidad y los derechos fundamentales", Revista Española de Derecho Constitucional, núm. 73, Madrid, año 2005.

1167 CAMPS MERLO, M. “Identidad sexual y Derecho. Estudio interdisciplinario del transexualismo”, ... op. cit., página 225.

1168 ÁLVAREZ CONDE, E. "Un nuevo paso en la consecución de la igualdad: a propósito de una ley integral para la igualad de trato y de oportunidades", en TEROL BECERRA, M. J. (Dir.), IV Foro Andaluz de los Derechos Sociales, Igualdad e Integración, Ed. Tirant Lo Blanch, Valencia, año 2011, página 16.“El principio de igualdad no implica que toda desigualdad constituye necesariamente una discriminación, pues no se prohíbe toda diferencia de trato en el ejercicio de los derechos y libertades, sino que la igualdad solamente es violada cuando dichas discriminaciones están desprovistas de una justificación objetiva y razonable. El juicio de razonabilidad se con- 


\section{5 | El libre desarrollo de la personalidad en el menor}

Sin duda el derecho más radical, en cuanto a su raíz y fuente de todos los demás, es el derecho de libertad de conciencia, cuya expresión primera es justamente el derecho de libertad de conciencia y, secuencialmente, al libre desarrollo de la personalidad (art. 10.1 CE). Es un derecho predicable no sólo de los menores de edad, pero que cobra especial importancia en relación con ellos, y no es fácil deslindar su contenido ni dibujar sus contornos o límites ${ }^{1169}$.

Aquí tiene su fundamento la especial protección jurídica que el ordenamiento español, incluído por cierto el autonómico ${ }^{1170}$, dispensa a la juventud o a la infancia cuando las tipifica como límites del ejercicio de las libertades de información y expresión a pesar de su consideración como garantías institucionales (art. 20.4 C.E.) como límite de la posibilidad de secreto sumarial o de vista oral en los procesos penales.

En relación al derecho a la libre formación de conciencia y la patria potestad en la toma de decisiones por los padres (art. 154), o en su caso por el juez (art. 159), sobre los hijos no emancipados, el Código Civil se refiere al "beneficio de los hijos" como criterio inspirador, añadiéndose en el primer caso "de acuerdo con su personalidad". No parece ninguna extrapolación entender que esa expresión alude a lo que la Convención sobre los Derechos del Niño de 1989 (artículo 3.1) y la Ley Orgánica de Protección de los Derechos del Menor de 1996 llaman “interés superior del niño”, que debe prevalecer sobre cualquier otro interés legítimo (art. 2). Tampoco parece necesario violentar esas expresiones para entender que ese interés del menor, de acuerdo con su personalidad, comprende la libertad emergente, germinal y en proceso de formación del niño y, por tanto, su derecho a la libre formación de su conciencia.

Es decir, tal cual se mencionó en el capítulo anterior el interés del menor deber ser puesto en relación con el art. 10.1 de la Constitución, es decir con el principio del libre desarrollo de la personalidad.

Si se analiza el art. $16 \mathrm{CE}$, puede afirmarse que los menores de edad son titulares plenos de sus derechos fundamentales, en este caso, de sus derechos a la libertad de creencia y a su integridad

vierte así en el elemento determinante para poder apreciar la violación del principio de igualdad, ya que nuestra Constitución no prohíbe cualquier tipo de desigualdad, sino que lo que exige es una falta de razonabilidad para poder apreciar la existencia de una desigualdad."

1169 Vid. ASENSIO SÁNCHEZ, M. A., "La patria potestad y la libertad de conciencia del menor", Ed. Tecnos, Madrid, año 2006; ALÁEZ CORRAL, B. "Minoría de edad y derechos fundamentales", Ed. Tecnos, Madrid, año 2003.

1170 Art 5. 1, Código de Derecho Foral de Aragón, Decreto Legislativo 1/2011: "El menor de edad tiene derecho a su desarrollo y a una formación conforme a su personalidad." 
Capitulo V El Principio del libre desarrollo de la personalidad y el Derecho de Familia. Su influencia el Principio de Igualdad, en la Autonomía de la voluntad y en el Interés superior del menor - El libre desarrollo de la personalidad en el menor

moral, sin que el ejercicio de los mismos y la facultad de disponer sobre ellos se abandonen por entero a lo que al respecto puedan decidir aquellos que tengan atribuida su guarda y custodia o, como en este caso, su patria potestad, cuya incidencia sobre el disfrute del menor de sus derechos fundamentales se modulará en función de la madurez del niño y los distintos estadios en que la legislación gradúa su capacidad de obrar (arts. 162.1, 322 y 323 CC o el art. 30 Ley 30/1992, de 26 de no viembre, de Régimen Jurídico de las Administraciones Públicas y del procedimiento Administrativo Común).

Ahora bien, el principio del libre desarrollo de la personalidad debe ser objeto de una reflexión en el mismo sentido, este principio no es un derecho, no tiene un titular, pero si implica una condición sine qua non, un prisma esencial para la interpretación de los derechos fundamentales. El libre desarrollo de la personalidad implica la libertad de conciencia del menor sujeta a su interés fundamental, puede ser restringida por quien tiene la patria potestad o la tutela, siempre y cuando dicha restricción sea conteste al interés mencionado, no al suyo propio ${ }^{1171}$.

Visto desde otro ángulos, en vez de restricciones debe de mencionarse libertad de creencia y proselitismo. Frente a tales prerrogativas de los padres, se alza como límite, además de la intangibilidad de la integridad moral de estos últimos, aquella misma libertad de creencias que asiste a los menores de edad, manifestada en su derecho a no compartir las convicciones de sus padres o a no sufrir sus actos de proselitismo, o máxime cuando la de éstos pudieran afectar negativamente a su desarrollo personal. Libertades y derechos de unos y otros que, de surgir el conflicto, deberán ser ponderados teniendo siempre presente el "interés superior de los menores de edad" (arts 15 y 16.1 $\mathrm{CE}$ en relación con el art. $39 \mathrm{CE})^{1172}$.

En relación del derecho de los padres a elegir la formación religiosa y moral de sus hijos y el derecho a la libre formación de conciencia este derecho aparece reconocido en al art. 27.3 de la Constitución ${ }^{1173}$. De acuerdo con el art. 10.2 de la misma y su interpretación debe hacerse teniendo

1171 STC, Pleno, núm. 215/1994 de 14 julio. RTC 1994/215; STC, Sala 1aa núm. 260/1994 de 3 octubre. RTC 1994/260; STC, Pleno, núm. 60/1995 de 17 marzo. RTC 1995/60

1172 Vid. STC, Sala segunda, núm. 141/2000 de 29 mayo. RTC 2000/141; STC, Pleno, núm. 154/2002 de 18 julio. RTC 2002/154; STS, Sala de lo contencioso-administrativo, sección 1ª de 11 febrero 2009. RJ 2009/1877; STS, Sala de lo contencioso-administrativo, sección $4^{\mathrm{a}}$, de 22 febrero 2011. RJ 2011/1260 . Vid. LLAMAZARES FERNÁNDEZ, D. "Derecho de la Libertad de conciencia.". Tomo II, Libertad de conciencia, identidad personal y solidaridad, Ed. Thomson Civitas, $3^{a}$ edición, Cizur Menor, Navarra, año 2007, página 55 y 56.

1173 Vid. CUBILLAS RECIO, M. "La enseñanza de la Religión en el sistema español y su fundamentación en el derecho de los padres sobre la formación religiosa de sus hijos", en Laicidad y Libertades, núm. 2, Universidad Complutense de Madrid, año 2002, páginas 157 a 219; CUBILLAS RECIO, M. "La enseñanza de la religión en el sistema español y su fundamentación en el derecho de los padres sobre la formación religiosa de sus hijos" en Laicidad y Libertades, núm. 2, Universidad Complutense de Madrid, año 2002, páginas 157 a 219. 
en cuenta el art. 26.3 DUDH, si bien ambos derechos son bastantes similares no deben confundir$\mathrm{Se}^{1174}$.

¿Cómo se puede armonizar el derecho que se reconoce a los padres con el derecho de los hijos a la libre formación de la conciencia? Huelga insistir en la evidente afirmación de que los padres no son propietarios o dueños de la conciencia de sus hijos y no menos evidente es que no pueden representarles en el ejercicio de ese derecho, según hemos visto, de acuerdo con el CC, otra cosa es que sean los primeros garantes del libre desarrollo de su personalidad.

La contradicción sólo puede salvarse teniendo en cuenta lo que a este propósito dicen la Convención sobre los Derechos del Niño y la La Ley Orgánica de Protección de los Derechos del Menor. En la primera, los Estados firmantes se comprometen a respetar los derechos y deberes de los padres de impartir al menor una educación "en consonancia con la evolución de sus facultades, dirección y orientación apropiadas para que el niño ejerza sus derechos” (art. 5), y más adelante, utiliza para referirse a esos mismos derechos y deberes los términos "guiar al niño en el ejercicio de su derecho" (art. 14.2). En la segunda se tipifica como de cooperación y no de sustitución el deber de los padres de facilitar que el menor ejerza el derecho de libertad y ideológica, de conciencia y religión (art. 6.3) $)^{1175}$.

Frente a la formación en valores y libre formación de la conciencia, la educación siempre debe estar encaminada al libre desarrollo de la personalidad, pero también a inculcar en el menor el respeto de los derechos fundamentales de los demás, el respeto a sus padres y a su propia identidad cultural, así como deben prepararle para asumir una vida responsable en una sociedad libre, con espíritu de comprensión, paz y tolerancia, igualdad de sexos y amistad entre todos los pueblos, grupos étnicos, nacionales y religiosos, y personas de origen indígena, tal cual lo manifiesta el art. 29.1, a ello debe añadirse lo estipulado por la CE en su art 27.2 "el respeto a los principios democráticos de convivencia”. Estos valores obligatoriamente deben formar parte de la educación, todos ellos son las semillas básicas donde se desarrolla su personalidad, más las creencias religiosas que sus propios progenitores quieran inculcar en ellos, siempre y cuando no contradigan el interés superior del menor.

1174 Cfr. STC, Pleno, núm. 5/1981 de 13 febrero. RTC 1981/5; Cfr. STC, Pleno, núm. 10/1983 de 21 febrero. RTC 1983/10 .

1175 Cfr. SERRANO POSTIGO, C. "Libertad religiosa y minoría de edad en el ordenamiento jurídico español" en Estudios de Derecho canónico y Derecho eclesiástico en Homenaje al profesor Maldonado, Universidad Complutense de Madrid, año 1983, página 818. 
La CE considera posible la transmisión de valores religiosos, exceptuados, en todo caso, los contradictorios con los mandatos imperativos que mandan o prohíben algo de la ética mínima común constitucionalizada. ¿Es compatible con el derecho a la libre formación de la conciencia la transmisión confesional de valores religiosos en edades en que el niño carece de capacidad de discernimiento suficiente para valorar las diferentes alternativas?, ¿no entraña esa transmisión confesional un riesgo o, incluso, un peligro seguro de condicionamiento de esa libertad?, ¿no implica necesariamente una desprotección y un desprecio de esa libertad? Sobre estas interrogantes cabe plantearse de que si bien los padres no tienen un derecho sobre sus hijos si tiene el derecho y el deber de educarles en el ámbito religioso y moral de la manera que esté de acuerdo y en armonía con sus propias convicciones.

Por lo que respecta al art. 27.2 de la Constitución, hay que resaltar que el legislador constituyente ha querido ser beligerante en materia educativa. FERNÁNDEZ-MIRANDA CAMPOA$\mathrm{MOR}^{1176}$, ha sostenido por la naturaleza del proceso educativo, por las personas a las que básicamente está destinado y por su condición de instrumento decisivo en la formación de la personalidad, no sólo se ha querido la educación en libertad, sino también la educación para la libertad ${ }^{1177}$. Consiente de que todo proceso educativo implica transmisión de valores y de pautas de comportamiento $^{1178}$, ha establecido que la finalidad de la educación será el pleno desarrollo de la personalidad ${ }^{1179}$. De todas maneras el apartado 2 del precepto constitucional enlaza directamente con el art. 26 de la Declaración Universal: "La educación tendrá por objeto el pleno desarrollo de la personalidad humana y el fortalecimiento del respeto a los derechos humanos y a las libertades fundamentales: favorecerá la comprensión, la tolerancia y la amistad entre todas las naciones y todos los grupos étnicos o religiosos, y promoverá el desarrollo de las actividades de las Naciones Unidas para el mantenimiento de la paz”.

Quizás sea momento de afirma que el derecho a la educación aparece íntimamente unido a la institución de la patria potestad, al ser las funciones educativas inherentes a la misma, ex artículo 154.1 del Código Civil español.

1176 FERNÁNDEZ-MIRANDA CAMPOAMOR, A. "El secreto profesional de los informadores”, Ed. Tecnos, Madrid, año 1990.

1177 GARCÍA CARRASCO, J. "Bases sociales y antropológicas de la educación intercultural”, en Educación intercultura en la perspectiva de la Europa unida. X Congreso Nacional de Pedagogía, Salamanca, año 1992.

1178 CORTINA, A. "La educación del hombre y del ciudadano", en Revista Iberoamericana de Educación, núm. 7, año 1995.

1179 Cfr. GONZÁLEZ MORENO, B. "El Estado social. Naturaleza jurídica y estructura de los derechos sociales", Ed. Civitas, Madrid, año 2002; GONZÁLEZ MORENO, B. "Estado de cultura, Derechos culturales, y Libertad religiosa”, Ed. Civitas, Madrid, año 2003. 
Volviendo a las interrogantes antes mencionadas, al plantearse la cuestión, de naturaleza bastante controvertida, de si los progenitores pueden imponer a los hijos su modelo educacional o, si, por el contrario la imposición de un determinado modelo educacional a los hijos lesionaría el derecho de éstos a la libre formación de su conciencia, de su personalidad. La respuesta es que, en este sentido y teniendo en consideración los aspectos más importantes que, en relación con la patria potestad como función hay que abordar, es preciso resaltar que el contenido del derecho de los progenitores viene mediatizado, necesariamente y de forma contundente, por su naturaleza de derecho-deber, en cuanto derecho se ejerce siempre frente al Estado, nunca frente a los hijos, y fundamentalmente consiste en poder exigir a la Administración, por un lado, la puesta en funcionamiento de medios necesarios para la satisfacción del derecho a la educación, y por otra parte, que los hijos no reciban una educación contraria a las convicciones de los padres. El derecho, asimismo, se extendería a la elección por parte de los progenitores de la enseñanza moral y religiosa que estimaren de acuerdo, pero asimismo tal derecho tendrá un importante límite. Efectivamente, los límites propiamente intrínsecos vendrían determinados por el hecho de que la educación elegida por los padres sea en interés del menor permitiendo su desarrollo como persona, vale decir, que faciliten el libre desarrollo de su personalidad, dentro del ámbito propio de los principios y valores constitucionales, respetando su dignidad. 
Conclusión 


\section{Consideraciones finales del presente trabajo. Una visión antropológica y civilista, influenciada por el Derecho Constitucional, de la problemática actual del Derecho de Familia en España.}

Ha sido un largo viaje, no tan sólo jurídico, un viaje en el cual se han intentado hermanar tanto los ámbitos constitucional como civil, aunque sin duda, detrás de ellos late la riqueza de la Filosofía del Derecho. La carretera escogida para este viaje ha sido el Derecho de Familia.

Durante el mismo ha habido un, espero, exitoso intento de inmersión en las aguas de la objetividad. No ha sido fácil emprender esta aventura de envergadura intelectual, una tesis doctoral al fin y al cabo es eso, aventurarse hacia un propósito que no es claro en un inicio, pero que cuan faro que aflora en la costa, poco a poco va agigantando su pequeñez, causada por la distancia, hasta volverse tan cercano y real cuando la nave toca los cimientos del puerto que la acoge.

El objeto de estudio ha sido la Familia, pero no considerada tan sólo como grupo, sino que atendiendo a la actual realidad legislativa, y aunque se intentó ir más allá, la doctrina y la jurisprudencia de las diversas materias tratadas, giran en torno al ordenamiento legal. Hoy en día el grupo no es lo importante, no es lo esencial, hoy en día impera la persona. Las personas que pueden integrar el grupo familiar, su personalidad, aunque esta se encuentra reducida al ámbito de la afectividad, son el centro del acontecer en el Derecho de Familia.

Estas personas presentan necesidades, estas últimas requieren respuestas y a ellas procura el sistema jurídico. ¿Por qué es importante dar respuesta a tales necesidades? Porque la familia tiene un sentido que resulta manifiesto y que consiste en ser el punto de articulación de lo público y lo privado.

Esta articulación existe debido a que una de las funciones principales del grupo familiar resulta ser la mediación en la personalización de los afectos más profundos del ser humano. No procuro caer en una sensibilidad barata cuando estimo que uno de los principales elementos, aunque no el único, del libre desarrollo de la personalidad son los afectos. Aunque estimo que el corazón de dicha personalidad es algo más, su centro es la integridad de la persona, reconociendo en dicho ámbito y sus derechos, a la persona propiamente tal, su centro es la dignidad. 
En el primer capítulo cuando me refiero a la relación Familia y Derecho, procuro partir de cierta concepción antropológica, de matiz personalista, debido que en mi opinión ha sido la que más eficaz y profundamente consigue esta articulación. Una de las funciones principales de la familia es permitir una comunicación de integridades que no hipoteca o condiciona la libertad real de las personas sino que la posibilita hacia un plano superior de entrega responsable, libre e igual, de conformidad a la personalidad que cada uno tiene. Menciono esto porque cuando existe tal comunicación estamos adentrándonos en un nivel de diálogo, en un espacio de igualdad, igualdad de cargas y roles, pero sobretodo igualdad de responsabilidades.

En el segundo capítulo, al referirme a la clave de la igualdad, ya sea como derecho, principio o valor, doy cuenta de la importancia que tiene en el entramado social que conforma el Estado de Bienestar. La familia, uno de los pilares que sustenta este Estado, es una de las posibles formas de convivencia, por las que puede optar cada persona de manera libre, por ello las diversas políticas familiares se amparan en la pluralidad y el respeto a las diversas decisiones que impliquen distintas formas de vida.

La protección que dispensa el Estado en sus intervenciones está orientada hacia cada una de las personas que integran las familias, más que a las familias mismas, y esta al dejar de ser la principal unidad de referencia ha provocado que el denominado interés familiar sea muy poco considerado, debido a que lo realmente importante son los intereses de los individuos, tal cual ya se afirmó. Asimismo, la diversas reformas acaecidas en el ordenamiento jurídico familiar pretenden lograr el bienestar de toda la sociedad, y esto implica necesariamente la igualdad social, igualdad entre mujeres y hombres, consiguiendo el desarrollo de medidas, como compartir las tareas domésticas, que permitan conciliar y articular la vida familiar y la vida laboral, entre otras. Enfatizo que el deber de compartir estas responsabilidades domésticas, tal cual ha manifestado GUILARTE MARTÍN-CALERO, responden al principio de igualdad que rige a los cónyuges en sede matrimonial, lo cual a su vez se refleja, en el mismo sentido, en materia de responsabilidad parental, cuando se atribuye a ambos progenitores, sin distinguir la titularidad y el ejercicio de la función o potestad parental. Por lo demás, se ha hecho necesario que tal igualdad imperante durante la relación conyugal sobrevenga en caso de $\operatorname{crisis}^{1180}$.

1180 "La regulación de la custodia compartida: una oportunidad para la consolidación de la carrera profesional de las mujeres", ....op. cit., página 792. 
En cuanto al matrimonio, este es considerado hoy en día, una construcción social histórica que en el estado actual ha perdido la función relevante de procrear para tener como objeto expresar fines de solidaridad, afecto y asistencia recíproca, tales fines no requieren de una diversidad de sexo, en este capítulo también me referí al denominado matrimonio homosexual.

Se sabe que el matrimonio existe en casi todas las sociedades humanas conocidas. Aunque las formas del mismo son variadas según el contexto cultural, este está presente desde el principio de la historia. Es una idea humana prácticamente universal que ha implicado la regulación de la reproducción, de la familia y la sociedad, de allí su importancia.

En nuestros tiempos se considera que son los afectos, y no el matrimonio, lo que hace una familia, el matrimonio en la actualidad presenta una naturaleza condicional, de manera que las parejas sólo permanecerían unidas mientras los dos siguen enamorados, mientras su autonomía lo permite.

En este punto me detengo para reflexionar. Estimo que el principio de igualdad ha sido un aporte básicamente público, es decir, proveniente del ámbito constitucional, mientras que la autonomía personal, lo ha sido desde el Derecho Privado y posiblemente ello sea tan notorio y a veces tan complejo de armonizar en el ámbito del Derecho de Familia debido a que si bien se requiere a los individuos, los pueblos, las naciones y los estados para construir un nuevo orden social, más humano, más digno, todos ellos no son suficientes sin la participación de la familia. La familia entonces emerge como espacio de comunicación personal libre, autónomo, donde la personalidad busca su desarrollo y ello se considerará viable siempre que exista una igualdad en la asunción de responsabilidades.

Finalmente me refiero a la relación entre el principio de igualdad y el derecho a la identidad, en base a que la igualdad ante la Ley, recogida en el artículo $14 \mathrm{CE}$, guiada por la directriz constitucional del artículo 39.2 de supremacía del interés del menor, lleva a que todo aquél que haya engendrado un hijo, en principio, deba hacerse cargo de sus necesidades, de su existir. De esta forma el principio de libre investigación de la filiación es un instrumento y un medio que evita la discriminación entre los hijos, independiente de su origen. Es decir, que todo menor tiene el derecho a que las personas que lo han engendrado se responsabilicen por su bienestar y den respuesta a los diversos deberes que impone la patria potestad, siempre que esto sea conducente a alcanzar el mejor bien del niño. Este indagar y averiguar, a raíz del artí- 
culo 39.2 CE, presenta el carácter de principio del ordenamiento jurídico, y rige la actividad política, social y económica.

En relación al tercer capítulo, se manifiesta que la autonomía de la voluntad es la fuente esencial básica del Derecho, ya sea para constituir el pacto político social como para fundar una familia, dar comienzo al matrimonio o provocar su término. Esta tiene su fundamento así como su justificación en la capacidad natural de toda persona, como sujeto, para adquirir obligaciones de tinte jurídico. Si bien se analiza sobre todo el rol de dicha autonomía en el ámbito de los negocios jurídicos familiares, el principal aporte, a mi juicio, que se efectúa, es el análisis que se realiza en torno a la libertad y dicha autonomía, debido a que tienden a emplearse como sinónimos, aunque a mi juicio el término autonomía alude más a la inexistencia de coacción externa. Esto resulta muy importante, porque la libertad es también fundamento del Estado de Derecho y de Bienestar constituyendo el terreno propicio para el desarrollo de la personalidad.

Asimismo resalto la relación entre autonomía de la voluntad y matrimonio. Debido a que se ha desarrollado un contexto que ha facilitado la disolución, muy distinto a las anteriores concepciones más proclives al mantenimiento de la unión conyugal, ello ha provocado que desaparezca toda injerencia del Derecho Civil en el aspecto personal de la relación, que queda relegado a la esfera íntima de la pareja. Por ello, aunque continúan reconociéndose determinados deberes conyugales de carácter personal, deja de tener trascendencia jurídica su cumplimiento. La ruptura del matrimonio se concibe como una decisión amparada por la libertad de la persona y en tal sentido no puede encontrar trabas, debido a que una mayor libertad individual, es presupuesto indispensable para el libre desarrollo de la personalidad.

En relación con esto, sostengo que, la actual configuración del matrimonio, tanto desde el punto de vista jurídico como social, hace más real la igualdad de los cónyuges, lo cual sin duda es a todas luces positivo y al mismo tiempo fomenta la autonomía de cada uno de ellos destacándose una cierta desconfianza hacia la tradicional interdependencia, olvidando que la vida familiar, nuclear, monoparental, cualquiera que esta sea, necesariamente la implica, y que esta procura civilizar y personalizar cualquier pretensión de ordenar la vida social o política.

El cuarto capítulo se centra en el interés del menor. El menor es una realidad, es una realidad humana en devenir, al cual se le debe proporcionar todos los medios idóneos para que su 
personalidad se desarrolle de manera estable y armónica, ya sea en el aspecto físico, espiritual, psicológico e intelectual, precisamente es en esta personalidad que paulatinamente va desarrollándose donde estriba el fundamento último de su especial protección.

Posiblemente la sociedad actual es de la idea de que una infancia feliz es la condición requerida para un desarrollo más libre y adecuado de la personalidad individual, ante ello se afirma que el interés del menor encuentra, en definitiva su fundamento en el libre desarrollo de la misma. Este interés se manifiesta no sólo en el ámbito familiar sino que también en aspectos contractuales, donde se le ha reconocido una capacidad para consentir, y donde se toma consciencia de las consecuencias que de cara al futuro puede tener el acto celebrado, pero incluso más, este interés se enmarca en la interpretación de los derechos fundamentales. Es decir, el juicio emitido por el propio menor y que concierne a tales derechos debe ser analizado bajo el prisma de su propio interés. Por ello, el discernimiento que el menor puede experimentar sobre sus decisiones, sobre sus actuaciones, resulta esencial para entender dicho interés en el caso concreto que le compete. Y si en la duda se encuentran contrapuestos su capacidad natural así como su interés deberá primar este último ${ }^{1181}$. De esta manera, opina BARRACA MAIRAL, nos encontramos ante una cierta connotación práctica de naturaleza deontológica a la hora de proceder a la aplicación de este principio, dadas sus concretas proyecciones morales y jurídicas ${ }^{1182}$.

En relación a la igualdad entre los cónyuges y al interés superior de los hijos se ha tratado la custodia compartida, pero estimo que su columna vertebral y factor decisivo en su elección es dicho interés.

El quinto capítulo se centró en el libre desarrollo de la personalidad y de como ha influido en el Derecho de Familia, al amparo del principio de igualdad, de la autonomía de la voluntad y del interés superior del menor. Esto se debe a su íntima relación con la dignidad. Esta clave, por lo demás, recorre prácticamente todo el presente estudio.

1181 VARGAS CABRERA, B “La protección del menor en el ordenamiento jurídico”, Ed. Comares, Granada, año 1994, página 9.

1182 "El Derecho y el niño: principio éticos y jurídicos fundamentales.", en "El menor en la legislación actual”, Fundación Antonio Nebrija, Madrid, 1998, página 42; Cfr. SÁNCHEZ HERNÁNDEZ, C. "Capacidad natural e interés del menor maduro como fundamentos del libre ejercicio de los derechos de la personalidad", en VV. AA. "Estudios jurídicos en homenaje al profesor Luis Diez-Picazo", Tomo I, Semblanzas, Derecho Civil, Parte General, Ed. Thomson-Civitas, Madrid, año 2003, páginas 951 a 974. 
El significado jurídico de la dignidad de la persona se ha determinado no sólo a través de su propio concepto, sobre todo en ámbito constitucional, sino también en relación con la idea de libertad del individuo. Lo anterior conlleva el respeto por sus propias decisiones, estas a su vez requieren de su autonomía y la necesidad de educarse en ella al interior de la sociedad.

Es fundamental entender la importancia de que al ser toda persona un ser libre, esta libertad es igual para todos en cuanto personas. Por ello el significado de la dignidad viene dado por la libertad como valor propio e intrínseco de cada hombre, lo cual apunta no únicamente a su desarrollo individual sino a la posibilidad abstracta de tal desarrollo, implica la titularidad de derechos y su ejercicio de manera independiente en diversos aspectos, entre ellos, el afectivo.

Sin duda que el binomio clave es: desarrollo de la personalidad y libertad. FERNANDO SESGADO ${ }^{1183}$ señaló en tal sentido que "de la dignidad de la persona fluye el principio de libertad", lo cual implica la posibilidad de decidir libre y racionalmente el modelo de conducta que se estime adecuado y que tal modelo sea respetado por los demás.

Ante ello, la personalidad actúa como presupuesto de la libertad, lo cual le otorga un significado jurídico a la dignidad, esta es la razón de que la Constitución de 1978 mencione conjuntamente como fundamentos del ordenamiento a la dignidad de la persona y al libre desarrollo de la personalidad ${ }^{1184}$. El hombre al gozar de una personalidad capaz de organizar su vida de manera responsable provoca que su dignidad exija un amplio ámbito para su desarro1lo. Esta identificación entre dignidad y personalidad se debe a que la primera esta contenida en dicha personalidad. Puede, en tal sentido manifestarse que la dignidad hace suyo el imperativo de que se proteja la personalidad y fomente su desarrollo en el marco político, social y económico, y por supuesto, en el marco familiar.

La personalidad permite que la dignidad se manifieste en el ámbito interno y externo, de tal manera que, el desarrollo de la primera implica un reconocimiento de como se es y de como se quiere llegar a ser, el Derecho protege este despliegue esencial.

1183 FERNÁNDO SEGADO, F. "La dignidad de la persona como valor supremo el Ordenamiento Jurídico", LÓPEZ MORENO, A. (Coord.) "Teoría y práctica en la aplicación e interpretación del Derecho”, Ed. Colex, Madrid, año 1999, página 45.

1184 OEHLING DE LOS REYES, A. “La dignidad de la persona ”... op. cit., página 147. 
En el ámbito del Derecho de Familia, lo anterior ha tenido consecuencias muy importantes. La inserción de la dignidad de la persona y su libre desarrollo, en la evolución de la sociedad, ha permitido desplazar a la procreación como elemento sustentador de la heterosexualidad del matrimonio y sustituirlo por la afectividad, como base de la relación de pareja y como cauce adecuado de ese libre desarrollo.

Esta afectividad mutua presente en el momento del matrimonio, unida a cierta vocación de estabilidad, es lo que constituye la esencia del mismo y esta afectividad se produce entre los cónyuges con independencia de cuál sea su orientación sexual, así lo ha entendido el legislador, aunque, por otra parte, se ha sostenido que la diferencia de sexo si importa para la función unitiva de los afectos y la ayuda mutua, pues la complementariedad afectivo - sexual, fundada en la diversidad, es fuente de fecundidad ${ }^{1185}$.

En su momento se destacó la opinión de CAMPS MERLO, sobre que el despliegue de la dignidad en el ámbito íntimo y social, ha influido en la evolución que ha ocurrido desde una visión teocéntrica de la realidad, de acuerdo con la cual la persona reconocía un significado intrínseco a su realidad sexual, a su identidad sexual, que podía ser aceptado o rechazado y manifestar tal decisión en las conductas sociales y culturales que decidiera asumir, a una visión antropocéntrica ${ }^{1186}$, amparada en su autonomía de la voluntad, en la que el hombre actúa decidiendo la naturaleza o significado de su propia identidad sexual personal.

Al finalizar este capítulo, hago referencia a la persona del menor y el libre desarrollo de la personalidad. Este principio modelará la naturaleza del proceso educativo. En tal sentido, no sólo se ha querido la educación en libertad, sino también la educación para la libertad. Consiente de que todo proceso educativo implica transmisión de valores y de pautas de comportamiento, la finalidad de la educación será el pleno desarrollo de la personalidad.

Para concluir, vuelvo a retomar las ideas esbozadas en el primer capítulo, ideas de matiz antropológico, en relación al grupo familiar. Si la familia es considerada como una experiencia fundamental, un espacio básico y original de capacitación personal, dará lugar a la experiencia de vivir de manera plena la evolución de la personalidad de quien la conforma. Al rescatar esta experiencia de vida y hacerla consciente de la propia dignidad, entonces,

1185 Cfr. LACALLE, M. (Coord.), “Mujer y varón. ¿Misterio o Autoconstrucción?”, CEU, Universidad Francisco de Vitoria y UCAM, Madrid, año 2008.

1186 "Identidad sexual y Derecho. Estudio interdisciplinario del transexualismo”, .... op. cit., páginas 219 y siguientes. 
perfectamente es posible dar paso a la autonomía plena, la libertad de los miembros del grupo familiar, libertad que ejercida de manera responsable constituye la autonomía personal ${ }^{1187}$.

Mi experiencia familiar me permiten afirmar que esta participación libre e igual, será fruto no del entusiasmo ni de las pasiones arrebatadas sino resultado de la más aburrida de la virtudes: la paciencia, la perseverancia. Y será esta misma paciencia la que entenderá que en las decisiones adoptadas la responsabilidad implicará el ceder mi interés frente a uno mayor. Mayor porque requiere más protección, mayor porque apunta al futuro, dicho interés es un escenario que deja entrever la existencia de un protagonista, el menor de edad.

Es momento de recurrir a RICOEUR ${ }^{1188}$, para plantear la vida familiar, como un intercambio de dos tradiciones morales, de la justicia y del amor. ¿Por qué? Porque tanto la una como la otra son éticas diversas y complementarias que en caso de gozar de la suficiente estabilidad y respaldo permiten el desarrollo de la persona humana, en su ámbito moral, físico, espiritual, sexual y afectivo, es decir el desarrollo de su personalidad plena.

Las relaciones familiares tienen que ser presididas por las ideas de dignidad personal y respeto mutuo, ellas deben presidir la vida familiar reflexiva, donde a veces ceden unos y en otras ceden otros. Sin duda que para una ética de la vida familiar la idea de justicia es necesaria pero insuficiente, el amor ofrece la posibilidad de ampliar el valor de todo lo compartido, desplazando la perspectiva del mutuo interés e independencia mutua por la perspectiva del mutuo desinterés y la interdependencia personal.

Si la vida familiar estuviera presidida sólo por la idea de justicia, la felicidad se conseguiría mediante el cálculo en las relaciones. Si estuviera presidida sólo por el amor habría fusión y unión de personas, pero no respeto, libertad real o crecimiento comunitario, carecería de igualdad y autonomía.

Estimo pertinente que a futuro, se contemple en el Derecho de Familia tres grandes elementos, la familia propiamente, el matrimonio y los miembros que la forman. No todas las familias se fundan en el matrimonio pero no por ello dejan de serlo, pero aún hoy existe la conciencia social de que el matrimonio no es una suma de cargas y roles. Posiblemente aún siga oculto en el corazón del Hombre de que es un camino de plenitud, es decir, de felicidad. Esta

1187 Vid. SANTOS URBANEJA, F. “Familia, Educación y Futuro”, en Revista de Derecho de Familia, núm. 10, enero - marzo de 2010, Ed. Lex Nova, Valladolid, páginas 235 y siguientes.

1188 RICOEUR, P. “Amor y justicia”, DOMINGO MORATALLA, T (Trad.), Ed.Trotta, Madrid, año 1993. 
realidad tiene su centro en la propia personalidad de quien la transita, pero no se confunde necesariamente con ella, esta realidad crece y se desarrolla en la experiencia cotidiana que se da.

Al fin y al cabo se trata de promover la igualdad, la autonomía, los diversos intereses protegidos. Cuando esta tarea se cumple entonces impera la dignidad humana que se desenvuelve en el principio del libre desarrollo de la personalidad. 
Bibliografía 
ABELLAN SALORT, J.C. "Autonomía, dependencia y vida social”, en LACALLE, M (Coord.), "Cuestiones disputadas de la vida en sociedad", Ed. Voz de Papel, Madrid, año 2006.

ABELLAN SALORT, J. C. (Edit.), "Derecho y Realismo. Introducción a la filosofía jurídica de M. VILLEY”, Universidad Francisco de Vitoria, Biblioteca de Derecho, Madrid, año 2005.

ABRIL STOFFELS, R y URIBE OTAROLA, A. "Mujer, derecho y sociedad en el siglo XXI”, Ed. Tirant Lo Blanch, monografías, núm. 677, Valencia, año 2010.

AGUILAR CUENCA, J. M. "El uso de los hijos en los procesos de separación: el síndrome de alienación parental", Revista de Derecho de Familia, núm. 29 octubre-diciembre, Ed. Lex Nova, Valladolid, año 2005.

AGUILAR RUIZ, L y HORNERO MÉNDEZ, C. "Los pactos conyugales de renuncia a la pensión compensatoria: autonomía de la voluntad y control judicial”, Revista Jurídica del Notariado, núm. 57, Madrid, año 2006.

AGUILAR RUIZ, L. "El Tribunal Constitucional y la función legislativa: el control del procedimiento legislativo y la inconstitucionalidad por omisión”, Revista de Derecho Público núm. 24, Madrid, año 1997.

AHUMADA RUIZ, M. A. "El control de constitucionalidad de las omisiones legislativas", RECEC, núm. 8, Madrid, año 1991.

ALÁEZ CORRAL, B. "Minoría de edad y derechos fundamentales", Ed. Tecnos, Madrid, año 2003.

ALBALADEJO, M. "Comentarios al Código Civil y Compilaciones Forales", Volumen IV, Ed. Edersa, 10ª edición, Madrid, año 2005.

ALBALADEJO, M. "Derecho Civil, Introducción y parte general". Volumen I, Ed. J. M. Bosch Editor S. A., 1ª edición, Barcelona, 12ª edición, año 2006.

ALBERDI, I. “La nueva familia española”, Ed. Taurus, Madrid, año 1999.

ALES URÍA ACEVEDO, M.“El derecho a la identidad en la filiación”, Ed. Tirant Lo Blanch, monografías núm. 787, Valencia, año 2012.

ALEXY, R. "Teoría de los derechos fundamentales". Centro de Estudios Constitucionales, 2a edición en español, Madrid, año 2008.

ALGARRA PRATS, E. "Del régimen de participación" en RAMS ALBESA, J y MORENO ÁLVAREZ, J. A. (Coords.) "El régimen económico del matrimonio. Comentarios al Código civil: especial consideración de la doctrina jurisprudencial", Ed. Dykinson S. L., Madrid, año 2006.

ALKORTA IDIAKEZ, I. "Nuevos límites del derecho a procrear" . Revista de Derecho Privado y Constitución, núm. 20, Enero-Diciembre, año 2006. 
ALMACELLAS BERNARDÓ Ma . A. "Camino hacia la madurez personal: Plan de acción tutorial para la educación secundaria obligatoria y bachillerato", Ed. Deescle De Brower, Madrid, año 2009

ALMENDROS GONZÁLEZ, M.A. "La protección social de la familia”, Ed. Tirant Lo Blanch, Valencia, año 2005.

ALMOGUERA SALLENT, Ma . "Hogares, familias y viviendas", Revista de Treballs de la Societat Catalana de Geografía, número 41, Barcelona, año 1996.

ALONSO GARCIA, E. "La interpretación de la Constitución”, Centro de estudios Constitucionales, Madrid, año 1984.

ALONSO GARCÍA, R. y SARMIENTO, D. "La carta de los Derechos Fundamentales de la Unión Europea. Explicaciones, concordancias y jurisprudencia", Ed. Thomson Civitas, Cizur Menor, año 2006.

ALONSO PÉREZ, M. "La Familia entre el pasado y la modernidad. Reflexiones a la luz del Derecho civil”, Actualidad Civil, La Ley 2338/2001, Sección Doctrina, Madrid, año 1988.

ALONSO PÉREZ, M. "La situación jurídica del menor en la Ley Orgánica 1/1996 de 15 de enero de Protección jurídica del Menor, de modificación del Código Civil y de la Ley de Enjuiciamiento Civil: luces y sombras", Revista Actualidad Civil, núm. 1, Madrid, año 1997.

ALONSO PEREZ, M., "La familia entre el pasado y la modernidad. Reflexiones a la luz del Derecho Civil", Actualidad Civil, núm. 1, Madrid, año 1998.

ALONSO SUÁREZ, C. y DE LAMA AYMÁ, A. "La protección civil de personas sometidas a manipulación mental", Ed. Tirant lo Blanch, Valencia, año 2003.

ALSACIO CARRASCO, L y MARÍN GARCÍA, I. "Juntos pero no revueltos: la custodia compartida en el nuevo artículo 92 CC”, INDRET, Revista para el análisis del Derecho. 3/2007, Barcelona, año 2007.

ÁLVAREZ ALARCÓN, A.; BLANDINO GARRIDO, M A.; SÁNCHEZ MARTÍN; P. "Las crisis matrimoniales. Nulidad, separación y divorcio". Ed. Tirant Lo Blanch, Valencia, año 2010.

ÁLVAREZ CONDE, E. "Curso de Derecho Constitucional, Volumen I. El Estado constitucional. El sistema de fuentes. Los derechos y libertades", Ed. Tecnos, S. A., Madrid, año 2008 .

ÁLVAREZ CONDE, E. "Un nuevo paso en la consecución de la igualdad: a propósito de una ley integral para la igualad de trato y de oportunidades", en TEROL BECERRA, M. J. (Dir.), "IV Foro Andaluz de los Derechos Sociales, Igualdad e Integración", Ed. Tirant Lo Blanch, Valencia, año 2011. 
ÁLVAREZ VELEZ, Ma I y ALCÓN YUSTAS, F. "EL Menor y su entrono familiar", en LÁZARO GONZÁLEZ, I. (Coord.), "Los menores en el Derecho español”, Ed. Tecnos, Madrid, año 2002.

ALVIRA, R. "Sobre la esencia de la familia", en CRUZ CRUZ, J. (Edit.), "Metafísica de la familia”, ,Ed. EUNSA, Pamplona, año 1995.

ALZAGA VILLAMIL, O. “Derecho Político español según la Constitución de 1978”, en VV. AA. "Constitución y Fuentes del Derecho", Centro de estudios Ramón Areces, Madrid, año 1997.

ALZAGA VILlAMIL, O. (Dir.), "Comentarios a las leyes Políticas. CE de 1978”, Tomo II, arts. 10 a 23, Revista de Derecho Público, Ed. Revista de Derecho Privado, Madrid, año 1984.

CELIA AMOROS, A. "Teoría feminista de la Ilustración a la globalización”, Ed. Minerva, Madrid, año 2005.

AMORÓS MARTÍ, P. Y OTROS. "La búsqueda de los orígenes en la adopción"; Anuario de Psicología, núm. 71, Facultad de Psicología, Universidad de Barcelona, año 1996

ANDRES IBAÑEZ, P. "Matrimonio homosexual: hay derecho", en El País, edición de 22 de abril de 2005.

APARICIO PÉREZ, M. A. "El Estado social en la jurisprudencia del TC", en "Estudios sobre el Estado Social”, Ed. Tecnos, Madrid, año 1993.

APARICIO PÉREZ, M. A. (Ed.). "Derechos y principios rectores en los estatutos de autonomía", Ed. Atelier, Barcelona, año 2008.

ARAMBURU Y MACHADO, M. "La capacidad civil. Estudio de las causas que determinan, modifican y extinguen, según la filosofía del derecho, la historia de la legislación y el Derecho vigente en España”, Empresa y Fundición Manuel Tello, Madrid, , año 1931.

ARANZAZU CALZADILLA MEDINA, Ma " "La adopción internacional en el derecho español”, Ed. Dykinson, Colección Monografías de Derecho Civil. I Persona y Familia. Madrid, año 2004.

NOVALES ALQUÉZAR, $\mathrm{M}^{\mathrm{a}}$. "Las obligaciones personales del matrimonio en el Derecho Comparado", Tomo II, Colegio de Registradores de la Propiedad y Mercantiles de España, Madrid, año 2008.

ARCH MARIN, M. y JARNE ESPARCIA, A. “Opinión y valoración de los diferentes sistemas de guarda y custodia por psicólogos forenses y juristas españoles. Un estudio piloto", Revista de Derecho de Familia, número 41, octubre-diciembre 2008.

ARCOS VIEIRA, M. L. en "La Desaparición de la Affectio Maritalis como Causa de Separación y Divorcio", Ed. Aranzadi, Cizur Menor, año 2000. 
ARECHEDERRA ARANZADI, L. I. "El consentimiento matrimonial (Comentario al art. 45 del Código civil)", Servicio de Publicaciones de la Universidad de Navarra, S.A., Pamplona, año 1989.

ARECHENDERRA ARANZADI, L. I. "El matrimonio es heterosexual", Actualidad Jurídica Aranzadi, núm. 658/2005, parte Opinión, Ed. Aranzadi, Pamplona, año 2005, BIB $2005 / 510$.

ARIAS RAMOS, J y ARIAS BONET, J. A. "Derecho Romano II", Obligaciones, Familia, Sucesiones, Revista de Derecho Privado, Madrid, año 1979.

ARISTÓTELES. “La Política”, Libro I, Clásicos Políticos, Madrid, año 1989.

ARREGUI, V y CHOZA, J. "Filosofía del hombre. Una antropología de la intimidad", Ed. Rialp, Madrid, año 1993.

ARROYO I AMAYUELAS, E. "El matrimonio del transexual (II) (El marco constitucional y conclusión)”, Revista de Derecho Privado, septiembre, Madrid, año 2002.

ASENSIO SÁNCHEZ, M. A. "La patria potestad y la libertad de conciencia del menor", Ed. Tecnos, Madrid, año 2006.

ASENSIO SÁNCHEZ, M. A. "Minoría de edad y derechos fundamentales: su ejercicio por el menor de edad", Revista General de Derecho Canónico y Derecho Eclesiástico del Estado, núm. 7, enero, Madrid, año 2005, página 7, www.iustel.com,

BALAGUER CALLEJÓN, Ma. L. "Igualdad y Constitución española”, Ed. Tecnos, Madrid, año 2010.

BALAGUER CALLEJÓN, F. “Aplicación de la Constitución y garantías de los derechos”, en Anuario de Derecho Público y Estudios Políticos, núm. 2, Madrid, años 1989 y 1990.

BALAGUER CALLEJÓN, F. "Fuentes del Derecho”, Ed. Tecnos, Madrid, año 1991.

BALLESTEROS GARRIDO, J.A. "Las condiciones generales de los contratos y el principio de autonomía de la voluntad”, Ed. J.M. Bosch, Barcelona, año 1999.

BALLESTEROS LLOMPART, J. “Ecologismo personalista”, Ed. Tecnos, Madrid, año 1995.

BALLESTEROS LLOMPART, J. "Postmodernidad, decadencia o resistencia”, Ed. Tecnos, Madrid, año 1997.

BAÑO LEÓN, J. M. "La igualdad como derecho subjetivo", Revista de Administración Pública, núm. 114, Madrid, año 1987.

BAÑO LEÓN, J. M. "La distinción entre derecho fundamental y garantía institucional en la Constitución española", en Revista Española de Derecho Constitucional, núm. 24, Madrid, año 1988. 
BARRACA MAIRAL, J. "El Derecho y el niño: principios éticos y jurídicos fundamentales", en "El menor en la legislación actual", varios autores, U. Antonio de Nebrija, Madrid, año 2002.

BARRÉRE UNZUETA, M.A. "Igualdad y discriminación positiva: un esbozo de análisis teórico-conceptual, en Género y Derechos Humanos”. Mira Editores, Zaragoza, año 2002.

BARRÉRE UNZUETA, Ma . A. "Discriminación, Derecho antidiscriminatorio y acción positiva a favor de las mujeres", Ed. Civitas, Madrid, año 1997.

BARRERO ORTEGA, A. "Libertad religiosa y deber de garantizar la vida del hijo (A propósito de la STC 154/2002, de 18 de julio)", Revista Española de Derecho Constitucional, núm. 75, septiembre-diciembre, Madrid, año 2005.

BASTIDA FREIJEDO, F. J., VILLAVERDE MENÉNDEZ, I., REQUEJO RODRÍGUEZ, P,. PRESNO LINERA, M. A., ALÁEZ CORRAL, B., FERNÁNDEZ SARASOLA, I. "Teoría general de los Derechos fundamentales en la Constitución española de 1978", Ed. Tecnos, Madrid, año 2004.

BELMONTE GARCÍA, O. "Pensar la violencia, la justicia y la libertad", Pontificia Universidad de Comillas, Madrid, año 2012

BENITO ALONSO, F. “Actuaciones frente a situaciones de riesgo y desamparo de menores: tutela por ministerio de ley y guarda”, Ed. La Ley, Madrid, año 1997.

BERCOVITZ RODRIGUEZ-CANO, R. "Sobre el matrimonio", Aranzadi Civil Mercantil núm. 22/2010, parte Tribuna, Ed. Aranzadi, Pamplona, año 2010

BERCOVITZ RODRÍGUEZ-CANO, R en BERCOVITZ RODRÍGUEZ-CANO y OTROS, "Comentarios al Código Civil", Ed. Thomson Aranzadi, año 2006.

BERCOVITZ RODRIGUEZ-CANO, R. "El matrimonio de los homosexuales", en Aranzadi Civil, núm. 15, Tribuna, Cizur Menor, año 2005.

BERCOVITZ RODRIGUEZ-CANO, R. "Derecho de la persona", Ed. Montecorvo, 1"a edición, Madrid, año 1976.

BERLIN, I. "Los conceptos de libertad", en "Cuatro ensayos sobre la libertad", Ed. Alianza, Madrid, año 2000.

BERMÚDEZ BALLESTEROS, $\mathrm{M}^{\mathrm{a}}$. del $\mathrm{S}$, "Criterios para la atribución y modificación de la guarda y custodia de los hijos en la práctica judicial”, Aranzadi Civil, Volumen I, Tomo X, Madrid, año 2001.

BERNAL PULIDO, C, "Tribunal Constitucional, legislador y principio de proporcionalidad. Una respuesta a Gloria Lopera", Revista Española de Derecho Constitucional núm. 74, Madrid, año 2005

BERNAL PULIDO, C. "El principio de proporcionalidad y los derechos fundamentales", Centro de Estudios Políticos y Constitucionales, Madrid, año 2005 
BERROCAL LANZAROT, A y ABELLAN SALORT, J. “Autonomía, libertad y testamentos vitales. Régimen jurídico y publicidad”. Colección Monografías de Derecho Civil.; I. Persona y familia. Ed. Dykinson, S.L., Madrid, año 2009.

BERRY BRAZELTON, T. "Necesidades básicas de la infancia. Lo que cada niño o niña precisa para vivir, crecer y aprender.”, Ed. Grao, Barcelona, año 2005. BETEGÓN, J.; GASCÓN, M.; PÁRAMO, J. R. DE; PRIETO, L. "Lecciones de Teoría del Derecho", Ed. McGraw Hill, Madrid, año 1997.

BLASCO GASCÓ, F. "Despropósitos de la Proposición de Ley de Régimen económico matrimonial valenciano", Revista Jurídica de la Comunidad Valenciana, núm. 21/enero 2007.

BO JANÉ, M y CABALLERO RIBERA, M. "El nuevo derecho del menor a ser oído: ¿sujeto activo en la determinación de su interés?”, Ed. La Ley, tomo 6, Madrid, año 1996.

BOBBIO, N. "Igualdad y Libertad”, Ed. Paidós, Barcelona, año 1993.

BORRAS RODRIGUEZ , A. "El interés del menor como factor de progreso y unificación", Revista Jurídica de Catalunya, Vol. IV, Barcelona, año 1994.

BORRAS RODRÍGUEZ, A. "El interés del menor como factor de progreso y unificación del Derecho Internacional Privado", Discurs d'ingrés en la Academia de la Jurisprudéncia I Legislació de Catalunya, Revista Jurídica de Cataluña, núm. 4, Barcelona, año 1994.

BRAZELTON, T. B. "Necesidades básicas de la infancia. Lo que cada niño o niña precisa para vivir, crecer y aprender.”, Ed. Grao, Barcelona, año 2005.

BUSTO LAGO, J. M. "Precisiones constitucionales sobre la investigación de la paternidad. La valoración de la prueba biológica (A propósito de la STC 29/2005, de 14 de febrero. La doctrina jurisprudencial y constitucional "ortodoxa"), Revista de Derecho Privado y Constitución., núm. 19, Madrid, año 2005.

BUSTOS PUECHE, J. E. "El Derecho civil ante el reto de la nueva genética”, Ed. Dykinson, Madrid, año 1996.

BUTTLER, J. "El género en disputa. El feminismo y la subversión de la identidad”. Ed. Paídos, México, año 2001.

CABANILLAS SÁNCHEZ, A. "Comentario al artículo 1328” en "Comentario al Código civil”, Tomo II, Ministerio de Justicia, Madrid, año 1991.

CABAÑAS GARCÍA, J. C. "El Derecho a la Igualdad en la Aplicación Judicial de la Ley", Ed. Thomson Reuters, Cizur Menor, año 2009.

CABEDO MALLOL, V. "Marco Constitucional de la protección de menores", Ed. Instituto de Iberoamérica y el Mediterraneo, Valencia, año 2006.

CABEZUELO ARENAS, A. L. " La cesación de la "affectio maritalis" como causa de separación en la práctica judicial. Un exponente de la interpretación sociológica de la norma", 
Ed. Aranzadi, Aranzadi Civil, Tomo 10, Volumen 3, Revista Doctrinal, Cizur Menor, año 2001.

CALVO CABELLO, J. L. "Discrecionalidad y arbitrariedad en la fijación del derecho y régimen de visitas. Análisis de diversos casos prácticos, en Derecho de visita, Teoría y praxis", EUNSA, Pamplona, año 1982.

CALVO CARAVACA, A y CARRASCOSA GONZÁLEZ, Javier. "Matrimonio entre personas del mismo sexo y Derecho internacional privado español”, Ed. La Ley, T. 1, Madrid, año 2006.

CALZADILLA MEDINA, M.A., "La adopción internacional en el Derecho Español”, Ed. Dykison, Madrid, año 2004.

CÁMARA VILLAR, G "Votos particulares y derechos fundamentales en la práctica del Tribunal Constitucional español”, Ministerio de justicia, Madrid, año 1993.

CAMPO IZQUIERDO, A. L. "La conflictividad y los procesos matrimoniales", Boletín de Derecho de Familia, El Derecho, núm. 59 EDB 2006/102528, Julio, Madrid, año 2006.

CAMPOS, A. "La transexualidad y el derecho a la identidad sexual", Valencia, año 2001, disponible en www.transexualitat.org

CAMPOY CERVERA, I. "Artículo 24. Derechos del niño", en MONEREO ATIENZA, C y MONEREO PÉREZ, J. L. (Dirs.), "La Europa de los Derechos. Estudio sistemático de la Carta de los Derechos Fundamentales de la Unión Europea”, Ed. Comares, Granada, año 2012.

CAMPS MERLO, M. "Identidad sexual y Derecho. Estudio interdisciplinario del transexualismo”, Ed. EUNSA, Pamplona, año 2012.

CAMPS, V. "Un marco ético para la bioética", en PALACIOS, M (Coord) "Bioética 2000", Ed. Nobel, Oviedo, año 2000.

CAMPUZANO TOMÉ, H. " La custodia compartida. Doctrina jurisprudencial de las Audiencias Provinciales”, Ed. Aranzadi S.A. Aranzadi Civil-Mercantil, núm. 22/2004, parte Estudio, Pamplona, año 2005, BIB 2005/563.

CAÑETE QUESADA, A. "El anteproyecto de Ley por el que se modifica el Código Civil en materia de separación y divorcio", Diario La Ley, núm. 6140, de 2 de diciembre de 2004.

CAPILLA RONCERO, F. “Autonomía de la voluntad y Derecho de la persona; o la autonomía personal en el Derecho privado", Diario La Ley, No 7675, Sección Tribuna, , Año XXXII, Ref. D-302, La Ley 13920, año 2011.

CARBONELL BENITO, G. "El interés del menor: criterios para su concreción y defensa a través de las figuras del Defensor del Menor y del Ministerio Fiscal", en VALLÉS, A. (Dir.) "La protección del menor”, Ed. Tirant Lo Blanch, Valencia, año 2009. 
CARD CIPRIANI, J. L. "La familia, forjadora de humanidad", en "Matrimonio, Familia y Vida. Homenaje al profesor Dr. Augusto Sarmiento”, Ed. EUNSA, Pamplona, año 2010.

CARIOTA FERRARA, L. "El negocio jurídico”, ALBALADEJO, M., (Trad.), Ed. Aguilar, Madrid, año 1956.

CARLOS DE CABO, M. “Teoría constitucional de la solidaridad”. Ed. Marcial Pons, Madrid, año 2006.

CARMONA Y CHOUSSAT, J. F., "Constituciones: Interpretación histórica y sentimiento constitucional. Cuatro ensayos sobre la organización política”, Ed. Thomson Civitas, Cizur Menor, año 2004.

CARRASCO PERERA, A., "Custodia compartida", Actualidad Jurídica Aranzadi, número 648, Parte Tribuna, Ed. Aranzadi, Pamplona, año 2004, BIB 2004/1707.

CARRASCO PERERA, A., "La custodia compartida llega al Tribunal Supremo". Actualidad Jurídica Aranzadi, número 790 (Tribuna), Cizur Menor, año 2009.CARRASCO PEREA, A. "El Derecho civil, señal, imágenes y paradojas", Ed. Tecnos, Madrid, año 1988.

CASADO CASADO, B. "El asentimiento de los padres biológicos en el procedimiento de adopción de menores", Revista de Derecho de Familia, núm. 35, abril-junio, Ed. Lex Nova, Valladolid, año 2007.

CASO SEÑAL, M. "La audiencia del menor en los procedimientos de familia: Guía de recomendaciones para la práctica de la exploración judicial”, en Familia y sucesiones, núm. 91, Ed. SEPIN, mayo-junio 2010, Madrid.

CASTÁN TOBEÑAS, J. "Derecho Civil español, común y foral”, Tomo I Volumen $2^{\circ}$, Ed. Reus S.A., 14 ${ }^{\mathrm{a}}$ edición, Madrid, año 1984.

CASTÁN TOBEÑAS, J. "Derecho civil español, común y foral”, Tomo I, Introducción y Parte General, Vol. $2^{\circ}$ (Teoría de la relación jurídica), Ed. Reus, Madrid, año 1952.

CASTÁN TOBEÑAS, J. "Derecho civil y foral". Tomo V, volumen I., Ed. Reus S.A. 11 a edición, Madrid, año 1987.

CASTÁN TOBEÑAS, J. "Los derechos del hombre”, Ed. Reus S.A., 4ª edición, Madrid, año 1992

CASTÁN VÁZQUEZ, J. M. "Derecho civil, común y foral”, Tomo V, Vol. 1, Ed. Reus, S.A., Madrid, año 1983.

CASTIELLA RODRÍGUEZ, J. J. "La vulnerabilidad del menor", $2^{\circ}$ parte, Revista jurídica del notariado, núm. 73, enero-marzo, Madrid, año 2010, Madrid.

CASTILLO MARTÍNEZ, C. C. "El Interés del menor como Criterio Prevalente en la Mediación Familiar", http://www.monografias.com/trabajos30/menores-criterio-prevalente-mediacion-familiar/menores/criterio/prevalente-madiación-familiar.shtml 
CASTILLO MARTÍNEZ, C. C. "La determinación en la guarda y custodia de los menores en los supuestos de crisis matrimonial o convivencial de sus progenitores. Especial consideración de la guarda y custodia compartida tras la Ley 15/2005, de 8 de julio", Actualidad Civil, número 15, Sección A Fondo, Quincena del 1 al 15 septiembre, Madrid, año 2007.

CENZANO BARTOLOMÉ, J., "Derechos fundamentales y libertades públicas", Ed. Tirant Lo Blanch, Valencia, año 2003.

CERVANTES Y SAAVEDRA, M DE. "Don Quijote de la Mancha", Centro Virtual Cervantes, Literatura, ClásicosHispánicos.http://cvc.cervantes.es/literatura/clasicos/quijote/edicion/parte2/cap51/cap51_02.htm

CERVILLA GARZÓN, M. a D. “Comentario a la Ley 41/2002, de 14 de noviembre, básica reguladora de la autonomía del paciente y de derechos y obligaciones en materia de información y documentación clínica", Actualidad Civil, núm. 12, marzo, Madrid, año 2003.

CHINCHILLA MARIN, C. "La familia en la jurisprudencia del Tribunal Constitucional", Aranzadi Civil-Mercantil, Volumen I, parte Estudio, Ed. Aranzadi, S.A., Pamplona, año 2005.

CIFUENTES, S. “Negocio jurídico”, Ed. Astrea, Buenos Aires, año 2004.

CISNEROS LABORDA, G. "Balance y perspectiva de la Constitución" en Revista valenciana d' estudis autonòmics, núm. 39-40, Generalitat Valenciana, Valencia, año 2003.

CLEMENTE MEORO, M. "Los efectos patrimoniales del matrimonio" en DIEZ-PICAZO GIMÉNEZ, G (Coord.). "Derecho de familia", Capítulo VII, Ed. Civitas Thomson Reuters, Cizur Menor, año 2012.

CODINA BLASCO, M. "Donde vive la libertad. Una lectura de Romano Guardini”, Ed. Biblioteca Nueva S.L., Madrid, año 2011.

COMITÉ DE DERCHOS HUMANOS: Observación General, número 18, año 1989, "No discriminación", Ginebra, Naciones Unidas. HRI/GEN/1/Rev. 7 at 168, 1. ${ }^{\circ}$ de noviembre de 1989.

COMTE-SPONVILLE, A. "Montaigne y la filosofía”, Ed. Paídos, Barcelona, año 2012.

CONSEJO DE ESTADO, Dictamen 16/12/2004, sobre el Anteproyecto de Ley por la que se modifica el Código Civil en materia de derecho a contraer matrimonio, http: www/boe/es/g/es/iberlex/bases_datosce/doc/php?colleccion=ce\&id=2004-2628.

CONSEJO GENERAL DEL PODER JUDICIAL, Comisión de Estudios e Informes , "Estudio sobre la reforma del Código Civil en materia de matrimonio entre personas del mismo sexo", 26 de enero, Madrid, año 2005.

CONSEJO GENERAL DEL PODER JUDICIAL, "Estudio de 26/01/2005 sobre la reforma del Código Civil en materia de matrimonio entre personas del mismo sexo" http//www.poderjudicial.es 
CONSEJO GENERAL DEL NOTARIADO "El nuevo Derecho de Familia, modificaciones legislativas y tendencias doctrinales", Ed. Thomson Civitas, Madrid, año 2006.

CORCHETE MARTÍN, Ma . J. "Algunos apuntes sobre la igualdad en la constitución española y su situación sobre la mujer", GONZÁLEZ BUSTOS, Ma. A. (Coord.) "La mujer ante el ordenamiento jurídico: soluciones a realidades de género", Ed. Atelier, Barcelona, año 2009.

CORRAL TALCIANI, H. "Familia y derecho. Estudios sobre la realidad jurídica de la familia”. Ed. de la Universidad de los Andes, Santiago de Chile, año 1994.

CORTINA, A. "La educación del hombre y del ciudadano", en Revista Iberoamericana de Educación, núm. 7, año 1995.

COSSIO, A, "El moderno concepto de personalidad y la teoría de los estados en el Derecho Civil”, Revista de Derecho Privado, Madrid, año 1943.

CREMADES, I. y GUTIÉRREZ-MASSON, L. "El proyecto de un código civil y la revolución”, en PORTALIS, J. E. M., "Discurso preliminar al Código Civil francés”, Ed. Civitas, Madrid, 1997.

CRUZ VILLALON, P. "El legislador de los derechos fundamentales", LÓPEZ PINA, A (Edit.), "La garantía constitucional de los derechos fundamentales: Alemania, España, Francia e Italia", Ed. Civitas, Madrid, año 1991.

CUBILLAS RECIO, M. "La enseñanza de la religión en el sistema español y su fundamentación en el derecho de los padres sobre la formación religiosa de sus hijos" en Laicidad y Libertades, núm. 2, año 2002.

D’ORS Y PÉREZ-PEIX, A. “Derecho Privado Romano”, Ed. EUNSA, $3^{\text {a }}$ edición, Pamplona, año 1977.

DAJCZAK, W. "La revolución antiformalista del Derecho Privado", en VV. AA. "Hacia un Derecho Global”, Ed. Thomson Aranzadi, The global law collection, Cizur Menor, año 2006

DAL VIGIL, E. "Los derechos en la Convención de Derecho del Niño y en la Constitución española", en BALADO, M y GARCÍA REGUEIRO, J. A. (Dir.) "La Constitución española de 1978 en su XXV aniversario”, Ed. J. M. Bosch S. A., Barcelona, año 2003.

DAMM ARNAL, A. "El punto sobre la I. Ideas en torno a la libertad individual, la responsabilidad personal y la propiedad privada." Unión Ed. S.A. Biblioteca de la libertad, Formato menor. Madrid, año 2012.

DE AMUNATEGUI RODRIGUEZ. C. "La libertad de pacto en el régimen de separación de bienes" en "Autonomía de la voluntad y negocios jurídicos de familia", (VV.A.A.), Ed. Dykinson, S.L. Madrid, año 2009. 
DE ÁNGEL YAGÜE, R. "La autonomía de la voluntad y la evolución de las formas de prestar el consentimiento", Diario La Ley, No 7800, Sección Tribuna, 17 Feb. 2012, Año XXXIII, Ref. D-74, La Ley 2021/2012.

DE ASIS, R. F. "La apertura constitucional: la dignidad de la persona y el libre desarrollo de la personalidad como fundamentos del orden político y de la paz social", en VV. AA., "Comentarios a la Constitución Socioeconómica Española", Ed. Comares, Granada, año 2002.

DE BAUVOIR, I Y PEREZ DEL RIO, T: "Los derechos de conciliación en la Ley 39/99: Interrupción o reducción de la actividad laboral para atender responsabilidades familiares", Revista Aequalitas, nº 4, Zaragoza, mayo, año 2000.

DE CASTRO Y BRAVO, F. "Derecho Civil de España”, edición facsimilar de la $2^{\mathrm{a}}$ de 1952 , Ed. Cívitas, Madrid, año 1986.

DE CASTRO Y BRAVO, F. “Derecho Civil de España”, Ed. Civitas, Madrid, año 1984.

DE CASTRO Y BRAVO, F. “Derecho Civil de España I”, Ed. Edersa, Madrid, año 1985.

DE LA CÁMARA ÁLVAREZ, M "La autonomía de la autonomía en el actual Derecho español sobre la familia", Boletín de Información de la Academia Granadina del Notariado, núm. 9, Ilustre Colegio Notarial de Granada, Mayo, año 1986.

DE LA CÁMARA ÁLVAREZ, M. "La separación de hecho y la sociedad de gananciales", Anuario de Derecho Civil, Madrid, año 1969.

DE LA CÁMARA ÁLVAREZ, M. "Los hijos no matrimoniales y la Constitución de 1978”, Actualidad Civil, II, Madrid, año 1981.

DE LA CÁMARA ÁLVAREZ, M. "El nuevo régimen jurídico de la filiación”, en VV. AA., "La Reforma del Derecho de Familia", Ed. Edersa, Sevilla, año 1982.

DE LA HERRÁN GASCÓN, A. "El Autoconocimiento como Eje de la Formación", Revista Complutense de Educación, 15 (1), Madrid, año 2004.

DE LA RASILLA, M. "El valor de la identificación en la determinación del interés superior del menor", en VV. AA., "Aproximación a la protección Internacional de los menores no acompañados en España”, Ed. La Merced Migraciones, Madrid, año 2010.

DE LA TORRE OLID, F. "El contrato de mediación familiar. Aspectos relevantes desde su positivización por la Ley Balear 18/2006", Diario La Ley, N 6765, Sección Doctrina, 25 de Julio de 2007, Año XXVIII, Ref. D-180, La Ley 2758/2007.

DE LA VALGOMA, Ma " "La ficción jurídica o porque el Derecho "miente" tanto" en "Estudios jurídicos en homenaje al profesor Luis Díez-Picazo", Ed. Thomson-Civitas, Madrid, año 2003.

DE LAMA AYMÁ, A. "La Protección de los Derechos de la Personalidad del Menor de edad", Ed. Tirant lo Blanch, Valencia, año 2006. 
DE LOS MOZOS Y DE LOS MOZOS J. En ALBALADEJO, M (Dir.), “Comentarios al Código Civil y Compilaciones forales”, Tomo XVIII-I, Ed. Edersa, Madrid, año 1984.

DE LOS MOZOS y DE LOS MOZOS, J. L. "La igualdad de los cónyuges y la organización y ejercicio de las potestades domésticas”, Documentación Jurídica (Volumen monográfico dedicado a la reforma española del Derecho de Familia de 1981), Volumen 1 (núms. 33 a 36), Enero-Diciembre, año 1982.

DE LOS MOZOS Y DE LOS MOZOS, J. L. "Familia y Derecho: de nuevo sobre las parejas no casadas", La Ley, núm. 7, Madrid, año 2009.

DE LOS RÍOS GONZÁLEZ, M. "Cambio de guarda y custodia. El Síndrome de Alienación Parental. Aspectos prácticos", Revista de Derecho de Familia, núm. 27, abril-junio, Ed. Lex Nova, Valladolid, año 2005.

DE OTTO Y PARDO, I. "La regulación del ejercicio de los derechos fundamentales. La garantía de su contenido esencial en el artículo 53.1 de la Constitución", en MARTIN-RETORTILLO, L y DE OTTO Y PARDO, I “Derechos fundamentales y Constitución”, Ed. Civitas, Madrid, año 1988.

DE OTTO Y PARDO, I. "Derecho Constitucional. Sistemas de fuentes”. Ed. Ariel, Barcelona, año 1995.

DE PALMA DEL TESO, A. “Administración pública y protección de la infancia. En especial, estudio de la tutela administrativa de los menores desamparados", INAP, Madrid, año 2006.

DE PRADA GONZÁLEZ, J. M., "La patria potestad tras la reforma del Código Civil”, Anales de la Academia Matritense del Notariado, T. XXV, año 1982.

DE TORRES PEREA, J. M. "Interés del menor y Derecho de Familia. Una perspectiva multidiscilinar”, Ed. Iustel, Madrid, año 2009.

DE VERDA Y BEAMONTE, J. R."La personalización del matrimonio en las reformas de 2005", en DE VERDA Y BEAMONTE, J. R. (Coord.), "Comentario a las Reformas de Derecho de Familia de 2005", Thomson Aranzadi, Cizur Menor, año 2006.

DE VERDA Y BEAMONTE, J. R. "Principio de libre desarrollo de la personalidad y ius connubii (A propósito del Auto del Tribunal Constitucional 222/1994)", en Revista de Derecho Privado, octubre, Madrid, año 1998.

DE VERDA Y BEAMONTE, J. R. "El libre desarrollo de la personalidad como principio inspirador de la Ley 13/2005, de 1 de julio, por la que se modifica el Código Civil en materia de derecho a contraer matrimonio", en DE VERDA Y BEAMONTE, J. R. (Coord.), "Comentarios a las Reformas de Derecho de Familia de 2005", Ed. Thomson Aranzadi, Cizur Menor, año 2006.

DEL CAMPO URBANO, S. "Análisis sociológico de la familia española”, Ministerio de Cultura, Madrid, año 1982 
DELGADO ECHEVARRÍA, J. "La transformación del Derecho de familia y la formación del jurista", en LACRUZ BERDEJO, J.L. (Coord.), "El nuevo régimen de la filiación. 1. Matrimonio y divorcio", Ed. Civitas, Madrid, año 1982.

DELGADO ECHEVERRIA, J en LACRUZ BERDEJO, "Elementos de Derecho Civil, I.", Ed. J. M. Bosch editor, 2 edición, Barcelona, año 1993.

DELGADO ECHEVERRÍA, J en LACRUZ BERDEJO, J.L. Et al., "Elementos de Derecho Civil”. Parte General, I, Vol. 2º, Personas”, Ed. Dykinson, Madrid, año 2004.

DELGADO ECHEVERRÍA, J. (Dir.), "Manual de Derecho Civil aragonés”, Ed. El Justicia de Aragón, 2a edición, Zaragoza, año 2006.

DELL'ANTONIO, V. A. M. "La partecipazione del minore alla sua tutela. Un diritto misconosciuto", Giuffrè, Milán, año 2001.

DÍAZ ALABART, S. "EL pseudo estatus familiae en el Código Civil. Una nueva relación familiar", Anuario de Derecho Civil, tomo LVIII, fascículo II, Madrid, abril-junio de 2005.

DÍAZ REVORIO, F. J. "Valores superiores e interpretación constitucional”, Centro de Estudios Políticos y Constitucionales, Madrid, año 1997.

DIEZ DÍAZ, J. “¿Derechos de la personalidad o Bienes de la Persona?”, Revista General de Legislación y Jurisprudencia, Madrid, año 1963.

DIEZ- PICAZO Y PONCE DE LEÓN, L. "Fundamentos de Derecho Civil Patrimonial", Tomo I, Ed. Civitas, $4^{\text {a }}$ edición, Madrid, 1993.

DIEZ PICAZO Y PONCE DE LEÓN, L. Prólogo al libro de ROCA I TRIAS, “Familia y ámbito social (de la casa a la persona”, Ed. Civitas, Madrid, año 1999.

DÍEZ-PICAZO Y PONCE DE LEÓN, L. "A vueltas con la autonomía privada en materia jurídica”, Diario La Ley, No 7765, Sección Tribuna, Diciembre, Año XXXII, Ref. D-485, La Ley 21915/2011, año 2011.

DÍEZ-PICAZO Y PONCE DE LEÓN, L. "El principio de protección integral de los hijos ("Tout pour l' enfant")", en "La tutela de los derechos del menor", $1^{\circ}$ Congreso Nacional de Derecho civil, dirigida por GONZÁLEZ PORRAS, J. M., Córdoba, año 1984.

DIEZ-PICAZO Y PONCE DE LEÓN, L."Familia y Derecho”, Ed. Civitas, Madrid, año 1984

DIEZ-PICAZO Y PONCE DE LEÓN, L y GULLÓN BALLESTEROS, A. "Instituciones de Derecho Civil, II”, Ed. Tecnos, Madrid, año 1998.

DIEZ-PICAZO Y PONCE DE LEÓN, L y GULLÓN, A. "Sistema de Derecho Civil", Volumen IV, Tomo 1, Ed. Tecnos, 11ª edición, Madrid, año, 2012.

DÍEZ-PICAZO Y PONCE DE LEÓN, L y GULLÓN BALLESTEROS, A. "Sistema de Derecho Civil", Volumen. I, Introducción. Derecho de la persona. Autonomía privada. Persona jurídica”, Ed. Tecnos, Madrid, año 2002. 
DÍEZ-PICAZO GIMÉNEZ, L. M. "Sistema de Derechos Fundamentales", Serie Derechos Fundamentales y Libertades Públicas, Ed. Thomson Civitas, Cizur Menor, año 2008.

DOLZ LAGO, M.-J. “¿Inconstitucionalidad de la Ley 1/2003, de 28 de enero, de la Generalitat, de derechos e información al paciente de la Comunidad Valenciana en relación con los menores de edad?", en Diario La Ley, núm. 5744, de 21 de marzo, Madrid, año 2003

DOMINGUEZ LOZANO, P. "La unión de personas del mismo sexo y sus implicaciones jurídicas", Revista de Derecho Privado y Constitución, núm. 20, enero-diciembre, Centro español de Estudios Constitucionales, Madrid, año 2006.

DOMINGUEZ LUELMO, A., "El matrimonio y su naturaleza tras la ley 15/2005: consecuencias jurídicas de la supresión de las causas de separación y divorcio", en Estudios de Derecho de Familia y de Sucesiones, ÁLVAREZ GONZALEZ, S. (Edit.), Santiago de Compostela, año 2009.

DOMINGUEZ PRIETO, X. M. “Antropología de la familia. Persona, matrimonio y familia”, Ed. Biblioteca de Autores Cristianos, serie de Estudios y ensayos, Madrid, año 2009.

DOMINGUEZ RODRIGO, L. M. "Los derechos procreativos como expresión del desarrollo al libre desarrollo de la personalidad en el seno de las unidades familiares no matrimoniales". GOMEZ-FERRER MORANT, R. (Coord), Libro homenaje al profesor José Luis Villar Palasí., Ed. Civitas, Madrid, año 1989.

DORAL GARCÍA DE PAZOS, J. A. "El interés de la familia" en Documentación Jurídica, monográfico dedicado a la reforma del Derecho de familia de 1981, volumen 1, Madrid, año 1982.

DURAN HERAS, Ma A. “La jornada interminable”, Ed. Icaria, Barcelona, año 1986.

ECHARTE FELIU, A. "Patria potestad en situaciones de crisis matrimonial", Ed. Comares, Granada, año 2000.

EEKELAAR, J. "The interest of the child and the Child's Wishes: the role of dynamic self-determinism" en "The best interest of the child. Reconciling Culture an Human Rights", Alston, P., Unicef, Oxford, año 1994.

EIRANOVA ENCINAS, E. "El nuevo Derecho de Familia como sistema funcional", Revista de Derecho de Familia, núm. 27, Ed. Lex Nova, Valladolid, año 2005.

ELÍAS MÉNDEZ, C., "La protección del menor inmigrante desde una perspectiva constitucional”, Ed. Tirant Lo Blanch, Valencia, año 2002.

ELOSEGUI ITXASO, M. "Diez temas de género. Hombre y mujer ante los derechos productivos y reproductivos". Ediciones Internacionales Universitarias (EIUNSA), Madrid, año 2002.

ELOSEGUI ITXASO, M. "Las acciones positivas para la igualdad de oportunidades laborales entre mujeres y hombres", en "Un análisis de la legislación alemana y la Directiva 
76/207/CEE desde la teoría de la argumentación de Robert Alexy", Centro de Estudios Políticos y Constitucionales y Universidad de Zaragoza, Madrid, año 2003.

ELVIRA BENAYAS, M. J. "Introducción a ciertas cuestiones del Derecho de familia en las sociedades multiculturales", Revista jurídica de la Universidad Autónoma de Madrid, núm. 18, año 2008.

ENÉRIZ OLAECHE, F. "La protección de los derechos fundamentales y las libertades públicas en la Constitución Española”, Universidad Pública de Navarra, Pamplona, año 2007.

ENGEL, M. "Familias ensambladas en todo el mundo. Análisis comparativo de los enfoques legales en países seleccionados", Fundación Familias S. XX1, http://www.familiassiglo21.org, año 2004.

ESCRIVÁ-IVARS, J. "Sistema matrimonial y derechos fundamentales sobre la nueva legislación matrimonial." en VV. AA. "La reforma del modelo de familia en el Código civil español”, Ed. Comares, Granada, año 2005.

ESCUDERO, A.; AGUILAR, L; DE LA CUZ, J. "La lógica del síndrome de alienación parental de Gadner (SAP): terapia de la amenaza". Revista de la Asociación española de Neuropsiquiatría, Año XXVIII, fascículo 2, núm. 102, Madrid, año 2008.

ESPIN CANOVAS, D. "Artículo 32. Derecho al matrimonio", en ALZAGA, O (Dir.) "Comentarios a la Constitucional española española de 1978", Tomo III, Ed. Edersa, Madrid, año 1996.

ESPÍN CANOVAS, D. "Manual de Derecho Civil español”, volumen IV, Familia, Ed. Reus, S. A., $7^{\text {a }}$ edición, Madrid, año 1982.

ESPINOSA CALABUIG "Custodia y visita de menores en el espacio judicial europeo", Ed. Marcial Pons, año 2007.

ESTEVE GARCÍA, F. "Las cláusulas generales antidiscriminatorias: ámbito de aplicación y efectos jurídicos", en AJA, E (Coord.) "Los derechos de los inmigrantes en España", , Ed. Tirant Lo Blanch, Valencia, año 2009.

FALCÓN Y TELLA, Ma J. "Equidad, Derecho y Justicia”. Ed. Universitaria Ramon Areces, Madrid, año 2005.

FAYER, C. "La familia romana aspetti giuridici ed antiquari”, Editor L'Ermua de Brestschneider, año 2005 Universidad de Huelva, VV. AA., Congreso Internacional de Derecho romano, "El derecho de familia de Roma al Derecho de familia actual", Huelva, año 2004.

FE, BAJO y BELTRÁN, J. L. “ Breve historia de la infancia”. Ed. Temas de Hoy, $1^{\text {a }}$ edición, Madrid, año 1998.

FERNÁNDEZ CASADO, Ma . D. "Una aproximación al principio del interés superior del menor" en Asociación de letrados de la Junta de Andalucía, "La protección jurídica del menor", Ed. Comares, Granada, año 1997. 
FERNANDEZ GALIANO, A. y DE CASTRO, B. "Lecciones de Teoría del Derecho y Derecho Natural", Ed. Universitas, Madrid, año 2000.

FERNÁNDEZ GARCÍA, Ma . Y. "El concepto jurídico indeterminado de servicio esencial en la Constitución española", Revista de Administración pública, núm. 170, mayo-agosto 2006, Madrid.

FERNÁNDEZ GONZALEZ, M. B. "El reconocimiento de los hijos no matrimoniales", Ed. Dykinson, Madrid, año 1998.

FERNANDEZ RODRIGUEZ, J. J. “La inconstitucionalidad por omisión. Teoría general, derecho comparado, el caso español”. Ed. Civitas, Madrid, año 1998.

FERNÁNDEZ SEGADO, F. "La dignidad de la persona en el ordenamiento constitucional español”, Revista Vasca de Administración Pública, núm. 43, Oñati, año 1995.

FERNÁNDEZ URZAINQUI, F. J. “Apuntes sobre la reforma de la patria potestad en el Fuero Nuevo", Revista Jurídica de Navarra, núm. 9, Pamplona, año 1990.

FERNÁNDEZ-CORONADO GONZÁLEZ, A. "La evolución jurídica del sistema matrimonial español desde la Constitución de 1978 a la admisión del matrimonio homosexual", en Revista Foro, núm. 3, Facultad de Derecho, Universidad Complutense de Madrid, año 2006.

FERNÁNDEZ-MIRANDA CAMPOAMOR, A. "El secreto profesional de los informadores", Ed. Tecnos, Madrid, año 1990.

FERNÁNDO SEGADO, F. "La dignidad de la persona como valor supremo el Ordenamiento Jurídico", LÓPEZ MORENO, A. (Coord.) “ Teoría y práctica en la aplicación e interpretación del Derecho”, Ed. Colex, Madrid, año 1999, página 45.

FERRAJOLI, L. "Los fundamentos de los derecho fundamentales", Ed. Trotta, Madrid, año 2002.

FERREIRO, J. "Uniones de hecho: perspectiva histórica y Derecho vigente", en "Uniones de Hecho", MARTINELL, J. M. y ARECES, M. T. (Editores), Lleida, año 1998.

FERRERES, V. "Justicia constitucional y democracia”, Centro de Estudios Políticos Constitucionales, Madrid, año 1997.

FERRI, E. "La autonomía privada", Ed. Comares, Granada, año 2001.

FIGUEROA GARCIA HERRERO, N. "Libertad y virtud. Un ensayo a propósito de Jean Jacques Rousseau”, Universidad de Los Andes, Bogotá, año 2009.

FOUCAULT, M. "History of sexuality”, Ed. Siglo XXI, Madrid, año 2005.

FRANK, R. "The Establishment and Consequences of Maternal and Paternal Affiliation", XXVIIth Colloquy on European Law Foundation for International Studies, Valletta, Septiembre 15 a 17, año 1997. 
FULCHIRON, H. "Autorité parentale et familles recomposée" en VV. AA. "Mélanges à la mémoire de D. Huet-Weiller: Droit des personnes et de la famille, liber amicorum, Paris, année1994.

FULCHIRON, H. "L'autorité parentale rénovée”, Defrénois, núm. 15, 37580, Paris, année 2002.

GALLEGO ANABITARTE, A. "Derechos fundamentales y garantías institucionales: análisis doctrinal y jurisprudencial (derecho a la educación; autonomía local; opinión pública)", Ed. Civitas, Madrid, año 1994.

GÁLVEZ MUÑOZ, L. "La cláusula general de igualdad", Revista de la Universidad de Murcia, núm. 21, año 2003.

GARAY GOYARROLA, J. Ma y MIREN GARAY, D. "Constitución Española Explicada", Ed. Londonbil S.L., Madrid, año 2006.

GARCÍA ABURUZA, M. P. "La protección a la Familia desde los Procesos Matrimoniales", Ed. Aranzadi, Cizur Menor, año 2009.

GARCIA CANTERO, G. “¿Unidad o pluralidad de modelos matrimoniales?” en "Modelos de Matrimonio y de Derecho de Familia en el siglo XXI", en Homenaje al Profesor Manuel Cuadrado Iglesias, Tomo I, Servicios de Publicaciones de la Universidad de Zaragoza, Ed. Aranzadi, , Cizur Menor, año 2008.

GARCÍA CANTERO, G. "Comentarios al Código Civil y Compilaciones forales" ALBALADEJO, M (Dir.). Tomo II, Artículos 42 a 107 del Código Civil, Ed. Edersa, 2a edición, Madrid, año 1982.

GARCIA CANTERO, G. "Sobre el llamado matrimonio homosexual. Análisis de algunas cuestiones debatidas", en Libro Homenaje al Profesor Manuel Amorós Guardiola, Centro de Estudios, Colegio de Registradores de la Propiedad y Mercantiles de Madrid, año 2006.

GARCÍA CARRASCO, J. "Bases sociales y antropológicas de la educación intercultural”, en Educación intercultura en la perspectiva de la Europa unida. X Congreso Nacional de Pedagogía, Salamanca, año 1992.

GARCIA DE ENTERRÍA, E. "La lucha contra las inmunidades del poder en el Derecho Administrativo" en Revista de Administración Pública, núm. 38, mayo-agosto, Madrid, año 1962.

GARCÍA DE ENTERRÍA, E. “Los fundamentos constitucionales del Estado”, en Revista Española de Derecho Constitucional, núm. 5, Centro de estudios políticos constitucionales, Madrid, año 1998.

GARCÍA DE ENTERRÍA, E y FERNÁNDEZ, T. R. "Curso de Derecho Administrativo I", Ed. Civitas, 10 a edición, Madrid, año 2000. 
GARCÍA GARCÍA, L. "Mediación familiar. Prevención alternativa al litigio en los conflictos familiares", Ed. Dykinson, Madrid, año 2003.

GARCÍA GARCIA, M. A. "El deber de actuar en interés de la familia", Revista de Derecho Privado, página 244, Madrid, año 1984.

GARCÍA GARCIA, M. A. "El llamado interés supraindividual o familiar" en Revista General Legislación y Jurisprudencia, Madrid, año 1982.

GARCÍA GARNICA, M. DEL C. "El Ejercicio de los Derechos de la Personalidad del Menor no Emancipado. Especial consideración al consentimiento y a los actos médicos y a las intromisiones en el honor, la intimidad y la propia imagen", Ed. Thomson Aranzadi, Cizur Menor, año 2004.

GARCIA MAYNEZ, E. "Introducción al estudio del Derecho", Ed. Porrúa, Ciudad de Méjico, año 1985.

GARCIA MEDINA, J. "Crisis matrimoniales y derechos de los menores", en GUILARTE MARTÍN-CALERO, C. (Coord.) "Aspectos civiles y penales de las crisis matrimoniales”, Ed. Lex Nova, Valladolid, año 2009.

GARCIA PASTOR, M. "La situación jurídica de los hijos cuyos padres no conviven: Aspectos personales", Ed. McGraw-hill, Madrid, año 1997.

GARCIA PRESAS, I. "La mediación familiar. Una alternativa en el proceso judicial de separación y divorcio”, Ed. La Ley, Madrid, año 2009.

GARCIA RUBIO M. P. y OTERO CRESPO, M. “Apuntes sobre la referencia expresa al ejercicio compartido de la guarda y custodia de los hijos en la Ley 15/2005”, Revista Jurídica de Castilla y León, Ed. Junta de Castilla y León, Valladolid, año 2006.

GARCIA RUBIO, Ma . P. en "Alimentos entre cónyuges y entre convivientes de hecho", Ed. Civitas, Madrid, año 1995.

GARCIA RUIZ, Y. "El origen biológico en la reproducción asistida: Nuevas tendencias normativas para una era global", Fundación Centro de Estudios Andaluces, Consejería de la Presidencia, núm. 9, mayo, Sevilla, año 2010.

GARCIA SERRANO, F. "Notas sobre el trabajo doméstico (A propósito de los artículos 1.319 y 1438 CC)", Anuario de Derecho Civil, T XXXVIII, Madrid, año 1985

GARCIA VICENTE, J.R. "Los principios del Derecho de las Acciones de filiación”, en ABRIL-CAMPOY, J. M., y AMAT LLARI, E. (Coords.) "Homenaje al Profesor Puig i Ferriol, L”, Tomo II, Ed. Tirant lo Blanch, Congresos y Homenajes, Valencia, año 2006.

GARCIA VILLALUENGA, L. "Mediación en conflictos familiares. Una construcción desde el Derecho de la familia", Ed. Reus S. A., Zaragoza, año 2006.

GARCIA VILLALUENGA, L y LINACERO DE LA FUENTE, M. "El derecho del adoptado a conocer sus orígenes en España y en el Derecho Comparado", Colección Observatorio de la Infancia, núm.1, Ministerio del Trabajo y Asuntos Sociales, Madrid, año 2006. 
GARRIDO DE PALMA, V. M. "El matrimonio y su régimen económico" en "El nuevo derecho de familia español”, Ed. Reus, Madrid, año 1982.

GARRIDO DE PALMA, V. M. "El matrimonio y sus regímenes económicos", II Congreso Internacional del Derecho Familiar, Madrid y Salamanca, 2 al 6 de octubre de 1978 (Ponencia).

GARRIGA GORINA, M. "La adopción y el derecho a conocer la filiación de origen. Un estudio legislativo y jurisprudencial”, Ed. Aranzadi, Pamplona, año 2000.

GARRIGA GORINA, M. "El criterio de la continuidad frente a la guarda conjunta". INDRET, Revista para el análisis del Derecho, 3/2008 (www.indret.com).

GASPAR LERA, S. "La investigación de la paternidad" en VV. AA., "El Derecho español a 200 años del Código de Napoleón”, Ed. Porrúa, Universidad Nacional Autónoma de México, año 2005.

GAUDEMET, J. “El matrimonio en Occidente”, Ed. Taurus, Madrid, año 1993.

GAVIDIA SÁNCHEZ, J. "La libertad de elegir como cónyuge a otra persona del mismo sexo y de optar entre el matrimonio y una unión libre (Análisis crítico de la constitucionalidad del matrimonio homosexual y del llamado "divorcio express")" en "La Reforma del Matrimonio. Leyes 13 y 15/2005”, Ed. Marcial Pons, Madrid, año 2007.

GETE-ALONSO CARRERA, M. C. "Comentarios a los artículos 67 a 71 del Código Civil", en la obra colectiva "Comentarios a las reformas del Derecho de familia", Vol. I, Madrid, año 1984.

GIL ROBLES, J. M. “Por un Estado de Derecho”, Ed. Ariel, Barcelona, año 1969.

GIMENEZ GLUCK, D. “Juicio de Igualdad y Tribunal Constitucional”, Ed. Bosch S.A., Barcelona, año 2004

GIMENO-BAYON COBOS, A. "Homosexualidad e intimidad", en GAFO, J (Ed.), "La homosexualidad un debate abierto", Ed. Desclée de Brouwer, Bilbao, año 1996.

GODOY MORENO, A. "La guarda y custodia compartida. Guarda conjunta y guarda alternativa”, en HERNÁNDEZ CATALÁN, G. y DE ANDRÉS IRAZAZÁBAL, C. (Coords.) "Diez años de Abogados de familia", Ed. La Ley-Actualidad, S.A.., Madrid, año 2003.

GOICOCHEA, A. "La idea democrática y la evolución hacia el Estado de Derecho (Discurso inaugural del Curso en la Academia Nacional de Jurisprudencia y Legislación”, Madrid, año 1932 .

GOIRIENA LEKUE, A. "La custodia compartida, el interés del menor y la neutralidad de género", Revista Aequalitas: Revista jurídica de igualdad de oportunidades entre mujeres y hombres, núm. 16, enero - junio, Instituto aragonés de la mujer, Zaragoza, año 2005.

GOIZUETA VÉRTIZ, J. "El Derecho de entrada y circulación”, en AJA, E. (Coord.), "Los derechos de los inmigrantes en España", Ed. Tirant Lo Blanch, Institut de Dret Públic, núm. 12, Novedades de Derecho Público, Valencia, año 2009. 
GÓMEZ BENGOECHEA, B. "Derecho a la identidad y filiación. Búsqueda de orígenes en adopción y en otros supuestos de filiación transfronteriza". Colección Monografías de Derecho Civil, Persona y Familia. Ed. Dykinson S.L., Madrid, año 2007.

GÓMEZ BENGOECHEA, B. "El Derecho a la búsqueda de orígenes” en GARCÍA GÓMEZ, M. E. (Coord.) "El camino a casa. Los derechos del niño en la adopción internacional", ACEBO Colección, Grupo 5, Madrid, año 2010.

GÓMEZ CAMPELO, E. "La Ley 54/2007 de adopción internacional: Un texto para el debate", Ed. Reus S.A., Familia y Derecho, Madrid, año 2009.

GÓMEZ LAPLAZA, C. “Transexualidad”, Aranzadi Civil, Madrid, año 2004.

GÓMEZ MAGÁN, P. "Síndrome de Alienación Parental”. Revista de Derecho de Familia, núm. 38, enero-marzo, Ed. Lex Nova, Valladolid, año 2008.

GÓMEZ SÁNCHEZ, Y. “Derecho Constitucional Europeo”, Ed. Sanz y Torres, Madrid, año 2005.

GOMEZ SÁNCHEZ, Y. “Familia y matrimonio en la Constitución española de 1978”, Organismos oficiales de la Administración, Madrid, año 1990.

GONZÁLEZ ALONSO, A. "La discrecionalidad y su control. Diferenciación con la arbitra riedad y con los conceptos jurídicos indeterminados", CEFLEGAL. Comentarios y casos prácticos. Centro de estudios financieros, Revista práctica de Derecho, Madrid, junio, año 2009.

GONZALEZ BEILFUSS, C. "Parejas de hecho, parejas registradas y matrimonios de personas del mismo sexo en el derecho internacional privado europeo", en NAVAS NAVARRO, S. (Coord.), "Matrimonio homosexual y adopción : perspectiva nacional e internacional", Ed. Reus S.A, Madrid, año 2006.

GONZALEZ GONZALEZ, C. "Guarda y custodia compartida: conflictividad y protección del menor" en Revista Aranzadi Doctrina, núm. 4/2012, parte Fichas de Jurisprudencia, Ed. Aranzadi S.A., Pamplona, BIB 2012/1189, año 2012,.

GONZALEZ MIRASOL, P. en "Autonomía sanitaria del menor y responsabilidad médica”, Diario La Ley, Nº 6326, Sección Doctrina, 26 Sep. 2005, Ref. D-213, La Ley, Nº 6327 , 27 Septiembre, Madrid, año 2005.

GONZÁLEZ MORENO, B. "El Estado social. Naturaleza jurídica y estructura de los derechos sociales", Ed. Civitas, Madrid, año 2002.

GONZÁLEZ MORENO, B. "El principio de igualdad en el ámbito del Derecho de familia: La custodia compartida", en GONZÁLEZ MORENO, B (Coord.) "Principios de igualdad y derechos fundamentales”, Ed. Tirant Lo Blanch, monografías, núm. 655, Valencia, año 2009.

GONZÁLEZ MORENO, B. "Estado de cultura, Derechos culturales, y Libertad religiosa", Ed. Civitas, Madrid, año 2003. 
GONZÁLEZ PÉREZ, J. “La dignidad de la persona”, Ed. Civitas, Madrid, año 1986.

GONZÁLEZ PILLADO, E y GRANDE SERRA, P. “Aspectos procesales civiles de la protección del menor”, Ed. Tirant Lo Blanch, Monografías núm. 321, Valencia, año 2006.

GONZALEZ-POSADA MARTÍNEZ, E y ROBLES CIFUENTES, H. "Los aspectos laborales de la Ley Orgánica para la Igualdad Efectiva de Mujeres y Hombres”, Ed. Aranzadi, Cizur Menor, año 2007.

GONZALEZ PAVEDA, P. "Tratado de Derecho de Familia, aspectos sustantivos y procesales: adaptados a las leyes 13/2005 y 15/2005”, Ed. Sepin, Madrid, año 2005.

GORDILLO CAÑAS, A. "Capacidad, incapacidades y estabilidad de los contratos", Ed. Tecnos, Madrid, año 1986.

GORDILLO CAÑAS, A. “Capacidad, incapacidades y estabilidad de los contratos”, Ed. Tecnos, Madrid, año 1986.

GORDILLO CAÑAS, A. “Comentario a la sentencia de 2 de julio de 1987” CCJC, núm. 370, Madrid, año 1987.

GOUTTENOIRE-CORNUT, A y MURAT, P. "L' intervention d' un tiers dans 1 vie d l'enfant", Droit de la familie, janvier, Paris, año 2003.

GOUTTENERE-CORNUT, A. "La loi du mars 2002 relative à l' autorité parentale”, Dossier, Actualit'Juridique Famille, avril , Paris, año 2002.

GRACIA VICENTE, F. “19 de octubre de 1983: Patria Potestad. Suspensión del ejercicio de guarda y custodia. Ejemplo corruptores. Competencia de los Tribunales Tutelares de Menores. Competencia del Tribunal Supremo", Ed. Civitas, Cuadernos Civitas de Jurisprudencia Civil, número 3, septiembre-diciembre, Madrid, año 1983.

GROSSI, P. “Mitología jurídica de la modernidad”, Ed. Trotta, Madrid, año 2003.

GUILARTE GUTIERREZ, V. "La mediación familiar: panacea cuestionable", Revista de Derecho de Familia, núm. 6, enero, Ed. Lex Nova, Valladolid, año 2000.

GUILARTE GUTIERREZ, V. "La sociedad de gananciales: desde la comunidad germánica al caos liquidatorio", en "Estudios jurídicos en Homenaje al profesor Luis Díez-Picazo," Tomo III, Ed. Thomson Civitas, Madrid, año 2003.

GUILARTE GUTIERREZ, V. en "Comentarios a la reforma de la separación y el divorcio (Ley 15/2005, de 8 de julio)”, Ed. Lex Nova, Valladolid, año 2005.

GUILARTE MARTÍN-CALERO, C. "Comentarios del nuevo artículo 92 del Código Civil" en GUILARTE GUTIERREZ, V. (Dir.) "Comentarios a la reforma de separación y divorcio, Ley 15/2005, de 8 de julio”, Ed. Lex Nova, Valladolid, año 2005.

GUILARTE MARTÍN-CALERO, C. "La custodia compartida alternativa”, INDRET, Revista para el análisis del Derecho, núm. 2, Barcelona, año 2008; “Criterios de atribución de 
la custodia compartida", INDRET, Revista para el análisis del Derecho, núm. 3, Barcelona, año 2010.

GUILARTE MARTÍN-CALERO, C. "La regulación de la custodia compartida: una oportunidad para la consolidación de la carrera profesional de las mujeres", en VV. AA., "Mujeres, contratos y empresa desde la igualdad de género", Ed. Tirant Lo Blanch, Valencia, año 2013.

GUILLÓ JIMENEZ, J. "La participación del menor en la sociedad”, en POUS DE LA FLOR, $M^{a}$. P. (Coord.), "La capacidad de obrar del menor: Nuevas perspectivas jurídicas.", Exlibris Ediciones, SL, Madrid, año 2009.

GULLÓN BALLESTEROS, A. "Sobre la Ley 1/1996, de protección del menor", Revista La Ley, Madrid, año 1996.

GUZMÁN ZAPATER, M. "El derecho a la investigación de la paternidad (En el proceso con elemento extranjero)", Ed. Civitas, Madrid, año 1996.

HAALAND MATLARY, J. "Ser mujer en términos de mujer: Desafíos paras las mujeres de Occidente: Una perspectiva católica" en "La mujer en el umbral del siglo XXI", Ed. Complutense, $1^{\text {a }}$ edición, Madrid, año 1998.

HARRIS-SHORT, S. \& MILES, J. "Family Law: text, cases and a materials", Oxford University Press, Oxford, año 2007.

HECK, P. “Jurisprudencia de intereses”, Ed. Comares, Granada, año 2011.

HEGEL, G.W. "Fenomenología del espíritu”, Ed. Fondo de Cultura Económica de España S. L., Madrid, año 1996.

HERAS HERNÁNDEZ, $\mathrm{M}^{\mathrm{a}}$ del M. "El contrato de acogimiento familiar de personas mayores”, Revista de Derecho Privado, julio-agosto, Madrid, año 2004.

HERNÁNDEZ CORROCHANO, E. "Modelos de familias en España: Entre la permanencia y el cambio. El caso concreto de Castilla y León". https://buleria.unileon.es/bitstream/handle/10612/1505/Hum8_art8.pdf?sequence=1.

HERNÁNDEZ IBÁÑEZ, C. "Destinatarios de las leyes autonómicas" en"La protección de los menores. Derechos y recursos para su atención”. Ed. Civitas, Madrid , año 1998.

HERNÁNDEZ IBÁÑEZ, C. "Cambio revolucionario en una institución milenaria : del matrimonio heterosexual al matrimonio homosexual", Revista La Ley, núm. 3, Madrid, año 2006.

HERRÁN ALONSO, J. C. "El orden jurídico de la libertad. La aportación de F. A. Hayek al estudio del Derecho.”, Unión Ed. S.A., Madrid, año 2010.

HERRERA CAMPOS, R. "La filiación no matrimonial tras la reforma del Código Civil de 13 de mayo 1981", Revista de Derecho Privado, Madrid, año 1983. 
HERRERA CAMPOS, R. "La investigación de la paternidad y la filiación no matrimonial", Ed. Comares, Granada, año 1987.

HERRERO GARCÍA, M. J. "Comentario al artículo 1319” en "Comentarios al Código civil", Tomo II, Ediciones del Ministerio de Justicia, Madrid, año 1991.

HERVADA XIBERTA, J. "Diálogos sobre el amor y el matrimonio", Ed. EUNSA, Pamplona, año 1987.

HERVADA XIBERTA, J. "Lecciones propedéuticas de Filosofía del Derecho", Ed. EUNSA, Pamplona, año 2008.

HIERRO, L. "Los Derechos Humanos del niño", en MARZAL A. (Edit.), "Derechos humanos del niño, de los trabajadores, de las minorías y complejidad del sujeto". Ed. J. M. Bosch-ESADE, Barcelona, año 1999.

HIERRO SÁNCHEZ-PESCADOR, L. "Los derechos humanos del niño". Separata del libro editado por ANTONIO MARZAL "Derechos humanos del niño, de los trabajadores de las minorías y complejidad del sujeto”. Ed. Bosch-ESADE, Barcelona, año 1999.

HUAITA ALEGRE, M. "Derecho de custodia, neutralidad de género, derechos humanos de la mujer e interés superior del niño o niña”. Ediciones LOM, Santiago de Chile, año 1999.

IBAN, C. L. "El matrimonio en la Constitución", en Revista de Derecho Privado, octubre, Madrid, año 1980.

IGLESIAS MIRANDA, F. "Las emociones en el proceso de mediación”, en MARTÍN DIZ. F. (Coord.), "La mediación en materia de familia y Derecho Penal", Ed. Andariva, Santiago de Compostela, año 2011.

IVARS RUIZ, J. "Guarda y custodia compartida. Aspectos procesales y sustantivos. Doctrina y jurisprudencia”, Ed. Tirant Lo Blanch, monografías, núm. 577, Valencia, año 2008.

IZQUIERDO TOLSADA, M. y CUENA CASAS, M. (Dirs.) "Tratado de Derecho de la Familia, Volumen I, Derecho de Familia y Derecho de la familia. La relación jurídico-familiar. El matrimonio y su celebración”. Ed. Aranzadi Thomson Reuters, Cizur Menor, año 2011.

JIMENA QUESADA, L. "Inconstitucionalidad por omisión y responsabilidad internacional", en "Cuadernos constitucionales de la cátedra Fadrique Furiol Cerió", núm. 58/59, Ed. McGraw-Hill, Madrid, año 1997.

JIMENEZ CAMPO, J. “Analogía secundum constitucionem”, Revista del Centro de Estudios constitucionales, núm. 13, septiembre - diciembre, Madrid, año 1992.

JIMENEZ CAMPO, J. "Derechos fundamentales, concepto y garantías”, Ed. Trotta, Madrid, año 1999.

JIMÉNEZ CAMPO, J. “La igualdad jurídica como límite al legislador”. Revista Española de Derecho Constitucional, núm. 9, Madrid, año 1983. 
JIMENEZ GARCÍA, F. "El respeto a la dignidad humana", en BENEYTO PÉREZ, J. Mª "Tratado de Derecho y Políticas de la Unión Europea", Tomo II, Derechos fundamentales, Ed. Aranzadi, Cizur Menor, año 2009.

JORDANO FRAGA, F. "La capacidad general del menor", Revista de Derecho Privado, T. LXVIII, enero-diciembre, Madrid, año 1984.

JOSSERAND, L. "Derecho Civil”, Tomo I, Volumen II, CUNCHILLA Y MANTEROLA, S. (Trad.), Ed. Bosch, Buenos Aires, año 1950.

KANT, E. "Fundamentación de la metafísica de las costumbres", en "Fundamentación de la metafísica de las costumbres-Crítica de la razón práctica-La paz perpetua", Capítulo $2^{\circ}$, GARCIA MORENTE, M (Trad.), Ed. Porrúa- Universidad Autónoma de México, año 1998.

KELSEN, H. "Justicia y Derecho Natural", en la obra colectiva: "Crítica del Derecho Natural”, DÍAZ, E. (Trad.), Ed. Taurus, Madrid, año 1966.

KEMELMAJER DE CARLUCCI, A. "El derecho humano a conocer el origen biológico y el derecho a establecer vínculos de filiación. A propósito de la decisión del Tribunal Europeo de Derechos Humanos del 13/02/2003 en el caso "Odiève c/ France" en www.jus.mendoza.gov.ar.

KONIG, R. "La familia en nuestro tiempo. Una comparación intercultural”, Ed. Siglo XXI ediciones, $2^{\mathrm{a}}$ edición, Madrid, año 1994.

LACALLE, M. (Coord.), “Mujer y varón. ¿Misterio o Autoconstrucción?”, CEU, Universidad Francisco de Vitoria y UCAM, Madrid, año 2008.

LACRUZ BERDEJO, J. L. y OTROS. "Elementos de Derecho Civil”, Parte General, Volumen Segundo, Ed. Dykinson, $2^{\mathrm{a}}$ edición, Madrid, año 2000.

LACRUZ BERDEJO, J. L. "Matrimonio y Divorcio. Comentarios al título IV del Libro Primero del Código Civil, Comentario al artículo 68", Ed. Civitas, $2^{\mathrm{a}}$ edición, Madrid año 1994, revisado por RAMS ALBESA, J y DELGADO ECHEVERRIA, J. Páginas 662 y siguientes.

LACRUZ BERDEJO, J. L. "El nuevo contractualismo en el Derecho de familia", Revista La Ley, núm. 3, Madrid, año 1982.

LACRUZ BERDEJO, J. L. y DELGADO ECHEVERRIA, J. "Elementos de Derecho Civil”, Ed. Dykinson, Madrid, año 2006.

LACRUZ BERDEJO, J. L. "El nuevo Derecho Civil de la mujer casada", Ed. Civitas, Madrid, año 1975.

LACRUZ BERDEJO, J. L. y otros. "Elementos de Derecho Civil, IV (Derecho de Familia)". Ed. Dykinson, $4^{\mathrm{a}}$ edición, Madrid, año 2010. 
LACRUZ BERDEJO, J. L.; SANCHO REBULLIDA, F; LUNA SERRANO, A; RIVERO FERNÁNDEZ, F; RAMS ALBESA, J en "Elementos de Derecho Civil IV. Derecho de Familia”. Ed. Bosch S. A., Barcelona, año 1997.

LACRUZ BERDEJO, J. L. "Elementos de Derecho Civil". Tomo IV. Familia, Ed. Dykinson, Madrid, año 2002.

LARA AGUADO, A., "El nombre en Derecho Internacional Privado", Ed. Comares, Granada, año 1998.

LASARTE ÁLVAREZ, C. "Merecido adiós al sistema causalista en las crisis matrimoniales", Actualidad Aranzadi, núm. 655, de 3 de febrero, Pamplona, año 2005

LATHROP GOMEZ, F. “Custodia compartida de los hijos”, Ed. La Ley Wolters Kluwer, Madrid, año 2008.

LATHROP GÓMEZ, F. “Custodia compartida y corresponsabilidad parental. Aproximaciones jurídicas y sociológicas”, Diario La Ley, núm. 7206/2009, año XXX parte Doctrina. La Ley - Actualidad, Las Rozas, año 2009.

LATORRE, A. "El libre desarrollo de la personalidad en la jurisprudencia del TC" en GARCÍA SAN MIGUEL, L. (Coord.), "El libre desarrollo de la personalidad. Artículo 10 de la Constitución", Publicaciones de la Universidad de Alcalá, Madrid, año 1995.

LAUROBA LACASA, E. "Los planes de parentalidad en el Libro segundo del Código civil de Cataluña”, Revista Jurídica de Cataluña, núm. 4, Barcelona, año 2012.

LAZARO GONZÁLEZ, I. (Coord.), “Los menores en el Derecho español”, Ed. Tecnos, Madrid, año 2002.

LEGAZ LACAMBRA, L. "La noción jurídica de la persona y los derechos del hombre", en REP, XI, 55, IEP, Madrid, año 1951, páginas 15 a 46.; el mismo autor en "Estado de Derecho” en RAP, núm. 6, CEPEC, Madrid, año 1991.

LEIBLE S. "El futuro del Derecho Privado Europeo", Diario La Ley, núm. 7085/2008, Año XXIX, parte Tribuna, Ed. La Ley - Actualidad, Las Rozas, año 2008.

LETE DEL RÍO, J. M. “Derecho de la persona”, Ed. Tecnos, Madrid, año 1996.

LINACERO DE LA FUENTE, Mª . "Protección jurídica de las personas mayores" . Actualidad Civil 19/2004, La Ley, Madrid, año 2004.

LINACERO DE LA FUENTE, Ma " "Protección jurídica del menor", Ed. Montecorvo, Madrid, año 2001.

LISSER, K. "El concepto del Derecho en Kant", Cuadernos del Centro de Estudios Filosóficos, Universidad Autónoma de México, año 1959.

LLAMAS POMBO, E. "Los efectos de las crisis matrimoniales a revisión" en "Nuevos conflictos en el Derecho de Familia", Ed. La ley, Madrid, año 2009. 
LLAMAZARES FERNÁNDEZ, D. "Derecho de la Libertad de conciencia.". Tomo II, Libertad de conciencia, identidad personal y solidaridad, Ed. Thomson Civitas, $3^{\text {a }}$ edición, Cizur Menor, año 2007.

LLAMAZARES FERNÁNDEZ, D. "El matrimonio homosexual”, en SOUTO PAZ, J. A. (Coord.), "El nuevo régimen legal del matrimonio civil en España", Ed. Comares, Granada, año 2008.

LLAMAZARES FERNÁNDEZ, D. "El sistema matrimonial español”, Ed. Universidad Complutense, Madrid, año 1994.

LLEBARÍA SAMPER, S. "Hacia la familia no matrimonial (Presente y futuro en Derecho civil catalán)”, Cedecs Ed. S.L., Barcelona, año 1997.

LLOPIS GINER, J. M. (Coord.) "El contenido del Convenio Regulador. Sus diferentes aspectos". Fundación Registral, Madrid, año 2006.

LOPERA MESA, G. P. "El principio de proporcionalidad y los dilemas del constitucionalismo", en "Comentario al libro de Carlos Bernal Pulido: El principio de proporcionalidad y los derechos fundamentales", Revista Española de Derecho Constitucional, núm. 73, Madrid, año 2005.

LOPERA MESA, G. P. "El principio de proporcionalidad y legislador penal”, Centro de estudios Políticos Constitucionales, Madrid, año 2006

LÓPEZ BARJA DE QUIROGA, J. "Los límites de la vida y la libertad de la persona”, Ed. Tirant Lo Blanch, Valencia, año 2011.

LOPEZ CALERA, N. M. . "Filosofía del Derecho" (Volumen II), Ed. Comares, Granada, año 1998.

LÓPEZ DE LA CRUZ, L. "El resarcimiento del daño moral ocasionado por el incumplimiento de los deberes conyugales", INDRET, Revista para el análisis del Derecho, Facultad de Derecho, Universidad Pablo de Olavide, núm. 4, Barcelona, año 2010.

LÓPEZ DE LA CRUZ, L. "La incidencia del principio de igualdad en la distribución de las responsabilidades domésticas y familiares. (La nueva redacción del artículo 68 del Código Civil tras la reforma operada por la Ley 15/2005, de 8 de julio)", en Revista de Derecho Privado, Ed. Reus S.A., marzo-abril, año Madrid, año 2007.

LÓPEZ GALIACHO, P. "Problemática jurídica de la transexualidad”, Ed. McGraw Hill, Madrid, año 1998.

LÓPEZ ORDIALES, J. J. "Custodia compartida. Cuestiones procesales" en SARAVIA GONZALEZ, A. M. y GARCIA CRIADO, J.J., (Dir.), "La jurisdicción de familia: especialización. Ejecución de resoluciones y custodia compartida". Consejo General del Poder Judicial, Estudios de Derecho Judicial, número 147-2007, Madrid, año 2008. 
LÓPEZ PINA, A. "La autonomía privada y los derechos fundamentales. Los intereses generales. Mandato constitucional.", UNED. Teoría y Realidad Constitucional, núm. 20, Madrid, año 2007.

LÓPEZ QUINTÁS, A. "Descubrir la grandeza de la vida: Una vida de ascenso a la madurez personal”, Ed. Deescle De Brower, Madrid, año 2009.

LÓPEZ SAN LUIS R. "La capacidad contractual del menor", Ed. Dykinson, Madrid, año 2003.

LÓPEZ SÁNCHEZ, F. "Necesidades en la infancia y en la adolescencia. Respuesta familiar, escolar y social.”, Ed. Pirámide, Madrid, año 2008.

LÓPEZ Y LÓPEZ, A. "Diversidad, feminismo y principio de igualdad", en LÓPEZ DE LA CRUZ, L y OTERO CRESPO, M. (Coords.) "El levantamiento del velo: La mujeres en el Derecho Privado", Ed. Tirant Lo Blanch, Homenajes y Congresos, Valencia, año 2010

LOPEZ Y LOPEZ, A."La garantía institucional de la herencia”, en VVAA, "Estudios de Derecho Público. Homenaje a Juan José Ruiz-Rico", Volumen I, Ed. Tecnos, Madrid, año 1997.

LOPEZ-GALIACHO, J. "Reflexiones en torno a las resoluciones de la Dirección General de los Registros y del Notariado de 8 y 31 de enero de 2001 sobre el derecho al matrimonio transexual", en Poder Judicial, núm. 63, Madrid, año 2001.

LORCA NAVARRETE, J. F. “Temas de Teoría y Filosofía del Derecho”, Ed. Pirámide, Madrid, año 1998.

LOUSADA AROCHENA, J. F. "El principio de transversalidad y el Derecho de la Seguridad Social”, Revista española de Derecho del Trabajo, num.106/2001 parte Estudios, Ed. Civitas S.A., Madrid, año 2001.

LUCAS VERDÚ, P. "Estimativa y políticas constitucionales", Servicio de Publicaciones de la Universidad Complutense de Madrid, año 1984.

LUJAN ALCARAZ, J. “ La protección de las familias numerosas desde la perspectiva del Derecho del Trabajo y la Seguridad Social”, Aranzadi Social núm. 19/2005, parte Tribuna, Aranzadi S.A., Pamplona, año 2006.

LUNA SERRANO, A. "La reforma de la legislación matrimonial”, en LACRUZ BERDEJO, J. L. (Coord.), "Matrimonio y divorcio. Comentarios al nuevo Título IV del libro primero del Código civill", Ed. Civitas, 2ª edición, Madrid, año 1994.

LUNA, A. "La reforma de la legislación matrimonial", en LACRUZ BERDEJO, J.L. (Coord.), "Matrimonio y Divorcio. Comentarios al Título IV del Libro primero del Código civil”, Ed. Civitas, Madrid, año 1994. 
MACÍA MORILLO, A. "Los efectos personales del matrimonio", DIEZ-PICAZO GIMÉNEZ, G (Coord.), "Derecho de familia", Capítulo VII, Ed. Civitas Thomson Reuters, Cizur Menor, año 2012.

MAGALDI, N. "Derecho a saber, filiación biológica y administración pública", Ed. Marcial Pons, Madrid, año 2004.

MANRESA Y NAVARRO, "Comentarios al Código Civil español”, VIII, Ed. Reus, $4^{\text {o }}$ edición, Madrid, año 1929.

MARI-KLOSE, M y NOS COLOM, A. "Itinerarios vitales: educación, trabajo y fecundidad de las mujeres" en "Opiniones y actitudes", Centro de Investigaciones sociológicas, Madrid, año 1999.

MARIAS J. “La mujer en el siglo XX”, Ed. Alianza, Madrid, año 1990.

MARÍN GARCÍA DE LEONARDO, M. T. "Problemas que genera la actual regulación de la guarda y custodia compartida en el proceso contencioso". Abogados de Familia, número 50, Sección Tribuna Abierta, Cuarto trimestre de 2008. Diario La Ley, número 7105, Sección Doctrina, 2 de feb, 2009. Año XXX, Ref. D-29, La Ley 40228, Madrid, año 2008.

MARÍN GARCÍA DE LEONARDO, M. T. "Remedios indemnizatorios en el ámbito de las relaciones conyugales", DE VERDA Y BEAMONTE, J. R. (Coord). "Daños en el Derecho de Familia", Ed. Thomson Aranzadi, Cizur Menor, año 2006.

MARÍN GARCÍA DE LEONARDO, M. T. “¿Es indemnizable la infidelidad?”, Revista de Derecho de Familia, núm. 47, abril-junio, Ed. Lex Nova, Valladolid, año 2010

MARÍN LÓPEZ, M. En BERCOVITZ RODRÍGUEZ-CANO Y OTROS AUTORES, "Comentarios al Código Civil", Ed. Thomson Aranzadi, Madrid, año 2006.

MARRAMAO, G. “Poder y secularización”, Ed. Península, Barcelona, año 1989.

MARTÍ, J. M. "La situación jurídica del menor y su formación”, en CATALÁ RUBIO, S. (Coord.) "Evolución del Derecho de Familia en Occidente", Colección estudios, Ediciones de la Universidad de Castilla-La Mancha, Cuenca, año 2007.

MARTI, J. M. "Comunidad política e institución del matrimonio" en CASTRO, A. (Ed), "Derecho de familia y libertad de conciencia en los países de la Unión Europea y el Derecho comparado", Universidad del País Vasco, San Sebastián, año 2001.

MARTÍN BERNAL, J.M., "Los derechos de la personalidad en la Constitución Española", Revista General de Legislación y Jurisprudencia, Madrid, año 1979.

MARTÍN SÁNCHEZ, I. "Derecho a convivir en pareja y libertad de conciencia", en MORALES, A. M. y MIQUEL, J. M. (Dirs.),'Derecho, sociedad y familia: cambio y continuidad.", Servicios de Publicaciones, UAM, Madrid, año 2007.

MARTÍN SÁNCHEZ, I. (Coord.), "Bioética, religión y salud”, Consejería de Sanidad y Consumo,Dirección General de Aseguramiento y Atención al Paciente, Madrid, año 2005 
MARTÍN SÁNCHEZ, M. "Matrimonio Homosexual y Constitución”, Ed. Tirant Lo Blanch, Monografías, núm. 589, Valencia, año 2008.

MARTÍN VIDA, Ma . A. "El concepto constitucional de familia a partir de la jurisprudencia del Tribunal Constitucional", Revista de la Facultad de Derecho de la Universidad de Granada, núm. 4, año 2001.

MARTÍN Y PÉREZ DE NANCLARES, J. M. “Art. 9. Derecho a contraer matrimonio y derecho a fundar una familia", MANGAS MARTÍN, A. (Dir.) "Carta de los Derechos Fundamentales de la Unión Europea”, Fundación BBVA, Bilbao, año 2008.

MARTINELL GUISPERT-SAUCH, J. M. "Tutela jurídica del libre desarrollo de la personalidad y juridificación de la vida afectiva de pareja en el Derecho español", en Laicidad y Libertades, núm. 5, Madrid, año 2005.

MARTINELL SEMPERE, A. (Coord.). "Cultura y desarrollo. Un compromiso para la libertad y el bienestar.”, Ed. Alkal S.A., Madrid, año 2010.

MARTÍNEZ CONTRERAS, J. "Sartre. La filosofía de un hombre”, Ed. Siglo XXI de Comunicación, Madrid, año 2005.

MARTÍNEZ DE AGUIRRE Y ALDAZ, C. En MARTÍNEZ DE AGUIRRE, C., DE PABLO CONTRERAS, P., PÉREZ ÁlVAREZ, M. A., PARRA LUCAN, M. A.“Curso de Derecho Civil, tomo I, Parte General y Derecho de la Persona", Ed. Colex, Madrid, año 2003.

MARTÍNEZ DE AGUIRRE Y ALDAZ, C. "El Derecho de familia en nuestro país se ha visto afectado por numerosas reformas legales, ocurridas básicamente en el último cuarto del siglo XX", en MARTÍNEZ DE AGUIRRE Y ALDAZ. (Coord..), DE PABLO CONTRERAS, P y PÉREZ ÁlVAREZ, M. A., "Curso de de Derecho Civil (IV) Derecho de familia", Ed. Colex, $2^{\mathrm{a}}$ edición, Madrid, año 2008.

MARTÍNEZ DE AGUIRRE Y ALDAZ, C. "A cada uno su familia, a cada familia su derecho (aproximación funcional a las nuevas formas de familia y elogio de la diversidad)". Nuevos modelos de familia en Teoría \& Derecho, núm. 2, Barcelona, año 2007.

MARTÍNEZ DE AGUIRRE Y ALDAZ, C. "Diagnóstico sobre el Derecho de Familia", Ed. Rialp, Madrid, año 1996.

MARTÍNEZ DE AGUIRRE Y ALDAZ, C. "La protección jurídico-civil de la persona por razón de la menor edad", Anuario de Derecho Civil, octubre-diciembre, Madrid, año 1992.

MARTÍNEZ DE MURGUIA, B. "Mediación y resolución de conflictos”, Ed. Paídos, Barcelona, año 1999.

MARTINEZ ESCRIBANO, C. "Consecuencias de la crisis matrimonial y autonomía de la voluntad", en GUILARTE MARTÍN-CALERO, C. (Dir.), "Aspectos civiles y penales de las crisis matrimoniales”, Ed. Lex Nova, Valladolid, año 2009. 
MARTÍNEZ ESCRIBANO, C. "Pactos prematrimoniales”, Ed. Tecnos, Madrid, año 2011.

MARTÍNEZ LÓPEZ-MUÑIZ, J. L. "Desquiciamiento inconstitucional de la familia protegida por el Derecho Civil", en VV. AA., "La reforma del modelo de familia en el Código civil español”, Ed. Comares, Granada, año 2005.

MARTINEZ LOPEZ-MUÑIZ, J. L. "La familia en la Constitución española”, en Revista española de Derecho Constitucional, año 20 núm. 58, enero-abril, Madrid, año 2000.

MARTÍNEZ LÓPEZ-MUÑIZ, J. L. "La familia en la Constitución española”, en Revista de Derecho Constitucional, núm. 58, enero-abril, Madrid, año 2000.

MARTÍNEZ LOPEZ-MUÑIZ, J. L. "La familia en la Constitución española", Revista Española de Derecho Constitucional, núm. 58, Madrid, año 2000.

MARTÍNEZ MORÁN, N. (Coord.), "Biotecnología, derecho y dignidad humana”, Ed. Comares, Granada, año 2003.

MARTÍNEZ RUANO, P. "La capacidad iusfundamental del menor", en SÁINZ-CANTERO CAPARRÓS, Ma . B. (Edit.), "Políticas Jurídicas para el Menor", Ed. Comares, Granada, año 2009.

MARTÍNEZ TAPIA, R. "Igualdad y razonabilidad en la justicia constitucional española". Servicio de Publicaciones de la Universidad de Almería, año 2000.

MARTÍNEZ VÁZQUEZ DE CASTRO, L. "El principio de libre desarrollo de la personalidad en el ámbito privado", Ed. Civitas Thomson Reuters, Cizur Menor, año 2010.

MARTÍNEZ VÁZQUEZ DE CASTRO, L. "Una posible concepción del matrimonio en el Código Civil. El estado de la cuestión." en VV. AA. "Estudios en Homenaje al Profesor Manuel Amorós Guardiola", Centro de Estudios, Colegio de Registradores de la Propiedad y Mercantiles de España, Madrid, año 2006.

MARTINEZ-CORTES GIMENOS, J. "La gestión del consorcio en la Ley 2/2003, de 12 de febrero", El Justicia de Aragón, Zaragoza, año 2007.

MARTINEZ-SICLUNA, C. "Legalidad y legitimidad. La teoría del poder", Ed. Actas, Madrid, año 1991.

MASSON, J. "Old Families into New: a Status for Step-Parents", en State, Law and the Family, de. M. Freeman, London, Tavistock, año 1989.

MASTERS, W.H. y JOHNSON, V.E. "Homosexualidad en perspectiva", Ed. Itermedia. Templeton, Buenos Aires, año 1979.

MATA SIERRA, Ma. T. "El principio de igualdad tributaria”, Ed. Thomson Reuters, Cizur Menor, año 2009.

MATEO PARDO, R. "La dignidad de la persona humana y su significación en la Constitución española de 1978 a través de la jurisprudencia del Tribunal Constitucional”, en Es- 
critos jurídicos en memoria de Luis Mateo Rodríguez, Tomo I, Universidad de Cantabría- Facultad de Derecho, Santander, año 1993.

MATEO Y VILLA, I. "Estatuto del cónyuge del progenitor. Legislación europea", Revista de Derecho de Familia, núm. 52, 3º trimestre, Ed. Lex Nova, Valladolid, año 2011.

MATÍA PORTILLA, F. J. "La protección de los Derechos Fundamentales en la Unión Europea", Ed. Civitas, Madrid, año 2002.

MEDINA GUERRERO, M. "La vinculación negativa del legislador a los derechos fundamentales", Ed. McGraw-Hill, Madrid, año 1996.

MENEZ-BLANCO, A. "Garantías institucionales y derechos fundamentales en la Constitución", en VVAA, "Estudios sobre la Constitución española", Homenaje al Profesor Eduardo García Enterría, Volumen I, Ed. Civitas, Madrid, año 1991.

MILLÁN PUELLES, A. “Sobre el hombre y la sociedad”, Ed. Rialp, Madrid, año 1976.

MILLÁN PUELLES, A. “El valor de la libertad”, Ed. Rialp, Madrid, año 1995.

MIQUEL GONZALEZ, J. M. "Cláusulas generales y desarrollo judicial del Derecho" en "La vinculación del juez a la ley", Anuario de la Facultad de Derecho de la Universidad Autónoma de Madrid, núm. 1, año 1997.

MOISA, B. "La autonomía de la voluntad y la predisposición contractual", Zavalia Editor, Córdoba, Argentina, año 2004.

MOLERO MARAÑÓN, Ma. L. "Derechos de conciliación: Derechos de Adaptación y, Reducción del Tiempo de Trabajo. Suspensión por Paternidad y Excedencias familiares", en VALDÉS DAL-RÉ y QUINTANILLA NAVARRO, B (Dirs.), "Igualdad de Género y Relaciones Laborales", Ministerio del Trabajo e Inmigración-Fundación Largo Caballero, Madrid, año 2008.

MOLINA NAVARRETE, C. "La multiculturalidad, el pluralismo de las relaciones de convivencia de pareja" en Revista de Derecho Privado y Constitución, Centro español de Estudios Constitucionales, núm. 21, enero-diciembre, Madrid, año 2007.

MONCHO PASCUAL, J. R., "La sociedad estamental: I. La asimetría como principio rector de la sociedad antigua", en "Algunos hitos del ideal igualitario", Ed. Nau Llibres, Valencia, año 1997.

MONCHO PASCUAL, J. R., "La sociedad estamental: II. La igualdad (y la esclavitud) en el medioevo cristiano", en "Algunos hitos del ideal igualitario", Ed. Nau Llibres, Valencia, año 1997.

MONCHO PASCUAL, J. R., "Recepción de la igualdad moderno-burguesa", en "Algunos hitos del ideal igualitario", Ed. Nau Llibres, Valencia, año 1997.

MONCHO PASCUAL, J. R., "Reservas a la igualdad burguesa", en "Algunos hitos del ideal igualitario", Ed. Nau Llibres, Valencia, año 1997. 
MONEREO ATIENZA, C. "Artículo 23. Igualdad entre mujeres y hombres" en MONEREO ATIENZA, C y MONEREO PÉREZ, J. L. (Dirs.) "La Europa de los Derechos. Estudio Sistemático de la Carta de los Derechos Fundamentales de la Unión Europea", Ed. Comares, Granada, año 2012.

MONTESINOS SÁNCHEZ, A. M.. "La conflictividad jurídica de las uniones homosexuales", en XVIII Jornadas de la Asociación Española de Canonistas, Salamanca, año 1999.

MONTÓN GARCÍA, M. "Derechos y garantías de los menores en el ámbito civil, su protección procesal en la Ley orgánica 1996 de 15 de enero", Universidad Complutense Facultad de Derecho, Servicios de Publicaciones, Madrid, año 2003.

MORANDÉ COURT, P. "Persona, Matrimonio y Familia". Ed. Universidad Católica de Chile, $2^{\circ}$ edición, Santiago de Chile, año 1994.

MORENO MOZO, F. “ Cargas del matrimonio y alimentos”, Ed. Comares, Granada, año 2008.

MORENO VELASCO, V. "Hacia una adecuada comprensión del ejercicio de la patria potestad”, Diario la Ley, Año XXX, Número 7267. Jueves, 22 de octubre, Madrid, año 2009.

MORENO-TORRES HERRERA, M. ${ }^{\text {a } L . ~ " L a ~ p e n s i o ́ n ~ c o m p e n s a t o r i a ", ~ e n ~ " L a ~ r e f o r m a ~ d e l ~}$ matrimonio (leyes 13 y 15/2005)", Ed. Marcial Pons, año 2007.

MOYA ESCUDERO, M. "La libertad de circulación en Europa: los nuevos estatutos personales”, Ed. Tirant Lo Blanch, Homenajes y Congresos, Valencia, año 2012.

MUÑOZ ARNAU, J. A. "Los límites de los derechos fundamentales en el Derecho Constitucional español”, Ed. Aranzadi, Pamplona, año 1998.

MUÑOZ GARCÍA, C. “Aspectos jurídicos de la mediación familiar”, Revista de Derecho Privado, marzo-abril, Madrid, año 2003.

MURILLO DE LA CUEVA, P y CARMONA CUENCA, E. "La tutela jurisdiccional de los derechos fundamentales por los tribunales ordinarios", Ed. Tirant Lo Blanch, Valencia, año 2008 .

MURILLO, M. "Matrimonio y homosexualidad. La constitucionalidad de la Ley 13/2005, de modificación del Código civil español sobre derecho a contraer matrimonio entre personas del mismo sexo", en Laicidades y Libertades. Escritos Jurídicos, núm. 5, año 2005.

NACIONES UNIDAS, CONSEJO ECONÓMICO Y SOCIAL, COMISION DE DERECHOS HUMANOS, Informe del Grupo de Trabajo acerca de un proyecto de convención sobre derechos del niño, E/CN.4/1989/48, 2 de marzo de 1989.

NAVARRO-VALLS, R. “Matrimonio y Derecho”, Ed. Tecnos, Madrid, año 2004.

NAVAS NAVARRO, S. "El bienestar y el interés del menor desde una perspectiva comparada" en "Estudios Jurídicos en Homenaje al Profesor Luis Díez-Picazo", Tomo I, Semblanzas, Derecho Civil, Parte General, Ed. Thomson Civitas, Madrid, año 2003. 
NAVAS NAVARRO, S. (Dir.), “Matrimonio homosexual y adopción”, Ed. Reus S.A., Zaragoza, año 2006.

NIETO, A. "El arbitrio judicial”, Ed. Ariel, Barcelona, año 2000.

NOREÑA SALTO, J. R. “Acerca del contenido esencial de los derechos fundamentales de configuración legal", Repertorio Aranzadi del Tribunal Constitucional num.18/2003,parte Estudio, Aranzadi S.A., Pamplona, año 2004.

NOVALES ALQUEZAR, Ma. A. "Derecho Antidiscriminatorio y Género: Las premisas invisibles", Fondo de Desarrollo de las Naciones Unidas para la Mujer: Universidad Central de Chile, Gobierno de Chile, Santiago de Chile, año 2004.

NOVALES ALQUEZAR, Ma . A. "Los deberes personales entres los cónyuges ayer y hoy", Ed. Comares, Granada, año 2007.

NUÑEZ RIVERO, C. "La protección del menor desde un enfoque de Derecho Constitucional", Revista de Derecho, UNED, núm. 9, Madrid, año 2011.

O'CALLAGHAN MUÑOZ, X. "Código Civil comentado y con jurisprudencia”, Ed. La Ley, Madrid, año 2004.

O’CALlaghan MUÑOZ, X. “Compendio de Derecho Civil”, Tomo IV, Ed. Edersa, $5^{\text {a }}$ edición, Madrid, año 2001.

O'CALlaghan MUÑOZ, X. "Compendio de Derecho Civil, Derecho de Familia", Tomo IV, Editorial Universitaria Ramón Areces, Madrid, año 2012.

Observatorio de la Infancia, "Menores de Edad en Andalucía", Datos cuantitativos. Informe, año 2009.

OCHAÍTA ALDERETE, E y ESPINOZA BAYAL, $\mathrm{M}^{\mathrm{a}}$. A. en MARTÍN LÓPEZ, $\mathrm{M}^{\mathrm{a}}$. T. (Coord.),“La protección de los menores. Derechos y recursos para su atención”, Ed. Civitas. Madrid, año 2002.

OCHOTORENA, J DE P. "Situaciones de desprotección infantil. Definiciones de desprotección y maltrato infantil. Importancia de la detección. Objetivos de los servicios de protección infantil", en el Curso sobre Menores y Familias en riesgo social organizado por la Universidad de Málaga y la Diputación Provincial de Málaga, 16 de marzo, año 2006.

OEHLING DE LOS REYES, A. "La dignidad de la persona. Evolución histórico-filosófica, concepto, recepción constitucional y relación con los valores y derechos fundamentales.”, Ed. Dykinson, S. L., Madrid, año 2010.

OLLERO TASSARA, A. "España: ¿Un Estado Laico?. La libertad religiosa en perspectiva constitucional.”, Ed. Thomson Civitas, Cizur Menor, año 2005.

OREJUDO PRIETO DE LOS MOZOS, P. "El empleo de la mediación en situaciones de secuestro internacional de menores", en ALDECOA LUZÁRRAGA, F y FORNER DELAYGUA, J. "La protección de los niños en el Derecho Internacional y en las Relaciones Internacionales”, Ed. Marcial Pons, Madrid, año 2010. 
ORGANIZACIÓN MUNDIAL DE LA SALUD, CIE-10, "Trastornos mentales y del comportamiento. Descripciones clínicas y pautas para el diagnóstico", Madrid, año 1992.

ORTI VALLEJO, A. "Derecho a la intimidad e informática (tutela de la persona por el uso de ficheros y tratamiento informático de datos personales. Particular atención a los ficheros de tipo privado", Ed. Comares, Granada, año 1994.

ORTÍZ DE ZÁRATE HIERRO, F. J. “Acceso a la justicia de los nuevos grupos sociales”, Actualidad Jurídica, Ed. Aranzadi, SA, Pamplona, año 2005.

ORTUÑO MUÑOZ, P. “El proyecto de Directiva Europea sobre la mediación”, en "Mediación y protección de menores en Derecho de Familia", Consejo General del Poder Judicial, Escuela Judicial, Cuadernos de Derecho Judicial, Madrid, año 2005.

ORTUÑO MUÑOZ, P. "Prólogo" en GARCÍA GARNICA, Ma DEL C. "Aspectos actuales de la Protección Jurídica del Menor”, Ed. Thomson Aranzadi, Cizur Menor, año 2008.

OURLIAC, P. Et DE MALAFOSSE, J. "Histoire du Droit privé", 2ème édition, Presses, Universitaires de France, Paris, año 1969.

PALACIOS, J., SÁNCHEZ-SANDOVAL, Y. \& LEÓN, E. “Adopción internacional en España", Estudios del Ministerio del Trabajo y Asuntos Sociales, núm. 49, año 2005.

PARDO GATO, J. R. "Derechos civiles forales y especiales. concordancias a partir del Código Civil. Legislación foral y especial de Aragón, Cataluña, Galicia, Islas Baleares, Navarra y País Vasco”, Ed. Bosh S.A., Barcelona, año 2013.

PAREJO ALFONSO, L.“Garantía institucional y autonomías locales”, Ed. Instituto de Estudios de Administración Local, Madrid, año 1981.

PARRA LUCÁN, M. A. "Autonomía de la voluntad y derecho de familia", Diario La Ley, No 7675, Sección Tribuna, , Año XXXII, Ref. D-304, La Ley nº 13922, Madrid, año 2011.

PASCUAL MEDRANO, M $\mathrm{M}^{\mathrm{a}}$.A., "Los derechos fundamentales y la Ley de Protección del Menor", Revista Jurídica de Navarra, núm. 22, Pamplona, año 1996.

PASTOR VITA, F. J. "Algunas consideraciones sobre la ley de reforma del Código Civil en materia de separación y divorcio.", Revista de Derecho de Familia, núm. 28, julio-septiembre, Ed. Lex Nova, Valladolid, año 2005.

PECES-BARBA, G. "Derecho Fundamentales", Centro de Estudios Constitucionales, Madrid, año 1993.

PECES-BARBA, G. “Los valores superiores”, Ed. Tecnos, Madrid, año 1984.

PECES-BARBA, G. en VV. AA.. "Introducción a la Teoría del Derecho", Ed. Tirant Lo Blanch, $3^{\text {a }}$ edición, Valencia, año 1997.

PEÑA GARCÍA, C. "Homosexualidad y matrimonio. Estudios sobre la jurisprudencia y la doctrina canónica". Publicaciones de la Universidad Pontificia Comillas, Madrid, año 2004. 
PEREDA GÁMEZ, J. "El cambio de las estructuras familiares y la modernización del Derecho de Familia (Notas para una tertulia)", en "Matrimonio homosexual y adopción", Ed. Reus, Madrid, año 2006.

PÉREZ CANOVAS, N. "Homosexualidad, homosexuales y uniones homosexuales en el Derecho español”, Ed. Comares, Granada, año 1996.

PÉREZ LUÑO, A. “Los Derechos Fundamentales”, Ed. Tecnos, Madrid, año 2004.

PÉREZ LUÑO, A. “Derechos Humanos, Estado de Derecho y Constitución”, 9a edición, Ed. Tecnos, Madrid, año 2005.

PÉREZ MARTÍN, A. J. "El procedimiento contencioso de separación y divorcio", en VV. AA. "Derecho de Familia", Ed. Lex Nova, 2º edición, Valladolid, año 1998.

PÉREZ MARTÍN, A. J. "Los hijos menores de edad en situación de crisis familiar", Ed. Dykinson, Madrid, año 2002.

PÉREZ MARTÍN, A. J. "La determinación del régimen económico matrimonial", Revista de Derecho de Familia, núm. 38, enero-marzo, Ed. Lex Nova, Valladolid, año 2008.

PÉREZ MILLA, J. “Matching y función pública autonómica en la adopción internacional: Los casos "Berta"”, Revista de Derecho de Familia, núm. 36, julio-septiembre, Ed. Lex Nova, Valladolid, año 2007.

PÉREZ MONGE, M. "La filiación derivada de técnicas de reproducción asistida", Centro de Estudios Registrales, Madrid, año 2002.

PÉREZ SOLA, N (Coords.) "Principios y derechos constitucionales de la personalidad. Su proyección en la legislación civil”, Ed. Tirant Lo Blanch, Monografías, núm. 698, Valencia, año 2010.

PÉREZ VILLALOBOS, M. C. "Las leyes autonómicas reguladoras de las parejas de hecho", Ed. Thomson-Civitas, Cizur Menor, año 2008.

PHILIPPE, M. D. "En el corazón del amor. Entrevista sobre el amor, el matrimonio y la familia”. Ed. Palabra, Madrid, año 2008.

PIEPER, J. “El Amor”, Ed. Rialp S.A., Madrid, año 1972.

PIETRO SANCHÍS, L. "Los derechos sociales y el principio de igualdad sustancial”, Revista del Centro de Estudios Constitucionales, núm. 22, septiembre-diciembre, Madrid, año 1995.

PINTO ANDRADE, C. "La custodia compartida”, Ed. Bosch S.A., Barcelona, año 2009.

PINTO ANDRADE, C. "Pactos matrimoniales en previsión de ruptura”, Ed. Bosch S. A., Barcelona, año 2010.

PIZARRO MORENO, E. "Reflexiones sobre el androcentrismo jurídico: el concepto de buen padre de familia. Propuestas para una renovación lingúístico-legal", en LÓPEZ DE LA 
CRUZ, L. y OTERO CRESPO, M. (Coords.), en "El levantamiento del velo: Las mujeres en el Derecho Privado", Ed. Tirant Lo Blanch, Homenajes y Congresos, Valencia, año 2011.

PLANA ARNALDOS, Ma . C. "Libertad ideológica y libre opción entre matrimonio y convivencia de hecho (Comentario a la STC 180/2001, de 17 de septiembre de 2001)", Revista de Derecho Privado y Constitución, núm. 15, Madrid, año 2001.

POLO SABAU, J. R. "Matrimonio y Constitución ante la Reforma del Derecho de Familia", Ed. Thomson Civitas, Cuadernos Civitas, Cizur Menor, año 2006.

POPPER, K.R. y ECLESS, J.“El yo y su cerebro”. Ed. Tecnos, Madrid, año 1989.

POUS DE LA FLOR, M. P. "La institución familiar en las parejas del mismo sexo", Ed. La Ley, T.3, Madrid, año 2005.

PRATS ALBENTOSA, L. "La autonomía de la voluntad en el siglo XXI: objeto del $11 .^{\circ}$ Congreso Notarial Español, conmemorativo del 150 Aniversario de la Ley del Notariado", Diario La Ley, No 7646, Sección Tribuna, 7 de Junio de 2011, Año XXXII, Ref. D-235, La Ley 12094, Madrid, año 2011.

PRESNO LINERA, M. A. "El Derecho Europeo de Familia", Ed. Thomson Aranzadi, Cizur Menor, año 2008.

PRETE SERRANO, J. J. "Prologo" en GIMENO Y GÓMEZ-LAFUENTE, J. L. y RAJOY BREY, E. (Coords), "Regímenes económicos y sucesiones. Derecho Común, Foral y Especial”. Tomo I. Centro de Estudios Registrales de Aragón, Ed. Thomson-Civitas, Cizur Menor, año 2008.

PRIETO ALVÁREZ, T. "La dignidad de la persona. Núcleo de la moralidad y el orden público, límite al ejercicio de libertades públicas", Ed. Thomson Civitas, Cizur Menor, año 2010 .

PRIETO SANCHÍS, L. "Estudios sobre derechos fundamentales", Ed. Debate, Madrid, año 1990.

PRIETO SANCHÍS, L. "Justicia constitucional y derechos fundamentales", Ed. Trotta, Madrid, año 2003.

PUIG BRUTEAU, J. "Fundamentos de Derecho Civil”, Tomo IV, Ed. Bosch S.A., Barcelona, año 1985 .

PULIDO QUECEDO, M. "De nuevo sobre las pruebas de investigación a la paternidad", BIB 2007/1315, Repertorio Aranzadi del Tribunal Constitucional num.12/2007 parte Tribuna, Ed. Aranzadi, SA, Pamplona. Año 2007, BIB 2007/1315.

QUESADA GONZÁLEZ, M. C. "El Derecho (¿Constitucional?) a conocer el Propio Origen Biológico", Anuario de Derecho Civil, T. I, enero-junio, Madrid, año 1994.

QUINTERO OLIVARES, G. (Dir.), “Comentarios al nuevo Código Penal”, Ed. Aranzadi, 7 edición, Pamplona, año 2008. 
RAGEL SÁNCHEZ, L. "Ejecución sobre bienes gananciales por deudas de un cónyuge”, Ed. Tecnos, Madrid, 1987.

RAGEL SÁNCHEZ, L. F. "Los deberes conyugales", en Anuario de la Facultad de Derecho de la Universidad de Extremadura, núms. 14 y 15, Cáceres, año 1998.

RAMOS CHAPARRO, E. "Ciudadanía y Familia: los estados civiles de la persona”, Ed. Cedecs, Barcelona, año 1999.

RAMOS CHAPARRO, E. “La persona y su capacidad civil”. Ed. Tecnos, Madrid, año 1995.

RAMOS CHAPARRO, E. "Niños y jóvenes en el derecho civil y constitucional", Revista de Derecho Privado y Constitución, núm. 7, Madrid, año 1995.

RAMS ALBESA, J. En VV. AA. “Autonomía de la voluntad y negocios jurídicos de familia”, Ed. Dykinson S.L., Madrid, año 2009.

RAMS ALBESA, J. En RAMS ALBESA y MORENO FLOREZ, R. M". (Coords.) "Comentarios al Código Civil”,, T.II, vol. 1, Ed. Bosch, Barcelona, año 2000.

RAMS ALBESA, J. “La sociedad de gananciales”, Ed. Tecnos, Madrid, año 1992.

RASCON GARCÍA, C. "Síntesis de historia e instituciones de derecho romano", Ed. Tecnos, Madrid, año 2006.

RAWLS, J. "Justicia como equidad. Materiales para una teoría de la justicia”. RODILLA, M. A. (Trad.), Ed. Tecnos, $2^{\text {a }}$ edición, Madrid, año 1999.

REAL ACADEMIA DE JURISPRUDENCIA Y LEGISLACION, "Informe aprobado el 21 de febrero de 2005 acerca del proyecto de modificación del Código Civil en materia del derecho a contraer matrimonio" http:/ /rajyl.insde.es

REAL ACADEMIA ESPAÑOLA, $21^{\mathrm{a}}$ y $22^{\mathrm{a}}$ edición, en Internet: www.rae.es

REBOLLEDO VARELA, A. L. "Belicosidad derivada de la elección del régimen económico matrimonial (I y II)". Publicación: Aranzadi Civil-Mercantil num. 15/2003 parte Estudio. Ed. Aranzadi, SA, Pamplona., año 2003. BIB 2003/1362.

REBOLLEDO VARELA, A. L. "El contrato de unión civil: la regulación de su contenido y efectos", Revista de Derecho de Familia, núm. 43, abril-junio, Ed. Lex Nova, Valladolid, año 2009.

RECASENS SICHES, L. "Vida humana, Sociedad y Derecho, fundamentación de la Filosofía del Derecho", Fondo de Cultura Económica, México D. F., año 1945.

REINA, V y MARTINELL, J. M. "Las uniones matrmoniales de hecho", Ed. Marcial Pons, Madrid, año 1996.

REQUENA HUERTAS, M. "La protección jurídica del menor en el ámbito del Consejo de Europa: el Convenio Europeo sobre el ejercicio de los derechos del niño" en CALVO 
GARCÍA, M. y FERNÁNDEZ SOLA, N. (Coords.) "Los derechos de la infancia y de la Adolescencia", Mira Editores, Zaragoza, año 2000.

REQUERO IBAÑEZ, J. L. "Reformas del Código Civil al servicio de una empresa ideológica", 678019_AJA_N_655-2005.Reformas_del_codigo.

REY MARTÍNEZ, F. “Homosexualidad y Constitución”, en Revista Española de Derecho Constitucional, núm. 73, Madrid, año 2005.

REY MARTÍNEZ, F. "El derecho fundamental a no ser discriminado por razón de sexo", Ed. McGraw-Hill, Madrid, año 1995.

REY MARTÍNEZ, F. "Homosexualidad y matrimonio", en Revista de Estudios Constitucionales, núm. 73, enero-abril, Madrid, año 2005.

REYES LOPEZ, M. a J. "Economía del matrimonio y empresa familiar”, en REYES LOPEZ, $\mathrm{M}^{\mathrm{a}} \mathrm{J}$, (Coord.) "La empresa familiar: encrucijada de intereses personales y empresariales”, Ed. Thomson Aranzadi, Cizur Menor, año 2004.

RIBERA BLANES, B. "La contribución a las cargas en el matrimonio en el régimen de separación de bienes", Ed. Tirant Lo Blanch, Valencia, año 2004.

RICHARDS, B. “¿What is identity?”, en GABER, I. y ALDRIDGE, J., “Culture, identity and transracial adoption, in the best interest of the child", Free Association Books Ltd., London, año 1994.

RICO CASAS, R. M. “¿Qué igualdad?. El principio de igualdad formal y no discriminación por razón de sexo en el ordenamiento jurídico español.", Ed. Dykinson, Madrid, año 2010 .

RICOEUR, P. “Amor y justicia”, DOMINGO MORATALLA, T (Trad.), Trotta, Madrid, año 1993.

RIEG, A. "Le rôle de la volonté dans l' acte juridique en droit civil francais et allemand". Librairie générale de droit y de jurisprudence. Paris, año 1961.

RIVERA FERNÁNDEZ, M. "Del régimen económico matrimonial: Art. 1315 CC" en ALBIEZ DOHRMANN, K y LÓPEZ FRÍAS, A. (Coords), "Jurisprudencia Civil comentada, Código Civil”, Tomo II, Ed. Comares, Granada, año 2000.

RIVERA FERNÁNDEZ, M. "Recorrido práctico sobre el activo de la sociedad legal de gananciales", Revista de Derecho de Familia, núm. 40, julio-septiembre, Ed. Lex Nova, Valladolid, año 2008.

RIVERO FERNÁNDEZ, F. “¿Mater semper certa est?, Problemas de determinación de la maternidad en el ordenamiento español”, Anuario de Derecho Civil, 1997-1, Madrid.

RIVERO FERNÁNDEZ, F. "La constitucionaidad del anonimato de gametos y el derecho de la persona al conocimiento de su origen biológico de la STC. 116/1999, de 17 de junio, al affaire odiève", Revista Jurídica de Cataluña (Legislación), volumen 103, núm. 1, Barcelona, año 2004. 
RIVERO FERNANDEZ, F. "La filiación en el umbral del Siglo XXI", Revista de la Facultad de Derecho de la Universidad de Granada, núm. 4, año 2001.

RIVERO HERNÁNDEZ, F. “Acerca de cierta jurisprudencia relativa a acciones de filiación”, Revista del Poder Judicial, núm. 75, Madrid, año 2004.

RIVERO HERNÁNDEZ, F. “El interés de menor”, Ed. Dykinson, Madrid, año 2007.

RIVERO HERNÁNDEZ, F. "La investigación de la mera relación biológica en la filiación derivada de técnicas de fecundación artificial”, La filiación a finales del siglo XX, II Congreso Mundial Vasco, Vitoria, año 1987.

RIVERO HERNÁNDEZ, F., "Comentarios al art. 91”, en LACRUZ BERDEJO, J.L. (Coord.), "Matrimonio y Divorcio. Comentarios al nuevo título IV del libro I del Código Civil", Ed. Civitas, $2^{a}$ edición, Madrid, año 1994.

RIVERO HERNÁNDEZ, F. "El derecho de visita”, Ed. J. Ma Bosch Editor, S.L., Barcelona, año 1996.

RIVERO HERNÁNDEZ, F. "La constitucionalidad del anonimato del donante de gametos y el derecho de la persona al conocimiento de su origen biológico (de la STC 116/1999, de 17 de junio al affaire Odievre)", Revista Jurídica de Cataluña (Legislación), volumen 103, $\mathrm{n}^{\circ} 1$, Barcelona, año 2004.

ROBLES MORCHÓN, G. "El libre desarrollo de la personalidad (Art. 10.1 de la C.E.)" en GARCIA SAN MIGUEL, L. (Coord.) "El libre desarrollo de la personalidad", Servicio de Publicaciones de la Universidad de Alcalá, Madrid, año 1995.

ROCA I TRIAS, E. "El matrimonio", en VVAA, "Derecho de familia", Ed. Tirant Lo Blanch, Valencia, año 1997.

ROCA I TRÍAS, E. "Adopción y datos biogenéticos: el proyecto "genoma humano" como auxiliar de las técnicas del desarrollo de la personalidad", Reunión internacional sobre el Derecho ante el proyecto genoma humano, 24 a 26 de mayo, Bilbao, año 1993.

ROCA I TRIAS, E. "Contestación: El interés del menor como factor de progreso y unificación del Derecho internacional privado", Revista Jurídica de Cataluña, Barcelona, año 1994.

ROCA I TRÍAS, E. "Familia y cambio social (De la casa a la persona)". Ed. Civitas, Madrid, año 1999.

ROCA I TRÍAS, E. "Familia, familias y derecho de la familia". Anuario de Derecho Civil, tomo XLIII, fasc. IV, oct.-dic. Madrid, año 1990.

ROCA I TRIAS, E. "Autonomía, crisis matrimoniales y contratos con ocasión de la crisis",

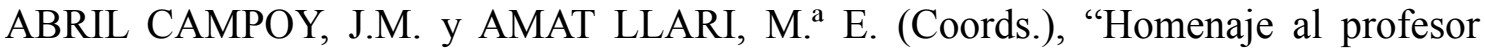
Lluis Puig I Ferriol”, Ed. Tirant lo Blanch, Valencia, año 2006.

ROCA I TRÍAS, E. "Familia, Formas familiares y Economía. Dos ensayos sobre metodología del derecho de familia" en ROCA I TRÍAS, E. y GUILARTE GUTIÉRREZ, V. "Patri- 
monio matrimonial en matrimonios indisolubles", Fundación Coloquio Jurídico Europeo, Madrid, año 2010.

ROCA I TRÍAS, E. "El interés del menor como factor de progreso y unificación del Derecho Internacional Privado (Contestació al Discurs d'ingrés en la Academía de Jurisprudéncia i Legislació de Catalunya de A. Borras)", Revista Jurídica de Catalunya, Barcelona, año 1994.

RODRIGUEZ CHACON, R. "Matrimonio, separación y divorcio en España: nueva regulación: estudio sistemático de las leyes 13/2005, de 1 de julio, y 15/2005, de 8 de julio". Ed. Experiencia, Barcelona, año 2005.

RODRIGUEZ GONZÁLEZ, J. I., "La autonomía del menor: su capacidad para otorgar el documento de instrucciones previas". Diario La Ley, N 6197, Sección Doctrina, 24 Feb. 2005, Año XXV, Madrid.

RODRIGUEZ JIMÉNEZ, S. y GONZÁLEZ MARTÍN, N. "El interés superior del menor en el marco de la adopción y tráfico internacional. Contexto mexicano.", UNAM, México, año 2011.

RODRIGUEZ LLAMAS, S. "La mediación familiar en España”, Ed. Tirant Lo Blanch, Monografías, núm. 678, Valencia, año 2010.

RODRIGUEZ RUIZ, B. “Matrimonio, Género y Familia en la Constitución Española” en Revista Española de Estudios constitucionales, Centro de Estudios Políticos y Constitucionales. No 91, año 31, Madrid, año 2011.

ROGEL VIDE, C. "Bienes de la personalidad, derechos fundamentales y libertades públicas", Publicaciones del Real Colegio de España, Bolonia, año 1985.

ROLDÁN FRANCO, Ma., en "El papel del consumo en la formación psicológica del niño y de la familia", en "Infancia, publicidad y consumo", Jornadas sobre Derecho de los menores, LÁZARO GONZÁLEZ, I., e MAYORAL NARROS, I (Coords.), en "Documentos de trabajo de la Facultad de Derecho de la Pontificia Universidad de Comillas", Madrid, año 2005.

ROMEO MALANDA, S "El valor jurídico del consentimiento" en "XVIII Congreso Nacional de Derecho Sanitario Actualización y puesta al día en Derechos de Información y autonomía de los pacientes: Especial referencia al consentimiento informado.”,página 4. http://www.aeds.org/XVIIIcongreso/ponencias/SRMalanda.pdf.

ROMERO COLOMA, A. Ma " Libertad religiosa del progenitor frente al beneficio del hijo menor", Revista de Derecho de familia, núm. 33, octubre-diciembre, Ed. Lex Nova, Valladolid, año 2006.

RONDON GARCÍA, L. M. "Bases para la mediación familiar", Políticas de Bienestar Social, Ed. Tirant Lo Blanch, Valencia, año 2012.

ROSADO VILLAVERDE, C.“La regulación estatutaria de los derechos y libertades”, Ed. Dykinson, S.L., Madrid, año 2012. 
RUBIO TORRANO, E. "Inconstitucionalidad del Art. 133, párrafo $1^{\circ}$, del Código Civil ( LEG 1889, 27)" BIB 2005/2546, Aranzadi Civil-Mercantil num. 17/2005 parte Tribuna, Ed. Aranzadi, S.A., Cizur Menor, año 2005.

RUIZ JIMÉNEZ, J. "La capacidad del menor en el ámbito sanitario", en POUS DE LA FLOR, Ma. P. "La capacidad de obrar del menor: nuevas perspectivas jurídicas", Exlibris Ediciones SL, Madrid, año 2009.

RUIZ MANERO, J. "Principios jurídicos", en GARZÓN VALDÉS, E. y LAPORTA, J. (Edits). "El Derecho y la justicia", Ed. Trotta-CSIC-BOE, Madrid, año 1996.

RUIZ RESA, J. D. "El concepto de interés en Ihering", Revista de la Facultad de Derecho de la Universidad de Granada, número 3, año 2000.

RUIZ-GIMÉNEZ CORTÉS, J en OSCAR ALZAGA VILLAAMIL (Dir.), "Comentarios a la Constitución española de 1978”, Tomo II, Cortes Generales, Eds. de Derecho reunidas, Madrid, año 1996.

RUIZ-RICO RUIZ, C. "El derecho constitucional a conciliar la vida laboral, familiar y personal”, Ed. Tirant Lo Blanch, Monografías, núm. 802, Valencia, año 2012.

RUIZ-RICO RUIZ, G. "Derechos de la personalidad como elementos de articulación de la Constitución política y la Constitución Civil”, Ed. Tirant Lo Blanch, Monografías, núm. 802, Valencia, año 2012.

RUSE, M. “La homosexualidad”, Ed. Cátedra, Madrid, año 1989.

SAINZ TORRES, M. "Los menores en las situaciones de crisis familiares" en LÁZARO GONZÁLEZ, I (Coord.), "Los menores en el Derecho español”, Ed. Tecnos, Madrid, año 2002.

SALANOVA VILLANUEVA, M. “¿Derecho del menor a ser separado de sus padres?. Nota a la Sentencia del Tribunal Europeo de Derechos Humanos de 10 de mayo de 2001 (TEDH 2001/332), Caso Z y otros V. Reino Unido.”, Aranzadi Civil, núm. 2, Madrid, año 2001.

SALANOVA VILLANUEVA, M. "El derecho del menor a no ser separado de sus padres", Revista de Derecho Privado y Constitución, núm. 7, septiembre - diciembre, Madrid, año 1995.

SALAS CARCELLER, A. "Uniones de hecho y premios económicos", Revista Aranzadi Doctrinal num.. 2/2010, parte Comentario, Ed. Aranzadi, SA, Pamplona, año 2010.

SALAZAR BORT, S. "La tutela especial de los hijos en la atribución del uso de la vivienda familiar en las crisis matrimoniales: el interés protegido", Ed. Tirant Lo Blanch, Valencia, año 2000 .

SALVADOR CODERCH, P. "Comentario al artículo 1 CF”, en EGEA FERNÁNDEZ Y FERRER I RIBA, J. (Dir.), “Comentaris al Codi de familia, a la Llei d' unions estables de 
parella i a la Llei de situacions convivencials d' ajuda mútua”, Ed. Tecnos, Madrid, año 2000 .

SALVADOR CODERCH, P. "Comentario al art. 45 CC.", en VV, AA., "Comentarios a las reformas del Derecho de familia”, Volumen I, Enciclopedia Jurídica Básica, Ed. Civitas, Madrid, año 1995.

SALVADOR GUTIÉRREZ, S. "Derechos Registrales del Menor" en RODRIGUEZ TORRENTE, J (Ed.), "El menor y la Familia, Conflictos e Implicaciones", Universidad Pontificia de Comillas, Madrid, año 1998.

SALVADOR GUTIÉRREZ, S., "Derecho a la Identidad", Actualidad Civil, IV, Madrid, AÑO 1999.

SANCHEZ DE LA TORRE, A. "Concepto jurídico de familia", Anales de la Real Academia de Jurisprudencia y Legislación, Madrid, año 2001.

SÁNCHEZ DE LA TORRE, A."El Derecho en la aventura europea de la libertad", Ed. Reus, Madrid, año 1987.

SANCHEZ DIAZ, P . "El trabajo en RENFE: un análisis de género". Sociología del trabajo, núm. 50, Madrid, años 2003/2004.

SÁNCHEZ FERRIS, R. "Estudios sobre las libertades”, Ed. Tirant Lo Blanch, $2^{\mathrm{a}}$ edición, Valencia, año 1995.

SÁNCHEZ GONZÁLEZ, $\mathrm{M}^{\mathrm{a}} \mathrm{P}$. “Acogimiento familiar para personas mayores y otras alternativas al internamiento en centros geriátricos", Revista Jurídica de Navarra, núm. 46, abril-junio, Pamplona, año 2003.

SÁNCHEZ GONZÁLEZ, Ma . P. "La intersexualidad como problema jurídico" en VV. AA. "Estudios jurídicos en homenaje al profesor Luis Díez-Picazo", Ed. Thomson-Civitas, Madrid, año 2003.

SANCHEZ GONZALEZ, Mª P. "Las fronteras del concepto jurídico de familia", La Ley, núm. 5, Madrid, año 2004.

SÁNCHEZ HERNÁNDEZ, C. "Capacidad natural e interés del menor maduro como fundamentos del libre ejercicio de los derechos de la personalidad", en "Estudios Jurídicos en Homenaje al profesor Luis Díez-Picazo", Tomo I, Semblanzas, Derecho Civil, Parte General, Ed. Thomson Civitas, Madrid, año 2003.

SÁNCHEZ HERNÁNDEZ, C. "Un caso de secuestro internacional de menores por parte del titular de la guarda y custodia: el interés del menor como criterio de decisión", Actualidad Civil, núm. 12, 22 al 28 de marzo, Madrid, año 1999.

SÁNCHEZ ROMÁN, F. "Derecho Civil”, Reimp. de la edición. de Madrid, Sucesores de Rivadeneyra, Madrid, año 1912.

SÁNCHEZ ROMAN, F. "Estudios de Derecho Civil, Historia General de la Legislación española", Tomo IV, Ed. Analecta, Ediciones y Libros, Navarra, año 2008 
SÁNCHEZ-CALERO ARRIBAS, B. "La intervención judicial en la gestión del patrimonio de los menores e incapacitados", Ed. Tirant Lo Blanch, Valencia, año 2006.

SANCHEZ-CALERO ARRIBAS, B. "El interés superior del menor y la interpretación restrictiva de las limitaciones a la capacidad de obrar de los menores en la Ley Orgánica 1/1996, de 15 de enero, de protección jurídica del menor". En HERRERA CAMPOS, R y BARRIENTOS RUÍZ, M.A. (Coords.), "Derecho y familia en el siglo XXI", Volumen II, , Ed. Universidad de Almería, año 2011.

SÁNCHEZ-CALERO ARRIBAS, B. "La actuación de los representantes legales en la esfera personal de los menores e incapacitados", Ed. Tirant Lo Blanch, Valencia, año 2005.

SANCHO CASAJUS, C. "Los derechos de la personalidad de los menores en Aragón”, página 69, en http://www.eljusticiadearagon.com/gestor/ficheros/_n004368_LOS\%20DERECHOS\%20DE\%20LA\%20PERSONALIDAD\%20DE\%20LŌ\%20MENORES $\% 20$ EN.pdf.

SANCHO REBULLIDA, F. "El concepto de estado civil, Estudios en homenajes al profesor Serrano, I". Valladolid, año 1965.

SANCHO REBULLIDA, F. y FUENMAYOR, AMADEO DE. "Comentario al Código Civil y Compilaciones Forales", ALBALADEJO, M (Dir.), Tomo II, arts. 42 a 107, Ed. Edersa, Jaén, año 1978.

SANTANA PÁEZ, E. en , HIJAS FERNÁNDEZ, E. (Coord.)“Los procesos de familia: una visión judicial”, Ed. Colex, $2^{\circ}$ edición, Madrid, año 2009.

SANTOS BRIZ, J. "Criterios Judiciales en la adjudicación del uso de la vivienda y ajuar familiares. Su aplicación en los distintos supuestos procesales" en VILADRICH, P. J (Coord.) "El hogar y el ajuar de la familia en las crisis matrimoniales, Bases conceptuales y criterios judiciales", EUNSA, Pamplona, año 1986.

SANTOS MORÓN, M. J. "Sobre la capacidad del menor para el ejercicio de los derechos fundamentales. Comentario a la STC 154/2002, de 18 de julio", La Ley, Revista Jurídica Española de Doctrina, Jurisprudencia y Bibliografía, núm. 5675, Madrid, año 2002.

SANTOS URBANEJA, F. "Familia, Educación y Futuro", Revista de Derecho de Familia, núm. 46, Ed. Lex Nova, enero-marzo, Valladolid, año 2010

SANTOS URBANEJA, F. “¿Qué significa el interés del menor?”, Revista de Derecho de Familia, núm. 15, Ed. Lex Nova, abril, Valladolid, año 2002.

SARAVIA GONZÁLEZ, A. M. a " "Guarda y custodia compartida. Principales novedades de la Ley 15/05 (cuestiones sustantivas)", en VV.AA, "La jurisdicción de familia: especialización. Ejecución de resoluciones y custodia compartida.", SARAVIA GONZÁLEZ A. M. ${ }^{a}$ y GARCÍA CRIADO, J.J. (Dir.), Consejo General del Poder Judicial, Estudios de Derecho Judicial, número 147-2007, Madrid, año 2008.

SARMIENTO, A. "Matrimonio y familia en la actual encrucijada" (en colaboración con FRANCESCHI, H), Ed. Ediplena, San vicente de Cañete-Lima, año 2001. 
SAURA MARTÍNEZ, L. F. "Uniones libres y la configuración del nuevo Derecho de familia", Ed. Tirant Lo Blanch, Valencia, año 1995.

SAVIGNY, F.C. DE. "Sistema de Derecho Romano actual”, Tomo I, Capítulo LIII, procedencia del original: GONGORA, F., Biblioteca de Catalunya, digitalizado el 18 de mayo de 2009.

SCAEVOLA, Q. M. "Código Civil comentado y concordado", Tomo III, arts. 108 a 198, Ed. Reus S.A., $5^{\text {a }}$ edición, Madrid, año 1942.

SECCIÓN PRÁCTICA, "Cambio de residencia del progenitor custodio en relación con la custodia de los hijos", Revista de Derecho de Familia, núm. 35, Ed. Lex Nova, abril-junio, Valladolid, año 2007.

SEIJAS QUINTANA, J.A. "Consecuencias de la separación y el divorcio: el interés del menor. Alimentos, guarda y custodia. Régimen de visitas. Aspectos internacionales. La vía convencional como medio de solución de conflictos. Especial referencia a los convenios de La Haya, Luxemburgo y Bruselas", Actualidad Civil, número 29, 14-20 de julio, Madrid, año 1997.

SERRANO ALONSO, E (Coord.) "Manual de Derecho de Familia". Ed. Edisofer S.L. Madrid, año 2000.

SERRANO ALONSO, E. "El nuevo matrimonio civil”, Ed. Edisofer, Madrid, año 2005.

SERRANO MOLINA, A. "El menor en el Derecho. Sistema normativo y principios rectores del Derecho de menores"en LÁZARO GOINZÁLEZ, I (Coord.) "Los menores en el Derecho español”, Ed. Tecnos, primera edición, Madrid, año 2002.

SERRANO POSTIGO, C. "Libertad religiosa y minoría de edad en el ordenamiento jurídico español" en Estudios de Derecho canónico y Derecho eclesiástico en Homenaje al profesor Maldonado, Universidad Complutense de Madrid, año 1983.

SERRANO, J. L. "La familia como asunto de estado el matrimonio como derecho del ciudadano. Lectura sintomal de la separación sistémica entre matrimonio y familia en la Constitución española de 1978", Revista Facultad de Derecho Universidad de Granada, núm. 4, año 2001.

SILLERO CROVETTO, B. y ASENCIO SÁNCHEZ, C. "La investigación de la paternidad: principio y derecho en nuestro ordenamiento jurídico", Actualidad Civil, Madrid, año 1998.

SORO RUSSELL, O. "Coloquio de las tergiversaciones en el Derecho de Familia", Revista Aranzadi Doctrinal, Pamplona, año 2011.

STERNBERG, J. "El triángulo del amor. Intimidad, pasión y compromiso", Ed. Paídos, Barcelona, año 1988.

STOLFI, G. "Teoría del negocio jurídico", SANTOS BRIZ, J (Trad.), en Revista de Derecho Privado, Madrid, año 1969. 
STOLKE, V. "La mujer es puro cuento: la cultura del género", en Estudios Feministas, 12 (2), maio-agosto, Florianópolis, año 2004.

STRIBANE, U. "El desarrollo del sentimiento de identidad desde una perspectiva psíquica infantil", Infancia y Sociedad, Ministerio de Asuntos Sociales, Madrid, noviembre-diciembre, año 1991.

SUAREZ CORTINA, M. "Libertad, armonía y tolerancia. La cultura constitucionalista en la España contemporánea”, Ed. Tecnos S.A., Madrid, año 2011

SUÁREZ ESPINO, M. L. "El derecho a la intimidad genética”, Ed. Marcial Pons, Madrid, año 2008.

SUAREZ LLANOS Mª L. "Teoría feminista, Política y Derecho", Ed. Dykinson, Madrid, año 2002.

SUAY RINCÓN, J. "El principio de igualdad en la justicia constitucional”, IEAL, Madrid, año 1985.

TALAVERA FERNÁNDEZ, P. en "La unión de hecho y el derecho a no casarse", Ed. Comares, Granada, año 2001.

TAMAYO HAYA, S. "De la paternidad biológica a la paternidad social" en BLASCO, F y Otros (Coords.) "Estudios jurídicos en homenaje a Vicente L. Montés Penadés". Tomo II, Ed. Tirant Lo Blanch, Homenajes y Congresos, Valencia, año 2011.

TAMAYO HAYA, S. "El interés del menor como criterio de atribución de la custodia", Revista de Derecho de familia, , núm. 41, Ed. Lex Nova, octubre-diciembre, Valladolid, año 2008 .

TAMAYO HAYA, S. "El statuto jurídico de los padrastros. Nuevas perspectivas jurídicas". Colección Scientia Iurídica, Ed. Reus S. A., Madrid, año 2009.

TAMAYO HAYA, S. "La posición jurídica de la mujer a través de las reformas del Derecho de familia" en LÓPEZ DE LA CRUZ, L y OTERO CRESPO, M. (Coords.) "El levantamiento del velo: La mujeres en el Derecho Privado", Ed. Tirant Lo Blanch, Homenajes y Congresos, Valencia, año 2010.

TAMAYO HAYA, S. "Las uniones de hecho y las relaciones paterno-filiales en el derecho europeo", Revista de Derecho de Familia, núm. 42, Ed. Lex Nova, enero-marzo,Valladolid, año 2009.

TIRAPU, D. "Perplejidades y contradicciones del pretendido matrimonio homosexual. Comentarios al Proyecto de Ley de reforma del Código Civil en materia de matrimonio", Revista General de Derecho Canónico y Derecho Eclesiástico del Estado, 8, Madrid, año 2005.

TOLDRÀ ROCA, Ma . D. en PADIAL ALBÁS, A y TOLDRÁ ROCA, Ma , D. "Estudios jurídicos sobre la protección de la infancia y la adolescencia", Ed. Tirant Lo Blanch, Valencia, año 2007. 
TORRERO MUÑOZ, M. "Las Crisis Familiares en la Jurisprudencia, Criterios para una mediación familiar”. Ed. práctica de Derecho S.L., Valencia, Año 1999.

TORRES DEL MORAL, A. "Principios de Derecho Constitucional español", Volumen 1, Universidad Complutense de Madrid, Facultad de Derecho, Madrid, año 1992.

TORRES DEL MORAL, A.. "Principios de Derecho Constitucional Español", Tomo I, Ed. Átomo, $2^{\mathrm{a}}$ edición, Madrid, año 1988.

TORRES GARCIA, T. "De la administración de la sociedad de gananciales" en DIEZ-PICAZO GIMENEZ, G. (Coord), "Derecho de Familia" , Ed. Thomson Reuters, Cizur Menor, año 2012.

TORRES PEREA, J. M., “Tratamiento del interés del menor en el Derecho alemán”, Revista Anuario de Derecho Civil, núm. LIX-2, abril, Madrid, año 2006.

TOVAR ESCUDERO, C. "Manifestaciones y expresiones de los niños afectados por alinea-

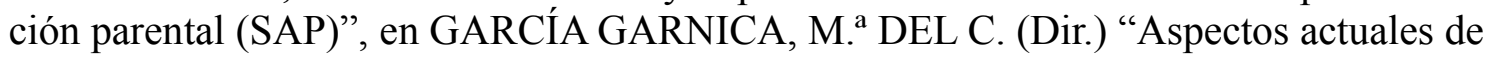
la Protección Jurídica del Menor. Una aproximación interdisciplinar”, Ed. Aranzadi, Cizur Menor, año 2008.

TRABUCCHI, A. "Instituciones de Derecho Civil", MARTÍNEZ-CALCERRADA (Trad.), en Revista de Derecho Privado, Tomo II, núm. 277, Madrid, año 1967.

TRIGUERO MARTÍNEZ, L. A. "Los derechos sociales fundamentales de los extranjeros en un escenario de reformas estructurales y perspectiva de futuro ante la Directiva de permiso único de residencia y trabajo.", Revista de Derecho Migratorio y Extranjería, núm. 30, Ed. Lex Nova, Valladolid, año 2012.

TRINIDAD NUÑEZ, P. "La cara oscura de las relaciones familiares: la protección internacional del niño frente a los miembros de su propia familia" en Anuario de la Facultad de Derecho Universidad de Extremadura, Volumen XXII, año 2004.

TRISEL OTIS, J. "Intercountry Adoption: Global Trade or Global Gift", 24 Adoption and Fostering 48, año 2000.

TRISELIOTIS, J. "Identity formation and the adopted person revisited", en KANTZ, I y TREACHER A, (Edits.), The Dynamics of Adoption: Social and personal perspectives, Jessica Kingsley, London, año 2000.

TUBER, S. (Coord.) “Del sexo al género. Los equívocos de un concepto”. Ed. Cátedra, Madrid, año 2011.

TUR AUSINA, R. "Garantía de Derechos y Jurisdicción Constitucional. Efectividad del amparo tras la sentencia estimatoria", Ed. Tirant Lo Blanch, Monografías, núm. 525, Valencia, año 2008.

UGARTEMENDÍA ECEIZABARRENA, J. I. "La tutela de la igualdad de trato como cauce de expansión del Derecho comunitario en el ordenamiento interno", en Revista Española de Derecho Constitucional, núm. 84, año 2008. 
UREÑA MARTÍNEZ ,M.. "Malos tratos a menores en el ámbito familiar”, Cuadernos de Aranzadi Civil núm. 33, Cizur Menor, año 2008.

UTRERA GUTIERREZ, J. L. "El marco jurídico de los puntos de encuentro familiar", Revista de Derecho de familia, núm. 9, Ed. Lex Nova, Valladolid, octubre. año 2000.

VALCARCEL, A. "El concepto de igualdad”, Ed. Pablo Iglesias, Madrid, año 1994.

VALLADARES RASCON, E. "El Derecho a contraer matrimonio y la Constitución”, Aranzadi Civil-Mercantil, nº 9, parte Estudio, Ed. Aranzadi S.A., Pamplona, año 2005.

VALLÉS, A. (Dir.), “La protección del menor”, Ed. Tirant Lo Blanch, Valencia, año 2009.

VALPUESTA FERNÁNDEZ, $M^{\mathrm{a}}$ del R. "El impulso de las mujeres en la transformación del Derecho de familia” en GARCÍA RUBIO, M. ${ }^{a}$ y VALPUESTA FERNÁNDEZ, M. a, "El levantamiento del velo: las mujeres en el Derecho Privado", Ed. Tirant Lo Blanch, Homenajes y Congresos, Valencia, año 2011.

VALPUESTA FERNÁNDEZ, Ma del R. "La Ley Orgánica para la Igualdad efectiva de Mujeres y Hombres", en Teoría y Derecho, Revista de Pensamiento Jurídico, núm. 1, Valencia, año 2007.

VALPUESTA FERNÁNDEZ, $M^{\mathrm{a}}$ del R. "Diversidad y ciudadanía: una reflexión desde el feminismo" en PERIÑÁN GOMEZ, B (Coord.), "Derecho, persona y ciudadanía: una experiencia jurídica comparada", Ed. Marcial Pons, Madrid-Barcelona-Buenos Aires, año 2010 .

VALPUESTA FERNÁNDEZ, $\mathrm{M}^{\mathrm{a}}$ del R. "El Derecho de Familia desde una perspectiva de género", en NAVAS NAVARRO, S. (Dir.), "Iguales y diferentes ante el Derecho Privado", Ed. Tirant Lo Blanch, Homenajes y Congresos, Valencia, año 2012.

VALPUESTA FERNÁNDEZ, $\mathrm{M}^{\mathrm{a}}$ del R. "Reflexiones sobre el Derecho de familia", Revista Teoría \& Derecho, núm. 2, Ed. Tirant Lo Blanch, Valencia, año 2007.

VALPUESTA FERNÁNDEZ, Ma . del R. "El impulso de las mujeres en la transformación del Derecho de Familia” en LÓPEZ DE LA CRUZ, L y OTERO CRESPO, M. (Coords.) "El levantamiento del velo: La mujeres en el Derecho Privado", Ed. Tirant Lo Blanch, Homenajes y Congresos, Valencia, año 2010.

VALPUESTA FERNÁNDEZ, Ma del R. En LÓPEZ Y LÓPEZ, A. M., MONTES PENEDÉS, V. L., ROCA I TRÍAS, E. (Edit.), "Derecho Civil. Parte General. Derecho de la persona.", Ed. Tirant Lo Blanch, Valencia, año 2003.

VALPUESTA FERNÁNDEZ, Ma del R. "La disciplina constitucional de la familia en la experiencia europea”, Ed. Tirant Lo Blanch, Valencia, año 2012.

VALPUESTA FERNÁNDEZ, Ma " "La Ley Orgánica para la Igualdad efectiva de Mujeres y Hombres", en Teoría y Derecho, Revista de Pensamiento Jurídico, núm. 1, Valencia, año 2007. 
VAN DEN AARDWEG, G.J.M. "Homosexualidad y esperanza. Terapia y curación en la experiencia de un psicólogo", Ed. EUNSA, Pamplona, año 1997.

VAN SPIJKER, H. “La homotropia”, Ed. Sígueme, Salamanca, año 1970.

VARELA GARCÍA, C. "Comentarios a la Ley Orgánica 1/1996, de 15 de enero, de protección jurídica del menor: principios programáticos y normas de conflicto”, Actualidad Civil, núm. 12, marzo, Madrid, año 1997.

VARGAS CABRERA, B. "La protección del menor en el ordenamiento jurídico", Ed. Comares, Granada, año 1994.

VARGAS CABRERA, B. "El Ministerio Fiscal y el principio del interés del menor", en PÉREZ ÁLVAREZ, M. A. (Coord.) "La desprotección social de los menores y las instituciones de amparo reguladas e la Ley Orgánica de protección del menor", Jornadas de Derecho Civil en Homenaje a Estanislao de Aranzadi, Servicio de Publicaciones, Universidad de Coruña, año 1999.

VARGAS GALLEGO, A. I. "Título II. Políticas públicas para la igualdad. Capítulo Primero. Principios generales" en "ROMÁN GARCÍA, F. (Dir.), "Análisis de la Ley Orgánica 3/2007, de 22 de marzo, para la igualdad efectiva de mujeres y hombres", El Derecho Editores, Madrid, año 2007.

VÁZQUEZ- PASTOR JIMENEZ, L. "La construcción de la ciudadanía del menor de edad", Ed. Tirant Lo Blanch, Monografías 619, Valencia, año 2009.

VÁZQUEZ-PASTOR JIMÉNEZ, L. "El transexualismo primario y su contemplación legal en el ordenamiento jurídico español", en NAVAS NAVARRO, S. (Dir.), "Iguales y diferentes ante el Derecho Privado", Ed. Tirant Lo Blanch, Homenajes y Congresos, Valencia, año 2012.

VERDÚN, J. "La mediación familiar en España y en Inglaterra", Revista de Treball Social, núm. 154, juny, any 1999.

VICO PENADO, J. “Liberación sexual y ética cristiana”, Ed. San Pablo, Madrid, año 1999.

VIDAL GIL, E. "Los derechos en la Convención de Derecho del Niño y en la Constitución española", en BALADO, M y GARCÍA REGUEIRO, J. A. (Dir.): "La Constitución española de 1978 en su XXV aniversario”, Ed. Bosch S.A., Barcelona, año 2003.

VIDAL MARTÍNEZ, J. "La figura del anonimato del donante en la regulación de las técnicas de reproducción asistida", Revista General del Derecho, septiembre, año 1994.

VIDAL MARTÍNEZ, J. “¿Se incluye el "cambio de sexo” transexualidad, en el "libre desarrollo de la personalidad", al que se refiere el artículo 10-1 de 1 Constitución Española? (Comentario a la sentencia del Tribunal Supremo Sala $1^{\circ}$ de 2 de julio de 1987)", Revista General de Derecho, Madrid, año 1989.

VIDAL MARTÍNEZ, J. “Acerca del valor permanente del Derecho Civil como Derecho de la persona en la era de la globalización" en "Estudios jurídicos en homenaje a Vicente 
Montés Penadés", Tomo II, Ed. Tirant Lo Blanch, Homenajes y Congresos, Valencia, año 2011.

VIDAL MARTÍNEZ, J."La figura del anonimato del donante en la regulación de las técnicas de reproducción asistida”, Revista General del Derecho, septiembre, Madrid, año 1994.

VIDAL, M y FERNÁNDEZ-MARTOS, J. M. "Aclaraciones fundamentales. Nombre, definición, tipos y normalidad" en "Homosexualidad: ciencia y conciencia", Ed. Sal Terrae, Santander, año 1981.

VIDALPRADO,C.www.academia.edu/826479/El derecho a conocer la filiacion biologica. "El derecho a conocer la filiación biológica (Con especial atención a la filiación materna)"

VILADRICH, J. P. "La palabra de la mujer”, Instituto de Ciencias para la Familia, Ed. Rialp, Pamplona, año 2000.

VILADRICH, P. J.“El modelo antropológico del matrimonio”. Instituto de Ciencias para la familia, Ed. Rialp, Pamplona, año 2005.

VILLAGRASA ALCAIDE, C. "Las reivindicaciones de los movimientos internacionales de infancia y adolescencia en el vigésimo aniversario de la Convención sobre los Derechos del Niño" en ADELCOA LUZÁRRAGA, F y FORNER DELAYGUA, J. (Dirs.) "La protección de los niños en el Derecho Internacional y en las relaciones internacionales.", Jornadas en conmemoración del 50 aniversario de la Declaración Universal de los Derechos del Niño y del 20 aniversario del Convenio de Nueva York sobre los Derechos del Niño, Colegio de Notaris de Catalunya, Ed. Marcial Pons, Barcelona, año 2010.

VILLAVERDE MENÉNDEZ, I. "Igualdad en la diversidad. Formas de Estado y Derecho fundamentales”, Centro de estudios Políticos y Constitucionales, Madrid, año 2012.

VILLAVERDE MENÉNDEZ, I. "Concepto, contenido, objeto y límites de los derechos fundamentales", en "La democracia. Estudios en homenaje al profesor Francisco Rubio Llorente”, Centro de estudios Políticos y Constitucionales, Madrid, año 2002.

VIVES MARTÍNEZ, G. "Custodia compartida, valoración de la prueba y victimización de los menores. Una visión objetiva desde la Magistratura y la experiencia”. Economist \& Iurist, Noviembre, Madrid, año 2007.

VON SAVIGNY, C. "Sistema de Derecho Romano actual”, Ed. Comares, Granada, año 2005.

VON THUR, A. "Derecho civil. Teoría general del derecho civil alemán." RAVÁ DE PALMA, T. (Trad.), Tomo 3, Volumen III, Ed. Marcial Pons, Madrid, año 2005.

VV. AA. "El derecho del adoptado a conocer sus orígenes en España y en el Derecho comparado", Observatorio de la infancia, Ministerio del Trabajo y Asuntos Sociales, Madrid, año 2006.

VV. AA. "La praxis del consentimiento informado en la relación sanitaria. Aspectos biojurídicos”, Cuadernos Prácticos, Ed. Difusión Jurídica, Madrid, año 2007. 
VV. AA. "Polémica sobre el origen y la universalidad de la familia", Ed. Anagrama, Barcelona, año 1986.

VV. AA. "Familia e interculturalidad", Colección Estudios Familiares, no 13, Universidad Pontificia de Salamanca, año 2003.

VV. AA. "Familia y cambio social en España", Centro de Investigaciones Sociológicas, Madrid, año 1982.

VV. AA., "Los derechos fundamentales y su protección constitucional", Ed. Colex, Madrid, año 2007.

VV. AA. "San Agustín”, Ed. Gredos, Madrid, año 2012.

VV. AA. "Problemática jurídica de los bienes y deudas que no se incluyeron en el inventario de la sociedad de gananciales", Revista de Derecho de Familia, núm. 40, julio-septiembre, Ed. Lex Nova, Valladolid, año 2008.

VV.AA. "Teoría General de los Derechos Fundamentales en la Constitución española de 1978”, Ed. Tecnos, Madrid, año 2004.

WINTERSBERGER, H. "Infancia y ciudadanía: el orden generacional del Estado de Bienestar”, en Revista Política y Sociedad, volumen 43, núm. 1, Madrid, año 2006.

YZQUIERDO TOLSADA, M y CUENA CASAS, M. (Dir). "Tratado de Derecho de familia", Volumen I. "Derecho de familia y Derecho de la familia. La relación jurídico- familiar. El matrimonio y su celebración”. Ed. Thomson Reuters, Cizur Menor, año 2011, Pamplona.

ZAGREBLESKY, G. "El derecho dúctil”. Ed. Trotta, Madrid, año 2011.

ZARRALUQUI SANCHEZ-EZNARRIAGA, L. "El convenio regulador y su aprobación judicial”, Boletín del Ilustre Colegio de Abogados de Madrid, núm. 8, 3 Epoca, año 1997.

ZARRALUQUI SÁNCHEZ-EZNARRIAGA, L. "El interés del menor en los casos de nulidad, separación y divorcio", en "El menor en la legislación actual", Fundación Antonio Nebrija, Madrid. Año 2002.

ZOCO ZABALA, C. "Violencia de género ocasional desde la perspectiva de la igualdad material y formal: Sentencias del Tribunal Constitucional, 100/2008, de 24 de julio, 82/2008, de 17 de julio, y 59/2008, de 14 de mayo", Repertorio Aranzadi del Tribunal Constitucional, núm. 20/2008, parte Estudio. Ed. Aranzadi S.A., Pamplona, año 2008.

ZUMAQUERO GIL, L. "El interés del menor en los tribunales españoles" en "La protección de los niños en el Derecho Internacional y en las relaciones internacionales", Jornadas en Conmemoración del 50 aniversario de la Declaración Universal de los Derechos del Niño y del 20 aniversario del Convenio de Nueva York sobre los Derechos del Niño, Colegi de Notaris de Catalunya, Ed. Marcial Pons, Madrid, año 2010. 